Department OF THE INTERIOR

Hubert Work, Secretary

U. S. GEOLOGICAL SURVEY

George Otis Smith, Director

Professional Paper 137

\title{
THE FAUNA OF THE RIPLEY FORMATION ON COON CREEK, TENNESSEE
}

BY

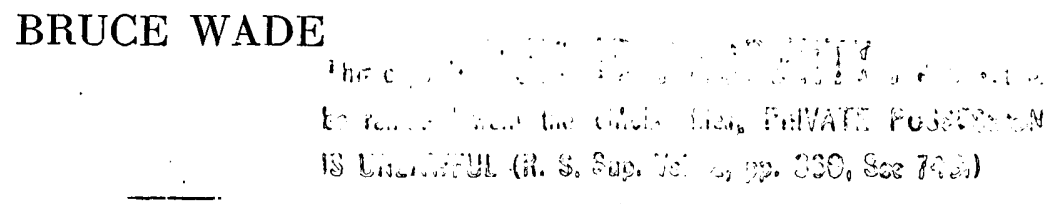

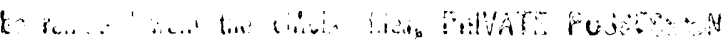

19 Lis

Prepared in cooperation with the GEOLOGICAL SURVEY OF TENNESSEE

WILBUR A. NELSON, State Geologist

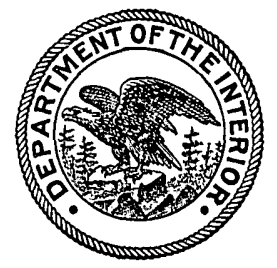

WASHINGTON

GOVERNMENT PRINTING OFFICE 


\section{CONTENTS}

Introduction

Acknowledgments _-

The Upper Cretaceous series of Tennessee.

Historical sketch

General geologic relations

Tuscaloosa formation

Eutaw formation

Selma formation

Ripley formation

Distribution and subdivisions

Coon Creek tongue

MeNairy sand member........

Owl Creek tongue.

Summary -

The Coon Creek fauna

The locality

Character of the sediment

State of preservation of the fossils

Biologic relations of the fauna

Character of habitat.

Stratigraphic and geographic distribution

Systematic descriptions $\ldots$

Coelenterata

Echinodermata

Vermes _...

Molluscoidea, by Ferdinand Canu and R. S. Bassler.

Mollusca _.

Arthropoda, by M. J. Rathbun...........

Vertebrata, by C. W. Gilmore...

Index

\section{IILUSTRATIONS}

Plates I-LXXII. Ripley fossils from Coon Creek, Tenn

FIgORE 1. Map of part of Tennessee, showing areas underlain by Upper Cretaceous formations

2. Diagrammatic section of Upper Cretaceous formations in Tennessee 


\title{
THE FAUNA OF THE RIPLEY FORMATION ON COON CREEK, TENNESSEE
}

\author{
By Bruce WADE
}

\section{INTRODUCTION}

This paper presents the results of a systematic study of an Upper Cretaceous fauna represented by unusually well preserved fossils recently discovered on Coon Creek, in McNairy County, Tenn., and points out the relation of this fauna to other known Cretaceous faunas. It also outlines briefly the general geologic relations of the Upper Cretaceous series in Tennessee.

Upper Cretaceous fossils are interesting because the animals and plants they represent lived at a time when evolutionary changes, especially among the Mollusca, were most active and when many new families and genera were introduced. They represent a stage of development intermediate between the more primitive Paleozoic and early Mesozoic and the much diversified Tertiary and Recent Mollusca. Many genera of this phylum that are present in the Upper Cretaceous do not appear in the later periods; yet nearly all of the genera occurring in the Tertiary and Recent appear in the Upper Cretaceous, though the species are not so highly diversified.

Gastropods are especially abundant in the Coon Creek fauna. As a class, gastropods are not preserved so readily as pelecypods, both on account of the smaller proportionate number of individuals and the comparative weakness of their shells. Gastropod shells inclosed in sediments as remote in age as the Upper Cretaceous are rarely preserved with their original shell form and material strong enough to be recovered from the sediments complete and unbroken.

The Coon Creek fauna is of special interest and importance in paleozoology not only because of the abundant and excellent fossils but also because it represents probably the largest assemblage of species from a single locality that has as yet been reported from the Upper Cretaceous sediments. A total of about 350 species have been collected from this one locality from a single horizon. This fauna includes 174 species of gastropods, among which 21 new generic groups have been recognized. These genera are not new because the Coon Creek fauna is wholly new and represents an assemblage of life entirely unknown to science but because it furnishes complete specimens with nuclear, ornamental, apertural, and other shell characters that reveal the true family and generic relations of several groups which have heretofore been improperly classified and undescribed. In nearly every group for which a new generic name has been proposed in this study there occur one or more species described in the American and European literature or one or more species undescribed but available in the American museums, but on account of the incompleteness of the specimens, former paleozoologists have questionably referred the forms of uncertain generic relations to the most nearly related group.

Thus the Coon Creek fauna, with its abundant perfect shells, should, if studied along with other good Upper Cretaceous fossils of the world, contribute to the advancement of biology in helping to establish true family and generic relationships among the late Mesozoic Mollusca, and, further, this fauna of so many species should fix sharply a stratigraphic horizon in the Upper Cretaceous strata which may be useful in the correlation of this series of rocks.

\section{ACKNOWLEDGMENTS}

A paper on the Gastropoda of the Coon Creek fauna was submitted to the board of university studies of the Johns Hopkins University in May, 1917, as a thesis for the degree of Doctor of Philosophy. During 1919 and 1920 the remainder of this fauna was studied, and a report on it is herein presented. Two rather extensive collections from the Coon Creek locality, one at the United States National Museum and one at the Johns Hopkins University, were available for this research.

In submitting this paper for publication the writer wishes to express his appreciation and gratitude for the kindness, encouragement, instruction, and inspiration extended to him during three years as a student in the geological laboratory of the Johns Hopkins University by the late Dr. W. B. Clark and his associates.

To Professor Berry the writer is especially indebted, for he was the first to recognize the importance of the Coon Creek fauna and proposed the subject for research. Furthermore, he contributed good advice and sound judgment on all questions that arose in the course of this study.

Without the assistance afforded by Miss Julia A. Gardner, who has for the past few years conducted 
extended research work in the Upper Cretaceous and Tertiary Mollusca of the Eastern States, many of the difficulties arising in the study of the Coon Creek Gastropoda would have been almost insurmountable.

The field work for this study was made possible by the late Dr. A. H. Purdue and by Wilbur A. Nelson, then State geologist of Tennessee. The writer is further indebted to the Tennessee Geological Survey for donating for this investigation the Coon Creek collection, with its rare and interesting specimens.

T. W. Stanton, L. W. Stephenson, J. B. Reeside, jr., W. P. Woodring, and C. W. Cooke, of the United States Geological Survey, have kindly examined many of the Coon Creek specimens and offered valuable suggestions as to their taxonomic relations and have permitted the writer to study the Upper Cretaceous and Eocene collections of the United States Geolagical Survey. To Mr. Stephenson, who has been engaged for several years in areal, stratigraphic, and faunal studies of the Coastal Plain Cretaceous deposits, the writer is especially indebted for. instruction, both in the field and in the museum. To Mr. Reeside, who has recently been studying Cretaceous ammonites, the writer is indebted for supervising his determinations and descriptions of the Coon Creek cephalopods. Drs. W. H. Dall and Paul Bartsch, of the United States National Museum, have examined many of the specimens and have aided in determining the biologic relations of many forms. Dr. R. S. Bassler and Miss Mary J. Rathbun, of the United States National Museum, have made a study of the Bryozoa and the Crustacea of this fauna. Drs. C. W. Gilmore and J. W. Gidley, also of the United States National Museum, have determined the vertebrate remains and contributed a few observations on that group. Dr. H. A. Pilsbry, of the Philadelphia Academy of Natural Sciences, gave permission for comparisons of the Coon Creek specimens with the Upper Cretaceous types in the academy's museum. Messrs. Maurice Cossmann and Henri Douvillé, of Paris, have examined a number of the specimens and have given authoritative opinions on several groups.

The writer wishes to express his appreciation for the work of Mr. W. O. Hazard, who photographed the specimens, and that of Miss.Frances Wieser, who retouched the photographs and assembled the plates.

\section{THE UPPER CRETACEOUS SERIES OF TENNESSEE}

\section{HISTORICAL SKETCH}

The first adequate map and separation of the Upper Cretaceous series of Tennessee into formational units was published by Safford ${ }^{1}$ in 1869. Troost and others had previously written a little about the

1 Safford, J. M., Geology of Tennessee, pp. 410-421, map, Nashville, 1869.
Cretaceous beds of this State but had not definitely described the formations. Safford's work was based on faunal and lithologic studies and has been little changed, even to the present day. In 1906 Glenn ${ }^{2}$ published a map and gave a good and serviceable account of the Upper Cretaceous of Tennessee. Nelson gave a short discussion of the Upper Cretaceous in 1911. ${ }^{3}$ The occurrence of the Tuscaloosa formation in Tennessee was shown by the work of Miser. ${ }^{4}$ on the Waynesboro quadrangle in 1913 . The McNairy sand member of the Ripley formation was differentiated by Stephenson ${ }^{5}$ in 1914, and in the same publication the Upper Cretaceous deposits of Tennessee were correlated with beds of the same age in the eastern part of the United States.

In 1916 Berry $^{6}$ published an account of about twenty-four species of fossil plants collected from the Ripley and Eutaw formations of McNairy and Hardin counties, Tenn. In 1916 and 1917 the writer ${ }^{7}$ published several short papers on the discovery of a large Ripley fauna in McNairy County and made some observations on it. $\mathrm{He}$ also contributed an article on the occurrence of the Tuscaloosa formation as far north as Kentucky. In 1919 Schroeder ${ }^{8}$ gave a very brief outline of the Cretaceous in connection with his report on the ball clays of west Tennessee. Late in 1919 Berry $^{\circ}$ published a comprehensive discussion of the Upper Cretaceous geology of Tennessee.

During 1915 and 1916 the writer mapped in detail the areal distribution of the Upper Cretaceous formations in McNairy, Decatur, and Chester counties, and in 1919 this work was carried northward and was completed in Henderson and Carroll counties and in a portion of Henry County. In 1921 the Tennessee Geological Survey completed the areal mapping of Henry, Benton, and Hardin counties. The outliers of Cretaceous gravels on the uplands of Stewart, Houston, Humphreys, and Dickson counties have not yet been mapped. When the

2 Glenn, L. C., Underground waters of Tennessee and Kentucky west of Tennessee River and of an adjacent area in Illinois: U. S. Geol. Survey Water-Supply Paper 164, pp. 23-29, pl. 1, 1906.

${ }^{3}$ Nelson, W. A., Clay deposits of west Tennessee: Tennessee Geol. Survey Bull. $5,1911$.

4 Miser, H. D., in Drake, N. F., Economic geology of the Waynesboro quadrangle: Resources of Tennessee, vol. 4, p. 107, 1913.

3 Stephenson, L. W., Cretaceous deposits of the eastern Gulf region: U. S. Geol. Survey Prof. Paper 81, p. 22, 1914.

${ }^{6}$ Berry, E. W., Contributions to the Mesozoic flora of the Atlantic Coastal Plain; XI, Tennessee: Torrey Bot. Club Bull., vol. 43, pp. 283-304, pl. 16, 1916.

7 Wade, Bruce, New genera and species of Gastropoda from the Upper Cretaceous: Acad. Nat. Sci. Philadelphia Proc., vol. 68, pp. 455-471, pls. 23, 24, 1917; An Upper Cretaceous Fulgur: Am. Jour. Sci., 4th ser., vol. 43, p. 293, figs. 1, 2, 1917; New and little-known Gastropoda from the Upper Cretaceous of Tennessee: Acad. Nat. Sci. Philadelphia Proc., vol. 69, pp. 280-304, pls. 17-19,1917; A remarkable Upper Cretaceous fauna from Tennessee: Johns Hopkins Univ. Circ., new ser., 1917, No. 3, pp. 73-101, March, 1917; The occurrence of the Tuscaloosa formation as far north as Kentucky: Idem, pp. 102-106.

${ }^{8}$ Schroeder, R. A., Ball clays of west Tennessee: Resources of Tennessee, vol. 9 , pp. 81-180, 1919.

9 Berry, E. W., Upper Cretaceous floras of the eastern Gulf region in Tennessee, Mississippi, Alabama, and Georgia: U. S. Geol. Survey Prof. Paper 112, 1919. 


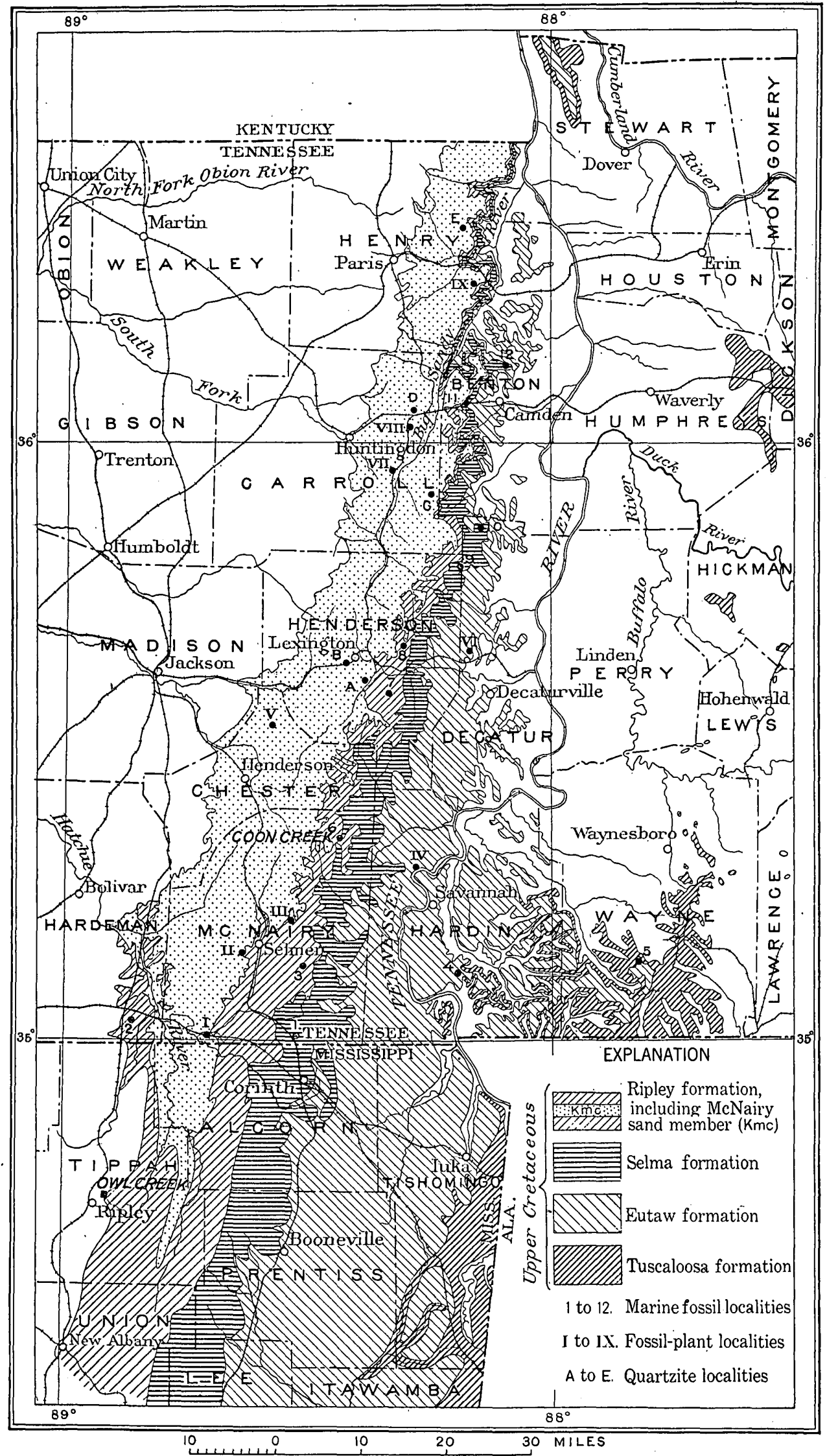

FigUre 1,-Map of part of Tennessee, showing areas underlain by Upper Cretaceous formations. 
field work in all these counties has been completed, information will be available for a complete areal and stratigraphic report on the Upper Cretaceous beds of Tennessee.

\section{GENERAL GEOLOGIC RELATIONS}

The Upper Cretaceous deposits of Tennessee outcrop in a wedge-shaped area which crosses the westcentral part of the State in a northward direction and lies largely west of Tennessee River. (See figs. 1 and 2.) This area is about 67 miles wide along the southern boundary of the State but narrows northward until at the Kentucky line it is only about 15 miles wide. Along the southern border, in Wayne, Hardin, McNairy, and Hardeman counties, these deposits have been segregated into the following lithologic units:

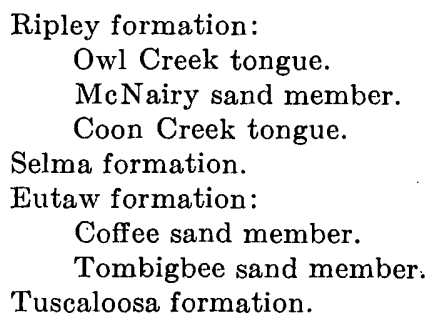

In the northern part of the State these sediments diminish greatly in thickness. The four major formational divisions may be recognized, but the members lose their identity.

\section{TUSCALOOSA FORMATION}

The Tuscaloosa is the basal formation of the Upper Cretaceous series in the eastern Gulf region of the Mississippi embayment. In western Alabama and eastern Mississippi this formation consists of irregularly bedded sands, clays, and gravels that have an' estimated total thickness of 1,000 feet. Stephenson ${ }^{10}$ has readjusted the nomenclature of the Upper Cretaceous in this region and has defined the Tuscaloosa with reference to the other formations of this series.

Toward the north the Tuscaloosa deposits become much thinner and are made up almost entirely of conglomerates that contain little sand and clay. Berry ${ }^{11}$ has made a study of these deposits and has found evidence in the fossil plants that the clays in the basal part of the formation in the region of maximum thickness are more ancient than plant-bearing clays that occur in the conglomerates about Iuka, in northeastern Mississippi, where the formation becomes much thinner. He shows that an Upper Cretaceous estuary existed for a long time in western Alabama before it transgressed into the northern part of Mississippi and Alabama.

Until recently the Tuscaloosa formation was thought to thin out and disappear in the vicinity of

\footnotetext{
10 Stephenson, L. W., op. cit.

11 Berry, E. W., Upper Cretaceous floras of the eastern Gulf region in Tennessee, Mississippi, Alabama, and Georgia: U. S. Geol. Survey Prof. Paper 112, 1919.
}

the Tennessee-Alabama line. In 1913 Miser mapped the areal geology of the Waynesboro quadrangle of
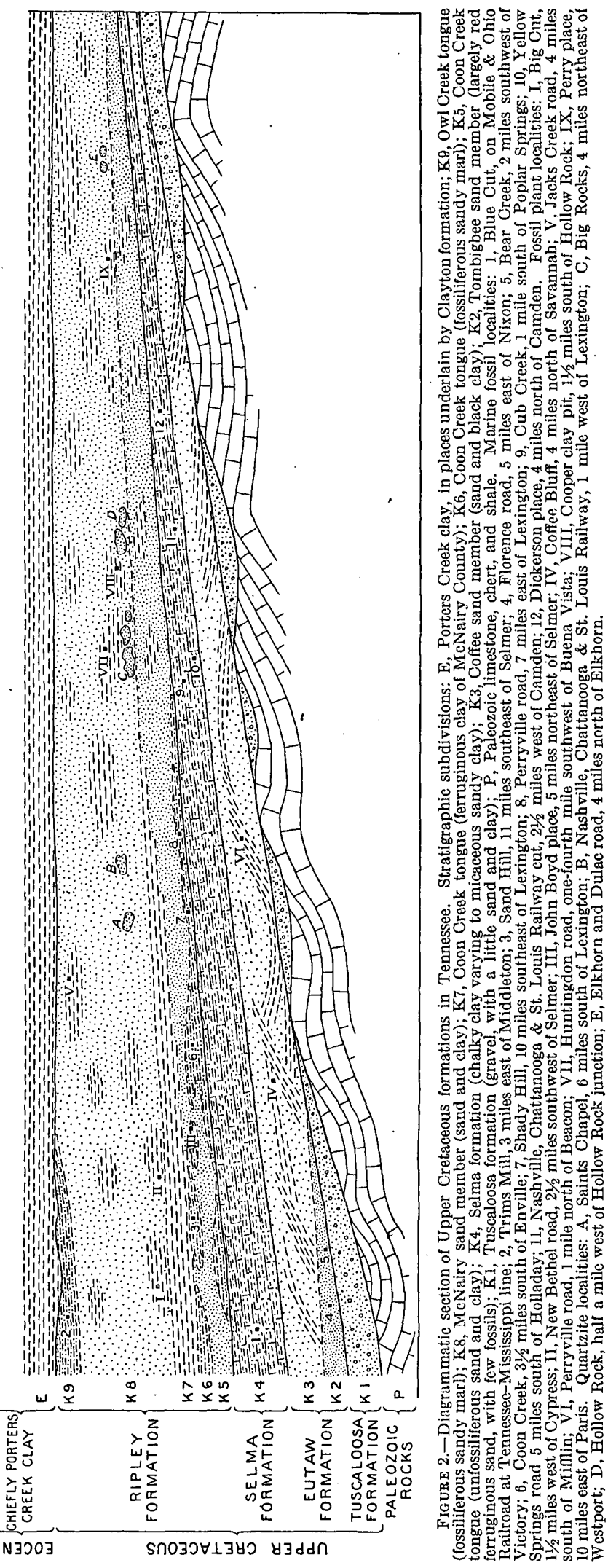

Tennessee and found that the Tuscaloosa was 150 feet thick and extended over a large part of Wayne 
County. ${ }^{12}$ Subsequent work by the Tennessee Geological Survey showed that remnants of the Tuscaloosa gravel occur in place on the Highland Rim of Tennessee as far north as northern Lewis County. ${ }^{13}$ Farther north, during the summer of 1916, the writer found undescribed occurrences of the Tuscaloosa formation, which show that the sediments of this transgressive phase of the Upper Cretaceous form a chain of local outlying areas across the State of Tennessee and as far north as the ridge west of Canton, Ky. ${ }^{14}$ The gravels which occur locally along the Nashvillc, Chattanooga \& St. Louis Railway between McEwen and Tennessee City and which cap the higher hills in this part of Dickson County, Tenn., form an important link in this chain.

A cut on the railroad about 2 miles east of McEwen shows about 30 feet of very compact hard white chert gravel, which is very typical of the Tuscaloosa belt across the State, resting on chert of the St. Louis formation. No paleontologic evidence has been obtained from the gravels about McEwen to determine their age, but after a study of the lithology as well as the geographic and topographic relations, the Tuscaloosa age of the gravels can hardly be doubted. These gravels are made up of well-rounded waterworn pebbles, most of which are an inch or less in diameter, although many are larger, and the deposits contrin cobbles as much as 6 inches in diameter. Many pebbles approach a spherical outline, and in this respect they differ from the river gravels that are common in terraces along the western Tennessee Valley. In the river gravels of that region the individual pebbles are commonly flat, elongated, and subangular. Small discoidal quartzite pebbles are conspicuous in the terrace conglomerates in many places. The Tuscaloosa conglomerates consist for the most part of pebbles and boulders derived from the lower Carboniferous (Mississippian) cherts, which are common in this part of the Mississippi basin. Waterworn sandstone and iron oxide pebbles have not been observed in the Tuscaloosa, and this is another feature which serves to distinguish the Upper Cretaceous gravels from the more recent terrace gravels in this part of the embayment region, even though the more recent gravels rest directly on the Upper Cretaceous gravels as they commonly do in the western Tennessee Valley.

South of McEwen, as stated above, the isolated areas of Tuscaloosa gravel may be traced along the Highland Rim across Lewis County into Wayne and Hardin counties and farther into Mississippi and Alabama, where they are overlain by marine Eutaw

${ }_{12}$ Miser, H. D., in Drake, N. F., Economic geology of the Waynesboro quadangle: Resources of 'Tennessee, vol. 4, p. 107, 1913.

13 Wade, Bruce, Geology of Perry County and vicinity: Resources of Tennessee, vol. 4 , p. 173, 1914 .

is Wade, Bruce, The occurreuce of the Tuscaloosa formation as far north as Kentucky: Jobus Hopkins Univ. Circ., new ser., 1917, No. 3, pp. 102-106, March, 1917. deposits, and consequently paleontologic evidence may be obtained.

The Tuscaloosa extends also north of McEwen. About 3 miles west of Canton, in Trigg County, $\mathrm{Ky}$., just east of the place where the Fulton and Nashville highway crosses the divide between Tennessee and Cumberland rivers, there is an exposure of Upper Cretaceous deposits which has already been described. This exposure occurs in the top of the divide, which is probably more than 300 feet above the water of Tennessee and Cumberland rivers. This divide is a northern extension of the western Highland Rim of Tennessee, and further study of the plateau between the Canton and McEwen localities will probably reveal isolated Tuscaloosa deposits that form an almost unbroken chain of the remnants of this formation from Kentucky across Tennessee into Mississippi and Alabama.

A study of a map ${ }^{15}$ of the Upper Cretaceous belt of the eastern Gulf region shows that Tennessee River flows from the east into the Cretaceous area in northwestern Alabama and then takes a northerly course just east of the Cretaceous area across Tennessee and Kentucky. The geologic map shows that the wide Tuscaloosa belt in western Alabama and eastern Mississippi disappears entirely just north of the point where Tennessee River flows into the belt, and in the same part of the State the Eutaw belt becomes abruptly narrow and disappears long before it reaches the northern limit of Tennessee. It has been previously shown that the Tuscaloosa formation, though probably not so thick and so widespread as in western Alabama and eastern Mississippi, was at one time an extensive formation and covered large areas in Tennessee and Kentucky and that the Eutaw formation extended farther east and north of the areas mapped. The erosion of the western Tennessee Valley has almost entirely removed the Tuscaloosa deposits toward the north and has likewise removed a large portion of the Eutaw deposits but to a less extent than the Tuscaloosa.

\section{EUTAW FORMATION}

In the southern part of the State the Eutaw formation is divided into two members, the Tombigbee sand and the Coffee sand. The Tombigbee sand is made up largely of red ferruginous sands that cap the hills of eastern Hardin County and western Wayne County. This member contains a small marine fauna near Burnsville, Miss., and fossils perhaps from the same horizon have been collected in Tennessee in Hardin County at a locality about 5 miles east of Nixon on the Florence road and a single species from a locality near the top of the ridge at the head of Bear Creek in

is Stephenson, L. W., Cretaceous deposits of the eastern Gull region: U. S. Geol Survey Prof. Paper 81, map, 1914. Berry, E. W., Upper Cretaceous floras of the eastern Gulî region: U. S. Geol. Survey Prof. Paper 112, map, 1919. 
FAUNA OF RIPLEY FORMATION ON COON CREEK, TENN.

Wayne County. Both these localities are shown on the map (fig. 1). This member is nowhere in Tennessee very sharply demarcated from the overlying Coffee member and probably does not extend northward any farther than the northern part of Hardin County.

The Coffee sand member of the Eutaw was first recognized and described by Safford and has been studied by subsequent writers. It is more than 200 feet in thickness and is typically exposed on Tennessee River at Coffee Bluff, 4 miles north of Savannah, in Hardin County. It is made up largely of a series of stratified and cross-bedded sands and clays. The sands are generally fine and of different colors; in many places they contain an abundance of scales of mica and in some places glauconite and pyrite. The sand is commonly interlaminated with thin layers of clay. Dark or black beds of clay containing very fragmentary leaves and in places thick beds of lignitized logs or fragments of wood are common. Some of the logs are partly or entirely silicified. Many of the larger logs are perforated by the Cretaceous woodburrowing pelecypod Teredo irregularis Gabb, ${ }^{16}$ many of which left thin irregular tubes an inch in diameter in the wood. The clays of the Coffee member are highly carbonaceous and contain an abundance of plant remains. Identifiable leaves from these clays, however, are very rare. Berry ${ }^{17}$ has identified 16 species from Coffee Bluff and 10 species from about the same horizon that were collected at a locality on the Scotts Hill road $5 \frac{1}{2}$ miles southwest of Decaturville, in Decatur County. A small collection of about five or six species was made in 1919 from this same member at a locality 1 mile north of Beacon, Decatur County. Amber is not uncommon in the beds that contain fragments of wood in this member of the Eutaw. A number of small pieces of amber have been collected at Coffee Bluff and a locality on the Lexington road $21 / 2$ miles west of Parsons, in Decatur County. One of the specimens from Coffee Bluff contains the wings of a Cretaceous caddis fly, Dolophilus praemissus Cockerell, ${ }^{18}$ which Professor Cockerell says is the only known specimen of an American amber insect.

Toward the north the Eutaw formation becomes much thinner, until in the vicinity of Dulac, in the northern part of Henry County, near the Kentucky line, this formation is only about 20 feet in thickness. At Riverview, a locality in Kentucky about 5 miles south of Paducah, on Tennessee River, an exposure of 15 feet of typically laminated Eutaw sands and clays may be observed. In the central part of Decatur County, Tenn., in the vicinity of Parsons and Decaturville, the basal part of the Eutaw contains irregular

${ }_{10} \mathrm{Gabb}, \mathrm{W} . \mathrm{H}$., Descriptions of new species of American Cretaceous and Tertiary fossils: Acad. Nat. Sci. Philadelphia Jour., 2d ser., vol. 4, p. 393, pl. 68, fig. 19,1860 .

17 Berry, E. W., Upper Cretaceous floras of the eastern Gulf region in Tennessee, Mississippi, Alabama, and Georgia: U. S. Geol. Survey Prof. Paper 112, p. 35, 1919. ${ }^{18}$ Cockerell, T. D. A., Some American fossil insects: U. S. Nat. Mus. Proc., vol. 51, p. 99, fig. 6, 1916 . lenses of fine chert and quartz gravels, in some places several feet in thickness. Some other localities in Tennessee where the Eutaw may be studied are Camden, Holladay, Darden, Scotts Hill, Grumps Landing, Pittsburg Landing, and Red Sulphur Springs. The general distribution of the formation is shown on the map (fig. 1).

\section{SELMA FORMATION}

In 1906 Glenn ${ }^{19}$ pointed out that the original term Selma chalk was applied very aptly in Mississippi and Alabama but was inappropriate in Tennessee. The Selma formation, as represented in the northern Gulf embayment region, consists of fossiliferous chalky clays and argillaceous, micaceous sands laid down during the time when the Upper Cretaceous sea was at its maximum stage of transgression. This stage may be traced across Tennessee by its lithology and fauna, which separate the underlying Eutaw sands and the overlying Ripley sands. There are no known unconformities in this Eutaw-Selma-Ripley succession, which evidently represents a single cycle of transgression and regression of the Upper Cretaceous sea in Turonian and Senonian time. This cycle passed very slowly and probably extended over a long period of time. The cross-bedded largely nonmarine sands and clays of the Eutaw were laid down. during the advancing stage of this sea. The Selma chalky sediments were laid down in this sea at its maximum expanse, at a stage when no coarse detritus was being washed in. Such a sea was especially favorable for marine organisms, various forms of which developed in great hordes, especially the Mollusca. Conditions favorable to marine life in the extreme northern part of the embayment were not of long duration. Orogenic changes brought in coarse sediments, and this sea began to recede, being filled with the sands that make up the Ripley formation. This recession did not take place suddenly and with uniformity but very gradually, with some oscillations and sinuosities of the strand line, which caused the development of the various members of the Ripley formation that are well exhibited in McNairy County and in the northern part of Mississippi.

The Selma formation is a chalky clay, more than 300 feet thick in the southern part of the State, but near the Kentucky line it is less than 50 feet thick and is made up of sandy micaceous clay. This formation is well exposed in the eastern part of McNairy County, where it gives rise to barren limy hills known as "bald knobs" or glades that are commonly covered with species of Ostrea, Gryphaea, Exogyra, and Anomia. Toward the north it becomes thinner and loses its chalky character, yet it may be readily reçognized. It may be studied in the vicinity of Chesterfield, in Henderson

19 Glenn, L. C., Underground waters of Tennessee and Kentucky wost of Tennessee River and of an adjacent area in Illinois: U. S. Geol. Survey Water-Supply Paper 164, p. 26, 1906. 
County; about 2 miles west of Holladay, in Benton County; $2 \frac{1}{2}$ miles west of Camden, on the Nashville, Chattanooga \& St. Louis Railway, in Benton County; 4. miles north of Camden, on the Big Sandy road; and about 2 miles west of Dulac, in Henry County. Marine fossils are less abundant in the northern part of the State. In Henry and Benton counties all the exposures of this formation have not yet been examined. Among the collections now at hand for study the most northerly locality at which a collection has been made from this formation is at the Dickinson place, 4 miles north of Camden, Benton County, on the Big Sandy road. From this locality a fauna of about 12 species has been obtained. Some of the same species with a few additional ones have been collocted in the new cut on the Nashville, Chattanooga $\&$ St. Louis Railway $21 / 2$ miles west of Camden.

Less than 40 species of marine fossils are known from the Selma formation, in contrast to more than 350 known from the Ripley formation. This probably does not mean that less than 40 species inhabited the Selma stage of the Upper Cretaceous sea in the embayment area, for it is most likely that the widely expanded, quiet Selma stage of this sea was quite favorable to marine life and that a very large percentage of the Ripley species were developed at that time. It does mean that the conditions where so little detritus was being brought in were unfavorable for the preservation of very many Upper Cretaceous species. Species of Ostrea, Exogyra, Gryphaea, Anomia, Paranomia, and Pecten are very common in the Selma at many localities, and the shells of these species are very hard and resistant, being made up of a dense sort of cryptocrystalline shell material which withstood the corrosive and chemical effects of the Cretaceous sea and the attacks of minute organisms while they were being buried in the very slowly accumulating limy muds. It is true that the shells of such species as Ostrea larva Lamarck and Anomia argentaria Morton are thin and fragile, yet they are formed of a compact shell material and are more resistant than such thick shells as those of a number of species of Cucullaea, Crassatellites, Pugnellus, and Volutomorpha. Perhaps this point may be brought out by the study of the shell materials and by the occurrence of the well-known species Paranomia scabra (Morton) ${ }^{20}$ in both the Ripley and the Selma. This bivalve is made up of two distinct shell materials - a thin hard, compact, resistant outer layer, similar to the shell material of certain species of Gryphaea, Ostrea, and Exogyra, and a softer inner layer of prismatic calcareous shell material which is similar to the shell material of most of the Ripley univalves and bivalves. In the Selma formation only the thin outer layer of Paranomia scabra is preserved. In the

\footnotetext{
${ }_{20}$ Morton, S. G., Synopsis of the organic remains of the Cretaceous group of the
} Unitod States, p. 62, 1834 .
Ripley formation, however, at localities where there are abundant shells of species unknown in the Selma, both the inner and outer layers of Paranomia scabra are perfectly preserved. Thus if the entire shell of this species were as soft as the inner layer this species too would be unknown in the Selma.

\section{RIPLEY FORMATION}

Distribution and subdivisions.-The Ripley formation has the greatest areal distribution of the Upper Cretaceous formations in Tennessee. It is extensively developed in both the northern and southern parts of the State. It crops out in a broad belt in general along the divide between Tennessee and Mississippi rivers, a hilly and sandy area with little fertility or agricultural productiveness. In certain localities this formation is highly fossiliferous and contains an abundance of beautifully preserved animal and plant remains, but these are rather exceptional, for the Ripley of Tennessee is made up largely of nonfossiliferous sands and clays. In the southern part of the State the Ripley formation has been segregated into the following lithologic and faunal divisions:

Owl Creek tongue.

McNairy sand member.

Coon Creek tongue.

In the central and northern parts of the State the Owl Creek tongue loses its identity and becomes a part of the McNairy sand member, which constitutes by far the larger part of the Tennessee Ripley.

Coon Creek tongue.-The Coon Creek tongue of the Ripley formation in the northern part of the State consists of ferruginous sands with few or no fossils, but in the southern part of the State it is glauconitic and fossiliferous. In some localities it contains beds of sandy marl, which have yielded a very large fauna of beautiful and usually well preserved marine fossils. An announcement of the discovery of these fossils and a somewhat detailed description of the Coon Creek locality, together with some preliminary observations on the fauna, were published in the Johns Hopkins University Circular for March, 1917.

The Coon Creek tongue is stratigraphically at the base of the Ripley formation and in the Exogyra costata zone. The Selma-Ripley contact. is well established at Blue Cut, on the Mobile \& Ohio Railroad, at the State line on the southern edge of McNairy County. From this point the contact may be readily traced by both lithologic and faunal relations to Coon Creek. The Coon Creek tongue evidently lies just above the Selma formation and at the base of the Ripley. The Coon Creek tongue is thus stratigraphically lower than the deposits along Owl Creek in Mississippi. At the Owl Creek locality the fossiliferous horizon is in the uppermost beds of the Ripley 
and is directly overlain by Eocene limestone. ${ }^{21} \mathrm{Be}-$ low the Owl Creek tongue is the southern equivalent of the McNairy sand member of the Ripley formation. ${ }^{22}$ The McNairy sand member lies stratigraphically above the Coon Creek tongue and is exposed to the west of it. (For geographic relations of the two localities see fig. 1.) The Coon Creek fauna is thus obviously older than the Owl Creek fauna.

The ferruginous clay portion of the Coon Creek tongue of the Ripley is well exposed in a cut on the Mobile \&. Ohio Railroad just.south of Falcon, in McNairy County. It consists of a series of stratified micaceous clays, about 100 feet thick, containing numerous concretions of limonite, which are very conspicuous on the eroded slopes in the central part of McNairy County. A scant and dwarfed marine fauna has been obtained from this clay in the southern part of the State. Toward the north this clay becomes sandy, loses its identity, and merges into the McNairy sand.

McNairy sand member.-The McNairy sand member is a thick series of nonmarine or near-shore marine deposits of sand and clay, including also a few irregular occurrences of quartzite. As shown on the map (fig. 1), the McNairy sand covers a wide belt of the Cretaceous area and is equally developed in both the northern and southern parts of the State. This member was first differentiated and described by Stephenson..$^{23}$ It is typically exposed at a cut on the Southern Railway near Cypress, McNairy County. Clay is mined from the McNairy sand at several localities in Carroll and Henry counties. ${ }^{24}$ Large conspicuous masses of quartzite or very hard fine-grained white sandstone occur irregularly in the lower part of the McNairy sand member at several isolated localities in Henderson, Carroll, and Henry counties. The more notable localities for quartzite are shown on the map (fig. 1) and in the section (fig. 2). These masses are exceedingly resistant to erosive agencies and are commonly left lying bare on the surface after the softer sands and clays, which formerly inclosed them, have been washed away. Their irregular, cavernous, and commonly grotesque shapes attract the attention of travelers and residents in these regions. The well-known "hollow rock," at Hollow Rock Junction, in Carroll County, has served as a landmark since early settlers first went into that part of the State. The most extensive occurrences of this quartzite are 2 miles south of Dollar, in Carroll County, where masses as large as a two-story house

\footnotetext{
${ }^{21}$ Harris, G. D., The Midway stage: Bull. Am. Paleontology, vol. J, No. 4, p. 24 1896.

-22 Stephenson, L. W., paper given before the Paleontological Society of America Dec. 29, 1916.

${ }^{23}$ Stephenson, L. W., Cretaceous deposits of the eastern Gulf region: U. S. Geol. Survey Prof. Paper 81, 1914.

${ }^{24}$ Nelson, W. A., Clay deposits of west Tennessee: Tennessee Geol. Survey Bull. $5,1911$.
}

may be observed in an area of 2 or 3 square miles. The origin of these masses is due to the cementation of local accumulations of very fine and pure quartz sands deposited along with the other McNairy sediments. Large masses of highly ferruginous hard sandstone are common in the Ripley, but the quartzites under discussion have a very low content of iron. Similar masses of quartzite are known in the Eocene deposits of Tennessee, Arkansas, and Mississippi.

Fossils are rare in the McNairy sand, and the few that have been known until recently comprised about 12 species of plants collected near Selmer ${ }^{25}$ and at Big Cut ${ }^{25}$ in McNairy County and three species from the southeastern part of Henry County. ${ }^{25}$ In 1919 Schroeder noted the abundance of fossil leaf impressions in the Cooper clay pit ${ }^{26}$ near Hollow Rock, Carroll County, but made no collection of these plants. Later in the summer of 1919 the writer made large collections of fossil plants from the Cooper clay pit and from some new localities, 3 miles south of Mifflin in Chester County, near Buena Vista in Carroll County, and from the Perry place, 10 miles east of Paris on the Manlyville road, in Henry County. These collections have all been submitted to Professor Berry, and a report on this heretofore unknown large Ripley flora of more than 120 species has been issued. ${ }^{27}$ Most of the specimens of this plant material and the best of them came from the Perry place. This locality is in a small gully on a farm belonging to Dr. J. R. Perry, where lenses of clay several feet thick are exposed. The fossil leaves occur in a 2 -foot layer of dark-brownish clay in the very bottom of the gully. This locality is about 18 miles southeast of Puryear and about the same distance northeast of the Grable clay pit. The Eocene plant locality at Puryear has been made famous by the recent studies of Professor Berry, ${ }^{28}$ who has collected and described from the clays of Wilcox age at that place one of the largest and most beautiful fossil floras known in America. The Grable clay pit, a recent opening in these clays about 20 miles southwest of Puryear, contains a great wealth of fossil plants. Owing to the filling of some of the old pits there is at present no locality in west Tennessee where so many beautiful fossil plants can be obtained as at the recent workings of the Grable pit and the neighboring Atkins pit. Of the Ripley plant localities next to the Perry place in importance is the Cooper clay pit. All the McNairy plant localities

26 Berry, E. W., Contributions to the Mesozoic flora of the Atlantic Coastal Plain; XI, Tennessee: Torrey Bot. Club Bull, vol. 43, pp. 283. 304, 1916; Upper Cretaceous floras of the eastern Gulf region in Tennessee, Mississippi, Alabama, and Georgia: U. S. Geol. Survey Prof. Paper 112, pp. 38, 39, 1919.

${ }^{26}$ Schroeder, R. A., Ball clays of west Tennessee: Resources of Tennessee, vol. 9, p. 154, 1919.

${ }^{27}$ Berry, E. W., The flora of the Ripley formation: U. S. Geol. Survey Prof. Paper 136, 1925 .

${ }^{29}$ Berry, E. W., The lower Eocene floras of southeastern North America: U. S. Geol. Survey Prof. Paper 91, 1916. 
are shown on the accompanying map (fig. 1) and in the diagrammatic section' (fig. 2).

Owl Creek tongue.-Stratigraphically above the McNairy sand member in southwestern McNairy and eastern Hardeman counties is the Owl Creek tongue of the Ripley formation. This tongue is a series of micaceous sands and marls, about 50 feet in thickness in Tennessee, which contains a portion of the Owl Creek marine fauna. About 50 species have been collected at 'Trimms Mill and other localities on Muddy Creek in Hardeman County. Among these is the Owl Creek form Scaphites iris Conrad. ${ }^{29}$ This northern extension of the Owl Creek tongue does not extend far into Tennessee. It is merely one of the major oscillatory stages of the retreating Ripley sea as it withdrew slowly from the northern part of the Mississippi embayment area.

\section{SUMMARY}

The general stratigraphic and areal relations of the Tennessee Upper Cretaceous are best summarized in the accompanying map and diagrammatic section, which show the positions of the large Ripley faunas and floras with reference to the rest of the Tennessee Cretaceous. The most valuable scientific results of the recent studies of the Tennessee Cretaceous are the discovery of the Coon Creek fauna and the flora at the Perry place and Hollow Rock. These abundant and excellent animal and plant remains are of nearly the same age, at the base of the Ripley. They not only mark definitely the lower Ripley with two different lines of evidence, making this a very useful horizon for reference in subsequent studies and intercontinental correlations of the Upper Cretaceous, but also these well-preserved remains furnish biologic evidence that is useful in the systematic classification of a few of the ancient animals and plants of Cretaceous time.

\section{THE COON CREEK FAUNA}

\section{THE IOCAIITY}

The locality here described is known as the Dave Weeks place, on Coon Creek. It is in the northeastern part of McNairy County, $31 / 2$ miles south of Enville, $71 / 2$ miles north of Adamsville, and one-eighth of a mile east of the main Henderson-Adamsville road. The beds containing the fossils are best exposed in the valley about 250 yards east of Dave Weeks's house, along the headwaters of Coon Creek, a small stream flowing northward into White Oak Creek, a tributary of Tennessee River.

Upper Cretaceous fossils have been. previously collected from a few places in this general region of the Mississippi embayment within a radius of $7 \frac{1}{2}$

${ }^{29}$ Conrad, T. A., Observations on a group of Cretaceous fossil shells found in Tippah County, Miss.: Acad. Nat. Sci. Philadelphia Jour., 2d ser., vol. 3, p. 335, pl. 35 , fig. 23,1858 . miles from the Dave Weeks place. Stephenson ${ }^{30}$ made a collection from the Exogyra ponderosa zone of the Selma formation at a point one-fourth of a mile west of Adamsville. He made another collection from the same zone 4 miles northeast of Adamsville, at a locality referred to as " 4 miles southwest of Coffee Landing." Fossils were found by Stephenson 3 miles west of Adamsville, in the Exogyra costata zone of the Selma formation. About 11 miles southwest of the Coon Creek locality and $21 / 2$ miles east of Purdy, Safford ${ }^{31}$ collected fossils in the uppermost part of the formation, which he designated the "Green sand." The horizon from which this last collection was made probably has the same stratigraphic position as the Coon Creek tongue. The best-known fossil locality in this general region is the classic Owl Creek locality ${ }^{2}$ in Tippah County, Miss., often referred to in the literature as Ripley, Miss. (See fig. 1.)

The sketch map. (fig. 1) has been inserted to show the location of Coon Creek and Owl Creek and to give in a general way the areal geology in the region about these localities. Big Cut and Coffee Landing, two other notable localities in the Cretaceous area of Tennessee, are shown on this map. The information that is given on the map for the area that lies south of the Tennessee-Mississippi line has been furnished by L. W. Stephenson, of the United States Geological Survey.

\section{CHARACTER OF THE SEDIMENT}

A thickness of more than 30 feet of the fossil-bearing beds is exposed along the banks of Coon Creek. For one-third of a mile this stream flows in a narrow $V$ shaped channel from 6 to 16 feet deep, which has been cut out during the last twenty years. The stream has a steep gradient, and its channel is deepened by every heavy rain. The channel fills quickly after a thundershower, and its sides are kept freshly scoured by the rushing water. White shells of Crassatellites, Cucullaea, Cyprimeria, Gryphaea, Ostrea, Drilluta, Lunatia, Baculites, and other genera project out of the dark grayish-blue matrix and glitter in the clear water and the'sunshine. In general aspect the exposure bears a striking resemblance to certain Tertiary beds. In broad physiographic relations, in the character of the matrix, and in the whiteness of the shells the Coon Creek locality resembles the well-known Upper Cretaceous locality of Brightseat, Md., which is 2 miles east of District Line and has yielded the most prolific Upper Cretaceous fauna of Maryland. The shells,

${ }^{30}$ Op. cit., p. 24.

31 Safford, J. M., Geology of Tennessee, p. 416, 1869.

32 Conrad, T. A., Observations on a group of Cretaceous fossil shells found in Tippah County, Miss.: Acad. Nat. Sci. Philadelphia Jour., 2d ser., vol. 3, pp 323-336, 1858; Descriptions of new species of Cretaceous and Eocene fossils of Mis sissippi and Alabama: Idem, vol. 4, pp. 275-298, 1860. Stephenson, L. W., op. cit p. 24 , table 2 
notably the bivalves, are probably more abundant at Brightseat but are not so well preserved as they are at Coon Creek. The sediments that contain the Coon Creek fauna are dark bluish-green and gray clayey sands. The sand is of medium fineness and consists of angular and rounded grains of quartz as the major constituent, with glauconite, small flakes of mica, and fragments of shells as minor constituents. Pieces of lignitic wood and small nodular masses of pyrite are common but not abundant. All these clastic materials are cemented together with a fine calcareous material, forming a compact impervious mass which varies locally in arenaceous and argillaceous content. There is locally sufficient lime for the matrix to become indurated into a very hard impure and concretionary limestone. When this rock is thoroughly weathered the shells are removed, leaving casts in a matrix which becomes yellowish brown by the oxidation of the glauconite and other ferruginous constituents.

\section{STATE OF PRESERVATION OF THE FOSSILS}

The well-preserved fossils of the Ripley formation attracted the attention of the early geologists and impressed them deeply. In 1856 Conrad $^{33}$ described 56 new species from Owl Creek and made the following observations about the fauna:

The Cretaceous strata of Mississippi have long been observed and partially noted by geologists, and the lamented Professor Tuomey has described a number of their fossil contents. I now introduce quite a distinct group of shells, which are embedded in a different matrix compared with the prevalent Cretaceous marls, greensands, and limestones. The discovery of these beautiful organic remains is due to the indefatigable exertions of Dr. W. Spillman, of Columbus, who has forwarded a collection of specimens more or less perfect, consisting of nearly 60 species, all of which appear to be unpublished except Scaphites conradi. The appearance of these shells is like that of Eocene species which have merely lost their animal matter and in this respect are very unlike the condition of similar genera in the contiguous rocks of the same era. The fossils are embedded in a sandy marl of a dark-gray color, the principal constituents of which are fine scales of mica and grains of quartz mixed with fragments of small shells; and though some of the very thin species are distorted, the stronger retain their original shapes and are generally very perfect. Species of Crassatella, Nucula, and Meretrix have the valves united as in life, as well as a few of the extremely thin Inocerami, though the latter are more or less distorted by pressure. The numerical proportion of species of Cephala and Acephala is nearly equal. The external sculpture of all is as sharply defined as in existing species. Besides Scaphites and Baculites there is only one shell in the collection which resembles a species of the greensand or limestone; and it is quite distinct. The rare genus Pulvinites is herein for the first time introduced as an American form. The analogous species, as well as that of Gervillia, occur in the Baculite limestone of France and Normandy, which I believe is referred by D'Orbigny to his Senonian stage, the same in which he included the Cretaceous fossils of North America.

${ }^{33}$ Conrad, T. A., Observations on a group of Cretaceous fossil shells found in Tippah County, Miss.: Acad. Nat. Sci. Philadelphia Jour., 2d ser., vol. 3, pp. 323-336, 1858.
It is interesting to find bivalves of so remote an era in sufficient preservation to exhibit generic characters as clearly defined as they are in living shells. In this condition are the hinges of Gervillia, Pulvinites, Ctenoides, and Cardium. There are also specimens of Baculites and Scaphites, which exhibit the interior divested of all extraneous matter and delight the eye with exquisite curves of the foliated septa, whilst the shells glow with brilliant iridescent tints.

This beautiful series of Cretaceous forms seems to be very limited in geographical distribution, so far as our present knowledge extends. It is probably unknown as yet beyond the limits of Tippah County, which borders on Tennessee. No account has been given of such a group by the State geologists of Tennessee or Alabama. Doctor Spillman informs me, "The fossils you have now under examination were found in the bluffs of Owl Creek, 3 miles north of the town of Ripley," and he concurs in opinion with me that they might properly be named the "Ripley group." He also remarks that Ammonites placenta occurs in it with the shell preserved, and that in connection with the Ripley group, or in the same locality, are "Exogyra costata, Gryphaea mutabilis, Ostrea plumosa, Natica petrosa, Nautilus dekayi, etc., with the shells more or less preserved, in an argillo-calcareous marl," but none of these species is contained in his collections sent me from Tippah County.

After this announcement of the discovery of wellpreserved Cretaceous fossils in northern Mississippi was made by Conrad, Safford collected a few Ripley fossils near Purdy, Tenn., and Holmes and others made collections of unusually well preserved shells at Eufaula, Ala., from the same horizon as that of the beds on Owl Creek. These collections were sent to Conrad and Gabb for study, and their contributions appeared in $1860 .^{34}$ Conrad described 54 additional new species and Gabb 4 new species collected from northern Mississippi, Alabama, and Tennessee. Since the work of these men, very little has been done on this unusually abundant fauna. Geologists have often visited Owl Creek and have made collections, but nothing has been published on the systematic paleontology except minor contributions. ${ }^{35}$ The most recent list of the Ripley collections in the National Museum from this region is that published by Stephenson in $1914 .^{36}$

The Coon Creek collection in the National Museum includes many small and fragile individuals and many that present delicate shell parts. The internal and external markings are not so well defined or are entirely absent in most Cretaceous specimens from other localities. The hinge areas, muscle scars, buttresses, pallial lines, and external sculpture are as sharp and as well defined in such genera as Cucullaea, Glycimeris, Crassatellites, Nucula, Cardium, Trigonia, and Paranomia as they are in the shells of Tertiary

${ }^{34}$ Conrad, T. A., Descriptions of new species of Cretaceous and Eocene fossils of Mississippi and Alabama: Acad. Nat. Sci. Philadelphia Jour., 2d ser., vol. 4, pp. 275-298, 1860. Gabb, W. M., Descriptions of new species of American Tertiary and Cretaceous fossils: Idem, pp. 375-404.

${ }_{35}$ Dall, W. H., Contributions to the Tertiary fauna of Florida: Wagner Free Inst. Sci. Trans., vol. 3, pt. 1, p. 73, 1890; Notes on some Upper Cretaceous Volutidae: Smithsonian Misc. Coll., vol. 50 (Quart. Issue, vol. 4, pt. 1), pp. 1-23, 1207.

${ }^{86}$ Stephenson, L. W., Cretaceous deposits of the eastern Gulf region: U.S. Geol. Survey Prof. Paper 81, p. '24, tables.1-9, 1914. 
and Recent bivalves. Even the ligaments are occasionally preserved and in their natural positions in attached valves of Cardium stantoni Wade, Glycimeris lacertosus Wade, and Leptosolen biplicata Conrad. Many of the Gastropoda, including species of such genera as Liopeplum, Gyrodes, Hyllus, Volutomorpha, and Pugnellus, are brilliantly glazed. The shells of Eutrephoceras, Baculites, Scaphites, and Turrilites are well preserved and abundant, but many individuals have been crushed by the weight of the superincumbent sediments. The protoconchs are well defined and in a perfect state of preservation on many of the Gastropoda, especially. such genera as Laxispira, Volutoderma, Paladmete, Thylacus, and many others. The protoconch is present and sharply differentiated in a new species of Teinostoma, which is strikingly like the Miocene form Teinostoma nana (Lea). The adult itself is only a little more than 1 millimeter in its greatest diameter, yet the shell and protoconch are both brilliantly glazed and look as fresh as if they were recent. The small and fragile scaphopod Cadulus obnutus (Conrad) is abundant and perfectly preserved. Such overspecialized and projecting shell parts as the anterior calcareous tube and the fringing tubules of the genus Clavagella and the spinose and flaring outer lips of such genera as Anchura and Volutoderma occur unbroken. Fragments of nonlignitized and nonpetrified wood are common and in weight, color, and woody fiber resemble Recent wood in state of preservation.

The occurrence of so many perfect shells in unconsolidated sediments as old as the Cretaceous is exceedingly rare. Although these fossils have retained their original characters and shell material, many of them are soft and fragile, so that some care is necessary in collecting and preparing them. They are easily removed from the strata with part of the matrix attached. This serves to protect the specimens in packing and shipping. When the collected material dries the sandy matrix may be readily cleared away, leaving most of the shells hard and fairly strong. The weaker specimens can be made harder and sufficiently strengthened to withstand handling and the effects of the atmosphere by a method of preparing which is used in the geological laboratory of Johns Hopkins University. After all foreign matter has been removed from the shells they are soaked about four minutes in paraffin heated to the boiling point. The hot wax permeates the shell walls and reinforces them. The shells are darkened slightly by the wax, but otherwise the method is entirely satisfactory.

No other single locality in the American Cretaceous that has yet been studied has produced so large an assemblage of such excellent fossils, which even rival the best Cretaceous collections from any of the wellknown European or Indian localities. Some of the well-known Cretaceous localities that have yielded prolific faunas which may be cited for comparison and reference are:

Owl Creek, Miss. ${ }^{37}$ Ripley formation.

Eufaula, Ala. ${ }^{37}$ Ripley formation.

Pataula Creek, Ga.37 Ripley formation.

Snow Hill, N. C. ${ }^{38}$ Black Creek formation.

Brightseat, Md. ${ }^{39}$ Monmouth formation.

Mount Laurel, N. J.40 Monmouth group.

Fox Hills, Moreau River, etc., western interior. ${ }^{41}$ Montana group.

Huerfano Park, Pugnellus-bearing sandstone of Colorado group. ${ }^{42}$ Colorado.

Phoenix, Oreg. ${ }^{43}$ Lower part of Chico formation.

Queen Charlotte Islands, Canada. ${ }^{44}$

Cardenas, Mexico..$^{5}$ Lower Senonian.

Lastro, Sergipe, Brazil.48 Senonian.

Quiriquina, Chile. ${ }^{47}$ Senonian.

Pondoland, South Africa.48 Senonian.

Chargeh Oasis, Libyan Desert..$^{9}$ Danian.

Central Tunis, Africa. ${ }^{50}$ Cenomanian.

Atherfield, England. ${ }^{51}$ "Wealden.

Blackdown, England..$^{51}$ Upper Greensand.

Aachen, Germany. ${ }^{52}$ Senonian.

Kunroed, Belgium. ${ }^{53}$ Maestrichtian.

Le Mans. ${ }^{54}$ Cenomanian.

Gosau, Austria. ${ }^{55}$ Turonian.

Comarapolliam, India. ${ }^{56}$ Arrialoor group.

An analysis of the Coon Creek fauna and comparisons with related faunas are given on pages 12-20. A new species of Scaphites, closely related to the well-known

${ }^{37}$ Stephenson, L. W., Cretaceous deposits of the eastern Gulf region: U. S. Geol Survey Prof. Paper 81, tables 2, 8, 1914. Conrad, T. A., Observations on a group of Cretaceous fossil shells found in Tippah County, Miss.: Acad. Nat. Sci. Philadelphia Jour., vol. 3, 2d ser., pp. 323-336, 1858; vol. 4, 2d ser., pp. 275-298, 1860.

88 Stephenson, L. W., The Cretaceous formations of North Carolina: North Carolina Geol. and Econ. Survey, vol. 5, p. 15, 1923. Conrad, T. A., Remarks on the Tertiary formation of the Atlantic slope: North Carolina Geol. Survey Rept. vol. 1, app. A, 1875.

30 Gardner, J. A., Maryland Geol. Survey, Upper Cretaceous, 1916.

${ }^{40}$ Weller, Stuart, New Jersey Geol. Survey, Paleontology, vol. 4, pp. 128-136 et seq.,1907.

“1 Meek, F. B., A report on the invertebrate Cretaceous and Tertiary fossils of the upper Missouri country: U. S. Geol. Survey Terr. Rept., vol. 9, 1876.

12 Stanton, T. W., The Colorado formation and its invertebrate fauna: U. S. Geol. Survey Bull. 106, 1893.

${ }^{43}$ Anderson, F. M., Cretaceous deposits of the Pacific coast: California Acad. Sci. Proc., 3d ser., vol. 2, 1902.

14 Whiteaves, J. F., On some invertebrates from the coal-bearing rocks of Queen Charlotte Islands: Canada Geol. Survey, Mesozoic fossils, vol. 1, pts. 1, 3, and 4, 1876-1900.

${ }^{45}$ Böse, Emil, La fauna de moluscos del Senoni ano de Cárdenas, San Luis Potosi: Inst. geol. México, Bol. 24, 1906.

${ }^{40}$ White, C. A., Contribuições a paleontologia do Brasil: Mus. nac. Rio de Janeiro Archivos, vol. 7, 1888. (Portuguese and English.)

${ }^{17}$ Wilckens, Otto, Revision der Fauna der Quiriquina-Schichten: Neues Jahrb., Beilage Band 18, p. 272, 1904.

${ }^{43}$ Woods, Henry, The Cretaceous fauna of Pondoland: South Alrican Mus. Annals, vol. 4, pt. 7, 1906.

19 Quzas, A., Beitrag zur Kenntniss der Fauna der obersten Kreidebildungen in der libyischen Wüste; Palaeontographica, Band 30, Abt. 2, pp. 153-334, 1902. (Also Inaug.-Diss., München, 1902.)

so Pervinquière, L., Études de paléntologie tunisienne, vols. 1 and 2, Paris, 1912. ${ }^{51}$ Woods, Henry, A monograph of the Cretaceous Lamellibranchia of England, vols. 1 and 2, Palaeont. Soc. London, 1899-1913.

s2 Holzapfel, Eduard, Die Mollusken der Aachener Kreide: Palaeontographica, Band 34, pp. 29-180, 1888; Band 35, pp. 139-268, 1889.

${ }^{53}$ Kaunhowen, Friedrich, Die Gastropoden der Maestrichter Kreide: Palaeont. Abh. (Dames \& Koken), Band 8 (neue Folge, Band 4), 1897.

s4 D'Orbigny, Alcide, Paléontologie française, Terrains crétacés, Paris, 1840-1860.

ss Zekeli, Friedrich, Die Gasteropoden der Gosaugebilde: K.-k. geol. Reichsanstalt $\mathrm{Abh}$., Band 1, 1852. Zittel, K. A., Die Bivalven der Gosaugebilde in den nordöstlichen Alpen: Akad. Wiss. Wien Denkschr., vol. 24, pp. 105-178, 1865; vol. 25 , pp. $77-198,1866$.

${ }^{50}$ Stoliczka, Ferdinand, India Geol. Survey Mem., Palaeontologia Indica, Cretaceous faunas of southern India, 1865-1870. 
form Scaphites nodosus Owen, ${ }^{57}$ is perhaps as diagnostic and as representative a form as any single species of the Coon Creek fauna that might be mentioned. The nodosus group of Scaphites is widely distributed in the marine Senonian deposits of the Upper Cretaceous of the world. It has been extensively studied and is an important aid in intercontinental correlations ${ }^{58}$ of these deposits.

At both Owl Creek, Miss., and Brightseat, Md., the fossil beds occur directly below the contact between the Cretaceous and the Eocene. This contact represents a long interval of erosion, during which the shell beds were at the surface or very near it and were probably subjected to the action of circulating meteoric waters, which had a disintegrating effect on the shells. The abundant springs at this horizon show that during late Pleistocene and Recent time this unconformable contact has furnished an easy channel for ground waters, which have attacked the unpetrified shells. At Coon Creek, on the other hand, the conditions are somewhat different. There is no overlying unconformable contact directly above the fossil beds, but instead there is a great thickness of overlying impervious Ripley clays. The shells were sealed by the Upper Cretaceous sea in compact calcareous sandy sediments and seem to have been unaffected by circulating ground waters until the advent of the present physiographic conditions. Even now these beds are so impervious that the ground water does not penetrate them, as is shown by the fact that well drillers have reported the strata perfectly dry. The character of the matrix at the three localities is essentially the same, so that the Coon Creek shells are well preserved probably because they have been protected from circulating ground waters, the action of which is so evident in most Cretaceous strata.

\section{BIOLOGIC RELATIONS OF THE FAUNA}

The Coon Creek fauna is both abundant and varied. About two weeks' collecting at this locality yielded a fauna of 199 genera and over 313 species, exclusive of the Crustacea and the Bryozoa, and further collecting will no doubt slightly increase this number. 'The study of the Crustacea has been made by Miss Mary J. Rathbun and the study of the Bryozoa by Ferdinand Canu and R. S. Bassler. There are 16 genera and 22 species of Bryozoa and 9 genera and 10 species of Crustacea, a total of 32 species in those two classes. The 199 genera in the other classes include, besides the Mollusca, 8 genera of Vertebrata ( 7 of the class Pisces and 1 of the class Reptilia); 2 of Echinodermata (1 of the class Echinoidea and 1 of the class Asteroidea);

37 Owen, D. D., Report of a geological survey of Iowa, Wisconsin, and Minnesota, p. 580, pl. 8, fig. 4, 1852. Meek, F. B., A report on the invertebrate Cretaceous and Tertiary fossils of the upper Missouri country: U. S. Geol. Survey Terr. Rept., vol. 9, pp. 426-430, 1876.

ss Frech, F., Ueber Scaphites: Centralbl. Mineralogie, 1915, pp. 553-568, 617-621. Kayser, E., Lehrbuch der Geologie, 5th ed., Teil 2, pp. 534-562, 1913.
2 of Vermes; 2 of Coelenterata (class Anthozoa); and a single species and genus of Brachiopoda. The Mollusca include 65 genera and 114 species of Pelecypoda, 2 genera and 4 species of Scaphopoda, 102 genera and 174 species of Gastropoda, and 4 genera and 5 species of Cephalopoda.

The Recent east coast molluscan fauna of the Middle Atlantic States has been estimated to include more than 500 species, and there is no reason to suppose that the Upper Cretaceous faunas were materially less diversified. On the contrary, the seas were warmer and conditions more favorable to molluscan life, so that probably not more than half the entire fauna has been discovered. The Coon Creek fauna flourished near the head of the Mississippi embayment, in about the same latitude as the Middle Atlantic States. It was probably in the same general climatic zone of the Cretaceous, so that any estimate of the east coast fauna should hold good for all the northern part of the Mississippi embayment as well. The evidence afforded by the Coon Creek material shows that the above estimate is probably conservative.

Corals are rather uncommon at Coon Creek. In the order Madreporaria and family Astraeidae is a single specimen of a small species of Trochosmilia. There are a number of specimens in this collection of two species of Micrabacia of the family Micrabaciidae. Species of Micrabacia are widely distributed in both the American and European Upper Cretaceous, as has been shown by the recent paper by Stephenson. ${ }^{59}$

Of the echinoderms both the asteroids and the echinoids are represented by poor and incomplete specimens. Numerous marginal plates of an asteroid occur in the Coon Creek collections and have been assigned to the genus Metopaster of the family Goniasteridae, a group well known from good material collected from the English chalk. ${ }^{60}$ Recently a species of this genus, Metopaster hortensae, was described from the Lower Cretaceous of Texas. $^{61}$ Of the family Spatangidae there are three species of Hemiaster.

Of the Vermes there are two species of Serpula and three species of Hamulus. The latter are abundant and form one of the noteworthy elements of the Coon Creek fauna. The writer has recently published a short paper describing the opercula of this interesting group of fossil annelids. ${ }^{2}$ The seaworms or Polychaeta, included in the suborder Tubicola, are distinguished by the fact that they inhabit variously formed tubes, to which they are not organically con-

59 Stephenson, L. W., North American Upper Cretaceous corals of the genus Micrabacia: U. S. Geol. Survey Prof. Paper 98, pp. 115-131, pls. 20-23, 1916.

${ }^{60}$ Sladen, W. P., and Spencer, W. K., A monograph of the British fossil Echinodermata from the Cretaceous formations, vol. 2, pp. 30, 97, 124, 128, Palaeont. Soc. London, 1907.

${ }^{61}$ Adkins, W. S., and Winton, W. M., Paleontological correlation of the Fredericksburg and Washita formations in north Texas: Texas Univ. Bull. 1945, p. 46, pl. 10, figs. 2-4, 1920.

${ }^{62}$ Wade, Bruce, The fossil annelid genus Hamulus Morton, an operculate SerpulaU. S. Nat. Mus. Proc., vol. 59, pp. 41-46, pls. 9, 10, 1921. 
nected and in which they can move freely by means of their setigerous foot tubercles. Owing to the investing tube, branchiae are developed only in the anterior region of the body, this being the only part which is ordinarily exposed to the action of sea water; hence the Tubicola are sometimes called the "cephalobranchiate" annelids. ${ }^{83}$

The protecting tube of the tubicolar annelids may be composed of carbonate of lime, of grains of sand or other foreign matter, or of chitinous material. When the tube is calcareous, it presents certain resemblances to the shells of some of the mollusks, such as Vermetus, Dentalium, or certain of the Rudistes. In the living state it is easy to make a distinction between these, for the tubicolar annelids are in no way organically attached to their tubes, whereas the mollusks are invariably attached to their shell by proper muscles. Some of the fossilized calcareous tubes, however, may with great difficulty be referred to their proper place. As a general rule, however, the calcareous tubes of annelids, such as Serpula, are less regular and symmetrical than those of Vermetus, which are partitioned by shelly septa that do not exist in the annelid tubes. Again, the tube of Dentalium is open at both ends, whereas it is closed at one end of the Serpulas. In the annelid genus Ditrupa, however, the tube is open at both ends, so that this distinction is one not universally applicable. The tubes of the serpuloid genus Hamulus are quite regular and symmetric, and its species have frequently been described as Dentalium. Tubes of certain species of Hamulus together with their opercula are similar to certain species of Rudistes, such as Radiolites lombricalis $\mathrm{D}^{\prime} \mathrm{Orbigny}{ }^{64}$ and Hippurites variabilis Munier-Chalmas, ${ }^{05}$ from the Upper Cretaceous of France, but this similarity is superficial and does not appear on careful examination. The apophyse of the operculum of Hamulus resembles very much the apophyse of the upper valve of certain of the Rudistes, but the operculum of Hamulus is truly an operculum of a circular aperture, whereas the upper valve of the Rudistes does not fit into a circular cavity of a lower valve. Another difference is the absence of any evidence of muscular attachments on the inner surface of the tubes of species of Hamulus.

The operculate form Hamulus onyx Morton is probably related to some such form as the existing species Serpula contortuplicata. ${ }^{08}$ A group of Serpulas with calcareous opercula-the Vermilias-is still abundant along the sea coasts to-day. Existing species with chitinous opercula are very common, and some of the forms that may be cited as analogous to Hamulus onyx

\footnotetext{
${ }_{03}$ Nicholson, H. A., and Lydekker, Richard, Manual of palaeontology, $3 \mathrm{~d}$ ed. vol. 1, Edinburgh and London, 1889.

of D’Orbigny, Alcide, Palcéntologie franģaise, Terrains crétacếs, vol. 4, p. 214, pl. 555 , figs. $4-7,1860$.

os Douville, Henri, Etudes sur les Rudistes; Revision des principales espèces d'Hippurites: Soc. géol. Franco Mémoires de paléontologie, Mém. 6, p. 50, pl. 7, flgs. 4-7, 0-12, 14, 15, 189 i.

of Nicholson, II. A., and Lydekker, Richard, op. cit., p. 471, fig. 333a.
}

are Eupomatus dipoma Schmarda and Pomatoceros tetraceros Schmarda, ${ }^{67}$ both from the vicinity of New South Wales, and also Crucifera websteri Benedict ${ }^{88}$ and Spirobranchus giganteus (Pallas) Mörch, ${ }^{69}$ from the Gulf of Mexico.

Fossil operculate Serpulas are rare. Among these may be mentioned the English Eocene species Serpula crassa Sowerby ${ }^{70}$ and the Maryland Upper Cretaceous form Ornataporta marylandica Gardner. ${ }^{71}$ The former has a calcareous operculum and a three-sided tube, which is usually. attached along one side to some foreign object. Gabb has described some serpuloid tubes with triangular cross section, Paliurus triangularis Gabb, ${ }^{72}$ from the Upper Cretaceous at Vincentown, N. J. Gabb's species has no known operculum, but its triangular tubes are somewhat analogous to those of Sowerby's Eocene species. There are specimens of Serpula heptagona ${ }^{73}$ with opercula from the Barton beds of the Eocene of England in the British Museum.

Of the class Brachiopoda there is one somewhat uncertain form described as Crania americana Wade and assigned to the family Craniidae of the order Neotremata. This form is imperfectly known at present, and further material may possibly show that it belongs to the Gastropoda and is related to some such group as Hipponix.

Probably the most interesting fact revealed by the figures cited above is that the number of univalve species is greater than the number of bivalve species. However, all three orders of the Pelecypoda are well represented. Of the order Prionodesmacea the three families represented by the greatest number of forms are the Arcidae, Ostreidae, and Mytilidae, the last two of which had their beginning in the Paleozoic. The Arcidae originated and suddenly became a prominent group in the later part of the Mesozoic and were highly developed in the Tertiary. Each of these three families is represented by four genera at Coon Creek. Of the Anomalodesmacea there are three families and five genera. The Teleodesmacea are well represented. Of this order, probably, the individuals of the families Cardiidae, Veneridae, and Corbulidae are most abundant. A comparison of these figures with lists of Cretaceous fossils from the east coast shows that the bivalves are relatively less abundant in the Coon Creek tongue than in the corresponding strata in New Jersey and the Middle Atlantic States. Ser-

${ }^{67}$ Schmarda, L. K., Neue wirbellose Thiere, pp. 29, 30, pl. 21, fig. 179, Leipzig, 1861. ${ }^{68}$ Benedict, J. E., Descriptions of ten species and one new genus of annelids from the dredgings of the U.S. Fish Commission steamer Albatross: U. S. Nat. Mus. Proc vol. 9 , p. 550, pl. 21, figs. $24,25,1886$.

${ }^{69}$ Idem, p. 551, pl. 23, figs. 38-42; pl. 24, figs. 43-47.

70 Agassiz, Louis, German translation of James Sowerby's Mineral conchology of Great Britain, 1814, p. 52, pl. 30, 1842.

7 Gardner, J. A., Maryland Geol. Survey, Upper Cretaceous, p. 748, pl. 47, figs. $16-18,1916$.

${ }_{72}$ Gabb, W. M., Notes on American Cretaceous fossils with descriptions of some new species: Acad. Nat. Sci. Philadelphia Proc., 1876, p. 324, pl, 17, figs. 11-13, 1877.

${ }^{73}$ Guide to the fossil invertebrate animals in the British Museum, 2d ed., p. 79, Loudon, 1911. 
eral genera, such as Cuspidaria, Myrtaea, Phacoides, Dosinia, and Solyma, are absent from the present collection from McNairy County, though further collecting may possibly reveal some of them.

At 'Coon Creek 114 species of pelecypods have been collected and are presented systematically in this paper. In comparison with other Upper Cretaceous bivalve faunas it may be noted that 71 species of pelecypods have been collected at Brightseat, $\mathrm{Md}$, from the Monmouth. ${ }^{74}$ The Ripley at Owl Creek, Miss. ${ }^{75}$ has furnished 54 species of bivalves, and the Matawan at Marlborough, N. J., ${ }^{76}$ has yielded 47 species. The largest bivalve fauna in the Cretaceous of western Europe occurs in the Turonian. All the French Turonian localities combined have furnished 202 species of this class. ${ }^{77}$ Probably 75 or 80 are as many as any one locality has furnished. The Schloenbachia rostata zone of the Upper Greensand of England has yielded a fauna of 149 species of bivalves. ${ }^{78}$ Most of these occur at Blackdown, England. In the noted Senonian fauna of the Aachen Cretaceous of Vaals, Germany, there are a total of 141 species of bivalves, and 71 of these come from the zone known as the Ober Quadraten-Schichten. ${ }^{79}$ In the Arrialoor group of the Upper Cretaceous of India there are 113 species of bivalves known, ${ }^{80}$ but of these about 32 are as many as have been collected from a single locality. Henry Woods ${ }^{81}$ has recently reported 29 species of bivalves from the Upper Senonian at Amuri Bluff, New Zealand.

The family Nuculidae of the taxodonts is represented at Coon Creek by three species of Nucula, and Nucula percrassa is one of the most abundant bivalves at this locality. In the family Ledidae there are two genera, Leda and Yoldia, each represented by two species. The Ledas are very small and inconspicuous; the Yoldias are somewhat larger but very fragile and rare. Of the Parallelodontidae there are three species of Nemodon and two species of Cucullaea in the Coon Creek collections. The Nemodons are rare, but the species Cucullaea vulgaris Morton is one of the conspicuous elements of the fauna, being represented by dozens of magnificent specimens. There are two species of the genus Limopsis of the family Limopsidae. The family Arcidae is represented by several species of four genera, Arca, Barbatia, Postligata, and Glycimeris.

" Gardner, J. A., Maryland Geol. Survey, Upper Cretaceous, p. 95, 1916.

75 Stephenson, L. W., Cretaceous deposits of the eastern Gulf region: U. S. Geol. Survey Prof. Paper 81, table 2, 1914.

76 Weller, Stuart, New Jersey Geol. Survey, Paleontology, vol. 4, p. 96, 1907.

77 D'Orbigny, New Jersey Geol. Survey, Paleontology, vol. 4, p. 96, 1907. 1847.

${ }^{78}$ Woods, Henry, A monograph of the Cretaceous Lamellibranchia of England, vol. 2, p. 441, Palaeont. Soc. London, 1913.

70 Holzapfel, Eduard, Die Mollusken der Aachener Kreide: Palaeontographica, Band 35, p. 260, 1889 .

80 Stoliczka, Ferdinand, India Geol. Survey Mem., Palaeontologia Indica, Cretaceous faunas of southern India, vol. 3, p. 490, 1871 .

81 Woods, Henry, The Cretaceous faunas of the northeastern part of the soutb island of New Zealand: New Zealand Geol. Survey Paleont. Bull. 4, p. 17, 1917.
Of the schizodonts, in the superfamily Pteriacea there are three genera, Inoceramus, Gervilliopsis, and Perna, or Pedalion, in the Pernidae, and one genus, Pteria, in the Pteriidae. The family relations of Pulvinites and Inoperna are here regarded as somewhat doubtful. Woods has assigned the European Cretaceous form Modiola flagellifera Forbes, ${ }^{82}$ which resembles very much the American Ripley species Inoperna carolinensis Conrad, to the Mytilidae. With only a' cast to study Fischer makes the genus Pulvinites synonymous with Hypotrema D'Orbigny ${ }^{83}$ and assigns it to the Anomiidae.

The genus Ostrea of the Ostreidae is represented by seven species in the Coon Creek beds, the largest number of species of a bivalve genus from this locality. Of this same family there are two species of Exogyra and one of Gryphaea. The family Trigoniidae is represented at Coon Creek by two species of the genus Trigonia, one species of which is exceedingly abundant and conspicuous in this fauna. Trigonia is one of the major elements during the Mesozoic. Another conspicuous genus in this Ripley fauna is the genus Pecten, of the Pectinidae, which is represented by five species, all known from perfect and magnificent specimens. Of the family Limidae there are two species of the genus Lima. Among the Anomiidae Paranomia scabra (Morton), the single species of this genus, is one of the most interesting Coon Creek forms. This species is widely distributed in the Upper Cretaceous of the eastern United States, but in most localities only the outer layer of the shell is preserved, and the true internal characters are known only from the excellent specimens of the Tennessee Ripley. The genus Anomia, of the same family, is represented by three species, one of which, Anomia argentaria Morton, is exceedingly abundant in the Ripley.

The family Mytilidae is represented by two genera-Lithophaga and Crenella. There are two species of Lithophaga, which are rather abundant in perforations of thick-shelled bivalves, such as Cucullaea, Crassatellites, and Veniella. This genus is reported as far back as the Carboniferous and is represented in the Recent tropic and subtropic seas by a little less than 50 species. The family Dreissensiidae is represented by one species of Dreissensia. Recent species of Dreissensia are found only in fresh and brackish waters. Some students of mollusks haveheld that this genus had its origin in the Tertiary, but Woods ${ }^{84}$ and later Miss Gardner ${ }^{85}$ have shown that this genus occurred in the Cretaceous but with a marine fauna.

82 Woods, Henry, A monograph of the Cretaceous Lamellibranchia of England, vol. 1, p. 99, pl. 17, figs. 1, 2, Palaeont. Soc. London, 1900.

83 Fischer, Paul, Manuel de conchyliologie, p. 934, Paris, 1887.

84 Woods, Henry, op. cit., vol. 1, p. 110, pl. 18, figs. 13, 15, pl. 19, figs. I-11, 1900

8s Gardner, J. A., Maryland Geol. Survey, Upper Cretaceous, p. 627, pl. 37, flgs. 8-11, 1916. 
In the order Anomalodesmacea of the superfamily Anatinacea the families Pholadomyacidae, Anatinidae, and Periplomatidae are each represented by one or two genera of one species each. The extremely fragile shells of species of this group are very difficult to recover from the Coon Creek sandy marl. One species of the very interesting genus Clavagella Lamarck, of the family Clavagellidae and superfamily Ensiphonacea, is abundant at Coon Creek, but perfect specimens are almost never obtained. Two species of the genus Liopistha Meek, of the family Poromyacidae, are also very common.

The order Teleodesmacea is the most varied and prolific order of the bivalves. The family Pleurophoridae is represented by one species each of Cyprina and Veniella. The former is very rare, but the latter is abundant at Coon Creek and is represented in the collections by numerous magnificent specimens. The family Astartidae is represented by four species of Vetericardia, two species of Crassatellites, one species of Etea (which Stephenson puts in the Pleurophoridae), and one species of Scambula.

A single small fragment of a shell questionably referred to Caprinella coraloidea Hall and Meek is the only representative of the family Caprinidae. When further material is obtained this imperfectly known form may possibly be found to belong to the Rudistes.

In the superfamily Lucinacea there is one species of the genus Vnicardium, of the family Unicardiidae; one species of Lucina, of the family Luciniidae; and one species of Tenea, of the family Diplodontidae. In the superfamily Cardiacea the genus Cardium is a prominent element, being represented by four species at Coon Creek, all of which are very common. The new species Cardium stantoni Wade is a very large and abundant form and is really one of the most magnificent species in the collection. There is one species of the widely distributed genus Protocardia. The family Isocardiidae is represented by a single species of the genus Isocardia.

The superfamily Veneracea is represented by several forms. In the family. Veneridae there are two species each of Cyclina and Meretrix and one species each of Aphrodina, Legumen, Cyprimieria, and Icanotia. Icanotia is an exceedingly rare form, known from only a fow Cretaceous species of Europe and India. The species Icanotia pulchra Wade is the first representative of this genus found in North America. The family Tellinidae of the superfamily Tellinacea is variously represented in the Coon Creek fauna by one species of Tellina, one species of Tellinimera, one species of Aenona, two species of Linearia, and one species of Liothyris. The very common American Upper Cretaceous form Leptosolen biplicata Conrad has been assigned to the family Solenidae, but recent studies of specimens from Coon Creek and 106913-26†-2
Owl Creek show internal shell characters that lead the writer to believe that the genus Leptosolen does not properly belong with the Solenidae. The superfamily Mactracea is represented by a single species of the genus Cymbophora, which is usually regarded as a subgenus under Spisula of the Mactridae.

The superfamily Myacea is a notable group. The genus Corbula of the family Corbulidae is represented by four species. One of these, Corbula crassiplica Gabb, is the commonest fossil at Coon Creek. There is one species of the genus Corbulamella Meek. One species of Panope, of the family Saxicavidae, is very common. This genus was fairly abundant in the Cretaceous and Tertiary and at present inhabits the cooler seas. One species of Gastrochaena of the Gastrochaenidae is abundant in the Ripley at Owl Creek, Miss., but is very rare at Coon Creek. In the superfamily Adesmacea there are two species of Martesia, of the Pholadidae, and one species of Teredo, of the Teredinidae.

The Scaphopoda are represented by the two families Dentalidae and Siphonodentaliidae. The Dentalidae originated in the Ordovician and were abundantly developed in the Cretaceous and Tertiary. They are represented at Coon Creek by one genus and three species, one of which is very common. The Siphonodentaliidae are first found in the Cretaceous. At Coon Creek they are abundantly represented by the minute form Cadulus obnutus (Conrad).

The Gastropoda of the Coon Creek fauna are unusually abundant and interesting; 174 species of them have been recognized and are presented systematically in this paper. This is probably the largest number of species of this class yet reported from an Upper Cretaceous fossil locality. The Gosau beds of the northeastern Alpine region have a molluscan fauna of Turonian and Lower Senonian age of over 500 species, which are represented by excellent fossils. The gastropods of that well-known fauna were monographed by Zekeli in 1852 . The two localities with the greatest number of species of univalves cited in his work ${ }^{86}$ are the Edelbachgraben and the Gosau localities in the Gosauthal, with 46 and 35 species, respectively. In D'Orbigny's classic work on the Terrains crétacés a total of 325 species of univalves are described from both the Lower and Upper Cretaceous of France. ${ }^{87}$ The total of the Upper Cretaceous species cited from all the French localities is 158 , of which 134 came from the Turonian and 24 from the Senonian. As each of these numbers represents the total of the species from all the French localities of the horizons mentioned, the number of forms from a single locality is much less. Stoliczka ${ }^{88}$ has reported

${ }^{80}$ Zekeli, Frederick, Die Gasteropoden der Gosaugebilde: K.-k. geol. Reichsanstalt Abh., Band 1, Tabellarische Übersicht, pp. 119-124, 1852.

${ }^{87}$ D'Orbigny, Alcide, Paléontologie française, Terrain crétacé, vol. 2, p. 406, 1843. ${ }^{88}$ Stoliczka, Ferdinand, op. cit., vol. 2, check list, pp. 461-476, 1868. 
48 species of gastropods in his well-known monograph on the Cretaceous faunas of southern India from the Comarapolliam locality of the Arrialoor group. Vogel ${ }^{89}$ cited 36 species of gastropods from the Upper Senonian locality at Irnich, on the Nordrand der Eifel, Germany.

The locality which furnished the greatest number of species in Kaunhowen's work ${ }^{90}$ on the Cretaceous gastropods of Holland and Belgium is called in that work "die harten Bänken von Kunroed." This locality has furnished 70 species of well-preserved shells of gastropods. The Upper Cretaceous locality which had yielded the greatest number of species and the finest shells of gastropods until the discovery of the Coon Creek locality was the place near Vaals, in Germany, referred to in Holzapfel's classic work ${ }^{91}$ as the "Grünsand von Vaals," and the total number from this place was only 95 .

In the Upper Cretaceous of North America the single locality which had heretofore furnished the greatest number of species of univalves was the Brightseat locality in the Monmouth formation of Maryland. The fauna of this locality, which has been monographed recently by Miss Gardner ${ }^{92}$ for the Maryland Geological Survey, includes 49 species of gastropods.

The Mount Laurel locality of the Monmouth group of New Jersey has furnished 35 species of gastropods, ${ }^{93}$ and it should be noted that at this locality the univalves outnumber the bivalves. The latest list of the classic Owl Creek locality ${ }^{94}$ of the Ripley formation of Mississippi cites only 30 species of gastropods. The total number of gastropods from the four most prolific localities of the Pugnellus-bearing sandstone of the Upper Cretaceous series of Colorado ${ }^{95}$ is 17. Pernambuco ${ }^{00}$ has furnished a gastropod fauna of 52 species, but probably some of these species are Eocene. The Senonian fauna of the Quiriquina beds ${ }^{97}$ on the small island of Quiriquina, just off the coast of Chile, in the bay of Talcahuana, has yielded 32 species.

There are 27 species of univalves in the well-preserved Senonian fauna in a sandy calcareous clay of Pondeland, South Africa, which was monographed by Woods ${ }^{98}$ in 1906 . In a monograph on the Danian

${ }^{80}$ Vogel, F., Das Ober-Senon von Irnich am Nordrand der Eifel (Inaug.-Diss.), pp. 34-50, Bonn, 1892.

go Kaunhowen, Friedrich, Die Gastropoden der Maestrichter Kreide: Palaeont, Abh. (Dames \& Koken), Band 8 (neue Folge, Band 4, Heft 1), pp. 1-132, 1897.

${ }^{91}$ Holzapfel, Eduard, Die Mollusken der Aachener Kreide: Palaeontographical Band 34, 1888 .

22 Gardner, J. A., Maryland Geol. Survey, Upper Cretaceous, check list, pp. 9094, 1916.

93, Weller, Stuart, New Jersey Geol. Survey, Paleontology, vol. 4, p. 105, 1907.

of Stephenson, L. W., U. S. Geol. Survey Prof. Paper 81, table 2, 1914.

9s Stanton, T. W., The Colorado formation and its invertebrate fauna: U. S. Geol. Survey Bull. 106, p. 29, 1893.

${ }^{90}$ White, C. A., Contribuições á paleontologia do Brazil: Mus. nac. Rio de Janeiro A rchivos, voi. 7, p 266, 1887. (Portuguese and English.)

${ }_{07}$ Wilckens, Otto, Revision der fauna der Quiriquina-Schichten: Neues Jahrb., Beilage Band 18, p. 272, 1904.

Bs Woods, Henry, The Cretaceous fauna of Pondoland: South African Mus. innals, vol. 4, pt. 7 , c.ieck list, p. 350,1906 . fauna of the Libyan Desert Quaas ${ }^{99}$ gives 29 species of gastropods from the Gebel Ter locality of the Chargeh Oasis.

The above citation of the most diversified Upper Cretaceous gastropod faunas shows that the assemblage in the Coon Creek sediments is unusually large for rocks of that age. Another very significant fact is that these 174 species are represented by excellent specimens. Of this number over 100 forms are new species, and 21 genera have been recognized which have not been previously differentiated and described. Sixteen of these new genera were described recently, ${ }^{1}$ and five additional new genera are proposed in this paper.

The list given above shows that the number of genera and species of the Gastropoda is considerably greater than the number of the Pelecypoda, yet probably in every cubic yard of the Coon Creek sediments the number of bivalve individuals exceeds that of the univalve individuals several times. In all the faunas previously reported from the Cretaceous deposits of the eastern United States the bivalve species are more numerous than the univalve species. This relation may indicate that in the Upper Cretaceous seas of those regions the pelecypods predominated in number of species as well as individuals, or perhaps that although a greater number of gastropod species existed in all the Upper Cretaceous seas their shells were not sufficiently preserved to be recovered from the sediments. The chance of preservation of gastropod shells is not so good as it is for pelecypodsfirst, because the number of individuals of each species of the Gastropoda is rarely ever as great as it is among the Pelecypoda; second, because the essential constituent of gastropod shells is aragonite, and this mineral is much less stable than calcite, which is the essential constituent of the majority of pelecypod forms; and third, because a gastropod shell is in greater danger of being crushed by the pressure of the inclosing sediments because of lack of support from within the shell. The body cavity of a gaping bivalve shell is almost of necessity filled by the sedimentary material, which is intruded less easily through the aperture in the spiral body cavity of a univalve. The shells thus unsupported within become crushed by the weight of the inclosing sediments and are then rapidly disintegrated.

In general, the Tertiary and Recent faunas of North America include a greater number of univalve species than of bivalve species, and perhaps about

${ }_{99}$ Quaas, A., Beitrag zur Kenntniss der Fauna der obersten Kreidebildungen In der Libyischen Wüste: Palaeontographica, Band 30, Abt. 2, pp. 153-334, Uebersichts-Tafel, 1902. (Also Inaug.-Diss., München, 1902; Johns Hopkins University Geol. Library, Geol. Pamphlet 5012.)

1 Wade, Bruce, New genera and species of Gastropoda from the Upper Cretaceous : Acad. Nat. Sci. Philadelphia Proc., vol. 68, pp. 455-471, pls. 23, 24, 1916; New and little-known Gastropoda from the Upper Cretaceous of Tennessee; Idem, vol 69. pp. 280-304, pls. $17,18,19,1917$ 
the sanie proportion existed in all the Cretaceous faunas. Yet the faunas, as they have been reported, may represent the natural proportions in which these animals lived in the Cretaceous sea. The gastropods may have become diversified in the Cretaceous, and this diversification possibly took place only in certain provinces, where the environment favored variation. Excavating and extensive collecting in localities where the shells are especially well preserved will probably throw some light on this subject.

The order Opisthobranchia is represented by four families and ten genera in the Coon Creek collection. Of these the family Acteonidae, which had its beginning in the Deronian and gained great prominence in the Mesozoic, is represented by the genera Acteon, Troostella, Tornatellcuea, and Acteonina. Acteon is the most common of these, being represented by five species. Troostella is a new genus known from a single species found at Coon Creek. This species is a large, beautifully glazed shell with a single low columellar plait and a sutural notch. The family Ringiculidae includes three genera-Ringicula, Cinulia, and Eriptycha. To the family Acteocinidae has been ussigned the new genus Goniocylichna. This new generic group is here proposed to include three species-a new form from the Ripley of Tennessee, which serves as the type of the genus; second, Trochacteon semicostatus Whiteaves, ${ }^{2}$ from the Upper Cretaceous of Vancourer Island; and third, Cylichna griesbachi Wtheridge," from the Upper Cretaceous of Zululand, South Africa. The family Scaphandridae of Fischer includes two genera, Cylichna and Scaphander, with one species each. 'True Scaphanders in deposits as old as the Cretaceous are rare.

The order Ctenobranchia is by far the most abundant of the three orders of Gastropoda found in this fauna and is represented by 71 genera. The family Conidae is represented by the single genus Conorbis. A single species of this genus is known from Coon Creek, and it is the first typical Conorbis to be recognized in the Upper Cretaceous strata. The family Cancellariidae is first differentiated in the Upper Cretaceous. It appears suddenly - in that period in much diversity and attains its maximum distribution in the late Tertiary and Recent. This family is represented at Coon Creek by two genera. The most abundant of these is Paladmete, a genus first recognized and described by Miss Julia Gardner, who has recently monographed the Upper Cretaceous Mollusca of Maryland. ${ }^{4}$ The type species of Paladmete is very abundant in Maryland and northern Mississippi. 'The genus is represented by

${ }^{2}$ Whiteaves, J. F., Canada Ceol. Survey, Mesozoic fossils, vol. 1, p. 354, pl. 44 กig. 5,1876 .

3 Etheridge, Robert, Cretaceous fossils of Natal: Geol. Survey Natal and Zıluland Second Rept., p. 86, pl. 3, figs. 14, 15, 1904

4 Gardner, J. A., Maryland Geol. Survey, Upper Cretaceous, p. 412, 1916. three species at Coon Creek. Mataxa, ${ }^{5}$ a new genus, is referred to the Cancellariidae. A species of Mataxa from southern India has been described by Stoliczka ${ }^{6}$ and assigned to the genus Narona of the Cancellariidae. A study of Stoliczka's description and figures, together with perfect specimens from Coon Creek, shows that these species belong to the same genus, which is evidently not Narona, so it seemed advisable to assign. these two forms to Mataxa as a new genus in the Cancellariidae. The genus Cancellaria is represented by one very elegantly sculptured species. The family Turritidae is represented in the Cretaceous by several forms but is not found in earlier strata. There are two genera of this family at Coon Creek-Turris and Turricula. The name Turricula, which is used here only as a group name, includes two groups of forms. Further research on Upper Cretaceous Gastropoda may result in establishing two genera for these two sections or groups. The genus Xancus, of the Vasidae, is represented by three species, which are well characterized by the manner of excavation of the inner lip and the number of columellar folds. This genus is well represented in the Upper Cretaceous and was identified quite recently from the Cretaceous by Miss Gardner. ${ }^{7}$ The Fusidae, which appeared in the Jurassic and are widely developed in the Tertiary and Recent, are represented at Coon Creek by seven generic groups. A single imperfect shell of one species has been doubtfully referred to Fusus. The genus Exilia, which was first reported from the Upper Cretaceous by Miss Gardner, ${ }^{8}$ occurs at Coon Creek in the form of a very slender and very much ornamented species. The genus Ornopsis, ${ }^{9}$ which was recently differentiated, is represented by three species. The form that was recently described as a subgenus, Anomalofusus, ${ }^{10}$ probably should have been given the rank of genus. The genus Falsifusus, ${ }^{11}$. which was described by Grabau a few years ago and heretofore not known earlier than the Eocene, is represented in the Ripley at Coon Creek by two species. Two new generic groups are here described and assigned to the Fusidae. The first of these, Stantonella, includes two species-the type from Coon Creek and another species described as Chemnitzia interrupta Conrad, ${ }^{12}$ from the Ripley at Owl Creek, Miss. The second new generic group of this family is Woodsella, also known from. two species-the type from Coon Creek and a closely

5 Wade, Bruce, New genera and species of Gastropoda from the Upper Cretaceous: Acad. Nat. 'Sci. Philartelphia Proc., vol. 68, p. 455, pl. 23, figs. 1, 2, 3, 1916.

- Stoliczka, Ferdinand, India Geol. Survey Mem., Palaeontologia Indica, Cretaceous fauna of southern India, vol, 2, p. 166, pl. 13, figs. 15, 16, 1867

7 Gardner, J. A., op. cit., p. 434

${ }^{8}$ Idem, p. 463.

9 Wade, Bruce, op. cit., p. 463.

${ }^{10}$ Idem, n. 461.

"Grabau, A. W., Phylogeny of Fusus and its allies: Smithsonian Misc. Coll., vol. 44 , article 4 , p. $80,1904$.

12 Conrad, T. A., Observations on a group of Cretaceous fossil shells found in Tippah County, Miss.: Acad. Nat. Sci. Philadelphia Jour., 2d ser., vol. 3, p. 333, pl. 35 , fig. 15, 1858. 
related species described as Cryptorhytis rigida (Bailey), ${ }^{13}$ from the Senonian of Pondoland, South Africa.

The family Fasciolariidae embraces five genera, Odontofusus, Piestochilus, Cryptorhytis, Fasciolaria, and Mesorhytis, all of which are known to occur only in the Cretaceous. The family Muricidae is represented by a single genus, Sargana, which is a new genus described by Stephenson. ${ }^{14}$

The family Busyconidae is interesting in that it appears rather suddenly in the Cretaceous with numerous diversified representatives. At Coon Creek it is represented by 10 genera and 14 species. The genera are Busycon, Pyropsis, Trochifusus, Perissolax, Rhombopsis, Pyrifusus, Serrifusus, Lirosoma, Boltenella, and Haplovoluta. Busycon in the strict sense, very commonly known as Futgur, is rarely found in the Cretaceous. This extension of the range of this common east coast Tertiary and Recent form is of particular interest. It is represented in the present Coon Creek collection by a single well-preserved specimen, a description of which has already been published. ${ }^{15}$ This specimen, aside from the absence of the protoconch, is perfect and presents generic characters which can not be mistaken. The species bears a striking resemblance to some of the medium-sized late Tertiary and Recent species. All the Fulgurs previously known have been confined to the Tertiary and Recent of the Atlantic States. The Eocene forms are small, rather thin-shelled species, so that the genus has been considered to have evolved during that period. The living Fulgurs have been very extensively studied and the life history carefully worked out. The limited geographic range has been explained in a large measure by the fact that the animal is deprived of an active free-swimming larval stage by the loss of the velum before the young form emerges from the egg capsule. The same fact might well be eited to explain the very meager distribution of Busycon in the Cretaceous. One of the earliest Tertiary species (described and referred to the genus Fulgur by Harris ${ }^{16}$ ) occurs in the Midway group of the Eocene, and beds of this group crop out about 30 miles west of Coon Creek.

There is one species each of Pyropsis and Perissolax. Trochifusus is a generic name proposed by Gabb ${ }^{17}$ for a group of forms no doubt generically different from Pyropsis in the strict sense but assigned to Pyropsis by most other students of Cretaceous gastropods. Rhombopsis is a name applied by Miss Gardner ${ }^{18}$ to a

\footnotetext{
13 Woods, Henry, The Cretaceous fauna of Pondoland: South African Mus. Annals, vol. 4. p. 7, p. 321, pl. 39, fig. 2; pl. 40, fig. 1, 1906 .

14 Stephenson, L. W., The Cretaceous formations of North Carolina: North Carolina Geol. and Econ. Survey, vol. 5, pt. 1, p. 377, 1923.

15 Wade, Bruce, An Upper Cretaceous Fulgur: Am. Jour. Sci., 4th ser., vol. 43, pp. 293-297, 1917.

${ }^{10}$ Harris, G. D., The Midway stage: Bull. Am. Paleontology, vol. 1, No. 4, p. 96 (210), pl. 9, fig. 13, 1896

17 Gabb, W. M., Notes on American Cretaceous fossils with descriptions of some new species: Acad. Nat. Sci. Philadelphia Proc. for 1876, p. 187, 1876.

18 Gardner, J. A., op. cit., p. 456.
}

genus described by Meek and given a preoccupied name. The genus Pyrifusus has a world-wide distribution in the Upper Cretaceous and is represented by two species at Coon Creek. A single imperfect specimen of a species of Serrifusus is known. The genus Lirosoma, which is well known in the Tertiary, is here for the first time reported from the Upper Cretaceous. Boltenella is a new genus, probably closely related to Busycon. Haplovoluta ${ }^{19}$ is another new genus of this family and probably closely related to Pyrifusus or to Hercorhynchus.

The family Buccinidae embraces two new genera of large, magnificent forms-Hydrotribulus, described in 1916, and Seminola, described in 1917..20 The Buccinidae also include one species eacb of the two genera Odontobasis and Pseudoliva. Of the family Tritonidae there is one genus, Tritonium. Columbellina is the only genus of the family Columbellariidae in the Coon Creek, and that genus is represented by only one species, which is the first of this genus to be found in the Upper Cretaceous deposits of North America. The family Purpuridae, an interesting group, contains three genera at Coon Creek-Morea, Ecphora, and Paramorea. Ecphora is a well-known genus in the Tertiary but has never before been recognized in the Cretaceous. Paramorea ${ }^{21}$ is a new genus near Morea and was described in 1917.

The Aporrhaidae appeared first in the Jurassic, reached their greatest development in the Cretaceous, and decreased in importance in the Tertiary. This family was monographed in 1875 by Gardner ${ }^{22}$ and in 1904 by Cossmann. ${ }^{23}$ Cossmann's classification is followed in this paper. The Aporrhaidae are one of the largest groups in the Upper Cretaceous, and a number of the American species are probably still unknown to science. Many of the species that are described are represented in the collections by very imperfect specimens. The genera that occur at Coon Creek are Anchura and Pterocerella. Complete specimens of all the species have not been obtained from Coon Creek, but extensive excavating will probably yield perfect specimens of all these forms. The family Strombidae is represented by only one genus-Pugnellus. There are two species of this genus, one of which is very common and is represented in the present collection by more than a dozen perfect specimens. but there are only two specimens of the other species.

The family Mathildiidae is represented by the genera Tuba, Mathildia, and Promathildia, all of

10 Wade, Bruce, New generic names for Upper Cretaceous Gastropoda: Am. Jour. Sci., 4th ser., vol. 45, p. 334, 1918.

${ }^{20}$ Wade, Bruce, New genera and species of Gastropoda from the Upper Cretaceous: Acad. Nat. Sci. Philadelphia Proc., vol. 68, p. 464, pl. 24, figs. 4, 5, 1916; New and little-known Gastropoda from the Upper Cretaceous of Tennessee: Idem, vol. 69, p. 290,1917

21 Wade, Bruce, of. cit., vol. 69, p. 295

22 Gardner, J. S., On the Gault Aporrhaidae: Geol. Mag., new ser., decade 2. vol. 2, pp. 49, 124, 198, 291, 1875; On the Cretaceous Aporrhaidae: Idem, p. 392.

${ }^{23}$ Cossmann, Maurice, Essais de paléoconchologie comparée, pt. 6, pp. 48-117, 1904; also pt. 10, annexe, p. 233, 1915. 
which are very rare in the Upper Cretaceous. The family Scalidae embraces the genera Scala, Proscala, Acirsa, and Hemiacirsa. Proscala is a new genus recently described by Cossmann. ${ }^{24}$ Acirsa and Hemiacirsa are forms well known in the Tertiary of Furope but are herein reported for the first time from the Upper Cretaceous. The Cerithiidae, a very abundant group in the Upper Cretaceous, are represented at Coon Creek by the genera Cerithium, Mesostoma, and Nudivagus. Nudivagus ${ }^{25}$ is a genus proposed recently which includes Pseudomelania astonensis, $^{28}$ from the Inferior Oolite of England, a species from the Arrialoor group of southern India (Cerithium (Fibula?) detectum), ${ }^{27}$ and a third species (the type) from Coon Creek. Thegenus Cerithiopsis, of the family Cerithiopsidre, is represented at Coon Creek by one species which occurs also in the Fox Hills sandstone of the western interior region and one new species. The family Trichotropidae is represented by two generaTrichotropis and a new genus for which the name Astandes has been proposed. Individuals and species of these genera are very rare. Trichotropis had an almost world-wide distribution in the Upper Cretaceous and is living to-day in the colder seas. In addition to the Coon Creek species of Astandes there is one in the Maestrichtian and another in the Senonian of Germany. In the family Melanopsidae the genus Melanatria or Faunus, which is common in the French Eocene, is here reported for the first time from the Upper Cretaceous.

In the family Vermetidae there are two generaSerpulorbis and Laxispira. Turritella, of the family Turritellidae, is represented by 6 species and is one of the more conspicuous groups in this McNairy County fauna. Xenophora, of the Xenophoridae, is very rare at Coon Creek and is represented in the present collection by a single imperfect specimen of $X$ enophora leprosa (Morton), which has a very wide distribution in the Ripley of the eastern United States. The family Naticidae, which appears for the first time in the Triassic, is well developed and widely distributed in the Upper Cretaceous. It is represented at Coon Creek by the genera Polinices, Gyrodes, Mammilla Amauropsis, and Ampullina. The well-known and widely distributed species Polinices halli (Gabb) is the most common gastropod at the Coon Creek locality, where it is represented by hundreds of perfect specimens. The genus Mammilla Schumacher is rare in both the Cretaceous and the Tertiary. The Coon Creek species here described is the first species of this genus to be reported from the American Cretaceous. The family Capulidae is represented by Capulus and by small fragile individuals of a single species of the genus

\footnotetext{
2 Cossmann, Maurice, op. cit., pt. 9, p. 100, 1912.

90 Wade, Bruce; op. cit., vol. 69, p. 296, pl. 19, Ags. 4, 5, 1917.

20 Huddleston, W. H., A monograph of the Inferlor Oolite Gastropoda, p. 245, pl. 18, figs. 8n, b, Palaeont. Soc. London, 1892.

${ }^{27}$ Stoliczka, Fordinand, India Geol. Survoy Mem., Palaeontologia Indica, Cretaccous faunas of southern India, vol. 2, p. 192, pl. 15, fig. 1, 1868.
}

Thylacus, which was described from Owl Creek by Conrad ${ }^{28}$ in 1860 . The individuals of this species are small and very fragile, yet they are abundant and perfectly preserved in their natural habitat. They occur in place fitting snugly to the columellar walls in the body cavities of larger gastropods. They have the internal muscular impression produced and leaving the wall of the shell at the anterior extremities and lack the calcareous foot plate characteristic of the genus Hipponix of this family. The family Littorinidae is represented by the genus Littorina, which is common in the Tertiary and Recent of the east coast and Gulf regions but until the present paper has not been reported from the Cretaceous of these regions.

The family Pyramidellidae is represented at Coon Creek by four genera-Obeliscus, Leiostraca, Odostomia, and Creonella. Creonella ${ }^{29}$ was described from two species in 1917.

There are four species of Eulima, of the Eulimidae, and three species of Rissoina, of the Rissoidae. The representatives of both these families are small and rare in the Coon Creek sediments but are perfectly preserved and may be recovered complete, even though their shells are very thin and fragile.

The order Aspidobranchia is represented by five families. The family Euomphatidae is represented at Coon Creek by two genera-Pseudomalaxis and Hippocampoides. Pseudomalaxis is represented by a single species, which bears a striking. resemblance to an Eocene species of this same genus. Hippocampoides is a genus which has been described recently ${ }^{30}$ and is known from two species from Coon Creek, one of which occurs in the Ripley of Mississippi. Schizobasis, of the Turbinidae, is a recently described genus known from two species at Coon Creek, one of which occurs also at Eufaula, Ala. ${ }^{31}$. In the family Umbonidae there is one species of the genus Teinostoma, which is very interesting, as it is the second species of this genus to be reported from the Upper Cretaceous. Furthermore this species is surprisingly like Teinostoma nanum (Lea) of the Miocene of the Middle Atlantic States. $^{32}$ There is one species of the genus Trochus of the Trochidae. In the family Delphinulidae there are two elegantly sculptured genera, Calliomphalus and Eucycloscala. Calliomphalus is represented at Coon Creek by two species, which are the first Upper Cretaceous species from North America to be referred to this genus. Eucycloscala, ${ }^{33}$ a genus which has been described recently, is known to contain several species, two from the Ripley of the Southern States and about six from the Jurassic and Cretaceous of Europe.

${ }^{28}$ Conrad, T. A., Descriptions of new species of Cretaceous and Eocene fossils of Mississippi and Alabama: Acad. Nat. Sci. Philadelphin Jour., 2d ser., vol. 4, p. 290, pl. 46, fig. 22, 1860 .

${ }^{29}$ Wade, Bruce, op. cit., vol. 69, p. 302, pl. 19; fig. 8, 1917.

so Wade, Bruce, op. cit., vol. 68, p. 466, 1916.

${ }^{31}$ Idem, p. 468.

${ }^{32}$ Martin, G. C., Maryland Ceol. Survey, Miocenc, p. 263, pl. 62, figs, 1a, b, c, $2 \mathrm{a}, \mathrm{b}, \mathrm{c}, 1904$.

${ }^{33}$ Cossmann, Maurice, op. cit., pt. 11, p. 19. 
FAUNA OF RIPLEY FORMATION ON COON CREEK, TENN.

A single imperfect specimen in the Coon Creek collection has been referred to Meek's species and genus Anisomyon patelliformis, ${ }^{34}$ of the suborder Thalassophila of the order Pulmonata. It is very improbable that this is a true pulmonate form. Further examples of this species will very likely show that it belongs to the genus Patella, a genus which occurs from the Silurian to the Recent.

Among the cephalopods both the nautiloid and ammonoid orders are present and are represented by abundant large, well-preserved specimens. It is interesting to find the remains of the most primitive order of Cephalopoda, which ranges from the Paleozoic to the Recent, associated with the abundant remains of the most highly complex and degenerate order, indicating that both thrived under the same conditions, yet the Ammonoidea became extinct and the Nautiloidea continue to live. The family Nautilidae is represented by one species of the genus Eutrephoceras. The most common cephalopods at Coon Creek are Baculites and Helicoceras, of the superfamily Lytoceratidae. Baculites is profusely developed and includes two species. The Scaphitidae include one new species of the genus Scaphites.

\section{CHARACTER OF HABITAT}

Conditions must have been especially favorable for molluscan life in the Upper Cretaceous sea in which the members of the Coon Creek assemblage grew. A glance at a tray of specimens impresses the observer with the fact that the shells are the remains of once flourishing animals. Very many of the shells are thick, stout, and of imposing dimensions. Evidently they belonged to robust, healthy, and well-fed organisms. The bivalve that has the greatest lateral dimensions is a species of Inoceramus, which was probably 15 inches in maximum diameter. One species of Cardium measures 5 inches in length, and a species of Cyprimeria $41 / 2$ inches. Exogyra costata and Gryphaea vesicularis occur in their typical massiveness. The shells of Cucullaea, Crassatellites, and Veniella are very abundant and evidently belonged to three vigorous groups of Mollusca which lived under conditions especially suited to the secreting of calcium carbonate. The great variety of forms developed in the Volutidae in the Upper Cretaceous has already been emphasized. All the species of this family are above medium size, and many of them are very large. Perfect specimens of Volutoderma in the collection attain an altitude of half a foot. There are broken specimens, which when perfect must have been almost a foot long. Volutomorpha is probably the giant of the Cretaceous gastropods. A fragment of several whorls of the spire of one species of Volutomorpha in

\footnotetext{
34 Meek, F. B., A report on the invertebrate Cretaceous and Tertiary fossils of the upper Missouri country: U. S. Geol. Survey Terr. Rept., vol. 9, p. 290, pl. 18. figs. $5 ; \mathrm{a}, \mathrm{b}, \mathrm{c} ; \mathrm{e}, \mathrm{f}, 1876$.
}

the collection represents a shell which would probably be at least 18 inches in length if it was complete. The genus Hyllus is large and inornate, and the genus Drilluta is elongate and elaborately sculptured. The shells of Pugnellus and Gyrodes seem to be relics of once thriving organisms which saw no hardships in life. Liopeplum, Polynices, Xancus, Hydrotribulus, Ornopsis, and other forms, though less in dimensions than some of the forms mentioned above, evidently grew in favorable surroundings. Species of such genera as Solariella, Columbellina, Acteon, and Cerithium are much smaller in size, yet their shells are thick and stout and must have grown where conditions were favorable for secreting calcium carbonate. The bivalves also show various ranges in size of thick, stout shells.

The Cephalopoda were the largest of the Coon Creek Mollusca. The genus Eutrephoceras is aburidantly represented by large thick-shelled cavernous individuals more than 6 inches in diameter. Orie species of Bacultites is very abundant and large. Although no complete large individuals have been recovered from the matrix, there are in the collection several large pieces of shells and body chambers from 6 to 18 inches long. A restoration, made recently by Professor Berry from fragments of an incomplete individual from Coon Creek, measures 58 inches. There are fragments of other individuals of the same species in the collection which would be much larger if the specimens were complete or restored. Although most of the Upper Cretaceous mollusks had thick, stout shells with coarse, vigorous ornamentation, many possessed small, delicate, fragile, and thin shells but have nevertheless been perfectly preserved. Individuals of species of Leda, Cadulus, and Teinostoma are smaller than a grain of wheat, Yoldia, Anatimya, Tenea, Liopistha, and Leiostraca are represented by delicate and fragile individuals. One species of Cre. nella is thinner than paper, yet it is elegantly sculptured,

It is impossible to postulate with assurance the depth of the water in which the Coon Creek fauna lived. Such families as the Pernidae, Volutidae, and Lytoceratidae, which are very prominent in the assem. blage, are usually regarded as dwellers in the open sea at a depth of about 50 fathoms. Yet the Nuculas, Corbulas, naticoids, and other forms are chiefly dwellers in shallow water near shore. Lobsters and true crabs lived in great abundance in the Ripley sea, as is shown by the abundant remains of these forms in the Coon Creek.sediments. There are probably five genera of the Eucrustacea, among which is a large crab, about 7 inches across from right to left, whose modern affinities live in the intertidal zone of the seas. No Foraminifera have been found, and only two very small individuals of two species of corals have been recovered, which, together with the very abundant 
crub remains, indicate near-shore or intertidal waters as the habitat of the Coon Creek fauna.

As regards the evidence furnished by the sediments, there is no well-marked cross-bedding that would result from strong current action. However, the very presence of clastic material, such as sand and clay, requires currents to account for transportation and shifting of these currents to explain the intermingling of those materials. The great abundance of pelecypods, which are organisms that feed largely on plankton, is indicative of water disturbed by currents instend of very calm seas, for plankton occurs mostly in water that is agitated by currents. No pebbles whatever have been observed in the sediments of the Coon Creek tongue; wood fragments, however, are common. All the evidence seems to indicate that the Coon Creok fauna lived in agitated waters near the coast of a low-lying land mass.

A study of the distribution and variation of the faunas with reference to the character of the sediments in the Ripley formation of northern Mississippi and southern Tennessee shows that the areas so favorable to molluscan life were rather small. The sediments bearing such an abundance of shells are limited both laterally and vertically in the Ripley strata and do not show a uniformly wide range over a large area, as is so commonly true of the Paleozoic fossiliferous beds. (See fig. 2, p. 4.) Southward the plentiful shells disappear, and the Coon Creek horizon in some places is marked by a very dark nonfossiliferous clny. Near Larton, McNairy County, the basal Ripley beds are represented by a glauconitic snnd which contains branching remains of the so-called fucoid Halymenites major Lesquereux. This sand extends farther southward and at Sand Hill is overlain by calcareous sediments containing an unstudied fruna of probably 50 species. About 3 miles farther southwest nonfossiliferous gypsiferous clays lie at the base of the Ripley. The topmost, the Coon Creek tongue, consists of ferruginous and micaceous clays which extend in a belt across the county These sediments contain a sparse dwarfed fauna of a. fow pelecypod genera, such as Cardium, Cyprimeria, and Pecten, none of which are as much as half an inch in maximum diameter. Gastropods, cephalopods, and large, massive bivalves, such as Exogyra or Gryphaea, are absent. Evidently conditions were unfavorable for molluscan life where these deposits were formed. Above these deposits lies the McNairy sand, and overlying that is the fossiliferous deposit of the Owl Creek tongue. The evidence thus seems to show that in local areas conditions were very favorable for rapid development of life, whereas in other areas the conditions were not suited to the growth of marine organisms. There were probably local biologic provinces which favored the development of local faunas, as may be observed in a comparison of the Owl Creek and Coon Creek faunas. Although these localities are within 60 miles of one another and in the same formation, the two faunas have a distinctly different aspect. Very many of the species 'are different, though some are identical. A number of genera from each locality are not common to the other. At Owl Creek the percentage of bivalve species is greater than that of the univalves, whereas at Coon Creek the fauna is striking for the predominance of the gastropod species. The cephalopod Sphenodiscus has not been found at Coon Creek, but at Owl Creek it is repre-. sented by two species. As stated above, the Owl Creek tongue is stratigraphically higher than the Coon Creek tongue, so that some differences in the faunas may be due to age, but the question arises whether so striking a difference in assemblages from areas in the same formation, located so near each other, could be caused except through the development of local biologic provinces. A study both of the sediments and of the faunas and their distribution seems to show that in this part of the Mississippi embayment of the Ripley area there were certain areas which were especially favorable for the growth of Mollusca. The sediments show that these areas were separated from one another by regions which were not so favorable for the growth of Mollusca, and such regions served to hinder free migration from one province to another. In these isolated "places of much life" variations arose through different biologic and physical conditions. Environmental changes were constantly taking place, owing to the shift and sinuosity of the strand line and the changes in character of sediments. In many provinces the faunas were destroyed entirely, in places some survived longer and were dwarfed, but in favorable places great hordes were crowded, and here evolutionary processes were most active.

\section{STRATIGRAPHIC AND GEOGRAPHIC DISTRIBUTION}

The following table lists the Coon Creek fauna and shows the areas and the age of the beds in which the species that make up this fauna and some of their allies have been found: 
The Coon Creek fauna and its range

[X indicates occurrence of same species; a indicates occurrence of allied species]

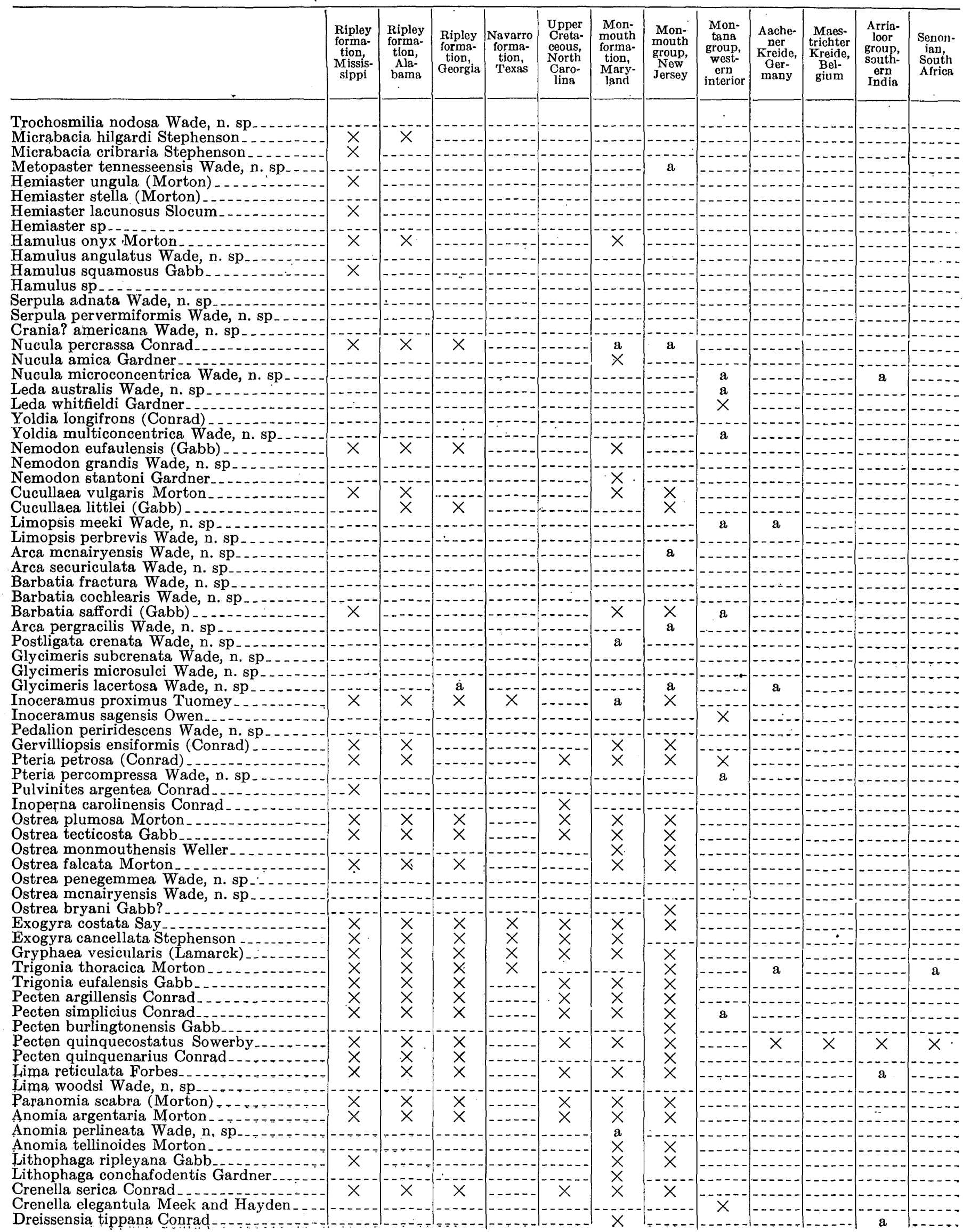


The Coon Creek fauna and its range-Continued

[X indicates occurrence of same species; a indicates occurrenice of allied species]

\begin{tabular}{|c|c|c|c|c|c|c|c|c|c|c|c|c|}
\hline . & $\begin{array}{c}\text { Riploy } \\
\text { forma- } \\
\text { tion, } \\
\text { Misssis- } \\
\text { sippi }\end{array}$ & $\begin{array}{c}\text { Ripley } \\
\text { forma- } \\
\text { tion, } \\
\text { Ala- } \\
\text { bama }\end{array}$ & $\begin{array}{l}\text { Ripley } \\
\text { forma- } \\
\text { tion, } \\
\text { Georgia }\end{array}$ & $\begin{array}{c}\text { Navarro } \\
\text { forma- } \\
\text { tion, } \\
\text { Toxas }\end{array}$ & $\begin{array}{l}\text { Upper } \\
\text { Creta- } \\
\text { ceous, } \\
\text { North } \\
\text { Caro- } \\
\text { lina }\end{array}$ & $\begin{array}{l}\text { Mon- } \\
\text { mouth } \\
\text { forma- } \\
\text { tion, } \\
\text { Mary- } \\
\text { land }\end{array}$ & $\begin{array}{l}\text { Mon- } \\
\text { mouth } \\
\text { group, } \\
\text { Neww } \\
\text { Jersey }\end{array}$ & $\begin{array}{c}\text { Mon- } \\
\text { tana } \\
\text { group, } \\
\text { west- } \\
\text { ern } \\
\text { interior }\end{array}$ & $\begin{array}{c}\text { Aache- } \\
\text { ner } \\
\text { Kreide, } \\
\text { Ger-- } \\
\text { many }\end{array}$ & $\begin{array}{c}\text { Maes- } \\
\text { trichter } \\
\text { Kreide, } \\
\text { Bel- } \\
\text { gium }\end{array}$ & $\begin{array}{l}\text { Arria- } \\
\text { loor } \\
\text { group, } \\
\text { south- } \\
\text { ern } \\
\text { India }\end{array}$ & $\begin{array}{l}\text { Senon- } \\
\text { ian, } \\
\text { South } \\
\text { Africa }\end{array}$ \\
\hline \multirow{2}{*}{\multicolumn{13}{|c|}{$\begin{array}{l}\text { Pholadomya occidentalis Morton } \\
\text { Pholadomya conradi Gardner }\end{array}$}} \\
\hline & & & & & & & & & & & & \\
\hline $\begin{array}{l}\text { Anatimya lata (Whitfield) } \\
\text { Periplomya elliptica (Gabb) }\end{array}$ & & & & & & & & & & ----- & --- & $--\cdots$ \\
\hline $\begin{array}{l}\text { Perıplomya elliptica (Gabb) } \\
\text { Periplomya applicata Conrad }\end{array}$ & & & & & & & & & & 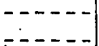 & --- & $n--n$ \\
\hline Clavagella armata Morton & & $x$ & & & & & & & & 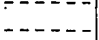 & $-1--1$ & 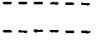 \\
\hline Liopistha protexta (Conrad) - & & $\hat{x}$ & $x$ & & & & & & a & $---1-1$ & $-1 .-1$ & $-1-n-1$ \\
\hline Liopistha inflata Whitfield..... & & & & & & & 公 & & & 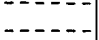 & 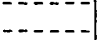 & $\begin{array}{ll}---n-1 \\
--n-2\end{array}$ \\
\hline Cyprina incerta Wade, n..sp... & & & & & & & & & & & & \\
\hline Veniella conradi (Morton) & & $x$ & $x$ & & & & & a & --- & 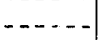 & -- & a \\
\hline Vetericardia crenalirata (Conrad) & & x & & & & & & a & a & ----- & $-\ldots$ & $\ldots-$ \\
\hline Vetericardia subangulata Wade, n. sp.... & & & & & & & & a & &.----- & $\ldots$ & ---- \\
\hline Vetericardia gregaria (Meek and Hayden)? & & & & & & & & $x$ & $\ldots .$. & ----- & $-\ldots$ & $-\ldots$. \\
\hline Vetericardia subcircula Wade, n. sp...... & & & & & & & & a & 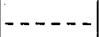 & $-\ldots--$ & &.---- \\
\hline Crassatellites vadosus (Morton) & & & $x$ & & & & & & --- & $-\cdots-\cdot$ & --- & $-\cdots$ \\
\hline Crassatellites linteus (Conrad) & & & & & & & & & & $-\cdots--$ & --- & $\cdots$ \\
\hline $\begin{array}{l}\text { Crassatellina carolinensis (Conrad) } \\
\text { Scambula perplana Conrad }\end{array}$ & & & & & & & & & & - n- & - & - \\
\hline Caprinolla coraloidea Hall and $\mathrm{Meek}$ & & & & & & & & & & -----1 & 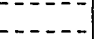 & $-1-1$ \\
\hline Unicardium concentricum Wade, n. sp. & & -- & & & & & & & & & & $\begin{array}{ll}-\infty & -\infty\end{array}$ \\
\hline Lucina ripleyana Wade, n. sp & & $\cdots$ & 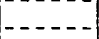 & & & & & a & &.--- & a & - \\
\hline Tenea parilis Conrad & & & & & & & & & & $-\cdots$ & --- & \\
\hline Cardium dumosum Conrad & x & & & & & & & & & $-\ldots$ & $-\ldots$ & -- \\
\hline Cardium tenuistriatum (Whitfield) & & & & & & & $x$ & $-\ldots-$. & $\ldots$ & $-\ldots-\ldots$ & -- & \\
\hline Cardium kümmeli Weller. & & X & $x$ & & & $x$ & X & & & $\ldots \ldots$ & $\ldots$ & - n \\
\hline Cardium stantoni Wade, n. sp $\ldots$ & a & & & & & a & a & & & 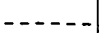 & $-\ldots$ & 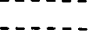 \\
\hline Protocardia parahillana Wade, n. sp $\ldots . .$. & & & & & & & & & & ---- & & -1 \\
\hline Isocardia conradi Gabb. & & & & & & & & & $-\cdots$ & $-\cdots--$ & $\ldots$ & $-\ldots-$ \\
\hline Cyclina parva Gardner & & - & -- & & - & & & & ----- & $-\cdots--$ & $\cdots$ & 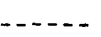 \\
\hline $\begin{array}{l}\text { Cyclina magna Wade, n. sp } \\
\text { Meretrix cretacea (Conrad) }\end{array}$ & & & & & & & & & $\mathbf{a}$ & 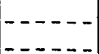 & & $a^{-\cdots}$ \\
\hline Meretrix eufaulensis (Conrad) & & $x$ & & & & & & a & & & a & $\begin{array}{c}a \\
-\ldots-1\end{array}$ \\
\hline Aphrodina tippana Conrad & & $x$ & $x$ & & & & & & & & $\ldots$ & $=--\infty$ \\
\hline Legumen planulatum (Conrad) & & $x$ & $x$ & & $x$ & $x$ & & & & $-\ldots$ & & \\
\hline Cyprimeria alta Conrad & $x$ & & $-\ldots$ & & & $\mathbf{a}$ & & & & $\ldots-\ldots$ & & \\
\hline Icanotia pulchra Wade, n. sp & & $\ldots$ & & $\ldots$ & & & & & & $\ldots$ & $\cdots$ & \\
\hline Tellina multiconcentrica Wade, n. sp..... & & & & & & & & $a$ & & $-\infty$ & & -- \\
\hline Tellinimera eborea Conrad & & $x$ & & & & X & & $\boldsymbol{a}$ & & & & - \\
\hline a eufalensis Conrad. & & x & $x$ & & & X & & & & 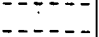 & & \\
\hline Linearia metastriata Conrad & $x$ & x & x & & $x$ & x & & & & $\begin{array}{ll}-1--- \\
---1-\end{array}$ & & 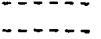 \\
\hline Tinearia ornatissima Weller & & & ----- & & & & X & & & $=---$ & & $-2--2$ \\
\hline Liothyris carolinensis Conrad . & & & & & & & & & & & & - \\
\hline Jeptosolen biplicata Conrad & & X & $\times$ & & $x$ & & & & & ---1 & & $-1-1$ \\
\hline Cymbophora gracilis (Meek and Hayden) & & & & & & & & & & $-\ldots$ & & a \\
\hline Corbula crassiplica Gabb_............. & & $x$ & $x$ & $\ldots$ & $\times$ & $x$ & $x$ & -- & & $--\cdot--$ & $-\ldots$ & $---\cdot$ \\
\hline Corbula monmouthensis Gardner....... & & --- & ---- & $-\ldots$. & $\cdots$ & $x$ & & $=-$. & -1 & $-\cdots--$ & $\ldots .$. & $-\ldots$ \\
\hline Corbula paracrassa Wade, n. sp & & $\therefore--$ & ---- & --- & & --- & - & -- & - & ----- & & 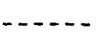 \\
\hline Corbula williardi Wade, n. sp & &.-- &.- & & & & & ---1 & à & --- & & $-\cdots$ \\
\hline Corbulamella suffalciata Wade, n. sp.... & & $-\ldots$ & $\ldots$ & & & & & a & - & --- & & - \\
\hline Panope decisa Conràd & & $-\ldots$ & - & & & & $x$ & $-\ldots-$. & $\ldots$ & $\ldots$ & $\ldots$ & -- \\
\hline Gastrochaena americana Gabb & & $-\ldots$ & $\ldots$ & & $-\ldots-1$ & & X & --- & - & --- & $\ldots$ & $\ldots$ \\
\hline Martesia truncata Wade, n. sp & & 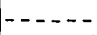 & - . . . & $\ldots$ & ---- & $\ldots$ & - . - & $\ldots$ & $\ldots$ & ---- & $-\ldots$ & ---- \\
\hline Martesia procurva Wade n. sp & & -- & $\ldots$ & & & & & & & & & $\ldots$ \\
\hline Teredo rectus Wade, n. sp & & $\ldots$ & - & & & & & $\ldots$ & & $-\ldots$ & & \\
\hline Dentalium intercalatum Wade, n. sp..... & & - n & - & & & & & $\mathrm{a}$ & & & & \\
\hline ornatum Wade, n. sp_... & & ..... &.--- & & $\ldots \ldots$ & & & a & a & & & \\
\hline um Gabb......... & & & & & & & & & & & & ----- \\
\hline Conrad) & & & & & & & $x$ & & & & & 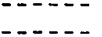 \\
\hline (Conrad) & $x$ & & & & & $x$ & & & & & & 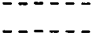 \\
\hline Acteon substriatus Wade, n. sp & & & & & & & & & & & & 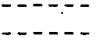 \\
\hline Acteon conicus Wade, n. sp & & $\ldots$ & $\ldots$ & & & & & & & & & 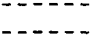 \\
\hline Acteon ellipticus Wade, n. sp & & $\ldots-\ldots$ & $\ldots$ & & $\begin{array}{ll}-1--1 \\
--1-\end{array}$ & $\ldots$ & & & & & & 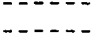 \\
\hline Acteon modicellus Conrad & $x^{-1}$ & & & & & & & & & & & \\
\hline Troostella perimpressa Wade, n. gen. and & & & & & & & & & & & & \\
\hline 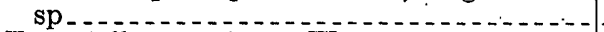 & & & & & & & & & & & & \\
\hline & & & & & & & & & & & & - - \\
\hline Tornatellaea globulosa Wade, n. sp_ & & & & & & & & & $\bar{a}$ & & & \\
\hline Acteonina orientalis Wade, n. sp & & & & & & & & & a & & & 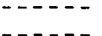 \\
\hline Acteonina parva Wade, n. sp & & & & & & & & & & & & \\
\hline Ringicula pulchella Shumard & $x$ & & $\mathrm{C}_{\mathrm{C}}$ & $x$ & & & & & & & & 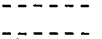 \\
\hline Cinulia paraquensis Wade, n. sp & & & & - - - - & & & & & & & & 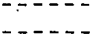 \\
\hline Eriptycha?americana Wade, n. sp & & & & $\begin{array}{ll}---- \\
--1 .-\end{array}$ & & & & & & & 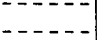 & a \\
\hline $\begin{array}{l}\text { Goniocylichna bisculpturata Wade, n. gen. } \\
\text { and sp }\end{array}$ & & & & & & & & & & & & \\
\hline Cylichna recta (Gabb) & & & & & & & & & & & & \\
\hline
\end{tabular}


The Coon Creek fauna and its range-Continued

[ $X$ indicates occurre̊nce of same species; $a$ indicates occurrence of allied species]

\begin{tabular}{|c|c|c|c|c|c|c|c|c|c|c|c|c|}
\hline . & $\begin{array}{c}\text { Ripley } \\
\text { forma- } \\
\text { tion, } \\
\text { Missis- } \\
\text { sippi }\end{array}$ & $\begin{array}{l}\text { Ripley } \\
\text { forma- } \\
\text { tion, } \\
\text { Ala- } \\
\text { bama }\end{array}$ & $\begin{array}{l}\text { Ripley } \\
\text { forma- } \\
\text { tion, } \\
\text { Georgia }\end{array}$ & $\begin{array}{c}\text { Navarro } \\
\text { forma- } \\
\text { tion, } \\
\text { Texas }\end{array}$ & $\begin{array}{l}\text { Upper } \\
\text { Creta- } \\
\text { ceous, } \\
\text { North } \\
\text { Caro- } \\
\text { lina }\end{array}$ & $\begin{array}{l}\text { Mon- } \\
\text { mouth } \\
\text { forma- } \\
\text { tion, } \\
\text { Mary- } \\
\text { land }\end{array}$ & $\begin{array}{l}\text { Mon- } \\
\text { mouth } \\
\text { group, } \\
\text { New } \\
\text { Jersey }\end{array}$ & $\begin{array}{c}\text { Mon- } \\
\text { tana } \\
\text { group, } \\
\text { west- } \\
\text { ern } \\
\text { interior }\end{array}$ & $\begin{array}{c}\text { Aache- } \\
\text { ner } \\
\text { Kreide, } \\
\text { Ger- } \\
\text { many }\end{array}$ & $\begin{array}{c}\text { Maes- } \\
\text { trichter } \\
\text { Kreide, } \\
\text { Bel- } \\
\text { gium }\end{array}$ & $\begin{array}{l}\text { Arria- } \\
\text { loor } \\
\text { group, } \\
\text { south- } \\
\text { ern } \\
\text { India }\end{array}$ & $\begin{array}{l}\text { Senon- } \\
\text { ian, } \\
\text { South } \\
\text { Africa }\end{array}$ \\
\hline $\begin{array}{l}\text { Scaphander rarus Wade, n. sp } \\
\text { Conorbis menairyensis Wade }\end{array}$ & & & & & & & & $\ldots$ & & & & $-\cdots$ \\
\hline $\begin{array}{l}\text { Paladmete cancellaria (Conrad) } \\
\text { Paladmete gardnerae Wade, n. sp. }\end{array}$ & & $\cdots$ & & & & & & $-\ldots$ & & & & ---- \\
\hline $\begin{array}{l}\text { Paladmete gardnerae Wade, n. sp. } \\
\text { Paladmete densata Wade, n. sp }\end{array}$ & & --- & ... & & & 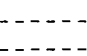 & & $\ldots$ & & & & $\ldots$ \\
\hline Cancellaria acuta Wade, n. sp & & $-\ldots$ & $-\cdots$ & $-\cdots--$ & 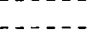 & $\cdots$ & a & $-\ldots$ & & a & & \\
\hline Mataxa elegans Wade & & $-\cdots--$ & & $-\ldots$ & --- & - & & $\ldots$ & & & a & 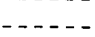 \\
\hline Turris proxima Wade, n. sp $\ldots . . . .$. & a & 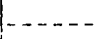 & & & & & & & & & ---1 & 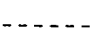 \\
\hline tricta Wade, n. sp $\ldots \ldots \ldots$ & & & & & & & & & & & & \\
\hline Conrad) $\ldots \ldots \ldots$ & & $-\ldots$ & - & & & & & &.- & --- & 列 & $\ldots$ \\
\hline $\begin{array}{l}\text { Wade, n. sp } \ldots \ldots \\
\text { Gardner }\end{array}$ & & $-\cdots-1$ & & & & & & & & & --- & $-\ldots$ \\
\hline $\begin{array}{l}\text { Turricula amica Gardner }- \\
\text { Turricula biacuminata Wade, } n\end{array}$ & & $\ldots .$. & & - & $\ldots-$ & & & $-\ldots \ldots$ & -- & $\ldots-$ & --- & 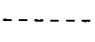 \\
\hline Turricula fasciolata Wade, n. sp & & $-\ldots$ & 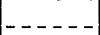 & 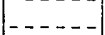 & -- & & & & & & & - \\
\hline la anomalocostata Wade, n. sp_. & & & & & & & & & & & & \\
\hline airyensis Wade, n. sp & & $\cdots$ & --- & 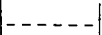 & -- & $-1+3+2$ & & $\mathbf{a}$ & & $-1+3+2$ & & \\
\hline spera Dall $\ldots \ldots \ldots$ & $\lambda$ & - - - & $-\ldots$ & - & $\ldots \ldots$ & $--1+3+2$ & -- & $\ldots$ & $\ldots$ & & & \\
\hline ea Wade, n. sp ...... & & $-\ldots$ & & - & $-\ldots$ & -- & 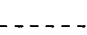 & - . - . & $\cdots$ & & & \\
\hline bilis Wade, n. sp ..... & & $\ldots$ & & $\ldots \ldots$ & & & & & & & & \\
\hline seensis Wade, n. sp & & $\ldots$ & - . - & a & $\ldots$ & - & & & & & & \\
\hline $2--1-2--$ & & $-\ldots$ & -- & $x$ & -- & $\ldots$ & & $\cdots+\cdots$ & 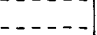 & & $\ldots$ & $\ldots \ldots$ \\
\hline ssa Wade, 1 & & $\ldots-\ldots$ & --- & $\ldots \ldots$ & $\cdots$ & - & & & -- & -- & $\cdots$ & $\ldots-$ \\
\hline nis Wade $\ldots .$. & & $\ldots$ & $-\ldots$ & $\ldots-\ldots$ & $\ldots$ & $-\ldots$ & & $\ldots \ldots$ & & & $\ldots$ & (n- \\
\hline Is (Conrad) $\ldots$. & & $x$ & $-\ldots$ & $\ldots$ & & & & & & & & \\
\hline ajor Wade & a & -- & -- & $-\ldots-1+$ & $\cdots$ & $\ldots$ & & ---1 & & & & $-\cdots-$ \\
\hline n Wade, n. sp & & $-\cdots$ & -1 & $-\ldots$ & 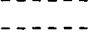 & $-\ldots$ & & 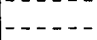 & & & & \\
\hline $\operatorname{sum}(\mathrm{Gabb}) \ldots$ & & --- & -- & ----- & $-\ldots$ & & & - & $\cdots$ & $\ldots$ & $-\ldots$ & ---- \\
\hline um (Conrad) ........ & $y$ & ---- & & $\ldots-\cdots$ & & $x$ & & $-\ldots$ & $\cdots$ & $-7+8>$ & & $-\ldots$ \\
\hline rinatum Wade, n. sp........ & & 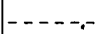 & $-\cdots$ & $-\ldots$. & & -- & & & & & & $\cdots--$ \\
\hline Conrad) $\ldots \ldots$ & & ---1 & & $\cdots$ & & -- & - & & & -- & - & $\ldots-\ldots$ \\
\hline s callilateris Wade $\ldots . . . . . . . . .$. & - - - & $-\ldots$. & $-\ldots$ & $--\cdots$ & ---- & & -- & - & -- & $-\ldots$ & ---- & $-\ldots$ \\
\hline Parafusus coloratus Wade & & $\ldots \ldots$ & --- & ----- & ---- &.-- & --- & ---1 & -- & 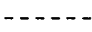 & $-\ldots$ & $---\cdots$ \\
\hline $\mathrm{de}_{-}-\mathrm{n}_{\mathrm{n}}$ & & $\cdots$ & $\ldots$ & $-\ldots-1$ & --- & $\ldots$ & - & --- & - & & & $-\cdots--$ \\
\hline ade, n. gen. and sp. & & $-\cdots$ & $\ldots$ & $-\cdots--$ & $\ldots$ & -- & & & & & & $\ldots$ \\
\hline racilis Wade, n. sp_... & & ---1 & 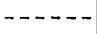 & -.... & $\ldots-n$ & -- & & $\cdots$ & --- & & & \\
\hline utabilis Wade, n. sp_... & & ---- & & $-\ldots$ & & & & -- & a & -5 & --- & $\cdots \cdots$ \\
\hline 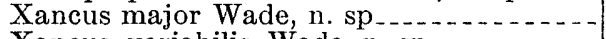 & & --- & --- & $-\cdots-$ & --- & $\cdots$ & $-\cdots$ & $\ldots .$. & -- & $\ldots$ & ---- & $---=-$ \\
\hline iabilis Wade $n$ sn & & ---1 & & ... & & $\cdots$ & & & $\ldots$ & $\ldots$ & & - \\
\hline sis Wade, n. sp & & $-1-1$ & - & --- & $=-1+3+$ & $\cdots$ & & & $\ldots$ & -1 & & $\cdots$ \\
\hline substriatus Wade. & & $-\ldots$ & & & & & & & & -- & & --70 \\
\hline 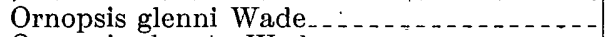 & &..$-\ldots$ & $\ldots$ & $\cdots-\cdots$ & 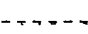 & $\ldots$ & 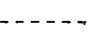 & & $\ldots$ & a & & \\
\hline ade $\ldots \ldots \ldots \ldots \ldots$ & & $-\ldots$ & & $\ldots$ & & $\cdots$ & & $=---$ & $\ldots$ & $\ldots-\cdots$ & $\ldots$ & $\ldots .$. \\
\hline Ornopsis digressa Wade, n. sp & & $-\cdots$ & & $\ldots$ & & & & & & & & \\
\hline Stantonella subnodosa Wade, n. gen. & & & & & & & & & & & & \\
\hline Vade, n. sp & & & & & & & & & & & & \\
\hline cus Wade & & & & & & $\mathrm{a}$ & & - & & & -- & - \\
\hline Wade, n, sp............ & & $\ldots$ & & & & & & 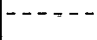 & $\ldots$ & a & -- & $=-$ \\
\hline Woodsella typica Wade, n. gen. and $\mathrm{sp}_{-}$ & & & & & & & & & & & & \\
\hline icostata Wade, n. sp & $\cdots$ & & $\because-$ & $-\ldots$ & & & $\mathbf{a}$ & & & & $\ldots-$ & \\
\hline cellatus Wade, n. sp ....... & & $\ldots$ & & $\ldots \ldots$ & $\ldots-\ldots$ & $\ldots-\ldots$ & $---\cdots$ & $\ldots \ldots$ & $\ldots$ & & $\cdots$ & $\ldots \ldots$ \\
\hline acilis Wade, n. sp $\ldots .$. & & $-\ldots$ & & & & & & a & 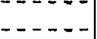 & & & $\ldots-\cdots$ \\
\hline nytis nobilis Wade, n. sp ......... & & $\ldots+\ldots$ & & - & & & & $\mathrm{a}$ & & & $\ldots$ & $\ldots$ \\
\hline Wade, n. $\mathrm{sp}_{\ldots} \ldots \ldots$ & & & & & & & & & & & $\ldots$ & \\
\hline ra Wade, n. sp.......... & & $-\ldots-$ & & & & & & a & & $-\infty$ & $a$ & \\
\hline ? ripleyana Wade, n. sp _..... & & & & & & & & & $\cdots$ & $\mathbf{a}$ & $----n$ & \\
\hline Veller) _........ & & $\ldots$ & & $x$ & X & & $x$ & $-\ldots$ & & & & \\
\hline con) cretaceum Wade & & $-.-1+3$ & $=$ &.- & - & & & & -- & & & \\
\hline Wade. & & $\ldots-$ & $-\ldots$ & $-\ldots$ & $-\ldots-1>$ & $\ldots$ & 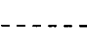 & - & a & & - & \\
\hline Wade & & $\ldots$ & a & 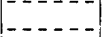 & $\ldots$ & - & $\ldots$ & - & $\ldots$ & $\ldots$ & $-\ldots .-$ & $-\ldots$ \\
\hline Ondo & & $-0-1$ & $\ldots-\ldots$ & $\ldots$ & & & & & $-\ldots$ & & & $\ldots \ldots$ \\
\hline Wade, n. sp & a & - & & & & & & & & & & a \\
\hline natus Wade, n. sp ....... & a & $\mathrm{a}$ & & & $\ldots$ & & - & - & $-\ldots$ & $\ldots$ & $\ldots$ & ---- \\
\hline us Wade, n. sp & & $\ldots \ldots$ & & & $\ldots$ &.- & & & $-\ldots$ & $\ldots$ & & $-\ldots-$ \\
\hline iatus Wade, n. sp ..... & & $\ldots$ & $-\ldots$ & $\ldots$ & $\ldots$ & -- & 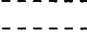 & ---- & $-\ldots$ & $-\ldots$ & $-\ldots--$ & ----- \\
\hline i (Weller) $\ldots \ldots$ & & & & & & & & & & & & \\
\hline sp & 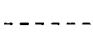 & $-\ldots$ & -- & 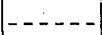 & & 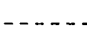 & ( & a & $-\ldots$ & & 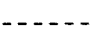 & - \\
\hline ade, n. sp & & & & & & & & & a & & & $\ldots$ \\
\hline$-5-2-1$ & & & & & & & & & & & & -- \\
\hline & - & & & & & & & 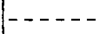 & & $\ldots$ & & -- \\
\hline esseensis Wade, n. sp & 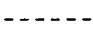 & & & 9 & & & & a & $\ldots$ & $\mathrm{a}$ & $\ldots$ & $-\cdots$ \\
\hline 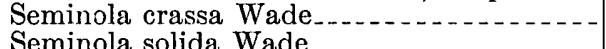 & a & $a^{-\cdots}$ & & a & & & & & & & & \\
\hline $\begin{array}{l}\text { minola solida Wade } \\
\text { dontobasis australis Wade, n. sp }\end{array}$ & & a & & 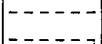 & & & & & & & & \\
\hline & & & & & & & & & & & & \\
\hline
\end{tabular}


The Coon Creck fauna and its range-Continued

[ $X$ indicates occurrence of sume species; a indicates occurrence of allied species]

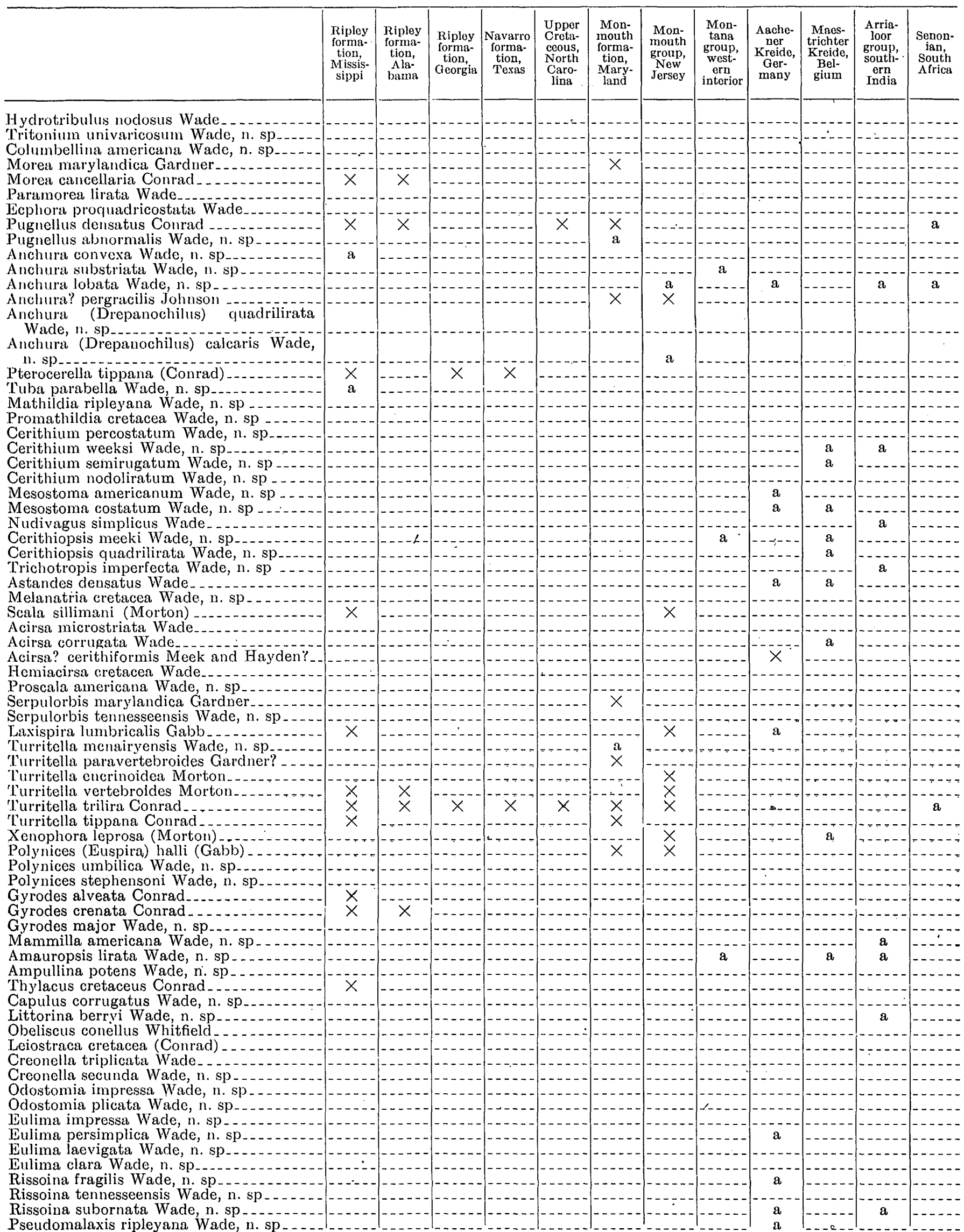


The Coon Creek fauna and its range-Continued

[ $X$ indicates occurrence of same species; $a$ indicates occurrence of allied species]

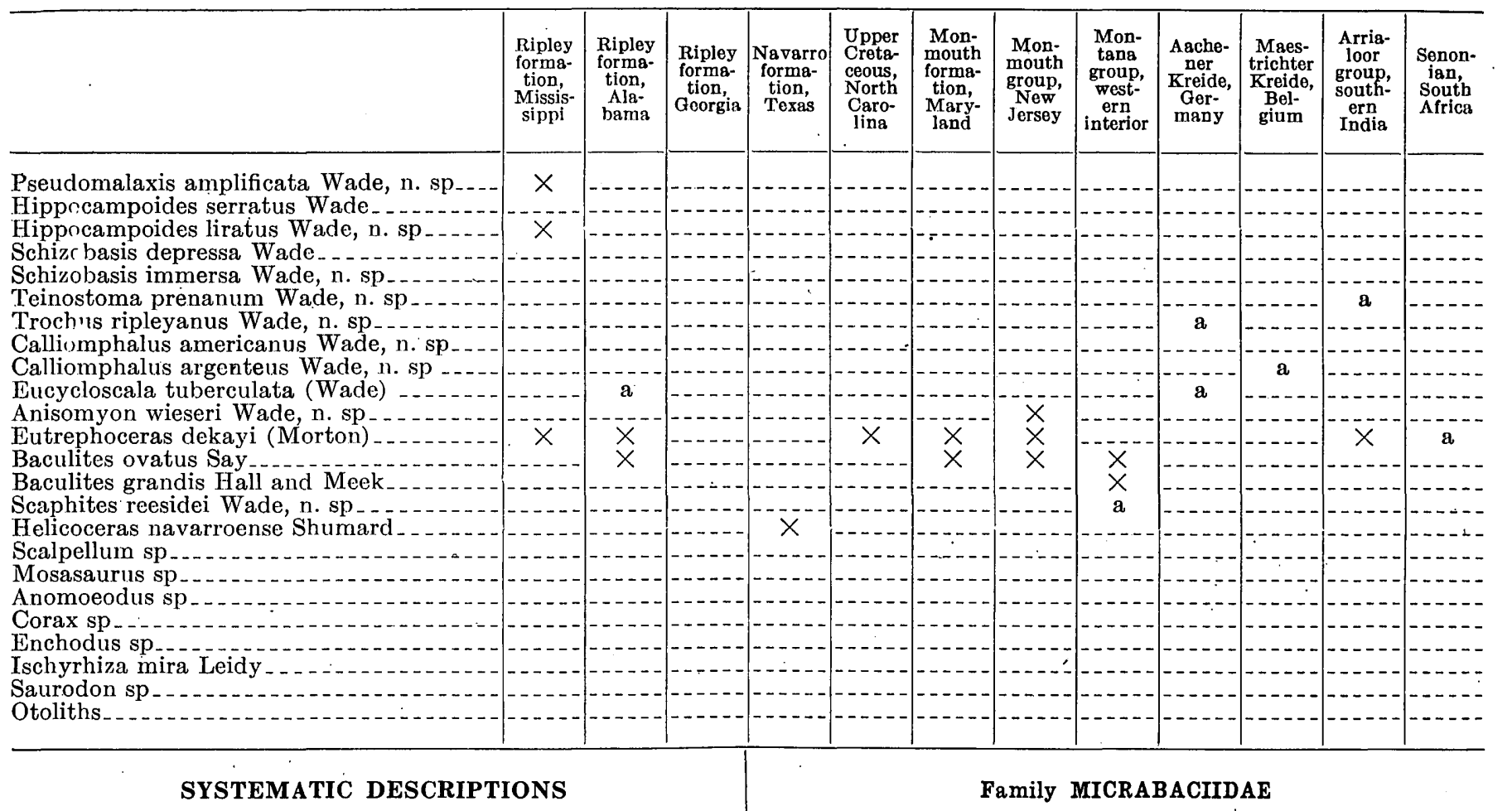

Phylum COELENTERATA

Class ANTHOZOA

Subclass HEXACORALLA

Order MADREPORARIA

Suborder APOROSA

Family ASTRAEIDAE

Genus TROCHOSMILIA Milne-Edwards

Trochosmilia nodosa Wade, n. sp.

Plate I, Figures 1, 2, 5

Corallur. conical; base nearly flat, slightly concave, upper surface a low, slightly curved cone with a perforation in the apex of the cone; base costate with a rough noncostate central plate about one-third the width of the base. Primary costae, or those extending from the outer margin to the central plate, number 12 ; secondary costae of two cycles and somewhat irregular in their occurrence and length; total of all three cycles of costae, 32. Intercostal spaces wider than the costae; septal faces granular or tuberculate, tubercles interlocking septa near center; inner characters unknown; outer or upper surface of the cone nodose and perforated. Diameter, 3.5 millimeters; elevation, 3 millimeters.

This species is very rare at Coon Creek. Only a single specimen is known, and this has not been sectioned to observe the inner structural characters. No closely related species is known in the American Upper Cretaceous.

Occurrence: Ripley formation, Dave Weeks place on Coon Creek, McNairy County, Tenn.

Collection: •U. S. National Museum.

\section{Genus MICRABACIA Milne-Edwards and Haime}

Micrabacia hilgardi Stephenson

Plate I, Figures 3, 4, 6-8

1916. Micrabacia hilgardi. Stephenson, U. S. Geol. Survey Prof. Paper 98, p. 120, pl. 22, figs. 1-6.

Stephenson describes this species as follows:

Corallum somewhat variable but in general moderately high, subdiscoidal, with steep, only slightly convex sides, suggesting a truncated cone; base flat, slightly convex or slightly concave; axial depression small and about 1 millimeter deep in the type, with steep sides. Dimensions of the type: Diameter, 5.5 millimeters; height, 3 millimeters.

The costae on the base or wall start with 6 and by successive bifurcations reach 96 on the periphery; they alternate with the septa. Each of the 6 original costae (first cycle) is the focus of a group; the original divides near the center into 2 (second cycle); these split about 0.5 millimeter from the center to form 4 (third cycle); the 4 split 1.25 to 1.5 millimeters from the center to form 8 (fourth cycle); and, finally, the 8 split on the periphery to form 16 (fifth cycle). The bifurcations of each cycle are at rather markedly irregular distances from the center. Up to the fourth cycle the costae are coarsely denticulate; those of the last cycle are thin, sharp, and finely denticulate and form a narrow band bordering on the periphery; they project slightly beyond the periphery. In the narrow intercostal loculi are synapticulae numbering 12 in the loculi extending to the center,' separated by slightly elongated perforations; the intercostal synapticulae and perforations are arranged in concentric rows.

The septa are thin and are separable into six groups, each group occupying the interspace between two of the six primaries. Total number of septa 96. The secondaries extend to the columella; the tertiaries are fused against the secondaries near the columella; the two outer quaternaries of each group are fused against the tertiaries nearer the center than the two inner ones; 
and the two outer quinaries of each subgroup formed about the tertiaries are fused against the quaternaries nearer the center than the two inner ones. The primary septa are slightly higher than the secondaries, and their inner edges descend steeply to the top of the columella; the members of each of the succeeding cycles are slightly lower than those of the preceding cycles. Margins of the septa finely denticulate, the denticulations numbering about 12 to 1 millimeter. Sides of septa with striae, tubercles, and synapticulae radiating fanlike from a point near the base of the columella. Each septum is joined to the wall (base) by synapticulae that connect with the intercostal synapticulae; these are separated by perforations that connect with the intercostal perforations.

Columella elliptical, spongy, trabecular, certain of the trabeculae terminating above. in more or less scattered, irregularly distributed papillae; length of the cross section a little less than one-fifth the diameter; width a little less than one-tenth the diameter.

This species differs from $M$. marylandica in size and form, being smaller and having straighter sides, which incline slightly more toward the center; the costae are not quite so thick, the costal denticulations are a little finer, the bifurcations of the separate cycles are at more irregular distances from the center, and the edges of the septa on the sides of the corallum do not alternate in prominence. In $M$. cribraria the corallum is flatter and only the outer cycle of basal costae are clearly distinguishable, the outer cycles being obscured by calcification; in $M$. rotatilis the corallum is flatter and the costae thinner, sharper, and much smoother, and the costae of the last cycle are much longer; in $M$. americana Meek and Hayden the corallum is flatter, the basal costae are thinner, and the costae of the last cycle are much longer and not so thin at the extremities; in M. mississippiensis the corallum is flatter, the basal costae are thinner and smoother, and the bifurcations of the separate cycles are at less regular distances from the center. In the European species $M$. moronula (Goldfuss) the denticulations on the margins of the septa are markedly coarser.

More than two dozen well-preserved specimens in the Coon Creek collections are referred to this species. These specimens show some variation among themselves and do not agree in every detail with the type of Micrabacia hilgardi from Mississippi, yet they are probably specifically identical.

Occurrence: Ripley formation, Dave Weeks place on Coon Creek, McNairy County, Tenn.

Collections: Johns Hopkins University, Vanderbilt University, U. S. National Museum.

Outside distribution: Ripley formation (Exogyra costata zone), Lee's old mill site, 2 miles northeast of Keownville, Union County, Miss. Upper part of Ripley formation (Exogyra costata zone), Eufaula, Ala., Mercers Mill Creek near Georgetown, Ga., and Chattahoochee River 2 miles below Eufaula, Ala.

\section{Micrabacia cribraria Stephenson}

Plate I, Figures 9, 10

1916. Micrabacia cribraria. Stephenson, U. S. Geol. Survey Prof. Paper 98, p. 117, pl. 20, figs. 1-3.

Stephenson describes this species as follows:

Corallum subdiscoidal; base nearly flat, upper surface convex, with axial depression slightly less than 1 millimeter deep. Dimensions of the type: Diameter, 6.5 millimeters, height, 2.5 millimeters.

The under side of the wall or base to a radial distance from the center of about 2 millimeters is irregularly tuberculated and presents numerous sievelike perforations roughly arranged in radial rows corresponding to the positions of the septa. The rough central area merges into a costate marginal band, the costae numbering 96 and alternating with the septa. The costae are thicker than the intercostal loculi, are roughly tuberculated, and on the periphery project prowlike somewhat beyond the edges of the septa. In each intercostal loculus are synapticulae separated by elongated perforations.

The septa are thin and form five complete cycles, arranged in six groups, one group in each of the interspaces bet:ree" the six primaries. Total number of septa, 96. The secondaries extend to the columella; the tertiaries fuse against the secondaries near the columella; the two outer quaternaries of the group fuse against the tertiaries nearer the center than the two inner ones; the two outer quinaries of each of the two subgroups formed about the tertiaries fuse against the quaternaries nearer the center than the two inner quinaries of each subgroup. The primary septa are slightly higher than the members of the higher cycles, and their upper margins curve sharply downward into the central depression; the secondaries are slightly lower than the primaries, and the tertiaries, quaternaries, and quinaries each become progressively slightly.lower. The margins of the septa are finely denticulate, the number being about 10 to 1 millimeter. Synapticulae are numerous; striae are present on the sides of the septae at the upper margins, apparently arranged fanlike, though only partly exposed.

Columella elliptical in cross section, spongy, trabecular, a certain number of the trabeculae terminating in more or less scattered, irregularly distributed papillae; length of cross section about one-fifth the diameter; width about one-tenth the diameter.

This species differ from the other species of American Micrabacia in the arrangement of the basal costae, which instead of extending to the center merge into a perforated, irregularly calcified, noncostate, sievelike area.

This species is rare at Coon Creek. Only two individuals are known. They do not agree in minute detail with the type of this species in that the central noncostate sievelike area is smaller than in the type; this difference, however, is probably not specific.

Occurrence: Ripley formation, Dave Weeks place on Coon Creek, McNairy County, Tenn.

Collection: U. S. National Museum.

Outside distribution: Snow Hill marl member of Black Creek formation (upper part of Exogyra ponderosa zone), Whiteley Creek Landing, Neuse River; Kerrs Cove, Black River, N. C. Lower part of Rilpey formation (upper part of Exogyra ponderosa zone), Union Springs, Ala., at "Conecuh Falls"; Central of Georgia Railway cut half a mile west of Union Springs. Lower part of Selma chalk (upper part of Exogyra ponderosa zone), questionably on the Tupc's road in Lee County, Miss., 8 miles west of Fulton.

\section{Phylum ECHINODERMATA \\ Class ASTEROIDEA \\ Family GONIASTERIDAE \\ Genus METOPASTER Sladen}

Metopaster tennesseensis Wade, n. sp.

Plate I, Figures 11-19

Marginal plates thick and subequidimensional; form variable, roughly the shape of a section of ir a a a a a

$\because$, asers pusarery

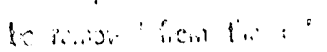

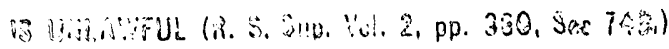


a cylinder; outer surface a subrectangular section of the face of a cylinder; inner surface of plates subrectangular; end surfaces trigonal or quadrilateral, depending upon the position of the plate; outer surface of plates covered with an epidermal layer pitted with numerous small shallow holes of variable size and spacing; inner surfaces smooth, flat to concave. Width, 5 millimeters; length, 4 millimeters; thickness, 3 millimeters.

This species is known only from several dozen disconnected marginal plates, hence its classification is rather uncertain. One of the similar forms described in the literature is Stellaster planensis Geinitz, ${ }^{35}$ from the Cenomanian of Saxony. Another analogous form known only from disconnected plates is Goniaster mammillata Gabb, ${ }^{36}$ from the Monmouth of New Jersey, a form assigned to the genus Pycinaster Spenrer ${ }^{37}$ by the author of that genus. Perhaps the Tenuissee species is more similar to Metopaster parkinsoni Forbes, ${ }^{38}$ from the Upper Chalk of England, than to any other known species.

Occurrence: Ripley formation, Dave Weeks place on Coon Creek, McNairy County, Tenn.

Collections: U. S. National Museum, Johns Hopkins University.

\section{Family SPATANGIDAE}

\section{Genus HEMIASTER Desor}

\section{Hemiaster ungula (Morton)}

Plate I, Figures 20, 21

1830. Spatangus sp. Morton, Am. Jour. Sci., 1st ser., vol. 17, p. 286.

1833. Spatangus ungulata. Morton, Am. Jour. Sci., 1st ser., vol. 23 ,p. 131, pl. 10, fig. 6 .

1834. Spatangus ungula. Morton, Synopsis of the organic remains of the Cretaceous group of the United States, p. 78 , pl. 10, fig. 6 .

1847. Micraster ungula. Agassiz and Desor, Catalogue raisonné des familles, des genres et des espèces de la classe des échinodermes, p. 141.

1848. Spatangus ungula. Bronn, Index palaeontologicus, vol. 1, p. 1161.

1859. Holaster ungula. Gabb, Catalogue of the invertebrate fossils of the Cretaceous formation of the United States, p. 19.

1891. Hemiaster ungula. Clark, Johns Hopkins Univ. Circ., vol. 10, p. 77.

1893. Hemiaster ungula. Clark, Johns Hopkins Univ. Circ., vol. 12 , p. 52.

1893. Hemiaster ungula. Clark, U. S. Geol. Survey Bull. 97, p. 85 , pl. 46 , fig. 2 .

35 Wanderer, Karl, Die wichtigsten Tierversteinerungen aus der Kreide des Königreiches Sachsens, p. 9, pl. 2, fig. 1, Jena, 1909.

${ }^{38} \mathrm{Gabb}, \mathrm{W}$. M., Note on the discovery of representatives of three orders of fossils new to the Cretaceous formation of North America: Acad. Nat. Sci. Philadelphia Proc. for 1876, p. 178, pl. 5, figs. 2, a, b, 1876. Clark, W. B., The Mesozoic Echinodermata of the United States: U. S. Geol. Survey Bull. 97, p. 32, pl. 5, figs. 1a-h, 1893 ${ }^{37}$ Sladen, W. P., and Spencer, W. K., A monograph on the British fossil Echinodermata from the Cretaceous formations, vol. 2, p. 110, Palaeont. Soc. London, 1907.

${ }^{38}$ Sladen, W. P., and Spencer, W. K., op. cit., vol. 2, p. 31, pl. 9, figs. 2a-2c, etc., 1893.
1905. Hemiaster ungula. Johnson, Acad. Nat. Sci. Philadelphía Proc., vol. 57, p. 7.

1907. Hemiaster ungula. Weller, New Jersey Geol. Survey, Paleontology, vol. 4, p. 301, pl. 16, figs. 5-11.

1915. Hemiaster ungula. Clark, U. S. Geol. Survey Mon. 54, p. 93 , pl. 48 , figs. $3 \mathrm{a}-\mathrm{q}$.

Clark in 1915 described this species as follows:

Test oval, cordiform, elevated; upper surface inflated, elevated posteriorly; lower surface flat; sides sloping; anterior sulcus narrow and deep. Ambulacra narrow; poriferous zones straight, depressed, petaloidal. Peripetalous fasciole deeply bent upward between the anterior and posterior paired ambulacra. Apical system small, compact. Peristome transversely oval near anterior margin. Periproct oval, supramarginal. Length, 31.25 millimeters; width, 28 millimeters; height, 21.9 millimeters.

This species has an oval cordate test that is very much elevated in the posterior portion. Anteriorly the upper surface slopes rapidly, so that the margin is much thinned down, losing the full round aspect of the previously described forms. The sharp ridge on the posterior portion of the test is terminated by a nearly vertical truncation of the posterior margin. The base is flat, save for the peristomial depression.

The ambulacra are narrow. The poriferous zones are petaloidal, straight, and deeply depressed on the upper surface. The unpaired ambulacrum is placed in the anterior sulcus and but slightly exceeds the other areas in width. The petals of the anterolateral pair are twice the length of the posterolateral. The pores of the paired ambulacra are elongated and separated, those of the single ambulacrum small, oval, and approximated.

The surface of the test is covered with small tubercles, between which are numerous minute granules. The peripetalous fasciole is distinct and bent outward between the anterior and posterior paired ambulacra.

The apical system is small and situated posterior to the center of the upper surface. The right anterolateral genital plate is very large and widely separates the posterior pair of oculars. The posterolateral genitals have large perforations.

The peristome is transversely oval, bilabiate, with a prominently projecting lower lip. The periproct is large and is situated at the upper part of the truncated face of the posterior margin.

Occurrence: Ripley formation, Dave Weeks place on Coon Creek, McNairy County, Tenn.

Collection: Philadelphia Academy of Natural Sciences, American Museum of Natural History, Johns Hopkins University, U. S. National Museum.

Outside distribution: Rancocas group, New Jersey; Ripley formation, Owl Creek, Miss.

\section{Hemiaster stella (Morton)}

1830. Spatangus stella. Morton, Am. Jour. Sci., 1st ser., vol. 18 ; p. 245 , pl. 4 , fig. 11.

1830. Spatangus stella. Morton, Acad. Nat. Sci. Philadelphia Jour., 1st ser., vol. 6, p. 200.

1834. Spatangus stella. Morton, Synopsis of the organic remains of the Cretaceous group of the United States, p. 78 , pl. 3 , fig. 18 .

1847. Hemiaster stella. Agassiz and Desor, Catalogue raisonné des familles, des genres et des espèces de la classe des échinodermes, p. 141.

1858. Hemiaster stella. Desor, Synopsis des échinides fossiles, p. 373 . 
1859. Hemiaster stella. Gabb, Catalogue of the invertebrate fossils of the Cretaceous formation of the United States, p. 19.

1864. Hemiaster stella? Meek, Check list of the invertebrate fossils of North America, Cretaceous and Jurassic, p. 3 .

1887. Hemiaster wetherbyi. De Loriol, Recueil zool. Suisse, vol. 4, p. 391, pl. 17, figs. 5-8.

1891. Hemiaster incrassatus. Clark, Johns Hopkins Univ. Circ., vol. 10, p. 77.

1893. Hemiaster stella. Clark, Johns Hopkins Univ. Circ., vol. 12 , p. 52.

1893. Hemiaster stella. Clark, U. S. Geol. Survey Bull. 97, p. 84 , pl. 46, figs. 1a-d.

1905. Hemiaster stella. Johnson, Acad. Nat. Sci. Philadelphia Proc., vol. 57, p. 7.

1907. Hemiaster stella. Weller, New Jersey Geol. Survey, Paleontology, vol. 4, p. 300, pl. 16, figs. 1-4.

1915. Hemiaster. stella. Clark, U. S. Geol.. Survey Mon. 54, p. 93, pl. 48 , figs. $2 a-d$.

Clark in 1915 described this species as follows:

Test small, oval, inflated, rounded before, truncated behind; upper surface elevated posteriorly, sloping anteriorly; anterior groove short, not reaching the ambitus. Ambulacra straight, depressed above. Apical system excentric and posterior. Peristome bilabiate and near the anterior border. Periproct small, high above posterior margin. Fasciole distinct. Length, 25 millimeters; width, 21.9 millimeters; height, 15.6 millimeters.

This form was originally described by Morton in 1830; later, in 1.833, it was considered by the same writer as the young of the species for which the name parastatus was then proposed. $H$. incrassatus is only a large form of $H$. stella, and Hemiaster wetherbyi is also apparently identical with the same species.

The test is small, oval, and cordate and much elevated on the posterior portion of the upper surface. The whole test has a rounded, full outline that is much increased by the absence of the usually deep anterior groove, which in $H$. stella does not reach the margin. The posterior border is nearly vertically truncated.

The ambulacra are depressed in the petaloidal portions, which in the anterolateral pair are twice as long as in the posterolateral. The poriferous zones are narrow; the pores have transverse slitlike openings. The unpaired ambulacrum is situated in the anterior groove.

The surface of the test is covered with innumerable small tubercles between which is a microseopic granulation. The peripetalous fasciole is very distinct, oval, and passes with a regular curve about the ends of the petaloidal areas. The surface of the test is covered with minute tubercles, between which are microscopic granules. The apical system is small and is situated posteriorly to the center of the upper surface of the test. The peristome is tranversely oval, bilabiate, and placed near the anterior margin. The periproct is small, oval, and situated at the upper part of the truncated posterior margin.

Occurrence: Ripley formation, Dave Weeks place on Coon Creek, McNairy County, Tenn., where it is known only from imperfect specimens, none of which are figured.

Collections: Johns Hopkins University, Philadelphia Academy of Natural Sciences, U. S. National Museum.

Outside distribution: Rancocas group, New Jersey.

\section{Hemiaster lacunosus Slocum}

Plate II, Figures 2, 3

1909. Hemiaster lacunosus. Slocum, Field Mus. Nat. Hist. Pub. 134, Geol. ser., vol. 4, No. 1, p. 10, pl. 2, figs. 1-17. 1915. Hemiaster lacunosus. Clark, U. S. Geol. Survey Mon. 54 , p. 97 , pl. 50 , figs. $3 \mathrm{a}-$ d; pl. 51 , figs. $1 \mathrm{a}-\mathrm{i}$.

Slocum describes this species as follows:

Test small, indistinctly cordate, ventral surface moderately convex, dorsal surface convex, strongly elevated in the posterior interambulacral area and gradually sloping with an indistinct anterior sulcus; anterior and lateral borders inflated, posterior margin truncated. Ambulacral areas petaloid; with straight petals situated in the depressions of the surface, the anterolateral pair nearly twice as long as the posterolateral pair; poriferous zones of the paired petals wide, pores transversely elongate and situated far apart. Anterior petal longer but narrower than the others and situated in a deep depression which grades into an indistinct anterior sulcus; poriferous zones of this petal narrow and far apart; pores small and round and separated by a tubercle. Interambulacral areas broad and composed of large plates. Surface of the test covered with a multitude of small tubercles with sunken areoles that increase in size toward the peristome. The tubercles have perforated mamelons and crenulated bosses, the interspaces being filled with microscopic granulations. Peripetalous fasciole wide and distinct, moderately bent inward between the petaloid areas except the two posterior ones. Apical disk sunken, small, and situated somewhat posterior to the center of the dorsal surface, the four genital plates distinctly perforated and separated by five small radial plates. Right anterior genital plate large, convex, and forming the madreporite. Peristome transversely arched, bilabiate, with prominent labrum. Periproct about the size of the peristome, elongated vertically, and situated near the top of the posterior truncation.

$H$. lacunosus resembles $H_{\text {I. }}$ parastatus in general form and proportions but is distinguished from that species by its smaller size and by the sunken areoles of the tubercles. Moreover, the posterior interambulacral area is rounded, while in $H$. parastatus it is in the form of a ridge. H. lacunosus is similar to $H$. stella in size but differs from it in the shape of the fasciole, the sunken areoles, and the form of the anterior margin. It resembles $H$. dalli in having sunken areoles, but in general form these two species are quite dissimilar. The specific name adopted refers to the sunken areoles by which the species is distinguished.

Occurrence: Ripley formation, Dave Weeks place on Coon Creek, McNairy County, Tenn.

Collections: U. S. National Museum, Field Museum. Outside distribution: Ripley formation, Mississippi.

\section{Hemiaster sp.}

Plate II, Figure 1

This species is represented in the collections by a few imperfect specimens which are not sufficient for specific identification. The form suggests Hemiaster comanchei Clark, ${ }^{30}$ from the Lower Cretaceous of Texas, but is hardly identical with that form; probably further collecting from the Ripley of Tennessee

${ }^{39}$ Clark, W. B., The Mesozoic and Cenozoic Echinodermata of the United States U. S. Geol. Survey Mon. 54, p. 90, pl. 4, 6, figs. 2a-d, 1915 . 
will yield material sufficient for making known a new descendant species from Hemiaster comanchei Clark.

Occurrence: Ripley formation, Dave Weeks place on Coon Creek, McNairy County, Tenn.

Collections: Johns Hopkins University, U. S. National Museum.

\section{Phylum VERMES \\ Class ANNELIDA \\ Order POLYCHAETA \\ Suborder TUBICOLA \\ Family SERPULIDAE \\ Genus HAMULUS Morton}

1834. Hamulus. Morton, Synopsis of the organic remains of the Cretaceous group of the United States, p. 73. (Type: Hamulus onyx Morton.)

1921. Hamulus. Wade, U. S. Nat. Mus. Proc., vol. 59, pp. 4146, pls. 9, 10.

Morton thus defined the genus:

Tubular, regular, involuted; volutions distinct; aperture circular.

Tubes with from three to seven axial ribs; larval or early stages attached, usually broken away and solitary in the adult, nuclear shell portions circular and often triangular in cross section; inner surface of tubes smooth; operculum calcareous, consisting of a circular anterior disk with a three-cornered, elongate posterior process or apophyse.

\section{Hamulus onyx Morton \\ Plate II, figures 4-7, 12}

1834. Hamulus onyx. Morton, Synopsis of the organic remains of the Cretaceous group of the United States, p. 73 , pl. 2 , fig. 8 ; pl. 16 , fig. 5 .

1859. Hamulus onyx. Gabb, Catalogue of the invertebrate fossils of the Cretaceous formation of the United States; p. 1.

1914. Hamulus onyx. Stephenson, U. S. Geol. Survey Prof. Paper 81, p. 24, tables 2, 8 .

1916. Hamulus onyx. Gardner, Maryland Geol. Survey, Upper Cretaceous, p. 747 (part).

1921. Hamulus onyx. Wade, U. S. Nat. Mus. Proc., vol. 59, p. 43 , pl. 9 , figs. $1,2,3,5,6$.

Morton describes the species as follows:

With six elevated, angular, longitudinal ribs extending from base to apex. Length about an inch. The imperfect specimen figured on Plate II was obtained by Dr. Blanding at Lynch's Creek, S. C., in the green sand, and on a former occasion was supposed to be a Dentalium. Plate XVI, Figure 5, however, represents the perfect shell from the older Cretaceous deposits of Erie, Ala. I have a small individual from New Jersey. It has never been found attached.

Type locality: Erie, Ala.

Tube small, compact, and rather strong; in form a very elongate, gently curved, ribbed or corrugated cone; shell of tube made up of two layers-an inner layer of lamellar calcareous material and an outer layer of chitinous calcareous material bearing the ex- ternal sculpture; nucleus or protoconch unknown; tube attached to some foreign object during nuclear stage; external sculpture consisting of six prominent axial ribs and sulci; transverse or incremental lines fine and very numerous in some individuals, very obscure in other individuals; internal surface smooth; aperture circular; apertural margin smooth and sharp; operculum tack-shaped with a three-cornered spike or tooth situated on the edge of the tack-head or basal circular plate; anterior surface of basal plate concave, marked with a few fine lines radiating from the center and a few irregular concentric lines; posterior side of the basal plate and the sides of the threecornered tooth or apophyse marked by irregularly ramifying and deeply impressed grooves or sulci, which probably represent the seats of muscular or ligamental attachments; posterior extremity of the tooth pointed and tripartite; operculum in place is entirely behind the anterior margin of the aperture, thus forming a water-tight stopper for the tube.

This species is one of the commonest fossils in the Ripley formation at Coon Creek. It is represented in the collections from that locality by hundreds of specimens, several dozen of which retain the operculum in place. A few immature forms have been found attached, but none of the specimens preserve the complete nucleus. This is broken away from all the specimens examined, leaving the apices perforate. 'This species is somewhat similar to the species Hamulus jonahensis (Cragin), ${ }^{40}$ from the Austin chalk of Texas, but does not possess the vigorous incremental sculpture that characterizes the tubes of the Texas species. The species Serpula sexsulcata Münster, ${ }^{41}$ a species of Hamulus from the Upper Cretaceous of Germany, has six axial ribs on the tube, but most commonly the European species of this genus are characterized by seven ribs instead of six. Two of these are Dentalium deformis D'Orbigny, from the Cenomanian, Le Mans, France, and Serpula septemsulcata Reich and Cotta, ${ }^{42}$ which is widely distributed in the Cenomanian of Saxony and is especially abundant in the Serpulitensand of Bannewitz, near Dresden. The Ripley species Hamulus major Gabb, ${ }^{43}$ from Eufaula, Ala., has only three or four low axial costae on its tubes, which are-less regular and symmetrical than the type species of this genus. The Oxfordian species Serpula vertebralis Sowerby, ${ }^{44}$ a Jurassic species found in both England and France, has only four axial ribs, but in many respects it resembles Hamulus

${ }^{40}$ Cragin, F. W., A contribution to the invertebrate paleontology of the Texas Cretaceous: Texas Geol. Survey Fourth Ann, Rept., pl. 29, figs. 12-14, 1883.

11 Goldfuss, G. A., Petrefacta Germaniae, vol. 1, p. 238, pl. 70, figs. 13, 1826-1844.

12 Geinitz, H. B., Grundriss der Versteinerungskunde, p. 252, pl. 16, figs. 18a, b, c,

Dresden, 1842. Wanderer, Karl, Die wichtigsten Tierversteinerungen aus der Kreide des Königreiches Sachsens, p. 21, pl. 3, fig. 12, Jena, 1909.

${ }^{3} \mathrm{Gabb}$, W. M., Descriptions of new species of American Tertiary and Cretaceous fossils: Acad. Nat. Sci. Philadelphia Jour., 2d ser., vol. 4, p. 399, pl. 68, flg. 46, 1860. 14 Sowerby, James, The mineral conchology of Great Britain, vol. 6, pl. 599, fig. 5 , 1829. Bronn, H. G., Lethaea geognostica, Band 6, p. 415, pl. 27, fig. 5, a, b, Stuttgart, 1852. 
onyx Morton and should be included in the genus Hamulus.

Occurrence: Ripley formation, Dave Weeks place on Coon Creek, McNairy County, Tenn.

Collections: Philadelphia Academy of Natural Sciences, Johns Hopkins University, Vanderbilt University, U. S. National Museum.

Outside distribution: Monmouth formation of Maryland; Selma chalk and Ripley formation of Mississippi and Alabama; Eutaw formation of Alabama.

\section{Hamulus angulatus Wade}

Plate II, Figures 14-17

1921. Hamulus angulatus. Wade, U. S. Nat. Mus. Proc., vol. 59, p. 45 , pl. 10, figs. $1,2,8,9$.

Tube small, thick and strong but brittle; in form an elongate, gently curved, and commonly slightly spiral cone; inner shell layer thick, outer layer thin; nucleus unknown; external surface marked by six low, sharp, angular axial ridges; interaxial spaces broad and gently concave, alternate interaxial spaces marked by a fine impressed axial line; growth lines obscure on the earlier stages of the shell; interrupted growth lines irregular and common near the aperture; aperture circular, its margin smooth and thin; internal surface smooth. An imperfect specimen measures in length 8 millimeters; in maximum diameter 3.5 millimeters.

The tubes of this species are brittle and are usually broken. They may be readily distinguished from those of Hamulus onyx Morton by their low, angular axial costae, broad, smooth, gently concave interaxial spaces, and the impressed axial line in alternate interaxial spaces.

Occurrence: Ripley formation, Dave Weeks place on Coon Creek, McNairy County, Tenn.

Collections: Johns Hopkins University, Vanderbilt University, U. S. National Museum.

\section{Hamulus squamosus Gabb}

Plate II, Figures 8,13

1859. Hamulus squamosus. Gabb, Catalogue of the invertebrate fossils of the Cretaceous formation of the United States, p. 1.

1860. Hamulus squamosus. Gabb, Acad. Nat. Sci. Philadelphia Jour., 2d ser., vol. 4, p. 398, pl. 68, fig. 45 .

1914. Hamulus squamosus. Stephenson, U. S. Geol. Survey Prof. Paper 81, p. 24, table 2.

1921. Hamulus squamosus. Wade, U. S. Nat. Mus. Proc., vol. 59, pl. 10, figs. 6,7 .

Gabb in 1860 described this species as follows:

Elongated, curved at the narrow end into a hook, sometimes with as much as three-fourths of a whorl, all in the same plane; mouth slightly constricted, nearly circular, edge thin; surface marked by two or three wrinkled longitudinal folds on each side and a heavy squamose plate, very irregular in the plane of the curve on each side. Length about 1 inch exclusive of the curve, greatest width of the plates $0.4 \mathrm{inch}$, diameter of rrouth 0.12 inch.

106913-26†-3
This species is closely related to Hamulus onyx Morton but may be readily distinguished by the broad winglike appendages on the first and fourth axial costae. Hamulus squamosus Gabb is evidently a mud-loving form, as it is extremely rare in the Coon Creek beds and common in the Selma formation.

Occurrence: Ripley formation, Dave Weeks place on Coon Creek, McNairy County, Tenn.

Collection: U. S. National Museum.

Outside distribution: Ripley formation, Lees Mill, Miss. Selma chalk, Mississippi, Alabama, and Georgia.

\author{
Hamulus sp. \\ Plate II, Figures 9-11
}

1921. Hamulus sp. Wade, U. S. Nat. Mus. Proc., vol. 59, p. 46 , pl. 10, figs. 3-5.

Operculum small and fragile, consisting of a circular disk and an elongate three-cornered posterior process or apophyse; circular disk marked on both the anterior and posterior sides by lines radiating from the center; margin of disk slightly serrate; position of apophyse on the disk excentric.

This species of operculum is known from a single individual, which was found detached from a tube. Most likely it belongs either to Hamulus squamosus Gabb or to Hamulus angulatus, probably the latter.

Occurrence: Ripley formation, Dave Weeks place on Coon Creek, McNairy County, Tenn.

Collection: U. S. National Museum.

\section{Genus SERPULA Linné \\ Serpula pervermiformis Wade, n. sp. Plate II, Figure 18}

Tubes very small, circular in cross section, highly intertangled and coiled; external surface roughened with transverse growth lines; internal surface smooth; shell or tube material of two layers. Diameter, 0.6 millimeter; length, $10+$ millimeters.

This gregarious species occurs as a mass of intertangled and intercoiled wormlike tubes attached to other large shells, such as Exogyra costata Say.

Occurrence: Ripley formation, Dave Weeks place on Coon Creek, McNairy County, Tenn.

Collection: U. S. National Museum.

\section{Serpula adnata Wade, n. sp. Plate III, Figure 1}

Small semitubes adnate to some smooth-surfaced foreign object; tubes straight or coiled; cross section circular or semicircular; inner surface smooth. Diameter, 0.8 millimeter; length, $10+$ millimeters.

This species is somewhat similar to Serpula pervermiformis Wade and is usually found on the smooth inner surfaces of large bivalves.

Occurrence: Ripley formation, Dave Weeks place on Coon Creek, McNairy County, Tenn.

Collection: U. S. National Museum. 


\section{Phylum MOLLUSCOIDEA}

Class BRYOZOA

By Ferdinand Canu and R. S. Bassler

The bryozoan fauna of the Ripley deposits at the Coon Creek locality consists of 22 species, almost all new to. science. Though small, it is interesting because of certain unexpected discoveries it has afforded. First, it contains a species of the genus Ammatophora, of which hitherto only a single recent species has been known; and, second, it contains two new genera of most unusual and remarkable structure. Of these the new genus Frurionella, which has an external aspect very close to that of Beisselina Canu, is in reality related very closely to Foveolaria Busk-in other words, it has a much more elementary structure than Beisselina. The second new genus, Dysnoetopora, appears indeterminable upon examination of the exterior, but thin sections have revealed two characters that have not heretofore been observed-namely, sinuous tubes and an internal gemmation that results from partitioning of the tubes.

The general affinities of the fauna are with the Upper Cretaceous of Europe as well as of North America and South America.

\section{Order CHEILOSTOMATA Busk}

\section{Suborder ANASCA Levinsen}

\section{Group MEMBRANIPORAE Canu and Bassler}

Genus CONOPEUM Norman

Conopeum ovatum Canu and Bassler, n. sp.

Plate IV, Figures 1-4

The zoarium is free, subcylindrical or somewhat compressed, bifurcated in the same plane. The zooecia are distinct, separated by a deep furrow, elongated, oval; the distal wall is very oblique and bears a large median septula and two lateral septulae visible exteriorly; the mural rim is thin, somewhat enlarged at the base with the termen sharp or slightly denticulated; the opesium is oval. The interopesial cavities are large, lozenge-shaped, much elongated; they contain in many specimens a kind of avicularium with special walls and without a pivot.

Opesia: $\mathrm{ho}=0.30$ millimeter; $\mathrm{lo}=0.18-0.20$ millimeter. Zooecia: $\mathrm{Lz}=0.45$ millimeter; $\mathrm{lz}=0.22-0.25$ millimeter. ${ }^{45}$

The great obliquity of the distal walls permits the three distal septulae to be seen. This structure is identical with that of Scrupocellaria and Heterocella and indeed of other species with articulated colonies.

The zooecia do not occur in regular quincunx but are arranged in longitudinal; irregular rows. This mode of gemmation is rather rare.

is In the statement of measurements ho represents the length and lo the width of the opesia, $L z$ and $l z$ similarly the length and width of the zooecia, $L v$ and $l v$ the same dimensions for the vibraculum, Lon and lon for the onychocellaria, $h a$ and $l a$ for the aperture, etc.
This species differs from Conopeum prismaticum Canu and Bassler, n. sp., in its nondetachable lamellae, oval opesium, and large interopesial cavities.

Occurrence: Ripley formation, Coon Creek, McNairy County, Tenn.

Conopeum parviporum Canu and Bassler, n. sp.

Plate IV, Figures 5, 6

The zoarium is free, subcylindrical or compressed, bifurcated on the plane of compression. The zooecia are distinct, separated by a deep furrow, elongated, small, somewhat oval; the mural rim is thin, slightly enlarged at the base with rounded termen; the opesium is somewhat oval. The interopesial cavities are large, lanceolate, with special walls.

Opesia: ho $=0.20-0.25$ millimeter; lo $=0.125$ millimeter. Zooecia: $\mathrm{Lz}=0.35-0.40$ millimeter; $\mathrm{lz}=0.20$ millimeter.

The zooecia are arranged in transverse rows. Their distal wall is very oblique and shows in some specimens a distal septula and two lateral septulae.

This species differs from Conopeum ovatum Canu and Bassler, n. sp., in its smaller micrometric dimensions and in its rounded termen. We have observed an example of total regeneration.

Occurrence: Ripley formation, Coon Creek, McNairy County, Tenn.

\section{Conopeum wadei Canu and Bassler, n. sp.}

Plate IV, Figure 11

The zoarium incrusts shells. The zooecia are distinct, separated by a furrow, elongated, elliptical, large, arranged in transverse rows; the mural rim is thin, with a sharp termen; the opesium is large, elliptical. The interopesial cavities are elongated, lanceolate, median, with special walls.

Opesia: ho $=0.40$ millimeter; $\mathrm{l} o=0.25$ millimeter. Zooecia: $\mathrm{Lz}-0.50$ millimeter; $\mathrm{lz}=0.25$ millimeter.

This species differs from the associated new species, Conopeum ovatum and C. parviporum, in its incrusting zoarium, in its large micrometric dimensions, and in the interopesial cavities, which are not confluent among each other. The distal septula is very large.

The specific name is given in honor of Mr. Bruce Wade, in recognition of his researches upon the paleontology and stratigraphy of the Cretaceous deposits of Tennessee.

Conopeum ovatum, C. parviporum, and C. wadei form with Membranipora langana Canu and $M$. maplestonei Canu, from the Rocaneen of Argentina, a special group, characterized by the arrangement of the zooecia in transverse rows, by the presence of the doubtful structures which are inserted in the interzooecial cavities and which resemble avicularia without the pirot, and finally by the great obliquity of the distal walls of the zooecia. These characters are observed also in Cupularia and in Lunularia. 
Before forming a distinct genus for this group, however, it is necessary to determine the physiologic functions of the interzooecial organs. They have the appearance of avicularia, but they are without the pivot and their form is not constant. They resemble also the vibracula of Lunularia and related genera, but they do not have the dissymmetrical articulation. It is preferable, therefore to wait for more information.

Occurrence: Ripley formation, Coon Creek, McNairy County, Tenn.

Conopeum prismaticum Canu and Bassler, n. sp.

Plate IV, Figures 7-10

The zoarium is free, bilamellar, with flabellate fronds; the lamellae are separable and formed of facettes of zooecia prismatic inferiorly. The zooecia are distinct, separated by a deep furrow, elongated, elliptical, deep, prismatic, fitted one in the other, independent and separable; the mural rim is thin, very oblique; the termen commonly bears short, flat, scattered spicules. The opesia have the same form as the zooecia. The interopesial cavities are small, triangular. The septulae are multiporous.

Opesia: ho $=0.35-0.40$ millimeter; lo $=0.17-0.20$ millimeter. Zooecia: $\mathrm{Lz}=0.45-0.50$ millimeter; $\mathrm{lz}=$ 0.25 millimeter.

The lamellae and the zooecia are separable; they are united by mesenchymatous tissue in the living form and by simple capillary adhesion in the fossils. This structure is common in the Tertiary and Recent Adeonidae, but here it is complicated by a prismatic architecture of the zooecia. Each of them is deep and presents at the base two regular walls which fit between two zooecia of the other lamella; each wall is porforated by a large septula, probably multiporous. Laterally there are also two superior walls, one small and one a little larger, with a large superior septula establishing communication with the adjacent zooecium. A longitudinal wall bears five or six septulae; the two basal walls close the zooecium inferiorly.

Exteriorly, on looking into the opesium, one can see three large septulae, one distal and two lateral. These are the superior septulae. The smaller inferior septulae are not visible.

The oblique spicules of the mural rim number five or six pairs; they are flat and truncated. They are very fragile, disappearing easily in fossilization. However, some vestiges of them always remain, even on the most altered fronds, thus permitting determination. Some zooecia have a larger opesium, contracted laterally; they have somewhat the form of certain large interzooecial avicularia. We are ignorant of their function.

The worn specimens differ from Conopeum ovatum in their lamellar fronds, in the smaller interopesial cavities, and in the elliptical opesium.

Occurrence: Ripley formation, Coon Creek, McNairy County, Tenn.

\section{Genus MEMBRANIPORINA Levinsen}

Membraniporina crassimargo Canu and Bassler, n. sp.

Plate IV, Figure 15

The zoarium incrusts shells. The zooecia are distinct, separated by a deep furrow, somewhat elongated, elliptical, regular. The mural rim is thick and rounded and bears two pairs of large spines. The opesia have the form of the zooecia. There are no dietellae.

Opesia: ho $=0.30$ millimeter; $10=0.20$ millimeter. Zooecia: $\mathrm{Lz}=0.45-0.50$ millimeter; $\mathrm{lz}=0.35$ millimeter.

There is in some specimens a small gymnocyst. It is difficult to determine the generic position of this species. It is not an Alderina, because there are no dietellae, nor does it belong to Grammella or Membraniporidra, because it has. spines. It is necessary to wait for more complete specimens.

The species differs from Membranipora annuloidea Ulrich and Bassler in the presence of only four spines.

Occurrence: Ripley formation, Coon Creek, McNairy County, Tenn.

\section{Genus ALDERINA Norman \\ Alderina nelsoni Canu and Bassler, n. sp. \\ Plate V, Figure 1}

The zoarium incrusts shells. The zooecia are distinct, separated by a furrow, elongated, elliptical or pyriform; the mural rim is thin, rounded, much enlarged and fiat at the base. The opesium is large, terminal, elliptical or oval.

Opesia: ho $=0.30$ millimeter; lo $=0.20-0.25$ millimeter. Zooecia: $\mathrm{Lz}=0.35$ millimeter; $\mathrm{l} z=0.30-0.32$ millimeter.

We have observed calcified zooecia in which the orifice is a thin crescentic slit.

The species differs from Alderina abortiva Canu, 1911 , in its much thinner mural rim and in the absence of calcified zooecia with perforated frontal: It differs very little from Alderina watersiana Canú, but its measurements are much larger. All these species have closed calcified zooecia, which appear to represent diseased polypides.

The specific name is given in honor of Mr. Wilbur A. Nelson, former State geologist of Tennessee.

Occurrence: Ripley formation, Coon Creek, McNairy County, Tenn.

\section{Geñus CALLOPORA Gray}

\section{Callopora anatina Canu and Bassler, n. sp.}

Plate IV, Figures 12-14

The zoarium incrusts shells. The zooecia are distinct, separated by a furrow, elongated, elliptical, arranged in quincunx; the mural rim is very thin above, enlarged at the base, flat, oblique, finely 
striated transversely; the termen is sharp and bears three pairs of anterodistal spines. The ovicell is hyperstomial, globular, salient, large. In the interzooecial angles there are two small, very salient avicularia. The interzooecial avicularia are large, with a form like the beak of a duck; the pivot is formed by two large teeth, very little separated. The ancestrula is very small and is without spines.

Opesia: ho $=0.30$ millimeter; lo $=0.20-0.25$ millimeter. Zooecia: $\mathrm{Lz}=0.45$ millimeter; $\mathrm{l} z=0.30-0.32$ millimeter.

This species is variable in its measurements and in its general aspect. The avicularia and spines are very fragile and disappear or become altered easily in fossilization. The distal spines are very small, and their presence is rather rare. On the other hand, the first pair of spines is larger and remains very constant in the ancestrular zooecia.

The opesium of the interzooecial avicularia is elliptical, and it is without a small canal in the beak.

In general aspect this species resembles Callopora trimorpha Canu, 1911, from the Rocaneen of Argentina, but it differs in the presence of large interzooecial avicularia.

Occurrence: Ripley formation, Coon Creek, McNairy County, Tenn.

\section{Callopora sulcata Canu and Bassler, n. sp. Plate V, Figure 5}

The zoarium incrusts shells. The zooecia are distinct, separated by a very deep furrow, much elongated, elliptical, arranged in quincunx. The mural rim is thin and rounded. The opesia are of the same form as the zooecia. The ovicell is very small, hyperstomial, somewhat convex. Two small simple avicularia are lodged in the inferior interzooecial angles.

Opesia: ho $=0.40$ millimeter; lo $=0.17-0.20$ millimeter. Zooecia: $\mathrm{Lz}=0.55$ millimeter; $\mathrm{lz}=0.25$ millimeter.

This species is of the Callopora lineata group and differs from the type in its larger micrometric dimensions and especially in the deep furrows that separate the zooecia. As in all the incrusting species, the form and size of the zooecia depend on irregularities in the substratum. Callopora lineata Linné has been found in the Rocaneen of Argentina (Canu).

Occurrence: Ripley formation, Coon Creek, McNairy County, Tenn.

\section{Callopora torquata Canu and Bassler, n. sp. \\ Plate IV, Figure 16}

The zoarium incrusts other bryozoans (Frurionella). The zooecia are small, distinct, separated by a furrow, elongated, elliptical. The mural rim is thick, rounded, garnished with small tuberosities, like a collar of pearls. The opesium is elliptical and elongated. In the interzooecial angles there are small salient avicularia, without pivot.

Opesia : ho $=0.20$ millimeter; lo $=0.125$ millimeter. Zooecia: $\mathrm{L} z=0.25-0.27$ millimeter; $\mathrm{Iz}=0.18-$ 0.20 millimeter.

This species differs from Membranipora munita Marsson, 1887, from the Campanian, in its incrusting zoarium (not bilamellar), in the absence of gymnocysts, in the more constant presence of adventitious avicularia, and in the much smaller measurements (ho $=0.20$ and not 0.37 millimeter). It differs from Cellepora (Dermatopora) monilifera Hagenow, 1851, from the Maestrichtian, in its mural rims, which are closer together and almost adjacent.

Occurrence: Ripley formation, Coon Creek, McN airy County, Tenn.

\section{Genus AMPHIBLESTRUM Gray}

Amphiblestrum denticulatum Canu and Bassler, n. sp.

Plate V, Figures 2-4

The zoarium incrusts shells over large areas. The zooecia are distinct, separated by a deep furrow, very little elongated, swollen, pyriform. The mural rim is thin, rounded, and granulated. The cryptocyst is rather large, slightly concave, finely granulated. The opesium is trifoliate, somewhat elongated or transverse, and bears numerous and very small denticles. The ovicell is small, salient, globular, transverse, deep, hyperstomial. The interzooecial avicularia are longer than the zooecia but much narrower; they are spatulate and their canalicules terminate in a broad rounded beak.

Opesia: ho $=0.20$ millimeter; lo $=0.20$ millimeter. Zooecia: $\mathrm{Lz}=0.35$ millimeter; $\mathrm{l} z=0.35$ millimeter. Avicularia: $\mathrm{Lav}=0.56$ millimeter; $\mathrm{lav}=0.20$ millimeter.

The micrometric measurements vary from single to double, a fact which gives to the zooecia such a variable aspect. We have observed many examples of total regeneration. There is only one pair of lateral dietellae in place of the two pairs characteristic of Amphiblestrum; but on the fossils the lateral dietellae are generally united.

As in the genus Callopora, there are now two groups in the genus Amphiblestrum, one group with small avicularia and another, which seems to be the older, with large interzooecial avicularia.

This species differs from Membranipora gothea Meunier and Pergens, 1886, from the Belgian Montian, in the presence of a furrow separating the zooecia (and not a salient thread) and in the occurrence of interzooecial avicularia. It differs from Cellepora velamen Goldfuss in its micrometric measurements, which are two times smaller.

Occurrence: Ripley formation, Coon Creek, McNairy County, Tenn. 
Genus AMmatophoRA Norman

Ammatophora cretacea Canu and Bassler, n. sp. Plate IV, Figure 17

The zoarium incrusts shells. The zooecia are distinct, separated by a deep furrow, elongated, ogival. The mural rim is thin, rounded, terminated at the ovicell by two salient pustules ("knobs" of Norman). The cryptocyst is irregular, of little depth, very finely granular. The opesium is orbicular or transverse, with a concave proximal border. The ovicell is hyperstomial, embedded in the distal zooecium, salient, globular, transverse. There are no dietellae.

Opesia: ho $=0.15$ millimeter; $l o=0.17$ millimeter. Zooecir: $\mathrm{Lz}=0.30-0.40$ millimeter; $\mathrm{l} z=0.30$ millimeter.

A single recent species constitutes this genus, and the discovery of a Cretaceous species is remarkable. The ovicell is somewhat different in form and position from that in the genotype, not being detachable, but all the other characters are quite identical, notably the distal armature serving as a support to the ovicell. Certainly in time Tertiary species will be discovered.

Occurrence: Ripleyformation, Coon Creek, McNairy County, Tenn.

\section{Genus MYSTRIOPORA Lang}

Mystriopora? stipata Canu and Bassler, n. sp. Plate IV, Figure 18

The zoarium incrusts other Bryozoa. The zooecia are small, indistinct, with the gymnocyst very much developed but buried by the numerous adventitious zooeciules. The mural rim is thin in front and much enlarged into a cryptocyst at the base. The opesium is elliptical or subtrifoliate. The ovicell is globular, salient, hyperstomial, invariably closed by the operculum. The zooeciules (avicularia or vibracula) are numerous, elongated, fusiform, arranged around the mural rim, on the invisible gymnocyst.

Opesia: ho $=0.10$ millimeter; $l o=0.10$ millimeter.

This species is very unusual and appears to belong to a new genus, but we have not enough specimens to determine the characters. Mystriopora Lang, from the Cenomanian, seems to have characters close to this genus, but the zooeciules are much rarer and the ovicell is not known. ${ }^{40}$ We have not observed the ovicell intact, and our observation may be incorrect.

Occurrence: Ripley formation, Con Creek, McNairy County, Tenn.

Genus FRURIONELLA Canu and Bassler, n. gen.

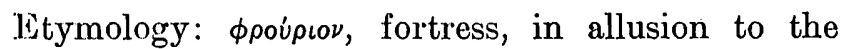
aspect of the zoarium.

The frontal is a very thick olocyst bearing an opesial avicularium and some scattered pores. The opesium

${ }^{16}$ Lang, W. D., On some new uniserial Cretaceous cheilcstome Polyzoa: Geol. Mag., decado 6, vol. 2, p. 502, pl. 17, fig. 7, 1915. is small and has the form of the aperture. The ovicell is hyperstomial, buried in the parietal thickening; it is closed by the operculum.

Genotype: Frurionella parvipora Canu and Bassler, n. sp.; Upper Cretaceous.

This new genus differs from Foveolaria Busk in its ovicell closed by the operculum and invisible exteriorly. The other characters are identical. (See Pl. $\mathrm{V}$, figs. 19, 20.)

\section{Frurionella parvipora Canu and Bassler, n. sp. \\ Plate V, Figures 6-18}

The zoarium is free, compressed, bifurcated on the same plane. The zooecia are indistinct; the frontal is convex and bears either very small scattered lateral pores or one or two much larger frontal pores. The opesium is small and elliptical and is surrounded by a very thin mural rim. The opesial avicularium is large, salient, elliptical, with a pivot; its beak is spatulate and arranged transversely; when destroyed it leaves a cicatrix as large as an opesium. The ovicell is visible only in the sections; it is hyperstomial and opens into the zooecia.

Opesia: ho $=0.15-0.17$ millimeter; $\mathrm{lo}=0.15-0.17$ millimeter. Zooecial length (in section), 0.75 millimeter. Length of avicularium, 0.25 millimeter.

The longitudinal section is that of Foveolaria save in the position of the ovicell. The opesium is peristomial, for the chitinous portion could not be placed at the bottom of the peristomie, where the tentacles could not emerge from it. The specimen shown in Figure 9 is interesting, for it reveals the true structure of the species. It bears three kinds of orifices. The orbicular orifices are ordinary opesia; the transverse orifices are the opesia of ovicelled zooecia; the orifices that are elongated and pyriform are opesia narrowed at the point of articulation of the opercular valve. The latter observation is most significant and leaves no doubt as to the true structure of the species, which belongs to the Malacostega in spite of the resemblance to the Ascophora.

In many specimens there is only a single median frontal pore (fig. 7). This feature is not an ascopore, for it does not appear in the sections. Commonly there are two frontal median pores (fig. 8), which may even unite and form a sort of longitudinal slit. Finally, on certain zooecia the median pores disappear and are replaced by scattered lateral pores of much smaller size. Their use is unknown.

The large opesial avicularia are rather constant, although they may disappear totally (fig. 10). The zoarial surface generally is smooth, but in some specimens it is granulated (fig. 12).

On the edge of the fronds many of the zooecia are transformed into avicularia with a pivot (fig. 11) whose physiologic function has not been discovered. 
The dimensions of the opesium and of the frontal pores are much smaller than in the associated Frurionella grandipora Canu and Bassler, n. sp.

Occurrence: Ripley formation, Coon Creek, McNairy County, Tenn.

\section{Frurionella grandipora Canu and Bassler, n. sp. Plate VI, Figures 1-3}

The zoarium is free, compressed, bifurcated on the the same plane. The zooecia are indistinct; the frontal is convex and generally bears two large median pores. The opesium is large, orbicular or transverse, surrounded by a very thin mural rim. The opesial avicularium is very large. When destroyed it leaves a eicatrix larger than the opesium. Some of the zooecia of the zoarial edge are transformed into avicularia.

Opesia: $h o=0: 20-0.25$ millimeter; lo $=0.15-0.20$ millimeter. Zooecisl length, $0.65-0.70$ millimeter. Tranverse opesia, 0.15 by 0.20 millimeter.

All the dimensions are larger than those in the associated Frurionella parvipora, and all the characters and variations in the two are identical.

Occurrence: Ripley formation, Coon Creek, McNairy County, Tenn.

\section{Family OPESIULIDAE Jullien \\ Genus MICROPORA Gray}

Micropora baccata Canu and Bassler, n. sp.

Plate VI, Figures 4-6

The zoarium incrusts shells. The zooecia are distinct, adjacent, with a common mural rim, very little elongated or transverse, ogival. The mural rim is thin and salient and is ornamented with pearlike granules. The cryptocyst is somewhat convex, finely granulated, perforated by two opesiules. The aperture is semielliptical, transverse. The peristome is salient and thick and bears six spines, of which the two distal are the largest and the most constant. The ovicell is small, endozooecial, convex, smooth. Above each ovicell and on the cryptocyst of the distal zooecium there are 4 to 6 flat bifurcated spicules forming a roof-like protection.

Aperture: $\mathrm{h} a=0.06$ millimeter; $\mathrm{l}=0.10$ millimeter. Zooecia: $\mathrm{Lz}=0.50$ millimeter; $\mathrm{lz}=0.45$ millimeter.

Our micrometric measurements are taken on the zoarial margin, for the zooecia diminish steadily in size to the ancestrula, which is very small. However, the ancestrula is able to engender large zooecia; the one which we have figured engenders only four zooecia (fig. 6).

We have observed a monstrous zooecium (fig. 4) the aperture of which bears a spatulate mandible and six opesiules still preserving the two distal spines.
Analogous transformations in many families of the Cheilostomata have been noted. ${ }^{47}$ Some zooecia have three or four opesiules.

'The protecting armature of the ovicell is very interesting. It no doubt was covered over by the ectocyst and formed a protective niche, where the young larvae underwent their evolution.

This species differs from Micropora vincentownensis Ulrich and Bassler by its more salient and beaded mural rim. It differs from Micropora convexa Canu, from the Rocaneen, in its less thickened peristome and different micrometric relations.

Micropora vincentownensis Ulrich and Bassler, $M$. convexa Canu, M. baccata Canu and Bassler, n. sp., Homalostega exsculpta Marsson, H. biforis Marsson, and $H$. erecta Marsson form a group without avicularia, with distal spines and opesiules distant from the mural rim, characterizing the Upper Cretaceous, of which it will perhaps be necessary to make a special genus when we know the essential characters better.

Occurrence: Ripley formation, Coon Creek, McNairy County, Tenn.

Suborder ASCOPHORA Levinsen

Family CRIBRILINIDAE Hincks

Genus MEMBRANIPORELLA Smitt

Membraniporella irregularis Canu and Bassler, n. sp. Plate VI, Figure 7

The zoarium incrusts shells. The zooecia are small, irregular, little distinct, separated by a salient thread, enlarged in front, narrowed behind. The frontal bears four pairs of large flat ribs. The apertura is semielliptical, transverse. The peristome is very thick and bears two large distal spines. The ovicell is large, little convex, irregularly costulated or embossed. The aperture of the ovicelled zooecir is larger. Some small avicularia are irregularly arranged between the zooecia on the salient mural rim.

Aperture: $\mathrm{ha}=0.05$ millimeter; $\mathrm{l} \mathrm{a}=0.10-0.125$ (ovicelled). Zooecia: $\mathrm{Lz}=0.40$ millimeter; $\mathrm{lz}=0.30$ millimeter.

It is difficult to give the characteristics of this species, all the elements of which are so irregular. It is very close to Membraniporella modesta Ulrich (lower Eocene) in its minor details, but it differs in its smaller micrometric dimensions and in its ovicelled zooecia, in which the aperture is larger. The operculum certainly closes the ovicell.

Occurrence: Ripley formation, Coon Creek, McNairy County, Tenn.

17 Canu, Ferdinand, and Bassler, R. S., North American early Tertiary Bryozoa: U. S. Nat. Mus. Bull. 106, p. 363, 1920. 


\section{Genus GEPHYROTES Norman}

Gephyrotes lamellaria Canu and Bassler, n. sp. Plate VI, Figures 8,9

The zoarium occurs in incrusting lamellar expansions. The zooecia are distinct, separated by a furrow of little depth, elongated, oval, narrowed inferiorly. 'The mural rim is thick, very salient, smooth. The frontal is formed of four pairs of flat costules separated by rectangular slits. The peristomie is salient, oblique, smooth, thick, and bears in its middle a large spirumen with very thick walls formed of a transverse slit or of two coalescent pores. The peristomice is semilunar, transverse, and permits the vestibular arch to be seen. The apertura (visible in the interior) is formed of a large anter separated from a smaller poster by two minute cardelles. The ovicell is little sulient, convex, smooth, closed by the operculum. On each sido of the peristomice and attached to the peristomie there are two triangular avicularia with a pivot, on which the beak is directed irregularly toward the median axis of the zooecia.

Peristomice: $h p=0.10$ millimeter, $l p=0.15$ millimeter. Apertura: $\mathrm{h} \Omega=0.10$ millimeter; $\mathrm{l} a=0.10$ millimeter. Zooecia: $\mathrm{L} z=0.50$ millimeter; $\mathrm{l} z=0.25$ millimeter.

This species differs from Cribritina crepidula Marsson, from the Campanian, which also bears two adventitious avicularia, in its much larger intercostular spaces, and in the presence of three or four pairs of costules (not six to eight). It differs from Membraniporella abboti Gabb and Horn, from the Upper Cretaceous Vincentown sand of New Jersey, in its thicker and more salient mural rim, in its transverse peristomice, and in the presence of a spiramen.

The study of the interior of the zooecia shows that the extcrior spiramen opens into the peristomie.

Occurrence: Ripley formation, Coon Creek, McNairy County, Tonn.

\section{Order CYCLOSTOMATA Busk}

Family (?)

Genus DYSNOETOPORA Canu and Bassler, n. gen.

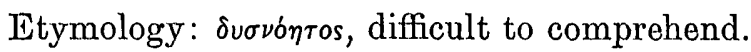

The tubes are club-shaped. The gemmation is internal and oriented. The tubes are sinuous.

Genotype: Dysnoetopora celleporoides Canu and Bassler, n. sp.; Upper Cretaceous.

Dysnoetopora celleporoides Canu and Bassler, n. sp.

Plate VI, Figures 10-17; Plate VII, Figures 10-12

The zonrium is free, cylindrical, branched; it is very light and floats on water. The surface is garnished with several kinds of pores, including (1) salient and orbicular peristomes (normal zogecia), (2) salient peristomes furnished with a small adventitious internal tube (proliferating zooecia), (3) irregular polygonal pores (zooecia not entirely developed), (4) peristomes little salient and very small (bases of new zooecia), and (5) large orifices elongated in the form of avicularia with lateral teeth.

Diameter of aperture, 0.13 millimeter; diameter of peristomes, 0.20 millimeter; length of avicularia, 0.45 millimeter; diameter of branches, '5-9 millimeters.

The exterior appearance of this species is that of a true Cellepora. On account of the deep and incomplete zooecia, the apertures with oral avicularia, and the $I_{\text {arge in terzooecial avicularia the illusion is complete. }}$ Nevertheless the species is a true cyclostome because (1) it has no chilostomatous ovicell; (2) in sections the zooecial walls are hollow or vesicular, as in all the other cyclostomes; (3) the central portions of the branches present real tubes, long and with diaphragms; and (4) the sections are absolutely and totally different from the sections of Cellepora, showing the irregular accumulation of the cheilostomatous zooecia. ${ }^{48}$

It now remains for us to try to comprehend this strange structure by the critical examination of thin sections. These show the following features:

The network presents a kind of lozenge-shaped areas; therefore the tubes are recurved. These lozengeshaped areas are irregular and rounded; therefore the tubes are recurved many times-that is, sinuous or oriented in different directions. The central tubes show clearly that the new tubes rise in the interior of the expanded portion of the older tubes and by partitioning.

The extraordinary features presented in the thin sections therefore result from the two very simple phenomena-internal gemmation and sinuous tubes. This simple observation explains all the variations of this species.

In longitudinal section the center is formed of a bundle of tubes enlarging gradually. By internal partitioning each tube engenders two others, one of which is much smaller than the other. This is a different method of gemmation from that of the other Cyclostomata, where each new tube is intercalated between two others. The partitioning appears clearly on the margin of the section.

In transverse sections two large polygonal zooecia are seen at the center, each engendering six polygonal tubes. The peripheral lozenge-shaped areas are very irregular. Some tubes whose direction fortunately conformed to that of the section, show that they are really quite sinuous and oriented in all directions, therefore confirming the deductions cited above.

The presence of heterozooecia similar to the cheilostomatous avicularia is not new. They are common in the Eleidae (=Eleocellaria of Canu).

${ }^{88}$ Canu, Ferdinand, and Bassler, R. S., op. cit., pl. 77, fig. 7; pl. 75, flg. 15; pl. 102, figs. $1-4$. 
Well-preserved branches are rather rare; here all the normal characters are visible. When the small internal tube has a broken wall the aperture of the large tube appears to be schizoporellidan, as in certain species of Cellepora. With age, abrasion, or fossilization the zoarial surface is altered, giving the more common aspect, as shown in our figure. The tangential section is similar to that in Heteropora.

Occurrence: Ripley formation, Coon Creek, McNairy County, Tenn.

\section{Family ASCOSOECIIDAE Canu}

Genus Polyascosoecia Canu and Bassler, 1920

Polyascosoecia tripora Canu and Bassler, n. sp.

Plate VII, Figures 1, 2

The zoarium is free, cylindrical, ramified; the base is expanded, concave, ornamented by sulci. The apertures are orbicular and small. The peristomes are thick, little salient, arranged in opposite rows of threes on each side of the median axis. They are separated by numerous vacuoles arranged at the bottom of longitudinal sulci.

Diameter of the orifice, 0.06-0.08 millimeter; diameter of the peristome, 0.14 millimeter; distance of transverse rows, 0.20 millimeter.

This species differs from Polyascosoecia lichenoides Goldfuss, 1827, from the Campanian and Maestrichtian, in its rounded dorsal and in the presence of three pores to the row instead of five. These differences are of little importance, and it is possibly the American representative of the species cited.

Occurrence: Ripley formation, Coon Creek, McNairy County, Tenn.

Family THEONOIDAE Busk

Genus ACTINOPORA D'Orbigny

Actinopora radiobifurcata Canu and Bassler, n. sp.

Plate VII, Figure 9

The zoarium incrusts shells; it is discoid, simple or composite. The fascicles are thick, triserial, salient, and isolated or bifurcated. The apertures are polygonal without peristome. The zoarial margins are thick and cellular.

Diameter of the aperture, 0.10 millimeter; zoarial diameter, 5.00 millimeters; number of fascicles, 18-20.

This species differs from Actinopora disticha Hagenow, of the Coniacian and Danian, in its more numerous fascicles. which are also more indistinct and multiserial and not biserial. It differs from Actinopora diadema Goldfuss, of the Campanian and Danian, in its incrusting zoarium. in its !oss silient fascicles, and in the presence of bifurcater fascicles. It differs from Actinopora robertsoniana $\mathrm{C}_{\mathrm{i}} \mathrm{nu}$, if the Rocaneen, in its greater zoarial dimensions and its triserial fascicles. The young specimens are $b$;rnicoid. The main char- acteristic of this species is the presence of large bifurcàted fascicles.

Occurrence: Ripley formation, Coon Creek, McNairy County, Tenn.

\author{
Family DIASTOPORIDAE Gregory \\ Genus BERENICEA Lamouroux \\ Berenicea papillosa Reuss \\ Plate VII, Figure 8
}

1899. Berenicea papillosa. Gregory, Catalogue of the Cretaceous Bryozoa in the British Museum, p. 81 (bibliography, geologic distribution).

1911. Diastopora (Berenicea) papillosa. Canu, Iconographie des bryozoaires fossiles de l'Argentine; II, Crétacé, p. 269, pl. 10, figs. 1-11 (bibliography).

Diameter of the aperture, 0.10 millimeter; diameter of the peristomes, $0.12-0.14$ millimeter; distance of the peristomes, 0.44-0.64 millimeter; separation of the peristomes, $0.40-0.44$ millimeter.

Our micrometric measurements agree perfectly with those of specimens from the Rocaneen of Argentina, but they are a little larger than those of European examples.

The ovicell has been found in specimens from Chatham, England, and appears to belong to the Diaperoeciidae, but as the ovicell is arranged transversely and is without oeciostome it is necessary to await a better generic reference.

Occurrence: Ripley formation, Coon Creek, McNairy County, Tenn.

\section{Family HETEROPORIDAE Pergens and Meunier Genus HETEROPORA Blainville}

Heteropora tennesseensis Canu and Bassler, n. sp. Plate VII, Figures 3-7

The zoarium is free, cylindrical, dichotomous. The orifices are circular, arranged in regular quincunx, surrounded by thick and somewhat salient peristomes. The mesopores are small, polygonal; they surround each orifice and are commonly grouped in small distinct areas. The ovicells are large.

Diameter of the orifice, $0.12-0.13$ millimeter; diameter of the peristome, $0.18-0.20$ millimeter; distance of the peristomes, 0.40 millimeter; separation of the peristomes, 0.40 millimeter; diameter of the branches, 2.00 millimeters; dimensions of the ovicell, 18 by 16 millimeters.

As the remains of the ovicells are very incomplete we can not form a more definite generic classification (Ascosoecia or Tretocycloecia?), but the dimensions of the ovicells are very large.

In longitudinal sections the tubes are cylindrical. The mesopores are irregular and are not parietal. Their terminal walls appear to be vesicular. This is 
not the same arrangement as in Sparsicavea, in spite of the exterior aspect and the large zones of mesopores.

This species is perhaps identical with Heteropora reticulata Marsson, of the Campanian, which Gregory in 1909 classed in Sparsicavea. From the figure alone we can not note any difference, but without the study of thin sections and without comparison of specimens from Rügen it is difficult to make the identification. This species differs from Leiosoecia parvicella Gabb and Horn, from the Upper Cretaceous Vincentown sand of New Jersey, in its much larger polygonal mesopores.

Occurrence: Ripley formation, Coon Creek, McNairy County, Tenn.

Class BRACHIOPODA

Order NEOTREMATA

Superfamily CRANIACEA

Family CRANIIDAE

Genus CRANIA Retzius

Crania? americana Wade, n. sp.

Plate III, Figures 2-5

Shell small and sessile; conical in outline; basal margin irregularly elliptical, made ragged by rough foreign object on which it is seated; apex blunt and smooth; external surface marked by numerous irregular radiating lines diverging from near the apex; posterior slope slightly grooved and marked by four radiating costae; concentric sculpture of faint incremental lines; left slope calloused; interior smooth; lower valve thin, attached to some foreign object; characters of inner surface unknown; a groove extending from the anterior margin to the central portion of the lower valve; shell material of attached valve porous. Altitude, 6 millimeters; maximum diameter, 13 millimeters; minimum diameter, 9 millimeters.

This species is somewhat similar to Crania gracilis Münster, ${ }^{49}$ from the Cenomanian of Golberode, Saxony, but differs somewhat in external sculpture, internal characters, and also in the groove of the lower valve so that this species can not be definitely assigned to this genus.

Occurrence: Ripley formation, Dave Weeks place on Coon Creek, McNairy County, Tenn.

Collection: U. S. National Museum.

10 Wandorer, Karl, Die wichtigsten Tierversteinerungen aus der Kreide des Königreiches Sachsens, p. 19, pl. 3, fig. 10, Jena, 1909.
Phylum MOLLUSCA

Class PELECYPODA

Order PRIONODESMACEA

Superfamily NUCULACEA

Family NUCUIIDAE

Genus NUCULA Lamarck

Nucula percrassa Conrad

Plate VIII, Figures 1-4

1856. Nucula percrassa. Conrad, Acad. Nat. Sci. Philadelphia Jour., 2 d ser., vol. 3, p. 327, pl. 35, fig. 4 .

1914. Nucula percrassa. Stephenson, U. S. Geol. Survey Prof. Paper 81, tables 2-6.

1916. Nucula percrassa. Gardner, Maryland Geol. Survey, Upper Cretaceous, pp. 512-573.

Conrad describes this species as follows:

Triangular, very thick, ventricose, inequilateral, densely radiated with minute impressed lines; anterior end subnasute, margin obliquely truncated; posterior side cuneiform, extremity slightly salient, basal margin rounded, sometimes slightly contracted anteriorly; within crenulated on the margin; submargin thickened; cicatrices deeply impressed; cardinal teeth thick, fosset oblique.

This species appears to be very abundant and in excellent preservation; one specimen has the valves united. The interior is silvery; the pallial impression very distinct, and an irregular line of five small cicatrices runs over the upper part of the valves in the direction of the shell's length. The form of this Nucula is very unlike any other American species.

This species is very abundant at Coon Creek and closely resembles Nucula slackiana Gabb. Miss Gardner $^{50}$ has very carefully pointed out the differences between this southern and that northern species as follows:

Nucula slackiana Gabb is abundant and readily recognizable. The shell substance is very thick and frequently weathers in such a way as to give an excellent cross section of the three layers which make up the shell-the outer radially sculptured, with the component prisms normal to the surface; the inner very thin, with the prisms laid parallel to the inner surface; the middle layer, which makes up the bulk of the shell, with the prisms laid oblique to the surface. It has been confused in the synonymies and collections with Nucula percrassa Conrad of the South Atlantic and Gulf States. Nucula percrassa has been reported from New Jersey by a number of authors, including Gabb, Meek, Whitfield, and Weller, but mostly in the form of casts. In Maryland the shell itself is well preserved and abundant. The comparison of a large series from Maryland with a series from Owl Creek, 3 miles north of Ripley, Miss., Conrad's type locality, makes it probable that the forms are distinct. Nucula slackiana Gabb runs higher and heavier than the Nucula percrassa of Conrad; a typical individual from Maryland measures 33.8 millimeters in length and 23

so. Gardner, J. A., Maryland Geol. Survey, Upper Cretaccous, pp. 512, 513, 1016. 
millimeters in altitude, while one from Ripley measures 25.3 millimeters in longitude and $\mathbf{1 9 . 5}$ in altitude. The umbones are less prominent in the northern species, less convex, and more feebly opisthogyrate, the lunule and escutcheon less sharply differentiated, and the ventral margin less flattened. There is a strong tendency in the $N$. percrassa toward a slight contraction of the ventral margin toward the posterior margin, thus giving to the rear end of the shell a nasute aspect which is absent in $N$. slackiana. The angle of divergence between the anterior and posterior series of hinge teeth is higher in Conrad's species, the muscle scars are usually deeper, and the crenulations upon the inner ventral margin finer, sharper, and farther produced into the interior of the valve.

The northern race is much more uniform in its characters, however, than the southern. Conrad's type is rather extreme. Many of the individuals from the Ripley are very much higher relatively, and though they do not quite bridge the gap between $N$. percrassa and $N$. slackiana, they materially diminish it. There is, however, a peculiar characteristic flattening of the umbones and of the ventral margin of the Gulf forms which is apparently not reproduced in any of the northern specimens.

Occurrence: Ripley formation, Dave Weeks place on Coon Creek, McNairy County, Tenn.

Collections: U. S. National Museum, Philadelphia Academy of Natural Sciences, Johns Hopkins University.

Outside distribution: Eutaw formation (Tombigbee sand member), Exogyra ponderosa zone, Mortoniceras subzone, of Georgia and Alabama. Eutaw formation (Tombigbee sand member), near Booneville, Miss. Ripley formation, Exogyra ponderosa zone of Georgia and Alabama; Exogyra costata zone, Eufaula, Ala.; extreme top of Exogyra costata zone, Pataula Creek, Ga. Selma chalk, Exogyra ponderosa zone, Booneville, Miss.; Exogyra costata zone, Prairie Bluff, Ala., and northern and east-central Mississippi.

\section{Nucula amica Gardner}

.Plate VIII, Figures 5,6

1916. Nucula amica. Gardner, Maryland Geol. Survey Upper Cretaceous, p. 514, pl. 19, figs. 5, 6.

Miss Gardner describes this species as follows:

Shell nacreous, small, moderately heavy, transversely ovate, trigonal in outline; umbones small, feebly inflated, inconspicuous, opisthogyrate, slightly posterior in position; lunule elongated, defined by the angulation of the valve and by the partial evanescence of the external sculpture; escutcheon large, cordate and appressed, defined by the abrupt evanescence of the disk sculpture, smooth excepting for a couple of sulcations subparallel to the dorsal margin; anterior end more produced than the posterior, obscurely angulated at the ventral margin, posterior end obliquely truncated, base line feebly arcuate; external surface sculptured with approximately forty concentric ridges uniform in size and spacing, obtuse and asymmetrical; their dorsal slope steeper than their ventral; entire exterior exclusive of the lunule and escutcheon overridden by very faint, microscopically fine radial lirations separated by interspaces of equal width; ligament internal, lodged in a chondrophore which extends obliquely forward from beneath the umbones; teeth very fine, even, and close-set, slightly $\mathrm{V}$-shaped; characters of adductors and pallial line lost; inner basal margin finely crenate.

Altitude, 6 millimeters; latitude, 8 millimeters; semidiameter, 2.3 millimeters.
Type locality: One mile. west of Friendly, Prince Georges County, [Md.]

Nucula amica is described from very much battered valves, but the sculpture is so unique that it justifies the introduction of the form into the literature.

This interesting little species, though not so abundant as Nucula percrassa Conrad, has a wider distribution. Nucula amica Gardner is represented by only four or five specimens in the Coon Creek collections. It is probably a relative or descendant of Nucula coloradoensis Stanton, ${ }^{51}$ from the Benton shale of Colorado. Another relative, from the Pierre shale and Fox Hills sandstone of the upper Missouri Cretaceous, is the beautiful Nucula cancellata Meek and Hayden. ${ }^{52}$ Along with these forms should be considered also Nucula bidorsata Stoliczka, ${ }^{53}$ from the Cotatoor group of India.

Occurrence: Ripley formation, Dave Weeks place on Coon Creek, McNairy County, Tenn.

Collections: Maryland Geological Survey, U. S. National Museum.

Outside distribution: Monmouth formation, Brightseat, Prince Georges County, Md.

Nucula microconcentrica Wade, n. sp.

Plate VIII, Figures 7, 8

Shell small and nacreous; outline subtrigonal with an arcuate base; umbones low and flat, inconspicuous; anterior in position and proximate; apical angle about $140^{\circ}$; anterior end subangular; posterior end rounded; basal margin arcuate ventrally; external surface very faintly sculptured by very fine irregularly spaced concentric lines; ligament internal, lodged in a small chondrophore which extends obliquely forward from beneath the umbones; teeth very fine, those of the posterior series a little larger and $\mathrm{V}$-shaped; pallial line and muscle scars unknown; ventral margin smooth. Latitude, 11 millimeters; elevation, 9 millimeters.

This species is not only rare at Coon Creek but is also extremely fragile, delicate, and difficult to collect as complete specimens. The species should be com- pared with Nucula obsoletistriata Meek and Hayden, ${ }^{54}$ from the Pierre shale of the western interior region: with Nucula mariae Rathbun, ${ }^{55}$ from the Senonian of the Province of Pernambuco, Brazil; and with Nucula tamulica Stoliczka, ${ }^{56}$ from the Arrialoor group of the Upper Cretaceous of southern India.

s1 Stanton, T. W., The Colorado formation and its invertebrate fauna: U. S. Geol. Survey Bull. 106, p. 94, pl. 21, fig: 9, 1893.

32 Meek, F. B., A report on the invertebrate Cretaceous and Tertiary fossils of the upper. Missouri country: U. S. Geol. Survey 'Terr. Rept., vol. 9, pp. 102, 103, pl. $28,1876$.

s3 Stoliczka, Ferdinand, India Geol. Survey Mem., Palaeontologia Indica, Cre taceous fauna of southern India, vol. 3, p. 329, pl. 17, figs. 22, 24-27, 1861.

st Meek, F. B., op. cit., p. 100, pl. 15, fig. 19c, d.

35 White, C. A., Contribuições á paleontologia do Brazil: Mus. nac. Rio do Janeiro Archivos, vol. 7, p. 69, pl. 5, figs. 18, 19, 1888. (Portuguese and English.)

bo Stoliczka, Ferdinand, India Geol. Survey Mem., Palaeontologia Indica, Cre. taceous fauna of southern India, vol. 3, p. 328, pl. 17, figs. 15-16, 1861. 
Occurrence: Ripley formation, Dave Weeks place on Coon Creek, McNairy County, Tenn.

Collection: U. S. National Museum.

Family LEDIDAE

Genus LEDA Schumacher

Leda australis Wade, n. sp.

Plate VIII, Figure 9

Shell small, convex, acutely ovate in outline; posterior end more produced than the anterior and sharply rostrate; anterior end evenly rounded; umbones moderately inflated, incurved and proximate; external sculpture of 15 to 25 strong concentric rugae with well-defined interspaces, equally as strong on umboncs as on ventral margins; concentric rugae end abruptly on $\mathrm{keel}^{\circ}$ of rostrate posterior margin; rugae entirely absent from the depressed area directly in front of the rostrum; teeth fine and sharp, becoming increasingly finer and convergent beneath the umbones; both posterior and anterior series number from 8 to 12 ; ligament pit small and indistinct, subumbonal; muscle scars small, placed at distal ends of hinge; pallial line running close to ventral margin; pallial sinus short and poorly defined on available specimens. Latitude, 2.5 millimeters; elevation, 1.5 millimeters.

This species is known from two specimens of one valve each. One of these specimens is from Coon Creek, and the other from Owl Creek. The species is very closely related to Leda whitfieldi Gardner, from which it is distinguished by its more ovate outline, stronger conceutric rugae over the umbones as well as the ventral part of the shell, and lastly, a prominent keel along the rostrum of each valve:

Occurrence: Ripley formation, Dave Weeks place on Coon Crcek, McNairy County, Tenn.

Colloctions: U. S. National Museum, Johns Hopkins University.

Outside distribution: Ripley formation, Owl Creek, Miss.

\section{Leda whitfieldi Gardner}

Plate VIII, Figures 10-12

1885. Nuculana pinnaformis. Whitfield, U. S. Geol. Survey Mon. 9, p. 108, pl. 11, fig. 8. (Also published by New Jersey Geol. Survey, 1886.) (Synonymy and fig. 7 cxcluded; not Leda pinnaformis Gabb, 1860.)

1916. Leda whilfieldi. Gardner, Maryland Geol. Survey, Upper Cretaceous, pp. 516, 517, pl. 19, figs. 10, 11, 12.

Miss Gardner describes this species as follows:

Shell small, convex, cuneate dorsally, arcuate ventrally, forming roughly a sector of $120^{\circ}$; posterior end more produced than the anterior and sharply rostrate; anterior end evenly rounded; umbones inflated, flattened upon their summits; incurved, proximate; external adult sculpture of twenty to thirty concentric rugae, strongest and most crowded toward the ventral margin, altogether absent upon the umbones and evanescent in the slightly depressed area directly in front of the rostrum; teeth fine but sharp, becoming increasingly finer and convergent beneath the umbones; both anterior and posterior series numbering from thirteen to seventeen; ligament pit trigonal, minute; subumbonal; muscle scars small, placed at the distal ends of the hinge; pallial line running close to the ventral margin; pallial sinus short, steeply ascending, squarely truncate.

Altitude, 3.7 milimeters; latitude, 6.5 milimeters.

Type locality: Haddonfield, N. J.

Forms referable to Leda whitfieldi were included by Whitfield under Leda pinnaformis Gabb, an error perpetuated by Weller and others. The differences are sufficiently obvious in Whitfield's two figures. Gabb's species is much higher relatively. with higher, more prominent umbones, a broader posterior keel. and a fine concentric sculpture. Leda whilfieldi is quite common in the Monmouth of Prince Georges County, Md.

The form figured by Whitfield from Haddonfield, N. J., which must serve as the type, is in the collection of the Philadelphia Academy of Natural Sciences.

Occurrence: Ripley formation, Dave Weeks place on Coon Creek, McNairy County, Tenn.

Collections: Maryland Geological Survey, Philadelphia Academy of Natural Sciences, U.S. National Museum.

Outside distribution: Monmouth formation, Brightseat, Prince Georges County, Md. Woodbury clay of Matawan group, New Jersey.

\section{Genus YOLDIA Moeller}

Yoldia longifrons (Conrad)

Plate VIII, Figures 13, 14

1860. Leda longifrons. Conrad, Acad. Nat. Sci. Philadelphia Jour., 2d ser., vol. 4, p. 281, pl. 46, fig. 18.

1864. Nuculana longifrons. Meek, Check list of the invertebrate fossils of North America, Cretaceous and Jurassic, p. 8.

1885. Nuculana longifrons. Whitfield, U. S. Geol. Survey Mon. 9, p. 107, pl. 11, figs. 16, 17. (Also published by New Jersey Geol. Survey, 1886.)

1905. Yoldia longifrons. Johnson, Acad. Nat. Sci. Philadelphia Proc., vol. 57, p. 8 .

1907. Yoldia longifrons. Weller, New Jersey Geol. Survey, Paleontology, vol. 4, p. 381, pl. 30, fig. 5 .

1916. Yoldia longifrons. Gardner, Maryland Geol. Survey, Upper Cretaceous, p. 518, pl. 19, fig. 13.

Conrad describes this species as follows:

Oblong, slightly ventricose, very inequilateral; hinge and basal margins parallel; anterior end acutely rounded, posterior obtusely rounded; cardinal teeth minute and very numerous.

Whitfield adds the following details:

Type locality: Eufaula, Ala.

Shell of moderate size, transversely subelliptical or subovate in form, a little narrower behind than in front of the beaks. Beaks very small and inconspicuous, situated rather more than one-third of the entire length from the anterior end of the valve. Cardinal margin very gently declining on each side of the beak; anterior end rounded, longest above the middie of the height; posterior end more narrowly rounded, longest just below the extremity of the hinge; basal line very gently curved in the middle and more abruptly so toward the extremities. Surface of the shell polished, but marked by extremely fine concentric striae of growth. In the interior the hinge line is marked by proportionally long curved teeth; those on the anterior side being largest and numbering fifteen or twenty, those of the posterior side very small and numerous. 
This species is very fragile and is represented in the Coon Creek collections by only three or four imperfect individuals.

Occurrence: Ripley formation, Dave Weeks place on Coon Creek, McNairy County, Tenn.

Collections: Maryland Geological Survey, Philadelphia Academy of Natural Sciences, U. S. National Museum.

Outside distribution: Woodbury clay (of Matawan group), New Jersey. Matawan formation, post 105, Chesapeake \& Delaware Canal, Del. Eutaw formation (Tombigbee sand member), Exogyra ponderosa zone, Mortoniceras subzone, of Georgia and Alabama. Ripley formation, Exogyra ponderosa zone, Union Springs, Ala.; Exogyra costata zone, Eufaula, Ala., and northern Mississippi. Selma chalk, Exogyra costata zone, of east-central Mississippi.

Yoldia multiconcentrica Wade, n. sp.

Plate VIII, Figures 15, 16

Shell of medium size and subovate in form; umbones low and inconspicuous, slightly anterior in position; lunule and escutcheon absent; anterior end less produced than posterior end, both ends subovate but the posterior end a little more acutely so; base line or ventral margin feebly arcuate; external surface sculptured by about 50 concentric ridges, a little unequal in size but of uniform spacing; radial sculpture absent; teeth fine and close-set, a little unequal in size and $V$-shaped in form, about the same number in front as behind the umbones; characters of adductors and pallial line unknown; basal margin smooth. Altitude, 4.7 millimeters; latitude, 8 millimeters.

This species is extremely rare at Coon Creek and is known from a single imperfect valve. The species may be readily separated from Yoldia longifrons (Conrad) by the difference in outlines and external sculpture. Probably Yoldia microdonta Meek, ${ }^{57}$ from the Mentor sandstone of Kansas, is a related species.

Occurrence: Ripley formation, Dave Weeks place on Coon Creek, McNairy County, Tenn.

Collection: U. S. National Museum.

Superfamily ARCACEA

Family PARALLELODONTIDAE

Genus NEMODON Conrad

Nemodon eufaulensis (Gabb)

Plate VIII, Figures 17, 18

1860. Arca (Macrodon) eufaulensis. Gabb, Acad. Nat. Sci., Philadelphia Jour., 2d ser., vol. 4, p. 398, pl. 68, fig. 39 (incorrectly cited as 38 ).

1885. Nemodon eufaulensis. Whitfield, U. S. Geol. Survey Mon. 9; p. 83, pl. 12, figs. 3, 4. (Also published by New Jersey Geol. Survey, 1886.) (Synonymy and fig. 5 excluded.)

${ }^{17}$ Meek, F. B., A report on the invertebrate Cretaceous and Tertiary fossils of the upper Missouri country: U. S. Geol. Survey Terr. Rept., vol. 9, p. 109, pl. 2 fig. 2,1876 .
1905. Nemodon eufaulensis. Johnson, Acad. Nat. Sci. Philadelphia Proc., vol. 57, p. 9.

1907. Nemodon eufaulensis. Weller, New Jersey Geol. Survey, Paleontology, vol. 4, p. 385, pl. 30, figs. 8-11 (?). (Casts only.)

1916. Nemodon eufaulensis. Gardner, Maryland Geol. Survey, Upper Cretaceous, p. 525, pl. 20, figs. 3, 4.

Gabb describes this species as follows:

Inequilateral; beaks large; umbones large and slightly grooved in the middle by a shallow sulcus, which extends nearly to the base of the shell; area very small; hinge line straight, lower edge of the hinge slightly curved; lateral teeth very long; anterior margin curved, basal sinuous, posterior margin curved, upper part inclined anteriorly; surface marked by numerous radiating ribs and smaller transverse lines. Length, 0.4 inch; width, 0.5 inch.

Locality: Eufaula, Ala.; Ripley group. My collection.

Miss Gardner adds the following details:

Shell transversely elliptical to subrhomboidal in outline, flexuous medially, moderately inflated in the umbonal region, flattened toward the ventral margin; umbones broad, subangular, medially depressed, low, moderately prominent, feebly prosogyrate, slightly anterior in position; ligament area very small and almost entirely in front of the umbones; hinge and ventral margins parallel; anterior lateral margin angulated dorsally, broadly rounded at the base; posterior lateral margin obliquely truncate; external sculpture of very fine, flattened, radial threadlets, 40 to 50 in number, least fine and most flattened laterally, particularly upon the posterior slope; interradials linear; concentric sculpture manifest in minute corrugations of the radials, particularly upon the disk; hinge teeth laminar, parallel or subparallel to the hinge line; anterior teeth parallel to the hinge, rather short, that nearest the hinge margin a little longer than the two beneath it; posterior teeth also three in number, discrepant in size and slightly oblique to the hinge; medial lamina the longest, produced beyond the distal extremity of the cardinal line; the one dorsal to it merely the locally elevated margin of the hinge plate, that ventral to it also produced beyond the cardinal margin but not more than half the length of the medial lamina, disappearing within the umbonal cavity; characters of cicatrices and pallian line obscure.

Gabb's type is in the collection of the Philadelphia Academy of Natural Sciences.

Johnson (see synonymy) was the first to call attention to the fact that the form described and figured by Conrad was not the Arca (Macrodon) eufaulensis of Gabb but a distinct species, to which he suggested that the name Nemodon conradi be assigned.

This Nemodon conradi is separated from the true $N$. eufaulensis by the less elongated outline, the more nearly central umbones, and by the presence of a fine radial sculpture over the entire external surface, the radials least elevated on the medial portion.

This is not abundant at Coon Creek. It is very fragile and is represented in the collections from that locality by only a few specimens.

Occurrence: Ripley formation, Dave Weeks place on Coon Creek, McNairy County, Tenn.

Collections: Maryland Geological Survey, Philadelphia Academy of Natural Sciences, U. S. National Museum.

Outside distribution: Matawan group (Merchantville clay and Marshalltown formation) of New Jersey. Monmouth formation, Brightseat, Brooks estate near 
Seat Pleasant, and McNeys Corners, all in Prince Georges County, Md. Monmouth group (Navesink marl and Tinton sand member of Redbank sand) of New Jersey. Ripley formation, Exogyra costata zone, Georgia, also Eufaula, Ala., and northern Mississippi; extreme top of Exogyra costata zone, Pataula Creek, Ga., and Chattahoochee River, Ala.

\section{Nemodon grandis Wade, n. sp.}

Plate IX, Figures 1, 2

Shell very large for genus, transversely elliptical to subrhomboidal in outline, moderately inflated in the umbonal region, flattening toward the ventral margin; umbones broad and low, moderately prominent, nearly orthogyrate, a little anterior in position; ligament area long and large for genus, greater portion of this area behind umbones; hinge and ventral margins nearly parallel; anterior lateral margin obtusely angulated dorsally, broadly rounded at the base; posterior lateral margin obliquely truncate; external sculpture nearly smooth, very fine radial threadlets on the umbones and the posterior and interior slopes; concentric sculpture of irregularly spaced growth lines and lines of linear pits representing the subdued radial sculpture; hinge teeth laminar, parallel to subparallel to hinge line; anterior teeth two, the one nearer the hinge a little the longer; posterior teeth three, the middle tooth the longest; cardinal area lanceolate and sculptured by three deep divergent grooves; character of muscle scars unknown; pallial line faint. Latitude, 71 millimeters; elevation, 30 millimeters.

This large and handsome species is very rare at Coon Creek and is represented in the collections by a single imperfect specimen. This species is easily distinguished from Nemodon eufaulensis (Gabb) Whitfield by the sculptured cardinal area, which is not developed on $N$. eufaulensis.

Occurrence: Ripley formation, Dave Weeks place on Coon Creek, McNairy County, Tenn.

Collection: U. S. National Museum.

\section{Nemodon stantoni Gardner}

Plate VIII, Figures 19, 20

1916. Nemodon stantoni. Gardner, Maryland Geol. Survey, Upper Cretaceous, p. 527, pl. 19, fig. 15.

Miss Gardner described this species as follows:

Shell transversely elongated, rudely trapezoidal in outline, the posterior basal margin obliquely produced; dorsal margin horizontal, more than two-thirds the entire length of the shell; anterior lateral margin obliquely truncated dorsally and meeting the hinge at an angle of $50^{\circ}$ or $55^{\circ}$, broadly and smoothly rounded ventrally; posterior lateral margin also obliquely truncated, meeting the dorsal margin at an angle of approximately $65^{\circ}$, produced ventrally and rounding rather sharply into the base, ventral margin more sharply upcurved behind than in front; straight medially but not parallel with the dorsal margin; umbones small, acute, proximate, placed a little in front of the median line; umbonal ridge acute in the umbonal region but becoming broader and more obtuse away from the umbones and obsolete near the margin; external surface sculptured with a microscopically fine radial lineation, least feeble anteriorly and over the umbonal ridge; hinge imperfect in the umbonal region of the unique type; distal teeth laminar, elongated parallel to the hinge margin, apparently two on each side, the dorsal tooth the more produced in the anterior series, the central the more produced in the posterior; characters of interior not known. Altitude, 16.5 millimeters; latitude, 33.5 millimeters; semidiameter, 4.5 millimeters.

This species is named for Dr. Timothy W. Stanton, chief paleontologist of the United States Geological Survey.

This species is closely related to Nemodon eufaulensis (Gabb) but is not marked by the broad medial depression running from the umbones to the ventral margin. This species also is fragile and is represented in the Coon Creek collection by only four specimens.

Occurrence: Ripley formation, Dave Weeks place on Coon Creek, McNairy County, Tenn.

Collections: Maryland Geological Survey, U. S. National Museum, Johns Hopkins University.

Outside distribution: Monmouth formation, Brightseat, Prince Georges County, Md.

\section{Genus CUCULLAEA Lamarck \\ Cucullaea vulgaris Morton \\ Plate IX, Figures 3, 4, 6, 7}

1830. Cucullaea vulgaris. Morton, Am. Jour. Ści., 1st ser., vol. 17, p. 285; vol. 18, pl. 3, fig. 21.

1830. Cucullaea vulgaris. Morton, Acad. Nat. Sci. Philadelphia Jour., 1st ser., vol. 6, p. 199.

1834. Cucullaea vulgaris. Morton, Synopsis of the organic remains of the Cretaceous group of the United States, p. 64 , pl. 3, fig. 8 ; pl. 13, fig. 5 .

1858. Cucullaea capax. Conrad, Acad. Nat. Sci. Philadelphia Jour., 2d ser., vol. 3 , p. 328 , pl. 35 , fig. 2 .

1858. Cucullaea tippana. Conrad, Acad. Nat. Sci. Philadelphia Jour., 2d ser., vol. 3, p. 328.

1862. Cucullaea vulgaris. Gabb, Acad. Nat. Sci. Philadelphia Proc. for 1861, p. 326.

1864. Cucullaea vulgaris. Meek, Check list of the invertebrate fossils of North America, Cretaceous and Jurassic, p. 8.

1864. Cucullaea tippana. Meek, Check list of the invertebrate fossils of North America, Cretaceous and Jurassic, p. 8.

1868. Idonearca vulgaris: Cook, Geology of New Jersey, p. 376 , text figure.

1868. Idonearca vulgaris. Conrad, in Cook, Geology of New Jersey, p. 725.

1877. Idonearca vulgaris. Gabb, Acad. Nat. Sci. Philadelphia Proc. for 1876, p. 313.

1885. Idonearca tippana. Whitfield, U. S. Geol. Survey Mon. 9, p. 95, pl. 12, figs. 19-21. (Also published by New Jersey Geol. Survey, 1886.)

1885. Idonearca vulgaris. Whitfield, U. S. Geol. Survey Mon. 9 , p. 98 , pl. 13, figs. 1-5. (Also published by $\mathrm{New}$ Jersey Geol. Survey, 1886.)

1885. Idonearca medians. Whitfield, U. S. Geol. Survey Mon. 9, p. 199, pl. 26, figs. 5, 6. (Also published by New Jersey Geol. Survey, 1886.)

1905. Cucullaea vulgaris. Johnson, Acad. Nat. Sci. Philadelphia Proc., vol. 57, p. 8.

1905. Cucullaea tippana. Johnson, Acad. Nat. Sci. Philadel. phia Proc., vol. 57, p. 8.

1907. Cucullaea vulgaris. Weller, New Jersey Geol. Survey, Paleontology, vol. 4, p. 397, pl. 32, figs. 5, 6. 
1907. Cucullaea tippana. Weller, New Jersey Geol. Survey, Paleontology, vol. 4 p. 394, pl. 31, figs. 5-10; pl. 32, figs. $1,2$.

1916. Cucullaea vulgaris. Gardner, Maryland Geol. Survey, Upper Cretaceous, pp. 529-532, pl. 20, figs. 8, 9; pl. 21, figs. $1,2$.

Morton in 1.830 characterized this species as follows:

Ventricose, triangular, flattened before; beak prominent and incurved; shell thick, with numerous delicate longitudinal striae.

Length an inch and a quarter; breadth an inch and threefourths.

Type locality: Chesapeake \& Delaware Canal, Del. Miss Gardner describes this species as follows:

Shell very thick and heavy, moderately large, evenly inflated, the young subquadrate in outline, the adults obliquely produced along the posterior keel; anterior margin squarely truncate dorsally, merging ventrally with a broad and gentle curve into the basal margin, which is approximately horizontal in the young but becomes increasingly oblique as the form matures; posterior lateral margin squarely truncate in the young forms, obliquely truncate in the adults; umbones very prominent, distant, orthogyrate, their summits somewhat flattened; external surface sculptured with exceedingly fine radial lirae, crowded but rather irregular in spacing, tending, however, to be arranged in pairs, often less feeble upon the posterior keel, though more distant and occasionally obsolete upon the flat. tened posterior area; radial sculpture relatively strong in the umbonal region, where it lends a somewhat punctate aspect to the shell by cutting up the grooves between the incrementals into a series of minute pits; concentric sculpture incremental in character but overriding the radial; resting stages crowded and conspicuous toward the ventral margin; cardinal area high rhomboidal, sulcated with concentric diamond-shaped ligament grooves, which vary in number with the age of the individual but may be as many as nine in the adult; hinge line straight, from a little less than one-half to more than two-thirds the total latitude; ventral margin of the hinge plate gently arcuate; dentition vigorous, the medial teeth discrete, the distal teeth hook-shaped, the number of vertical teeth larger both absolutely and relatively in the adult form; muscle scars very prominent, the anterior high up under the hinge plate, the posterior buttressed by a prominent radial groove; pallial line simple rather near the base; inner margins not crenulated.

The casts of $C$. vulgaris Morton, the form in which the species most commonly occurs along the middle Atlantic slope, are conspicuous for the high, compressed umbones and the obliquely produced posterior keel. The groove is very deep but is not greatly produced dorsally. The great thickness of Cucullaea shell, particularly in the medial portion, leaves a relatively small cavity, thus giving a surprisingly compressed cast.

C. capax, described by Conrad from the Ripley of Mississippi, is probably identical with $C$. vulgaris, though it may be consistently more inflated. The fact that the northern form is represented most frequently by casts and the southern by the original shell makes it difficult to determine their exact relationship.

Occurrence: Matawan formation, Camp Fox, Chesapeake \& Delaware Canal; post 198, Chesapeake \& Delaware Canal; Camp U \& I, Chesapeake \& Delaware Canal; post 157, Chesapeake \& Delaware Canal, Del.; north shore Round Bay, Severn River, Anne Arundel County, Md. Monmouth formation, John Higgins farm, 2 miles west of Delaware City [Del.]; Bohemia Mills, Cayots Corner, Brightseat, Brooks estate near Seat Pleasant, Fort Washington, Prince Georges County [Md.].
This species is one of the most common bivalves in the Upper Cretaceous of the Coastal Plain area. It not only has a wide geologic distribution, both vertically and horizontally, but it has a wide range in specific morphologic form. The species is represented in the Coon Creek collection by dozens of perfect specimens, which vary greatly in size, cardinal areas, teeth, muscle scars, and other individual features. Both valves of many individuals still remain attached, and in some specimens the original chitinous ligament still covers the cardinal areas.

The old individuals are the ones that show greatest variations. Apparently some of the very oldest individuals are the smaller forms, whereas other older individuals grow into very large, thick shells. Some of the common features of old specimens are a widening of the ligament area, disappearance of teeth, and the shortening of the posterior muscle buttress. Older individuals from Coon Creek may be readily separated from older individuals from Owl Creek by the shorter hinge line and flat posterior extremity of the Owl Creek shells. Young from the two localities are identical.

Cucullaea shumardi Meek and Hayden, ${ }^{58}$ from the Fox Hills sandstone of the western interior, is a very closely related species. Cucullaea glabra Parkinson, ${ }^{59}$ from the Blacksdown greensand, is one of the commonest Upper Cretaceous fossils in England. It is abundant at Blacksdown, where its development is comparable to the development of Cucullaea vulgaris Morton at Coon Creek. Along with this English and American species should be mentioned two other allied species, Cucullaea subglabra (D'Orbigny) and Cucullaea mülleri Holzapfel, ${ }^{60}$ from Vaals, Germany. Cucullaea zealandica Woods, ${ }^{61}$ from the Upper Senonian of Omuri Bluff, New Zealand, has a similar shape and dentition to those of Cucullaea vulgaris Morton but is sculptured externally with radial costae and probably is not very closely related to the American species.

Occurrence: Ripley formation, Coon Creek, Sand Hill, McNairy County, Tenn.

Collections: Maryland Geological Survey, U. S. National Museum, Academy of Natural Sciences of Philadelphia, Yale University.

Outside distribution: Matawan and Monmouth formations of Maryland. Matawan group (Merchantville clay), New Jersey. Monmouth group (Navesink marl), New Jersey. Ripley formation, Exogyra costata zone, Eufaula, Ala., and Pontotoc, Union, and

${ }_{58}$ Meek, F. B., op. cit., p. 86, pl. 28, figs. 15a-g; pl. 29, fig. 4.

${ }^{50}$ Woods, Henry, A monograph of the Cretaceous Lamellibranchia of England, vol. 1, pp. 57-60, pl. 11, figs. 8a-c, 9a, b, 10-12; pl. 12, figs. 1a, b, 2, 3a, b, 4, 5, Paleont. Soc. London, 1903

60 Holzapfel, Eduard, Die Mollusken der Aachener Kreide: Palacontographica, Band 35, p. 206, pl. 22, figs. 3, 5; p. 27, pl. 23, fig. 1, 1889 .

61 Woods, Henry, The Cretaceous faunas of the northeastern part of the south island of New Zealand: New Zealand Geol. Survey Paleont. Bull. 4, p. 20, pl. 6, flg. 7 ; pl. 7, fig. 1, 1917 . 
Tippah counties, Miss. Selma chalk, Exogyra costata zone, Wilcox County and along Tombigbee River, Ala., also in east-central Mississippi.

\section{Cucullaea littlei (Gabb) Plate IX, Figure 5}

1877. Idonearca littlei. Gabb, Acad. Nat. Sci. Philadelphia Proc. for 1876, p. 316 .

1905. Cucullaea littlei. Johnson, Acad. Nat. Sci. Philadelphia Proc., vol. 57, p. 9.

1907. Cucullaea littlei. Weller, New Jersey Geological Survey, Paleontology, vol. 4, p. 800, pl. 33, figs. $1,2$.

1914. Cucullaea littlei. Stephenson, U. S. Geol. Survey Prof. Paper 81, check list, table 9.

Gabb characterizes the species as follows:

Shell very large, oblique, gibbous; beaks large, prominent remote, incurved; area broad; anterior end prominent, narrowly rounded, retreating below; posterior end obliquely sloping; base very straight, most prominent below the beaks; internal plate very large, prominent and continued up into the cavity under the beaks. Surface marked by coarse lines of growth.

Type locality: Pataula Creek, Ga.

Weller gives the following details:

Shell very large, the dimensions of a large internal cast being length, 115 millimeters; height, 89 millimeters; thickness, 100 millimeters. Anterior margin regularly rounding from the anterior extremity of the hinge line into the convex ventral margin; posterior basal margin rather bluntly rounded, the posterior margin obliquely truncate, slightly convex; hinge line arcuate. Beaks large and prominent, widely separated and much elevated above the hinge line in the cast. Valves strongly ventricose, the umbonal ridge broadly rounded, the posterior dorsal slope abrupt, the posterior surfaces of the two valves meeting at the posterior margin in nearly a plane. Indentation of the posterior muscular ridge strong and deep, 12 millimeters in the type specimen. Hinge character not observed.

This is the largest species of the genus and is represented in the New Jersey collection by a single individual from the Tinton beds, in which the beaks are somewhat more obtuse and the valves more ventricose than in the type of the species, in the collection of the Philadelphia Academy of Sciences. The specimen, however, does not differ essentially from other southern examples of the species in the collection of the National Museum at Washington. The species is characterized by its great size and its strongly ventricose valves. In the absence of an angular umbonal ridge the species resembles $C$. antrosa, but it is more oblique than that species and is much larger than any specimen of $C$. antrosa that has been observed.

This large, magnificent species is known from Coon Creek only by fragments of three individuals. These fragments, together with fragments of this species recently discovered at Brightseat, $\mathrm{Md}$., are interesting in that they extend the known distribution of this giant of Cucullaeas.

Occurrence: Ripley formation, Dave Weeks place on Coon Creek, McNairy County, Tenn.

Collections: New Jersey Geological Survey, Maryland Geological Survey, U. S. National Museum, Philadelphia Academy of Natural Sciences.

Outside distribution: Rancocas group, New Jersey. Monmouth formation, Maryland. Ripley formation, Pataula Creek, Ga.; Eufaula, Ala.

\section{Family LIMOPSIDAE}

Genus LIMOPSIS Sasso

Limopsis meeki Wade, n. sp.

Plate X, Figures 4, 4a, 5

Shell small and stout; subcircular to suboval in outline, lenticular; umbones small, inflated, proximate, submedial in position; dorsal margin or hinge line nearly straight; anterior ventral line circular, posterior side flatter or truncate; external surface finely and regularly striated concentrically from umbones to the base with an occasional strongly defined resting stage; hinge somewhat arched on the inside, equaling nearly half the length of the shell, and provided with six or seven teeth on each side of the small triangular pit for the reception of the ligament; cardinal area small; anterior adductor scar small, elliptical in shape, resting on a slight buttress under the anterior extremity of the hinge plate; posterior adductor scar larger, suboval in shape, and situated nearer the ventral margin than the anterior muscle scar; pallial line simple; ventral margin smooth. Latitude, 6.5 millimeters; elevation, 7 millimeters.

This species is closely related to Limopsis parvula Meek and Hayden, ${ }^{22}$ from the Pierre shale of the western interior. Another form but perhaps more distantly related is Limopsis höninghausi Müller, ${ }^{63}$ from the Aachen Cretaceous, Vaals, Germany. The most distantly related species known from the Cretaceous is Limopsis transversa Gabb, ${ }^{64}$ from Placer County, Calif.

Occurrence: Ripley formation, Dave Weeks place on Coon Creek, McNairy County, Tenn.

Collections: Johns Hopkins University, U. S. National Museum.

\section{Limopsis perbrevis Wade, n. sp.}

Plate X, Figures 1, 2

Shell very small and short; umbones high, convex, incurved at the tips and proximate, submedial in position; outline of shell roughly trapezoidal; anterior margin truncate, ventral margin arcuate; hinge line straight and about half the length of the shell; ligament area a low obtuse triangle; ligament lodged in a shallow acute triangular pit directly beneath the umbones; external surface delicately reticulate; hinge plate slightly arcuate ventrally; teeth of a single series, 15 or 20 in number, very short, straight and vertical beneath the umbones but becoming longer and more oblique distally; pallial line distinct and near the ventral margin.

This species has a more prominent umbone and is more typically arcoid in form than the other Coon Creek species, Limopsis meeki Wade. It is rare at

62 Meek, F. B., op. cit., p. 97 , pl. 28, flg. $17 \mathrm{a}$, b, c.

${ }^{63}$ Holzapfel, Eduard, op. cit., p. 212, pl. 23, figs. 6, 10

6. Gabb, W. M., California Geol. Survey, Paleontology, vol. 1, p. 200, pl. 260, fig. 186,1864 . 
this locality and is at present known from only a few specimens.

Occurrence: Ripley formation, Dave Weeks place on Coon Creek, McNairy County, Tenn.

Collection: U. S. National Museum.

\section{Family ARCIDAE}

Genus ARCA Linné

Arca menairyensis Wade, n. sp.

Plate X, Figures 3, 6

Shell of medium size; umbones rather high, convex, incurved at the tips and proximate, slightly anterior in position; outline nearly trapezoidal; anterior end broadly rounded, posterior end obliquely truncate; base line nearly horizontal, gently incurved medially; hinge line straight, almost as long as the total length of the shell; hinge area narrow and cuneate, the broad end situated anteriorly; ligamental area smooth and free from sulcations; external sculpture primarily radial and secondarily reticulate by a certain beading of the radial costae; radial costae strong and separated by deeply channeled sulci; radial costae unequal, the smaller ones situated on the medial part of the shell, 32 to 35 in number; hinge plate very gently arcuate ventrally; hinge teeth of a single series, very short and straight beneath the umbones but becoming larger and more oblique distally, 18 in number; anterior adductor scar well defined, large and subovate in outline; posterior adductor scar invisible in available specimens; pallial line distinct, incurving a little medially; ventral margins crenate. Latitude, 19 millimeters; elevation, 13 millimeters.

This species should be compared with Arca obesa Whitfield Weller, ${ }^{65}$ of the Matawan deposits of New Jersey and Maryland.

Occurrence: Ripley formation, Dave Weeks place on Coon Creek, McNairy County, Tenn.

Collection: U. S. National Museum.

\section{Arca securiculata Wade, n. sp.}

Plate X, Figures 7, 8

Shell of medium size, rough and strong; umbones rather high, convex, incurved and proximate, slightly anterior in position; outline of valve roughly trapezoidal; anterior end well rounded; posterior end truncate; ventral margin curved, distinctly incurved postmedially; hinge line straight; ligament area narrow, marked by two or three grooves, divergent from a point under the umbones; external surface deeply sculptured by strong radial costae, about 40 in number, unequal in size and spacing; on the posterior umbonal ridge two strong radials on each valve are produced beyond the ventral margin and interlock; radial ridges or costae irregularly beaded or reticulated by growth lines; hinge teeth of one gently curved series, short

as Gardner, J. A., Maryland Geol. Survey, Upper Cretaceous, p. 532, 1916. and straight under the umbones and becoming larger and divergent distally; adductor scars and pallial line unknown; ventral margin crenate. Latitude, 35 millimeters; elevation, 20 millimeters.

This species is characterized by the extending interlocking radials on the ventral margin of the posterior umbonal ridge. This feature, together with the differences in length, outline, and ligament areas, separates this species from Arca mcnairyensis Wade, n. sp.

Occurrence: Ripley formation, Dave Weeks place on Coon Creek, McNairy County, Tenn.

Colléction: U. S. National Museum:

\section{Genus BARBATIA Gray \\ Barbatia fractura Wade, n. sp. \\ Plate X, Figures 9-11}

Shell large, very roughly elongate ovate, inequilateral, height about equal to three-fifths the length; dorsal margin slightly arcuate; anterior lateral margin short and truncate; ventral margin arcuate, irregularly curved; posterior margin consisting of a short truncate line dorsally and a well-rounded ventral line; umbones broad and flat, moderately conspicuous and incurved feebly, and situated on the anterior portion of the shell; external surface sculptured by numerous inequal radial lines and grooves, sculpture almost entirely absent on umbones and posterior half of shell; ligamental area obtuse triangular, sulcated by 9 or 10 concentric diamond-shaped ligamental grooves; hinge teeth very numerous, of a single series, very short and straight or even absent under the umbones but becoming longer and more oblique distally; internal surface marked by radial lines near the pallial line; anterior adductor scar large and Dshaped; posterior adductor scar somewhat larger and subcircular to ovate in outline; pallial line simple and near the smooth ventral margin. Latitude, 62 millimeters; elevation, 39 millimeters.

This species is known from a single valve, which is slightly imperfect and evidently part of an old individual.

Occurrence: Ripley formation, Dave Weeks place on Coon Creek, McNairy County, Tenn.

Collection: U. S. National Museum.

Barbatia cochlearis Wade, n. sp.

Plate X, Figures 12, 13

Shell large, elongate-ovate in outline; height about equal to three-fifths the length; dorsal margin very gently arcuate; anterior margin well rounded; posterior margin subcircular; ventral margin incurved directly beneath the umbones; umbones situated anteriorly, low and inconspicuous; external surface highly sculptured, with numerous fine radial lines of unequal size and spacing; radials interrupted at irregular intervals by concentric growth lines that run parallel to the ventral margin; ligament area 
narrow and obtusely triangular on each valve; this area is marked by about eight deep concentric diamond-shaped ligamental grooves; hinge teeth of two series, a posterior and an anterior group, separated by a short smooth region in central part of the cardial row; teeth very short and fine under and near the umbones but larger and divergent at the distal ends of each series; internal surface marked by very fine irregular radial lines; anterior adductor not entirely known, but from available evidence it is ovate in shape and of a medium size; posterior adductor scar very large. and D-shaped; parallel line simple and gently incurved under the umbones; ventral margin smooth. Latitude, 56 millimeters; elevation, 35 millimeters.

This species is closely related to Barbatia fractura Wade, from Coon Creek, but may be easily separated from that form by differences in general outline, character of external sculpture, and shape of umbone ridges leading off from the beaks toward the ventral margins. Both of these species deserve to be compared with Barbatia micronema Meek, ${ }^{68}$ from the Colorado group of the western interior region of the United States, and also with Barbatia mackayi Woods, ${ }^{67}$ from the Amuri beds of New Zealand.

Occurrence: Ripley formation, Dave Weeks place on Coon Creek, McNairy County, Tenn.

Collection: U. S. National Museum.

\section{Barbatia saffordi (Gabb)}

Plate X, Figure 14; Plate XI, Figures 1, 2

1860. Arca saffordi. Gabb, Acad. Nat. Sci. Philadelphia Jour., 2d ser., vol. 4, p. 397 , pl. 68 , fig. 38 (incorrectly cited as 37).

1860. Arca saffordi. Meek, Check list of the invertebrate fossils of North America, Cretaceous and Jurassic, p. 9.

1868. Trigonarca saffordi. Cook, Geology of New Jersey, p. 725.

1869. Arca saffordi. 'Safford, Geology of Tennessee, p. 416.

1872. Trigonarca (Breviarca) safjordi. Conrad, Acad. Nat. Sci. Philadelphia Proc. for 1872 , p. 55, pl. 2, fig. 3.

187.5. Trigonarca (Breviarca) saffordi. Gabb, in Kerr, Report of the geological survey of North Carolina, vol. 1, appendix $A$, p. $\dot{3}$.

1885. Breviarca saffordi. Whitfield, U. S. Geol. Survey Mon. 9, p. 87, pl. 12, figs. 11, 12. (Also published by New Jersey Geol. Survey, 1886.)

1905. Arca saffordi. Johnson, Acad. Nat. Sci. Philadelphia Proc., vol. 57, p. 9.

1907. Breviarca saffordi. Weller, 1907, New Jersey Geol. Survey, Paleontology, vol. 4, p. 404, pl. 30, figs. 21-24. (Casts only.)

1909. Breviarca saffordi. Grabau and Shimer, North American index fossils, vol. 1 , p. 408 , fig. 527 .

1916. Arca saffordi. Gardner, Maryland Geol. Survey, Upper Cretaceous, p. 537, pl. 21, figs. 3, 4 .

of Stanton, T. W., The Colorado formation and its invertebrate fauna: U. S. Geol. Survey Bull. 106, pp. 89, 90, pl. 21, figs. 1-4, 1893 .

o7 Woods, Henry, The Cretaceous faunas of the northeastern part of the south Island of New Zealand: New Zealand Geol. Survey Paleont. Bull. 4, p. 19; pl. 6, Qggs. 4a, b, 1917.

$106913-26 \dagger-4$
Gabb characterizes this species as follows:

Gibbous, nearly equilateral; beaks small, overhanging the area; umbones broad; area narrow and transversely striate; anterior margin narrower and straighter than the posterior, which is regularly curved; surface marked by obscure radiating and concentric lines; hinge rather broad, curved; teeth large.

Length, 0.2 inch; width 0.26 inch; height of valve 0.1 inch.

Locality: Hardeman County, Tenn., Professor Safford. Also found in the Ripley group of New Jersey.

\section{Miss Gardner gives the following details:}

Shell small, inflated; umbones rather high, convex, incurved at the tips and proximate, submedial or slightly anterior in position; outline rudely trapezoidal; anterior end broadly rounded or squarely truncate; posterior end slightly produced obliquely; base line nearly horizontal medially, evenly rounded anteriorly, obtusely angulated posteriorly; posterior area delimited by a ridge running from the umbones to the posterior ventral inargin, growing increasingly obscure toward the base; hinge line straight, approximately three-fourths of the total length of the shell; hinge area quite low, rhomboidal in double valves; ligament confined to a smaller rhomb below the umbones, outlined by a rather deep linear sulcation transversely striated in slightly weathered individuals; external sculpture delicately reticulate over the entire surface with the exception of the anterior and posterior submargins; radial lirae very fine, particularly upon the posterior slope, tending to alternate in strength upon the medial area and anterior slope, numbering between 40 and 50 in all; concentric lirations broader and flatter than the radial threadlets, which they overrun; interspirals linear in the umbonal region, less narrow away from the umbones, thus making the interstices between the reticulate lirae more squarish in outline toward the base; hinge plate slightly arcuate ventrally; hinge teeth set in a single series, very short and straight beneath the umbones but becoming longer and more oblique distally; number usually 23 in all, those behind the umbones exceeding by one or two those in front of them; muscle scars well defined, the posterior outlined in part by the elevated ridge in front of it; pallial line distinct, very close to the ventral margin.

Arca saffordi Gabb has been discussed chiefly from casts, so that the diagnostic characters of the surface sculpture have not been emphasized. Gabb mentions the presence of a concentric sculpture in his original description, but it seems to have been disregarded by the subsequent New Jersey paleontologists. Arca cretacea Conrad is apparently more rounded in outline, the radial sculpture is coarser and dominates the concentric, and the hinge teeth are fewer and more oblique. $A$. saffordi Gabb is the analogue in the east-coast faunas of A. exigua Meek and Hayden, of the Fort Pierre group of the western interior. $A$. exigua is a little larger than its eastern relative, quite a little higher relatively, and more inflated.

There are no generic characters by which this species can be separated from Arca, subgenus Barbatia. Breviarca was used by Conrad to include subcircular or cordiform species with numerous minute cardinal teeth arranged in a broad arc.

This species is very abundant at Coon Creek. Shells from this locality are thicker and stouter and possess a greater number of teeth than individuals of the same species from Maryland.

Óccurrence: Ripley formation, Dave Weeks place on Coon Creek, McNairy County; Muddy Creek, Southern Railway, Hardeman County, Ten!,

Collections: Maryland Geological Survey,', Philadelphia Academy of Natural Sciences, New Jersey Geological Survey, U. S. National Museum. 
Outside distribution: Matawan formation, Ulmsteads Point, Ind. Woodbury clay of Matawan group of New Jersey. Monmouth formation, Bohemia Mills, Brightseat, and McNeys Corners, Md. Ripley formation, Owl Creek, Miss.

\section{Arca pergracilis Wade, n. sp.}

Plate XI, Figures 4, 5

Shell small, inflated; umbones of medium height, feebly concave, incurved at the tips and proximate, slightly anterior in position; outline distorted Dshaped; anterior end broadly rounded; obtusely angulated posteriorly; ventral valve arcuate; hinge line straight approximately three-fourths the entire length of the shell; ligament confined to a long, narrow area between the teeth and umbones; external sculpture beautifully reticulate over the entire surface; radial lirae fine, irregular in size and spacing; concentric lirations broader, flatter, and less numerous than the radial threadlets; hinge teeth of a single series very short and straight beneath the umbones, becoming longer and more oblique distally, twelve or thirteen in number; muscle scars small and not clearly defined; pallial line faint; a short internal radial is situated directly beneath the concave depression of the umbone; a second internal radial is a sharp, raised line directly beneath the posterior edge of the umbonal slope. Altitude, 8 millimeters; latitude, 9 millimeters.

This species is well characterized by its two internal radials and its reticulate external sculpture. It is probably closely related to Arca (Nemoarca) cretacea Conrad, ${ }^{88}$ from Haddonfield, N. J.

Occurrence: Ripley formation, Dave Weeks place on Coon Creek, McNairy County, Tenn.

Collection: U. S. National Museum.

\section{Genus POSTLIGATA Gardner}

Postligata crenata Wade, n. sp.

Plate XI, Figures 3, 6

Shell small and strong; subcircular in outline, lenticular; umbones small, submedial in position, nearly flat with little inflation, prosogyrate; lunule and escutcheon absent; dorsal margins sloping gently but curved so as not to break the circular outline of the shell; external surface very finely and regularly striated concentrically from the umbones to the base, with strongly defined resting stages common; ligament opisthodetic, lodged in three to five grooves oblique to the dorsal margin; hinge taxodont but obtusely angular and slightly interrupted directly beneath the umbone; teeth $V$-shaped, subequal, about 12 in number in the anterior series and 16 in the posterior series; adductor scars elliptical, subequal in number, situated on faint buttresses along the medial horizontal, the anterior slightly higher than the posterior one;

${ }^{68}$ Conrad, T. A., Description of new fossil Mollusca, principally Cretaceous: Am. Jour. Conchology, vol. 5, p. 97, pl. 9, fig. 21, 1869. pallial line simple and distinct; inner ventral margins crenate. Latitude, 9 millimeters; elevation, 9 millimeters.

This species is very closely related to Postligata wordeni Gardner, ${ }^{69}$ the type of the genus from the Monmouth formation of Maryland.

Occurrence: Ripley formation, Dave Weeks place on Coon Creek, McNairy County, Tenn.

Collections: Johns Hopkins University, U. S. National Museum.

\section{Genus GLYCIMERIS Da Costa}

Glycimeris subcrenata Wade, n. sp.

Plate XI, Figures 7, 8

Shell of medium size and strong; circular in outline and flatly lenticular; umbones inconspicuous, medial, feebly inflated; lunule and escutcheon absent; entire margin almost a perfect circle; external surface smooth, but on close examination fine radial lines and irregularly occurring growth lines may be seen; radial lirae very numerous, best developed on the umbonal slope on the medial portion of the shell; ligament orthodetic, lodged in a small obtusely triangular area which is marked by four fine shallow concentric ligament sulci; hinge plate broad, gently arcuate; taxodont teeth interrupted and divided into two series by a vacant space directly beneath the umbones, about 12 in the anterior series and about 10 in the posterior series; adductor scars conspicuous and situated on a slight buttress; pallial line simple; internal area between muscle scars and pallial line excavated; subventral margin very slightly crenate. Latitude, 26 millimeters; elevation, 25 millimeters.

This species differs from Glycimeris microsulci Wade, n. sp., in being flatter and more nearly circular and in possessing a ventral margin which is practically smooth and not crenate. The species is very rare, being known at present from a single valve.

Occurrence: Ripley formation, Dave Weeks place on Coon Creek, McNairy County, Tenn.

Collection: U.S. National Museum.

Glycimeris microsulci Wade, n. sp.

Plate XI, Figures 9, 10

Shell of medium size and deeply excavated, subcircular in outline and ventricose in shape; umbones medial, inflated, and rather conspicuous; lunule and escutcheon absent; dorsal posterior margin truncate; dorsal anterior margin truncate to gently arcuate; ventral margin well rounded or arcuate; external surface marked by numerous impressed radial lines with comparatively broad interspaces forming low, broad ribs, which disappear near the ventral margin and on the anterior portion of the shell; concentric growth lines irregular, conspicuous and most numerous near

${ }^{69}$ Gardner, J. A., Maryland Geol. Survey, Ujpper Cretaceous, p. 543, pl. 27, Ags. 7-9, 1916. 
the ventral margins; ligament orthodetic, lodged in a small oblong or subtrapezoidal area between the beaks and the teeth, ligament area marked by nine or ten fine concentric sulci radiating from a vertical line directly beneath the umbones; teeth divided into two short series of seven or eight each in number; adductor scars subtriangular and prominently situated on two low buttresses; two other smaller muscle scars are situated directly beneath the cardinal plates directly beneath the two series of teeth; pallial line simple; ventral margin feebly crenate. Latitude, 27 millimeters; elevation, 27 millimeters.

This species is well characterized by.its finely sulcate ligament area and its two projecting secondary muscle scars beneath the two series of teeth on the cardinal plate. In shape, external sculpture, and fine, sulcate character of the ligament area this species resembles Glycimeris subconcentrica (Lamarck), ${ }^{70}$ from the Turonian of Le Mans, France.

Occurrence: Ripley formation, Dave Weeks place on Coon Creek, McNairy County, Tenn.

Collection: U. S. National Museum.

Glycimeris lacertosa Wade, n. sp.

Plate XI, Figures 11, 12

Shell large, stout and robust, angulo-arcuate in outline; umbones prominent and inflated, proximate, and commonly flattened at the apices from rubbing against one another; dorsal anterior and dorsal posterior truncate, forming a variable obtuse apical angle, which is most pronounced in large individuals; basal margin broadly arcuate; external surface marked by low, broad radial sculpture, which is interrupted by numerous concentric growth lines; radial sculpture absent in narrow areas, on both anterior and posterior slopes; ligament orthodetic, lodged in an obtusely triangular area, which is marked by several deeply channeled diamond-shaped concentric sulci; hinge plate heavy, broad, and arcuate; taxodont teeth divided into three series-an anterior and a posterior series, each composed of 8 or 10 strong teeth of variable shape and setting and a series of 6 to 12 finer vertical teeth, situated directly beneath the umbones; the adductor scars large and conspicuous, situated on slight buttresses; the anterior scar is subtriangular and the posterior scar is subovate; two smaller oblong, secondary muscle scars are situated beneath large teeth on the hinge plate; pallial line sharp and simple; ventral margin marked by numerous deep indentations or crenulations. Latitude, 61 millimeters; elevation, 54 millimeters.

This species is very common at Coon Creek and is represented in the collections by dozens of perfect specimens. There are many individual variations in these specimens, such as general outline, size of ligamental area, number and setting of teeth, and external

${ }^{70} D^{\prime}$ Orbigny, Alcido, Paléontologie française, Terrains crétacés, vol. 3, p. 192, pl. $3^{07, \text { flgs. 13-16, } 1847 .}$ sculpture. Some closely related species are Glycimeris mortoni Conrad, ${ }^{71}$ which is widely distributed in the Upper Cretaceous of the east coast of the United States; Glycimeris geinitzii (D'Orbigny), ${ }^{72}$ from the Aachen Cretaceous of Vaals, Germany; and Glycimeris marrotiana (D'Orbigny), ${ }^{73}$ from the Senonian of the Pyrenees Basin, France.

Occurrence: Ripley formation, Dave Weeks place on Coon Creek, McNairy County, Tenn.

Collections: Johns Hopkins University, U. S. National Museum.

\section{Superfamily PTERIACEA \\ Family PERNIDAE \\ Genus INOCERAMUS Sowerby \\ Inoceramus proximus Tuomey \\ Plate XII, Figure 2}

1854. Inoceramus proximus. Tuomey, Acad. Nat. Sci. Philadelphia Proc., vol. 7, p. 171.

1860. Inoceramus proximus. Meek and Hayden, Acad. Nat. Sci. Philadelphia Proc. for 1860 , p. 428.

1861. Inoceramus proximus. Gabb, Synopsis of the Mollusca of the Cretaceous formation, p. 185 (Am. Philos. Soc. Proc., vol. 8, p. 241).

1864. Inoceramus proximus. Meek, Check list of the invertebrate fossils of North America, Cretaceous and Jurassic, p. 10.

1876. Inoceramus proximus. Meek, U. S. Geol. Survey Terr. Rept., vol. 9, p. 53, pl. 12, figs. 7a-b.

1885. Inoceramus sagensis. Whitfield, U. S. Geol. Survey Mon. 9 , p. 76 , pl. 14, fig. 15 ; pl. 15, figs. 1,2 . (Also published by New Jersey Geol. Survey, 1886.)

1907. Inoceramus proximus. Weller, 1907, New Jersey Geol. Survey, Paleontology, vol. 4, p. 424, pl. 40, figs. 1-6; pl. 41 , fig. 1.

Tuomey characterized the species as follows:

Shell compressed, inequilateral; ribs concentric, regularly curved, approximating.

The closely arranged ribs characterize this species.

Type.locality: Columbus, Miss.

Weller gives the following details:

Shell in large examples attaining a height of 100 millimeters or more and a length of 120 millimeters or more. The valves subovate in outline, moderately convex, the hinge line about two-thirds the length of the shell, the beak but little elevated above the hinge line. The anterior margin sloping forward from the beak and rounding gradually into broadly rounded basal margin, posterior margin broadly rounded and meeting the hinge line in an obtuse angle. Surface of the shell marked by more or less rounded or subangular, concentric undulations, which are often somewhat irregular in the strength of their development and their distances apart. In addition to the undulations the surface of the shell is marked by fine concentric striae separated by intervals of 1 millimeter or less.

The Coon Creek specimens here assigned to this species do not agree in every detail with specimens

${ }^{71}$ Conrad, T. A., Descriptions of Miocene; Eocene, and Cretaceous shells: Am. Jour. Conchology, vol. 5, p. 44, pl. 1, fig. 14, 1869.

${ }^{2}$ Holzapfel, Eduard, Die Mollusken der Aachener Kreide: Palaeontographica, Band 35, p. 200, pl. 23, figs. 11, 12; pl. 24, figs. 1-10, 1889.

${ }^{73}$ D'Orbigny, Alcide, Paleontologie française, Terrains crêtacés, vol. 3, p. 192, pl. 307 , figs. 13-16, 1847. 
from the type locality of the species, but they agree with what is the general conception of Inoceramus proximus Tuomey. This species and species very similar to it are widely distributed in the Upper Cretaceous of America. Inocerami are exceedingly variable forms, and dozens of species have been described. They form a group which is badly in need of monographic treatment; but before such a study is undertaken extensive collecting should be done at the type localities of the different species of this genus, for much of the material in the present collections is fragmentary.

Occurrence: Ripley formation, Dave Weeks place on Coon Creek, McNairy County, Tenn.

Collections: New Jersey Geological Survey, Johns Hopkins University, U. S. National Museum.

Outside distribution: Matawan group, New Jersey. Ripley formation, Mississippi and Alabama. Navarro formation, Texas.

\section{Inoceramus sagensis Owen}

Plate XII, Figure 1

1852. Inoceramus sagensis. Owen, Report of a geological survey of Wisconsin, Iowa, and Minnesota, p. 582, pl. 7 ; fig. 3.

1852. IInoceramus nebrascensis. Owen, Report of a geological survey of Wisconsin, Iowa, and Minnesota, p. 582, pl. 8, fig. 1.

1876. Inoceramus sagensis var. nebrascensis. Meek, U. S. Geol. Survey Terr. Rept., vol. 9, pl. 13, fig. 2.

1880. Inoceramus sagensis. Whitfield, in Newton and Jenney, Report on the geology and resources of the Black Hills of Dakota, p. 393, pl. 7, fig. 12; pl. 8, fig. 2.

Owen characterizes this species as follows:

Subovate or ovato-rhomboidal, convex, a winglike extension of the anterior margin. Beaks blunt, slightly prominent. Angle formed by the hinge line and axis a little less than a right angle. Broad, concentric, festoon-like, oval wrinkles of the surface. Length, 4 inches; width, 3 inches.

Whitfield gives the following details:

Shell large, the general form being oblate or more or less transversely broad oval, with moderately convex valves and large, somewhat tumid, and slightly incurved beaks, situated but a short distance from the anterior end and projecting above the line of the hinge. Hinge line straight, equal to about half or a little more than half the length of the shell below; anterior and posterior ends rounded, the former longest above the middle and the latter below the middle of the valve; basal line obliquely rounded, more or less prolonged behind in the direction of the umbonal ridge; extremity of the hinge line rounding to the posterior margin, with a long and gradually increasing slope. Valves most ventricose along the umbonal ridge and on the umbones, retaining considerable ventricosity toward the anterior margin, which is often quite abrupt, but sloping more gradually posteriorly and becoming much compressed and flattened on the postero-cardinal extension.

Surface of the valves marked by strong concentric undulations of varying size and distance, and often by finer concentric lining in the depressions between. Faint indications of radiating lines are also frequently seen on the exfoliated surfaces.

The specimens of this species are subject to very great variation-in fact, there is scarcely a single feature that is in any degree constant in its character through many individuals. In convexity they vary from depressed convex to highly gibbous. They also differ exceedingly in the strength and number of the concentric undulations, some having been noticed where the undulations become obsolete and the shell suddenly geniculated, giving a strongly deformed character to to the valves.

Occurrence: Ripley formation, Dave Weeks place on Coon Creek, McNairy County, Tenn.

Collections: Johns Hopkins University, U. S. National Museum.

Outside distribution: Pierre shale, Cheyenne River, S. Dak., and at many localities in South Dakota, Montana, Wyoming, Colorado, and New Mexico.

Genus PEDALION Solander

Pedalion periridescens Wade, n. sp.

Plate XII, Figures 3, 4

Shell large and nacreous; umbones acute angular; dorsal margin truncate; postero-ventral margin rounded; dorso-anterior margin strongly ccacave; external surface marked with growth lines and very faint concentric undulations; ligamental area long and wedge-shaped; crossed at right angles by six to ten broad, low concave teeth separated by shallow concave grooves of equal width; ventral extremities of these teeth jutting out and forming a bluntly serrate lower margin of the ligamental area; adductor scar subovate and centrally located; two series of small irregular byssal pits occur beneath inner extremities of the teeth and beneath the incurved anterior dorsal margin; pallial line unknown.

This species is well characterized by its regular teeth and acute apex. It is probably related to Pedalion excavata (White), ${ }^{74}$ from the Chico formation of California, the first Cretaceous species to be referred to this genus in the United States. Pedalion subspatulata (Reuss), ${ }^{75}$ from the Upper Cretaceous of Bohemia, is a related form of this species. Along with these species should be mentioned two species from the Cretaceous of England and France, Pedalion rauliniana (D'Orbigny) ${ }^{76}$ and Pedalion oblonga (Seeley). ${ }^{77}$

Occurrence: Ripley formation, Dave Weeks place on Coon Creek, McNairy County, Tenn.

Collections: Johns Hopkins University, U. S. National Museum.

"White, C. A., On invertebrate fossils from the Pacific coast: U. S. Geol. Survey Bull. 51, p. 37, pl. 7, fig. 1, 1889.

75 Fric, Anton, Studien im Gebiete der böhmischen Kreideformation: Archiv naturwiss. Landesd. Böhmen, Band 5, No. 2, p. 111, fig. 79, a, b, c, 1883.

${ }_{70}$ Woods, Henry, A monograph of the Cretaceous Lamellibranchia of England, vol. 2, p. 92, pl. 12, figs. 6, 7a-b, 8, 9, Palaeọnt. Soc. London, 1905.

7 Seeley, H. G., Notes on Cambridge paleontology: Annals and Mag. Nat. Hist., 3d ser., vol. 7, p. 121, pl. 6, fig. 6, 1861. 


\section{Genus GERVILLIOPSIS Whitfield}

Gervilliopsis ensiformis (Conrad)

Plate XIII, Figures 1-3

1858. Gervillia ensiformis. Conrad, Acad. Nat. Sci. Philadelphia Jour., 2d ser., vol. 3, p. 328, pl. 34, fig. 19.

1861. Gervillia ensiformis. Gabb, Synopsis of the Mollusca of the Cretaceous formation, p. 124 (Am. Philos. Soc. Proc., vol. 8, p. 180).

1864. Gervillia ensiformis. Meek, Check list of the invertebrate fossils of North America, Cretaceous and Jurassic, p. 9.

1868. Gervillia ensiformis. Conrad, in Cook, Geology of New Jersey, p. 726.

1885. Gervilliopsis ensiformis. Whitfield, U. S. Geol. Survey Mon. 9, p. 73, pl. 15, figs. 8-11; pl. 16, fig. 5. (Also published by New Jersey Geol. Survey, 1886.)

1887. Dalliconcha ensiformis. White, Acad. Nat. Sci. Philadelphia Proc. for 1887 , p. 35 , pl. 2, fig. 6 .

1902. Gervilleia ensiformis. Frech, Centralbl. Mineralogie, 1902 , p. 615.

1905. Gervilliopsis ensiformis. Johnson, Acad. Nat. Sci. Philadelphia Proc., vol. 57, p. 10.

1907. Gervilliopsis ensiformis. Weller, New Jersey Geol. Survey, Paleontology, vol. 4, p. 421, pl. 37, figs, 4-5; pl. 38, figs. 1-3.

1914. Gervilliopsis ensiformis. Stephenson, U. S. Geol. Survey Prof. Paper 81, p. 24, table 2.

Whitfield describes this species as follows:

Shell of moderately large size and thickened, falciform, very oblique, the body of the shell finally becoming parallel to the hinge or even slightly recurved, narrowing posteriorly and flattened on the surface. Hinge line straight, short, not more than one-fourth the length of the shell in grown individuals; posterior wing only moderately elevated, and the posterior margin rapidly. sloping backward from its extremity to the body of the shell, being squarely truncate at right angles to the hinge. Beak of the shell small and terminal, elevated above the wing and continuing in a ridge to the surface of the valve. Greatest width of the shell opposite the posterior extremity of the hinge. Surface of the shell lamellose and marked by numerous concentric varices of growth, and on the basal portion of the right valve indications of fine radiating lines occur. Hinge area moderately wide, marked by several transverse ligamental pits, arranged at a little more than one-fourth of an inch apart, and also by numerous oblique corrugations. Muscular imprints large and obliquely situated. Substance of the shell highly nacreous throughout and iridescent.

Shells of this species are very abundant at Coon Creek, but they are so fragile that it is almost impossible to collect a complete specimen. This species is closely related to Gervilliopsis solenoides (Defrance), ${ }^{78}$ from the Senonian of Europe. A considerable number of specimens of Gervilliopsis from different localities and horizons of the Upper Cretaceous of Europe and India have been referred to Gervilliopsis solenoides (Defrance) by many authors, among whom are Sowerby (1826), Goldfuss (1836), Reuss (1846), Müller (1847), D'Orbigny (1847), Alth (1850), Zittel (1866), Farve (1869), Stoliczka (1871), Geinitz (1873), Brauns (1876), Fritsch (1877-1893), Nötling (1885), Griepenkerl (1889), Holzapfel (1889), Lündgren (1894),

${ }^{78}$ Eolzapfel, Eduard, op. cit, p. 223, pl. 24, figs. 11, 12.
Vogel (1895), and Müller (1898). Another species to which Gervilliopsis ensiformis (Conrad) is closely allied is Gervilliopsis forbesiana (D'Orbigny), ${ }^{79}$ from the Cretaceous of England.

Occurrence: Ripley formation, Dave Weeks place on Coon Creek, McNairy County, Tenn.

Collections: New Jersey Geological Survey, Philadelphia Academy of Natural Sciences, Maryland Geological Survey, U. S. National Museum, Yale University.

Outside distribution: Monmouth formation of Maryland and New Jersey. Ripley formation of Alabama and Mississippi.

\section{Family PTERIIDAE \\ Genus PTERIA Scopoli \\ Pteria petrosa (Conrad) \\ Plate XIII, Figure 7}

1853. Avicula petrosa. Conrad, Acad. Nat. Sci. Philadelphia Jour., 2d ser., vol. 2, p. 274, pl. 24, fig. 15.

1854. 'A vicula linguaeformis. Evans and Shumard, Acad. Nat. Sci. Philadelphia Proc., vol. 7, p. 163.

1859. ?Avicula linguaeformis. Meek, in Hind, Report on the Assiniboine and Saskatchewan exploring expedition, p. 183 , pl. 1 , fig. 7 .

1864. PPteria linguiformis. Meek, Check list of the invertebrate fossils of North America, Cretaceous and $\mathrm{Ju}-$ rassic, p. 9.

1864. Pteria petrosa. Meek, Check list of the invertebrate fossils of North America, Cretaceous and Jurassic; $\ddot{p}: 9$.

1876. ?Pteria linguiformis. Meek', U. S. . Geol. Survey Terr. Rept., vol. 9, p. 32, pl. 16, figs. 1a-1d.

1879. ?Pteria linguiformis. White, U. S. Geol. and Geog. Survey Terr. Eleventh Ann. Rept., pp. 180, 197, 205.

1880. ?Pteria linguiformis. Whitfield, in Newton and Jenney, Report on the geology and resources of the Black Hills of Dakota, p. 384, pl. 7, figs. 2, 3 .

1885. ?Pteria linguiformis. Whiteaves, Contr. Canadian Paleontology, vol. 1, pt. 1, p. 31 .

1885. Pteria petrosa. Whitfield, U. S. Geol. Survey Mon. 9, p. 68, pl. 14, fig. 10. (Also published by New Jersey Geol. Survey, 1886.)

1907. Pteria petrosa. Weller, New Jersey Geol. Survey, Paleontology, vol. 4, p. 429, pl. 42, figs. 1, 2.

1914. Pteria petrosa. Stephenson, U. S. Geol. Survey Prof. Paper 81, table 2, p. 24.

1916. Pteria petrosa. Gardner, Maryland Geol. Survey, Upper Cretaceous, p. 548, pl. 21, fig. 10.

Conrad characterized the species as follows:

Subquadrangular, very oblique, ventricose; anterior hinge extremity sharply angulated; anterior margin obliquely subtruncated inferiorly; posterior extremity subangulated.

Type locality: Chesapeake \& Delaware Canal, Delaware.

Weller describes this species as follows:

Shell oblique, winged in front and behind, the hinge line straight, with the beaks in front of the middle. Both valves rather strongly convex. but the left a little more so than the right. Posterior wing compressed, of moderate length, pointed

70 Woods, Henry, op. cit., vol. 2 , p. 85 , pl. 11 , flgs. 26,27 , pl. 12 , figs. $1-5$ 
behind; its posterior margin concave; anterior wing narrower, pointed in front, less compressed than the other, its free margin nearly straight or slightly concave; in the right valve it is separated from the body of the shell by a narrow or shallow sulcus, which extends from the anterior side of the beak downward and usually a little obliquely backward to the antero-ventral margin; just in front of the marginal extremity of this sulcus the surface is slightly bulged so as to leave a byssal opening between the valves. The antero-ventral margin slopes obliquely backward from the anterior extremity of the hinge line; it is slightly concave to the base of the anterior wing, beyond which point it becomes slightly convex, curving more and more below into the rounded postero-basal margin; the posterior margin oblique below and sinuate above. Surface of the shell marked only by concentric lines of growth, which are inconspicuous on the internal casts.

The dimensions of a large specimen are: Length from the anterior extremity of the hinge line to the postero-basal margin, 51 millimeters; length of hinge line, 37 millimeters; distance to beak from the anterior extremity of the hinge line, 12 millimeters; convexity of right valve, 10 millimeters.

This species is represented in the Coon Creek collections by several very fragile shells. It is of unusual interest because of its supposed occurrence in the Pierre shale and Fox Hills sandstone of the western interior and because of closely allied forms in the Upper Cretaceous of southern India and other forms in the Lower Greensand of England.

Occurrence: Ripley formation, Dave Weeks place on Coon Creek, McNairy County, Tenn.

Collections: Maryland Geological Survey, New Jersey Geological Survey, U. S. National Museum.

Outside distribution: Monmouth formation, Cecil County, Md. Magothy formation ("Cliffwood clay") and Wenonah sand (of Matawan group) of New Jersey. Black Creek formation, North Carolina and South Carolina. Ripley formation, Exogyra costata zone, Alcorn County, Miss. Pierre shale, western interior, if Pteria linguaeformis is identical.

Pteria percompressa Wade, n. sp.

Plate XIII, Figure 4

Shell fragile, nacreous, of medium size, obliquely ovate-subtrigonal or linguiform in outline, distinctly winged, strongly convex, the left valve more convex than the right, strongly inflated along umbonal ridge from beak to basal posterior margin; umbones small at the very apices and projecting only slightly above the dorsal margin, situated one-third of the way from the anterior extremity of the dorsal margin; anterior wings form a short, thick triangular rostrum that projects prominently in front of the shell; posterior wings narrow and flat, lying on the posterior slope of the shell in a less conspicuous position; external surface smooth, shell slightly. iridescent; ligament area distinct, long, and narrow; teeth unknown; adductor scar large but indistinct, ovate in shape and subcentral in position.

An imperfect individual measured in latitude, I3 millimeters; in elevation, 24 millimeters.
This species may be regarded as somewhat intermediate between Pteria petrosa (Conrad) and Pteria linguiformis var. subgibbosa Meek, ${ }^{80}$ a form which has been also recognized on Battle River in Canada and which probably deserves to be rated as a species.

Occurrence: Ripley formation, Dave Weeks place on Coon Creek, MeNairy County, Tenn.

Collections: U.S. National Museum, Johns Hopkins Iniversity.

\section{Family ? \\ Genus PULVINITES Defrance \\ Pulvinites argenitea Conrad \\ Plate XIII, Figures 5, 6, 8, 9}

1858. Pulvinites argentea. Conrad, 1858, Acad. Nat. Sci. Philadelphia Jour., 2d ser., vol. 3, p. 330, pl. 34, fig. 5. 1860. Pulvinites argentea. Conrad, Acad. Nat. Sci. Philadelphia Jour., 2d ser., vol. 4, p. 298, pl. 46, fig. 51.

1867. Pulvinites argentea. Conrad, Am. Jour. Conchology, vol. 3, pp. $9,10$.

1871. Pulvinites argentea. Stoliczka, India Geol. Survey Mem., Palaeontologia Indica, Cretaceous fauna of southern India, vol. 3 , pp. 394, 395.

1914. Pulvinites argentea. Stephenson, U. S. Geol. Survey Prof. Paper 81, p. 24, tables 2, 8.

Conrad characterizes this species as follows:

Transversely subovate, compressed; perforated valve slightly concave; foramen oval; from its upper margin a channel extends to the apexi substance of shell silvery, thin; cardinal plate broad, with about thirteen radii or teeth; the lower valve presents within the appearance of two muscula: impressions, the one above the other, the former striated.

The present species of this rare genus is allied to $P$. adansonii but differs from the figures of that species in having a broader hinge plate and much less curvature of the posterior margin. It closely resembles an Anomia exteriorly. $P$. adansonii characterizes the Upper Cretaceous rocks of Europe.

This species is common at Coon Creek and is represented in the collections by a few individuals with both valves attached. The upper valve has a large adductor scar in the central portion of the shell and a sircular foramen beneath the cardinal plate instead of two adductor scars, as on the lower valve. There is a small muscle scar or byssal pit situated between the upper adductor scar and the cardinal plate of the lower valve, whereas on the upper valve the corresponding byssal pit is between the foramen and the lower adductor scar. As the foramen occupies the position of the absent upper adductor muscle scar in the upper valve on this species it seems evident that this adductor passed through this foramen and was attached to some foreign object.

Occurrence: Ripley formation, Dave Weeks place on Coon Creek, McNairy County, Tenn.

Collections: Maryland Geological Survey, U. S. National Museum, Vanderbilt University.

Outside distribution: Ripley formation, Owl Creek and White Oak Creek, Miss., and Chattahoochee River, Ga.

${ }_{80}$ Meek, F. B., A report on the invertebrate Cretaceous and Tertiary fossils of the upper Missouri country: U. S. Geol. Survey Terr. Rept., vol. 9, p. 33, pl, 28, fig. 12 , 1876. 


\section{Genus INOPERNA Conrad}

\section{Inoperna carolinensis Conrad}

Plate XIII, Figure 10

1875. Inoperna carolinensis. Conrad, in Kerr, Report of the geological survey of North Carolina, vol. 1; appendix A, p. 5, pl. 1, fig. 22.

Conrad describes this species as follows:

Shell slightly arcuate toward the posterior.end, much compressed, gradually expanding to the posterior extremity, which is rounded.

The outline and larger ribs distinguish this species from the allied forms. The compression of the valves may be owing to pressure, one valve being perfectly flat.

Only one imperfect specimen of this very unusual form has been found at Coon Creek. This specimen is not sufficient for a more detailed description than that given above, but it is sufficient to show the elongate, transversely wrinkled valve that is straight and free from wrinkles near the margins. It is a very characteristic form and readily recognizable from a mere fragment.

This species belongs to a generic group different from Modiola and also has affinities in the Jurassic. It may be compared with Modiola sowerbiana (D'Orbigny), Modiola perplicata (Etallon), Modiola medus (D'Orbigny), and Modiola icaunensis (De Loriol), all from the Jurassic of Europe and probably belonging to the genus Inoperna. Inoperna carolinensis Conrad resembles in some respects Inoperna flagellifera (Forbes), ${ }^{81}$ a form which is widely distributed in the Upper Cretaceous of Europe and India.

Occurrence: Ripley formation, Dave Weeks place on Coon Creek, McNairy County, Tenn.

Collection: U. S. National Museum.

Outside distribution: Black Creek formation, Snow Hill, N. C.

\section{Superfamily OSTRACEA \\ Family OSTREIDAE \\ Genus OSTREA Lamarck \\ Ostrea plumosa Morton \\ Plate XIV, Figures 1-3, 7}

1833. Ostrea plumosa. Morton, Am. Jour. Sci., 1st ser., vol. 23, p. 293.

1834. Ostrea plumosa. Morton, Synopsis of the organic remains of the Cretaceous group of the United States, p. 51 , pl. 3 , fig. 9 .

1858. Ostrea denticulifera. Conrad, Acad. Nat. Sci. Philadelphia Jour., 2d ser., vol. 3 , p. 330 , pl. 34 , figs. 1,8 .

1864. Ostrea plumosa. Meek, Check list of the invertebrate fossils of North America, Cretaceous and Jurassic, p. 6.

1868. Ostrea plumosa. Conrad, in Cook, Geology of New Jersey, p. 724.

1869. Ostrea plumosa. Coquand, Monographie du genre Ostrea, terrain crétacé, p. 61 , pl. 32 , fig. 9 .

2 Frī̌, Anton, Studien im Gebiete der böhmischen Kreideformation; VI, Die Chlomeker Schichten: Archiv naturwiss. Landesd. Böhmen, vol. 10, p. 59, fig. 69, 1897. Forbes, Edward, Report on the fossil Invertebrata from southern India: Gool. Soc. London Trans., 2d ser., vol. 7, p. 152, pl. 16, fig. 9, 1846.
1877. Ostrea plumosa. Gabb, Acad. Nat. Sci. Philadelphia Proc. for 1876, p. 320.

1884. Ostrea plumosa. White, U. S. Geol. Survey Fourth Ann. Rept., p. 299, pl. 37, figs. 5, 6.

1885. Ostrea plumosa. Whitfield, U. S. Geol. Survey Mon. 9 , p. 31, pl. 3, figs. 12, 13. (Also published by New Jersey Geol. Survey, 1886.)

1885. Anomia argentaria. Whitfield, U. S. Geol. Survey Mon. 9, pl. 4, fig. 9. (Also published by New Jersey Geol. Survey, 1886.)

1905. Ostrea plumosa. Johnson, Acad. Nat. Sci. Philadelphia Proc., vol. 57, p. 10.

1907. Ostrea plumosa. Weller, New Jersey Geol. Survey, Paleontology, vol. 4, p. 439, pl. 42, figs. 16-18.

1907. Ostrea denticulifera. Weller, New Jersey Geol. Survey, Paleontology, vol. 4, p. 436, pl. 43, figs. 1, 2.

1914. Ostrea plumosa. Stephenson, U. S. Geol. Survey Prof. Paper 81, p. 24, tables 2-8.

1916. Ostrea plumosa. Gardner, Maryland Geol. Survey, Upper Cretaceous, p. 556.

Morton in 1833 characterized this species as follows:

Ovato-triangular; lower valve convex, crenated near the hinge; forsum marked with delicate striae, radiating with fasciculi from the beak to the margin.

Miss Gardner adds the following details:

Shell of medium size, extremely variable in outline, usually flattened or feebly convex and more or less constricted and falcate in the umbonal region; umbones inconspicuous, narrow as a rule and well over toward the posterior margin; external surface very finely sculptured radially, the ornamentation usually manifested in the form of linear sulci, frequently bifurcating and irregularly spaced; sculpture occasionally almost or altogether obsolete, particularly in the umbonal region and sometimes taking the form of fine radial corrugations; incremental sculpture quite sharp, especially on weathered surfaces; ligament area narrow, the medial depression ill defined; submargins sharply crenulated; muscle impression elongated, often pyriform, posterior.

In $O$. plumosa Morton the natural tendency toward variation has been greatly exaggerated by weathering. The radial sculpture is restricted to a very thin surface layer, which may be decorticated without leaving any apparent scar. The outline, though variable, is usually characterized by a decided constriction in the umbonal region.

Occurrence: Ripley formation, Dave Weeks place on Coon Creek, M.cNairy County, Tenn.

Collections: Maryland Geological Survey, Philadelphia Academy of Natural Sciences, New Jersey Geological Survey, U. S. National Museum.

Outside distribution: Monmouth formation, Brightseat, Prince Georges County, Md. Matawan group (Woodbury clay, Marshalltown formation, and Wenonah sand), New Jersey. Black Creek formation, North Carolina and South Carolina. Peedee sand, North Carolina and South Carolina. Eutaw formation (Tombigbee sand member), Exogyra ponderosa zone, Mortoniceras subzone, Georgia and Russell County, Ala. Ripley formation, Exogyra ponderosa zone, Georgia, Bullock County, Ala., and Clay, Lee, and Chickasaw counties, Miss.; Exogyra costata zone, Georgia, Chattahoochee River and Eufaula, Ala., and Chickasaw and Pontotoc counties, Miss. Selma chalk, Exogyra ponderosa zone, Warrior River, Ala., 
and Tennessee; Exogyra costata zone, Tombigbee River, Ala.

\section{Ostrea tecticosta Gabb}

Plate XIV, Figures 4, 5

1860. Ostrea tecticosta. Gabb, Acad. Nat. Sci. Philadelphia Jour., 2 d ser., vol. 4, p. 403, pl. 68, figs. 47, 48.

1864. Ostrea tecticosta. Meek, Check list of the invertebrate fossils of North America, Cretaceous and Jurassic, p. 6.

1868. Ostrea tecticosta. Conrad, in Cook, Geology of New Jersey, p. 724.

1869. Ostrea tecticosta. Coquand, Monographie du genre Ostrea, terrain crétacé, p. 50, pl. 17, figs. 10, 11.

1877. Ostrea pusilla. Gabb, Acad. Nat. Sci. Philadelphia Proc. for 1876, p. 321.

1884. Ostrea tecticosta. White, U. S. Geol. Survey Fourth Ann. Rept., p. 301, pl. 50, figs. 3, 4.

1885. Ostrea tecticosta. Whitfield, U. S. Geol. Survey Mon. 9, p. 33, pl. 3, figs. 1, 2. (Also published by New Jersey Geol. Survey, 1886.)

1905. Ostrea tecticosta. Johnson, Acad. Nat. Sci. Philadelphia Proc., vol. 57, p. 10

1907. Ostrea tecticosta. Weller, New Jersey Geol. Survey, Paleontology, vol. 4, p. 443, pl. 43, figs. 18, 19.

1914. Ostrea tecticosta. Stephenson, U. S. Geol. Survey Prof. Paper 81, p. 24, tables 2-8.

1916. Ostrea tecticosta. Gardner, Maryland Geol. Survey, Upper Cretaceous, p. 560, pl. 24, figs. 2-4.

Gabb characterizes this species as follows:

Elongated, irregularly oval, arcuate; beaks acuminate, ligament area triangular, oblique; muscular impressions rather large; lower valve generally attached, deep, usually deepest along the median line but becoming flattened toward the basal margin; surface marked by numerous prominent, imbricating ribs, radiating from the middle line and not from the beaks; upper valve not so deep as the lower; surface only marked by the usual lines of growth; upper half of the internal margins of both valves denticulate, corresponding in the lower valve with the external plications.

Type localities: Tennessee and New Jersey.

Ostrea tecticosta Gabb is well characterized by the 20 to 25 sharp, concentric lamellae of the lower valve and the corrugations radiating from the median horizontal, slightly more crowded on the ventral margin, gradually becoming finer toward the dorsal margin, irregular only in the region of the scar of attachment. The muscle scar is large, ovate or semielliptical, and posterior in position. The upper valve is smaller than the lower, flattened and ovatecuneate in outline. Its external surface is sculptured with fine-edged concentric lamellae similar to those developed on the lower valve but more crowded. The radial sculpture is reduced to faint striations or is altogether absent. The umbones of both valves are high, narrow, and acute, the ligament area correspondingly high.

Occurrence: Ripley formation, Coon Creek and Sand Hill, McNairy County, Tenrı. Selma formation, Blue Cut, Gravel Hill, McNairy County, Tenn.
Collections: Maryland Geological Survey, New Jersey Geological Survey, Philadelphia Academy of Natural Sciences, Yale University, U. S. National Museum.

Outside distribution: Wenonah sand (of Matawan group) New Jersey. Black Creek formation, North Carolina and South Carolina. Peedee sand, North Carolina and South Carolina. Ripley formation, Exogyra ponderosa zone, Chattahoochee River, Ala.; Exogyra costata zone, Georgia, Eufaula, Ala., and Lowndes, Chickasaw, Pontotoc, and Lee counties, Miss. Selma chalk, Exogyra costata zone, Sumter County, Ala., and east-central Mississippi.

\section{Ostrea monmouthensis Weller}

Plate XIV, Figures 6, 8

1907. Ostrea monmouthensis. Weller, New Jersey Geol. Survey, Paleontology, vol. 4, p. 442, pl. 43, fig. 15.

1916. Ostrea monmouthensis. Gardner, Maryland Geol. Survey, Upper Cretaceous, p. 558, pl. 23, figs. 4,5 .

Weller describes this species as follows:

Shell slightly oblique, subovate in outline, the dimensions of the type specimen being, length, 28 millimeters; width, 22 millimeters. Upper valve depressed convex, nearly smooth, marked only by inconspicuous concentric lines of growth. Along the ventral margin the edge is folded into sharply angular teeth, which do not extend as plications into the body of the shell, these toothlike crenulations becoming smaller and at last disappearing upon the lateral margins of the shell. Lower valve not known.

It is with some hesitation that a species of so variable a group of shells as the oysters has been proposed for a single specimen, but it has not been possible to identify it with any of the described forms, and it seems to be so distinct that it is probable that additional examples, should they be found, could be recognized without difficulty. The shell has much the general outline of the specimen referred to $O$. crenulimarginata by Whitfield, but that shell entirely lacks the characteristic denticulation of the ventral margin of this species.

Miss Gardner gives the following details:

Type locality: Crawfords Corner, Monmouth County, N. J. The species is fairly common in the Monmouth of Prince Georges County at Brightseat, but strangely enough it is represented by right valves only. The form differs from the cover valves of $O$. tecticost $a$ not only in the development of a marginal frill but also in the heavier texture of the shell, larger size, less cuneate outline, broader, lower umbones and ligament area, and in the character of the concentric sculpture, the external surface of $O$. tecticosta being adorned with densely crowded concentric lamellae, while that of $O$. monmouthensis is merely roughened by more or less irregular concentric striations.

Occurrence: Ripley formation, Dave Weeks place on Coon Creek, McNairy County, Tenn.

Collections: Maryland Geological Survey, New Jersey Geological Survey, U. S. National Museum.

Outside distribution: Monmouth formation, Brightseat, Prince Georges County, Md. Navesink marl, New Jersey. 


\section{Ostrea falcata Morton}

Plate XIV, Figures 9-13

1827. Ostrea falcata. Morton, Acad. Nat. Sci. Philadelphia Jour., 1st ser., vol. 6, p. 50, pl. 1, fig. 2.

1830. Ostrea falcata. Morton, Am. Jour. Sci., 1st ser., vol. 17, p. 284; vol. 18, pl. 3, figs. 19-20.

1834. Ostrea falcata. Morton, Synopsis of the organic remains of the Cretaceous group of the United States, p. 50, pl. 3 , fig. 5 .

1860. Ostrea falcata. Owen, Second report of a geological reconnaissance of the middle and southern counties of Arkansas, pl. 7, fig. 5 .

1868. Ostrea larva. Cook, Geology of New Jersey, p. 375, text fig.

1868. Ostrea larva. Conrad, in Cook, Geology of New Jersey, p. 724 .

1869. Ostrea ungulata. Coquand, Monographie du genre Ostrea, p. 58, pl. 21, figs. 11, 12 (part).

1884. Ostrea (Alectryonia) larva. White, U. S. Geol. Survey Fourth Ann. Rept., p. 296, pl. 42, fig. 8 (part).

1885. Ostrea larva. Whitfield, U. S. Geol. Survey Mon. 9, p. 34, pl. 3, figs. 5, 6 (part). (Also published by New Jersey Geol. Survey, 1886.)

1905. Ostrea falcata. Johnson, Acad. Nat. Sci. Philadelphia Proc., vol. 57, p. 11.

1907. Ostrea falcata. Weller, New Jersey Geol. Survey, Pàleontology, vol. 4, p. 444, pl. 43, figs. 3-6.

1916. Ostrea larva var. falcata. Gardner, Maryland Geol. Survey, Upper Cretaceous, p. 552, pl. 22, fig. 4.

Morton, in 1827, characterized this species as follows:

O. falcata, testa falciformi, auriculata, tenui; valvula superiore planulata, inferiore convexa; plicis, juxta rostrum nascentibus, ad marginem anteriorem divaricatis; margine posteriori leviter undata.

Weller adds the following details:

Type locality: St. Georges, Chesapeake \& Delaware Canal, Del.

Shell of medium size, laterally arcuate. The dimensions of an average specimen are: Length along the arcuate median line from beak to posterior extremity, 47 millimeters; distance between beak and posterior extremity, 28 millimeters; width of shell at middle, 16 millimeters; length of hinge line, 20 millimeters. Shell usually more or less strongly auriculate, the ears subequal or with one ear somewhat larger than the other. Hinge line straight. Shell marked with from seven to ten deep plications, which originate along the lower or convex margin and extend nearly to the beak, not leaving a conspicuous nonplicate central area, the plications toward the anterior hinge extremity decreasing regularly in size; along the upper or concave margin the shell is marked by a series of short, marginal plications. Lower valve moderately convex, with a small scar of attachment; upper valve much flatter, its plications similar to those of the lower valve.

This large falcate, mesially plicate species is typically developed in the base of the Coon Creek beds and ranges downward into the underlying Selma formation, where it occurs in great profusion. Hundreds of these very delicate shells may be collected from numerous bare clay hills or "bald knobs" of McNairy County. Exogyra ponderosa and Gryphaea vesicularis usually occur in great numbers with Ostrea falcata.

Occurrence: Ripley formation, Coon Creek, Sand Hill, Gravel Hill, McNairy County, Tenn. Selma for- mation, numerous clay hills in southern McNairy County.

Collections: Maryland Geological Survey, New Jersey Geological Survey, Philadelphia Academy of Natural Sciences, Yale University, U. S. National Museum.

Outside distribution: Matawan formation, Maryland. Matawan and Monmouth groups, New Jersey. Widely distributed in the Gulf region but not differentiated.

\section{Ostrea penegemmea Wade, n. sp.}

Plate XIV, Figures 18, 19

Shell of medium size and nacreous; outline irregular; subovate to trigonal; umbones small and usually indistinct; ligament area short and subtrapezoidal in shape; external surface not sculptured by a definite pattern; irregularly spaced incremental lines best developed on the lower half of the shell; strong concentric undulations occur on some shells; faint irregular radial lines occur on the lower half of the shells of some individuals; lower or right valve hollow; upper or left valve nearly flat; inner margins directly below the ligament area commonly feebly crenate or dentate; muscle scar large, pyriform, and situated in the medial area of the shell near the dorsal margin; pallial line indistinct. Latitude, 30 millimeters; elevation, 27 millimeters.

This species is characterized by its nacreous shell, simple margins, and delicate external sculpture. It is perhaps related to Ostrea prudentia White, ${ }^{82}$ from the Colorado group of the western interior.

Occurrence: Ripley formation, Coon Creek, McNairy County, Tenn. Selma formation, 7 miles east of Lexington, Henderson County, Tenn.

Collection: U. S. National Museum.

\section{Ostrea menairyensis Wade, n. sp.}

Plate XIV, Figures 14-17

Shell of medium size; outline very irregular; umbones small and pointed; anterior dorsal margin commonly straight but in some specimens arcuate; posterior dorsal margin in many specimens incurved; ventral margin roughly arcuate; external surface strongly sculptured by numerous irregular, concentric, roughedged incremental lines; which become broader and less distinct on the ventral half of the shell; numerous fine radial lines occur between the incremental lines on the upper half of the shell; ligamental area small and trapezoidal; inner margins of shell finely dentate; muscle scar large and D-shaped, situated in a medial area near the dorsal margin; pallial line indistinct. Latitude, 45 millimeters; elevation, 40 millimeters.

This species is well characterized by its strioconcentric ornamentation and its pointed beaks. The species probably bears some relation to Ostrea plumosa

${ }^{82}$ Stanton, T. W., The Colorado formation and its invertebrate fauna: U.S. Geol. Survey Bull. 106, p. 54, pl. 1, figs. 3, 4, 1893. 
Morton but may be readily separated from that form by its different general outline and ornamentation.

Occurrence: Ripley formation, Dave Weeks place on Coon Creek, McNairy County, Tenn.

Collections: Johns Hopkins University, U. S. National Museum.

\section{Ostrea bryani Gabb?}

Plate XVI, Figures 4,5

1877. Ostrea bryani. Gabb, Acad. Nat. Sci. Philadelphia Proc. for 1876 , p. 321 .

1884. Ostrea bryani. White, U. S. Geol. Survey Fourth Ann. Rept., p. 293.

1885. Gryphaea bryani var. precedens (Gabb). Whitfield, U. S. Geol. Survey Mon. 9, p. 194, pl. 26, figs. 7-8. (Also published by New Jersey Geol. Survey, 1886.)

1885. Gryphaea bryani. Whitfield, U. S. Geol. Survey Mon. 9 , p. 206, pl. 27, figs. 6-9. (Also published by New Jersey Geol. Survey, 1886.)

1885. Ostrea blandiformis. Whitfield, U. S. Geol. Survey Mon. 9 , p. 205, pl. 27, figs. 1-5. (Also published by New Jersey Geol. Survey, 1886.)

1905. Gryphaea bryani. Johnson, Acad. Nat. Sci. Philadelphia Proc., vol. 57, p. 11.

1907. Gryphaea bryani. Weller, New Jersey Geol. Survey, Paleontology, vol. 4, p. 448, pl. 44, figs. 1-5.

Weller describes this species as follows:

Shell oblique, more or less strongly extended laterally to the left, looking upon the upper valve; moderately thick, more or less subtrigonal or subovate and exceedingly irregular in outline; lower valve strongly or moderately and very irregularly convex, sometimes flattened or even concave to beyond the middle of its length, attached or free, the scar of the attachment variable, usually small or of moderate size; surface markings exceedingly irregular, consisting of concentric, more or less squamose lines, which are often produced into irregularly spinose processes near the hinge line in those specimens which have been strongly attached; surface also marked on many examples by a few rather broad, irregular, radiating costae; hinge area triangular, with a deep ligamental groove in the middle, whose apex is deflected to the left. Upper valve flat, slightly concave or slightly convex, sometimes convex toward the beak, becoming concave toward the base; the surface marked by concentric squamose lines, hinge area directed from $45^{\circ}$. to $90^{\circ}$ in the general plane of the valve.

The dimensions of an average-sized, rather convex. lower valve are: Greatest length, obliquely from the beak to the postero-basal margin, 42 millimeters; greatest width, at about right angles to the last dimension, 28 millimeters; convexity, 19 millimeters.

The Coon Creek species figured here can not be assigned with assurance to this species. It has the same shape and form, yet the Coon Creek species is much smaller and thinner and is free from external sculpture. The form is common in the Ripley of McNairy County and is represented in the collection by a number of individuals.

Occurrence: Ripley formation, Dave Weeks place on Coon Creek, McNairy County, Tenn.

Collections: Typical form, New Jersey. Geological Survey, Maryland Geological Survey, Philadelphia Academy of Natural Sciences; doubtful form, U. S. National Museum.

Outside distribution: Rancocas group, New Jersey.

\section{Genus EXOGYRA Say}

Exogyra costata Say

Plate XV, Figures 1, 2

1820. Exogyra costata. Say, Am. Jour. Sci., 1st ser., vol. 2, p. 43.

1828. Exogyra costata. Morton, Acad. Nat. Sci. Philadelphia Jour., 1st ser., vol. 6, p. 85, pl. 6, figs. 1-4.

1830. Exogyra costata. Morton, Am. Jour. Sci., 1st ser., vol. 17, p. 284.

1834. Exogyra costata. Morton, Synopsis of the organic remains of the Cretaceous group of the United States, p. 55 , pl. 6 , figs. $1-4$.

1840. Exogyra costata. Troost, Fifth geological report on the State of Tennessee, p. 46.

1849. Exogyra costata. Roemer, Texas, p. 396.

1852. Exogyra costata. Roemer, Die Kreidebildungen von Texas, p. 72.

1857. Exogyra costata. Conrad, U. S. and Mexican Boundary Survey Rept., vol. 1, pt. 2, pp. 154, 155, pl..9, figs. $2 a, 2 b$, pl. 10, fig. 1 .

1858. Exogyra interrupta. Conrad, Acad. Nat. Sci. Philadelphia Jour., 2d ser., vol. 3, p. 330, pl. 34, fig. 15.

1858. Fxogyra costata. Emmons, Report on the North Carolina geological survey, p. 278, fig. A.

1860. Exogyra costata. Owen, Second report of a geological reconnaissance of the middle and southern counties of Arkansas, pl. 7, fig. 4.

1864. Exogyra costata. Meek, Check list of the invertebrate fossils of North America, Cretaceous and Jurassic, p. 6.

1868. Exogyra costata. Cook, Geology of New Jersey, p. 374, text fig.

1869. POstrea torosa. Coquand, Monographie du genre Ostrea, terrain crétacé, p. 38 , pl. 14, figs. 1-4; pl. 15, figs. 1,2 (part).

1871. Exogyra costata. Stoliczka, India Geol. Survey Mem., Palaeontologia Indica, Cretaceous fauna of southern India, vol. 3, p. 461, pl. 11, figs. 1-3; pl. 12, fig. 1 .

1877. Exogyra costata. Gabb, Acad. Nat. Sci. Philadelphia Proc. for' 1876, p. 323.

1884. Exogyra costata. White, U. S. Geol. Survey Fourth Ann. Rept., p. 304, pl. 57, figs. 1, 2.

1885. Exogyra costata. Whitfield, U. S. Geol. Survey Mon. 9, pp. 39-41, pl. 16, figs. 1, 2 (part). (Also published by New Jersey Geol. Survey, 1886.)

1896. Exogyra costata. Say, Bull. Am. Paleontology, vol. 1, p. 291 (No. 5, p. 21).

1901. Exogyra costata. Hill, U. S. Geol. Survey Twenty-first Ann. Rept., pt. 7, pl. 47, figs. 1, 1a.

1902. Exogyra costata. Hill and Vaughan, U. S. Geol. Survey Geol. Atlas, Austin folio (No. 76), illustration sheet, fig. 52.

1906. Exogyra costata. Böse, Inst. geol. México Bol. 24, pp. 51-54, pl. 6 , fig. 3 ; pl. 7 , fig. 1 ; pl. 8 , figs. 2 , 3 ; pl. 9 , fig. 3 .

1906. Exogyra costata. Veatch, U. S. Geol. Survey Prof. Paper 46, pl. 12, figs. 2, 2a.

1907. Exogyra costata. Weller, New Jersey Geol. Survey, Paleontology, vol. 4, pp. 456-458, pl. 47, fig. 1.

1914. Exogyra costata. Stephenson, U. S. Geol. Survey Prof. Paper 81 , p. 50 , pl. 16 , figs. 3 , 4 ; pl. 17 , figs. 1,2 ; pl. 18 ; pl. 19 , figs. $1-4$; pl. 20 , fig. 1 .

1916. Exogyra costata. Gardner, Maryland Geol. Survey, Upper Cretaceous, pp. 564-566, pl. 25, fig. 5 ; pl. 26 ; pl. 27 , figs. 1,2 .

1919. Exogyra costata. ' Böse, Texas Univ. Bull. 1902, p. 14.

Say in 1820 described this species as follows: 
$E$. costata, apex lateral, with about two volutions; inferior valve convex, costate, transversely corrugated, costae of the disk somewhat dichotomous, sometimes fornicated; within, a single profound cicatrix placed rather nearer to the inner side; hinge with two nearly parallel, profoundly excavated grooves, of which the inner one is shorter, and corrugated; superior valve flat, slightly concave, destitute of costae, outer half exhibiting the increments, outer edge abruptly reflected from the interior surface to the superior but not elevated above it; hinge with a single groove on the edge; cicatrix profound. Length, 4 inches; breadth, $31 / 2$ inches. Cabinet of the Academy of Natural Sciences, Peale's Museum. This interesting shell is the largest and most perfect of its class which has yet been found in the Ancient Alluvial deposit of New Jersey. It is not uncommon. I have seen many specimens. They vary somewhat in the costae, being sometimes almost antiquated, sometimes nearly smooth. The aged shells become extremely thick and ponderous.

\section{Stephenson describes the species as follows:}

Shell of adult specimens thick and massive, becoming ponderous in some overgrown specimens; subcircular to subovate in outline; dimensions of an average-sized specimen, length 105 millimeters, height 115 millimeters, convexity 65 millimeters; the dimensions of the largest specimen in the collections, length 162 millimeters, height 200 millimeters, convexity 100 millimeters; valves unequal. Left or lower valve much larger than right valve, convex, and attached in proximity to beak to an external object; the beak more or less deformed by the scar of attachment; apical portion of shell spirally coiled within the margin; hinge and other internal shell characters essentially the same as in Exogyra ponderusa Roemer; outer surface of shell characterized by regularly arranged, prominent, often rugged, radiating, entire or bifurcating costae, which in typical normal specimens extend in curves conforming. to the spiral twist of the shell from the beak to the margin; the costae are separated by depressions which are usually narrower than the costae themselves; in occasional nontypical specimens the costae are weakly developed and in large overgrown individuals the costae become faint or disappear entirely in the direction of the margin; in cross section the costae vary in shape from semicircular to squarish; the costae vary in maximum width on different adult individuals from 3 to 8 millimeters; many specimens are further ornamented by concentric imbricating growth lamellae, which vary greatly in prominence from mere growth lines to broad, thin projections, in some specimens extending outward from the summits of the costae in spinelike folds; in some specimens the summits of the costae are ornamented with slight protuberances; in most specimens there is a more or less distinctly marked umbonal edge extending from the back around to the posterior margin in a curve corresponding to the spiral twist of the shell; along the umbonal ridge the costae bifurcate frequently, those in front and below the ridge extending with a slight backward curve to the lower margin, and those above and to the rear of the ridge extending with a strong upward curve to the upper posterior margin. Upper or right valve flatly spiral, roughly disk-shaped or operculiform, the outer surface varying from slightly convex to slightly concave, the valve inclosed within and slightly depressed below the projecting margin of the lower valve; hinge and other internal shell characters essentially the same as in Exogyra ponderosa Roemer; beak depressed, not prominent; surface of shell ornamented with numerous concentric sharp-edged lamellae, separated by narrow, deep depressions; radiating costae absent or but faintly developed on most specimens but on some specimens are fairly prominent on upper posterior one-third of the shell surface.

The exact locality from which the type specimen of this species was taken is not known, but it is believed by Weller to have come from Mullica Hill, N. J., a Navesink marl (Monmouth group) locality. In general this species occurs in beds stratigraphically higher than those in which the species Exogyra ponderosa occurs, but there are apparent exceptions.

\section{Miss Gardner adds the following information:}

The representatives of the species occurring in the Middle Atlantic States are much less strongly costate than those of the Gulf. In the majority of adults found in Maryland the radial sculpture does not persist beyond the dorsal half of the shell, and even within that restricted area it does not heavily corrugate the shell, as in the typical southern $E$. costata. Indeed, the differences are so obvious and so constant that a subspecific separation would not seem amiss, but in that case the New Jersey and Maryland race must be regarded as typical.

Stoliczka has reported the form from the Ootatoor group of southern India, supposed by him to be correlated with the Cenomanian and lower Pläner of Europe. Judging from the figures, however, the Indian form is less convex and ponderous than the American, with a more regular outline and a less regular sculpture. It would be interesting, indeed, if this highly specialized form should occur in India, since it is not known either from the western United States or from the European continent.

A recent paper by Emil Böse ${ }^{83}$ states that Exogyra costata originated in the southwestern United States in the Buda limestone, of Cenomanian age, and extended up through the Navarro formation, of Campanian age. The best authorities on the Cretaceous of the United States say that Exogyra costata does not occur below the Navarro formation.

Occurrence: Ripley formation, Coon Creek, Sand Hill, Blue Cut, Gravel Hill, and other localities in Chester, Henderson, and McNairy counties, Tenn.

Collections: Maryland Geological Survey, New Jersey Geological Survey, U. S. National Museum, Philadelphia Academy of Natural Sciences, Yale University, and others.

Outside distribution: Monmouth and Matawan formations, Maryland. Monmouth group (Navesink marl, Redbank sand, and Tinton sand member of the Redbank), New Jersey. In the eastern Gulf region the species is generally distributed through the zone of Exogyra costata, which includes the Ripley formation (typical marine beds) of northern Mississippi and approximately the upper half or two-thirds of the Ripley formation (typical marine beds) of eastern Alabama and Georgia. In the Carolinas the species occurs throughout the Peedee sand. In Arkansas the species ranges through the Marlbrook marl, the Nacatoch sand, and the Arkadelphia clay. In Texas the species is a common fossil in the Navarro formation and its equivalent the "Webberville" formation. In Mexico the species occurs in the Cardenas division of the socalled lower Senonian. In southern India, in the' Ootatoor formation, Stoliczka has reported the species, but the form occurring there is probably distinct from $E$. costata.

${ }_{83}$ Böse, Emil, On a new Exogyra from the Del Rio clay and some observations on the evolution of Exogyra in the Texas Cretaceous: Texas Univ. Bull. 1902, pp. 1416,1919 


\section{Exogyra cancellata Stephenson}

Plate XVI, Figures 1-3

1914. Exogyra costata var. cancellata. Stephenson, U. S. Geol. Survey Prof. Paper 81, p. 53, pl. 20, figs. 2-4; pl. 21, figs. 1, 2, 1914 .

1916. Exogyra costata var. cancellata. Gardner, Maryland Geol. Survey, Upper Cretaceous, pp. 566-568, pl. 27, fig. 3, 1916.

1923. Exogyra cancellata. Stephenson, North Carolina Geol. and Ecen. Survey, vol. 5, pt. 1, p. 182, pl. 50, figs. 5,6 ; pl. 51 , figs. 1,2 .

Stephenson describes this species as follows:

Shell of adult moderately thick, subcircular to subovate in outline; dimensions of an average specimen, length 92 millimeters, height 89 millimeters, convexity 41 millimeters; dimensions of a rather large specimen, length 117 millimeters, height 123 millimeters, convexity 58 millimeters. Left or lower valve much larger than right valve and strongly convex; attached in proximity of beak to an external object, the beak usually somewhat deformed by the scar of attachment; general form, hinge characters, and other internal shell characters essentially the same as in Exogyra costata Say; surface of shell ornamented with more or less distinct, low, bifurcating, nodular costae, the nodes produced by concentric depressions regularly arranged in such a manner as to give to the surface of the shell a checkered or cancellated appearance; the nodes on the costae are in some specimens more prominently connected concentrically than in the direction of the radiating costae, thus producing distinct concentric ridges; in nontypical specimens the costae are weakly developed and there is a corresponding strong development of concentric growth lamellae; in adult specimens the costae apparently without exception become faint and disappear in the direction of the margin, there being an area bordering the margin varying in width on which concentric imbricating lamellae form the only ornamentation; extending from the beak to the posterior margin in a curve corresponding to the spiral twist of the shell there is a more or less distinctly defined shallow depressed area, which broadens gradually in the direction of the margin; along the posterior margin of this depression, which perhaps corresponds to the umbonal ridge in Exogyra costati Say, the radiating costae repeatedly bifurcate, those in front of this margin extending downward in the direction of the lower margin of the shell and those behind the margin extending upward in a rather sharp curve to the upper posterior margin of the shell. Upper or right valve operculiform, roughly ovate in outline and inclosed within the projecting margin of the lower valve; usually distinctly concave on outer surface and convex on inner surface; hinge and other internal characters essentially the same as in Exogyra costata Say; beak depressed, not prominent, with nearly flat spiral twist or coil; surface ornamented with numerous concentrically arranged sharp-edged lamellae, separated by deep, narrow depressions, the lamellae being more prominent toward the outer margin of the shell, the inner, strongly concave portion of the surface being nearly smooth; costae either absent or but very faintly developed toward postero-dorsal margin.

This variety has not previously been differentiated from the typical form of the species. However, it possesses a distinctive ornamentation, always recognizable, which justifies its recognition as a variety; there is even a suggestion that the form developed parallel to rather than from Exogyra costata Say, in which case it should, perhaps, be given specific and not varietal rank.

In the latest work cited Stephenson recognized this form as a distinct species.
Occurrence: Ripley formation, Dave Weeks place on Coon Creek, McNairy County, Tenn. Selma formation, Blue Cut, McNairy County, Tenn.

Collections: Maryland Geological Survey, U. S. National Museum, Philadelphia Academy of Natural Sciences.

Outside distribution: Monmouth group (Navesink marl?), New Jersey. Matawan and Monmouth formations, Maryland.

\section{Stephenson says}

This variety makes its first appearance approximately coincident with the initial appearance of the typical strongly costate forms-that is, at the base of the zone of Exogyra costata; it has not been found in association with typical specimens of Exogyra ponderosa Roemer. In the lowermost beds of its stratigraphic range, especially in Mississippi, it appears to exceed in numbers the typical costate forms. In the successively higher beds it appears to decrease in numbers, and it is absent, so far as known, from the upper 80 or 100 feet of strata in Mississippi and western Alabama, and probably from a somewhat greater thickness in the Chattahoochee region. In the Carolinas the form occurs in the Peedee sand, the known localities being near the base of that terrane-that is, near the base of the zone of Exogyra costata. In Arkansas the variety occurs abundantly in the Marlbrook marl. In Texas the variety has been obtained from three localities, all of which are probably near the base of the Navarro formation. The first locality is one-half mile north of Cooper, Delta County, and the second and third are 4 and $4 \frac{1}{2}$ miles, respectively, east of Crandall, Kaufman County. Three typical specimens of this variety, brought from Mexico in 1906 by Dr. T. W. Stanton, were given to him at San Luis Potosi and were said to have been collected from a locality near Ciudad del Maiz, State of San Luis Potosi.

\section{Gryphaea vesicularis (Lamarck)}

Plate XVII, Figures 1, 2; Plate XVIII, Figures 1, 2; Plate XIX, Figures 1, 2

1768. Species not named. Knorr, Sammlung von Merckwürdigkeiten der Natur, pt. 2, 1st sec., pl. B, IV, fig. 2.

1799. Species not named. Faujas de Saint-Fond, Histoire naturelle de la Montagne de St. Pierre de Maestricht, pl. 22, fig. 4; pl. 25, figs. 2, 5 .

1806. Ostrea vesicularis. Lamarck, Mus. hist. nat. Annales, vol. 8 , p. 160 , No. 5 .

1816. Species not named. William Smith, Strata identified by organized fossils, p. 7, pl. 3, figs. 5-7.

1819. Ostrea vesicularis. Lamarck, Histoire naturelle des animaux sans vertèbres, vol. 6, p. 219.

1820. Ostrea convexa. Say, Am. Jour. Sci., 1st ser., vol. 2, p. 42.

1822. Ostrea vesicularis. Brongniart, Description géologique des environs de Paris, pl. 3, fig. 5 .

1827. Ostrea vesicularis. Nilsson, Petrificata suecana, No. 2, p. 29, pl. 7, figs. 3-5; pl. 8, figs. 5, 6 .

1828. Gryphaea convexa. Morton, Acad. Nat. Sci. Philadelphia Jour., 1st ser., vol. 6, p. 79, pl. 4, figs. 1, 2.

1828. Gryphaea mutabilis. Morton, Acad. Nat. Sci. Philadelphia Jour., 1st ser., vol. 6 , pl. 81 , pl. 4 , fig. 3 .

1830. Gryphaea convexa. Morton, Am. Jour. Sci., 1st ser., vol. 17, p. 283.

1830. Gryphaea mutabilis. Morton, Am. Jour. Sci., 1st ser., vol. 17, p. 283.

1831. Gryphaea expansa. Sowerby, Geol. Soc. London Trans., 2 d ser., vol. 3 , pp. 349,418 , pl. 38 , fig. 5 .

1832. Ostrea vesicularis. Deshayes, Encyclopédie méthodique, Histoire naturelle des vers, vol. 2, p. 291. 
1833. Ostrea vesicularis. Goldfuss, Petrefacta Germaniae, vol. 2, p. 23, pl. 81, fig. 2. (Synonymy excluded.)

1834. Gryphaea convexa. Morton, Synopsis of organic remains of the Cretaceous group of the United States, p. 53, pl. 4, figs. 1, 2.

1834. Gryphaea mutabilis. Morton, Synopsis of the organic remains of the Cretaceous group of the United States, p. 53 , pl. 4 , fig. 3 .

1835. Pycnodonte radiata. Fischer de Waldheim, Soc. imp. nat. Moscou Bull., vol. 8, p. 119, pl. 1, fig. 20.

1835. Gryphaea dilatata. Phillips, Illustrations of the geology of Yorkshire, pl. 6, fig. 1.

1836. Ostrea vesicularis. Deshayes and Milne-Edwards, Histoire naturelle des animaux sans vertèbres par Lamarck, 2d ed., vol. 7, p. 246.

1837. Gryphaea vesicularis. Bronn, Lethaea geognostica, vol. 2, p. 670 , pl. 32 , fig. 1.

1837. Oslrea vesicularis. D'Archiac, Soc. géol. France Mém., vol. 2, p. 183.

1837. Ostrea vesicularis. Dujardin, Soc. géol. France Mém., vol. 2 , p. 229.

1837. Ostrea vesicularis. Hisinger, Lethaea svecica; p. 46, pl. 1.2, fig. 2.

1840. Gryphaea convexa. Troost, Fifth geological report on the State of Tennessee, p. 46.

1842. Ostrea vesicularis. Leymerie, Soc. géol. France Mém., vol. 5, p. 29.

1844. Ostrea vesicularis. D'Orbigny, in X. Hommaire de Hell, Les steppes de la Mer.Caspienne, vol. 3, Paléontologie, p. 441.

1846. Ostrea vesicularis. Reuss, Die Versteinerungen der böhmischen Kreideformation, pl. 29, figs. 21, 22; pl. 30 , figs. $1-8$.

1846. Ostrea vesicularis. Geinitz, Grundriss der Versteinerungskunde, pl. 20, fig. 18.

1847. Ostrea vesicularis. D'Orbigny, Paléontologie française, Terrains crétacés, vol. 3 , p. 742 , pl. 7 , fig. 1 .

1847. Ostrea vesicularis. Bayle, Cours de géologie à l'École nationale des ponts et chaussées, pl. 6, fig. 62 .

1851. Ostrea vesicularis. Leymerie, Soc. géol. France Mém., 2 d ser., vol. 4, p. 202, pl. 10, figs. 2, 3 .

1852. Gryphaea vesicularis. Bronn and Roemer, Lethaea geognostica, vol. 2, pt. 5, p. 264, pl. 32, fig. 1.

1852. Gryphaea vesicularis. Conrad, Official report of the United States expedition to explore the Dead Sea and the River Jordan, pl. 18, figs. 103, 104.

1860. Gryphaea vesicularis. Owen, Second report of a geological reconnaissance of the middle and southern counties of Arkansas, pl. 8, fig. 6 .

1863. Gryphaea vesicularis. Schafhäutl, Süd-Bayerns Lethaea geognostica, p. 143, pl. 12, figs. 5, 6 .

1864. Gryphaea vesicularis. Meek, Check list of the invertebrate fossils of North. America, Cretaceous and Jurassic, p. 6.

1868. Pycnodonte vesicularis. Cook, Geology of New Jersey, p. 374, text figs.

1868. Gryphaea vesicularis. Conrad, in Cook, Geology of New Jersey, p. 724.

1869. Ostrea vesicularis. Coquand, Monographie du genre Ostrea, terrain crétacé, p. 35, pl. 13, figs. 2-4, 10. (Not figs. 5-9.)

1869. Gryphaea vesicularis. Safford, Geology of Tennessee, $p$. 416.

1871. Gryphaea vesicularis. Stoliczka, India Geol. Survey Mem., Palaeontologia Indica, Cretaceous fauna of southern India, vol. 3 , p. 465 , pl. 42 , figs. $2-4$; pl. 43, fig. 1 ; pl. 45, figs. 7-12.

1878. Pycnodonte vesicularis. Bayle, Expl. carte géol. France, vol. 4 , atlas, pt. 1, pl. 135, figs. 1-7.
1884. Gryphaea vesicularis. White, U. S. Geol. Survey Fourth Ann. Rept., p. 303, pl. 48, figs. 1-5.

1885. Gryphaea vesicularis. Whitfield, U. S. Geol. Survey Mon. 9, p. 36, pl. 3. figs. 15,16 ; pl. 4, figs. $1-3$; pl. 5 . (Also published by New Jersey Geol. Survey, 1886.)

1897. Gryphaea vesicularis. Noetling, India Geol. Survey Mem., Palaeontologia Indica, ser. 16, vol. 1, p. 39, pl. 10 , figs. 1,2 .

1901. Gryphaea vesicularis. Imkeller, Palaeontographica, vol. 48 , p. 40 , pl. 2, figs. 2-4; pl. 3, figs. 7-9.

1901. Gryphaea vesicularis. Hill, U. S. Geol. Survey Twentyfirst Ann. Rept., pt. 7, pl. 47, fig. 2.

1902. Ostrea (Pycnodonte) vesicularis. Choffat, Faune cretacique du Portugal, vol. 1, ser. 3, p. 103, pl. 2, fig. 18.

1902. Gryphaea vesicularis. Wanner, Palaeontographica, vol. 30 , pt. 2 , No. 3 , p. 119 , pl. 17, figs. 10-12.

1902. Gryphaea vesicularis. Taff, U. S. Geol. Survey Twentysecond Ann. Rept., pt. 3, -pl. 50, figs. 1-3; pl. 51, figs. 1, 1a; pl. 52, figs. 1, 1a.

1902. Gryphaea vesicularis. Hill and Vaughan, U. S. Geol. Survey. Geol. Atlas, Austin folio (No. 76), fig. 51.

1904. Pycnodonte vesicularis. Douville, Mission scientifique en Perse, par J. de Morgan, vol. 3, pt. 4, Paléontologie, p. 278, pl. 36, fig. 23.

1905. Gryphaea convexa. Johnson, Ácad. Nat. Sci. Philadelphia Proc., vol. 57, p. 11.

1905. Gryphaea mutabilis. Johnson, Acad. Nat. Sci. Philadelphia Proc., vol. 57, p. 11.

1906. Gryphaea vesicularis. Böse, Inst. geol. México Bol. 24, p. 49, pl. 4, figs. $1-3$; pl. 7, fig. 2 ; pl. 9, fig. 4 ; pl. 12, fig. 6.

1906. Gryphaea vesicularis. Veatch, U. S. Geol. Survey Prof. Paper 46, pl. 10, figs. 1-2a.

1906. Ostrea (Gryphaea) vesicularis. Boule and Trevenin, Annales de paléontologie, vol. 1, p. 49 (7), pl. 2, fig. 3.

1907. Gryphaea convexa. Weller, New Jersey Geol. Survey, Paleontology, vol. 4, p. 451, pl. 45, figs, 1, 2, 1907.

1907. Gryphaea mutabilis. Weller; New Jersey Geol. Survey, Paleontology, vol. 4, p. 452, pl. 46, fig. 1 .

1907. Gryphaea dissimilaris. Weller, New Jersey Geol. Survey, Paleontology, vol. 4 , p. 453 , pl. 46 , figs. $2,3$.

1913. Gryphaea vesicularis. Woods, A monograph of the Cretaceous Lamellibranchia of England, vol. 2, pt. 9, p. 360 , pl. 55, figs. 4-9; text figs. 143-182, Palaeont. Soc. London.

1914. Gryphaea vesicularis. Stephenson, U. S. Geol. Survey Prof. Paper 81; p. 24, tables 2-8.

1916. Gryphaea (Pycnodonte) vesicularis. Gardner, Maryland Geol. Survey, Upper Cretaceous, pp. 572-578, pl. 28; pl. 29, figs. 1, 2, 3; pl. 31 ; pl. 32; pl. 33, figs. 1-3.

Miss Gardner describes this species as follows:

Shell strongly inequivalve, subequilateral, as a rule, subcircular to semicircular in outline, often more or less auriculate posteriorly; thin to ponderous; umbones central or anterior, orthogyrate, that of the left valve often strongly inflated and turned inward; left valve convex, often conspicuously so, attached in the umbonal region; right valve usually a little smaller than the left, flattened or concave; incremental sculpture well defined in both valves, the component layers so obvious in the ponderous individuals that they have the appearance of having slipped one over the other, the free ventral edges being visible on the external surface and their dorsal edges on the interior; radial sculpture absent upon the left valve but of ten quite strongly developed upon the right; ligament area trigonal, the medial sulcus broad and shallow, indenting the inner margin, area of the left valve strongly undercut, that of the right valve truncated; the ligament area of the two valves forming a V-shaped trough, thus allowing the cover valve to 
be opened quite widely; vermicular corrugations developed on either side of the ligament pit; muscle scar very distinct, even profound in some of the more ponderous individuals, placed a little behind the median line and quite high up.

No Upper Cretaceous group is more sadly in need of monographic treatment than that of $P$. vesicularis (Lamarck), nor does any bear promise of yielding more interesting results in general correlations. The group is world-wide in its distribution-it has been reported from the east coast, the Gulf, and the western interior of North America, England, central Europe, Russia, and southern India and is usually one of the most prominent elements in the faunas in which it occurs. This wealth of material from widely separated localities has made the problem of separating geographic from chronologic influences an exceedingly delicate one and a problem which demands for its proper solution a consideration of all the types of variation at all the occurrences.

Occurrence: Ripley formation; Coon Creek, Sand Hill, Blue Cut, and Enville, McNairy and Henderson counties, Tenn. Selma formation, Gravel Hill, Morris Chapel, Blue Cut, McNairy County, Tenn.

Collections: Maryland Geological Survey, New Jersey Geological Survey, Geological Survey of India, Philadelphia Academy of Natural Sciences, U. S. National Museum, British Museum, Vanderbilt University, Yale University.

Outside distribution: Matawan and Monmouth formations of Delaware and Maryland ("Gryphaea convexa (Say)"). Monmouth group (Navesink marl) ("Gryphaea mutabilis Morton"), Matawan group (Marshalltown formation) ("Gryphaea dissimilaris Weller"'), and Rancocas group (Hornerstown marl), New Jersey.

"Gryphaea vesicularis Lamarck," sensu lato: Black Creek formation and Peedee sand, North Carolina and South Carolina. Eutaw formation (Tombigbee sand member), Exogyra ponderosa zone, Alcorn County, Miss. Ripley formation, Exogyra ponderosa zone, Georgia; Exogyra costata zone, Georgia and Tennessee, Wilcox and Pike counties, Chattahoochee River, Eufaula, and Tombigbee River, Wilcox and Sumter counties, Ala., east-central Mississippi, and Lee, Pontotoc, Chickasaw, Clay, Alcorn, and Union counties, Miss.; extreme top of Exogyra costata zone, Pataula Creek, Ga., Chattahoochee River, Ala., and Lee, Chickasaw, and Prentiss counties, Miss. Pierre shale, western interior, rare and of doubtful identity. Senonian, Mexico, England, France, Germany, Bohemia, Switzerland, Spain, Portugal, Belgium, Russia, Poland, Egypt, Algiers, and Syria. Arialoor formation, southern India.

\section{SuperfamilyăTRIGONIACEA}

\section{Family TRIGONIIDAE}

\section{Genus TRIGONIA Bruguière}

\section{' $\quad$ Trigonia thoracica Morton}

Plate XX, Figures 1, 2

1834. Trigonia thoracia. Morton, Synopsis of the organic remains of the Cretaceous group of the United States, p. 65 , pl. 15, fig. 1 .
1852. Trigonia thoracica. Roemer, Die Kriedebildungen von Texas, p. 52.

1860. Trigonia thoracica. Gabb, Acad. Nat. Sci. Philadelphia Jour., 2d ser., vol. 4, p. 34, pl. 47, fig. 10.

1861. Trigonia thoracica. Gabb, Synopsis of the Mollusca of the Cretaceous formation, p. 177 (Am. Philos. Soc. Proc., vol. 8, p. 23).

1864. Trigonia thoracica. Meek, Check list of the invertebrate fossils of North America, Cretaceous and Jurassic, p. 9.

1868. Trigonia thoracica. Conrad, in Cook, Geology of New Jersey, p. 725.

1870. Trigonia limbata. Credner, Deutsche geol. Gesell. Zeitschr., vol. 22, p. 23.

1876. Trigonia thoracica. Gabb, Acad. Nat. Sci. Philadelphia Proc. for 1876, p. 32.

1885. Trigonia mortoni. Whitfield, U. S. Geol. Survey Mon. 9, p. 112 , pl. 14, figs. 5-6. (Also published by New Jersey Geol. Survey, 1886.)

1905. Trigonia thoracica. Johnson, Acad. Nat. Sci. Philadelphia Proc., vol. 57, p. 11.

1907. Trigonia thoracica. Weller, New Jersey Geol. Survey, Paleonotology, vol. 4, p. 460, pl. 48, figs. 1-4.

1914. Trigonia thoracica. Stephenson, U. S. Geol. Survey Prof. Paper 81, p. 24, table 2.

Morton characterized this species as follows:

Specific character: Obovate, with oblique very prominent ribs, about 12 in number.

Gabb in 1860 described this species as follows:

Inequilateral, truncated posteriorly, alated; obliquely ribbed, the most anterior ribs almost parallel with lunule; ribs about 17 , compressed laterally, nodulose except near the origin, where they are entire and sharp; edge deeply serrate, each process corresponding to one of the ribs; anterior end slightly truncated obliquely; lunule marked by a series of finely nodulated ribs, which point posteriorly; surface between the ribs marked by delicate lines of growth.

Locality and position: "Ripley group," Tennessee. This fossil has been also found in the Ripley group in Alabama at Eufaula, Barbour County, in the white limestone, Prairie Bluff, Ala., and in the marl of New Jersey.

This beautiful species can not be confounded. with $T$. alaeformis if we examine the relations of the ribs. In our species, except for the swell of the shell, they are straight. In the figure in Sowerby's Mineral Conchology the ribs are sinuous, 26 in number, thicker, and not so nodulose. They are all nearly the same angle with the lunule, which is nearly twice the width of that of $T$. thoracica. In this the most anterior ribs form a very acute angle with the lunule, and the ribs become more and more faint until the last is threadlike and hardly visible, while in the former species they are thick and robust to the extremity of the shell. An important difference is visible in the shape. The beak is proportionally smaller and the edge much more serrate in this than in the former species. While $T$. alaeformis is very elongate anteriorly, T. thoracica is obliquely truncated backward. They both have a small plate inside the shell, near the anterior extremity, but it is smaller in $T$. thoracica. The anterior muscular impression in our species is rounded, quadrilateral; in Sowerby's it is crescentic, with the base up.

This shell also differs from $T$. emoryi Conrad in the latter being more inflated, in having at least 28 ribs, being proportionally more elongated anteriorly, and in having a much wider lunule, and the ribs on the lunule inclining first anteriorly and then bending back, while in this species they have a backward inclination from their origin. 
Weller gives the following details:

Shell large, the dimensions of an average-sized individual being: Length, 48 millimeters; height, 42 millimeters; convexity, 11 millimeters. Ovate, subtrigonal in outline, the valves moderately convex in front, becoming compressed posteriorly; the beaks nearly anterior, slightly incurved. Anterior margin broadly rounded, often becoming a little straightened as it approaches the posterior extremity of the shell; posterior margin obliquely subtruncate above; dorsal margin gently concave from the beak to the posterior hinge extremity. Surface of the valve divided into two portions by an angular curved furrow, passing backward from just behind the beak, subparallel with the dorsal margin, to a point in the posterior margin of the shell a short distance below the posterior hinge extremity; the lower portion of the valve constitutes much the greater part and is marked by about 15 ribs, about 10 of which are very strong, subangular, more or less nodose, with broad concave interspaces, and occupying the greater portion of the shell; the more anterior of these ribs are shorter and curve strongly forward; the more posterior ones curve slightly downward; between these strong ribs and the curved divisional furrow is a subtriangular area occupied by much smaller, somewhat nodose furrows, which usually have a more or less distinct upward curvature as they approach the posterior border. The upper , portion of the valves is divided into two regions, being nearly in the plane of the valve below and abruptly inflected above to the hinge line to form a long, rather broad escutcheon; this region is marked with 12 or 14 subangular ribs, which originate along the divisional furrow, curving backward and upward across the escutcheon to the hinge line. The entire surface is also marked by more or less irregular concentric lines of growth.

This species is very common at Coon Creek and is represented in the collections by dozens of perfect specimens, which show all the internal characters of these very beautiful shells. The genus Trigonia is one of the most prolific and most widely distributed Mesozoic genera. In the Cretaceous of England alone, as shown by Lycett, ${ }^{84}$ there are about 40 species of this genus; probably as many more species of this genus are now known from the Cretaceous of the rest of the world. The following forms in general outline and ornamentation resemble Trigonia thoracica Morton:

Trigonia emoryi Conrad, from the Cenomanian of Cerro de Muleros, Mexico. ${ }^{85}$

Trigonia scabra Lamarck, from the Senonian of Tunis. ${ }^{86}$

Trigonia vaalsiensis Böhm, from the Aachen Cretaceous of Vaals, Germany. ${ }^{87}$

Trigonia shepstonei Griesbach, from the Senonian of Pondoland, South Africa. ${ }^{88}$

Occurrence: Ripley formation, Coon Creek, Sand Hill, McNairy County, Tenn.

Collections: Maryland Geological . Survey, U. S. National Museum, Yale University, New Jersey Geological Survey, Vanderbilt University.

"84 Lycett, John, A monograph of the British fossil Trigoniae, Palaeont. Soc. London, 1879.

${ }_{80}$ Böso, Emil, Monografía geológica y paleontológica del Cerro de Muleros: Inst. geol. México Bol. 25, p. 121, pl. 24, figs. 1-5; pl. 25, figs. 1, 3, 5, 1910.

${ }^{80}$ Pervinquière, L., Étude do paléontologie tunisienne, vol. 2, p. 120, pl. 15, figs. $1-3,1912$.

87 Holzapfel, Eduard, Die Mollusken der Aachener Kreide: Palaeontographica, Band 35, p. 198, pl. 21, figs. 1-6, 1889 .

${ }_{88}$ Woods, Henry, Cretaceous fauna of Pondoland: South African Mus. Annals, vol. 4, pl. 7, p. 292, pl. 35, flgs. 1, 2, 1906 . ,
Outside distribution: Monmouth group, New Jersey. Ripley formation, Alabama and Mississippi, and contemporaneous deposits in Arkansas and Texas.

\section{Trigonia eufalensis Gabb}

Plate XX, Figures 3, 4

1860. Trigonia eufalensis. Gabb, Acad. Nat. Sci. Philadelphia Jour., 2d ser., vol. 4, p. 396, pl. 68, fig. 32 .

1864. Trigonia eufalensis. Meek, Check list of the invertebrate fossils of North America, Cretaceous and Jurassic, p. 9.

1868. Trigonia eufalensis. Conrad, in Cook, Geology of New Jersey, p. 725 .

1885. Trigonia eufalensis. Whitfield, U. S. Geol. Survey Mon. 9, p. 113. pl. 14, figs. 1-4. (Also published by New Jersey Geol. Survey, 1886.)

1905. Trigonia eufalensis. Johnson, Acad. Nat. Sci. Philadelphia Proc., vol. 57; p. 11.

1907. Trigonia eufalensis. Weller, New Jersey Geol. Survey, Paleontology, vol. 4, p. 462, pl. 48, figs. 5-10.

1914. Trigonia eufalensis. Stephenson, U. S. Geol. Survey Prof. Paper 81, p. 24, tables 2-8.

1916. Trigonia eufalensis. Gardner, Maryland Geol. Survey, Upper Cretaceous, p. 582, pl. 34, figs. 1, 2.

Gabb describes this species as follows:

Subtriangular; resembles $T$. alaeformis 'Sowerby in outline, not quite so elongate anteriorly; beaks posterior; lunule distinct; surface marked by about 14 ribs, the more anterior of which proceed from the lunule anteriorly and then cross the shell at right angles with the lunule, exhibiting a tendency to being nodose, especially near the lunule; lunule marked by 10 or 12 transverse ribs; cardinal margin somewhat incurved, anterior elongate and subbiangular, basal sinuous and deeply serrate, posterior regularly rounded; internally, hinge teeth small, muscular impressions deep; pallial line entire; a small toothlike ridge or process extends along the middle of the alation, as in T. alaeformis.

Type locality: Eufaula, Ala.

Miss Gardner adds the following details:

Shell thick, heavy, prismatic, rudely trigonal in outline, moderately convex; umbones anterior, incurved, opisthodetic, flattened upon their summits but prominent by reason of their position at the apex of an angle of approximately $120^{\circ}$; lunule not differentiated, escutcheon defined, not only by the sculpture but also by an abrupt change in the plane of the shell; anterior portion of the shell sculptured by 12 to 15 prominent concentric ridges, rather sharply rounded upon their summits, dorsally inclined, especially in the umbonal region, more prominent, symmetrical, and feebly rugose ventrally, regularly arranged but much more closely spaced along the concave margin than the convex; ligament marginal, the groove in which it was lodged short linear and opisthodetic; cardinal teeth of left valve massive, trigonal, transversely striated, inner faces of hinge margins also striated in order to clasp the divergent teeth of the right valve; muscle impressions deeply excavated, the anterior slightly more so than the posterior; pallial line simple, distant from the hinge margin.

This species is the smallest and most abundant member of this remarkable genus within the confines of Marlyand. It is separated from $T$. cerulea Whitfield by the more prominent umbones, the more convex posterior dorsal, the more attenuated posterior extremity and the fewer rugose and relatively coarser external costae.

Occurrence: Ripley formation, Dave Weeks place on Coon Creek, McNairy County, Tenn. 
Collections: Maryland Geological Survey, New Jersey Geological Survey, Philadelphia Academy of Natural Sciences, U. S. National Museum.

Outside distribution: Monmouth formation, (?) 2 miles west of Delaware City, Del., on John Higgins farm; (?) Bohemia Mills, Cecil County, Md.; mouth of Turner's Creek, Kent County, Md.; Brightseat, Brooks estate near Seat Pleasant, Friendly, 1 mile west of Friendly, McNeys Corners, and Fort Washington, all in Prince Georges County, Md. Matawan group (Merchantville clay, Woodbury clay, and Wenonah sand), New Jersey. Black Creek formation, North Carolina and South Carolina. Peedee sand, North Carolina and South Carolina. Eutaw formation (Tombigbee sand member), Exogyra ponderosa zone, Mortoniceras subzone, Georgia. Ripley formation, Exogyra costata zone, Georgia and Eufaula, Ala.; extreme top of Exogyra costata zone, Pataula Creek, Ga.

\section{Superfamily PECTINACEA}

\section{Family PECTINIDAE}

\section{Genus PECTEN Müller}

\section{Pecten argillensis Conrad}

Plate XX, Figures 8, 9

1860. Pecten argillensis. Conrad, Acad. Nat. Sci. Philadelphia Jour., 2d ser., vol. 4, p. 283.

1864. Pecten argillensis. Meek, Check list of the invertebrate fossils of North America, Cretaceous and Jurassic, p. 7.

1869. Camptonectes bellisculptus. Conrad, Am. Jour. Conchology, vol. 5, p. 99, pl. 9, fig. 11.

1885. Camptonectes (Amusium) burlingtonensis. Whitfield, U.S. Geol. Survey Mon. 9, p. 53, pl. 8, figs. 3-7, 9 (not fig. 8) (part; not Pecten burlingtonensis Gabb, 1860). (Also published by New Jersey Geol. Survey, 1886.)

1905. Pecten bellisculptus. Johnson, Acad. Nat. Sci. Philadelphia Proc., vol. 57, p. 11.

1907. Pecten argillensis. Weller, New Jersey Geol. Survey, Paleontology, vol. 4, p. 472, pl. 49, figs. 1-4.

1914. Pecten argillensis. Stephenson, U. S. Geol. Survey Prof. Paper 81, p. 24, tables 2-8.

1916. Pecten argillensis. Gardner, Maryland Geol. Survey, Upper Cretaceous, p. 588, pl. 34, figs. 3-5.

Conrad in 1860 characterized this species as follows:

Suborbicular, very thin, compressed; radiated only on the upper part with minute lines; disk covered with closely. arranged fine lamelliform striae, except on the umbo and adjacent parts, where they are distant; posterior margin opposite the ear carinated. (Upper valve.)

Type locality: Owl Creek, Tippah County, Miss.

Miss Gardner gives the following details:

Shell rather thin and fragile, compressed, subequivalve; outline, exclusive of the auricles, a sector of approximately $90^{\circ}$; hinge line straight, a little more than half as wide as the shell; aúricles broad but rather low; surface ornamentation elaborate but not conspicuous, radial sculpture of finely incised lines, 2 to 4 to the millimeter, on the disks of the adults, straight in the medial portion but sweeping in gentle-curves toward the lateral margins, deeper and a little broader posteriorly than anteriorly; concentric lines 30 to 40 in number, overriding and intercepting the radials, finely and evenly crenulated and in the umbonal region of perfectly preserved adults minutely moniliform; auricles very unequal, the anterior broader and relatively lower than the posterior; posterior auricle sculptured with approximately 15 coarse lirations running oblique to the hinge margin, rendered minutely scabrous by the overriding incrementals; anterior auricle long and narrow, alate in outline, the striations radiating from the umbonal extremity, sweeping in rather abrupt curves to the dorsal margin; byssal sinus narrow and very deep; the area between the auricle and the disk not sculptured; characters of interior not known.

Pecten argillensis is identical with Pecten bellisculptus Conrad, which was doubtless described from a type on which the delicate beaded sculpture was better preserved than on the type of $P$. argillensis Conrad. The species is one of the most abundant representatives of its genus in Maryland, but unfortunately it is so fragile that perfectly preserved individuals are obtainable only with the greatest difficulty.

In some respects the Coon Creek representative of this species resembles Pecten virgatus D'Orbigny, ${ }^{89}$ from the Cenomanian of France, and Pecten curvatus Geinitz, ${ }^{90}$ from the Cenomanian of England and Germany, but differs from both these European forms in having a well-defined concentric sculpture.

Occurrence: Ripley formation, Dave Weeks place on Coon Creek, McNairy County, Tenn.

Collections: Maryland Geological Survey, New Jersey Geological Survey, U. S. National Museum, Philadelphia Academy of Natural Sciences.

Outside distribution: Monmouth formation, Brightseat, Brooks estate near Seat Pleasant, and 1 mile west of Friendly, all in Prince Georges County, Md. Matawan group (Merchantville clay, Woodbury clay, Marshalltown formation, and Wenonah sand), New Jersey. Monmouth group (Navesink marl), New Jersey. (?) Black Creek formation, North Carolina and South Carolina. Eutaw formation (Tombigbee sand member), Exogyra ponderosa zone, Mortoniceras subzone, Lowndes County and (?) Prentiss County, Miss. Ripley formation, Exogyra costata zone, Georgia, Eufaula, Ala., and Chickasaw, Union, and Tippah counties, Miss.; extreme top of Exogyra costata zone, Pataula Creek, Ga., Chattahoochee River, Ala., and Lowndes and Union counties, Miss.

\section{Pecten simplicius Conrad}

\section{Plate XX, Figure 7}

1860. Pecten simplicius. Conrad, Acad. Nat. Sci. Philadelphia Jour., 2d ser., vol. 4, p. 283, pl. 46, fig. 44.

1864. Sincyclonema? simplicius. Meek, Check list of the invertebrate fossils of North America, Cretaceous and Jurassic, p. 7.

1868. Pecten simplicius. Conrad, in Cook, Geology of New Jersey, p. 725.

1877. Sincyclonema simplicius. Gabb, Acad. Nat. Sci. Philadelphia Proc. for 1876, p. 319.

80 D’Orbigny, Alcide, Paléontologie française, Terrain crétacê, vol. 3, p. 602, pl. 334, figs. 7-10.

${ }^{\circ 0}$ Woods, Henry, A monograph of the Cretaceous Lamellibranchia of England. vol. 1, p. 159, pl. 29, fig. 7, pl. 37, fig. 16, Palaeont. Soc. London, 1904. 
1885. Amusium simplicum. Whitfield, U. S. Geol. :Survey Mon. 9, p. 51, pl. 7, figs. 11, 12. (Also published by New Jersey Geol. Survey, 1886.)

1907. Pecten simplicius. Weller, New Jersey Geol. Survey, Paleontology, vol. 4, p. 480 , pl. 51, fig. 6

1914. Pecten simplicius. Stephenson, U. S. Geol. Survey Prof. Paper 81, tables 2, 7, 8.

1916. Pecten simplicius. Gardner, Maryland Geol. Survey, Upper Cretaceous, p. 595, pl. 34, figs. 8, 9.

Conrad in 1860 characterized this species as follows:

Ovate, thin, smooth and shining; ears moderate, nearly equal; both valves slightly convex; the upper valve slightly tumid on the umbo; inner margin minutely crenulated.

Type locality: Eufaula, Ala., or Tippah County, Miss.

Miss Gardner describes this species as follows:

Shell small, smooth, lustrous, moderately" compressed, the left valve a little more so than the right; anterior and posterior lateral margins converging at an angle of from $70^{\circ}$ to $90^{\circ}$, base broadly and evenly arcuate; hinge line straight, a little less than half the latitude of the shell, auricles small, trigonal, the anterior slightly larger than the posterior and sinuated in the right valve to accommodate the byssus; sinuses between the auricles and the disk clearly defined; external surface highly polished, smooth excepting for faint incremental striations and an occasional microscopically fine radial shagreening; characters of the interior unknown.

This Pecten, though small, is a conspicuous fossil in the Cretaceous marls of the eastern United States by reason of its wide distribution and its shining surface. Pecten simplicius Conrad resembles very closely and is perhaps the analogue of Pecten membranaceus Nilsson, ${ }^{01}$ one of the commonest fossils of the Senonian and Turonian of Europe and a form that has been recorded from many of the remote Upper Cretaceous provinces of the world. Woods ${ }^{22}$ gives a synonymy of nearly thirty authors who have identified and figured Pecten membranaceus Nilsson from Sweden, Hanover, Maastricht, Aachen, Saxony, Bohemia, Lemberg, Alpine Gosau, Bavaria, South India, New Zealand, Cockburn Islands and other places. Pecten simplicius is not known from the Upper Cretaceous of the western interior region of the United States. Perhaps the most closely related form of that region is Pecten rigida Hall and Meek, ${ }^{{ }^{3}}$ a form that may be readily identified by its sculpture.

Occurrence: Ripley formation, Dave Weeks place on Coon Creek, McNairy County, Tenn.

Collections: Maryland Geological Survey, Philadelphia Academy of Natural Sciences, U. S. National Museum:

Outside distribution: Matawan formation, Ulm- steads Point, Anne Arundel County, Md. Monmouth - formation, Brightseat, Brooks estate near Seat 'Pleasant, Friendly, 1 mile west of Friendly, and

\footnotetext{
01 Nilsson, S., Petrificata suecana, p. 23, pl. 9, fig. 16, 1827.

${ }^{02}$ Woods, Henry, The Cretaceous faunas of the northeastern part of the south island of Now Zoaland: New Zealand Geol. Survey Paleont. Bull. 4, p. 25, 1917

is Meek, F. B., A report on the invertebratc Cretaceous and Tertiary fossils of the upper Missouri.country: U. S. Geol. Survey Terr. Rept., vol. 9," p. 27, pl. 10, figs. 5a, b, 1876.
}

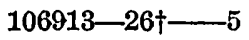

McNeys Corners, all in Prince Georges County, Md. Monmouth group (Redbank sand and its Tinton sand member), New Jersey. Black Creek formation, North Carolina and South Carolina. Eutaw formation (Tombigbee sand member), Exogyra ponderosa zone, Mortoniceras subzone, Georgia. Ripley formation, Exogyra costata zone, Georgia and Eufaula, Ala.; extreme top of Exogyra costata zone, Pataula Creek, Ga., Chattahoochee River, Ala., and Lowndes County, Miss.

\section{Pecten burlingtonensis Gabb \\ Plate XX, Figures 5, 6, 10, 11}

1860. Pecten burlingtonensis. Gabb, Acad. Nat. Sci. Philadelphia Jour., 2d ser., vol. 4, p. 304, pl. 48, fig. 25.

1861. Pecten burlingtonensis. Gabb, Synopsis of the Mol. lusca of the Cretaceous formation, p. 157 .(Am. Philos. Soc. Proc., vol. 8, p. 213).

1864. Pecten burlingtonensis. Meek, Check list of the invertebrate fossils of North America, Cretaceous and Jurassic, p. 7.

1868. Syncyclonema burlingtonensis. Conrad, in Cook, Geology of New Jersey, p. 725.

1870. Camptonectes burlingtonensis. Conrad, Am. Jour. Con. chologý, vol. 6 , p. 76 .

1885. Camptonectes (Amusium) burlingtonensis. Whitfield, U. S. Geol. Survey Mon. 9, p. 53, pl. 8, figs. 7, 8. (Also published by New Jersey Geol. Survey, 1886.)

1905. Pecten burlingtonensis. Johnson, Acad. Nat. Sci. Philadelphia Proc., vol. 57, p. 11.

1905. Pecten perlamellosus. Johnson, Acad. Nat. Sci. Philadelphia Proc., vol. 57, p. 12.

1907. Pecten burlingtonensis. Weller, New Jersey Geol. Survey, Paleontology, vol. 4, p. 470, pl. 49. figs. 5-9, 1907.

Weller describes this species as follows:

Shell in large individuals attaining a height of 57 millimeters and $a$ width of 62 millimeters; hinge line straight, one-half or a little less than one-half the width of the shell, with a central triangular cartilage pit, the body of the shell broadly subovate in outline, the auriculations moderately large and nearly equal in size; the cardinal slopes a little concave, diverging from the beak at an angle of $90^{\circ}$ or more, the shoulders of the valves prominent and above the middle of the height of the shell. Left valve depressed convex, with the auriculations sharply differentiated. Right valve nearly flat, with a moderately deep byssal sinus. Surface of the valves marked by concentric bands, which are continuous across the auriculations, and by exceedingly fine, impressed, radiating striae, which are continuous upon the auriculations and the umbo, where they are about equal in width with the interspaces, but on the outer portion of the shell they become more or less discontinuous, the inner portion of the concentric bands often being nearly smooth, while on the outer portion they are completely striate but with the interspaces between the striae broader than the striae themselves.

This species is common at Coon Creek and is represented in the collections by perfect specimens that show all the shell characters of both valves. The external sculpture shows much variation. Usually the sharp concentric lines are more widely spaced on the left valve than they are on the right. The byssal notch on the right valve is very deep and is serrate at its base. The adductor scar is subovate and situated in the upper half of the valve near the hinge. 
Occurrence: Ripley formation, Dave Weeks place on Coon Creek, McNairy County, Tenn.

Collections: New Jersey Geological Survey, Philadelphia Academy of Natural Sciences, U. S. National Museum.

Outside distribution: Monmouth group, New Jersey.

\section{Pecten quinquecostatus Sowerby}

Plate XXI, Figures 1-5

1814. Pecten quinquecostatus. Sowerby, Mineral conchology of Great Britain, vol. 1, p. 122, pl. 56, figs. 4-8.

1819. Pecten versicostatus. Lamarck, Histoire naturelle des animaux sans vertèbres, vol. 6, p. 181.

1822. Pecten quinquecostatus. Brongniart, Desscription géologique des environs de Paris, pl. 4, fig. 1.

1827. Pecten quinquecostatus. Nilsson, Petrificata suecana, p. 19, pl. 9, fig. 8; pl. 10, fig. 7 .

1830. Pecten quinquecostatus. Morton, Am. Jour. Sci., 1st ser., vol. 17 , p. 285 ; vol. 18 , pl. 3 ; fig. 5 .

1832. Pecten versicostatus. Deshayes, Encyclopédie méthodique, Histoire naturelle des vers, vol. 3, p. 727.

1834. Pecten quinquecostatus. Morton, Synopsis of the organic remains of the Cretaceous group of the United States, p. 57 , pl. 19 , fig. 1 .

1836. Pecten quinquecostatus. Goldfuss, Petrefacta Germaniae, vol. 2 , pl. 93, fig. 1 .

1838. Pecten quinquecostatus. Bronn, Lethaea geognostica, vol. 2 , pp. $678-680$, pl. 30 , fig. 17.

1846. Janira quinquecostatus. D'Orbigny, Paléontologie française, Terrains crétacés, vol. 3 , p. 632, pl. 444, figs. 1-5.

1850. Janira mortoni. D'Orbigny, Prodrome de paléontologie stratigraphique, vol. 2, p. 253.

1862. Neithea mortoni. Gabb, Acad. Nat. Sci. Philadelphia Proc. for 1861, p. 365 .

1864. Neithea mortoni. Meek, Check list of the invertebrate fossils of North America, Cretaceous and Jurassic, p. 7.

1868. Neithea mortoni. Conrad, in Cook, Geology of New Jersey, p. 725.

1870. Pecten quadricostatus. Credner, Deutsche geol. Gesel्. Zeitschr., Band 22, p. 232.

1871. Vola quinquecostata. Stoliczka, India Geol.' Survey Mem., Palaeontologia Indica, Cretaceous fauna of southern India, vol. 3 , p. 437, pl. 31, figs. 1-6; pl. 38, figs. 4-9.

1885. Neithea quinquecostata. Whitfield, U. S. Geol. Survey Mon. 9, p. 56, pl. 8, figs. 12-14. (Also published by New Jersey Geol. Survey, 1886.)

1903. Pecten quinquecostatus. Woods, A monograph of the Cretaceous Lamellibranchia of England, vol. 1, p. 202, pl. 39, figs. $14-17$; pl. 40 , figs. 1-5, Palaeont. Soc. London.

1906. Pecten quinquecostatus. Woods, South African Mus. Annals, vol. 4, pt. 7, p. 298, pl. 25, fig. 14, 1906.

1907. Neithea quinquecostata. Weller, New Jersey Geol. Survey, Paleontology, vol. 4, p. 481, pl. 51, figs. 7-12, 1907.

1914. Pecten quinquecostatus. Stephenson, U. S. Geol. Survey Prof. Paper 81, p. 24, tables 2-9, 1914.

1916. Pecten quinquecostatus. Gardner, Maryland Geol. Survey, Upper Cretaceous, p. 596, pl. 34, fig. 10, 1916.

Sowerby described this species as follows:

Subtriangular, rather oblique, front semicircular, toothed; convex valves gibbous, ribbed, principal costae six, with four lesser ones between each; surface finely transversely striated. Upper valve flat-toothed. The obliquity of this shell is slight, the length not much greater than the width; the lines of growth frequently being deep and crossed by the ribs give the shell a fringed or furbelowed aspect; the flat valve has diverging striae and notches corresponding in number with the costae upon the hollow valve. The whole surface is covered with minute transverse striae, which in the chalk specimens are often nearly obliterated. Figures 4 and 5 are from the Sussex chalk near Lewes, by favor of G. A. Mantell, Esq.; they very much accord with those of the greensand from Wiltshire, figured below, but appear to be longer and to have the transverse striae of growth very remarkable. The shell represented at Figure 5 is a curiosity, showing the inner side of the flat valve, which is slightly convex within. I gathered the small shell, Figure 6, at Chute farm; it is a young deep under valve, with the transverse striae of growth neatly arching between the larger six costae. Figures 7 and 8 show the upper and under valves of different specimens; they are from the greensand at Chute and are chiefly siliceous; for the use of one I am indebted to Thomas Meade, Esq. Such are said to be found at Devizes and Blackdown with the upper valve. It is possible that these are different species from those in the Chalk; the costae are less prominent, and the striae more distinct; at present, however, I can consider them only as varieties. Table 56, Figure 3 , represents a specimen in ferruginous sandstone from Chute, which may possibly prove to be a distinct species. Its length exceeds its breadth by one-fifth, and on the sides of the larger costae are two lesser ones, which are partly blended with them; the surface is nearly smooth. I have only seen this specimen.

\section{Miss Gardner gives the following details:}

Shell rather large for a Cretaceous Pecten; cordate, very strongly inequivalve, subequilateral, lower valve highly convex, the upper flattened or feebly concave; maximum diameter at or a little behind the median horizontal; umbo of right valve very prominent, evenly inflated, rising well above the hinge line, orthogyrate; dorsal margins diverging at an angle of approximately $90^{\circ}$, produced so that the ventral and lateral margins subscribe an arc of only about $180^{\circ}$; external surface of lower valve sculptured with five or rarely six elevated, evenly rounded primaries, subequal in size and spacing, and between each pair three or four more or less equal secondaries; submargins sculptured with rather fine close-set radials, five in number, as a rule; ornamentation of upper valve more uniform in character, usually of 20 to 25 subequal and equispaced, wellrounded, and elevated radials; incremental sculpture fine and sharp; hinge line rather short, not far from five-ninths of the maximum latitude, overhung by the umbo of the right valve; auricles only slightly unequal, the anterior a little more produced and relatively lower and less strongly lirate than the posterior; posterior auricle receding below the hinge line, the anterior feebly constricted to form the byssal notch; characters of interior of shell not known.

The identity of the American species with the European has been questioned since the day of D'Orbigny. The Maryland representation is very meager and offers very little assistance toward the solution of the problem. As in Pycnodonte vesicularis the true affinities of the group should be worked out once for all by an exhaustive study of material from all the representative localities. If the two forms prove distinct Sowerby's name must be retained for the European fossil and D'Orbigny's mortoni substituted for the American. It is the personal conviction of the writer that the two forms !are identical, or at least that they can not be separated on a geographical basis. D'Orbigny's criterion certainly will not stand-that is, that the American form differs from the European in the presence of five instead of four secondaries between each pair of primaries. The normal number in the American form is four, as it is in the European and South Indian, but, as in the foreign types, this number is occasionally increased to five or 
reduced to three. The outline and relative proportions vary within rather narrow limits throughout the occurrence, and though there is a suspicion that the maximum diameter may. fall a little nearer the median horizontal in the American individuals, this can not be verified without the examination of much more material than is available at present.

This species is common at Coon Creek and is represented in the collections by a number of specimens which range from one-half inch to 3 inches in maximum dimension. The number of secondary costae is usually three, but in some individuals there are groups of three and four secondary costae on the same shell. In shape and general appearance the Tennessee form is strikingly similar to Woods's typical text figure of Pecten quadricostatus Sowerby ${ }^{94}$ except for the very much enlarged ears of the latter form. The adductor scars of both valves are large and subovate, situated in the upper posterior portion of the shell. It is highly important that specimens of the European species Pecten quinquecostatus and Pecten quadricostatus Sowerby be obtained for comparison with the Tennessee material in order to establish the identity of this widely distributed American species.

Occurrence: Ripley formation and Selma formation, McNairy County, Tenn.

Collections: Maryland Geological Survey, New Jersey Geological Survey, U. S. National Museum, Geological Survey of India, Yale University, Vanderbilt ,University.

Outside distribution: Magothy formation, Good Hope Hill, District of Columbia. Matawan formation, post 236, Camp Fox, Chesapeake \& Delaware Canal, and post 192, Camp U \& I, Del. Monmouth formation, John Higgins farm, 2 miles west of Delaware City, Del., and (?) Fredericktown, Cecil County, and Waterbury, Anne Arundel County, Md. Rancocas formation, (?) Noxontown Pond, Del. Matawan group (Merchantville clay and Marshalltown formation), New Jersey. Monmouth group (Navesink marl), New Jersey. Eutaw formation (Tombigbee sand member), Exogyra ponderosa zone, Mortoniceras subzone, Georgia, Russell County, Warrior River, and Tombigbee River, Ala., and Tombigbee River, Miss. Ripley formation, Exogyra.costata zone, Georgia, Chattahoochee River, Ala., and Wilcox, Pontotoc, and Chickasaw counties, Miss. Selma chalk, Exogyra ponderosa zone, Monroe and Prentiss counties, Miss., and Tennessee; Exogyra costata zone, Tombigbee River, Ala., east-central Mississippi, and Lee, Clay, and Alcorn counties, Miss. Cenomanian (?), Mexico and England. Turonian and Senonian, central Europe. Ootatoor, Trichinopoli, and Arrialoor formations, southern India. Senonian, Pondoland, South Africa.

of Woods, Henry, A monograph of the Cretaceous Lamellibranchia of England, vol. 1, pp. 213-214, flgs. 3, 4, 5, Palaeont. Soc. London, 1903.

\section{Pecten quinquenarius Conrad}

Plate XXI, Figures 6-9

1853. Pecten quinquenarius. Conrad, Acad. Nat. Sci. Philadelphia Jour., 2d ser., vol. 2, p. 275, pl. 24, fig. 10.

1861. Pecten tenuitesta. Gabb, Acad. Nat. Sci. Philadelphia Proc. for 1861, p. 327.

1861. Neithea quinquenaria. Gabb, Synopsis of the Mollusca of the Cretaceous formation, p. 148 (Am. Philos. Soc. Proc., vol. 8, p. 204).

1864. Neithea quinquenaria. Meek, Check list of the invertebrate fossils of North America, Cretaceous and Jirassic, p. 7 .

1864. Pecten tenuitesta. Meek, Check list of the invertebrate fossils of North America, Cretaceous and Jurassic, p. 7.

1868. Pecten tenuitesta. Conrad, in Cook, Geology of New Jersey, p. 725.

1885. Pecten planicostatus. Whitfield, U. S. Geol. Survey Mon. 9, p. 48, pl. 8, figs. 10-11. (Also published by New Jersey Geol. Survey, 1886.)

1885. Pecten quinquenarius. Whitfield, U. S. Geol. Survey Mon. 9, p. 47, pl. 7, figs. 13-16. (Also published by New Jersey Geol. Survey, 1886.)

1905. Pecten tenuitesta. Johnson, Acad. Nat. Sci. Philadelphia Proc., vol. 57, p. 11.

1905. Pecten quinquenarius. Johnson, Acad. Nat. Sci. Philadelphia Proc., vol. 57, p. 11.

1907. Pecten tenuitesta. Weller, New Jersey Geol. Survey, Paleontology, vol. 4, p. 467, pl. 50, fig. 9 .

1907. Pecten quinquenarius. Weller, New Jersey Geol. Survey, Paleontology, vol. 4, p. 476, pl. 50, figs. 10-13.

1914. Pecten tenuitesta. Stephenson, U. S. Geol. Survey. Prof. Paper 81 , p. 24, Tables 2, 3, 4, 8, 9 .

1914. Pecten quinquenarius. Stephenson, U. S. Geol. Survey Prof. Paper 81, Tables 2, 8, 9.

Conrad's original description is as follows:

Shell ovate, much compressed, with five distinct ribs, broad and rounded on one valve, narrow and subangulated on the opposite valve. (A cast.)

Whitfield describes a right valve of this species as follows:

Shell of medium size, slightly oval transversely; in outline a little wider than high. Valves plano-convex in profile when united. Hinge line much shorter than the width of the shell below. Ears large; slightly unequal; that of the flat valve (right) somewhat sinuate on the anterior side. Cardinal slope of valves somewhat concave between the beaks and the lateral margins of the body of the shell. Surface of the valves marked by strong, wide, rounded, radiating ribs, about five on the flat valve and six on the convex valve. On the convex valve, as shown upon the impression left in the fine blue.marl, there have been fine, even, and closely arranged concentric lines crossing the folds and passing up over the auriculations-in fact, covering the entire surface of the valve. The opposite flat valve has not been marked by concentric lines, as was the convex valve, the surface of the cast, inside and outside impressions, being apparently smooth. No remains of radiating lines on the folds can be seen.

Weller thus describes a left valve of this species (as Pecten tenuitesta): 
Left valve depressed convex or nearly flat, equilateral, and aside from the auriculations nearly subcircular in outline. The dimensions of an imperfect impression of the left valve are: Height, about 40 millimeters; width, 41.5 millimeters; length of hinge line, about 22 millimeters. Auriculations of moderate size, subèqual, but slightly depressed below the general surface. Surface marked by about 30 low rounded ribs, which are much narrower than the flattened interspaces, the stronger ribs continue to the beak and never bifurcate, the smaller ones being added by intercalation; the auriculations are entirely free from radiating ribs; besides the radiating ribs the entire surface is marked by exceedingly fine, regular, concentric striae. The shell substance is apparently very thin.

Several specimens of this species have been collected with both valves attached. These valves differ widely from one another so that it is perfectly natural that when found only separated by various students of the Upper Cretaceous they should have been regarded as two distinct species. Stephenson, ${ }^{95}$ in 1914, was the first to suggest that these two forms described as separate species were but different valves of the same species. There is considerable variation between the specimens from Coon Creek and the specimens from New Jersey, but this variation is probably not great enough to make the forms specifically separate.

Occurrence: Ripley formation, Dave Weeks place on Coon Creek, McNairy County, Tenn.

Collections: New Jersey Geological Survey, Maryland Geological Survey, U. S. National Museum.

Outside distribution: Monmouth group, New Jersey. Ripley formation, Owl Creek, Dumas, and Troy, Miss., Eufaula, Ala., and Urseys Mill and elsewhere in Georgia. Selma chalk, Scooba and Starksville, Miss.

\section{Family LIMIDAE \\ Genus LIMA Cuvier \\ Lima reticulata Forbes \\ Plate XX, Figure 12}

1845. Lima reticulata. Forbes, Geol. Soc. London Quart. Jour., vol. 1, p. 62, text figs.

1864. Lima reticulata: Meek, Check list of the invertebrate fossils of North America, Cretaceous and Jurassic, p. 7.

1868. Radula reticulata. Conrad, in 'Cook, Geology of New Jersey, p. 725.

187.1. Radilla reticulata. Stoliczka, India Geol. Survey Mem., Palaeontologia Indica, Cretaceous fauna of southern India, vol. 3, p. 416.

1885. Radula reticulata. Whitfield; U. S. Geol. Survey Mon. $\therefore 9$, p. 63, pl. 9, figs. 8, 9. '(Synonymy excluded.) (Also published by New Jersey Geol. Survey, 1886.)

1907. Lima reticulata. Weller, New Jersey Geol. Survey, Paleontology, vol. 4, p. 492, pl. 54, figs. 3, 4.

1914. Lima reticulata. Stephenson, U. S. Geol. Survey Prof. Paper 81, p. 24, tables 2-8.

1916. Lima reticulata. Gardner, Maryland Geol. Survey, Upper Cretaceous, pl. 600, p. 34, figs. 12, 13.

Forbes describes this species as follows:

L. testa ovata, obliqua, inflata, tenui, longitudinaliter sulcata, sulcis reticulatis, numerosis. Habitat, Nov. Jersey.

${ }^{85}$ Stephenson, L. W., Cretaceous deposits of the eastern Gulf region: U. S. Geol Survey Prof. Paper 81, table 8, 1914.
Whitfield gives the following description:

Shell small, moderately oblique, strongly ovate, and inflated. Hinge short; beaks proportionally strong and projecting beyond the cardinal line. Valves nearly equal; anterior margin straight, and not at all gaping; auriculations small but distinct, rectangular or very slightly pointed at their outer angles. Surface radiately ribbed, those of the anterior and and posterior slopes faintly marked or obsolete, ribs (about 30) distinct, with five or more indistinct on each side; subangular on the middle of the valves and rounded toward the sides, crenulate or subspinose on the larger specimens when well preserved, but of ten appearing nearly smooth. Entire surface marked by concentric lines, which give a roughened surface when perfect, giving the reticulated character indicated by the specific name. The shells are all small, seldom exceeding three-fourths of an inch in length, and are very fragile. The right valve appears to be a little less ventricose and the beak shorter than the left in all the specimens' which $I$ have seen where the two are united.

\section{Miss Gardner adds the following information:}

There is apparently a large amount of variation in this small species, and, as the type is not in this country, it is difficult to determine its proper limits. In Maryland the forms referred to this group are all young and of rather doubtful affinities, so that they throw no light upon the characters of the race. Radula denticulicosta Gabb is probably distinct if Gabb was correct in his observation that "at both the anterior and posterior sides the ribs disappear for about one-sixth the width of the shell."

This species is allied to Lima decussata Goldfuss, ${ }^{98}$ which is widely distributed in the Upper Cretaceous of Europe. A more distantly related form is Lima obliquistriata Forbes, ${ }^{97}$ from the Arrialoor group of southern India. Another oblique form is Lima buttoni Woods, ${ }^{98}$ from the Senonian of New Zealand.

Occurrence: Ripley formation, Dave Weeks place on Coon Creek, McNairy County, Tenn.

Collections: Maryland Geological Survey, New Jersey Geological Survey, U. S. National Museum.

Outside distribution: Monmouth formation, Prince Georges County, Md. Matawan group (Merchantville clay, Woodbury clay, Marshalltown formation, and Wenonah sand), New Jersey. Monmouth group (Navesink marl), New Jersey. Black Creek formation, North Carolina and South Carolina. Peedee sand, North Carolina and South Carolina. Eutaw formation (Tombigbee sand member), Exogyra ponderosa zone, Mortoniceras subzone, Georgia and Russell County, Ala. Ripley formation, Exogyra ponderosa zone, Union Springs, Ala., and Booneville, Miss.; Exogyra costata zone, Georgia, Eufaula, Ala., east-central Mississippi, and Alcorn, Union, and Tippah counties, Miss. Selma chalk, Exogyra costata zone, east-central Mississippi; extreme top of Exogyra costata zone, Pataula Creek, Ga.

${ }^{\circ 6}$ Woods, Henry, A monograph of the Cretaceous Lamellibranchia of England, vol. 2, p. 50, pl. 7, figs. 18, 19, 20, Palaeont. Soc. London, 1904.

${ }^{07}$ Stoliczka, Ferdinand, India Geol. Survey Mem., Palaeontologia Indica, Cre. taceous faunas of southern India, vol. 3, p. 421, pl. 30, figs. 2-5, 13, 1871.

${ }^{9 B}$ Woods, Henry, The Cretaceous faùnas of the northeastern part of the south island of New Zealand: New Zealand Geol. Survey Paleont. Bull. 4, p. 27, pl. 12, figs. 12-16, 1917. 


\section{Lima woodsi Wade, n. sp.}

Plate XXII, Figures 1, 2

Shell small, thin, and very fragile; subcircular in outline; umbones inconspicuous, auricles very short; posterior hinge line straight; dorsal anterior margin incurved and folded in to such an extent as to bring the short anterior auricle within the peripheral line of the shell; ventral margin broadly semicircular; external sculpture smooth, but under a glossy coat there are numẹrous irregular incremental lines; ligament area small, subtriangular, and concave, situated obliquely behind the apex of the umbones; adductor scar large and circular, located in the median posterior portion of the shell; pallial line simple.

Altitude, 19 millimeters; diameter, 20 millimeters.

Only two left valves of this species are known. This scarcity of the species is no doubt due to the very delicate and fragile nature of these shells. Lima woodsi in shape and external characters closely resembles Lima grenieri Coquand, ${ }^{90}$ from the Turonian of Tunis, in northern Africa. Another related form, which is widely distributed in the Senonian of Europe, is Lima hoperi Mantell." Lima clypeiformis D'Orbigny, ${ }^{2}$ from the Cenomanian of France, does not have the strongly infolded dorso-posterior margin that is characteristic of the Tennessee species and the two other species cited.

Occurrence: Ripley formation, Dave Weeks place on Coon Creek, McNairy County, Tenn. Selma formation, 7 miles east of Lexington on Perryville road, Henderson County, Tenn.

Collection: U. S. National Museum.

\section{Superfamily ANOMIACEA \\ Family ANOMIIDAE \\ Genus PaRANOMIa Conrad \\ Paranomia scabra (Morton)}

Plate XXII, Figures 3-9

1834. Placuna scabra. Morton, Synopsis of the organic remains of the Cretaceous group of the United States, p. 62.

1860. Placunanomia (Paranomia) saffordi. Conrad, Acad. Nat. Sci. Philadelphia Jour., 2d ser., vol. 4, p. 290, pl. 46, fig. 21.

1860. Placunanomia lineata. Conrad, Acad. Nat. Sci. Philadelphia Jour., 2d ser., vol. 4, p. 291, pl. 46, fig. 20.

1861. Placunanomia lineata. Gabb, Synopsis of the Mollusca of the Cretaceous formation, p. 167 (Am. Philos. Soc. Proc., vol. 8, p. 223).

1861. Placunanomia saffordi. Gabb, Synopsis of the Mollusca of the Cretaceous formation, p. 167 (Am. Philos. Soc. Proc., vol. 8, p. 223).

\footnotetext{
${ }^{90}$ Pervinquière, L., Études de paléontologie tunisienne, vol. 2, p. 150, pl. 9, flg 14, 1912.

1 Woods, Henry, A monograph of the Cretaceous Lamellibranchia of England, vol. 2 , p. 17, pl. 4, flgs. 7-12, Palaeont. Soc. London, 1904.

2 D'Orbigny, Alcide, Paléontologie française, Terrains crétacés, vol. 3, p. 543, pl 417, flgs. $9-10,1847$
}

1861. Placunanomia scabra. Gabb, Synopsis of the Mollusca of the Cretaceous formation, p. 167 (Am. Philos. Soc. Proc., vol. 8, p. 223).

1864. Placunanomia lineata. Meek, Check list of the invertebrate fossils of North America, Cretaceous and Jurassic, p. 6 .

1864. Placunanomia saffordi. Meek, Check list of the invertebrate fossils of North America, Cretaceous and Jurassic, p. 6.

1864. Placunanomia scabra. Meek, Check list of the invertebrate fossils of North America, Cretaceous and Jurassic, p. 6.

1867. Paranomia lineata. Conrad, Am. Jour. Conchology, vol. 3, p. 8.

1867. Paranomia scabra. Conrad, Am. Jour. Conchology, vol. 3, p. 8.

1885. Paranomia scabra. Whitfield, U. S. Geol. Survey Mon. 9 , p. 44 , pl. 10, fig. 10 . (Also published by New Jersey Geol. Survey, 1886.)

1886. Paranomia lineata. Whitfield, U. S. Geol. Survey Mon. 9, p. 45, pl. 9, fig. 10. (Also published by New Jersey Geol. Survey, 1886.)

1898. Paranomia saffordi. Dall, Wagner Free Inst. Sci. Trans., vol. 3 , pt. 4, p. 773 .

1898. Paranomia lineata. Dall, Wagner Free Inst. Sci. Trans., vol. 3 , pt. 4 , p. 773 .

1905. Paranomia scabra. Johnson, Acad. Nat. Sci. Philadelphia Proc., vol. 57, p. 12.

1905. Paranomia lineata. Johnson, Acad. Nat. Sci. Philadelphia Proc., vol. 57, p. 12.

1905. Paranomia saffordi. Johnson, Acad. Nat. Sci. Philadelphia Proc., vol. 57, p. 12.

1907. Paranomia scabra. Weller, New Jersey Geol. Survey, Paleontology, vol. 4, p. 500, pl. 52, figs. 10-13.

1914. Paranomia scabra. Stephenson, U. S. Geol. Survey Prof. Paper 81, p. 24, tables 2-8.

19.16. Paranomia scabra. Gardner, Maryland Geol. Survey, Upper Cretaceous, p. 605 .

1916. Paranomia lineata. Gardner, Maryland Geol. Survey, Upper Cretaceous, p. 606, pl. 35, figs. 11, 12.

Weller describes this species as follows:

Shell thin and fragile, broadly and irregularly subovate in outline, the dimensions of the largest individual observed being: Length from beak to opposite border, 55 millimeters; width at right angles to the last dimension, 54 millimeters. The dimensions of an individual of more nearly average size are: Length, 31 millimeters; width, 34 millimeters: The upper valve depressed convex, the surface marked by distant rounded, elevated radiating ribs, which are frequently more or less wavy in their direction and become stronger toward the front of the shell. At irregular intervals the ribs are produced into hollow spines, directed away from the beak, which become larger and more distant as the ribs increase in length toward the front of the shell; the spaces between the ribs are broad and flat, being three or four times as wide as the ribs, and on the best preserved shells are marked with rather delicate concentric lines. The lower valve is convex toward the beak, where it is apparently broadly perforate, becoming concave toward the front of the valve. The surface markings are similar to those of the upper valve, though in some cases the ribs and spines seem to be less strongly developed.

This species occurs most commonly in the Marshalltown clay marl, from which formation near Swedesboro a large number of individuals retaining the shell have been collected. None of them are so large as the specimen illustrated by Whitfield under the name of $P$. lineata, but they all exhibit the same essential specific characters as that shell. Whitfield was in 
error, however, in considering the specimen he used for study as a perforate valve, the apparent perforation near the beak being only a fracture. In none of the Swedesboro specimens, which are perfectly preserved up to the beak, is any perforation.shown on the convex valve, but in several of these which become concave toward the front there is apparently a broad perforation close to the beak, although there is some reason for doubting the presence of an actual perforation in this valve, as it seems to be absent from some specimens which are complete to the beak.

There seems to be no sufficient reason for recognizing the two species of Paranomia in Whitfield's monograph. The type of Morton's species, P. scabra, illustrated by Whitfield, is only a fragment of a shell belonging to the same species as one illustrated as $P$. lineata, although it is somewhat more irregular and rougher than usual. Morton's name, having priority, is adopted for the species. $P$. saffordi Conrad, from Tennessee, must also be considered as a synonym.

A study of numerous well-preserved and perfect specimens of this species furnishes evidence that the three above-mentioned species are but modifications of one highly variable form. This material shows also the heretofore unknown internal shell characters and the larval development of this interesting species. The shells are made up of two distinct layers - a soft limy internal layer, which in most specimens from other localities is dissolved away, and a hard chitinous outer spinose layer, which is usually preserved. The muscle scars and other internal shell characters are marked in the inner soft limy layer. There are two ovate adductor scars near one another and situated in the upper central portion of each valve. The uppermost adductor scar on the right valve is connected by a line or scar to the closed foramen beneath the obscure triangular cardinal plate, showing that in the young stage of this shell this adductor passed through this foramen and was attached to the foreign object on which the larva developed. As the shell grew into adult stages this muscle left the foreign object, became attached to the lower valve, and migrated into a central position in the adult. The line or narrow scar connecting this upper adductor scar and the foramen scar is the path of migration.

The protoconch preserved in the umbo of the left valve of this species is regularly subovate in outline, very much in contrast to the irregular outline of the adult. This protoconch is free from radial sculpture and has a rather prominent, pointed little beak, rather analogous to the protoconch or larval stage of Anomia ornata Gabb; $;^{3}$ Anomia perlineata Wade, from Coon Creek; and Anomia pseudoradiata D'Orbigny, ${ }^{4}$ from the Lower Cretaceous of England.

Occurrence: Ripley formation and Selma formation, McNairy County, Tenn:

Collections: Maryland Geological Survey, New Jersey Geological Survey, U. S. National Museum, Vanderbilt University, Yale University.

\footnotetext{
3 Gardner, J., A., Maryland Geol. Survey, Upper Cretaceous, p. 612, pl. 35, figs. $5,6,1916$.

- Woods, Henry, A monograph of the Cretaceous Lamellibranchia of England, vol. 1, p. 27, pl. 5, fig. 1-3, Palaeont. Soc. London, 1899.
}

Outside distribution: Monmouth and Matawan formations, Maryland. Matawan group (Merchantville clay and Marshalltown formation), New Jersey. Peedee sand, North Carolina and South Carolina. Eutaw formation (Tombigbee sand member), Exogyra ponderosa zone, Alcorn County, Miss. Ripley formation, Exogyra costata zone, Georgia, Eufaula, Ala., east-central Mississippi and Pontotoc County, Miss. Selma chalk, Exogyra ponderosa zone, Warrior River, Ala., and Monroe and Chickasaw counties, Miss:; Exogyra costata zone, Tombigbee River and Sumter County, Ala., east-central Mississippi, and Chickasaw, Pontotoc, and Alcorn counties, Miss.

\section{Genus ANOMIA Linne}

\section{Anomia argentaria Morton}

Plate XXII, Figures 10-13

1833. Anomia argentaria. Morton, Am. Jour. Sci., 1st ser., vol. 23 , p. 293 , pl. 5 , fig. 10 .

1834. Anomia argentaria. Morton, Synopsis of the organic remains of the Cretaceous group of the United States, p. 61 , pl. 5, fig. 10 .

1864. Anomia argentaria.' Meek, Check list of the invertêbrate fossils of North America, Cretaceous and Jurassic, p. 6.

1868. Anomia argentaria. Conrad, in Cook, Geology of New Jersey, p. 724.

1875. Anomia argentaria. Conrad, in Kerr, Report "of the geological survey of North Carolina, vol. 1, appendix A, p. 13.

1877. Anomia argentaria. Gabb, Acad. Nat. Sci. Philadelphia Proc. for 1876 ; p. 319 .

1885. Anomia argentaria. Whitfield, U. S. Geol. Survey Mon 9 , p. 42 , pl. 4 , figs. 10 , 11 (not fig. 9). '(Also published by New Jersey Geol. Survey, 1886.)

1905. Anomia argentaria. Johnson, Acad. Nat. Sci. Philadelphia Proc., vol: 57, p. 12.

1906. Anomia argentaria. Böse, Inst. geol. México Bol. 24, p. 38 , pl. 1, fig. 8 .

1907. Anomia argentaria. '.Weller, New Jersey Geol. Survey, Paleontology; vol. 4, p. 496, pl. 54, figs. 11-15.

1913. "Anomia subtruncata." Böse, Inst. geol. México Bol., 30, p. 41.

1914. Anomia argentaria. Stephenson, U. S. Geol. Survey Prof. Paper 81, p. 24, tables 2-8.

1916. Anomia argentaria. Gardner, Maryland Geol. Survey, Upper Cretaceous, p. 608, pl. 35, figs. 1, 2.

Morton in 1833 characterized this, species as follows:

Thin, round, with numerous concentric striae.

Miss Gardner gives the following details:

Shell subcircular or irregular in outline, with a silvery sheen both within and without, thin but tough, of moderate size, the adults from 15 to 30 millimeters in circumference; left valve usually convex, though varying widely in the degree of convexity; right valve, through which the byssus is extruded, flattened; umbones central, almost marginal, very inconspicuous, scarcely interrupting the regular outline of the valve; external surface ornamented with thin, concentric overlapping lamellae, which are frequently radially lineated; ligament submarginal, attached beneath the umbo of the left valve; hinge edentulous; interior scarred with a large major byssal impression, medial in position and quite high up under the umbones and 
ventral to it, the minor byssal impression, and the posterior muscle adductor; a third byssal scar of minute size underneath the dorsal margin, a little in front of the umbones; inner ventral margins simple.

This species is one of the most abundant bivalves in the Upper Cretaceous faunas of Maryland. For all the shell is so thin it is very tenacious and easily separable from the matrix It is an unusually well characterized species, and even the fragments can be determined with assurance by the silvery sheen, the crowded concentric laminae, and in the majority of individuals by the fine radial lineation:

The form varies to a certain extent, as do all members of this variable genus, in the outline, the degree of compression of the valves, and particularly in the development of the radial sculpture. However, limits must be placed even for variable species, and it is not probable that they should be made wide enough to include $A$. tellinoides Conrad, which is constant in its transversely ovate outline, lack of luster, rather distant concentric lamination, and absence of radial striations.

This species has a very wide stratigraphic and geographic distribution in the Upper Cretaceous of the eastern United States. It is probably related to Anomia subquadrata Stanton, ${ }^{5}$ of the Colorado formation of the western interior, and to Anomia papyracea D'Orbigny, ${ }^{\circ}$ of the Turonian of England and France.

Occurrence: Ripley formation, Coon Creek and Sand Hill, McNairy County, Tenn. Selma formation, Big Cut, Gravel Hill, McNairy County, Tenn.

Collections: Maryland Geological Survey, U. S. National Museum, New Jersey Geological Survey, Philadelphia Academy of Natural Sciences, Yale University, Vanderbilt University.

Outside distribution: Matawan formation, post 198, Chesapeake \& Delaware Canal, Del., and head of Magothy River, Gibsons Island, Anne Arundel County, Md. Monmouth formation, 2 miles west of Delaware City, Del., on John Higgins farm and mouth of Turners Creek, Kent County, Md., and Brightseat, railroad cut west of Seat Pleasant, the Brooks estate near Seat Pleasant, Friendly, and 1 mile west of Friendly, all in Prince Georges County, Md. Rancocas formation (?), Noxontown Pond, Del. Magothy formation ("Cliffwood clay"), New Jersey. Matawan group (Merchantville clay, Woodbury clay, Marshalltown formation, and Wenonah sand), New Jersey. Monmouth group (Navesink marl and Redbank sand), New Jersey: Black Creek formation, North Carolina and South Carolina. Peedee sand, North Carolina and South Carolina. Eutaw formation (Tombigbee sand member), Exogyra ponderosa zone, Mortoniceras subzone, Georgia, Russell and Dallas counties, Ala., and Tombigbee River, Clay County, Miss.; Exogyra ponderosa zone, Alcorn County, Miss., Georgia, and Union Springs and Russell County, Ala.; Exogyra costata zone, Georgia, Chattahoochee River and Eufaula, Ala., east-central Mississippi, and Lee, Pontotoc, Chickasaw, Union, and Tippah counties,;

\footnotetext{
- Stanton, T. W., The Colorado formation and its invertebrate fauna: U. S. Geol. Survoy Bull. 106, p. 66, pl. 8, figs. 8, 9, 1893.

o Woods, Henry, A monograph of the Cretaceous Lamellibranchia of England, vol. 1, p. 31, pl. 5, flgs. 13-16, Palacont. Soc. London, 1904.
}

Miss. Selma chalk, Exogyra ponderosa zone, Elmore County, Ala., and Clay, Monroe, Alcorn, and Prentiss (?) counties, Miss.; Exogyra costata zone, Wilcox and Sumter counties, Ala., east-central Mississippi, and Chickasaw, Lee, Clay, Alcorn, and Prentiss counties, Miss.; extreme top of Exogyra costata zone, Pataula Creek, Ga., and Lowndes County, Miss. Senonian, Mexico.

\section{Anomia perlineata Wade, n. sp.}

Plate XXIII, Figures 1, 2

Shell moderately large, thin and fragile; irregular to subcircular in outline; umbones inconspicuous, submarginal, medial in position; external surface bisculptate, larval portion of shell smooth to faintly marked with a few radiating lines, which develop into very numberous fine tuberculate irregular lines on the lower half of the shell; ligament submarginal, attached beneath the umbo of the left valve in a narrow elongate transverse pit; hinge edentulous; interior coated with lime, marked by a large circular adductor scar situated in the upper central portion of the shell and a smaller adductor or byssal scar which joins the major scar at its lower posterior margin; pallial line simple; margins sharp and irregular. Altitude, 35 millimeters; maximum diameter, 37 millimeters.

Only the left valve of this species is known. There are a number of specimens of it, however, and they present a wide range of variations in shell convexity, sculpture, and shape of the smaller muscle scar. This species is probably related to Anomia ornata Gabb, ${ }^{7}$ from the Ripley of Georgia and the Monmouth of Maryland, but differs from that species in the number and shape of muscle scars as well as external sculpture. The sculpture of Anomia perlineata resembles that of the European Lower Cretaceous species Anomia pseudoradiata D'Orbigny. ${ }^{8}$ Another species with the same type of sculpture is Anomia linensis Whiteaves, ${ }^{0}$ from the Upper Cretaceous of the Queen Charlotte Islands, Canada.

Occurrence: Ripley formation, Dave Weeks place on Coon Creek, McNairy County, Tenn.

Collections: U. S. National Museum, Johns Hopkins University.

\section{Anomia tellinoides Morton}

Plate XXIII, Figures 3, 4

1833. Anomia tellinoides. Morton, Am. Jour. Sci., 1st ser., vol. 23, p. 294, pl. 5, fig. 10.

1834. Anomia tellinoides. Morton, Synopsis of the organic remains of the Cretaceous group of the United States, p. 61, pl. 5, fig. 11 .

1864. Anomia tellinoides. Meek, Check list of the invertebrate fossils of North America, Cretaceous and Jurassic, p. 7.

\footnotetext{
7 Gardner, J. A., Maryland Geol. Survey, Upper Cretaceous, p. 612, pl. 35, figs. 1, 6, 1916.

8 Woods, Henry, A monograph of the Cretaceous Lamellibranchia of England, vol. 1, p. 27, pl. 5, figs. 1-3, Palaeont. Soc. London, 1899.

${ }^{\circ}$ Whiteaves, J. F., Canada Geol. Survey, Mesozoic fossils, vol. 1, pt. 4, p. 301,
} pl. 39, fig. 2, 1900. 
1868. Anomia tellinoides. Conrad, in Cook, Geology of New Jersey, p. 724.

1905. Anomia tellinoides. Johnson, Acad. Nat. Sci. Philadelphia Proc., vol. 57, p. 12.

1907. Anomia argentaria. Weller, New Jersey Geol. Survey, Paleontology, vol. 4, p. 496 (part; description and figures excluded).

1916. Anomia tellinoides. Gardner, Maryland Geol. Survey, Upper Cretaceous, p. 610, pl. 35, figs. 3, 4.

Morton's original description is as follows:

Irregular but mostly subovate, with concentric undulations. Both these species are common in New Jersey; the latter resembles A. ephippium, to which it is referred in the first part of this synopsis.

Type locality: New Jersey.

Miss Gardner describes this species as follows:

Shell rather thin but tenacious, inequilateral, transversely ellipsoidal in outline, the lower valve moderately convex; anterior portion of the shell constricted in front of the umbones; anterior margin broadly and evenly rounded; posterior portion of shell symmetrical, rounded; base arcuate; umbones low, not very conspicuous; with ill-defined apices placed as a rule a little behind the median line; external surface sculptured with an indistinct and rather distant concentric lamination; ligament submarginal, attached beneath the umbo of the left valve; hinge plate not developed, edentulous; pedal and byssal scars indistinct.

This species has been confused in the synonymies with $A$. argentaria. The forms are certainly closely related, but there is not sufficient evidence of their identity. A. tellinoides is transversely ovate in outline, rather than subcircular, the surface is less silvery, the concentric lamination less crowded, and the radial striations much less commonly developed than in the more prolific $A$. argentaria.

Occurrence: Ripley formation, Dave Weeks place on Coon Creek, McNairy County, Tenn.

Collections: Maryland Geological Survey, Philadelphia Academy of Natural Sciences, U. S. National Museum.

Outside distribution: Monmouth formation, Delaware and New Jersey.

\section{Superfamily MYTILACEA Family MYTILIDAE

Genus IITHOPHAGA Bolten \\ Lithophaga ripleyana Gabb \\ Plate XXIII, Figures 5, 6}

1862. Lithophagus ripleyanus. Gabb, Acad. Nat. Sci. Philadelphia Proc. for 1861, p. 326.

1864. Lithophagus ripleyanus. Meek, Check list of the invertebrate fossils of North America, Cretaceous and Jurassic, p. 10.

1877: Lithophaga ripleyana. Gabb, Acad. Nat. Sci. Philadelphia Proc. for 1876, p. 311.

1885. Lithodomus ripleyana. Whitfield, U. S. Geol. Survey Mon. 9, p. 67, pl. 17, figs. 4, 5 (part). (Also published by New Jersey Geol. Survey, 1886.)

1905. Lithophaga ripleyana. Johnson, Acad. Nat. Sci. Philadelphia Proc., vol. 57, p. 13.

1907. Lithophaga ripleyana. Weller, New Jersey Geol. Survey, Paleontology, vol. 4 , p. 512 , pl. 56, figs. 19-2 (part).
1914. Lithophaga ripleyana. Stephenson, U. S. Geol. Survey Prof. Paper 81, p. 24, table 2 .

1916. Lithophaga ripleyana. Gardner, Maryland Geol. Survey, Upper Cretaceous, p. 618, pl. 36, figs. 4-6.

Gabb in 1862 described this species as follows:

Tube subcylindrical, nearly straight, gradually tapering, broadest on the dorsal surface; opposite face narrow, rounded; extremity abrupt, rounded, and faintly subtrilobate. Shell subquadrate. Beaks terminal and projecting beyond the buccal end of the shell, very much incurved, so as to appear somewhat spiral. Umbones broad, slightly flattened in the middle. Cardinal margin straight anteriorly, depressed posteriorly, merging into the anal border, which is subtruncate and most prominent above. Basal edge broadly emarginate. Surface marked by numerous irregular concentric lines.

Type locality: Big Timber Creek, between Gloucester and Red Bank, N. J.

Miss Gardner adds the following details:

Form gregarious, rudely cylindrical, constricted mesially; protective covering built up of thin concentric layers of calcite, usually conforming rather closely to the outline of the shell; shell itself very thin, nacreous in texture; umbones terminal, prosogyrate, well rounded at their tips; anterior portion inflated, truncate; shell, in the majority of the individuals, feebly depressed in front of the obscure carina, which extends from the umbones toward the posterior ventral margin, the depression being reflected in the slight concavity of the base; posterior end strongly and symmetrically arcuate; dorsal margin approximately horizontal; external surface smooth, excepting for the incremental sculpture, which is rather conspicuous, particularly in the posterior portion of the shell; characters of interior not known.

The species frequently occurs in clusters, the individuals being attached at the posterior extremity. The degree of medial constriction is not constant.

L. ripleyana Gabb is relatively more elongated transversely than L. affinis Gabb, a coexistent species over much of the area of its occurrence, and is much less inflated.

Lithodomus subcylindrica Stoliczka ${ }^{10}$ from the Ootatoor group of the Upper Cretaceous of India, probably belongs to this genus and is distantly related to Lithophaga ripleyana Gabb.

Occurrence: Ripley formation, Dave Weeks place on Coon Creek, McNairy County, Tenn.

Collections: Maryland Geological Survey, New Jersey Geological Survey, Philadelphia Academy of Natural Sciences, U. S. National Museum.

Outside distribution: Matawan formation, opposite post 239, post 236, Camp Fox, Chesapeake \& Delaware Canal, Del. Monmouth formation, Bohemia Mills, Cecil County, Md., and Brightseat, Brooks estate near Seat Pleasant, and Friendly, all in Prince Georges County, Md. Matawan group (Merchantville clay and Wenonah sand), New Jersey. Monmouth group (Navesink marl), New Jersey. Ripley formation, Exogyra costata zone, Union County, Miss.

${ }^{10}$ Stoliczka, Ferdinand, India-Geol. Survey Mem., Palaeontologia Indica, Cretaceous fauna of southern India, vol. 3, p. 376, pl. 23, figs. 18, 19, 1871. 


\section{Lithophaga conchafodentis Gardner}

\section{Plate XXIII, Figures 4,8}

Lithophaga conchafodentis. Gardner, Maryland Geol. Survey, Upper Cretaceous, p. 619, pl. 36, figs. 7, 8, 9, 1916.

Miss Gardner describes this species as follows:

Shell nacreous in texture, moderately large for the genus, subcylindrical to rectangular in outline, exceedingly thin and fragile; umbones nearly terminal, small, full but angular, flattened upon their summits, acute, prosogyrate; posterior area cut off by a carina which persists from the umbones to the posterior basal margin, acute near the umbones but evanescing toward the base; anterior end very short and obscurely truncate; posterior end much produced, strongly rounded at its extremity; the dorsal and ventral margins rudely parallel, the dorsal slightly convex, the ventral broadly and feebly constricted; external surface smooth excepting for a rather vigorous incremental sculpture; ligament submarginal, opisthodetic; hinge edentulous; adductor scars and pallial characters obscure.

Altitude, $5 \pm$ millimeters; latitude, $13 \pm$ millimeters; semidiameter, $3.5 \pm$ millimeters.

The remains of this small borer are found in the tests of Exogyra and Pycnodonte. It differs from $L$. ripleyana, which it most strongly resembles, not only in its habitat but also in the less inflated valves and less produced posterior extremity.

Type locality: Brightseat, Md.

Occurrence: Ripley formation, Dave Weeks place on Coon Creek, McNairy County, Tenn.

Collections: Maryland Geological Survey, U. S. National Museum.

Outside distribution: Monmouth formation, Bright. seat, Prince Georges County, Md.

\section{Genus CRENELLA Brown}

\section{Crenella serica Conrad}

Plate XXIII, Figures 9, 10

1860. Crenella (Stalagmium) serica. Conrad, Acad. Nat. Sci. Philadelphia Jour., 2d ser., vol. 4, p. 281, pl. 46, fig. 23.

1864. Crenella (Stalagmium) sericea. Meek, Check list of the invertebrate fossils of North America, Cretaceous and Jurassic, p. 11.

1907. Crenella serica. Weller, New Jersey Geol. Survey, Paleontology, vol. 4 , p. 510 , pl. 56 , figs. 7,8

1914. Crenella serica. Stephenson, U. S. Geol. Survey Prof. Paper 81 , p. 24, tables 2-8.

1916. Crenella serica. Gardner, Maryland Geol. Survey, Uppèr Cretaceous, p. 624, pl. 36, figs. 16-18.

Conrad describes this species as follows:

Longitudinally oblong-ovate, very ventricose, finely striated concentrically and with microscopic, closely arranged radiating lines; summit very prominent. Locality: Eufaula, Barbour County, Ala.

\section{Miss Gardner adds the following details:}

Shell very small and gibbous, between 3 and 4 millimeters in altitude, the interior regularly ovate in outline; umbones inflated, strongly prosogyrate and incurved, proximate; external surface sculptured with prominent and regularly spaced incrementals and resting stages; radial sculpture microscopically fine, not overriding the concentric; ligament lodged in a narrow groove running backward from beneath the apices of the um- bones; inner margins strongly crenulate, the area directly beneath the umbones slightly flattened and broadened and bearing four.or five pseudotaxodont denticles; a more extended but less clearly defined area developed in some individuals upon the medial portion of the posterior lateral margin; muscle scars and pallial lines indistinct. Crenella serica Conrad is a very abundant little bivalve in the Monmouth of Prince Georges County.

This species is very rare at Coon Creek. In all the collections from that locality only a single valve of one individual is known. Crenella serica Conrad is similar to Crenella inflata (Müller) Holzapfel, ${ }^{11}$ from the Aachen Cretaceous of Vaals, Germany, in its prosogyrate character of the umbo and further in the radiating external sculpture, but the German species does not have as well-developed incremental lines as the American species.

Occurrence: Ripley formation, Dave Weeks place on Coon Creek, McNairy County, Tenn.

Collections: Maryland Geological Survey, New Jersey Geological Survey, U. S. National Museum.

Outside distribution: Monmouth formation, Brightseat, Brooks estate near Seat Pleasant, Friendly, and 1 mile west of Friendly, all in Prince Georges County, Md. Matawan group (Marshalltown formation), New Jersey. Monmouth group (Redbank sand), New Jersey. Peedee sand, North Carolina and South Carolina. Ripley formation, Exogyra costata zone, Georgia and Eufaula, Ala. Selma chalk, Exogyra costata zone, Tombigbee River, Sumter County, Ala., east-central Mississippi, and Alcorn, Union, and Tippah counties, Miss.; extreme top of Exogyra costata zone, Pataula Creek, Ga., and Lowndes County, Miss.

\section{Crenella elegantula Meek and Hayden}

1862. Crenella elegantula. Meek and Hayden, Acad. Nat. Sci. Philadelphia Proc. for 1861, p. 441.

1864. Crenella elegantula. Meek, Check list of the invertebrate fossils of North America, Cretaceous and Jurassic, p. 11.

1876. Crenella elegantula. Meek, U. S. Geol. Survey Terr. Rept., vol. 9, p. 75, pl. 28, figs. 6a-6c.

1907. Crenella elegantula. Wheeler, New Jersey Geol. Survey, Paleontology, vol. 4, p. 511, pl. 56, fig. 6.

1916. Crenella elegantula. Gardner, Maryland Geol. Survey, Upper Cretaceous, p. 625, pl. 36, fig. 19.

Meek and Hayden describe this species as follows:

Shell small, very thin and pearly, obliquely ovato-cordate, ventricose; postero-basal and basal margins rounded; dorsal border sloping posteriorly with an arcuate outline and rounding into the anal margin behind; anterior border rounding obliquely backward into the base; umbonal region of both valves very gibbous; beaks prominent, terminal, pointed, distinctly incurved and directed obliquely forward at the extremities; hinge margin smooth; free border minutely crenulated. Surface (as seen by aid of a magnifier) beautifully ornamented by extremely fine, regular, closely arranged radiating striae, which increase chiefly by bifurcation and continue of uniform size on all parts of the shell; crossing these are numerous equally fine but much less distinct concentric lines and occasional stronger

"1 Holzapfel, Eduard, Die Mollusken der Aachener Kreide: Palaeontographical Band 35, p. 220, pl. 25, figs. 17-19, 1889. 
marks of growth. Length, measuring obliquely forward and upward from the base to the beaks, 0.55 inch; diameter, from base to hinge, measuring at right angles to the greatest length, 0.4 inch; convexity, 0.37 inch. This beautiful little shell is very closely allied to $C$. sericea of Conrad but differs in being uniformly more broadly ovate in form and in having less elevated and less distinctly incurved beaks, while its concentric markings are not near so strongly defined.

Type locality: Deer Creek, near North Platte River, Wyo.

The species is recognized in McNairy County from only a few fragile specimens. It is more than double the size of Crenella serica Conrad, relatively broader, and less inflated and less prominently sculptured concentrically. No figure of this very fragile form was made.

Occurrence: Ripley formation, Dave Weeks place on Coon Creek, McNairy County, Tenn.

Collections: Maryland Geological Survey, New Jersey Geological Survey, U. S. National Museum.

Outside distribution: Monmouth formation, Brightseat, Prince Georges County, Md: Monmouth group, in Tinton sand member of Redbank sand, New Jersey. Ripley formation, Exogyra costata zone, Owl Creek, Tippah County, Miss. Pierre shale, western interior.

\section{Family DREISSENSIIDAE \\ Genus DREISSENSIA Van Beneden \\ Dreissensia tippana Conrad \\ Plate XXIII, Figures 11, 12}

1858. Dreissena tippana. Conrad, Acad. Nat. Sci. Philadelphia Jour., vol. 3, p. 328 , pl. 34, fig. 14.

1864. Dreissena tippana. Meek, Check list of the invertebrate fossils of North America, Cretaceous and Jurassic, p. 10.

1914. Dreissena tippana. Stephenson, U. S. Geol. Survey Prof. Paper 81, p. 24, tables 2-8.

1916. Dreissena tippana. Gardner, Maryland Geol. Survey, Upper Cretaceous, p. 628, pl. 37, figs. 8-11.

Conrad describes this species as follows:

Falcate, with distinct lines of growth; front excavated, the margin acutely angular; the dorsal and posterior margin forms a regular curve; base rounded; beaks acute.

Miss Gardner adds the following details:

Type locality: Owl Creek, Tippah County, Miss.

Shell thick, prismatic, strongly falcate in outline, evenly convex, acutely keeled from the umbones to the ventral margin, the carinal angle usually more than $90^{\circ}$ and giving to the front view of the double valves a canoe-shaped outline; outline of posterior margin evenly rounded from beaks to base; external surface smooth except for incremental striations and, toward the ventral margin, rather pronounced resting stages; ligament groove rather shallow and elongated, hinge edentulous; umbonal septum narrow but quite high; character of muscle impressions and pallial sinus not preserved; inner margins simple.

In Maryland the species is represented chiefly in the form of casts, most frequently of the double valves, to which portions of the brown prismatic shell substance still adhere, although at some localities perfect specimens have been collected. The form differs quite widely in relative proportions, but it does not seem wise to regard these mutations as of more than individual import.

This species is common at Coon Creek. Both valves are frequently found together and attached to shells of Crassatellites vadosus (Morton), showing its sessile nature and proving its marine habitat. The shells of Dreissensia tippana are nacreous and lamellose and are very difficult to collect complete; even though they occur in the matrix in a perfect state of preservation.

Dreissensia tippana Conrad is very closely related to Dreissensia lanceolata (Sowerby), ${ }^{12}$ and perhaps on a comparison of real specimens they would be found identical. Dreissensia lanceolata (Sowerby) occurs at various horizons and in a number of localities in Europe, ${ }^{13}$ India, ${ }^{14}$ New Zealand, ${ }^{15}$ and Canada. ${ }^{16}$

Occurrence: Ripley formation, Dave Weeks place on Coon Creek, McNairy County, Tenn.

Collections: Maryland Geological Survey, U. S. National Museum.

Outside distribution: Matawan formation, Ulmsteads Point, Anne Arundel County, Md. Monmouth formation, Fredericktown (?), Cecil County, and Brightseat, Brooks estate near Seat Pleasant, and locality 1 mile west of Friendly, all in Prince Georges County, Md. Ripley formation, Exogyra costata zone, Georgia, Eufaula, Ala., and Union and Tippah counties, Miss.; extreme top of Exogyra costata zone, Pataula Creek, Ga., and Chattahoochee River, Ala.

\section{Order ANOMALODESMACEA \\ Superfamily ANATINACEA \\ Family PHOLADOMYACIDAE \\ Genus PHOLADOMYA Sowerby \\ Pholadomya occidentalis Morton \\ Plate XXIII, Figures 13-15}

1833. Pholadomya occidentalis. Morton, Am. Jour. Sci.; 1st ser., vol. 23 , p. 292 , pl. 8 , fig. 3 .

1834. Pholadomya occidentalis. Morton, Synopsis of the organic remains of the Cretaceous group of the United States, p. 68 , pl. 8 , fig. 3 .

1864. Pholadomya occidentalis. Meek, Check list of the invertebrate fossils of North America, Cretaceous' and Jurassic, p. 14 (part).

1868. Pholadomya occidentalis. Conrad, in Cook, Geology of New Jersey, p. 727.

12 Woods, Henry, A monograph of the Cretaceous Lamellibranchia of England. vol. 1, p. 110, pl. 18, figs. 13-15, pl. 19, figs. 1-11, Palaeont. Soc. London, 1900.

${ }_{13}$ D'Orbigny, Alcide, Paléontologie française, Terrains crétacés, vol. 3, p. 270 , pl. 338, figs. $5,6,1844$.

14 Stoliczka, Ferdinand, India Geol. Survey Mem., Palaeontologia Indica, Cre taceous fauna of southern India, vol. 3, pp. 372, 381, pl. 32, figs. 2, 35, 1871.

15 Woods, Henry, The Cretaceous faunas of the northeastern part of the south island of New Zealand: New Zealand Geol. Survey Paleont. Bull. 4, p. 24, pl. 10, figs. $6 \mathrm{a}, \mathrm{b}$.

${ }_{16}$ Whiteaves, J. F., Canada Geol. Survey, Mesozoic fossils, vol. 1, pt. 3, p. 236, pl. 22 , fig. 5,1884 . 
1885. Pholadomya occidentalis. Whitfield, U. S. Geol. Survey Mon. 9, p. 175, pl. 24, figs. 1-3. (Also published by New Jersey Geol. Survey, 1886.)

1905. Pholadomya occidentalis. Johnson, Acad. Nat. Sci. Philadelphia Proc., vol. 57, p. 13.

1907. Pholadomya occidentalis. Weller, New Jersey Geol. Survey, Paleontology, vol. 4, p. 513, pl. 56, figs. 1-3. (Synonymy excluded.)

1914. Pholadomya occidentalis. Stephenson, U. S. Geol. Survey Prof. Paper 81, p. 24, tables 2-9.

1916. Pholadomya occidentalis. Gardner, Maryland Geol. Survey Upper Cretaceous, p. 630 , pl. 37 , figs. 1-3.

Morton in 1833 described this species as follows:

Oblong-angular, ventricose near the beaks; with 25 to 30 narrow, elevated; subtortuous costae, having broad, slightly concave intervening spaces. Length, 2 inches; breadth, 3 inches. An extremely variable species. I possess five specimens (all more or less broken), in all of which there is a difference in the number and relative position of the ribs.

Type locality: Chesapeake \& Delaware Canal.

Weller adds the following details:

The dimenisions of an average-sized specimen are: Length; about 70 millimeters; height, 47 millimeters; thickness, 45 millimeters. Shell subovate or subelliptical in lateral outline, and cordate from in front. Hinge line straight, about twothirds as long as the shell; anterior margin rounding from the cardinal extremity into the basal margin or obliquely subtruncate; basal margin gently convex, becoming straighter posteriorly; posterior margin more narrowly rounded than the anterior. Beaks large and broad, situated from one-fifth to one-fourth the length. of the shell from the anterior extremity, strongly .incurved and nearly in contact, moderately elevated above the hinge line. Valves most prominent at about their midheight in front of the middle of the shell; from this point the surface curves rather abruptly to the ventral anterior and cardinal margins and much more gently to the gaping posterior margin; the cardinal margins back of the beaks are slightly inflected to form a rather distinct, concave cardinal area of moderate width on each valve. Surface of each valve marked by 25 or 30 more or less irregular and wavy; rounded radiating costae of moderate strength; much narrower than the intervening depressions and closer together in the middle of the. shell than at either the anterior or posterior portions; in the middle of the shell every other costa on large individuals has usually been intercalated between two others at some distance below the beak; the shell is also marked by more or less irregular concentric undulations. This species is one of the most characteristic members of the Merchantville clay marl fauna; where it sometimes occurs in considerable numbers.

\section{Miss Gardner says:}

The species is not'known from Maryland, but it occurs in the form of poorly preserved casts along the Chesapeake \& Delaware Canal in Delaware: It is readily recognizable by the well-rounded gibbous valves and the irregular elevated radial lirae. The more southern and apparently later $P$. conradi, described by Conrad under the name of $P$. occidentalis, has been accepted as a synonym by the later workers, although the two shells are obviously distinct. The northern form 'runs larger than the southern, is much more nearly cylindrical and less trigonal in outline, the umbones are broader, more evenly rounded, set farther back from the anterior extremity, and very much less prominent.

Only two imperfect specimens of this species are known in the Coon Creek collections. The genus is represented in the Cretaceous by a number of species.
Pholadomya speetonsis Woods, ${ }^{17}$ from the Speeton clay (Lower Cretaceous) of England, and Pholadomya royana D'Orbigny, ${ }^{18}$ from the Senonian of France, are both large elongate forms with conspicuous radiate sculpture analogous to Pholadomya occidentalis Morton and Pholadomya conradi Gardner.

Occurrence: Ripley formation, Dave Weeks place on Coon Creek, McNairy County, Tenn.

Collections: Maryland Geological Survey, U. S. National Museum, New Jersey Geological Survey; Philadelphia Academy of Natural Sciences.

Outside distribution: Matawan formation, Delàware. Magothy formation ("Cliffwood clay"), New Jersey. Matawan group (Merchantville clay and Woodbury clay), New Jersey.

\section{Pholadomya conradi Gardner}

\section{Plate XXIV; Figure 1}

1860. Pholadomya occidentalis. Conrad, Acad. Nat. Sci. Philadelphia Jour., 2d ser., vol 4, p. 276.

1860. Pholadomya occidentalis. Owen, Second report of a geological reconnaissance of the middle and southern counties of Arkansas, pl. 8, fig. 9.

1916. Pholadomya conradi. Gardner, Maryland Geol. Survey, Upper Cretaceous, p. 632 , pl. 38 , fig. 1.

Conrad describes this species as follows:

Subovate, very inequilateral, inflated anteriorly; ribs about 25 , irregular, prominent, acute, posteriorly distant, crenulated by rugose concentric striae, on the umbo tuberculate-crenate; summit very prominent; anterior margin obliquely truncated. Length, $31 / 4$ inches, height, $23 / 4$ inches.

Type locality: Tippah County, Miss.

Miss Gardner gives the following details:

Shell very thin and nacreous, approximately equivalve, very inequilateral; umbones rather narrow and compressed, obtusely angulated, rising high above the dorsal margin, almost at the anterior extremity; anterior end broadly and very feebly arcuate; posterior end symmetrically produced and strongly arcuate; external surface sculptured with 25 or 26 sharply elevated radial lirae, beaded in the umbonal region by the intersecting incrementals and minutely undulated by the growth sculpture, even to the ventral margin.

Pholadomya conradi $\mathrm{n}$. $\mathrm{sp}$. has been confused with $P$. occidentális Morton, so characteristic of the New Jersey and Delaware Matawan. The later species ( $P$. conradi) runs smaller and is; less inflated in general outline, while the very high, rather narrow, subangulated umbones, rising from the extreme anterior end of the shell, lend it an aspect that is very characteristic and quite distinct from the subcylindrical outline of $P$. occidentalis Morton.

This species is very rare at Coon Creek; only one imperfect specimen is known from that locality.

Occurrence: Ripley formation, Dave Weeks place on Coon Creek, McNairy County, Tenn.

Collections: Maryland Geological Survey, U. S. National Museum.

17 Woods, Henry, A monograph of the Cretaceous Lamellibranchia of England, vol. 2, p. 248, pl. 41, figs. 4a, b, Palneont. Soc. London, 1909.

18 D'Orbigny, Alcide, Palcontologie française, Terrains crétacés, vol. 3, p. 360, pl. 367 , figs. $1-3,1845$. 
Outside distribution: Monmouth formation, Brightseat, Prince Georges County, Md. Ripley formation, Exogyra costata zone, Eufaula, Ala., and Union and Tippah counties, Miss.; extreme top of Exogyra costata zone, Chattahoochee River, Ala.

\section{Family ANATINIDAE}

\section{Genus ANATIMYA Conrad}

Anatimya lata (Whitfield)

1885. Pholas? lata. Whitfield, U. S. Geol. Survey Mon. 9' p. 189, pl. 25, fig. 17. (Also published by New Jersey Geol. Survey, 1886.)

1907. Anatimya lata. Weller, New Jersey Geol. Survey, Paleontology, vol. 4, p. 521, pl. 57, fig. 13.

Whitfield describes this species as follows:

Shell large and proportionally very broad between dorsal and basal margins, the relative height and length being about as 2 to 3 respectively. The general outline is slightly ovate, widest at the anterior end and gradually narrowing posteriorly, the beak being a little in advance of the middle and showing somewhat above the cardinal line in the slightly compressed and somewhat crushed specimen of an internal cast of a left valve, the only one yet seen. Anterior and posterior ends rounded, the latter one most narrowly so; basal line slightly emarginate just behind the middle of its length; cardinal line apparently arcuate throughout. Surface of the shell, as shown on the cast, convex, with a broad sulcus passing across the valve from beak to base, reaches the latter behind the middle. Anterior to the sulcus the surface is radially ribbed, the rays being somewhat alternate in size over a portion of the space. At the bottom of the broad sulcus there is a single larger and stronger rib, which passes from the beak directly to the base of the shell, which it reaches at the point of greatest emargination. Posterior to this larger rib the surface is destitute of radiating lines, the surface being marked only with broad irregular concentric sulci; which extend over the entire surface parallel to the margin of the shell.

The Coon Creek material which is here referred to this species is very fragmentary. It does not agree in every detail with Whitfield's form; nevertheless it is probably specifically the same.

Occurrence: Ripley formation, Dave Weeks place on Coon Creek, McNairy County, Tenn.

Collections: New Jersey Geological Survey, U. S. National Museum.

Outside distribution: Matawan group (Wenonah sand), New Jersey.

\section{Genus PERIPLOMYA Conrad \\ Periplomya elliptica (Gabb) \\ Plate XXIV, Figure 2}

1862. Anatina elliptica. Gabb, Acad. Nat. Sci. Philadelphia Proc. for 1861, p. 324.

1864. Anatina elliptica. Meek, Check list of the invertebrate fossils of North America, Cretaceous and Jurassic, p. 15 .
1868. Anatina elliptica. Conrad, in Cook, Geology of New Jersey, p. 727.

1877. Periplomya elliptica. Gabb, Acad. Nat. Sci. Philadelphia Proc. for 1876, p. 305.

1885. Periplomya elliptica. Whitfield, U. S. Geol. Survey Mon. 9 , p. 177, pl. 23, figs. 14, 15. (Also published by New Jersey Geol. Survey, 1886.)

1905. Periplomya elliptica. Johnson, Acad. Nat. Sci. Philadelphia Proc., vol. 57, p. 13.

1907. Periplomya elliptica. Weller, New Jersey Geol. Survey, Paleontology, vol. 4, p. 522, pl. 57, figs. 8-11.

1916. Periplomya elliptica. Gardner, Maryland Geol. Survey, Upper Cretaceous, p. 633.

Gabb described the species in 1862 as follows:

Shell subelliptical, equivalve, nearly equilateral; beak central, pointing posteriorly, very small; umbones small. Cardinal margin slightly convex. Buccal margin broad, nearly straight and sloping inward toward the basal edge, which is very broadly rounded, being nearly straight just opposite the beaks. Anal extremity hardly more than half as broad as the buccal, and with the hinge line between it and the beaks, regularly concave. There is a broadly rounded ridge extending from the umbones toward the anterior basal margin, gradually becoming obsolete as it approaches the edge. Shell thin and marked on the surface by small, irregular concentric ridges. Length, 0.9 inch (from beaks to basal margin); width, 1.3 inch.

Type locality: Mullica Hill, N. J.

Whitfield adds the following details:

Shell small, inequivalve, and very inequilateral, subovate in outline, largest across the anterior side of the beaks and strongly constricted just behind them, the posterior end being narrowed on the hinge line and excavated at this point. Valves somewhat ventricose, the right one less convex than the left, and very decidedly depressed in the central region and toward the basal line, showing a decided twist or arcuation of the valves as seen in a basal view. Anterior end broadly rounded, and the posterior pointedly rounded. Beaks small, appressed, incurved, and apparently directed backward, as is usual in this group of shells, from the expansion or inflation of the anterior side of the hinge line. Cardinal margin, as seen on the cast, inflected both in front of and behind the beaks, forming an apparent lunule and escutcheon on the cast, probably produced mainly from a thickening of the hinge plate within. Muscular imprints and pallial line and hinge not observed.

A single imperfect, cast has been referred to this species. It shows, however, the compressed valves, the acute umbones, the constriction behind the umbones, and the spoon-shaped cartilage pit which characterize the species.

Occurrence: Ripley formation, Dave Weeks place on Coon Creek, McNairy County, Tenn.

Collections: Maryland Geological Survey, Phila. delphia Academy of Natural Sciences, U. S. National Museum.

Outside distribution: Monmouth formation, Seat Pleasant, Prince Georges County, Md. Manasquan(?) formation, New Jersey. 


\section{Family PERIPLOMATIDAE \\ Genus PERIPLOMA Schumacher \\ Periploma applicata Conrad \\ Plate XXIV, Figure 3}

1858. Periploma applicata. Conrad, Acad. Nat. Sci. Philadelphia Jour., 2d ser., vol. 4, p. 324.

1860. Periploma applicata. Conrad, Acad. Nat. Sci. Philadelphia Jour., vol. 4, p. 276, pl. 46, fig. 1.

1905. Periploma applicata. Johnson, Acad. Nat. Sci. Philadelphia Proc., vol. 57, p. 13.

Conrad describes this species as follows:

Oblong oval, equilateral, compressed, thin and fragile; right valve convex depressed; left valve flattened or slightly concave, with an oblique anterior carinated line; valves smooth in the middle, roughened with rugose concentric lines posteriorly; anterior end truncated or obtusely rounded, nearly direct; basal margin contracted in the middle. Length $13 / 4$ inches.

Type locality: Owl Creek, Miss.

This species is not uncommon at Coon Creek, but its shells are so very thin and fragile that it is rarely collected, never as a perfect specimen. The species is somewhat similar to some of the European Cretaceous species of Thracia. ${ }^{19}$ Without a better knowledge of the interior shell characters of Periploma applicata Conrad, its generic relations can not be determined.

Occurrence: Ripley formation, Dave Weeks place on Coon Creek, McNairy County, Tenn.

Collections: Johns Hopkins University, U. S. National Museum.

Outside distribution: Ripley formation, Owl Creek, Miss.

\section{Superfamily ENSIPHONACEA \\ Family CLAVAGELIIDAE \\ Genus Claviaglia Lamarck \\ Clavagella armata Morton \\ Plate XXIV, Figures 4, 5}

1834. Clavagella armata. Morton, Synopsis of the organic remains of the Cretaceous group of the United States, p. 69 , pl. 9, fig. 11.

1862. Clavagella armata. Gabb, Acad. Nat. Sci. Philadelphia Proc. for 1861, p. 364 .

1861. Clavagella armata. Gabb, Synopsis of the Mollusca of the Cretaceous formation, p. 109 (Am. Philos. Soc. Proc., vol. 8, p. 165).

1864. Clavagella armata. Meek, Check list of the invertebrate fossils of North America, Cretaceous and Jurassic, p. 15.

1885. Clavagella armata. Whitfield, U. S. Geol. Survey Mon. 9, p. 192, pl. 25, fig. 24. (Also published by New Jersey Geol. Survey, 1886.)

1907. Clavagella armata. Weller, New Jersey Geol. Survey, Paleontology, vol. 4, p. 525, pl. 58, figs. 1, 2.

Morton describes this species as follows:

Disk obtusely compressed, divided by an irregular fissure, and armed with four or five tubular spines; two or three other

10 Woods, Henry, A monograph of the Cretaceous Lamellibranchia of England, vol. 2, p. 242, pl. 11, Palaeont. Soc. London, 1909. spines below the disk; bivalve concentrically furrowed or striated.

Weller adds the following details:

The dimensions of a complete internal cast of the shell, exclusive of the tube, are: Length, 14 millimeters; height, 8.5 millimeters; thickness, 7.5 millimeters. Shell subovate in outline; the beaks small, situated a little in front of the middle, slightly recurved. Anterior and posterior margins rather sharply rounded; ventral margin convex throughout. The anterior margin with several tubular spines. Valve rather strongly convex, the right one free, the left one attached to the tube. Surface of the cast smooth, the muscular impressions more or less strongly marked, sometimes scarcely distinguishable.

This species is fairly common at Coon Creek, but a perfect specimen has not been collected, so long and slender are the branching tubular spines that extend out from these shells. Several of the specimens show a spinose collar around the posterior portion of the shell.

Occurrence: Ripley formation, Coon Creek, McNairy County, Tenn.

Collections: New Jersey Geological Survey, Johns Hopkins University, U. S. National Museum.

Outside distribution: Monmouth group, New Jersey. Ripley formation, Alabama.

\section{Superfamily POROMYACEA \\ Family POROMYACIDAE \\ Genus LIOPISTHA Meek \\ Liopistha protexta (Conrad) \\ Plate XXIV, Figure 6}

1853. Cardium protextum. Conrad, Acad. Nat. Sci. Philadelphia Jour., 2d ser., vol. 2, p. 275, pl. 24, fig. 12.

1860. Fragilia protexta. Conrad, Acad. Nat. Sci. Philadelphia Jour., 2d ser., vol. 4, p. 275.

1864. Papyridea (Liopistha) protexta. Meek, Check list of the invertebrate fossils of North America, Cretaceous and Jurassic, p. 12.

1868. Liopistha protexta. Conrad, in Cook, Geology of New Jersey, p. 726.

1876. Liopistha protexta. Meek, U. S. Geol. Survey Terr. Rept., vol. 9, p. 227, text figs. 20-24.

1885. Liopistha protexta. Whitfield, U. S. Geol. Survey Mon. 9, p. 140, pl. 20, figs. 1-3. (Also published by New Jersey Geol. Survey, 1886.)

1905. Liopistha protexta. Johnson, Acad. Nat. Sci. Philadelphia Proc., vol. 57, p. 13.

1907. Liopistha protexta. Weller, New Jersey Geol. Survey, Paleontology, vol. 4 , p. 526 , pl. 58, figs. 4-6.

1914. Liopistha protexta. Stephenson, U. S. Geol. Survey Prof. Paper 81, p. 24; tables 2-8.

1916. Liopistha protexta. Gardner, Maryland Geol. Survey, Upper Cretaceous, p. 636, pl. 36, fig. 15.

Conrad in 1853 described this species as follows:

Suboval or subtriangular, inequilateral, ventricose; ribs about 28 in number, narrow, rounded, obsolete on the posterior submargin; posterior extremity obliquely truncated; beaks prominent; basal margin rounded; umbonal slope undefined; posterior end gaping. (A cast.) 
Type locality: Burlington .County, N. J.

Miss Gardner adds the following details:

Shell of moderate size and rather heavy for the genus, gaping posteriorly, transversely ovate-trigonal in outline, evenly inflated, the maximum diameter falling near the medial portion of the shell; umbones evenly rounded, the apices proximate, incurved and feebly opisthogyrate, set a little in front of the median vertical and well up above the dorsal margins; anterior and posterior dorsal slopes very gentle, the posterior a little more produced and not quite so low as the anterior; anterior end well rounded, posterior end obscurely truncate; base line strongly and symmetrically arcuate; external surface sculptured with 26 to 35 angular radials, approximately uniform in size and spacing over the medial portion of the shell, separated by slightly wider concave interspaces; radials diminishing in prominence anteriorly but persistent almost to the margin, evanescing much more abruptly posteriorly, leaving the posterior sixth of the shell smooth; incremental sculpture overrunning the radials and minutely nodulating them in the umbonal region, imbricating them away from the umbones; characters of interior not known.

Liopistha protexta Conrad is abundant and widespread in the Upper Cretaceous of the east coast and Gulf. For that reason and because its stratigraphic distribution is apparently restricted it has been used by Stephenson as the guide. fossil for the so-called Liopistha protexta subzone, which he has traced through 'Georgia, Alabama, and Mississippi.

This species is rare at Coon Creek and is represented in the collections from that locality by a few imperfect specimens only. These specimens are strongly tuberculate- that is, the crests of the radial costae are studded with numerous low, short spinelike processes. This characteristic is developed to a less degree in specimens of this species from Owl Creek, Miss. This subspinous sculpture of the radials is a feature that characterizes some of the individuals of the European Senonian species Liopistha aequivalvis (Goldfuss), as is shown by some of the specimens figured by Holzapfel..$^{20}$

Occurrence: Ripley formation, Coon Creek, Sand Hill, McNairy County, Tenn.

Collections: Maryland Geological Survey, U. S. National Museum, New Jersey. Geological Survey, Philadelphia Academy of Natural Sciences.

Outside distribution: Monmouth formation, Bohemia Mills, Cecil County, Md.; Millersville, Anne Ärundel County, Md.; Brightseat, Brooks estate near Seat Pleasant, railroad cut 1 mile west of Seat Pleasant, and locality 2 miles south of Oxon Hill, all in Prince Georges County, Md. Manasquan formation, Noxontown Pond, Del. Matawan group (? Wenonah sand), New Jersey. Monmouth group (Navesink marl, Redbank sand, and Tinton sand member of the Redbank), New Jersey. Peedee sand, North Carolina and South Carolina. Ripley formation, Exogyra costata zone, Eufaula, Ala., and Chickasaw, Lee, Pontotoc, Union, Tippah, and Alcorn counties, Miss.; extreme top of Exogyra costata zone, Pataula Creek, Ga., and Chattahoochee River, Ala. Selma chalk, Exogyra costata zone, Wilcox County, Ala., and east-central Mississippi.

20 Holzapfel, Eduard, Die Mollusken der Aachener Kreide: Palaeontographia, Band 35, p. 150, pl. 9, flgs. 6, a, 1889.

\section{Liopistha inflata Whitfield}

Plate XXIV, Figures 7, 8

1885. Liopistha inflata. Whitfield, U: S. Geol. Survey Mon. 9 , p. 142 , pl. 20, figs. 4,5 . (Also published by New Jersey Geol. Survey, 1886.)

Whitfield describes this species as follows:

Shell rather smaller than those of $L$. protexta Conrad and very ventricose, with exceedingly large and inflated beaks, which are nearly central, very strongly incurved, and in "close contact. Length of the shell only about one-fourth or onefifth longer than high, and the thickness through the valves nearly or quite equaling the height. Anterior end but little shorter than the posterior and more narrowly rounded. Surface of the casts marked by numerous low, nearly flattened, indistinct radii, which increase in fineness anteriorly and are obsolete on the posterior cardinal slope.

This species is quite readily distinguished from $L$. protexta by its shorter and more ventricose form, more strongly inflated beaks, which are larger and much more prominent. The less strongly marked ribs is also a marked feature... It is not sufficiently near any of the other described species to be readily mistaken. It is most nearly allied in form to $L$. (Papyridea) bella Conrad, ${ }^{21}$ but that one is described as having prominent angular ribs, which are tuberculated on some parts of the shell, which these are not.

Type locality: Holmdel; N. J.

This species is common at Coon Creek and is represented in the collections by abundant material, which establishes the validity of this species that both Weller and Gardn̈er regarded as representing only individual variations of Liopistha protexta (Conrad).

Occurrence: Ripley formation, Dave Weeks place on Coon Creek, McNairy County, Tenn.

Collections: Johns Hopkins University, New Jersey Geological Survey, U. S. National Museum.

Outside distribution: Monmouth group, New Jersey.

\section{Superfamily CYPRICARDIÀCEA \\ Family PLEUROPHORIDAE \\ Genus CYPRINA Lamarck \\ Cyprina incerta Wade, n. sp. Plate XXIV, Figure 9}

Shell large and thin, transversely elongate, subovate in outline; umbones prominent, inflated proximate and prosogyrate; anterior margin well rounded: posterior dorsal margin truncate; lunule very small; escutcheon narrow, deep; and elongate; external sculpture concentric and 'of two types; angular posterior umbonal slope marked by numerous rugose concentric lines, region in front of this area nearly smooth, marked by low, irregular concentric lines; internal characters unknown. Imperfect specimen: Altitude, 33 millimeters; latitude, 50 millimeters.

This species is characterized by the rugose concentric sculpture on the angular posterior umbonal slope: The species can not be assigned with assurance

$"$ Conrad, T. A., Observations on a group of Cretaceous fossil shells found in Tippab County, Miss.: Acad. Nat. Sci. Philadelphia Jour., 2d ser., vol. 3, p. 326, 1858. 
to the genus Cyprina, for its internal characters are unknown; however, in general aspect of external features it seems to be a member of this group.

Occurrence: Ripley formation, Dave Weeks place on Coon Creek, McNairy County, Tenn.

\section{Collection: U. S. National Museum.}

\section{Genus VENIELLA Stoliczka \\ Veniella conradi (Morton) \\ Plate XXIV, Figures $14-16$}

1833. Venilia conradi. Morton, Am. Jour. Sci., 1st ser., vol. 23 , p. 294, pl. 8, figs. $1,2$.

1834. Venilia conradi. Morton, Synopsis of the organic remains of the Cretaceous group of the United States, p. 67, pl. 8, figs. 1, 2.

1862. Venilia trigona. Gabb, Acad. Nat. Sci. Philadelphia Proc. for 1861, p. 324.

1864. Venilia conradi. Meek, Check list of the invertebrate fossils of North America, Cretaceous and Jurassic, p. 13.

1868. Venilia conradi. Conrad, in Cook, Geology of New Jersey, p. 727.

1869. Goniosoma inflata. Conrad, Am. Jour: Conchology vol. 5, p. 44, pl. 1, fig. 10 .

1870. Venilia elevata. Conrad, Am. Jour. Conchology, vol. 6, p. 74, pl. 3, figs. 7, 7á.

1871. Veniella conradi. Stoliczka, India Geol. Survey Mem., Palaeontologia Indica, Cretaceous fauna of southern India, vol. 3, p. 190.

1876. Veniella conradi. Meek, U. S. Geol. Survey Terr. Rept., vol. 9, p. 148, text figs. 9-11.

1885. Veniella conradi. Whitfield, U. S. Geol. Survey Mon.9, p. 144, pl. 19, figs. 8-10. (Also published by New Jersey Geol. Survey, 1886.)

1885. Veniella trigona. Whitfield, U. S. Geol. Survey Mon. : 9, p. 149, pl. 19, figs. 11-14.

1885. Veniella inflata. Whitfield, U. S. Geol. Survey Mon. 9, p. 147 , pl. 19, figs. 4,5 .

1885. Veniella elevata. Whitfield, U. S. Geol. Survey Mon. 9, p. 148 , pl. 19 , figs. 6,7 .

1905. Veniella conradi. Johnson, Acad. Nat. Sci. Philadelphia Proc., vol. 57, p. 13.

1905. Veniella trigona. Johnson, Acad. Nat. Sci. Philadelphia Proc., vol. 57, p. 13.

1905. Veniella elevata. Johnson, Acad. Nat. Sci. Philadelphia Proc., vol. 57, p. 13.

1905. Veniella inflata. Johnson, Acad. Nat. Sci. Philadelphia Proc., vol. 57, p. 13.

1907. Veniella conradi. Weller, New Jersey Geol. Survey, Paleontology, vol. 4, p. 534, pl. 58, figs. 18, 19.

1907. Veniella trigona. Weller, New Jersey Geol. Survey, Paleontology, vol. 4, p. 537, pl. 59, figs. 1-3.

1914. Veniella conradi. Stephenson, U. S. Geol. Survey Prof. Paper 81, p. 24, tables 2-8.

1916. Veniella conradi. Gardner, Maryland Geol. Survey, Upper Cretaceous, p. 643, pl. 38, figs. 2-7.

Morton in 1833 characterized this species as follows:

Trigonal, ventricose, concentrically sulcated; beaks long and incurved; diameter an inch and a half.

Type locality: New Jersey.

Miss Gardner adds the following details:

Shell thick, heavy, prismatic, rudely cordate or trigonal in outline; umbones very prominent, inflated to their very apices, which are turned inward and forward and placed in the adult forms within the anterior third; posterior carina strongly defined, persisting from the umbones to the posterior ventral margin; lunule very wide, differentiated by a faintly incised line and the evanescence of the heavy concentric sculpture; escutcheon suggested by an obscure keel ruinning from the umbones to the extremity of the dorsal margin at a distance a little more than midway between the posterior carina and the hinge margin; escutcheon much more sharply defined in the young forms than in the adults; anterior portion of shell smoothly rounded, even nasute in the young; base line approximately horizontal; posterior dorsal and distal margins merging into one, another in the adults, the lateral margin squarely truncate in the young; external surface broadly corrugated in the umbonal region, the summits of the obtuse ridges thus formed crowned with sharp laminar plates uniform in thickness throughout their extent, although the altitude attained sometimes approaches a centimeter; laminae often broken away, leaving only a faint scar, which is soon eradicated by exposure; the number of processes thus developed rarely exceeding five; ventral portion of adult shell evenly rounded and sculptured only' with heavy growth, lines and crowded resting. stages; ligament external, opisthodetic, seated upon a short but rather stout nymph; hinge plate heavy, two cardinals in the right valve, the anterior trigonal and placed opposite the lateral, the posterior robust, obliquely elongated and compressed, feebly sulcated medially; a stout rounded anterior lateral tubercle developed on the ventral side of the hinge plate near the anterior cardinal; posterior lateral grooved, profound, the inner surfaces finely striated transversely; two cardinals present also in the left valve, both of them posteriorly produced, the anterior stout and feebly sulcated, the posterior laminar and united with the basal margin; anterior lateral sharp, trigonal, with a deep pocket behind it for the reception of the corresponding lateral in the right valve; posterior lateral elevated, produced; muscle impressions distinct, the anterior excavated; pallial line entire.

The young of the species are subquadrate in outline and when fully armed present a very different aspect from the cordate adults, from which the laminar plates have been broken away and all traces of them obliterated. However, all the changes in outline and sculpture may be observed in a single individual, so that there is no doubt of the absolute identity of the $V$. conradi and V. trigona. Even though there were, Morton's well-figured type is a fully adult form with all the characters of the individual described later by Gabb under the name of V. trigona.

Four other species with prominent umbones and such a characteristic trigonal outline are two from the Upper Cretaceous of the western interior-Veniella mortoni Meek and Hayden, ${ }^{22}$ from the Benton shale, and Veniella goniophora Meek, ${ }^{23}$ also from the Benton; Veniella drui (Munier-Chalmas), ${ }^{24}$ from the Senonian of Tunis, northern Africa; and Veniella santaeluciensis Etheridge, ${ }^{25}$ from the Upper Cretaceous of Natal, southeast Africa.

Occurrence: Ripley formation, Coon Creek, Sand Hill, McNairy County, Tenn.

Collections: Maryland Geological Survey, Philadelphia Academy of Natural Sciences, New Jersey Geological Survey, U. S. National Museum.

${ }^{22}$ Meek, F. B., A report on the invertebrate Cretaceous and Tertiary fossils of the upper Missouri country: U. S. Geol. Survey Terr. Rept., vol. 9, p. 154, pl. 4, figs. 3a, b, 1876.

${ }^{23}$ Idem, p. 152, pl. 4, flg. 4

24 Pervinquière, L., Études de paléontologie tunisienne, vol. 2, p. 230, pl. 15, figs. 9-13, 1912.

${ }_{25}$ Etheridge, Robert, The Umsinene River deposit, Zululand: Natal and Zululand Geol. Survey Third Rept., p. 79, pl. 3, figs. 1, 2, 1907. 
Outside distribution: Magothy formation(?), Good Hope Hill, District of Columbia. Matawan formation, post 157, Chesapeake \& Delaware Canal, Del., and Ulmsteads Point, Anne Arundel County, Md. Monmouth formation, Millersville(?) and Anne Arundel County, Md.; Bohemia Mills, right bank of Bohemia Creek near Scotchman Creek, Cecil County, Md.; east of mouth of Turners Creek, Kent County, Md.; Brightseat, railroad cut west of Seat Pleasant, Brooks estate near. Seat Pleasant, 1 mile west of Friendly, McNeys Corners, and Fort Washington, all in Prince Georges County, Md. Matawan group (Merchantville clay and Wenonah sand), New Jersey: Monmouth group (Navesink marl, Redbank sand, and Tinton sand member of the Redbank), New Jersey. Black Creek formation, North Carolina and South Carolina. Eutaw formation (Tombigbee sand member), Exogyra ponderosa zone, Mortoniceras subzone, Georgia and Prentiss County, Miss. Transition beds from Eutaw to Selma, Exogyra ponderosa zone, Mortoniceras subzone, Dallas County, Ala. Ripley formation, Exogyra ponderosa zone, Barbour County, Ala.; extreme top of Exogyra ponderosa zone, Pataula Creek, Ga. Selma chalk, Exogyra ponderosa zone, Lee County, Miss.; Exogyra costata zone, Wilcox County, Ala., and east-central Mississippi.

\section{Superfamily ASTARTACEA \\ Family ASTARTIDAE \\ Genus VETERICARDIA Conrad \\ Vetericardia crenalirata (Conrad) \\ Plate XXIV, Figures 12, 13}

1860. Astarte crenalirata. Conrad, Acad. Nat. Sci. Philadelphia Jour., 2d ser., vol. 4, p. 282, pl. 46, fig. 25 .

1861. Astarte crenulirata. Gabb, Synopsis of the Mollusca of the Cretaceous formation, p. 100 (Am. Philos. Soc. Proc., vol. 8, p. 156.)

1864. Astarte crenulata. Meek, Check list of the invertebrate fossils of North America, Cretaceous and Jurassic, p. 11 ,

1868. Gouldia? crenulirata. Conrad, in Cook, Geology of New Jersey, p. 726.

1869. Vetocardia crenalirata. Conrad; Am. Jour. Conchology, vol. 5, pl. 1, fig. 23.

1872. Vetericardia crenalirata. Conrad, Acad. Nat. Sci. Philadelphia Proc. for 1872 , p. 52, pl. 1, fig. 4:

1885. Vetericardia crenulirata. Whitfield, U. S. Geol. Survey Mon, 9, p. 128, pl. 18, figs. 5-7. (Also published by New Jersey Geol. Survey, 1886.)

1907. Vetericardia crenalirata. Weller; New Jersey Geol. Survey, Paleontology, vol. 4, p. 566, pl. 62, figs. 9, 10

1914. Vetericardia crenalirata.. Stephenson, U. S. Geol. Survey Prof. Paper 81, p. 24, tables 2-8.

Conrad in 1860 described this species as follows:

Triangular convex; costae about 20 , concentric, very prominent, slightly incurved, crenulated by minute radiating lines; margin within crenulated, crenae rounded on the posterior margin, and the rest tuberculiform.

Type locality: 'Eufaula, Ala.
Whitfield adds the following details:

Shell small, not exceeding one-fourth of an inch in length in adult individuals, subtriangular or broadly subelliptical in outline, with very ventricose valves and proportionally large, suberect beaks, which are situated a little in advance of the middle. Surface marked by from 13 to 18 concentric varices, according to the size of the shell, which gradually increase in strength with increased growth of the shell. These become obsolete at the margin of the proportionally large and deeply impressed lunule. Interspaces flattened at the bottom and about as wide as the sharply elevated varices. There are also fine but distinct elevated radiating lines crossing the ridges and interspaces, becoming much stronger on the spaces than on the ridges. In the interior the muscular imprints are faintly marked and of moderate size, and the margin of the valves is strongly and deeply crenulated by radiating ridges. Hinge plate moderately strong and the teeth well marked.

Species of this group, which is characterized by small stout trigonal shells, are common and widely distributed in the Upper Cretaceous of the world, as shown by the species mentioned below, which are tentatively assigned to it. Vetericardia crenalirata Conrad is characterized by a combination of radial and concentric sculpture which is not common to other related species of this group. Vetericardia benedeni (Müller), ${ }^{26}$ from the Aachen Cretaceous of Vaals, Germany, possesses only the radial sculpture, whereas Vetericardia gregaria (Meek and Hayden), ${ }^{27}$ from the Pierre shale of the úpper Missouri Cretaceous; Astarte formosa (Sowerby), ${ }^{28}$ from the Upper Greensand, Blackdown, England; Vetericardia trigonoides (Stoliczka), ${ }^{29}$ from the Trichinopoly group of the Cretaceous of southern India; Vetericardia griesbachi (Woods), ${ }^{30}$ from the Senonian of Pondoland; and a few other known species are characterized by. strong concentric sculpture.

Occurrence: Ripley formation, Dave Weeks place on Coon Creek, McNairy County, Tenn.

Collections: New Jersey Geological Survey, Philadelphia Academy of Natural Sciences, U. S. National Museum.

Outside distribution: Monmouth and Matawan groups, New Jersey. Ripley formation, Alabama and Mississippi.

\section{Vetericardia subangulata Wade, n. sp. Plate XXIV, Figures 10, 11}

Shell of medium size and fairly strong; subtrigonal in outline; umbones elevated and rather conspicuous, incurved and proximate, located in advance of the middle of the valves; dorsal anterior and posterior

${ }^{26}$ Holzapfel, Eduard, Die Mollusken der Aachener Kreide: Palaeontographica, Band 35, p. 193, pl. 19, fig. 10, 1889.

${ }_{27}$ Meek, F. B., A report on the invertebrate Cretaceous and Tertiary fossils of the upper Missouri country: U. S. Geol. Survey Terr. Rept., vol. 9, p. 124, pl. 17, figs. $9 a, b, 1876$.

28 Woods, Henry, A monograph of the Cretaceous Lamellibranchia of England, vol. 2, p. 110, pl. 15, figs. 8-13, Palaeont. Soc. London, 1906.

${ }^{29}$ Stoliczka, Ferdinand, India Geol. Survey Mem., Palaeontologia Indica, Cretaceous faunas of southern India, vol. 3, p. 290, pl. 10, figs. 4-8, 1871. is.

${ }^{30}$ Woods, Henry, Cretaceous fauna of Pondoland: South African Mus. Annals, vol. 4, pt. 7, p. 300 , pl. 35, figs. 18, 19, 1906. 
margins truncate, sloping off from the apex, making an angle of $90^{\circ}$ with one another, ventral margin well rounded anteriorly, incurved and truncate posteriorly; posterior marginal slope area well defined; external surface marked with more than 30 strong, closely spaced concentric costae; one fairly strong cardinal in the left valve, laterals only feebly developed; adductor scars faint, small, and ovate in shape; pallial line simple; inner margin feebly crenate. Altitude, 10 millimeters; latitude, 12 millimeters.

This species is well characterized by its external sculpture and its elongate dorsal marginal slope. This last feature is a character which serves to separate this species from the smaller related species Vetericardia gregaria (Meek and Hayden).

Occurrence: Ripley formation, Dave Weeks place on Coon Creek, McNairy County, Tenn.

Collection: U. S. National Museum.

\section{Vetericardia gregaria (Meek and Hayden)?}

Plate XXV, Figures 1-3

1856. Astarte gregaria. Meek and Hayden, Acad. Nat. Sci. Philadelphia Proc., vol. 8, p. 84.

1876. Eriphyla gregaria. Meek, U. S. Geol. Survey Terr. Rept. vol. 9 , p. 124, pl. 17, figs. 9a, b.

Meek in 1876 described this species as follows:

Shell very small, 'rather thin, rounded subtrigonal, a little longer than high, moderately convex; anterior side rounded below and slightly sinuous above; base forming a very nearly semicircular curve; posterior side more broadly rounded than the other; dorsum sloping abruptly from the beaks with a slightly concave outline in front, convex and declining more gradually behind; pallial border not crenate within; beaks elevated, rather pointed, incurved, approximate, and a little oblique, located slightly in advance of the middle. Surface ornamented by distinct regular concentric costae and fine obscure lines of growth. Length, 0.21 inch; height, 0.19 inch; transverse diameter of the two valves, $0.14 \mathrm{inch}$.

Meek compares this species with Astarte similis Münster, as figured in Zittel's work on the Gosau beds of the Alps. The Ripley form and the Pierre form are not alike in every detail, so that there is ground for questioning the identity of the two forms.

Occurrence: Ripley formation, Dave Weeks place on Coon Creek, McNairy County, Tenn.

Collection: U. S. National Museum.

Type of the species described from Pierre shale on Yellowstone River 150 miles above its mouth.

Vetericardia subcircula Wade, n. sp.

Plate XXV, Figures 4,5

Shell very small and stout; rounded, subtrigonal in outline; umbones elevated, rather pointed, incurved, proximate, and a little oblique, located slightly in advance of the middle; dorsal anterior and posterior margins truncate, ventral margin broadly rounded; external sculpture dominantly concentric; numerous strong equal concentric ridges on the umbonal region; negr the ventral margin the concentric lines become more widely spaced, making the interlinear spaces broad and flat; very faint radial lines may be observed on the posterior slope of some individuals; right valve has one strong cardinal tooth between two sockets for smaller cardinals of the left valve; lateral teeth not well developed; adductor scars well defined, small and ovoid; pallial line simple; ventral margin crenulated. Altitude, 7 millimeters; latitude, 7.5 millimeters.

This species is well characterized by its concentric sculpture, which evanesces or becomes widely spaced near the ventral margin. It does not have the strong tuberculate sculpture caused by strong concentric and radial ridges that is typical of Vetericardia crenalirata Conrad. Vetericardia subcircula is related perhaps to the concentrically ornamented form Vetericardia gregaria (Meek and Hayden) ${ }^{31}$ from the Pierre shale of the upper Missouri Cretaceous of the western interior and from the Ripley formation of Tennessee.

Occurrence: Ripley formation, Dave Weeks place on Coon Creek, McNairy County, Tenn.

Collections: Johns Hopkins University, U. S. National Museum.

\section{Family CRASSATELLITIDAE}

\section{Genus CRASSATELLITES Krüger}

Crassatellites vadosus (Morton)

Plate XXV, Figures 6-8

1834. Crassatella vadosa. Morton, Synopsis of the organic remains of the Cretaceous group of the United States, p. 66, pl. 13, fig. 12 .

1858. Crassatella ripleyana. Conrad, Acad. Nat. Sci. Philadelphia Jour., 2d ser., vol. 3, p. 327, pl. 35, fig. 3.

1864. Crassatella vadosa. Meek, Check list of the invertebrate fossils of North America, Cretaceous and Jurassic, p. 11 .

1871. Crassatella vadosa. Stoliczka, India Geol. Survey Mem., Palaeontologia Indica, Cretaceous fauna of southern India, vol. 3, p. 295.

1877. Crassatella vadosa. Gabb, Acad. Nat. Sci. Philadelphia Proc. for 1876, p. 310.

1878. Crassatella vadosa. Conrad, in Cook, Geology of New Jersey, p. 736.

1885. Crassatella vadosa. Whitfield, U. S. Geol. Survey Mon. 9, p. 116, pl. 17, figs. 12-15. (Also published by New Jersey Geol. Survey, 1886.)

1905. Crassatellites vadosus. Johnson, Acad. Nat. Sci. Philadelphia Proc., vol. 57, p. 14.

1905. Crassatellites rifleyana. Johnson, Acad. Nat. Sci. Philadelphia Proc., vol. 57, p. 14.

1907. Crassatellites subplanus. Weller, New Jersey Geol. Survey, Paleontology, vol. 4, p. 553 (part), pl. 61, figs. 1, 2 (?).

1916. Crassatellites vadosus. Gardner, Maryland Geol. Survey, Upper Cretaceous, p. 649, pl. 39, figs. 1-4.

Morton describes this species as follows:

Ovato-triangulate, slightly compressed; with about 30 distinct, concentric striae. Length, $1 \frac{1}{4}$ inches; breadth, 1 inch.

Type locality: Prairie Bluff, Ala.

a Meek, F B., op. cit., p. 124, pl.17, figs. 9a, b. 
Miss Gardner gives the following information: 。

Shell of medium size, thick, heavy, rudely trigonal in outline; anterior and lateral margins rounded, posterior more or less produced and truncated, ventral margin approximately horizontal; umbones orthogyrate or turned a little forward, proximate, often thickened, flattened upon their summits, placed back from the anterior margin a distance of one-third of the total latitude; lunule broadly lenticular, sharply defined, the portion in the left valve a trifle broader and nore feebly striated by the incrementals than that of the right; escutcheon more sharply defined, broader and a trifle larger in the right valve than in the left; posterior area outlined by an obtuse ridge passing from the umbones to the posterior ventral margin; external surface sculptured with low concentric ridges, close set but irregular in arrangement, suggesting an exaggerated incremental sculpture; a few pronounced resting stages, usually developed toward the ventral margin; radial sculpture manifested only in the sharp denticulations on the inner margins; hinge plate very heavy; ligament pit a small scoop-shaped affair, extending obliquely backward from directly beneath the tips of the umbones; cardinals two in number in the left valve, three in the right, the anterior cardinal of the right very thin and laminar and fused at the base with the dorsal margin; the middle cardinal heavy, trigonal, transversely striated; the posterior cardinal laminar, largely effaced by the resilium, originating near the base of the anterior cardinal and diverging from it at an angle of approximately $60^{\circ}$; cardinals of the left valve much more nearly equal than those of the right; the posterior rather thin just under the umbones, where it forms the anterior margin of the ligament pit, but expanding rapidly toward its ventral extremity; left cardinals striated on their inner faces, separated by a deep trigonal pit for the reception of the right anterior cardinal; small sulcus near the base of the left posterior cardinal provided for the laminar posterior cardinal of the right valve; no trace of true laterals developed, but the posterior dorsal margin of the right valve and the anterior dorsal margin of the left valve beveled to function as laterals and received in grooves in the opposite valves; muscle impressions subequal, placed near the median horizontal, the anterior more deeply excavated than the posterior; anterior pedal scar very distinct, set under the hinge plate a little dorsal to the anterior adductor; pallial line entire; inner margins finely crenulated from the ventral extremity of the lunule to the ventral extremity of the escutcheon.

C. vadosus Morton shows a wide range of variation in age characters. The young are thin; rather compressed and truncated but not produced posteriorly; with increasing age the form becomes apparently more inflated because of the umbonal thickening and obliquely produced posteriorly.

Conrad's C. rip'eyana is doubtless a synonym, which includes the larger and heavier individuals. The young are quite uniform in outline and sculpture, but after the form has passed the typical $C$. vadosus stage there is a strong tendency for it to become produced posteriorly and to develop a rather heavy carina with the concomitant medial depression stage represented by the $C$. ripleyana. The species differs constantly from C. subplanus in the heavier, less compressed and more inequilateral shell, the less prominent keel, and the much heavier and more trigonal hinge plate.

Although this species has not been reported from New Jersey it would be by no means surprising if the numerous casts from the Monmouth, which have been referred to $C$. subplanus Conrad, would find their true affinities with $C$. vadosus Morton, which is by far the most abundant representative of the genus in Maryland and constitutes, indeed, one of the major factors in the Monmouth fauna.

This is one of the commonest bivalves in Coon Creek beds and is represented in the collections by dozens of perfect specimens, ranging from minute individuals 1 millimeter in length to large old-age adults.

Occurrence: Ripley formation, Coon Creek, Sand Hill, top of Blue Cut Hill, McNairy County, Tenn.

Collections: Maryland Geological Survey, Philadelphia Academy of Natural Sciences, New Jersey Geological Survey, U. S. National Museum, Yale University, Vanderbilt University.

Outside distribution: Monmouth formation, Millersville (?), Anne Arundel County, Md., and Brightseat, railroad cut west of Seat Pleasant, Brooks estate near Seat Pleasant and Fort Washington, all in Prince Georges County, Md. Monmouth group (Navesink marl and Tinton sand member of Redbank sand), New Jersey. Ripley formation, Exogyra costata zone, Union and Tippah counties, Miss. Selma chalk, Exogyra costata zone, Wilcox County, Ala., and east-central Mississippi.

\section{Crassatellites linteus (Conrad)}

1860. Crassatella lintea. Conrad, Acad. Nat. Sci. Philadelphia Jour., 2d ser., vol. 4, p. 279, pl. 46, fig. 5 .

1864. Crassatella lintea. Meek, Check list of the invertebrate fossils of North America; Cretaceous and Jurassic, p. 11.

1868. Crassatella lintea. Conrad, in Cook, Geology of New Jersey, p: 726.

1905. Crassatellites linteus. Johnson, Acad. Nat. Sci. Philadelphia Proc., vol. 57, p. 14.

1907. Crassatellites subplanus. Weller, New Jersey Geol. Survey, Paleontology, vol. 4, p. 553, pl. 61, figs. 3, 4 (part, synonymy and figs. 1, 2 excluded).

1916. Crassatellites linteus. Gardner, Maryland Geol. Survey, Upper Cretaceous, p. 653, pl. 39, figs. 6, 7.

Conrad in 1860 described this species as follows:

Subovate or subtriangular, convex, inequilateral; disk concentrically ridged and finally striated, slightly contracted near the umbonal slope, which is rounded; posterior extremity subtruncated; apex slightly prominent; posterior dorsal line nearly straight, very oblique; margin within finely crenulated; lunule long and lanceolate.

Type locality: Alabama.

Miss Gardner adds the following details:

Shell rather small for the genus and rather thin; compressed subovate to ovate-trigonal in outline; umbones rising a little above the dorsal margin, their apices acute and prosogyrate, slightly anterior in position; lunule and escutcheon clearly differentiated but very narrow because of the compression of the valves; anterior end broadly and symmetrically rounded in front of the umbones; posterior dorsal margin gently sloping; lateral margin obscurely and obliquely truncate; base line rounding smoothly into the anterior lateral margin, obtusely angulated at the union with the posterior; posterior keel obscure but persistent from the umbones to the posterior ventral margin, better defined by the change in the direction of the growth lines than by any variation in the plane; external surface sculptured with a very irregular concentric lineation, sharpest and most regular in the umbonal region, and occasional more or less accentuated growth lines and resting stages; ligament external, lodged beneath the umbones, the resilium buttressed ventrally by the posterior cardinal, which it has largely effaced; medial right cardinal stout, trigonal, subumbonal, transversely striated laterally; anterior cardinal laminar; hinge dentition in left valve 
restricted to two subequal cardinals, the posterior a little the larger, both of them striated upon their inner faces; no trace of laterals developed but anterior margin of left valve and posterior margin of right valve beveled to function as laterals and received in shallow sockets in the corresponding valve; muscle impressions distinct, impressed in the adults, placed high up at the distal extremities of the hinge; pallial line simple, distinct, rather distant from the base line.

C. linteus Conrad has been considered, without justification, as the young of some of the clearly allied and larger forms, such as $C$. vadosus and $C$. subplanus. Aside from the fact that it shows no evidence of immaturity, the shell is thinner and more compressed and much less strongly carinated posteriorly than $C$. vadosus of the same size. The resemblance to $C$. subplanus is more striking, but the concentric sculpture is finer and more sharply impressed in the former, and as a rule the umbones are set farther forward and are more strongly prosogyrate.

C. linteus has a distribution in Maryland very similar to that of vadosus but is very much less prolific.

Occurrence: Ripley formation, Dave Weeks place on Coon Creek, McNairy County, Tenn.

Collections: Maryland Geological Survey, U. S. National Museum, New Jersey Geological Survey, Philadelphia Academy of Natural Sciences.

Outside distribution: Monmouth formation, Brightseat, Brooks estate near Seat Pleasant, Friendly, 1 mile west of Friendly, and Fort Washington, all in Prince Georges County Md. Matawan group (Marshalltown formation and Wenonah sand), New Jersey. Monmouth group (Navesink marl, Redbank sand, and Tinton sand member of the Redbank), New Jersey.

\section{Genus ETEA Conrad}

\section{Etea carolinensis Conrad}

Plate XXV, Figures 9, 10

1875. Etea carolinensis. Conrad, in Kerr, Report of the geological survey of North Carolina, vol. 1, appendix, p. 6 , pl. 1, fig. 14 .

1905. Etea carolinensis. Johnson, Acad. Nat. Sci. Philadelphia Proc., vol. 57, p. 14.

1907. Etea carolinensis. Weller, New Jersey Geol. Survey, Paleontology, vol. 4, p. 541, pl. 59, figs. 4,6 .

1914. Etea carolinensis. Stephenson, U. S. Geol. Survey Prof. Paper 81, p. 24, tables 2, 8.

1916. Crassatellina carolinensis. Gardner, Maryland Geol. Survey, Upper Cretaceous, p. 646.

1923. Veniella (Etea) carolinensis. Stephenson, North Carolina Geol. and Econ. Survey, vol. 5, pt. 1, p. 264, pl. 66 , figs. 9-12.

Conrad characterizes this species as follows:

Shell suboval, short, equilateral, compressed, with distinct lines of growth; posterior end truncated, nearly direct.

Type locality: Snow Hill, N. C.

Weller describes this species as follows:

The dimensions of a shell of average size, preserving both valves, are: Length, 33 millimeters; height, 22.5 millimeters; thickness, 14 millimeters. Length of the largest individual observed, 14 millimeters. Shell very oblique and inequilateral. the beaks obtuse, slightly incurved, situated about three-eighths of the entire length of the shell from the anterior extremity. Anterior margin somewhat narrowly rounded and passing into the basal margin; basal margin moderately convex anteriorly, becoming straight or usually slightly concave posteriorly; posterior basal extremity acutely angular; posterior margin rather short, obliquely truncate; postero-dorsal margin straight, except near the beak, where it becomes slightly convex, making an angle of about $136^{\circ}$ with the truncate posterior margin. Surface of the shell marked with a sharply angular or subcarinate, usually straight umbonal ridge passing from the beak to the postero-basal extremity of the shell; postero-dorsal slope concave from the umbonal ridge to the cardinal margin, where the shell is sharply inflected to form a large and nearly flat escutcheon; in front of the umbonal ridge a broad, more or less indefinite depression passes from the beak to the sinuosity in the posterior portion of the ventral margin; in front of the beak the surface is inflected to form a rather large and broad lunule. Entire surface of the shell covered with strong concentric lines of growth, which are more or less irregular in the strength of their development. Hinge of right valve with a large bifid cardinal tooth directed obliquely backward from beneath the beak, and a much smaller simple one directed forward; between these two teeth is a deep triangular pit, and behind the posterior one is a much narrower pit; two large lateral teeth are present, one in front and one behind the beak; the anterior one is nearer the beak, with a broad and deep pit between it and the hinge line; the posterior one is more elongate and slender and is also separated from the hinge line by a deep pit. The hinge of the left valve has two cardinal teeth, a large bifid one immediately beneath the beak and a thin, very oblique one behind, with a large oblique, triangular pit between the two; there are two strong lateral teeth, one in front and one behind, the anterior one being nearer the beak and usually stronger but not so much extended longitudinally as the posterior one. Muscular impressions large and strong, of about equal size; pallial line parallel with the truncated posterior margin for a short distance below the posterior muscular impression, then bending abruptly forward and continuing subparallel with the shell margin.

This species is represented in the Coon Creek collections by several perfect specimens which show all the internal shell characters. The figures and description of the species Crassatella tricarinata Römer, ${ }^{33}$ from the Chlomeker Schichten, Tannenberg, Bohemia; strongly suggest the genus Etea.

Stephenson compared the types of Etea and Crassatellina and reached the conclusion that they are not congeneric. He regards Etea as a subgenus under Veniella.

Occurrence: Ripley formation, Dave Weeks place on Coon Creek, McNairy County, Tenn.

Collections: Maryland Geological Survey, U. S. National Museum, New Jersey Geological Survey, Philadelphia Academy of Natural Sciences.

Outside distribution: Matawan formation, post 105, Chesapeake \& Delaware Canal, Del. Marshalltown formation, New Jersey. Black Creek formation, North Carolina and South Carolina. Peedee sand, North Carolina and South Carolina. Eutaw formation, basal part of Exogyra ponderosa zone, Russell County, Ala.; Tombigbee sand member of Eutaw formation, Mortoniceras subzone, Georgia, Russell County, Ala., and Prentiss County, Miss. Ripley formation,.. Exogyra ponderosa zone, Barbour County, Ala.; Exogyra costata zone, Union County, Miss.; extreme top of Exogyra

ss Frič, Anton, Studien im Gebiete der böhmischen Kreideformation: Archiv naturwiss. Landesd. Böhmen, Band 10, No. 4, p. 52, fig. 54, 1897. 
costata zone, Pataula Creek, Georgia; Selma chalk, Exogyra costata zone, east-central Mississippi.

\section{Genus SCAMBUIA Conrad}

Scambula perplana Conrad

Plate XXV, Figures 11, 12, 15, 16

1869. Scambula perplana. Conrad, Am. Jour. Conchology, vol. 5 , p. 48 , pl. 9, figs, 7-8.

1872. Scambula perplana. Conrad, Acad. Nat. Sci. Philadelphia Proc. for 1872, p. 51, pl. 1, fig. 2.

1885. Scambula perplana. Whitfield, U. S. Geol. Survey Mon. 9 , p. 123 , pl. 18, figs. 8-10. (Also published by New Jersey Geol. Survey, 1886.)

1905. Crassatellites (Scambula) perplanus. Johnson, Acad. Nat. Sci. Philadelphia Proc., vol. 57, p. 14.

1907. Scambula perplanus. Weller, New Jersey Geol. Survey, Paleontology, vol. 4, p. 562, pl. 61, figs. 13-14.

1914. Scambula perplana. Stephenson, U. S. Geol. Survey Prof. Paper 81, p. 24, tables 2, 8.

Conrad in 1869 described this species as follows:

Elongated, triangular, flat; disk uneven, faintly striated concentrically; a few prominent fine concentric ribs on the umbo; anterior margin obliquely truncated; posterior dorsal margin concave; apex acute, perfectly•erect.

Whitfield adds the following details:

Shell small, triangularly ovate, very transverse, with very sharp, pointed, and recurved beaks, situated just within the middle third of the length of the shell and nearest to the anterior end. Valves flat, marked by fine concentric lines of growth and a few (three or four) broad oblique undulations of the surface which pass from the posterior hinge line backward to the basal margin. There are also a few obliquely concentric wrinkles on the antero-cardinal margin which extend only a short distance over the disk of the valve. Along the position of the posterior umbonal ridge the surface striae are abruptly deflected upward, marking the position of the ridge and defining the posterior slope of the valve. Posterior end of the valve narrow and truncate; anterior end obtusely angular; basal margin regularly and broadly arcuate. Inner margin of the valves crenulate; muscular scars small and faintly marked.

Occurrence: Ripley formation, Dave Weeks place on Coon Creek, McNairy County, Tenn.

Collections: Philadelphia Academy of Natural Sciences, New Jersey Geological Survey, U. S. National Museum.

Outside distribution: Matawan group, New Jersey: Ripley formation, Mississippi and Georgia.

Superfamily CHAMACEA

Family CAPRINIDAE

\section{Genus CAPRINELLA D'Orbigny}

Caprinella coraloidea Hall and Meek?

Plate XXV, Figures 13, 14

1854. Caprinella coraloidea. Hall and Meek, Am. Acad. Arts and Sci. Mem., new ser., vol. 5, p. 380, pl. 1, fig. 3.

A small shell fragment from Coon Creek is doubtfully assigned to this species. The shell texture of the form from Tennessee is very similar to the texture of the form from South Dakota, but without a more com- plete specimen a definite determination can not be made. Several localities in Alabama, Mississippi, and Texas have yielded large imperfect specimens with the same shell structure which are referred to Radiolites.

Occurrence: Ripley formation, Dave Weeks place on Coon Creek, McNairy County, Tenn.

Collection: U. S. National Museum.

Outside distribution: Pierre shale, Sage Creek, S. Dak.

\section{Superfamily LUCINACEA \\ Family UNICARDIIDAE \\ Genus UNICARDIUM D'Orbigny}

Unicardium concentricum Wade, n. sp.

Plate XXV, Figures 17, 18

Shell small and very fragile; subcircular in outline; umbones proximate, prosogyrate and prominently inflated, apices projecting well above the hinge line; entire margin subcircular, with the posterior portion slightly flattened; external surface strongly sculptured with numerous highly raised sharp lines, irregularly spaced and strongest near the ventral margin; edentulous; ligamental area a long and narrow groove situated just behind the umbones; muscle scars and pallial line obscure. Altitude, 22 millimeters; latitude, 23.5 millimeters.

This species is well characterized by its inflated umbones and sharp concentric sculpture. In this sculptural feature it differs from the form from the Monmouth of New Jersey, Unicardium umbonatum Weller, ${ }^{34}$ which is the only other species of this genus positively known from the Upper Cretaceous of the United States. In sculptural features Unicardium concentricum Wade, n. sp., resembles Unicardium ringmeriense (Mantell), ${ }^{35}$ which occurs in both the Upper Greensand and the Chalk Marl of England.

Occurrence: Ripley formation, Dave Weeks place on Coon Creek, McNairy County, Tenn.

Collection: U. S. National Museum.

\section{Family LUCINIDAE Genus LUCINA Bruguière \\ Lucina ripleyana Wade, n. sp. \\ Plate XXV, Figures 19-21}

Shell very small and thin, subcircular in outline, equivalve; lunule small; escutcheon elongate; umbones small, proximate and prosogyrate; dorsal margin directly in front of the umbones, strongly incurved or notched, remainder of the shell margin roundly curved; external surface sculptured by numerous fine deeply channeled concentric grooves; ligamental area poorly defined; dentition well developed; both pos-

34 Weller, Stuart, New Jersey Geol. Survey. Paleontology, vol. 4, p. 569, pl. 62, figs. 16-17, 1907.

${ }^{35}$ Woods, Henry, A monograph of the Cretaceous Lamellibranchia of England, vol. 2, p. 164, pl. 25, figs. 13, 14, Palaeont. Soc. London, 1907. 
terior and anterior laterals well developed; two strong cardinals in the left valve, only one in the right; muscle scars small and ovate, situated above the median horizontal; pallial line simple; ventral margin finely crenate. Altitude, 4 millimeters; latitude, 4 millimeters.

This species is well characterized by its concentric sculpture and its notched dorsal anterior margin. Except for differences in outline and external sculpture it resembles Lucina juvenis Stanton, ${ }^{38}$ from the Pugnellus-bearing sandstone of Colorado. Another similar species is Lucina fallax Forbes, ${ }^{37}$ from the Ootatoor and Arrialoor groups of the Upper Cretaceous of India.

Occurrence: Ripley formation, Dave Weeks place on Coon Creek, McNairy County, Tenn.

Collection: U. S. National Museum.

\section{Family DIPLODONTIDAE \\ Genus TENEA Conrad}

Tenea parilis Conrad

Plate XXVI, Figure 1

1860. Mysia (Diplodonta) parilis. Conrad, Acad. Nat. Sci. Philadelphia Jour., 2d ser., vol. 4, p. 278, pl. 46, fig. 16.

1870. Tenea parilis. Conrad, Am. Jour. Conchology, vol. 6, p. 73, pl. 3, fig. 12 .

1875. Tenea parilis. Conrad, in Kerr, Report of the geological survey of North Carolina, vol. 1, appendix, p. 8, pl. 2, fig. 25.

1884. Tenea parilis. Tryon, Systematic and structural conchology, vol. 3 , p. 216 , pl. 119 , fig. 72 .

1885. Dosinia gabbi. Whitfield, U. S. Geol. Survey Mon. 9, p. 161, pl. 22, figs. 4, 5. (Also published by New Jersey Geol. Survey, 1886.)

1885. Tenea pinguis. Whitfield, U. S. Geol. Survey Mon. 9, p. 163 , pl. 22, figs. 1, 2 (not T. pinguis Conrad).

1905. Tenea parilis. Johnson, Acad. Nat. Sci. Philadelphia Proc., vol. 57 , p. 15

1907. Tenea parilis. Weller, New Jersey Geol. Survey, Paleontology, vol. 4, p. 572, pl. 62, figs. 1-6.

1916. Tenea parilis. Gardner, Maryland Geol. Survey, Upper Cretaceous, p. 661.

Conrad in 1860 characterized this species as follows:

Shell suborbicular, equilateral, ventricose, direct; surface entire; hinge with the anterior cardinal channel very profound.

Type locality: Tippah County, Miss.

Miss Gardner adds the following details:

Shell thin, fragile, ovate in outline, moderately convex, slightly inequilateral, lunule and escutcheon not defined; umbones inflated to their very apices, proximate, incurved, and prosogyrate, placed a little in front of the median vertical; anterior and ventral margins well rounded, merging gradually into one another, the outline of the posterior margin sometimes rounded, sometimes obscurely truncate obliquely; external surface smooth excepting for faint incremental striations, which are least feeble near the posterior extremity; ligament opisthodetic, lodged in a submarginal groove extending backward

so Stanton, T. W., The Colorado formation and its invertebrate fauna: U. S. Geol. Survey Bull. 106, pl. 98, p. 22, figs. 2, 3, 1893 .

37 Stoliczka, Ferdinand, India Geol. Survey Mem., Palaeontologia Indica, Cretaceous fauna of southern India, vol. 3, p. 256, pl. 14, figs. 3-5, 7, 8, 1871. for some distance from the tips of the umbones; hinge plate narrow, very fragile; armature in the right valve consisting of a thin, laminar, hook-shaped cardinal directly beneath the umbones, its posterior arm vertically directed, its anterior arm approximately horizontal; right posterior cardinal slender, laminar, obliquely elongated, parallel to the dorsal margin; anterior lateral developed as a thin plate proximate to and directly facing the anterior portion of the hooked cardinal; hinge of left valve consisting of an anterior $\Lambda$-shaped cardinal which fits between the left anterior lateral and the vertical arm of the cardinal hook of the right valve, a very thin, laminar medial cardinal which is accommodated between the anterior lateral and the horizontal arm of the hook, and a thin, laminar, obliquely elongated posterior cardinal; muscle scars small, not very distinct, placed high up near the distal extremities of the dorsal margins; pallial sinus narrow but quite deep, steeply ascending; inner margins simple.

This species is common at Coon Creek, but it is so fragile that a perfect specimen can hardly ever be obtained from the marl.

Occurrence: Ripley formation, Dave Weeks place on Coon Creek, McNairy County, Tenn.

Collections: Maryland Geological Survey, Philadelphia Academy of Natural Sciences, New Jersey Geological Survey, U. S. National Museum.

Outside distribution: Magothy formation, Good Hope Hill, District of Columbia. Matawan formation, post 105, Chesapeake \& Delaware Canal, Del., and Ulmsteads Point(?), Anne Arundel County, Md. Monmouth formation, Fredericktown, Cecil County, Md., and Brightseat, Brooks estate near Seat Pleasant, McNeys Corners, Friendly, 2 miles south of Oxon Hill, and Fort Washington(?), all in Prince Georges County, Md. Magothy. formation ("Cliffwood clay"), New Jersey. Matawan group (Merchantville clay, Woodbury clay, and Wenonah sand), New Jersey. Monmouth group (Navesink marl, Redbank sand, and Tinton sand member of the Redbank), New Jersey. Ripley formation, Owl Creek, Miss.

\section{Superfamily CARDIACEA \\ Family CARDIIDAE \\ Genus CARDIUM}

Cardium dumosum Conrad

Plate XXVI, Figures 2, 3

1870. Cardium (Criocardium) dumosum. Conrad, Am. Jour. Conchology, vol. 6, p. 75 .

1885. Cardium (Criocardium) dumosum. Whitfield, U. S. Geol. Survey Mon. 9, p. 133, pl. 20, figs. 9, 13? (not figs. 10-12). (Also published by New Jersey Geol. Survey, 1886.)

1905. Cardium dumosum. Johnson, Acad. Nat. Sci. Philadelphia Proc., vol. 57, p. 15.

1907. Cardium dumosum. Weller, New Jersey Geol. Survey, Paleontology, vol. 4, p. 590, pl. 65, figs. 7-10.

1914. Cardium dumosum. Stephenson, U. S. Geol. Survey Prof. Paper 81, p. 24, table 2.

1916. Cardium dumosum. Gardner, Maryland Geol. Survey, Upper Cretaceous, p. 668.

Conrad describes this species as follows:

Cordate equilateral, ventricose; umbo broad; summit very prominent; ribs very numerous, small, closely arranged, con- 
vex; interstices furnished with numerous long, slender spines; posterior margin subtruncated or slightly convex; height, $11 / 8$ inches; length the same.

Type locality: Haddonfield, N. J.

The spinose Cardiums, C. kümmeli Weller, C. dumosum Conrad, and C. tenuistriatum Whitfield, are represented in Maryland merely by casts of the interior or fragments of casts of the exterior. Weller has admirably differentiated the three species from material in a better state of preservation than any available from Maryland, and his diagnoses have been quoted at considerable length. He says:

The dimensions of a large individual are: Height, 18 millimeters; width, 18 millimeters; convexity of one valve, 6 millimeters. Shell subcircular in outline but slightly inequilateral, moderately convex. Beaks situated at about the midlde of the hinge line, rather small and incurved; umbones prominent, the anterior and posterior cardinal slopes about equally steep; shell slightly compressed at both cardinal extremities. Surface of the shell marked with about 54 rounded radiating costae, with interspaces of about equal width; from the bottom of every third interspace on the central portion of the shell there arises a row of laterally flattened spines 1 to 2 millimeters in length, their distance apart being about equal to the space occupied by two costae; the two intervening interspaces are occupied by rows of much smaller tubercles a little compressed laterally, situated at intervals about one-third the distance between the spines in each row. On the anterior and posterior slopes of the shell several rows of spines alternate with single rows of tubercles. The longest spines occur upon the posterior cardinal slope.

This species is very common at Coon Creek. Owing to the extremely fragile nature of the shells and their numerous long spines, which interlock the shell with the sand, it is almost impossible to recover a perfect specimen.

Occurrence: Ripley. formation, Dave Weeks place on Coon Creek, McNairy County, Tenn.

Collections: Maryland Geological Survey, Philadelphia Academy of Natural Sciences, U. S. National Museum.

Outside distribution: Matawan formation, post 105(?), Chesapeake \& Delaware Canal, Del. Monmouth formation, Brightseat, Brooks estate near Seat Pleasant, and 2 miles southwest of Oxon Hill, all in Prince Georges County, Md. Matawan group (Woodbury clay and Wenonah sand), New Jersey. Monmouth group (Redbank sand), New Jersey. Eutaw formation (Tombigbee sand member), Exogyra ponderosa zone, Prentiss County, Miss. Ripley formation, Exogyra costata zone, Union and Tippah counties, Miss.

\section{Cardium tenuistriatum (Whitfield)}

\section{Plate XXVI, Figure 4}

1885. Cardium eufalensis. Whitfield, U. S. Geol. Survey Mon. 9, p. 132, pl. 20, figs. 18, 19 (not fig. 17). (Not $C$. eufalense Conrad, 1860.) (Also published by New Jersey Geol. Survey, 1886.)

1885. Cardium (Criocardium) dumosum. Whitfield, U. S. Geol. Survey Mon. 9, p. 133, pl. 20, figs. 10-12 (not figs 9 and 13?). (Not C. dumosum Conrad, 1870.)
1885. Cardium (Criocardium) multiradiatum. Whitfield, U. S. Geol. Survey Mon. 9, p. 135, pl. 21, figs. 1-3. (Not C. multiradiatum Gabb, 1860.)

1885. Fragum tenuistriatum. Whitfield, U. S. Geol. Survey Mon. 9, p. 139, pl. 20, figs. 15, 16.

1907. Cardium tenuistriatum. Weller, New Jersey Geol. Survey, Paleontology, vol. 4, p. 591, pl. 65, figs. 13-19. 1916. Cardium tenuistriatum. Gardner, Maryland Geol. Survey, Upper Cretaceous, p. 669.

Whitfield describes Fragum tenuistriatum as follows:

Shell below a medium size, irregularly trapezoidal or subtriangular in outline, highly ventricose and sharply angular along the posterior umbonal ridge, with a nearly vertical postero-cardinal slope. Beaks large, prominent, and attenuated, projecting considerably above the hinge line. Anterior side of the shell short and regularly rounded; posterior vertically truncate and the basal line oblique, being prolonged below toward the posterior umbonal angle. Surface marked, on the body of the shell at least, by very fine, semiobsolete radiating striae, the posterior cardinal slope not showing evidence of striations on the cast, the only condition under which it has been observed. Hinge features unknown.

The shell has all the generic features of the genus Fragum, as far as can be determined from the external form, while the striations of the surface are much finer than is usually the case; but no ornamentation can be detected on the striations, and the features of the hinge are not visible. It is the only form of similar character yet known to me in the formations of the State.

Type locality: Marlboro, N. J.

Weller describes this species as follows:

The dimensions of an internal cast are: Height, 44 millimeters; width, 37 millimeters; thickness, 35 millimeters. Large examples sometimes attain a height of over 60 millimeters. Shell irregularly subovate in lateral view and cordate in end view. Hinge line arcuate; anterior and basal margins, from the extremity of the hinge line to the middle of the basal margin, describing a nearly regular arcuate curve; postero-basal margin curving more sharply around the postero-basal extremity of the shell into the posterior margin; posterior margin much straighter than the anterior, usually gently convex but sometimes nearly or quite straight. Beaks situated at about the middle of the hinge line, rather prominent, elevated, pointed and incurved, considerably more prominent in the casts than in the specimens with the shell preserved. Valves gibbous, most prominent but not angular along a line from the beaks to the postero-basal extremity, the posterior slope more abrupt than the anterior. Muscular impressions rather large, the posterior one scarcely impressed and often scarcely distinguishable upon the casts; the anterior ones more strongly impressed. Each valve with a strong somewhat curved cardinal tooth beneath the beak, with a pit for the reception of the tooth of the opposite valve; in each valve is a single anterior and posterior, rather strong lateral tooth, somewhat remote but nearly equidistant from the cardinal tooth. The inner free margin of the valves is crenate. Externally the shell is marked by flat radiating costae wider than the interspaces; from the interspaces rise rows of laterally compressed spinules or tubercles which are longer and stronger upon the anterior and posterior slopes toward the hinge extremities; on the central portion of the shell each third row of processes is more conspicuous than the two intervening rows, the spines being longer and larger, one of them occupying the space of two or three of the smaller ones of the intervening rows, the smaller ones sometimes being scarcely more than tubercles but little elevated above the surface of the ribs of the shell; upon the anterior and posterior slopes of the shell the rows of larger and smaller spines alternate, there being but a single row of smaller spines between the larger ones. 
This species is by far the commonest and most widely distributed Cardium in the Cretaceous faunas of New Jersey. It exhibits considerable variation, especially in the straightness of the posterior margin of the shell and in the prominence of the postero-basal extremity, but the casts can almost always be easily recognized by the strong convexity or gibbosity of the valves and the abrupt posterior slope as compared with the anterior. The surface markings of the shell most closely resemble those of $C$. dumosum, but the radiating costae are comparatively broader and flatter with narrower interspaces, and consequently the spines upon the surface are more compressed laterally. C. dumosum is also more nearly equilateral, with less convex valves than this species, and does not attain so large a size.

It has been a matter of much difficulty to determine to what species this common shell should be referred. Previous to the publication of Whitfield's monograph it seems usually to have been referred to C. multiradiatum or to C.eufalense. Whitfield has apparently illustrated different individual internal casts of the species under four different specific heads. His Figures 18 and 19 of $C$. eufalense represent a more than usually gibbous cast of this species, the true C. eufalense being a fundamentally different shell, without the spines rising from the interspaces between the ribs and consequently not even a member of the subgenus Criocardium. Whitfield's Figures 10 and 11 of C.dumosum represent a more than usually rounded form of the species under discussion; the specimen is larger, more convex, and has a steeper posterior slope than the true $C$. dumosum. Figure 12 of the same author, an enlargement to illustrate the surface characters of $C$. dumosum, also proves, upon examination of the specimen, to be taken from a member of the species under consideration; the illustration . is not an accurate representation of the charcters of the specimen, the costae being too narrow, the interspaces too wide, and the spines not enough compressed laterally. The internal cast used by Whitfield as the original for his Figures 1 and 2 of $C$. multiradiatum seems to be a member of this species also; a specimen in the recent collections of the Survey from the Navesink marl near Crawfords Corner agrees almost exactly with this illustration, and it is undoubtedly a member of the species under discussion. The enlarged illustration, Figure 3, given to represent the surface characters of this same species, is much overdrawn, the original mold from which the gutta-percha impression was taken being altogether too imperfect to show to what species it belongs.

In the European Upper Cretaceous there are several spinose Cardiums that have a rather wide horizontal and vertical distribution. [t is difficult to show their exact relation to the American spinose Cardiums, but those somewhat similar to Cardium tenuistriatum (Whitfield) are Cardium carolinum D'Orbigny, ${ }^{30}$ Cardium alternatum D'Orbigny, ${ }^{40}$ Cardium productum Sowerby, ${ }^{41}$ Cardium moutonianum D'Orbigny, ${ }^{42}$ and Cardium pustulosum Münster..$^{43}$

Occurrence: Ripley formation, Dave Weeks place on Coon Creek, McNairy County, Tenn.

Collections: Maryland Geological Survey, Columbia University, New Jersey Geological Survey, U. S. National Museum.

30 'D'Orbigny, Alcide, Palćontologie française, 'Terrains crétacés, vol. 3, p. 29, pl 245,1844 .

6 Idom, p. 30 , pl. 246.

"Idein, p. 31, pl. 247. Holzapfel, Eduard, Dio Mollusken der Aachener Kreide Palaeontographica, Band 35, p. 174, pl. 17, figs. 1-5, 1889

42 D'Orbigny, Alcide, op. cit., vol. 3, p. 34, pl. 24s, 1844.

13 Fric, Anton, Studion im Gebiete der böhmischen Freideformation: Archiv naturwiss. Landesd. Böhnen, Band 4, A $\rho, 1$, p. 113, fig. 65, 1877.
Outside distribution: Matawan formation, Park Point and Ulmsteads Point, Anne Arundel County, Md. Monmouth formation, Jones farm, Burklows Creek, Cecil County, Md. Matawan group (Merchantville clay, Marshalltown formation, and Wenonah sand), New Jersey. Monmouth group (Navesink marl), New Jersey.

\section{Cardium kümmeli Weller}

Plate XXVI, Figures 5, 6

1907. Cardium kümmeli. Weller, New Jersey Geol. Survey, Paleontology, vol. 4, p. 585, pl. 66, figs. 1-3.

1914. Cardium kümmeli. Stephenson, U. S. Geol. Survey Prof. Paper 81, p. 24, tables 2-8.

1916. Cardium kümmeli.. Gardner, Maryland Geol. Survey, Upper Cretaceous, p. 673

Weller describes this species as follows:

The dimensions of a rather small internal cast of a right valve are: Height, 45 millimeters; width, 34 millimeters; convexity, 17.5 millimeters. Large individuals sometimes attain a height of 70 millimeters or more. Shell subovate in lateral view, cordate in end view. Beaks of the internal casts greatly elevated above the hinge line, pointed and incurved. Hinge line arcuate; anterior margin regularly rounded from the extremity of the hinge line to the middle of the basal margin; postero-basal margin a little more sharply rounded; posterior margin convex, a little straighter than the anterior. Valves strongly convex or gibbous, most prominent but not at all angular along an oblique line from the beaks to the posterobasal extremity, the posterior slope more abrupt than the anterior. Muscular impressions large, the anterior ones deeply impressed above, the posterior one scarcely differentiated from the general surface of the casts. Hinge characters not seen. Inner free margins of the valves apparently not crenate. Shell substance thick, rugose externally. The surface markings consist of strongly elevated, rounded radiating costae, narrower than the interspaces; on a specimen about 55 millimeters in length the distance between these ribs from center to center at the middle portion of the shell margin is about 2 millimeters or a little less. Each third interspace is occupied by a row of strong and thick spines rising 1 or 2 millimeters above the tops of the costae when complete, subcircular in cross section, their bases occupying the entire width of the furrow, the space between successive spines being about equal to the thickness of the spines themselves; in some cases the bases of the spines are thickened longitudinally so that they occupy essentially the entire furrow, in which case the two bounding costae with the row of spines rising from the intervening furrow appear to form altogether one broad rib supporting a row of strong spines. The two furrows intervening between the rows of strong spines are each occupied by a row of very much smaller, laterally compressed spines whose bases are more or less connected.

There is considerable variation shown in the surface markings of different individuals of this species, and the extremes might be taken as the representatives of distinct species or even of distinct subgenera. In its typical form, as seen in the Tinton beds, the species exhibits clearly the characteristics of the subgenus Criocardium, the rows of spines rising from the interspaces between the radiating costae of the shell. In some specimens the bases of the larger spines or nodes are confluent and appear to entirely fill the interspace occupied by them, so that the two bounding costae with the row of spines together seem to constitute a single broad rib crowned with a row of strong nodes. At the same time the rows of secondary nodes are sometimes confluent at their bases and form a continuous 
secondary rib, perhaps nodose on top, and about equaling in height and size the primary costae, so that there seem to be three costae of nearly equal size in the broad interspace between the rows of large nodes and their including bounding costae. In the extreme development of the rows of secondary nodes their bases are confluent and they increase in size and height so as to occupy the whole of the interspaces, obliterating entirely the primary costae, so that the surface of the shell is apparently marked by radiating rows of tubercles, which apparently do not rise from interspaces between costae but directly from the surface, each third row being much larger and stronger than the two intervening ones.

It is possible that larger collections of more perfectly preserved material than is now available would show that more than one species has been included under this head, but so far as can be determined from present.collections, all these forms seem to run together. The typical form of the species, however, is that in which the nodes rise distinctly from the interspaces, showing the characters clearly of the subgenus Criocardium, and which has been recognized only in the Tinton beds.

In its somewhat elongate and slender form the species in the form of internal casts somewhat resembles the casts of $C$. spillmani, and they have sometimes been so identified. It does not grow so large as that species, however; it lacks the radiating ribs usually impressed upon the posterior slope of $C$. perelongatum, and the anterior muscular scar is not so low in position.

In the collections of the National Museum at Washington this species is represented by numerous examples from the . South, which have usually been referred to C. dumosum. These southern specimens are perfectly preserved shells which are smaller than the usual examples from the Tinton beds in New Jersey, but their surface markings are identical with those of the type specimen. The species differs from $C$. dumosum in its more elongate form and in the much coarser surface markings. C. tippana is another allied form in which the surface markings are fully as coarse as in C. kümmeli, but there is only a single row of smaller tubercles between the larger ones in that species, instead of two as in C. kümmeli.

Type locality: Beers Hill cut, New Jersey.

The Coon Creek representatives of this species are considerably smaller than those from New Jersey. This species is very strikingly similar to Cardium proboscideum Sowerby, ${ }^{44}$ from the Gault of England, a species very admirably described and figured recently by Henry Woods.

Occurrence: Ripley formation, Dave Weeks place on Coon Creek, McNairy County, Tenn.

Collections: Maryland Geological Sürvey, New Jersey Geological Survey, U. S. National Museum.

Outside distribution: Matawan formation, Camp Fox, post 236, post 218, Camp U \& I, post 196, oneeighth of a mile west of Summit Bridge, Chesapeake $\&$ Delaware Canal, Del., and 1 mile west of Chesterfield, Anne Arundel County, Md. Monmouth formation, on John Higgins farm, 2 miles of Delaware City, Del. Brooks estate near Seat Pleasant and 1 mile west of Friendly, both in Prince Georges County, Md. Monmouth group (Navesink marl and Tinton sand member of Redbank sand), New Jersey. Ripley formation, Exogyra costata zone, Eufaula, Ala.,

14 Woods, Henry, A monograph of the Cretaceous Lamellibranchia of England, vol. 2, p. 205, pl. 32, figs. 18, 19; pl. 33, figs. 1-3, Palaeont. Soc. London, 1908. and Quitman, Union, and Tippah counties, Miss.; extreme top of Exogyra costata zone, Pataula Creek, Ga., and Barbour and Henry counties, Ala.

Cardium stantoni Wade, n. sp.

Plate XXVI, Figures 7-10; Plate XXVII, Figures 8, 9

Shell large and strong; ovate or roughly subtrigonal in outline; umbones incurved, pointed and proximate, rather conspicuous and rising well above the hinge, prosogyrate and slightly anterior in position; anterior dorsal slope curved or subangular; posterior dorsal slope short and less steep; anterior ventral extremity angular; ventral margin well rounded, dorsal margin straight; ligament external, short, and strong lodged in a narrow groove just behind the umbones; external surface smooth except for faint growth lines and deep concentric, irregular, constrictions and ridges on the lower half of the shell; cardinal plate strong, dentition well developed, consisting of two cardinals in the right valve and one strong cardinal in the left valve, a strong anterior and posterior lateral in the right valve, and corresponding deep sockets in the right valve, anterior lateral situated well down on the anterior margin and not on the same horizontal as the posterior lateral; adductor scars large subtriangular in shape; situated beneath, and a little in front of the laterals is a secondary adductor scar on the side of the anterior lateral support; pallial line simple and faint; anterior inner margin smooth; posterior half of the inner margin strongly dentate, dentition representing the extremities of internal radial ribs in the inner shell material, which are slightly visible along the umbonal slope on the exterior of the shell. Altitude, 127 millimeters; latitude, 74 millimeters; thickness, 70 millimeters.

This species is characterized by its subtrigonal outline, the low position of its anterior lateral, and the strong concentric folds on the lower half of th: hell. These are features which serve to separate this species from the closely related species Cardium spillmani Conrad, ${ }^{45}$ from the Ripley formation at Owl Creek, Miss. A comparison of immature shells of these species shows that the interior ventral margin of Cardium spillmani is evenly rounded, whereas that of $C$. stantoni is subangular. The shoulders of $C$. spillmani are even, whereas in $C$. stantoni the shoulders are very uneven, the posterior one being elevated and the anterior one drooped.

This species is represented by some of the most elegant specimens in the Coon Creek collections. Several specimens have been recovered with both valves attached in a perfect state of preservation and even the ligament preserved and in place. The species is named in honor of Mr. T. W. Stanton, chief paleontologist of the United States Geological Survey.

15 Conrad, T. A., Observations on a group of Cretaceous fossil shells found in Tippah County, Miss.: Acad. Nat. Sci. Philadelphia Jour., 2d ser., vol. 3, p. 326, pl. 34, fig. 3, 1858 . 
Occurrence: Ripley formation, Dave Weeks place on Coon Creek, McNairy County, Tenn.

Collections: Johns Hopkins University, Yale University, Vanderbilt University, U. S. National Museum.

\section{Genus PROTOCARDIA Beyrich}

Protocardia parahillana Wade, n. sp.

\section{Plate XXVII, Figure 1}

Shell small and fragile; subquadrilateral in outline; umbones rather small, prosogyrate, and proximate; hinge line nearly straight, anterior and ventral margin well rounded; posterior margin truncate; sculpture concentric on the anterior three-fourths of the shell and radial on the posterior fourth; anterior portion marked also with faint radial lines, making a low reticulate ornamentation on the anterior threefourths of the shell; posterior umbonal slope marked by about 16 strongly elevated, flat-topped radial costae; extreme posterior dorsal margin unornamented; cardinal tooth small; anterior lateral laminate and rather prominent in the left valve, posterior lateral unknown; adductor scars unknown; anterior ventral margin smooth; posterior margin dentate. Altitude, 7 millimeters; latitude, 7 millimeters.

This species is well characterized by its form and dual type of sculpture. It resembles Protocardia salinaensis Meek, ${ }^{40}$ from the Mentor formation of Kansas. It is analogous also to Protocardia subhillana (Leymerie) ${ }^{47}$ and Protocardia hillana (Sowerby). ${ }^{48} P$. hitlana has a very wide lateral and vertical distribution, being found in various localities in Europe, Asia, Africa, and Mexico in sediments ranging from the Albian through the Senonian in age.

Occurrence: Ripley formation, Dave Weeks place on Coon Creek, McNairy County, Tenn.

Collection: U. S. National Museum.

\section{Superfamily ISOCARDIACEA \\ Family ISOCARDIIDAE \\ Genus ISOCARDIA Lamarck \\ Isocardia conradi Gabb \\ Plate XXVII, Figure 6}

1860. Isocardia conradi. Gabb, Acad. Nat. Sci. Philadelphia Jour., 2d ser., vol. 4, p. 393, pl. 68, figs. 21, 21 a.

1861. Glossus conradi. Gabb, Synopsis of the Mollusca of the Cretaceous formation, p. 130 (Am. Philos. Soc. Proc., vol. 8, p. 186).

1864. Glossus conradi. Meek, Check list of the invertebrate fossils of North America, Cretaceous and Jurassic, p. 12.

1868. Bucardia conradi. Conrad, in Cook, Geology of New Jersey, p. 726.

${ }^{16}$ Meek, F. B., A report on the invertebrate Cretaceous and Tertiary fossils of the upper Missouri country: U. S. Geol. Survey Terr. Rept., vol. 9, p. 174, pl. 2, figs. $13 a, b, c, 1876$.

${ }^{7}$ D'Orbigny, Alcide, Paleontologie française, Terrains crétacés, vol. 3, p. 19, pl. 239 , figs. $7,8,1844$.

${ }^{8}$ Woods, Henry, A monograph of the Cretaceous Lamellibranchia of England, vol. 2, p. 197, pl. 31, figs. 6a-c; pl. 32, figs. 1-6, Palaeont. Soc. London, 1908.
1885. Isocardia conradi. Whitfield, U. S. Geol. Survey Mon. 9, p. 200, pl. 26, figs. 3-4. (Also published by New Jersey Geol. Survey, 1886.)

1907. Isocardia conradi. Weller, New Jersey Geol. Survey, Paleontology, vol. 4. p. 599, pl. 66, figs. 13, 14 .

Gabb in 1860 described this species as follows:

Triangular, equivalve; beaks large, inclined anteriorly; umbones large; anterior margin nearly straight, basal sinuate, posterior subangular below, nearly straight above; surface marked by fine concentric lines.

Weller adds the following details:

The dimensions of the type specimen are: Length, 35 millimeters; height, 30 millimeters; thickness, 26.5 millimeters. Shell subtriangular in lateral view and cordate in front view. Beaks much elevated and enrolled, situated in front of the middle of the shell. Anterocardinal margin long and concave, sloping steeply; anterior margin short, sharply rounded; basal margin long, rather strongly convex through the greater part of its length, becoming concave near its posterior extremity; postero-basal extremity acutely subangular; posterior and postcardinal margins continuous, very long, gently convex, sloping steeply from the beaks to the postero-basal angle. Valves strongly ventricose, with an angular umbonal ridge subparallel with the post-cardinal margin; post-cardinal slope steep; in front of the umbonal ridge is a slight sinus becoming more conspicuous toward the ventral margin, in front of the sinus the surface is somewhat regularly convex through the central part of the valve, with the anterior slope abrupt and somewhat inflected to the antero-cardinal margin; surface of cast marked by concentric lines.

The Coon Creek specimens of this species are so fragile that it is almost impossible to recover a complete individual from the marl. One specimen shows the dentition, however, and it is very similar to that represented in Holzapfel's species Isocardia zitteli,40 from the Aachen Cretaceous of Vaals, Germany.

Occurrence: Ripley formation, Dave Weeks place on Coon Creek, McNairy County, Tenn.

Collections: Philadelphia Academy of Natural Sciences, U. S. National Museum.

Outside distribution: Rancocas group (Vincentown sand), New Jersey.

\section{Superfamily VENERACEA \\ Family VENERIDAE \\ Genus CYCLINA Deshayes \\ Cyclina parva Gardner . \\ Plate XXVII, Figures 2, 3}

1916. Cyclina parva. Gardner, Maryland Geol. Survey, Upper Cretaceous, p. 678 , pl. 41 , figs. 5,6 .

Miss Gardner describes this species as follows:

Shell porcellanous, rather heavy for its size, subcircular in outline, moderately inflated, the maximum convexity above the median horizontal; umbones subcentral, rather prominent, with fine prosogyrate apices placed a little in front of the median vertical; lunule and escutcheon not differentiated; dorsal margins obliquely truncate, the anterior shorter and more gently sloping than the posterior; anterior extremity broader

49 Holzapfel, Eduard, Die Mollusken der Aachener Kreide: Palaeontographica, Band 35, p. 177, pl. 15, figs. 2-4, 1889. 
and smoothly rounded; posterior extremity obscurely truncate; base line evenly arcuate; external surface smooth, excepting for faint concentric striations and two or three well-defined resting stages, the striae least feeble toward the lateral and ventral margins but absent altogether in the immediate vicinity of the umbones; ligament external, opisthodetic, mounted on a rather short and slender nymph; cardinals three in number in each valve, radiating fanlike from beneath the umbones; the anterior cardinal in the right valve thin, laminar, and somewhat produced; the middle cardinal stouter, widening ventrally; the posterior obliquely produced and asymmetrically. bifid; anterior and medial cardinal of the left valve united beneath the umbones, the anterior slender, laminar, elongated, the medial shorter, slightly elongated, and stouter, the posterior very slender and not very much produced; adductor scars relatively large, narrow but elongated, placed well up near the extremities of the hinge line; pallial sinus distinct, acutely angulated at about $90^{\circ}$, the breadth and depth approximately equal; pallial line distant; inner ventral margins simple. Altitude, 3.7 millimeters; latitude, 4 millimeters; semidiameter, 1.4 millimeters.

Type locality: Brooks estate near Seat. Pleasant, Prince Georges County, Md.

Coon Creek is the second locality where this very small shell has been found. This apparent scarcity of the species is due probably to the very delicate nature of the shell rather than to its absence in the Upper Cretaceous marls of various localities.

Occurrence: Ripley formation, Dave Weeks place on Coon Creek, McNairy County, Tenn.

Collections: Maryland Geological Survey, U. S. National Museum.

Outside distribution: Monmouth formation, Prince Georges County, Md.

\section{Cyclina magna Wade, n. sp.}

\section{Plate XXVIII, Figures 1, 2}

Shell of medium size, thin and fragile, circular in outline, strongly inflated; umbones central in position, rather prominent, with prosogyrate apices placed a little in front of the median vertical; escutcheon differentiated by a fine impressed line, area of escutcheon fairly large and broadly lanceolate in shape, its ornamentation not differing from that of the remainder of the shell; entire margin almost perfectly circular; external surface smooth except for faint concentric lines and about eight strong resting stages, most of which are near the ventral margin of the shell; ligament opisthodetic, lodged in a long, narrow groove behind the umbones, just beneath the dorsal margin; three cardinals of the right valve; anterior cardinal short and pointed, situated obliquely in front of the umbones and directly beneath the middle cardinal, which is strongly curved and roof-shaped, forming a shelter as it were above the anterior cardinal; posterior cardinal long and narrow, subparallel to the ligament pit and radiating diagonally backward from the apieces of the umbones; internal characters unknown. Altitude, 30 millimeters; diameter, 29 millimeters.
This species is well characterized by its almost perfectly circular outline and its strongly curved or notched middle cardinal. The only other Cretaceous species known with such a cardinal is Cytherea tumida Müller, ${ }^{50}$ from the Aachen Cretaceous of Germany, probably a related species of the same genus as the two American species of Cyclina.

Occurrence: Ripley formation, Dave Weeks place on Coon Creek, McNairy County, Tenn.

Collection: U. S. National Museum.

\section{Genus MERETRIX Lamarck \\ Meretrix cretacea (Conrad)}

Plate XXVII, Figures 4, 7

1870. Aeora cretacea. Conrad, Am. Jour. Conchology, vol. 6, p. 72 , pl. 3, fig. 8 .

1885. Aeora cretacea. Whitfield, U. S. Geol. Survey, Mon. 9, p. 167, pl. 23 , figs. 16,17 .

1905. Aeora cretacea. Johnson, Acad. Nat. Sci. Philadelphia Proc., vol. 57, p. 16.

1907. Meretrix cretacea. Weller, New Jersey Geol. Survey, Paleontology, vol. 4, p. 608, pl. 68, figs. 4-7.

1916. Meretrix cretacea. Gardner, Maryland Geol. Survey, Upper Cretaceous, p. 679.

Conrad describes this species as follows:

Subtriangular, subequilateral, convex; end margins acutely rounded; umbo slightly prominent; lunule lanceolate, slightly defined by an impressed line; ventral margin rounded.

Type locality: Haddonfield, N. J.

Weller adds the following details:

Shell below medium size; the dimensions of an average example are: Height, 16.5 millimeters; approximate length, 23 millimeters; convexity of one valve, 5 millimeters; somewhat triangularly subelliptical in outline. Valves moderately convex, beaks small situated anterior to the middle; anterocardinal margin concave; anterior margin rather sharply rounded above, curving more gently below and passing without interruption into the broadly rounded ventral margin; posterior margin rather short, obscurely subtruncate; post-cardinal margin long, gently convex, meeting the antero-cardinal margin at the beak in an angle of $120^{\circ}$. Postero-cardinal margin somewhat inflected, especially toward the beak; antero-cardinal margin inflected in front of the beak to form a shallow lunule of moderate width. Surface of shell marked by more or less irregular concentric lines of growth only. Hinge of the left valve with three cardinal teeth diverging from beneath the beak, the two anterior ones of about equal length, extending directly beneath the beak with a triangular pit between them, the posterior one much more oblique and more elongate. In front of the cardinal teeth is a single low lateral beneath the lunule and parallel with the shell margin. In the right valve there are two divergent, bifid cardinal teeth with a pit beneath the lunule for the reception of the anterior lateral tooth of the opposite valve.

Only a few specimens of this species are known from Coon Creek, and part of its internal characters are unknown. Cyprimeria (Cyclorisma) faba Sowerby, ${ }^{51}$ from the Upper Greensand, Blackdown, England, is in some respects similar to the species under consider-

${ }^{60}$ Holzapfel, Eduard, op. cit., p. 168, pl. 12, figs. 9-12.

${ }_{51}$ Woods, Henry, A monograph of the Cretaceous Lamellibranchia of England, vol. 2, p. 187, pl. 29, figs. 7-15, Palaeont. Soc. London, 1908. 
ation. Meretrix euglypha Woods, ${ }^{52}$ from the Senoniàn of Pondoland, Africa, is another species related to Meretrix cretacea Conrad. Some more affinities are Meretrix hörnesi (Zittel), ${ }^{53}$ from the Alpine Gosau beds; Meretrix fabulina Stoliczka, ${ }^{54}$ from the Trichinopoly and Ootatoor groups of India; Meretrix koffraria (Etheridge), ${ }^{55}$ from the Senonian of Zululand, Africa; and finally another American species from the Upper Cretaceous of California, Meretrix arata Gabb. ${ }^{56}$

Occurrence: Ripley formation, Dave Weeks place on Coon Creek, McNairy County, Tenn.

Collections: Maryland Geological Survey, New Jersey Geological Survey, Philadelphia Academy of Natural Sciences, U. S. National Museum.

Outside distribution: Matawan formation, Summit Bridge, Chesapeake \& Delaware Canal, Del. Matawan group (Woodbury clay and Marshalltown formation), New Jersey.

\section{Meretrix eufaulensis (Conrad)}

Plate XXVIII, Figures 3, 4

1860. Callista eufaulensis. Conrad, Acad. Nat. Sci. Philadelphia Jour., 2d ser., vol. 4, p. 282 , pl. 46 , fig. 24 .

1861. Callista eufaulensis. Gabb, Synopsis of the Mollusca of the Cretaceous formation, p. 105 (Am. Philos. Soc. Proc., vol. 8, p. 161).

1864. Dione eufalensis. Meek, Check list of the invertebrate fossils of North America, Cretaceous and Jurassic, p. 13.

1885. Callista delawarensis. Whitfield, U. S. Geol. Survey Mon. 9, p. 153, pl. 22, fig. 10 . (Also published by New Jersey Geol: Survey, 1886.)

1907. Meretrix eufaulensis. Weller, New Jersey Geol. Survey, Paleontology, vol. 4, p. 609, pl. 68, figs. 8-10.

Conrad describes this species as follows:

Suboval or suborbicular, convex; margins regularly and almost equally rounded; umbo broad; summit prominent; disk with regular concentric impressed lines, which do not extend to the base; anterior cardinal tooth compressed and elongated.

Weller adds the following details:

The dimensions of a very perfect valve are: Height, 16 millimeters; length, 19 millimeters; convexity, 4 millimeters. Shell subovate in outline; the beaks at about the anterior third, rather small, directed anteriorly, scarcely incurved. Anterocardinal margin concave just in front of the beak; anterior, ventral, postero-cardinal margins convex; the posterior margin broader than the anterior. Valves regularly convex, the surface sloping more abruptly to the cardinal margins; in front of the beaks is a narrow, scarcely impressed lunule. Hinge of the left valve with two cardinal teeth diverging from beneath the beak, leaving a triangular pit between, and a much thinner, more elongate tooth directed obliquely backward close up to the ligamental area; in front of the cardinal teeth is a

s2 Woods, Henry, Cretaceous fauna of Pondoland: South African Mus. Annals, vol. 4, pt. 7, p. 305, pl. 36, flgs. 7-10, 1906.

ss Zittel, K. A., Die Bivalven der Gosaugebilde in den nordöstlichen Alpen: K. Akad. Wiss. Wien Deukschr., Band 24, pt. 1, p. 126, pl. 3, fig. 5, 1865.

st Stoliczka, Ferdinand, Geol. Survey India Mem., Palaeontologia Indica, Cretaceous fauna of southern India, vol. 3, p: 174, pl. 16, figs. 31-33, 1870.

ss Etheridge, Robert, Cretaceous fauna of Natal: Geol. Survey Natal and Zululand Second Ann. Rept., p. 81, pl. 2, figs. 20-22, 1904.

30 Gabb, W. M., California Geol. Survey, Paleontology, vol. 1, p. 166, pl. 30, flg. 250,1864 . single strong lateral tooth beneath the lunule, parallel with the shell margin. Surface of the shell marked by fine concentric striae of growth; those covering the area from the beak downward about 10 or 12 millimeters are very regular, the interspaces gradually increasing until the outer ones are about 0.5 millimeter apart. Beyond this regularly marked area the lines of growth are less conspicuous and not so regular.

This species resembles Meretrix deweyi (Meek and Hayden) ${ }^{57}$ which is found in several localities in the Pierre shale and Fox Hills sandstone of the upper Missouri Cretaceous. Another related species is Meretrix discoidalis (Stoliczka), ${ }^{58}$ from the Arrialoor group, Ninnyoor, India.

Occurrence: Ripley formation, Coon Creek, Sand Hill, McNairy County, Tenn.

Collections: Johns Hopkins University, U. S. National Museum, New Jersey Geological Survey.

Outside distribution: Monmouth and Matawan groups, New Jersey. Ripley formation, Alabama.

\section{Genus APHRODINA Conrad}

\section{Aphrodina tippana Conrad}

Plate XXVIII, Figures 5-7

1858. Meretrix tippana. Conrad, Acad. Nat. Sci. Philadelphia Jour., 2d ser., vol. 3, p. 326, pl. 34, fig. 18.

1864. Dione tippana. Meek, Check list of the invertebrate fossils of North America, Cretaceous and Jurassic, p. 13.

1868. Aphrodina tippana. Conrad, in Cook, Geology of New Jersey, p. 727.

1869. Aphrodina tippana. Conrad, Am. Jour. Conchology, vol. 4 , p. 246 , pl. 18 , fig. 5 .

1885. Aphrodina tippana. Whitfield, U. S. Geol. Survey Mon. 9 , p. 154 , pl. 22 , figs. 6,7 .

1905. Aphrodina tippana. Johnson, Acad. Nat. Sci. Philadelphia Proc., vol. 57, p. 16.

1907. Meretrix tippana. Weller, New Jersey Geol. Survey, Paleontology, vol. 4, p. 607, pl. 68, figs. 1, 2 (part).

1916. Antigona (Aphrodina) tippana. Gardner, Maryland Geol. Survey, Upper Cretaceous, p. 681, pl. 40, figs. 3, 4.

Conrad in 1858 described this species as follows:

Subtriangular, obsoletely striated concentrically; anterior sides slightly compressed, with an ascending basal margin, extremity rather acutely rounded, distant from the apex; base a little prominent in the middle, subtruncated on either side; posterior end but slightly more obtuse than the anterior; beaks prominent.

Type locality: Owl Creek, Tippah County, Miss. Miss Gardner adds the following details:

Shell rather large and heavy, ovate-trigonal in outline, evenly but strongly inflated; lunule narrow, elongated, defined by an impressed line; area behind the umbones somewhat flattened but escutcheon not differentiated; umbones rather prominent by reason of their position at the apex of an angle of a little more than $90^{\circ}$; umbones evenly rounded but not strongly inflated, the apices incurved, prosogyrate, slightly anterior in position; anterior extremity strongly arcuate, even a little nasute in front of the lunule; posterior dorsal margin obliquely arcuate, the lateral margin obscurely truncate; ventral margin convex, more strongly upcurved in front than behind; external

${ }^{67}$ Meek, F. B., op. cit., p. 182, pl. 17, figs. 15 a-e.

${ }^{38}$ Stoliczka, Ferdinand, India Geol. Survey Mem., Palaeontologia Indica, Cretaceous fauna of southern India, vol. 3, p. 175, pl. 7, figs. 30,31, 1870 . 
surface concentrically striated with a vigorous incremental sculpture, which becomes increasingly prominent toward the ventral margin; ligament external, opisthodetic, mounted on rather a slender nymph, which extends a little less than half way down the dorsal margin; cardinals three in number in each valve, the anterior cardinal of the right valve short and slender, the middle cardinal trigonal, the posterior laminar and elongated anterior cardinal of the left valve trigonal and stouter than that of the right; the middle cardinal rather short and slender, the posterior elongated parallel to the lunular margin in the right valve, received in a double socket in the left; muscle impressions distinct but not conspicuous, the anterior semi-elliptical, the posterior subcircular; pallial line distinct, the sinus linguiform and obliquely ascending almost but not quite to the median horizontal.

Aphrodina tippana Conrad is one of the most widely distributed and most characteristic species of the Exogyra costata zone. Weller has determined some casts from the Matawan of New Jersey by this name, but they seem to show at least a subspecific difference in the shorter, relatively higher outline and the less produced, more broadly rounded posterior end.

Another closely related American species of this genus is Aphrodina regia Conrad, ${ }^{59}$ from Snow Hill, N. C. Forms related to these species are common and widely distributed in the Upper Cretaceous of the world. They form a group that has been variously assigned to such genera as Venus, Tapes, Cyprimeria, and Cytherea.. Holzapfel assigns the group to the genus Tapes. Tapes faba (Sowerby), ${ }^{60}$ from the Aachen Cretaceous, is somewhat similar to the two American species. Woods refers this group to the genus Clementia Gray. Clementia ovalis (Sowerby), ${ }^{61}$ from the Upper Greensand of England, is probably an ancestral relative of Aphrodina tippana Conrad.

Occurrence: Ripley formation, Dave Weeks place on Coon Creek, McNairy County, Tenn.

Collections: Maryland Geological Survey, Philadelphia Academy of Natural Sciences, U. S. National Museum.

Outside distribution: Monmouth formation, Brightseat, Prince George County, Md. Magothy formation, New Jersey. Ripley formation, Exogyra cosata zone, Union, Tippah, and Alcorn counties, Miss., Georgia, and Eufaula, Ala.; extreme top of Exogyra costata zone, Chattahoochee River, Ga.

\section{Genus LEGUMEN Conrad}

\section{Legumen planulatum (Conrad)}

\section{Plate XXIX, Figure 1}

1853. Solemya planulata. Conrad, Acad. Nat. Sci. Philadelphia Jour., 2d ser., vol. 2, p. 274, pl. 24, fig. 11.

1858. Legumen ellipticus. Conrad, Acad. Nat. Sci. Philadelphia Jour., 2d ser., vol. 3, p. 325, pl. 34, fig. 19.

1858. Legumen appressus. Conrad, Acad. Nat. Sci. Philadelphia Jour., 2 d ser., vol. 3, p. 325.

\footnotetext{
so Conrad, T. A., in Kerr, W. C., Report of the geological survey of North Carolina, vol. 1, appendix, p. 7, pl. 2, fig. 7, 1875.

${ }_{60}$ Holzapfel, Eduard, Die Mollusken der Aachener Kreide: Palaeontographica, - Band 35, p. 65, pl. 13, figs. 7-10, 1889 .

o1 Woods, Henry, A monograph of the Cretaceous Lamellibranchia of England, vol. 2, p. 191, pl. 29, figs. 19-26, Palaeont. Soc. London, 1908.
}

1864. Legumen appressa. Meek, Check list of the invertebrate fossils of North America, Cretaceous and Jurassic, p. 15.

1864. Legumen elliptica. Meek, Check list of the invertebrate fossils of North America, Cretaceous and Jurassic, p. 15.

1864. Legumen planata. Meek, Check list of the invertebrate fossils of North America, Cretaceous and Jurassic, p. 15.

1868. Legumen ellipticus. Conrad, in Cook, Geology of New Jersey, p. 727.

1868. Legumen appressus. Conrad, in Cook, Geology of New Jersey, p. 727.

1877. Legumen planulatus. Gabb, Acad. Nat. Sci. Philadelphia Proc. for 1876, p. 304.

1885. Legumen planulatum. Whitfield, U. S. Geol. Survey Mon. 9, p. 184, pl. 25, figs. 3, 4. (Also published by New Jersey Geol. Survey, 1886.)

1885. Legumen appressum. Whitfield, U. S. Geol. Survey Mon. 9 , p. 185 , pl. 25 , figs. $6-8$.

1885. Legumen ellipticum. Whitfield, U. S. Geol. Survey Mon. 9, p. 184, pl. 25, fig. 5.

1905. Legumen planulatum. Johnson, Acad. Nat. Sci. Philadelphia Proc., vol. 57, p. 17.

1905. Legumen ellipticum. Johnson, Acad. Nat. Sci. Philadelphia Proc., vol. 57, p. 17.

1907. Legumen planulatum. Weller, New Jersey Geol. Survey, Paleontology, vol. 4, p. 612, pl. 69, figs. 3-7.

1914. Legumen planulatum. Stephenson, U. S. Geol. Survey Prof. Paper 81, p. 24, tables 2-8.

1916. Legumen planulatum. Gardner, Maryland Geol. Survey, Upper Cretaceous, p. 684, pl. 41, figs. 5-7.

Conrad in 1853 described this species as follows:

Elliptical, compressed, sides flattened; end margins rounded; hinge and basal margins nearly parallel.

Type locality: Monmouth County, N. J.

Miss Gardner adds the following details:

Shell very thin and porcellanous, much compressed, transversely ellipsoidal in outline, slightly expanding posteriorly; dorsal and ventral margins subparallel; posterior extremity strongly arcuate, anterior end of shell slightly constricted directly in front of the umbones; the lateral margin evenly and strongly convex; lunule and escutcheon not defined; umbones very low and compressed, with sharp and prosogyrate apices placed within the anterior third; external surface adorned with a sharp incremental sculpture, almost obsolete in the umbonal region and along the extreme dorsal margin, sharpest and most regular near the anterior ventral margin; radial sculpture not developed; ligament submarginal, seated on a nymph not quite half as long as the posterior dorsal margin; cardinals three in number in each valve; the anterior and middle cardinals of the right valve thin, laminar, and rather short, diverging beneath the umbones at rather a small angle; the posterior cardinal also thin and laminar, finely bifid, much elongated and set close under the nymph, to which it is approximately parallel; anterior cardinal of left valve thin and laminar but quite prominent, fitting between the anterior and middle cardinals of the right valve; the middle and posterior cardinals of the left valve laminar and elongated, the posterior more produced and narrowly sulcate, both of them placed far back under the dorsal margin and diverging from one another and from the ligament nymph at a very small angle, in order that they may receive the posterior cardinal of the right valve; muscle impressions small, obscure; pallial line running close to the ventral margin; sinus short, broad, acutely angulated at its anterior extremity. 
Occurrence: Ripley formation, Coon Creek, Trims Mill, McNairy County, Tenn. Selma formation, Gravel Hill, McNairy County, Tenn.

Collections: Maryland Geological Survey, New Jersey Geological Survey, Philadelphia Academy of Natural Sciences, U. S. National Museum, Yale University.

Outside distribution: Matawan formation, threequarters of a mile southwest of Ulmsteads Point, Anne Arundel County, Md. Monmouth formation, Freeman's Creek, Kent County, Md., and Brightseat, Brooks estate near Seat Pleasant, Friendly, McNeys Corners, and 2 miles south of Oxon Hill, all in Prince Georges County, Md. Matawan group (Merchantville clay, Woodbury clay, and Wenonah sand), New Jersey. Monmouth group (Navesink marl and Redbank sand), New Jersey. Black Creek formation, North Carolina and South Carolina. Eutaw formagtion (Tombigbee sand member) Exogyra ponderosa zone, Mortoniceras subzone, Georgia. Ripley formation, Exogyra ponderosa zone, Barbour County, Ala.; Exogyra costata zone, Schley County, Ga., Eufaula, Ala., and Union and Tippah counties, Miss.; extreme top of Exogyra costata zone, Pataula Creek, Gr. Selma chalk, Exogyra costata zone, Wilcox County, Ala., and east-central Mississippi.

\section{Genus CYPRIMERIA Conrad}

\section{Cyprimeria alta Conrad}

Plate XXIX, Figures 2-4; Plate XXX, Figure 1

1875. Cyprimeria alta. Conrad, in Kerr, Report of the geo_ logical survey of North Carolina, vol. 1, appendix A, p. 27.

- Shell large and strong; valves slightly unequal, the right a little more convex; outline subcircular; umbones slightly inflated, the apices rounded, acute, prosogyrate, and anterior; lunule not differentiated; escutcheon deep, narrow, and long; anterior dorsal slope steeper and more uniform than the posterior; anterior end of the shell broadly and smoothly rounded; posterior obliquely truncate; vertical margin well rounded; a narrow posterior area differentiated by the increased prominence of the incremental sculpture; external surface sculptured with incremental lines, concentric threads, or striations, sharp and regular in the immediate vicinity of the umbones, almost obsolete over the medial portion, and irregular with occasional resting stages toward the ventral margin, uniformly coarse over the posterior area from the umbones to the base; ligament submarginal, supported on a strong nymph; hinge plate heavy, three cardinals in each valve radiating from beneath the umbones; adductor scars well defined, large and subelliptical, situated well above the medial horizontal; pallial line slightly sinuous behind; ventral margin smooth. Altitude, 95 millimeters; latitude, 105 millimeters.

This species is common at Coon Creek and is represented in the collections by a number of magnificent specimens. It is analogous to Cyprimeria major Gardner, ${ }^{62}$ of the Monmouth fauna of Maryland.

Occurrence: Ripley formation, Dave Weeks place on Coon Creek, McNairy County, Tenn.

Collections: John Hopkins University, Yale University, Vanderbilt University, U. S. National Museum.

Outside distribution: Ripley formation, Owl Creek, Miss.

\section{Genus ICANOTIA Stoliczka \\ Icanotia pulchra Wade, n. sp. \\ Plate XXIX, Figures 5, 6 .}

Shell large and thick but fragile; outline elongateovate or subelliptical; umbones low and inconspicuous, situated on the anterior third of the shell; posterior dorsal side straight; anterior dorsal slope short; anterior end sharply rounded or broadly subangular; ventral margin broadly arcuate; posterior end well rounded; external sculpture dominately radial; radial costae strongest and most widely spaced on the posterior half of the shell, much smaller and more numerous on the anterior half of the shell; incremental lines numerous and irregular; escutcheon elongate and narrow; ligament external, lodged in a deep groove directly behind the umbone; cardinal area narrow; one small cardinal tooth in the left valve between a large and a small socket; anterior adductor scar fairly large and ovate, situated near the cardinal teeth; posterior adductor scar large and circular, situated at about three-fifths the distance from the umbones to the posterior extremity of the shell; a small D-shaped secondary muscle scar situated directly above the posterior adductor scar; pallial sinus profound and broad. Latitude, 75 millimeters; elevation, 33 millimeters.

This beautiful species is known from a single valve, but it is of particular interest, for it is the first specimen of this very rare and interesting genus to be found in the American Cretaceous. Very few species of Icanotia are known, and none of them are closely related to the American form. Five of them are as follows:

Icanotia impar (Zittel), Gosau, Austria. Turonian. ${ }^{63}$

Icanotia elicita Stoliczka, Karapandy, India. Arrialoor. ${ }^{64}$ Icanotia elegans (D'Orbigny), Le Mans, France. Turonian. ${ }^{65}$

Icanotia discrepans D'Orbigny, Tours, France. Turonian. ${ }^{66}$

Icanotia sp. Woods, Blackdown, England. Upper Greensand. ${ }^{67}$

02. Gardner, J. A., Maryland Geol. Survey, Upper Cretaceous, p. 689, pl. 40, figs. 11, 12; pl. 41, figs. 1-4; pl. 42, fig. 1; pl. 43, fig. 1, 1916.

${ }_{03}$ Zittel, K. A., Textbook of paleontology (transl. by C. R. Eastman), 2d ed., vol. 1, p. 494, fig. 814, 1913 .

of Stoliczka, Ferdinand, India Geol. Survey Mern., Palaeontologia Indica, Cretaceous fauna of southern India, vol. 3, p. 168; pl. 4, fig. 16, 1871.

os $\mathrm{D}^{\prime}$ Orbigny, Alcide, Paléontologie française, Terrains crétacés, vol. 3, p. 423, pl. 381, figs. 1, 2, 1845.

${ }_{68}$ Idem, p. 424, pl. 381, figs. 3-5, 1845 .

67 Woods, Henry, A monograph of the Cretaceous Lamellibranchia of England, vol. 2, p. 431, pl. 62, fig. 14, Palaeont. Soc. London, 1913. 
Occurrence: Ripley formation, Dave Weeks place on Coon Creek, McNairy County, Tenn.

Collection: U. S. National Museum.

\section{Superfamily TELLINACEA}

Family TELLINIDAE

Genus TELLINA Linné

Tellina multiconcentrica Wade, n. sp.

Plate XXX, Figures 2, 3

Shell small and thin; outline subelliptical; umbones rather prominent but low, inflated; dorsal margin arcuate; anterior margin well rounded; ventral margin nearly straight; posterior margin sharply curved; sculpture subdued, consisting of myriads of fine irregular concentric lines and less numerous, faint radial lines; internal characters unknown; shell made up of two layers of calcareous material; outer layer is broken away on the umbones of the type. Altitude, 13.4 millimeters; latitude, 26.4 millimeters.

This species is well characterized by its microscopically fine concentric lines on the external surface and further by its straight or slightly incurved ventral margin. It is less symmetrical in form than Tellina scitula Meek and Hayden ${ }^{68}$ from the Fox Hills sandstone of the western interior.

Occurrence: Ripley formation, Dave Weeks place on Coon Creek, McNairy County, Tenn.

Collection: U. S. National Museum.

\section{Genus TelLINIMERA Conrad \\ Tellinimera eborea Conrad}

1860. Tellina (Tellinimera) eborea. Conrad, Acad. Nat. Sci. Philadelphia Jour., 2d ser., vol. 4, p. 278, pl. 48, fig. 14.

1864. Tellina (Tellinimera) eborea. Meek, Check list of the invertebrate fossils of North America, Cretaceous and Jurassic, p. 14.

1868. Tellinomera ebôrea. Conrad, in Cook, Geology of New Jersey, p. 727.

1870. Tellimera eborea. Conrad, Am. Jour. Conchology, vol. 6, p. 73 .

1884. Tellinimera eborea. Tryon, Structural and systematic conchology, vol. 3, p. 169, pl. 112, fig. 100.

1885. Tellimera eborea. Whitfield, U. S. Geol. Survey Mon. 9 , p. 164 , pl. 23 , figs. 12,13 . (Also published by New Jersey Geol. Survey, 1886.)

1905. Tellinimera eborea. Johnson, Acad. Nat. Sci. Philadelphia Proc., vol. 57, p. 16.

1907. Tellinimera eborea. Weller, New Jersey Geol. Survey, Paleontology, vol. 4, p. 621, pl. 70, figs. 19 (?), 21 (?).

1916. Tellinimera eborea. Gardner, Maryland Geol. Survey, Upper Cretaceous, p. 696, pl. 42, figs. 5, 6.

Conrad originally described this species as follows:

Equilateral, subtriangular, compressed, reflexed posteriorly, and subangulated; anterior end rounded; disk with concentric, regular, slightly impressed lines; substance very thin; anterior cardinal tooth slightly oblique, the posterior one very oblique.

Type locality: Alabama.

Miss Gardner adds the following details:
Shell thin, fragile, polished, compressed, inequilateral, transversely trigonal-ovate in outline; umbones flattened, opisthodetic, conspicuous only by reason of their position at the summit of an angle of not far from $100^{\circ}$; posterior area flattened, the keel rather ill defined, however, and evanescent toward the ventral margin; anterior dorsal slope very gentle, the lateral margin rounding evenly into the horizontal base; posterior dorsal slope very steep, the posterior lateral margin obscurely truncate; external surface sculptured with sharp, concentric striations which are absent in the umbonal region but grow increasingly deeper toward the ventral margin; ligament external, opisthodetic; hinge with the characters of the genus.

The species superficially resembles Aenona eufalensis Conrad but is more compressed, more inequilateral, and more strongly striated concentrically.

Tellina scitula Meek and Hayden, ${ }^{69}$ from the Fox Hills sandstone of the upper Missouri Cretaceous, is probably a related species of the genus Tellinimera.

Occurrence: Ripley formation, Dave Weeks place on Coon Creek, McNairy County, Tenn.

Collections: Maryland Geological Survey, Philadelphia Academy of Natural Sciences," New Jersey Geological Survey.

Outside distribution: Monmouth formation, onehalf mile east of Millersville, Anne Arundel County, Md., and Brightseat, Brooks estate near Seat Pleasant, 1 mile west of Friendly, and 2 miles south of Oxon Hill, all in Prince Georges County, Md. Matawan group (Merchantville clay, Woodbury clay, and Wenonah sand), New Jersey. Cretaceous, Alabama.

\section{Genus AENONA Conrad}

Aenona eufalensis Conrad

Plate XXX, Figures 4, 5

1860. Tellina eufalensis. Conrad, Acad. Nat. Sci. Philade!phia Jour., 2d ser., vol. 4, p. 277, pl. 46, fig. 15.

1864. Tellina eufalensis. Meek, Check list of the invertebrate fossils of North America, Cretaceous and Jurassic. p. 14.

1870. Aenona eufalensis. Conrad, Am. Jour. Conchology, vol. 6, p. 74.

1885. Aenona eufalensis. Whitfield, U. S. Geol. Survey Mon. 9, p. 168, pl. 23, figs. 2, 3. (Hinge incorrectly drawn.) (Also published by New Jersey Geol. Survey, 1886.)

1905. Aenona eufalensis. Johnson, Acad. Nat. Sci. Philadelphia Proc., vol. 57, p. 16.

1907. Aenona eufalensis. Weller, New Jersey Geol. Survey, Paleontology, vol. 4, p. 623, pl. 70, figs. 24, 25. (Hinge incorrectly drawn.)

1914. Aenona eufalensis. Stephenson, U. S. Geol. Survey Prof. Paper 81, p. 24, tables 2, 8.

1916. Aenona eufalensis. Gardner, Maryland Geol. Survey, Upper Cretaceous, p. 697, pl. 42, figs. 3, 4.

Conrad in 1860 described this species as follows:

Subtriangular, convex, entire; inequilateral; anterior end subtruncated; hinge margins equally declining; summit not prominent; posterior end acutely. rounded; left valve furnished with one bifid and one rudimentary cardinal tooth; laterdl distinct.

Type locality: Eufaula, Ala.

${ }^{69}$ Meek, F. B., op. cit., p. 197, pl. 30, figs. 1a, b, 1876 
Miss Gardner adds the following details:

Shell thin, polished, very fragile, rather compressed, transversely elongated, subtrigonal in outline, subequilateral; umbones slightly bulbous at their tips, orthogyrate, placed a little behind the median line; umbonal angle not far from $135^{\circ}$; anterior slope a little more gentle and a little more produced than the posterior; base line evenly and gently arcuate; external surface smooth, excepting for a few incremental striations near the base; bands of concentric color markings frequently retained, the umbones being, as a rule, darker than any other portion of the shell; ligament external, opisthodetic, the nymph short and rather slender; hinge plate narrow; armature of left valve moderately concentrated, consisting of a short laminar cardinal fused anteriorly with the dorsal margin and, on the other side of the triangular pit, a very short trigonal cardinal, feebly sulcated longitudinally; anterior and posterior laterals subequal, symmetrically placed with respect to the umbones, double; more elevated medially than toward the extremities; two cardinals developed in the right valve, the anterior short, thin, and laminar, the posterior placed directly beneath the umbones, short but stout and broadly sulcate; dorsal margins beveled to function as laterals but no true laterals developed; muscle scars rather large but obscure; pallial sinus very broad, reaching approximately to the median vertical, not confluent with the pallial line.

The species differs from 'Tellinimera eborea Conrad, which it superficially resembles, in the more nearly equilateral outline due to the relatively shorter and more angular anterior end of the latter. It differs, furthermore, in the absence of the sharp, concentric striations which characterize $T$. eborea.

This species has such a delicate dentition, which is rarely preserved or shown in figures of forms described in the literature, that it is impossible to cite any allied species of this genus.

Occurrence: Ripley formation, Dave Weeks place on Coon Creek, McNairy County, Tenn.

Collections: Maryland Geological Survey, New Jersey Geological Survey, Philadelphia Academy of Natural Sciences, U. S. National Museum.

Outside distribution: Monmouth formation, Brightseat, Brooks estate near Seat Pleasant, Friendly, 1 mile west of Friendly, McNeys Corners, and 2 miles southwest of Oxon Hill, all in Prince Georges County, Md. Matawan group (Woodbury clay), New Jersey. Ripley formation; Exogyra costata zone, Quitman County, Ga., Eufaula, Ala., and Union and Tippah counties, Miss.; extreme top of Exogyra costata zone, Pataula Creek, Ga., and Chattahoochee River, Ala.

\section{Genus IINEARIA Conrad}

\section{Linearia metastriata Conrad}

\section{Plate XXXI, Figures 1, 2}

1860. Linearia metastriata. Conrad, Acad. Nat. Sci. Philadelphia Jour., 2d ser.., vol. 4, p. 279, pl. 46, fig. 7 .

1864. Linearia metastriata. Meek, Check list of the invertebrate fossils of North America, Cretaceous and Jurassic, p. 14.

1870. Linearia melastriata. Conrad, Am. Jour. Conchology, vol. 6 , p. 73 , pl. 3 , fig. 11 .

1885. Linearia metastriata. Whitfield, U. S. Geol. Survey Mon. 9, p. 165, pl. 23, figs. 6, 7. (Also published by New Jersey Geol. Survey, 1886.)
1905. L.nearia metastriata. Johnson, Acad. Nat. Sci. Philadelphia Proc., vol. 57, p. 16.

1907. Linearia metastriata. Weller, New Jersey Geol. Survey, Paleontology, vol. 4, p. 618, pl. 70, figs. 8, 9.

1914. Linearia metastriata. Stephenson, U. S. Geol. Survey Prof. Paper 81, p. 24, tables 2, 8.

1916. Linearia metastriata. Gardner, Maryland Geol. Survey, Upper Cretaceous, p. 699.

Conrad originally described this species as follows:

Oblong-oval, convex, subequilateral; posterior end subtruncated; disk with fine concentric lines and distinct radiating lines anteriorly, and larger crenulated radii posteriorly; the rest of the surface with microscopic radiating lines; cardinal tooth under the apex widely bifid; lobes small and slender.

Type locality: Eufaula, Ala.

Miss Gardner adds the following details :

Shell transversely oval in outline; anterior end evenly rounded, posterior obscurely truncate; external surface very finely. cancellated, concentric sculpture of 50 to 60 acute lirations, which evenly override the radials in the medial portion of the disk but are minutely undulated by them anteriorly and even more sharply posteriorly; radial sculpture confined to striations on the interspaces between the concentric lirae on the medial portion of the disk, appearing posteriorly as six to nine low, radiating lirae, unequal in size and spacing; radial sculpture on anterior portion of shell much finer and sharper; radials twelve to fifteen in number, approximately uniform in size and spacing, nodulated by the overriding concentric laminae; ligament external, opisthodetic, mounted on rather a slender nymph, which is separated from the rest of the shell by a linear sulcus; hinge of left valve armed with two laminar cardinals, the posterior a little more slender than the anterior, their inner faces flattened and proximate, diverging at a very small angle and subparallel to the dorsal margin; a single moderately robust, posteriorly directed cardinal developed in the right valve with rather a deep pit in front of it and a more shallow one behind it for the reception of the cardinals of the left valve; a feeble elevation on the forward margin of the anterior socket, probably the analogue of the anterior cardinal in the right valve; dorsal margins of right valve beveled to function as. laterals, received in the left by double grooves which are developed at the distal extremities of the hinge plate; characters of muscle scars and pallial sinus obscure.

Meek and Hayden have questionably referred a form (Linearia? formosa Meek and Hayden ${ }^{70}$ ) with strong concentric sculpture and very faint radial sculpture to this genus. Their species comes from the Fox Hills sandstone near the mouth of Cannonball River, N. Dak. Linearia concentrica (D'Orbigny), ${ }^{71}$ from the Neocomian of France, is similar in form and external sculpture to Linearia metastriata Conrad but has a slightly different hinge. Another Lower Cretaceous form, which resembles this species of the eastern United States, is Linearia subtenuistriata D'Orbigny, ${ }^{72}$ from the Upper Greensand, Blackdown, England. The wide vertical and horizontal distribution of this related group of forms is further shown by the occurrence of another similar

${ }^{70}$ Meek, F. B., A report on the invertebrate Cretaceous and Tertiary fossils of the upper Missouri country: U. S. Geol. Survey Terr. Rept., vol. 9, p. 199, pl. 30, flg. 2, 1876.

${ }^{1}$ D'Orbigny, Alcide, Paléontologie française, Terrains crétacés, vol. 3, p. 410, pl. 378 , figs. $1-6,1845$.

3 Woods, Henry, A monograph of the Cretaceous Lamellibranchia of England, vol. 2, p. 175, pl. 27, figs. 10-13, Palaeont. Soc. London, 1907. 
species, Linearia sculptilis Stoliczka, ${ }^{73}$ in the Arrialoor group, Comarapolliam, India.

Occurrence: Ripley formation, Dave Weeks place on Coon Creek, McNairy County, Tenn.

Collection: Maryland Geological Survey, Philadelphia Academy of Natural Sciences, New Jersey Geological Survey, U. S. National Museum.

Outside distribution: Monmouth formation, Brightseat, Brooks estate near Seat Pleasant, and Friendly, all in Prince Georges County, Md. Magothy formation ("Cliffwood clay"), New Jersey. Matawan group (Merchantville clay, Woodbury clay, Marshalltown formation, and Wenonah sand), New Jersey. Monmouth group (Redbank sand), New Jersey. Black Creek formation, North Carolina, and South Carolina. Eutaw formation (Tombigbee sand member), Exogyra ponderosa zone, Mortoniceras subzone, Stewart County, Ga. Ripley formation, Exogyra costata zone, Quitman County, Ga., Eufaula, Ala., and Union, Tippah, and Alcorn counties, Miss.; extreme top of Exogyra costata zone, Pataula Creek, Ga.

\section{Linearia ornatissima Weller}

Plate XXX, Figures 6, 7

1907. Linearia ornatissima. Weller, New Jersey Geol. Survey, Paleontology, vol. 4, p. 619, pl. 70, figs. 10-12.

1914. Linearia ornatissima. Stephenson, U. S. Geol. Survey Prof. Paper 81, p. 24, table 2.

Weller describes this species as follows:

Shell small, the dimensions of the type specimen being, length, 6 millimeters; height, 4.3 millimeters; nearly equilateral, broadly subtriangular in outline, with the basal angles rounded; beak central; the cardinal margins meeting at the beak in an angle of about $120^{\circ}$, anterior and posterior margins subsequently rounded, their greatest extension below the mid-height of the shell; ventral margin gently convex. Valves depressed convex, most prominent. on the umbo, the surface sloping abruptly to the cardinal margins and gently to the lateral and basal margins. Surface marked by strong radiating ribs anteriorly and posteriorly, which gradually become fainter toward the median portion of the ventral margin; on the umbo and on an area extending ventrally from the umbo nearly to the basal margin the shell is smooth; the anterior and posterior ribs do not continue to the beak but disappear along the margins of the central smooth area; all the ribbed portion of the shell is also marked by strong, regular concentric costae, somewhat stronger in the depressions between the ribs than upon the ribs themselves.

The Coon Creek specimens that are referred to this species are somewhat larger and more highly sculptured on the umbonal region. This species is very closely related to Linearia metastriata Conrad but is less elongate. In some respects Linearia ornatissima Weller resembles the highly ornate species Linearia semicostata (Reuss), ${ }^{74}$ from the Turonian and Senonian of Bohemia.

75 Stoliczka, Ferdinand, India Geol. Survey Mem., Palaeontologia Indica, Cretaceous fauna of southern India, vol. 3, p. 131, pl. 5, figs. 6-7, 1870.

7 Friz, Anton, Studien im Gebiete der böhmischen Kreideformation: Archiv naturwiss. Landesd. Böhmen, Band 4, No. 1, p. 126, fig. 102, 1877.
Occurrence: Ripley formation, Dave Weeks place on Coon Creek, McNairy County, Tenn.

Collections: New Jersey Geological Survey, U. S. National Museum.

Outside distribution: Woodbury clay of the Matawan group of New Jersey. Ripley formation, Owl Creek, Miss.

\section{Genus LIOTHYRIS Conrad}

Liothyris carolinensis Conrad

Plate XXXI, Figures 3, 5, 6

1875. Linearia (Liothyris) carolinensis. Conrad, in Kerr, Report of the geological survey of North Carolina, Appendix A, p. 9, pl. 1, figs. 20, 23, 24.

Conrad described this species as follows:

Shell subovate, convex; beaks situated behind the middle; umbonal slope undefined; anterior end acutely rounded, posterior end truncated, direct.

Shell fairly large and fragile; subovate in outline; umbones low and proximate, situated a little behind the middle of the shells; anterior and posterior dorsal margins nearly straight, sloping off rather gradually from the umbones; anterior margin well rounded; posterior margin well rounded and gaping slightly; ventral margin gently arcuate; external surface smooth except for fine irregular incremental lines; the external surface is beautifully and irregularly banded with bands of light and dark shell material; dentition well developed, two cardinals and a posterior and anterior lateral sockets in the right valve; in the left a single laminar cardinal and feeble laminar laterals; adductor scars large, subovate, and situated above the median horizontal; pallial line deeply sinuous; ventral margin smooth.

Occurrence: Ripley formation, Dave Weeks place on Coon Creek, McNairy County, Tenn.

Collections: Johns Hopkins University, U. S. National Museum.

Outside distribution: Black Creek formation, Snow Hill, N. C.

\section{Superfamily SOLENACEA}

Family SOLENIDAE

Genus LEPTOSOLEN

\section{Leptosolen biplicata Conrad}

Plate XXXI, Figures 4, 7

1858. Siliquaria biplicata. Conrad, Acad. Nat. Sci. Philadelphia Jour., 2d ser., vol. 3, p. 324, pl. 24, fig. 17.

1861. Siliquaria biplicata. Gabb, Synopsis of the Mollusca of the Cretaceous formation, p. 170 (Am. Philos. Soc. Proc., vol. 8, p. 226).

1864. Siliquaria biplicatq. Meek, Check list of the invertebrate fossils of North America, Cretaceous and Jurassic, p. 15.

1867. Leptosolen biplicata. Conrad, Am. Jour. Conchology, vol. 3, pp. 15, 138.

1868. Leptosolen biplicatus. Conrad, in Cook, Geology of New Jersey, p. 727. 
1877. Leptosolen biplicata. Gabb, Acad. Nat. Sci. Philadelphia Proc: for 1876, p. 304.

1885. Leptosolen biplicata. Whitfield, U. S. Geol. Survey Mon. 9, p. 183, pl. 25, figs. 1, 2. (Also published by New Jersey Geol. Survey, 1886.)

1905. Leptosolen biplicata. Johnson, Acad. Nat. Sci. Philadelphia Proc., vol. 57, p. 17.

1907. Leptosolen biplicata. Weller, New Jersey Geol. Survey, Paleontology, vol. 4, p. 624, pl. 70, figs. 30, 31.

1914. Leptosolen biplicata. Stephenson, U. S. Geol. Survey Prof. Paper 81, p. 24, tables 2, 8.

1916. Leptosolen biplicata. Gardner, Maryland Geol. Survey, Upper Cretaceous, p. 703, pl. 42, figs. 7, 8.

Conrad in 1858 described this species as follows:

Thin, convex, with two radiating folds or depressions anteriorly; basal line slightly contracted or incurved; anterior side short; extremity truncated; posterior margin obtusely rounded, posterior side concentrically lineated; valves somewhat contracted obliquely from beak to base.

Type locality: Owl Creek, Tippah County, Miss.

Miss Gardner adds the following details:

Shell very thin, porcellanous, compressed, rudely cylindrical in outline; dorsal and ventral margins parallel, the posterior symmetrically arcuate, the anterior rounding, somewhat obliquely, into the base; lunule and escutcheon not defined; umbones very inconspicuous, scarcely rising above the dorsal margin, set back from the anterior extremity a distance of approximately one-fourth the total latitude; posterior area differentiated by the abrupt strengthening of the concentric sculpture along a line extending from the umbones to the posterior extremity of the basal margin, concentric sculpture reduced to faint and rather irregular incremental striations upon the anterior and medial portions of the shell, least feebly medially and appearing upon the posterior area as sharp-edged, regularly overlapping concentric laminae; radial sculpture not developed; ligament marginal, opisthodetic, seated upon a nymph about one-eighth as long as the posterior dorsal margin; a single very prominent subumbonal cardinal in each valve; shell reinforced within by a rather heavy deposit of calcite along a vertical dropped from the umbones; the ridge thus formed broadest and most elevated dorsally and gradually evanescing toward the base; muscle scars subequal, inconspicuous; pallial sinus profound.

Casts of the interior are remarkable for their cylindrical outline and for the deep sulcus formed by the internal rib, which cuts across the umbo and persists a little more than half way down to the ventral margin.

Meek, in 1876, pointed out the differences between Leptosolen biplicata Conrad and the species Leptosolen conradi Meek, ${ }^{75}$ from the Mentor formation of Kansas.

The following Upper Cretaceous species from Europe and India resemble Leptosolen biplicata:

\section{Leptosolen dupinianus D'Orbigny. England. ${ }^{76}$ Leptosolen petersi (Reuss). Eastern Alps. ${ }^{77}$ Leptosolen concentristriatus (Müller). Germany. ${ }^{78}$ Leptosolen truncatula (Reuss). Bohemia. ${ }^{79}$}

75 Meek, F. B., op. cit., p. 253, pl. 2. figs. 12a, b.

${ }_{70}$ Woods, Henry, A monograph of the Cretaceous Lamellibranchia of England, vol. 2, p. 221, pl. 35, figs. 7, 8, Palaeont. Soc. London, 1904.

" Zittel, K. A., Die Bivalven der Gosaugebilde in den nordöstlichen Alpen: K. Akad. Wiss. Wien Denkschr., Band 24, pt. 1, p. 5, pl. 1, fig. 3, 1865

${ }_{78}$ Müller, G., Beitrag zur Kenntniss der oberen Kreide am nördlichen Harzrande:

K. prouss. geol. Landesanstalt Jahrb., 1887, p. 431, pl. 18, fig. 5, 1888 .

79 Reuss, A. E., Die Versteinerungen der böhmischen Kreideformation, pt. 2, p. 17, pl. 36, figs. $13,16,17,1848$.
Leptosolen moreana D'Orbigny. France. ${ }^{80}$

Leptosolen limata Stoliczka. Southern India. ${ }^{81}$

Occurrence: Ripley formation, Dave Weeks place on Coon Creek, McNairy County, Tenn.

Collections: Maryland Geological Survey, New Jersey Geological Survey, Philadelphia Academy of Natural Sciences, U. S. National Museum.

Outside distribution: Monmouth formation, Brightseat, Brooks estate near Seat Pleasant, 1 mile west of Friendly, and 2 miles southwest of Oxon Hill, all in Prince Georges County, Md. Magothy formation ("Clifford clay"), New Jersey. Matawan group (Merchantville clay, Woodbury clay, and Wenonah sand), New Jersey. Monmouth group (Navesink marl and Redbank sand), New Jersey. Black Creek formation, North Carolina and South Carolina. Eutaw formation, basal part and Exogyra ponderosa zone, Chattahoochee County, Ga. Tombigbee sand member of Eutaw formation, Exogyra ponderosa zone, Mortoniceras subzone, Stewart County, Ga. Ripley formation, Exogyra ponderosa zone, Stewart County, Ga.; Exogyra costata zone, Eufaula, Ala., and Union, Tippah, and Alcorn counties, Miss.; extreme top of Exogyra costata zone, Pataula Creek, Ga., and Chattahoochee River, Ala.

\section{Superfamily MACTRACEA \\ Family MACTRIDAE \\ Genus CYMBOPHORA Gabb \\ Cymbophora gracilis (Meek and Hayden) \\ Plate XXXI, Figure 8}

1860. Mactra gracilis. Meek and Hayden, Acad. Nat. Sci. Philadelphia Proc. for 1860, p. 179.

1876. Mactra (Cymbophora) gracilis. Meek, U. S. Geol. Survey Terr. Rept., vol. 9, p. 200, pl. 17, figs. 18a, b.

Meek and Hayden describe this species as follows:

Shell small, rather thin, subovate, moderately gibbous; anterior margin rounded, a little shorter and broader than the other; base forming a broad semi-ovate curve, being usually more prominent toward the front than behind; posterior side rather narrowly rounded or subtruncate at the extremity; beaks moderately prominent and located slightly in advance of the middle; escutcheon comparatively large, lanceolate in form; surface marked by distinct, regular lines of growth (hinge unknown).

The Tennessee form herein figured can not be assigned with assurance to Meek and Hayden's species, for it is much smaller and is sculptured with rather definite regular concentric ridges. There is a rather striking similarity between the Tennessee representatives of this species and the Senonian species Mactra? zulu Etheridge, ${ }^{82}$ from Natal, East Africa.

so D'Orbigny, Alcide, Paléontologie française, Terrains crétacés, vol. 3, p. 324, pl. 350 , figs. $8-10,1845$

81 St,oliczka, Ferdinand, India Geol. Survey Mem., Palaeontologia Indica, Cretaceous fauna of southern India, vol. 3, p. 101, pl. 1, figs. 12, 13, 1870.

82 Ftheridge, Robert, Cretaceous fauna of Natal: Natal and Zululand Geol. Sur. vey Second Rept., p. 82, pl. 2, figs. 17-19, 1904. 
Occurrence: Ripley formation, Dave Weeks place on Coon Creek, McNairy County, Tenn.

Collection: U. S. National Museum.

Outside distribution: Pierre shale, 150 miles above mouth of Yellowstone River, Mont.

\section{Family CORBULIDAE \\ Genus CORBULA Lamarck \\ Corbula crassiplica Gabb \\ Plate XXXI, Figures 9, 13}

Superfamily MYACEA

1860. Corbula crassiplica. Gabb, Acad. Nat. Sci. Philadelphia Jour., 2d ser., vol. 4, p. 394, pl. 58, fig. 25.

1864. Corbula crassiplicala. Meek, Check list of the invertebrate fossils of North America, Cretaceous and Jurassic, p. 15.

1868. Corbula crassiplicata. Conrad, in Cook, Geology of New Jersey, p. 727.

1869. Corbula crassiplica. Safford, Geology of Tennessee, p. 416.

1875. Corbula perbrevis.' Conrad, in Kerr, Report of the geological survey of North Carolina, vol. 1, Appendix, p. 11 , pl. 2, fig. 5 .

1885. Corbula crassiplica. Whitfield, U. S. Geol. Survey Mon. 9, p. 178, pl. 23, fig. 30. (Also published by New Jersey Geol. Survey, 1886.)

1905. Corbula crassiplica. Johnson, Acad. Nat. Sci. Philadelphia Proc., vol. 57, p. 17.

1907. Corbula crassiplica. Weller, New Jersey Geol. Survey, Paleontology, vol. 4; p. 641, pl. 72, figs. 27, 28.

1914. Corbula crassiplica. Stephenson; U. S. Geol. Survey Prof. Paper 81, p. 24, tables 2-8.

1916. Corbula crassiplica. Gardner, Maryland Geol. Survey, Upper Cretaceous, p. 713, pl. 43, figs. 6, 7.

Gabb describes this species as follows:

Subtriangular, heavily ribbed, thick; beaks large and incurved; umbones large and round; umbonal ridge small and marked by a distinct groove immediately in advance of it, rest of the shell marked by about a dozen very coarse transverse ribs except on the umbones, which are smooth, apparently from attrition. Inside hinge large, caudal prolongation marked by two pitlike depressions. Length, 0.15 inch; width, 0.2 inch; height of right valve, 0.07 inch.

Type locality: From a cut on the Memphis \& Charleston Railroad [now a part of the Southern Railway], where it crosses the Tennessee and .Mississippi State line [in McNairy County, Tenn.].

\section{Miss Gardner adds the following details:}

Shell small, high, trigonal, slightly inequilateral, very conspicuously inequivalve; right valve almost as high as it is wide, strongly inflated in the umbonal region, the apices incurved, acute, prosogyrate, and placed a little in front of the median vertical; left valve oblong trigonal in outline, the altitude usually less than three-fourths of the latitude, the shell evenly inflated and the umbones rather low and subcentral; anterior dorsal and lateral margins of both valves evenly rounded, posterior dorsal margin oblique, much more produced in the right valve than in the left; lateral margin obliquely truncate; base line broadly and evenly rounded in the left valve, quite strongly arcuate in the anterior portion of the right but feebly constricted in front of the posterior keel, which extends in the form of a sharply elevated ridge from the umbonal region to the posterior basal margin; area behind the keel sharply differ- entiated from that in front of it, its lateral margin in the right valve thin and slightly reflected; external surface of right valve corrugated with 15 to 20 prominent concentric plications, about half of which are confined to the umbonal region and become increasingly fine and sharp toward the apices, the other half very coarse and heavy, often somewhat irregular in size and spacing toward the base but approximately uniform in prominence from the anterior margin to just in front of the posterior keel, where they abruptly evanesce; keel and area behind it sculptured only with strong incrementals; left valve smooth excepting for irregular incremental sculpture; ligament internal, supported by a rather prominent lamelliform chondrophore in the left valve; resilial pit in right valve quite profound; dentition restricted to a single, subumbonal, sharply conical tooth in the right valve and a subumbonal socket for its reception in the left; adductor scars not very distinct, quite well up toward the dorsal margins, pallial sinus broad but not very deep, pallial line much more distant from the base in the right valve than in the left, because of the overlapping ventral margin of the larger valve.

Dimensions: Right valve, latitude, 5 millimeters; altitude 4 millimeters. Left valve, latitude, 3 millimeters, altitude 2.7 millimeters. Maximum diameter of double valves, 2.5 millimeters.

This species is by far the most abundant representative of the genus in the Upper Cretaceous faunas of Maryland and is one of the most prolific of the smaller bivalves in the Monmouth of Prince Georges County. It is readily recognizable by the strong discrepancy of the valves in size, outline, and sculpture and by the robust concentric plications upon the disk of the right valve.

Weathered individuals of this species present a most deceptive appearance; the entire external sculpture and posterior keel and area are decorticated, leaving a high, trigonal subequilateral shell with no trace of concentric plications or posterior keel.

In many respects Corbula crassiplica resembles Corbula elegans Sowerby, ${ }^{83}$ a form from the Upper Greensand. This species is the most abundant fossil found in the Coon Creek beds of McNairy County.

Occurrence: Ripley formation, McNairy and Chester counties, Tenn. Selma formation, McNairy, Chester, Henderson, Carroll, and Benton counties, Tenn.

Collections: Maryland Geological Survey, U. S. National Museum, New Jersey Geological Survey, Philadelphia Academy of Natural Sciences, Yale University, Vanderbilt University.

Outside distribution: Monmouth formation, Brightseat, Brooks estate near Seat Pleasant, 1 mile west of Friendly, and McNeys Corners, all in Prince Georges County, Md. Matawan group (Merchantville clay, Woodbury clay, and Wenonah sand), New Jersey. Monmouth group (Navesink marl and Redbank sand), New Jersey. Black Creek formation, North Carolina and South Carolina. Eutaw formation (Tombigbee sand member), Exogyra ponderosa zone, Prentiss County, Miss.; Mortoniceras subzone, Stewart County, Ga. Ripley formation, Exogyra costata zone, Schley County, Ga., Eufaula, Ala., and Union, Tippah, and

${ }^{83}$ Woods, Henry, A monograph of the Cretaceous Lamellibranchia of England, vol. 2, p. 216, pl. 34, figs. 23-28, Palaeont. Soc: London, 1904. 
Alcorn counties, Miss. ; extreme top of Exogyra costata zone, Pataula Creek, Ga.

\section{Corbula monmouthensis Gardner}

Plate XXXI, Figures 10, 14

1916. Corbula monmouthensis. Gardner, Maryland Geol. Survey, Upper Cretaceous, p. 715, pl. 44, figs. 4-8.

Miss Gardner describes this species as follows:

Shell rather large for the genus, ovate trigonal in outline, inequilateral and inconspicuously inequivalve; umbones subcentral in position, subequal in the two valves, somewhat flattened upon their summits, the apices acute and prosogyratc; right valve more inflated than left in the anterior portion and with a wider posterior area, which is angulated near its dorsal margin and slightly reflected over the left valve; anterior margins of both valves broadly and evenly rounded; posterior dorsal slope more gentle in the right valve than in the left; the lateral margin produced and obtusely angulated in the right, obliquely truncate in the left; base line more strongly arcuate in the larger valve; external sculpture in both valves of very fine, sharp lamellae closely overlapping, the free edges directed toward the umbones, least feeble on the anterior and ventral portions of the disk, very faint in the umbonal region and evanescent near the posterior keel; ligament internal, supported by a rather inconspicuous lamelliform chondrophore behind the umbone in the left valve; resilial pit in the right valve broad but rather shallow, the solitary tooth subumbonal in position, stout, obtusely conical; receiving socket in left valve also subumbonal, long but not very deep; adductor muscle scars relatively long, rather indistinct; pallial sinus broad, shallow; pallial line rather near the basal margin.

Dimensions: Altitude, 6.9 millimeters; latitude, 11.4 millimeters; maximum diameter of double valves, 5 millimeters.

This is the largest of the Corbulae in the Maryland Cretaceous.

The Tennessee forms of this species are not so large as the Maryland forms by one-third, and they are also not so highly sculptured and show a tendency toward a smooth surface, especially on the umbonal region.

Occurrence: Ripley formation, Dave Weeks place on Coon Creek, McNairy County, Tenn.

Collections: Maryland Geological Survey, U. S. National Museum.

Outside distribution: Monmouth formation, Seat Pleasant, Prince Georges County, Md.

Corbula paracrassa Wade, n. sp.

Plate XXXI, Figures 11, 12

Shell small and short, ovate-trigonal in outline, inequilateral, inequivalved; umbones of right valve especially much inflated, incurved and proximate; anterior margin well rounded; ventral margin arcuate; posterior and dorsal posterior margins truncate; external surface sculptured with concentric lines or well-rounded ridges, about 35 in number on the right valve; left valve only faintly sculptured on the umbonal area, ligament internal, supported by a rather prominent lamelliform chondrophore in the left valve; resilial pit in right valve quite profound; dentition restricted to a simple subumbonal, sharply conical tooth in the right valve and a subumbonal socket in the left; adductor scars not very distinct; pallial line simple; ventral margin smooth.

Altitude, 3.5 milimeters; latitude, 3.5 milimeters.

This species is well characterized by its short shells with strongly inflated umbones. It is a much smaller form than Corbula crassiplica Gabb and has finer sculpture.

Occurrence: Ripley formation, Dave Weeks place on Coon Creek, McNairy County, Tenn.

Collection: U. S. National Museum.

Corbula williardi Wade, n. sp.

Plate XXXI, Figures 17, 18

Shell very small and short; subglobose in outline, inequilateral, inequivalved; umbones rather conspicuous and inflated, proximate; dorsal posterior and anterior margins truncate, anterior margin well rounded, ventral margin arcuate; external surface of both right and left valves sculptured with numerous fine concentric rolls or ridges; ligament internal; dentition consisting of a single sharply conical tooth in the right valve and a socket in the left; adductor scars small and faint; pallial line simple, ventral margin smooth. Altitude, 2.5 millimeters; latitude, 3 millimeters.

This species is characterized by its minute subglobose shells, which are concentrically sculptured on both valves. In some respects this species resembles the small species Corbula beisseli Holzapfel, ${ }^{84}$ from the Senonian of Vaals and Aachen, Germany.

This species is named in honor of Mr. T. E. Williard, of the United States Geological Survey, who has assisted in preparing the Coon Creek specimens for study and figuring.

Occurrence: Ripley formation, Dave Weeks place on Coon Creek, McNairy County, Tenn.

Collection: U. S. National Museum.

\section{Genus CORBULAMELLA Meek and Hayden}

Corbulamella suffalciata Wade, n. sp.

Plate XXXI, Figures 15, 16, 19, 20

Shell large and strong for this genus, ovate-trigonal in outline and strongly inflated, inequilateral, inequivalve, right valve slightly overlapping the left along the posterior and ventral margins; anterior ends of both valves broadly rounded; posterior end narrow and obliquely truncate; ventral margin more arcuate in right valve than in left; umbones prominent, incurved, prosogyrate; posterior keel connecting umbones and ventral posterior margin less acute and conspicuous at its anterior extremity; posterior area narrow and regular, external surface sculptured by numerous irregular concentric undulations, which are strongest toward the ventral margin and evanesce on

84 Holzapfel, Eduard, Die Mollusken der Aachener Kreide: Palaeontographica, Band 35, p. 146, pl. 10,'figs. 6-10, 1889. 
the umbones; ligament internal, supported by a laminar chondrophore in the left valve; resilial pit in the right valve broad and shallow; cardinal tooth in the right valve stout, conical; adductor well defined, elliptical in shape, the posterior scar the more prominent and situated on a spoon-shaped buttress characteristic of this genus; pallial sinus obscure; pallial line impressed. Altitude, 9 millimeters; latitude, 13 millimeters.

This species is characterized by large, stout shells, which are well sculptured near the ventral margins and almost free from any ornamentation on the umbonal areas. This species is the second of this genus to be reported from the North American Cretaceous deposits. Corbulamella suffalciata is larger, more elongate, and more nearly equivalve than Corbulamella gregaria Meek and Hayden, ${ }^{85}$ the type of this genus, from the Pierre shale of Montana. Another species of this genus is Corbulamella striatula Goldfuss, ${ }^{80}$ from the lower Senonian of Suderode and Quedlinburg.

Occurrence: Ripley formation, Dave Weeks place on Coon Creek, McNairy County, Tenn.

Collections: Johns Hopkins University, U. S. National Museum.

\section{Family SAXICAVIDAE}

\section{Genus PANOPE Menard}

\section{Panope decisa Conrad}

Plate XXXII, Figures 8,9

1853. Panopaea decisa. Conrad, Acad. Nat. Sci. Philadelphia Jour., 2d ser., vol. 2, p. 275, pl. 24, fig. 19.

1864. Panopaea decisa. Meek, Check list of the invertebrate fossils of North America, Cretaceous and Jurassic, p. 15.

1868. Glycymeris decisa. Conrad, in Cook, Geology of New Jersey, p. 727.

1885. Panopea decisa. Whitfield, U. S. Geol. Survey Mon. 9, p. 181, pl. 24, figs. 5-8. (Also published by New Jersey Geol. Survey, 1886.)

1905. Panopea decisa. Johnson, Acad. Nat. Sci. Philadelphia Proc., vol. 57, p. 18.

1907. Panopea decisa. Weller, New Jersey Geol. Survey, Paleontology, vol. 4, p. 646, pl. 73, figs. 3, 4 .

1914. Panopea decisa. Stephenson, U. S. Geol. Survey Prof. Paper 81, p. 24, tables 2, 5, 8, 9.

1916. Panope decisa. Gardner, Maryland Geol. Survey, Upper Cretaceous, p. 721.

Conrad in 1853 described this species as follows:

Oblong, ventricose, concentrically waved or furrowed; slightly contracted posteriorly; posterior hinge line nearly parallel with the base; posterior margin truncated obliquely

${ }^{85}$ Meek, F. B., op. cit., p. 247, pl. 17, figs. 3a-d.

${ }^{80}$ Frech, Fritz, Die Versteinerungen der unter-senonen Thonlager zwischen Suderode und Quedlinburg: Deutsche geol. Gesell. Zeitschr., Band 39, p. 173, pl. 12, figs. 5-8, 1887. inward; basal margin nearly straight; beaks situated ab sut one-third the shell's length from the anterior margin.

Type locality: Burlington County (?), N. J., or Chesapeake \& Delaware Canal (?), Del.

Whitfield adds the following details:

Shell moderately large and ventricose, with moderately large projecting beaks, which are situated a little nearer the anterior end, widely gaping at the posterior end and closed anteriorly. Anterior extremity rounded, longest below the middle, anterior end truncated, projecting near the cardinal line and receding below. Surface of the shell marked by very strong, broad concentric undulations, most strongly developed on the middle of the valves and becoming nearly obsolete on some specimens both anteriorly and posteriorly. The valves are also often depressed along the posterior umbonal slope, showing a distinct furrow at the bending of the undulations of the surface at this point.

The internal features of the species are not easily made out from the imperfect casts under examination, the shell having been too fragile to leave the impressions of pallial line or muscular scars so as to be traced with any degree of certainty. The hinge, however, has been considerably thickened and has left the imprint of its features on some of the specimens, so that by the use of gutta-percha its features have been fairly shown. There is positive evidence of only a single projecting tooth in each valve, which has been long and incurved.

There was a great world-wide development of Panope during Cretaceous and Jurassic time, as is shown by the numerous species described in the literature. Eight species have been described from the Cretaceous and Jurassic of Alaska. ${ }^{87}$ Six species have been described from the Cretaceous of England. ${ }^{88}$

The most closely related species to Panope decisa Conrad are probably Panope elliptica Whitfield ${ }^{80}$ and Panope monmouthensis Gardner, ${ }^{90}$ from the Upper Cretaceous of New Jersey and Maryland.

Occurrence: Ripley formation, Dave Weeks place on Coon Creek, McNairy County, Tenn.

Collections: Maryland Geological Survey, Philadelphia Academy of Natural Sciences, New Jersey Geological Survey, U. S. National Museum.

Outside distribution: Matawan formation, post 105, Chesapeake \& Delaware Canal, Del. Matawan group (Merchantville clay, Woodbury clay, and Wenonah sand), New Jersey. Monmouth group (Navesink marl and Redbank sand), New Jersey. Peedee sand, North Carolina and South Carolina. Eutaw formation (Tombigbee sand member), Exogyra ponderosa zone, Prentiss County, Miss. Ripley formation, Exogyra costata zone, Marion County, Ga., and Owl Creek, Tippah County, Miss.

87 Eichwald, Eduard, Geognostisch-paleontologische Bemerkungen über di Halbinsel Mangischlak und die aleutischen Inseln, pp. 158-162, pls. 12-13, 1871.

9s Woods, Henry, A monograph of the Cretaceous Lamellibranchia of England, vol. 2, pp. 222-232, pls. 35-38, Palaeont. Soc. London, 1909.

${ }^{89}$ Whitfield, R. P., Brachiopoda and Lamellibranchiata of the Raritan clays and greensand marls of New Jersey: U. S. Geol. Survey Mon. 9, p. 219, pl. 28, figs. $24,25,1885$. (Also published by New Jersey Geal. Survey, 1886.)

80 Gardner, J. A., Maryland Geol. Survey, Upper Cretaceous, p. 722, pl. 45, flgs. 4, 5, 1916. 
Family GASTROCHAENIDAE

Genus GASTROCHAENA Spengler

Gastrochaena americana Gabb

Plate XXXII, Figures 5-7

1860. Gastrochaena americana. Gabb, Acad. Nat. Sci. Philadelphia Jour., 2d ser., vol. 4, p. 393, pl. 68, fig. 20.

1861. Gastrochaena americana. Gabb, Synopsis of the Mollusca of the Cretaceous formation, p. 124 (Am. Philos. Soc. Proc., vol. 8, p. 180).

1861. Polorthus americana. Gabb, Acad. Nat. Sci. Philadelphia Proc. for 1861, p. 367:

1864. Gastrochaena americana. Meek, Check list of the invertebrate fossils of North America, Cretaceous and Jurassic, p. 15.

1864. Polorthus americanus. Meek, Check list of the invertebrate fossils of North America, Cretaceous and Jurassic, p. 16.

1872. Polorthus americanus. Gabb, Acad. Nat. Sci. Philadel. phia Proc. for 1872 , p. 259 , pl. 8, fig. 8 .

1885. Gastrochaena americana. Whitfield, U. S. Geol. Survey Mon. 9, p. 203, pl. 26, figs. 17-18. (Also published by New Jersey Geol. Survey, 1886.)

1905. Gastrochaena americana. Johnson, Acad. Nat. Sci. Philadelphia Proc., vol. 57, p. 18.

1907. Gastrochaena americana. Weller, New Jersey Geol. Survey, Paleontology, vol. 4, p. 649, pl. 74, fig. 13.

1914. Gastrochaena americana. Stephenson, U. S. Geol. Survey Prof. Paper 81, p. 24, table 2.

Gabb in 1860 characterized this species as follows:

Elongated conical, transversely wrinkled; termination of widest end round.

Weller adds the following details:

Tubes solitary, elongate conical, the larger extremity rounded; attaining a length in the largest examples of 75 millimeters and a maximum diameter of about 12 millimeters; the minor diameter is usually about 5 or 6 millimeters; diameter increasing gradually. and more or less irregularly, usually being 1 millimeter in a length of from 6 millimeters to 16 millimeters. Surface irregularly marked by annular wrinkles and constrictions arising from what have been the rounded extremity of the tube at different stages of its growth. Some specimens have almost the appearance of worn specimens of Orthoceras, but with the septa convex toward the larger instead of the smaller extremity. No remains of a bivalve shell have ever been observed.

Shell very thin and fragile, elongate, abruptly flattened in front at right angles to the plane of the shell or axis of the tube; umbones small, incurved, and proximate, situated on the anterior angle of the shells; ventral 'margin widely constricted medially; posterior margin well rounded; ligament external and situated well behind the umbones; external sculpture rather obscure, consisting of growth lines parallel to the ventral margin, anterior flattened surface roughened by growth lines; internal characters unknown; valves widely gaping posteriorly.

This species is very rare at Coon Creek and is known from only two very fragmentary tubes, which preserve in an imperfect manner the two inner valves, which were heretofore undescribed. These valves are so extremely fragile that they can not be prepared for fig- uring. This species, or one closely related to it, is very common at Owl Creek, Miss., and specimens from that locality in the U.S. National Museum, which are figured in the plates of this report, also show wellpreserved bivalve shells of the animal that secreted these tubes. This form is related to Gastrochaena whitfieldi Weller, ${ }^{11}$ from the Monmouth group of New Jersey.

Occurrence: Ripley formation, Dave Weeks place on Coon Creek, McNairy County, Tenn.

Collections: Johns Hopkins University, U. S. National Museum.

Outside distribution: Rancocas group (Vincentown sand), New Egypt, N. J. Ripley formation, Mississippi.

\section{Superfamily ADESMACEA}

Family PHOLADIDAE

Genus MARTESIA Leach

Martesia truncata Wade, n: sp.

Plate XXXII, Figures 1, 2

Shell fairly large and very fragile, rather short and broad for the genus; umbones inflated, proximate, and situated well up on the anterior portion of the shell; anterior margin well rounded; posterior dorsal slope straight and steep; posterior margin truncate almost at right angles to the axis of the shell; ventral margin nearly straight; external surface beautifully sculptured on the anterior two-thirds of the shell with numerous concentric lines, which are cut on the medial portion of the shell by a deeply impressed radial sulcus; posterior areal slope smooth, except for faint grow th lines; internal characters of valves unknown; tubes secreted very thin, crooked, and undulating, increasing in size rather rapidly. An imperfect specimen measures in. altitude, 11 millimeters; in latitude, 13 millimeters.

This species is characterized by its short, high form, its beautiful concentric sculpture on the anterior portion of the shell, and the smooth posterior slope area. It is larger than Martesia cretacea Gabb, ${ }^{92}$ from the Matawan group of New Jersey, and has only one radial sulcus, whereas the New Jersey species is characterized by two. The English Upper Greensand species, Martesia constricta (Phillips), ${ }^{93}$ is more elongate and has different external sculptural features. The Coon Creek species, like some of the living species, seems to have been especially adapted to burrowing in logs. Most of the wood fragments observed in the Coon Creek sediments are entirely riddled by this species. Occurrence: Ripley formation, Dave Weeks place on Coon Creek, McNairy County, Tenn.

Collection: U. S. National Museum.

01 Weller, Stuart, New Jersey Geol. Survey, Paleontology, vol. 4, p. 648, pl. 73, figs. 19-12, 1907.

${ }^{22}$ Idem, p. 654, pl. 74, figs. 8-11.

${ }^{93}$ Woods, Henry, A monograph of the Cretaceous Lamellibranchia of England, vol. 2, p. 231, pl. 38, figs. 3-10, Palaeont. Soc. London, 1909. 


\section{Martesia procurva Wade, n. sp.}

Plate XXXII, Figures 3, 4, 10-13

Shell small and fragile; form rather variable, elongate, and bent or curved anteriorly; umbones low and inconspicuous; shape of margins variable, ventral margin usually strongly constricted or incurved; external sculpture variable; extreme anterior and posterior portions of shell smooth, except for growth lines; medial portion of shell generally sculptured with oblique ridges parallel to the anterior margin; radial sculpture on the upper anterior slope of some individuals; ligament internal, seated on a short chondrophore; a long bent rodlike projection or styloid myophore is attached beneath the umbone and projects into the anterior portion of the shell cavity; posterior adductor scar elliptical and elongate, well defined; pallial line obscure. Altitude, 5 millimeters; latitude, 8.2 millimeters.

This species is well characterized by its bent and abnormally developed anterior. The species is doubtfully assigned to Martesia, for some of its characters are those of the Pholadidae and some are those of the Teredinidae. The species burrows into thick-shelled bivalves, such as Veniella, Cucullaea, and Crassatellites, and is very common.

Occurrence: Ripley formation, Dave Weeks placo on Coon Creek, McNairy County, Tenn.

Collection: U. S. National Museum.

\section{Family TEREDINIDAE}

Teredo rectus Wade, n. sp.

Plate XXXIII, Figure 1

Tubes thick and strong, very elongate and cylindrical; generally straight but in some specimens gently curved; apical characters unknown; external surface of tube smooth except for numerous circular incremental lines; surface of anterior portions of tube in some specimens undulating or slightly wrinkled; inner surface smooth; aperture circular, thin and slightly flaring; character of valves of animals secroting tube unknown. Imperfect individual: Length, 80 millimeters; maximum diameter, 6 millimeters; thickness of tube wall, 1.3 millimeters.

Some individuals of this species about 300 to 400 millimeters in length and 12 millimeters in diameter have been observed in the Coon Creek sediments. These very long specimens are usually broken and are not easily collected.

Occurrence: Ripley formation, Dave Weeks place on Coon Creek, McNairy County, Tenn.

Collections: U. S. National Museum, Johns Hopkins University, Vanderbilt University.
Class SCAPHOPODA

Family DENTALIIDAE

Genus DENTALIUM Linné

Dentalium intercalatum Wade, n. sp.

Plate XXXIII, Figures 18, 19

Shell large and strong; in form a very acuminate cone or tusk-shaped, slightly curved; apex very sharp; characters of orifice unknown; external surface ornately sculptured with sharp axial ridges and raised concentric lines; about 13 or 14 primary axial ridges on the apex; on the anterior portion of the shell these become widely spaced, and the interaxial space becomes filled with one to three secondary intercalary lines of variable size and length; raised concentric lines exceedingly numerous and variable in size and spacing; aperture subcircular, its margin sharp and uneven; inner surface of tube near aperture slightly crenulated with short, shallow axial sulci. An imperfect specimen measures in length, 65 millimeters; in maximum diameter, 9.2 millimeters.

This magnificent species is very common at Coon Creek. It is well characterized by its axial and concentric sculpture. The two American species to which this species is most closely related are Dentalium ripleyanum Gabb, ${ }^{94}$ from the Ripley formation at Eufaula, Ala., and Dentalium gracile Meek and Hayden, ${ }^{95}$ from the Montana group of the western interior. Dentalium alternans Müller, ${ }^{90}$ from the Aachen Cretaceous, is another analogous species.

Occurrence: Ripley formation, Dave Weeks place on Coon Creek, McNairy County, Tenn.

Collections: Johns Hopkins University, Vanderbilt University, U. S. National Museum.

\section{Dentalium inornatum Wade, n. sp. \\ Plate XXXIII, Figures 2, 3}

Shell or tube small and fragile, elongate subtubular or subconical, gently curved and flattened along the medial and anterior portions of the tube; apical tip broken away; apertural margin broken away; external surface smooth and glazed; faint irregular growth lines may be observed beneath the glazed surface; internal surface smooth; aperture subelliptical. Slightly imperfect individual, length, 6.2 millimeters; maximum diameter, 1.6 millimeters.

of Gabb, W. M., Descriptions of new species of American Tertiary and Cretaccous fossils: Acad. Nat. Sci. Philadelphia Jour., 2d ser., vol. 4, p. 393, pl. 68, fig. 1i; pl. 69 , fig. 48,1860 .

${ }^{3}$ Meek, F. B., A report on the invertebrate Cretaceous and Tertiary fossils of the upper Missouri country: U. S. Geol. Survey Terr. Rept., vol. 9, p. 266, pl. 18, figs. $13 a-d, 1876$.

${ }^{06}$ Holzapfel, Eduard, Die Mollusken der Aachener Kreide: Palacontographica, Band 34, p. 178, pl. 20, figs. 7, 9, 1888. 
This species is characterized by highly glazed, slightly curved and flattened subconical tubes. It is analogous to the European form from the Aachen Cretaceous described by Holzapfel as Entalis gardneri. ${ }^{97}$ The Tennessee species is perhaps closely related to the smooth form Dentalium pauperculum Meek and Hayden,$^{08}$ from the western interior.

Occurrence: Ripley formation, Dave Weeks place on Coon Creek, McNairy County, Tenn.

Collection: U. S. National Museum.

\section{Dentalium ripleyanum Gabb}

Plate XXXIII, Figures 4, 9

1860. Dentalium ripleyanum. Gabb, Acad. Nat. Sci. Philadelphia Jour., 2d ser., vol. 4, p. 393 , pl. 68 , fig. 17.

Gabb describes this species as follows:

Very slightly arcuate, moderately thick; surface marked by faint longitudinal ribs, especially on the inner side of the curve, and by obsolete lines crossed by circular lines of growth.

Length of fragment, 0.5 inch; greatest external diameter, 0.15 inch.

Type locality: Eufaula, Ala.

This species is very rare at Coon Creek; one or two specimens only have been obtained from that locality. These show a well-defined axial sculpture on the apical end of the tube, but this evanesces anteriorly, and near the aperture the external surface of the tube is smooth.

Occurrence: Ripley formation, Dave Weeks place on Coon Creek, McNairy County, Tenn.

Collections: Philadelphia Academy of Natural Sciences, U. S. National Museum.

Outside distribution: Ripley formation, Eufaula, Ala.

\section{Family SIPHONODENTALIIDAE \\ Genus CADULUS Philippi \\ Cadulus obnutus (Conrad) \\ Plate XXXIII, Figures 7, 8}

1869. Gadus obnutus. Conrad, Am!. Jour. Conchology, vol. 5, p. 101, pl. 9, fig. 18.

1905. Cadulus obnutus. Johnson, Acad. Nat. Sci. Philadelphia Proc., vol. 57, p. 18.

1907. Cadulus obnutus. Weller, New Jersey Geol. Survey, Paleontology, vol. 4, p. 663, pl. 75, figs. 3-4.

1914. Cadulus obnulus. Stephenson, U. S. Geol. Survey Prof. Paper 81, p. 24, tables 2, 8 .

Conrad describes this species as follows:

Slightly curved, gradually tapering above, more suddenly toward the mouth, which is small.

Weller adds the following notes:

Shell small, the length of an average specimen being 4 millimeters and its maximum diameter 1 millimeter; slightly arcuate, contracted at each end, somewhat inflated in the central region. Surface smooth.

\footnotetext{
97 Flolzapfel, Eduard, op. cit., p. 174, pl. 20, fig. 10, 1888

8 Meek, F. B., and Hayden, F. V., Descriptions of new organic remains from the Tertiary, Cretaceous, and Jurassic rocks of Nebraska: Acad. Nat. Sci. Philadelphia Proc. for 1860, p. 78, 1860.
}

The Tennessee specimens referred to this species are a little more inflated medially than the New Jersey specimens. The species is common at Coon Creek and is represented by a number of well-preserved individuals, all of which have both the anterior and posterior extremities of the tube broken away.

Occurrence: Ripley formation, Dave Weeks place on Coon Creek, McNairy County, Tenn.

Collections: Philadelphia Academy of Natural Sciences, New Jersey Geological Survey, U. S. National Museum.

Outside distribution: Matawan group (Woodbury clay), Haddonfield, N. J.

\section{Class GASTROPODA}

\section{Order OPISTHOBRANCHIA}

Suborder TECTIBRANCHIATA

Family ACTEONIDAE

Genus ACTEON Montfort

Acteon linteus (Conrad)

Plate XXXIII, Figures 5, 6

1858. Solidulus linteus. Conrad, Acad. Nat. Sci. Philadelphia Jour., 2d ser., vol. 3, p. 334, pl. 35, fig. 10.

1916. Acteon linteus. Gardner, Maryland Geol. Survey, Upper Cretaceous, p. 397 , pl. 18 , figs. 3,4 .

Conrad describes this species as follows:

Elliptical, with very numerous close revolving lines, most distinct on the inferior half, interstices regularly and elegantly striated transversely. A beautiful species but the specimen much distorted, which I have endeavored in the figure to restore to something of its original shape.

Miss Gardner gives the following details:

Shell ovate to subcylindrical in outline; height of aperture more than one-half the total altitude; whorls five to six in number, minutely tabulated, feebly inflated, increasing in size with a moderate degree of rapidity; external surface sculptured with fine, regularly spaced, squarely channeled linear sulci, seven to eight in number upon the penultima and between 25 and 30 on the body, interareas low and flattened, more than double the width of the sulci; fortuitous secondary spirals developed midway between the primaries on the medial portion of the ultima; sulci microscopically punctated by the incrementals; suture lines distinct; impressed body whorl evenly rounded at the base; aperture rather narrow; outer lip almost vertical, patulous anteriorly; inner lip constricted at the base of the ultima; columella reinforced near its extremity and bearing a single very oblique plication, which almost or quite evanesces before reaching the aperture; parietal wall entirely free from callus.

Dimensions, figured specimen: Altitude, 14 millimeters; maximum diameter, 5.7 millimeters.

The sulci on the anterior part of the ultima of the specimens from Tennessee are more closely spaced than they are in the specimens from Maryland. This species is very rare in Tennessee and is represented in the present collection by a single specimen.

Occurrence: Ripley formation, Dave Weeks place on Coon Creek, McNairy County, Tenn. 
Collections: Maryland Geological Survey, Tennessee Geological Survey, U. S. National Museum.

Outside distribution: Monmouth formation, Brightseat, Prince Georges County, Md. Ripley formation, Owl Creek, Tippah County, Miss.

\section{Acteon substriatus Wade, n. sp.}

Plate XXXIII, Figures 10, 11

Shell large for this genus and ovoid in outline; height of aperture about three-fifths the entire length of the shell; protoconch small and flattened; whorls of spire four, slightly inflated and increasing markedly in size; sculpture finely striated, consisting of irregularly spaced impressed spiral sulci, 25 to 30 in number on body; primary sulci feebly punctate and widely spaced on medial portion of body, interspaces marked by two to four fine shallow sulci; suture line distinctly impressed; aperture rather wide, outer lip rounded and faintly dentate on inner margin, patulous anteriorly; inner lip constricted at base of ultima and reflected anteriorly; columella marked by a single low, wellrounded fold, which evanesces before reaching the aperture; parietal wall washed at the constriction of the inner lip by a thin callus. Elevation, 24 millimeters; maximum diameter, 11.6 millimeters.

This species resembles Acteon cretacea $\mathrm{Gabb}^{90}$ in size and general outline but differs from it in showing well-developed primary and secondary spiral sulci. Acteon substriatus occurs perfectly preserved in the Coon Creek beds but so delicate and fragile is the shell that unbroken specimens of this species have not been recovered from the matrix.

Occurrence: Ripley formation, Dave Weeks place - on Coon Creek, McNairy County, Tenn.

Collection: U. S. National Museum.

\section{Acteon conicus Wade, n. sp.}

Plate XXXIII, Figures 12, 13

Shell of medium size and conical in outline of spire; elevation of spire and length of aperture about equal; protoconch smooth and slightly elevated, coiled one and a half times; whorls of conch three, increasing in size rather markedly, body whorl semicircular in cross section and short for genus; sculpture striate, consisting of squarely channeled, regularly spaced spiral sulci, 16 on the ultima and 6 on the penultima, interareas smooth and a little wider than sulci, which are slightly punctated by feeble elevated lines; suture impressed; aperture wide and semicircular in outline; outer lip broken away in type specimen; external sculpture shows through body wall, forming feeble elevated lines posterior to the margin of the outer lip; inner lip very slightly constricted at base of ultima; columella marked by a prominent sharp fold, which

Gabb, W. M., Description of new species of Cretaceous fossils from New Jersey, Alabama, and Mississippi; Açad. Nat. Sci. Philadelphia Proc. for 1861, p. 318, 1801 . evanesces at the margin of the aperture; parietal wall free from callus. Elevation, 8.4 millimeters; maximum diameter, 4.6 millimeters; length of aperture, 4.2 millimeters.

This form differs greatly from typical species of this genus in possessing a much attenuated spire and a short well-rounded body, yet it has a single columellar plait, and its protoconch is very typical of an Acteon. In general outline it resembles certain species of Tornatella but may be readily distinguished from these by its single columellar fold.

Occurrence: Ripley formation, Dave Weeks place on Coon Creek, McNairy County, Tenn.

Collection: U. S. National Museum.

Acteon ellipticus Wade, n. sp.

Plate XXXIII, Figures 16, 17

Shell of medium size and nearly elliptical in outline; height of aperture more than two-thirds the entire length of the shell; protoconch smooth and flattened; whorls of conch three, nearly involute; body whorl slightly inflated; sculpture ornately striate, consisting of regularly spaced impressed spiral sulci, about 35 on ultima and 4 on penultima; sulci regularly pitted with conspicuous well-rounded depressions, which are separated by sharp partitions, giving each sulcus the appearance of the impression of a small, tightly twisted cord; sulci and interspaces of equal width; sulci slightly crowded and more oblique anteriorly; suture line impressed; aperture narrow; outer lip nearly vertical, patulous anteriorly, constricted at base of ultima; columella marked by a single low, oblique fold, which evanesces before reaching the margin of the aperture; parietal wall free from callus. Elevation, 15.8 millimeters; maximum diameter, 7.5 millimeters; length of aperture, 12.2 millimeters.

This species is characterized by its depressed spire, its subelliptical outline, and its ornately sculptured spiral sulci. In size and general outline it slightly resembles Acteon linteus (Conrad), but it may be readily distinguished from that species by the features mentioned.

Occurrence: Ripley formation, Dave Weeks place on Coon Creek, McNairy County, Tenn.

Collection: U. S. National Museum.

Acteon modicellus Conrad

Plate XXXIII, Figures 14, 15

1860. Actaeon modicellus. Conrad, Acad. Nat. Sci. Philadelphia Jour., 2d ser., vol. 4, p. 287.

Conrad describes the species as follows:

Elliptical, very small, rather thick in substance; revolving lines impressed and striato-punctate; columellar plait obtuse; spire conical.

A very small species, requiring a lens to distinguish its sculpture, 
Shell ovate to subcylindrical in outline; height of aperture two-thirds the length of body; spire broken away from specimens in collection; sculpture ornately striated, consisting of roundly channeled spiral sulci, 16 in number on body whorl; interareas rather high and flattened, little wider than sulci and varying slightly in width on each individual; well-rounded pits formed in sulci by the crossing of fine sharp incrementals, which do not show on interareas; suture line impressed; aperture narrow, acute posteriorly; outer lip slightly rounded, patulous anteriorly; inner lip constricted at base of body; columella marked by a strong, well-rounded plait, which evanesces at the margin of the aperture; parietal wall washed with callus behind columellar plait.

An individual with apex broken away measured in altitude, 3.7 millimeters; in maximum diameter, 2 millimeters.

This species has a type of sculpture like that of Acteon ellipticus, but it has only about half as many sulci on the body whorl and has a more elevated spire. The specimens from Tennessee have not been compared with Conrad's type of this species, so they can not be referred with certainty to Acteon modicellus, as there is no figure of this form, and the original description is very brief.

Occurrence: Ripley formation, Dave Weeks place on Coon Creek, McNairy County, Tenn.

Collection: U. S. National Museum.

Outside distribution: Ripley formation, Owl Creek, -Tippah County, Miss.

\section{Genus Troostella Wade, n. gen.}

Etymology: T'roostella, a name given in honor of Gerard Troost, the first State geologist of Tennessee. Type: Troostella perimpressa Wade.

Shell of medium size and strong; spire elevated and short; protoconch unknown; conch ovoid or olivoid in shape, paucispiral; external surface glazed, marked with sharply impressed spiral lines and faint incremental lines; suture deeply impressed, posterior margin of whorl not adnate to the preceding whorl, thus leaving a narrow groove; aperture subovate; inner surface of labrum smooth; inner lip reflected and excavated; columella marked by one low strong fold; umbilical chink shallow.

This genus is well characterized by a glazed, spirally impressed olivoid shell with a single columellar plait and a deep sutural groove. ' In general aspect this genus resembles the Callianax ${ }^{1}$ section of Olivella, but it does not possess the anterior siphonal notch characteristic of that group. In some respects it suggests certain species of Acteonina D'Orbigny, notably Acteonina obesa Stoliczka, ${ }^{2}$ but that genus has a

1 Cossmann, Maurice, Essais de paléoconchologie comparée, pt. 3, p. 56, pl. 2, fig. 27,1890 .

i Stoliczka, Ferdinand, India Geol. Survey Mem., Palaeontologia Indica, Cretaceous faunas of southern India, vol. 2, p. 412, pl. 28, fig. 31, 1868. smooth columella. Troostella is regarded as probably nearest certain species of Actaeonella D'Orbigny (such as Actaeonella voluta Zekeli), ${ }^{3}$ a group which is profusely developed in the Turonian of Europe.

Troostella perimpressa Wade, n. sp.

Plate XXXIV, Figures 1, 2

Shell of medium size, stout, and brittle; ovoid or olivoid in shape; spire elevated but short; whorls about four, increasing gradually in size; protoconch unknown; exterinal surface glazed and marked with numerous deeply impressed spiral lines, irregularly. spaced, widely separated and few on the medial portion of the shell; incremental lines common near the aperture; suture deeply impressed or characterized by a sutural groove caused by inadnate posterior margin of the whorls; body evenly rounded both anteriorly and posteriorly, rather abruptly constricted at the anterior extremity; aperture rather wide, subovate; inner surface of labrum smooth; inner lip reflected and adnate to the anterior half of the body whorl; parietal wall washed with callus; columella marked by a single oblique low but strong fold; umbilical chink shallow. Altitude, 26 millimeters; maximum diameter, 14 millimeters.

This species is well characterized by irregular and punctured spiral grooves on the external surface, a feature common to other genera of this family. No closely related species of this genus is known.

Occurrence: Ripley formation, Dave Weeks place on Coon Creek, McNairy County, Tenn.

Collection: U. S. National Museum.

\section{Genus TORNATELLAEA Conrad}

Tornatellaea cretacea Wade, n. sp.

Plate XXXIV, Figures 3,4

Shell small, subovate in outline; spire moderately high, its altitude a little more than the entire length of the shell; protoconch small and elevated, coiled twice; whorls of conch three or four, subcylindrical and slightly shouldered; sculpture spirally striate, consisting of feebly punctate, irregularly spaced impressed lines; interspaces wider than sulci, widest on medial and posterior parts of whorls; interspaces at irregular intervals marked by a fine secondary sulcus; primary sulci 21 in number on ultima and 7 on penultima of type; sulci finer and more numerous anteriorly on some individuals; suture impressed; aperture narrow, rounded anteriorly and angular posteriorly; outer lip vertical posteriorly, its margin thin, but thickened and crenulated within, pesterior to the margin; crenulations extend within the body on the wall posterior to the outer lip; inner lip constricted at the base of the ultima; columella marked by two strong, sharp,

3 Zekeli, Friedrich, Die Gasteropoden der Gosaugebilde: K.-k. geol. Reichsanstalt Abh., Band 1, p. 42, pl. 7, figs. 6a-c, 1852. 
: oblique folds; parietal wall free from callus. Elevation, 12 millimeters; maximum diameter, 6.4 millimeters; length of aperture, 7 millimeters.

This species is characterized by the elevated and subcylindrical outline of the whorls. It is represented by a number of specimens from Coon Creek which show some variation in size and relative elevation of spire.

Occurrence: Ripley formation, Dave Weeks place on Coon Creek, McNairy County, Tenn.

Collection: U. S. National Museum.

Tornatellaea globulosa Wade, n. sp.

Plate XXXIV, Figures 5, 6

Shell small, ovate in outline; length of aperture a little greater than the elevation of the spire; protoconch small; slightly elevated and coiled twice; whorls of conch three, slightly inflated, and increasing markedly in size; sculpture spirally striate, consisting of regularly spaced microscopically punctuate sulci, 25 to 30 on ultima and 6 to 8 on penultima; interareas wider than sulci; suture impressed, being deeply furrowed on some individuals; aperture narrow and subovate in outline; outer lip thin and smooth at margin but finely crenulate within body; inner lip constricted at base of body; columella marked by two prominent oblique plaits which are conspicuous at the margin of the aperture; parietal wall free from callus. Elevation, 7.8 millimeters; maximum diameter, 5 millimeters; length of aperture, 5 millimeters.

This species may be separated from Tornatellaea cretacea by its depressed spire, squat outline, and more numerous spirals on the body whorl. Tornatellaea globulosa shows slight variations in height of spire and in number of spirals on body whorl in different individuals. The species Acteon mülleri Bosquet, ${ }^{i}$ from the Aachen Cretaceous of Vaals, Germany, has two columellar folds and probably belongs to the same generic group as the two Tennessee species of Tornatellaea.

Occurrence: Ripley formation, Dave Weeks place on Coon Creek, McNairy County, Tenn.

Collection: U. S. National Museum.

\section{Genus ACTEONINA D'Orbigny \\ Acteonina orientalis Wade, n. sp. \\ Plate XXXIV, Figures 8, 9}

Shell of medium size, slender and spindle-shaped in outline, very thin and fragile; aperture more than two-thirds the length of the body whorl; spire elevated, number of whorls unknown; sculpture spirally striate, consisting of regularly spaced, squarely channeled sulci, between 25 and 30 on the body; interareas low and flattened, more than double the width of the sulci; fortuitous secondary spirals developed midway

4 Holzapfel, Eduard, Die Mollusken der Aachener Kreide: Palaeontographica, Band 34, p. 83, pl. 6, figs. 11a, b, 1888. between the primaries; sulci microscopically punctated by the incrementals; suture impressed; body whorl rounded at base; aperture narrow, acutely angular posteriorly and rounded anteriorly; outer lip nearly vertical; inner lip slightly constricted at the base of the body; columella smooth; parietal wall free from callus. Dimensions of an imperfect specimen: Elevation, 16.1 millimeters; muximum diameter, 7.1 millimeters.

This species is represented in the present collection by two imperfect specimens. Perfect examples have been observed in the Coon Creek beds, and these show a slim, much elevated spire. In sculptural features this species resembles Acteon linteus (Conrad), but it may be readily distinguished from that form by its smooth columella and more elevated spire. Acteonina lineolata Reuss, ${ }^{5}$ from the Aachen Cretaceous of Vaals, Germany, is probably a closely related species but is smaller than the Tennessee species.

Occurrence: Ripley formation, Dave Weeks place on Coon Creek, McNairy County, Tenn.

Collection: U. S. National Museum.

\section{Acteonina parva Wade, n. sp. \\ Plate XXXIV, Figures 7, 12.}

Shell very small and fragile; in outline an elongated oval; height of spire more than half the total altitude; protoconch very small, coiled twice, elevated but flat at the very apex; whorls of conch two, inflated and increasing gradually in size; sculpture microscopic, spirally striate, consisting of about 17 sulci on the ultima and 11 on the penultima, sulci regularly spaced and not deeply impressed, concave in cross section, crossed by faint, regularly occurring incremental elevated lines which form in the spiral furrows regularly spaced shallow pits that give the shells a very delicate but elegant ornamentation; interareas about twice as wide as the sulci; suture impressed; body whorl evenly rounded medially; aperture ovate in outline; outer lip broken away in type; inner lip slightly constricted at the base; columella smooth; parietal wall slightly impressed and free from callus. Elevation, 3.2 millimeters; maximum diameter, 1.5 millimeters.

The fact that this form is so minute and has only two whorls would seem to indicate that it is a young shell, yet its tiny protoconch seems to be in the right proportion for an adult shell, and the whole form presents a certain "finished" appearance that would lead one to believe that the form is grown or at least nearly so. This species is represented in the present collection by a single specimen, and no doubt further collecting will throw more light on this minute shell. The species is well characterized by its delicate yet elegant and regular external sculpture.

${ }^{3}$ Holzapfel, Eduard, op. cit., p. 78, pl. 6, figs. 17a, b. 
Occurrence: Ripley formation, Dave Weeks place on Coon Creek, McNairy County, Tenn. Collection: U. S. National Museum.

\section{Family RINGICULIDAE Genus RINGICULA Deshayes}

Ringicula pulchella Shumard

Plate XXXIV, Figures 10, 11

1862. Ringicula pulchella. Shumard, Boston Soc. Nat. Hist. Proc., vol. 8, p. 192.

1914. Ringicula pulchella. Stephenson, U. S. Geol. Survey Prof. Paper 81, check list, tables 2 and 8.

Shell small, ovate in outline; spire elevated and acute, its altitude about one-third that of the entire shell; whorls four in number and increasing gradually in size, whorls biconvex in profile; protoconch very imall and coiled one and a half times, the most posterior tip slightly heterostrophous; sculpture punctostriate, consisting of 16 regularly spaced impressed spiral sulci on the body whorl and 6 on the penultima, interspaces smooth and flat, a little wider than the spiral sulci; suture impressed; body inflated, convex, and abruptly constricted at the base; aperture more than two-thirds as high as the entire shell, broader and somewhat patulous anteriorly; aperture strongly varicose, the varix extending backward beyond the posterior suture of the body whorl; dorsal side of varicose outer lip reticulated by impressed incremental and spiral lines; ventral margin of the outer lip marked by numerous fine denticles; inner lip strongly constricted at base of the body, excavated and thickened near the anterior extremity; inner lip heavily calloused and bearing three conspicuous plications, the anterior one very oblique, the middle one bifurcated on the inner lip, and the posterior one bent and rumning backward in a crooked course on the calloused inner lip; base strongly emarginate. Altitude, 7.4 millimeters; maximum diameter, 5.2 millimeters.

Only one example of this elegant.little form is present in this collection, and it is perfectly preserved in every detail. The species is well characterized by its outer lip, which is dentate in front and reticulated behind, and further by the three strong plications on the innor lip, the anterior extremities of the posterior plications being oddly modified.

Occurrence: Ripley formation, Dave Weeks place on Coon Creek, McNairy County, Tenn.

Collections: U. S. National Museum, Johns Hopkins University.

Outside distribution: Ripley formation, Tippah and Union counties, Miss.; Chatfield, Tex.

\section{Genus CINULIA Gray}

Cinulia paraquensis Wade, n. sp.

Plate XXXIV, Figures 21, 22

Shell small and fragile; globose or subovoid in outline; spire short; protoconch small; whorls of conch about four, increasing in size rather markedly; sculpture spirally grooved, grooves sculptured in a beautiful zigzag pattern; body whorl inflated and rounded; suture impressed; aperture broad and subovate, indented at the anterior extremity of the columella by a shallow anterior siphonal notch; outer lip broken away in the type; inner lip excavated; columella flexed or arched, marked by two oblique folds. Altitude, 3.8 millimeters; maximum diameter, 2.4 millimeters.

This species is well characterized by beautifully sculptured regular zigzag spiral grooves. It is much smaller but is perhaps related to Cinulia aquensis Holzapfel, ${ }^{6}$ from the Aachen Cretaceous of Vaals, Germany.

Occurrence: Ripley formation, Dave Weeks place on Coon Creek, McNairy County, 'Tenn.

Collection: U. S. National Museum.

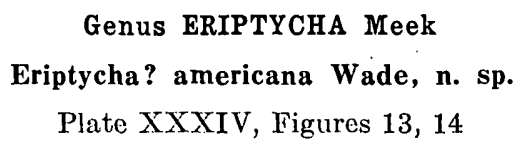

Shell very small and subglobose, height of spire less than half the length of the aperture; whorls of conch one and a half, increasing abruptly in size; protoconch very small and nearly involved by the first whorl of the conch, protoconch coiled twice, the axis of first whorl slightly oblique to axis of second whorl and volutions of the conch; sculpture striate, consisting of about 18 spirally impressed sulci on the body, sulci microscopically punctate; interareas flat and smooth, of nearly equal width, widest on the medial part of the body; suture faintly impressed; body inflated and evenly rounded both anteriorly and posteriorly; aperture subcrescent in shape, wide and rounded anteriorly; outer lip well rounded, patulous anteriorly and varicose, varix produced backward to suture line, inner margin of outer lip sharply crenate; inner lip constricted at the base of the body; columella marked by a strong sharp fold just behind the anterior commissure, and behind the strong plait are two weaker plications; parietal wash heavy, forming a marginal ridge on the body parallel to the inner lip. Altitude, 3.8 millimeters; maximum diameter, 2.9 millimeters.

This elegant little species is represented in the Coon Creek collection by several perfectly preserved individuals. So fär as known it is the first form from North America that has been referred to this genus. Three species have been described from the Cretaceous of southern India and two from Europe. Of the described species the nearest to the American form is probably Eriptycha decurtata $\left(\right.$ Sowerby $\left.^{7}\right)$, which is the type of the genus and occurs in the Gosau beds of Austria. Another species of this genus, which has.

${ }^{6}$ Holzapfel, Eduard, op. cit., p. 85, pl. 7, fig. 17.

7 Zekeli, Friedrich, Dio Gasteropoden der Gosaugebilde: K.-k. geol. Reichsanstalt $A$ bh., Band 1, p. 45, pl. 8, figs. 1, 3, 1852. Meek, F. B., A report on the invertebrate Cretaceous and Tertiary fossils of the upper Missouri country: U. S. G eol. Survey Terr. Rept., vol. 9, p. 283, 1876. 
been described as Eriptycha perampla by Henry Woods, ${ }^{8}$ occurs in the Senonian beds of Pondoland, South Africa. The depressed spire and general aspect of Eriptycha? americana suggest the group of Oligoptycha Meek, of which Cinulia (Oligoptycha) concinna Hall and Meek is the type. ${ }^{9}$ The typical Oligoptycha, however, has only one columellar fold instead of three, as in the species from Tennessee under discussion.

In generic characters the species from 'Tennessee do not agree with either Eriptycha or Avellana, but until the group has received further study the species above described is assigned tentatively to Meek's genus Eriptycha.

Occurrence: Ripley formation, Dave Weeks place on Coon Creek, McNairy County, Tenn.

Collection: U. S. National Museum.

\section{Family ACTEOCINIDAE}

Genus GONIOCYLICHNA Wade, n. gen.

Etymology: $\gamma \omega \nu i \alpha$, angle, and Cylichna Lovén, a genus of univalves. Type: Goniocylichna bisculpturata Wade, n. gen. and sp.

Shell small, form subcylindrical; spire very low, rising only slightly above the plane of the body whorl; protoconch very small; sculpture axial on the posterior margin of the whorl and spiral on the anterior portion of the whorl; suture characterized by a distinct spiral shelf, caused by the abrupt truncation of the posterior margin of the whorls, thus giving a stair-step pattern to the slope of the spire; body rounded anteriorly and abruptly angular posteriorly; aperture wide in front and narrow behind; outer lip thin and smooth; inner lip excavated; columella smooth.

This generic group is here proposed to include three known species-the type, from the Ripley formation of Tennessee; second, Trochacteon semicostatus Whiteaves, ${ }^{10}$ from the Upper Cretaceous of Vancouver Island; third, Cylichna griesbachi Etheridge, ${ }^{11}$ from the Upper Cretaceous of Natal, East Africa. The genus is well characterized by its abruptly truncate posterior extremity and its dual type of sculpture. It is somewhat similar to Goniocylindrites $\mathrm{Meek}^{12}$ or Retusa Brown. ${ }^{13}$ The spire of Goniocylichna Wade is intermediate in form between those of Goniocylindrites Meek and Conactaeon Meek. ${ }^{14}$

8 Woods, Henry, The Cretaceous fauna of Pondoland: South African Mus. Annals, vol. 4, pt. 7, p. 329, pl. 41, fig. 2, 1906 .

- Meek, F. B., op. cit.; p. 284, pl. 11, figs. 6 bis, a, b, c, 1876.

10 Whiteaves, J. F., Mesozoic fossils, vol. 1, p. 354, pl. 44, fig. 5, Canada Geol Survey, 1876.

11 Etheridge, Robert, Cretaceous fossils of Natal: Natal and Zululand Geol Survey Second Rept., p. 86, pl. 3, figs. 14, 15, 1904.

${ }_{12}$ Meek, F. B., Remarks on the family Actaeonidae, with descriptions of some new genera and subgenera: Am. Jour. Sci., 2d ser., vol.35, p. 91, 1863. Cossmann,

Maurice, Essais de paléoconchologie comparée, pt. 1, p. 65, pl. 2, figs. 2, 3, 1893

13 Cossmann, Maurice, op. cit., pt. 1, p. 82, pl. 3, flgs. 24-25.

14 Meek, F. B., op. cit., p. 87 . Cossmann, Maurice, op. cit., pt. 1, p. 63, pl. 2, figs, 5,6 .
Goniocylichna bisculpturata Wade, n. sp.

Plate XXXIV, Figures 15, 16

Shell small and fragile; subcylindrical in outline; spire very low with a stair-step type of slope; protoconch very small and indistinct on the type; sculpture of two patterns, consisting of a short, sharply impressed axial line along the posterior margin of the whorls and spirally impressed lines on the remainder of the whorl; suture broadly channeled; body cylindrical, almost including previous whorls, truncate behind and rounded in front; aperture broad in front, narrow behind; outer lip thin and smooth, patulous in front; inner lip excavated and reflected; columella smooth or gently twisted. Altitude, 4.4 millimeters; maximum diameter, 2.5 millimeters.

Occurrence: Ripley formation, Dave Weeks place on Coon Creek, McNairy County, Tenn.

Collection: U. S. National Museum.

\section{Family SCAPHANDRIDAE}

\section{Genus CYLICHNA Lovén}

Cylichna recta (Gabb)

Plate XXXIV, Figures 18-20

1860. Bulla recta. Gabb, Acad. Nat. Sci. Philadelphia Jour. 2d ser., vol. 4, p. 302, pl. 48, fig. 16.

1864. Cylichna recta. Meek, Check list of the invertebrate fossils of North America, Cretaceous and Jurassic, p. 16.

1892. Cylichna recta. Whitfield, U. S. Geol. Survey Mon. 18, p. 164 , pl. 20 , figs. 10,11 . (Also published by New Jersey Geol. Survey.)

1905. Cylichna recta. Johnson, Acad. Nat. Sci. Philadelphia Proc., vol. 57, p. 19.

1907. Cylichna recta. Weller, New Jersey Geol. Survey, Paleontology, vol. 4, p. 814, pl. 99, figs. 17, 18.

1916. Cylichna recta. Gardner, Maryland Geol. Survey, Upper Cretaceous, p. 411, pl. 18, figs. 10, 11 .

Gabb describes this species as follows:

Shell small, subcylindrical; spirc very much depressed; mouth nearly straight and narrow. A cast.

Miss Gardner adds the following details:

Shell small, involute, subcylindrical in outline; aperture more produced than the body whorl both posteriorly and antcriorly; external sculpture smooth medially, sculptured with finely incised lines upon the anterior third and the posterior fourth; the posterior spirals, numbering only about half a dozen, are more distantly spaced than the 12 or 15 anterior spirals; aperture narrow, expanding slightly in front and somewhat patulous; outer lip thin, sharp, approximately vertical, and parallel to the body wall; columella reinforced and slightly reversed at the base of the body; parietal wall entirely free from callous.e

This small species is exceedingly rare in Maryland.

This species is represented in the Coon Creek collection by a single specimen, which is much smaller than the figured specimen from Maryland and shows spiral sculpture over the entire length of the body. 
The Tennessee example is considered a young individual of Cylichna recta, yét further collecting at Coon Creek may show that it belongs to another species.

Occurrence: Ripley formation, Dave Weeks place on Coon Creek, McNairy County, Tenn.

Collections: Maryland Geological Survey, Philadelphia Academy of Natural Sciences, New Jersey Geological Survey, Johns Hopkins University.

Outside distribution: Matawan group (Wenonah sand), New Jersey. Monmouth formation, Brightseat, Prince Georges County, Md. Ripley formation, Owl Creek, Tippah County, Miss.

\section{Genus SCAPHANDER Montfort}

Scaphander rarus Wade, n. sp.

Plate XXXIV, Figures 25, 26

Shell small and very fragile; cylindrical or ovoid in outline; spire perforate at the summit; body whorl covering all the others; external surface spirally channeled; spiral ridges flat and of unequal width, spiral channels roughened or punctate, a thin layer of epidermal matter on the posterior extremity; aperture narrow, outer margin lower than the axis of the shell; outer lip thin and spatulose; inner lip reflected; columella gently flexed; umbilical chink small. Altitude, 4.6 millimeters; maximum diameter, 1.6 millimeters.

This species is of special interest, as this genus is so little known in the Cretaceous. The genus is well represented in the Tertiary. There are several species of this genus in the Eocene of the southern United States. Scaphander rarus is somewhat similar to Scaphander alabamensis Aldrich, ${ }^{15}$ from the Eocene at Greggs Landing, Ala. It is quite probable that Cylichna? volvaria Meek and Hayden, ${ }^{16}$ from the Fox Hills sandstone of the western interior, is a species of Scaphander and related to the Tennessee species above described.

Occurrence: Ripley formation, Dave Weeks place on Coon Creek, McNairy County, Tenn.

Collection: U. S. National Museum.

Order CTENOBRANCHIA
Superfamily TOXOGLOSSA
Family CONIDAE
Genus CONORBIS Swainson
Conorbis mcnairyensis Wade
Plate XXXIV, Figures 23,24

1917. Conorbis mcnairyensis. Wade, Acad. Nat. Sci. Philadelphia Proc., vol. 69, p. 280, pl. 17, figs. 1, 2.

1918. Conorbis menairyensis. Cossman, Rev. critique paléozoologie, année 22, Nos. 1-2, p. 20.

\footnotetext{
16 Aldrich, T. E., New or little known Tertiary Mollusca from Alabama and Texas: Bull. Am. Paleontology, vol. 1, No. 2, p. 6, pl. 2, fig. 2, 1895.

10 Meek, F. B., A report on the invertebrate Cretaceous and Tertiary fossils of tho upper Missouri country: U. S. Geol. Survey Terr. Rept., vol. 9, p. 275, pl. 31, flgs. $2 \mathrm{a}, \mathrm{b}, 1876$.
}

Shell very small and biconic in outline; spire elevated, its altitude equal to about half that of the entire shell; whorls abruptly shouldered or strongly tabulated, the maximum diameter falling in front of the median horizontal; volutions closely appressed and increasing gradually in size, probably four in a perfect individual; sculpture subdued and irregular; welldefined axial costae not developed; spirals low and crowded; about 6 in number on the penultima and more than 16 on the ultima, spirals crossed by numerous irregular, sharply incised incremental lines, which give the surface of the shell a subcancellate aspect; suture impressed; body shouldered posteriorly and sloping gently and evenly in front; aperture narrow; margin of outer lip broken away; inner lip concave medially; columella slightly flexed near the anterior extremity; umbilicus indicated by a narrow depression along the outer margin of the reflected inner lip. Altitude, 4.3 millimeters; maximum diameter, 2.5 millimeters.

This form is represented by a single specimen. The species has been referred to the genus Conorbis, since it shows all the generic features revealed in the type of the genus, Conus dormitor (Sowerby), ${ }^{17}$ from the Eocene of western Europe. The Tennessee form is probably the first typical Conorbis to be reported from the Upper Cretaceous. An imperfect individual from the Senonian of Rio Piabas, Brazil, has been described under the name Conorbis restitutus, ${ }^{18}$ but the correctness of this generic determination has been questioned by Cossmann. ${ }^{19}$

Occurrence: Ripley formation, Dave Weeks place on Coon Creek, McNairy County, Tenn.

Collections: Johns Hopkins University, U. S. National Museum.

\section{Family CANCELLARIIDAE \\ Genus PALADMETE Gardner \\ Paladmete cancellaria (Conrad) \\ Plate XXXV, Figures 1, 2}

1858. Trichotropis cancellaria. Conrad, Acad. Nat. Sci. Philadelphia Jour., 2d ser., vol. 3, p. 333, pl. 35, fig. 8 .

1916. Paladmete cancellaria. Gardner, Maryland Geol. Survey, Upper Cretaceous, p. 413, pl. 18, figs. 14, 15.

Conrad describes this species as follows:

Acutely subovate; volutions five; spire subscalariform; body whorl ventricose; longitudinal ribs narrow, prominent, distant; revolving lines prominent, distant, with an occasional minute intermediate line; columella profoundly incurved; labium reflected; base subumbilicated; shoulder of body volution with minute revolving lines, and one larger than the others.

Miss Gardner adds the following details:

Shell small, nassoid in outline, spire a little higher than the aperture; whorls seven in number, the earlier turns increasing

${ }_{17}$ Cossmann, Maurice, Essais de paléoconchologie comparée, pt. 2, p. 149, pl. 8 , figs. 16, 18, 1896.

18 White, C. A., Contribuições á paleontologia do Brazil: Mus. nac. Rio de Janeiro Archivos, vol. 7, p. 119, pl. 10, figs. 4, 5, 1888. (Portuguese and English.) 10 Cossmann, Maurice, op. cit., p. 150. 
regularly in size, broadly convex, the later tabulated posteriorly; nuclear turns approximately three in number, the initial whorl and a half very small and largely immersed in the succeeding volution, the final nuclear turn relatively elevated and broadly convex; external surface cancellated, axial sculpture of about 15 narrow, rounded, sharply pinched costals, separated by wider concave intercostals; axials tending to become irregular and to evanesce upon the final half turn and upon the base of the pillar; axials overridden by narrow, flattened, equisized and equispaced spiral fillets, uniform in character upon the costal and intercostal areas, separated by channeled interspaces, slightly wider than the spirals; primaries four in number upon the penultima and five or six on the ultima; two or three secondaries developed upon the shoulder and three or four at the base of the body; body whorl evenly rounded anteriorly; aperture holostomous, ovate to lenticular, outer lip thin, simple, broadly arcuate; inner lip excavated at the base; aperture constricted at its anterior extremity to form an incipient canal; parietal wall calloused; umbilicus closed by the reverted labium; area directly behind it feebly depressed.

Conrad's description implies a perforate shell, but there has been not even a chink of an umbilical opening in any of the numerous individuals examined from the Gulf as well as from Maryland.

Paladmete cancellaria is widely distributed through the Monmouth of the Gulf and the Middle Atlantic coast.

This species is common in the Coon Creek beds and is represented in the Tennessee collection by a number of perfectly preserved specimens.

Occurrence: Ripley formation, Dave Weeks place on Coon Creek, McNairy County, Tenn.

Collections: U. S. National Museum, Maryland Geological Survey, Vanderbilt University.

Outside distribution: Ripley formation, Union and Tippah counties, Miss. Monmouth formation, Anne Arundel and Prince Georges counties, Md.

\section{Paladmete gardnerae Wade, n. sp.}

\section{Plate XXXV, Figures 3, 6}

Shell small, acutely subovate in outline, length of aperture greater than height of spire; whorls of conch three or four, increasing rather markedly in size; protoconch small and smooth, naticoid in outline, and coiled two and a half times; sculpture elaborate, dominately axial; costae elevated, irregularly spaced and curved, evanescent anteriorly, 16 to 21 in number on body whorl; 3 to 8 of these costae fortuitously much enlarged, greatly resembling varices if not true varices; spiral lines crowded, sharply impressed, irregularly spaced, more than 30 upon ultima, secondary intermediate spirals near aperture, spirals overriding axial sculpture; suture impressed; body whorl subtrapezoidal in outline; aperture wide, subovate, being angular at the anterior commissure, forming an incipient canal; outer lip broadly arcuate, thin and simple at margin but some distance within body commonly marked by a row of low denticles; inner lip excavated at the base; columella smooth; parietal wall washed with callus. Altitude, 13.3 millimeters; maximum diameter, 9.8 millimeters; length of aperture, 7.6 millimeters.

This species is characterized by its stout form and subovate outline and further by its crowded spirals and fortuitous varicose costae. Like Paladmete cancellaria it is very common in the Coon Creek beds but may be readily distinguished from that species.

The specific name is given in honor of Miss Julia A. Gardner, the author of the genus.

Occurrence: Ripley formation, Dave Weeks place on Coon Creek, McNairy County, Tenn.

Collection: U. S. National Museum.

\section{Paladmete densata Wade, n. sp.}

Plate XXXV, Figures 7, 8

Shell small and thin, nassoid in outline; length of aperture a little longer than the length of the spire; whorls two or three, increasing markedly in size, subrectangular in outline; protoconch small and smooth, elevated but early two turns nearly immersed in the succeeding volution; sculpture cancellate, with axials predominating; 12 costals on ultima, elevated and rounded, unequal in size, separated by deep concave intercostals of unequal width, intercostals wider than costals, all axial sculpture evanescing on the very anterior part of the ultima; axial sculpture overridden by primary and secondary spiral fillets; primary fillets equisized and equispaced, eight primaries on ultima and three on penultima; seven or eight secondary fillets on shoulder and two to six in interspaces on body; suture slightly impressed; body whorl squarely shouldered and abruptly constricted posteriorly; aperture holostomous, ovate; outer lip arcuate, thin and simple at margin but thickened within by a row of low crowded denticles, which may occur some distance within the body cavity on the inner wall of the ultima; inner lip excavated at the base; columella smooth; parietal wall calloused. Altitude, 7.9 millimeters; maximum diameter, 5.3 millimeters; length of aperture, 4.1 millimeters.

This species in general features resembles Paladmete cancellaria (Conrad), but Paladmete cancellaria contains no denticles in the margin of the outer lip or within the body cavity on the inner wall of the ultima and is not marked by spiral sculpture that corresponds specifically with Paladmete densata.

Occurrence: Ripley formation, Dave Weeks place on Coon Creek, McNairy County, Tenn.

Collection: U. S. National Museum.

\section{Genus CANCELLARIA Lamarck}

\section{Cancellaria acuta Wade, n. sp.} Plate XXXV, Figures 4, 5

Shell small and elongate, fusiform in outline; spire acuminate, its height one and a half times as 
great as the aperture; whorls four, convex, increasing gradually in size; protoconch small and smooth, naticoid, and coiled two and a half times; sculpture subcancellate, the spiral element predominating; lirae regularly spaced and crowded, 15 to 18 on ultima and 6 or 7 on penultima; interspaces squarely channeled and deep; axial lines sharply elevated, overriding spirals and forming at this intersection sharp elevations, which give the shell a finely tuberculate surface; axials regularly spaced on spire but becoming distant and irregular on the body and especially near the aperture; three or four of the axials greatly enlarged and resembling varices, if not true varices; suture impressed; body whorl convex, being smoothly rounded or slightly constricted anteriorly into a very short anterior canal; aperture subovate, being produced anteriorly into a short open canal; outer lip evenly rounded and thickened within, where it is marked by a row of 12 or 13 denticles; inner lip thinly calloused but not covering the spirals; which appear within the aperture on the columella; columella marked by two sharp oblique plaits; parietal wall washed with callous. Altitude, 15.5 millimeters; length of spire, 9.2 millimeters; maximum diameter, 7.4 millimeters.

This elegant little shell is well characterized by its ornate sculpture and high spire. The species Cancellaria cingulata Kaunhowen, ${ }^{20}$ which has been described from the Maestrichtian of Belgium, seems to be related to the species from Tennessee but not closely. The European form has a shorter spire and a longer aperture. The species from New Jersey, Cancellaria subalta Conrad, ${ }^{21}$ is very near Cancellaria acuta, but the axial grooves of the former are deeper, making its sculpture coarser and more strongly reticulate.

Occurrence: Ripley formation, Dave Weeks place on Coon Creek, McNairy County, Tenn.

Collection: U. S. National Museum.

\section{Genus MataXA Wade}

1916. Mataxa. Wade, Acad. Nat. Sci. Philadelphia Proc., vol. 68, p. 455. Etymology: $\mu a ́ \tau a \xi a$, cocoon. Type: Mataxa elegans Wade.

Shell of medium size and thickness; spire obtuse, its altitude less than half the entire length of the shell; protoconch large and smoothly polished, the earliest volutions for the most part submerged and increasing rapidly in size, thrice-coiled in the type species; conch solid and slightly glazed, paucispiral; external sculpture subdued; axial sculpture subdued or absent; aperture broadly lenticular and produced anteriorly in a comparatively long recurved canal; outer lip expanded and dentate internally; parietal wall

${ }^{90}$ Kuunhowen, Friedrich, Die Gastropoden der Maestrichter Kreide: Palaeont. Abh. (Dames \& Koken), Band 8 (neue Folge, Band 4, Heft 1), p. 96, pl. 13, fig. 3, 1897.

${ }^{21}$ Conrnd, T. A., Descriptions of now fossil Mollusca, principally Cretaceous: Am. Jour. Conchology, vol. 5, p. 100, pl. 9, fig. 22, 1869. widely and heavily glazed; columella marked by two strong oblique plaits situated far in and behind two or more marginal plaits.

This genus is proposed for a species represented at Coon Creek by perfectly preserved elegant shells and a species, Narona eximia, which was described" and figured by Stoliczka ${ }^{22}$ in 1867 from southern India and referred to the Cancellariidae. It differs from Cancellaria, in general, by the development of a welldefined canal, by its lack of sharp and conspicuous cancellate sculpture, and further by its less acuminate spire. It differs from Narona, a subgenus of Cancellaria, in having a longer canal, a spire less acutely elevated, and an anterior columellar plait more elevated than the posterior instead of less so. Probably Mataxa is nearer the rare recent subgenus $M a s s y l a^{23}$ than any other form in the genus Cancellaria, but in this comparison, too, there are generic and time differences so great that it seems advisable to assign the forms from Tennessee and southern India to a new genus. Mataxa differs from Massyla in possessing a thicker. stouter, and more solidly built shell, in having a comparatively long recurved canal, and further in nuclear characters. The protoconch of Masslya is trochoid, whereas in the nucleus of Mataxa the early volutions are for the most part submerged.

\section{Mataxa elegans Wade}

Plate XXXV, Figures 9, 10

1516. Mataxa elegans. Wáde, Acad. Nat. Sci. Philadelphia Proc., vol. 68, p. 456, pl. 23, figs. 1, 2, 3 .

1917. Mataxa elegans. Cossmann, Rev. critique paléozoologie, année 20, No. 3, p. 99.

Shell of medium size, ovate in outline; spire less than half the entire length of the shell; whorls of conch, three and a half; protoconch large, smooth, and obtuse, thrice coiled, the first and second volutions for the most part immersed and coiled in a single plane, the final whorl of the protoconch moderately elevated, increasing markedly in size; surface of conch slightly glazed and inconspicuously sculptured; axials reduced to fine incrementals and one or two exaggerated resting stages; spiral sculpture consists of low, broad, flattened bands, eight in number on the penultima of the type, the two posterior the widest and separated from one another by a wide and rather deep sulcus; body spirals very obscure, increasingly so toward the aperture, more than 30 in number interspaces wider than the spirals and very shallow, excepting directly in front of the suture; suture impressed; aperture more than half the entire length of the shell, lenticular in outline, and produced anteriorly into a comparatively long canal; outer lip marked internally by 10 or 12 regularly spaced lirate

${ }^{22}$ Stoliczka, Ferdinand, India Geol. Survey Mem., Palaeontologia Indica, Cretaceous fauna of southern India, p. 166, pl. 12, 1867.

${ }^{23}$ Adams, H. and A., Genera of Recent Mollusca, vol. 1, p. 278, 1855. 
denticles; columella reinforced with two rather strong oblique folds a little less than halfway between the base of the body and the anterior extremity of the aperture and a less prominent marginal fold and occasionally a fourth feeble plication behind the margin; anterior fasciole rather short, moderately wide, emarginate at the extremity. Altitude, 23.4 millimeters; maximum diameter, 13 millimeters; spiral angle, $57^{\circ}$.

This form is well characterized by its somewhat buccinoid outline and rather low, obtuse spire, subdued spiral sculpture, the slightly flaring outer lip, and the plicate inner lip. This species is represented in the Coon Creek collection by two perfect specimens, which are in a remarkable state of preservation for shells as old as the Cretaceous. The individuals possess a certain freshness of appearance and shell color that remind one of recent gastropods lately recovered from the water.

Occurrence: Ripley formation, Dave Weeks place on Coon Creek, McNairy County, Tenn.

Collection: John Hopkins University, Vanderbilt University, U. S. National Museum.

\section{Family TURRITIDAE}

Genus TURRIS Bolten

\section{Turris proxima Wade, n. sp.}

Plate XXXV, Figures 11, 12

Shell large and fusiform in outline; elevation of spire equal in length to aperture with its produced anterior canal; whorls of conch seven to nine; flatly convex in outline and increasing gradually in size; apex broken away in all available specimens and apical characters unknown; sculpture dominantly axial; costae well rounded and elevated, irregularly spaced, 16 to 18 on the ultima, undulating posteriorly, where they parallel the margin of the aperture, but evanescing anteriorly; spiral sculpture conspicuous on the anterior slope of the body but becoming less prominent on the anterior canal and the posterior parts of the volutions; whorls of spire marked by four equispaced low spiral fillets, which override the costals on the posterior whorls but become faint and inconspicuous on the body; anterior slope of body free from axials but marked by eight strong, widely and irregularly spaced subangular lirae, which grade anteriorly into a series of low, crowded lirae on the anterior canal, the latter series evanescing on the anterior portion of the anterior canal; siphonal fasciole narrow and marked by irregularly occurring nodes, more numerous than the costae; fasciole bordered anteriorly by a narrow, slightly concave sulcus; suture impressed; body whorl slightly inflated and abruptly constricted anteriorly, produced into a long, slightly curved anterior canal; aperture lenticular and produced anteriorly into a long, narrow canal; outer lip marked both in front and behind by broad sinuses, the posterior siphonal sinus the deeper and occurring on the shoulder of the whorl in front of the fasciolar area; anterior sinus angular, occurring near the middle of the anterior slope of the body whorl; inner lip excavated; columella smooth but slightly enlarged at the base of the body; parietal wall glazed and in some specimens bearing an obscure tooth directly in front of the posterior commissure; callus thickened on medial portion of pillar, where it forms an axial furrow with the pillar; canal very long and narrow, slightly bent in some forms. A slightly imperfect individual measures in altitude, 88. millimeters; in maximum diameter, 26.5 millimeters.

This species is represented in the present collection by a number of well-preserved specimens, which are probably very closely related to Turris tippana (Conrad), ${ }^{24}$ from Owl Creek, though they differ in the character of the external sculpture. The axial costae in the Coon Creek species are coarser and less numerous. The Coon Creek species also has a much greater range in size.

Occurrence: Ripley formation, Dave Weeks place on Coon Creek, McNairy County, Tenn.

Collection: U. S. National Museum.

$$
\begin{aligned}
& \text { Turris constricta Wade, n. sp. } \\
& \text { Plate XXXVI, Figures 5, } 10
\end{aligned}
$$

Shell of medium size and fusiform in outline; spire elevated, its altitude less than half the entire length of the shell; apical angle lower on the posterior part of the spire, becoming slightly higher on the younger whorls; whorls of conch seven or eight, closely appressed; apex broken away and characters of protoconch unknown; sculpture both axial and spiral, the former dominant; axial costae rounded and strongly elevated, 14 to 17 on body; costae flexuous, uniform in strength from the posterior fasciole to the anterior suture and a little less than halfway down to the base of the ultima; spiral sculpture on the posterior whorls consists of four low, equispaced fillets, which override the axial costae; anterior slope of body whorl and posterior end of the anterior canal marked by five or six widely and irregularly spaced, abruptly elevated, narrow spiral lirae, which disappear on the anterior half of the anterior canal; siphonal fasciole narrow and marked by irregularly occurring nodules more numerous than the costae; fasciole bordered anteriorly by a narrow spiral sulcus; suture impressed; body whorl abruptly constricted at the base of the body, especially near aperture, where the line of demarcation between the body and anterior canal is well defined, aperture lenticular, produced anteriorly into

${ }^{24}$ Conrad, T. A., Observations on a group of Cretaceous fossil shells found in Tippah County, Miss.: Acad. Nat. Sci. Philadelphia Jour., 2d ser., vol. 3, p. 331, p. 35, lfig. 5, 1858. 
a long, narrow, practically straight anterior canal; outer lip marked anteriorly and posteriorly by broad sinuses, the posterior siphonal sinus the deeper and occurring at the constriction at the base of the body; columella smooth but slightly enlarged at the base of the body; parietal wall glazed and sometimes bearing an obscure tooth directly in front of the posterior commissure; anterior canal long and practically straight. Altitude, 62 millimeters; length of aperture and canal, 19.4 millimeters.

Occurrence: Ripley formation, Dave Weeks place on Coon Creek, McNairy County, Tenn.

Collection: U. S. National Museum.

\section{Genus TURRICULA Schumacher}

Turricula ripleyana (Conrad)

Plate XXXVI, Figures 6, 7 .

1859. Turris ripleyana. Conrad, Acad. Nat. Sci. Philadelphia Jour., 2d ser., vol. 3, p. 332, pl. 35, figs. 21, 29(?).

Conrad describes this species as follows:

Elongated, slender; spire subequal in length to body volution and beak; volutions ribbed longitudinally; ribs slight and somewhat curved about where they are interrupted by a deep revolving furrow, which causes the appearance of a prominent line bordering the suture; surface of shell with revolving lines distinct on the body whorl and beak.

Shell of medium size and slender, fusiform in outline; whorls broadly convex, closely appressed and increasing gradually in size, more than six; apex broken away and character of protoconch unknown; sculpture both axial and spiral, the former dominating; axial costae strong, well rounded, and elevated, ten on body, interaxial spaces broadly concave and wider than the axial elevations, all axial sculpture evanescing at the base of the body; spirals well defined and crowded, equally developed on crest of costae as in axial furrows; 19 or 20 spirals on the body and 5 or 6 on whorls of the spire; lirae somewhat rectangular and separated by deep, squarely channeled sulci, which are narrower than the lirae posteriorly but become wider at the base of the body; a few of the lirae are tortuitously bifid by a fine secondary spiral sulcus; siphonal fasciole narrow, slightly undulated, the increments of the siphonal notch showing faintly near aperture; fasciolar area marked by 10 or 12 sharp, fine secondary spiral lines; suture impressed; body whorl abruptly shouldered posteriorly and gently constricted anteriorly into a long anterior canal; aperture rather narrow and lenticular, produced anteriorly into a long canal; outer lip broadly arcuate; inner lip smooth and excavated at the base of the body; columella smooth and slightly enlarged at the base of the body; parietal we!l evenly washed with callus; anterior canal of medium length and straight.
This species is characterized by its strong spiral sculpture and further by its unnodulated posterior fasciole, which is marked by numerous sharply impressed spiral lines.

Occurrence: Ripley formation, Dave Weeks place on Coon Creek, NcMairy County, Tenn.

Collection: U. S. National Museum.

Outside distribution: Ripley formation, Owl Creek, Tippah County, Miss.

\section{Turricula gracilis Wade, n. sp.}

Plate XXXVI, Figures 11, 12

Shell large and fusiform in outline, both spire and beak much elongated; elevation of spire equal in length to aperture with its produced anterior canal; whorls of conch eight to ten, subcylindrical in outline and increasing gradually in size; protoconch small, subcylindrical, elevated, and coiled two and a half times; whorls or protoconch loosely appressed; sculpture dominantly axial; costae elevated and rounded, irregularly spaced, 12 to 16 on later whorls, uniform in strength from fasciole to anterior suture; spiral sculpture low, varying from rounded elevations to wider bandlike fillets, strongest in axial depressions but present on crest of most of the axial elevations; 13 to 16 spirals on body and posterior part of pillar but disappearing on the anterior portion of the pillar; spiral interspaces not sharply impressed and narrower than spiral elevations; siphonal fasciole about onefourth as wide as the whorls and irregularly nodulated, bordered anteriorly by a concave undulating spiral furrow; suture lines distinct, impressed; body whorl subcylindrical posteriorly and sloping gently anteriorly into a long anterior canal; aperture narrow and lanceolate, produced anteriorly into a very long canal; outer lip simple; inner lip gently constricted at the base of the body; columella smooth; parietal wall evenly covered by a broad callous area. A slightly imperfect specimen measures in altitude, 58 millimeters; elevation of spire, 33.1 millimeters; maximum diameter, 14.6 millimeters.

This species is characterized by its acute, very much elevated spire and a much produced anterior canal, which give the shell a very slender outline. It may be separated from Turricula ripleyana by its slim outline and by its less strongly developed spiral sculpture and nodulate posterior fasciole. Turricula amica has more abruptly elevated axials and a fasciolar band marked by very fine, sharp spiral lines. Turricula gracilis is represented in the collection by a number of perfectly preserved specimens ranging from young forms to adults.

Occurrence: Ripley formation, Dave Weeks place on Coon Creek, McNairy County, Tenn.

Collection: U. S. National Museum. 


\section{Turricula amica (Gardner)}

Plate XXXVI, Figures 1, 2

1916. Surcula amica. Gardner, Maryland Geol. Survey, Upper Cretaceous, p. 420 , pl. 14, figs. 8,9

Miss Gardner describes this species as follows:

Shell fusiform in outline, rather slender; whorls of spire flattened, closely appressed, increasing gradually in size; body whorl rather abruptly constricted at the base; apical angle approximately $25^{\circ}$; apex broken away in all available material, so that neither the exact number of volutions nor the nuclear characters are determinable; both axial and spiral sculpture developed, the former dominant; axial costae very narrow, rounded, abruptly and prominently elevated; uniform in strength from the fasciole to the anterior suture and, on the ultima, well down to the base, 12 or 13 in number upon the later whorls; spiral sculpture of very low, broadly rounded lirae separated by linear interspaces, 6 or 7 in number upon the later whorls of the spire, 15 to 18 upon the ultima and pillar; siphonal fasciole about one-fourth as wide as the whorl, closely appressed behind, and obtusely nodulated by the costae of the preceding volution, margined anteriorly by a shallow, broadly undulated depression; suture lines distinct, impressed; aperture probably a little less than half as high as the entire shell; rather narrow, lenticular in outline; labrum broadly and symmetrically arcuate; labium smooth, quite deeply excavated at the base of the body; parietal wall evenly washed with callus; pillar probably straight and rather long.

Dimensions (imperfect individual): Altitude, 23.5 millimeters; maximum diameter, 11 millimeters.

Type locality: Friendly, Prince Georges County [Md.].

This species suggests Drillia tippana Conrad in general contour and in the character of the axial sculpture. There is nothing, however, in Conrad's type to suggest the presence of a well developed and rather prominent spiral sculpture analogous to that of S. amica, n. sp.

Occurrence: Ripley formation, Dave Weeks place on Coon Creek, McNairy County, Tenn.

Collections: Maryland Geological Survey, U. S. National Museum.

Outside distribution: Monmouth formation, Seat Pleasant and Friendly, Prince Georges County, Md.

Turricula biacuminata Wade, n. sp.

Plate XXXVI, Figures 13, 14

Shell of medium size, fusiform, elongate, and slender; spire elevated and acute, its elevation less than half the total altitude of the shell; whorls eight or nine, flatly convex, increasing gradually in size; protoconch trochoid, smooth, and coiled four times; sculpture spirally striate, consisting of close-set, equally spaced, elevated lirae subrectangular in cross section, 8 or 9 on the penultima and more than 25 on the body and pillar; interspaces deeply impressed and about as wide as the spiral elevations, lirae irregularly punctated by incremental lines; incremental lines indistinct and anal notch between shoulder on suture ill defined; posterior fasciole absent; suture impressed; body gently constricted posteriorly and sloping slowly in front into a long anterior canal, which is broad along the posterior portion, constricted near the middle and slightly bent near the anterior extremity; aperture narrow and elongate, produced into a long, narrow, open anterior canal; outer lip broken away; inner lip nearly straight; columella strong and smooth, parietal wall smooth and glazed. Altitude, 47.4 millimeters; elevation of spire, 25.3 millimeters; maximum diameter, 9.9 millimeters.

This species is well characterized by its long, slender form and spiral sculpture, which is not crossed by any axial ornamentation. It differs from Turricula fasciolata in having no posterior fasciolar band and from Turricula anomalocostata in being entirely free from axial elevations.

Occurrence: Ripley formation, Dave Weeks place on Coon Creek, McNairy County, Tenn.

Collection: U. S. National Museum.

\section{Turricula fasciolata Wade, n. sp. \\ Plate XXXVI, Figures 3, 4}

Shell small, very slender and fusiform in outline; spire elevated and acute, its altitude a little greater than half the total'length of the shell; whorls of conch seven, closely appressed and increasing gradually in size; protoconch trochoid, coiled four times; sculpture dominantly spiral, axial elevations absent on later whorls but present as subdued nodular elevations on the two earliest whorls of the spire; spiral lirae low and irregular, slightly nodulated, 12 or 14 on the penultima and more than 30 on the ultima; spiral interspaces not sharply channeled and about as wide as the lirae; posterior fasciole not clearly defined but represented by numerous oblique lines, which are the posterior extremities of incremental lines, indicating stages of the anal notch between the shoulder and the posterior suture; suture impressed; body constricted posteriorly and sloping gently in front into a long, narrow anterior canal; aperture flatly lenticular and produced anteriorly into a long, straight canal; outer lip broken in the type; inner lip excavated at the base and straight along the anterior canal; columella strong and smooth; parietal wall washed with a glaze of callus; pillar straight and pointed at the anterior extremity. Altitude, 18.7 millimeters; elevation of spire, 9.7 millimeters; maximum diameter, 4.6 millimeters.

This species is well characterized by the oblique axial lines along the posterior fasciole and the subdued axial costae on the earlier whorls. Only one specimen of the species is known at present, and it is perfectly preserved except that it has lost the margin of the outer lip.

Occurrence: Ripley formation, Dave Weeks place on Coon Creek, McNairy County, Tenn.

Collection: U. S. National Museum. 
Turricula anomalocostata Wade, n. sp.

Plate XXXVII, Figures 4, 8, 11

Shell of medium size, rugose, fusiform in outline, elongate and slender; spire elevated and acute, its elevation less than half the total altitude of the shell; whorls seven, slightly shouldered, closely appressed; protoconch smooth, trochoid and coiled three and a half times; sculpture irregularly axial and persistently spiral, axial costae absent on the earlier whorls of the spire, on later whorls very irregular in strength, occurrence, and spacing, consisting of wrinkle-like elevations and depressions, which are in places slightly oblique to the axis of the shell; spiral ornamentation well defined, consisting of close-set, elevated threadlike lirae, 7 to 9 on the ultima and more than 30 on the body and anterior canal; lirae wider than the deeply channeled interspiral spaces; spiral sculpture closer and weaker on anterior canal; lirae irregular and microscopically nodulated by incremental lines; incremental lines indicate stages of a deep, narrow anal notch between the suture and the shoulder on the later whorls; suture impressed; body abruptly constricted posteriorly and sloping rapidly in front into a long, narrow anterior canal, which may be either straight or bent at the anterior extremity; aperture narrow and lenticular, produced anteriorly into a long, narrow open canal; outer lip broken away base of the body and either straight or curved along the anterior canal; columella strong and smooth; parietal wall washed with callus, which hides the spiral sculpture along a narrow area parallel to the inner lip. Altitude, 28.5 milimeters; elevation of spire, 12.2 millimeters; maximum diameter, 10.5 millimeters.

This species is well characterized by the irregular axial costae on the later whorls and further by its abruptly constricted whorls a little in front of the anterior suture. The species is represented in the present Coon Creek collection by several wellpreserved individuals.

Occurrence: Ripley formation, Dave Weeks place on Coon Creek, McNairy County, Tenn.

Collection: U. S. National Museurn.

\section{Turricula menairyensis Wade, n. sp.}

\section{Plate XXXVI, Figures 8,9}

Shell small and fragile, symmetrically and moderately elongate fusiform; spire elevated, its length about equal to that of the aperture and canal; whorls four or five, increasing gradually in size; protoconch small, smooth and trochoid, coiled three times; sculpture ornate; axials well defined but slender, nearly straight on the early two whorls but becoming strongly flexed on the later whorls, indicating a pronounced posterior siphonal notch just in front of the suture; about 18 axial elevations on the body, where they are more closely and less regularly spaced than on the early whorls of the spire; axial costae evanesce on the anterior slope of the body; spiral sculpture well developed and overriding axials, consisting of 9 low lirae on the whorls of the spire and about 28 on the body and the anterior canal; interspaces a little wider than the spiral threads; suture impressed; body very slightly constricted behind and sloping gradually in front to a gently curved anterior canal; aperture lanceolate, produced in front into a long, gently curved open canal; margin of outer lip thin, sinuous just in front of the posterior commissure; inner lip excavated medially; columella smooth; parietal wall glazed. Altitude, 7.1 millimeters; maximum diameter, 2.1 millimeters.

The elegant little shells of this species are well characterized by their spiral and axial sculpture. The axial costae are straight on the early two whorls of the spire but become strongly flexed and sinuous on the later whorls. Probably the most closely related known species is Turricula minor (Evans and Shumard), ${ }^{25}$ from the Fox Hills sandstone of the upper Missouri Cretaceous.

Occurrence: Ripley formation, Dave Weeks place on Coon Creek, McNairy County, Tenn.

Collection: U. S. National Museum.

\section{Superfamily RACHIGLOSSA}

Family VOLUTIDAE

Genus VOLUTOMORPHA Gabb

\section{Volutomorpha aspera Dall}

Plate XXXVII,' Figures 1, 9

Volutomorpha aspera. Dall, Smithsonian Misc. Coll., vol. 50 (Quart. Issue, vol. 4, pt. 1), p. 17, fig. 5, 1907.

\section{Dall describes this species as follows:}

Shell considerably crushed and wanting the earlier whorls but showing one well-marked plait; the last whorl with about 13 narrow ribs, obsolete in front of the suture, prominent at the shoulder, weaker over the body; the whorl between the suture and the shoulder constricted and more or less axially wrinkled; posterior sinus at the appressed suture; the sinus is narrow and shallow; spiral sculpture of rather close-set cords with narrower interspaces; there are about 26 spirals in front of the shoulder on the last whorl; surface with a thin wash of enamel and an obscure callous ridge in front of the suture; outer lip thin, slightly expanded, strongly denticulate at the edge in front of the suture; spire elevated but defective in the type. Longitude of last whorl 62, of aperture 47 , maximum diameter 32 millimeters.

Ripley formation of the Upper Cretaceous, at Ripley, Miss. U. S. Nat. Mus., 20404.

${ }^{25}$ Evans, John, and Shumard, B. F., St. Louis Acad. Sci. Trans., vol. 1, p. 41, 1857. Meek, F. B., A report on the invertebrate Cretaceous and Tertiary fossils of the upper Missouri country: U. S. Geol. Survey Terr. Rept., vol. 9, p. 384, pl. 40, figs. $9 \mathrm{a}, \mathrm{b}, \mathrm{c}, 1876$. 
The rough surface sculpture and strong spiral threading sufficiently distinguish this species from any of the others.

Only two imperfect specimens of this species are known in the Coon Creek collections.

Occurrence: Ripley formation, Dave Weeks place on Coon Creek, McNairy County, Tenn.

Collection: U. S. National Museum.

Outside distribution: Ripley formation, Ripley, Miss.

Volutomorpha gigantea Wade, n. sp.

Plate XXXVII, Figures 2, 3, 5-7; Plate XXXVIII, Figure 1; Plate XXXIX, Figures 1, 3

Shell unusually large and fusiform in outline; spire elevated but its altitude less than the length of the aperture; whorls six or more; increasing markedly in size in early whorls and less markedly in later whorls; relative length of whorls increasing greatly with age; sculpture both axial and spiral; axials dominant on early whorls but evanescing on the body; 16 to 18 axial costae on the early whorls, abruptly elevated but disappearing on the body, axial sculpture on the body represented by indistinct wrinkles and numerous incremental lines on the posterior slope of the body; spiral sculpture wel defined and overriding axials, consisting of narrow fillets, rectangular in cross section, widely spaced on the body and growing very faint on the anterior slope of the ultima, nine on the penultima but decreasing gradually to one or two in the earlier whorls; posterior fasciole well developed, consisting of a wellrounded spiral ridge between the shoulder and suture, which is marked by three or four low spiral threads, fasciolar ridge interrupted at short intervals by varix-like processes formed by the growth stages of the posterior sinus; suture obscured by the ragged margin of the posterior fasciole; body abruptly shouldered posteriorly in early whorls but becoming well rounded in the later whorls; aperture unknown in. adult but elongate and broad in young; posterior sinus broad and shallow; columellar plaits three on the type, all well defined, but the most posterior plait poorly developed in some individuals. A fragment of a spire measures in altitude, 212.8 millimeters; length of penultima, 109.6 millimeters.

This species is well characterized by its spirally striate, varicose posterior fasciole and further by three folds on the columella. It is the largest Cretaceous volute known and probably one of the largest Upper Cretaceous univalves. This species is represented in the present Coon Creek collection by two imperfect adult specimens and a perfect young specimen, which has three columellar plaits but is assigned with some doubt to this species.

Occurrence: Ripley formation, Dave Weeks place on Coon Creek, McNairy County, Tenn.

Collection: U. S. National Museum.
Volutomorpha mutabilis Wade, n. sp.

Plate XXXVII, Figure 10; Plate XL, Figure 6

Shell brilliantly glazed, very large and fusiform in outline, with a much elongated body; spire less than one-third the entire length of the body; spiral angle low on the younger whorls but becoming high on the later whorls; whorls of conch five or six; increasing markedly in size; protoconch very small and shelly; sculpture elaborate, axials dominating, 19 to 21 on the body, abruptly elevated, strongest on the posterior half of the whorls and evanescing on the anterior slope of the body; axial depressions varying in width, usually wider than elevations; costae disappearing on the body near the margin of the aperture on older individuals and axial sculpture represented by incremental lines; spirals well defined, consisting of narrow elevated fillets, which override the axials, forming subdued tubercles at the intersections; spiral ridges widely spaced on the later whorls and growing faint near margin of aperture on old individuals; spirals 19 to 23 on the body and 2 to 5 on the penultima; posterior fasciole represented by a spiral ridge, which is marked by two or three spiral striae; between the posterior fasciole and the shoulder is a shallow sulcus, which may or may not be striate; suture obscured by glaze, which covers the entire surface; body slightly inflated, much elongate, constricted posteriorly and sloping gradually to the front into a broad, slightly curved anterior canal; aperture lenticular, produced anteriorly into a short, open canal, notched posteriorly by a deep siphonal sinus; outer lip expanded, its margin marked by projecting denticles which occur at the terminations of the spiral cords, dentate margin represented incrementally on older individuals; inner lip excavated medially; columella marked by two oblique plaits, the anterior one the stronger; parietal wall calloused; anterior fasciole not well defined. A flattened individual measures in altitude 147.7 millimeters; length of spire, 39.2 millimeters; maximum diameter, 62 millimeters.

This species is characterized by its round shoulder and its striate posterior fasciole, which is free from the varices that characterize Volutomorpha rustica and Volutomorpha gigantea. The species is probably nearer Volutomorpha retifera Dall than any of the described representatives of this genus in the Gulf States Cretaceous sediments. Volutomorpha mutabilis is one of the most common univalves in the Coon Creek beds. It is represented in the present collection by more than a dozen and a half well-preserved individuals, which show much variation in size, sculpture, and spiral characters. Nearly every individual is colored bright brownish yellow, a tint which very probably indicates that the shell was once beautifully colored. 
Occurrence: Ripley formation, Dave Weeks place on Coon Creek, McNairy County, Tenn.

Collections: U.S. National Museum, Johns Hopkins University, Vanderbilt University.

\section{Genus VOLUTODERMA Gabb}

Volutoderma tennesseensis Wade, n. sp.

Plate XLI, Figures 1, 5

Shell fragile, large, very elongate and ensiform in outline; whorls seven to nine, appressed, increasing gradually in size in the immature stages of the shell, body whorl very much elongated in adult; spire elevated, very acute, apical angle becoming greater in adult stage of the shell; protoconch partly broken away, very small and elevated; sculpture dominantly spiral; nxial ribs well rounded, seven to nine on earlier whorls but disappearing entirely on body of adult forms, varix-like incrementals near margin of aperture; spiral sculpture consisting of sharp, narrow ridges irregularly spaced, widest on the posterior half of the whorls; 20 ridges on the body and 3 on the penultima; interspaces concavely excavated and crossed by numerous fine incremental lines, most conspicuous near margin of aperture; some interspaces marked by faint secondary spiral threads; spirals overriding axials; suture indistinct, obscured by serrate sutural margin of varix-like processes or spines showing the various stages of the posterior sinus; body gently rounded anteriorly and slightly constricted at the base, where it merges almost imperceptibly into a very long, gently curved anterior canal; aperture lanceolate, marked posteriorly by a sinus and produced anteriorly into a broad, open canal; outer lip expanded, very broadly arcuate, patulous anteriorly, reflected along the outer margin; on the inner margin broad, shallow crenulations occur under the spiral elevations; inner lip nearly straight, broadly concave medially; columella marked by three or four well-defined oblique plaits, which terminate behind the margin of the aperture; parietal wall brilliantly glazed by an enamel-like callus, which extends far out on the body opposite the aperture; a thick mass of callus on the body in front of the posterior sinus; anterior canal straightly curved; a concave depression runs along the axis of the anterior canal between the inner margin of the aperture and the narrow elongate anterior fasciole; posterior portion of this depression is glazed by callus and the reflected inner lip, but anteriorly the glaze does not extend all the way across this depression to the ridge of the anterior fasciole. Altitude, 226.8 millimeters; elevation of spire, 48 millimeters; maximum diameter, 52.2 millimeters.

The striking shells of this species are very common in the Coon Creek beds. They range from 2 to 12 inches in length. The shells are very fragile, and"many of the specimens are fragmentary as they occur in the sediments; howcrer, several perfect specimens have been obtained from the Coon Creek beds. The species Volutoderma tennesseensis seems to be an intermediate form between Volutoderma texana (Conrad) ${ }^{26}$ and $V$. protracta Dall.

Occurrence: Ripley. formation, Dave Weeks place on Coon Creek, McNairy County, Tenn.

Collection: U. S. National Museum.

\section{Volutoderma protracta Dall \\ Plate XXXIX, Figure 4}

1907. Volutoderma protracta. Dall, Smithsonian Misc. Coll., vol. 50 (Quart. Issue, vol. 4, pt. 1), p. 21, fig. 10.

Dall describes this species as follows:

Shell very elongate, thin, with 8 whorls; pillar straight, with three feeble plaits lagging behind the aperture; on the early whorls 7-8 rounded axial ribs, obsolete on the later whorls; whorls slightly constricted in front of the appressed suture; sutural margin with conspicuous imbricated scales and striation axially directed; crossed by $3-5$ faint spiral threads; on the body of the last whorl are 19-20 sharp spiral ridges with much wider, somewhat excavated interspaces; the spiral ridges are sometimes gently undulated but not nodulous, and there are occasionally faint intercalary threads; outer lip thin, slightly reflected; posterior sinus close to the edge of the suture. Longitude, 155; of spire above first whorl, about 40; maximum diameter, 36 millimeters.

Several individuals of the Coon Creek collection have been referred with some-hesitation to this species. Their spiral sculpture greatly resembles that of Volutoderma tennesseensis, yet their very slender outline and much elevated spire, whose whorls are slightly constricted behind the suture of succeeding volutions, together with the fact that the individuals under. discussion have three plications on the columella instead of four or more, seem to be sufficient grounds for assigning them to Dall's species, Volutoderma protracta.

Occurrence: Ripley formation, Dave Weeks place on Coon Creek, McNairy County, Tenn.

Collection: U. S. National Museum.

Outside distribution: Ripley formation, Owl Creek, Tippah County, Miss.; Navarro formation, Kaufman, Tex.

Volutoderma appressa Wade, n. sp.

Plate XXXIX, Figures 2, 6

Shell very elongate and thin; length of aperture more than twice as great as the elevation of the spire; whorls of conch, six or eight, increasing gradually in size; protoconch unknown; sculpture conspicuously spiral, with eight or nine wrinkle-like axial ridges on the earlier whorls but disappearing near the margin of the aperture on the body; spiral ridges sharp and

'Conrad, T. A., Descriptions of Cretaceous and Tertiary fossils: Report on the United States and Mexican boundary survey, vol. 1, pt. 2, p. 158, pl. 14, figs. 2a, b, 1857 . 
narrow and inequispaced, 23 on the body, closely spaced and becoming very faint anteriorly, near the posterior suture spiral ridges indistinct; just in front of suture is a very much depressed spiral interspace marked by a secondary spiral ridge; sutural margin serrated by numerous fine spurlike projections formed by the growth stages of the posterior siphon; suture impressed and undulating; body slender, closely appressed posteriorly and gently sloping anteriorly into a long, slightly curved anterior canal; aperture lanceolate, posterior sinus shallow; anterior canal long and open; outer lip broadly arcuate and thin; inner lip nearly straight, very slightly concave medially; columella marked by three plications; parietal wall washed by a broad, thin glaze of callus; anterior fasciole low and poorly defined. Altitude, 98.2 millimeters; elevation of spire, 28.5 millimeters; maximum diameter, 22.4 millimeters.

In general outline and external sculpture this form greatly resembles Volutoderma tennesseensis, from which it is distinguished by the deep, broad spiral sulcus just in front of the suture. Volutoderma appressa has only three columellar plaits, whereas the columella of $V$. tennesseensis is usually marked by four or more plications.

Occurrence: Ripley formation, Dave Weeks place on Coon Creek, McNairy County, Tenn.

Collection: U. S. National Museum.

\section{Genus DRILLUTA Wade}

1916. Drilluta. Wade, Acad. Nat. Sci. Philadelphia Proc., vol. 68 , p. 458. Etymology: A contraction of the generic terms Drillia and Voluta. Type: Drilluta communis Wade.

Shell strong and fusiform; spire elevated; whorls numerous, increasing slowly in diameter; protoconch very small and smooth; sculpture dominantly axial, the costae interrupted in front of the sutural line by a well-defined but rather narrow fasciole; aperture lenticular, produced anteriorly into a long, gently recurved canal; outer lip broadly arcuate, simple within; inner lip calloused; columella bearing one well-defined oblique fold, commonly with one or two minor folds behind it, all of which evanesce before reaching the aperture.

This genus includes a well-defined and widely distributed group of the Volutidae, of which some are undescribed and some that have been described have been variously assigned to such genera as Drillia, Voluta, Fasciolaria, and Fusus. Drilluta may be readily separated from Drillia by the absence of a posterior siphonal notch and further by the presence of columellar plaits. The typical Voluta has a lower spire and numerous transverse folds. Fasciolaria has a more inflated body whorl and is not characterized by a well-defined posterior fasciole, as is Drilluta.
Fusus, on account of its smooth columella, can not be confused with Drilluta.

\section{Drilluta communis Wade}

Plate XXXVIII, Figures 4, 5

1916. Drilluta communis. Wade, Acad. Nat. Sci. Philadelphia Proc., vol. 68, p. 459, pl. 23, figs. 5, 6 .

1917. Drilluta communis. Cossmann, Rev. critique paléozoologie, année 20, No. 3, p. 99.

Shell of medium size and fusiform in outline; spire elevated, its altitude approximately half the entire length of the shell; apical angle higher on the posterior part of the spire, becoming slightly lower on the younger whorls; protoconch very smooth and trochoid, coiled about three times; eight whorls of conch, closely appressed; both axial and spiral sculpture developed, the former dominant, axial costae rounded and abruptly elevated, 11 to 17 to the whorl, 14 on the penultima of the type, costae flexuous, uniform in strength from the posterior fasciole to the anterior suture and a little less than halfway down to the base of the body on the ultima; fasciole narrowed, indistinctly marked on the early whorls, defined in the later whorls by the abrupt disappearance of the axial costae; spiral sculpture of fine crowded impressed lines on apical whorls, becoming faint and almost disappearing on the medial part of older whorls but reappearing as coarse, impressed lines on slope of body whorl, becoming faint and disappearing on anterior fasciole; suture impressed; body whorl sloping down smoothly into a broad pillar; aperture lanceolate, produced anteriorly into a very feebly recurved canal; inner lip callous; outer lip simple; columella marked by one well-defined fold and one or two weaker posterior folds, all of which evanesce before reaching the aperture, plications invisible in the aperture. Altitude, 62 millimeters; length of aperture, 31 millimeters; maximum diameter, 20 millimeters; spiral angle, $40^{\circ}$ on posterior whorls, decreasing to $25^{\circ}$ on anterior whorls.

This species is one of the most abundant and bestpreserved univalves at Coon Creek. It shows a considerable range in size and external ornamentation. Some of the young individuals exhibit a fine spiral sculpture over the entire length of the shell. The number of columellar plaits is variable. These terminate far within the body whorl, distant from the margin of the aperture, and in many individuals are almost entirely obscured, although they are revealed by sectioning the spire.

The species Turris? kaffrarium (Griesbach) ${ }^{27}$ from the Senonian of Pondoland, South Africa, which originally was described and referred to the genus

${ }^{27}$ Griesbach, C. L., On the geology of Natal, in South Africa: Geol. Soc. London Quart. Jour., vol. 27, p. 64, pl. 3, fig. 5, 1871. Woods, Henry, The Cretaceous fauna of Pondoland; South African Mus, Annals, vol. 4, pt. 7, p. 325, pl. 40, figs. 8, 8, 1906. 
Cerithium by Griesbach and later questionably referred to Turris by Woods, is very likely a species of the genus Drilluta. Although the South African species is not specifically related closely to the type of this genus, yet it presents characters that seem to indicate that it belongs in the same section as Drilluta communis.

Occurrence: Ripley formation, Dave Weeks place on Coon Creek, McNairy County, Tenn.

Collection: U. S. National Museum.

\section{Drilluta distans (Conrad)}

Plate XXXVIII, Figures 6, 7

1860. Drillia? distans. Conrad, Acad. Nat. Sci. Philadelphia Jour., 2 d ser., vol. 4 , p. 286, pl. 46 , fig. 49.

Conrad describes this species as follows:

Fusiform; spire and aperture about equal in length; whorls slightly convex inferiorly, ridged below the suture; ridge crenatestriate; ribs rounded, distant; revolving lines distant on the beak and toward the summit, elsewhere obsolete; beak slightly produced.

Shell of medium size and fusiform in outline; spire elevated, its height about the same as the length of the aperture, spiral slope slightly convex; whorls of conch six or seven, closely appressed, and increasing in size rather markedly; protoconch broken away; sculpture dominantly axial; axial costae distant, low, and broadly rounded, 9 to 12 on the body, of equal strength from posterior fasciole to anterior suture but evanescing on the anterior slope of the body; spiral sculpture nearly absent on spire except for numerous very faintly impressed fine lines on the younger whorls; anterior slope of the body from the posterior commissure to the medial portion of the beak marked by about 16 equispaced impressed spiral sulci; posterior siphonal fasciole narrow and poorly defined on apical whorls, more distinct anteriorly and nodulated by irregularly spaced abrupt elevations or nodes; suture impressed; body whorl broadly convex and sloping steeply into a long recurved anterior canal; aperture lanceolate, produced anteriorly into a slightly recurved canal; outer lip simple; inner lip excavated; parietal wall washed with a thin, wide callus; columella marked by one well-defined oblique plait and one to three weaker posterior folds, all of which evanesce before reaching the margin of the aperture:

This species is characterized by its distant and low, broadly rounded axial costae. Its apical whorls are less numerous and increase more notably in size than in Drilluta communis and further are not sculptured by numerous well-defined spiral lines. $D$. distans is not so abundant at Coon Creek as Drilluta communis.

The author has elsewhere ${ }^{28}$ made an error in citing Owl Creek as the type locality of Drilluta distans.

${ }^{28}$ Wade, Bruce, New genera and species of Gastropoda from the Upper Cretaceous: Acad. Nat. Sci. Philadelphia Proc., vol. 68, p. 459, 1916.
Conrad's type was collected by. Tuomey at Eufaula, Ala.

Conrad's type can not be located in either the museum of the Philadelphia Academy of Natural Sciences or the U.S. National Museum, and there are no specimens from Eufaula available. The original description is brief, and the figure is an imperfect pen sketch, so that this shell can not at present be assigned with finality to Conrad's species.

Occurrence: Ripley formation, Dave Weeks place on Coon Creek, McNairy County, Tenn.

Collection: U. S. National Museum.

Outside distribution: Ripley formation, Eufaula, Ala.

\section{Drilluta major Wade}

Plate XXXVIII, Figures 2, 3

1916. Drilluta major. Wade, Acad. Nat. Sci. Philadelphia Proc., vol. 68, p. 460, pl. 23, figs. 7, 8.

1917. Drilluta major. Cossmann, Rev. critique paléozoologie, annee 20 , No. 3 , p. 99.

Shell thick and large, fusoid in outline; whorls seven, closely appressed, increasing gradually in size; apex acute, broken away, but protoconch as indicated by the scar probably very small; whorls of spire slightly flattened dorso-ventrally, constricted posteriorly, ultima merging smoothly into a wide anterior canal; external ornamentation coarse and elaborate; axial sculpture consists of rounded, strongly elevated costae waving backward along the shoulder, 11 to 14 to the volution, costae becoming shorter and less prominent on approaching the aperture; on young whorls costae reach from posterior fasciole to anterior suture but become shorter anteriorly and occur only along the shoulder of the whorl; posterior part of whorl constricted and marked by a narrow posterior fasciole set with closely spaced spinose, varix-like processes; most of these processes broken away in type; spiral sculpture absent on first three apical whorls, becoming more prominent anteriorly until conspicuous on body whorl; more than 30 strongly elevated spirals on body whorl, spirals more widely spaced on medial portion of body whorl; spirals along medial portion of body somewhat arcuate on type with most gentle slope anteriorly; body whorl sloping gently into a broad pillar; aperture lenticular and produced anteriorly into a canal; inner lip calloused, parietal wall thinly washed; columella marked by a strong oblique fold in front of one or two less prominent folds, all of which become obsolete before reaching the opening of the aperture. An imperfect specimen measures in altitude, 85 millimeters; maximum diameter, 32 millimeters; spiral angle, $30^{\circ}$.

This magnificent species was represented in the author's first collection from Coon Creek by two individuals, both of which, though imperfect, show the essential characters of the shell. It is well characterized by the elaborate axial and spiral ornamentation, the 
very acuminate spire, and further by the spinose varixbearing posterior fasciole.

Recent collecting at Coon Creek has afforded perfect specimens, which show the anterior extremity of the species. The length of the aperture and the produced anterior canal is a little greater than that of the spire. The body whorl slopes gently into a long, recurved anterior canal, which is pointed anteriorly. The species has a wide variation in size, ranging from 60 to more than 120 millimeters in altitude.

Occurrence: Ripley formation, Dave Weeks place on Coon Creek, McNairy County, Tenn.

Collections: Johns Hopkins University, Vanderbilt University, U. S. National Museum.

Drilluta dimurorum Wade, n. sp.

Plate XXXIX, Figures 5, 7

Shell large and fusiform; whorls closely appressed, probably seven or eight; spire acute; apical whorls broken away in type of species, older volutions slightly flattened dorso-ventrally, constricted posteriorly; sculpture coarse and elaborate; axials rather strongly elevated and waving backward along the shoulder, rounded on the younger whorls but becoming subangular on the body, where fortuitous secondary axials appear in the interspaces on the medial portion of the body; primary costae 14 to 16 on the ultima, strongest on shoulder and evanescing on the anterior portion of the ultima; spiral sculpture well defined, consisting of angular, impressed sulci, wide and deep on the anterior slope of the body, becoming narrow and very faint on the posterior part of the body; posterior fasciole narrow and marked by very many closely spaced spinous, trough-shaped processes; suture impressed; body broadly convex and sloping gradually into a broad anterior canal; aperture lenticular and produced anteriorly into a canal; outer lip simple; inner lip concave; columella marked by one strong narrow oblique fold in front of a very faint incipient plait; parietal wall thinly glazed with a callus, which does not obliterate the spiral sculpture.

Length of an imperfect specimen, 72 millimeters; maximum diameter, 30 millimeters.

This species is characterized by coarse well-developed primary costae with fortuitous secondary costae in the intervening furrows. It differs from Drilluta major in the character of the posterior fasciole and in having a less ornate sculpture and a more prominent single columellar plait.
Occurrence: Ripley formation. Dave Weeks place on Coon Creek, McNairy County, Tenn.

Collection: U. S. National Museum.

Genus LIOPEPLUM Dall

Liopeplum subjugosum (Gabb)

Plate XLI, Figures 2-4

1855. Voluta jugosa. Tuomey, Acad. Nat. Sci. Philadelphia Proc., vol. 7, p. 169 (not Sowerby).

1861. Voluta subjugosa. Gabb, Synopsis of the Mollusca of the Cretaceous formation, p. 93 (Am. Philos. Soc. Proc., vol. 8, p. 149).

1890. Liopeplum subjugosum. Dall, Wagner Free Inst. Sci. Trans., vol. 3 , pt. 1 , p. 83 , pl. 6, fig. 12a.

1914. Liopeplum subjugosum. Stephenson, U. S. Geol. Survey Prof. Paper 81 , check list, table 2.

Dall describes this species as follows:

Shell thick, brilliantly glazed, with five or more whorls; nucleus small, whorls turreted; spiral sculpture of a few weak threads on the foremost part of the shell on and near the siphonal fasciole and mostly buried in callus; transverse sculpture of (on the last whorl) 14 or 15 rounded, thick, strong waves, beginning at the shoulder, which they coronate, and extending about one-third of the way forward with equal or narrower interspaces; these ribs or waves cease quite suddenly, and on the preceding whorls their anterior terminations are covered by a spiral elevated ridge of callus, which overshadows the obscure suture, from which it is separated by a narrow space, thus forming between the ribbed shoulder of one whorl and the spiral callus of the other a deep channel; aperture long and narrow, the canal not constricted; outer lip simple, nearly straight in the middle, receding deeply between the suture and the shoulder, thus making a sinus for the glaze-secreting process of the mantle; pillar concave in the middle, a little twisted, with a strong siphonal fasciole upon which, in the adult, is a thick mass of callus on the anterior half, on which ride one weaker posterior and three strong anterior plaits, behind which on the body of the whorl there is only a thin layer of callus. Approximate dimensions of adult: Longitude, 45; longitude of aperture, 28; maximum diameter, 16 millimeters.

A study of a number of specimens of this species shows that the form may present many variations. The altitude ranges from 40 to 75 millimeters. The relative elevation of the spire to the number of whorls of the conch is inconstant. The axial costae which coronate the shoulders disappear near the margin of the aperture on the younger forms and practically all of the body whorl of older individuals. The sides of the body may be convex, straight, or concave. The columellar plaits vary from two to four in number.

Occurrence: Ripley formation, Dave Weeks place on Coon Creek, McNairy County, Tenn.

Collections: U. S. National Museum, Johns Hopkins University.

Outside distribution: Ripley formation, Owl Creek, Tippah County, Miss. 


\section{Liopeplum leiodermum (Conrad)}

Plate XLII, Figures 3, 4

1860. Volutilithes (Athleta) leioderma. Conrad, Acad. Nat. Sci Philadelphia Jour., 2d ser., vol. 4, p. 292, pl. 46, fig. 32.

1865. Lioderma lioderma. Conrad, Acad. Nat. Sci. Philadelphia Proc. for 1865, p. 184.

1890. Liopeplum lioderma. Dall, Wagner Free Inst. Sci. Trans., vol. 3, pt. 1, p. 73.

1905. Liopeplum leioderma. Johnson, Acad. Nat. Sci. Philadelphia Proc., vol. 57, p. 25.

1916. Liopeplum leiodermum. Gardner, Maryland Geol. Survey, Upper Cretaceous, p. 430.

Conrad in 1860 described this species as follows:

Subfusiform, smooth, and polished; spire scalariform, angle callous; shoulder over the aperture with a projecting callus; aperture long, effuse; labrum slightly notched or sinuous at the superior extremity; columella four-plaited; plaits very oblique; superior one obsolete.

Shell of medium size, subfusiform, with a highly polished external surface; spire elevated, but its height much less than the length of the aperture; four or five whorls, increasing in size rather notably; protoconch unknown; sculpture, except for numerous incremental lines that appear through the glazed surface, absent on last whorls; early whorls of spire, however, obscurely costate, consisting of about 14 low, closely spaced, tubercle-like costae along the shoulder of the early two or three whorls of the spire; on the later whorls these costae evanesce or become obscured by callus; incremental lines numerous and showing only through the glazed surface; spiral sculpture obscure and occurring only on the shoulders of the early whorls of the spire, where very faint spiral lines show through the glazed surface; a strong spiral ridge of callus occurs just behind the suture and advances far out on the body beyond the aperture; suture obscure; body sharply constricted behind, slightly. flattened medially and sloping gently in front into a broad pillar; aperture broadly lenticular, produced in front into a short open canal, marked at the posterior commissure by a shallow, angular siphonal notch; outer lip thin and simple; inner lip excavated medially; columella strong, marked by two distinct but feeble plaits; parietal wall washed with callus; anterior fasciole broad and very oblique, obscured by callus.

This species is the smallest and most fragile of the four species of Liopeplum occurring at Coon Creek. The Coon Creek collection contained several individuals of Liopeplum liodermum, all of which show some variation in the ornamentation of the spire and the extent of the development of the spinal ridge of callus just behind the suture. None of these individuals are absolutely identical with the type of the species in the Museum of the Philadelphia Academy of Natural Sciences, yet the differences are probably not great enough to be regarded:as specific. The entire group of Liopepla show much variation and seem to have been very unstable volutes in the Ripley sea.

Occurrence: Ripley formation, Dave Weeks place on Coon Creek, McNairy County, Tenn.

Collections: Philadelphia Academy of Natural Sciences, U. S. National Museum, Maryland Geological Survey, Vanderbilt University.

Outside distribution: Ripley formation; Tippah County, Miss. Monmouth formation, Prince Georges County, Md.

Liopeplum carinatum Wade, n. sp. Plate XLII, Figures 1, 2

Shell large and thick, subolivoid in outline; surface brilliantly glazed; spire much shorter than aperture; four or six whorls, increasing gradually in size: protoconch unknown; sculpture absent, external surface smooth and unmarked except for incremental lines, which appear through the glaze; suture entirely obscured by a strong, highly elevated spiral ridge of callus situated above and a little behind the suture, giving each whorl of the spire a button-shaped aspect; spiral ridge of callus advancing about onefourth the way around the body in front of the inner margin of the aperture; body whorl slightly inflated, constricted posteriorly and tapering gradually anteriorly into a broad, short anterior canal; aperture long and narrow, produced anteriorly into a short canal whose incrementals show through the glazed surface and form a well-defined anterior siphonal fasciole; posterior siphonal notch shallow and subangular; outer lip simple and smooth within; inner lip gently constricted medially; columella marked by two folds; parietal wall washed with callus. A slightly imperfect individual measures in altitude 49.1 millimeters; maximum diameter, 20.7 millimeters.

This species is well characterized by the strong spiral-shaped keel of callus just behind the suture on the whorls of the spire and further by the absence of a well-developed shoulder.

Occurrence: Ripley formation, Dave Weeks place on Coon Creek, McNairy County, Tenn.

Collection: U. S. National Museum.

\section{Liopeplum canalis (Conrad) \\ Plate XLII, Figures 5, 6}

1858. Conus canalis. Conrad, Acad. Nat. Sci. Philadelphia Jour., 2d ser., vol. 3, p. 331, pl. 35, fig. 22.

1890. Liopeplum canalis. Dall, Wagner Free Inst. Sci. Trans., vol. 3, pt. 1, p. 73 .

1914. Liopeplum canalis. Stephenson, U. S. Geol. Survey Prof. Paper 81, check list, table 2.

Conrad characterizes this species as follows:

Spire prominent, volutions profoundly angular in consequence of a deep channel revolving at the suture.

Shell fairly large and subbiconic in outline, length of aperture greater than the elevation of the spire; 
whorls of conch five or six, increasing regularly in size and rather markedly; sculpture absent, external surface covered with a glaze and all ornamentation obliterated except for incremental lines, which show through the glaze; suture impressed and covered with a prominent well-rounded spiral ridge of callus, which occurs over the shoulder of the whorl and the area of the whorl between the shoulder and the suture of a subsequent volution, the suture itself being covered by this ridge; this spiral callus ridge forms a deep concave canal with the shoulder of the subsequent whorl; body flattened dextro-ventrally, slightly inflated medially, abruptly constricted posteriorly, and sloping gently toward the anterior into a broad, short anterior canal; aperture long and narrow, produced anteriorly into a short, straight canal and marked posteriorly by a shallow subangular siphonal notch; outer lip simple and smooth; inner lip broadly excavated; columella marked by two or three very oblique plaits, the anterior two the more prominent; columella and parietal wall washed with callus; pillar broad and short, marked by a wide anterior fasciole, which shows through the enamel-like glaze of the shell.

Several imperfect specimens in the Tennessee collection have been assigned to this species with some hesitation, for Conrad's type has apparently been lost. In general features this species resembles Liopeplum carinatum, but that species is more slender and does not possess an abruptly constricted shoulder like that of Liopeplum canalis.

Occurrence; Ripley formation, Dave Weeks place on Coon Creek, NcNairy County, Tenn.

Collection: U. S. National Museum.

Outside distribution: Ripley formation, Owl Creek, Tippah County, Miss.

\section{Genus PARAFUSUS Wade}

1917. Hyllus. Wade, Acad. Nat. Sci. Philadelphia Proc., vol. 69 , p. 281.

1918. Parafusus. Wade, Am. Jour. Sci., 4th ser., vol. 45, p. 334. Etymology: $\pi \alpha \rho a ́$, near; Fusus, a genus of gastropods. Type: Parafusus callilateris (Wade).

1920. Wadia. Cossmann, Rev. géologie, année 1, No. 9, p. 375.

Shell large and suboroid in outline; spire obtuse or only slightly elevated; whorls closely appressed, increasing in size rapidly to a much inflated body; protoconch unknown; sculpture absent, external surface free fron ornamentation except for incremental lines which show through the glazed surface; sutures obscured by callus; body slightly inflated and in some specimens flattened dorso-ventrally, gently constricted behind, in front sloping gradually into a broad, slightly curved short anterior canal; aperture broad and lenticular, distinctly notched in front or produced into a short canal, slightly notched posteriorly; outer lip simple and broadly arcuate; inner lip excavated near the anterior extremity; columella marked by one or two strong oblique columellar folds; parietal wall glazed with callus, which in some forms is very heavy! anterior fasciole broad and obscured by a callus.

This genus was proposed for a group of volutes represented by two species from Coon Creek and a third species from Owl Creek which are characterized by large inornate shells with expanded bodies and low spires. This group is probably nearer to Liopeplum ${ }^{20}$ than to any other described genus but differs from that genus essentially in the character of the spire, the outline of the body, and further in the obliqueness and number of the columellar plaits. Another closely related group of volutes in the Upper Cretaceous is represented by the species Melo pyriformis Forbes, from the Arrialoor, southern India, ${ }^{30}$ a species which Cossmann has referred to the genus Scaphella. ${ }^{31}$

The name Hyllus, originally proposed for this genus, was preoccupied, and it was therefore necessary to substitute Parafusus. Cossmann had failed to see the publication of this second name when he proposed to call the genus Wadia.

\section{Parafusus callilateris Wade}

Plate XIJIII, Figures 11, 12

1917. Hyllus callilateris. Wade, Acad. Nat. Sci. Philadelphia Proc., vol. 69, p. 282, pl. 17, figs. 5, 6.

1918. Hyllus callilateris. Cossmann, Rev. critique paléozoologie, année 22, Nos. 1-2, p. 20.

1918. Parafusus callilateris. Wade, Am. Jour. Sci., 4th ser., vol. 45 , p. 334

Shell large and subovoid in outline; spire elevated but its height probably less than the length of the aperture; number of whorls unknown; volutions increasing in size rather markedly; apex broken away, protoconch unknown; sculpture absent, external surface free from ornamentation except incremental lines, which show through the glazed surface, especially on the anterior fasciole; suture hidden by callus; body slightly flattened dorso-ventrally, somewhat inflated and sloping gently posteriorly and likewise anteriorly, where it merges into a broad curved anterior canal, which is marked by a wide, low anterior fasciole, partly hidden by callus; aperture broad and lenticular, distinctly notched or canaliculate anteriorly, but the posterior notch is not well defined; outer lip simple and well rounded; inner lip excavated near the anterior extremity; columella marked by a single strong oblique fold; parietal wall heavily calloused; callus deposited over practically the entire surface of the shell and very conspicuously developed on the side of the body opposite the aperture into a broad, thick, wellrounded ridge. An imperfect individual measures

${ }^{29}$ Dall, W. H., Contributions to the Tertiary fauna of Florida: Wagner Free Inst. Sci. Trans., vol. 3, pt. 1, p. 73, 1890.

${ }^{30}$ Stoliczka, Ferdinand, India GeoT. Survey Mem., Palaeontologia Indica, Cretaceous fauna of southern India, vol. 2, p. 83, pl. 6, figs. 9, 9a, 1868.

il Cossmann, Maurice, Essais de paléoconchologie comparée, pt. 3, p. 127, 1898. 
in altitude 97 millimeters; length of aperture, 67.3 millimeters; maximum diameter, 58 millimeters.

In 1860 Conrad $^{32}$ figured a form and referred to it in his index of the figures of the plate as Ancilla cretacensis, but there is no reference in his text to the species nor has mention of it been found elsewhere in his writings. This figure does not show all the shell features, but it presents characteristics that seem sufficient to indicate that Conrad's form is a species of the new genus Parafusus.

The species Parafusus callilateris is the type of the genus and is represented in the present collection by one specimen, which is well preserved except for the loss of the apex. The species is well characterized by the broad, flat body, with a heavy deposit of callus on the body opposite the inner lip, and further by the single columellar plait.

Occurrence: Ripley formation, Dave Weeks place on Coon Creek, McNairy County, Tenn.

Collection: Johns Hopkins University, U. S. National Museum.

\section{Parafusus coloratus Wade}

Plate XLIII, Figures 8, 9

1917. Hyllus coloratus. Wade, Acad. Nat. Sci. Philadelphia Proc., vol. 69, p. 283, pl. 17, figs. 3, 4.

1918. Hyllus coloratus. Cossmann, 1918, Rev. critique paléozoologie, année 22, Nos. 1, 2, p. 20.

1918. Parafusus coloratus. Wade, Am. Jour. Sci., 4th ser., vol. 45, p. 334 .

1920. Wadia coloratus. Cossmann, Rev. géologie, année 1, No. 9, p. 375.

Shell of medium size and oroid outline; length of aperture and anterior canal greater than the elevation of the spire; whorls of conch probably four, increasing in size rather markedly; sculpture absent; external surface smooth and free from ornamentation except for incremental lines, which show through a brillant glaze; suture indistinct, hidden by a glazed callus, which coats the entire surface of the shell; body evenly rounded posteriorly and medially but gently constricted anteriorly into a short, broad anterior canal, which is marked by a gently elevated anterior fasciole formed by increments of the anterior siphonal notch; aperture lenticular, produced anteriorly into a short canal; posterior siphonal notch shallow and subangular, directly in front of posterior commissure, notch indicated behind margin of aperture by incremental lines; outer lip simple and smooth; inner lip excavated; columella marked by two strong oblique folds; parietal wall thinly washed with callus. An imperfect individual measures in altitude 5.2 millimeters; maximum diameter, 2.4 millimeters.

${ }^{12}$ Conrad, T. A., Descriptions of new species of Cretaceous and Eocene fossils of Mississippi and Alabama: Acad. Nat. Sci. Philadelphia Jour., 2d ser., vol. 4, pl. 47, flg. 14, p. 288, 1860.
There are two specimens of this species, and both are incomplete. One of them shows a dark-yellow banding, which is fixed in the glaze of the external surface and is no doubt a remnant of an original color pattern. The species is well characterized by the two columellar folds, which are conspicuous on the inner lip, the inornate external surface, and further by the subelliptical outline of the shell. This species differs from Parafusus callilateris in being much smaller and in having two columellar plaits instead of one, and further in not having a heavy deposit of callus on the body opposite the inner lip.

Occurrence: Ripley formation, Dave Weeks place on Coon Creek, McNairy County, Tenn.

Collections: Johns Hopkins University, U. S. National Museum.

\section{Genus TECTAPLICA Wade}

1916. Tectaplica. Wade, Acad. Nat. Sci. Philadelphia Proc., vol. 68, p. 457. Etymology: tecta, hidden; plica, fold. Type: Tectaplica simplica Wade.

Shell of medium size, thick and strong; rudely biconic in outline; spire about one-third the entire length of the shell; apex acute; protoconch broken away, scar small; whorls very much appressed; sculpture dominantly axial; aperture lanceolate, produced anteriorly into a slightly bent canal; outer lip simple; inner lip callous; parietal wall glazed; columella marked by three weak but well-defined folds, terminating far within the margin of the aperture.

This genus is well characterized by a thick, strong, and simple shell, which has a columella marked by feeble folds. It is one of the most primitive of the volutes and may be considered as ancestrally related to Volutilithes. It differs from Volutilithes in having a less elongate spire, which is flattish on the sides and not interrupted by pronounced shoulders. Volutilithes is typically spinose and has an inner lip, usually well excavated and marked by prominent folds, which extend well out of the inner lip.

\section{Tectaplica simplica Wade}

Plate XLIII, Figures $3,4,7$

1916. Tectaplica simplica. Wade, Acad. Nat. Sci. Philadelphia Proc., vol. 68 , p. 457 , pl. 23 , fig. 4 .

1917. Tectaplica simplica. Cossmann, Rev. critique paléozoologie, année $2 \dot{2}$, No. 3, p. 99.

Shell of medium size, biconic in outline, spire acuminate, less than one-third the entire length of the shell; whorls of conch six, very closely appressed; axial slopes flattish; protoconch broken away, scar small; external sculpture dominantly axial, consisting of 10 prominent broadly rounded costae, increasing toward the aperture, crossed by very many faint spiral ridges; summit of costae unmarked by lirae; 
posterior fasciole indicated by the weakening of the axial sculpture; sutures inconspicuous, aperture lanceolate, produced anteriorly into a long canal; outer lip simple; inner lip callous and parietal wall glazed, callus concentrated just below the posterior commissure of the aperture; columella marked by three well-defined but feeble folds, terminating within the aperture; posterior fasciole indicated by abrupt constriction of incrementals. Altitude, 35 millimeters; maximum diameter, 13 millimeters; spiral angle, $59^{\circ} 20^{\prime}$.

This very simple, primitive volute was represented in the writer's first collection from Coon Creek by a single individual. The folds of this form terminate so far within the aperture that it is necessary to section the spire in order to observe the columellar plaits.

In 1916 collecting at Coon Creek yielded only one additional specimen; showing the scarcity of the species. The shells are compact and stout, so their scarcity in the Cretaceous sediments can not well be explained by saying that the shells were too fragile for preservation.

From a study of the description and figures of the species Voluta florencis Harris, ${ }^{33}$ from the Midway of Alabama and Georgia, it seems that this Eocene species might better be referred to the genus Tectaplica than to the much broader generic group of Voluta. Related species of this strong and simple Ripley volute might well be expected in the Eocene of the Gulf States.

Occurrence: Ripley formation, Dave Weeks place on Coon Creek, McNairy County, Tenn.

Collection: U. S. National Museum.

Genus PaRVIVoluta Wade, n. gen.

Etymology: parvus, small; Voluta, a well-known genus of gastropods. Type: Parvivoluta concinna Wade, n. sp.

Shell small and fusiform in outline; spire acute, its altitude less than the length of the aperture; whorls of conch closely appressed and increasing gradually in size; protoconch unknown; sculpture elaborate, consisting of prominent axials overridden by welldefined and numerous spirals; aperture lenticular and produced into a short, open canal; outer lip simple; columella marked by a single well-defined fold behind. which are one or two weaker plications; parietal wall with or without callus; anterior canal broad and short.

This genus is proposed for a group which in general outline and pattern of external sculpture resembles Volutomorpha, but that group has two or three welldeveloped columellar plaits, whereas Parvivoluta has 8s Harris, G. D., The Midway stage: Bull. Am. Paleontology, vol. 1, No. 4, p.
196, pl 8, fligs, 6a, 1896. one well-defined fold in front of one or two weaker ones. The surface of Parvivoluta is unglazed, whereas the entire surface of Volutomorpha and some of the other volutes is covered with a coat of enamel. The Volutomorphas are among the largest of the Upper Cretaceous gastropods, one species having an altitude of about 18 inches, whereas the altitude of the type of Parvivoluta is less than half an inch. Parvivoluta differs from Tectaplica in character of external sculpture and in the number of columellar folds, Tectaplica having several very feeble plications on the columella. The shell of Tectaplica is thick and stout, whereas that of Parvivoluta is thinner and more fragile. Parvivoluta differs from Drilluta in having no posterior siphonal fasciole.

The species Volutilithes orbignyana Müller, ${ }^{34}$ from the Aachen Cretaceous of western Germany, is probably a closely related species belonging to this group of volutes.

\section{Parvivoluta concinna Wade, n. sp.} Plate XLIII, Figure 10

Shell very small and subbiconic in outline; height of spire a little less than the length of the aperture; whorls four, closely appressed; protoconch broken away, its scar very small; sculpture elaborate, consisting of well-rounded axial elevations, which are overridden by numerous spiral lirae; axials 14 in number, strongest on the shoulders of the whorls and evanescing on the anterior slope of the body; spiral elevations relatively much stronger than the axial costae, but the former are very sharp and close-set, more than 25 on the ultima and 8 or 9 on the penultima; suture impressed; body well rounded posteriorly and sloping steeply anteriorly into a short anterior canal; aperture narrow and produced into a short anterior canal; outer lip broadly arcuate and simple; inner lip constricted at the base of the body; columella marked by a single well-defined fold, behind which are two very faint lines that may be incipient folds; parietal wall free from glaze. Altitude, 11 millimeters; length of aperture, 6.3 millimeters.

This species is characterized by a single strong fold on the columella and further by a sharp, well-defined spiral sculpture. Only one specimen of the species is known, and it was necessary to section the spire of this individual in order to study the columellar plaits. The Coon Creek form differs from the German form referred to in the generic description in having sharply defined spiral threads and further in not having a callus area developed on the parietal wall.

Occurrence: Ripley formation, Dave Weeks place on Coon Creek, McNairy County, Tenn.

Collection: U. S. National Museum.

34 Holzapfel, Eduard, Die Mollusken der Aachener Kreide: Palaeontographica, Band 34, ?p. 97 , Taf. 9, figs. 8, 9, 1888. 
Genus PaleopsephaEA Wade, n. gen.

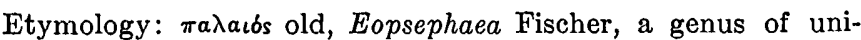
valves. Type: Palaeopsephaea mutabilis Wade, $\mathrm{n}$. gen. and $\mathrm{sp}$.

Shell of medium size and strong; fusiform in outline; spire elevated and acute; whorls numerous, closely appressed, and increasing in size gradually; protoconch small; naticoid, coiled two and a half times; external sculpture dominantly axial but spiral sculpture well developed in some species; suture appressed; body constricted a little behind and sloping gently in front into a broad, slightly curved anterior canal; aperture lanceolate, produced in front into an open canal; outer lip thin and in some specimens feebly dentate; inner lip excavated and broadly washed with callus; columella marked by about three oblique folds.

This genus is well characterized by high fusiform, strongly axial, costate, volutoid shells. This new group is proposed to include two species from the Ripley formation of Tennessee-Paleopsephaea mutabilis Wade, n. sp., and Paleopsephaea pergracilis Wade, $\mathrm{n}$. sp.-two species from the middle Turonian of Saxony-Volutilithes subsimplicatus (D'Orbigny) Wanderer ${ }^{35}$ and Volutoderma roemeri (Geinitz) Wanderer-and a Senonian species from the Aachen Cretaceous of western Europe-Volutilithes nana (Müller) Holzapfel..$^{30}$ Holzapfel ${ }^{37}$ and Müller ${ }^{38}$ refer to the species Volutilithes subsimplicatus D'Orbigny forms that have well-defined posterior fascioles. If such forms are typical of D'Orbigny's species, ${ }^{30}$ it probably belongs in the genus Drilluta; 40 however, Wanderer's species from Saxony, as shown by his figures and descriptions, have no posterior fascioles and very probably belong in the new group Paleopsephaea. This new group belongs to the Volutidae and is very closely related to Drilluta Wade and Eopsephaea Fischer. Species of the last-named genus are common in the Eocene. Paleopsephaea differs from Eopsephaea in having a less conspicuous protoconch and no well-defined anterior fasciole. It is more slender and elongate fusiform than any of the three species mentioned above. It does not possess the well-defined posterior fasciole of the genus Drilluta nor the large, spacious whorls of Cryptorhytis, which are circular in cross section.

ss Wanderer, Karl, Die wichtigsten Tierversteinerungen aus der Kreide des Königreiches Sachsens, p. 56, pl. 8, figs. 34, 35, Jena, 1909.

${ }_{30}$ Holzapfel, Edward, Die Mollusken der Aachener Kreide: Palaeontographica, Band 34, p. 100, pl. 0, fig. 12, 1888.

${ }^{87}$ Idem, p. 95, pl. 10, figs. $1-3$.

${ }_{38}$ Muller, G., Dio Molluskenfauna des Untersenon von Braunschweig und Ilsede I, Lamellibranchiaten und Glossophoren: $\mathrm{K}$. preuss. geol. Landesanstalt Abh., neue Folge, Heft 25, p. 123, pl. 16, flgs. 10, 18, 21, 1898.

$80 \mathrm{D}$ 'Orbigny, Alcide, Prodrome de paléontologie stratigraphique universelle des animaux mollusques, vol. 2, p. 229, 1850.

${ }^{0}$ Wade, Bruce, New genera and species of Gastropoda from the Upper Cretaceous of McNairy County, Tenn.: Acad. Nat. Sci. Philadelphia Proc., vol. 68, p. $450,1016$.
Paleopsephaea mutabilis Wade, n. sp.

Plate XL, Figures 4, 5, 8

Shell of medium size and strong, fusiform in outline; spire elevated and acute, its elevation a little less than the length of the aperture; whorls closely appressed and increasing in size gradually, eight or nine volutions; protoconch scar small; sculpture dominantly axial; costae abruptly elevated, highest along the periphery, unequal in strength and spacing, eight or ten on the ultima; axial ribs evanesce on anterior slope of body and also on posterior slope just in front of the suture; interaxial depressions broadly concave and wider than the costae; spiral sculpture indistinct, consisting of fine, faintly impressed spiral lines, which may be absent on the medial portion of the whorls on some individuals but on others occur over the entire surface from the suture to the anterior extremity of the pillar; suture appressed and undulating about the axial elevations; body constricted a little behind and sloping gently into a broad, slightly curved anterior canal; aperture lanceolate; outer lip thin and simple; inner lip excavated medially; parietal wall washed by a broad, thin layer of callus, which extends some distance out on the body opposite the iñner lip; columella marked by three or four oblique folds, the anterior of which is the stronger.

A slightly imperfect individual measures in altitude 36.7 millimeters; maximum diameter, 13.1 millimeters.

This species is common at Coon Creek and is represented in the present collection by a number of specimens which show a wide range in outline and characters of external ornamentation. Four specimens in the collection, which have very strong axial costae and no spiral ornamentation, differ enough probably to be regarded as representatives of another species or at least of a varietal group. A single individual which has a very slender shell, sharply sculptured with spiral lirae, may represent still another species or variety, though, for the present, all three of these groups are regarded as one species and are referred to the new genus Paleopsephaea. The species Volutilithes nana (Müller), ${ }^{41}$ from the Aachen Cretaceous of Vaals, Germany, is probably a closely related species of this genus. The German form, however, has a more slender spire and more distant axial costae in the external ornamentation than the Tennessee specimens of this group.

Occurrence: Ripley formation, Dave Weeks place on Coon Creek, McNairy County, Tenn.

Collection: U. S. National Museum.

1 Holzapfel, Eduard, Die Mollusken der Aachenier Kreide: Palaeontographica, Band 34, p. 100, pl. 9, fig. 12, 1888. 
Paleopsephaea pergracilis Wade, n. sp.

Plate XL, Figures 3, 7

Shell of medium size and thin, fusiform in outline; spire acuminate and slender; whorls seven, closely appressed and increasing in size gradually; sculpture elaborate and rough; strong axial costae or wrinkles very conspicuous on the medial portion of the whorls; these costae widely and irregularly spaced, six on the body, axial costae overriden by numerous closely spaced spiral threads, which are roughened by numerous incremental lines; suture appressed and wavy; body constricted behind and sloping gently in front into a long, narrow anterior canal; aperture lenticular, produced in front into a narrow, straight, and open canal; outer lip gently arcuate and faintly denticulate; inner lip excavated and washed with callus; columella marked with three low, oblique plaits.

An imperfect individual measures in altitude of body, 35 millimeters; maximum diameter, 17 millimeters.

This species is well characterized by very slender shells, which have strong widely spaced axial costae overriden by numerous rough spiral threads.

Occurrence. Ripley formation, Dave Weeks place on Coon Creek, McNairy County, Tenn.

Collection: U. S. National Museum.

\section{Family VASIDAE}

\section{Genus XANCUS Bolten}

Xancus major Wade, n. sp.

Plate XLIII, Figures 1, 2; Plate XLIV, Figures 1, 2

Shell large and pyriform in outline; spire low but acute in the apex, its elevation less than one-fourth the total altitude of the shell, spiral angle increasing greatly with age; whorls, four or five, closely appressed; sculpture elaborate and rough; dominantly spiral; axials irregular, consisting of broad rounded ribs on the portion of the whorls of greatest diameter; ribs evanesce within a short distance on the anterior slope of the body and are absent on a narrow spiral ridge and a concave sulcus between the shoulder and suture; the posterior extremities of the axial ribs show on the whorls of the spire, 14 on the penultima; incremental lines numerous and well defined, intersecting the spiral depression and elevations, giving the shell a roughened surface; spiral sculpture consisting of strong elevated threads irregularly spaced and overriding the spirals, 5 on the penultima and more than 25 on the body and the anterior canal; on the anterior slope of the body whorl of the type is a band with no well-defined spirals occupying a space the width of about four spirals and interspirals; spiral depressions wider than the spiral ridges and becoming wider on the anterior canal, where a few secondary spirals occur; directly in front of the suture is a spiral ridge marked by incrementals of the posterior sinus; suture appressed; body inflated and well rounded, abruptly constricted posteriorly to form an obscure shoulder and sloping steeply in front into a broad anterior canal; aperture ovate, produced anteriorly into a broad, open canal; outer lip thin and simple; inner lip broadly excavated in the middle and reflected on the anterior part of the pillar; columella marked by two distinct but not strong plications; pillar broad and slightly curved; anterior fasciole indistinct. Altitude, 76.8 millimeters; elevation of spire, 10 millimeters; maximum diameter, 44.7 millimeters.

This species is well characterized by its much inflated, well-rounded body and further by its spiral ridges, which are roughened by the intersection with the incremental lines.

Occurrence: Ripley formation, Dave Weeks place on Coon Creek, McNairy County, Tenn.

Collection: U. S. National Museum.

\section{Xancus variabilis Wade, n. sp. \\ Plate XLIV, Figures 3, 4}

Shell fairly large and strong, pyriform in outline; spire low, about one-fourth the total altitude of the shell, pointed at the apex; whorls of conch five or six, increasing markedly in size to a much inflated body; sculpture vigorous, consisting of both axials and spirals; axial ribs strong, about 15 on the ultima, persisting from the shoulder to the anterior slope of the body; only the posterior extremities of the ribs show on the whorls of the spine, axial ribs irregular in strength and spacing; axials overriden by strong spiral threads or rounded fillets, 13 to 15 fillets on the body and pillar, 1 to 3 on the whorls of the spire; fillets stronger on crest of the axial elevations than on axial depression; fillets and spiral interspaces of about the same width on the posterior half of the body, but interspaces become wider on the anterior slope of the body and the anterior canal; on the anterior slope of the body there is a spiral band with no ornamentation except incremental lines, which occupies an area equal to about two spiral fillets; between the shoulder and the suture there is a similar band, unornamented. except for incremental lines; suture appressed; body inflated abruptly, constricted posteriorly and less so anteriorly, thus giving a subrectangular profile to the left side of the body; anterior slope of the body steep, merging into a narrow anterior canal; aperture ovate, produced anteriorly into a narrow canal and notched posteriorly just in front of the suture; outer lip reflected; columella marked by two to five plications, close and well defined but not strong; parietal wall covered with a broad area of callus. Altitude, 38.9 millimeters; elevation of the spire, 9.5 millimeters; maximum diameter, 24 millimeters. 
This species is common at Coon Creek and is represented in the present collection by a number of wellpreserved individuals which show much variation in ornamentation of the external surface, in profile, and in number of columellar plications. This species differs from Xancus major not only in size but in having a body that is not so well rounded anteriorly and further an external surface not roughened by numerous incremental lines as in that species. The columellar plications on this species are variable in number, prominence, and development. "These folds are invisible in the apertures of many specimens and can not be observed without sectioning the spire. In sculpture and general outline Xancus variabilis closely resembles Pyrifusus subdensatus Conrad ${ }^{42}$ and related species of that genus and may be easily confused with those forms if the diagnostic columellar plications are not observed. The species Rapa monheimi Müller, from the Senonian of Vaals, Germany, which has been referred to Conrad's genus Hercorhynchus by Cossmann, ${ }^{43}$ presents a general form and sculpture that readily suggests the form from Tennessee, Xancus variabilis, but no columellar folds are known to exist on Rapa monheimi.

Occurrence: Ripley formation, Dave Weeks place on Coon Creek, McNairy County, Tenn.

Collection: U. S. National Museum.

\section{Family FUSIDAE}

Genus FUSUS Lamarck

Fusus? monairyensis Wade, n. sp.

Plate XLIII, Figures 13, 14

Shell small and fusiform; spire elevated and acute, apex broken away in type; sculpture both axial and spiral; axials 11 on the body, consisting of strong, well-rounded, regularly spaced elevations, which persist from first spiral in front of posterior suture to anterior suture on whorls of spire but evanesce on the anterior slope of the body; spirals well defined and overriding axials, consisting of seven or eight narrow fillet-like elevated bands, which are widest on the crest of the axial costae; spiral interspaces of same width as elevated bands; spirals weaker and more crowded on the anterior slope of the body and the anterior canal; spiral elevations and depressions both slightly punctuate or roughened by the intersection of fine incremental lines; suture impressed, body evenly rounded, both posteriorly and anteriorly, merging

\footnotetext{
19 Conrad, T. A., Observations on a group of Cretaceous fossil shells, found in Tippah County, Miss.: Acad. Nat. Sci. Philadelphia Jour., 2d ser., vol. 3, p. 332, pl. 35, flg. 12, 1958.

${ }^{3}$ Cossmann, Maurice, Essais de paléonconchologie comparée, pt. 4, p. 73, pl. 2, flg. 21, 1901 .
}

in front into a long, narrow anterior canal, which is nearly straight; aperture lenticular and produced anteriorly into a long, narrow canal; outer lip broken away; inner lip excavated at the base of the body; columella smooth, its anterior extremity excavated by the anterior canal, leaving a very thin knife-edge along the front part of the pillar; parietal wall covered with a thin coat of callus. An imperfect individual measures in altitude 19.4 millimeters; length of aperture and canal, 11.9 millimeters; maximum diameter, 7.2 millimeters.

Only one specimen of this species is known, but although an imperfect individual it is sufficient to show the well-defined axial and spiral sculpture of the form and the unusual anterior extremity of its columella. The features of the shell are those of a Fusus, but no form near the species Fusus? mcnairyensis has been found described in the literature, so the form is questionably referred to Fusus.

Occurrence: Ripley formation, Dave Weeks place on Coon Creek, McNairy County, Tenn.

Collection: U. S. National Museum.

\section{Genus anomalofusus Wade}

1916. Anomalofusus. Wade, Acad. Nat. Sci. Philadelphia

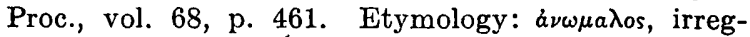
ular; Fusus, a genus of gastropods. Type: Fusus (Anomalofusus) substriatus Wade.

Shell of medium size and elongate, fusiform in outline; spire acuminate and of approximately the same length as the aperture; protoconch naticoid and smooth, coiled about three times; axials most prominent ornamentation, costae irregular in size and spacing; spiral sculpture consisting of many fine elevated lirae of different sizes, which override axials; suture impressed, aperture lenticular and produced anteriorly into a canal; outer lip thickened and dentate within, broadly notched between suture and medial part of outer margin of aperture; inner lip thinly calloused, columella smooth and slightly sinuous.

The nuclear characters, sharp cancellate sculpture, and intermediately thickened outer lip, which is broadly notched in front of the suture, seem to assign this form to the rank of a subgenus under Fusus. This form bears some resemblance to Phos in general outline but is much more slender. Phos is characterized by a columella which is much more sharply twisted. Anomalofusus has a longer canal than any of the Buccinidae and lacks the abruptly excavated columella, plicate in front, which is characteristic of Phos. Besides nuclear characters, Anomalofusus differs from Fusus in its shorter canal and further by its thickened and notched outer lip. 
Anomalofusus substriatus Wade

Plate XLIV, Figures 5-7

1916. Fusus (Anomalofusus) substriatus. Wade, Acad. Nât. Sci. Philadelphia Proc., vol. 68 , p. 462 , pl. 23 , figs. $9,10,11$.

1917. Anomalofusus substriatus. Cossmann, Rev. critique paléozoologie, année 22, No. 3, p. 99.

Shell of medium size and elongate, fusiform in outline; spire acuminate and of approximately the same length as the aperture; whorls of conch three to five, roundly shouldered; protoconch naticoid and smooth, coiled about three times; external sculpture elaborate, axials predominating, costae well rounded and elevated, irregular in size and spacing, reaching from anterior to posterior suture on spiral whorls but evanescing on anterior part of body; spiral sculpture consisting of about 14 small primary elevated lirae and in each interspace there are from one to three very fine secondary lirae; primary lirae lacking on a narrow band just in front of suture; both primary and secondary lirae override costae; suture impressed; aperture lenticular and produced anteriorly into a canal; outer lip thickened and dentate within, broadly notched between suture and medial part of outer margin of aperture; inner lip calloused; columella smooth and slightly sinuous. An immature individual measures in altitude, 17.5 millimeters; length of aperture, 9.5 millimeters; maximum diameter, 7.5 millimeters; spiral angle, $35^{\circ}$.

This elegantly sculptured gastropod is abundant at Coon Creek. There is a wide range in the maturity of individuals: some have only one whorl of the conch, whereas the older ones have five whorls. The protoconch is preserved and is conspicuous on most specimens.

Occurrence: Ripley formation, Dave Weeks place on Coon Creek, McNairy County, Tenn.

Collection: U. S: National Museum.

\section{Genus ORNOPSIS Wade}

1916. Ornopsis. Wade, Acad. Nat. Sci. Philadelphia Proc., vol.

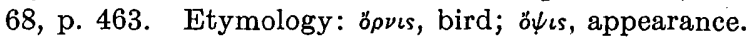
Type: Ornopsis glenni Wade.

Shell fairly large and strong; body whorl inflated: spire varying in relative altitude; protoconch very small, smooth, paucispiral, and trochoid; both axial and spiral sculpture well developed; aperture pyriform, abruptly constricted; and sinistrally inclined; outer lip marginally crenate; parietal wall washed by a callus; columella marked by a strong laterally compressed laminar plait situated at the entrance of the anterior canal.

This genus is characterized by a peculiar narrow flexed canal and a sharp laminar plait on the columella directly behind the entrance of the anterior canal. In these respects it differs from the other Fusidae.
Ornopsis elevata greatly resembles the genus Latirus in general outline but differs from it in the character of the anterior canal. Odontofusus of the Fasciolariidae has a more elevated spire, a more feeble columellar fold, and a nearly straight anterior canal. In its close compact spire Ornopsis resembles some of the Buccinidae, but here again the apertural features are distinctly different.

\section{Ornopsis glenni Wade}

Plate XLIV, Figures 8, 9, 12, 13

1916. Ornopsis glenni. Wade. Acad. Nat. Sci. Philadelphia Proc., vol. 68, p. 463, pl. 24, fig. 1 .

1917. Ornopsis glenni. Cossmann, Rev. critique paléozoologie, annee 20 , No. 3, p. 99.

Shell fairly large and strong; elevation of spire less than length of aperture; protoconch very small, smooth, paucispiral and trochoid; volutions of conch six, increasing in size from a very small apical whorl to an inflated body whorl; external ornamentation well defined, axials elevated, well rounded, and short, beginning at shoulder and quickly evanescing in front of the periphery of the body, becoming less prominent toward aperture and disappearing almost entirely in some individuals; costae of varying size and spacing, 12 on body of type; spiral lines sharply impressed, more than 30 on body whorl, becoming fine and oblique on interior canal, shoulder broad, feebly convex; suture impressed; body whorl abruptly constricted into a slender anterior canal; aperture pyriform, produced anteriorly into a narrow 'canal sinistrally inclined; outer lip sharp and marginally crenate; parietal wall washed with a callus, thickest at posterior extremity of aperture; columella flattened at the entrance of the canal into a shelf-like fold. Altitude, 48 millimeters; length of aperture and canal, 33 millimeters; maximum diameter, 24 millimeters; spiral angle $60^{\circ}$.

This form is well characterized by its pointed apex, much inflated body, and further by the flattened shelf-like fold. It is one of the most abundant gastropods at Coon Creek, being represented in the collection by many perfect specimens. It is the type of the genus and is named in honor of Dr. L. C. Glenn, professor of geology at Vanderbilt University.

Since this description was written an individual of this species has been found at Coon Creek which has a maximum diameter almost twice as great as that of the type. This large individual is incomplete, so that its altitude, which is proportionately as great as the diameter, is unknown. This large shell presents some features not common to the type of the species, but evidently it is not specifically distinct and is merely an overgrown form. It is not regarded as a normal adult, for there are dozens of apparently adult specimens in the Coon Creek collection of the same size as the type. There is a tendency for the axial depres- 
sions on the body of the large shell to disappear, thus giving the body a sort of abnormal inflation. With the disappearance of the axial depressions the posterior extremities of the axial elevations form a well-defined shelf around the body some distance in front of the suture.

Kaunhowen ${ }^{44}$ described and figured from the Maestricht Cretaceous of Europe an imperfect specimen of a species which he referred to the subgenus Hemifusus of the genus Fusus. His figure shows only the part of the shell near the aperture, but that reveals the characteristic shelf-like flexure of the columella at the base of the body as well as the coarse axial sculpture and fine spiral sculpture common to the genus Ornopsis, so that it seems probable that Fusus (Hemifusus) nereidiformis (Brinkhorst) belongs to the genus Ornopsis and may be near Ornopsis glenni.

Occurrence: Ripley formation, Dave Weeks place on Coon Creek, McNairy County, Tenn.

Collections: Johns Hopkins University, Vanderbilt University, U. S. National Museum.

\section{Ornopsis elevata Wade}

Plate XLIV, Figures 10, 11; Plate XLV, Figures 1, 2

1916. Ornopsis elevata. Wade, Acad. Nat. Sci. Fhiladelphia Proc., vol. 68, p. 464, pl. 24, figs. 2 and 3.

1917. Ornopsis elevata. Cossmann, Rev. critique paléozoologie, année 20, No. 3, p. 99.

Shell of medium size, rugose; spire elevated, its altitude approximately the same as the length of the aperture; protoconch broken away; external sculpture dominantly axial; the costae elevated and rounded, highest upon the shoulder, becoming faint tow ard the anterior, evanescent anteriorly, and absent altogether upon the posterior fasciole, about 12 on body whorl, irregularly spaced toward aperture; space between shoulder and posterior suture separated by slightly narrower concave intercostals; spiral sculpture of rather low, crowded lirae separated by deeply impressed lines, about 20 on body whorl; lirae as well marked on the summit of the axials as in intercostal spaces; suture line. impressed; body whorl smoothly constricted anteriorly into a narrow anterior canal; posterior part of aperture ovate but broken anteriorly by a rather long, narrow anterior canal; inner lip calloused; columella flattened at the entrance of the canal into a flat shelf-like fold. Altitude, 34.5 millimeters; maximum diameter, 17.2 millimeters; spiral angle, $44^{\circ} 51^{\prime}$.

This species differs from Ornopsis glenni in possessing a higher, more acuminate spire and a less inflated body whorl.

More recent collecting at Coon Creek has afforded several perfect specimens, which reveal the characters

4 Kaunhowen, Fredrich, Die Gastropoden der Maestrichter Kreide: Palaeont. Abh. (Dames \& Koken), Band 8 (Neve Folge, Band 4), Heft 1, p. 88, pl.13; fig, 13,
1807 .

$106913-26 \dagger-9$ of the anterior canal of this species. The body is abruptly constricted anteriorly and merges into a very long, narrow anterior canal, which is slightly curved. Spiral sculpture occurs on this canal, but the anterior fasciole is absent in most individuals. The anterior canal is open but narrow.

Occurrence: Ripley formation, Dave Weeks place on Coon Creek, McNairy County, Tenn.

Collections: U. S. National Museum, Johns Hopkins University, Vanderbilt University.

Ornopsis digressa Wade, n. sp.

Plate XLV, Figures 3, 4

Shell of medium size and fragile; spire elevated and acuminate; whorls seven, well rounded; protoconch smooth, very small, trochoid, and coiled twice; sculpture elaborate; axial costae abruptly elevated and high on the spire but becoming low, irregular, and flexed on the body; incremental lines on the body indicate stages of a broad marginal sinus on the shoulder; spiral sculpture low and crowded, consisting of microscopically beaded lirae of unequal size, weaker both posteriorly and anteriorly but stronger on the medial portion of the body; suture impressed, sutural margin of body indicated by the band made by posterior termination of axials some distance in front of the suture; body whorl abruptly constricted into a slender anterior canal; aperture pyriform; produced anteriorly into a narrow canal sinistrally inclined; outer lip indented by a broad sinus between the suture and the shoulder; inner lip excavated at the base of the body; columella flattened or twisted at the entrance of the anterior canal into an obscure fold; parietal wall washed by a broad callus. An imperfect individual measures in altitude 39.4 millimeters; elevation of spire, 21.2 millimeters; maximum diameter, 18.5 millimeters.

This species is characterized by its fine beaded spiral lirae, which override the abruptly elevated axial costae on the spire. The whorls are evenly rounded, and the inner lip more excavated than in either Ornopsis glenni or 0 . elevata. O. digressa differs slightly from the other known species of the genus in that the shelf-like fold at the entrance of the anterior canal is not so well defined nor so conspicuous as in the other species.

Occurrence: Ripley formation, Dave Weeks place on Coon Creek; McNairy County, Tenn.

Collection: U. S. National Museum.

Geenus Stantonelda Wade, $n$. gen.

Etymology: A name given in honor of T. W. Stanton, who has contributed largely to the knowledge of the Cretaceous of the western interior of the United States. Type: Stantonella subnodosa Wade, n. gen. and sp.

Shell fairly large, strong, and rough; subfusoid in outline; spire of medium height; whorls not numerous 
but increasing markedly in size to a rather inflated body; protoconch unknown; sculpture dominantly axial, the costae interrupted in front of the sutural line by a well-defined narrow fasciole; aperture lenticular, produced in front into a short, open canal; outer lip smooth and broadly arcuate; inner lip excavated medially, commonly calloused; columella smooth, slightly flexed or enlarged at the entrance of the anterior canal; pillar short and strong.

This new genus is proposed to include a group of univalves known from two species-the type, from the Ripley formation of Tennessee, and the species Chemnitzia interrupta Conrad, ${ }^{45}$ from the Ripley at $\mathrm{Owl}^{-}$ Creek, Miss., a species only provisionally assigned to the genus Chemnitzia. The genus Stantonella is well characterized by a slightly inflated body whorl, strong axial sculpture, a well-defined posterior fasciole, and a smooth columella. No very closely related form is known. In many respects it resembles certain of the Volutidae, but its columella is smooth. Perhaps it belongs to the Fusidae that are distantly related to Ornopsis; however, its columella is entirely different from the columella of that genus.

\section{Stantonella subnodosa Wade, n. sp.}

\section{Plate XLV, Figures 7, 8}

Shell fairly large, strong, and rugose, subfusoid in outline; spire elevated but rather low; whorls about five or six, closely appressed and increasing in size markedly to an inflated body; sculpture elaborate, consisting of strong axial costae and smaller, more numerous spiral threads; 15 axial costae on the body of the type, strong and subnodose at the posterior extremities just in front of the sutural fasciole, irregular but strong on the medial portion of the body whorl and evanescing on its anterior slope; spirals impressed and irregularly spaced; posterior fasciole prominent and made rough by numerous axial lines; suture impressed, wavy, and irregular; body slightly inflated, doubly shouldered behind and gently constricted in front into a short anterior canal; aperture lenticular, produced in front into a short, open canal; outer lip arcuate, smooth within; inner lip excavated, thinly washed with callus; pillar short and strong; anterior fasciole not definitely defined. Altitude, 44 millimeters; maximum diameter, 26 millimeters.

This species is well characterized by its axial and spiral sculpture and posterior fasciole. It is somewhat similar to Stantonella interrupta (Conrad) ${ }^{46}$ but may be readily distinguished from that form by its less inflated body. The posterior fasciole of the species from Mississippi is distinctly nodose, whereas the fasciole of

4s Conrad, T. A., Observations on a group of Cretaceous fossil shells found in Tippah County, Miss.: Acad. Nat. Sci. Philadelphia Jour., 2d ser., vol. 3, p. 333, pl. 35, flg. 15, 1858.

is Conrad, T. A., op. cit., p. 333, p. 35, flg. 15 the species from Tennessee is merely roughened by numerous axial lines.

Occurrence: Ripley formation, Dave Weeks place on Coon Creek, McNairy County, Tenn.

Collection: U. S. National Museum.

$$
\begin{gathered}
\text { Genus EXILIA Conrad, } \\
\text { Exilia ripleyana Wade, n. sp. } \\
\text { Plate XLV, Figures } 13,14
\end{gathered}
$$

Shell small and fusiform in outline; spire elevated and acute; whorls convex and increasing in size gradually; apex broken away; protoconch unknown; sculpture both axial and spiral; axials dominant, abruptly elevated and somewhat rounded costae, about 16 on the body, axial costae slightly protractive and flexuous, equally spaced, persistent from suture to suture on whorls of spire but evanescing on the anterior part of the body; axials overridden by crowded equispaced threadlike spiral lirae, which are microscopically nodulated by the intersection with incremental lines; suture distinctly impressed; body constricted in front and sloping into a straight, narrow canal; aperture narrow and lenticular, produced in front into an open canal; outer lip thin and arcuate; inner lip excavated at the base of the body; columella smooth; parietal wall thinly glazed with callus; anterior canal pointed at the anterior extremity.

An imperfect individual measures in altitude 8.5 millimeters; maximum diameter, 3 millimeters.

This is the second species of this genus to be described from the Cretaceous of America. Exilia cretacea Gardner, ${ }^{47}$ from the Monmouth formation of Maryland, was the first. The Tennessee species differs from the Maryland form in having a less abruptly constricted body and further in the character of the spiral ornamentation.

Occurrence: Ripley formation, Dave Weeks place on Coon Creek, McNairy County, Tenn.

Collection: U. S. National Museum.

\section{Genus FALSIFUSUS Grabau 48 \\ Falsifusus mesozoicus Wade}

Plate XLV, Figures 5, 6

1917. Falsifusus mesozoicus. Wade, Acad. Nat. Sci. Philadelphia Proc., vol. 69, p. 284, pl. 17, figs. 11, 12.

1918. Falsifusus mesozoicus. Cossmann, Rev. critique paleozoologie, annee 22, Nos. 1-2, p. 20.

Shell small and fragile, fusiform in outline, spire elevated and acute, anterior canal very long, slender and straight; elevation of spire much less than length of aperture and canal; angle of spire increasing with age; whorls five, closely appressed, whorls of spire

"Gardner, J. A., Maryland Geol. Survey, Upper Cretaceous, p. 464, pl. 14, flg. $13,1916$.

8 Grabau, A. W., Phylogeny of Fusus andi ts allies: Smithsonian Misc. Coll., vol. 44, p. 80, 1904. 
sharply convex or subangular in cross section; body inflated; protoconch small, smooth, and trochoid, coiled three times; scuplture of body axial and spiral; axials strong, about 10 on the body; axial ribs angular and spinose on the keel of the shoulder of the body but well rounded or nodulated on the whorls of the spire; axials absent on the shoulder and obsolete on the base of the body; spiral sculpture elaborate and may be described in groups as follows: Half a dozen subequal lirae on the shoulder, three on the sides of the whorls of the spire, including the spiral, which outlines the periphery; twice as many on the medial portion of the body with intercalated secondaries; four or five irregular and obscure spirals on the posterior portion of the base; four stronger equal and equispaced lirae upon the anterior portion of the base; about a dozen increasingly finer spirals upon the pillar; suture impressed and undulated by the costae of the preceding whorl; body abruptly constricted anteriorly. into a long, slender anterior canal; aperture narrow, ovate, produced in front into a long, narrow canal with proximate, parallel margins; outer lip thin and simple; inner lip excavated at the base of the body; columella smooth, slightly twisted at the entrance of the anterior canal; parietal wall thinly glazed. Altitude, 20.4 millimeters; maximum diameter, 8.2 millimeters.

The slender and fragile shells of this species are well characterized by the spinose terminations of the axials along the shoulder angle of the body, the elaborate spiral sculpture, and the slightly bent slender pillar. The Maestrichtian species Fusus bicinctus Kaunhowen, ${ }^{49}$ from Belgium, is probably a related species of this genus. Kaunhowen's species has a higher spire and a much longer pillar than the species from Tennessee and resembles the type of the genus more closely. These two species are the first Upper Cretaceous forms to be referred to Grabau's genus Falsifusus.

Occurrence: Ripley formation, Dave Weeks place on Coon Creek, McNairy County, Tenn.

Collections: Johns Hopkins University, U. S. National Museum.

\section{Falsifusus convexus Wade, n. sp.}

Plate XLV, Figures 11, 12

Shell of medium size and fusiform in outline; spire elevated but its altitude less than the length of the aperture and the anterior canal; whorls five or six, closely appressed and very convex, increasing gradually in size; angle of spire constant; protoconch broken away; sculpture subdued; axial costae 11, low and well rounded, strongest on the periphery, absent both on the sutural margin and the anterior slope of

10 Kaunhowen, Friedrich, Dle Gastrcpoden der Maestrichter Krelde: Palaeont. Abh. (Dames \& Koken), Band 8 (neue Folge, Band 4, Heft 1), p. 82, pl. 10, fgs. 1, $2,3,4,1887$. the body, irregularly spaced; interaxial spaces broadly concave and wider than the costal ridges; spiral threads low and closely spaced, overriding the axials, more than 30 on the body and pillar, a group of eight very closely spaced spiral threads forming a conspicuous band at the base of the body; body well rounded or convex, constricted equally both in front and behind, merging rapidly in front into a narrow anterior canal; aperture broad and ovate, with proximate, parallel margins; outer lip well rounded and simple; inner lip excavated medially; parietal wall glazed; columella smooth, slightly twisted or reinforced with a callus at the entrance of the anterior canal. An individual with pillar broken away at the entrance of the anterior canal measures in altitude, 18.6 millimeters; maximum diameter 11.7 millimeters.

This species is represented in the present collection by two individuals, both of which are imperfect. The species is well characterized by its convex whorls and the band of crowded spiral lirae at the base of the body. It is larger than Falsifusus mesozoicus, and its whorls are more convex. Its spiral sculpture differs very much in detail from that of the other Coon Creek species of this genus.

Occurrence: Ripley formation, Dave Weeks place on Coon Creek, McNairy County, Tenn.

Collection: U. S. National Museum.

Genus WOODSELra Wade, n. gen.

Etymology: Name given in honor of Henry Woods, of Cambridge, England, who has contributed largely to the knowledge of Cretaceous Mollusca. Type: Woodsella typica Wade, n. sp.

Shell of medium size and strong, fusiform in outline; body. whorl only slightly inflated; elevation of spire about equal to the length of the aperture and the anterior canal; whorls closely appressed, increasing gradually in size; posterior part of whorls has a concave depression or sulcus, with a tumid margin or ridge near the suture; protoconch small; sculpture strong, axial and spiral elements both present, the former most prominent; aperture pyriform, outer lip simple or crenulate; parietal wall washed with callus; columella reinforced near the entrance of the anterior canal; anterior canal strong, slightly curved in the type.

This new genus is proposed to include a group of forms known from two species-the type, from Coon Creek, Tenn., and Voluta rigida Bailey, ${ }^{50}$ from the Senonian of Pondoland, South Africa. A form from the Cretaceous of India, to which the name rigida has also been applied, differs from the African species in having columellar plaits and has therefore been assigned by different authors to such genera as Voluta,

so Bailey, W. H., Description of some Cretaceous fossils from South Africa: Geol. Soc. London Quart. Jour., vol. 11, p. 459, pl. 12, fig. 4, 1855. Woods, Henry, The Cretaceous fauna of Pondoland: South African Mus. Annals, vol. 4, pt. 7, p. 321, pl. 39, fig. 2; pl. 40, flg. 1, 1906. 
Fasciolaria, Rostellites, and Cryptorhytis, all of which are characterized by columellar plaits. The two species for which this new generic group is proposed have smooth columellas. They resemble the type species of Ornopsis, of the Fusidae, but lack the characteristic sharp fold on the columella at the entrance of the anterior canal, which is typical of that genus. Woodsella is less fulguroid in outline than Boltenella of the Busyconidae. It probably belongs to the Fusidae near Falsifusus or Serrifusus, both of which are represented by Ripley species.

Woodsella typica Wade, n. sp.

Plate XLVI, Figures 1, 5

Shell fairly large and strong; fusiform in outline; spire elevated, its height about equal to the length of the aperture and the anterior canal; whorls about five, closely appressed, increasing gradually in size to a slightly inflated body, posterior part of whorls with a concave depression or sulcus, having a tumid margin or ridge near the suture; protoconch unknown; sculpture well developed, both axial and spiral elements present; 10 axial ridges on the body, very strong on the shoulder and the medial portions of the whorls but evanescing anteriorly and posteriorly; growth lines parallel to the axial ridges common near the aperture; very numerous low spiral threads override the axial ridges and cover the entire shell except a small area on the anterior portion of the canal; aperture pyriform; outer lip thin; inner lip excavated; parietal wall washed with callus; columella smooth but slightly twisted or reinforced near the entrance of the anterior canal; anterior canal stout and curved anteriorly, a shallow depression or chink just in front of the curve and at the margin of the inner lip; canal narrow and open. A slightly imperfect specimen measures in altitude 41 millimeters; maximum diameter, 24 millimeters; length of aperture and canal, 29 millimeters.

This species is well characterized by the strong axial costae and its low spiral threads. It differs from Woodsella rigida (Bailey), ${ }^{51}$ the other known species of this genus, in having a more inflated body, lower spiral threads, and a more curved canal.

Occurrence: Ripley formation, Dave Weeks place on Coon Creek, McNairy County, Tenn.

Collection: U. S. National Museum.

\section{Family FascrorarIrdaE}

\section{Genus ODONTOFUSUS Whitfleld}

Odontofusus curvicostata Wade, n. sp.

Plate XLII, Figures 7-9

Shell fairly large and fusiform; spire elevated and acute; whorls five or six, closely appressed, well rounded in early volutions but obtusely shouldered

u Woods, Henry, op. cit., p. 321, pl. 39, figs. 2a, b, c; pl. 40, fig. 1,1906 in later volutions, increasing markedly in size; protoconch trochoid and small and smooth, coiled twice; sculpture dominantly axial, costae abruptly elevated, strong and flexuous, regular on earlier whorls but irregular and near the aperture broken up into secondary costae and growth lines; posterior fasciole not a sharply marked band but indicated by a constriction of the whorls, the posterior evanescence of the costae and the wrinkle-like terminations of the incrementals; spiral ornamentation subdued, posteriorly consisting of very fine, crowded impressed spiral lines, which may or may not override the axial elevations and are commonly absent on the later whorls; on the anterior slope of the body there is a series of 8 or 10 strong, relatively wide and conspicuous spirals; this series merges both anteriorly and posteriorly into faint, crowded spirals; suture appressed; body slightly inflated in adult, constricted posteriorly and sloping steeply in front into a broad, slightly curved anterior canal; aperture sublenticular and produced anteriorly into an open canal; outer lip broken in types, but flexures of axial lines indicate a broad notch on the shoulder; inner lip concave medially; columella marked by a single strong fold with one to three weaker posterior plaits; parietal wall washed by a thin, wide layer of callus; pillar slightly curved but nearly straight in some individuals; anterior fasciole inconspicuous.

An immature shell of this species measures in altitude 33.6 millimeters; elevation of spire, 15.3 millimeters; maximum diameter, 15.4 millimeters. An imperfect specimen measures in elevation of spire 24.4 millimeters; maximum diameter, 25.2 millimeters.

This species is well characterized by its flexed axial sculpture and ill-defined posterior fasciole and further by its obtusely shouldered body and slightly curved anterior canal. Young individuals show an elegant beaded microscopic spiral ornamentation, which overrides the axial elevations, and furthermore young forms do not show the flexed axials, which are so well defined in adults of the species.

This species is doubtfully referred to the genus Odontofusus, for the type of that genus is a cast, and it is difficult to identify a shell by comparison with an internal cast. Whitfield ${ }^{52}$ says in his generic description that Odontofusus has a single columellar plait, and yet the Coon Creek species has one welldefined columellar plication in front of two or three feeble folds. Possibly, however, only the strong plication is preserved in the cast, and if shells of Odontofusus were known from the type locality weaker plications behind the strong fold might be observed in the columella. Weller would, no doubt, refer the Coon Creek species to this genus, for he has figured ${ }^{53}$ a very closely related species from Owl Creek, Miss.,

s2 Whitfield, R. P., Gastropoda and Cephalopoda of the Raritan clays and greensand marls of New Jersey: U. S. Geol. Survey Mon. 18, p. 65, 1892.

bs Weller Stuart, Now Jersey Geol. Survey, Paleontology, vol. 4, p. 761, fig. 6, 1907 . 
as typical of the New Jersey species Odontofusus medians Whitfield. The Owl Creek specimen figured has one weak fold behind the strong one.

Occurrence: Ripley formation, Dave Weeks place on Coon Creek, McNairy County, Tenn.

Collection: U. S. National Museum.

\section{Genus PIESTOCHILUS Meek}

- Piestochilus cancellatus Wade, n. sp.

\section{Plate XLV, Figures 15, 16}

Shell of medium size, slender, and elongate fusiform; spire elevated and acuminate, its elevation greater than half the total altitude of the shell, eight whorls closely appressed, regularly increasing in size, their sides flattened, causing the slopes of the spire to be continuous lines; protoconch partly broken away, elevated and coiled twice or more, very small; sculpture cancellate but axials not so well defined as spirals; axial ribs low, closely but irregularly spaced, about 25 on the body, persistent on whorls of the spire from suture to suture but evanescing on the anterior slope of the body; axial sculpture absent in the spiral depressions; spirals well defined, consisting of spiral fillets of varying width separated by deep, squarely channeled furrows; 6 or 7 spiral fillets on the whorls of the spire and more than 35 on the body and anterior canal; spirals feebler and more crowded on the anterior slope of the body and pillar; suture impressed; maximum diameter of the body in front of the median horizontal, body abruptly constricted in front and merging into a narrow, slightly curved anterior canal; aperture narrow and lenticular, produced into a long anterior canal; outer lip thin and simple; inner lip excavated at the base of the body; columnella reinforced with callus and marked by a single feeble plication; parietal wall glazed with callus along the inner margin of the aperture. Altitude, 39.2 millimeters; elevation of spire, 20.4 millimeters; maximum diameter, 9.2 millimeters.

There are three or four well-preserved specimens of this elegant species in the present Coon Creek collection. The species is well characterized by the cancellate sculpture and the acuminate spire, the slopes of which are straight lines.

Occurrence: Ripley formation, Dave Weeks place on Coon Creek, McNairy County, Tenn.

Collection: U. S. National Museum.

Piestochilus pergracilis Wade, n. sp.

Plate XLV, Figures 9, 10

Shell large, very slender, fusiform and biacuminate; spire elevated and very acute, its elevation much more shan half the total altitude of the shell; whorls 10 or 12 , elongated and flatly biconvex in profile, increasing gradually in size; protoconch small, naticoid, coiled two and a half times; sculpture elaborate, consisting of axial and spiral ornamentation on the body; axial costae strong, well rounded, equispaced and persistent from suture to suture on early whorls but becoming irregular and disappearing entirely on the body; numerous incremental lines well defined on the body; spirals consisting of narrow rectangular fillets, 8 on the whorls of the spire and more than 25 on the body; interspiral depressions and spiral elevations of equal width on whorls of the spire but becoming irregular on the later whorls; spirals crowded and not sharply defined on the anterior slope of the body and pillar; spiral elevations override axial costae; suture impressed; body not shouldered and sloping gradually into a long, narrow, straight anterior canal; aperture lanceolate; outer lip thin, its margin very broadly sinuous some distance in front of the suture, as indicated by incremental lines; inner lip excavated at the base of the body and straight along the margin of the pillar; columella marked by a single distinct but feeble oblique plication behind which in some individuals are two very indistinct plications; parietal wall washed with callus. An immature individual measures in altitude, 57.4 millimeters; elevation of spire, 31.5 millimeters; maximum diameter, 12.1 millimeters.

Some individuals of this species attain an elevation of more than 110 millimeters. The form is characterized by the very slender outline of the shell and further by the prominent axial ribs on the early whorls of the spire. The nearest known species is probably Fasciolaria (Piestochilus) culbertsoni Meek and Hayden, ${ }^{54}$ from the Fox Hills sandstone of South Dakota. The species from Tennessee differs from the one from Montana, however, in the character of the spiral sculpture and in possessing well-defined axial ribs on the spire, which are absent on the later whorls of the species from Montana.

Occurrence: Ripley formation, Dave Weeks place on Coon Creek, McNairy County, Tenn.

Collection: U. S. National Museum.

\section{Genus CRYPTORHYTIS Meek}

Cryptorhytis nobilis Wade, n. sp.

Plate XLVI, Figures 3, 4

Shell of medium size and strong, fusiform in outline; spire elevated, its height less than half the total altitude of the shell; whorls of conch six, closely appressed and increasing in size rather markedly; protoconch very small, trochoid, coiled twice; sculpture elaborate, axials dominant, consisting of short, abruptly elevated costae on the part of the whorl of maximum diameter; costae begin abruptly on the shoulder some distance in front of the suture and evanesce abruptly on the anterior slope of the body; sutural margin marked by numerous wrinkle-like axial lines between the shoulder and suture, forming a

st Meek, F. B., A report on the invertebrate Cretaceous and Tertiary fossils of the upper Missouri country: U S. Geol. Survey Terr. Rept., vol. 9, p. 360, pl. 32, 0g. $1,1876$. 
band which simulates a fasciolar band; spiral sculpture crowded, consisting of impressed lirae, very numerous and submicroscopic in size, on the posterior half of the body, but coarser and more distant on the anterior slope of the body, becoming fine and closeset again on the anterior canal; suture impressed and nodulating; body abruptly constricted posteriorly between the shoulder and the suture and sloping steeply in front into a broad, slightly recurved anterior canal; aperture lenticular and produced anteriorly into a gently curved canal; outer lip simple; inner lip excavated at the base of the body; columella marked by one to three plaits; parietal wall thinly glazed; anterior fasciole inconspicuous. Altitude, 32.9 millimeters; elevation of șpire, 14.4 millimeters; maximum diameter, 14.2 millimeters.

This species is common in the Coon Creek beds and is represented in the present collection by a number of well-preserved specimens. It is characterized by a crowded, submicroscopic spiral sculpture and further by its slightly curved pillar and inconspicuous anterior fasciole. Cryptorhytis nobitis is probably closely related to $C$. flexicostata Meek and Hayden, ${ }^{55}$ from the Fox Hills sandstone of the upper Missouri Cretaceous. The western species, however, has a single plait on the columella, whereas the forms from Tennessee have two or more. The ornamentations of the external surfaces are analogous, though different in detail. Meek refers this genus to the Fasciolariidae; the European authors, however, have all referred closely related forms of this group to the Volutidae. Further study of related American species with reference to European and southern Indian forms probably will determine where the genus Cryptorhytis belongs. Gabb ${ }^{50}$ has questionably referred to the genus Fasciolaria an Eocene species, Fasciolaria? io, from California, which may be distantly related to the two species from Tennessee that are here assigned to the genus Cryptorhytis.

Occurrence: Ripley formation, Dave Weeks place on Coon Creek, McNairy County, Tenn.

Collections: U. S. National Museum, Johns Hopkins University, Vanderbilt University.

\section{Cryptorhytis torta Wade, n. sp.}

Plate XLVI, Figures 9, 10

Shell of medium size and strong, fusiform in outline; spire elevated, its elevation a little less than half the total altitude of the shell; whorls of conch five or six, closely appressed and increasing gradually in size; protoconch broken away, its scar small; sculpture elaborate, axials dominant, consisting of short, abruptly elevated curved costae on the part of the whorl of maximum diameter, costae rise on the shoulder

${ }^{35}$ Meek, F. B., op. cit., p. 367, pl. 19, fig. 2.

${ }^{s 0}$ Gabb, W. M., California Geol. Survey, Paleontology, vol. 1, p. 101, pl. 28, fig. 214, 1864, abruptly some distance in front of the suture and evanesce suddenly on the anterior slope of the body; sutural margin marked by numerous wrinkle-like axial lines, which are the posterior extremities of incremental lines; incrementals curve backward parallel to the costal elevations along the shoulder and indicate a wide marginal notch at this point; spiral sculpture crowded posteriorly, consisting of very numerous submicroscopic impressed lirae, which override the axial elevations on the whorls of the spire; spirals on anterior slope of body stronger and wider than on the posterior half of the body; suture impressed and undulating; body abruptly constricted posteriorly and sloping steeply anteriorly into a broad, much recurved anterior canal; aperture lenticular and produced anteriorly into a long, open canal; outer lip broken away, but incrementals indicate a wide notch in the shoulder; inner lip deeply and broadly excarated at the base of the body; columella marked by a single strong fold, behind which at some distance is a feeble incipient fold; parietal wall washed with a thin brilliant glaze that extends far out on the body opposite the aperture; pillar much twisted; anterior fasciole indicated by a ridge whose posterior extremity is covered with callus; umbilical chink covered with callus. A slightly imperfect individual measures in altitude, 35.4 millimeters; elevation of spire, 16.5 millimeters; maximum diameter, 17.4 millimeters.

This species is represented in the present collection by a single individual. In outline and sculpture it greatly resembles Cryptorhytis nobilis but differs from that form essentially in having a much twisted pillar, and further the axial sculpture is more curved along the shoulder of Cryptorhytis torta, and the stages of the marginal notch on the shoulder are better defined than they are in Cryptorhytis nobilis.

Occurrence: Ripley formation, Dave Weeks place on Coon Creek, McNairy County, Tenn.

Collection: U. S. National Museum.

$$
\begin{gathered}
\text { Genus MESORHYTIS Meek } \\
\text { Mesorhytis obscura Wade, n. sp. } \\
\text { Plate XLVI, Figures } 2,6
\end{gathered}
$$

Shell of medium size, rather elongate fusiform and biacuminate in outline; spire elevated, its elevation equal to about half the total altitude of the shell; whorls appressed, slightly biconvex in profile and increasing slowly in size; slopes of spire nearly straight; whorls six or seven; protoconch broken away, its scar small; sculpture cancellate, consisting of about 30 low, close-set axial ribs on the body crossed by about 30 spiral threads of nearly the same strength and spacing as the axials; spirals, however, are more irregular-some are a little broader than others, some bifid, and there are some fortuitous secondary spirals; on the anterior canal spirals are well developed, axials feeble; suture impressed; 
body slightly constricted posteriorly and sloping gently in front into a long, straight pillar; aperture lenticular, produced into a straight, open canal; outer lip thin and simple; inner lip constricted at the base of the body and straight along the pillar; columella strong and marked on the inside by two feeble folds, between which is a much weaker plication; parietal wall glazed with callus along the margin of the inner lip. Altitude, 35.4 millimeters; elevation of the spire, 18 millimeters; maximum diameter, 9.6 millimeters.

The type of the genus Mesorhytis is a species described from the Fox Hills sandstone of the Upper Cretaceous of the western interior region..$^{57}$ That species, Fasciolaria? (Mesorhytis) gracilenta Meek has three strong columellar plications, which are very conspicuous on the inner lip; the species from Tennessee has three feeble transverse plaits on the columella, which can not be seen in the aperture and may be observed only by sectioning the spire. The sculpture of the surface and the general outline of the shell, together with the three feeble columellar folds, seem sufficiently near those of the type species to refer the species from Tennessee to the same group as Fasciolaria? (Mesorhytis) gracilenta Meek. Instead of the rank of subgenus, as was proposed by Meek, the group no doubt deserves generic rank, as has been given by Cossmann. ${ }^{58}$ The species from southern India, Turricula arrialoorensis Stoliczka, ${ }^{50}$ which has been referred by Cossmann ${ }^{58}$ to the genus Mesorhytis, has strong columellar folds and well-developed axial costae on the outer surface of the shell and is more closely related apparently to Meek's type species than to the species from Tennessee under discussion.

Occurrence: Ripley formation, Dave Weeks place on Coon Creek, McNairy County, Tenn.

Collection: U. S. National Museum.

\section{Genus Fasciolaria Lamarck}

Fasciolaria? ripleyana Wade, n. sp.

Plate XL, Figures 1, 2

Shell of medium size and strong; elongate fusiform in outline; spire acuminate; whorls about six, convex or very gently shouldered; protoconch very small, elevated, coiled two and a half times; external sculpture fine and sharp, consisting of both axials and spirals, the former predominating, about 25 axials on the body whorl, consisting of sharp, irregularly spaced ridges, strongest on the shoulders of the whorls and overridden by very numerous fine spiral lines; suture appressed; aperture lenticular and produced anteriorly into a short canal; outer lip thin and smooth; inner lip calloused; columella marked

77 Meok, F. B., op. cit., p. 364, fig. 45.

o8 Cossmann, Maurice, Essaís de paléoconchologie comparée, pt. 3, p. 172, 1899.

Bo Stoliczka, Fordinand, India Geol. Survey Mem., Palaeontologia Indica, Cretacoous fauna of southern India, vol. 2, p. 104, pl. 9. figs. 15, 16, 168, 1868. by four thin, sharp, well-elevated plaits, the anterior of which is the least pronounced. Altitude, 22.5 millimeters; maximum diameter, 9 millimeters; length of aperture, 13 millimeters.

This species is well characterized by its fusiform outline, its spiral and axial sculpture, and its columella marked by four well-defined plaits. It is questionably assigned to Fasciolaria, but it possesses characters that suggest both Plejona Bolten and the well-known genus Mitra. The shell is very ordinary looking in its appearance and shell characters, but no closely related species has been found described and figured in the literature. The species is very rare at Coon Creek. Only a single individual is known in the collections, and it is, fortunately, a perfect specimen.

Occurrence: Ripley formation, Dave Weeks place on Coon Creek, McNairy County, Tenn.

Collection: U. S. National Museum.

Family PURPURIDAE

Genus MOREA Conrad

\section{Morea marylandica Gardner}

Plate LI, Figures 3,18

1916. Morea marylandica. Gardner, Maryland Geol. Survey, Upper Cretaceous, p. 466, pl. 18, fig. 13.

Miss Gardner describes this species as follows:

Shell rather small for the genus, ovate-elliptical in outline; aperture probably about two-thirds of the total altitude; spire very imperfect but probably composed of only a few flattened whorls, minutely tabulated posteriorly; body whorl slightly oblique and very feebly constricted at the base; external sculpture ornate, reticulate, the spirals dominant; axials about 25 in number, low, obtusely angulated, uniform in size and spacing, separated by intercostals of approximately equal width; spirals low, flattened fillets, 12 in number on the body of the type, for the most part equisized and equispaced, overriding the costals and somewhat nodulated at the intersections; areas included between the costals and spirals forming a series of squarish pits; space between the two posterior spirals upon the ultima wider than the rest and quite strongly concave, cut up by the costae into numerous rectangular pits; aperture rather narrow; outer lip broadly arcuate; parietal wash very heavy; siphonal fasciole distinct; anterior extremity ,emarginate; other apertural characters concealed by the solid matrix.

Dimensions (imperfect specimen): Altitude, 19 millimeters; maximum diameter, 12 millimeters.

Type locality: Two miles southwest of Oxon Hill, on Mrs. Linton's branch, Prince Georges County [Md.].

This species runs smaller and relatively more elongate than its southern analogue, $M$. cancellaria Conrad. In general aspect it is much less rude and heavy than Conrad's species, and the external sculpture, though similar in character, is much finer and more delicate.

Occurrence: Ripley formation, Dave Weeks place on Coon Creek, McNairy County, Tenn.

Collections: Maryland Geological Survey, U. S. National Museum.

Outside distribution: Monmouth formation, Prince Georges County, Md. 


\section{Morea cancellaria Conrad}

Plate LI, Figures 11, 12

1860. Morea cancellaria. Conrad, Acad. Nat. Sci. Philadelphia Jour., 2d ser., vol. 4, p. 290, pl. 40, fig. 30.

1914. Morea cancellaria. Stephenson, U. S. Geol. Survey Prof. Paper 81, check list, table 2.

Conrad describes this species as follows:

Cancellate; revolving furrows profound, equal except on the shoulder; where the lines cross the ribs they form square tubercles; ribs eight on the body, whorl; spire short, conical; whorls four, lower whorl tricostate; base finely bicarinate with transverse, curved lines; umbilicus channel angulo-concave, long and narrow; aperture elliptical; labrum margin crenate or waved. Length, 1 inch; width, five-eighths inch.

A beautiful shell, with a widely reflexed labium, and the tubercles showing through the deposit on the upper part.

Shell of medium size; ovate-elliptical in outline, conspicuously cancellate; spire low, its elevation less than a third the total altitude of the shell; whorls four, increasing markedly in size, slightly tabulated anteriorly; sculpture cancellate, spiral element a little stronger; axials 26 on the body, uniform in size and spacing, retractive, persistent on the body from suture to ridge of anterior fasciole; costae separated by intercostals of approximately equal width; spirals strong, consisting of eight fillets, equal in width and spacing, interspiral furrows deep and wider than fillets; intersections of spiral and axial elevations form low, flat rectangular tubercles; the posterior margin of the body consists of a strong cordlike ridge crossed very obliquely by the posterior extremities of the axial costae; the spiral depression in front of this cordlike ridge is broad and deep; suture open and deeply impressed; body slightly oblique and constricted a little at the anterior extremity, where it terminates in a well-rounded anterior fasciole or umbilical keel, marked by numerous incremental ines; aperture lenticular, notched anteriorly; outer lip thin and crenulated; inner lip reflected and heavily calloused; columella marked by a single very oblique fold near the base of the body; umbilicus narrow and shallow, partly filled by the reflected inner lip.

Occurrence: Ripley formation, Dave Weeks place on Coon Creek, McNairy County, Tenn.

Collections: U. S. National Museum, Johns Hopkins University.

Outside distribution: Ripley formation, Eufaula, Ala., and Owl Creek, Tippah County, Miss.

\section{Genus Paramorea Wade}

1917. Paramorea. Wade, Acad. Nat. Sci. Philadelphia Proc.,

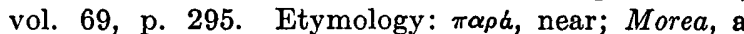
genus of gastropods. Type: Paramorea lirata Wade.

Shell small and porcelaneous, ovate-conic in outline; spire acute, less than half the total altitude of the shell; protoconch scar small; conch solid and slightly glazed, paucispiral; axial sculpture absent; spiral sculpture well defined; aperture ovate, deeply notched in front; outer lip well rounded, its margin simple or slightly crenulated; inner lip excavated and thinly glazed; columella slender and marked by a feeble oblique plait or twist of the pillar near the anterior extremity; unibilical chink narrow, oblique, and deep; canal short and broad.

This genus is proposed to include a single species from Coon Creek which seems to represent a group of univalves related to Morea. This species is well characterized by its sharp spiral sculpture, deeply notched aperture, and further by its very oblique and narrow umbilicus or umbilical chink with a general aspect and generic features that do not allow it to fit naturally into any known genus of related shells. The type of the genus Morea $^{60}$ was described from the Ripley formation. Two or three species other than the type also occur at that horizon, so that it is not surprising to find another group related to this unique genus in the Upper Cretaceous of the Southeastern States. The genus Paramorea differs from Morea in having instead of a well-defined umbilicus a narrow and oblique chink; in the development of only spiral ornamentation, instead of both spiral and axial; in the acute spire; and in the absence of a strongly reflected inner lip, such as that of Morea. In general aspect-that is, in the acute spire, strong spiral sculpture, and narrow umbilicus - this genus greatly resembles Trichotropis in features such as are presented by the recent North Atlantic species Trichotropis borealis Broderip and Sowerby, ${ }^{61}$ but it differs from that form in having a strong anterior notch or short open canal. In 1889 C. A. White described and figured from the Chico series of Shasta County, Calif., a species represented by an imperfect specimen which he questionably referred to the genus Stomatia. This form, Stomatia obstricta White, ${ }^{82}$ although it is represented by a cast, presents an outline together with a spiral ornamentation and an indication of an umbilical chink which suggest the genus Paramorea. Until more perfect specimens of the California species are known its generic position will probably remain uncertain.

\section{Paramorea lirata Wade}

Plate LII, Figures 1, 2

1917. Paramorea lirata. Wade, Acad. Nat. Sci. Philadelphia Proc., vol. 69, p. 296, pl. 17, figs. 9, 10.

1918. Paramorea lirata. Cossmann, Rev. critique paléozoologie, année 22, Nos. 1-2, p. 21.

Shell small and porcelaneous, ovate-conic in outline; spire acute, its elevation a little less than the length

60 Conrad, T. A., Descriptions of new species of Cretaceous and Eocene fossils of Mississippi and Alabama: Acad. Nat. Sci. Phtiadelphia Jour., 2d ser., vol. 4, p. 290, pl. 46, fig. 30, 1860.

61 Adams, H. and A., Genera of Recent Mollusca, vol. 1, p. 279, pl. 29, fig. 6, 1858

02 White, C. A., On invertebrate fossils from thelPacific coast: U. S. Geol. Survey Bull. 51, p. 18, pl. 4, figs. 10, 11, 1889. 
of the aperture; whorls closely appressed and shouldered, increasing in size rather markedly; protoconch scar small; sculpture sharply spiral, consisting of 6 well-defined lirae on the penult and 13 on the ultima; lirae strongest and most widely spaced on the posterior edge of the whorls; on the anterior portion of the body the spiral threads are closely spaced, the interspaces being narrower than the lirae; lirae intersected and slightly interrupted by incremental lines; suture distinct; body abruptly constricted posteriorly, forming a narrow shoulder; body convex medially and well rounded in front; aperture ovate, deeply notched anteriorly; outer lip evenly rounded, very slightly crenulated along the margin, subangular and a little thickened at the entrance of the anterior canal; inner lip excavated; parietal wall washed with a thin callus; columella slender, marked by a very feeble and oblique fold or twist of the pillar near the anterior extremity; umbilical chink very narrow and oblique, the last of the body spirals abnormal and constituting an obtuse umbilical keel; anterior canal short and open. Altitude, 7.3 millimeters; maximum diameter, 4.7 millimeters

Only a few individuals of this elegant little species, which is the type of the genus, are known. They are well characterized by their spiral ornamentation, by the deeply notched aperture, and further by the very oblique and narrow umbilical chink. The shell material is porcelaneous and hard. One of the specimens has a brownish axial banding fixed in the shell material, which seems to be a remnant of an ancient color pattern.

Occurrence: Ripley formation, Dave Weeks place on Coon Creek, McNairy County, Tenn.

Collections: Johns Hopkins University, U. S. Na-॰ tional Museum.

\section{Genus ECPHORA Conrad}

\section{Ecphora proquadricostata Wade}

\section{Plate LII, Figure 3 .}

1917. Ecphora proquadricostata. Acad. Nat. Sci. Philadelphia Proc., vol. 69, p. 293, pl. 18, fig. 7.

1918. Ecphora proquadricostata. Cossmann, Rev. critique paléozoologie, année 22, Nos. 1-2, p. 21.

Shell small and fragile, umbilicate pyriform; spire depressed; four or five whorls, increasing markedly in size; line of separation between conch and protoconch not sharply marked, two and a half nuclear turns; the initial turn is minute and completely submerged in the rounded second whorl, which becomes increasingly higher toward its close; the shoulder angle commences at the beginning of the third turn, and toward the close of this turn this angle develops into a spiral; sculpture spiral, consisting of four regularly spaced and abruptly elevated narrow spiral ridges on the body whorl and only two on the volutions of the spire; interspiral spaces concave and pro- found, approximately twice as wide as the spirals; spiral depressions crossed by numerous faint incremental lines; suture line appressed and following the second spiral; body laterally expanded, equally strongly constricted anteriorly and posteriorly, forming a broad shoulder behind and a decided constriction at the base of the body; aperture subcircular, produced in front into a short, slightly curved canal with proximate parallel margins; outer lip thickened a little along the margin, serrated by the extremities of the four spiral ridges, shallow sulcus occurring on the inner surface beneath each spiral ridge of the outer surface; two low denticles developed between each pair of sulci along the inner margin of the outer lip; inner lip broadly excavated at the base of the body, sharply angulated at the entrance of the anterior canal; umbilicus profound; umbilical keel prominent, slightly varicose and flaring. Altitude, 11.4 millimeters; maximum diameter, 9.5 millimeters.

This species is well characterized by its low but acute spire, by its four strong spiral ridges, and further by a slightly dentate inner margin of the outer lip. It is represented in the collection from Coon Creek by four or five specimens; the one selected for the type is perfectly preserved, and its generic relations can hardly be doubted. This elegant little species is of special interest, for it is the first representative of this genus, so well known in the later Tertiary of the Atlantic Coastal Plain, to be found in the Upper Cretaceous. No Eocene representatives are known from the Coastal Plain of the United States, so that the discovery of a typical Ecphora in the Upper Cretaceous indicates that species of this well-known genus may be expected in the earliest Tertiary marine sediments of the southeastern United States. About half a dozen species of Ecphora from the Oligocene and the Miocene are given in 1903 by Cossmann ${ }^{63}$ as follows:

Oligocene:

Stenomphalus cancellatus Sandberg. France.

Rapana tampaensis Dall. United States.

Peristernia succincta T. Woods. Australia. Miocene:

Ecphora quadricostata Conrad. United States.

Stenomphalus wiechmanni Von Koenen. Germany.

Rapana moulinsi Brochon. France.

The protoconch of Ecphora proquadricostata is similar to that of E. quadricostata Conrad, ${ }^{84}$ the type of the genus, though different in detail. Both are small; shelly, coiled two and a half times, and not sharply differentiated from the conchs. Both nuclei are elevated or trochoid, but that of the type species is the higher. The apical tips or initial points of the protoconchs of both species are immersed in the later

${ }^{63}$ Cossmann, Maurice, Essais de paléoconchologie comparêe, pt. 5, pp. 64, 65, 1903 ${ }^{64}$ ConRad, T. A., Descriptions of a new genus and of twenty-nine new Miocene and one Eocene fossil shells of the United States: Acad. Nat. Sci. Philadelphia Proc., vol. 1, p. 310, 1843. See synonymy in Martin, G. C., Maryland Geol. Survey, Mincene, p. 207, 1904. 
nuclear turns, but this is probably more pronounced in $E$. proquadricostata.

Occurrence: Ripley formation, Dave Weeks place on Coon Creek, McNairy County, Tenn.

Collections: Johns Hopkins University, Vanderbilt University, U. S. National Museum.

\section{Family MURICIDAE}

\section{Genus Sargana Stephenson}

\section{Sargana stantoni (Weller)}

Plate XLVI, Figures 7, 8

1907. Rapana stantoni. Weller, New Jersey Geol. Survey, Paleontology, vol. 4, p. 754, pl. 89, figs. 1-3.

1914. Rapana stantoni. Stephenson, U. S. Geol. Survey Prof. Paper 81, check list, table 8 .

1923. Sargana stantoni. Stephenson, North Carolina Geol. and Econ. Survey, vol. 5, p. 377, pl. 93, figs. 1-5.

Weller describes this species as follows:

Shell subpyriform, with a large, vertically corrugated umbilicus; the dimensions of the type specimen are: Height of shell, 24 millimeters; maximum diameter, 25 millimeters; height of aperture, 12 millimeters; width of aperture, 11 millimeters. Volutions about three and one-half or four in number, the spire depressed, the suture ill defined; the anterior portion of the shell rather abruptly contracted from the body of the shell. Aperture subcircular, slightly higher than wide, with a very narrow anterior canal; the outer lip with a rather thick, slightly undulating margin; inner lip rather thick. Surface of outer volution marked by seven strong revolving ribs separated by somewhat wider rounded furrows, with an eighth less conspicuous one upon the anterior, canaliculate portion; the first three of these ribs next to the suture occupy the upper surface of the volution, the interval between the first and second being somewhat greater than between the other ribs; the revolving ribs are crossed by strong vertical folds at somewhat variable intervals, but which are usually a little more distant than the revolving ribs; at the points where the vertical and revolving ribs cross, the surface of the shell is elevated in conspicuous nodes; surface also marked by fine, more or less irregular lines of growth.

This species has a highly specialized ornamentation of the external surface and a varicose umbilical keel. It has a wide distribution, ranging from New Jersey to Texas. The species. is represented at Coon Creek by numerous perfectly preserved individuals which show a wide range in size. Some of the smaller specimens are strongly spinous. Trophon condoni White, ${ }^{65}$ from the Chico formation of California, is probably a distantly related form.

Occurrence: Ripley formation, Dave Weeks place on Coon Creek, McNairy County, Tenn.

Collections: New'Jersey Geological Survey, U. S. National Museum, Johns Hopkins University, Vanderbilt University.

Outside distribution: Matawan group (Marshalltown formation), New Jersey. Peedee sand, North Carolina. Ripley formation, Mercers Mill Creek, Ga. Navarro formation, Navarro County, Tex.

os White, C. A., On invertebrate fossils from the Paciflc coast: U. S. Geol. Surves Bull. 51, p. 21, pl. 3, figs. 4, 5, 1889.

\section{Family BUSYCONIDAE}

Genus BUSYCON Bolten

Busycon (Protobusycon) cretaceum Wade

Plate XLVII, Figures 1, 4

1917. Busycon (Protobusycon) cretaceum. Wade, Am. Jour. Sci., 4th ser., vol. 43, p. 296, figs. 1, 2.

1917. Protobusycon cretaceum. Cossmann, Rev. critique paléozoologie, année 20, No. 3, p. 100.

Shell rather small for the genus; outline typically fulguroid; spire low, less than one-fourth the entire length of the shell; earlier volutions broadly rounded, later whorls broadly and somewhat obliquely shouldered, the periphery falling about two-thirds of the distance from the posterior to the anterior suture; apex obtuse; protoconch broken away in the type, the scar large; the remaining whorls four in number, increasing rapidly in size to a much inflated body; external sculpture inconspicuous and rather irregular; axial sculpture restricted to a series of low subspinose protuberances crowning the shoulder keel, 10 in number upon the last whorl of the spire, horizontally elongated and irregular in size and spacing upon the final half of the ultima; a second obscure keel outlining the base of the body, obsolete toward the aperture, the keel beset with four or possibly five rudimentary spines; incrementals vigorous and crowded toward the aperture, especially upon the shoulder; spiral sculpture obscure and irregular, the lirae approximately 10 on the medial portion of the body of the type, tending to alternate in size, minutely crenulated by the incrementals; surface of spire so badly decorticated that the character of the finer sculpture can not be determined; line of demarcation between the base of the body and the anterior canal outlined by a shallow sulcus; incrementals very sharply folded along the sulcus, the fold directed toward the aperture and terminating as a slight projection at the margin of the labrum; posterior portion of whorl closely appressed; suture inconspicuous; aperture pyriform, feebly sulcate at the posterior commissure, terminating anteriorly in a long, open canal; outer lip broadly arcuate, notched at the shoulder, the incrementals produced into a series of varix-like spines; labrum feebly insinuated also at the base of the body, directly in front of the basal sulcus; inner margin of the aperture very strongly excavated; parietal wall widely and heavily glazed; columella smooth, sinuous; anterior canal broad, slightly recurved, probably feebly emarginate at the anterior extremity. Altitude, 63.2 millimeters; length of aperture, including canal, 50 millimeters; maximum diameter, 35.2 millimeters.

This very interesting species is represented in the Coon Creek collection by the single specimen figured, which, aside from the loss of the protoconch, is well preserved. In shape and elevation of the body, angle 
of the shoulder, subspinose angulation of the posterior portion of the body, and general aspect it is curiously similar to Fulgur carica (Gmelin), ${ }^{66}$ so abundant in the recent faunas. The impressed line at the base of the body does not appear on any of the later Tertiary and recent representatives of the genus and may possibly be explained as an inherited character from a more primitive type that had an abruptly constricted body whorl, such as that of Pyropsis and Tudicla. Much more probably, however, the basal sulcus and marginal notch are in some way analogous to the more or less well-defined band and marginal notch used in many of the recent groups, notably in Strombus, for the extrusion of the eye stalks. Although the sulcus is peculiar to Protobusycon, the abrupt basal constriction is shared by some of the Eocene members of the group and by Busycon stellatum Dall, ${ }^{67}$ of the Florida Oligocene.

Occurrence: Ripley formation, Dave Weeks place on Coon Creek, McNairy County, Tenn.

Collection: U. S. National Museum.

\section{Genus BOLTENELIA Wade}

1917. Boltenella. Wade, Acad. Nat. Sci. Philadelphia Proc. vol. 69, p. 285. Etymology: Name given in honor of Bolten, who applied the name Busycon to the type genus of this family. Type: Boltenella excellens Wade.

Shell of medium size, thin, fulguroid in outline; elevation of spire less than the length of the aperture and anterior canal; whorls closely appressed and increasing rapidly in size; protoconch smooth and paucispiral, fairly large and bulbous but not greatly inflated; sculpture. subdued, both axial and spiral elements present; aperture pyriform; outer lip simple; parietal wall washed with callus; columella reinforced near the entrance of the anterior canal; pillar slender, either straight or curved.

This genus is proposed to include a group of forms known from two species-one from Coon Creek, represented by several well-preserved individuals, and another from the Upper Cretaceous of Vaals, Germany, well illustrated and described by Holzapfel. The German species, Hemifusus coronatus (Roemer) Holzapfel, ${ }^{88}$ has been variously assigned by different authors since the days of Roemer to such genera as Pyrula, Fusus, Rapa, Tritonidea, Tudicla, and lastly to Hemifusus by Holzapfel. The discovery of a related species in the Ripley formation of Tennessee is further evidence of the existence of a well-defined group, characterized by a fulguroid outline, a large, paucispiral protoconch, and further by the subdued spiral and axial ornamentation of the outer surface, as

${ }^{60}$ Clark, W. B., Maryland Geol. Survey, Pliocene and Pleistocene, p. 179, pls $43,44,45$, figs. $1-6,1906$.

07 Dall, W. F., Molluscan faun of the Orthaulax pugnax zone: U. S. Nat. Mus. Bull. 90, p 67, pl. 10, figs. 7, 9, 1915.

${ }^{69}$ Holzapfol, Eduard, Die Mollusken der Aachener Kreide: Palaeontographica, Band 34, p. 105, pl. 11, figs. 8-13, 1888 . well as a slender pillar in front of an inflated body. The fulguroid outline and fairly large protoconch seem sufficient to tie the group to the family Busyconidae, yet there are many features that suggest the Fusidae. The genus Boltenella is probably intermediate between these two families, more nearly like the Busyconidae yet not near enough to true Busycon to be included in the subgenus Protobusycon ${ }^{60}$ (type Busycon (Protobusycon) cretaceum Wade), as it is a much smaller form and has a different type of anterior canal and external ornamentation. Among the Fusidae it resembles Falsifusus Grabau, ${ }^{70}$ but that group is typically more slender. Its spire is elevated and acuminate, and the canal is very long and straight. It is not typically fulguroid in outline, as is the group for which the name Boltenella is proposed.

\section{Boltenella excellens Wade \\ Plate XLVII, Figures 5, 6}

1917. Boltenella excellens Wade, Acad. Nat. Sci. Philadelphia Proc., vol. 69 , p. 286, pl. 18, figs. 3,4 .

1918. Boltenella excellens Cossmann, Rev. critique paléozoologie, année 22, No. 1-2, p. 20.

Shell of medium size and thin; elevation of the spire less than the length of the aperture; whorls five, closely appressed and strongly shouldered by a broad concave shelf, increasing in size from a minute apical whorl to a much inflated body; protoconch fairly large and bulbous, smooth and naticoid, coiled two and a half times; sculpture well defined but somewhat subdued; axials elevated and low, well rounded and short, persisting on the whorls of the spire to the anterior suture but evanescing a little in front of the shoulder angle of the body; axial ribs nodulated on the body, nodes occurring directly upon the shoulder angle, whereas the axials persist for a short distance across the shoulder; spiral sculpture low and fine, slightly irregular, with secondary spirals developed in the interspiral depressions near the aperture; spirals microscopically roughened by the intersection of numerous incremental lines; suture appressed and undulated by the axial ribs of the preceding whorl; body much inflated, shouldered behind, rounded or globose in front, and merging into a long anterior canal, which may be straight or curved; aperture broadly ovate, grooved at the posterior commissure and produced in front into a narrow canal; outer lip thin and simple; inner lip excavated at the base of the body; columella smooth, reinforced at the entrance of the anterior canal by a deposit of callus; parietal wall thinly glazed, outer margin of the wash sharply defined. Altitude, 38.4 millimeters; elevation of spire, 13.5 millimeters; maximum diameter, 18.7 millimeters.

\footnotetext{
60 Wade, Bruce, An Upper Cretaceous Fulgur: Am. Jour. Sci., 4th ser., vol, 43 p. 293, figs. 1, 2, 1917 .

${ }^{70}$ Grabau, A. W., Phylogeny of Fusus and its allies: Smithsonian Misc. Coll.,
} vol. 44, pp. 80, 81, fig. 4, 1904. 
This species is represented in the Coon Creek collection by several well-preserved specimens, a few of which show the protoconch. The species is characterized by fulguroid shells which are ornamented on the external surface by both axial and spiral sculpture. They have a broad, slightly concave shoulder, and the angle of the shoulder is nodulated on the body by the axial elevations.

Occurrence: Ripley formation, Dave Weeks place on Coon Creek, McNairy County, Tenn.

Collections: Johns Hopkins University, U. S. National Museum.

\section{Genus HAPLOVOLUTA Wade}

1917. Scobina. Wade, Acad. Nat. Sci. Philadelphia Proc., vol. 69, p. 286.

1918. Haplovoluta. Wade, Am. Jour. Sci., 4th ser., vol. 45, p. 334. Etymology: á $\pi \lambda$ bos, simple; Voluta, a genus of gastropods. Type: Haplovoluta bicarinata Wade.

1920. Brucia. Cossmann, Rev. géologie, année 1, No. 9, p. 376.

Shell moderately large and strong, top-shaped in outline; spire acute at the apex, its elevation less than half the total altitude of the shell; protoconch scar small; whorls closely appressed, obliquely shouldered, whorls of spire unicarinate; body flattened along the narrow peripheral region, abruptly constricted in front of the periphery; sculpture spiral, spinose and laminated in the type species; incrementals sinuous in character, forming a reentrant angle along the posterior keel; aperture subovate, produced in front into a narrow canal; outer lip sinuous at the shoulder angle; inner lip reflected, not invariably adnate to the body and pillar, a chink occasionally present between the inner lip and pillar; anterior canal slender and elongate, commonly curved or bent near the anterior extremity.

This genus has an acute spire and is characterized by a highly inflated body with a narrow peripheral region abruptly constricted in front of this periphery. The canal is long and variable. The sculpture is dominantly spiral, with laminar, somewhat zigzag incremental lines. This genus is proposed to include two known species, one from Coon Creek and another from Ripley and Dumas, Miss., both of which are represented by several well-preserved specimens which present generic features that can not be included within the limits of any of the described groups. The general form of the genus suggests Hercorhynchus ${ }^{71}$ or possibly Pyrifusus. However, the strong sinuation of the axials along the shoulder is a character by which it may be readily separated from any of the previously known Busyconidae. There is a tendency toward low, obtuse spires in most of the genera of this family, yet some forms, such as Pyrifusus, are acute at the apex. With age, however, this low angle of the spire

7 Conrad, T. A., Descriptions of new species of Cretaceous and Eocene fossils of Mississippi and Alabama: Acad. Nat. Sci. Philadelphia Jour., 2d ser., vol. 4, p.286, pl. 46, flg. 4, 1860; Notes on recent and fossil shells, with descriptions of new genera: Am. Jour. Conchology, vol. 4, p. 247, 1868. greatly increases, a feature very characteristic of Haplovoluta. The strongly inflated, bicarinate body of the Upper Cretaceous form Rapa cancellata (in part) Stoliczka, ${ }^{72}$ from southern India, resembles Haplovoluta somewhat, but the form from southern India is umbilicate and not acute spirally. Rapa has a well-defined umbilicus. Pyropsis differs from Haplovoluta in having a low spire and no laminar incremental ornamentation. These characters will also serve to separate Haplovoluta from Trochifusus. ${ }^{73}$

\section{Haplovoluta bicarinata Wade}

Plate XLVII, Figures 3, 7

1917. Scobina bicarinata. Wade, Acad. Nat. Sci. Philadelphia Proc., vol. 68, p. 287, pl. 18, figs. 1, 2.

1918. Scobina bicarinata. Cossmann, Rev. critique paléozoologie, année 22, Nos. 1-2, p. 20.

1918. Haplovoluta bicarinata. Wade, Am. Jour. Sci., 4th ser., vol. 45, p. 334 .

Shell of medium size and top-shaped; spire acute at the apex, its elevation less than half the total altitude of the shell; angle of spire increasing with age; whorls six, closely appressed, increasing in size to an inflated body, whorls of spire strongly shouldered and unicarinate; protoconch scar small; body broad and angular, the peripheral area narrow, flattened, bicarinate, the posterior body slope broad and conspicuous; the anterior slope is a little more gentle and a little broader than the posterior slope, especially in old individuals; sculpture both axial and spiral, spiral ornamentation consisting of the two carinae on the periphery and six or seven low spiral ridges on the anterior slope of the body and on the anterior canal; posterior slope of whorls free from well-defined sculpture; spirals intersected by deeply angular and laminar axials, which are irregularly spaced and about 20 or less in number on the body; spirals spinose at the intersections of the incrementals; spines strongest along the posterior carina, anterior carina an aggregation of six or seven strong spiral threads that terminate sharply at the incremental lines, making axials at these points finely serrate; three or four similar threads appear between the two carinae on the peripheral area; on the anterior slope the short spines are low or tuberculate; aperture ovate, slightly angular behind and produced in front into a long, narrow canal with proximate parallel margins; margin of outer lip thin, deeply angulated at the posterior carina, abruptly constricted at the base of the body; inner lip excavated medially, reflected and adnatio on the body and the anterior canal on immature individuals but not in adults, a deep, broad and elongate cavity developed in mature forms between the inner lip and the anterior canal; columella smooth; anterior canal slender, slightly curved or bent in an irregular manner near

72 Stoliczka, Ferdinand, Indis Geol. Survey Mem., Palaeontologia Indica, Cretaceous fauna of southern India, vol. 2, p. 154, pl. 12, figs. 12-16, 1868.

${ }^{73} \mathrm{Gabb}, \mathrm{W}$. M., Notes on American Cretaceous fossils, with descriptions of some new species: A cad. Nat. Sci. Philadelphia Proc. for 1876, p. 285, 1877. 
the auterior extremity. A slightly imperfect individual measures in altitude, 26.6 millimaters; maximum diameter, 25.2 millimeters.

This species is well characterized by its pyriform outline and especially by its bicarinate, widely expanded body, which is ornamented with laminar spinose axial lines. It is common at Coon Creek and is represented in the present collection by a number of individuals which show a wide variation in form and size. Further collecting at the type locality may result in the isolation of other species of this group. An undescribed tricarinate species of this genus occurs at Owl Creek, Miss.

Occurrence: Ripley formation, Dave Weeks place on Coon Creek, McNairy County, Tenn.

Collections: Johns Hopkins University, U. S. National Museum.

\section{Genus IIROSOMA Conrad}

Lirosoma cretacea Wade

Plate XLVII, Figures 2, 11

1917. Lirosoma cretacea. Wade, Acad. Nat. Sci. Philadelphia Proc., p. 288, pl. 18, figs. 5, 6 .

1918. Lirosoma cretacea. Cossmann, Rev, critique paléozoologie, année 22, Nos. 1-2, p. 21.

Shell fairly large and stout, pyriform; spire low and obtuse, its elevation less than half the total altitude of the shell; whorls five to eight, strongly and evenly convex, increasing markedly in size; protoconch rather small, smooth and very low, coiled two and a half times, initial turn minute and completely immersed in the succeeding whorl, remaining nuclear turns very low and broadly rounded, becoming increasingly higher toward the close of the protoconch; sculpture very ornate, incremental striations very numerous and well developed in interspiral depressions but obsolete for the most part on the crests of the spiral fillets, axial ribbing irregular in strength and occurrence, tending to develop into varices at more or less regular intervals; about 14 spiral bands or fillets on the body, becoming low and crowded on the anterior canal, fillets narrow, rectangular in cross section, widely and irregularly spaced; suture sharply impressed; body well rounded, constricted in front into a narrow, slightly curved anterior canal; aperture pyriform; outer lip broken away; inner lip excavated at the base of the body, reflected but adnate along the middle of the pillar; columella smooth, enlarged at the entrance of the anterior canal; parietal wash very thin. An immature individual measures in altitude 24.9 millimeters; in maximum diameter, 14.8 millimeters.

This species is well characterized by its stout fusiform outline, deeply impressed suture, and highly ornate external surface. Only two individuals are known. They were collected from Coon Creek and are the first representatives of this genus to be reported from the Creteceous. It is interesting to find these shells in the American Cretaceous, as the genus is already well known in the American Tertiary. Lirosoma cretacea resembles $L$. sulcosa Conrad, ${ }^{74}$ the type of the genus, which comes from the Chesapeake Miocene, in general form, lirate ornamentation, and character of the protoconch, but it differs widely from the Miocene species in detail of sculpture and in the presence of irregular axial ribs, which tend to develop into varices at more or less regular intervals. The species Tortifusus cumirostra Conrad, from the Miocene of North Carolina and Virginia, is regarded by Cossmann $^{75}$ as another species of Lirosoma.

The genus Ranularia Schumacher is another group of forms that should be considered in determining the generic relations of the Upper Cretaceous species described above. The French Eocene form Ranularia piraster (Lamarck), which is figured and regarded by Cossmann ${ }^{76}$ as very typical of that genus, has a stout fusiform outline, lirate sculpture, and varicose axialsall of which present a general aspect that strongly suggests the Cretaceous species under discussion. Ranularia piraster, however, has a dentate inner margin on the outer lip, a feature characteristic of the Tritonidae but not present on Lirosoma cretacea and uncommon in the Busyconidae.

Occurrence: Ripley formation, Dave Weeks place on Coon Creek, McNairy County, Tenn.

Collections: Johns Hopkins University; U. S. National Museum.

\section{Genus PYROPSIS Conrad \\ Pyropsis proxima Wade, n. sp. \\ Plate XLVII, Figures 8-10}

Shell large and turnip-shaped; spire depressed and nearly flat; whorls three and a half, increasing very markedly in size, subtriangular in cross section; protoconch strong and smooth, loosely coiled one and a half times, nearly. flat; sculpture spirally striate, consisting of about 25 elevated threads of unequal size and spacing, very feeble on the earlier whorls but becoming stronger on approaching the aperture of the body of an adult; spiral elevations crossed by numerous incremental lines and irregularly tuberculate; peripheral margin subangular and not keeled but spinous; suture deeply impressed, body subtrapezoidal, merging in front into a comparatively short spikelike pillar, which is slightly bent near the anterior extremity; aperture equant, slightly emarginate at the peripheral margin and the posterior commissure, produced into a very narrow anterior canal; outer lip thickened and feebly crenulate at the terminations of the spiral lirae; inner lip reflected, heavily calloused

"Conrad, T. A., On the geology and organic remains of a part of the peninsula of Maryland: Acad. Nat. Sci. Philadelphia Jour., 1st ser., vol. 6, p. 220, pl. 9 , flg. 8, 1830. Martin, G. C., Maryland Geol. Survey, Miocene, p. 183, pl, 48, fig. 1, 1904.

73 Cossmann, Maurice, Essais de paléoconchologie comparée, pt. 4, p. 79, 1901 ${ }^{76}$ Cossmann, Maurice, op. cit., pt. 5, p. 97, pl. 3, fig. 12, 1903. 
and adnate to the body just in front of the posterior commissure but not adnate along the base of the body and anterior canal; umbilical chink profound. Altitude, 48.7 millimeters; maximum diameter, 39.4 millimeters.

In outline and general aspect this species is very near the type of the genus Pyropsis perlata Conrad. ${ }^{77}$ The body of Pyropsis proxima is not tricarinate, nor is the peripheral margin keeled, as in the type species. The form is represented in the Coon Creek beds by well-preserved shells, which reveal the nuclear characters of the genus. No closely related species of this genus is known from Europe or South America. The species Pyropsis africana Woods ${ }^{78}$ is probably more closely related to the type species and the Coon Creek species than to the forms Pyropsis hombroniana (D'Orbigny) ${ }^{78}$ from the Quiriquina beds of Chile, and Rapa cancellata (Sowerby), ${ }^{80}$ from the Trichinopoly beds of southern India, two species which Woods compares with his form from the Senonian of Pondoland, South Africa.

Occurrence: Ripley formation, Dave Weeks place on Coon Creek, McNairy County, Tenn.

Collection: U. S. National Museum.

\section{Genus TROCHIFUSUS Gabb}

1877. Trochifusus. Gabb, Acad. Nat. Sci. Philadelphia Proc. for 1876, p. 285.

Trochifusus perornatus Wade, n. sp.

Plate XLVIII, Figures 1-6

Shell large and pyriform; spire depressed, rising slightly above the body whorl; whorls of conch four, closely appressed and increasing markedly in size, body almost involving the preceding whorls; protoconch smooth, with three volutions; no sharp line of demarcation separates it from the conch; sculpture heavy, consisting of strong tuberculate spiral ridges, which tend to become spinous posteriorly; spirals irregularly spaced, but in general ridges and interspaces are of about the same width and persist from the suture over the body and well up on the anterior part of the anterior canal; the number of spiral ridges increases with age; there are 23 on the body and pillar of the type; axial sculpture absent except for incremental lines, which are well developed near the margin of the aperture; tubercles numerous and variable in strength; suture impressed and obscure; body abruptly constricted posteriorly and less abruptly in front, where it merges into a broad, long, and straight anterior canal; aperture broad and

\footnotetext{
77 Conrad T. Descriptions of new species of Cretaceous and Eocene fossils of Mississippi and Alabama: Acad. Nat. Sci. Philadelphia Jour., vol. 4, 2d ser., p. 288 , pl. 46, flg. 39,1860 .

18 Woods, Henry, The Cretaceous fauna of Pondoland: South African Mus. Annals, vol. 4, pt. 7, p. 322, pl. 38, fig. 17; pl. 39, figs. 1a, b, c, 1906.

79 Wilckens, Otto, Revision der Fauna der Quiriquina-Schichten: Neues Jahrb., Beilage Band 18, p. 213, pl. 18, figs. 8, 9, 1904.

80 Stoliczka, Ferdinand, India Geol. Survey Mem., Palaeontologia Indica, Cretaceous fauna of southern India, vol. 2, p. 154, pl. 12, figs. 12-16; pl. 13, figs. 1-4, 1868.
}

ovate, slightly notched posteriorly and produced anteriorly into a long, open canal; outer lip obscurely crenulated; inner lip excavated medially; columella reinforced with callus at the entrance of the anterior canal; parietal wall washed with callus. An imperfect individual measures in altitude 58.6 millimeters; maximum diameter, 46.2 millimeters.

This species is well characterized by its low spire and ornate sculpture, which consists of numerous tuberculate spiral ridges. It is common at Coon Creek, and the individuals show much variation among themselves in size, elevation of spire, and external ornamentation.

Occurrence: Ripley formation, Dave Weeks place on Coon Creek, McNairy County, Tenn.

Collection: U. S. National Museum.

$$
\text { Trochifusus spinosus Wade, n. sp. }
$$

Plate XLVIII, Figure 7; Plate XLIX, Figures 1-3

Shell large, with an unusually long, straight pillar; turnip-shaped in outline; spire low but standing well up above the body whorl; whorls four or five, closely appressed; protoconch smooth and flat, its whorls thin and more than two; no sharp line of demarcation separating the protoconch from the conch; sculpture elaborate, consisting of strong, spinous spiral ridges; spines are most conspicuous on first and second ridges in front of the suture, these ridges being separated by a broad, concave interspiral space, which is unornamented except for incremental lines and very finely marked spiral lines on the earlier whorls; the spines are excavated in front and represent stages of the emargination of the aperture; spiral ridges, more than 22 on the body and anterior canal, oblique and not strongly developed and disappearing almost entirely on the anterior extremity of the anterior canal; spiral ridges closely spaced on the body but more widely separated near the aperture, where intermediate spirals are developed; axial sculpture absent except for incremental lines, which are well developed, especially near the aperture; suture impressed but obscured by spines along the sutural margin of the later whorls; body well rounded, constricted posteriorly, forming an obtuse shoulder and merging in front into a disproportionally large, long anterior canal; aperture broad and pyriform, slightly notched posteriorly and produced into a long, narrow, and straight anterior canal; outer.lip expanded and varicose in old individuals; inner lip excavated at base of body; columella smooth; parietal wall washed with a callus that is very heavy in adults, forming a reflected inner lip; a heavy mass of callus just in front of the posterior commissure on the inner lip. A young individual measures in altitude 82.4 millimeters; maximum diameter, 28.4 millimeters.

This species is characterized by a very long anterior canal, spinose spiral ridges, and a broad and unsculp- 
tured concave band between the first and second spiral ridges on the posterior part of the body. It is fairly common at Coon Creek, and the form shows a wide range in size, some specimens having a total elevation of more than 125 millimeters. The shells are fragile, and perfect specimens are obtained witb some difficulty.

Occurrence: Ripley formation, Dave Weeks place on Coon Creek, McNairy County, Tenn.

Collection: U. S. National Museum.

Trochifusus interstriatus Wade, n. sp.

\section{Plate XLIX, Figures 7, 8}

Shell fairly large and pyriform; spire depressed but standing well up above the body; whorls three or four, closely appressed, increasing markedly in size and strongly tabulated: protoconch smooth, with three volutions; no sharp line of demarcation separates it from the conch; sculpture spirally striate, consisting of about 15 fairly strong spinose or tuberculate spiral ridges on the body and anterior canal; ridges irregular in number, spacing, and strength; interspaces on the body marked by very fine spiral lines; spines, are strongest on the first and second ridges in front of the suture on the body whorl, absent on the whorls of the spire; the interspace between the first and second ridges in front of the suture is wide and marked by numerous fine spiral lines; suture impressed; body abruptly shouldered and inflated, constricted both behind and in front, where it merges into a broad, slightly curved anterior canal; aperture pyriform; outer lip broken away, but incremental lines indicate that it was emarginate along the shoulder and suture; inner lip reflected and adnate to the body and the posterior portion of the anterior canal but not adnate along the middle portion of the anterior canal, thus leaving a crevice, which is the anterior opening of a very oblique spiral perforation around the columella formed by this interspacing between the reflected inner lip and the columella. A slightly imperfect individual measures in altitude 38.9 millimeters; maximum diameter, 26.6 millimeters.

This species is characterized by the microscopic spiral lines in the spiral interspaces. It is most like Trochifusus spinosus but difters from that species in size and profile of spire and in having a shorter, slightly bent anterior canal and a somewhat different reflection of the inner lip.

Occurrence: Ripley formation, Dave Weeks place on Coon Creek, McNairy County, Tenn.

Collection: U. S. National Museum.

\section{Genus PERISSOLAX Gabb}

\author{
Perissolax whitfieldi (Weller)
}

Plate XLIX, Figures 6, 9

1892. Pyropsis octolirata. Whitfield, U. S. Geol. Survey Mon. 18, p. 26, pl. 2, fig. 8, 9. (Also published by New Jersey Geol. Survey.) (Not $P$. octolirata Conrad, 1858.)

1907. Pyropsis whitfieldi. Weller, New Jersey Geol. Survey, Paleontology, vol. 4, p. 750, pl. 88, figs. 14-16.

1916. Pyropsis whitfieldi. Gardner, Maryland Geol. Survey, Upper Cretaceous, p. 451.

Weller describes this species as follows:

Shell small, subglobular or subpyriform in form, with about three ventricose, rapidly expanding volutions; the dimensions of a nearly complete internal cast being: Height, 19.5 millimeters, which might be increased to 25 millimeters if the anterior canal were complete; maximum diameter, 16 millimeters; height of spire, 5.5 millimeters. Spire low conical, volutions distinctly flattened adjacent to the suture, marked by from six to nine spiral ridges or costae upon the casts, which are crossed by vertical ridges at about equal intervals or slightly more distant than the spiral lines, the two sets of markings dividing the surfaces into a number of square, depressed spaces; anterior beak short, apparently straight, and rather pointed; aperture elongate, pointed above and below, about half as wide as long. In the casts the suture is distinct and of ten strongly marked.

This species is of about the same size as $P$. retifer, from which it may be distinguished by the distinctly flattened band on the upper side of the volutions adjacent to the suture; the spire is also slightly more depressed, and the lower side of the outer volution contracts a little more rapidly to the anterior beak. The species has only been seen in the condition of internal casts and by Whitfield was referred to $P$. octolirata. It differs from $P$. octolirata, however, in the presence of vertical ribs and apparently also in the flattening of the upper margin of the volutions.

This species is represented in the Coon Creek collection by a number of well-preserved shells that reveal nuclear characters. The protoconch is small and elevated, coiled twice or more, very unlike the larger flat protoconch of Pyropsis, which may be seen in Pyropsis proxima, a Coon Creek species which is very near Conrad's type species, Pyropsis perlata. ${ }^{81}$ In my opinion this species is not Pyropsis but belongs, as well-preserved material indicates, to Gabb's genus Perissolax. ${ }^{82}$ Individuals from Coon Creek that are assigned to the species show considerable variation among themselves in ornamentation and outline.

Occurrence: Ripley formation, Dave Weeks place on Coon Creek, McNairy County, Tenn.

${ }^{81}$ Conrad, T. A., Descriptions of new species of Cretaceous and Eocene fossils of Mississippi and Alabama: Acad. Nat. Sci. Philadelphia Jour., 2d ser., vol. 4, p. 288, pl. 46, fig. 39, 1860 .

${ }^{82} \mathrm{Gabb}$, W. M., Synopsis of the Mollusca of the Cretaceous formation, p. 66 (Am. Philos. Soc. Proc., vol. 8, p. 122), 1861. 
Collections: New Jersey Geological Survey, Philadelphia Academy of Natural Sciences, Maryland Geological Survey, U. S. National Museum, Vanderbilt University.

Outside distribution: Monmouth group (Navesink marl), New Jersey. Monmouth formation, Brightseat and Friendly, Prince Georges County, Md.

\section{Genus RHOMBOPSIS Gardner}

Miss Gardner characterizes this genus as follows: ${ }^{83}$

In 1876 Meek united under Pyrifusus the typical species of Conrad and a group of forms differing from $P$. subdensatus in the higher, more evenly inflated spire, the sinuous outer lip, and the flattened columella. The latter he assigned to the subgenus Neptunella, a name unfortunately' preoccupied by Gray in 1853. It seems probable, however, that the differences are of more than subgeneric significance. Rhombopsis, a name suggested by the conspicuously rhomboidal outline of the shell, may be substituted for the preoccupied Neptunella.

\section{Rhombopşis orientalis Wade, n. sp.}

Plate XLIX, Figures 4, 5

Shell fairly large and fusiform in outline; spire elevated, acute at the apex; volutions seven, increasing in size fairly markedly; protoconch partly broken away in type; very small and smooth, naticoid, probably coiled twice; sculpture elaborate, dominantly axial; axial costae 13 or 14 on the body, regular on whorls of the spire but becoming irregular on the ultima; axials abruptly elevated along the shoulder of the whorl but do not persist to the posterior suture, although extending to the anterior suture on the whorls of the spire; axials evanesce on the anterior slope of the body; incremental lines appear on the ultima and indicate stages of a broad sinus along the shoulder; numerous distinct, elevated, threadlike spirals of irregular strength and spacing override the axial elevations; about 14 spirals on the penultima, irregularly nodulated by the intersection with incremental lines; suture impressed; body abruptly constricted posteriorly and sloping steeply into a broad anterior canal, so that the region of the maximum diameter of a whorl forms a shoulder some distance in front of the suture; aperture lenticular; outer lip thin, its outer margin broadly sinuous along the shoulder or a little behind the shoulder; inner lip slightly excavated at the base of the body; columella smooth; parietal wall thinly calloused; anterior canal broken away in type. An imperfect individual measures in altitude, 37 millimeters; in elevation of spire, 24.3 millimeters; in maximum diameter, 19 millimeters.

This species is represented in the present collection from Tennessee by a single individual, and the anterior canal of this specimen is broken away, so the species

9a Maryland Geol. Survey, Upper Cretaceous, p. 456, 1916. can not be assigned with assurance to the genus Rhombopsis. The group Neptunella was regarded as a subgenus under Pyrifusus by Meek, ${ }^{84}$ the author of the group, and was later given the rank of genus by Whitfield. ${ }^{85}$ No species of this genus from the Upper Cretaceous of the Gulf region has been found in the literature. Rhombopsis orientalis bears some resemblance to Rhombopsis subturritus (Meek and Hayden) ${ }^{86}$ but differs from that form both in spiral sculpture and in general outline of the spire.

Occurrence: Ripley formation, Dave Weeks place on Coon Creek, McNairy County, Tenn.

Collection: U. S. National Museum.

Rhombopsis microstriatus Wade, n. sp.

Plate L, Figures 1, 2

Shell of medium size, fusiform in outline; spire elevated but its elevation less than half the total altitude of the shell; whorls six, strongly appressed at the suture and increasing markedly in size; protoconch broken away, its scar small; sculpture both axial and spiral; axial ribs 12 on the body, well rounded, most prominent at the periphery, absent on a narrow concave band directly in front of the suture and evanescing on the anterior slope of the body; spiral sculpture of numerous fine threads of uniform size and spacing on the whorls of the spire and the posterior part of the body but becoming a little coarser on the anterior slope of the body, where there are fortuitous secondary spirals; suture appressed; body inflated, abruptly constricted both anteriorly and posteriorly but more gentle in front, where it merges into a narrow curved anterior canal; aperture subovate and produced in front into a curved canal; outer lip broken away, probably broadly sinuous along the shoulder; inner lip broadly excavated at the base of the body; columella smooth, slightly enlarged or twisted at the base of the body; parietal wall washed with a narrow band of callus. An imperfect individual measures in altitude, 31.8 millimeters; elevation of spire, 12.5 millimeters; maximum diameter, 14.1 millimeters.

Only one specimen of this species is known, and the anterior extremity of the anterior canal of that individual is broken away. It differs from Rhombopsis orientalis in having a more inflated body and a less acuminate spire and further in having a finer and smoother spiral ornamentation. The twist in the columella at the entrance of the anterior canal of Rhombopsis microstriatus is unusually strong for this genus, and further collection may furnish specimens that show such generic features as to assign the species under discussion to another group.

84 Meek, F. B., A report on the invertebrate Cretaceous and Tertiary fossils of the upper Missouri country: U. S. Geol. Surrey Terr. Rept., vol. 9, p. 344, 1876.

Bs Whitfeld, R. P., Gastropoda and Cephalopoda of the Raritan clays and greensand marls of New Jersey: U. S. Geol. Surrey Mon. 18, p. 56, 1802

${ }_{80}$ Meek, F. B. op. cit., p. 347 , pl. 32, figs. 3, a, b, 1876. 
Occurrence: Ripley formation, Dave Weeks place on Coon Creek, McNairy County, Tenn.

Collection: U. S. National Museum.

\section{Genus PYRIFUSUS Conrad \\ Pyrifusus subdensatus Conrad \\ Plate L, Figures 5, 6}

1858. Pyrifusus subdensatus. Conrad, Acad. Nat. Sci. Philadelphia Jour., 2d ser., vol. 3, p. 332, pl. 35, fig. 12.

1914. Pyrifusus subdensatus. Stephenson, U. S. Geol. Survey Prof. Paper 81 , check list, table 2.

Conrad describes this species as follows:

Subpyriform; spire short, subscalariform, volutions four (?), longitudinally ribbed and spirally lineated, lines minute; body whorl wide, contracted above, where there are longitudinal wrinkles and revolving lines; below are prominent ribs becoming obsolete about the middle, and prominent revolving lines over the whole surface below the shoulder.

Shell of medium size, pyriform in outline; spire low, acute at the apex, its elevation about one-fourth the total altitude of the shell; whorls closely appressed, broadly convex, coiled four or five times, increasing markedly in size; protoconch broken away, its scar small; sculpture heavy, both axial and spiral; 15 to 17 axial costae, evanescing within a short distance behind the periphery on the body, persisting as irregular undulatory ribs down to the anterior slope of the body; 13 spiral elevations on the body, closely spaced on the periphery of the shell, where they override the axials, and forming low nodules at the intersections; sutural margin free from heavy sculpture; suture obscured by a spiral ridge; along the posterior margin of the whorls between this ridge and the shoulder is a conspicuous unornamented concave spiral band; body constricted posteriorly and sloping rapidly into a broad anterior canal; aperture ovate, produced in front into an open canal and slightly notched posteriorly; outer lip protruding near the base of the body and dentate along its margin; inner lip excavated in the middle; columella smooth; parietal wall glazed with a heavy callus, the margin of which is sharply defined.

This species may be compared with Strombus fenestratus Müller (Pollia fenestratus Holzapfel and Pirifus fenestratus Cossmann), ${ }^{87}$ which occurs in the Aachen Cretaceous or lower Senonian of wéstern Europe. A less closely related species of this genus from the Trichinopoly group of southern India has been described by Stoliczka as Tritonidea granulata. ${ }^{88}$

Occurrence: Ripley formation, Dave Weeks place on Coon Creek, McNairy County, Tenn.

Collections: U. S. National Museum, Johns Hopkins University, Vanderbilt University.

Outside distribution: Ripley formation, Owl Creek, Tippah County, Miss.

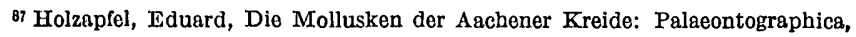
Band 34, p. 109, p. 10, flgs. 13, 14, 1888. Cossmann, Maurice, Essals de paléoconchologie comparée, pt. 4, p. 84, pl. 6, fig. 22, 1801.

${ }^{88}$ Stoliczka, Ferdinand, India Geol. Survey Mem., Palaeontologia Indica, Cretaceous fauna of southern India, vol. 2, p. 125, p. 11, flgs. 6, 7, 7a, 1868. 106913-26†-10
Pyrifusus subliratus Wade, n. sp.

Plate L, Figures 7, 8

Shell of medium size and pyriform; spire low but acuminate at apex, spiral angle increasing greatly with age; whorls six, closely appressed and increasing markedly in size; protoconch broken away on available specimens; sculpture dominantly spiral, but axials are well developed on the periphery; axial costae 15 to 18 , slightly protractive and undulating, irregularly spaced, absent on the sutural margin and evanescing within a short distance on the anterior slope of the body; incremental lines very numerous and persistent over all sculpture from anterior canal to suture; spiral fillets 10 to 12 on the body, irregularly spaced; spiral interspaces wider than fillets, much wider on anterior canal and in some places marked by fortuitous secondary spirals; fillets on periphery striated with four to six very finely impressed spiral lines, which are best developed near the margin of the aperture; fillets override axials and form low tubercles at the intersections; sutural margin broad and marked by numerous incremental lines; suture obscure; body constricted posteriorly and sloping rapidly in front into a broad anterior canal; aperture broad and pyriform, marked posteriorly by a shallow notch and in front by a broad, open canal; outer lip thin along the margin and crenulated; inner lip reflected and not closely adhering to the parietal wall along the anterior part of the anterior canal, where there is a deep umbilical chink; columella enlarged at the entrance of the anterior canal. Altitude, 37.2 millimeters; maximum diameter, 26.4 millimeters.

This species differs from Pyrifusus subdensatus in having a well-defined umbilical chink and further in possessing more widely spaced and less numerous spiral elevations. The spiral elevations on the periphery of Pyrifusus subliratus are marked by fine impressed lines.

Occurrence: Ripley formation, Dave Weeks place on Coon Creek, McNairy County, Tẻnn.

Collection: U.S. National Museum.

\section{Genus SERRIFUSUS Meek}

\section{Serrifusus tennesseensis Wade, n. sp.}

Plate L, Figures 3, 4

Shell of medium size and fusiform; spire elevated, its altitude less than half the total length of the shell; whorls four or five, increasing rapidly in size; protoconch broken away; sculpture dominantly axial, consisting of 12 short, abruptly elevated axial costae, which form tuberculate projections on the keel-like shoulder of the whorls; spiral ornamentation is absent on the posterior half of the whorl, but the anterior slope of the body is marked by eight or ten low spiral elevations; suture appressed; body abruptly constricted posteriorly and sloping steeply anteriorly into 
a broad anterior canal; aperture badly broken in type; outer lip expanded; inner lip constricted at the base; columella smooth; parietal wall slightly glazed. An imperfect specimen measures in altitude, 34.4 millimeters; in elevation of spire, 15.2 millimeters; in maximum diameter, 19.1 millimeters.

This species is represented in the present collection from Coon Creek by a single specimen, and it is imperfect. The form is probably near a variety of Serrifusus dakotensis described by Meek, ${ }^{89}$ but it is distinct from that form in having a different spiral ornamentation on the anterior part of the body and further in having stronger axial costae.

The species Fusus binkhorsti Kaunhowen, ${ }^{90}$ from the Maestrichtian of Belgium, has a spire and strong axial sculpture that suggest the species from Tennessee. The species from Belgium is represented by figures of two incomplete specimens, which may be compared only with a fragmentary individual from Coon Creek, so that it is impossible to say with assurance whether the American and the Belgian species belong to the same genus.

The species Fusus koeneni Müller, ${ }^{91}$ from the lower Senonian of Braunschweig, Germany, is another form which probably belongs to the genus Serrifusus and may be compared with $S$. tennesseensis.

Occurrence: Ripley formation, Dave Weeks place on Coon Creek, McNairy County, Tenn.

Collection: U. S. National Museum.

\section{Family BUCCINIDAE \\ Genus SEMINOLA Wade}

1917. Seminola. Wade, Acad. Nat. Sci. Philadelphia Proc., vol. 69, p. 290. Etymology: Seminoles, a tribe of Indians who formerly lived in the southeastern Coastal Plain region. Type: Seminola crassa Wade.

1920. Ripleya. Cossmann, Rev. géologie, année 1, No. 9, p. 376.

Shell compact, of medium size or large, globose; spire low; whorls not very numerous, increasing rapidly in size to an inflated body; protoconch unknown; both axial and spiral sculpture developed, the axial more or less obsolete on the body of the adult; suture obscure or deeply impressed; body well rounded medially, constricted and folded inward at the base of the body, where a deep sulcus, parallel to the spiral sculpture, separates the body from the pillar; aperture broad and subovate, produced anteriorly into a short recurved canal; outer lip simple or varicose, a strong toothlike projection occurring on the margin at the anterior extremity of the spiral sulcus at the base of the body; inner lip excavated medially;

\footnotetext{
${ }^{80}$ Meek, F. B., op. cit., pp. 375-377, pl. 32, fig. 7a.

0 Kaunhowen, Friedrich, Die Gastropoden der Maestrichter Kreide: Palaeont. Abh. (Dames \& Koken), Band 8 (neue Folge, Band 4), p. 87, pl. 11, figs. 3, 3a, b, 1898. 91 Müller, G., Die Molluskenfauna des Untersenon von Braunschweig und Ilsede; I, Lamellibranchiaten und Glossophoren: K. preuss. geol. Landesanstalt Abh., neue Folge, Heft 25, p. 120, pl. 16, fig. 4, 1898.
}

columella reinforced, marked by an oblique plication near the anterior extremity and along the margin of the anterior canal; parietal wall calloused, in some specimens heavily; pillar broad and short, slightly recurved; umbilical chink shallow; anterior fasciole broad, oblique, heavily corrugated.

This genus is well characterized by globose shells of different sizes, having both spiral and axial sculpture variously developed. The pillar is broad and short, being separated from the body by a deep spiral sulcus that terminates with a toothlike projection on the margin of the outer lip, a shell character which possibly indicates the former position of the eyestalk of the animal. The genus is proposed to include five species heretofore unknown in the literature-two from Coon Creek, one from Owl Creek, and two from the Ripley of Texas-and one species from Pataula Creek, Ga., described by Gabb under the name Nassa globosa. ${ }^{92}$ There is no figure of this species, but the type, which is imperfect, may be seen at the Museum of the Academy of Natural Sciences of Philadelphia. The generic determination of Gabb's species was questioned by Johnson ${ }^{93}$ in 1905 . The evidence furnished by recently discovered material from Coon Creek shows that these related species from the Ripley do not belong to the genus Nassa but represent a large undescribed group of magnificent forms which belong to the family Buccinidae. This group is no doubt near Meek's genus Odontobasis. ${ }^{94}$ Seminola differs from Odontobasis in having a globose or ovoid form rather than a fusiform outline. Another closely related genus of the Buccinidae is Pseudoliva Swainson, ${ }^{95}$ represented in the Senonian by Pseudoliva zitteli Pethö, ${ }^{98}$ from Hungary. The spiral groove in Pseudoliva occurs well up on the body and is nothing more than a deep spiral sulcus in the sculpture pattern; it differs very decidedly from the deep spiral sulcus at the base of the body of Seminola. The Nassidae usually have a crenulate or dentate outer lip, lack the marginal fold on the anterior end of the columella, and do not have such a deep spiral sulcus at the base of the body, which terminates in a tooth on the outer lip of the aperture.

Cossmann thinks that the name Seminola is not available for this genus because of the prior use of Seminolus for a genus in another class. It seems to the writer that the two names are sufficiently different to permit both to stand.

${ }^{22} \mathrm{Gabb}, \mathrm{W} . \mathrm{M}$., Notes on American Cretaceous fossils, with descriptions of some new species: Acad. Nat. Sci. Philadelphia Proc. for 1876, p. 282, 1877.

${ }^{93}$ Johnson, C. W., Annotated list of the types of invertebrate Cretaceous fossils in the collection of the Academy of Natural Sciences, Philadelphia: Acad. Nat. Sci. Philadelphia Proc., vol. 57, p. 23, 1905.

" Meek, F. B., A report on the invertebrate Cretaceous and Tertiary fossils of the upper Missouri country: U. S. Geol. Survey Terr. Rept., vol. 9, pp. 351-354, text figs. 41, 42, 43, pl. 191, figs. 1, a, b, c, 1876.

os' Cossmann, Maurice, Essais de paléoconchologie comparée, pt. 4, pp. 191, 192, 1901.

${ }^{06}$ Zittel, K. A., Text-book of paleontology, English ed., vol. 1, p. 556, flg. 1012, 1913. 


\section{Seminola crassa Wade}

Plate L, Figures 9-12

1917. Seminola crassa. Wade, Acad. Nat. Sci. Philadelphia Proc., vol. 69, p. 291, pl. 19, figs. 6, 7.

1918. Seminola crassa. Cossmann, Rev. critique paléozoologie, année 22, Nos. 1-2, p. 21.

Shell large and globose; spire low and obtuse, its elevation about one-third the total altitude; whorls six, increasing rapidly in size to a much inflated body; sculpture elaborate, axials sharply rounded, coarse and strong, 12 on the later whorls of the type, short and retractive, very prominent on the shoulders of the whorls but disappearing abruptly just in front of an undulating sutural band and persisting, though with somewhat diminished strength, to the anterior suture and on the first part of the body to the base; on the final half turn, however, the axials are restricted almost entirely to the posterior third; spiral sculpture low and irregular, consisting of half a dozen equal and equispaced coarse and somewhat flattened cords upon the penult and twice as many on the early part of the ultima; secondary spirals are introduced near the base of the first half, and these increase in prominence so that toward the aperture they are almost as strong as the primaries; there are two or three feeble secondary spirals on the sutural band; suture deeply impressed, strongly canaliculate on the later volutions; body constricted posteriorly, sloping steeply in front to the base, where it is abruptly constricted or wrinkled, forming a conspicuous spiral sulcus, which separates the body from the anterior canal; aperture subovate, grooved posteriorly and produced anteriorly into a short, broad, slightly recurved canal; outer lip thin and crenulated along the margin in harmony with the spiral sculpture, thickened or varicose in very old individuals; inner lip excavated and calloused; parietal wash very thick and heavy in old individuals; columella reinforced, marked by a very oblique fold near the anterior extremity and along the margin of the anterior canal; anterior canal short and broad; umbilical chink shallow; anterior fasciole a broad and oblique ridge, registering the incremental stages of the anterior canal, extremity broadly and rather deeply emarginate. An immature individual measures in altitude, 54.5 millimeters; in maximum diameter, 35 millimeters.

This magnificent species is common at Coon Creek, but even though the shells are thick and fairly strong the. specimens are nearly always crushed as they occur in the matrix, so that perfect specimens are rarely obtained. The shells attain considerable dimensions; imperfect specimens in the collection show that some individuals had an altitude of about 80 millimeters and a maximum diameter of about 50 millimeters. The species is well characterized by the retractive axials, which are unusually elevated and strongly rounded. The interaxials are unusual be- cause they are so deep and narrow. The spiral sculpture consists of both primary and secondary cords. The peculiar spiral sulcus at the base of the body is conspicuous on the outer wall of the shell but produces little or no effect on the inner surface of the shell wall within the body cavity.

Occurrence: Ripley formation, Dave Weeks place on Coon Creek, McNairy County, Tenn.

Collections: Johns Hopkins University, Vanderbilt University, U. S. National Museum.

\section{Seminola solida Wade}

Plate LI, Figures 1, 2

1917. Seminola solida. Wade, Acad. Nat. Sci. Philadelphia Proc., p. 292, pl. 19, figs. 1, 2.

1918. Seminola solida. Cossmann, Rev. critique paléozoologie, année 22 , Nos. 1-2, p. 21.

Shell of medium size and rather stout or coarse, globose in outline; spire low and obtuse, its elevation about one-third the total altitude of the shell; whorls five on an incomplete individual, increasing in size to an inflated body; sculpture elaborate, both axial and spiral; axial costae 17 or 18 on the body, subequal and subequispaced, very narrow, abruptly elevated, somewhat incremental in character, terminating abruptly at the shoulder and diminishing in strength upon the anterior slope of the body; intercostal spaces concave and not so wide as the costae; spirals less coarse than axials but overriding them; fillets 10 on the ultima and 2 on the penultima; spirals equal and equispaced, more prominently elevated on the summits of the costals than in the intercostal areas; an unornamented sutural ridge developed just behind the shoulder and in front of the suture, closely appressed to the preceding whorl; suture impressed, crenulated by the costals of the preceding whorl; body abruptly constricted, cut off from the anterior canal by a conspicious spiral sulcus; aperture pyriform, produced anteriorly into a short, sharply recurved canal; outer lip crenulated along the margin in harmony with the spirals; inner lip heavily calloused, excavated medially; columella reinforced, marked by a strong oblique marginal fold; parietal wash heavy and terminating in a sharp line along its outer margin; umbilical chink shallow and obscure; anterior fasciole well defined, deeply emargined at its extremity. Altitude, 24.4 millimeters; maximum diameter, 19.4 millimeters.

This species is well characterized by its low spire and globose outline. It differs from Seminola crassa in its much smaller size, in the character of its pillar, and in having long axial costae parallel to the axis, persisting from the shoulder to a point well down on the anterior part of the body. The axial costae of Seminola crassa are retractive and more deeply impressed, even in young individuals. S. solida has an anterior canal and marginal columellar fold much the same as Gabb's species of this genus, which was de- 
scribed under the name Nassa globosa, ${ }^{97}$ but that species is much larger, and its external ornamentation tends to become obsolete on the later whorls.

Occurrence: Ripley formation, Dave Weeks place on Coon Creek, McNairy County, Tenn.

Collections: Johns Hopkins University, Vanderbilt University, U. S. National Museum.

\section{Genus ODONTOBASIS Meek}

Odontobasis australis Wade, n. sp.

Plate LI, Figures 13, 14; Plate LII, Figures 13, 14

Shell of medium size and fragile; subfusiform in outline; spire acuminate; early whorls and protoconch unknown; external sculpture elaborate, consisting of both axial and spiral elements; axial costae 12 on the body, strong and high, overridden by numerous spiral threads; suture appressed; body well rounded, constricted both anteriorly and posteriorly, produced in front into a short anterior canal; posterior slope of pillar marked by an oblique spiral sulcus; aperture lenticular, produced in front into a short open canal; outer lip arcuate, its inner surface marked by low denticles; inner lip excavated; columella marked by two low oblique folds. Elevation of body, 8.5 millimeters; maximum diameter, 5.2 millimeters.

This species is characterized by its strong axial costae, which are overridden by numerous sharp spiral threads, and further by the dentate inner surface of the outer lip. It is closely related to Odontobasis ventriosa Meek, ${ }^{08}$ from the Pierre shale of the western interior region.

The small specimen figured on Plate LII, which is somewhat doubtfully referred to this species, was discovered after the description was written. The altitude of the spire is slightly more than one-third the altitude of the shell.

Occurrence: Ripley formation, Dave Weeks place on Coon Creek, McNairy County, Tenn.

Collection: U. S. National Museum.

\section{Pseudoliva? attenuata Wade, n. sp.}

Plate LI, Figures 4, 5

Shell small and fragile; spire acuminate and very much attenuated; whorls three or four, loosely coiled and increasing in size gradually; protoconch unknown, its scar small; external sculpture elaborate, subcancellate, consisting of very numerous axial and spiral threads; axials wavy and strongest on the posterior portion of the whorls, evanescing anteriorly; anterior slope of the body marked by a deep oblique spiral sulcus, terminating anteriorly on the outer lip just behind the anterior siphonal notch; suture impressed; body whorl elongate, flattened laterally; aperture lenticular, notched anteriorly; outer lip broken in the type; inner lip gently excavated and calloused.

${ }^{n} \mathrm{Gabb}$, W. M., Notes on American Cretaceous fossils, with descriptions of some new species: Acad. Nat. Sci. Philadelphia Proc. for 1876, p. 282, 1877.

${ }_{98}$ Meek, F. B., cp. cit., p. 354, pl. 19, flgs. 1, a, b, c.
Altitude, 6 millimeters; maximum diameter, 2 millimeters.

This species is characterized by a very much attenuated spire and an oblique spiral sulcus on the anterior slope of the body. The generic classification of this species is very uncertain. It is probably not a Pseudoliva, and the discovery of other specimens may lead to the establishment of a new generic group to include this form.

Occurrence: Ripley formation, Dave Weeks place on Coon Creek, McNairy County, Tenn.

Collection: U. S. National Museum.

\section{Genus HYDROTRIBULUS Wade}

1916. Hydrotribulus. Wade, Acad. Nat. Sci. Philadelphia Proc., vol. 68, p. 464 . Etymology: $\delta \delta \omega \rho$, water;

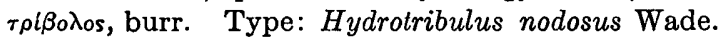

Shell moderately large and solid, top-shaped in outline; spire less than half the entire length of the shell; protoconch scar small; sculpture vigorous, the axials undulatory, the spirals more sharply defined; aperture pyriform and produced anteriorly into a narrow recurved canal; outer lip expanded and abruptly constricted at the base of the body, dentate within; parietal wall heavily glazed, in some specimens bearing a toothlike process directly in front of the posterior commissure; inner lip excavated and calloused, reflected anteriorly, entirely concealing the umbilicus; edge of pillar flattened at entrance of canal, simulating a fold.

This genus is characterized by a fairly low spiral angle, vigorous rugose cancellate sculpture, a much inflated body, and further by a much excavated and reflected inner lip, which conceals an umbilicus. Besides the Coon Creek species it is represented by an undescribed species from Owl Creek, Miss., and another from Brightseat, Md., and by a species in the Senonian of Aachen, Germany. The German species was first described by Müller in 1851 and assigned to the genus Rapa. Since then it has been variously assigned by other paleontologists to such genera as Fusus, Pyrella, Hemifusus, Pyropsis, and finally to Tudicla by Holzapfel, ${ }^{99}$ who discussed the species in 1888. A study of the description and figures of the German form, together with the Coon Creek species and specimens from the Maryland and Mississippi localities, indicated that these species belong to a well-defined group, and it seemed advisable to propose for their reception a new genus, Hydrotribulus, of the family Buccinidae. This genus resembles Pyrifusus in general aspect but differs from it in having a shorter recurved anterior canal and a pillar which is flattened and recurved in a unique manner at the entrance of the canal. Tudicla has a much flatter spire, a more globose body, and a much more abruptly

90 Holzapfel, Eduard, Die Mollusken der Aachener Kreide: Palaeontographica, Band 34, p. 106, pl. 11, flgs. 4-7, 1888. 
constricted, longer, and straighter canal. Hydrotribulus differs from Strepsidura in characters of the anterior canal and aperture and in its characteristic rugose cancellate sculpture.

\section{Hydrotribulus nodosus Wade}

Plate LI, Figures 6, 7

1916. Hydrotribulus nodosus. Wade, Acad. Nat. Sci. Philadelphia Proc., vol. 68 , p. 465 , pl. 24, figs. 4,5 .

1917. Hydrotribulus nodosus. Cossmann, Rev. critique palészoologie, année 20, No. 3, p. 99.

Shell fairly large and very heavy, with a rugosely cancellate sculpture; top-shaped in outline; spire rather low, its altitude less than the length of the aperture, sides converging at an angle of $70^{\circ}$; whorls of conch five, increasing rapidly in size to a much inflated body, obliquely shouldered, the peripheral angle of the spire falling in Iront of the medial hori. zontal; sculpture vigorous, both axial and spiral, restricted almost entirely to the area in front of the periphery; axials elevated and broadly rounded, 16 on the body whorl of the type, subequal in size and regularly spaced; spiral sculpture of broad, elevated fillets, most prominent on the body, subnodose at the intersections of the axials, which they override, two on the whorls of the spire and four on the medial portion of the ultima, separated by shallow channels of approximately the same width as the fillets; shoulder sloping at an angle of about $45^{\circ}$, very feeble convex; sculpture with retractive undulations corresponding in number and proportion to the axials, with an obscure secondary liration and revolving a little behind the periphery; base of body and anterior canal threaded with flattened spirals, which become increasingly narrow anteriorly; suture very deeply channeled, undulated in harmony with the preceding volution, body whorl constricted rather abruptly into a broad anterior canal; aperture pyriform, produced anteriorly into a narrow canal; outer lip broadly expanded, crenulated at the margin, and corresponding in position with the interspiral areas; inner lip broadly concave, nonplicate; parietal wall heavily glazed and bearing an obscure tooth directly in front of the posterior commissure; edge of pillar flattened at the entrance of the canal, simulating a fold; canal sharply recurved, moderately long and narrow, with parallel proximate margins; umbilicus closed by the reflected inner wall of the aperture but indicated by a depression between the callus and the anterior fasciole. Altitude, 44 millimeters; length of aperture and canal, 28 millimetcrs; maximum diameter, 32.4 millimeters; spiral angle, $70^{\circ}$.

This elegant species is represented in the collection from Coon Creek by perfectly preserved specimens. The species is characterized by the obliquely shouldered whorls, the prominent subnodose intersections of the banded spirals, and the undulatory axials, and further by the low spiral angle and outline of cross section of body.

Occurrence: Ripley formation, Dave Weeks place on Coon Creek, McNairy County, Tenn.

Collection: Johns Hopkins University, Vanderbilt University, U. S. National Museum.

\section{Superfamily TAENIOGLOSSA \\ Family TRITONIDAE \\ Genus TRITONIUM Iink}

- Tritonium univaricosum Wade, n. sp.

Plate LI, Figures 9, 10

Shell fairly large and thick; spire turreted, its elevation about half the total altitude of the shell; whorls five or six, closely appressed, obtusely shouldered, and increasing gradually in size; apex broken away and protoconch unknown; sculpture strong, both axial and spiral, both elements being well rounded; axials widely spaced, absent between the suture and shoulder and evanescing abruptly on the anterior slope of the body; axial costae overridden by spiral lirae, the intersections slightly nodose; there is a single well-developed varix, which is rather strong and tuberculate on the shoulder; it is situated near the margin of the aperture and persists from the suture to the base of the body; spiral elevations both primary and secondary; lirae alternating on the body and anterior canal, but four secondary lirae on the concave depression behind the suture; suture impressed and undulating; body obtusely shouldered posteriorly and abruptly constricted in front into a narrow, sinistrally bent anterior canal; aperture circular in outline, slightly notched along the shoulder and produced in front into a narrow curved canal; outer lip thin along the margin, thickened within, and marked by eight denticles between the posterior notch and the anterior canal; inner lip reflected, marked by four or five marginal denticles; columella enlarged at the entrance of the anterior canal; umbilical chink impressed; anterior fasciole represented by a ridge on the pillar. An individual with apex broken away measures in altitude, 46.6 millimeters; in maximum diameter, 27.4 millimeters.

This species is well characterized by its axial and spiral sculpture and further by the dentate outer lip. It is rare at Coon Creek. Collecting during two summers has yielded only two specimens, one of which is perfect except for the loss of the apex of the spire. No very closely related species has been found in the Upper Cretaceous literature, and this is probably the first true Tritonium to be discovered in Upper Cretaceous strata. In 1902 Cossmann ${ }^{1}$ pointed out that no typical Tritonidae were known in sediments older than the "Paleocene" and that the species Tritonium

1 Cossmann, Maurice, Observations sur quelques coquilles crótaciques recueillies en France, $5^{\circ}$ article: Assoc. française av. sci., Compt. rend. $37^{\text {me }}$ session, Montauban, 1902, p. 546, pl. 3, figs. 23, 24, 26, 1903. 
loricatum Zekeli and Tritonium gosauicum Zekeli, ${ }^{2}$ from the Turonian of the Gosau beds, were not true Tritoniums but belonged to Meek's genus Cantharulus. ${ }^{3}$

Occurrence: Ripley formation, Dave Weeks place on Coon Creek, McNairy County, Tenn.

Collection: U. S. National Museum.

\section{Family STROMBIDAE \\ Genus PUGNELLUS Conrad \\ Pugnellus densatus Conrad \\ Plate LII, Figures 4, 5}

1858. Strombus densatus. Conrad, Acad. Nat. Sci. Philadelphia Jour., 2d ser., vol. 3, p. 330, pl. 25, fig. 14.

1860. Pugnellus densatus. Conrad, Acad. Nat. Sci. Philadelphia Jour., 2d ser., vol. 4, p. 284.

1864. Pugnellus densatus. Meek, Check list of the invertebrate fossils of North America, Cretaceous and Jurassic, p. 20.

1901. Pugnellus densatus. Hill, U. S. Geol. Survey Twentyfirst Ann. Rept., pt. 7, pl. 48, fig. 2.

1905. Pugnellus densatus. Johnson, Acad. Nat. Sci. Philadelphia Proc., vol. 57, p. 23.

1906. Pugnellus densatus. Veatch, U. S. Geol. Survey Prof. Paper 46, pl. 10, fig. 3.

1907. Pugnellus densatus. Weller, New Jersey Geol. Survey, Paleontology, vol. 4, p. 720 , pl. 83, fig. 6 .

1914. Pugnellus densatus. Stephenson, U. S. Geol. Survey Prof. Paper 81, check list, tables 2, 8, 9.

1916. Pugnellus densatus. Gardner, Maryland Geol. Survey, Upper Cretaceous, p. 486.

Conrad describes this species as follows:

Lip expanded, very thick; costae disappearing on the middle of the volution; labrum suddenly thickened, with a groove behind the raised margin; a calcareous deposit sometimes coats the whole shell, rising into an oblique, thick, prominent ridge, the upper margin of which is on a line with the apex.

Shell of medium size and thick; highly polished and brownish yellow; outline asymmetric, much distorted by heavy deposits of callus and a thick, expanded outer lip; spire acute but low, its elevation less than one-third the total altitude of the shell; whorls five or six, closely appressed and globose, increasing markedly in size; protoconch small, smooth and elevated, coiled more than once (observed only in young individuals); spiral and nuclear characters hidden in adults by glaze and callus, which is thickly deposited, even as a thickened, well-rounded, and upturned ridge or mass on the very apex of the spire; sculpture absent on adults, except for five $\theta^{\circ}$ or six strong protractive axial costae on the final half turn of the shell; unglazed, early spiral whorls of young marked by numerous impressed microscopic spiral lines; suture hidden by callus but impressed on young individuals; body gently rounded, abruptly constricted in front, merging into a narrow, dextrally inclined

2 Zekeli, Friedrich, Die Gastropoden der Gosaugebilde: K.-k. geol. Reichsanstalt Abb., Band 1, pp. 82, 83, pl. 15, figs. 1, 3, 1852.

8 Meek, F. B., op. cit, p. 378 , pl, 32, fig. 5 . anterior canal; aperture narrow and elongate; outer lip expanded, reflected, and thickened, produced backward upon the penultima and extending in front to the anterior extremity of the pillar; inner lip very much constricted at the base of the body; parietal wall washed with a callus that extends from the apex of the spire to the base of the body in a thick irregular mass.

This species is common in the sediments at Coon Creek and is represented in the present collection by a number of perfect shells. Nearly all these shells are bright yellowish brown when they are recovered from the matrix. This color may be a remnant of a once brilliant shell color.

Pugnellus densatus has a wide geographic distribution in the east Atlantic and Gulf States, ranging from New Jersey to Texas, and a geologic occurrence in the Monmouth or the Ripley and the Matawan. Probably when all the Upper Cretaceous gastropods of this wide region are described several forms will be known. A kindred form has been recently described as Pugnellus goldmani by Miss Gardner, ${ }^{4}$ from the Monmouth of Maryland, and another very large but related new species, $P$. abnormalis, occurs at Coon Creek.

The genus is widely distributed in the Upper Cretaceous of the world and is especially characteristic of the Indo-Pacific region, having been found in the Libyan Desert, Madagascar, Baluchistan, southern India, Borneo, New Zealand, Colorado, California, Utah, Wyoming, Quiriquina. (Chile), and southern Patagonia. There are three species of Pugnellus in the Cretaceous of southern India, and apparently the one most closely related to Pugnellus densatus is $P$. uncatus (Forbes), ${ }^{5}$ which occurs in both the Trichinopoly and Arrialoor groups. Woods ${ }^{6}$ has figured an incomplete specimen from the Senonian of South Africa, which has a spire and an axial sculpture on the body somewhat similar to Pugnellus densatus.

Occurrence: Ripley formation, Dave Weeks place on Coon Creek, McNairy County, Tenn.

Collections: Philadelphia Academy of Natural Sciences, Maryland Geological Survey, New Jersey Geological Survey, Vanderbilt University, U. S. National Museum.

Outside distribution: Matawan group (Wenonah sand), New Jersey. Black Creek formation, North Carolina and South Carolina. Monmouth formation, Prince Georges County, Md. Ripley formation, Eufaula, Ala., and Union and Tippah counties, Miss.

4 Gardner, J. A., Maryland Geol. Survey, Upper Cretaceous, p. 469, pl. 17, figs. $5,6,1916$.

s Stoliczka, Ferdinand, India Geol. Survey Mem., Palaeontologia Indica, Cretaceous fauna of southern India, vol. 2, p. 22, pl. 3, figs. 9-13, 1868.

6 Woods, Henry, The Cretaceous fauna of Pondoland: South African Mus. Apnals, vol. 4, pt. 7, p. 320, ipl. 38, fig. 16, 1906. 
Pugnellus abnormalis Wade, n. sp.

Plate LII, Figures 6, 7

Shell large and thick, outline asymmetric and much distorted by callus and an abnormal outer lip; spire elevated but low, its elevation less than one-third the total altitude of the shell; sculpture if present entirely obscured by callus, which covers the entire shell; external surface glazed and colored yellowish brown; suture entirely hidden by callus; body slightly inflated and abruptly constricted in front; produced into a narrow anterior canal; aperture broad and elongate; outer lip abnormal, produced backward upon the ultima and extending in front to the anterior extremity of the anterior canal, the medial portion of the outer lip extended into a thick, irregularly shaped mass of callus with a concave impression on the ventral side and terminating in a deep groove on the posterior side of the mass of callus; inner lip excavated at the base of the body; parietal wall covered with a thick deposit of callus, which extends as a very high narrow ridge to the posterior extremity of the spire, where it caps the apex with a dorsally bent false apex; columella smooth. A slightly imperfect individual measures in altitude, 82.6 millimeters; maximum diameter, including expanded outer lip, 63.8 millimeters.

Only one individual of this species is known. It is well characterized by its unusual shape and abnormal developinent of callus. It differs from Pugnellus densatus in having no axial sculpture and further in characters of the outer lip.

Occurrence: Ripley formation, Dave Weeks place on Coon Creek, McNairy County, Tenn.

Collections: U.S. National Museum, Johns Hopkins University.

\section{Family APORRHAIDAE}

The Aporrhaidae appeared first in the Jurassic age and reached their greatest development in the Cretaceous seas. The family decreased in numbers in Tertiary time and is now, in common with many other Cretaceous families, represented only by a few species. There appear to be only three living species known, yet they are types of the largest Cretaceous group.

The family was monographed by J. S. Gardner ${ }^{2}$ in 1875. Later, in 1904, Cossmann $^{8}$ gave a comprehensive systematic presentation of the sections, subgenera, and genera of the family. Probably a large percentage of the American Cretaceous species of this most interesting group of gastropods are unknown to science. Many of the species that have been described are represented by very poor and fragmentary material.

\footnotetext{
1 Grdner, J. S., On the Gault A porrhaidae: Geol. Mag, new ser., decade 2 vol. 2, pp. $48-58,124-130,198-203,291-298,1875$. On the Cretaceous Aporrhaidae Idem, pp. 392-400.

8 Cossmann, Maurice, Essais do paléoconchologie comparée, pt. 6, pp. 48-117, 1904; pt. 10, annexe, p. 233,1915
}

\section{Genus ANCHURA Conrad}

Anchura convexa Wade, n. sp.

Plate LII, Figures 8, 9

Shell fairly large and strong; spire turreted and acute; whorls more than eight, convex, increasing gradually in size; apex broken away, protoconch unknown; sculpture nodulate, consisting of both spiral and axial elements, axial ribs low and protractive, very numerous and close on the early whorls but becoming wider and less distinct upon the body; spiral elevations low, obscured by the axials on the spire but more distinct on the body, spiral elevations five on the penultima and ten on the ultima; spiral interspaces marked by fine secondary lirae; low tubercles or nodules formed at the intersections of the spirals and axials; on the expanded outer lip the third spiral elevation in front of the suture persists as an elevation, but the adjacent three spiral ridges break up into a number of secondary lirae, which spread out in fan shape over the expanded outer lip; suture impressed; body convex and well rounded; that part of the body minus the apertural features is almost spherical in outline, body. produced in front into a short, narrow, and pointed anterior canal; aperture brilliantly glazed with callus; inner aperture lenticular, produced in front into a narrow open canal, extended posteriorly into a shallow heavily calloused notch to the posterior suture of the penultima; outer lip widely expanded and thickened internally, its outer margin slightly lobed in front and produced backward into an acutely angular extension, posterior margin of outer lip sinuous and marked by one or two obscure tubercles, the posterior extension of the outer lip adnate to the spire and extending as far back as the antepenultima; inner lip arcuate, strongly constricted at the base of the body, heavily calloused; columella smooth; parietal wash heavy, its margin sharply defined and extending to the posterior commissure.

An imperfect individual measures in altitude, 32.5 millimeters; maximum diameter, dorso-ventrally, 15 millimeters; extension of outer lip, 14.1 millimeters.

This species is well characterized by its short, stocky outline, convex whorls, and further by the thick parietal callus. Anchura abrupta Conrad $^{\circ}$ is a closely related species from Owl Creek, Miss.

Occurrence: Ripley formation, Dave Weeks place on Coon Creek, McNairy County, Tenn.

Collection: U.S. National Museum.

\section{Anchura substriata Wade, n. sp.}

\section{Plate LII, Figure 10}

Shell large, outer lip abnormally expanded; spire very acuminate, its elevation greater than half the total altitude of the shell; spiral angle low at the apex

$\theta$ Conrad, T. A., Descriptions of new species of Cretaceous and Eocene fossils of Mississippi and Alabama: Acad. Nat. Sci. Philadelphia Jour., 2d ser., vol, 4, p. 284, pl. 47, fig. 1, 1860. 
and increasing in size with age; whorls 13 or 14 , feebly convex, increasing in size gradually; protoconch small and elevated, coiled three times, its whorls well rounded and regular; sculpture elaborate, consisting of both axial and spiral elements; axial elevations low and broadly sinuous, best developed on the whorls of the spire and disappearing almost entirely on the body; axial elevations overridden by spirals; low, irregular-shaped nodules developed at their intersections on the later whorls; primary spiral fillets 12 or 14 on the body and 6 on the whorls of the spire; spiral depressions marked by 3 to 6 fine secondary spiral threads; the fourth spiral fillet from the suture persists as an elevation to the most posterior point of the expanded outer lip, and the adjacent four spiral ridges break up into secondary lirae and spread out with the secondary threads in the interspaces in fan shape over the expanded outer lip; suture impressed; body very slightly constricted posteriorly and abruptly constricted in front, where it merges into a narrow, smooth, and straight anterior canal aperture glazed with callus; inner aperture broadly lenticular, produced in front into a narrow open canal, slightly notched posteriorly and extending in a curved groove on the inner side of the outer lip to the most posterior point of this lip; this groove is obscured by callus in old-age stages; outer lip very widely expanded into a wide abnormal lip, which near the outer margin is slightly lobed in front and produced backward into a long, sharp, slightly curved, spur-shaped projection; extreme outer margin broadly arcuate; outer lip thin in young adults but very much thickened on the inner side of old adults; inner lip excavated medially; columella smooth; parietal wash thin and extending far out on the adjacent body region. A slightly imperfect individual measures in altitude, 81.6 millimeters; elevation of spire, 43 millimeters; maximum diameter, including the expanded outer lip, 50 millimeters.

This species is characterized by its high, very acute spire and further by the well-developed broadly sinuous axial ribs. Its pillar is feeble and smooth. The outer margin of the outer lip is arcuate. In general aspect it resembles Anchura convexa, but it differs from that form in size and detail of external sculpture. In many respects it greatly resembles Anchura haydeni White, ${ }^{10}$ which occurs in the Pierre shale of Colorado. It differs from Anchura abrupta Conrad mainly in the shape of the outer lip. The species Rostellaria noneliana (D'Orbigny), ${ }^{11}$ from the Turonian of France, and Aporrhais securifera Forbes, ${ }^{12}$ from the Trichinopoly group of southern

\footnotetext{
10 White, C. A., Cretaceous fossils of the western States and Territories: U. S. Geol. and Geog. Survey Terr. Eleventh Ann. Rept., p. 312, pl. 7, fig. 1a, 1879.

${ }^{11}$ Cossmann, Maurice, Essais de paléoconchologie comparée, pt. 10, p. 233, pl. 12, figs. $31,32,1915$

12 Stoliczka, Ferdinand, India Geol. Survey Mem., Palaeontologia Indica, Cretsceous fauna of southern India, vol. 2, p. 28, pl. 2, flgs. 2-4, 1868.
}

India, are probably related ancestral forms of the Senonian species of this group.

The shells of Anchura substriata are very common at Coon Creek, but perfect specimens are rarely obtained, not only because the shells are very fragile but also because the high spire, the slender pillar, and the expanded outer lip are so extended that they break away easily, and for these reasons many of the individuals were imperfect before they were covered up in the sediments.

Occurrence: Ripley formation, Dave Weeks place on Coon Creek, McNairy County, Tenn.

Collection: U. S. National Museum.

\section{Anchura lobata Wade, n. sp.}

Plate LII, Figures 11, 12

Shell of more than medium size; thin but tough and strong; spire turreted, its elevation a little greater than half the total altitude of the shell; whorls seven, increasing gradually in size, convex, and closely appressed; protoconch small and smooth, trochoid, and coiled three times; sculpture dominantly axial; axial costae abruptly elevated but low, angular on the crest, and protractive, more widely spaced on the body and disappearing near the aperture; low varicose ribs appear at irregular intervals; varices not protractive but parallel to the axis; spiral sculpture consists of fine, crowded, slightly impressed lines on the spire but absent on the body; suture impressed; body inflated and very abruptly constricted in front, where it merges into a narrow, sharp anterior canal; inner aperture lenticular and produced in front into a narrow, straight canal; outer lip expanded into a broad wing-shaped appendage, lobed anteriorly and produced backward into a pointed spur-shaped projection; outer margin slightly thickened; posterior commissure extended backward upon the penultima; inner lip excavated; columella smooth; parietal wall washed with a thin, wide brilliant glaze of callus. Altitude, 48.4 millimeters; maximum diameter, including the expanded outer lip, 27.2 millimeters.

This species is eharacterized by its low, angular protractive axial ribs, which are varicose at irregular intervals, and further by its faint microscopic spiral sculpture. In this respect it differs from Anchura pennata (Morton), ${ }^{13}$ a closely related species that occurs in the Monmouth of New Jersey and the Ripley of Alabama. A related species has been described as Anchura infortunata ${ }^{14}$ by White from the Emscherian of the province of Sergipe, Brazil. The two species Anchura prolabiata White, ${ }^{15}$ from the Colorado group of the western interior of the United

${ }_{13}$ Weller, Stuart, New Jersey Geol. Survey, Paleontology, vol. 4, p. 711, flgs. $10-17,1907$.

14 White, C. A., Contribuições á paleontologia do Brazil: Mus. nac. Rio de Janeiro Archivos, vol. 7, p. 173, pl. 11, fig. 20, 1887. (Portuguese and English.)

${ }^{16}$ Stanton, T. W., The Colorado formation and its invertebrate fauna: U. S. Geol. Survey Bull. 106, p. 143, pl. 31, fig. 2, 1893. 
States, and Rostellaria schlotheimi Roemer, ${ }^{16}$ from the sands of Vaals, near Aachen, Germany, are both members of this group which have deeply sinuated outer lips but in other respects greatly resemble the species from Tennessee. Four members of this group have been reported by Fric ${ }^{17}$ from the Emscherian of Bohemia. The two species Alaria papilionacea Goldfuss ${ }^{18}$ and Alaria tegulata Stoliczka ${ }^{18}$ are members of the group from the Upper Cretaceous of southern India and are probably distantly related to the European and American species. Woods ${ }^{19}$ has the spire of an incomplete specimen from Pondoland, South Africa, which shows a strong slightly curved axial sculpture, overridden by fine spiral lines, and ornamentation highly characteristic of the species Anchura lobata Wade.

Occurrence: Ripley formation, Dave Weeks place on Coon Creek, McNairy County, Tenn.

Collection: U. S. National Museum.

\section{Anchura? pergracilis Johnson}

Plate LIII, Figures 1, 2

1898. Anchura sp.? (young). Johnson, New Jersey Geol. Survey Ann. Rept. for 1897, p. 264.

1898. Anchura? pergracilis. Johnson, Acad. Nat. Sci. Philadelphia Proc. for 1898, p. 463, text fig. 2.

1905. Anchura pergracilis. Johnson, Acad. Nat. Sci. Philadelphia Proc., vol. 57, p. 22.

1907. Anchura pergracilis. Weller, New Jersey. Geol. Survey, Paleontology, vol. 4, p. 713, pl. 81, figs. 18, 19.

1916. Anchura pergracilis. Gardner, Maryland Geol. Survey, Upper Cretaceous, p. 476.

Johnson in 1898 described this species as follows:

Shell fusiform, whorls convex, the body whorl with about 18 and the spiral whorls with 15 equidistant flexuous longitudinal ribs; numerous fine revolving lines, more prominent between the ribs and somewhat obsolete on the angles of the ribs, cover the entire shell; suture deeply impressed. The length of the largest specimen (including the two apical whorls, which are wanting) is about 20 millimeters.

Anchura? pergracilis Johnson is well characterized by its relatively small size, very slender outline, and numerous sigmoidal costae. There are several wellpreserved specimens of this species in the Coon Creek collection, but none show any signs of the expanded outer lip common to the other species of this genus. No doubt Johnson properly questioned his generic determination when he described this species, for it is very probable that this species is not a true Anchura nor a member of any of the described genera in the family Aporrhaidae but rather is a member of an undescribed generic group. An Eocene species, which has a simple outer lip and the same slender form, together with the same characters of spiral and axial sculpture,

10 Cossmann, Maurice, Essais de paléoconchologie comparée, pt. 6, p. 95, pl. 7, fig. 13,1804 .

17 Frič, Anton, Studien im Gebiete der böhmischen Kreideformation; V, Priesener Schlchten: Archiv naturwiss. Landesd. Böhmen, Band 9, No. 1, p. 85, 1893; VI, Dio Chlomeker Schichten: Idem, Band 10, No. 4, p. 46, 1897.

18 Stoliczka, Ferdinand, op cit., vol. 2, pp. 31, 32, pl. 2, figs. 9, 10, 11-13, 1868.

10 Woods, Henry, The Cretaceous fauna of Pondoland: South African Mus. Annals, vol. 4, pt. 7, p. 319, pl. 38, flgs. 14a, b, 1906. which may belong to the same group as the Cretaceous species, has been figured by Cossmann as Rostellaria lucida Sowerby.20 Further study of the Upper Cretaceous and Eocene gastropods of eastern North America will perhaps throw more light on the true generic relationship of Anchura? pergracilis Johnson.

Occurrence: Ripley formation, Dave Weeks place on Coon Creek, McNairy County, Tenn.

Collections: Philadelphia Academy of Natural Sciences, New Jersey Geological Survey, Maryland Geological Survey, U. S. National Museum.

Outside distribution: Magothy formation ("Cliffwood clay") New Jersey. Matawan group (Woodbury clay), New Jersey. Monmouth formation, Prince Georges County, Md.

\section{Subgenus DREPANOCHILUS Meek}

Anchura (Drepanochilus) quadrilirata Wade, n. sp. Plate LIII, Figures 3, 4

Shell of medium size and very fragile; spire acute, its elevation about half the total altitude of the shell; whorls more than six, convex, increasing in size gradually; apex broken away; protoconch unknown; sculpture strongly axial on the whorls of the spire and on the posterior half of the body but spiral on the anterior half of the body; axials abruptly elevated and angular along the crest, not as broad as the concave interspaces, which become much wider on the lateral whorls, axial ribs 18 on the type, slightly varicose at irregular intervals, about one or two to each whorl; spiral sculpture consists of four strong ridges on the base of the body; the most posterior of these ridges occurs along the medial line of the body and extends out as a carina of the acutely expanded outer lip; on the whorls of the spire and along the base of the body and the anterior canal there are numerous microscopic spiral threads, which override the axial ribs; suture impressed; body convex, well rounded in front and merging into a short anterior canal; aperture broad; outer lip expanded into a narrow acuminate projection bent a little backward from the medial horizontal toward the body; the outer lip widens rapidly, extending to the anterior extremity of the anterior canal in front and to the posterior suture of the penultima behind; inner lip excavated medially; columella smooth; parietal wash thin and wide, its outer limit marked by a sharp line. An imperfect individual measures in altitude, 31.4 millimeters; in maximum diameter, dorso-ventrally, 13.3 millimeters.

This species is well characterized by the four strong spiral ridges on the base of the body. It is represented by a single known individual, which was collected at Coon Creek. This individual is unfortunately imperfect and does not show all of the

${ }^{20}$ Cossmann, Maurice, Essais de paleoconchologie comparé, pt. 6, p. 20, pl. 3, fig. 19, 1904 
expanded outer lip. So far as is now known, no American species that has been described has strong axial sculpture on the posterior half of the body and only strong spiral sculpture on the anterior portion of the ultima. The type of the subgenus DrepanochilusRo:ellaria americana Evans and Shumard, which is a species renamed by Cossmann $D$. evansi ${ }^{21}$-has welldeveloped spirals on the body, but the axials tend to become obsolete. The dual type of body sculpture may be observed in the species Drepanochilus calcarata (Sowerby),22 from the Blackdown beds, and Drepanochilus toxochila (Gardner), ${ }^{23}$ from the Gault of England.

Occurrence: Ripley formation, Dave Weeks place on Coon Creek, McNairy County, Tenn.

Collection: U. S. National Museum.

Anchura (Drepanochilus) calcaris Wade, n. sp.

Plate LIII, Figures 5, 8, 13

Shell smooth, fusiform in outline, with a spurshaped outer lip; spire turreted, its elevation a little greater than half the total altitude of the shell; seven or eight whorls, increasing gradually in size; protoconch small and smooth, trochoid in outline and coiled three and a half times; sculpture elegant, consisting of both axials and spirals; axial costae strong, abruptly elevated, persisting from suture to suture on the whorls of the spire and extending partly over the anterior slope of the body; crests of the axials angular, about 17 upon the body; at irregular intervals the axial costae are enlarged and well rounded, varix-like in appèarance, one or two occurring on each whorl of the spire; axials overridden by many crowded microscopic spiral threads, which are absent on the crest of the varices; suture impressed; body slightly inflated and convex, produced in front into a narrow and pointed anterior canal; aperture lenticular, produced anteriorly into a narrow open canal; outer lip expanded into a long, gracefully upturned narrow projection that greatly resembles a cock's spur in outline; the ventral side of this expanded outer lip is longitudinally grooved; in front of this projection upon the anterior slope of the outer lip are two low toothlike protuberances; inner lip excavated at the base of the body; columella smooth; parietal wall widely glazed with a callus that ends with a sharp margin on the body opposite the aperture. An individual with anterior extremity broken away measures in altitude, 21.2 millimeters; in maximum diameter, including the expanded outer lip, 17.3 millimeters.

This species is well characterized by the varicose axial costae, the curved spur-shaped outer lip, and

${ }^{21}$ Cossmann, Maurice, Essais de paléoconchologie comparée, pt..6, pl. 6, figs. 11, $12,1904$.

22 Gardner, J. S., On the Cretaceous A porrhaidae: Geol. Mag., new ser., decade 2, vol. 2, p. 398, pl. 12, figs. 1-12, 1875. Cossmann, Maurice, op. cit., pt. 6, pl. 4, fig. 10; pl. 5, figs. 1, 2, 4, 1904.

'3ardner, J. S., op. cit., p. 399, pl. 12, figs. 16, 17, 1875. the two toothlike projections on the anterior slope of the outer lip. In these respects it differs from Anchura solitaria Whitfield, ${ }^{24}$ a closely related species from the Navesink marl of the Monmouth group of New Jersey. Drepanochilus calcaris is common in the Coon Creek beds, but its shells are very fragile, so that perfect individuals are rarely obtained. The "Paleocene" species Chenopus analogus Deshayes ${ }^{25}$ has an inflated body and spire sculptured much like the Tennessee Ripley species. Cossmann ${ }^{25}$ refers the two species Aporrhais castorensis Whitfield ${ }^{26}$ and Aporrhais ruida White, ${ }^{27}$ from the Colorado group of the western interior, to this group, but these species are evidently not specifically closely related to the form from Coon Creek, $D$. calcaris.

Occurrence: Ripley formation, Dave Weeks place on Coon Creek, McNairy County, Tenn.

Collection: U. S. National Museum.

\section{Genus PTEROCERELLA Meek}

Pterocerella tippana (Conrad)

Plate LIII, Figures 6, 7

1858. Harpago tippana. Conrad, Acad. Nat. Sci. Philadelphia Jour., 2d ser., vol. 3, p. 331, pl. 35, fig. 25.

1861. Harpago tippanus. Gabb, Synopsis of the Mollusca of the Cretaceous formation, p. 56 (Am. Philos. Soc. Proc., vol. 8, p. 112).

1864. Plerocerella tippana. Meek, Check list of the invertebrate fossils of North America, Cretaceous and Jurassic, pp. 20, 36.

1868. Pterocerella tippana. Gabb, Am. Jour. Conchology, vol. 4 , p. 146 , pl. 14 , fig. 20.

1883. Pterocerella tippana. Tryon, Structural and systematic conchology, vol. 2, p. 195, pl. 60, fig. 90 .

1904. Chenopus tippanus. Cossmann, Essais de paleoconchologie comparée, pt. 6, p. 70, fig. 3 .

1907. Plerocerella tippana. Weller, New Jersey Geol. Survey, Paleontology, vol. 4, p. 718, pl. 83, figs. 1, 2.

1914. Pterocerella tippana. Stephenson, U. S. Geol. Survey Prof. Paper 81, check list, tables 1, 8.

Weller describes this species as follows:

Shell with a spire of moderate height, with about six volutions, having an apical angle of about $48^{\circ}$. The dimensions of a nearly perfect specimen from Texas are: Total height, exclusive of the winglike extensions of the aperture, 35 millimeters; height of spire, 18 millimeters; maximum diameter of body volution, 23 millimeters; extension of the processes on the border of the outer lip, from 18 millimeters to 33 millimeters. The volutions are marked by a revolving keel a little below the midheight of each volution, the sutures not impressed below the surface of the spiral, concave band between the carinae of succeeding volutions. Greatest height of the body volution, exclusive of the winglike extensions, about equal to the greatest height of the spire, marked by a second less sharply angular revolving rib, which is situated about as far below the upper

24 Whitfield, R. P., Gastropoda and Cephalopoda of the Raritan clays and greensand marls of New Jersey: U. S. Geol. Survey Mon. 18, p. 17, pl. 14, flg. 9, 1892. (Also published by New Jersey Geol. Survey.) Weller, Stuart, New Jersey Geol. Survey, Paleontology, vol. 4, p. 714, pl. 81, fig. 6.

${ }^{25}$ Cossmann, Maurice, Essais de paléoconchologie comparée, pt. 6, p. 73, pl. 5 , figs. $6,7,1904$.

${ }^{26}$ Stanton, T. W., The Colorado formation and its invertebrate fauna; U. S, Geol. Survey Bull. 106, p. 143, pl. 31, fig. 1, 1893.

${ }^{27}$ Idem, p. 144, pl. 30, figs. 3, 4. 
carina as that is below the upper suture, and by three other less distinctly marked ones near the anterior margin, the two lower of which are distinctly recurved. When the outer lip of the aperture is complete it is produced into six elongate, divergent, conspicuous winglike processes, which are strengthened along their median lines by thickened ribs or carinae, the median carinae of five of these processes being continuations of the ribs upon the body volution of the shell. The most posterior of the processes is a branch from near the base of the one next to it, and its median line is subparallel to the axis of the spire. Surface of the shell marked only by fine inconspicuous lines of growth.

This species was originally described from a portion of the body volution and parts of the upper winglike processes of the outer lip, and no figure or description of the complete example has previously been given. The nearly perfect individual which has served as a basis for the foregoing description and the accompanying illustration of the species is from Texas and is preserved in the collection of the National Museum at Washington. In New Jersey no example preserving the wings of the aperture has been observed, but one small although nearly perfect internal cast, exclusive of these processes, has been collected, which differs in no essential respect from the larger examples from Texas.

This species is common at Coon Creek, but so far not a single perfect specimen has been recovered from the sediments, so fragile and ramifying are the shells. A spire of one individual reveals the characters of the protoconch. It is small, trochoid, and smooth, coiled three times. The line of demarcation between the first whorl of the conch and the last whorl of the protoconch is not sharp. Such a wide range of so highly specialized a species is uncommon, and an assemblage of perfect specimens from all the localities cited might show that more than one species is represented in the group.

Occurrence: Ripley formation, Dave Weeks place on Coon Creek, McNairy County, Tenn.

Collections: New Jersey Geological Survey, U. S. National Museum.

Outside distribution: Matawan group, New Jersey. Ripley formation, Pataula Creek, Ga., and Tippah County, Miss. Navarro formation, Chatfield, Tex.

\section{Family COLUMBELLARIIDAE}

\section{Genus COLUMBELIINA D'Orbigny}

Columbellina americana Wade, n. sp.

Plate LIII, Figures 14, 15

Shell small and thick; spire short and outer lip conspicuous; elevation of spire about one-third the total altitude; whorls strongly tabulated, two and a half in number; apex flattened; protoconch submerged; sculpture spiral, consisting of two or three spiral ridges on the penultima and six on the body and about five weaker crowded spirals on the pillar; spiral ridges on the body strong and undulated, interspiral spaces deeply channeled and a little wider than the spiral ridges; suture impressed; body abruptly constricted and square-shouldered posteriorly, sloping steeply in front into a narrow slightly bent pillar; aperture wide and trough-shaped, sloping into a narrow inner aperture, produced in front into a short, narrow canal, slightly notched at the shoulder; outer lip strongly varicose, marked on the inside by six low denticles between the anterior canal and the posterior notch; inner lip reflected upon the body opposite the aperture, where the spiral ridges show feebly through the adnate lip; columella smooth; parietal wall covered with the adnate inner lip. Altitude, 6.9 millimeters; elevation of spire, 2.3 millimeters; maximum diameter, 5 millimeters.

The elegant little shells of this species are characterized by their strong, nodulated spiral ridges and varicose, internally dentate outer lip. There is no known American species of this genus with which it may be compared. The type of the genus comes from the Neocomian of France. In general aspect Columbellina americana greatly resembles Columbellina subaloysia Peron. ${ }^{28}$ The altitude of the Lower Cretaceous species is about twice that of the Upper Cretaceous species, and the spire of the Lower Cretaceous species is a little more acute.

Occurrence: Ripley formation, Dave Weeks place on Coon Creek, McNairy County, Tenn.

Collections: U. S. National Museum, Johns Hopkins University.

\section{Family CERITHIIDAE}

Genus CERITHIUM Bruguière

Cerithium percostatum Wade, n. sp.

Plate LIII, Figure 12; Plate LV, Figure 14

Shell small and strong, in outline a slender cone; spire acute; whorls 9 , square in cross section, volutions flattened on a line with the general slope of the spire, increasing gradually and regularly in size from the apex to the ultima; protoconch broken away, its scar small; sculpture dominantly axial; costae strong and distant, nine on the body; axial ribs persistent from suture to suture, the same number on each whorl and occurring at regular intervals, so that the costae form nine almost straight ridges from the apex to the bottom of the ultima across all the whorls of the spire; interaxial spaces wide and concave; spiral ornamentation consists of very fine crowded impressed lines in the interaxial depressions and the base of the body; suture impressed; body square in outline, lower inner anterior corner marked by a narrow and shallow notch; outer lip broken away; inner lip excavated and parietal wall free from callus; columella strong and smooth, terminating in a short recurved

${ }^{28}$ Peron, Alphonse, Études paléontologiques sur les terrains du département de l'Yonne; Céphalopodes et gastropodes de l'étage néocomien: Soc. sci. hist. nat. Yonne Bull., vol. 53, pt. 2, p. 147, pl. 4, 1899. Cossmann, Maurice, Essais do paléconchologie comparée, pt. 6, p. 109, pl. 7, figs. 8, $9,1904$. 
pillar at the anterior extremity. Altitude, 18 millimeters; maximum diameter, 7.1 millimeters.

This species is well characterized by the strong, regularly occurring, and widely spaced costae that form almost straight ridges from the apex to the base of the ultima. No closely related form is known in the American Cretaceous, so that comparisons can not be made. Cerithium percostatum is rare at Coon Creek, and only two specimens have been recovered from the sediments at that locality. Cerithium fenestratum Zekeli, ${ }^{29}$ of the Gosau beds of the Turonian, in the Alpine region, has strong axial costae that persist from suture to suture and also whorls that are rectangular in cross section, both of which are features that characterize Cerithium percostatum.

Occurrence: Ripley formation, Dave Weeks place on Coon Creek, McNairy County, Tenn.

Collection: U. S. National Museum.

\section{Cerithium weeksi Wade, n. sp.}

Plate LIV, Figures 1, 2

Shell of medium size and turreted; external surface very ornate; spire acuminate, spiral angle increasing in size a little with age; whorls 15 or more, increasing gradually in size; protoconch small and trochoid, coiled three times; sculpture elaborate, consisting of spinous and beaded spiral lirae, unequal in strength and spacing; on each whorl there are two or three primary spiral elevations along which occur, at more or less regular intervals, low spines and slight axial elevations, which with the spines form obscure costae; between the primary spinous lirae there occur from three to six slightly beaded secondary lirae or spiral threads of unequal strength and spacing; just behind the sutures is a rather strong beaded secondary lira, which is the angular keel occurring between the sides and base of the body; very strong axial elevations or wrinkles in the sides of the shell occur sparingly as varices; base of body marked by numerous beaded spiral lirae of unequal size and spacing; suture impressed; body trapezoidal in outline, produced in front into a short recurved pillar; aperture nearly circular, notched both in front and behind; outer lip reflected and varicose, faintly crenate on the inside opposite the major spiral ridges; inner lip reflected and adnate to the body, deeply excavated medially; columella twisted or morked by a fold at the anterior extremity, but no fold occurs along the whorls of the spire; canal short and recurved. A small, slightly imperfect individual, showing aperture, measures in altitude, 18.2 millimeters; in maximum diameter, 7.3 millimeters. Some imperfect individuals in the present collection have a maximum diameter of more than 10 millimeters and were probably 35 or 40 millimeters in altitude.

This species is well characterized by its beaded and spinous spiral lirae of unequal strength and occurrence

${ }^{2 \theta}$ Zekeli, Friedrich, Die Gasteropoden der Gosaugebilde: K.-k. geol. Reichsanstalt Abh., Bard 1, p. 117, pl. 24, figs. 8, 9, 1852. and further by its very acuminate spire. This form is a member of a large group of very ornate, small Cerithiums that are abundant in both the Cretaceous and the Tertiary. Highly ornate Cerithiums are very profuse in the Gosau beds of the Alpine region. Of these forms probably the one most closely related to the Tennessee species is Cerithium reticosum Sowerby. ${ }^{30}$ The primary and secondary spiral sculpture is much alike on both, and irregular varices are common to both. The same general features in external ornamentation may be seen on Cerithium limbatum Stoliczka, ${ }^{31}$ from the Arrialoor group of the Cretaceous of southern India. No very closely related species is known from the Aachen Cretaceous of Germany. Cerithium reticosum Sowerby has been reported from the the upper part of the Maestrichtian beds of western Europe. ${ }^{32}$ From the North American Cretaceous, so far as is now known, no very closely related species has been described.

This species is common in the Coon Creek beds and is represented in the Tennessee collection by a number of well-preserved specimens. The species is named in honor of Dave Weeks, the man who owns the place on Coon Creek where the fossils were collected. Mr. Weeks has very kindly given permission for extensive excavating in his fields and has assisted greatly in procuring the present collection of fossils.

Occurrence: Ripley formation, Dave Weeks place on Coon Creek, McNairy County, Tenn.

Collections: U.S. National Museum, Johns Hopkins University, Vanderbilt University.

Cerithium semirugatum Wade, n. sp.

Plate LIV, Figure 21; Plate LV, Figure 6

Shell small and fragile, turreted in outline; spire acuminate; protoconch unknown; external sculpture ornate, consisting of four nodose spiral elevations of unequal size and spacing, the anterior one the stronger; base of body whorl marked by faint spiral threads; suture appressed, body regular, produced anteriorly into a short recurved pillar; aperture ovate, produced in front into a short recurved canal; outer lip thin; inner lip reflected on the pillar; columella strongly twisted anteriorly; canal short, open, curved, and narrow. An imperfect specimen measures in altitude, 5 millimeters; maximum diameter, 2 millimeters; length of aperture, 1.6 millimeters.

This species is related to Cerithium nodoliratum Wade, n. sp., but may be separated from that form by the four less regular nodose spirals of Cerithium semirugatum and its more closely appressed whorls. Furthermore, the base of the body of Cerithium semirugatum is marked with spiral threads, whereas the base of

${ }^{30}$ Zekeli, Frederich, op. cit., p. 99, pl. 19; figs. 1-3.

31 Stoliczka, Ferdinand, India Geol. Survey Mem., Palaeontologis Indica, Cretaceous fauna of southern India, vol. 2, p. 194, pl. 15, fig. 13, 1868.

${ }^{32}$ Kaunhowen, Friedrich, Die Gastropoden der Maestrichter Kreide: Palaeont. Abh. (Dames \& Kohen), Band 8 (neue Folge, Band 4, Heft 1), p. 63, pl. 6, fig. 5, 1898. 
Cerithium nodoliratum is generally unornamented. Cerithium semirugatum resembles Cerithium reticosum Sowerby, ${ }^{33}$ from the Maestricht Cretaceous of Belgium.

Occurrence: Ripley formation, Dave Weeks place on Coon Creek, McNairy County, Tenn.

Collection: U. S. National Museum.

\section{Cerithium nodoliratum Wade, n. sp.}

Plate LIV, Figures 4, 5

Shell of medium size and fragile; in outline very sharply turreted; spire acuminate; spiral angle acute and constant with age; whorls about 14, increasing in size very gradually; protodonch unknown; sculpture elaborate and regular, consisting of three beautifully sculptured nodose spiral elevations, rectangular in cross section; interspiral spaces a little wider than the spiral elevations and marked with faint spiral lines; numerous stronger axial elevations and growth lines; low spiral elevation on the outer margin of the base of the body whorl; base of body not otherwise definitely ornamented; suture deeply impressed; body whorl regular, produced in front into a short recurved anterior canal; aperture subovate, produced in front into a short recurved canal; outer lip thin; inner lip reflected on the anterior canal; columella slightly twisted anteriorly; canal open, short, and recurved. Altitude, 25 millimeters; maximum diameter, 6.4 millimeters; length of aperture, 7 millimeters.

This species is characterized by its nodose lirate spiral sculpture. It resembles in many respects Cerithium potosianum Böse, ${ }^{34}$ from the lower Senonian near Cardenas, San Luis Potosi, Mexico.

Occurrence: Ripley formation, Dave Weeks place on Coon Creek, McNairy County, Tenn.

Collection: U. S. National Museum.

\section{Genus MeSOSTOMa Deshayes}

Mesostoma americanum Wade, $n$. sp.

Plate LIV, Figures 7, 8

Shell very small, porcelaneous, and trochoid in outline; spire elevated and acute; apex broken away in the type; four or five whorls, circular in cross section and increasing gradually in size; sculpture elaborate, axials dominant, costae abruptly elevated and strong, terminating abruptly a little in front of the suture on the posterior part of the body and evanescing on the brink of the anterior slope of the body volution; about 10 axial elevations on the body, regularly spaced and overridden by seven or eight spiral threads; the base of the body is free from well-defined spirals; intersections of spirals and axials slightly tuberculate; suture impressed; body convex

38 Kaunhowen, Friedrich, op. cit., p. 63, pl. 6, fig. 5 .

${ }^{34}$ Böse, Emil, La fauna de moluscos del senoniano de Cárdenas, San Luis Potosi Inst. geol. México Bol. 24, p. 69, pl. 15, flgs. 23, 25, 26, 1906 on the sides and flattened at the base; aperture subovate, slightly emarginate in front, forming an incipient anterior canal; outer lip broken away; inner lip excavated medially; umbilical chink narrow and deep; columella smooth. An imperfect individual measures in altitude, 2.1 millimeters; maximum diameter, 1.5 millimeters.

This elegant little species is well characterized by its spiral and axial ornamentation, which is subtuberculate at the intersections of the costae and lirae. The flat base of the body whorl and the incipient anterior canal are features of this species and also characterize Mesostoma striatacostata (Müller) Holzapfel, ${ }^{35}$ from the Aachen Cretaceous, Vaals, Germany. Mesostoma americanum is rare in the Ripley formation. A single imperfect specimen has been recovered from the Coon Creek beds.

Occurrence: Ripley formation, Dave Weeks place on Coon Creek, McNairy County, Tenn.

Collection: U. S. National Museum.

Mesostoma costatum Wade, n. sp.

Plate LIV, Figures 10, 11

Shell very small, about 1 millimeter in altitude, fragile, and cone-shaped in outline; spire not very acute, its elevation little more than half the total altitude; whorls of conch two and a half, closely appressed and increasing in size regularly; protoconch fairly large and nearly flat, coiled twice, line of demarcation between it and conch not very sharp; sculpture axial; sides of whorls marked by strong, closely spaced, and well-rounded costae, persistent from suture to suture, about 15 on the body; base of ultima smooth; suture impressed; body flat on the sides, abruptly constricted in front, making a flat base to the body; aperture broadly ovate; outer lip thin and simple; inner lip excavated, slightly reflected in front, almost obscuring the umbilical chink; columella smooth. Altitude, 1.1 millimeters; maximum diameter, 0.7 millimeter.

This species is characterized by very small, fragile shells with strong axial costae. It differs from Mesostoma americanum in not having whorls circular in cross section and further in having axial sculpture alone on the outer surface instead of the cancellate ornamentation that characterizes Mesostoma americanum. Mesostoma costatum is smaller and has not so many whorls as Mesostoma mülleri Holzapfel, ${ }^{36}$ which occurs in both the lower and upper Senonian of western Germany and Belgium.

Occurrence: Ripley formation, Dave Weeks place on Coon Creek, McNairy County, Tenn.

Collection: U. S. National Museum.

${ }^{36}$ Holzapfel, Eduard, Die Mollusken der Aachener Kreide: Palaeontographica, Band 34, p. 130, pl. 14, figs. 4-6, 1888.

${ }^{80}$ Holzapfel, Eduard, Die Mollusken der Aachener Kreide: Palaeontographica, Band 34, p. 134, pl. 14, fig. 7; pl. 15, fig. 1, 1888. Kaunhowen, Friedrich, op. cit., p. 59, pl. 3, fig. 5, 1898. 


\section{Genus NUDIVAGUS Wade}

1917. Nudivagus. Wade, Acad. Nat. Sci. Philadelphia Proc. vol. 69, p. 296. Etymology: nudus, unadorned; vagus', a straggler. Type: Nudivagus simplicus Wade.

Shell fairly large and simple, elongate conical; spire elevated and acute; aperture less than one-third as high as the entire shell; whorls of conch numerous, flattened and wide, increasing in size gradually; protoconch small and trochoid, coiled about three times; line between the conch and protoconch poorly defined; external surface usually smooth and glazed; sculpture absent and subdued; incremental varices locally present; suture simple and distinct; body abruptly constricted in front of the periphery into the short, curved anterior canal; aperture lenticular, angular behind and produced in front into a short canal; outer lip thin and simple; inner lip excavated; parietal wall glazed; columella smooth.

This genus is proposed to include a group of gastropods characterized by simple elongate-conical shells with unadorned external surfaces. The aperture is subovate, considerably narrowed toward each end, and terminates anteriorly in a short canal. Besides the type, two other species are known, one of which was described by Stoliczka under the name of Cerithium (Fibula?) detectum, ${ }^{37}$ from the Arrialoor group of beds of the Upper Cretaceous of southern India. The other species was described by Huddleston under the name of Pseudomelania astonensis, ${ }^{38}$ from the upper division of the Inferior Oolite of England. Nudivagus differs from Cerithium, however, in the character of the aperture and in the absence of a strongly twisted columella and from Clava in having a nonplicate columella. Nudivagus is probably near Gymnocerithium $^{39}$ but differs from that genus in having less numerous whorls, which are of greater height and less convexity. The new genus differs from Pseudomelania in the presence of an anterior canal. Meek's genus Closteriscus ${ }^{40}$ includes elongate-conical forms somewhat similar to Nudivagus in outline and lack of external ornamentation, but Closteriscus has welldefined toothlike internal varices, not found in the body cavities of Nudivagus.

\section{Nudivagus simplicus Wade \\ Plate LIV, Figures 6, 14}

1917. Nudivagus simplicus. Wade, Acad. Nat. Sci. Philadelphia Proc., vol. 69, p. 297, pl. 19, figs. 4, 5.

1918. Nudivagus simplicus. Cossmann, Rev. critique paléozoologie, année 22, Nos. 1-2, p. 21.

Shell fairly large and simple, thick but very friable, outline elongate conical; spire elevated and acute, its

\footnotetext{
${ }^{37}$ Stoliczka, Ferdinand, India Geol. Survey Mem., Palaeontologia Indica, Cretaceous fauna of southern India, vol. 2, p. 192, pl. 15, fig. 1, 1868.

${ }_{88}$ Huddleston, W. H., A monograph of the Gastropoda of the Inferior Oolite, p. 245, pl. 18, figs. 8a, b, Palaeont. Soc. London, 1896.

${ }^{89}$ Cossmann, Maurice, Essais de paléoconchologie comparée, pt. 7, p. 36, pl. 7 fig. 17,1906 .

10 Meek, F. B., A report on the invertebrate Cretaceous and Tertiary fossils of the upper Missouri country: U. S. Geol. Survey Terr. Rept., vol. 9, p. 306, 1876.
}

elevation more than twice as great as the length of the aperture; whorls ten, closely appressed, obliquely flattened, increasing gradually and regularly in size from the apex to the ultima; protoconch not distinctly separate from the conch, consisting probably of three volutions, which slope less steeply than do those of the conch; external surface highly polished; sculpture absent, except for very fine and crowded spirals and faint incrementals, discernible with a.lens in the glaze of the external surface; suture indicated by a simple slightly impressed spiral line; body abruptly constricted in front of the periphery and produced into a narrow recurved pillar; aperture lenticular; terminating anteriorly in a narrow, rather long recurved canal; outer lip thin and simple; inner lip excavated medially, washed with a thin callus; columella smooth. A slightly imperfect individual measures in altitude, 76.2 millimeters; maximum diameter, 22.5 millimeters.

This species is the type of the genus and is well characterized by its broad, flat whorls and the fine crowded spiral lines that show through the glaze of the external surface. The shells are relatively thick but not strong. They are fairly common at Coon Creek but are so fragile that not a single perfect specimen has yet been recovered from the sediments.

Occurrence: Ripley formation, Dave Weeks place on Coon Creek, McNairy County, Tenn.

Collections: Johns Hopkins University, U. S. National Museum.

\section{Family CERITHIOPSIDAE \\ Genus CERITHIOPSIS Forbes and Hanley}

Cerithiopsis meeki Wade, n. sp.

Plate LIV, Figures 23, 24

Shell small and slender, in outline very sharply turreted; spire acuminate, with a spiral angle constant in age in the same individual but differing slightly in different individuals; whorls about 12 , increasing in size very gradually; protoconch unknown; sculpture dominantly spiral, consisting of three nearly equally spaced, strongly elevated spiral cords or lines; interspiral spaces marked by numerous short, feeble axial lines, varying in strength and distribution; suture deeply impressed; body whorl regular, abruptly constricted in front and produced into a short curved anterior canal; aperture unknown; columella marked near the anterior extremity by a strong torsion or fold. An imperfect individual measures in altitude, 7 millimeters; in maximum diameter, 2.2 millimeters.

This species is characterized by its small, acuminately turreted form and by its strong trilirate spiral sculpture. The species perhaps bears some relation to Cerithiopsis moreauensis Meek and Hayden, ${ }^{41}$ from the Fox Hills of South Dakota.

${ }^{11}$ Meek, F. B., and Hayden, F. V., Descriptions of new species of Gastropoda and Cephalopoda from the Cretaceous formations of Nebraska Territory: Acad. Nat. Sci. Philadelphia Proc., vol. 8, p. 70, 1856. 
The specimens from Tennessee show no evidence of the one or two smaller folds behind the strong plication on the columella, as mentioned in Meek and Hayden's description of their species. Cerithium triptychum Kaunhowen, ${ }^{42}$ from the Maestrichter Cretaceous of western Europe, no doubt belongs to the same genus and is specifically near Cerithiopsis moreauensis.

Occurrence: Ripley formation, Dave Weeks place on Coon Creek, McNairy County, Tenn.

Collection: U. S. National Museum.

Cerithiopsis quadrilirata Wade, n. sp.

Plate LIV, Figure 17

Shell very small and fragile; spire very high and acuminate; whorls more than 16, increasing in size very gradually; sides of whorls flattened to the line of the spiral slope; protoconch unknown; external sculpture dominantly spiral, consisting of four welldefined spiral lirae, the second and third a little smaller than the first and fourth and a little more widely spaced from one another; interliral grooves deeply channeled and marked by numerous microscopic axial lines or punctations; suture not definitely defined; body whorl normal; apertural features unknown. A slightly imperfect specimen measures in altitude, 11 millimeters; maximum diameter, 1.8 millimeters.

This species is closely related to Cerithiopsis moreauensis Meek and Hayden but differs from that form in having slightly unequal spiral lirae instead of three equally prominent spiral lirae. Cerithiopsis quadritirata Wade, n. sp., is analogous to Cerithiopsis bicostata (Kaunhowen), ${ }^{43}$ from the Maestricht Cretaceous of western Europe.

Occurrence: Ripley formation, Dave Weeks place on Coon Creek, McNairy County, Tenn.

Collection: U. S. National Museum.

\section{Family TRICHOTROPIDAE}

\section{Genus TRICHOTROPIS Sowerby and Broderip}

Trichotropis imperfecta Wade, n. sp.

Plate LIV, Figures 3, 18

Shell fairly large and turbinate; spire elevated, its apex broken away in the type; whorls markedly increasing in size to a much inflated body; sculpture ragged, consisting of numerous irregular and broken spiral threads, which cover the entire surface of the shell; irregular spiral ridges are developed near the aperture; a peripheral keel is well developed, and in front of this keel, on the early part of the body, there is an obscure secondary keel; numerous resting stages break the spiral sculpture and give the surface of the body an irregularly plaited appearance; suture impressed; body obtusely shouldered, area between shoulder and suture concave, body abruptly con-

9 Kaunhowen, Friedrich, op. cit., p. 67, pl. 6, figs. 18, 18a, 1897.

"Idem, figs. 17, 17a, stricted in front; aperture broadly ovate, an incipient notch in front; outer lip expanded, its margin broken away in the type; inner lip excavated; parietal wall calloused; umbilicus narrow and relatively shallow; umbilical keel acute and uneven. An imperfect individual measures in maximum diameter, 41.3 millimeters; length of aperture, 29.5 millimeters.

This most interesting species is very rare at Coon Creek and is represented in the present collection by a single imperfect specimen. The species is well characterized by its external sculpture, which on account of the jagged, plaited, and striate character of the shell ornamentation may be identified from a fragment of a shell. No closely related species is known from the Cretaceous of North America with which the shell may be compared. Trichotropis imperfecta no doubt bears some relation but not a close one to Trichotropis koninckii Müller, ${ }^{44}$ which has been recognized in the Aachen Cretaceous of Vaals, Germany, and also in the Trichinopoly group of the Upper Cretaceous of southern India.45

Occurrence: Ripley formation, Dave Weeks place on Coon Creek, McNairy County, Tenn.

Collection: U. S. National Museum.

\section{Genus ASTANDES Wade}

1917. Astandes. Wade, Acad. Nat. Sci. Philadelphia Proc., vol.

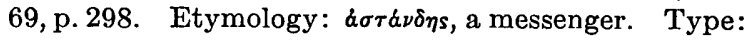
Astandes densatus Wade.

Shell small and trochoid in outline; aperture of the type specimen less than half the entire length of the shell; protoconch small, smooth, and trochoid; whorls of conch circular in cross section and increasing gradually in size; external sculpture both axial and spiral; axials well rounded and retractive; spirals lirate; suture impressed; body equally constricted in front and behind; aperture D-shaped and produced in front into a short, shallow canal; outer lip thickened and dentate; parietal wall washed with a callus; umbilicus imperforate.

This genus is very much like Cerithioderma Conrad ${ }^{46}$ in general outline, in the circular cross section of the whorls, and in the axial and spiral sculpture, but it 'differs from Cerithioderma in the less acuminatespire and the imperforate umbilicus. It resembles Paladmete Gardner ${ }^{47}$ but differs from that group in having a short anterior canal. The genus is proposed to include a species recently discovered at Coon Creek and two other known species in the European Upper Cretaceous. One of these occurs in the Aachen Cretaceous of Vaals, Germany, and was

44 Holzapfel, Eduard, Palaeontographica, Band 34, p. 149, pl. 15, figs. 6, 7, 8,9, 1888. 13 Stoliczka, Ferdinand, India Geol. Survey Mem., Palaeontologia Indica, Cretaceous fauna of southern India, vol. 2, p. 158, pl. 13, flg. 7-9, 1868.

is Conrad, T. A., Acad. Nat. Sci. Philadelphia Jour., 2d ser., vol. 4, p. 295, pl. 47, fig. 30, 1860. Cossmann, Maurice, Essais de paléoconchologie comparée, pt. 7, p. $191,1006$.

17 Gardner, J. A., Maryland Geol. Survey, Upper Cretaceous, p. 412, pl. 18, figs. $14,15,1916$. 
described in 1851 by Müller as Tritonium cretaceum, ${ }^{48}$ the other is a closely related form from the Maestrichtian of Belgium, which Kaunhowen ${ }^{49}$ compares with Müller's species from Vaals, though he does not apply a name to it. Astandes differs from Tritonium or Nyctilochus in lacking true varicose axials and in having a shorter and much less strongly developed anterior canal.

\section{Astandes densatus Wade}

Plate LIV, Figures 19, 20

1917. Astandes densatus. Wade, Acad. Nat. Sci. Philadelphia Proc., vol. 69, p. 299, pl. 17, figs. 7, 8.

1918. Astandes densatus. Cossmann, Rev. critique paléozoologie, annee 22, Nos. 1-2, p. 21.

Shell small and nearly trochoid in outline; spire moderately elevated and more than half the length of the entire shell; protoconch small and smooth; whorls of conch six, circular in cross section and increasing in size gradually; external sculpture both axial and spiral; axials fairly coarse, well rounded, and retractive, evanescing on the base of the body; axials overridden by numerous elevated spiral lines; aperture D-shaped, produced anteriorly into a short, shallow canal; outer lip slightly thickened and dentate; parietal wall washed with a callus. Altitude, 11.5 millimeters; maximum diameter, 7 millimeters.

This species is characterized by the elevated spiral lines, which override the protractive axials, and further by the dentate outer lip. It is represented in the present collection by several individuals. No closely related American species is known, but the form from Tennessee may be compared with the Maestrichtian species Tritonium cf. T. cretaceum (Müller) Kaunhowen, ${ }^{50}$ which resembles it very much in form of aperture and in character of external ornamentation but differs in details of external sculpture.

Occurrence: Ripley formation, Dave Weeks place on Coon Creek, McNairy County, Tenn.

Collection: U. S. National Museum.

\section{Family MELANOPSIDAE}

\section{Genus MELANATRIA Bowdich}

Melanatria cretacea Wade, n. sp.

Plate LV, Figures 1a, 1b, 2

Shell large and fragile, form cerithoid; spire very long and acute; apex broken away; whorls numerous, flat and narrow, increasing in size gradually; sculpture dominantly axial; costae abruptly elevated and strong, distant and irregularly spaced; costae on early whorls persistent from suture to suture, but on the posterior part of last two or three whorls the posterior

\footnotetext{
18 Holzapfel, Eduard, Die Mollusken der Aachener Kreide: Palaeontographica, Band 34, p. 113, pl. 10, figs 597, 1888.

10 Kaunhowen, Friedrich, Die Gastropoden der Maestrichter Kreide: Palaeont, Abh. (Dames \& Koken), Band 8 (neue Folge, Band 4), p. 77, pl . 9, figs. 4, 4a; pl. 13. flg. 12,1897 .

so Kaunhowen, Friedrich, op. cit., p. 77, pl. 9, fig. 4; pl. 13, flg. 12, 1898.
}

extremities of the costae evanesce and the costae terminate very abruptly near the middle of the whorls and become subspinose on the body; costae nine on the last whorl of the imperfect type; spiral sculpture inconspicuous, consisting of six or seven shallow squarely channeled impressed lines; interspiral spaces low and marked by faint, fortuitous spiral lines; spirals override the costae of the early whorls of the spire but are absent on the crests of the axial elevations on the later whorls; suture impressed and slightly undulating; body broken away from type and apertural features unknown; columella slender and smooth. An imperfect individual measures in altitude, 63 millimeters; maximum diameter, 32.2 millimeters.

This species is well characterized by its large, cerithoid form and the dual character of its axial costae. Without a complete specimen for study this form can not be assigned with assurance to the genus Melanatria, but a comparison with Melanatria $d u$ fresnei (Deshayes) in the Geological Museum of the Johns Hopkins University, from the Thanetian of the French Eocene, and another species, Melanatria cuvieri (Deshayes), ${ }^{51}$ from the Sparnacian, figured and discussed by Cossmann, shows that the Tennessee specimen very probably belongs to this group. From the sculptural features and the general aspect of the shell it is also possible that the specimen here described as Melanatria cretacea might belong to the same genus as Cerithium simonyi Zekeli, ${ }^{52}$ from the Turonian of the Alps, which Cossmann assigned to the genus Pyrazus. However, it seems most probable that it belongs to the genus Melanatria.

Occurrence: Ripley formation, Dave Weeks place on Coon Creek, McNairy County, Tenn.

Collection: U. S. National Museum.

Family VERMETIDAE

Genus SERPULORBIS Sassi

Serpulorbis marylandica Gardner

Plate LV, Figure 3

1916. Serpulorbis marylandica. Gardner, Maryland Geol Survey, Upper Cretaceous, p. 482, pl. 17, figs. 8, 9.

Miss Gardner describes this species as follows:

Type of two component tubes equal in size and increasing in diameter with equal rapidity; each surrounded by a discrete calcareous layer, fused along the line of contact of the tubes into a single shelly covering; tubes performing one and one-half volutions, superimposed one above the other at the beginning of the coil but tending toward a lateral contact near the anterior extremity, coiled in such a plane that the upper of the tubes is in contact at the aperture with the lower of the preceding volution; external surface smooth; cross section of aperture circular.

\$1 Cossmann, Maurice, Essais de paléoconchologie comparée, pt. 8, p. 161, pl. 3, fig. 23, 1909 .

S2 Zekeli, Friedrich, Die Gasteropoden der Gosaugebilde: K.-k. geol. Reichsanstalt Abh., Band 1, D. 114, pl. 23, figs. 6, 7, 1852. 
The species is doubtless similar in composition to the form described by Conrad under the name of Diploconcha. The fusing of the constituent tubes along the contacts is a common phenomenon in the recent gregarious Vermetidae and is a character of no systematic value whatever.

The species suggests $S$. rotula Weller but is larger and less regularly coiled.

Occurrence: Ripley formation, Dave Weeks place on Coon Creek, McNairy County, Tenn.

Collections: Maryland Geological Survey, U. S. National Museum.

Outside distribution: Monmouth formation, Prince Georges County, Md.

\section{Serpulorbis tennesseensis Wade, n. sp. \\ Plate LV, Figures 4, 7 .}

Shell tubular, irregularly twisted, attached to other shells of the same species or to foreign objects or free; type has two component tubes, adnate during the later half but free and distant during the early stages; tubes increasing gradually in size, marked by four or five axial lines; incremental lines absent on the older part of the tubes but very numerous along the adult part of the shells, causing numerous faint transverse ridges on an otherwise smooth external surface; aperture simple and circular. Maximum diameter, 7 millimeters; minimum diameter, 3 millimeters.

This species suggests Serpulorbis marylandica but differs from it in having faint external sculpture and no definite coiling of the tubes.

Occurrence: Ripley formation, Dave Weeks place on Coon Creek, McNairy County, Tenn.

Collection: U. S. National Museum:

\section{Genus LAXISPIRA Gabb}

Laxispira lumbricalis Gabb

Plate LV, Figures 5, 8

1877. Laxispira lumbricalis. Gabb, Acad. Nat. Sci. Philadelphia Proc. for 1876, p. 301, pl. 17, figs. 6, 7.

1883. Laxispira lumbricalis. Tryon, Structural and'systematic conchology, vol. 2, p. 309, pl. 79, fig. 14.

1892. Laxispira lumbricalis. Whitfield, U. S. Geol. Survey Mon. 18, p. 148, pl. 18, fig. 25.

1905. Laxispira lumbricalis. Johnson, Acad. Nat. Sci. Philadelphia Proc., vol. 57, p. 22.

1907. Laxispira lumbricalis. Weller, New Jersey Geol. Survey, Paleontology, vol. 4, p. 706, pl. 81, figs. 1, 2.

1914. Laxispira lumbricalis. Stephenson, U. S. Geol. Survey Prof. Paper 81, check list, table 2.

1916. Laxispira lumbricalis. Gardner, Maryland Geol. Survey, Upper Cretaceous, p. 485.

Gabb describes this species as follows:

Shell with a circular cross section; whorls about as far apart as the diameter of the whorls, three or four in number; surface marked by numerous small, closely placed revolving ribs.

Weller adds the following details:

The dimensions of a large specimen and internal cast are: Height, 29 millimeters; maximum diameter, 12.5 millimeters; apical angle, about $28^{\circ}$; number of volutions, about $41 / 2$; height of aperture, 8.5 millimeters; width of aperture, 6.3 millimeters. Shell forming an open spiral, in which the volutions are not in $106913-26 \dagger-11$ contact, the sutural space in the casts being nearly as wide as the diameter of the volutions. Cross section of the volutions nearly circular, except in the outer volution of mature shells, in which, near the aperture, the shell is slightly compressed, making the aperture higher than it is wide and straighter on the inner than on the outer lip. Surface of the shell marked with fine, raised, revolving lines, from two to four of which occupy the space of 1 millimeter, and by transverse lines of growth.

The shells of this interesting genus from Coon Creek are not assigned with certainty to this species, as good specimens from the type locality are not available for comparison. Although the shells from Tennessee in general features greatly resemble the figures of the shells from New Jersey, the former show a development of secondary spirals and a certain modulation of the primary spiral ridges which are not mentioned in the descriptions or shown in the figures of the specimens from the type locality. These shells are common at Coon Creek but very fragile, so that perfect specimens are rarely obtained. Some of the specimens in the present collection show the nuclear characters. The protoconch is small, smooth, and trochoid, coiled two and a half times, and then begins to become loosely coiled and merges imperceptibly into the shell of the conch.

Laxispira turritelliformis Vogel, ${ }^{53}$ from the upper Senonian of Irnich, Germany, and Laxispira cochleiformis Müller, ${ }^{74}$ from the Aachen Cretaceous, have been compared with the American species by Vogel. Laxispira pinguis Holzapfel, ${ }^{54}$ of the Aachen Cretaceous, and Laxispira trochleata Böhm, ${ }^{55}$ from the upper Senonian of Bavaria, are two other European species that are probably related to the American species under discussion.

Occurrence: Ripley formation, Dave Weeks place on Coon Creek, McNairy County, Tenn.

Collections: Philadelphia Academy of Natural Sciences, U. S. National Museum, Maryland Geological Survey, New Jersey Geological Survey, Vanderbilt. University.

Outside distribution: Matawan group (Merchantville and Woodbury clays), New Jersey. Matawan formation, Chesapeake \& Delaware Canal, Del. Ripley formation, Union and Tippah counties, Miss.

\section{Family TURRITELLIDAE \\ Genus TURRITELLA Lamarck \\ Turritella menairyensis Wade, n. sp.}

Plate LVI, Figure 2

Shell of medium size for genus, elongate conic and a little stout; whorls 9 to 11, flattened and increasing gradually in size; protoconch broken away; sculpture

s3 Vogel, F., Das Ober-Senon von Irnich am Nordrand der Eifel (Inaug.-Diss.), p. 31, pl. 1, fig. 3, 1892.

ot Holzapfel, Eduard, Die Mollusken der Aachener Kreide: Palaeontographica, Band 34, p. 155, 1888.

ss Böhm, Johannes, Die Kreidebildungen des Fürbergs und Sulzbergs bei Siegsdorf in Oberbayern: Palaeontographica, Band 38, p. 65, pl. 2, flg. 18, 1891. 
spiral, consisting of very fine unequal lirae of primary and secondary strength and alternating in occurrence, 9 or 10 each on the later whorls; the base of the body is marked by numerous low crowded lirae; suture deeply impressed, anterior slope of sutural channel steeper than posterior slope; body well rounded in front, maximum diameter in front of medial horizontal on body as well as whorls of the spire; aperture, except inner lip, broken away; inner lip reflected and sharp, not closely adnate to the base of the body. A slightly imperfect individual measures in altitude, 34.6 millimeters; in maximum diameter, 13.5 millimeters.

This species is probably closely related to Turritella delmar Gardner, ${ }^{56}$ from the Matawan formation of Maryland. Turritella menairyensis is less abundant at Coon Creek than other species of this genus. The shells are thin and fragile, and perfect specimens are rarely obtained.

Occurrence: Ripley formation, Dave Weeks place on Coon Creek, McNairy County, Tenn.

Collection: U. S. National Museum.

\section{Turritella paravertebroides Gardner?}

Plate LVI, Figure 5

1916. Turritella paravertebroides. Gardner, Maryland Geol. Survey, Upper Cretaceous, p. 488, pl. 17, fig. 1.

Miss Gardner describes this species as follows:

Shell elongate turreted; the whorls flattened, probably 14 or 15 in number, regularly increasing in size, converging at an angle of approximately $20^{\circ}$; axial sculpture not developed; spiral sculpture uniform in character over the entire surface of the shell; primaries normally five in number though occasionally one more or less; well-rounded moderately elevated cords, subequal in size and spacing, at least upon the anterior half of the whorl, of ten more distant and less prominent upon the posterior; interspiral areas flattened; entire surface overrun with microscopically fine crowded striae, 6 to 11 in number on each of the interspiral areas of the later whorls; suture line impressed, placed nearer the posterior spiral than the anterior of the preceding turn; the posterior slope of the sutural channel steeper than the anterior; body whorl obtusely carinated at the periphery; the base flattened and microscopically striate.

This species, like most of the group, shows a wide range in variation. There is quite a little difference in the relative strength of the spirals, although they never approach in sharpness the primaries of the true vertebroides. The second in front of the posterior suture is usually a little stronger than the rest, and in the immature individuals the first spiral in front of the posterior suture is feeble or undeveloped.

Turritella paravertebroides is apparently the analogue in Maryland of the abundant and characteristic vertebroides of the Gulf and New Jersey. It differs conspicuously from Morton's well-known species in the more subdued sculpture. The primary spirals are never so sharply elevated, and unlike vertebroides they are relatively more prominent upon the posterior portion of the whorl. The secondary sculpture is finer and more regular, the whorls are less constricted at the sutures, the periphery of the body is not acutely carinated, nor is it outlined by a prominent spiral, and the base is striated, though faintly so. Weller 57

s6 Gardner, J. A., Maryland Geol. Survey, Upper Cretaceous, p. 487, pl. 17, figs. 3, 4.1916.

${ }^{37}$ Weller, Stuart, New Jersey Geol. Survey, Paleontology, vol, 4, pl. 78, fig. 14, 1907. figured a second specimen, which has not been described apparently, although it is widely distributed, not only through New Jersey but the Gulf as well. From this unnamed form $T$. paravertebroides differs in its rather larger size, more flattened whorls, sculptured apical region, the broader primaries with numerous intercalated secondaries, and a less strongly lirated base.

A single imperfect specimen in the Coon Creek collection is doubtfully referred to this species.

Occurrence: Ripley formation, Dave Wèeks place on Coon Creek, McNairy County, Tenn.

Collections: Maryland Geological Survey, U. S. National Museum.

Outside distribution: Monmouth formation, Brightseat, Prince Georges County, Md.

\section{Turritella encrinoides Morton}

Plate LVI, Figurè 4

1834. Turritella encrinoides. Morton, Synopsis of the organic remains of the Cretaceous group of the United States, p. 47 , pl. 3 , fig. 7 .

1864. T'urritella encrinoides. Meek, Check list of the invertebrate fossils of North America, Cretaceous and Jurassic, p. 18.

1868. Turritella encrinoides. Conrad, in Cook, Geology of New Jersey, p. 729.

1876. Turritella encrinoides. Gabb, Acad. Nat. Sci. Philadelphia Proc., vol. 57, p. 301.

1892. Turritella encrinoides. Whitfield, U. S. Geol. Survey Mon. 18, p. 143, pl. 18, figs. 19-22.

1892. Turritella pumila?. Whitfield, U. S. Geol. Survey Mon. 18, p. 187, pl. 22, figs. 5, 6. (Not T. pumila Gabb.)

1905. Turritella encrinoides. Johnson, Acad. Nat. Sc̀i. Philadelphia Proc., vol. 57, p. 21.

1907. Turritella encrinoides. Weller, New Jersey Geol. Survey, Paleontology, vol. 4, p. 694, pl. 78, figs. 10-13.

1916. Turritella encrinoides. Gardner, Maryland Geol. Survey, Upper Cretaceous, p. 492.

Morton describes the species as follows:

Of this fossil I have met with several fragments, yet scarcely perfect enough for description. I have figured one of them to show the difference between this and the former species ( $T$. vertebroides Morton), as the two occur in the same strata.

Weller adds the following details:

Type locality: New Jersey (?).

Shell acutely angular, the angle of divergence of the sides being about $20^{\circ}$. Suture not strongly impressed, situated in an angular, rounded furrow; surface of the volutions depressed convex, nearly flat in the central portion and curving more abruptly to the sutures above and below. Surface marked by three major revolving costae, which are flattened on top; in addition to the major costae there are lower, angular revolving ribs situated as follows: One between the lower suture and the first major costa, one between the first and second costae, two between the second and third costae, and two between the third major costa and the upper suture. In the casts the sutures are rather close, especially between the lower and larger volutions; the lower volutions are more or less quadrangular in cross section, the upper ones being rounder, due undoubtedly to the internal thickening of the shell with age.

There is a single individual of this species in the Coon Creek collection.

Occurrence: Ripley formation, Dave Weeks place on Coon Creek, McNairy County, Tenn. 
Collections: New Jersey Geological Survey, Maryland Geological Survey, U. S. National Museum, Vanderbilt University.

Outside distribution: Monmouth group (Navesink marl), New Jersey. Monmouth formation, Cecil County, Md. Matawan formation, Chesapeake \& Delaware Canal, Del.

\section{Turritella vertebroides Morton Plate LVI, Figure 1}

1834. Turritella vertebroides. Morton, Synopsis of the organic remains of the Cretaceous group of the United States, p. 47 , pl. 3, fig. 13 .

1861. T'urritella vertebroides. Gabb, Synopsis of the Mollusca of the Cretaceous formation, p. 92 (Am. Philos. Soc. Proc., vol. 8, p. 148).

1864. Turritella vertebroides. Meek, Check list of the invertebrate fossils of North America, Cretaceous and Jurassic, p. 19.

1868. Turritella vertebroides. Conrad, in Cook, Geology of New Jersey, p. 729.

1892. Turritella vertebroides. Whitfield, U. S. Geol. Survey Mon. 1S, p. 146, pl. 18, figs. 13-18.

1905. Turritella vertebroides. Johnson, Acad. Nat. Sci. Philadelphia Proc., vol. 57, p. 21.

1907. Turritella verlebroides. Weller, New Jersey Geol. Survey Palcontolog., vol. 4, p. 693, pl. 78, figs. 14-17. '

1914. Turritella vertebroides. Stephenson, U. S. Geol. Survey, Prof. Paper 81, check list, tables 2, 3, 5, 6, 8 .

Morton describes this species as follows:

Turreted, sublate; volutions about five, rounded, with fine spiral striae, and about five elevated spiral ribs on each whorl.

Weller adds the following details:

Shell acutely angular, the apical angle about $20^{\circ}$; the dimensions of a large individual from Alabama are: Maximum diameter, 20 millimeters; length with apex broken, 64 millimeters; number of volutions preserved, 10. Suture moderately impressed, situated a little below the center of a rounded revolving furrow; surface of the volutions depressed convex from suture to suture. Surface marked by four or five subequal, augular revolving costae, with several much finer ones occupying each of the interspaces, and by fine transverse lines of growth which describe a concave curve in passing downward from the suture. In the casts the volutions are moderately close, the surface is smooth and rounded, curving rather abruptly into the subtures above and below.

Occurrence: Ripley formation, Dave Weeks place on Coon Creek, McNairy County, Tenn.

Collections: New Jersey Geological Survey, U.S. National Museum, Johns Hopkins University.

Outside distribution: Monmouth group, New Jersey. Ripley formation, Mississippi and Alabama. Selma chalk, Alabama.

\section{Turritella trilira Conrad Plate LVI, Figure 3}

1860. T'urrilella trilira. Conrad, Acad. Nat. Sci. Philadelphia Jour., 2d ser., vol. 4, p. 285.

1861. Turritella corsicana. Shumard, Boston Soc. Nat. Hist. Proc., vol. 8, p. 196.

1864. Turrilella corsicana. Meek, Check list of the invertebrate fossils of North America, Cretaceous and Jurassic, p. 18.
1864. Turritella trilira. Meek, Check list of the invertebrate fossils of North America, Cretaceous and Jurassic, p. 18.

1901. Turritella trilineata. Hill, U. S. Geol. Survey Twentyfirst Ann. Rept., pt. 7, pl. 48, fig. 3.

1906. Turritella trilira. Veatch, U. S. Geol. Survey Prof. Paper 46, pl. 11, fig. 4 .

1907. Turritella trilira. Weller, New Jersey Geol. Survey, Paleontology, p. 899, pl. 79, figs. 4, 5.

1914. Turritella trilira. Stephenson, U. S. Geol. Survey Prof. Paper 81, check list, tables 2, 5, 6, 8.

1916. Turritella trilira. Gardner, Maryland Geol. Survey, Upper Cretaceous, p. 489.

Conrad describes this species as follows:

Turreted; whorls with three equidistant, very acute, prominent ribs; revolving lines microscopic, closely arranged.

Miss Gardner adds the following details:

Shell turreted, large for the genus, attaining a maximum altitude of plus or minus 80 millimeters and a diameter of more than 20 millimeters; whorls probably 16 or more in number in a perfect individual, the earlier whorls flattened, the later feebly convex, converging at an angle of about $25^{\circ}$; external surface sculptured with three sharply and very prominently elevated laminar equisized and equilateral ridges, separated by symmetrically concave interspaces, the posterior spiral a little nearer the suture line than the anterior; interspiral areas threaded with microscopically fine lirae, which are minutely crenulated by the incrementals; suture lines distinct, impressed but inconspicuous by reason of the overhanging spiral ridges placed about midway on the upcurve of the interspiral between the posterior lamina and the anterior lamina of the preceding turn; interspiral areas between the laminae of succeeding whorls scarcely wider than those between the laminae of the same whorl; base very finely and evenly threaded; casts characterized by evenly rounded whorls, separated by rather deep sutural channels.

This species is one of the more common gastropods at Coon Creek. It is remarkable for its widespread distribution in the Upper Cretaceous of the Atlantic and Gulf Coastal Plain. Turritella bonei Bailey,58 from the Senonian of Pondoland, South Africa, has three spiral lirae but differs widely from $T$. trilira in character of the sutural angle.

Occurrence: Ripley formation, Dave Weeks place on Coon Creek, McNairy County, Tenn.

Collections: Maryland Geological Survey, New Jersey Geological Survey, U. S. National Museum, Vanderbilt University.

Outside distribution: Matawan group (Wenonah sand), New Jersey. Matawan formation, Anne Arundel County, Md. Monmouth formation, Prince Georges County, Md. Black Creek formation, North Carolina and South Carolina. Peedee sand, North Carolina and South Carolina. Eutaw formation, Georgia and Mississippi. Ripley formation, Georgia, Alabama, and Mississippi. Selma chalk, Alabama. Brownstown(?), Austin, Marlbrook, Nacatoch, and Arkadelphia formations, Arkansas. Taylor and $\mathrm{Na}$ varro formations, Texas.

s8 Woods, Henry, The Cretaceous fauna of Pondoland: South African Mus. Annals, vol. 4, pt. 7, p. 317, pl. 38, figs. 11, 12, 1906. 


\section{Turritella tippana Conrad}

Plate LVI, Figure 9

1858. Turritella tippana. Conrad, Acad. Nat. Sci. Philadelphia Jour., 2d ser., vol. 3, p. 333, pl. 35, fig. 19.

1864. Turritella tippana. Meek, Check list of the invertebrate fossils of North America, Cretaceous and Jurassic, p. 19.

1907. Turritella tippana. Weller, New Jersey Geol. Survey, Paleontology, vol. 4, p. 700, pl. 79, figs. 6, 7 .

1914. Turritella tippana. Stephenson, U. S. Geol. Survey Prof. Paper 81, check list, tables 2, 3.

1916. Turritella tippana. Gardner, Maryland Geol. Survey, Upper Cretaceous, p. 491.

Conrad describes this species as follows:

Subulate; sides straight; volutions carinated with revolving lines, two on each volution larger than the others, remote, one nearly equal in size, nearly medial, and three other fine lines; whorls of spire slightly carinated at base.

Weller adds the following details:

The dimensions of a large example, incomplete at the apex, are: Height, 69 millimeters; greatest diameter, 22 millimeters; apical angle, about $19^{\circ}$; number of volutions shown, 10 . Suture situated in the bottom of a broad, concave revolving channel. Surface of the volutions between the margins of the sutural channel nearly flat or slightly convex, marked by four or five strong revolving costae, the three lower ones being subequidistant, the upper one more remote; in the broader interspace between the uppermost strong costa and the one next below is a much finer rib, and a similar one about midway on the slope from the uppermost strong costa to the suture, although this last one is sometimes strong enough, especially in the larger shells, to be counted as one of the major ribs; in each of the interspaces between the three lowermost strong costae on the larger volutions there is frequently a much smaller raised line; and on the slope of the lowermost one of these costae to the lower suture another one somewhat stronger than those in the interspaces above. The surface is also marked by very fine transverse lines of growth.

This species is common at Coon Creek and is represented in the present collection by a number of wellpreserved individuals. It is characterized by shells of medium size and very acuminate spires. The external ornamentation is elaborate.

Occurrence: Ripley formation, Dave Weeks place on Coon Creek, McNairy County, Tenn.

Collections: U. S. National Museum, Maryland Geological Survey, New Jersey Geological Survey, Vanderbilt University.

Outside distribution: Matawan group (Marshalltown formation), New Jersey. Monmouth formation, Prince Georges County, Md. Ripley formation, Union and Tippah counties, Miss.

\section{Family XENOPHORIDAE}

Genus XENOPHORA Fischer de Waldheim

\section{Xenophora leprosa (Morton)}

Plate LVI, Figures 7, 8

1834. Trochus leprosus. Morton, Synopsis of the organic remains of the Cretaceous group of the United States, p. 46 , pl. 15, fig. 6 .
1864. Phorus leprosus. Meek, Check list of the invertebrate fossils of North America, Cretaceous and Jurassic, p. 18.

1868. Onustus leprosus. Conrad, in Cook, Geology of New Jersey, p. 728.

1892. Xenophora leprosa. Whitfield, U. S. Geol. Survey Mon. 18 , p. 135, pl. 17, figs. 16-19. (Also published by New Jersey Geol. Survey.)

1892. Xenophora? conchyliophora. Dall, Wagner Free Inst. Sci. Trans., vol. 3, pt. 2, p. 360.

1905. Xenophora leprosa. Johnson, Acad. Nat. Sci. Philadelphia Proc., vol. 57, p. 21.

1907. Xenophora leprosa. Weller, New Jersey Geol. Survey, Paleontology, vol. 4, p. 690, pl. 68, figs. 1-3.

1914. Xenophora leprosa. Stephenson, U. S. Geol. Survey Prof. Paper 81, check list, tables 4 and 5 .

1916. Xenophora leprosa. Gardner, Maryland Geol. Survey, Upper Cretaceous, p. 495.

Morton describes this species as follows:

Compressed: Spire composed of about four volutions, presenting an unequal rugged surface. Diameter from an inch to an inch and a half.

Whitfield adds the following details:

Shell small or below a medium size, trochiform or broad conical; the spire having an apical angle of less than $90^{\circ}$; base flat or concave, usually more or less depressed in the center, with the margin of the volution more or less rounded, and in old individuals sometimes distinctly rounded; casts showing a small umbilical perforation, but the axis probably solid in the shell; volutions probably seven or eight, but in the casts the upper ones are usually absent and seldom show more than four or four and a half; one small specimen retaining the upper whorls, to the number of four and a half, measures only fiveeighths of an inch in diameter. This one, if continued below to the size of the larger one figured, would possess at least eight volutions; whorls obliquely flattened on their surfaces in the direction of the spire, with only a small portion of their edges rounded or vertical, and the surfaces deeply and abundantly scarred by the cicatrices of foreign substances which have been attached to the surface of the shell during life; aperture compressed, transversely ovate or trapezoidal, and the outer margin much prolonged.

This species is represented in the present Coon Creek collection by a single imperfect shell. It is probably related to the well-known European Senonian species Xenophora onusta Nilsson, ${ }^{59}$ which is widely distributed in the zone of Belemnitella mucronata Schlotheim and Actinocamax quadratus Blainville. This European species, like the American species under discussion, is known only from casts. The imperfect specimen of Xenophora leprosa is part of the original shell of this organism and shows on its outer surface impressions of foreign shells that may be determined specifically. No doubt further collecting at Coon Creek will yield perfect specimens of this species of this most interesting genus. The species, however, is rare at Coon Creek, and the shells are extremely fragile.

BP Kaunhowen, Friedrich, Die Gastropoden der Maestrichter Kreide: Palaeont. A bh. (Dames \& Koken), Band 8 (neue Folge, Band 4, Heft 1), p. 50, pl. 3, fig. 15, 1897. (See also synonymy of this reference.) 
Occurrence: Ripley formation, Dave Weeks place on Coon Creek, McNairy County, Tenn.

Collections: Maryland Geological Survey, Philadelphia Academy of Natural Sciences, New Jersey Geological Survey, U. S. National Museum, Vanderbilt University.

Outside distribution: Monmouth formation, along the Chesapeake \& Delaware Canal, Del. Navesink marl, New Jersey. Selma chalk, Wilcox County, Ala., and east-central Mississippi.

\section{Family NATICIDAE}

Genus POLINICES Montfort

Polinices (Euspira) halli (Gabb)

Plate LVI, Figures 11, 12

1860. Lunatia halli. Acad. Nat. Sci. Philadelphia Jour., 2d ser., vol. 4, p. 391, pl. 68, fig. 11.

1864. Lunatia halli. Meek, Check list of the invertebrate fossils of North America, Cretaceous and Jurassic, p. 20.

1868. Lunatia halli. Conrad, in Cook, Geology of New Jersey, p. 729.

1892. Lunatia halli. Whitfield, U. S. Geol. Survey Mon. 18, p. 130 , pl. 15, figs. 13-16.

1905. Lunatia halli. Johnson, Acad. Nat. Sci. Philadelphia Proc., vol. 57, p. 21.

1907. Lunatia halli. Weller, New Jersey Geol. Survey, Paleontology, vol. 4, p. 677 , pl. 76, figs. 11-14 (synonymy and figs. 9, 10, 15-19 excluded).

1916. Polinices (Euspira) halli. Gardner, Maryland Geol. Survey, Upper Cretaceous, p. 499, pl. 13, figs. 1, 2.

Gabb describes this species as follows:

Elongated, subglobose, spire high, whorls five, rounded and angulated above; mouth elliptical; umbilicus open; surface smooth or minutely wrinkled.

Miss Gardner gives the following details:

Type locality: New Jersey.

Shell of moderate size, rather heavy but not very stout, whorls five or six in number, regularly increasing in size, evenly but not strongly inflated, obtusely shouldered posteriorly; aperture a little more than one-half and body whorl a little more than three-fourths the total altitude; external surface smooth excepting for incremental scratches; aperture semielliptical to ovate, the outer margin strongly arcuate, patulous anteriorly, the maximum expansion a little in front of the medial line; inner margin slightly concave; umbilical pit small.

The synonymy of this species is in a well-nigh hopeless state of confusion. The type of the species is a cast from the Monmouth of New Jersey. Weller has included under this species a series of relatively lower, less inflated forms from the Matawan, which seem too distant to be included even within the wide limits of sex variation in outline of this group.

This species is a much less inflated shell than either Natica obliquata Hall and Meek or Natica concinna Hall and Meek.

This species is probably the most abundant gastropod in the Coon Creek beds. It is represented in the present collection from Tennessee by several dozen perfect individuals, which show a wide variation in size.

Occurrence: Ripley formation, Dave Weeks place on Coon Creek, McNairy County, Tenn.
Collections: Maryland Geological Survey, New Jersey Geological Survey, Philadelphia Academy of Natural Sciences, Vanderbilt University.

Outside distribution: Matawan group (Merchantville clay and Wenonah sand), New Jersey. Monmouth group (Navesink marl), New Jersey. Monmouth formation, Prince Georges County, Md.

\section{Polinices umbilica Wade, n. sp. Plate LVI, Figures 6, 10}

Shell small with a squat outline; spire low; whorls four or five, increasing markedly in size, tabulated; sculpture absent except for microscopic incremental lines that show through the glaze of the external surface; suture deeply impressed; body abruptly constricted along the posterior extremity into a narrow shoulder, well rounded medially and constricted in front; aperture reniform; outer lip thin and simple; slightly patulous anteriorly; inner lip nearly straight and slightly notched opposite the umbilicus; umbilicus narrow and profound. Altitude, 10.4 millimeters; maximum diameter, 9.5 millimeters.

This species differs from Polinices halli not only in size but in a depressed spire, an open umbilicus, and a notched inner lip. It is rare at Coon Creek, being represented in the present collection by a single specimen.

Occurrence: Ripley formation, Dave Weeks place on Coon Creek, McNairy County, Tenn.

Collection: U. S. National Museum.

Polinices stephensoni Wade, n. sp.

Plate LVI, Figures 13, 14

Shell of medium size and naticoid; spire low but acute at the apex; whorls four or five, closely appressed and increasing markedly in size; protoconch broken away, its scar small; sculpture absent, except for incremental lines that appear through the glazed external surface; suture appressed; body enlarged but not abnormally so for the genus; posterior margin of whorls squarely constricted, forming a well-defined slightly concave, narrow shoulder at the posterior extremity of the volutions; aperture holostomous, broadly ovate; outer lip simple and thin, patulous anteriorly; inner lip reflected, adnate to the body wall behind the umbilicus and flat in front of the umbilicus; umbilical chink narrow and shallow. Altitude, 27 millimeters; maximum diameter, 23.2 millimeters.

This species is characterized by the well-defined narrow shoulder along the posterior extremities of the whorls. It probably bears some relation to Euspira spissata Stoliczka, ${ }^{60}$ from the Ootatoor and Valudayur groups of southern India.

Polinices stephensoni is common at Coon Creek and is represented in the present collection by a

60 Stoliczka, Ferdinand, India Geol. Survey Mem., Palaeontologia Indica, Creta. ceous fauna of southern India, vol. 2, p. 303, pl. 22, flgs. 3, 4, 1868. 
number of perfect specimens. The specific name is given in honor of Mr. L. W. Stephenson.

Occurrence: Ripley formation, Dave Weeks place on Coon Creek, McNairy County, Tenn:

Collection: U. S. National Museum, Johns Hopkins University, Vanderbilt. University.

\section{Genus GYRODES Conrad \\ Gyrodes alveata Conrad}

Plate LVII, Figures 6, 9

1860. Natica (Gyrodes) alveata. Conrad, Acad. Nat. Sci. Philadelphia Jour., 2d ser., vol. 4, p. 289, pl. 46, fig. 45.

Conrad describes this species as follows:

Channel of spire wide and marginal by a carina; spires slightly prominent, apex acute; whorls slightly contracted below the carina, five in number; umbilicus moderate in diameter, without a revolving line.

This species is abundant at Coon Creek, but its shells are so fragile that perfect specimens are obtained with difficulty. One specimen in the collection retains the protoconch, which is elevated, very small and smooth, coiled twice or more.

Occurrence: Ripley formation, Dave Weeks place on Coon Creek, McNairy County, Tenn.

Collections: Vanderbilt University, U. S. National Museum.

Outside distribution: Ripley formation, Owl Creek, Tippah County, Miss.

\section{Gyrodes crenata. Conrad}

Plate LVII, Figures 1-3

1860. Natica (Gyrodes) crenata. Conrad, Acad. Nat. Sci. Philadelphia Jour., 2d ser., vol. 4, p. 289.

1861. Gyrodes crenata. Gabb, Synopsis of the Mollusca of the Cretaceous formation, p. 60 (Am. Philos. Soc. Proc., vol. 8, p. 116).

1861. Gyrodes infracarinata. Gabb, Acad. Nat. Sci. Philadelphia Proc. for 1861, p. 319.

1861. Gyrodes spillmani. Gabb, Acad. Nat. Sci. Philadelphia Proc. for 1861, p. 320.

1864. Gyrodes crenata. Meek, Check list of the invertebrate fossils of North America, Cretaceous and Jurassic, p. 21.

1864. Gyrodes infracarinata. Conrad, in Cook, Geology of New Jersey, p. 729.

1892. Gyrodes infracarinata. Whitfield, U. S. Geol. Survey Mon. 18, p. 125, pl. 15, figs. 13-16.

1892. Gyrodes crenata. Whitfield, U. S. Geol. Survey Mon. 18 , p. 126, pl. 16, figs. 5, 6 .

1905. Gyrodes crenata. Johnson, Acad. Nat. Sci. Philadelphia Proc., vol. 57, p. 21.

1905. Gyrodes spillmani. Johnson, Acad. Nat. Sci. Philadephia Proc., vol. 57, p. 21.

1907. Gyrodes crenata. Weller, New Jersey Geol. Survey, Palaeontology, vol. 4, p. 685, pl. 77, figs. 10-12.

1914. Gyrodes crenata. Stephenson, U. S. Geol. Survey ProfPaper 81, check list, tables 2, 7, 8.

Conrad describes this species as follows:

Channel on the spire rather wide, not profound; apex flattened; shoulder obliquely plicated; umbilicus patulous, cari- nated within near the base, and the periphery acutely carinated and crenulated; volutions visible to the apex in the umbilicus.

Weller adds the following details:

Shell of medium size, the dimensions of a rather large internal cast being: Maximum width, 30 millimeters; height, 23 millimeters; height of aperture, 20 millimeters; width of aperture, 13.5 millimeters. Depressed globular above with a depressed spire, broadly umbilicate below. Volutions about four in number, the outer one of which forms fully two-thirds of the bulk of the entire shell, largest below the middle, the casts slightly flattened on top adjacent to the suture, strongly angular on the base bordering the umbilicus. Aperture large, oblique, widest below the middle. In specimens preserving the. shell, or in impressions of the exterior, a distinct band of elevated crenulations or transverse nodes marks the top of the volutions just below the suture and forms a decided ridge around the spiral portion of the shell. Surface of the shell marked by fine lines of growth parallel with the margin of the aperture, and passing over the line of nodes on the upper surface of the volution.

Only one specimen of this species has been recovered from the Coon Creek sediments, and this individual is well preserved, showing nuclear characters as well as those of the shell. The protoconch is small, naticoid, and coiled three times.

Occurrence: Ripley formation, Dave Weeks place on Coon Creek, McNairy County, Tenn.

Collections: Philadelphia Academy of Natural Sciences, New Jersey Geological Survey, U. S. National Museum.

Outside distribution: Matawan group (Merchantville clay and Wenonah sand), New Jersey. Ripley formation, Union Springs, Ala., and Tippah County, Miss.

\section{Gyrodes major Wade, n. sp.}

Plate LVII, Figures 4, 7, 11

Shell very large for the genus and naticoid; spire depressed but elevated well above the body volution; whorls closely appressed, coiled five or six times, increasing markedly in size; protoconch small and naticoid, coiled about three times; sculpture inconspicuous, absent except on flat crenulated narrow spiral bands, on both the posterior and anterior parts of the whorls; crenulations protractive on the anterior band and retractive on the posterior band; crenulations become low and irregular near the aperture; suture impressed; body inflated, flattened both anteriorly and posteriorly; aperture holostomous, subovate in outline; outer lip slightly sigmoid and strongly retractive posteriorly; inner lip adnate to the body above the umbilicus, excavated in front of the umbilicus; umbilicus broad and profound, extending through the shell to the apex. Altitude, 53 millimeters; maximum diameter, 62.2 millimeters; length of aperture, 58.2 millimeters.

This species is very common at Coon Creek and is represented by very large, brilliantly glazed shells. The species is near Gyrodes crenata Conrad but differs 
from it in not having a strong ridge along the umbilical keel nor as strong crenulations along the anterior and posterior extremities of the whorls. The adult size of Gyrodes major is about three times as great as that of Gyrodes crenata. G. major is also related, probably, to Gyrodes pansus Stoliczka, ${ }^{81}$ from the Ootatoor group of southern India.

Occurrence: Ripley formation, Dave Weeks place on Coon Creek, McNairy County, Tenn.

Collection: U. S. National Museum.

\section{Genus MAMmiLLA Schumacher}

Mammilla americana Wade, n. sp.

Plate LVII, Figures 10, 14

Shell large and thin; naticoid in outline, spire mammoid in shape, low but elevated well above the body volution; whorls, closely appressed, coiled four or five times, increasing rather abruptly into a large body whorl; external surface smooth with no sculpture except for numerous incremental lines; suture simple; body inflated; aperture holostomous, subovate or $D$ shaped in outline; outer lip thin; inner lip gently excavated anteriorly, calloused posteriorly; umbilicus broad and profound.

Altitude, 42 millimeters; .maximum diameter, 46 millimeters; length of aperture, 39 millimeters.

This species is well characterized by its simple mammoid form. It is the first species.from the Upper Cretaceous of North America to be referred to this genus. Species of this genus are rare in both the Cretaceous and Tertiary of the world. Mammilla americana Wade resembles Mammilla carnatica Stoliczka, ${ }^{\text {,2 }}$ from the Arrialoor group of the Upper Cretaceous of India.

Occurrence: Ripley formation, Dave Weeks place on Coon Creek, McNairy County, Tenn.

Collection: U. S. National Museum.

\section{Genus AMAUROPSIS Mörch}

Amauropsis lirata Wade, n. sp.

Plate LVII, Figures 5,8

Shell of medium size and fragile; spire elevated and very acute, its altitude less than the length of the aperture; whorls six, tabulated, increasing gradually in size to an inflated body whorl; protoconch broken away, its scar very small; sculpture faint, consisting of numerous feebly impressed lines that show through the glaze of the external surface; lirae more numerous on the anterior half of the body; numerous irregular incremental lines intersect the spirals, presenting a subdued uneven ornamentation of the surface; suture deeply impressed and sulcate, caused by a folding in of the posterior margin of the whorls; body slightly

\footnotetext{
ol Stoliczka, Ferdinand, India Geol. Survey Mem., Palacontologia Indica, Cretaccous fauna of southern India, vol. 2, p. 305, pl. 22, figs. 9-13, 1868.

02 Stoliczka, Ferdinand, op. cit., vol. 2, p. 307, pl. 22, fig. 5, 1868.
}

elongated and gently constricted in front; aperture large and conspicuous, holostomous and $D$-shaped in outline, flaring anteriorly; outer lip broadly rounded and patulous in front, its margin simple; inner lip straight and reflected; umbilical chink almost hidden by the reflected inner lip. Altitude, 30.6 millimeters; maximum diameter, 20.2 millimeters; length of aperture, 19.3 millimeters.

This species is well characterized by its high spire, broad flaring aperture, sulcate suture, and lirate sculpture. This species presents well the generic features shown in the recent form Amauropsis cornea Müller, cited by Adams ${ }^{63}$ as typical of the genus. In the American Upper Cretaceous the Tennessee species may be compared with the small, delicately striate form Amauropsis paludinaeformis Meek and Hayden, ${ }^{64}$ from the upper part of the Pierre shale in North Dakota. Natica laevis Kaunhowen, ${ }^{05}$ from the Maestrichtian of western Europe, has a high spire, a canaliculate suture, and an elongate ovate aperture, much like the American species, and probably might be referred to the same genus instead of Natica. Amauropsis pannucea Stoliczka, ${ }^{68}$ from the Arrialoor and Trichinopoly groups of the Upper Cretaceous of southern India, is another closely related species.

Occurrence: Ripley formation, Dave Weeks place on Coon Creek, McNairy County, Tenn.

Collection: U. S. National Museum.

\section{Genus AMPULLINA Lamarck}

Ampullina potens Wade, n. sp.

Plate LVII, Figures 12, 13

Shell fairly large, thick and stout, bulbiform in outline; elevation of spire less than half the entire length of the shell; whorls of conch five or six, increasing markedly in size; protoconch broken away in the type, its scar small; sculpture absent except for fine incremental lines, which are best developed near the aperture and show through the glaze of the external surface; suture impressed; body abruptly constricted posteriorly, forming a narrow shelf along the closely appressed posterior extremity; maximum diameter along the median horizontal; body flattened behind, well rounded in front; aperture holostomous, comparatively narrow and subovate in outline; outer lip patulous in front; inner lip nearly straight and callous; umbilical chink shallow. Altitude, 34.9 millimeters; elevation of spire, 14.6 millimeters; maximum diameter, 26 millimeters.

This species is characterized by thick, stout shells, the whorls of which are longitudinally flattened.

${ }^{63}$ Adanıs, H. and A., Genera of Recent Mollusca, vol. 2, p. 621, pl. 137, flg. 5, 1858 . 04 Meek, F. B., A report on the invertebrate Cretaceous and Tertiary fossils of the upper Missouri country: U. S. Geol. Survey Terr. Rept., vol. 9, p. 318, pl. 19, fig. 15, 1876.

${ }^{65}$ Kaunhowen, Friedrich, Die Gastropoden der Maestrichter Kreide: Palaeont. Abh. (Dames \& Koken), Band 8 (neue Folge, Band 4), p. 55, ftgs. 12, 13, 13a, 1898. ${ }^{66}$ Stoliczka, Ferdinand, op. cit., vol. 2, p. 299, pl. 21, fig. 10; pl. 22, fig. 1, 1868. 
Only one individual of this species is known, and it is the first representative to be described from the Cretaceous of eastern North America. Ampullina. potens seems to be related somewhat to Ampullina bulbiformis (Sowerby) Stoliczka, ${ }^{67}$ which has been reported from the Gosau beds of the Alpine region and from both the Trichinopoly and Ootatoor of the C̈retaceous of southern India. The species Ampullina bulbiformis (Sowerby) is referred to the genus Amauropsis by many authors and has been identified by Stanton ${ }^{68}$ in the Colorado group of the western interior region.

Occurrence: Ripley formation, Dave Weeks place on Coon Creek, McNairy County, Tenn.

Collection: U. S. National Museum.

\section{Family CAPULIDAE}

\section{Genus THYLACUS Conrad}

Thylacus cretaceus Conrad

Plate LVIII, Figures 1, 5, 11

1860. Thylacus cretaceus. Conrad, Acad. Nat. Sci. Philadelphia Jour., vol. 4, 2d ser., p. 290, pl. 46, fig. 22.

Conrad characterizes this species as follows:

Oblong, contracted below the middle; apex prominent, terminal.

Shell small and fragile, ear-shaped and irregular in form or subcapuloid, oblong; apex near margin of aperture, conch not regularly coiled but twisted about $45^{\circ}$; protoconch small and smooth, naticoid, coiled two and a half times; sculpture absent except for strong asymmetric incremental lines; aperture subovate, twisted, holostomous, margins thin and simple; inner surface of body cavity smoothly glazed; horseshoe-shaped muscle supports well defined, the anterior extremities of which are in the shapes of knife blades and stand out from the body walls and not adnate. Length, 8.1 millimeters; width, 4.7 millimeters.

This interesting species is well characterized by its asymmetric ear-shaped form, its naticoid protoconch, and the well-defined horseshoe-shaped muscle supports. The young individuals are more regular and capuloid in form. They strongly suggest Capulus verus J. Böhm, ${ }^{69}$ from the Aachen Cretaceous of Vaals, Germany, but that form, so far as known, does not show the horseshoe-shaped muscle supports. Although the shells of the species of Thylacus cretaceus are small and very fragile, yet they are abundant and well preserved in the Coon Creek sediments. They occur in place in their natural habitat, fitting snugly to the columellar walls within the body cavities of larger gastropods.

This species is the type of the genus which was described from Owl Creek by Conrad in 1860.

o7 Sowerby, G. B., in Sedgwick, Adam, and Murchison, R. I., A sketch of the structure of the eastern Alps: Geol. Soc. London Trans., 2d ser., vol. 3, p. 418, pl, 38, fig. 13, 1832. Stoliczka, Ferdinand, op. cit., vol. 2, p. 30, pl. 65, figs. 11-15, 1868.

os Stanton, T. W., The Colorado formation and its invertebrate fauna: U. S. Geol. Survey Bull. 106, p. 137, pl. 30, figs. 2-4, 1893.

${ }^{60}$ Holzapfel, Eduard, Die Mollusken der Aachener Kreide: Palaeontographica, Band 34, p. 151, pl. 15, figs. 11a, b, c, d, 13, 1888.
Occurrence: Ripley formation, Dave Weeks place on Coon Creek, McNairy County, Tenn.

Collections: U. S. National Museum, John Hopkins University.

Outside distribution: Ripley formation, Owl Creek, Tippah County, Miss.

\section{Genus CAPULUS Montfort}

Capulus corrugatus Wade, n. sp.

Plate LVIII, Figure 4

Shell fairly large and extremely fragile, in form a low cone with a slightly spiral apex; protoconch unknown; external surface smooth or spirally corrugated; outer lip or portion of aperture most distant from the apex usually corrugated and inner lip usually smooth. Elevation, 10 millimeters; maximum diameter, 30 millimeters.

This species is known from only a few imperfect specimens that show a wide variation in form. The apices of some individuals are not spiral or curved, whereas the apices of others are. The species Capulus spangleri Henderson ${ }^{70}$ is a closely related form from the Montana group of Colorado.

Occurrence: Ripley formation, Dave Weeks place on Coon Creek, McNairy County, Tenn.

Collection: U. S. National Museum.

\section{Family LITTORINIDAE Genus IITTORINA Férussac \\ Littorina berryi Wade, n. sp. Plate LVIII, Figures 2, 3}

Shell of medium size and conical in outline; spire elevated and blunt at the apex, its elevation greater than half the total altitude of the shell; whorls six, increasing in size rather markedly; protoconch broken away, its scar small; sculpture dominantly spiral, spiral ridges or narrow fillets strong and rectangular in cross section, four on the whorls of the spire and 14 on the body; spiral ridges of equal size and widely spaced on the posterior half of the body, but lower and crowded on the base of the body; spiral ridges slightly beaded and roughened by incremental lines; incremental lines numerous and well defined in the wide and deeply channeled interspiral spaces; suture adnate along the crest of the fifth spiral ridge in front of the preceding suture, thus causing a deep impression in the sutural region and producing a sort of flattening along the posterior margin of the whorls; body regular, its maximum diameter falling in front of the median horizontal, abruptly constricted in front; aperture ovate or subcircular; outer lip thin, slightly patulous in front, feebly crenulated internally beneath the spiral ridges; inner lip reflected, spreading out as a thin glaze of callus on the body between the base and the posterior commissure; columella smooth; umbilical chink slight. Altitude, 26.4 millimeters; elevation of

${ }^{70}$ Henderson, Junius, New species of Cretaceous invertebrates from northern Colorado: U. S. Nat. Mus. Proc., vol. 34, p. 261, pl. 13, 1908. 
spire, 16.4 millimeters; maximum diameter, 16.3 millimeters.

This species is well characterized by its spiral ridges and incremental lines and further by its thin outer lip, which is slightly cremulate. So far as known this is the second species of Littorina to be reported from the North American Cretaceous, the first being Littorina compacta Gabb, ${ }^{71}$ from the Cretaceous of the Pacific coast. The species from Tennessee is more like Littorina acicularis Stoliczka, ${ }^{72}$ from the Trichinopoly group of southern India, than it is like the species from California.

The conspicuously lirate shells of Littorina berryi, with their numerous sharply defined incremental lines, closely resemble the conical, spirally sculptured species Omphalia ventricosa ${ }^{73}$ and 0 . ovata ${ }^{74}$ Zekeli, from the Gosau beds of the northeast Alpine region. Typical Omphalias or Glauconias, however, are umbilicated and have deeply emarginated outer lips.

Littorina berryi is represented in the present Tennessee collection by several well-preserved specimens. The species is named in honor of Prof. E. W. Berry, of the Johns Hopkins University, who has contributed so largely to the knowledge of American Cretaceous deposits, especially the littoral and near-shore sediments, of which the genus Littorina is typical.

Occurrence: Ripley formation, Dave Weeks place on Coon Creek, McNairy County, Tenn.

Collection: U. S. National Museum, Johns Hopkins University.

\section{Family RISSOIDAE \\ Genus RISSOINA D’'Orbigny}

Rissoina fragilis Wade, n. sp.

Plate LVIII, Figure 22

Shell very small and fragile, in outline a sharp cone; spire acuminate, its elevation greater than half the total altitude; apex broken away; whorls increasing gradually in size to an inflated body whorl; sculpture absent, external surface glazed with enamel; suture impressed slightly; body inflated and elongate, sloping rapidly in front; aperture narrow and elliptical; outer lip thin, sinuous at the posterior margin, produced medially, and patulous in front; inner lip excavated medially; columella smooth, reinforced at the anterior extremity by a slight thickening of the inner lip. An imperfect individual measures in altitude, 2.8 millimeters; in maximum diameter, 1.4 millimeters.

Only one individual of this species is known, and the apex of this specimen is broken away. The species is well characterized by a slender shell that

\footnotetext{
${ }^{7}$ Gabb, W. M., Californta Geol. Survey, Paleontology, vol. 1, p. 131, pl. 20, fig. 89, 1864 .

72 Stoliczka, Fordinand, op. cit., vol. 2, p. 266, pl. 20, figs. 9, 10, 1868.

73 Zekeli, Friedrich, Die Gasteropoden der Gosaugebilde: K.-k. geol. Reichsanstalt Abh., Band 1, p. 30, pl. 3, fig. 4. 1852.

${ }^{74}$ Idem, p. 28, pl. 2, flg. 4.
}

has an enameled external surface. In size and general outline this species resembles Rissoina acuminata Müller, ${ }^{75}$ from the Aachen Cretaceous of Vaals, Germany, but it differs from that species in having an enameled external surface. One species of this genus, Rissoina alabamensis Aldrich, ${ }^{76}$ has been described from the Midway of the Alabama Eocene. The Eocene species is about the same in size and, like the species from the Ripley of Tennessee described above, has no ornamentation, but the species from Tennessee has a more elongate body and the whorls are more oblique.

Occurrence: Ripley formation, Dave Weeks place on Coon Creek, McNairy County, Tenn.

Collection: U. S. National Museum.

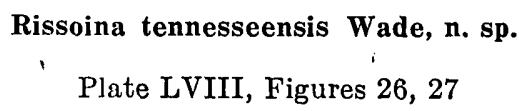

Shell small and elongate; spire acuminate, its elevation about three-fourths the total altitude of the shell, spiral angle regular; whorls six, broadly convex, and increasing in size gradually; protoconch small and trochoid, coiled three times; no sharp line of demarcation between it and the conch; sculpture subdued, absent on early whorls of the spire; on later whorls the surface is pitted or shagreen, formed by the intersection of feebly impressed spiral lines and incrementals, incrementals well defined and sigmoid on the ultima; suture impressed; body slightly enlarged, constricted a little posteriorly and sloping rapidly in front; aperture broadly elliptical; outer lip strong and conspicuous, patulous in front, where it extends beyond the base of the body, and receding at the posterior commissure; inner lip reflected and adnate to the body, excavated in the middle; columella smooth. Altitude, 7.2 millimeters; maximum diameter, 3 millimeters.

This species and Rissoina fragilis, so far as known at present, are the first species from the North American Upper Cretaceous to be referred to this genus. Rissoina tennesseensis is common at Coon Creek and is represented in the present collection by several well-preserved specimens. In size and general aspect this species resembles the type of the genus, Rissoina incerta (Deshayes) D'Orbigny, ${ }^{77}$ which occurs in the upper Gault of France. The French species, however, differs from the Tenyessee species in possessing a thickened outer lip and in not having a shagreen or roughened outer surface.

Occurrence: Ripley formation, Dave Weeks place on Coon Creek, McNairy County, Tenn.

Collection: U. S. National Museum.

78 Holzapfel, Eduard, op. cit., p. 137, pl. 14, fig. 10, 1888.

${ }^{76}$ Aldrich, T. H., New or little known Tertiary Mollusca from Alabama and Texas: Bull. Am. Paleontology, vol. 1, No. 2, p. 13, pl. 2, ffg. 8, 1895.

77 D'Orbigny, Alcide, op. cit., vol. 2, p. 62, pl. 155, figs. 11-13, 1843. 
Rissoina subornata Wade, n. sp.

Plate LVIII, Figures 23, 24

Shell small and fragile; spire acuminate but only a little greater in length than the enlarged body whorl; whorls strongly convex, about four in number, increasing in size rather markedly; protoconch unknown; sculpture subdued or absent on early whorls, low but sharply defined on the body, consisting of numerous spiral threads and irregular axial growth lines that form a subcancellate type of sculpture; body inflated, constricted both anteriorly and posteriorly; suture impressed; aperture ovate; outer lip thin and smooth, patulous in front, extending beyond the base of the body; inner lip excarated; columella smooth. Altitude (slightly imperfect specimen), 4.5 millimeters; maximum diameter, 2 millimeters.

This species is characterized by low cancellate sculpture on the later volutions and further by strongly convex whorls. It is very closely related to the Ripley species Rissoina tennesseensis Wade and is nearer to Rissoina acuminata Müller ${ }^{78}$ of the European and Indian Upper Cretaceous, than it is to the other Ripley species, Rissoina fragilis Wade.

Occurrence: Ripley formation, Dave Weeks place on Coon Creek, McNairy County, Tenn.

Collection: U. S. National Museum.

Superfamily PTENOGLOSSA

Family SCALIDAE

Genus SCALA Klein

Scala sillimani (Morton)

Plate LIV, Figures 12, 13, 15, 16

1834. Scalaria sillimani. Morton, Synopsis of the organie remains of the Cretaceous group of the United States, p. 47 , pl. 13 , fig. 9 .

1861. Scala sillimani. Gaßb, Synopsis of the Mollusca of the Cretaceous formation, p. 79 (Am. Philos. Soc. Proc., vol. 8, p. 135).

1864. Scala sillimani. Meek, Check list of the invertebrate fossils of North America, Cretaceous and Jurassic, p. 20.

1892. Scalaria sillimani. Whitfield, U. S. Geol. Survey Mon. 18, p. 138, pl. 18, fig. 2. (Also published by New Jersey Geol. Survey.)

1905. Scala sillimani. Johnson, Acad. Nat. Sci. Philadelphia Proc., vol. 57, p. 20.

1907. Scala sillimani. Weller, New Jersey Geol. Survey, Paleontology, vol. 4, p. 672, pl. 76, figs. 2, 3.

1914. Scala sillimani. Stephenson, U. S. Geol. Survey Prof. Paper 81, check list, tables 2, 4, 5, 6, 8 .

Morton describes this species as follows:

Shell turreted; volutions contiguous, rounded, with very prominent reflected costae and very minute spiral striae; body whorl carinated near the base.

Whitfield gives the following details:

Shell of medium size, measuring nearly 1 inch in length and rapidly tapering, the apical angle being about $30^{\circ}$ or $35^{\circ}$; volutions five or more, very round and full but closely compacted; the suture line deep and sharp but close; aperture (as shown

${ }^{78}$ Holzapfel, Eduard, op. cit., p. 137, pl. 14, fig. 10. on the only specimen in hand, which is a matrix containing the shell of one side of the specimen in place and from which a guttapercha cast is taken for description and figure) is round, but the margin is not preserved; surface of the shell marked by oblique varices, which have a slightly backward direction in crossing from the upper to the lower side of the volution. The varices are thin and recurved and number eight on one-half of the circumference of the last volution but decrease somewhat in number toward the apex of the spire; axis imperforate, the base of the last volution bordered by a raised carina, below which the varices do not appear to extend. So far as can be ascertained from the specimen, I should judge that the varices were slightly produced in the upper part to subspines around the base of the preceding volution. The minute surface character of the shell can not be ascertained from the specimen in use, as only the inside of the substance is revealed, but Dr. Morton describes it as marked by "very minute spiral striae," which one would suppose would naturally be the case. Mr. Gabb also speaks of it having "much finer" revolving striae than his Scala (Opalia) thomasi, which is also a New Jersey species, and says that each rib is reflected back into a little lip or notch at the angle of the basal carina.

Occurrence: Ripley formation, Dave Weeks place on Coon Creek, McNairy County, Tenn.

Collections: U. S. National Museum, Philadelphia Academy of Natural Sciences, New Jersey Geological Survey, U. S. National Museum.

Outside distribution: Matawan group (Wenonah sand and Marshalltown formation), New Jersey. Monmouth group (Redbank sand and Navesink marl), New Jersey. Ripley formation, Tippah County, Miss. Selma chalk, Wilcox and Sumter counties, Ala., and Kemper County, Miss.

\section{Genus ACIRSA Mörch}

\section{Acirsa microstriata Wade}

Plate LV, Figure 12

1917. Acirsa microstriata. Wade, Acad. Nat. Sci. Philadelphia Proc., vol. 69, p. 399, pl. 18, fig. 8.

1918. Acirsa microstriata. Cossmann, Rev. critique paléozoologie, année 22, Nos. 1-2, p. 21.

Shell of medium size, thin and strong; form an elongate simple slender cone; spire acuminate; 11 volutions on the type individual, which has the apical tip broken away, probably 14 on the original; whorls increasing regularly in size from apex to ultima; volutions flattened laterally; penultima and ultima very slightly constricted toward the sutures; protoconch unknown; sculpture barely visible to the unaided eye; axial sculpture restricted to strong and conspicuous incremental lines, occurring at irregular intervals, and to low, obscure, and unequal axial wrinkles on the periphery of the whorl; spiral sculpture microscopically fine but sharp, consisting of about 15 closely spaced feebly impressed lines to each of the whorls of the spire but about 35 on the sides and base of the body; suture simple and appressed; posterior edges of whorls very sharp in front of suture; peripheral angle obtuse, base of body broadly rounded; aperture holostomous, obliquely ovate, angulated at the posterior commissure; 
outer lip rounded and slightly effuse at the anterior, its curvature higher than that of the inner lip; inner lip smoothly glazed and reflected, concealing the umbilical chink; parietal wash thin; columella smooth. Altitude, 31.5 millimeters; maximum diameter, 9.9 millimeters.

Only one shell of this species is known, and this individual, aside from the loss of its apical tip, is as strong and well preserved as if it were a Recent shell. Chemnitzia cerithiformis Meek and Hayden, ${ }^{70}$ from the Fox Hills group of the upper Missouri Cretaceous, probably belongs to the same genus. In 1860 Meek and Hayden ${ }^{80}$ in a check list referred this species to the genus Scala (Acirsa), but in the final description it was assigned to the genus Chemnitzia. After a study of Cossmann's very comprehensive work on the Scalidae ${ }^{81}$ and of three species, including Chemnitzia cerithiformis, recently collected from Coon Creek, it seems that Meek and Hayden's species was an Acirsa and that the other two species from Tennessee are congeneric.

Occurrence: Ripley formation, Dave Weeks place on Coon Creek, McNairy County, Tenn.

Collection: U. S. National Museum.

\section{Acirsa corrugata Wade}

\section{Plate LV, Figure 13}

1917. Acirsa corrugata. Wade, Acad. Nat. Sci. Philadelphia Proc., vol. 69 , p. 300 , pl. 18 , fig. 9 .

1918. Acirsa corrugata. Cossmann, Rev. critique de paléozoologie, année 22, Nos. 1-2, p. 21.

Shell small and slender; form elongate conic; spire acuminate; whorls 11 , slightly convex and increasing in size very gradually; protoconch scar small; sculpture elaborate, consisting of both axial and spiral elements; axial elevations strong and crowded on the early whorls of the spire but becoming lower and more widely spaced on the later volutions; spiral sculpture overriding the axials but very obscure on their summits; spiral sculpture consisting of low, crowded thread like lirae, 16 to 20 on the later whorls of the spire, and with slightly wider additional spirals on the base of the body; interspiral areas marked by very fine and regular pittings; suture distinctly impressed; body very slightly constricted in front of the posterior margin; peripheral angle obtuse; base of body obliquely flattened or very broadly rounded; aperture holostomous, broadly and obliquely ovate, angulated at the posterior commissure; outer lip thin and simple, slightly patulous in front; inner lip excavated medially, thin, and reflected, adnate to the body wall; columella

${ }^{70}$ Meck, F. B., A report on the invertebrate Cretaceous and Tertiary fossils of the upper Missouri country; U. S. Geol. Survey Terr. Rept., vol. 9, p. 339, pl. 32, figs. $10 \mathrm{a}, \mathrm{b}, 1876$.

${ }_{80}$ Meek, F. B., and Hayden, F. V., Description of new organic remains from the Tertiary, Cretaceous, and Jurassic rocks of Nebraska: Acad. Nat. Sci. Philadelphia Proc. for 1860, p. $185,1860$.

81 Cossmann, Maurice, Essais de paléoconchologie comparée, pt. 9, pp. 16-102, 1912. smooth. Altitude, 14.7 millimeters; maximum diameter, 4.1 millimeters.

This species is well characterized by its sharply defined axial costae, which are crowded on the early whorls of the spire but become more widely spaced. on the later volutions, and further by the fine regular pittings in the interspiral spaces. Both Acirsa corrugata and Acirsa microstriata differ from Acirsa? cerithiformis (Meek and Hayden) ${ }^{82}$ in the more elongate and slender outline and the details of the external ornamentation. Acirsa corrugata is smaller than Acirsa microstriata, and unlike that species it exhibits a well-developed axial sculpture over the entire shell.

The very elegantly ornamented species Scalaria dense-striata Kaunhowen, ${ }^{83}$ from the Maestrichtian of western Europe, is probably a member of the genus Acirsa and may be compared with Acirsa corrugata.

Occurrence: Ripley formation, Dave Weeks place on Coon Creek, McNairy County, Tenn.

Collection: U. S. National Museum.

\section{Acirsa? cerithiformis Meek and Hayden?}

Plate LIV, Figures 9, 22

1865. Scalaria cerithiformis. Meek and Hayden, Acad. Nat. Sci. Philadelphia Proc., vol. 8, p. 63. (Not Watelet, 1853.)

1860. Turbonilla cerithiformis. Meek and Hayden, Acad. Nat. Sci. Philadelphia Proc. for 1860, p. 185.

1860. Scala (Acirsa) cerithiformis. Meek and Hayden, Acad. Nat. Sci. Philadelphia Proc. for 1860, p. 422.

1864. Scala (Acirsa) cerithiformis. Meek, Check list of the invertebrate fossils of North America, Cretaceous and Jurassic, p. 20.

187̧1. Scalaria meeki. Nyst, Soc. malacologique de Belgique Annales, vol. 6, p. 44.

1876. Chemnitzia cerithiformis. Meek, U. S. Geol. Survey Terr. Rept., vol. 9, p. 339 , pl. 32 , figs. 10 , a, b.

Meek in 1876 described this species as follows:

Shell elongate conical; spire turreted; volutions about eight, convex, increasing rather gradually from the apex, last one rounded and but little produced below; suture distinct but not very deep; surface ornamented by numerous small, slightly arched vertical costae, crossed by much smaller threadlike revolving lines; aperture rather broad, ovate, being angular above, most convex on outer side, and subangular or narrowly rounded and slightly effuse at the inner side of its base; inner lip thin or nearly obsolete. Length, about 1.65 inches; breadth, $0.68 \mathrm{inch}$; length of aperture, $0.55 \mathrm{inch}$; breadth of same, 0.37 inch. Slopes of spire very nearly straight, with a divergence of $28^{\circ}$.

The little vertical costae on this shell number about 22 to 23 on each turn and are usually separated by depressions some three or four times their breadth. They are rather angular but not very prominent. About 13 of the small revolving lines may be counted on the second turn, where they are separated by spaces nearly twice their own breadth. On the last whorl a smaller line and sometimes two or three smaller ones are developed between each two of the larger revolving lines, so as to give the whole a more crowded and irregular appearance.

82 Meek, F. B., op. cit., p. 339, pl. 32, figs. 10a, b. 1876.

${ }^{83}$ Kaunhowen, Friedrich, Die Gastropoden der Maestrichter Kreide: Palacont. Abh (Dames \& Koken), neue Folge, Band 4, Heft 1, p. 43, pl. 3, figs. 3, 4, 1897. 
Two imperfect individuals from Coon Creek show in part the features characteristic of the shell, so that it may be tentatively assigned to this species. Further collecting at the locality in McNairy County may yield material that will show definitely that the species from Tennessee is not-identical with the western species. With the imperfect specimens now in hand the writer hesitates to establish a new species.

Occurrence: Ripley formation, Dave Weeks place on Coon Creek, McNairy County, Tenn.

Collections: U. S. National Museum, Johns Hopkins University.

Outside distribution: Fox Hills sandstone, Moreau trading post, South Dakota.

\section{Genus HEMIACIRSA De Boury}

\section{Hemiacirsa cretacea Wade}

Plate LV, Figure 9

1917. Hemiacirsa cretacea. Wade, Acad. Nat. Sci. Philadelphia Proc., vol. 69 , p. 302 , pl. 19, fig. 3 .

1918. Hemiacirsa cretacea. Cossmann, Rev. critique paléozoologie, année 22, Nos. 1-2, p. 21

Shell fairly large for the group, slender, turreted, and conical in outline; spire acuminate, that of the type slightly curved, possibly an individual characteristic due to three accidents in the life of the animal, each of which resulted in the breaking of the shell (as scars on the type specimen show) on the same side of the spire, or possibly a specific character of this many-whorled form; whorls flattened, very closely appressed posteriorly, less tightly coiled toward the aperture; whorls twelve and a half on the imperfect type; at least two have been broken away; volutions increasing gradually in size; protoconch unknown; sculpture dominantly axial; axial costae abruptly elevated and subangular on the crests, somewhat flexuous; costae 16 on the body of the type, regularly spaced, persistent from suture to suture on the whorls of the spire; interaxial spaces concave and a little wider than the costae; spiral sculpture subdued but well defined in the interaxial depressions, consisting of 11 lines on the body whorl and about the same number on the whorls of the spire; spiral lines on base of body very faint; suture impressed; base of body nearly flat; angular edge between base and sides of body well rounded, aperture ovate; margin of outer lip broken away; inner lip strongly and smoothly excavated medially; parietal wall washed with a thin glaze of callus; columella smooth. A shell whose apex is broken away measures in altitude 39.4 millimeters; in maximum diameter, 11.1 millimeters.

This species is well characterized by its long, slender, rather large spire, its flattened base, and its well-defined axial costae but obscure spirals. Whether the bend in the spire is an individual or specific character of this many-whorled species can not be determined without additional material. Only one specimen is known at present, but it is of special significance, as it is the first evidence of the presence of this genus in the Upper Cretaceous. In Europe a number of species of Hemiacirsa have been reported, ranging in age from the Montian ${ }^{84}$ up to the Recent species now living in the Gulf of Lyons. One species only is known from the eastern United States. This species is Hemiacirsa perlaqueata (Conrad), a form originally described as Turritella perlaqueata by Conrad, ${ }^{85}$ later referred to the genus Trachyrhynchus Mörch by Martin, ${ }^{86}$ and finally to the genus Hemiacirsa by Cossmann ${ }^{87}$ in 1912.

Occurrence: Ripley formation, Dave Weeks place on Coon Creek, McNairy County, Tenn.

Collection: U. S. National Museum.

\section{Genus PROSCALA Cossmann}

Proscala americana Wade, n. sp.

Plate LV, Figures 10, 11

Shell of medium size and strong; form turreted and conical; spire long and acute; volutions flattened on a line with the general slope of the spire, increasing gradually in size from the apex to the ultima; whorls 10 or 12 , narrow and almost rectangular in cross section: protoconch broken away; sculpture dominantly axial; costae distant and pronounced, abruptly elevated but not high, persistent from suture to suture; spiral sculpture microscopic, consisting of very faintly impressed and crowded lines on the base of the body and in the broad concave interaxial spaces; suture impressed; body flattened on the sides and constricted almost at right angles in front, forming a broadly rounded base to the body; aperture almost perfectly lenticular; outer lip simple; inner lip reflected a little in the middle and hiding any umbilical chink; columella smooth. An individual with apex broken away measures in altitude, 30.4 millimeters; maximum diameter, 9.1 millimeters.

This species is well characterized by its simple aperture and axial costae and further by the microscopic axial lines. In the present collection several well-preserved specimens probably represent the first North American Cretaceous species to be referred to the genus Proscala, which was described by Cossmann in 1912. In its simple and well-defined axial ornamentation the American species greatly resembles the type of the genus, Proscala albensis (D'Orbigny), ${ }^{88}$ which occurs in the Neocomian of France. The Lower Cretaceous species, however, is more slender and its whorls more elongate.

84 Cossmann, Maurice, Essais de paléoconchologie comparée, pt. 9, pp. 97, 98, 1912.

8s Conrad, T. A. [New species of fossil shells from the medial Tertiary deposits of Calvert Cliffs, Md.]: Acad. Nat. Sci. Philadelphia Proc., vol. 1, p 32, 1841.

86 Martin, G. C., Maryland Geol. Survey, Miocene, p. 239, pl. 57, fig. 9, 1904.

8i Cossmann, Maurice, op. cit., p. 97.

${ }^{88}$ Cossmann, Maurice, Essais de paléocon chologie comparée, pt. 9, p. 101, pl. 3 , figs. 31, 44, 1912. 
Occurrence: Ripley formation, Dave Weeks place on Coon Creek, McNairy County, Tenn.

Collection: U. S. National Museum.

$$
\begin{gathered}
\text { Family MATHILDIDAE } \\
\text { Genus TUBA Lea } \\
\text { Tuba parabella Wade, n. sp. } \\
\text { Plate LIII, Figures } 9,10
\end{gathered}
$$

Shell of medium size and strong, turbinate or trochoid; spire acute but its elevation medium in height; whorls eight, convex and circular in cross section, increasing in size regularly and rather markedly; protoconch scar small; sculpture very ornate, consisting of strong beaded spiral threads of unequal size, crowded and increasing in number toward the anterior, 6 or 8 on the early whorls and about 24 on the body, those at the base of the body low and of equal strength but not so conspicuously beaded as the threads on the sides of the whorls; beaded effect of threads produced by numerous narrow, sharply elevated axial lines across the crests of the spiral ridges; strongest spiral lira along the periphery of the whorls and in front of the median horizontal; the stronger lirae alternate with the weaker ones; suture distinctly impressed; body well rounded both in front and behind; aperture circular; outer lip thin and simple; anterior half of inner lip reflected but not hiding the umbilical chink; parietal wall washed with a thin callus; columella smooth and slender. Altitude, 25.4 millimeters; maximum diameter, 14.5 millimeters.

This species is very near Tuba bella Conrad, ${ }^{89}$ from the Ripley at Eufaula, Ala. Conrad's type can not be located in either the Museum of the Philadelphia Academy of Sciences or the National Museum. However, from a study of Conrad's description and figure the form from Tennessee seems to be distinct. It differs from Tuba bella in having a broader base and a slightly less acute spire and further in having more numerous spiral lirae on both the body and the whorls of the spire. There is not enough difference in the strength of the spiral lines for them to be divided up into ribs and lines as in the Alabama species. Another species of this genus from the Senonian is $T u b a$ subcyclostoma (Matheson) Cossmann, ${ }^{90}$ which comes from a locality near the mouth of the Rhone in France.

Occurrence: Ripley formation, Davie Weeks place on Coon Creek, McNairy County, Tenn.

Collections: Johns Hopkins University, U. S. National Museum.

${ }^{80}$ Conrad, T. A., Descriptions of new species of Cretaceous and Eocene fossils of Mississippi and Alabama: Acad. Nat. Sci. Philadelphia Jour., 2d ser., vol. 4, p. 289, pl. 46, flg. 38,1860 .

io Cossmann, Maurice, Essais de paléoconchologie comparée, pt. 9, p. 15, 1912.
Genus MATHILDIA Semper

Mathildia ripleyana Wade, n. sp.

Plate LIII, Figures 11, 16, 17

Shell small and fragile, conical in outline; spire acuminate, turreted; protoconch heterostrophous, small, and smooth; whorls of conch five, increasing in size rather markedly; external sculpture rather elaborate, consisting of unequal subspinose or granular spiral lirae; the strongest lira situated on the medial anterior of the whorls is very prominent and keel-like; a much smaller. prominent lira occurs in the anterior shoulder of the whorls and shows as a rather conspicuous sutural thread; several other much smaller unequal spiral threads both in front and behind the largest lira; suture well defined; body whorl angular in front, with a distinct anterior base; aperture subhexagonal, produced in front into an anterior notch or shallow canal; inner lip excavated; columella smooth. Altitude, 6 millimeters; maximum diameter, 3.2 millimeters.

This species is well characterized by its unequal granulated or subspinose spiral threads. It is very rare at Coon Creek and is known from only two specimens, which are of special interest in that they are the first representatives of this genus to be recognized in the American Cretaceous. It resembles in some respects Mathildia douvillei Cossmann, ${ }^{81}$ from the Albian of France, but differs from that species in detail of spiral sculpture. Two species of this genus have been recognized from the Tertiary of the Mississippi embayment area-Mathildia inaequistriata (Meyer), from the Jackson, ${ }^{22}$ and Mathildia regularis (Meyer), from the Vicksburg. ${ }^{93}$

Occurrence: Ripley formation, Dave Weeks place on Coon Creek, McNairy County, Tenn.

Collection: U. S. National Museum.

\section{Genus PROMATHILDIA Andreae}

Promathildia cretacea Wade, n. sp.

Plate LIII, Figures 18, 19

Shell very small and fragile; spire turreted, very long and acute, in form a very much attenuated regular cone; whorls numerous, separated by a deep sutural impression; protoconch unknown; external sculpture dominantly lirate, consisting of two strong spiral lirae on the early whorls and a third smaller posterior lira, which becomes equal to the two larger

01 Cossmann, Maurice, op. cit., p. 10, pl. 1, flgs. 3-5.

${ }^{92}$ Meyer, Otto, Contributions to the Eocene paleontology of Alabama and Mis. sissippi: Alabama Geol. Survey Bull. 1, p. 68, pl. 2, fig. 4, 1886.

${ }^{83}$ Aldrich, T. H., Bull. Am. Paleontology, No. 2, p. 172, pl. 1, fig. 1, 1895 
lirae on the later half of the shell; interspiral channels well defined and marked by numerous microscopic axial threads; sutural line marked by a low spiral ridge within a deep sutural depression; apertural features unknown; columella smooth. An imperfect individual measures in altitude, 3.4 millimeters; in maximum diameter, 0.8 millimeters.

This species is of very great interest in that it represents a group of very much attenuated turritelloid forms common in the Jurassic, occurring in the Eocene, but not hitherto known in the Upper Cretaceous. This species probably belongs in Cossmann's section Clathrobaculus, ${ }^{94}$ yet the protoconch is unknown. The species from Tennessee resembles Promathildia bacillaris Cossmann, from the Cuisian (Eocene), Liancourt, France, and both the Cretaceous and Eocene species under discussion are somewhat analogous to Promathildia binaria Hébert and Deslongchamps, ${ }^{95}$ from the Inferior Oolite of Beaminster, England.

Occurrence: Ripley formation, Dave Weeks place on Coon Creek, McNairy County, Tenn.

Collection: U. S. National Museum.

\section{Superfamily GYMNOGLOSSA \\ Family PYRAMIDELIIDAE \\ Genus OBELISCUS Humphrey}

Obeliscus conellus Whitfield

1892. Obeliscus conellus. Whitfield, U. S. Geol. Survey Mon. 18 , p. 151 , pl. 19, fig. 1.

1905. Pyramidella conellus. Johnson, Acad. Nat. Sci. Philadelphia Proc., vol. 57, p. 20.

1907. Obeliscus conellus. Weller, New Jersey Geol. Survey, Paleontology, vol. 4, p. 672, pl. 76, fig. 1.

Whitfield describes this species as follows:

Shell minute, the extreme length of the only specimen known, being only about one-sixth of an inch. Apical angle $38^{\circ}$ or $40^{\circ}$ giving a sharply conical spire; volutions five in number, very slightly scaliform, with channeled sutures but with the surface of the volutions flattened in the direction of the spire; apex apparently rounded; body volution subangular at the line of contact with the lip; aperture acute-ovate, sharp at the upper margin and possibly pointed below (the specimen is imperfect at the base); columella slender, rounded, slightly prolonged, marked by a proportionally very strong toothlike ridge just below the swell of the volution; outer lip of the aperture sharp; axis imperforate; surface smooth but not polished on the specimen, though the dullness present may be the effect of solution.

Weller says:

This species is known from a single specimen less than 5 millimeters in height, which is possibly an immature shell.

Another individual of this species has been discovered at Coon Creek, which is imperfect but of the same size as the type, which would seem to indicate that both were adult shells. The Coon Creek speci-

or Cossmann, Maurice, op. cit., pt. 9, p. 8, pl. 1, figs. 9-11.

os Hudleston, W. H., A monograph of the Inferior Oolite Gastropoda, p. 234, pl. 7, fig. 7, Palaeont. Soc. London, 1892. men shows well-defined lirations on the inner surface of the outer body wall.

Occurrence: Ripley formation, Dave Weeks place on Coon Creek, McNairy County, Tenn.

Collections: New Jersey Geological Survey, U. S. National Museum.

Outside distribution: Matawan group (Woodbury clay) of New Jersey.

\section{Genus LeIOSTRACA H. and A. Adams \\ Leiostraca cretacea (Conrad) \\ Plate LVIII, Figures 6, 7}

1869. Eulima cretacea. Conrad, Am. Jour. Conchology, vol. 5, p. 100 , pl. 9, fig. 15 .

1892. Leiostraca cretacea. Whitfield, U. S. Geol. Survey Mon. 18 , p. 150 , pl. 19 , figs. $2-5$. (Also published by New Jersey Geol. Survey.)

1905. Eulima cretacea. Johnson, Acad. Nàt. Sci. Philadelphia Proc., vol. 57, p. 20, 1905.

1907. Leiostracea cretacea. Weller, New Jersey Geol. Survey, Paleontology, vol. 4, p. 671, pl. 75, figs. 15-17.

Conrad describes this species as follows:

Subulate, whorls 11(?), slightly truncate at the base, except the last volution, which is subangular or acutely rounded medially.

Whitfield gives the following details:

Shell small, slender, subulate, spire very much elevated, smooth and polished; volutions nine or more, flattened between the sutures, the upper edge of any volution slightly smaller than the lower edge of the one immediately above it, making the sutures remarkably distinct for a shell of this group; body volution rounded, subangular in the lower part and rather rapidly contracted below to the short columella; aperture ovate elliptical, acute above and rounded below; outer lip thin and sharp; inner lip smoother, without callus or ridges; surface polished, entirely destitute of lines or other markings. On one individual, on which the lip is broken away for one-third of the volution, there occurs a distinct spiral ridge above the columella proper and just below the junction of the outer lip with the body of the volution, within the aperture.

Occurrence: Ripley formation, Dave Weeks place on Coon Creek, McNairy County, Tenn.

Collections: Philadelphia Academy of Natural Sciences, New Jersey Geological Survey, U. S. National Museum.

Outside distribution: Matawan group, Haddonfield, N. J.

\section{Genus CREONELLA Wade}

1917. Creonella. Wade, Acad. Nat. Sci. Philadelphia Proc., vol. 69, p. 302. Etymology: A diminutive of Creon, king of Corinth. Type: Creonella triplicata Wade.

Shell small and smooth, in outline a simple, slender cone; whorls closely appressed and increasing in size gradually; whorls of spire generally flat and narrow; protoconch, which is very small and heterostrophous, has only two volutions; sculpture absent except for microscopic incremental lines in the glaze of the external surface; suture sharply impressed; body well rounded in front; aperture ovate; outer lip thin 
and simple, inner surface of the outer wall of the body strongly lirate; inner lip excavated medially; columella marked by two plaits, the posterior of which is the stronger; just behind the strong columellar plait on the body is another plait similar to a columellar fold; parietal wall glazed with callus; umbilicus imperforate.

This genus is well characterized by three conspicuous folds on the inner lip. The most posterior of these folds is situated on the body of the preceding whorl, and the other two occur on the columella. The posterior one of the columellar plaits is the stronger, and on either side of it there is a deep columellar sulcus. The genus is probably near Pyramidella, but the umbilicus of that genus is typically imperforate. The genus Creonella is proposed for a group represented by two species from Coon Creek which are unlike any known species of this family in either the Upper Cretaceous or the early Tertiary. A representative of the genus Obeliscus, $O$. canellus Whitfield, ${ }^{90}$ which occurs at Coon Creek and also in the Monmouth of New Jersey, has a single columellar plait. Otherwise, in the simple, slender, conical forms of the inornate shells, the two groups resemble each other very much.

\section{Creonella triplicata Wade}

Plate LVIII, Figures 8, 25

1917. Creonella triplicata. Wade, Acad. Nat. Sci. Philadelphia Proc., vol. 69, p. 303 , pl. 19, fig. 8 .

1918. Creonella triplicata. Cossmann, Rev. critique paléozoologie, année 22, Nos. 1-2, p. 21.

Shell small and slender, in outline a very sharp cone; spire acuminate; angle of spire constant; whorls closely appressed, numerous and narrow, seven in the imperfect type; probably almost twice as many in a perfect form; sculpture absent except for protractive incrementals of irregular strength and spacing that scar the glazed external surface; suture distinctly impressed; body very abruptly constricted in front of the periphery; peripheral angle well rounded; aperture narrow; outer lip broken away; inner surface of labrum corrugated within, with about half a dozen prominent lirae; subequal, closely and evenly spaced; columella marked by two strong transverse folds, behind which and on the body is another fold; the posterior of the columellar plaits is the strongest of these three plaits; on either side of the strong columellar fold are two deep spiral sulci around the columella. An imperfect individual measures in altitude, 14.4 millimeters; maximum diameter, 3.3 millimeters.

This species is well characterized by its narrow, numerous whorls and its very sharp, strongly impressed suture. The species is known from only two specimens, neither of which is perfect, but they are sufficiently preserved to show all characteristic features.

${ }^{00}$ Whitfleld, R. P., Gastropoda and Cephalopoda of the Raritan clays and greenzand marls of New Jersey: U. S. Geol. Survey Mon. 18, p. 151, pl. 19, fig. 1, 1892.
Occurrence: Ripley formation, Dave Weeks place on Coon Creek, McNairy County, Tenn.

Collection: U. S. National Museum.

\section{Creonella secunda Wade, n. sp. Plate LVIII, Figure 12}

Shell very small and fragile, paucispiral; in outline a very small cone; spire acute; whorls closely appressed, increasing in size slowly; volutions five; rotoconch very small and heterostrophous, with only two volutions, the last of which is not sharply differentiated from the first whorl of the conch; sculpture absent except for very fine incremental lines that may be observed in the glaze of the external surface with a hand lens; suture sharply impressed; body enlarged a little and slightly convex; aperture broadly elliptical to ovate; outer lip thin and simple; inner lip excavated medially; columella marked by two well-defined folds, the posterior of which is much the stronger, just behind the posterior columellar plait on the body is a weaker fold; parietal wall washed by a narrow area of glaze, its outer margin being sharply defined; inner surface of the outer body wall is marked by 10 or 12 well-defined spiral lirae. Altitude, 3.9 millimeters; maximum diameter, 1.8 millimeters.

This species is known from a single specimen, and it is as perfect and fresh in appearance as if it were a recent shell. This species is characterized by its slightly enlarged and convex body. It differs from Creonella triplicata in being much smaller and in having broader and less numerous volutions of the spire. Its body cavity is proportionally much larger, and its columellar folds are not so strong and conspicuous.

Occurrence: Ripley formation, Dave Weeks place on Coon Creek, McNairy County, Tenn:

Collection: U. S. National Museum.

\section{Genus ODOSTOMIA Fleming}

Odostomia plicata Wade, n. sp.

Plate LVIII, Figures 18, 19

Shell small and fragile, conical in outline; spire acuminate but rather short; whorls three or four, convex, increasing markedly in size to an enlarged body whorl; sculpture absent except for interrupted growth lines near the aperture; suture impressed; body enlarged, well rounded in front; aperture broad and ovate; outer lip thin; inner lip excavated; columella marked by a single strong fold. Altitude, 3.5 millimeters; maximum diameter, 2 millimeters.

This simple inornate conical species is known from a single shell. This species and its affinity Odostomia 'impressa, also from the Ripley of Tennessee, resemble Odostomia trapaquara (Harris), ${ }^{97}$ from the Aquia formation of the Eocene of Maryland, but are more convex in cross section of whorls.

${ }^{97}$ Clark, W. B., and Martin, G. C., Maryland Geol. Survey, Eocene, p. 156, pl. 29 , fig. 3,1901 . 
Occurrence: Ripley formation, Dave Weeks place on Coon Creek, McNairy County, Tenn.

Collection: U. S. National Museum.

Odostomia impressa Wade, n. sp. Plate LVIII, Figures 9, 10

Shell small and fragile, conical in outline; spire acute; whorls convex, four or five in number, increasing gradually in size to a rather large body whorl; protoconch unknown; sculpture absent except for a deeply impressed spiral line just in front of the suture; growth lines faint; suture impressed; body inflated, well rounded in front; aperture broad and ovate; outer lip thin and smooth at its margin, but the inner surface of the labrum marked by about half a dozen lirae; inner lip reflected and excavated; columella marked by two plaits situated above the middle of the aperture. Altitude, 5 millimeters; maximum diameter, 2.5 millimeters.

This species is characterized by the deeply impressed spiral line just in front of the suture and further by two columellar plaits and a lirate inner labrum. It is closely related to Odostomia plicata Wade, n. sp. These two species seem to represent a section of this genus which has no. known closely related affinities in the Upper Cretaceous of the eastern United States.

Occurrence: Ripley formation, Dave Weeks place on Coon Creek, McNairy County, Tenn.

Collection: U. S. National Museum.

\section{Family EULIMIdaE \\ Genus EULIMA Risso \\ Eulima impressa Wade, n. sp. \\ Plate LVIII, Figure 13}

Shell very small and in outline a slender cone; spire acuminate, its elevation more than three-fourths the total altitude of the shell; whorls closely appressed, increasing gradually and regularly in size; spiral slopes straight, with sutures sharply but not deeply impressed; whorls of conch six or seven; protoconch broken away in the type; sculpture absent, external surface glazed; suture sharply but not deeply impressed; body flattened on the sides and abruptly constricted in front; aperture elliptical; outer lip thin along the margin, slightly patulous in front; inner lip excavated; columella smooth. An imperfect individual measures in altitude, 4 millimeters; maximum diameter, 1.5 millimeters.

This species greatly resembles both Eulima persimplica Wade and Bulima laevigata Wade in general aspect but differs from these species in having asharply impressed sutural line.

Occurrence: Ripley formation, Dave Weeks place on Coon Creek, McNairy County, Tenn.

Collection: U. S. National Museum.
Eulima persimplica Wade, n. sp.

Plate LVIII, Figures 14, 15

Shell very small and in outline a simple, very acute little cone; spire acuminate; whorls eight, closely appressed, increasing gradually in size; protoconch broken away, its scar small; sculpture absent, external surface enameled; suture very faint, not impressed and invisible except under a lens; body well rounded in front; aperture ovate; outer lip thin and simple, slightly patulous in front; inner lip excavated medially; columella smoth. Altitude, 5.5 millimeters; maximum diameter, 1.5 millimeters.

This species is well characterized by its simplicity and the entire absence of shell ornamentation. It is probably closely related to Eulima aquensis Holzapfel, from the Aachen Cretaceous of Germany. ${ }^{08}$ The outer lip of the German species, however, is slightly thickened and more patulous than that of the Tennessee species.

Occurrence: Ripley formation, Dave Weeks place on Coon Creek, McNairy County, Tenn.

Collection: U. S. National Museum.

Eulima laevigata Wade, n. sp.

Plate LVIII, Figures 16, 17

Shell very small and in outline a slender cone; spire acuminate, its elevation about three-fourths the total altitude of the shell; whorls closely appressed, increasing gradually and regularly in size; spiral slopes straight, with no impressions at the sutures; whorls of conch six; protoconch trochoid, minute, coiled three times; sculpture absent, external surface enameled; suture very faint, not impressed and invisible except under a lens; body flat on the sides and abruptly constricted in front, being subangular along the periphery; aperture broadly elliptical; outer lip simple; inner lip excavated; columella smooth. Altitude, 3.2. millimeters; maximum diameter, 1.6 millimeters.

This species greatly resembles Eulima persimplica Wade, n. sp., but the relative maximum diameter of this species is greater than of E. persimplica. The body whorl of $E$. persimplica is well rounded, whereas that of $E$. laevigata tends to be subangular along the periphery of the ultima.

Occurrence: Ripley formation, Dave Weeks place on Coon Creek, McNairy County, Tenn.

Collection: U. S. National Museum.

Eulima clara Wade, n. sp.

Plate LVIII, Figures 20, 21

Shell large for genus, elongate and slender, external surface brilliantly glazed; spire elevated and acuminate; number of whorls unknown, as type is imperfect; sculpture obscure, consisting of numerous irregular incremental lines, which appear through the glaze of

${ }^{88}$ Holzapfel, Eduard, op. cit., pl. 21, fig. 12. 
the external surface, and five or six faintly impressed spiral lines at the base of the body; suture slightly impressed; body elongate and abruptly constricted in front; aperture subovate, acutely angular behind and well rounded in front; outer lip patulous in front, its margin thin and simple; inner lip excavated; columella smooth. An imperfect individual measures in length of aperture, 6.4 millimeters; in maximum diameter, 5.6 millimeters.

This species is rare in the Ripley, and only one imperfect individual is known. This specimen, however, shows the elongate form of the shell, the brilliantly glazed outer surface, and the faint spiral lines at the base of the body, all of which characterize the species. No closely related species of this genus is known from the American Upper Cretaceous. In size and general fentures the species suggests Eulima requieniana D'Orbigny, from the Turonian of the Paris Basin. ${ }^{90}$ The French species, however, is much larger and has a callus on the inner lip that is not present in the species from Tennessee.

Occurrence: Ripley formation, Dave Weeks place on Coon Creek, McNairy County, Tenn.

Collection: U. S. National Museum.

Order ASPIDOBRANCHIA

\section{Superfamily RHIPIDOGLOSSA}

Family EUOMPHAIIDAE

\section{Genus PSEUDOMALAXIS Fischer}

Pseudomalaxis ripleyana Wade, n. sp.

Plate LIX, Figures 5-8, 12

Shell small and button-shaped, spire on upper surface practically flat, slightly concave at the apex but becoming convex on the later whorls; whorls nearly square in cross section and increasing gradually in size; altitude of whorl near aperture the maximum altitude of the shell; whorls four in number and closely appressed; protoconch small and flat, coiled twice, inverted; sculpture subdued, consisting of numerous fine incremental lines and finely but elegantly beaded ridges along the umbilical and peripheral keels; suture minutely impressed; body including previous whorls; base of body angular, the outer slope from the umbilical keel toward the posterior steeper than the inner slope; aperture holostomous and nearly square in outline, the length of the inner side less than that of the other dimensions; umbilicus broad and shallow. Altitude, 1.8 millimeters; maximum diameter, 8 millimeters.

This species is well characterized by an elegantly beaded ridge along the peripheral and umbilical keels and further by the nearly square cross section of the closely adnate whorls. There is no closely re-

${ }^{90}$ D'Orbigny, Alcide, Paléontologie franģaise, Terrain crétacé, vol. 2, p. 67, pl. 155, flg. 18,1843 .

$106913-26 \dagger-12$ lated species of this genus known from the North American Upper Cretaceous. One other closely related species is known from the Upper Cretaceous of North America, and this comes from California. It has been described as Discohelix leana by Gabb ${ }^{1}$ but possesses few characters in common with the species from Tennessee. Cossmann ${ }^{2}$ has referred Gabb's species as well as the species Discohelix simplex Holzapfel, ${ }^{3}$ from the Cretaceous near Aachen, to the genus.Pseudomalaxis, but neither is closely related to the species from Coon Creek. P. ripleyana is curiously similar in shape, sculpture, and general aspect to $D i s$ cohelix verilli Aldrich, a form from the Eocene of Alabama that is regarded by Cossmann as a very typical Pseudomalaxis.

Occurrence: Ripley formation, Dave Weeks place on Coon Creek, McNairy County, Tenn.

Collection: U. S. National Museum.

Pseudomalaxis amplificata Wade, n. sp.

Plate LIX, Figures 1-4

Shell fairly large and fragile, discoidal in outline; spire involute and immersed, forming a broad, shallow funnel from both anterior and posterior sides; whorls three or four, rectangular in cross section and increasing very markedly in size to a much expanded body whorl; altitude of body whorl near the aperture the maximum altitude of the shell; protoconch small and smooth, naticoid in form, elevated, coiled two and a half times; sculpture subdued, consisting of numerous incremental lines, which are slightly sigmoid on the anterior and posterior portions of the body and bend or wave backward between the anterior and posterior keels, these keels being marked by low irregularly occurring nodes; body enlarged and including all previous whorls; suture not closely appressed; aperture holostomous, flaring slightly, outer margin excavated. Altitude, 10 millimeters; length of aperture, 15 millimeters.

This species is very rare at Coon Creek, and no related species is known from the literature. This same species or one very closely related occurs in the Ripley formation at Owl Creek, Miss.

Occurrence: Ripley formation, Dave Weeks place on Coon Creek, McNairy County, Tenn.

Collection: U. S. National Museum.

\section{Genus HIPPOCAMPOIDES Wade}

1916. Hippocampoides. Wade, Acad. Nat. Sci. Philadelphia Proc., vol. 68, p. 466. Etymology: i

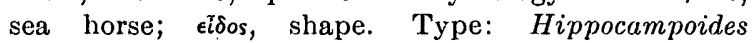
serratus Wade.

Shell rather small, flattened or feeble apically, widely and deeply umbilicate; protoconch minute, planorboid, paucispiral; whorls of conch relatively

1 Gabb, W. M., Californin Geol. Survey, Paleontology, vol. 1, p. 119, pl. 20, fig. $75,18 f 4$.

Cossmann, Maurice, Essais de paléoconchologie comparée, pt. 10, p. 143, 1915. ${ }^{3}$ Holzapfel, Eduard, Die Mollusken der Aachener Kreide: Palaeontographica, Band 34, p. 167, pl. 19, fig. 2, 1888. 
few, increasing rapidly both in diameter and altitude toward the aperture; external surface usually smooth; peripheral margin acutely angulated, in many places sharply serrate; aperture holostomous; umbilicus funicular, the outer margin acute, conspicuously produced anteriorly.

This flattened form is assigned to the family Euomphalidae because of its flat spire, its deep and wide umbilicus, the outer margin of which is produced conspicuously, and its angular peripheral margin. Hippocampoides resembles Discohelix somewhat but differs from it in having a protoconch not inverted and further in not having a whorl with a quadrate cross section. It may be separated from Straparollus by the height of the spire and cross section of body whorl.

\section{Hippocampoides serratus Wade}

Plate LIX, Figures 9-11

1916. Hippocampoides serratus. Wade, Acad. Nat. Sci. Philadelphia Proc., vol. 68, p. 467, pl. 24, figs. 11, 12, 13.

1917. Hippocampoides serratus. Cossmann, Rev. critique paléozóologie, année 20 , No. 3 , p. 99.

Shell rather small, flattened or very feebly convex, apically concave laterally, the altitude increasing toward the aperture, profundly umbilicate; protoconch minute, planorboid, depressed below the plane of the initial whorl of the conch, the one and onehalf component volutions rather loosely coiled and approximately uniform in diameter; line of demarcation between conch and protoconch indicated by a slight but very abrupt increase in the diameter of the whorl; conch thrice coiled, the whorls increasing regularly and very markedly in diameter; external surface smooth and probably polished in the original state; peripheral keel acute, sharply and on the final half turn profusely serrate, the indentation nearest the aperture running almost halfway to the suture line; the deepest of the serrations are coincident with pronounced resting stages, so that the last half turn seems to be made up of a series of overlapping triangular plates; suture line rather deeply impressed; aperture semielliptical in outline, the aperture half again as great as that of the body whorl at its initiation but less than half that of the body whorl at its close; peristome adnate along the body wall, very feebly emarginate both at the peripheral and at the umbilical keels, approximately straight. between the notches; umbilicus very wide, profound, persistent to the apex, funicular, the outer margin acute, probably serrated; area between the peripheral and umbilical keels symmetrically concave. Altitude, 11 millimeters; length of aperture, 5 millimeters; maximum diameter, 19.2 millimeters.

This species is noted for the auriculate outline of the apical aspect, the deep serrations of the periphery, the marked increase of the altitude of the shell toward the aperture, the lateral concavity, and the profound umbilicus, approximately half as wide as the entire shell and margined by an acutely angulated keel. The edge of the keel has been macerated, but there is evidence that it was strongly serrate.

Occurrence: Ripley formation, Dave Weeks place on Coon Creek, McNairy County, Tenn.

Collection: U. S. National Museum.

Hippocampoides liratus Wade, n. sp.

Plate LIX, Figures 13-15

Shell of medium size, flattened or feebly convex, the altitude increasing toward the aperture, profoundly umbilicate; whorls three or four, markedly increasing in size, cross section of whorls quadrilateral, the posterior side concave in the early whorls but convex near the aperture of old individuals; protoconch small and paucispiral; sculpture irregularly lirate, consisting of numerous unevenly sculptured spiral threads, which give the shell a roughened surface; peripheral keel acute, with a few short, irregularly occurring serrations; suture along peripheral keel; aperture quadrilateral, flaring or trumpet-shaped in old individuals; peristome adnate along the body wall; umbilical keel pronounced, marked by a few irregularly occurring feeble serrations or spines; intermediate in position between the umbilical keel and the peripheral keel there is a strong spiral ridge, which may be slightly spinose and is variable in strength and development; umbilicus profound and funicular. An immature individual measures in altitude, 10.8 millimeters; maximum diameter, 17.2 millimeters.

This species is well characterized by its lirate external sculpture and feebly serrate peripheral and umbilical keels.

Occurrence: Ripley formation, Dave Weeks place on Coon Creek, McNairy County, Tenn.

Collection: U. S. National Museum.

\section{Family TURBINIDAE}

\section{Genus SCHIZOBASIS Wade}

1916. Schizobasis. Wade, Acad. Nat. Sci. Philadelphia Proc., vol. 68 , p. 468 . Etymology: $\sigma \chi l \zeta \epsilon \iota \nu$, to split; $\beta \dot{\alpha} \sigma \iota s$, base. Type: Schizobasis depressa Wade.

Shell of medium size, thick, porcelaneous, depressed and globose, very low and smoothly rounded; protoconch lost in type species; conch paucispiral, the component whorls increasing regularly and rapidly in diameter; sculpture coarse and dominantly spiral; sutures obscure; aperture circular, interrupted posteriorly by a slight shallow siphonal notch and anteriorly by a slit, which marks the entrance of the anterior canal; outer lip not thickened, simple within; inner lip excavated, heavily reinforced; anterior canal rather short and the parallel proximate margins distorted so that it appears as a narrow slit that cuts across the base of the shell directly at right angles with the axis; callus almost filling the umbilicus; umbilicus imper- 
forate, the umbilical region spread out in a trigonal area and flattened against base of columella, from which it is separated by a profound sulcus; depressed umbilical keel marked by growth stages or in many specimens by poorly defined varices.

This genus is characterized by a depressed spire and by a peculiar anterior canal, which is short and deep and at right angles to the axis of the shell, resembling a slit in the anterior part of the aperture. It does not secm to be near anything that has been heretofore described, and it has been assigned to the family Turbinidae only after some hesitation. The Turbinidae have a much depressed shell and sculptural and nuclear characters much like those of Schizobasis, but none of that family have the short, well-defined canal which characterizes this new genus. The recent Turbo cornutus, which is common in the Indo-Pacific, has a very shallow anterior canal. The genus Sargana, of the Thaisidae, has a much depressed spire, a shallow posterior notch, and a narrow anterior canal, inclosed in a varicose umbilical keel, and altogether it has points analogous to Schizobasis. Sargana, however, has an entirely different sculpture and a much produced anterior canal, which are family characters, probably distinct enough to bar Schizobasis from the Thaisidae. Turbo differs from Schizobasis in being nacreous and in having no well-defined canal. An undescribed species of Schizobasis occurs at Eufaula, Ala.

\section{Schizobasis depressa Wade}

Plate LIX, Figures 17-19

1916. Schizobasis depressa. Wade, Acad. Nat. Sci. Philadelphia Proc., vol. 68, p. 469, pl. 24, figs. 8, 9, 10.

1917. Schizobasis depressa. Cossmann, Rev. critique paléozoologie, année 20 , No. 3, p. 99.

Shell of medium size, thick, porcelaneous, depressed and globose, spire very low and smoothly rounded, rising slightly above the body whorl; protoconch broken away in type species; conch paucispiral, three and a half component whorls, increasing regularly and rapidly in diameter, outer wall of one and a half whorls of the apex broken away from spire of type; sculpture coarse and dominantly spiral; seven low, round spirals on body whorl, evanescing rather abruptly on body near aperture of adult, posterior spiral less rounded and very near posterior suture, obscuring suture line, interspiral spaces much narrower than spirals; a deep spiral sulcus at base of body between anterior spiral and umbilical keel; spiral sculpture consists of irregularly occurring unequal costre shown on top of spirals and absent in interspiral spaces; costae receding anteriorly, parallel to outer margin of aperture; aperture circular, interrupted posteriorly by a slight shallow siphonal notch and anteriorly by a slit which marks the entrance of the anterior canal; outer lip simple; inner lip excavated, henvily reinforced; anterior canal rather short, with parallel proximate margins distorted so that it appears as a narrow slit cutting across the base of the shell directly at right angles with the axis; callus almost filling the umbilicus; umbilical keel showing two poorly defined varices; umbilical region spread out in a trigonal area and flattened against the base of the columella. Elevation, 18.4 millimeters; maximum diameter, 23.3 millimeters; spiral angle, $125^{\circ} 40^{\prime}$.

This species, which is the type of this interesting genus, is represented in the present Coon Creek collection by five or six perfectly preserved specimens.

Occurrence: Ripley formation, Dave Weeks place on Coon Creek, McNairy County, Tenn.

Collection: U. S. National Museum, Johns Hopkins University, Vanderbilt University.

\section{Schizobasis immersa Wade, n. sp.}

Plate LIX, Figures 22, 23

Shell of medium size, thick, porcelaneous, depressed, with a distorted appearance; spire nearly immersed by the body whorl, the posterior extremity of which is equal in height to the apex of the spire; whorls of conch two, increasing rapidly in size; protoconch large, nearly flat and smooth, coiled three times; sculpture dominantly spiral; eight low, rounded spirals on the body whorl becoming indistinct near the aperture of the adult; posterior spirals stronger, less rounded, and near the suture obscuring suture line; interspiral spaces much narrower than spirals; a deep sulcus at base of the body between anterior spiral and umbilical keel; spiral sculpture consists of irregularly occurring unequal costae shown on top of spirals and absent in interspiral spaces; costae retractive or receding anteriorly, parallel to outer margin of aperture; aperture circular, interrupted posteriorly by a slight, shallow siphonal notch and anteriorly by a slit which marks the entrance of the anterior canal; outer lip much thickened posteriorly; inner lip excavated, heavily reinforced; anterior canal a little more than half the length of the aperture; callus almost filling umbilicus; umbilical keel showing two or more irregular varices; umbilical keel projects obliquely some distance behind the posterior of the body wall, extending across the spiral sulcus at the base of the body. Altitude, 24.4 millimeters; maximum diameter, 25.5 millimeters.

There is a single individual of this species from Coon Creek, and it is perfectly preserved in every detail. One or two specimens are known from Eufaula, Ala. The species resembles Schizobasis depressa but differs from that species in being longer from apex to tip of anterior canal, even though $S$. depressa has a slightly elevated spire and $S$. immersa has a spire which does not project above the top of the body whorl. The sculpture of $S$. immersa is not as coarse as that of $S$. depressa. The angle between the plane of the aperture and the axis of the shell of Schizobasis immersa is 
more acute than is the corresponding angle of the type species of the genus.

Occurrence: Ripley formation, Dave Weeks place on Coon Creek, McNairy County, Tenn.

Collection: U. S. National Museum.

Outside distribution: Ripley formation, Eufaula, Ala. Family UMBONIIDAE

\section{Genus TEINOSTOMA Adams}

Teinostoma prenanum Wade, n. sp.

Plate LIX, Figures 16, 20, 21

Shell very small and orbicular, external surface highly glazed, posterior surface convex; spire obscure and not projecting above the posterior extremity of the body whorl; whorls of conch two, the body almost concealing the first volution; protoconch very minute and loosely coiled one and a half times; sculpture absent, except for faint incremental lines that appear through the porcelaneous glaze of the outer surface; suture faintly impressed; body flattened at right angles to the axis of the shell, subelliptical in cross section; aperture broken away in available specimens; umbilical region glazed with callus. Altitude, 0.8 millimeter; maximum diameter, 1.7 millimeters.

This species is probably the first of this genus to be reported from the Cretaceous of North America. In general aspect this Cretaceous species is so much like Teinostoma nanum (Lea); ${ }^{4}$ of the Miocene of the Middle Atlantic States, that the shells of the two species may not be readily distinguished when they are placed together. The Miocene species, however, has a greater altitude, and the cross section of its body whorl is more circular in outline. Teinostoma prenanum is rare in the Ripley; only two individuals have been recovered from the Coon Creek beds.

In a discussion of the family Umboniidae in 1868 Stoliczka ${ }^{5}$ called attention to the fact that Teinostoma cretaceum (D'Orbigny) (Rotella cretacea D'Orbigny ${ }^{\circ}$ ) was the only species of this genus then known from the Cretaceous. If any species of this group have been described from the Cretaceous since Stoliczka's writing they are unknown to the present writer. D'Orbigny's type specimen of $T$. cretaceum came from Pondicherry, and Stoliczka has reported the same species from the Arrialoor group at Comarapolliam, ${ }^{7}$ both in southern India. The species from southern India is a small inornate shell of about the same size and shape as the species from Tennessee but has a little higher spire and a periphery a little more angular.

Occurrence: Ripley formation, Dave Weeks place on Coon Creek, McNairy County, Tenn.

Collection: U. S. National Museum.

4 Martin, G. C., Maryland Geol. Survey, Miocenn, p. 263, pl, 62, flgs. 1a, b, c, $2 \mathrm{a}, \mathrm{b}, \mathrm{c}, 1904$.

3 Stoliczka, Ferdinand, op. cit., vol. 2, p. 346, 1868.

- D'Orbigny, Alcide, Voyage au pole sud et dans l'Océanie sur les corvettes

l'Astrolabe et la Zélée, Paléontologie, pl. 4, figs. 18-21, 1854.

7 Stoliczka, Ferdinand, op. cit., vol. 2, p. 350, pl. 25, fig. 7, 1868.

\section{Family TROCHIDAE}

Genus TROCHUS Linné

Trochus ripleyanus $W$ ade, $n$. sp.

Plate LIX, Figures 24, 25

Shell large and fairly strong for the group; spire acuminate, one and a half times the length of the aperture; whorls five, strongly convex and increasing in size gradually; protoconch smooth, naticoid, and coiled two and a half times; body whorl inflated, abruptly constricted in front; suture impressed; sculpture well defined, consisting of numerous fine spiral threads overriding strong, abrupt axial costae; axials about 15 on the body, evanescing on the anterior part of the body; spiral threads well defined on the anterior portion of the ultima; axial costae 15 on the body whorl, costae of unequal size and spacing; suture impressed; body enlarged, abruptly constricted in front; aperture ovate, produced in front into a short canal; outer lip thin; inner lip excavated; columella smooth; pillar short and slender. Altitude, 8 millimeters: maximum diameter, 33.8 millimeters.

This elegant species is well characterized by its strong axial costae and threadlike spirals. It resembles in some respects Trochus ryckholti Müller, ${ }^{8}$ from the Aachen Cretaceous of Vaals and Königsthor, Germany, but does not possess such an abruptly constricted anterior slope of the body whorl.

Occurrence: Ripley formation, Dave Weeks place on Coon Creek, McNairy County, Tenn.

Collection: U. S. National Museum.

\section{Family DELPHINULIDAE \\ Genus CaLliomphalus Cossmann \\ Calliomphalus americanus Wade, $n$. sp. \\ Plate LX, Figures 1-3}

Shell small and nacreous within, form typically trochoid and umbilicate; spire of medium height; whorls four or five, circular in cross section, diameter of cross section of whorls increasing gradually toward the aperture, lateral extension of whorls increasing markedly; protoconch flat, coiled twice; sculpture striate, consisting of crowded low but well-defined subtuberculate spiral threads, 12 on the penult and 23 on the ultima; the numerous low tubercles on the crests of the spiral lirae are most prominent on the posterior part of the body but gradually evanesce anteriorly and are absent on the base of the body; tubercles arranged in retractive rows parallel to the incremental lines; suture impressed; body broadly umbilicate; aperture subcircular, being subangulated at both the anterior and posterior commissures and at a point a little below the middle of the inner lip; outer lip well rounded and simple; umbilicus broad and profound;

${ }^{8}$ Holzapfel, Eduard, Die Mollusken der Aachener Kreide: Palaeontographica, Band 34, p. 174, pl. 19, figs. 7, 8, 1888. 
umbilical keel tuberculate; the low tubercles are the anterior extremities of irregular axial elevations or wrinkles on the umbilical slope. Altitude, 9 millimeters; maximum diameter, 9.9 millimeters.

This species is well characterized by the circular cross section of the whorls, the slightly angular inner lip, and the tuberculate spiral threads. No species of this genus is known from the Upper Cretaceous of the United States with which the species from Tennesseo may be compared. In general aspect this species rosembles Turbo boimstorfensis Griepenkerl, ${ }^{2}$ a form from the Senonian of Germany that might well be ussigned to Cossmann's genus Calliomphalus. The German species, however, does not possess a welldefined umbilical keel like that of the species from Tennessee. Another species which probably belongs to this genus and may be compared with C.americanus is Turbo rimosus var. granulata Kaunhowen. ${ }^{10}$ The species Turbo chihuahuensis Böse, ${ }^{11}$ from the Upper Cretaceous (Vraconian), of La Encantada, Mexico, is another related species of this genus that deserves mention.

Occurrence: Ripley formation, Dave Weeks place on Coon Creek, McNairy County, Tenn.

Collections: Johns Hopkins University, Vanderbilt University, U. S. National Museum.

Calliomphalus argenteus Wade, n. sp.

Plate LX, Figures 4-7, 11

Shell small and nacreous within; form typically trochoid and umbilicate; spire of medium height and acute; whorls five, increasing in size rather markedly, maximum diameter in front of median horizontal; posterior slope more gentle than anterior slope; protoconch small, nearly flat, and coiled twice, the last whorl being ornamented by obscure axial costae; sculpture of conch ornate, consisting of numerous, sharply tuberculate axial lirae of unequal strength; the strongest and most conspicuous lirae are the one around the periphery and the one around the umbilical keel; lirae on the posterior slope of the body or the area behind the periphery 5 to 7 and much stronger than the lirae on the anterior slope or base of the body, where they number about 12 ; tubercles or spines strongest on the posterior part of the body and the umbilical keel; the arrangement of the spines tends to be along retractive lines parallel to the incremental lines, but this regularity does not always persist, and on some individuals the arrangement is very asymmetric; suture distinctly impressed; anterior slope of

\footnotetext{
- Griepenkerl, Otto, Die Versteinerungen der senonen Kreide von Königslutter im Horzogthum Braunschweig: Palaeont. Abh. (Dames \& Koken), Band 4, Heft 5 , p. 73 , pl. 8 , figs. 13 a-c, 1889 .

10 Kaunhowen, Friedrich, Die Gasteropoden der Maestrichter Kreide: Palaeont Abh. (Dnmes \& Koken), Band 8 (neue Folge, Band 4, Heft 1), p. 33, pl. 2, figs. $4,5,0,1807$.

"1 Böso, Emil, Descripción de la fauna cretácea de La Encantada, placer de Gua dalupe, Estado de Chihuahua: Inst. geol. México Bol. 25, p. 139, pl. 30, figs. 2-4,
} 1010 . body much steeper than posterior slope, which is long and a little more gentle than the slope of the line of the spire; aperture holostomous and circular, its margin thin and simple; umbilicus profound and funnelshaped. Altitude, 8.3 millimeters; maximum diameter, 7.6 millimeters.

This species is well characterized by its very ornate sculpture and circular aperture-two features which readily distinguish this form from $C$. americanus. C. argenteus may be compared with Trochus decrescens Kaunhowen, ${ }^{12}$ from the Maestrichtian beds of western Europe, a form which also probably might well be referred to Cossmann's genus Calliomphalus. It is of particular interest to find two corresponding species of the same genus in both the Ripley and the Maestrichtian. The species Solarium bailyi Gabb, ${ }^{13}$ from the Senonian of Pondoland, South Africa, probably belongs to the same genus as the above-mentioned forms and should be considered here in comparison with the two species from Tennessee under discussion.

Occurrence: Ripley formation, Dave Weeks place on Coon Creek, McNairy County, Tenn.

Collection: U. S. National Museum.

\section{Genus EUCYCLOSCALA Cossmann}

\section{Eucycloscala tuberculata (Wade)}

Plate LX, Figures 13, 14

1916. Urceolabrum tuberculatum. Wade, Acad. Nat. Sci. Philadelphia Proc., vol. 68, p. 470, pl. 24, figs. 6, 7.

1917. Eucycloscala tuberculatum. Cossmann, Rev. critique paléozoologie, année 20, No. 3, p. 99.

Shell small, solid, porcelaneous, and ornately sculptured; spire elevated and acute; protoconch scar small; whorls circular in cross section and four in number; external ornamentation elaborate, axials dominant, costae 14 on penult, equally spaced and evanescing on base of the body; spirals forming five rows of tubercles at intersection with costae on body whorl; interspiral space at base of body rather wide, an isolated row of tubercles on anterior margin of the umbilicus; suture impressed and crenate; aperture circular; peristome heavily reinforced and calloused, resembling the mouth of a jug; rim of aperture half as wide as opening; umbilicus profound and funicular. Altitude, 5 millimeters; width of aperture, 1 millimeter; maximum diameter of body, 3.4 millimeters; apical angle, $60^{\circ}$.

This elegant little species is hard and well preserved, being rather common in the Coon Creek sediments. It differs from the species from Eufaula in not having fine secondary lirae between the primary spirals and on the band at the base of the body whorl. It differs from the German species of this genus ${ }^{14}$ in having

\footnotetext{
12 Kaunhowen, Friedrich, op. cit., p. 35, pl. 2, figs. 13, 14, 1897.

${ }^{13}$ Woods, Henry, South African Mus. Annals, vol. 4, pt. 7, p. 315 , pl. 38, figs. 4, 5, 1906.

14 Holzapfel, Eduard, op. cit., p. 170, pl. 18, figs. 3-7, 1888.
} 
sharper axials and tubercles at the intersection of the costae and spirals; the German form has radial lines on the reinforced aperture, whereas the aperture of the form from Tennessee is smooth.

Another species of. this genus is Liotia parva Vogel, ${ }^{15}$ from the Upper Senonian of Germany. It was with this German species as type that Cossmann established the genus Eucycloscala prior to 1916; consequently the genus was not new when the name Urceolabrum was proposed by the author. ${ }^{16}$

Occurrence: Ripley formation, Dave Weeks place on Coon Creek, McNairy County, Tenn.

Collections: U.S. National Museum, Johns Hopkins University, Vanderbilt University.

\section{Order PULMONATA \\ Family SIPHONARIDAE \\ Genus ANISOMYON Meek and Hayden}

Anisomyon wieseri Wade, n. sp.

Plate LX, Figure 10

Shell thin, subovate or patelliform, in shape a low, flat cone, the outline of the base a little broader toward the posterior or longer side; summit rather low and pointed at the very apex, located in advance of the middle; lateral slopes convex but nearly flat, converging at the apex at an angle of about $135^{\circ}$; external surface smooth except for concentric growth lines; internal shell characters unknown. Length, 17 millimeters; width, 14.5 millimeters; elevation, 5 millimeters.

This species differs from Anisomyon patelliformis Meek and Hayden ${ }^{17}$ in being flatter and in having a smooth external surface. This form is very rare at Coon Creek. It is named in honor of Miss Frances Wieser, of the United States Geological Survey, who has very carefully retouched the photographs of the Coon Creek specimens that are reproduced as illustrations in this report.

Occurrence: Ripley formation, Dave Weeks place on Coon Creek, McNairy County, Tenn.

Collections: Johns Hopkins University, U. S. National Museum.

\section{Class CEPHALOPODA \\ Subclass TETRABRANCHIATA \\ Order NAUTILOIDEA \\ Suborder ORTHOCHOANITES \\ Family NAUTILIDAE \\ Genus EUTREPHOCERAS Hyatt \\ Eutrephoceras dekayi (Morton) \\ Plate IXXI, Figures 1, 2}

1833. Nautilus dekayi. Morton, Am. Jour. Sci., 1st ser., vol. 23 , p. 291 , pl. 8 , fig. 4 .

$1 s$ Vogel, F., Das Ober-Senon von Irnich am Nordrand der Eifel (Inaug.-Diss., Universität zu Bonn), p. 27, fig. 2, 1892.

${ }^{16}$ Cossmann, Maurice, Rev. critique paléozoologie, année 20, No. 3, p. 99, 1917.

17 Meek, F. B., and Hayden, F. V., On a new genus of patelliform shells from the

Cretaceous rocks of Nebraska: Am. Jour. Sci., 2d ser., vol. 29, p. 35, pl. 1, 1860.
1834. Nautilus dekayi. Morton, Synopsis of the organic remains of the Cretaceous group of the United States, p. 33 , pl. 8 , fig. 4 ; pl. 13, fig. 4 .

1834: Nautilus perlatus. Morton, Synopsis of the organic remains of the Cretaceous group of the United States, p. 33.

1856. Nautilus dekayi. Hall and Meek, Am. Acad. Arts and Sci. Mem., new ser., vol. 5, p. 406.

1856. Nautilus dekayi. Meek and Hayden, Acad. Nat. Sci. Philadelphia Proc., vol. 8, p. 280.

1859. Nautilus dekayi. Meek, in Hind, Northwest Territory, Reports of progress, together with a preliminary and general report on the Assiniboine and Saskatchewan exploring expedition, p. 91, pl. 2, figs. 9, 10.

'1860. Nautilus dekayi. Conrad, Acad. Nat. Sci. Philadelphia 'Jour., 2d ser., vol. 4, p. 276 . (Not $N$. dekayi as figured by Ernest Favre in Description des mollusques fossiles de la craie des environs de Lemberg en Galicie, pl. 3, figs. 1-3.)

1864. Nautilus dekayi. Meek, Check list of the invertebrate fossils of North America, Cretaceous and Jurassic, p. 25.

1868. Nautilus dekayi. Conrad, in Cook, Geology of New Jersey, p. 731.

1876. Nautilus dekayi. Gabb, Acad. Nat. Sci. Philadelphia Proc. for 1876 , p. 277.

1876. Nautilus dekayi. Meek, U. S. Geol. Survey Terr. Rept., vol. 9 , p. 496, pl. 28 , figs. 1a-1c.

1892. Nautilus dekayi. Whitfield, U. S. Geol. Survey Mon. 18, p. 243 , pl. 37 , figs. $1-6$; pl. 38, figs. 1-4. (Also published by New Jersey Geol. Survey.)

1894. Eutrephoceras dekayi. Hyatt, Am. Philos. Soc. Proc., vol. 32 , p. 555 , pl. 13 , figs. $4-8$; pl. 14 , figs. 1 .

1905. Eutrephoceras dekayi. Johnson, Acad. Nat. Sci. Philadelphia Proc., vol. 57, p. 28.

1907. Nautilus dekayi. Weller, New Jersey Geol. Survey, Paleontology, vol, 4, p. 817, pl. 100, figs. 1-5.

1914. Nautilus dekayi. Stephenson, U. S. Geol. Survey Prof. Paper 81, p. 24, tables 2-8.

1916. Eutrephoceras dekayi. Gardner, Maryland Geol. Survey, Upper Cretaceous, p. 379, pl. 13, fig. 9.

Morton in 1834 characterized this species as follows:

Shell very ventricose, with numerous indulated, transverse striae; aperture laterally and profoundly expanded.

Meek in 1876 said of this species :

Shell subglobose, broadly rounded on the periphery and sides; umbilicus closed; volutions increasing rapidly in size, or more than doubling their diameter each turn, about half as wide again as high, all hidden but the last or outer one; aperture much wider than long, transversely reniform, the lateral extremities being rounded, and the inner side deeply sinuous for the reception of the inner whorls; lip having a wide, shallow sinus along the peripheral side, prominently rounded on the lateral margins, and again sinuous near each umbilicus; septa moderately concave, and about 16 or 18 to each turn; siphuncle small, located one-fourth to one-third of the distance across toward the periphery from the margin of the inner side; surface of adult or medium-sized specimens nearly smooth, or having very obscure lines of growth, crossed by faint traces of longitudinal striae; on young individuals, or the inner volutions of larger ones, these lines are quite distinct in both directions and form a very neat, cancellated style of ornamentation; internal casts sometimes showing a slender longitudinal line on the center of the periphery.

The proportions are shown by the following measurements of a young individual: Length, 1.84 inch; breadth of aperture, 1.7 inch; diameter of aperture in the direction of the length of greater diameter of shell, 0.72 inch. Some imperfect adult 
individuals before me, too much broken to afford exact measurements, were evidently as much as three times the linear dimensions of that from which the foregoing measurements were taken.

This common species has been wrongly identified with several foreign forms. D'Orbigny, in his Prodrome de paleontologie, expressed the opinion that his own $N$. laevigatus, published in 1846 (not his $N$. laevigatus, 1840) is synonymous with it; also the Indian $N$. spharicus and $N$. orbignyanus Forbes and a Chilean form referred by Professor Forbes to $N$. laevigatus. Mr. Blanford, however, considers both of the Indian shells merely varieties of $N$. bouchardianus D'Orbigny and entirely distinct from $N$. dekayi Morton. I have not the necessary specimens at hand to express any decided opinion in regard to the Indian shells figured by Mr. Blanford, all belonging to the one species of $N$. bouchardianus; but I can fully concur with him in the opinion that they are certainly distinct from $N$. dekayi Morton. The latter differs, as stated by Mr. Blanford, in having its umbilicus always filled with a solid shelly kind of columella, formed by the thickening of the lip at its connection with the body of the shell on each side instead of being perforated. $N$. dekayi also has its aperture constantly more transverse, and its siphuncle always nearer the inner side, as may be seen by our Figure 1a, Plate XXVII, which represents very nearly the typical form of the species, as I know from a direct comparison with Dr. Morton's type specimen, now in the Museum of the Academy of Natural Sciences at Philadelphia, from which type specimen the foregoing outline cut showing the position of the siphuncle was drawn.

It is true that Dr. Morton also referred doubtfully to $N$. dekayi undèr the provisional name of ' $N$. perlatus a more compressed form from Alabama that would doubtless agree more nearly in the outline of its aperture and in several other respects with some of the Indian forms, as well as with the Chilean $N$. orbignyanus Forbes. I have not seen specimens of the Alabama shell showing the position of its siphuncle, but I very much doubt its identity (judging from its form only) with $N$. dekayi proper, as I have seen no tendency among our specimens (that do not differ also in the position of the siphuncle) to assume this more compressed form. N. J.

Type locality: Monmouth and Burlington counties,

This species is common at Coon Creek. It is represented by specimens showing a wide range in size, some attaining a maximum diameter of 15 or 18 inches.

Occurrence: Ripley formation, Dave Weeks place on Coon Creek, McNairy County, Tenn.

Collections: Maryland Geological Survey, U. S. National Museum.

Outside distribution: Monmouth formation, Brightseat, Brooks estate near Seat Pleasant, and 3 miles south of Oxon Hill, all in Prince Georges County, Md. Monmouth group (Navesink marl and Redbank sand), New Jersey. Ripley formation, extreme top of Exogyra costata zone, North Carolina; Exogyra costata zone, Eufaula, Ala., and Pontotoc, Tippah, and Union counties, Miss. Selma chalk, Exogyra costata zone, Wilcox County, Tombigbee River, and Sumter County, Ala., and east-central Mississippi. Pierre shale, at many localities in western exterior region.

\section{Order AMMONOIDEA \\ Suborder EXTRASIPHONATA \\ Family BACULITIDAE \\ Genus BACULITES Lamarck \\ Baculites ovatus Say \\ Plate LX, Figure 9}

1820. Baculites ovata. Say, Am. Jour. Sci., 1st ser., vol. 2, p. 41.

1828. Baculites ovata. Morton, Acad. Nat. Sci. Philadelphia Jour.; 1st ser., vol. 6, p. 89, pl. 5, figs. 5, 6 .

1830. Baculites ovatus. Morton, Am. Jour. Sci., 1st ser., vol. 17 , p. 280 ; vol. 18 , p. 249 , pl. 1 , figs. $6-8$.

1830. Baculites ovatus. Morton, Acad. Nat. Sci. Philadelphia Jour., 1st ser., vol. 6, p. 196, pl. 5, figs. 5, 6; pl. 8, figs. 6-8.

1834. Bacillites ovatus. Morton, Synopsis of the organic remains of the Cretaceous group of the United States, p. 42 , pl. 1, figs. $6-8$.

1853. Baculites ovatus. Marcou, A geological map of the United States and the British provinces of North America, explanatory text, p. 46, pl. 7, fig. 5 .

1856. Baculites ovatus. Hall and Meek, Am. Acad. Arts and Sci. Mem., new ser., vol. 5, p. 399, pl. 5, figs. 1a-1c; pl. 6, figs. 1-7.

1864. Baculites ovatus. Meek, Check list of the invertebrate fossils of North America, Cretaceous and Jurassic, p. 23.

1868. Baculites ovatus. Conrad, in Cook, Geology of New Jersey, p. 730

1876. Baculites ovatus. Meek, U. S. Geol. Survey Terr. Rept., vol. 9 , p. 394 , pl. 20 , figs. $1 \mathrm{a}-1 \mathrm{~b}, 2 \mathrm{a}-2$ d.

1877. Baculites ovatus. White, U. S. Geog. Surveys W. 100th Mer. Rept., vol. 4, p. 199, pl. 19, figs. 4a-4c, 5a-5c.

1889. Baculites ovatus. Whiteaves, Contr. Canadian Paleontology, vol. 1, p. 181.

1892. Baculites ovatus. Whitfield, U. S. Geol. Survey Mon. 18, p. 275, pl. 46, figs. 3-9. (Also published by New Jersey Geol. Survey.)

1896. Baculites ovata. Say, Bull. Am. Paleontology, vol. 1, No. 5, p. 19 (=p. 289). (Reprint, Harris.)

1905. Baculites ovatus. Johnson, Acad. Nat. Sci. Philadelphia Proc., vol. 57, p. 26.

1907. Baculites ovatus. Weller, New Jersey Geol. Survey, Paleontology, vol. 4, p. 821, pl. 109, fig. 5 .

1914. Baculites ovatus. Stephenson, U. S. Geol. Survey Prof. Paper 81, p. 24, tables 2-8.

1916. Baculites ovatus. Gardner, Maryland Geol. Survey, Upper Cretaceous, p. 325, pl. 7, figs. 2, 3.

Say in 1820 described this species as follows:

$B$. ovata, elongated; transverse septa subovate, six-lobed and a smaller one behind; lobes of the superior faces of the septa three on each side, with a minute one between each, dentated at their edges; anterior lobe (nearest the siphuncle) small, not sinuous; second lobe with a single projection each side and sinus at tip; third lobe dilated, with a small sinus each side and more obtuse and profound one at tip; posterior lobe hardly larger than the lateral intermediate ones. Greatest diameter of the transverse section, 1.2 inches; smaller diameter, 0.7 inch; length of the segment, about $0.5 \mathrm{inch}$.

Meek in 1876 gave the following additional details:

Shell attaining a large size, elongated and rather gradually tapering; section ovate, the antisiphonal side being more broadly rounded than the opposite (or very rarely a little 
flattened?); aperture of the same form as the transverse section; extension of the lip on the siphonal side long, tapering, and narrowly rounded at the end; lateral sinuses of same deep and about one-half to one-third the greater diameter of the shell; antisiphonal margin of the lip prominently rounded in outline; surface of young and medium-sized specimens generally nearly smooth, while the nonseptate part of the adult shell is provided with broad, indefined, obliquely transverse ridges or undulations that arch parallel to the obscure lines of growth and become nearly or quite obsolete as they approach the siphonal side, on which they are rarely represented by very small, irregular ridges, scarcely distinct from the marks of growth.

Septa moderately closely arranged, or sometimes a little crowded; siphonal lobe nearly twice as wide as long and provided with two large terminal widely separated, more or less spreading branches, each of which has sometimes three and sometimes two nearly equal digitate branchlets at the end and two or three similar lateral ones on the outer side; first lateral sinus about as wide as long but narrower than the siphonal lobe and divided at the free end into two short, nearly equal branches, each of which is again less deeply subdivided into about two to three or four sinuous, spreading, and digitate branchlets; first lateral lobe oblong-ovate, being longer and narrower than the siphonal lobe and deeply divided at its end into two very nearly equal branches with each four to five spreading and digitate subdivisions, in part generally so arranged as to give the main branches a tripartite appearance at their extremities; second lateral sinus of nearly the same size as the first and, excepting in unimportant details, similarly branched and subdivided; second lateral lobe broader and shorter than the first and bearing two large, equal, tripartite, sinuous, and digitate terminal branches and small digitate and simple lateral branchlets; third lateral sinus much smaller than either of the others, with two unequal, short, sinuous, and dentate terminal divisions and a few irregular, short, smaller lateral spurs; dorsal or antisiphonal lobe (ventral lobe of D'Orbigny and others) scarcely as large as one of the terminal branches of the siphonal lobe, longer than wide, with three or four small lateral branches and normally a trifid free extremity.

Occurrence: Ripley formation, Dave Weeks place on Coon Creek, McNairy County: Tenn.

Collections: Maryland Geological Survey, U. S. National Museum.

Outside distribution: Matawan group (Merchantville clay and Woodbury clay), New Jersey. Monmouth group (Navesink marl), New Jersey. Unrecorded horizon, Alabama (Morton). Pierre shale, in South Dakota, Montana, Colorado, and Wyoming.

\section{Baculites grandis Hall and Meek}

Plate LX, Figures 8, 12

1854. Baculites grandis. Hall and Meek, Am. Acad. Arts and Sci. Mem., new ṡer., vol. 5, p. 402, pl. 7 , figs. 1,2 ; pl. 8 , figs. 1,2 , pl. 6 , fig. 10 .

1876. Baculites grandis. Meek, U. S. Geol. Survey Terr., vol. 9 , p. 398 , pl. 33 , figs. 1a, b, c.

Hall and Meek describe the species as follows:

Shell elongate; section varying from ovate to subcordiform; surface of cast marked by very broad and strongly elevated undulations, which commence at the dorsum and pass obliquely downward, increasing rapidly in size, and, crossing the sides of the shell in a broad curve, terminate abruptly on the ventrolateral region. Undulations less distinct toward the smaller extremity and finally become obsolete. Septa very deeply lobed, principal divisions scarcely divergent. Dorsal lobe three-fourths as long and twice as wide as the superior lateral lobe; terminated on each side by a narrow elongated branch, which is irregularly sinuate and digitate at the extremity. Dorsal saddle shorter and wider than the superior lateral lobe, formed by four branches, the two terminal ones much the larger and each of them bifid at the extremity by a small sinus; the whole outline more or less sinuous and the extremities digitate. Superior lateral lobe longer by one-fifth than the inferior lateral lobe, narrower than the ventral saddle, divided at its extremity by a deep sinus into two equal parts, which are simply digitate; above these are two unequal branches on each side; terminal sinus much deeper than the lateral ones. Ventral saddle longer and about as wide as the dorsal saddle, more deeply divided at its extremity by the auxiliary lobe into two nearly equal branches, each of which is bifid and the extremities digitate, ventral side with three and dorsal side with two auxiliary branches. Inferior lateral lobe shorter and broader than the superior lateral lobe, divided at its extremity into two nearly equal branches, the one on the dorsal side bifid at the tip and the other digitate, with an auxiliary branch on the ventral side. Ventral lobe as long as the auxiliary lobe of the ventral saddle, but wider at the base, digitate at its extremity.

Angle of the apex about $5^{\circ}$. Length, as deduced from the measurement of fragments, by the convergence of the dorsal and ventral sides, $5 \frac{1}{2}$ feet or more. Longest diameter of a fragment not distorted by pressure, 3.7 inches; shorter diameter from the surface of undulations, 3.3 inches; in the depressions between the undulations, 2.95 inches.

The species is nearly related to $B$. ovatus of Say, from which it differs in its much greater size, larger apical angle, much stronger and more extended undulations, which cross the entire lateral surface of the shell. The section is more obtusely ovate; the lobes of the septa are much deeper, narrower, and less divergent in their branches; the digitations are sharper and more directly pointed in the longitudinal direction of the shell. The auxiliary lobe of the ventral saddle is longer in this species, while the extremities of the terminal branches are less deeply bifid than in $B$. ovatus. In this species the two terminal branches of the superior lateral lobe are simply digitate, while in B. ovatus they are deeply bifid, with obtuse sinuosities. Externally, in its undulations on the sides, this species resembles $B$. anceps of Lamarck but will be readily distinguished by the absence of a dorsal carina and by its much deeper lobes with less divergent divisions. A comparison of the details of the divisions of the lobes and saddles shows a constant difference in the two species.

Fragments of this species are common at Coon Creek. One specimen has been restored by Prof. E. W. Berry and measures about 5 feet in length. The sutures of the specimens from Tennessee referred to this species, like those of the types as observed by Meek, ${ }^{18}$ are very similar to the sutures of Baculites ovatus Say, yet with our present knowledge of this group it still seems proper to regard Baculites grandis as a distinct species.

Occurrence: Ripley formation, Dave Weeks place on Coon Creek, McNairy County, Tenn.

Collections: Johns Hopkins University, Vanderbilt University, U. S. National Museum.

Outside distribution: Pierre shale, Bear Creek and Cheyenne River, S. Dak.

${ }_{18}$ Meek, F. B., A report on the invertebrate Cretaceous and Tertiary fossils of the upper Missouri country: U. S. Geol. Survey Terr. Rept., vol. 9, p. 399, 1876 . 


\section{Family SCAPHITIDAE \\ Genus SCAPHITES Parkinson \\ Scaphites reesidei Wade, $n$. sp. \\ Plate LXI, Figures 3-7}

Inner whorls of this species not seen. Earlier whorls exposed are at a diameter of about 25 millimeters. The succeeding three-fourths of a whorl are septate, the last septum lying at a diameter of 50 millimeters. From the diameter of 25 millimeters to the diameter of 35 millimeters the whorl is somewhat crushed laterally, though evidently it was much compressed in the original uncrushed state. The remainder of the septate part of the shell is uncrushed and compressed in form. At the beginning of the living chamber, of which a part is preserved, the whorl swells suddenly and is relatively stout. On the septate part the flanks are flattened but merge evenly into the high arched venter, and there is no distinct umbilical shoulder. On the living chamber the umbilical shoulder is fairly high and well rounded, the flank arched but merging evenly into the: well-rounded venter. The umbilicus is very narrow.

The ribs throughout are narrow, sharp, and of moderate height, with flat interspaces. The ribs begin in the umbilicus, bend slightly backward for a short distance as they pass outward, then forward till they reach the outer half of the flank, where they form a distinct but shallow geniculation by bending backward, and pass straight across the venter. The ribs thus have a shallowly sigmoid form. Just inside the line of geniculations and at the middle of the flank there appears, a quarter whorl before the last septum, a row of nodes, one on every third rib, which increase in size and height toward the youngest part of the specimen. These nodes have a flat anterior face and a rounded posterior face, separated by a distinct sharp transverse edge. At many of the nodes of this row pairs of intercalated ribs arise, and here and there an umbilical rib forks. At the outside of the line of geniculations many of the ribs fork and a few intercalated ribs arise. Between the flank and the venter a second row of nodes arises three-fourths of a.whorl before the last septum - that is, at the earlier part of the type visible. These nodes, like the inner row, have a flat anterior face and a rounded posterior face with a sharp transverse edge between. They are simply obscure swellings at first, then become gradually higher until on the living chamber they are really blunt spines. The last node of the outer row seems to be lower than the preceding node and may indicate that the nodes decrease toward the aperture. At first there is a node for every other ventral rib, then one for every third,.fourth, and on the living chamber for every sixth ventral rib. Each rib that enters an outer node forks. On the entire type 15 umbilical ribs and 70 ventral ribs are visible.
The external suture of the species is that of the genus as restricted by Nowak, ${ }^{19}$ who separated the forms like the genotype $S$. aequalis Sowerby from those like $S$. tridens Kner and those like $S$. constrictus Sowerby. Nowak used the names Holcoscaphites, Acanthoscaphites, and Hoploscaphites, respectively, for these groups, though it seems to the writer that Scaphites should be restricted in scope, not replaced by another generic name with the same type species. The writer also believes that Hoploscaphites is synonymous with Discoscaphites Meek, ${ }^{20}$ for an examination of Meek's types and other material shows all the sutural and other characters demanded by Nowak's description. The lobes and saddles decrease progressively in size inward from the external lobe, although the second lateral saddle is unusually high.

The first lateral lobe is bifid, as in all Scaphites, but the second lateral lobe is still trifid, though asymmetrical and approaching a bifid form. The second lateral is about three-fourths the height of the first. There seem to be three auxiliary lobes, with the second a little larger than the first.

This species is based on the type, a specimen preserving the septate whorls and part of the living chamber, and on a smaller crushed fragment. Its distinguishing characters are the sharp, narrow ribs with relatively wide, flat interspaces, the position of the inner row of nodes, the compressed form of the septate whorl, the high arched venter, and the abrupt swelling of the living chamber. It is closest among American species to some forms of Scaphites nodosus Owen var. quadrangularis $\mathrm{Meek}^{21}$ and in fact might be included under nodosus in the extremely wide sense in which that name has been applied. However, modern usage would certainly divide the forms now comprised under the name into several species, and there is ample justification for separating the present form as distinct. From Scaphites quadrangulari our species may easily be separated by the arched venter, the position of the inner nodes, which lie farther out on the flank, and the compressed form. Meek compared his forms with Scaphites constrictus Sowerby, but the whole nodosus group differs from the specimens figured under that name by practically all the European students in form, sculpture, and, as Nowak ${ }^{22}$ has shown, in suture. Meek also made comparisons with Scaphites compressus Roemer (not D'Orbigny), the type of $S$. roemeri D'Orbigny. To judge by Roemer's figure ${ }^{23}$ and another of his type by Frech, ${ }^{24}$ neither

19 Nowak, Jan, Untersuchungen über die Cephalopoden der oberen Kreide in Polen; Theil 2, Die Skaphiten: Acad. sci. Cracovie Bull. int., année 1911, p. 564. 1912.

${ }^{20}$ Meek, F. B., A report on the invertebrate Cretaceous and Tertiary fossils of th upper Missouri country: U. S. Geol. Survey Terr. Rept., vol. 9, pp. 413-417, $187 \AA$. ${ }^{21}$ Meek, F. B., op. cit., p. 428.

22 Nowak, Jan, op. cit., p. 552.

${ }^{23}$ Roemer, F. A., Die Versteinerungen der norddeutschen Kreidegebirges, p. 91, pl. 15, fig. 1, Hannover, 1849.

${ }^{24}$ Frech, Fritz, Ueber Scaphites: Centralbl. Mineralogie, 1915, No. 18, pp. 553568; No. 21, pp. 617-621. 
Meek's species nor ours is very close. Frech assooiated Scaphites nodosus and its relatives with Scaphites binodosus Roemer and S. inflatus Roemer, ${ }^{25}$ but certainly Roemer's figures and descriptions, those by Schlüter, ${ }^{26}$ and those by Frech himself show material differences from the American forms and do not justify the use of the European names for the American species. The writer believes that the present literature affords no foreign Scaphites closely comparable with the American nodosus group.

This species is named in honor of J. B. Reeside, jr., of the United States Geological Survey. Mr. Reeside during recent years has been working on Cretaceous ammonites and has aided very materially in the determinations and desoriptions of the Coon Creek cephalopods.

Occurrence: Ripley formation, Dave Weeks place on Coon Creek, McNairy County, Tenn.

Collection: U. S. National Museum.

Family TURRILITIDAE Hyatt (=LYTOCERATIDAE Neumayr)

\section{-Subfamily TURRILITINAE Hyatt \\ Genus HELICOCERAS D'Orbigny}

The genus Helicoceras D'Orbigny belongs to a group of aberrant ammonites with high-spired coil. The other genera commonly included in the group are Turrilites Lamarck, in which the whorls are in contact and regular throughout, and Heteroceras D'Orbigny; in which all the whorls are in contact except the last, which is separated and bent into a horseshoe form. Helicoceras D'Orbigny has the whorls all regular but separated throughout growth. Various subgenera have been instituted, especially by Hyatt. Meek proposed under Helicoceras three subgenera-Patoceras, distinguished by a smooth band on the siphonal side; Spiroceras, distinguished by continuous ribs and three rows of nodes on the siphonal side; and Helicoceras in the strict sense, distinguished by continuous ribs and sometimes two rows of nodes on the siphonal side. The species described below belongs to Helicoceras proper, in the sense in which Meek used the term. Of Hyatt's genera it could fall only in Didymoceras, but this group has a retroversal final whorl, of which there is no evidence in the specimens seen.

Helicoceras navarroense Shumard

Plate LXI, Figures 8-11; Plate LXII, Figures 1, 2

1862. Helicoceras navarroense. Shumard, Boston Soc. Nat. Hist. Proc., vol. 8, p. 190.

Shumard describes this species as follows:

Shell large, dextral and sinistral, composed of distant, free convex volutions; large volution rounded, gradually enlarging to within a short distance of the aperture, where it becomes

${ }_{25}$ Roemer, F. A., op. cit., p. 90 , pl. 13, fig. 6 , and pl. 14, fig. 3.

${ }_{28}$ Schluter, Clemens, Cephalopoden der oberen deutschen Kreide, pp. 78-79, pl. 24, flgs. 1-6,; pl. 27, fg. 8, Cassel, 1876. suddenly expanded and flattened above and below; dorsum (venter) ornamented with two revolving series of prominent nodes, one series situated near the middle and the other at the base of the volution. On the anterior third of the volution the nodes are flattened and the inferior ones project obliquely downward and forward. The nodes of one series usually alternate with those of the other, but sometimes they are nearly opposite. The surface is likewise marked with prominent rounded, oblique annular costae, which are indistinct on the ventral (dorsal) side and frequently bifurcate at the nodes.

The diameter of the last volution, a short distance from the expanded aperture, is about 15 lines; diameter of the base, $31 / 2$ inches.

Of this fine species I have seen only the last and a portion of the succeeding volution of an apparently mature shell, from which the entire height may be estimated at not less than 6 inches.

Found by Dr. G. G. Shumard at Chatfield Point, Navarro County [Tex.]

Shumard did not figure his specimens, but the writer has good material from the type locality for comparison and has no doubt of the identity of the specimens from Coon Creek, which include one fragment, one and one-fourth whorls in length with the last half whorl unseptate, and a fragment of another individual that comprises a quarter of a whorl near the end of the septate part. The specimens have no sign of a contact furrow, and as far as preserved the shell is a perfectly regular spiral without even an incipient retroversal stage. The writer can add little to Shumard's description except to figure the form and suture.

Helicoceras navarroense may be distinguished from most American species of the family by the wide separation of the whorls and from the other species by the coarse sculpture and high nodes.

Occurrence: Ripley formation, Dave Weeks place on Coon Creek, McNairy County, Tenn.

Collection: U. S. National Museum.

Outside distribution: Navarro formation, Chatfield Point, Navarro County, Tex.

\section{Phylum ARTHROPODA \\ Class CRUSTACEA \\ Order DECAPODA}

By Mary J. Rathbun, Associate in Zoology, United States National Museum

These descriptions are based on two collections from McNairy County, one of the southern border counties of Tennessee. The larger part of the material was obtained by Mr. Bruce Wade for the United States Geological Survey, at four stations, as follows:

The Dave Weeks place, on Coon Creek, in the northeast part of McNairy County, $31 / 2$ miles south of Enville and $71 / 2$ miles north of Adamsville. Ripley formation.

The Boyd place, at the head of Crooked Creek, on the hill east of the house. Ripley formation.

Half a mile northwest of Gravel Hill. On the line between the Selma and Ripley formations.

State Line cut on the Southern Railway, 1 mile northwest of Wenasoga, Miss. On the line between the Selma and Ripley formations. 
The second collection is the property of the Department of Geology of Vanderbilt University, Nashville, Tenn., and was kindly loaned through Dr. L. C. Glenn. It was obtained by Dr. Glenn at a single locality near the Tennessee-Mississippi line a few hundred yards west of the station in the State Line cut near Wenasoga, Miss., and on the line between the Selma and Ripley formations.

The following species are represented in these two collections, all but the first in the Wade collection and those marked with an asterisk (*) in the Glenn collection:

*Peneus wenasogensis Rathbun, n. sp.

Podocratus canadensis (Whiteaves).

*Hoploparia tennesseensis Rathbun, n. sp.

*Hoploparia menairyensis Rathbun, n. sp.

Enoploclytia sculpta Rathbun, n. sp.

Eryma flecta Rathbun, n. sp.

*Callianassa mortoni Pilsbry.

* Dakoticancer overana Rathbun.

Raninella testacea Rathbun, n. sp.

*Avitelmessus grapsoideus Rathbun.

Of these species, Podocratus canadensis was already known from Alberta, Vancouver, and South Dakota; Callianassa mortoni is not uncommon on the Atlantic slope in New Jersey, Delaware, and Maryland; Dakoticancer overana was described from South Dakota, and Avitelmessus grapsoideus from North Carolina and Mississippi. The six remaining species are described as new.

\section{Family PENEIDAE \\ Genus PENEUS Weber}

1795. Peneus. Weber, Nomenclator entomologicus, p. 94. (Penaeus of authors.)

Peneus wenasogensis Rathbun, n. sp.

Plate LXIII, Figures 1-6, 8-11

The telson is much thicker at the proximal end than elsewhere and becomes gradually thinner toward the distal portions. All the tips are lacking. The upper and lower surfaces meet laterally in a subacute edge, which is slightly arched upward in profile, whereas the lower line is considerably more arched. (See Pl. LXIII, figs. 10, 11.) A deep median groove on both upper and lower surfaces; upper groove narrowing at both ends (figs. 1, 2, 8, 9); lower groove widest anteriorly and narrowing gradually posteriorly (figs. 3-6). A blunt ridge either side of the groove; halfway between each ridge and the lateral margin there is a longitudinal row of unequal but rather large elongate punctae, the anterior ones being depressed in a furrow.

The common Recent species of the southern coast of the United States ( $P$. setiferus ${ }^{27}$ and $P$. brasitien_ sis ${ }^{28}$ ) have the telson more compressed and more ${ }^{27}$ Linnê, K. von, Systema naturae, 12th ed., vol. 1, pt. 2, p. 1054, 1767. (Cancer setiferus.)

${ }^{28}$ Latreille, P. A., Nouveau dictionnaire d'histoire naturelle, vol. 25 , p. 156 , 1817. (Penaeus brasiliensis.) hollowed underneath, the sides more rapidly convergent, and the submedian crests more acute than the species here described.

Type locality: Tennessee, in State Line cut, a few hundred yards west of the station, near Wenasoga, Miss.; on the line between Selma and Ripley formations; L. C. Glenn, collector.

Collection: Vanderbilt University; four incomplete telsons.

\section{Family PaLINURIDAE}

Genus PODOCRATUS Becks MS., Geinitz

1849. Podocratus. Becks MS., in Geinitz, Das Quadersandsteingebirge oder Kreidegebirge in Deutschland, Freiberg, p. 96.

1862. Podocrates. Schlüter, Deutsche geol. Gesell. Zeitschr., vol. 14, p. 710 .

1897. Linuparus (part). Ortmann, Am. Jour. Sci., 4th ser., vol. 4, p. 296.

Differs from the Recent genus Linuparus White ${ }^{20}$ in having two frontal horns instead of a broad, depressed, slightly bisected plate.

\section{Podocratus canadensis (Whiteaves) \\ Plate LXIII, Figures 12, 16}

1885. Hoploparia? canadensis. Whiteaves, Roy. Soc. Canada Trans. for 1884, vol. 2, section 4, pp. 237-238; Canada Geol. Survey, Contr. Canadian Palaeontology, vol. 1, pt. 1, p. 87, pl. 11.

1895. Podocrates canadensis. Whiteaves, Roy. Soc. Canada Proc. and Trans., 2d ser., vol. 1, p. 133.

1900. Linuparus (Podocrates) canadensis. Woodward, Geol. Mag., new ser., decade 4, vol. 7, p. 396, pl. 16, fig. 1 . Hornby Island, Vancouver.

1903. Linuparus canadensis. Whiteaves, Canada Geol. Survey,

- Mesozoic fossils, vol. 1, pt. 5, p. 325.

Carapace behind the cervical suture tricarinate, the lateral carinae bowed out slightly in the posterior half; greatest length about $11 / 2$ times the greatest width between carinae. Carinae armed with irregular acorn-shaped spines, inclined forward, and with accessory flattened granules on their posterior slopes. Many of them are broken off, but there are indications of nine on the median carina, the third from the rear being double - that is, two smaller ones approximately side by side, one a little behind the other. The lateral carinae have each at least twelve spines. Intercarinal and lateral surfaces covered with small, unequal, flattened, distant, forward-pointing granules.

It seems highly probable that this fragment is correctly identified as conspecific with the type from the Upper Cretaceous of Highwood River, a tributary of Bow River, Alberta. In the type, to be sure, there is a deep longitudinal furrow near and on either side of the median ridge of the after part of the carapace; these furrows are very likely the result of pressure, as Whiteaves suggests in his original description. The

${ }^{29}$ White, A., List of Crustacea in the British Museum, p. 70, London, 1847. 
Tennessee specimen has a similar furrow on the right half, midway between crests. Whiteaves later (1903) includes in the synonymy Linuparus atavus Ortmann, 1897, from the Upper Cretaceous of South Dakota.

Locality: Half a mile northwest of Gravel Hill, McNairy County, Tenn., on line between Selma and Ripley formations, July 9, 1915; Bruce Wade, collector. No. 10272; one specimen, showing only that part of the carapace behind the cervical suture.

\section{Family ASTACIDAE}

\section{Genus HOPLOPARIA McCoy}

1849. Hoploparia. McCoy, Annals and Mag. Nat. Hist., 2d ser., vol. 4, p. 175.

Hoploparia tennesseensis Rathbun, $n$. sp.

Plate LXIV; Plate LXV, Figures 1, 3, 6

The smallest specimen, left chela (specimen $a$ ), is the holotype; it is the best preserved, is free from the matrix, and is almost black. The dactylus is broken off not far from its base, the immovable finger near its middle. The surface is covered with very numerous fine scalelike granules, more raised and granule-like on the lower than on the upper surface. On the fingers these scales become oblong punctae. On the outer margin of the propodus there is a longitudinal groove, which begins not far from the carpus and ends a little before the break in the finger (Pl. LXIV, fig. 1). Just below the inner margin and on the proximal threefifths there is a row of three tubercles or spines directed distad and with equidistant interspaces, the proximal tubercle close to the carpus (PI. LXIV, figs. $2,4)$. Just above the margin and equidistant from the two proximal tubercles of the row there is a single tubercle. Of the prehensile teeth the first three on the propodal finger are low and worn, very flat; next comes a large tooth, lower than wide, then a small tooth, then a large one, and a small one next the break; on the dactylus there is on the prehensile edge a large but much worn tooth followed by a somewhat smaller but more prominent tooth; on the opposite edge there is a tubercle in line with the row of three on the manus.

Specimen $b$ shows a left manus, which is only partly exposed from the matrix and has the fingers broken off near their bases; the surface is like that of $a$, and the outer groove is visible. The cheliped seems to be in its natural position in relation to the body; another, a little smaller cheliped lying alongside, might be supposed to be the mate to the other, but it too seems to have a left manus, if one may judge from the shallow depression on the under surface adjoining the immorable finger.

In specimen $c$, another manus, the roughnesses of the surface are much lower and more inconspicuous than in specimen $a$, and the outer surface, though flattened, shows slight traces of a groove. The first five prehensile teeth or tubercles increase in height in order of place and are followed by a wide space; then a small tooth, a large one, a narrow space, a large tooth, a minute one, a viéry large one, two small ones, then the break; there is a very large tooth at the base of the dactylus (Pl. LXV, fig. 1).

Specimen $d$ is similar in size and shape to specimen c. Outer layer of shell mostly lacking, outer groove faint. The three tubercles below inner margin strong, as also the one above the row. On the propodal finger there are three tubercles that increase in size up to a large one, then two small ones. The dactylus bears the customary large, basal prehensile tooth, and the opposite edge (the inner edge of the chela) has a large tooth or tubercle similar to that seen in $a$.

In specimen $e$ the manus has thickened very much, the outer layer is entirely absent, but the four large tubercles are present, as well as the one on the outside of the dactylus, and its large basal prehensile tubercle. The immovable finger is absent.

In specimen $f$, which is of about the same size as specimen $e$, the granulation of the surface is partly evident. There is a faint indication of the outer groove, and two of the submarginal tubercles are preserved, but both fingers are almost lacking, except that the dactylus shows the large tubercle on opposite sides of its proximal end.

Specimen $g$ (Pl. LXIV, fig. 5) is much stouter in proportion to its length than any of the smaller specimens. It is much mutilated but shows the characteristic texture. The tubercles of the manus are broken away, and the fingers are lacking.

A fragment of a chela (specimen $m$ ) has the upper articulating condyle of the manus with the dactylus more prominent than in other specimens and the four basal teeth of the propodal finger, and in a lesser degree the basal tooth of the dactylus, ground down almost to their bases.

A small section of a very large finger (specimen $o$ ) is armed with an elongate tooth and appears to have come from the distal half of the finger.

Only one specimen (specimen $i$ ) shows the dista] portion of the fingers; they are strongly curved toward each other and overlap, but one is longer than the other; their teeth are not visible (Pl. LXV, fig. 3).

Measurements (in millimeters) of chelae of 7 specimens of Hoploparia tennesseensis from Dave Weeks place on Coon Creek, Tenn.

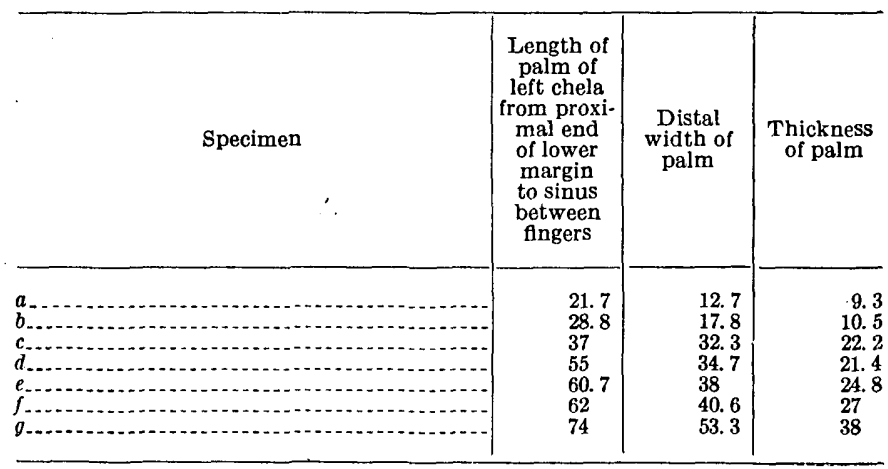


Only one specimen (b) permits even approximate measurements of the body. Length of carapace, about 48.6 millimeters; length of first four segments of abdomen, about 51 millimeters. A larger specimen has the first three segments of the abdomen about 50 millimeters long; in a smaller one they are 35 millimeters long.

The surface of the carapace is covered with scalelike granules, the abdomen with punctae. The material comprises portions of seven curapaces and three abdomens; all are incomplete and for the most part badly preserved. Carapace high in the middle, the shell being cracked along the median line in the only two specimens in which it is preserved. The cervical and $\lambda$-shaped hepatic sutures are deep and fade out before reaching the margin of the carapace. In front of the hepatic suture, and above the line where it forks, there is a longitudinal row of three distant spines, and above it a longitudinal row of two spines. On the frontal region there are two narrow blunt ridges, one on either side of the middle; these converge anteriorly; behind them are i few small spines. The rostrum appears to be short.

The pleura of the second and third segments of the abdomen (specimen $l$ ) are sculptured, chiefly by a submarginal groove and their margins are broadly rounded. The upper border of the pleura is marked by a low, blunt ridge (Pl. LXV, fig. 6).

The hand of this species suggests that of $H$. gabbi Pilsbry ${ }^{30}$ but is of different shape, gabbi having more convex margins and being wider near the middle of the palm, whereas in tennesseensis the palm is widest at its distal end. Besides, the tubercles or spines reach in gabbi rather near the finger, but in our species they are restricted to the proximal three-fifths of the palm.

Type locality: Dave Weeks place on Coon Creek, in northeast part of McNairy County, Tenn., 31/2 miles south of Enville and $71 / 2$ miles north of Adamsville; Ripley formation; Bruce Wade, collector. No. $10198 ; 12$ specimens ( $a$ to $l$ ), of which 9 show portions of the chelipeds and 5 show portions of the body. Type, U. S. National Museum, No. 73117.

Other localities: State line cut on Southern Railway in McNairy County, Tenn., 1 mile northwest of Wenasoga, Miss.; on line between Selma and Ripley formations, June 28, 1915; Bruce Wade, collector. No. 10271; two fragments of chelae $(m$ and $n)$.

State Line cut in McNairy County, Tenn., a few hundred yards west of the station, near Wenasoga, Miss.; on line between Selma and Ripley formations; L. C. Glenn, collector. In the collection of Vanderbilt University there are three fragments of carapace $(p, q, r)$ and one fragment of a large finger $(o)$.

so Pilsbry, H. A., Crustacea of the Cretaceous formations of New Jersey: Acad. Nat. Sci. Philadelphia Proc., vol. 53, p. 115, pl. 1, figs. 11-14, 1901. New Jersey Geol. Survey, Paleontology, vol. 4, p. 846, pl. 110, flgs. 12-15, 1907. Holoparia gabbi in Maryland Geol. Survey, Upper Cretaceous, p. 361, pl, 10, figs. 1-4, 8, 9, 1916.

\section{Hoploparia menairyensis Rathbun, n. sp.}

Plate LXV, Figures 2, 4, 5, 7, 8

The carapace behind the cervical suture is rough with distant granules, which are small, round, and pearly, less flattened and scaly than in $H$. tennesseensis, although some granules show a minute puncture on the anterior side. Immediately in front of the cervical suture the granules are scarce, but farther forward and toward the middle they are more crowded and flattened and interspersed with large shallow pits. On the left side at the angle of the orbit there is a small sharp spine.

Type locality: Half a mile northwest of Gravel Hill, McNairy County, Tenn.; on line between Selma and Ripley formations, July 9, 1915; Bruce Wade, collector. No. 10272; one specimen consisting of a very incomplete carapace; U. S. National Museum, No. 73118.

Other locality: State Line cut, in McNairy County, Tenn., a few hundred yards west of the station, near Wenasoga, Miss.; on line between Selma and Ripley formations; L. C. Glenn, collector. One specimen received from Vanderbilt University, a little smaller than the type, with very little of the outer layer remaining; it shows, however, the same sort of granulation; the frontal portion with the rostrum is delineated. The rostrum is nearly as long as the distance from its base to the cervical suture; it has a median carina and is bordered on either side by a higher carina, very irregularly roughened with spines or tubercles; these three carinae are continued backward on the carapace proper for a short distance; outside and parallel to their posterior ends, but not reaching as far forward as the orbital border, there is another very short carina, making in all five carinae on the carapace. The sides of the rostrum are nearly straight and regularly converge to the tip (broken off). A blunt uneven ridge leads back from the orbital angle to the cervical suture and is twice interrupted.

I am not sure that the two specimens are the same species. More complete material will be necessary to determine that point.

\section{Genus ENOPLOCLYTIA McCoy}

1849. Enoploclytia. McCoy, Annals and Mag. Nat. Hist., 2d ser., vol. 4, p. 330.

Enoploclytia sculpta Rathbun, n. sp.

Plate LXVI

Very few specific characters are distinguishable, except on the abdomen. The telson has a straight outer margin parallel to the axis; an anterior portion is set off from the remainder by a curved furrow. This piece may possibly be the sixth segment but seems to be a part of the seventh. Segments 4, 5, 
and 6 have a deep transverse groove dividing them into two parts; surface punctate. The posterior portion of segment 6 is a little shorter than the anterior portion. On both sides of the posterior portion, at some distance from, the middle, there is a transverse row of larger punctae, into each of which there projects from the anterior side a small sharp tooth. On the anterior portion there is a subcircular median depression opening on the anterior edge of the segment and largely filled by a 3-lobed and stalked design suggesting a clover leaf; the median lobe is larger than the lateral ones. On each side there are further sculpturings, less striking; in one place the depression is bordered anteriorly by a crenulated line, the crenules projecting into the depression. All the depressions of the abdomen and the exposed appendages are closely and microscopically punctate. The anterior portion of segment 5 is shorter than the posterior portion; it has two small rounded depressions on each side opening on the anterior margin. Of the interspaces, the median is narrower than the lateral.

Two fragments with uneven surfaces may represent the pleopods which form part of the tail fan; their separate areas are partly bordered by crenulated edges.

The recognizable parts of the pereiopods consist (1) in the distal portion of a merus of doubtless the first foot; it is stout and increases to the distal end; (2) in the tips of the terminal segment of the same foot. One is sufficiently uncovered to show five longitudinal ridges and the same number of rather deep grooves; a short distance from the tip there is a tubercle, which indicates the prehensile edge.

A detached piece, 8 millimeters long, of antennal flagellum contains about 20 segments.

The sculptures of the abdomen are sufficient to identify this species. The long, slender fingers suggest those of E. leachii (Mantell) ${ }^{31}$ and E. minor Woodward. ${ }^{32}$

A long nodule, in which part of the abdomen and many small fragments are visible, seems to include the whole length of the animal, both the body and the elongate first feet. Length (approximate) of abdomen, from the middle of the fourth segment to extremity, 27 millimeters; estimated length of abdomen, 48 millimeters; length, perhaps discontinuous, from end of telson to end of first pereiopod, 150 millimeters.

Type locality: Dave Weeks place on Coon Creek, in northeast part of McNairy County, Tenn., 31/2 miles south of Enville and $71 / 2$ miles north of Adamsville; Ripley formation; Bruce Wade, collector. No. 10198; one specimen, U. S. National Museum, No. 73119.

\footnotetext{
s1 Mantell, G. A., The fossils of the South Downs or illustrations of the geology of Sussex, p. 221, pl. 29, London, 1822. Fric, Anton, and Kafka, Joseph, Die Crustaceen der böhmischen Kreídeformation, p. 27, pl. 9, fig. 9, text figs. 48-52, Prag, 1887. ${ }^{82}$ Woodward, Henry, Further notes on podophthalmous crustaceans from the Upper Cretaceous formation of British Columbia: Geol. Mag., new ser., decade 4, vol. 7, p. 434,1900 .
}

\section{Genus ERYMA Meyer}

1840. Eryma. Meyer, Neue Gattungen fossiler Krebse, p. 18. Eryma flecta Rathbun, n. 'sp.

Plate LXIII, Figures 7, 13-15

Propodus of left cheliped with immovable finger. On the upper surface (PI. LXIII, fig. 14) the greater part of the outer layer is lacking. Both inner and outer margins are convex, the outer being divided from the corresponding margin of the finger by a shallow sinus. Both margins of the finger also are convex in their basal portion, the finger broad at base and tapering toward the distal end. The surface is densely covered with fine punctae, and there is a narrow and shallow depression leading from the finger back onto the palm.

The inner surface (Pl. LXIII, fig. 15) is regularly rounded and increases in width from the carpus to the dactylar end. Inner edge of finger broken, but there are remains of several low, irregular teeth.

On the lower surface (Pl. LXIII, fig. 13) a large and deep depression leads upward and backward from the sinus in the outer margin; inward from this depression the surface attains its highest point and is surmounted by a tubercle, the top of which is broken off. Two other tubercles, one larger and one smaller, are nearer the inner edge and form an elongate triangle with the first.

On the outer surface (Pl. LXIII, fig. 7) the finger bends slightly downward from the sinus just behind its origin; the surface is thinnest at this sinus.

There will be doubt about the generic position of this species until other portions of the animal are found.

Inner length of palm or propodus of left cheliped, 9.8 millimeters; length from proximal end of outer margin to margin beneath bases of fingers, 13.2 millimeters; width (greatest) at distal end, 7 millimeters; greatest thickness, 4 millimeters. Finger of propodus (tip missing) not quite'so long as inner edge of palm. Width of finger at base, 3.4 millimeters.

Type locality: Half a mile northwest of Gravel Hill, McNairy County, Tenn.; on line between Selma and Ripley formations. July 9, 1915; Bruce Wade, collector. No. 10272 ; U. S. National Museum, No. 73115.

\section{Family CALLIANASSIDAE}

Genus CALLIANASSA Leach

1814. Callianassa. Leach, Edinburgh Encyclopedia, p. 400.

\section{Callianassa mortoni Pilsbry}

Plate LXVII, Figures 1, 2, 4-9

1901. Callianassa mortoni. 'Pilsbry, Acad. Nat. Sci. Philadelphia Proc., vol. 53, p. 112, pl. 1, figs. 1-7. New Jersey and Delaware.

1905. Callianassa mortoni. Johnson, Acad. Nat. Sci. Philadelphia Proc., vol. 57, p. 28. 
1907. Callianassa mortoni. Weller, New Jersey Geol. Survey, Paleontology, vol. 4, 1907, p. 849, atlas, pl. 111, figs. 1-15.

1916. Callianassa mortoni. Pilsbry, Maryland Geol. Survey, Upper Cretaceous, p. 363, pl. 11, figs. 1-3. Delaware and Maryland.

Pilsbry describes the major cheliped of the male. To his description I would add that the upper margin of the carpus ends anteriorly in a sharp triangular tooth pointing distad; this corner is usually broken off. Also the punctre on the upper half of the outer side of the manus vary from four to five in smaller specimens to three in large ones.

The major manus of the female, of which there are three specimens, differs from that of the male in having the upper edge straight and horizontal, not bent over at the proximal end (Pl. LXVII, fig. 2). On the outer surface there are five punctae in a longitudinal row leading to the dactylus. I suspect that the specimens set aside by Pilsbry as $C$. mortoni var. marylandica are hands of females.

The minor chela of the male is so unlike the major chela that if it were isolated one would say that it represented a different species. But at the Tennessee locality the minor cheliped is commonly found associated with its major cheliped, the two lying in a natural position with their inner surfaces apposed (Pl. LXVII, figs. 8, 9). There are thirteen such pairs in the collection in which both chelipeds are determinable; the major cheliped reaches well beyond the minor; in medium-sized specimens the minor chela overreaches the major carpus by the length of its fingers.

The manus of the minor cheliped (Pl. LXVII, figs. 8,9 ) is very little longer than broad; the lower margin is straight, the upper is slightly curved. The outer surface is mainly very convex; the margins are very thin, straight and crenulated, and just within each margin there is a longitudinal depression. A little below the upper depression there is a narrow furrow, which runs back from just above the articulating nodule at the dactylar end and which divides the surface into a narrow upper, convex strip that is coarsely granulate and a broad lower area that is partly and irregularly granulate, the granules clustered nearer the distal end.

The fingers are narrow and widely separated (Pl. LXVII, fig. 9); the propodal finger has mostly flat inner and outer surfaces and an acute, crenulated lower edge, just above which, outside and inside, there is a row of punctae. The thick upper edge is concavely beveled on both sides, the inner bevel twice as wide as the outer. The three ridges thus formed are tuberculate, and there is a row of punctae just above the lateral rows of tubercles. The dactylus is deeply grooved, the grooves coarsely and sparingly punctate, and the intervening ridges coarsely tuberculate. Of the three outer ridges, the lower one unites with the intermediate one near the middle of the finger.

Localities: Dave Weeks place on Coon Creek, in northeast part of McNairy County, Tenn., 31/2 miles south of Enville and 71/2 miles north of Adamsville; Ripley formation; Bruce Wade, collector. No. 10198; 39 specimens.

Half a mile northwest of Gravel Hill, McNairy County, Tenn.; on line between Selma and Ripley formations, July 9, 1915; Bruce Wade, collector. No. $10272 ; 36$ specimens.

State Line cut on Southern Railway, in McNairy County, Tenn., 1 mile northwest of Wenasoga, Miss.; on line between Selma and Ripley formations, June 28, 1915; Bruce Wade, collector. No. 10271; 2 specimens.

State Line cut, a few hundred yards west of the station, near Wenasoga, Miss.; on line between Selma and Ripley formations; L. C. Glenn, collector. Vanderbilt University, 49 specimens.

\section{Family DAKOTICANCRIDAE}

\section{Genus DAKOTICANCER Rathbun}

1917. Dakoticancer. Rathbun, U. S. Nat. Mus. Proc., vol. 52, p. 385.

\section{Dakoticancer overana Rathbun}

Plate LXVII, Figure 3

1917. Dakoticancer overana. Rathbun, U. S. Nat. Mus. Proc., vol. 52, p. 386, pls. 32 ; 33, figs. 6-14. Pierre shale, Upper Cretaceous, South Dakota.

The specimens agree in all respects with the type specimens from South Dakota. None have remains of fingers. One male in the Vanderbilt University collection, from which the abdomen is absent, shows the appendages in place; they are stout and short, not reaching beyond that somite of the sternum which bears the fourth pereiopods.

Localities: Half a mile northwest of Gravel Hill, McNairy County, Tenn.; on line between Selma and Ripley formations, July 9, 1915; Bruce Wade, collector. No. 10272; five specimens.

State Line cut on Southern Railway, McNairy County, Tenn., 1 mile northwest of Wenasoga, Miss.; on line between Selma and Ripley formations, June 2S, 1915; Bruce Wade, collector. No. 10271; one specimen.

State Line cut on Southern Railway, McNairy County, a few hundred yards west of the station, near Wenasoga, Miss.; on line between Selma and Ripley formations; L. C. Glenn, collector. Vanderbilt University, seven specimens. 


\section{Family RANINIDAE}

Genus RANINELLA A. Milne Edwards

1862. Raninella. Milne Edwards, Compt. Rend., vol. 55, p. 492.

Raninella testacea Rathbun, n. sp. Plate LXVIII

The carapace is very arcuate from side to side and in an antero-posterior direction is moderately deflexed in front of the middle of the gastric region. The lateral margins are convex in front of the posterior third, and the carapace is widest at its anterior third, or at the penultimate lateral spine. The surface is closely paved with flat, subhexagonal granules, which are risible to the naked eye, as are also the scattered punctae. There is an almost total absence of dorsal inequalities. The exceptions are a pair of crescentic furrows at the middle of the carapace, defining the inner limit of the branchial region; a shallow longitudinal median depression, widening posteriorly and occupying the posterior third or fourth of the carapace; and a longitudinal furrow on the rostrum: The rostrum is narrow and insignificant and apparently ended in two spines, which are broken off in the only specimen that has a rostrum. It is advanced beyond the remainder of the anterior margin, which is armed on each side with four spines and slopes back in a transversely oblique direction. The spines seem to be in pairs, those of each pair separated by a shallower sinus than that between the pairs. Between the rostrum and the first spine there is a slight prominence below the margin of the carapace, which may be a part of the eyestalk. Behind the anterolateral spine, which is strong and elongate, there are four smaller spines on the lateral margin which also diminish in size from the anterior to the posterior spine.

Chelipeds stout, of moderate length. The carpus and distal half of the merus are each provided on the outer side with a prominent laminate crest having a lobate edge; remainder of outer and upper surface of merus rough, partly with spines arranged in longitudinal rows and partly with short transverse granulated or spinose ridges. There are two or three longitudinal rows of spines on the upper surface of the carpus, and a spine at the anterior angle. The palm has a smooth outer face, widens from the proximal to the distal end, an $d$ is bordered above by two rows of four or five spines each and below by one row of seven or eight spines. The propodal finger is flat, lanceolate, strongly bent down, and about as long as the upper border of the palm.

Very little can be made out of the remaining legs. The last two segments of one leg are partly exposed and show considerable blue-green opaline iridescence; and that segment which I take to be the terminal one is narrow, flat, and sublanceolate.
Relationships: Although the sternum and the maxillipeds of this species are not visible, I am confident that its place is among the Raninidae. It has hands of characteristic raninoid shape, with the propodal finger much deflexed, so that the dactylus must have been applied largely against the distal border of the palm; in the opposite direction the palm is produced for a long distance parallel to its articulation with the carpus until it almost touches the merus. The carpus in turn is elongate, with its distal articulation longitudinally oblique. The carapace is almost free of deep suture lines. In this respect, as well as in the shape of the carapace, Raninella testacea bears a strong resemblance to the so-called Palaeocorystes harveyi Woodward, ${ }^{33}$ from the Cretaceous of Vancouver Island, and the probabilities are that they are congeneric.

Length of carapace of holotype, 41 millimeters; greatest width, 30 millimeters; width between anterolateral angles, 25.2 millimeters. The length of the larger of the paratypes is at least 55.5 millimeters; its greatest width is roughly 44 millimeters.

Type locality: Dave Weeks place on Coon Creek, in northeast part of McNairy County, Tenn., 31/2 miles south of Enville and $71 / 2$ miles north of Adamsville; Ripley formation; Bruce Wade, collector. No. 10198; U. S. National Museum, three specimens, No. 73121.

\section{Family ATELECYCLIDAE}

\section{Genus AVITELMESSUS Rathbun}

\section{Avitelmessus grapsoideus Rathbun}

Plates LXIX, LXX

1923. Avitelmessus grapsoideus. Rathbun, North Carolina Geol. and Fcon. Survey, vol. 5, p. 404, pl. 101; pl. 102, fig. 4.

In the large type specimen the anterolateral rim bears two strong erect spines, but in smaller specimens there are instead five or six small spines (Pl. LXIX, fig. 5). The sides of the frontal process may be parallel or curved inward a little; it may reach forward as far or even a little farther than the outer angles of the orbit. The tubercle present on the type specimen in the upper sinus of the inner half of the orbit is absent from smaller individuals. The eyestalk at its base is stout but in a short distance tapers to a moderate diameter.

The merus of the maxilliped is broadly suboval, with a slight hollowing of the antero-internal margin for the insertion of the palp; there is a low, longitudinally oblique elevation just within the middle. The first two articles of the palp taken together appear to be about as long as the merus (Pl. LXIX, fig. 3).

${ }^{33}$ Woodward, Henry, On some podophthalmatous Crustacea from the Cretaceous formation of Vancouver and Queen Charlotte islands: Geol. Soc. London Quart Jour., vol. 52, p. 225, text fig. 4, 1896. Whiteaves, J. F., Canada Geol. Survey, Mesozoic fossils, vol. 1, p. 317, text fig. 17, 1903. (Copy of Woodward's figure.) 
The spines of the chelipeds are more numerous in the half-grown than in the old. The three margins of the merus are equally spinous. The upper surface of the palm is narrower than in the holotype, and the hollow in the latter is really part of the inner surface, as are also the three conical spines described as on the inner edge of the upper surface; they are normally on an oblique ridge, which becomes elevated with age; outer surface rough with short spines arranged somewhat in longitudinal rows.

No complete ambulatory leg was found in the collections, but various fragments, among them a few which I take to represent dactyls, are present. Their tips are lacking, but so far as the segments show they are less flattened and more tapering than the propodal segments; also smoother, having spines on the upper margin, sides smooth (where the outer layer of shell is visible), lower edge nearly smooth but marked with two rows of large pits (Pl. LXX, figs. 2-7, 11).

One male (Vanderbilt University) in which the greater part of the sternum and maxillipeds, but not the carapace, is preserved, is of very large size, the carapace at least 110 millimeters long. In the same collection are the two smallest specimens, one with carapace 26.3 millimeters wide, the other 28.8 millimeters wide.

A medium-sized male, No. 10198, measures in length of carapace, 58 millimeters; in width, 59 millimeters.

Localities: Dave Weeks place on Coon Creek, in northeast part of McNairy County, Tenn., $31 / 2$ miles south of Enville and $71 / 2$ miles north of Adamsville; Ripley formation; Bruce Wade, collector. No. 10198; specimens of 9 or more individuals, mostly of good size. Also from the same place and collector, one large male, collected August 22, 1921.

Boyd place at head of Crooked Creek, McNairy County, Tenn., on hill east of house; Ripley formation, July 22, 1915; Bruce Wade, collector. No. 10273; 2 large specimens and fragments of two others

Half a mile northwest of Gravel Hill, McNairy County, Tenn.; on line between Selma and Ripley formations, July 9, 1915; Bruce Wade, collector.'No. 10272 ; fragments of perhaps only one specimen.

State Line cut on Southern Railway, McNairy County, Tenn., 1 mile northwest of Wenasoga, Miss.; on line between Selma and Ripley formations, June 28, 1915; Bruce Wade, collector. No. 10271; two carapaces and fragments of at least five other specimens.

A few hundred yards west of the station in State Line cut near Wenasoga, Miss.; on line between Selma and Ripley formations; L. C. Glenn, collector. Vanderbilt University; remains of at least 35 specimens, some of which are very fragmentary.

106913-26†-13

\section{Class EUCRUSTACEA}

Order THORACICA

Family PELADIDAE

Genus SCALPELLUM Leach

Scalpellum sp.

Plate LXII, Figures 3, 4, 6, 7

Cardinal plate arcuate, with a well-defined apex on the medial portion of the external surface; external surface sculptured with radial and incremental lines; interior surface deeply grooved, groove deepest and narrowest beneath the apex; scutal plate nearly flat, with six unequal sides; external surface marked by numerous irregular, concentric growth lines; internal surface concave and smooth.

These two plates were not found fogether, and it is impossible to say if they belong to the same species. Should additional specimens be obtained sufficient for establishing a new species, the species might very properly be called Scalpellum gabbi Wade, n. sp., in honor of W. M. Gabb, who described Scalpellum conradi Gabb, ${ }^{34}$ the first known American Cretaceous cirriped. The two species Scalpellum maximum Sowerby and Scalpellum quadratum Darwin, ${ }^{35}$ both from the Priesener Schichte of the Bohemian Cretaceous, are forms distantly related to the two American species.

Occurrence: Ripley formation, Coon Creek, McNairy County, Tenn.

Collection: U. S. National Museum.

\section{Phylum VERTEBRATA}

Class REPTILIA

\section{Family MOSASAURIDAE}

By C. W. Gilmore, of the United States National Museum

Plate LXII, Figures 5, 8; Plates LXXI, LXXII

The four bones submitted for examination and report all pertain to the extinct family of reptiles known as the Mosasauridae. No. 9609 (U. S. Nat. Mus.) is the coronoid of the right side (Pl. LXXI, figs. $6,8)$, one of the elements of the lower jaw. No. 9605 (U. S. Nat. Mus.) is the centrum of a dorsal vertebra (Pl. LXII, fig. 8). No. 9607 (U. S. Nat. Mus.) is a cervical vertebra (Pl. LXII, fig. 5). No. 10540 (U.S. Nat. Mus.) is the posterior portion of a right dentary that originally carried ten teeth (Pl. LXXII, figs. 1, 2). The crowns of all except the sixth and eighth, counting

${ }^{34} \mathrm{Gabb}$, W. M., Note on the discovery of representatives of three orders of fossils new to the Cretaceous formation of North America: Acad. Nat. Sci. Philadelphia Proc. for 1876, p. 178, pl. 5, figs. 3, 4, 1876.

ss Frič, Anton, Studien im Gebiete der böhmischen Kreideformation: Archiv naturwiss. Landesd. Böhmen, Band 9, No. 1, p. 109, flgs. 142, 143, 1893. 
from the posterior end, are missing. The crown of the sixth tooth is perfectly preserved and, except for its smaller size, closely resembles the type of Elliptonodon compressus Emmons, ${ }^{36}$ from the Upper Cretaceous of North Carolina. However, as that genus and species is of very uncertain standing, owing to the fact that it was founded on the crown of a single tooth, the close resemblance noted above may not have much significance. On the alveolar border the ten teeth occupy a space 280 millimeters in length. The crown of the sixth tooth from the posterior end of the series is curved backward, subelliptical in cross section, and bluntly pointed. The inside surface is more flattened or less convex than the outer; bicarinate; anterior ridge becoming obsolete near the base of the crown. Antero-posterior diameter of crown at base, 19.5 millimeters; transverse diameter, 17 millimeters: height of crown, 27 millimeters. All these specimens are from the Ripley formation of the Upper Cretaceous, as exposed on Coon Creek, McNairy County, Tenn., and none were found in such association as to indicate that they belong to the same individual. No less than 10 genera and 29 species of mosasauroid reptiles have been described from the Upper Cretaceous deposits of the eastern United States, many of them based upon scattered teeth and fragmentary parts of the skeleton, so that in the present state of our knowledge of the Mosasauridae it is practically impossible to determine the genus to which these single bones pertain.

${ }^{86}$ Emmons, Ebenezer, Report of the North Carolina geological survey, p. 222, flgs. $41,42,1858$.
The mosasaurs were marine or sea-living reptiles, having long, slender bodies and a long, powerful, compressed tail, and the limbs were modified into short swimming paddles. They ranged in length from 8 feet in the small species to nearly 40 feet in the largest species. The long, pointed skull had jaws filled with sharply pointed teeth, which indicates the predatory nature of these animals. They doubtless lived largely upon fish and probably also on other small animals, such as birds, pterodactyls, and the smaller individuals of their own kind.

\section{Class PISCES}

By J. W. Giduey, of the United States National Museum

Plate LXII, figs. 9, 10; Plate LXXI, Figures 1-5, 7, 9-11

The fish remains collected from the Ripley formation at the Dave Weeks place, on Coon Creek, McNairy County, Tenn., and submitted for determination include several forms that belong to rather widely divergent groups. The best of these forms are here figured. Those of the lot determined include Anomoedus sp., a tooth of the pharyngeal plate (No. 9610, U. S. Nat. Mus.; Pl. LXXI, fig. 11); Ischyrhiza mira Leidy (No. 9611, U. S. Nat. Mus.; Plate LXII, fig. 10); Enchodus sp. (No. 9612a, U. S. Nat. Mus.; Pl. LXXI, figs. 7, 9, 10) ; Saurodon? sp. (No. 9613, U. S. Nat. Mus.; Pl. LXXI, figs. 1, 2, 5); otolith (No. 9614, U. S. Nat. Mus.; Pl. LXXI, figs. 3, 4); vertebra of a selachian (No. 9608, U. S. Nat. Mus.; Pl. LXII, fig. 9). 


$\overline{\mathrm{C}}$

PLATES I-LXXII 


\section{PLATE I}

\section{Ripley Fossils from Coon Creek, Tenn.}

1, 2, 5. Trochosmilia nodosa Wade, n. sp., type of species (p. 26). 1, Calice; 2, profile view; 5, apical view. (U. S. Nat. Mus. catalog No. 32703.)

3, 4, 6-8. Micrabacia hilgardi Stephenson (p. 26). 3, Profile view; 4, 6, calice;, , 8, apical views. (U. S. Nat. Mus. catalog No. 32704.)

9, 10. Micrabacia cribraria Stephenson (p. 27). 9, Apical view; 10, basal view. (U. S. Nat.Mus. catalog No. 32705.)

11-19. Metopaster tennesseensis Wade, n. sp. (p. 27). 11-13, Marginal plate of type of species (11, bottom view; 12, 13, top views), 14-17, 19, a marginal plate (14, 17; top. views; 15, 19, end views; 16 , bottom view); 18, a basal plate bottom view. (U. S. Nat. Mus. catalog No. 32706.)

20, 21. Hemiaster ungula (Morton) Clark (p. 28). 20, Basal view; 21, top view. (U. S. Nat. Mus. catalog No. 32707.) 194 
U. S. GEOLOGICAL SURVEY

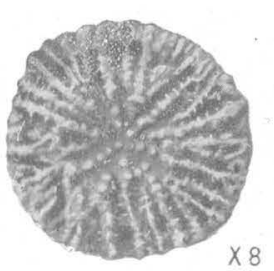

1

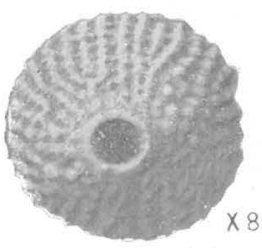

5

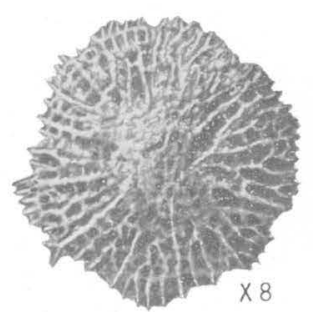

9

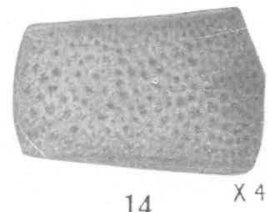

14

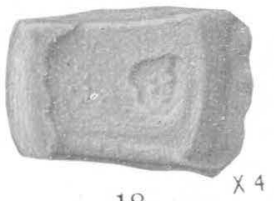

18

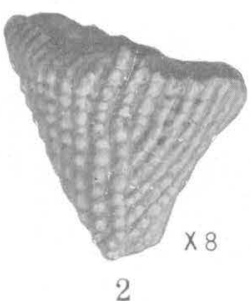

2

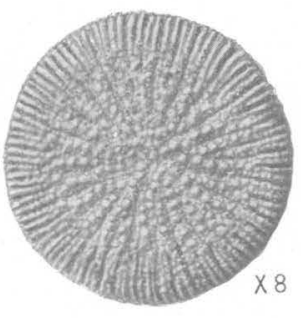

6

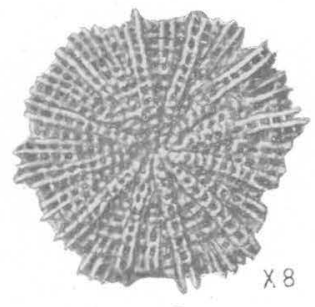

10

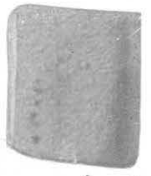

15
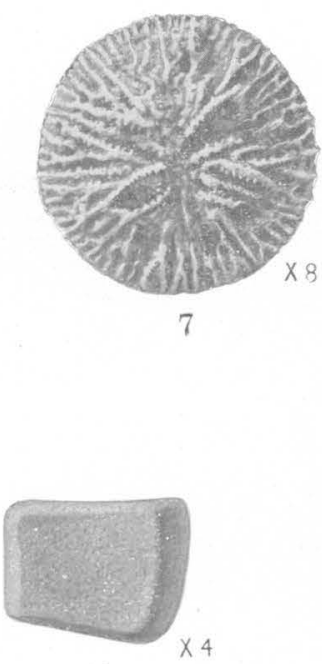

11

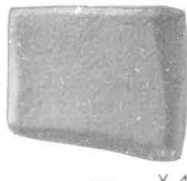

$16 \times 4$

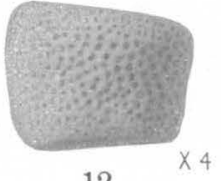

12

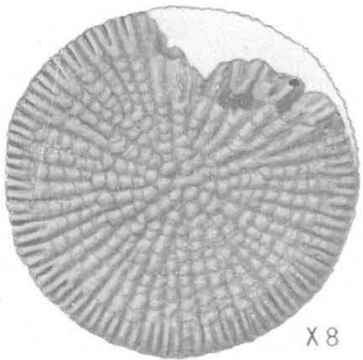

4
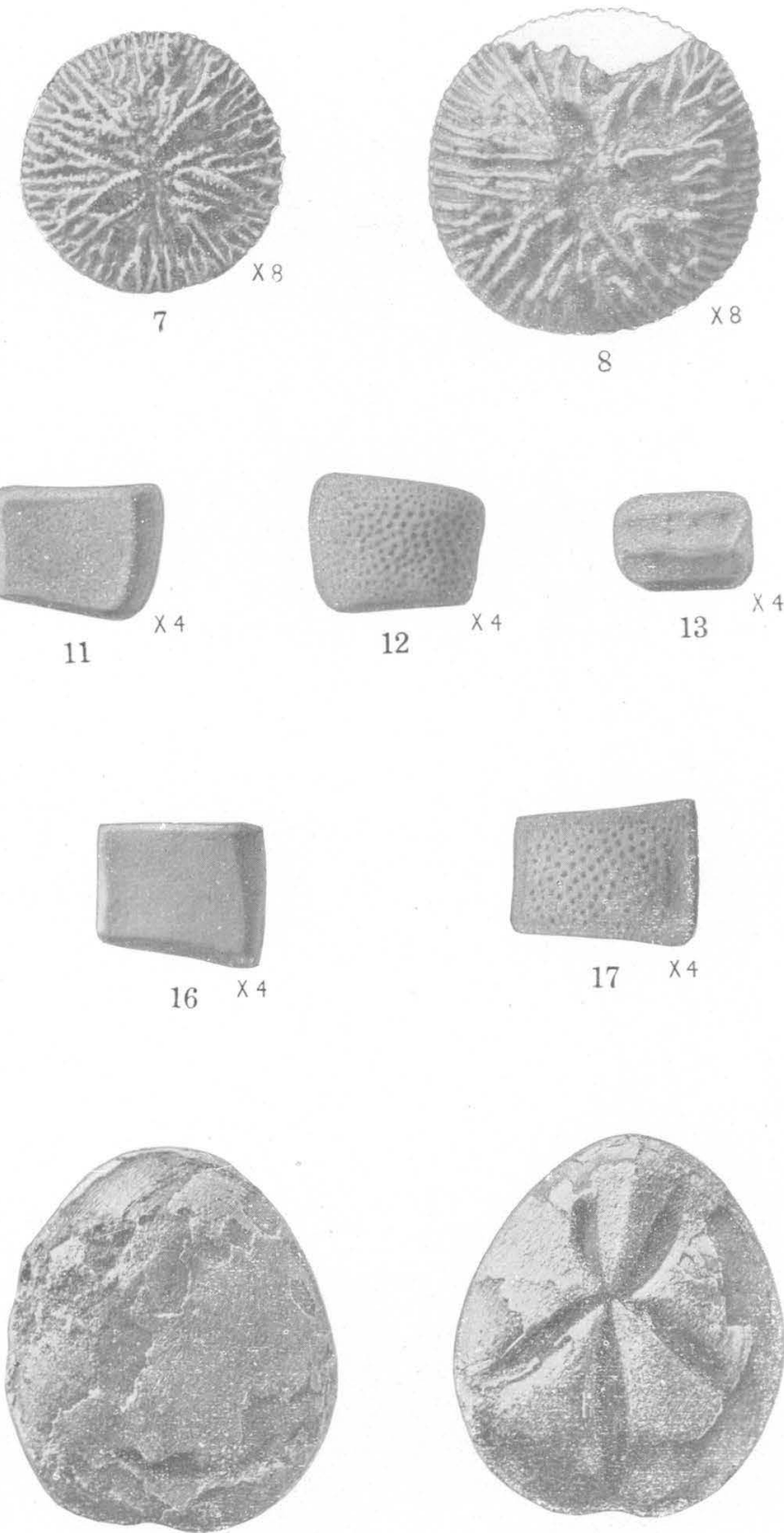

20

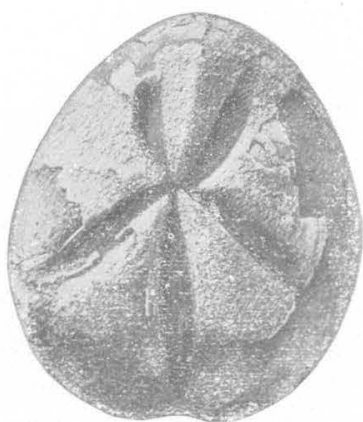

21

RIPLEY FOSSILS FROM COON CREEK, TENN. 
U. S. GEOLOGICAL SURVEY
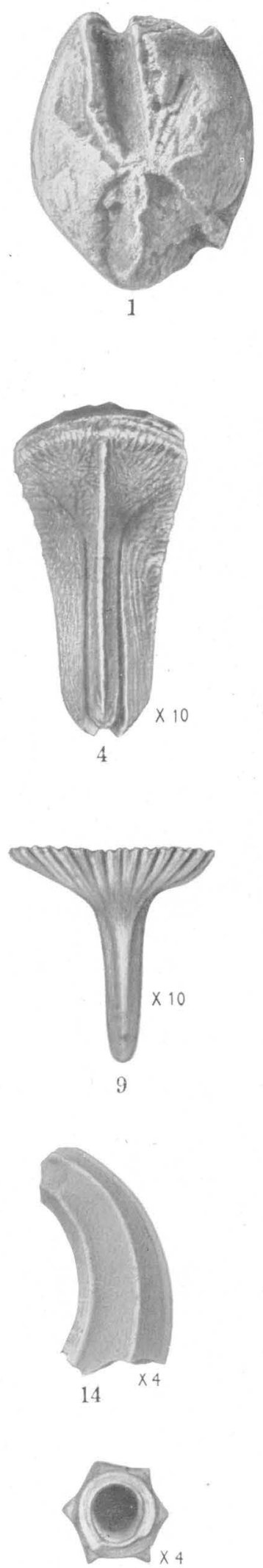

16
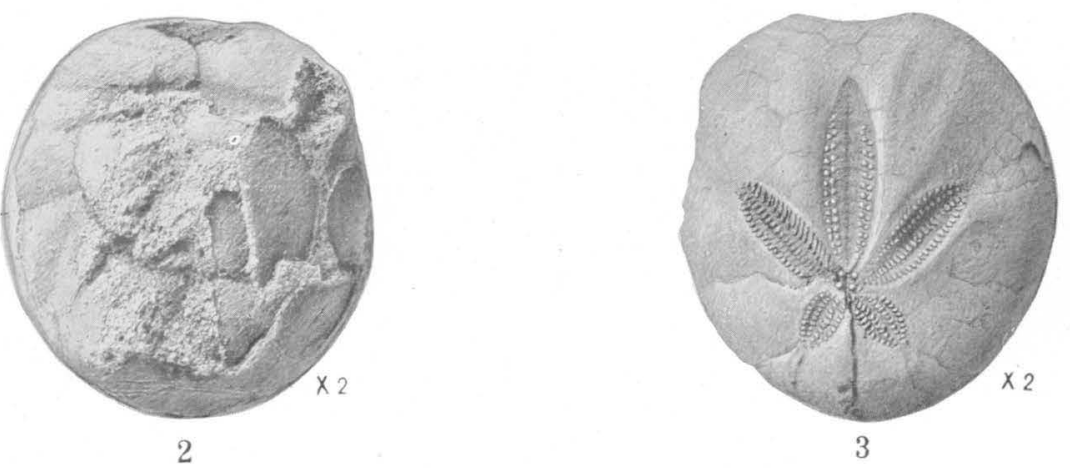
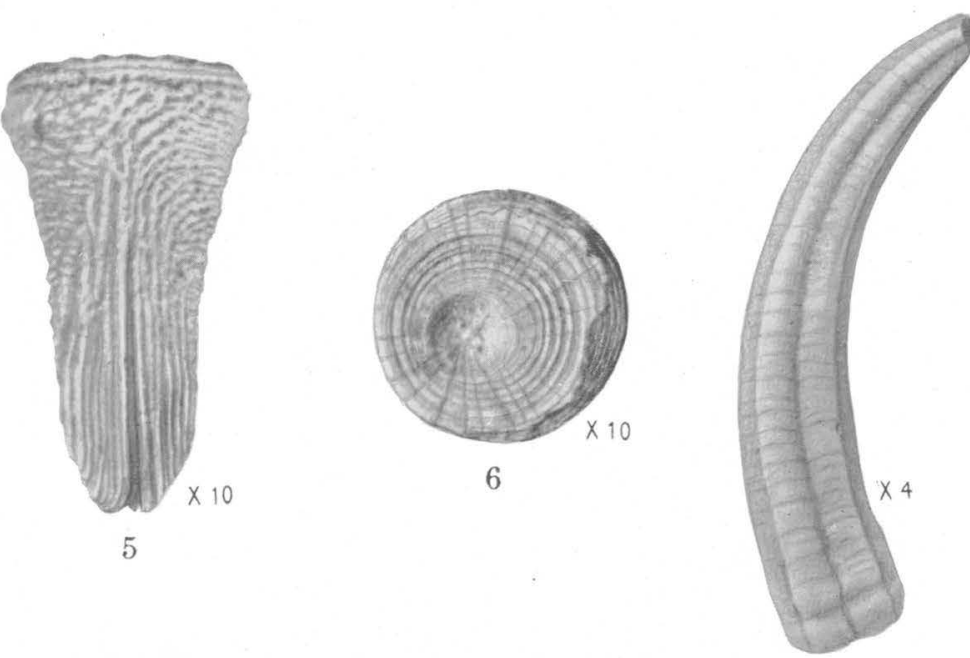

7

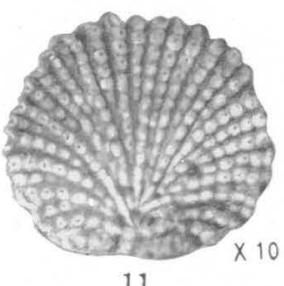

10

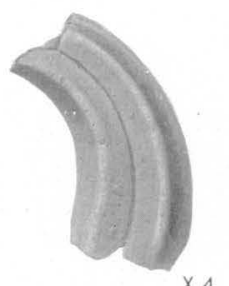

15

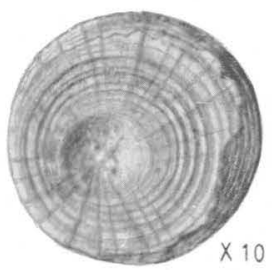

6

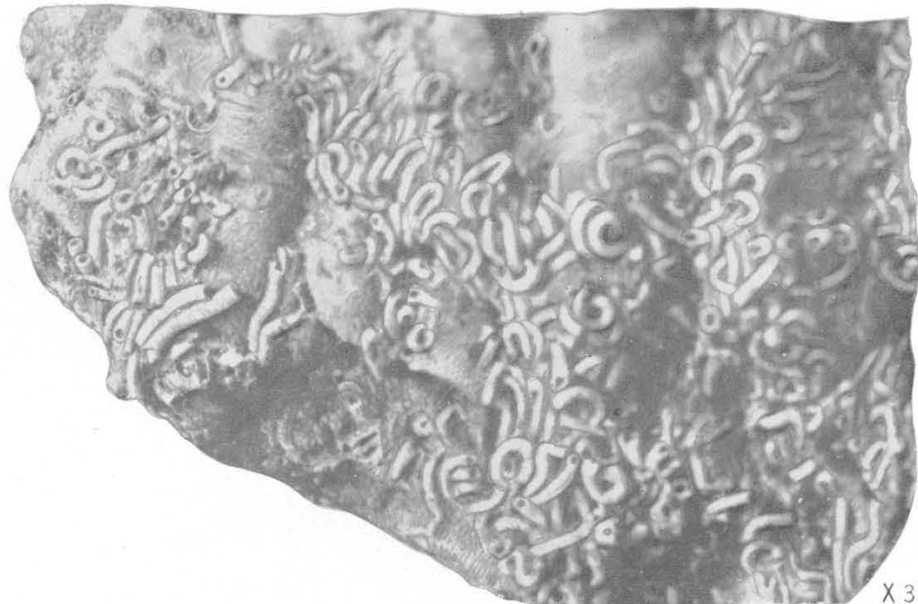

18
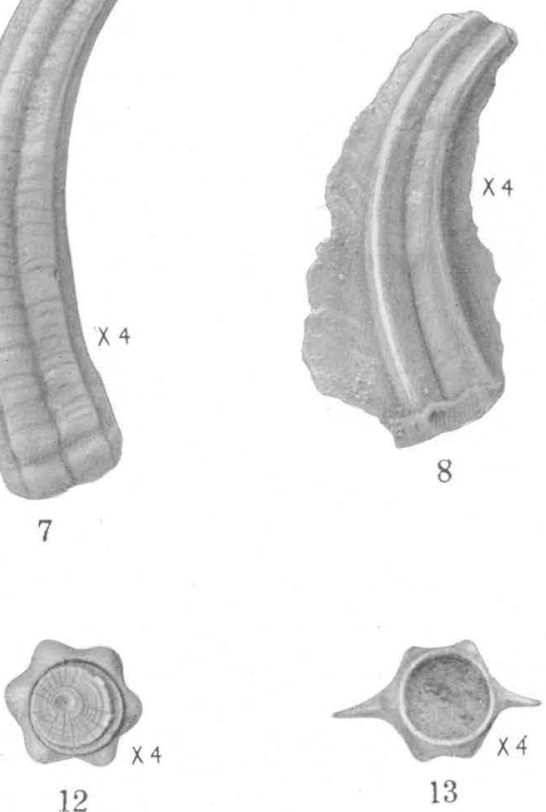

2

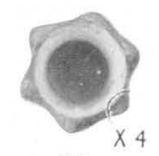

17

RIPLEY FOSSILS FROM COON CREEK, TENN. 


\section{PLATE II}

\section{Ripley Fossils from Coon Creek, Tenn.}

1. Hemiaster sp. (p. 29), imperfect specimen, top view. (U. S. Nat. Mus. catalog No. 32708.)

2, 3. Hemiaster lacunosus Slocum (p. 29). 2, Basal view; 3, top view. (U. S. Nat. Mus. catalog No. 32709.)

4-6. Hamulus onyx Morton, operculum (p. 30). 4, Front view; 5, side view; 6, basal view. (U. S. Nat. Mus. catalog No. 32460 .)

7, 12. Hamulus onyx Morton (p. 30). 7, Side view; 12, basal view showing operculum in place. (U. S. Nat. Mus. catalog No. 32460.)

8, 13. Hamulus squamosus Gabb (p. 31). 8, Side view; 13, apertural view. (U. S. Nat. Mus. catalog No. 32461.)

9-11. Hamulus sp., operculum (p. 31). 9, Front view; 10, rear view; 11, basal view. (U. S. Nat. Mus. catalog No. 32462. )

14-1\%. Hamulus angulatus Wade (p. 31). 14, Side view; 15, side view showing one of the axial grooves in the type of the species;

16, apertural view; 17, apertural view of the type of the species. (U. S. Nat. Mus. catalog No. 32459.)

18. Serpula pervermiformis Wade, n. sp. (p. 31), type of the species. (U. S. Nat. Mus. catalog No. 32710.) 
PLATE III

\section{Ripley Fossils from Coon Crefk, Tenn.}

1. Serpula adnata Wade, n. sp. (p. 31), type of species. (U. S. Nat. Mus. catalog No. 32711.)

2-5. Crania? americana Wade, n. sp. (p. 39). 2, Basal plate attached to shell of an Exogyra; 3, type of species attached to shell of an Exogyra; 4, apical view of type of species; $\mathbf{5}$, internal view of type of species. (U.S. Nat. Mus. catalog No. 32712.) 

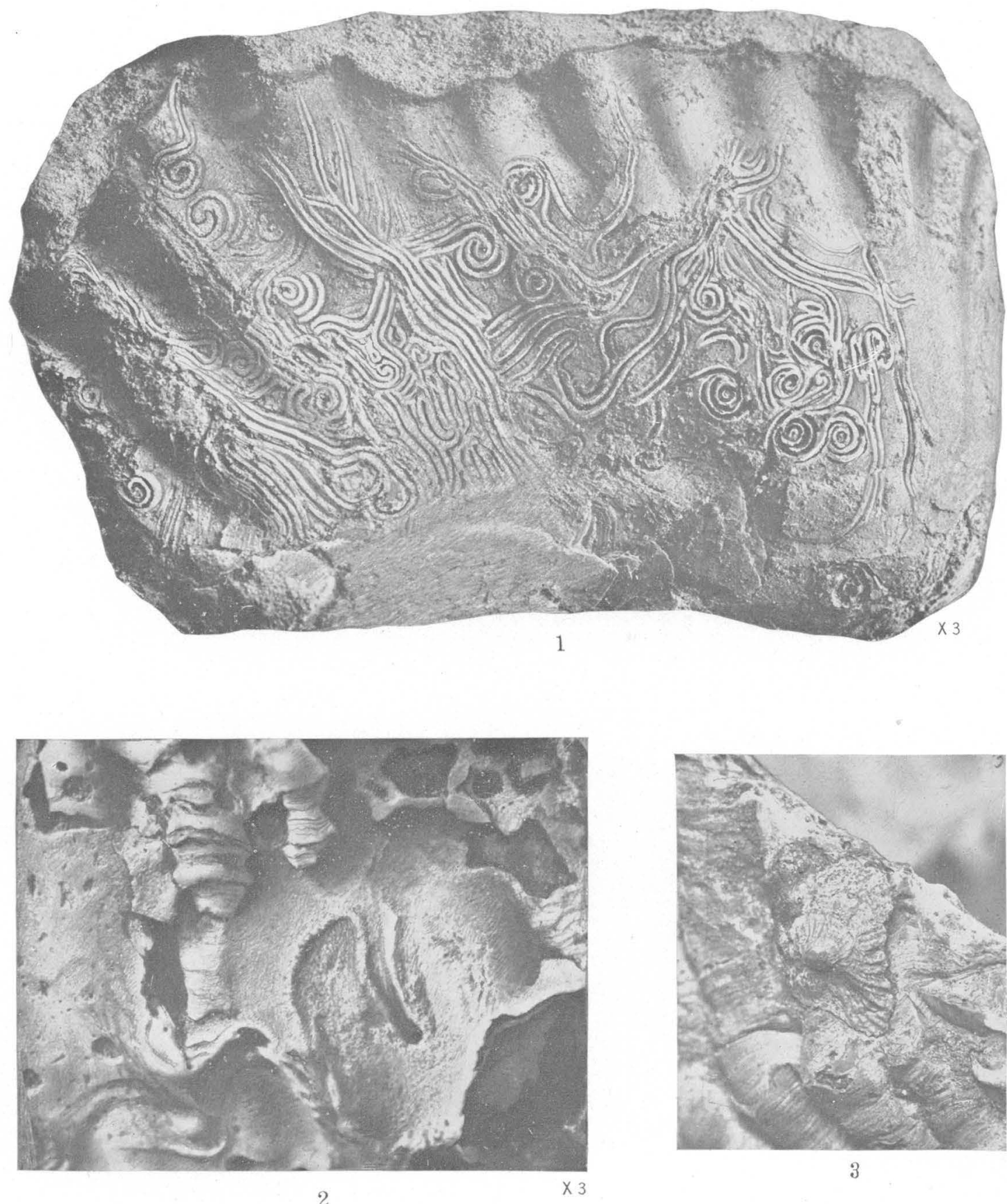

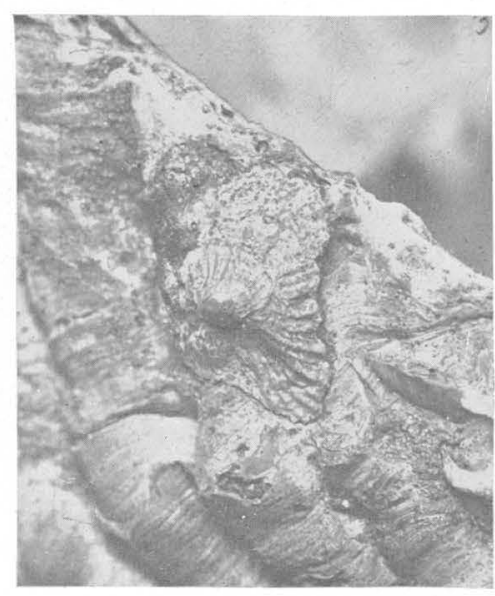

3

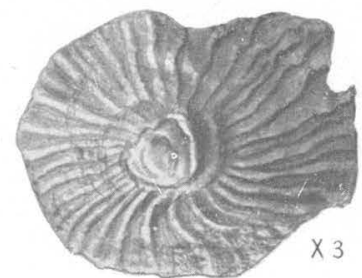

4

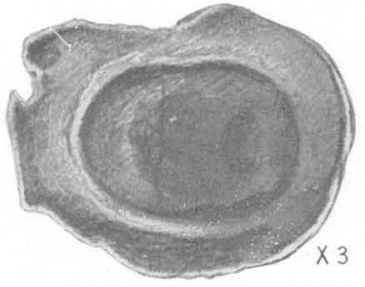

5

RIPLEY FOSSILS FROM COON CREEK, TENN. 

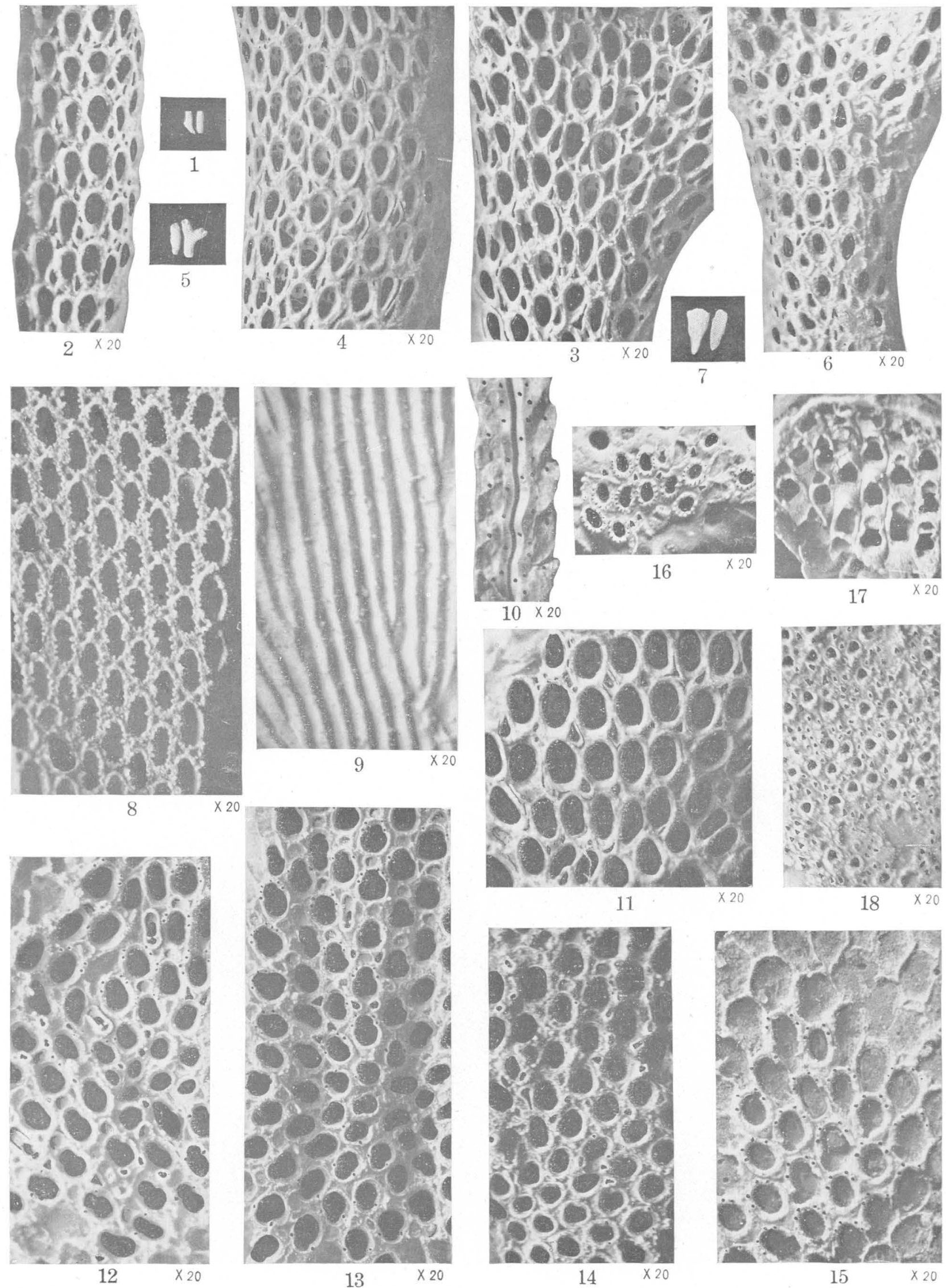

RIPLEY FOSSILS FROM COON CREEK, TENN. 


\section{PLATE IV}

\section{Ripley Fossils from Coon Creek, Tenn.}

1-4. Conopeum ovatum Canu and Bassler, n. sp. (p. 32). 1, Fragments of the free zoarium; 2 , surface of a subcylindrical fragment; $\mathbf{3}$, portion of a branched specimen; $\mathbf{4}$, surface showing the septulae and interopesial cavities with special walls. (U. S. Nat. Mus. catalog No. 69964.)

5, 6. Conopeum parviporum Canu and Bassler, n. sp. (p. 32). 5, The free semicylindrical zoarium; 6, the bifurcated specimen; several of the zooecia show regeneration. (U. S. Nat. Mus. catalog No. 69965.)

7-10. Conopeum prismaticum Canu and Bassler, n. sp. (p. 33). 7 , Two fragments of the free bilamellar fronds; 8 , surface showing zooecial termen provided with spines; 9 , dorsal side of a detached lamella; 10, longitudinal fracture of a lamella, exhibiting the independent zooecial walls and the arrangement of the septulae. (U. S. Nat. Mus. catalog No. 69967.)

11. Conopeum waddei Canu and Bassler, n. sp. (p. 32). The incrusting zoarium, showing the large dimensions and the nonconfluent interopesial cavities. (U. S. Nat. Mus. catalog No. 69953.)

12-14. Callopora anatina Canu and Bassler, n. sp. (p. 33). 12, The incrusting zoarium; ordinary zooecia with prominent duckbilllike avicularia; 13, zooecia in the vicinity of the ancestrula, with few large avicularia; 14, avicularian zooecia with spines rarely developed. (U. S. Nat. Mus. catalog No. 69961.)

15. Membraniporina crassimargo Canu and Bassler, n. sp. (p. 33), the incrusting zoarium exhibiting the four spines on the mural rim.. (U. S. Nat. Mus. catalog No. 69972.)

16. Callopora torquata Canu and Bassler, n. sp. (p..34), the minute incrusting zoarium with zooecia provided with small tuberosities on the mural rim. (U. S. Nat. Mus. catalog No. 69962.)

17. Ammalophora cretacea Canu and Bassler, n. sp. (p. 35), the incrusting zoarium. (U. S. Nat. Mus. catalog No. 69952.)

18. Mystriopora? stipata Canu and Bassler, n. sp. (p. 35), surface of incrusting zoarium. (U. S. Nat. Mus. catalog No. 69955.) 


\section{PLA'TE V}

\section{Ripley Fossils from Coon Creek, Tenn.}

1. Alderina nelsoni Canu and Bassler, n. sp: (p. 33), the incrusting type specimen, preserving several calcified zooecia. (U. S. Nat. Mus. catalog No. 69969.)

2-4. Amphiblestrum denticulatum Canu and Bassler, n. sp. (p. 34). 2, Portion of a zoarium exhibiting ordinary ovicelled and regenerated zooecia and interzooecial avicularia; 3 , ovicelled zooecia; 4, worn portion, illustrating the dietellae. (U. S. Nat. Mus. catalog No. 69956.)

5. Callopora sulcata Canu and Bassler, n. sp. (p. 34), zooecia with the separating furrows characteristic of the species. (U. S. Nat. Mus. catalog No. 69957.)

6-18. Frurionella parvipora Canu and Bassler, n. sp. (p. 35). 6, Zoarial fragments; 7 , a specimen having small interopesia avicularia, some of which open into the opesium; 8, zooecial surface with the two frontal pores replaced by a longitudinal slit; 9, surface of specimen showing three kinds of zooecia-(1) elongate zooecia narrowed at the level of articulation of the opercular valve, (2) ovicelled zooecia, and (3) ordinary zooecia; 10, specimen bearing zooecia without oral avicularia; 11, edge of zoarium showing zooecia transformed into avicularia; 12, a specimen with granulated frontal; the transverse opesia belong to ovicelled zooecia; 13, a specimen in which many small frontal pores replace the usual one or two larger pores; 14, longitudinal thin section through a large salient opesiular avicularium; 15, longitudinal section through an ovicelled zoarium (ol, olocystal wall; op, opesium; ov, òvicell; oa, opesial acivularium); 16, meridian thin section; 17, transverse thin section cutting a marginal zooecium and illustrating the olocystal structure; 18, another transverse thin section cutting the zooecia $(z)$ and an oral avicularium $(a)$. (U. S. Nat. Mus. catalog No. 69959.)

19, 20: Foveolaria elliptica Busk (p. 35). 19, Longitudinal section showing an ovicell and an avicularium; 20, an articulated operculum. These figures are introduced from Levinsen to show identity of structure with that of Frurionella. 

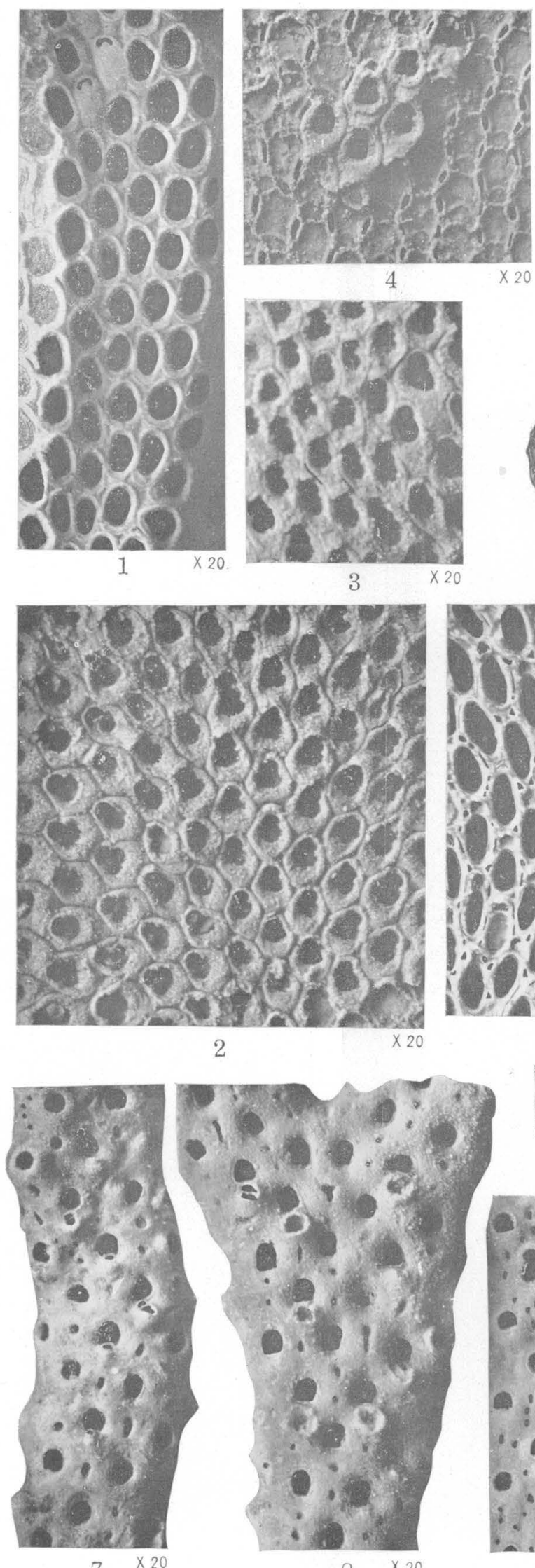

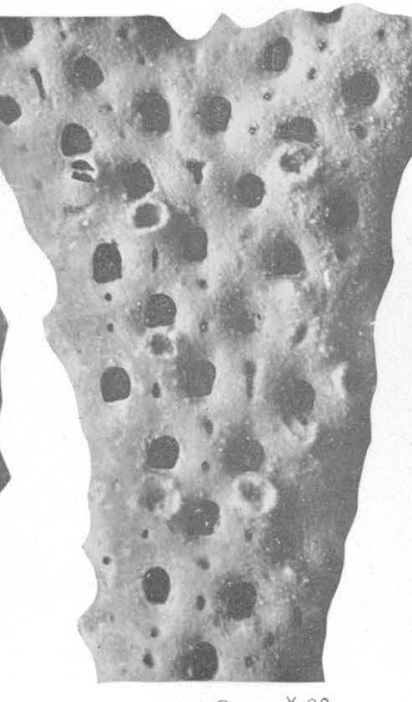

$8 \times 20$

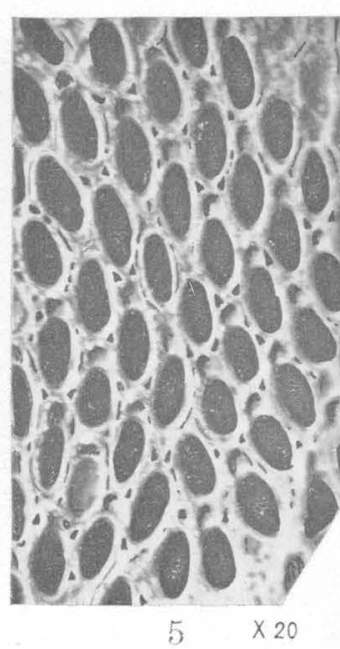

IIII

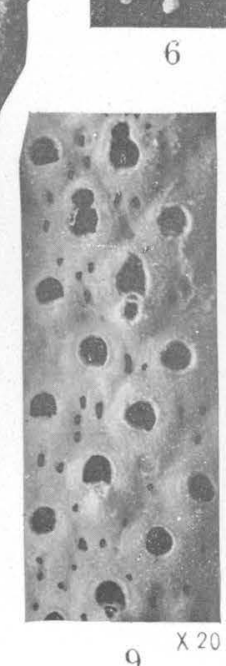

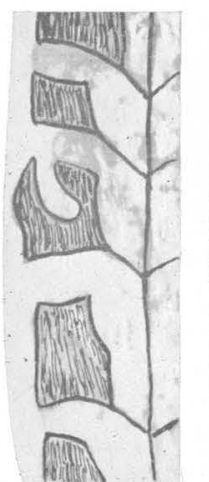
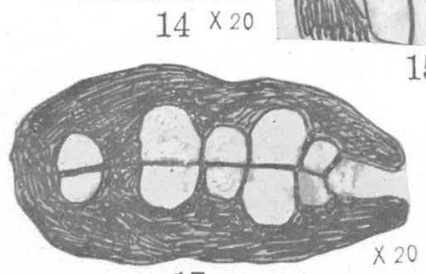

17
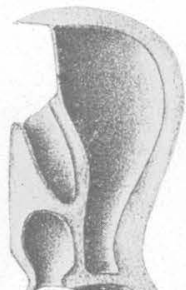

19
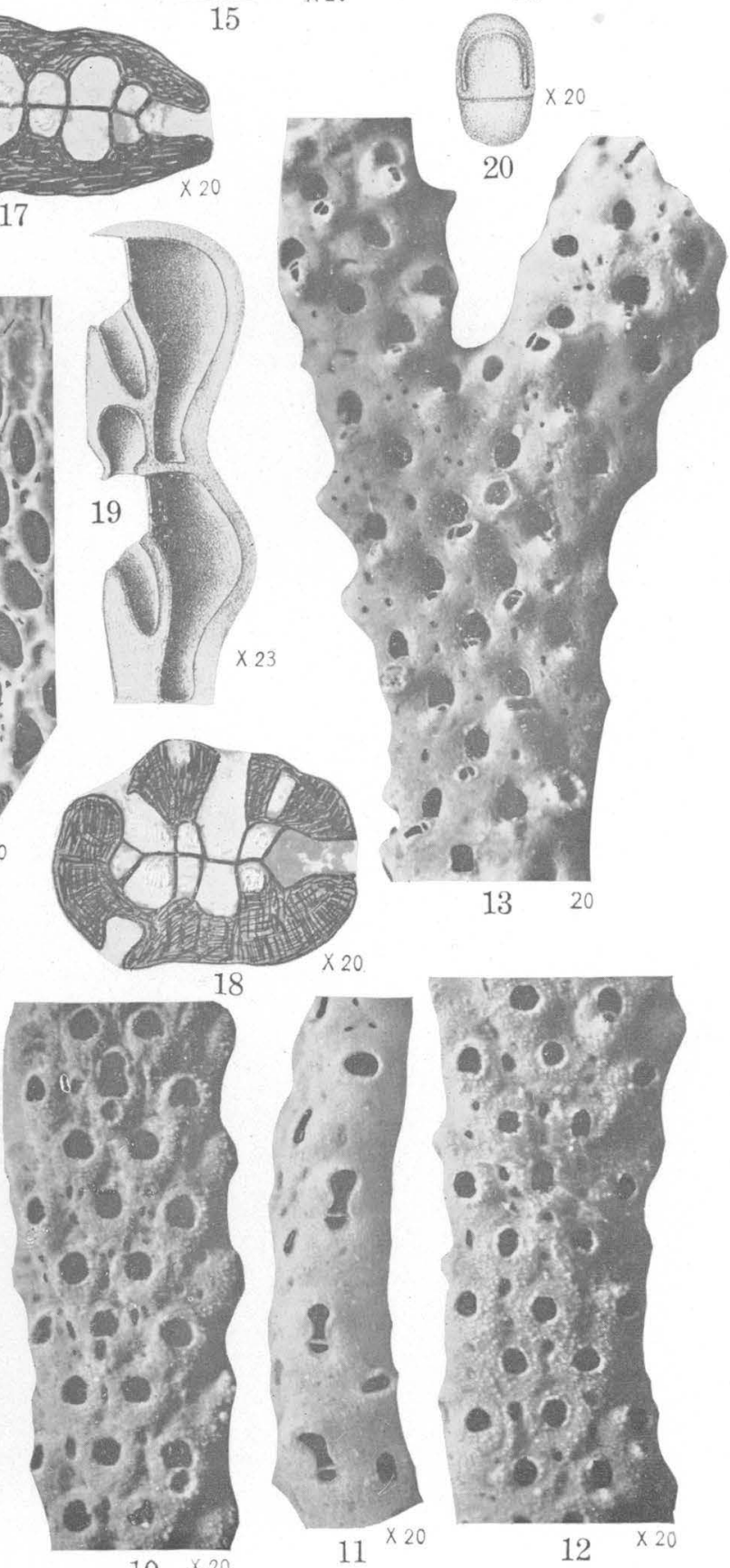

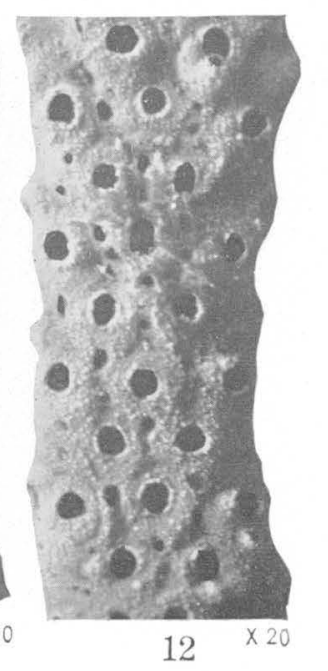

RIPLEY FOSSILS FROM COON CREEK, TENN. 

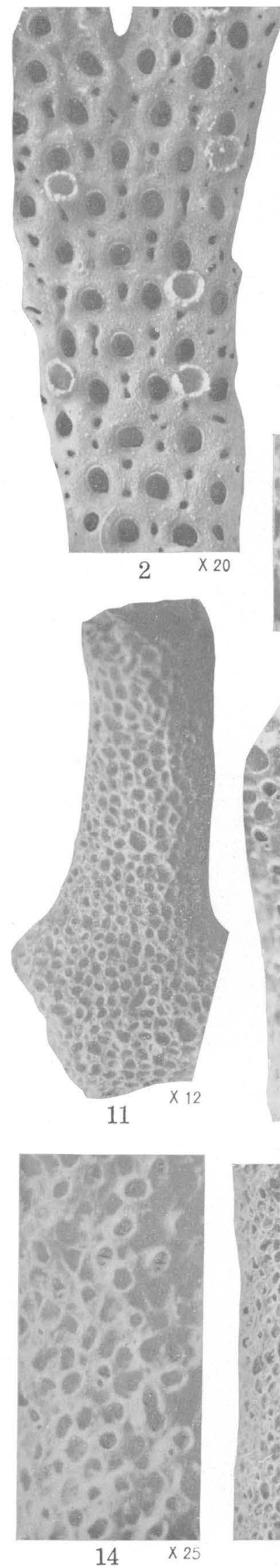
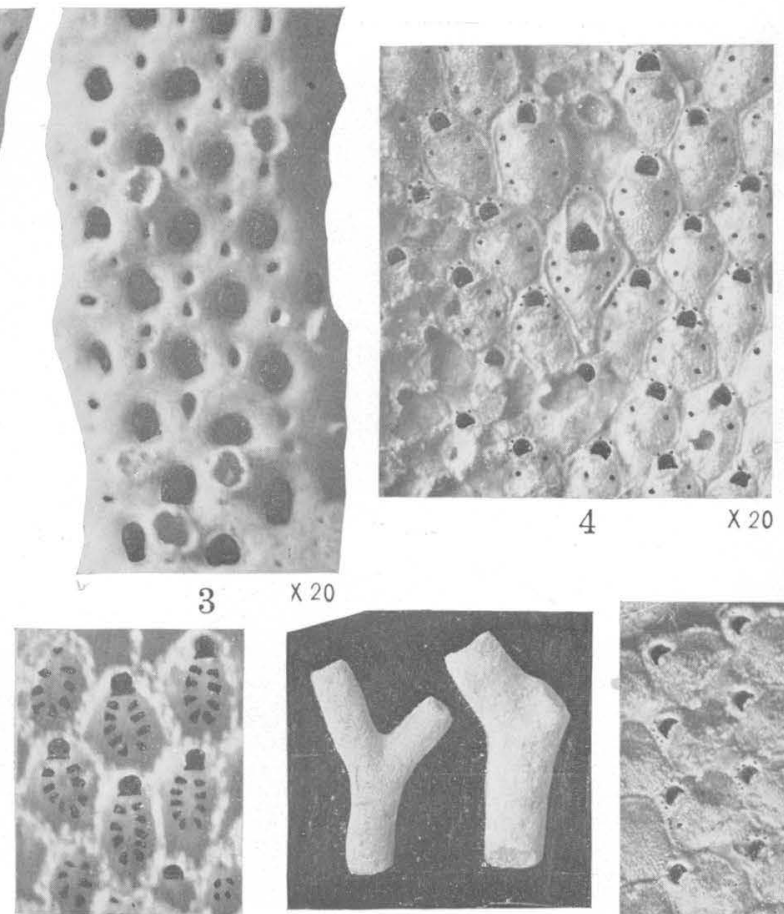

$9 \times 20$

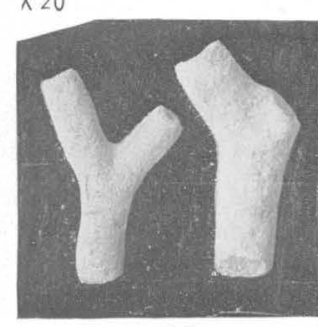

10

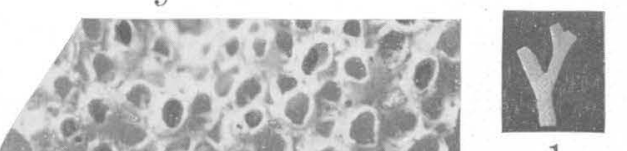

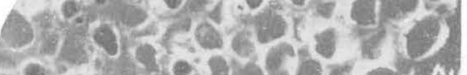

r. for be

- torsers

a of al)

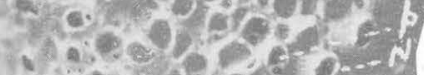

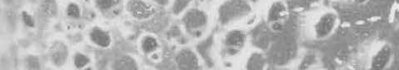

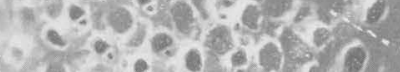

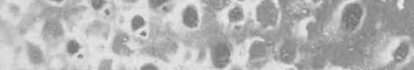

The $00^{3}, 13$

7n:50)

16.0.

12
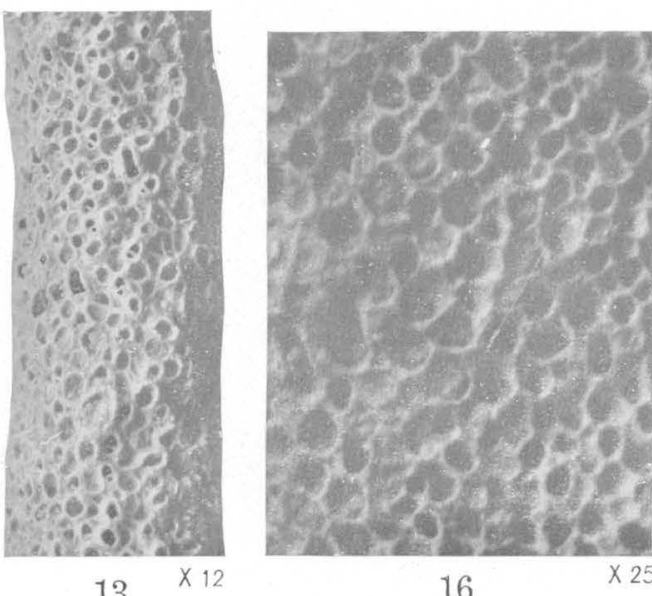

16
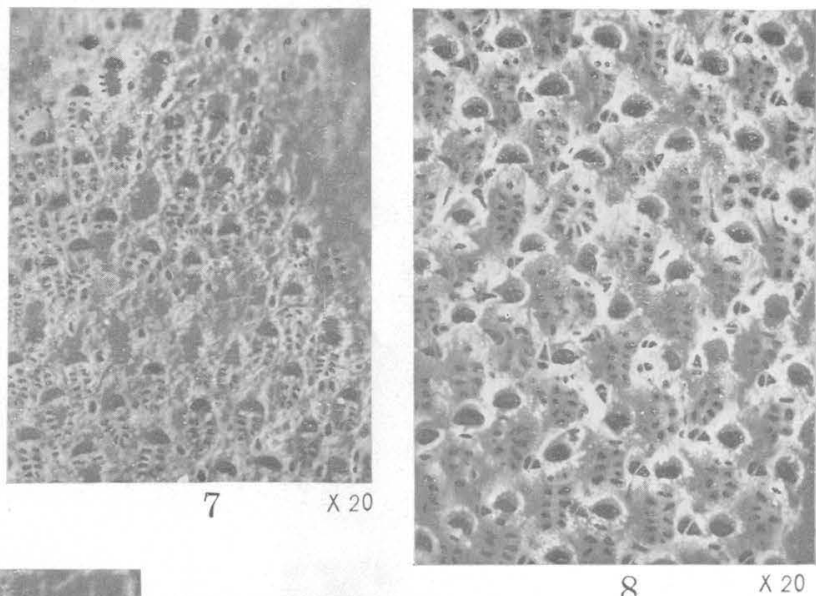

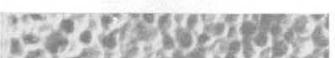

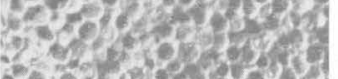

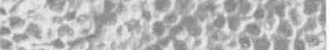

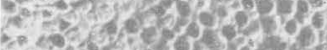

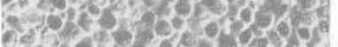

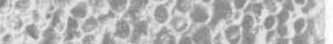

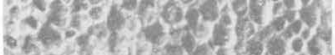

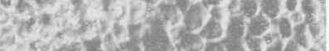

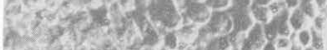

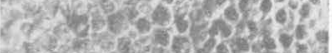

Tho 10 ret

2.7.

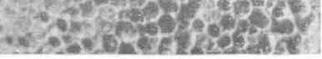

15

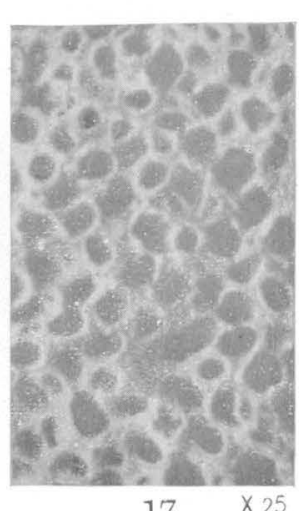

17

RIPLEY FOSSILS FROM COON CREEK, TENN. 


\section{PLATE VI}

\section{Ripley Fossils from Coon Creek, Tenn.}

1-3. Frurionella grandipora Canu and Bassler, n. sp. (p. 36). 1, The free compressed zoarium; 2, surface showing that the opesium is orbicular or transverse and is surrounded by a thin mural rim; 3, another photograph of the same specimen, showing an opesium that is without the mural rim. (U. S. Nat. Mus. catalog No. 69958.)

4-6. Micropoía baccata Canu and Bassler, n. sp. (p. 36). 4, The incrusting zoarium; an avicularian zooecium is present among the ordinary zooecia; 5, a specimen illustrating the spicules protecting the ovicell; $\mathbf{6}$, ancestrular area; the ancestrula engenders large zooecia proximally and small ones distally. (U. S. Nat. Mus. catalog No. 69954.)

\%. Membraniporella irregularis Canu and Bassler, n. sp. (p. 36). Shows the incrusting zoarium. (U. S. Nat. Mus. catalog No. 69957.)

8, 9. Gephyrotes lamellaria Canu and Bassler, n. sp. (p. 37). 8, Surface of zoarium, illustrating the variations in shapes of the spiramen; 9, view of the interior of the zooecia showing two very small cardelles in the aperture. (U. S. Nat. Mus. catalog No. 69968.)

10-1\%. Dysnoetopora celleporoides Canu and Bassler, n. sp. (p. 37). (See also Pl. VII, 10-12.) 10, Examples of the freebranching zoarium; 11, a specimen that has the surface somewhat altered; 12, a well-preserved specimen showing the various types of zooecia ( $n$, normal; $p$, proliferating zooecium; $i$, incomplete zooecium; $a v$, avicularian zooecium); 13, another well-preserved specimen illustrating the essential characters of the species; 14, the same specimen, exhibiting the large avicularian tubes; 15, 16, the most common aspect of the species; 17, another aspect of the species. (U. S. Nat. Mus. catalog No. 69960.) 


\section{PLATE VII}

\section{Ripley Fossils from Coon Creek, Tenn.}

1, 2. Polyascosoecia tripora Canu and Bassler, n. sp. (p. 38). Show the free cylindrical-branched zoarium. (U. S. Nat. Mus. catalog No. 69963.)

3-7. Heteropora tennesseensis Canu and Bassler, n. sp. (p. 38). 3, Fragments of the ramose zoarium; 4, a well-preserved speci. men showing zones of mesopores; $\mathbf{5}$, a branch that shows remains of the ovicell; $\mathbf{6}$, extremity of a branch; 7, surface. (U. S. Nat. Mus. catalog No. 69971.)

8. Berenicea papillosa Reuss (p. 38). Shows the incrusting zoarium. (U. S. Nat. Mus. catalog No. 69970.)

9. Actinopora radiobifurcata Canu and Bassler, n. sp. (p. 38). Shows the discoid incrusting zoarium with bifurcated fascicles. (U. S. Nat. Mus. catalog No. 69966.)

10-12. Dysnoetopora celleporoides Canu and Bassler, n. sp. (p. 37). (See also Pl. VI, 10-17). 10, Tangential thin section; 11, transverse thin section showing the sinuosity of the tubes and their abnormal orientation; 12, longitudinal thin section illustrating in the center the gemmation by internal partitions. (U. S. Nat. Mus. catalog No. 69960.) 

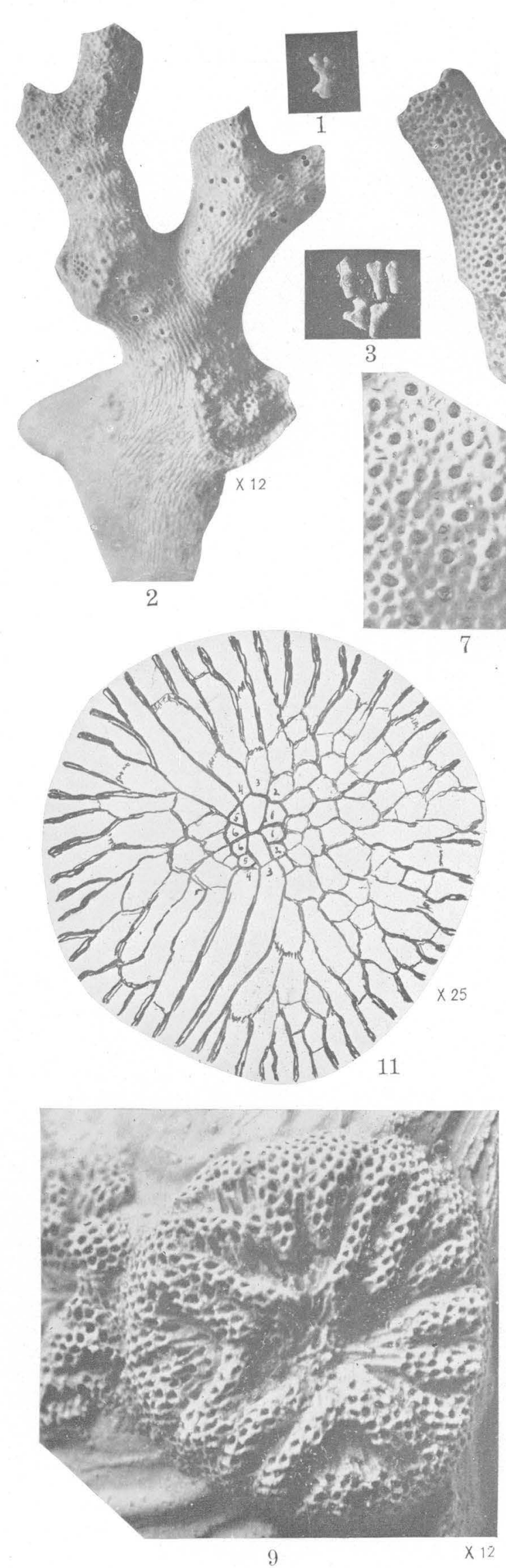

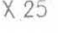
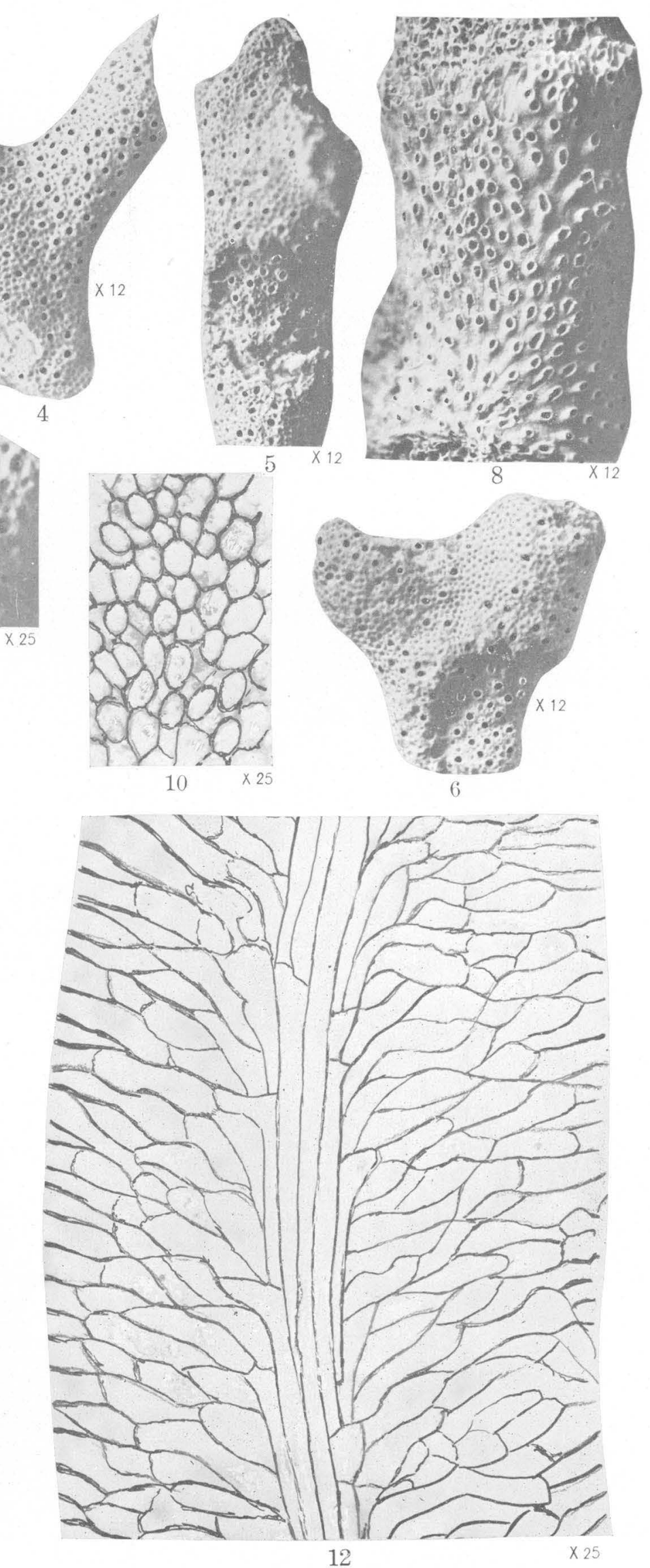

RIPLEY FOSSILS FROM COON CREEK, TENN. 
U. S. GEOLOGICAL SURVEY

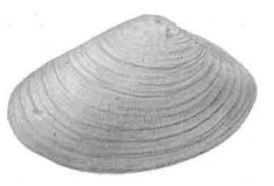

1

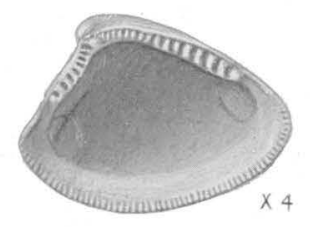

5

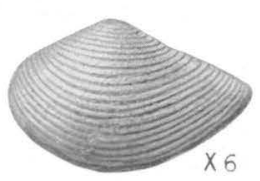

9

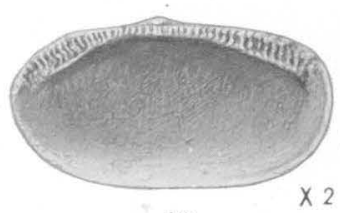

13

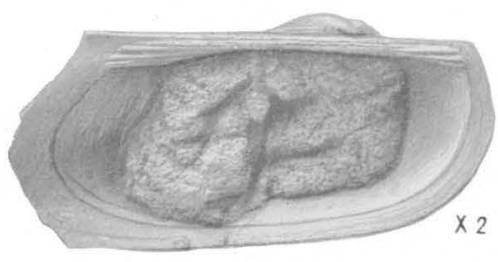

17
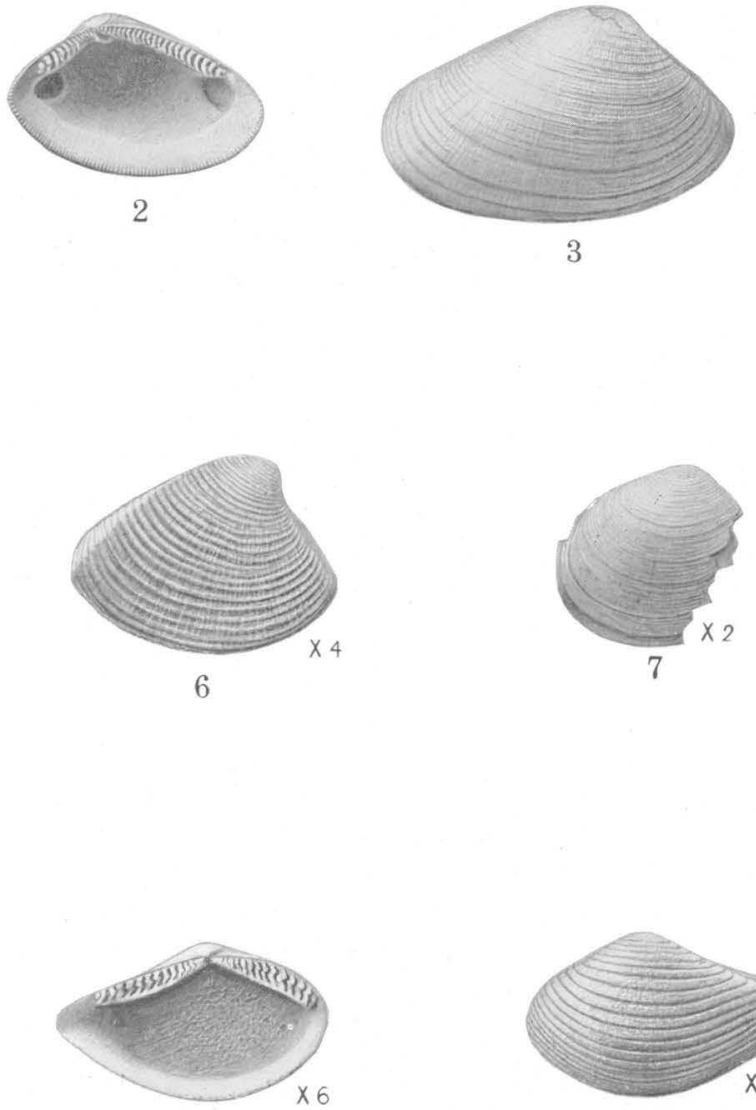

10

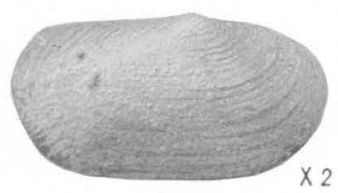

14

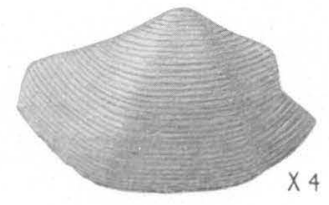

15

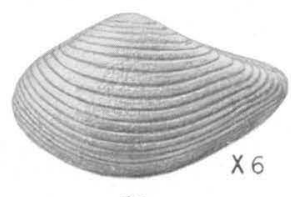

11
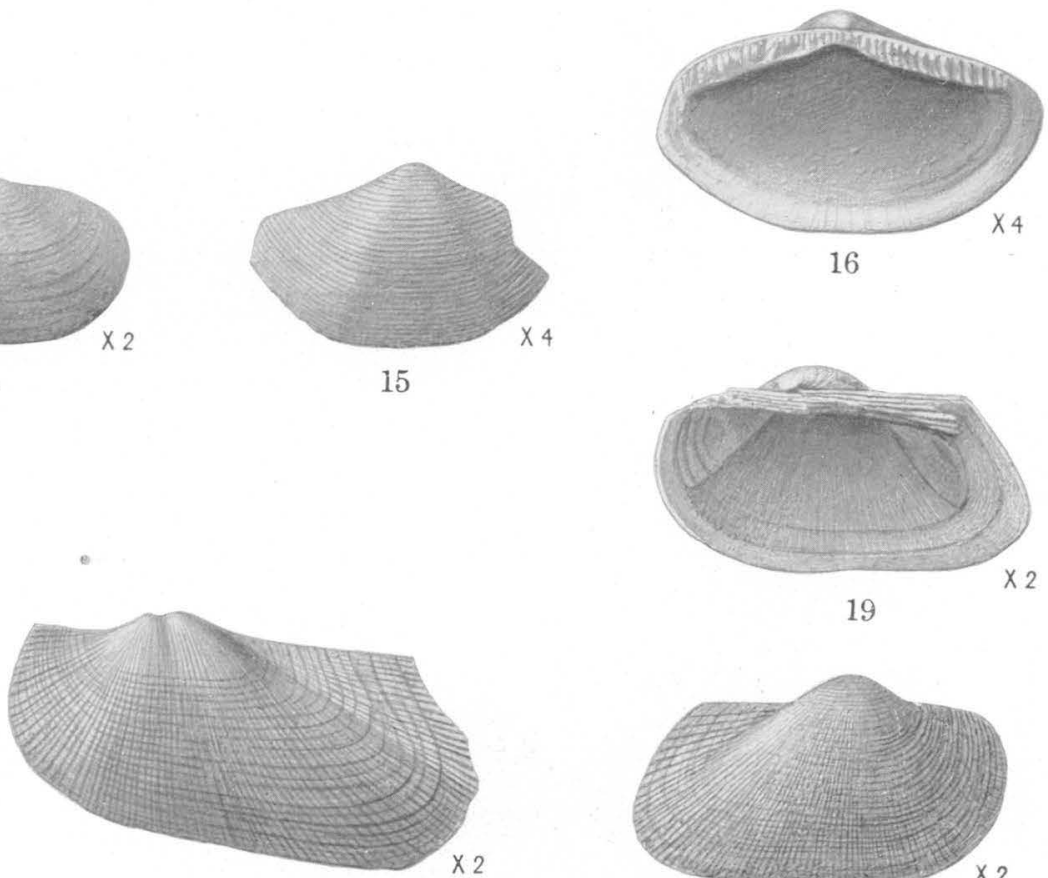

18
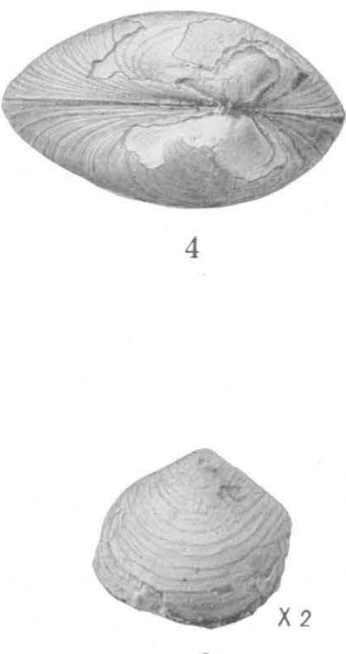

8

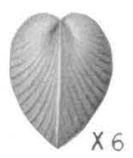

12 


\section{PLATE VIII}

\section{Ripley Fossils from Coon Creek, Tenn.}

1-4. Nucula percrassa Conrad (p. 39). 1-3, Left valve (1, 3, exterior views; $\boldsymbol{2}$, interior view); $\mathbf{4}$, dorsal view of two valves attached (U. S. Nat. Mus. catalog No. 32713.)

5, 6. Nucula amica Gardner, left valve (p. 40). 5, Interior view; 6, exterior view. (U. S. Nat: Mus. catalog No. 32714. )

7, 8. Nucula microconcentrica Wade, n. sp. (p. 40). 7, Left valve of type, exterior view; 8, exterior view of another left valve. (U. S. Nat. Mus. catalog No. 32715.)

9. Leda australis Wade, n. sp. (p. 41), left valve of type, exterior view. (U. S. Nat. Mus. catalog No. 32716.)

10-12. Leda whitfieldi Gardner (p. 41). 10, 11, Left valve (10, interior view; 11, exterior view); 12, posterior view of both valves attached. (U. S. Nat. Mus. catalog No. 32717.)

13, 14. Yoldia longifrons (Conrad), left valve (p. 41). 13, Interior view;"14, exterior view. (U. S. Nat. Mus. catalog No. 32718.) 15, 16. Yoldia multiconcentrica Wade, n. sp. (p. 42). 15, Exterior view of left valve of type; 16, interior view of a left valve. (U. S. Nat. Mus. catalog No. 32719.)

17, 18. Nemodon eufaulensis (Gabb), left valve (p. 42). 17, Interior view; 18, exterior view. (U. S. Nat. Mus. catalog No. 32720.)

19, 20. Nemodon stantoni Gardner, right valve (p. 43). 19, Interior view; 20, exterior view. (U. S. Nat. Mus. catalog No. 32721. ) $.106913-26 \dagger-15$. 
PLATE IX

\section{Ripley fossils from Coon Creek, Tenn.}

1, 2. Nemodon grandis Wade, n. sp., left valve of type (p. 43). 1, Interior view; 2, exterior view. (U. S. Nat. Mus. catalog.No. 32722.)

3, 4, 6, 7. Cucullaea vulgaris Morton, right valves (p. 43). 3, 6, Interior, views; 4, 7 , exterior views. (U. S. Nat. Mus. catalog No. 32723.)

5. Cucullaea littlei (Gabb) (p. 45), exterior view of left valve of specimen from the Ripley formation at Eufaula, Ala. (U. S. Nat. - Mus. catalog No. 21142.)

202 

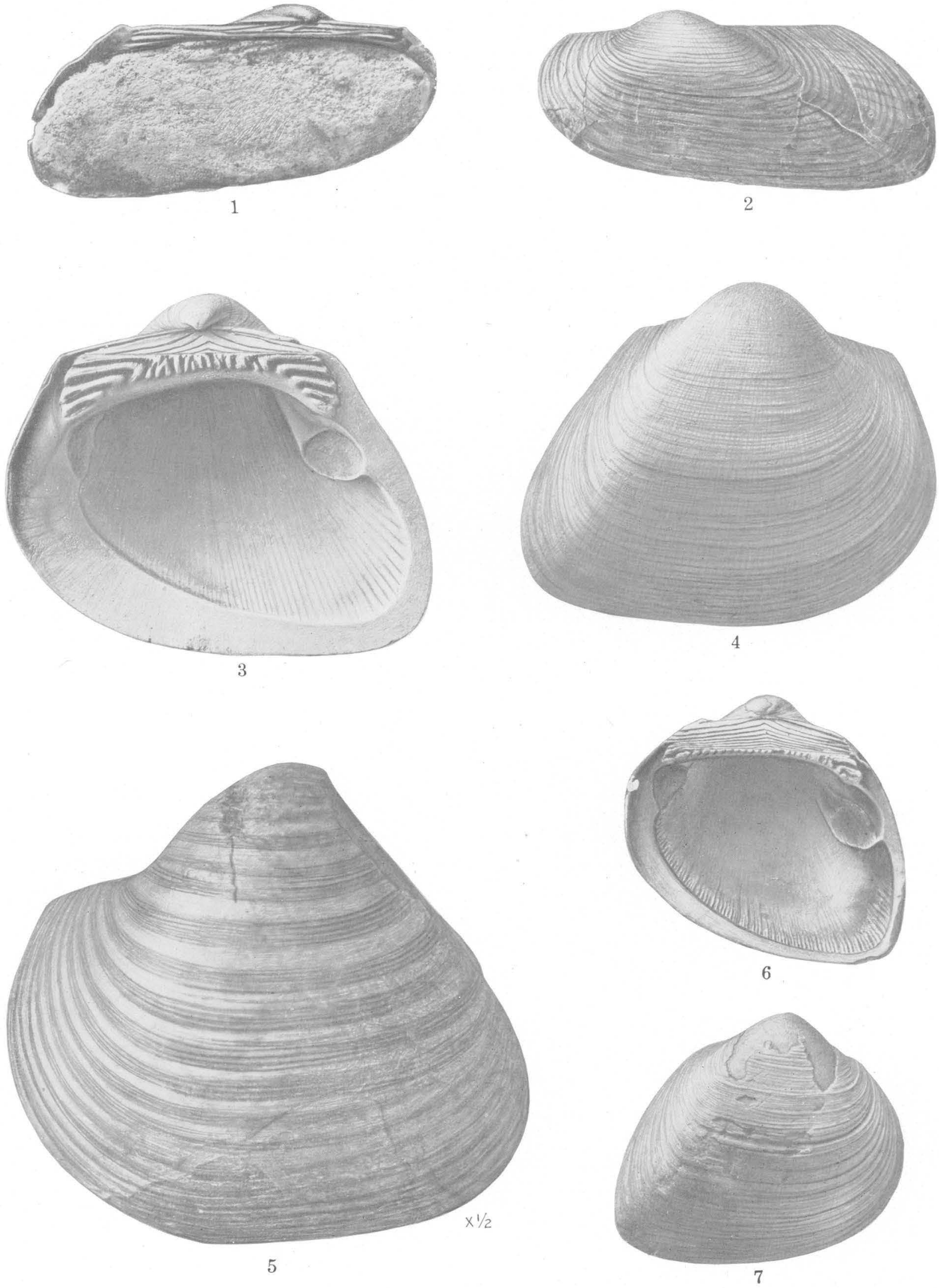

RIPLEY FOSSILS FROM COON CREEK, TENN. 
U. S, GEOLOGICAL SURYEY

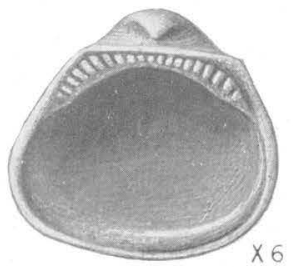

1

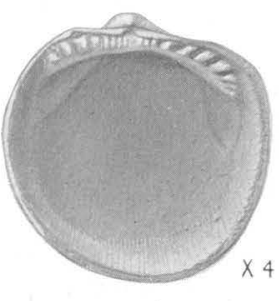

4
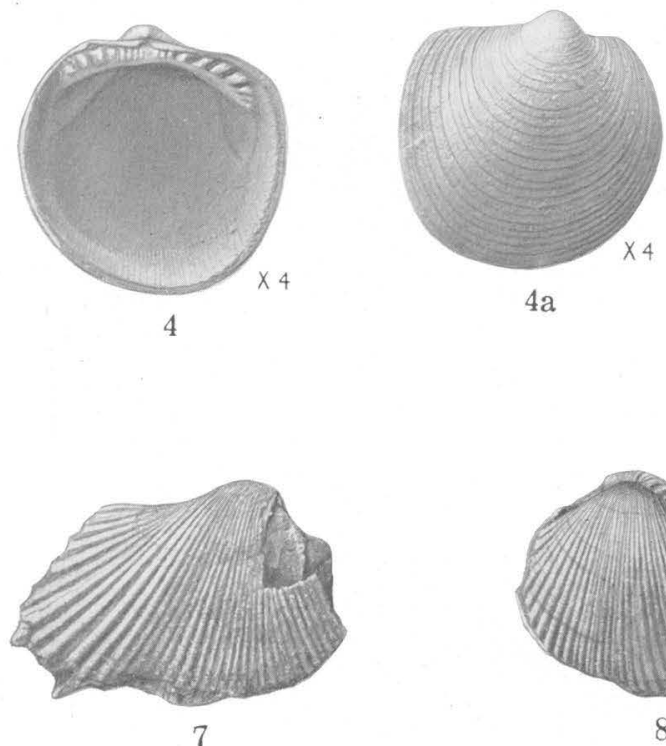

$4 \mathrm{a}$

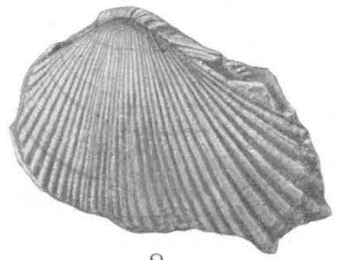

8

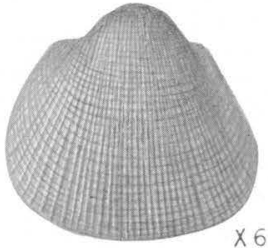

2

PROFESSIONAL PAPER 137 PLATE $\mathrm{x}$
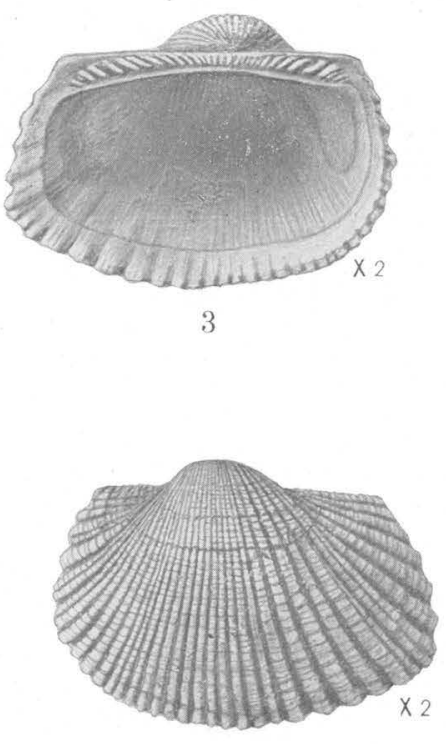

6
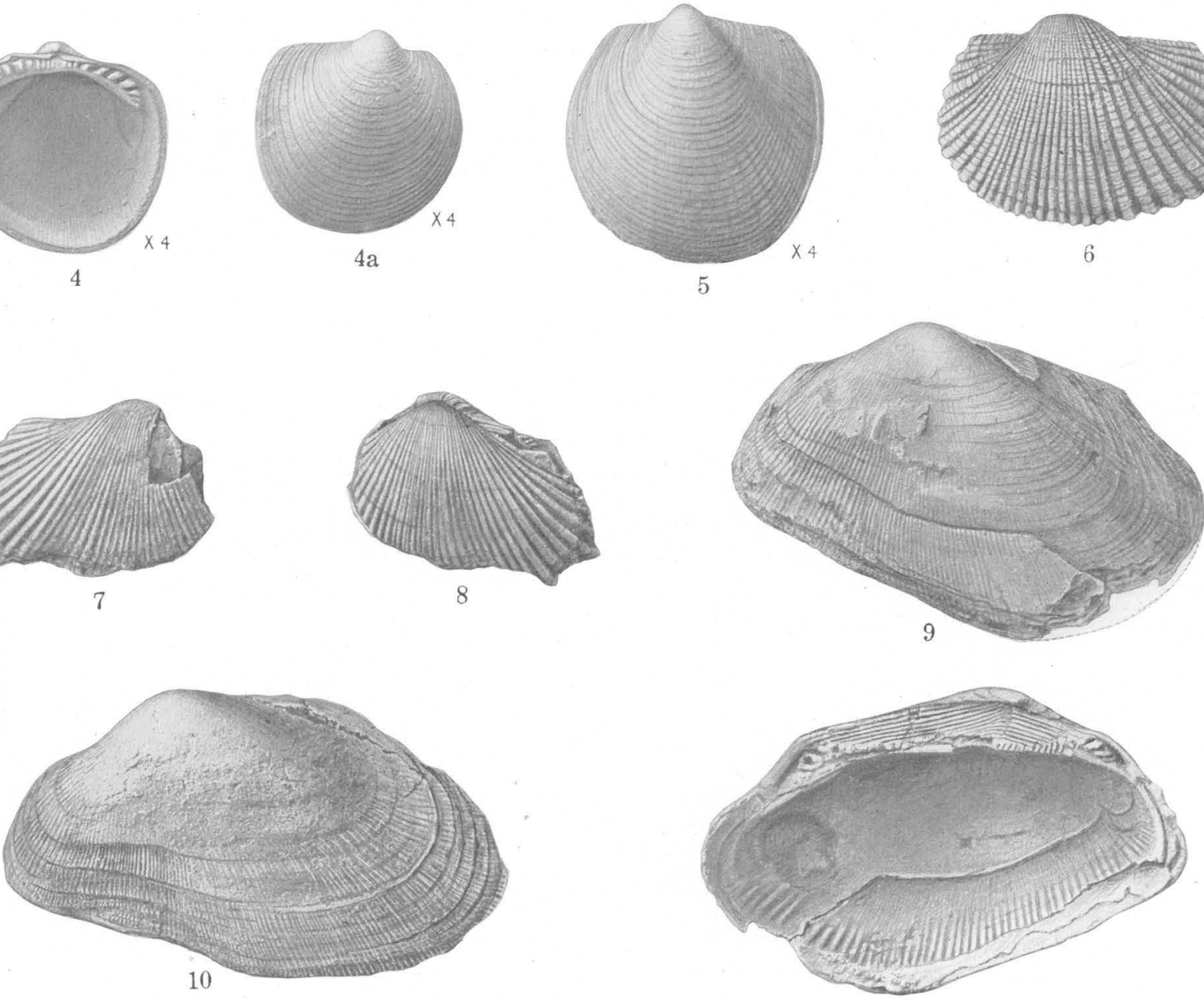

11
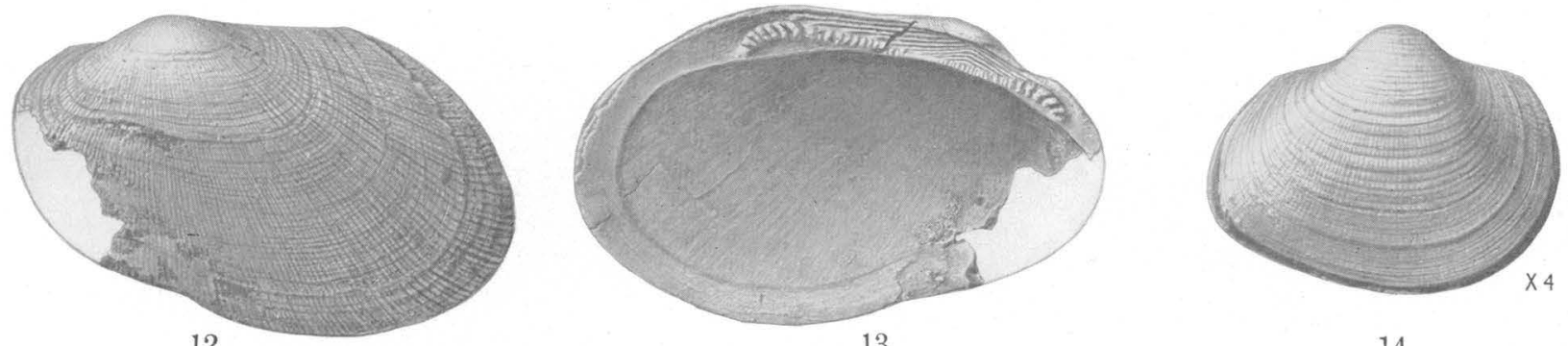

14

RIPLEY FOSSILS FROM COON CREEK, TENN. 


\section{PLATE X}

\section{Ripley Fossils from Coon Creek, Tenn.}

1, 2. Limopsis perbrevis Wade, n. sp., left valve (p. 45). 1, Interior view; 2, exterior view. (U. S. Nat. Mus. catalog No. 32724.)

3, 6. Arca mcnairyenisis Wade, n. sp., left valve of type (p. 46). 3, Interior view; 6, exterior view. (U. S. Nat. Mus. catalog No. 32725.)

4, 4a, 5. Limopsis meeki Wade, n. sp. (p. 45). 4, 4a, Left valve of type (4, interior view; 4a, exterior view); 5, exterior view of a right valve. (U. S. Nat. Mus. catalog No. 32726.)

7, 8. Arca securiculata Wade, n. sp. (p. 46). 7, Exterior view of right valve of type; 8, exterior view of left valve of type. (U. S. Nat. Mus. catalog No. 32727.)

9-11. Barbalia fractura Wade, n. sp. (p. 46). 9, Exterior view of left valve of type; 10, exterior view of a left valve; 11, interior view of valve of type. (U. S. Nat. Mus. catalog No. 32728.)

12, 13. Barbatia cochlearis Wade, n. sp., left valve of type (p. 46). 12, Exterior . view; 13, interior view. (U. S. Nat. Mus. catalog No. 32729.)

14. Barbatia saffordi (Gabb) (p. 47), exterior view of right valve. (U. S. Nat. Mus. catalog No. 32730.) 


\section{PLATE XI}

\section{Ripley fossils from Coon Creek, Tenn.}

1, 2. Barbatia saffordi (Gabb), right valve (p. 47). 1, Interior view; 2, exterior view. (U. S. Nat. Mus. catalog No. 32730.) 3, 6. Postligata crenata Wade, n. sp., right valve of type (p. 48). 3, Exterior view; 6, interior view. (U. S. Nat. Mus. catalog No. 32731.)

4, 5. Arca pergracilis Wade, n. sp., left valve of type (p. 48). 4, Interior view; 5, exterior view. (U. S. Nat. Mus. catalog No. 32732.)

7, 8. Glycimeris subcrenata Wade, n. sp., right valve of the type (p. 4S). 7, Exterior view; 8, interior vicw. (U. S. Nat. Mus. catalog No. 32733.)

9, 10. Glycimeris microsulci Wade, n. sp., right valve of type (p. 48). 9, Interior view; 10, exterior view. (U. S. Nat. Mus. catalog No. 32734.)

11, 12. Glycimeris lacertosa Wade, n. sp., left valve of type (p. 49). 11, Interior view; 12, exterior view. (U. S. Nat. Mus. catalog No. 32735.) 
U, S, GEOLOGICAL SURVEY
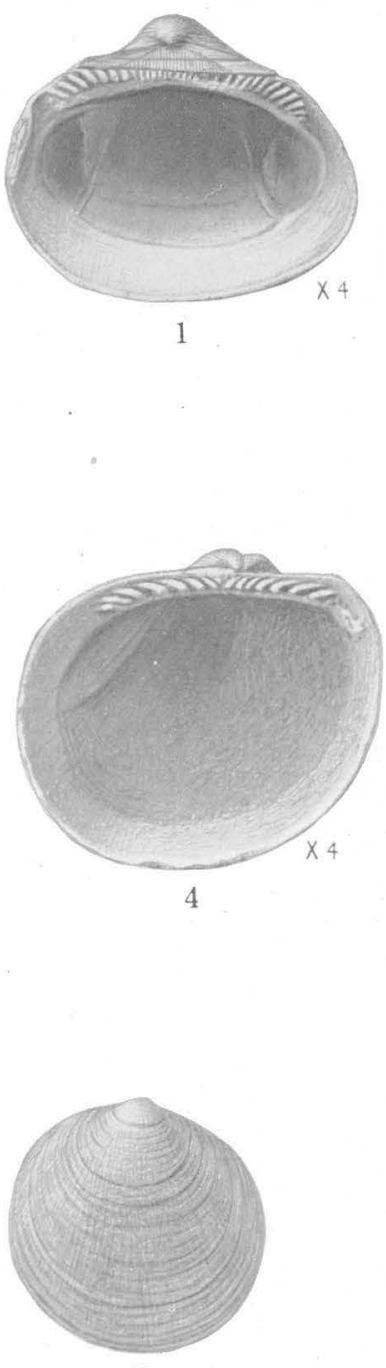

7

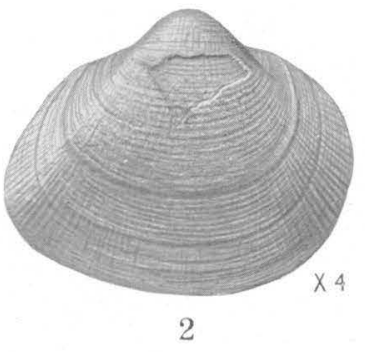

PROFESSIONAL PAPER 137 PLATE XI
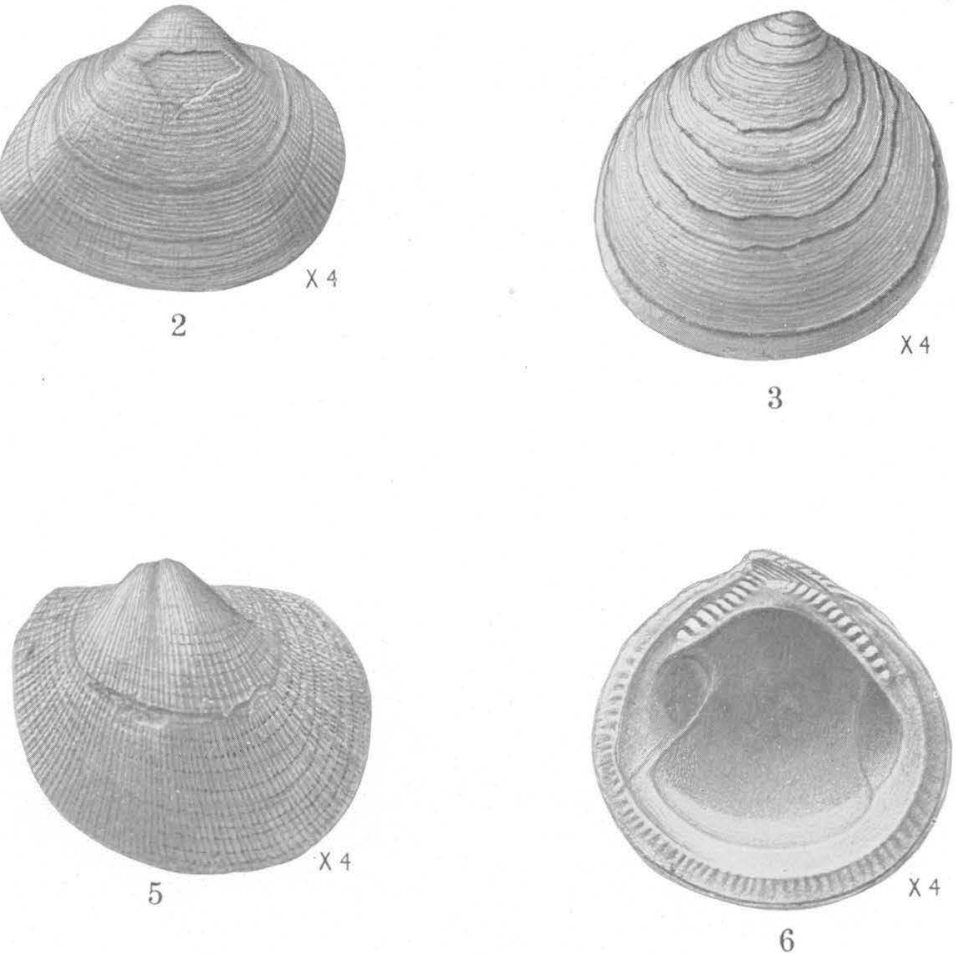

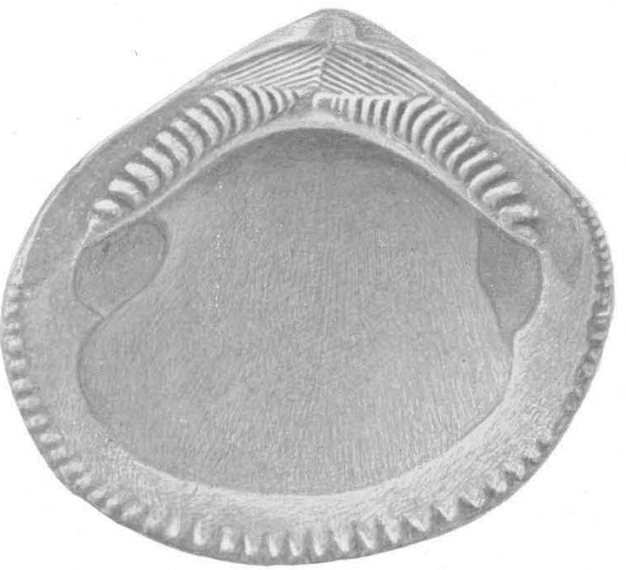

11
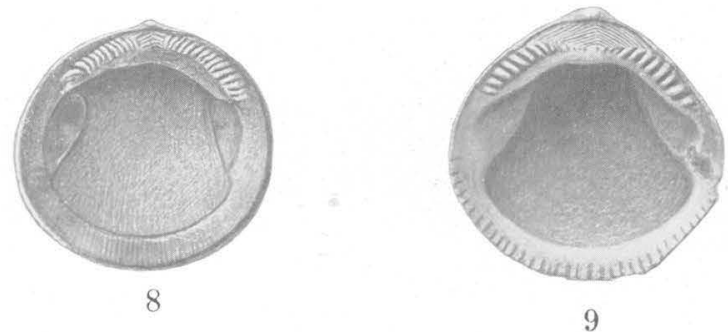
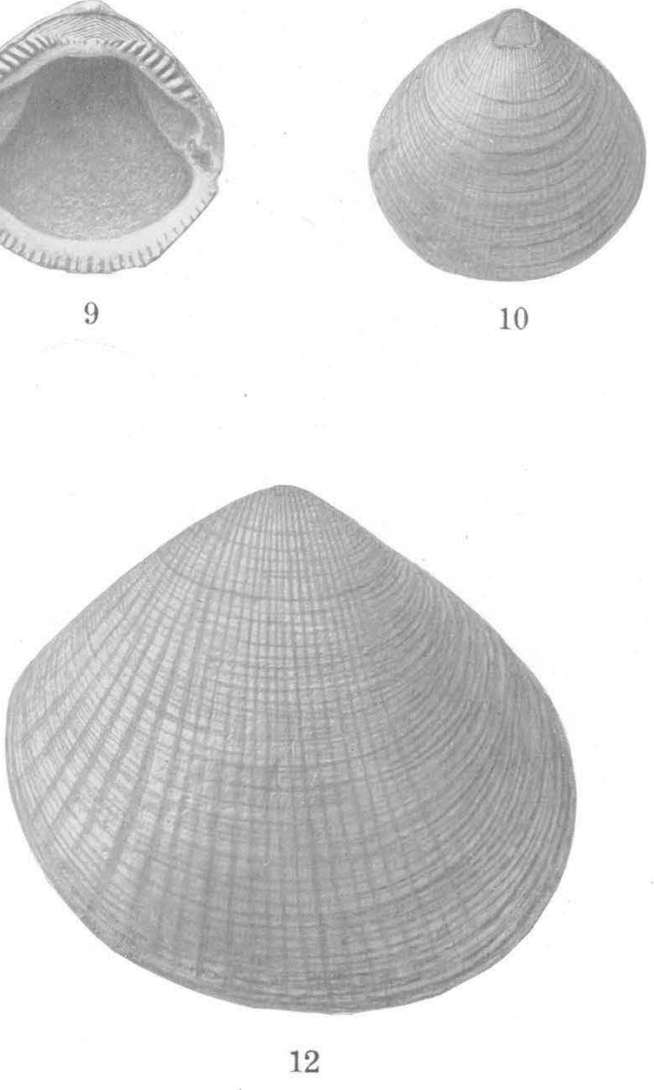

RIPLEY FOSSILS FROM COON CREEK, TENN. 

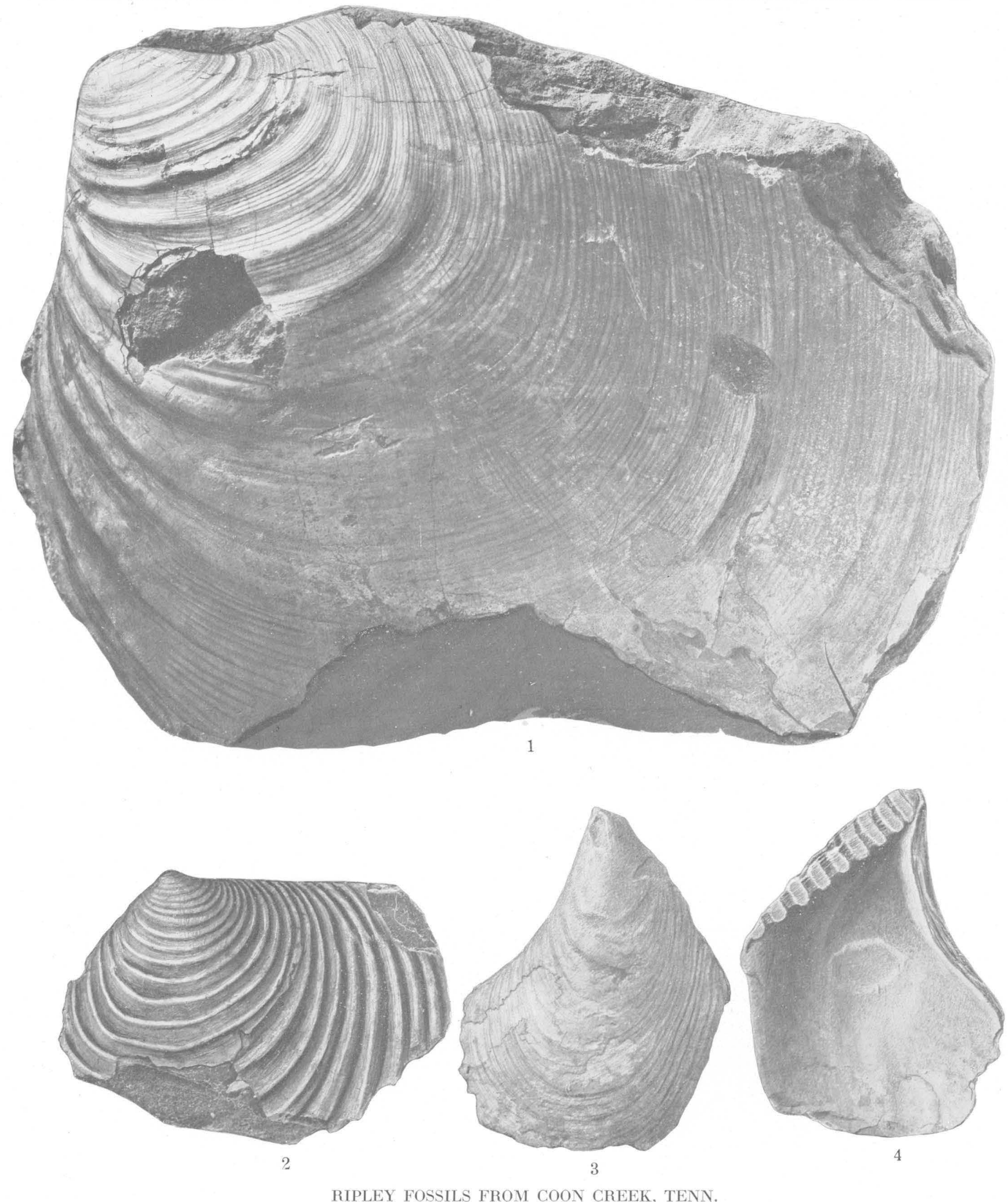


\section{PLATE XII}

Ripley fossils from Coon Creek, Tenn.

1. Inoceramus sagensis Owen (p. 50), exterior view of left valve. (U. S. Nat. Mus. catalog No. 32736.)

2. Inoceramus proximus Tuomey (p. 49), exterior view of left valve. (U. S. Nat. Mus. catalog No. 32737.)

3, 4. Pedalion perividescens Wade, n. sp., right valve of type (p. 50). 3, Exterior view; 4, interior view.

(U. S. Nat. Mus. catalog No. 32738.) 


\section{PLATE XIII}

\section{Ripley Fossils from Coon Creek, Tenn.}

1-3. Gervilliopsis ensiformis (Conrad), right valve (p. 51). 1, 3, Exterior views; 2, interior view. (U. S. Nat. Mus. catalog No. 32739.)

4. Pteria percompressa Wade, n. sp. (p. 52), exterior view of right valve of type. (U. S. Nat. Mus. catalog No. 32740 )

5, 6. Pulvinites argentea Conrad (p. 52). 5, Interior view of right valve; 6, exterior view of left valve. (U. S. Nat. Mus. catalog No. 32741.)

7. Pteria petrosa (Conrad) Meek (p. 51), exterior view of right valve. (U. S. Nat. Mus. catalog No. 32742.)

8, 9. Pulvinites argentea Conrad (p. 52). 8, Exterior view of right valve; 9, interior view of left valve. (U. S. Nat. Mus. catalog No. 32741.)

10. Inoperna_carolinensis Conrad (p. 53); external view of fragment of right valve. (U. S. Nat. Mus. catalog No. 32743. ) 

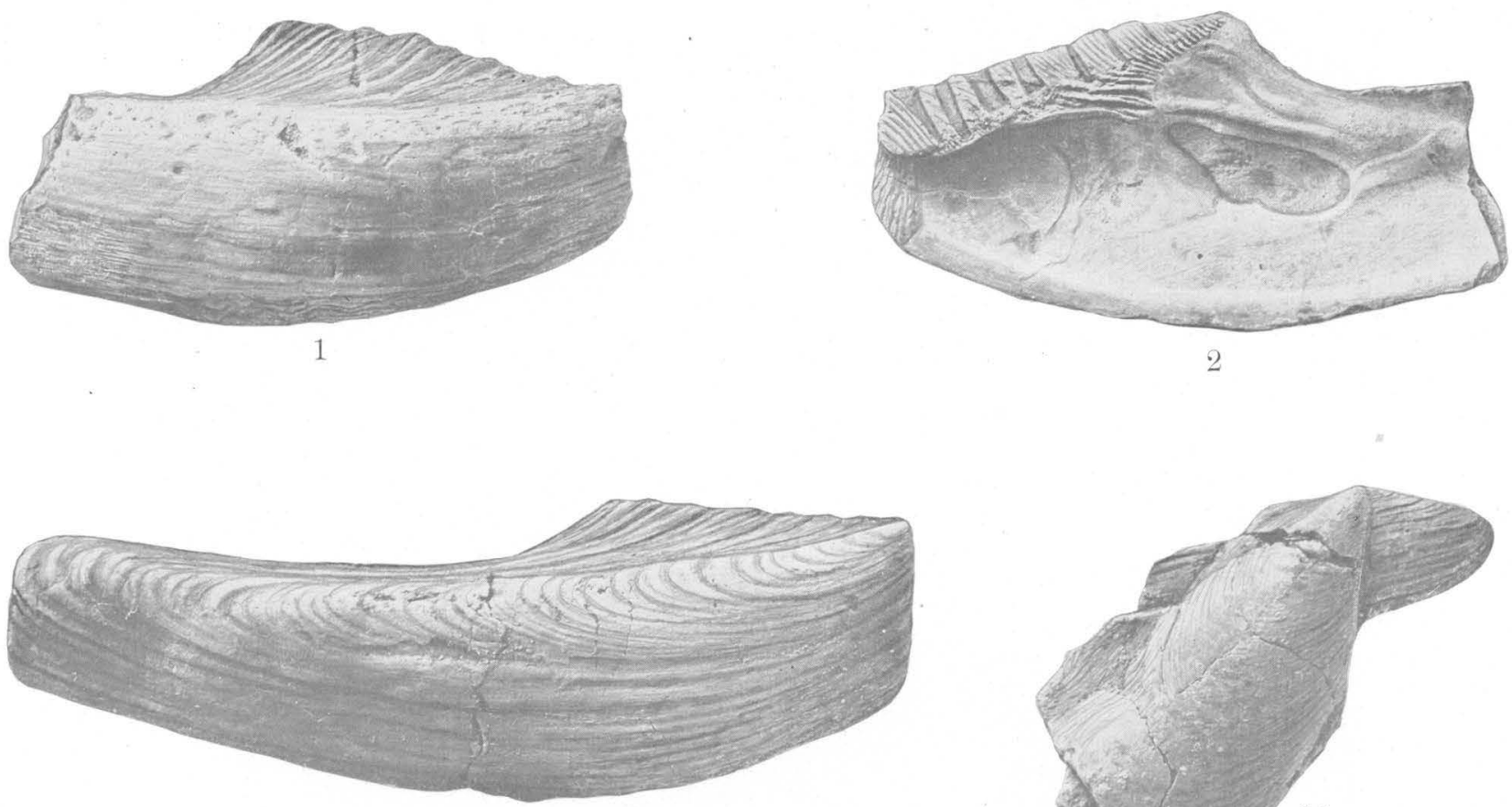

3
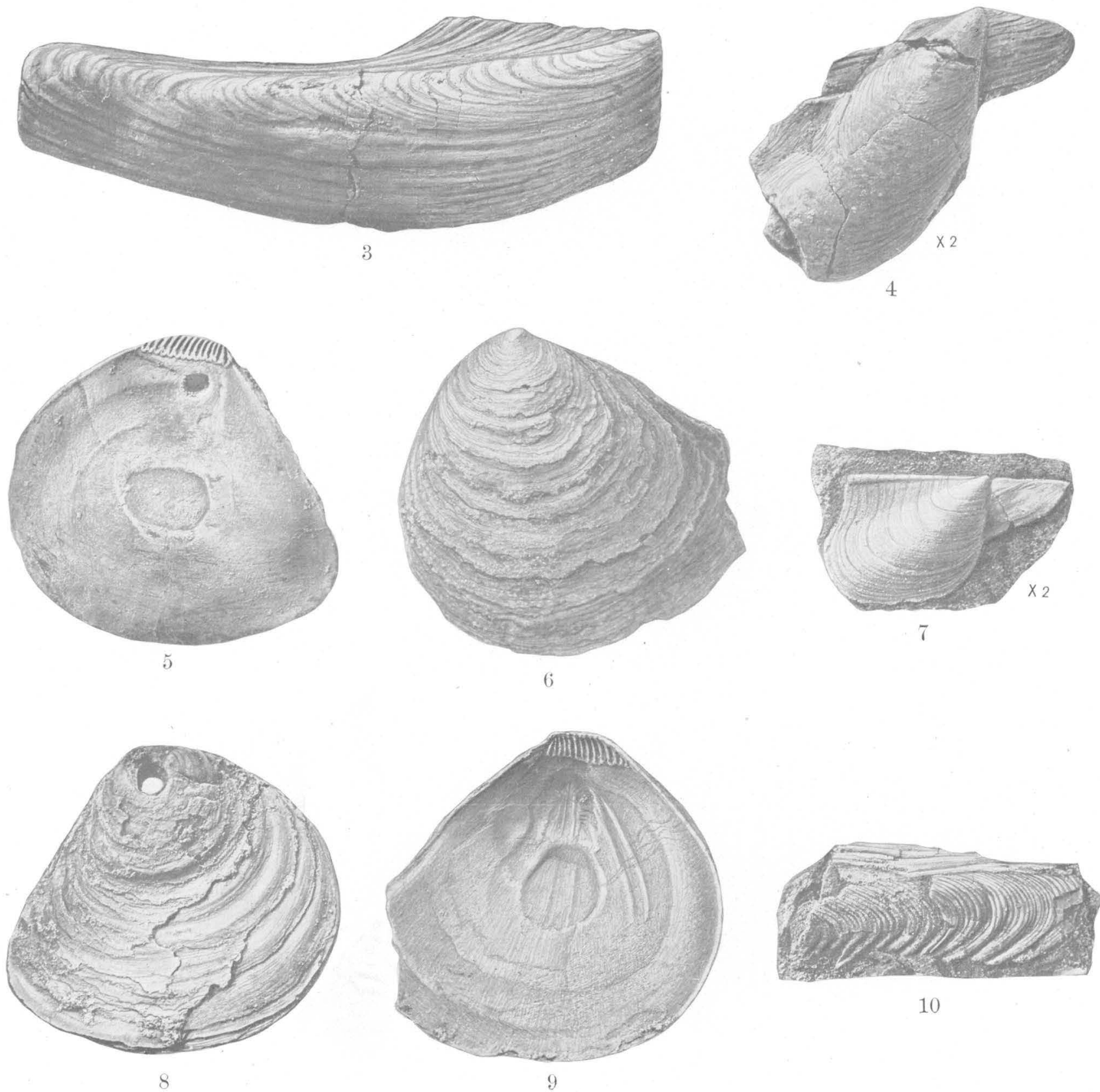

10

8

RIPLEY FOSSILS FROM COON CREEK, TENN. 
T. S. GEOLOGICAL SURVEY
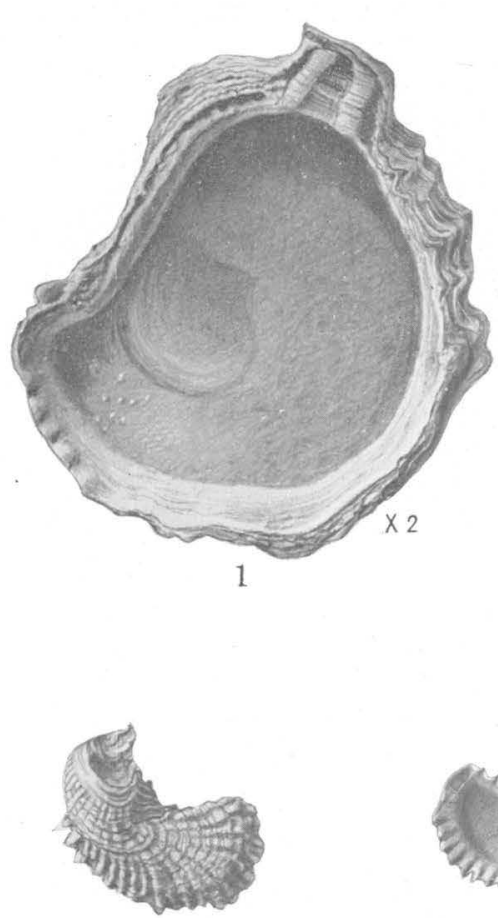

4

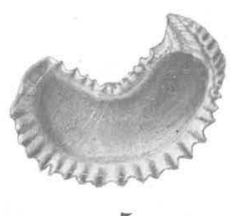

5

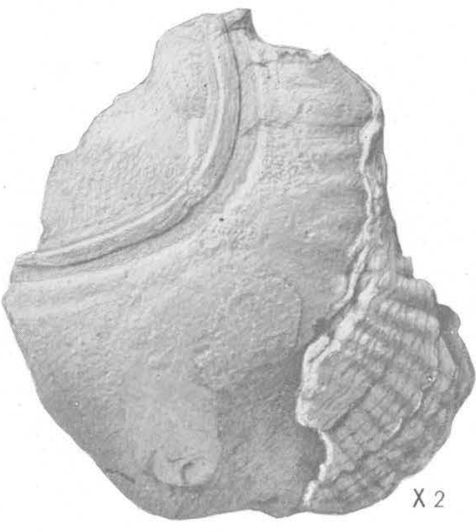

2

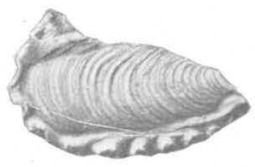

6

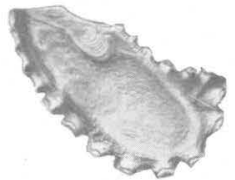

8

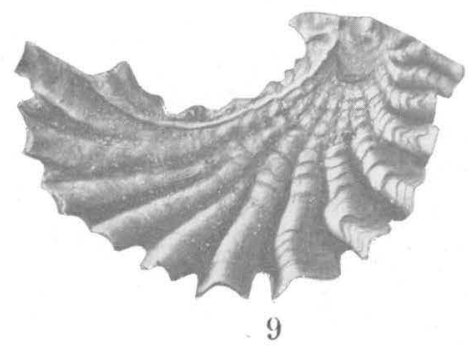

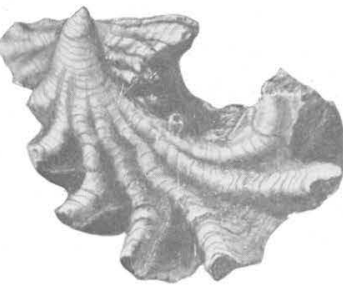

12

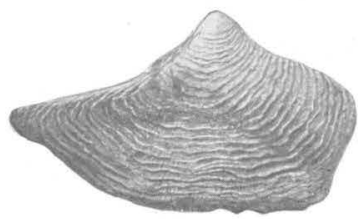

16

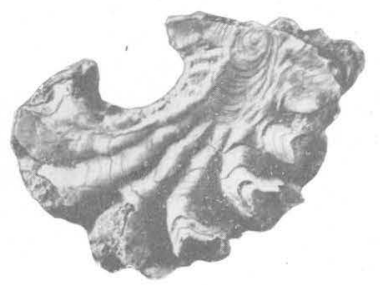

13

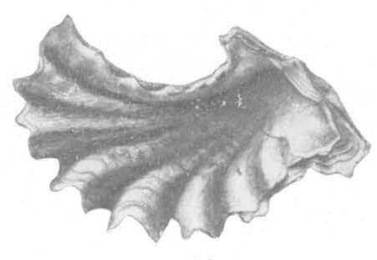

10
PROFESSIONAL PAPER 137 PLATE XIY
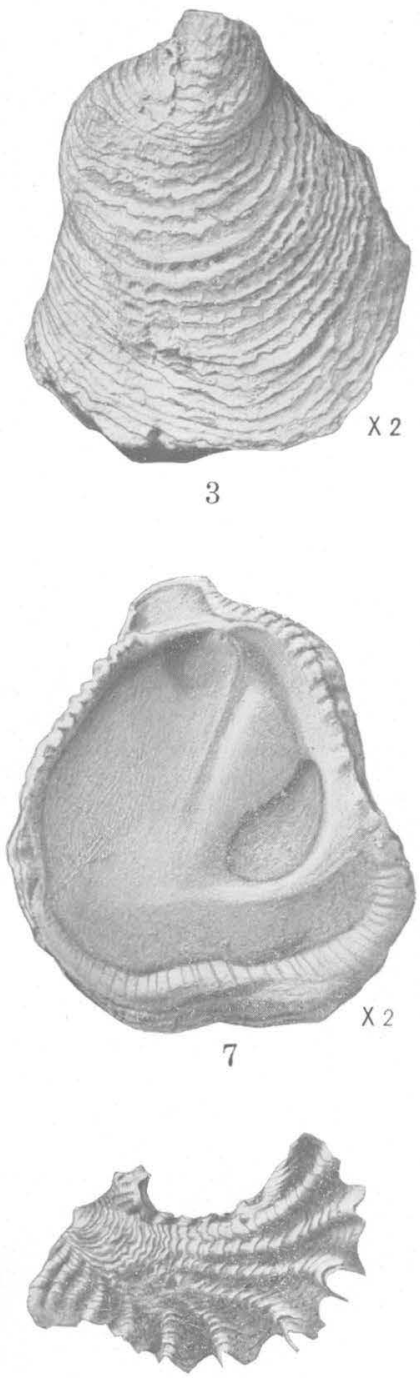

11

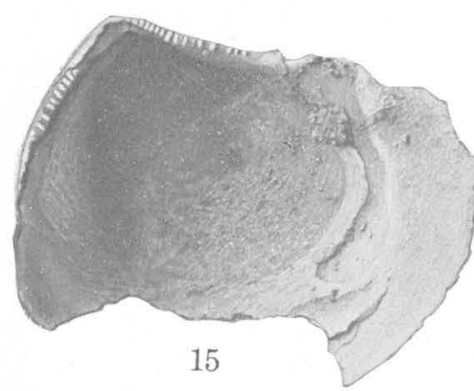

14

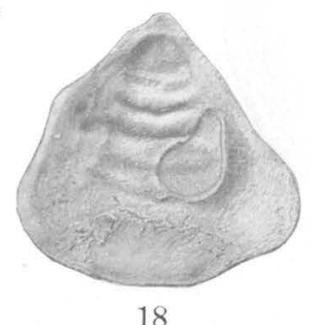

18

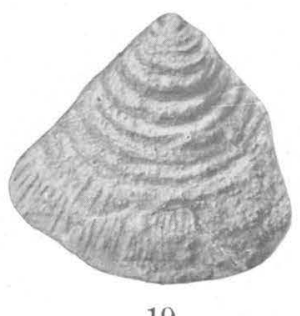

19

RIPLEY FOSSILS FROM COON CREEK, TENN. 


\section{PLATE XIV}

\section{Ripley Fossils from Coon Creek, Tenn.}

1-3, \%. Ostrea plumosa Morton (p. 53). 1, 2, Left valve (1, interior view; 2, exterior view); 3, 7, right valve (3, exterior view; $\boldsymbol{\gamma}$, interior view). (U. S. Nat. Mus. catalog No. 32744.)

4, 5. Ostrea tecticosta Gabb, left valve (p. 54). 4, Exterior view; 5, interior view. (U. S. Nat. Mus. catalog No. 32745 .)

6, 8. Ostrea monmouthensis Weller, right valve (p. 54). 6, Exterior view; 8, interior view. (U. S. Nat. Mus. catalog No. 32746.) 9-13. Ostrea falcata Morton (p. 55). 9, 13, Exterior views of right valve; 10-12, left valve (10, interior view; 11, 12, exterior views). (U. S. Nat. Mus. catalog No. 32747.)

14-17. Ostrea mcnairyensis Wade, n. sp. (p. 55). 14, 15, right valve of type (14, exterior view; 15, interior view); 16, exterior view of right valve; 17, interior view of right valve. (U. S. Nat. Mus. catalog No. 32748.)

18, 19. Ostrea penegemmea Wade, n. sp., right valve of type. (p. 55). 18, Interior view; 19, exterior view. (U. S. Nat. Mus. catalog No. 32749.) 


\section{PLATE XV}

\section{Ripley fossils from Coon Creek, Tenn.}

1, 2. Exogyra costata Say (p. 56). 1, Exterior view of right valve; 2, exterior view of left valve. (U. S. Nat. Mus. catalog No. 32750.) 


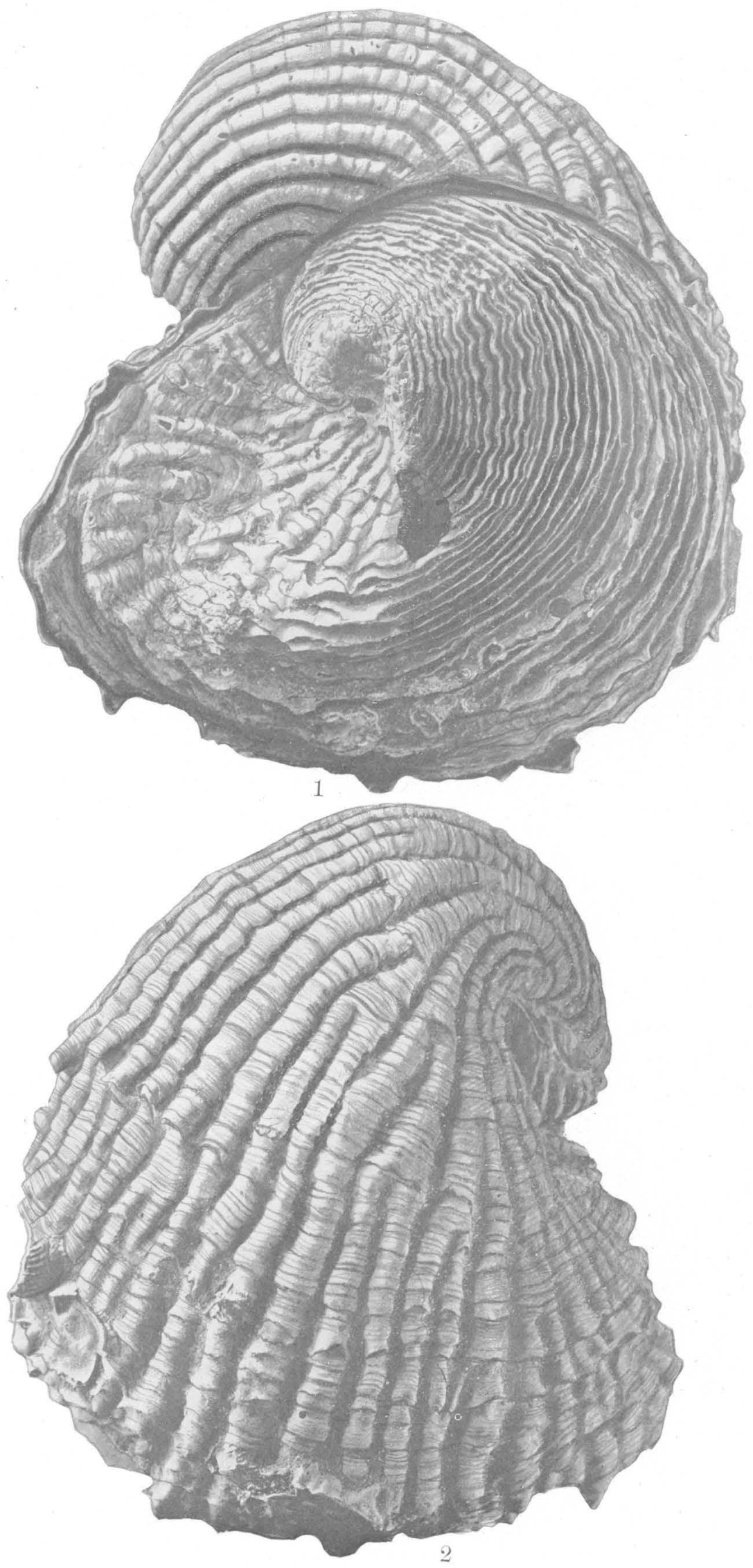

RIPLEY FOSSILS FROM COON CREEK, TENN. 

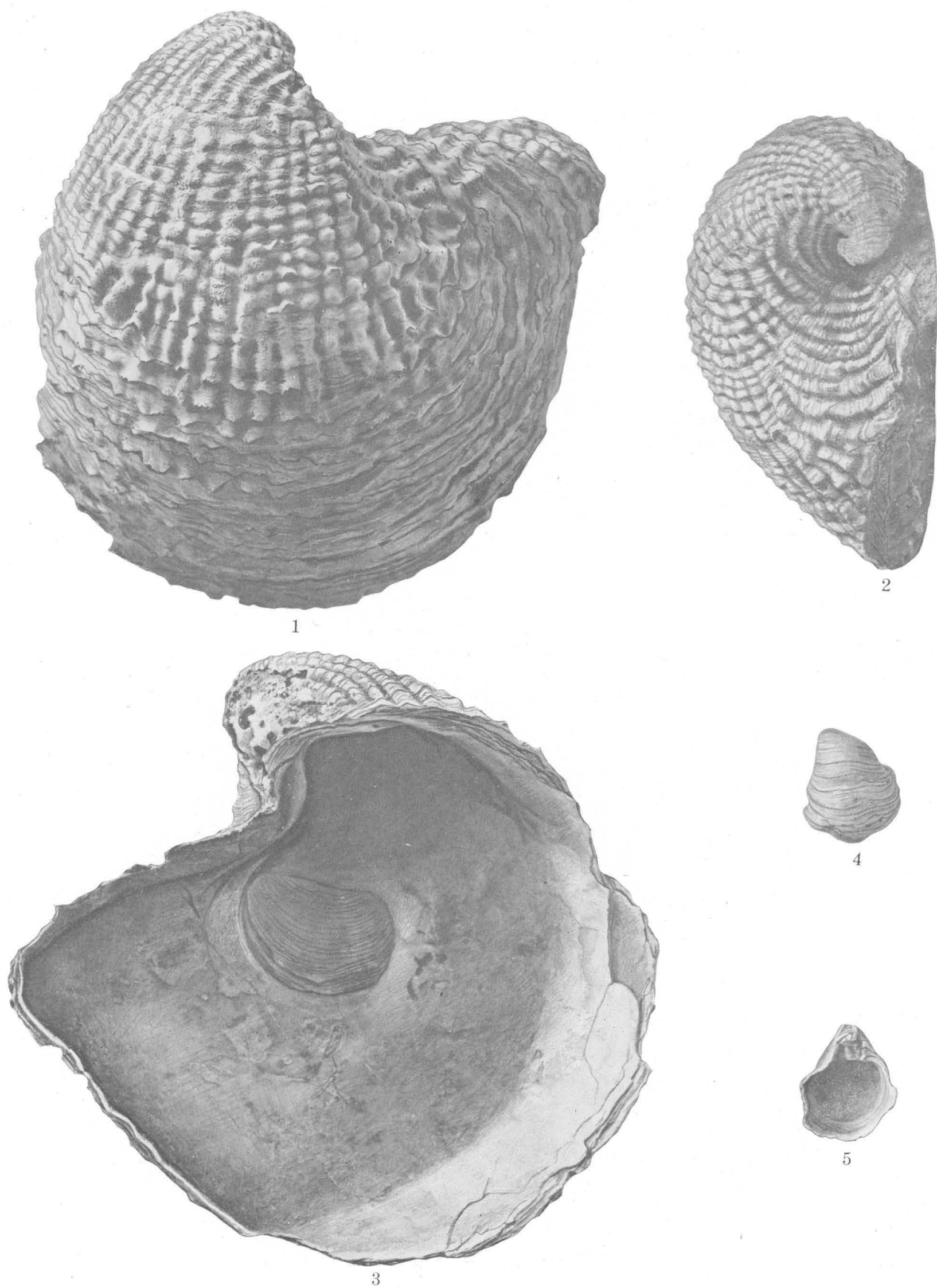

RIPLEY FOSSILS FROM COON CREEK, TENN.

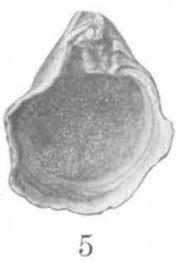




\section{PLATE XVI}

Ripley fossils from Coon Creek, Trinn.

1-3. Exogyra cancellala Stephenson, left valve (p. 58). 1, Exterior view; 2, posterior view; 3, interior view. (U. S. Nat. Mus catalog No. 32751.)

4, 5. Ostrea bryani Gabb?, left valve (p. 56). 4, Interior view; 5, exterior view. (U. S. Nat. Mus. catalog No. 32752.$)$

$106913-26 \dagger-16$ 
PLATE XVII

Ripley Fossils from Coon Creek, Tenn.

1, 2. Gryphaea vesicularis (Lamarck), right valve (p. 58). 1, Interior view; 2, exterior view. (U. S. Nat. Mus. catalog No. 32753 .) 210 
U. S. GEOLOGICAL SURVEY

PROFESSIONAL PAPER 137 PIATE XVII
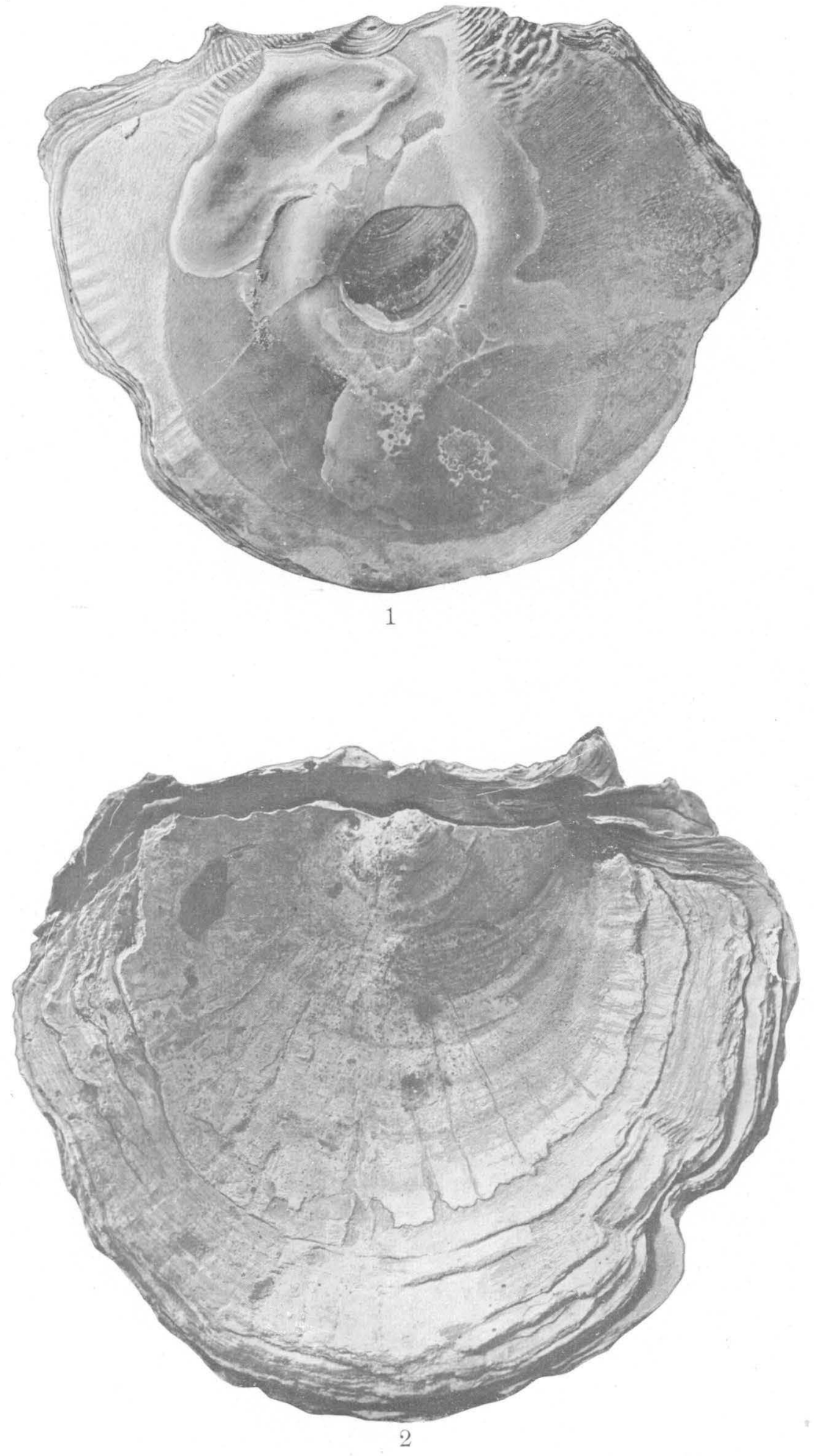

RIPLEY FOSSILS FROM COON CREEK, TENN. 

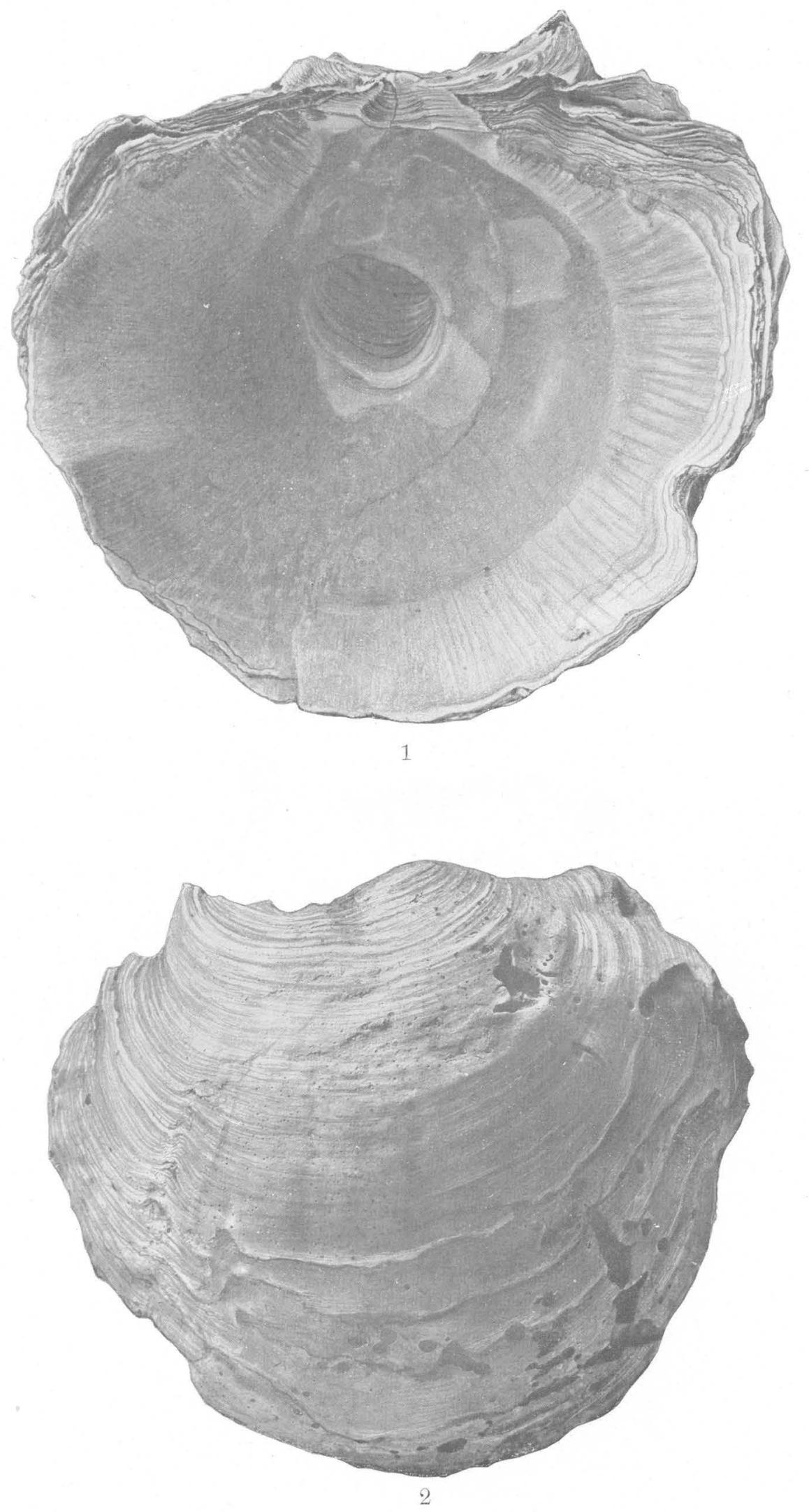

RIPLEY FOSSILS FROM COON CREEK, TENN. 


\section{PLATE XVIII}

\section{Ripley Fossils from Coon Creek, Tenn.}

1, 2. Gryphaea vesicularis (Lamarck), left valve (p. 58). 1, Interior view of left valve; 2, exterior view. (U. S. Nat. Mus. catalog No. 32753.) 
PLATE XIX

Ripley Fossils from Coon Creek, Tenn.

1, 2. Gryphaea vesicularis (Lamarck) (p. 58). 1, Exterior view of right valve; 2, exterior view of left valve. (U. S. Nat. Mus catalog No. 32753.) 

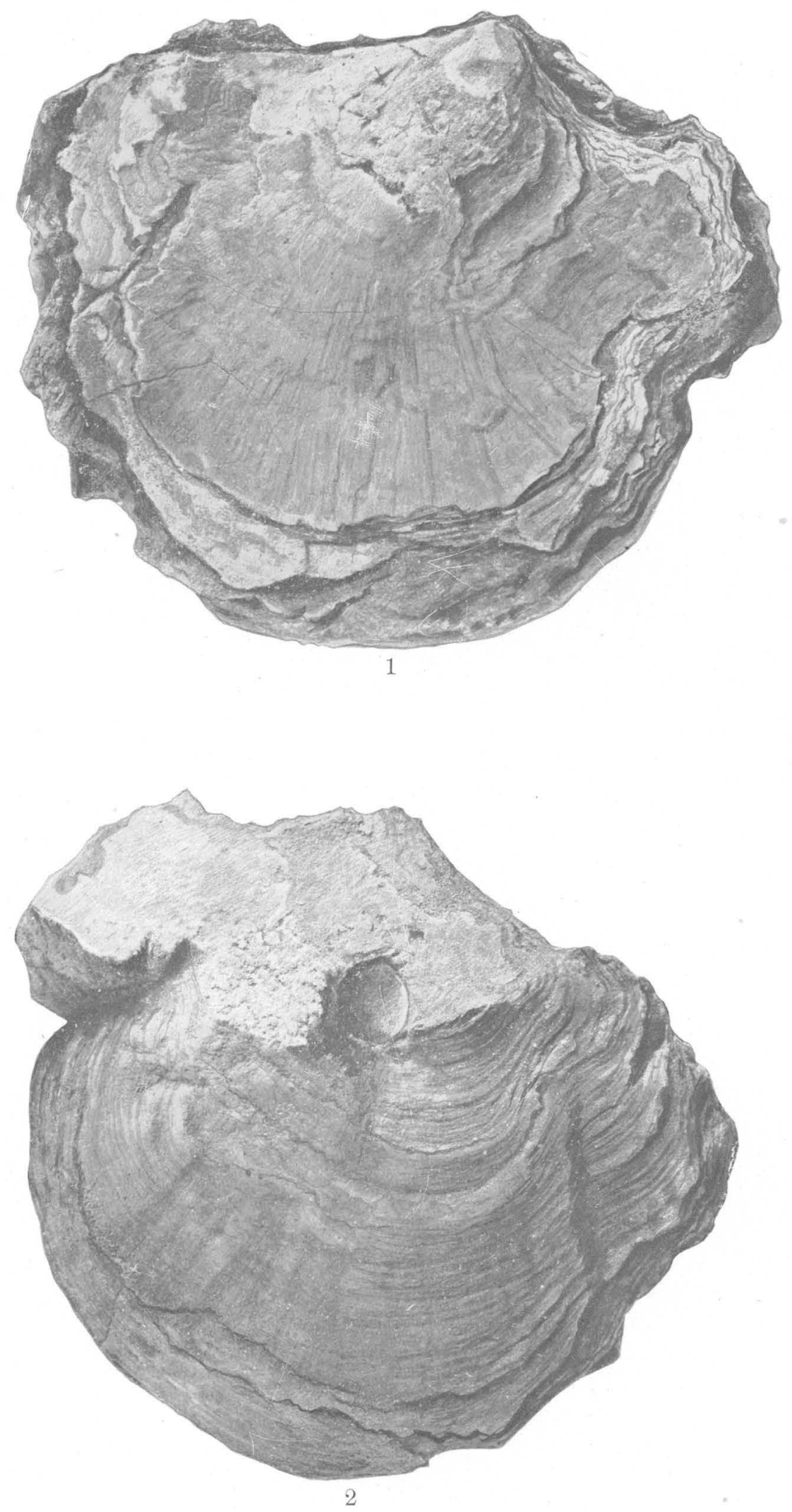

RIPLEY FOSSILS FROM COON CREEK, TENN. 

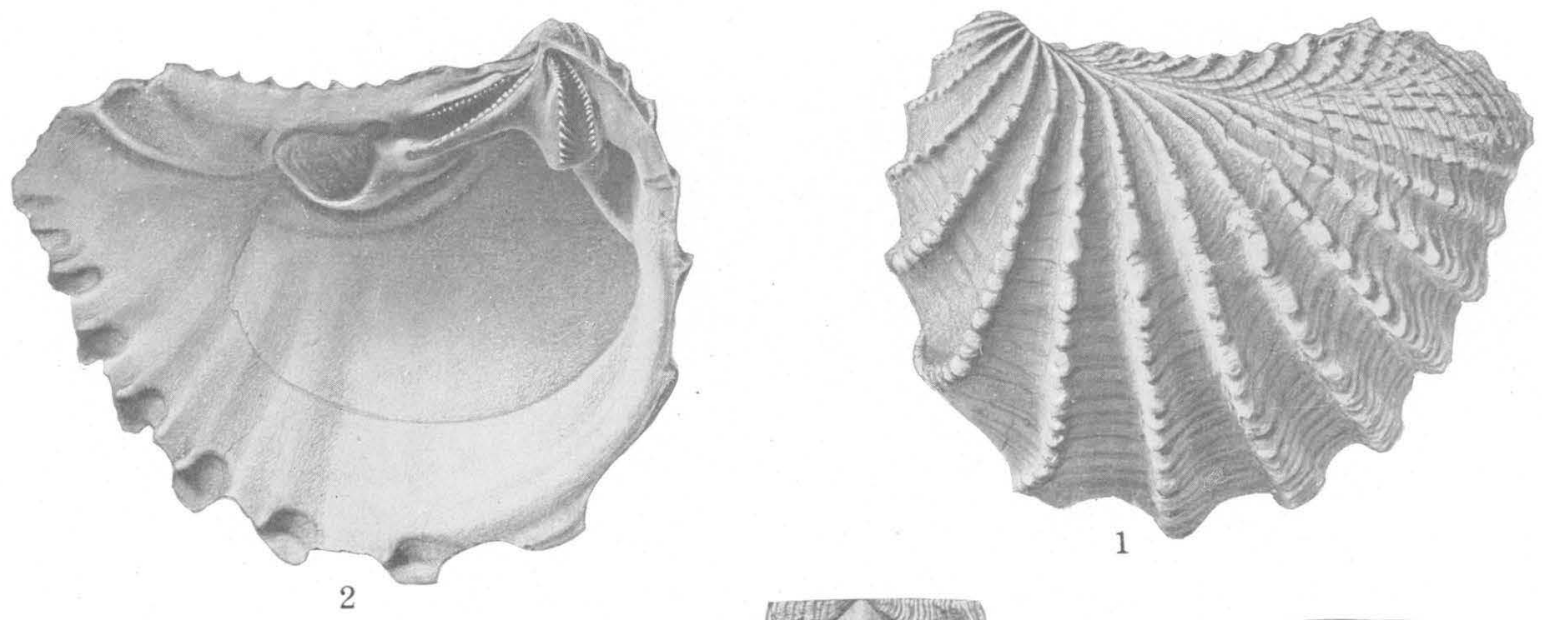

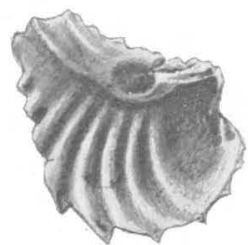

3
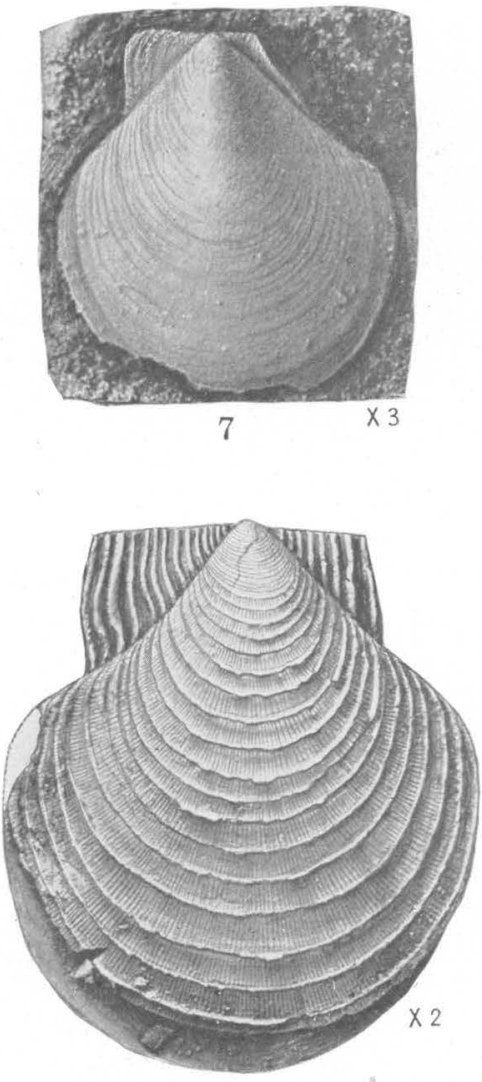

10

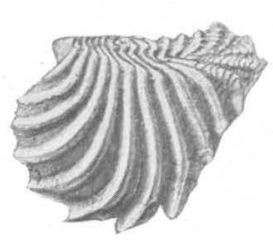

4
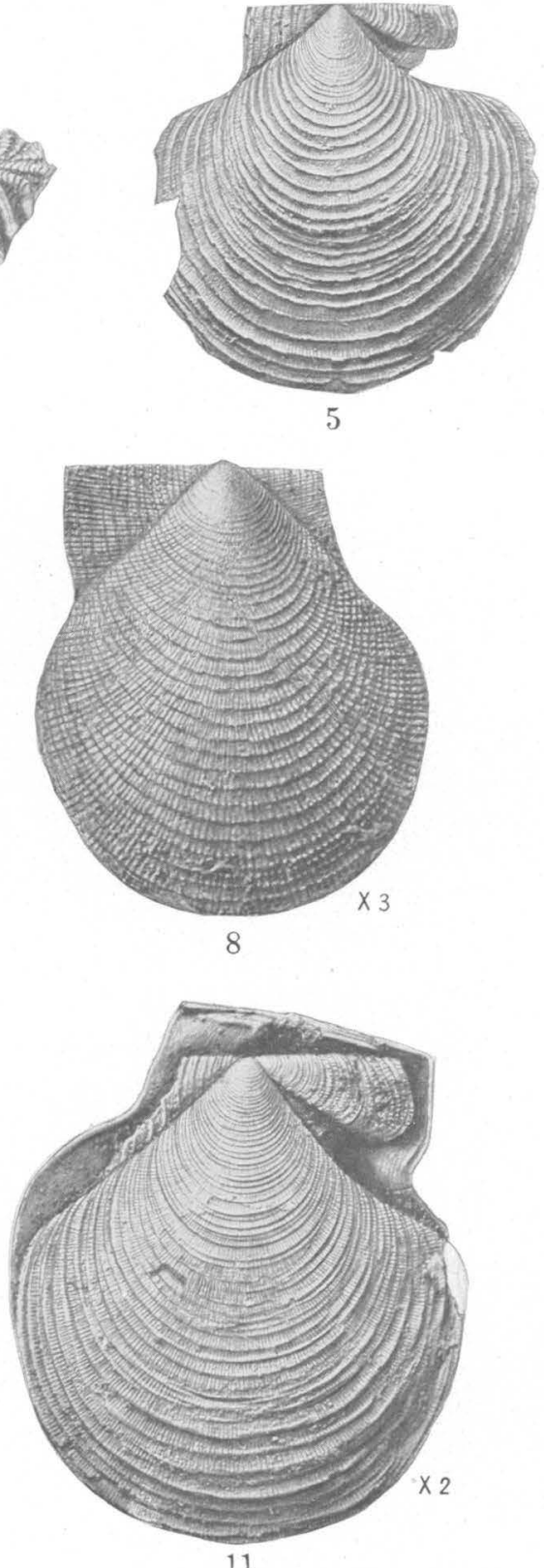

11
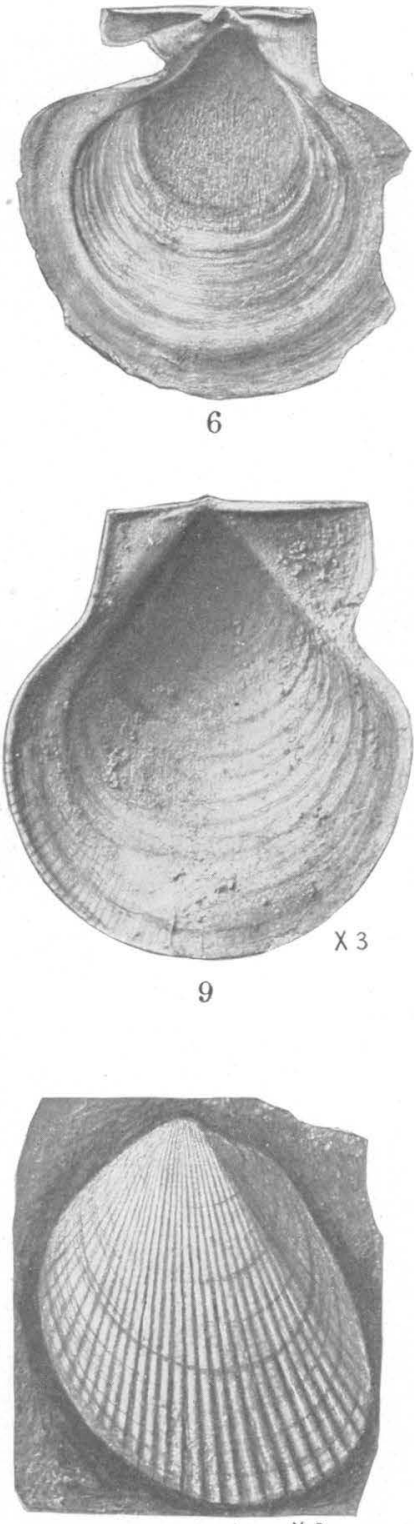

12

RIPLEY FOSSILS FROM COON CREEK, TENN. 


\section{PLATE $\mathrm{XX}$}

\section{Rtpley fosstls from Coon Cireek, Tenn.}

1, 2. Trigonia thoracica Morton, left valve (p. 60): 1, Exterior view; 2, interior view. (U. S. Nat: Mus. catalog No. 32754.) 3, 4. Trigonia eufalensis Gabb, left valve (p. 61). 3, Interior view; 4, exterior view. (U. S. Nat. Mus. catalog No. 32755.)

5, 6, 10, 11. Peclen burlingtonensis Gabb (p. 63). 5, 6, 11, Right valve (5, 11, exterior views; 6, interior view); 10, left valve exterior view. (U. S. Nat. Mus. catalog No. 32756.)

7. Pecten simplicius Conrad (p. 62), external view of left valve. (U. S. Nat. Mus. catalog No. 32757.)

8, 9. Pecten argillensis Conrad (p. 62). 8, Exterior view; 9, interior view. (U. S. Nat. Mus. catalog No. 32758.)

12. Lima reticulata Forbes (p. 66), exterior view of right valve. (U. S. Nat. Mus. catalog No. 32759.) 


\section{PLATE XXI}

Ripley Fossils from Coon Creek, Tenn.

1-5. Pecten quinquecostatus Sowerby (p. 64). 1-3, 5, Right valve (1, 5, exterior views; 2, interior view; 3, posterior view); 4, left valve, interior view. (U. S. Nat. Mus. catalog No. 32760.)

6-9. Pecten quinquenarius Conrad (p. 65). 6, 8, 9, Left valve (6, 8, exterior views; 9, interior view); 7 , right valve, exterior view. (U. S. Nat. Mus. catalog No. 32761.) 
U. S. GEOLOGICAL SURVEY
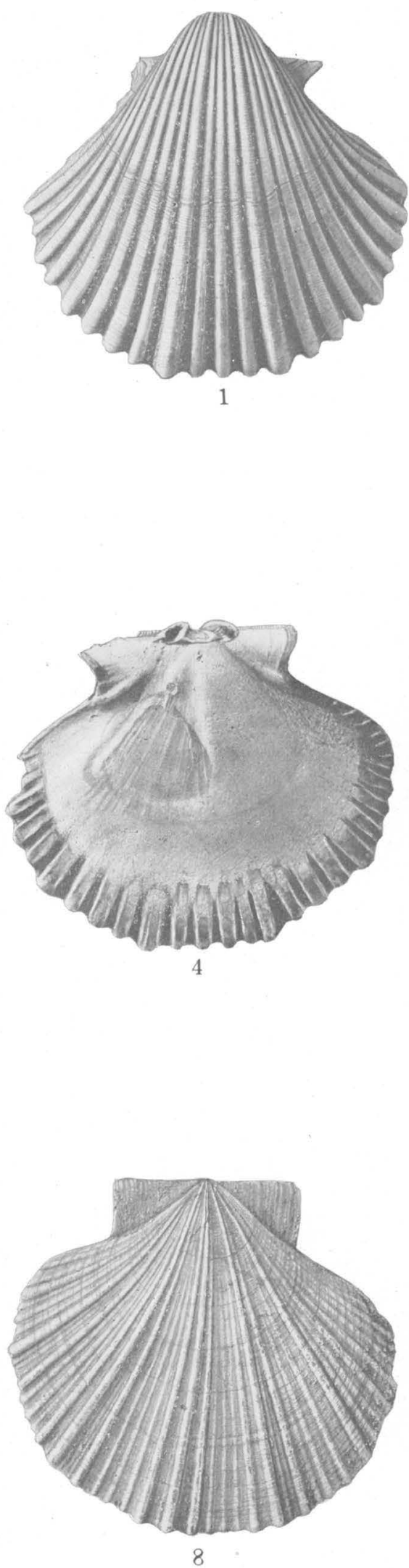
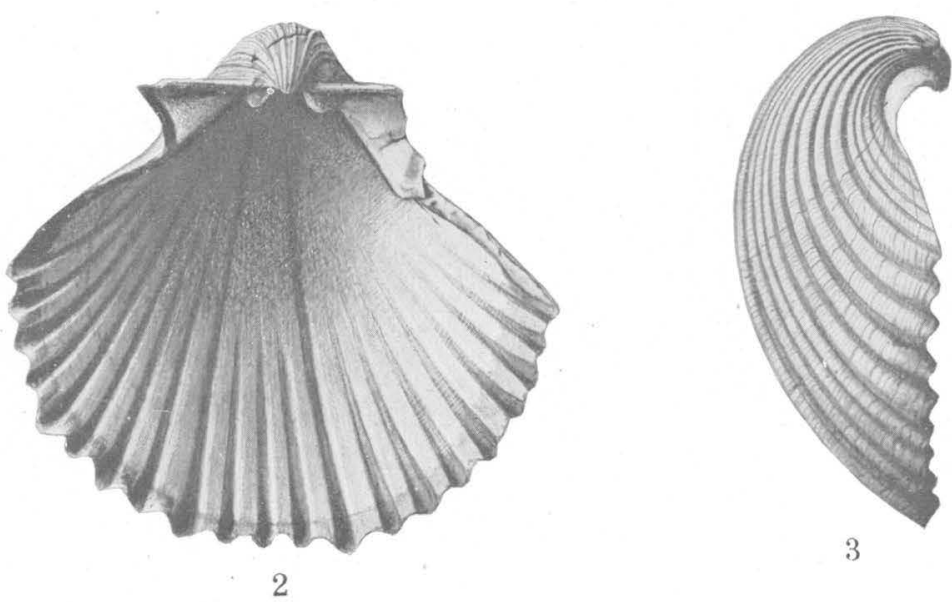

3
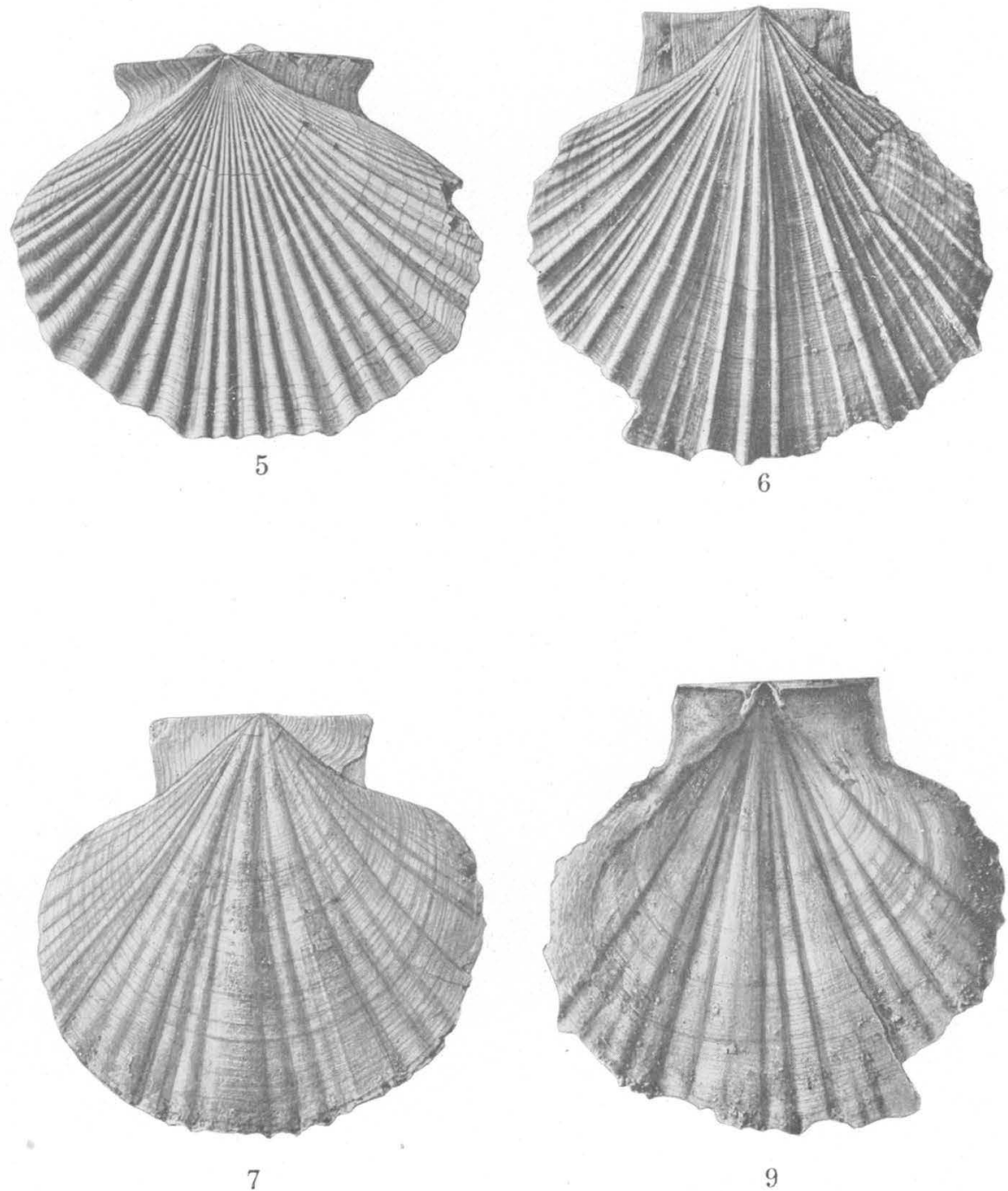

RIPLEY FOSSILS FROM COON CREEK, TENN. 
U. S. GEOLOGICAL SURVEY
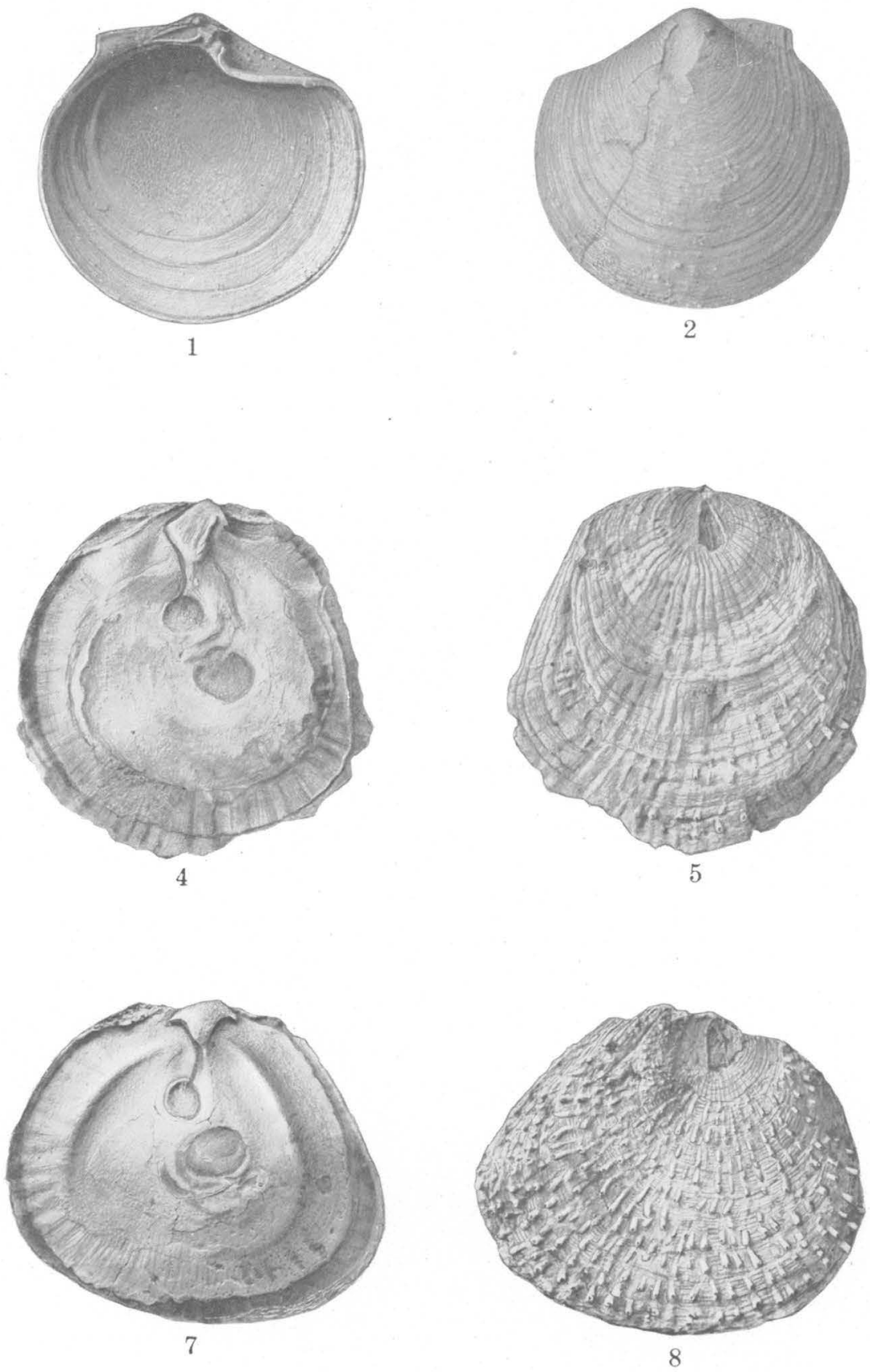

PROFESSIONAL PAPER 137 PLATE XXII
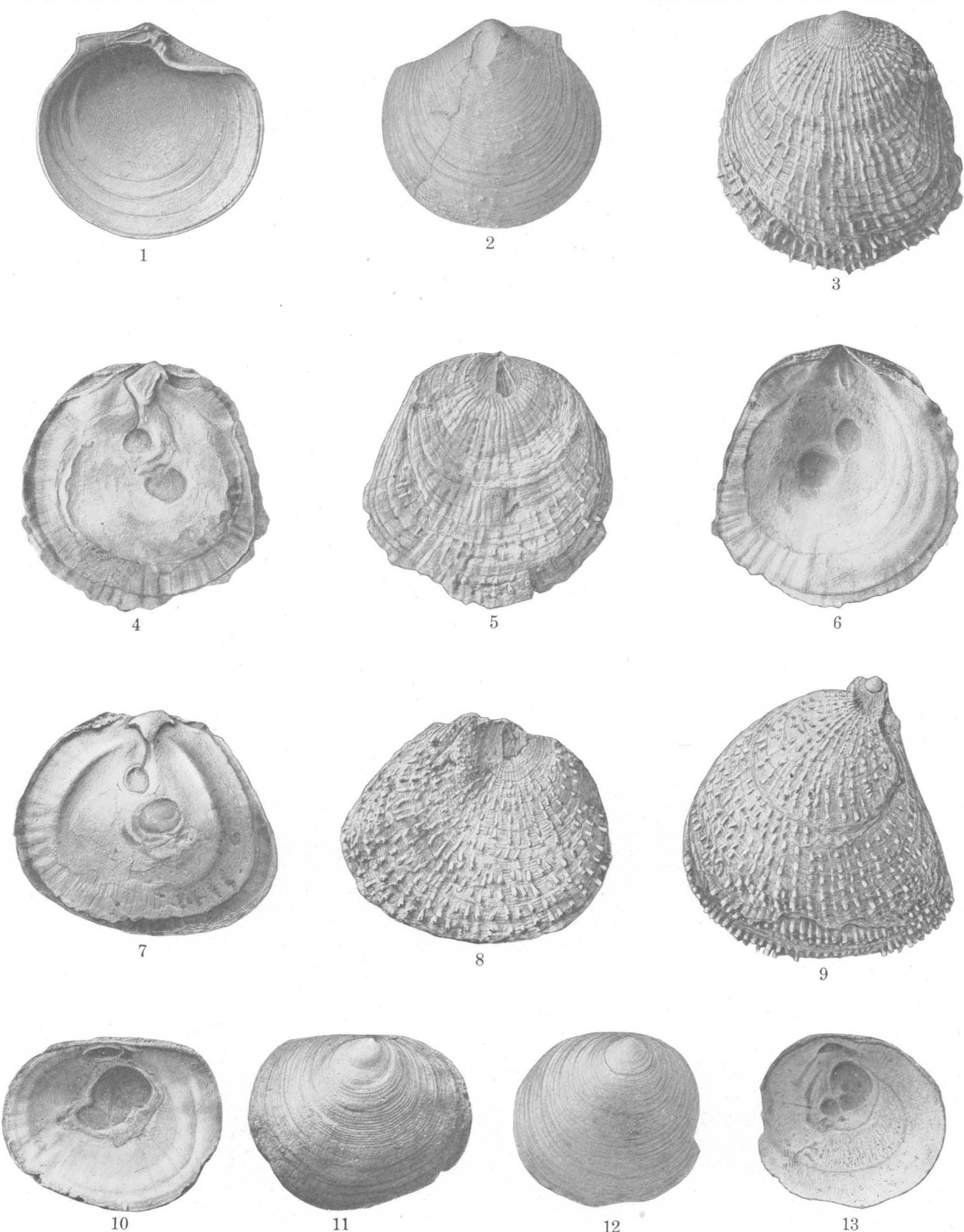

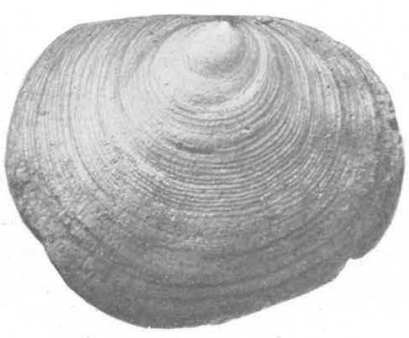

11

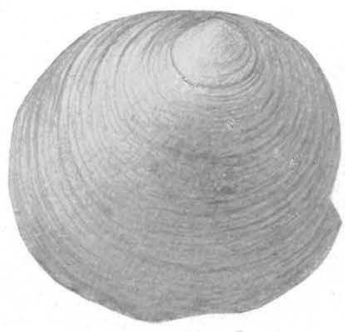

12

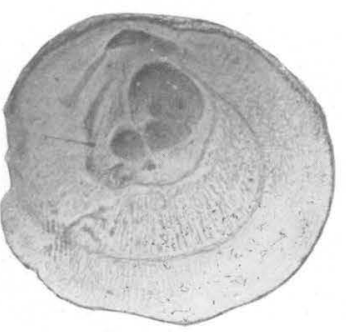

13

RIPLEY FOSSILS FROM COON CREEK, TENN. 


\section{PLATE XXII}

\section{Ripley fossils from Coon Creek, Tenn.}

1, 2. Lima woodsi Wade, n. sp., left valve of type (p.67). 1, Interior view; 2, exterior view. (U. S. Nat. Mus. catalog No. 32762 .)

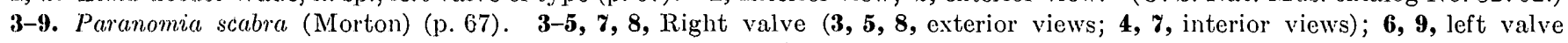
(6, interior view; 9, exterior view). (U. S. Nat. Mus. catalog No. 32763.)

- 10-13. Anomia argentaria Morton (p. 6S). 10, 11, Left valve (10, interior view; 11, exterior view); 12, 13, right valve (12, exterior view; 13, interior view). (U. S. Nat. Mus. catalog No. 32764.) 


\section{PLATE XXIII}

\section{Ripley fossils from Coon Creek, Tenn.}

1, 2. Anomia perlineata Wade, n. sp., left valve of the type (p. 69). 1, Exterior view; 2, interior view. (U.S. Nat. Mus. catalog No. 32765.)

3, 7. Anomia tellinoides Morton, right valve (p. 69). 3, Interior view; 7, exterior view. -(U. S. Nat. Mus. catalog No. 32766.)

4, 8. Lithophaga conchafodentis Gardner, left valve (p. 71). 4, Exterior view; 8, interior view. (U. S. Nat. Mus. catalog No. 32767.)

5, 6. Lithophaga ripleyana Gabb (p. 70). 5, Exterior view of right valve; 6, anterior view of valves attached. ' (U. S. Nat. Mus. catalog No. 32768.)

9, 10. Crenella serica Conrad (p. 71). 9, Exterior view of left valve; 10, exterior view of right valve. (U. S. Nat. Mus. catalog No. 32769.)

11, 12. Dreissensia tippana Conrad, right valve (p. 72). 11, Interior view; 12, exterior view. (U.S. Nat. Mus. catalog No. 32770.) 13-15. Pholadomya occidentalis Morton (p. 72). 13, Anterior view of two valves attached; 14, dorsal view of two valves attached; 15, exterior view of left valve. (U. S. Nat. Mus. catalog No. 32771.)

216 

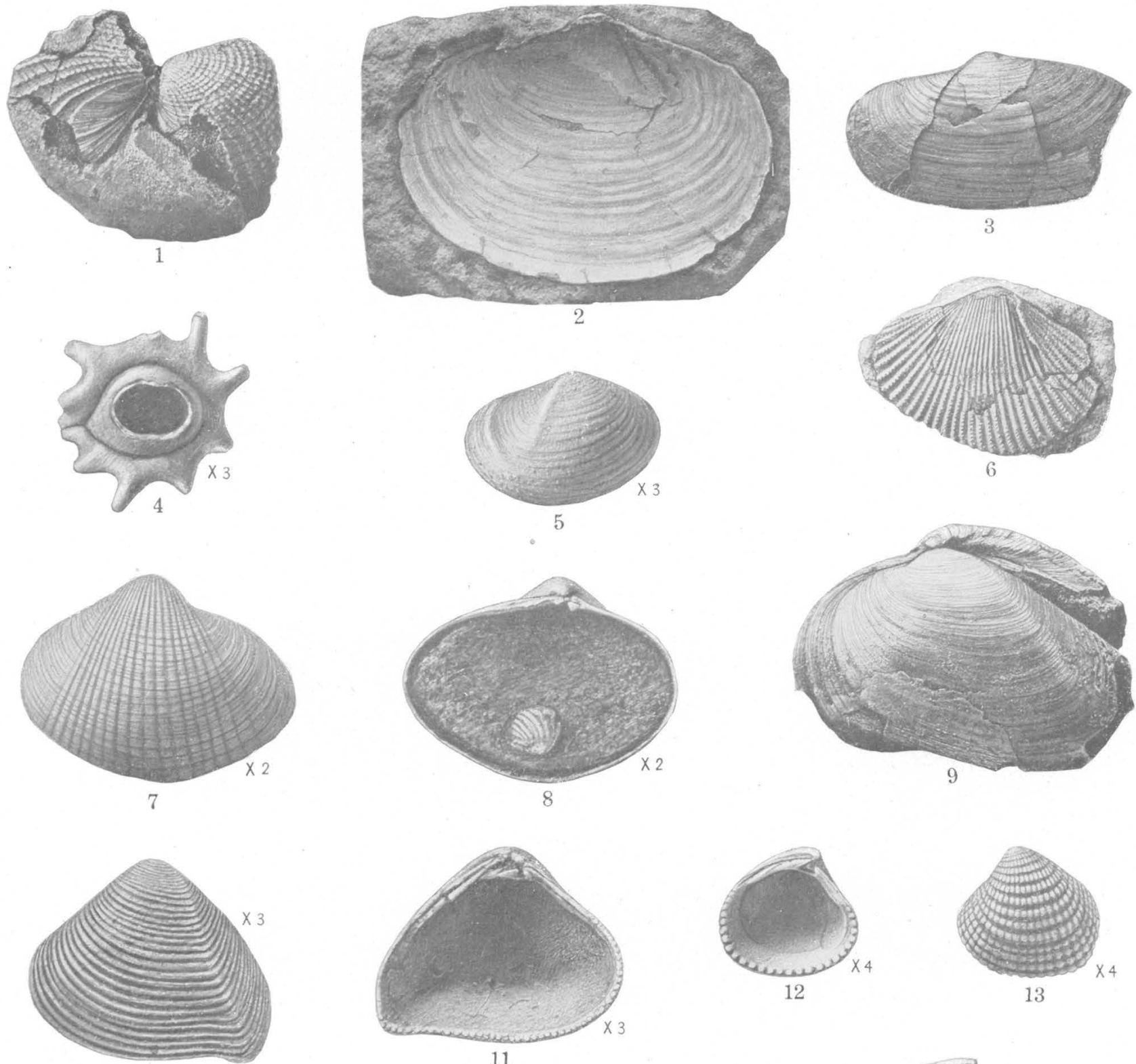

10
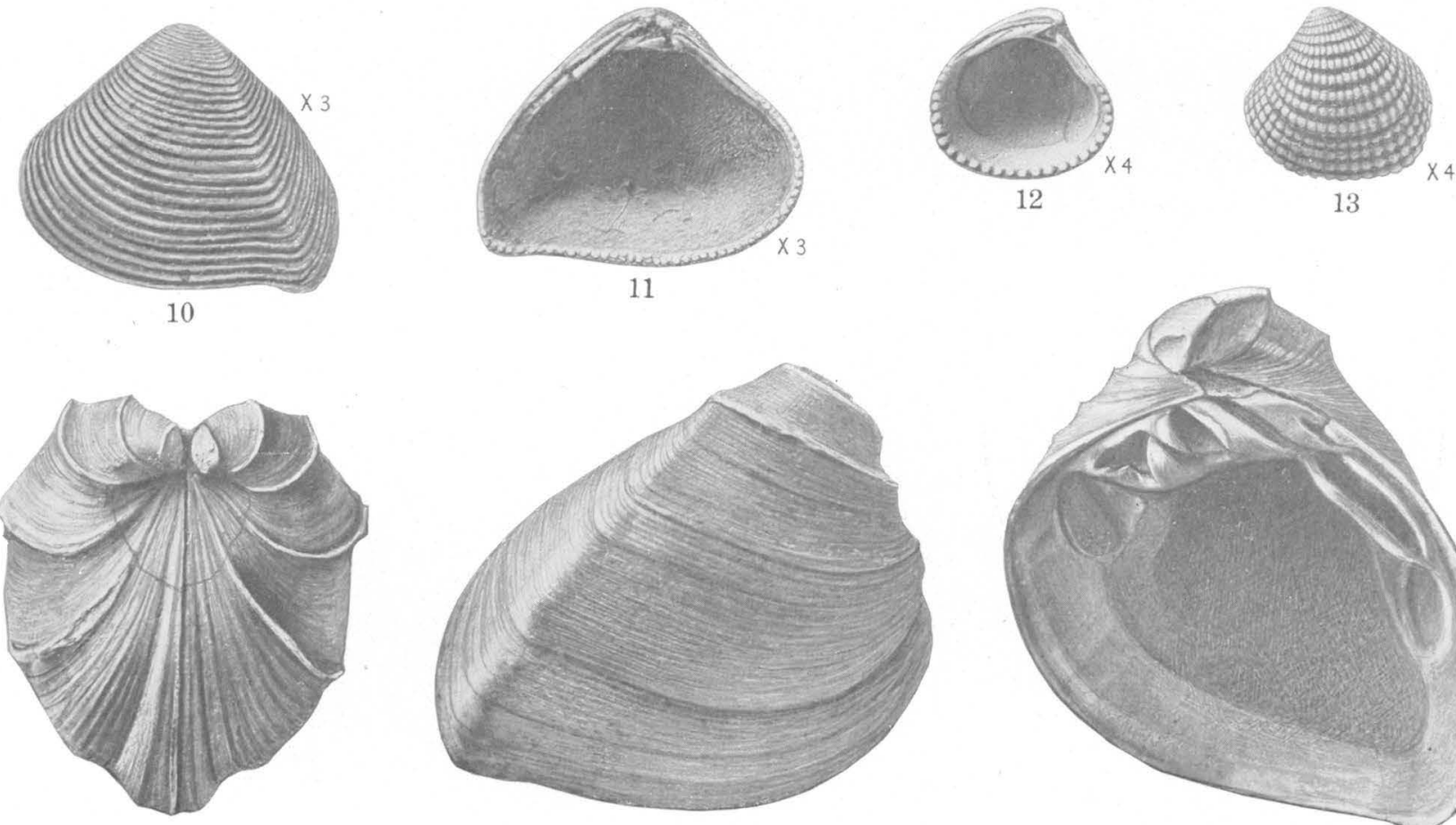

14

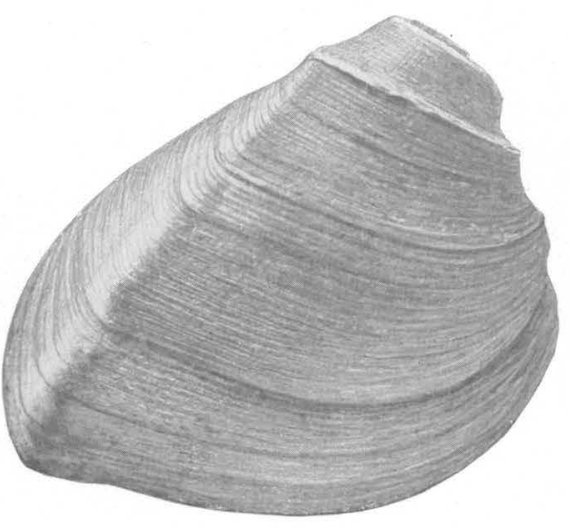

15

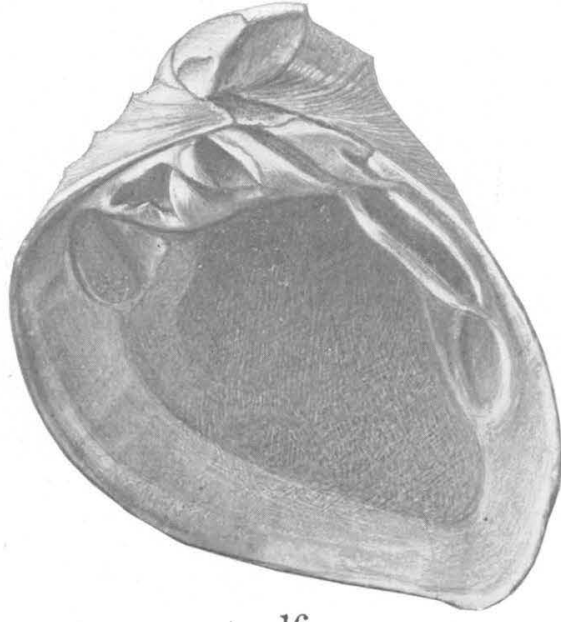

16

RIPLEY FOSSILS FROM COON CREEK, TENN. 
U. S, GEOLOGICAL SURVEY

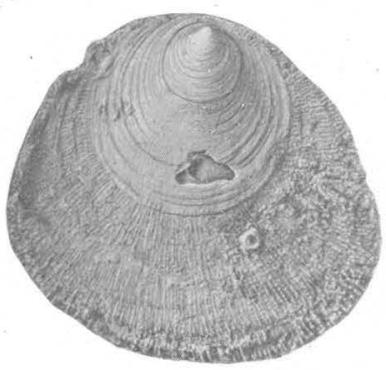

1
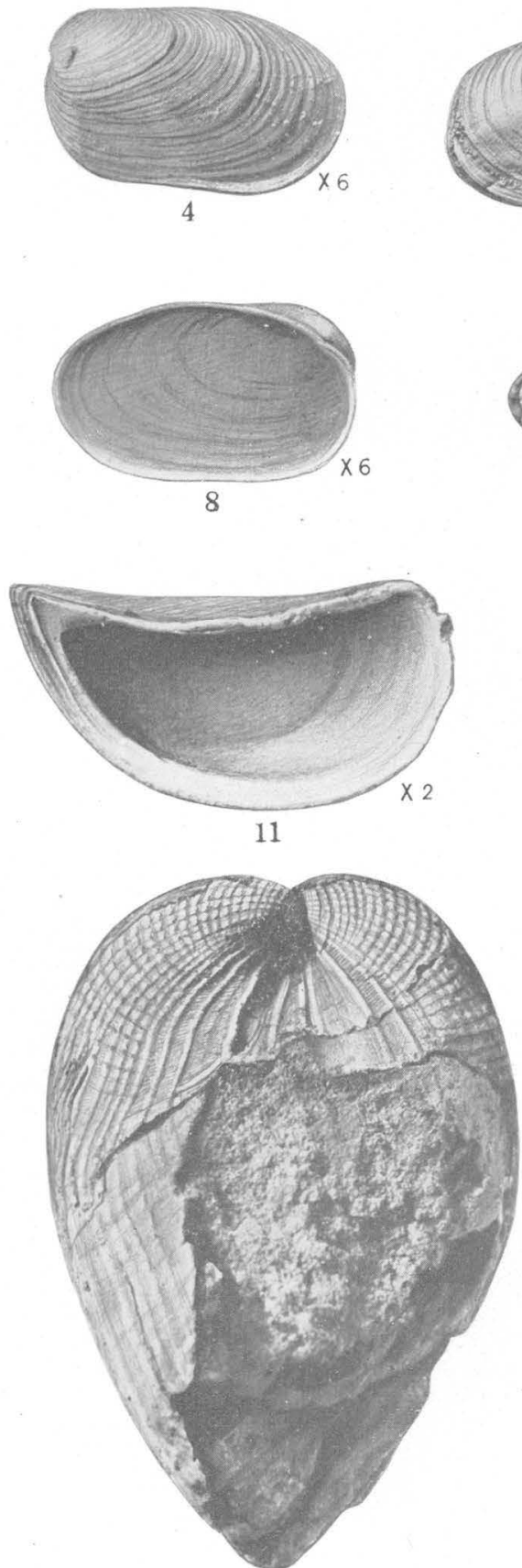

14
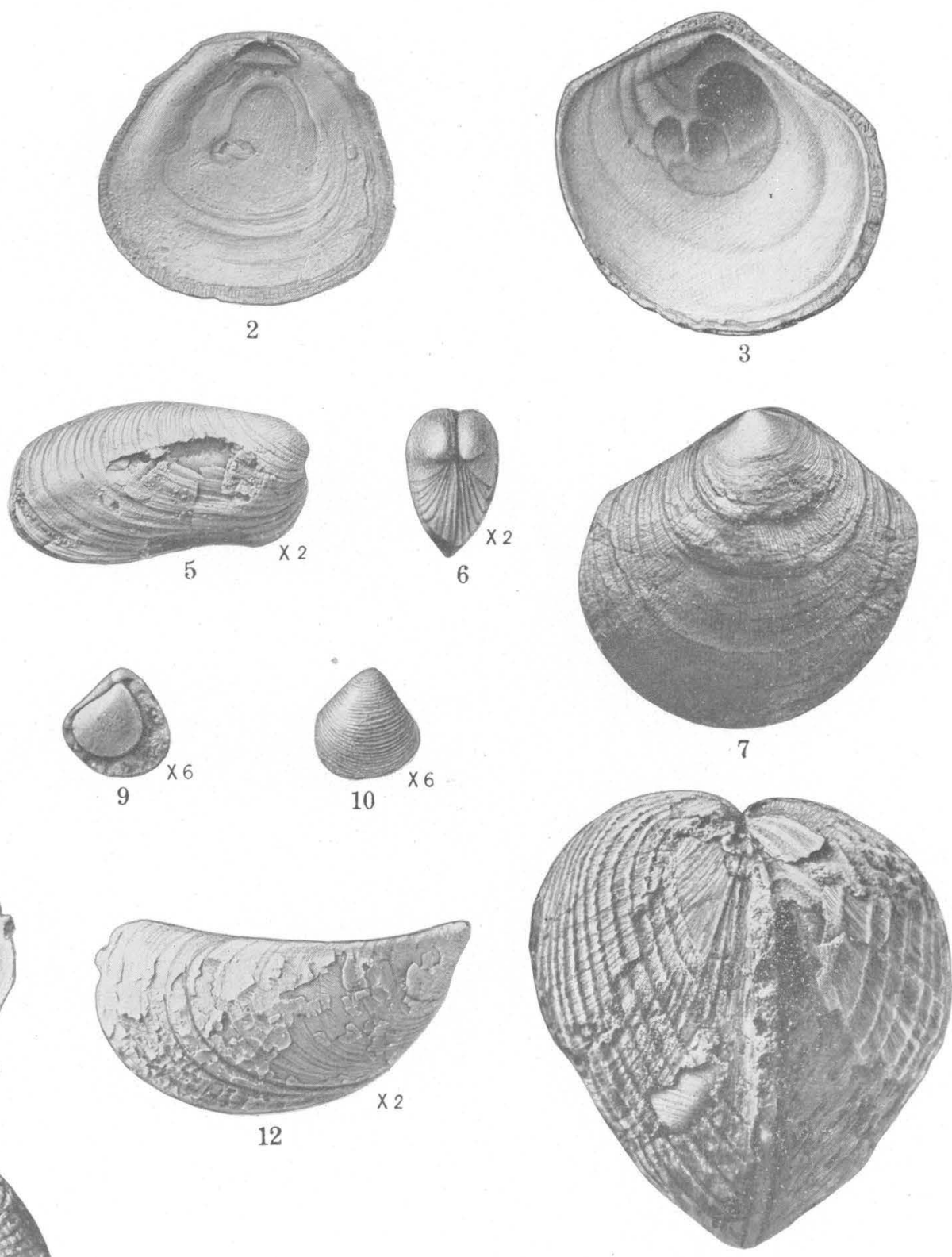

13

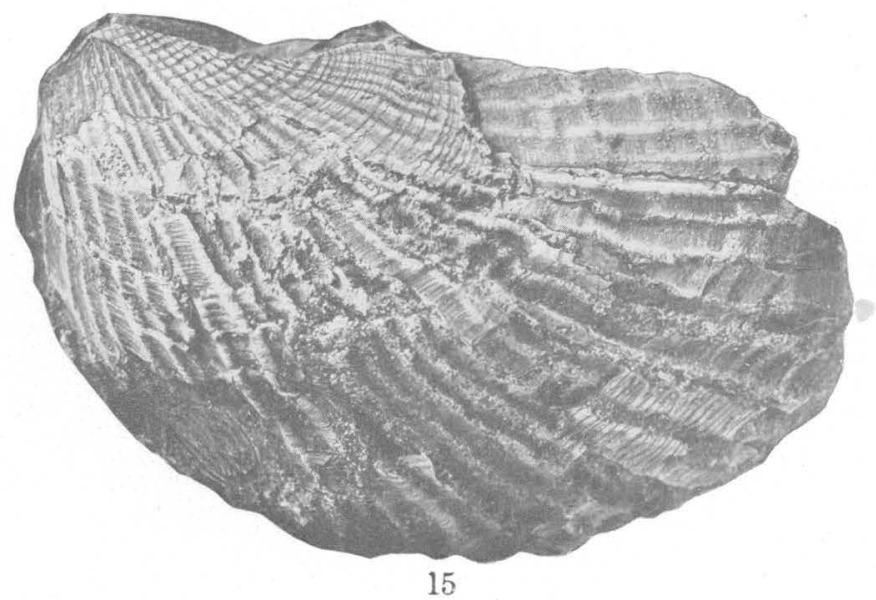

15

RIPLEY FOSSILS FROM COON CREEK, TENN, 


\section{PLATE XXIV}

\section{Ripley fossils from Coon Creek, Tenn.}

1. Pholadomya conradi Gardner (p. 73), anterior view of valves attached. (U. S. Nat. Mus. catalog No. 32772.)

2. Periplomya elliptica (Gabb) (p. 74), exterior view of left valve. (U. S. Nat. Mus. catalog No. 32773.)

3. Periploma applicata Conrad (p. 75), exterior view of right valve. (U. S. Nat. Mus. catalog No. 32774.)

4, 5. Clavagella armata Morton (p. 75). 4, Exterior view, showing anterior spinose collar; 5, exterior view of right valve. (U.S. Nat. Mus. catalog No. 32775.)

6. Liopistha protexta (Conrad) (p. 75), exterior view of right valve. (U. S. Nat. Mus. catalog No. 32776.)

7, 8. Liopistha inflata Whitfield, right valve (p. 76). 7, Exterior view of right valve; 8, interior view of right valve. (U.S. Nat. Mus. catalog No. 32777.)

9. Cyprina incerta Wade, n. sp. (p. 76), exterior view of left valve of the type. (U. S. Nat. Mus. catalog No. 32778.)

10, 11. Vetericardia subangulata Wade, n. sp., left valve of type (p. 78). 10, Exterior view; 11, interior view. (U. S. Nat. Mus. catalog No. 32779.)

12, 13. Vetericardia crenalirata (Conrad), right valve (p. 78). 12, Interior view; 13, exterior view. (U. S. Nat. Mus. catalog No. 32780.)

14-16. Veniella conradi (Morton) (p. 77). 14, Anterior view of valves attached; 15, 16, right valve (15, exterior view; 16, interior view). (U. S. Nat. Mus. catalog No. 32781.).

106913-26†—17 


\section{PLATE XXV}

\section{Ripley Fossils from Coon Creek, Tenn.}

1-3. Vetericardia gregaria (Meek and Hayden)?, right valve (p. 79). 1, 3, Exterior views; 2, interior view. (U. S. Nat. Mus. catalog No. 32782.)

4, 5. Vetericardia subcircula Wade, n. sp., right valve of type (p. 79). 4, Exterior view; 5, interior view. (U. S. Nat. Mus. catalog No. 32783.)

6-8. Crassatellites vadosus (Morton) (p. 79). 6, Interior view of left valve; $\boldsymbol{7}$, exterior view of right valve; 8 , anterior view of two valves attached. (U. S. Nat. Mus. catalog No. 32784.)

9, 10. Crassatellina carolinensis (Conrad), left valve (p. 81). 9, Interior view; 10, exterior view. (U. S. Nat. Mus. catalog No. 32785.)

11, 12, 15, 16. Scambula perplana Conrad, left valve (p. 82). 11, 12, 16, Exterior views; 15, interior view. (U. S. Nat. Mus. catalog No. 32786.)

13, 14. Caprinella coraloidea Hall and Meek? (p. 82). 13, Side view of shell fragment; 14, fragment showing shell structure. (U. S. Nat. Mus. catalog No. 32787.)

17, 18. Unicardium concentricum Wade, n. sp., right valve of type (p. 82). 17, Interior view; 18, exterior view. (U. S. Nat. Mus. catalog No. 32788.)

19-21. Lucina ripleyana Wade, n. sp. (p. 82). 19, Posterior view of two valves attached; 20, 21, left valve of type (20, interior view; 21, exterior view). (U. S. Nat. Mus. catalog No. 32789.) 

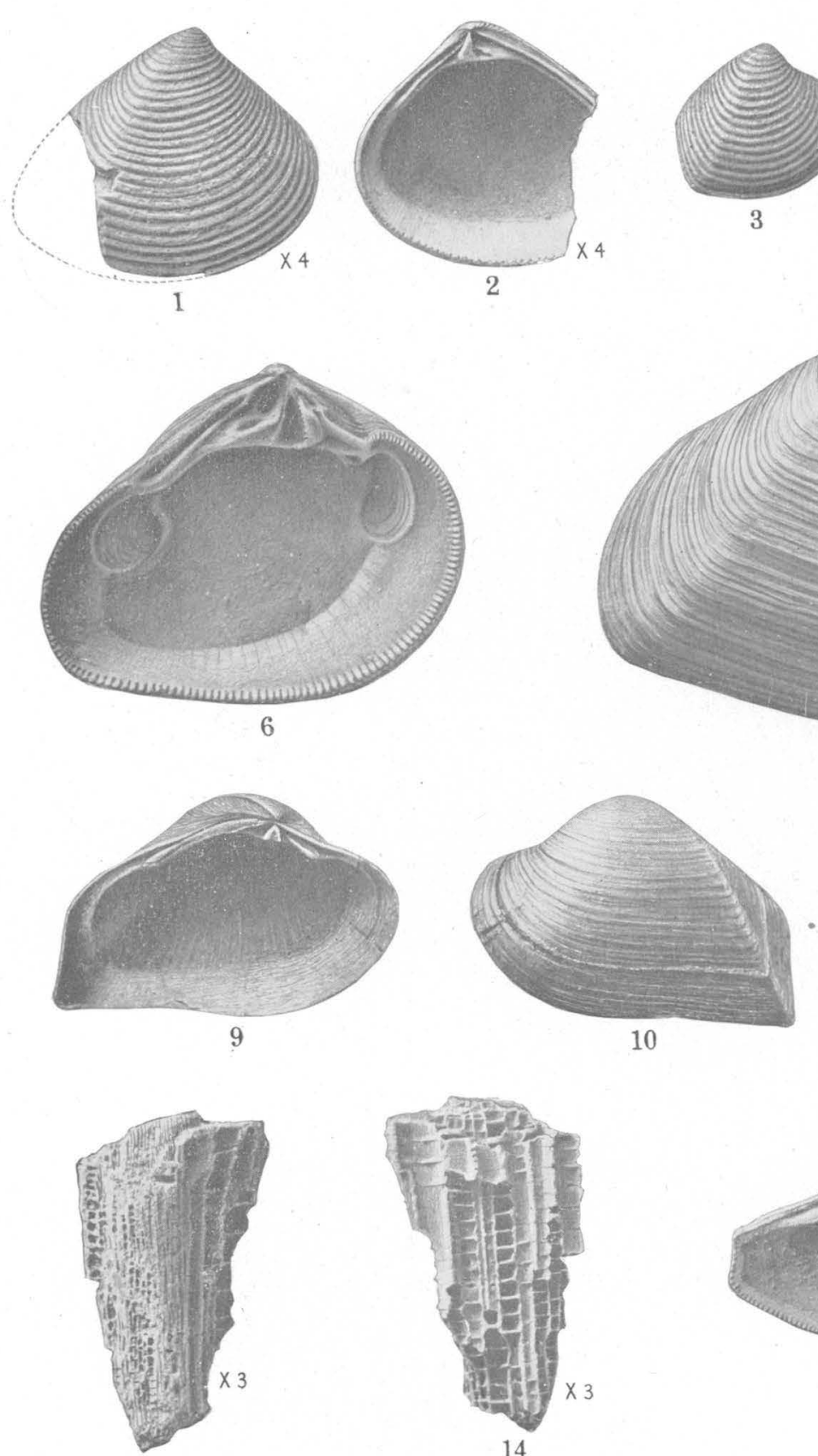

13
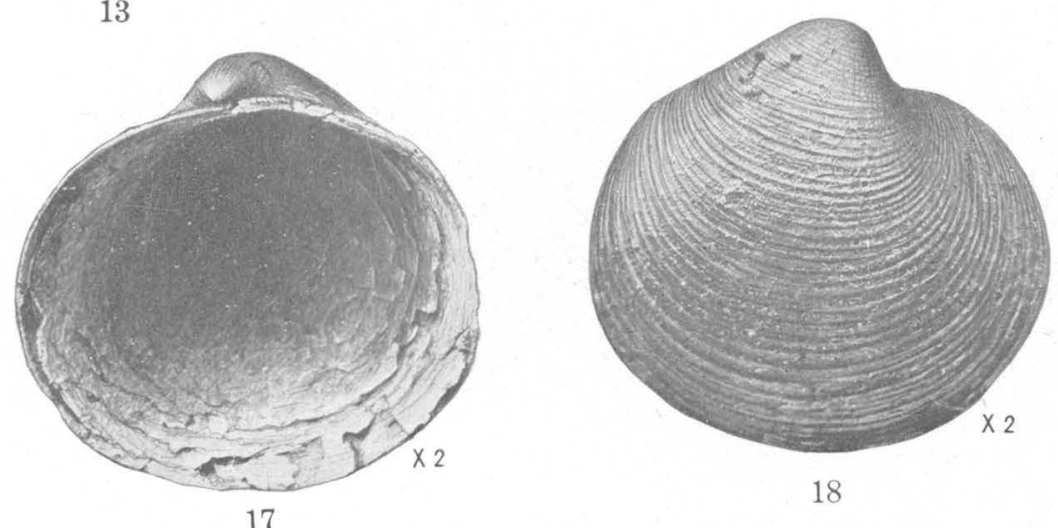

18
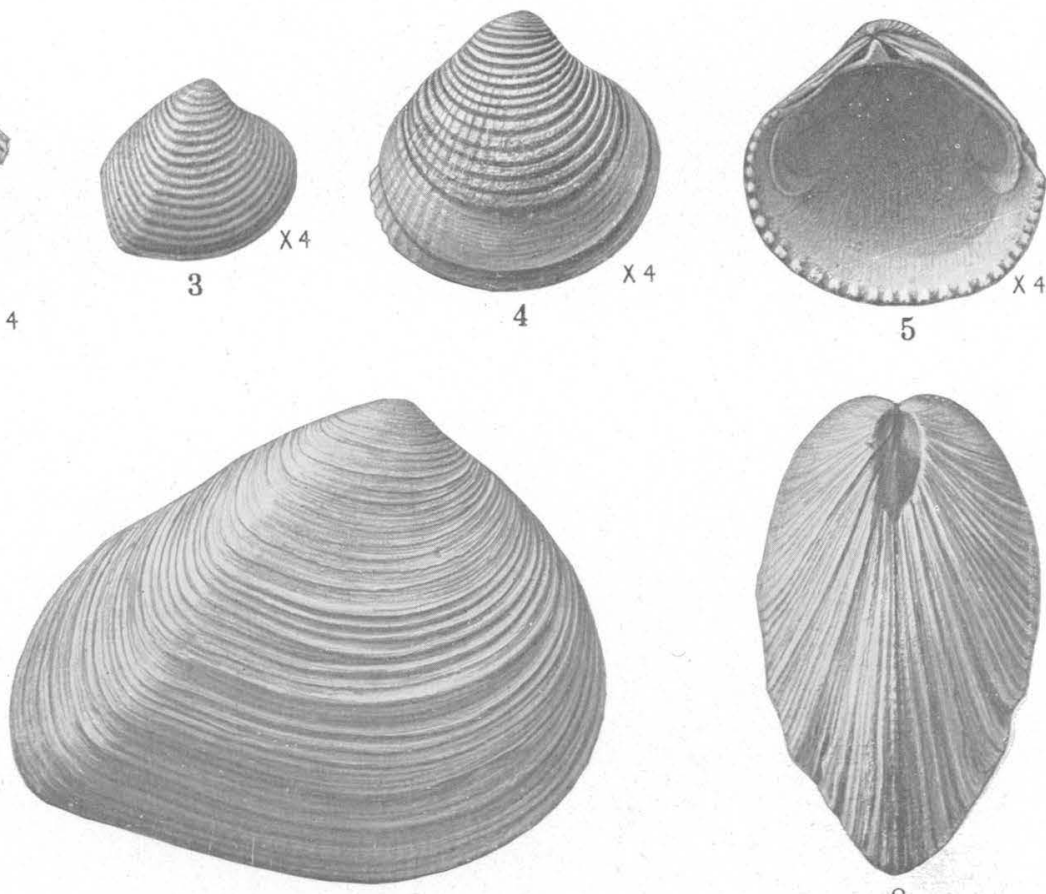

7
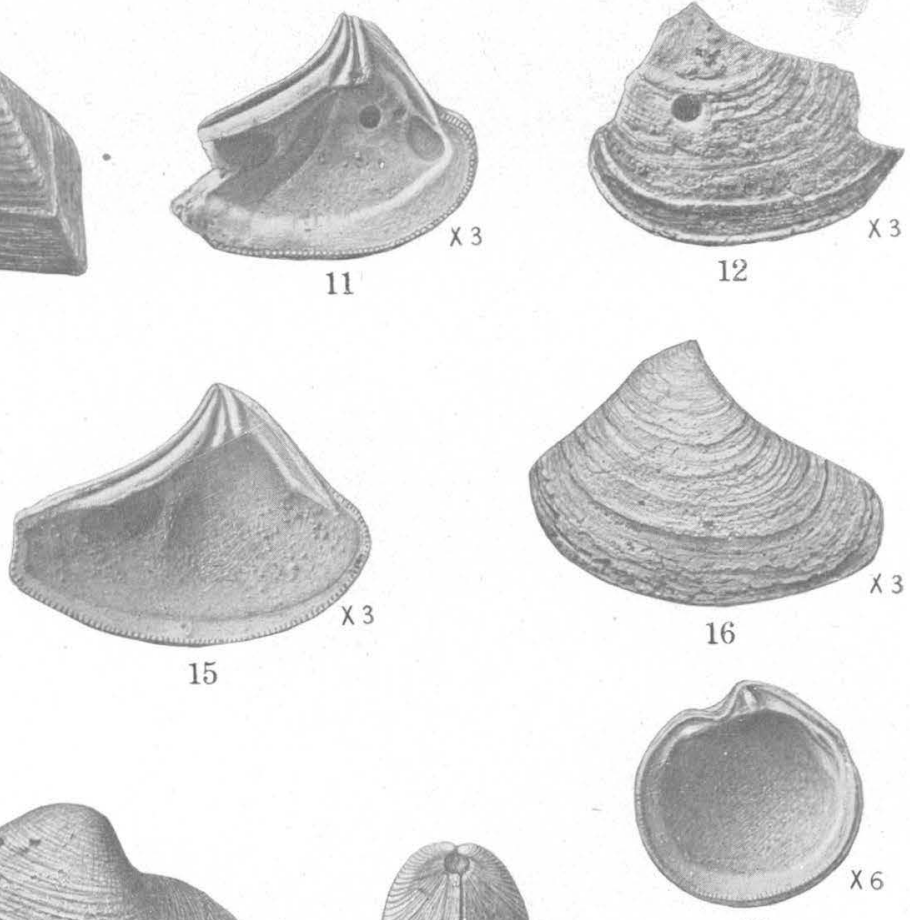

20

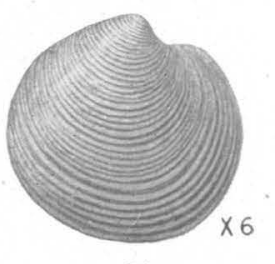

21

RIPLEY FOSSILS FROM COON CREEK, TENN. 

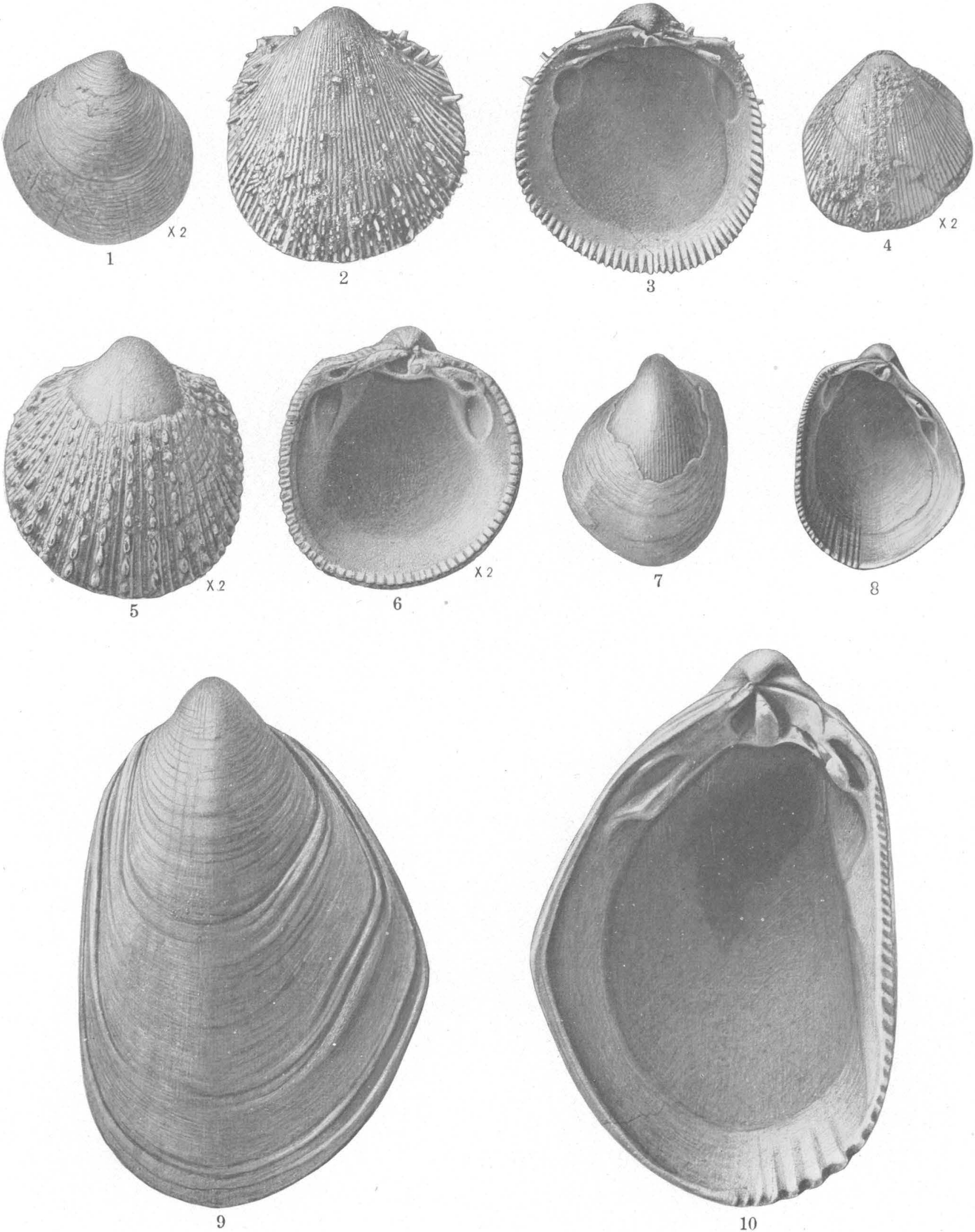

RIPLEY FOSSILS FROM COON CREEK, TENN. 


\section{PLATE XXVI}

\section{Ripley fossils from Coon Creek, Tenn.}

1. T'enea parilis Conrad (p. S3), external view of left valve. (U. S. Nat. Mus. catalog No. 32790.)

2, 3. Cardium dumosum Conrad, right valve (p. 83). 2, Exterior view; 3, interior view. (U. S. Nat. Mus. catalog No. 32791.) 4. Cardium tenuistriatum (Whitfield) (p. S4), exterior view of right valve. (U. S. Nat. Mus. catalog No. 32792.)

5, 6. Cardium kïmmeli Weller, left valve (p. 85). 5, Exterior view; 6, interior view. (U. S. Nat. Mus. catalog No. 32793. )

7-10. Cardium stantoni Wade, n. sp. (p. 86). $\boldsymbol{7}, \mathbf{8}$, Left valve (7, exterior view; 8 , interior view); 9, 10, right valve of type (9, exterior view; 10, interior view). (U. S. Nat. Mus. catalog No. 32794.) 


\section{PLATE XXVII \\ Ripley fossils from Coon Creek, Tenn.}

1. Protocardia parahillana Wade, n. sp. (p. 87), exterior view of right valve of type. (U. S. Nat. Mus. catalog No. 32795.$)$

2, 3. Cyclina parva Gardner, right valve (p. 87). 2, Exterior view; 3, interior view. (U. S. Nat. Mus. catalog No. 32796 .)

4, \%. Meretrix cretacea (Conrad), right valve (p. 88). 4, Interior view; 7 , exterior view. (U. S. Nat. Mus. catalog No. 32797.)

5. Protocardia parahillana Wade, n. sp. (p. 87), interior view of right valve of type. (U. S. Nat. Mus. catalog No. 32795 .)

6. Isocardia conradi Gabb (p. 87), exterior view.of right valve. (U. S. Nat. Mus. catalog No. 32798.)

8, 9. Cardium stantoni Wade, n. sp. (p. 86): 8, Anterior view of two valves attached; 9 , posterior view of attached valves, showing ligament in place. (U. S. Nat. Mus. catalog No. 32794.) 
GELOGICAL SURVEY
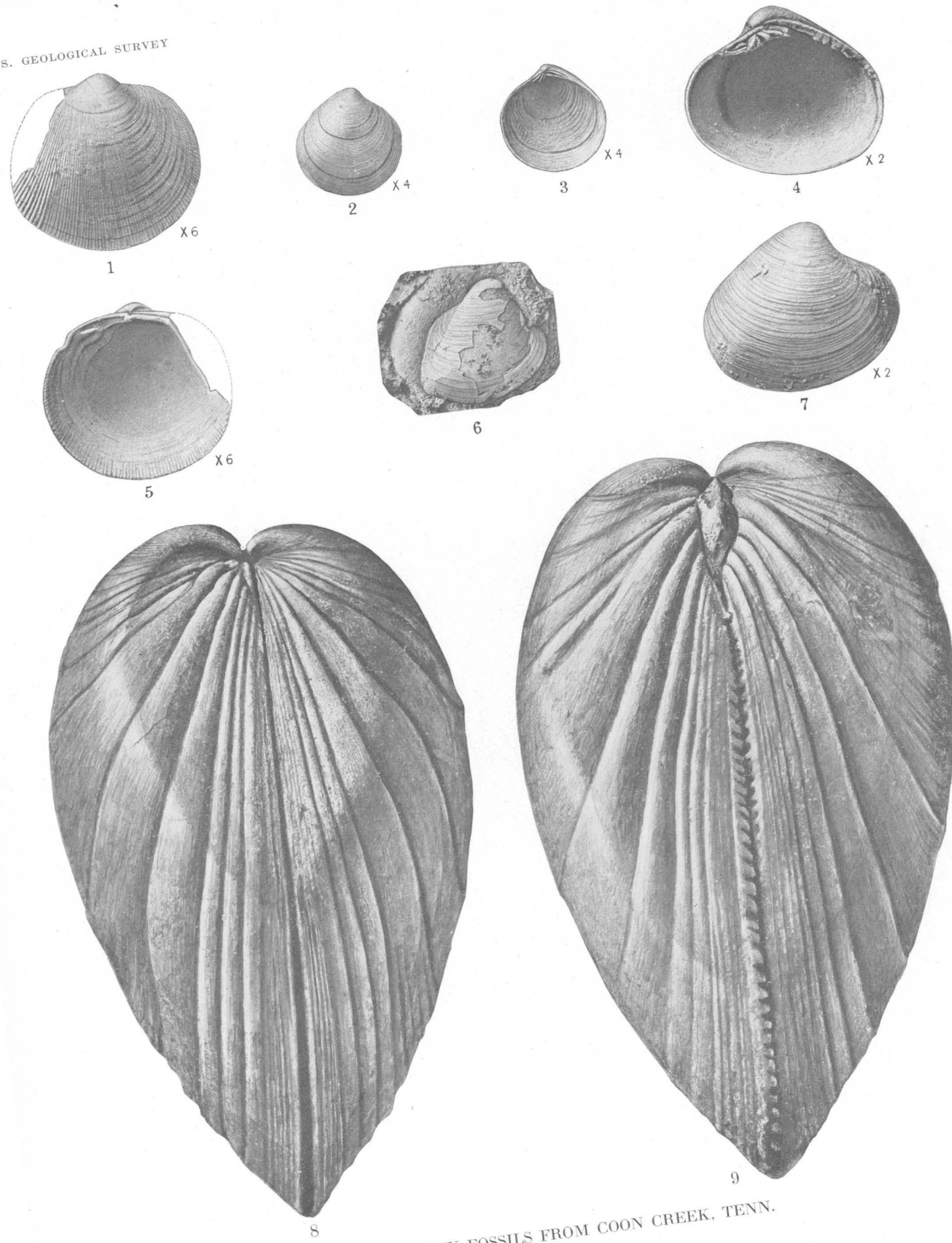

FROM COON CREEK. TENN. 

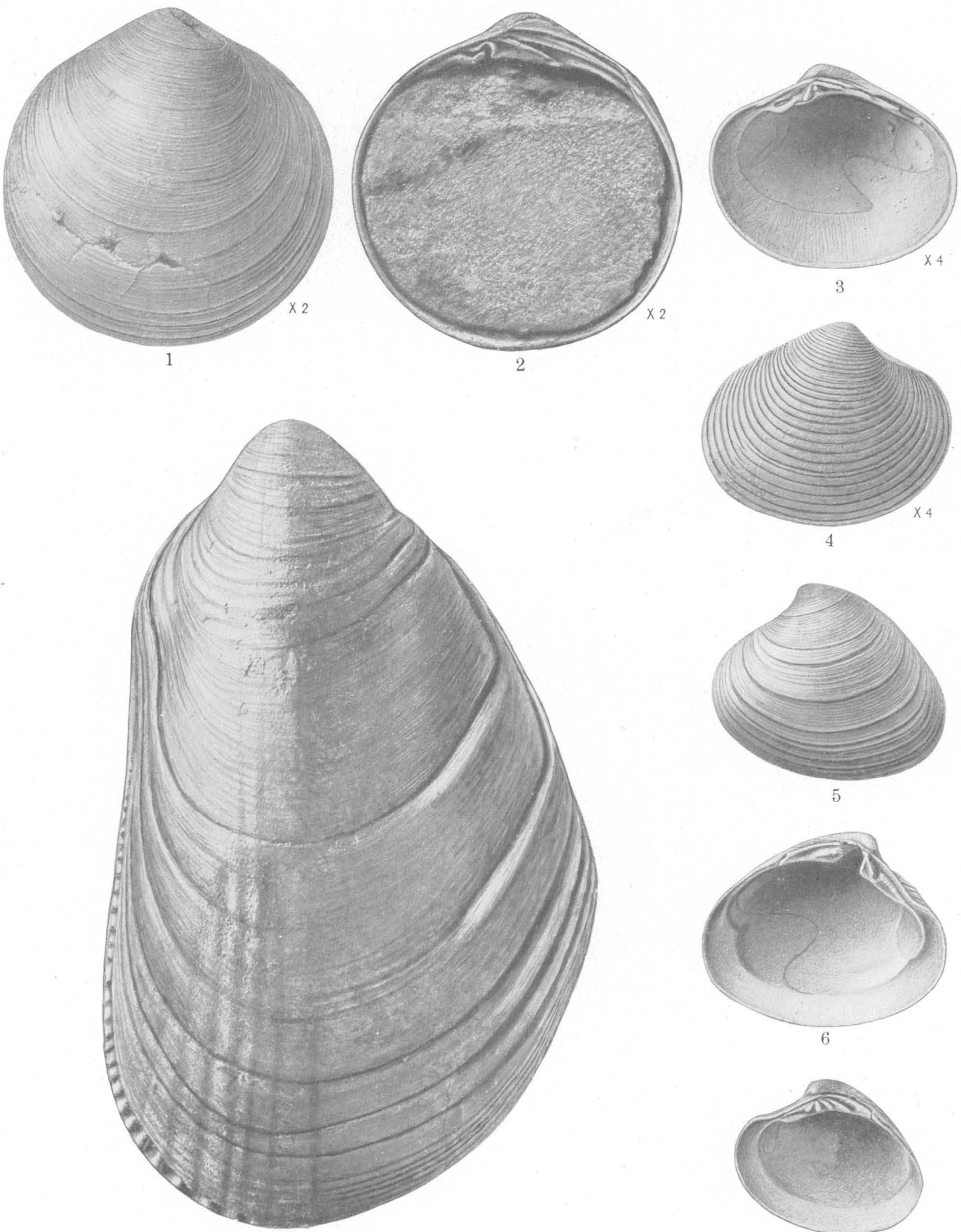

8

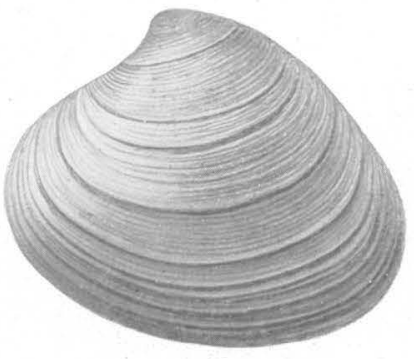

5

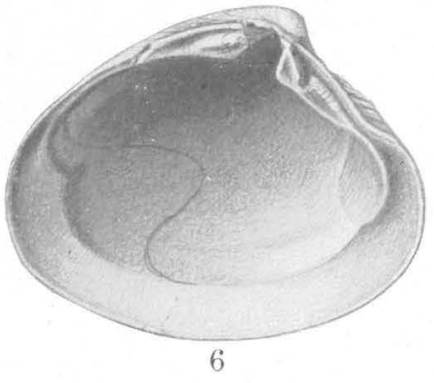

RIPLEY FOSSILS FROM COON CREEK, TENN.

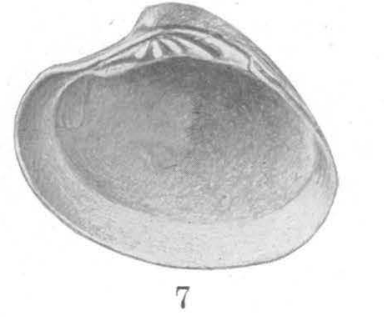




\section{PLATE XXVIII \\ Ripley fossils from Coon Creek, Ténn.}

1, 2. Cyclina magna Wade, n. sp., right valve of type (p. 88). 1, External view; 2, internal view. (U. S. Nat. Mus. catalog No. 32799.)

3, 4. Meretrix eufaulensis (Conrad), right valve (p. 89). 3, Interior view; 4, exterior view. (U.'S. Nat. Mus. catalog No. 32800.) 5-\%. A phrodina lippana Conrad, right valve (p. 89). 5, Exterior view; 6, 7, interior views. (U. S. Nat. Mus. catalog No. 32801.) 
PLATE XXIX

Ripley fossils from Coon Creek, Tenn.

1. Legumen planulatum (Conrad) (p. 90), exterior view of right and left valves. (U. S. Nat. Mus. catalog No. 32802.)

2-4. Cyprimeria alta Conrad (p. 91). 2, 4, left valve (2, interior view; 4, exterior view); $\mathbf{3}$, posterior view of both valves attached. (U. S. Nat. Mus. catalog No. 32803.)

5, 6. Icanotia pulchra Wade, n. sp., left valve of type (p. 91). 5, Interior view; 6, exterior view. (U. S. Nat. Mus. catalog No. 32804.) 

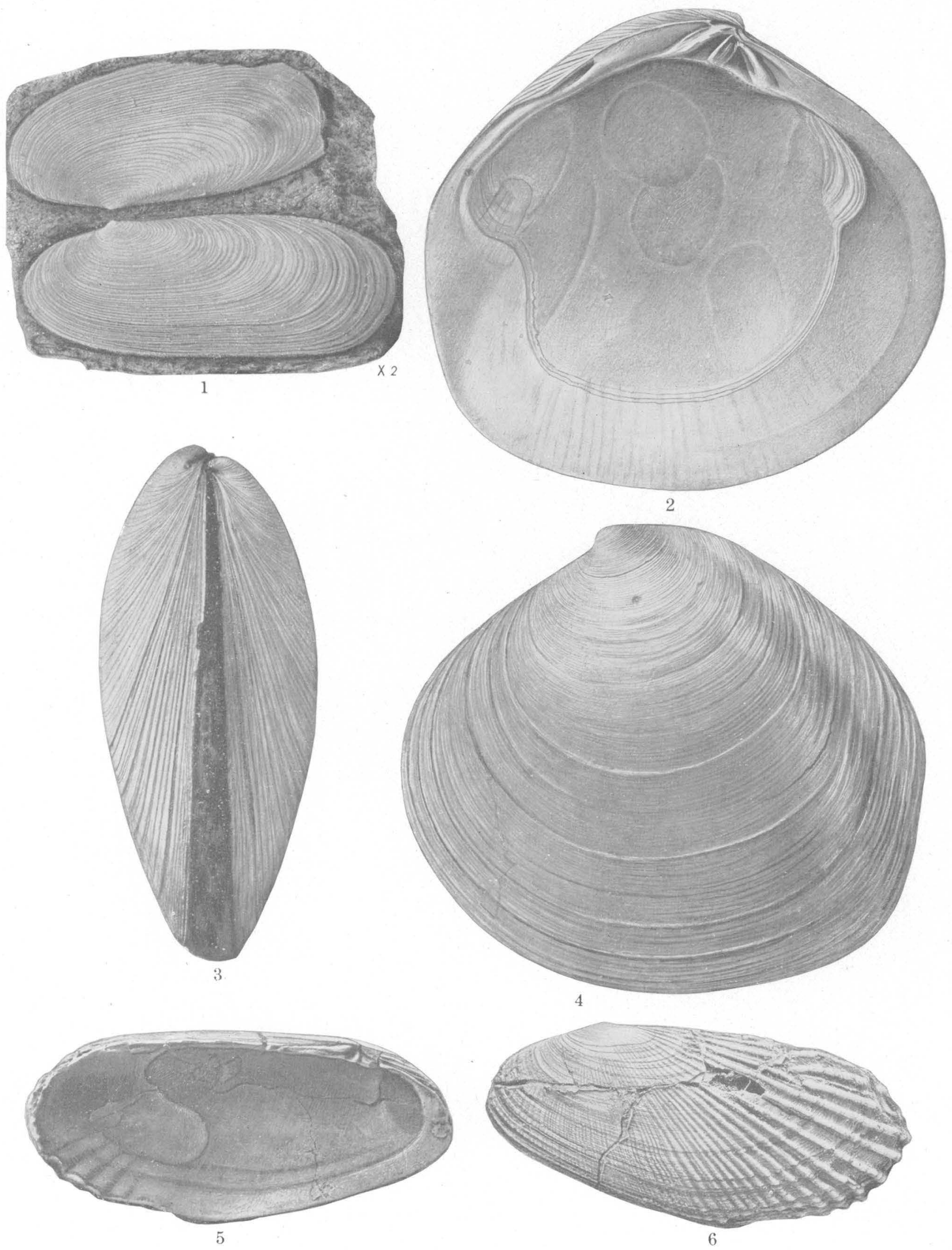

RIPLEY FOSSILS FROM COON CREEK, TENN. 
U. S. GEOLOGICAL SURVEY
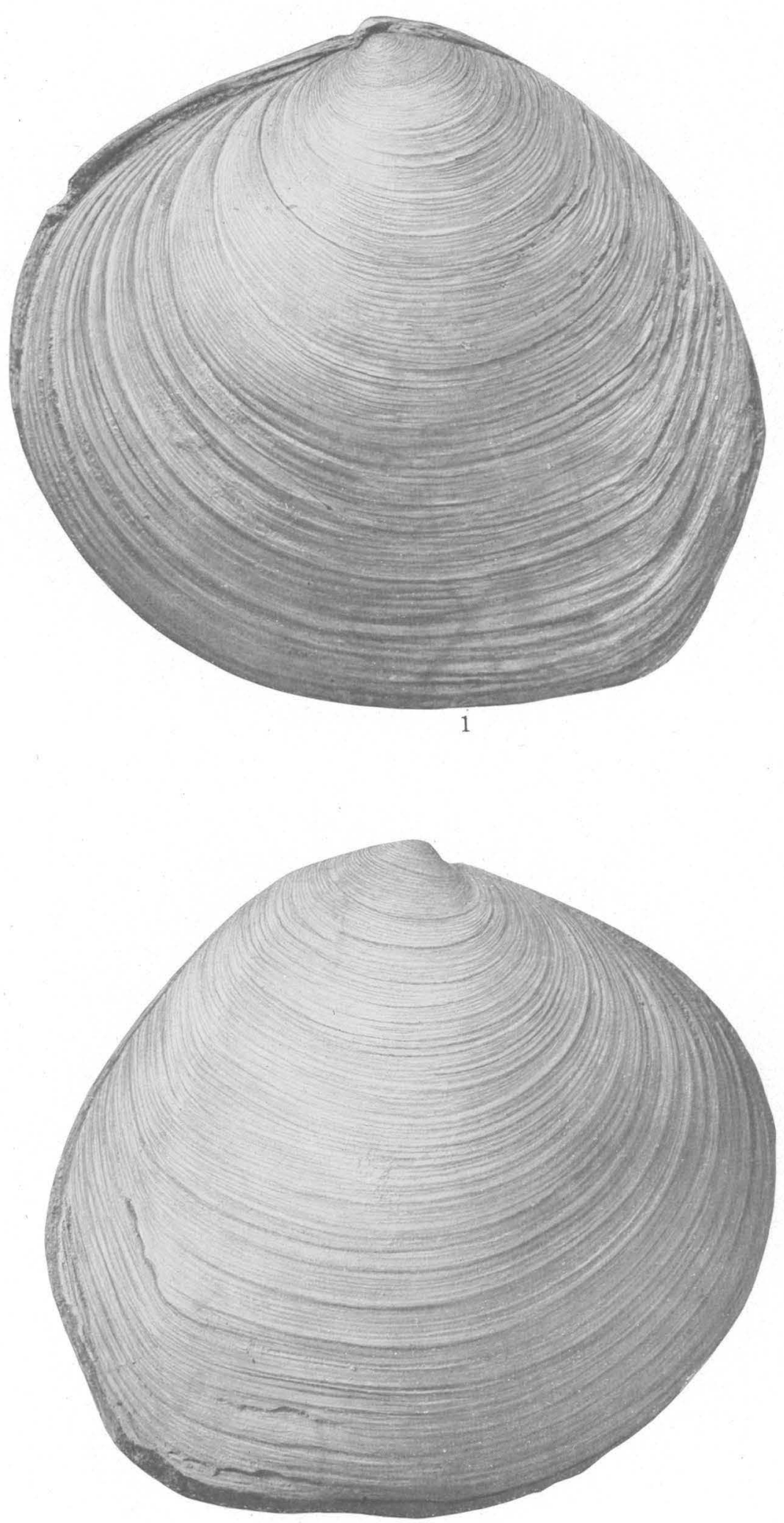

8
PROFESSIONAL PAPER 137 PLATE XXX
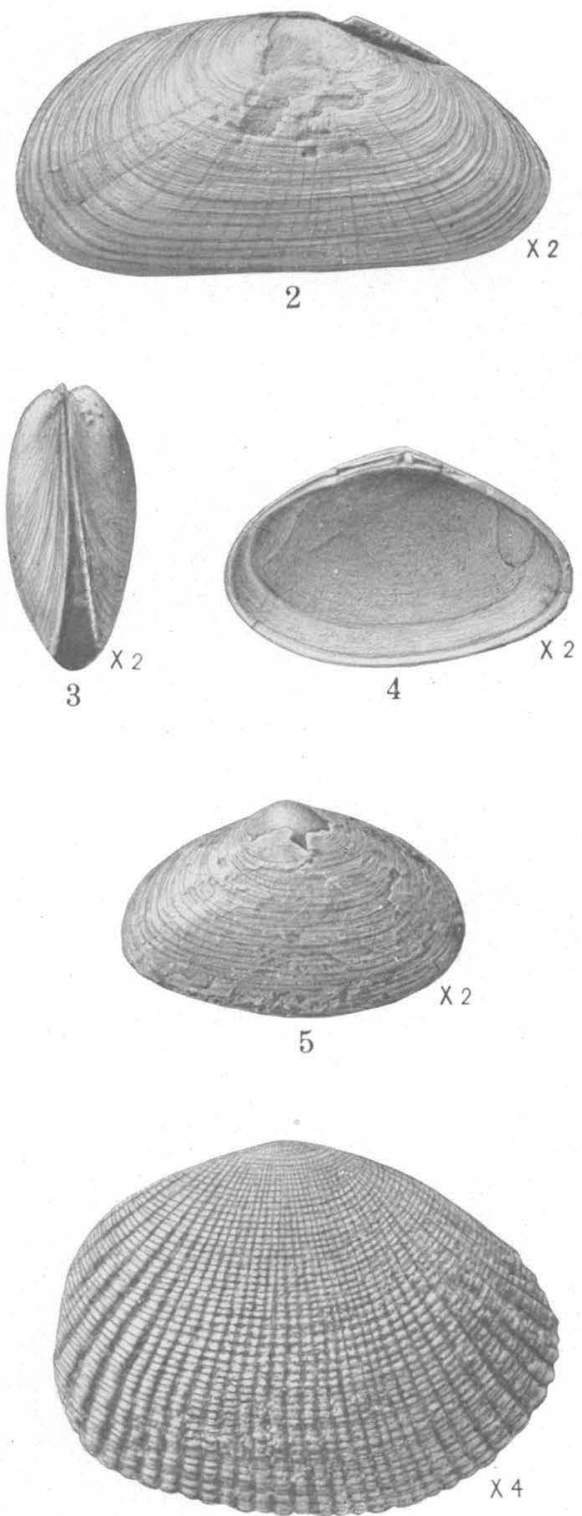

6

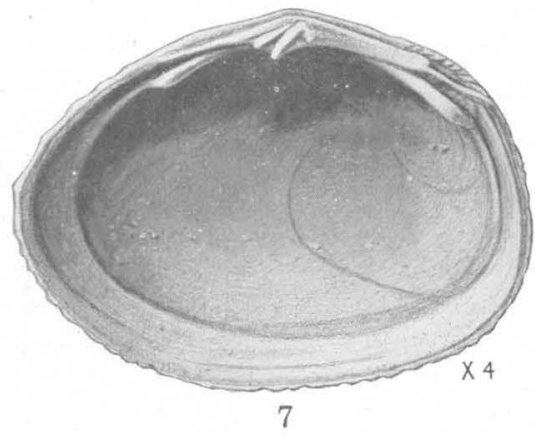

RIPLEY FOSSILS FROM COON CREEK, TENN. 


\section{PLATE XXX \\ Ripley Fossils from Coon Creek, Tenn.}

1. Cyprimeria alta Conrad, exterior view of left valve (p. 91). (U. S.. Nat. Mus. catalog No. 32803.)

2, 3. Tellina multiconcentrica Wade, n. sp. (p. 92). 2, Exterior view of left valve of type; 3, posterior view of valves of type attached. (U. S. Nat. Mus. catalog No. 32805.)

4, 5. Aenona eufalensis Conrad, right valve (p. 92). 4, Interior view; 5, exterior view. (U. S. Nat. Mus. catalog No. 32806.$)$

6, 7. Linearia ornatissima Weller, left valve (p. 94). 6, Exterior view; 7, interior view. (U. S. Nat. Mus. catalog No. 32807. ) 


\section{PLATE XXXI \\ Ripley Fossils from Coon Creek, Tenn.}

1, 2. Linearia metastriata Conrad, left valve (p. 93). 1, Interior view; 2, exterior view. (U. S. Nat. Mus. catalog No. 32808 .)

3, 5, 6. Liothyris carolinensis Conrad (p: 94). 3, Left valve, interior view; 5, 6, right valve (5, exterior view; 6, interior view). (U. S. Nat. Mus. catalog No. 32809.)

4, \%. Leptosolen biplicata Conrad (p. 94). 4, Exterior view of right valve; 7 , interior view of another valve. (U. S. Nat. Mus. catalog No. 32810.)

8. Cymbophora gracilis (Meek and Hayden) (p. 95), exterior view of left valve. (U. S. Nat. Mus. catalog No. 32811.)

9, 13. Corbula crassiplica Gabb (p. 96). 9, Right valve, exterior view; 13, left valve, exterior view. (U. S. Nat. Mus. catalog No. 32812.)

10, 14. Corbula monmouthensis Gardner (p. 97). 10, Left valve, exterior view; 14, right valve, exterior view. (U. S. Nat. Mus. catalog No. 32813.)

11, 12. Corbula paracrassa Wade, n. sp. (p. 97). 11, Left valve of type, exterior view; 12, right valve of type, exterior view. (U. S. Nat. Mus. catalog No. 32814.)

15, 16, 19, 20. Corbulamella suffalciata Wade, n. sp. (p. 97). 15, Right valve of type, interior view; 16, right valve, exterior view; 19, posterior view; 20, anterior view. (U. S. Nat. Mus. catalog No. 32815.)

17, 18. Corbula williardi Wade, n. sp. (p. 97). 17, Right valve of type, exterior view; 18, left valve of type, exterior view. (U. S. Nat. Mus. catalog No. 32816.) 
U. S. GEOLOGICAL SURVEY
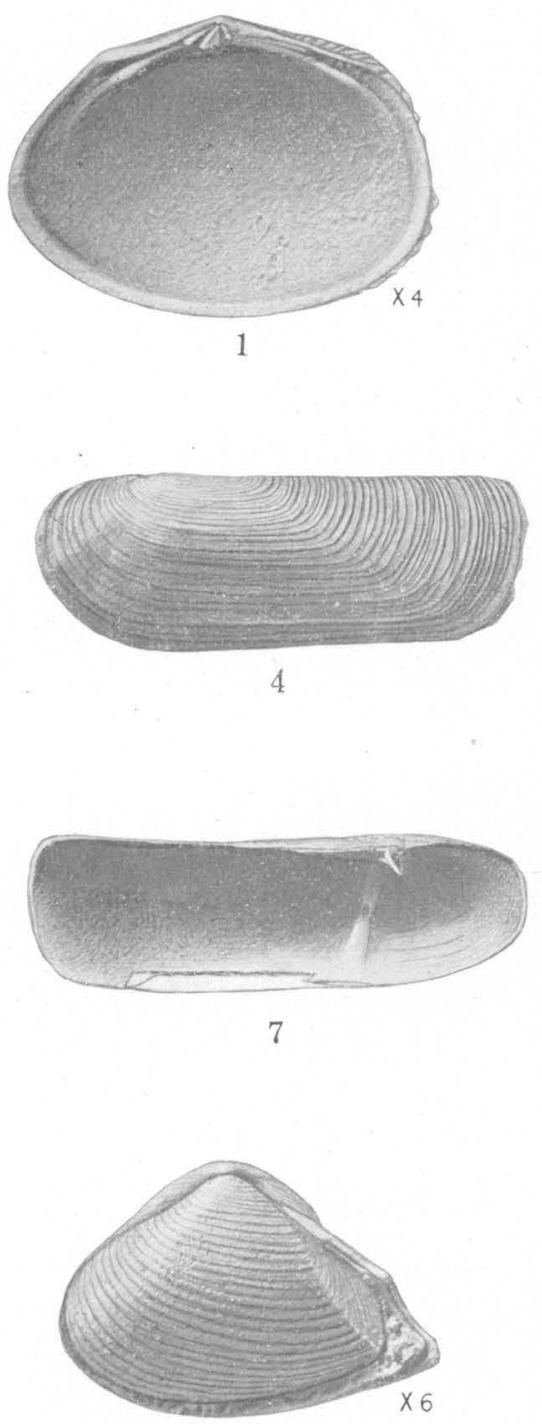

10
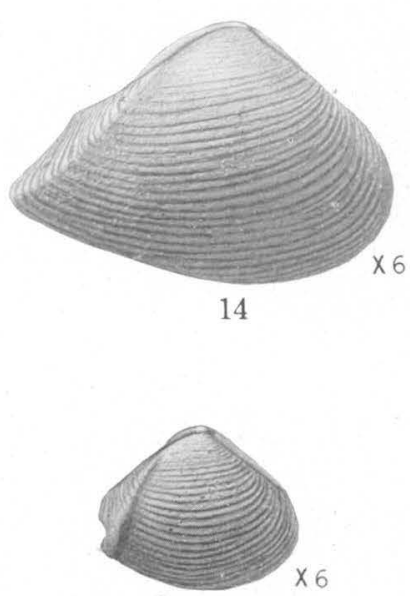

17
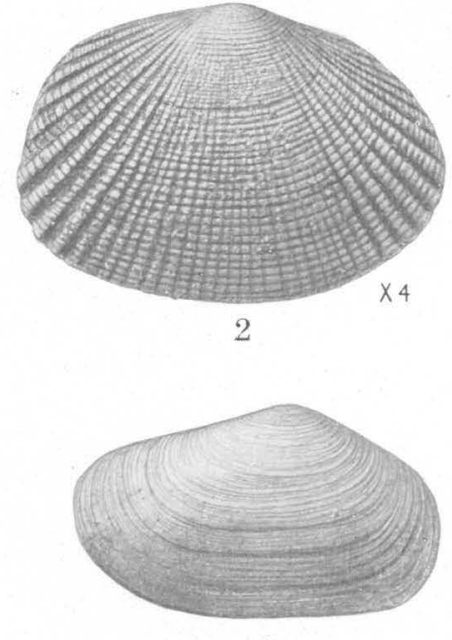

5
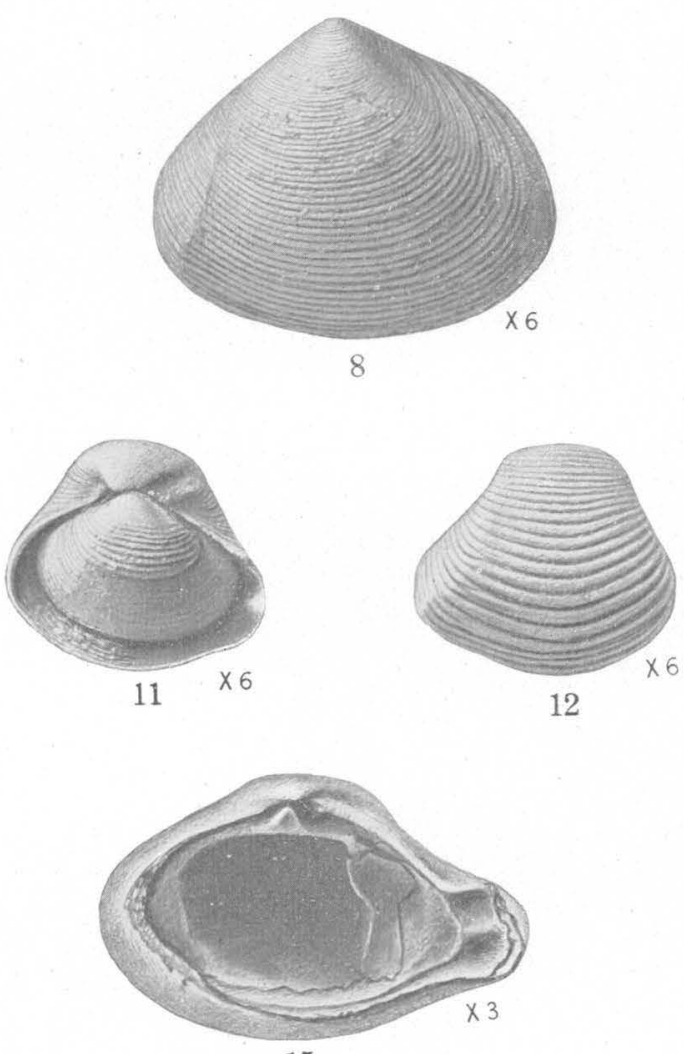

15

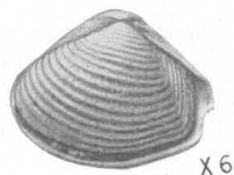

18

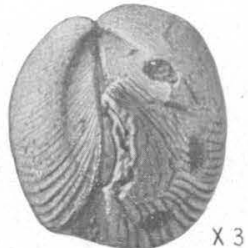

19
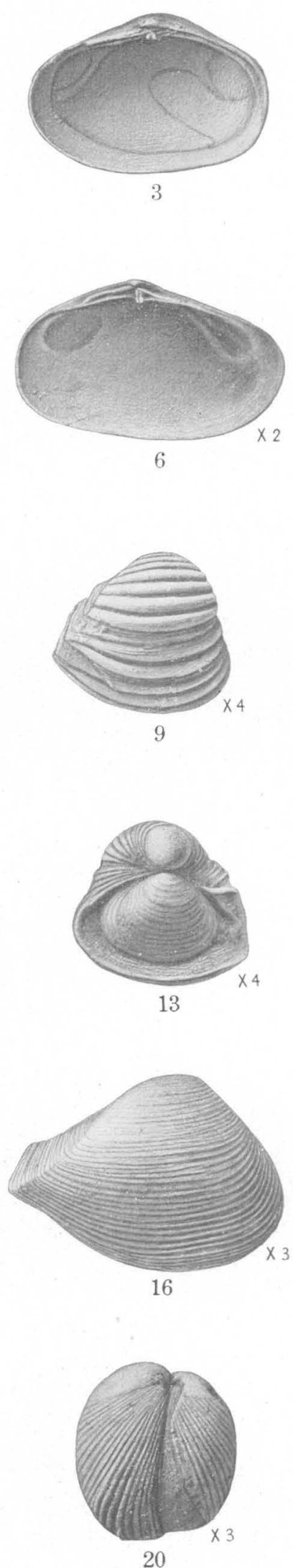

RIPLEY FOSSILS FROM COON CREEK, TENN. 


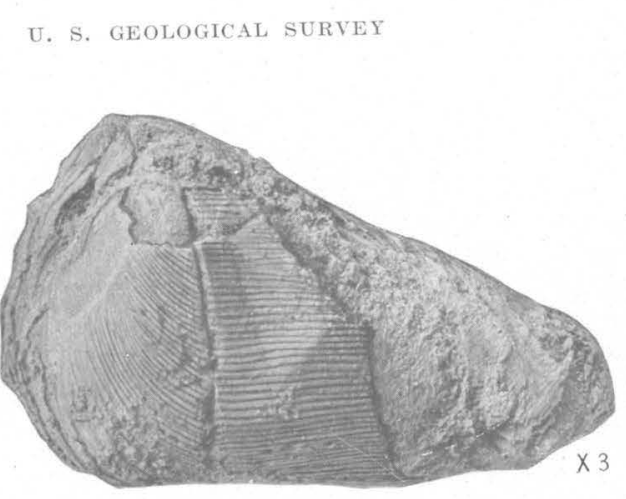

1

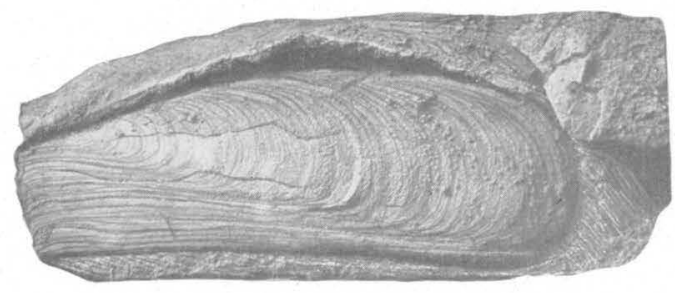

7
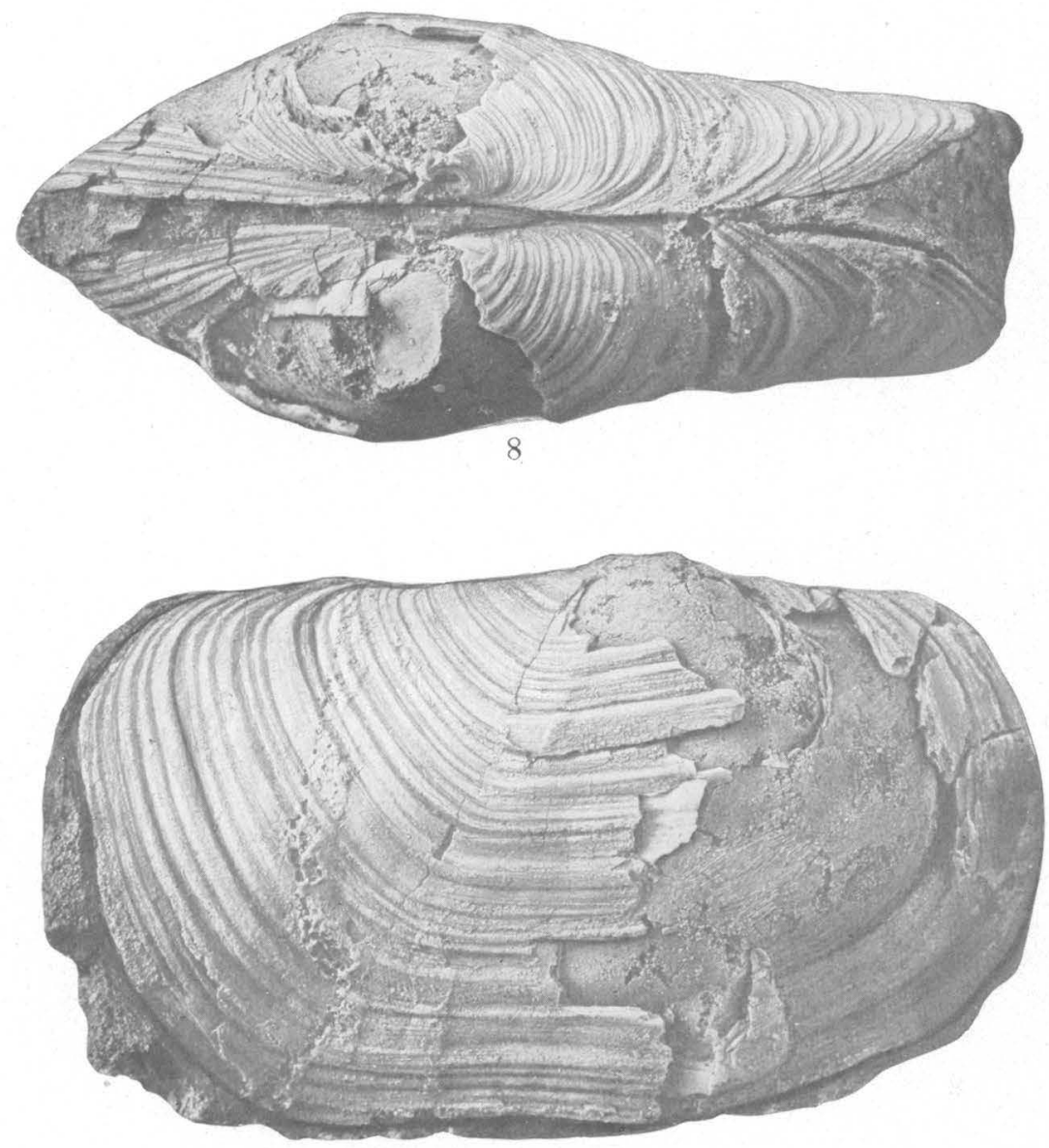

PROFESSIONAL PAPER 137 PLATE XXXII
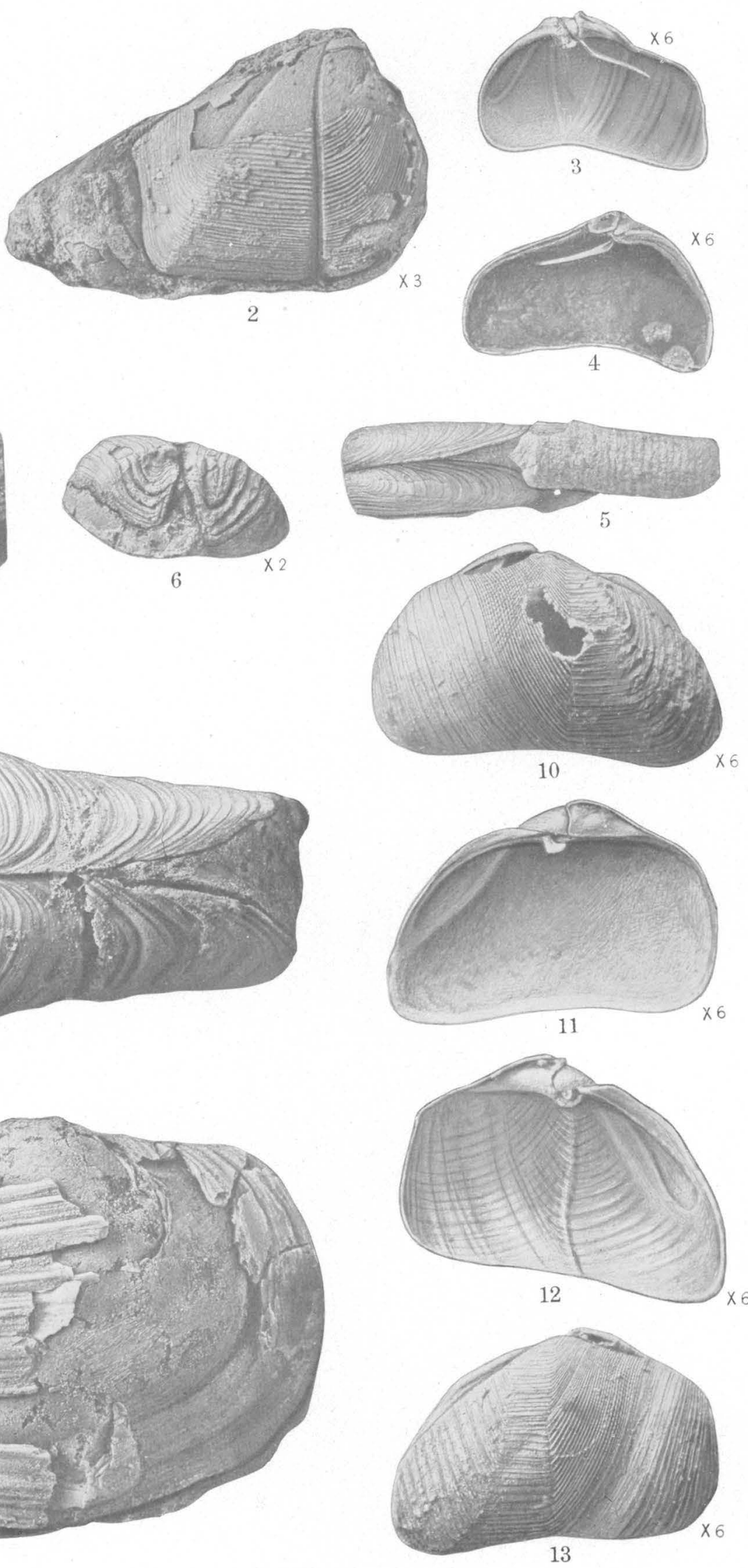

13

RIPLEY FOSSILS FROM COON CREEK, TENN. 


\section{PLATE XXXII}

\section{Ripley Fossils from Coon Creek, Tenn.}

1, 2. Marlesia truncata Wade, n. sp. (p. 99). 1, Left valve of type, exterior view; 2, right valve of type, exterior view. (U. S. Nat. Mus. catalog No. 32817.)

3, 4, 10-13. Martesia procurva Wade, n. sp. (p. 100). 3, Right valve of type, interior view; 4, left valve, interior view; 10, 11, left valve (10, exterior view; 11, interior view); 12, 13, right valve (12, interior view; 13, exterior view). (U. S. Nat. Mus. catalog No. 32818.)

5-\%. Gastrochaena americana Gabb (p. 99). 5, Two valves attached and a portion of a tube specimen from Owl Creek, Miss.; 6, anterior view of two valves attached; 7, exterior view of left valve. (U. S. Nat. Mus. catalog No. 20681.)

8, 9. Panope decisa Conrad (p. 98). 8, Valves attached, dorsal view; 9, right valve, exterior view. (U. S. Nat. Mus. catalog No. 32819.)

106918-26:-18 


\section{PLATE XXXIII}

\section{Ripley fossils from Coon Creek, Tenn.}

1. Teredo rectus Wade, n. sp. (p. 100), side view of type. (U. S. Nat. Mus. catalog No. 32820.)

2, 3. Dentalium inornatum Wade, n. sp. (p. 100), side views of type. (U. S. Nat. Mus. catalog No. 32821.)

4, 9. Dentalium ripleyanum Gabb (p. 101). 4, Side view; 9, end view. (U. S. Nat. Mus. catalog No. 32822.)

5, 6. Acteon linteus (Conrad) (p. 101). 5, Back view; 6, front view. (U. S. Nat. Mus. catalog No. 32823.)

7, 8. Cadulus obnutus (Conrad) (p. 101). 7, End view; 8, side view. (U. S. Nat. Mus. catalog No. 32824.)

10, 11. Acteon substriatus Wade, n. sp. (p. 102). 10, Back view of type; 11, front view. (U. S. Nat. Mus. catalog No. 32825.)

12, 13. Acteon conicus Wade, n. sp., type (p. 102). 12, Back view; 13, front view. (U. S. Nat. Mus. catalog No. 32826 .)

14, 15. Acteon modicellus Conrad (p. 102). 14, Back view; 15, front view. (U. S. Nat. Mus. catalog No. 32827.)

16, 17. Acteon ellipticus Wade, n. sp., type (p. 102). 16, Back view; 17, front view. (U. S. Nat. Mus. catalog No. 32828.)

18, 19. Dentalium intercalatum Wade,.n. sp. (p. 100), side views of type. (U. S. Nat. Mus. catalog No. 32829.) 226 

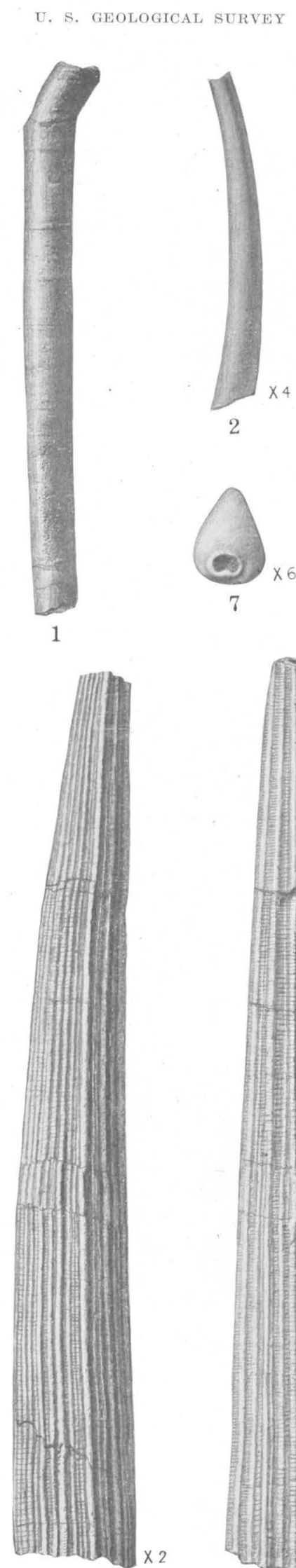

19
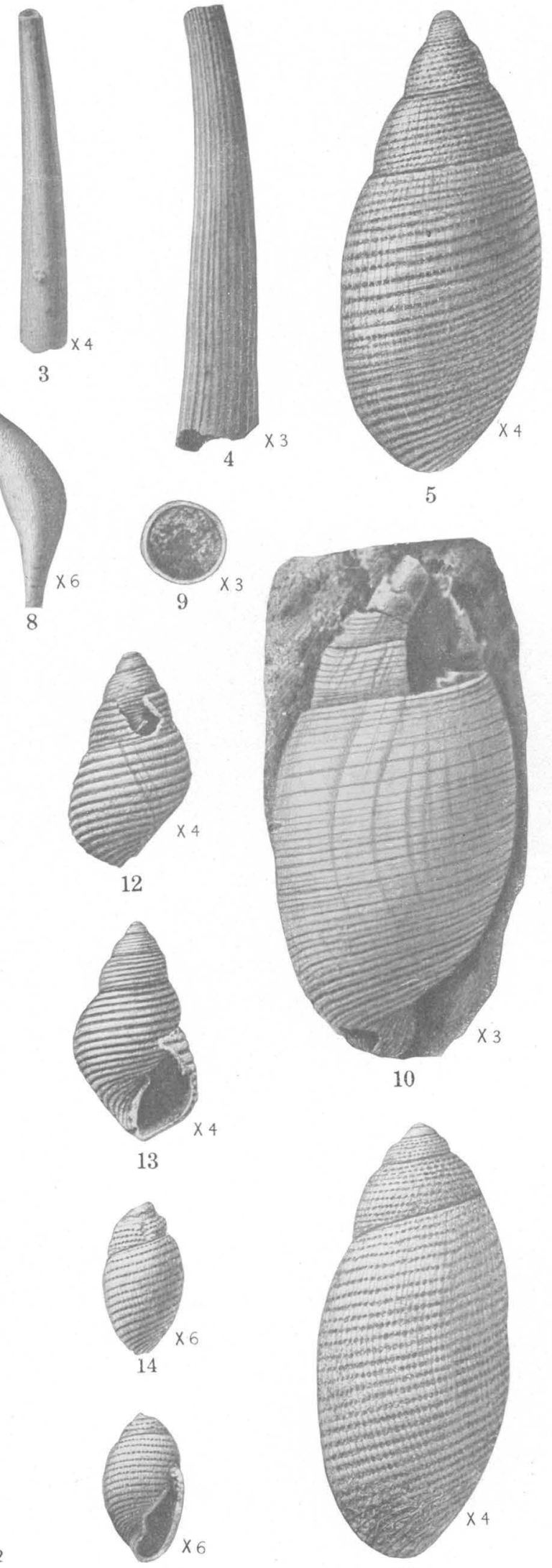

15
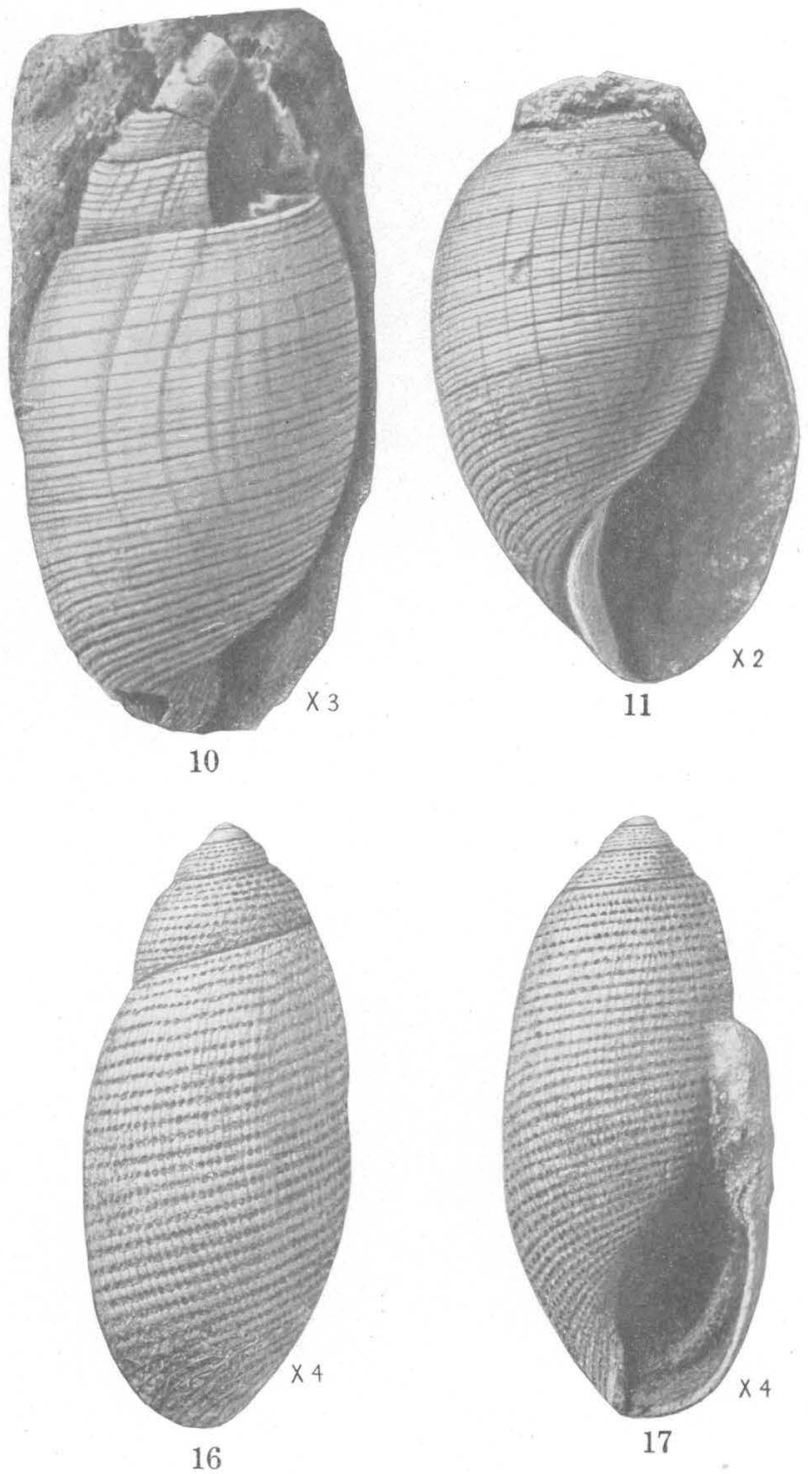

RIPLEY FOSSILS FROM COON CREEK, TENN.
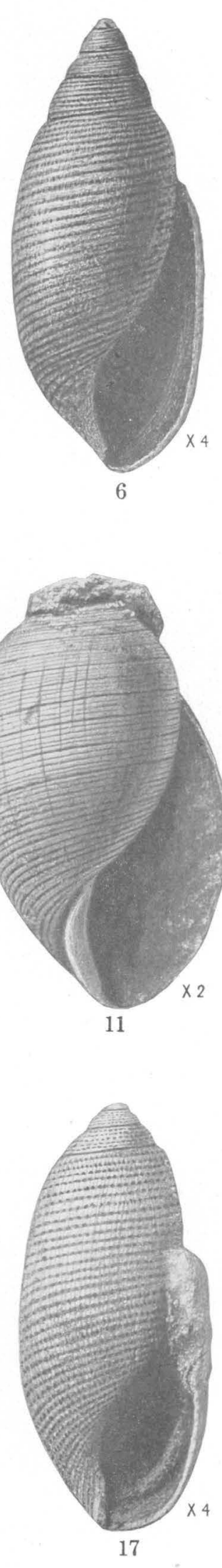

PROFESSIONAL PAPER 137 PLATE XXXIII 

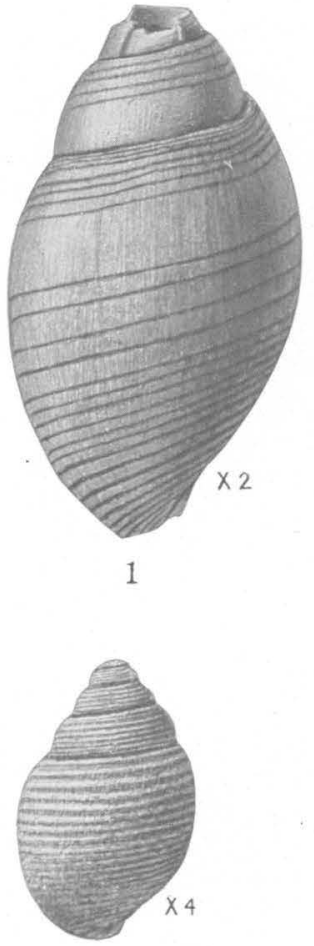

5

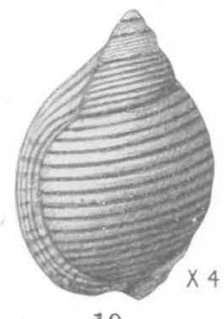

10

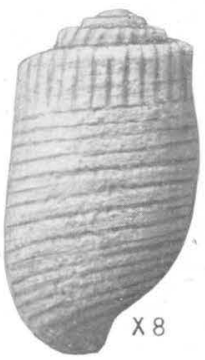

15

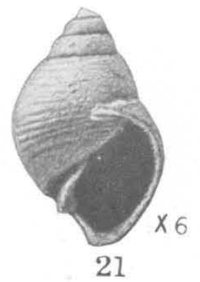

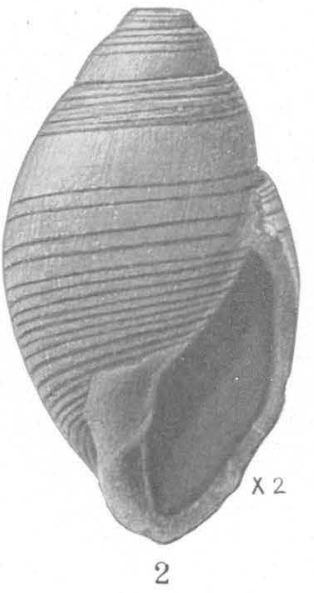
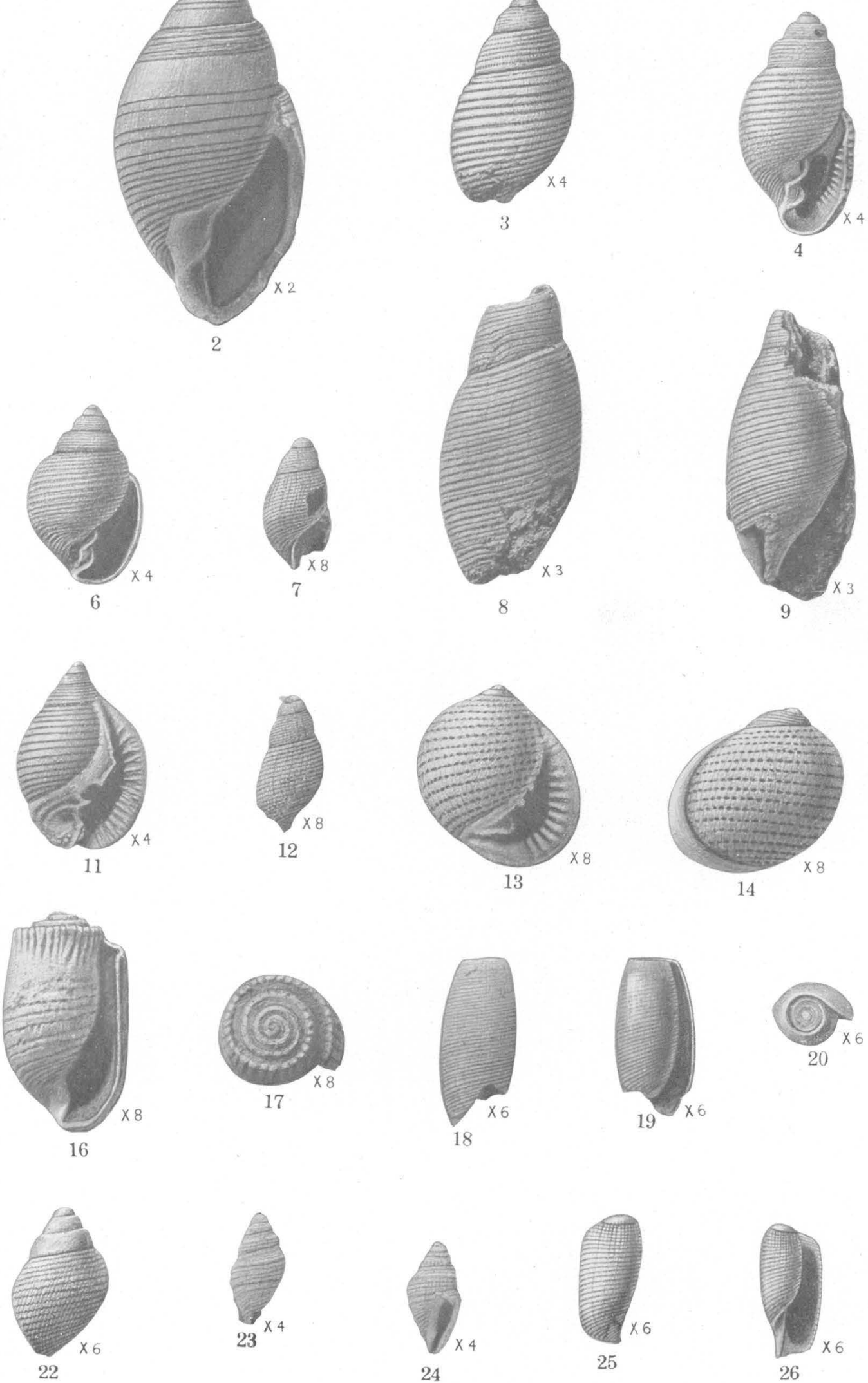

RIPLEY FOSSILS FROM COON CREEK, TENN. 


\section{PLATE XXXIV \\ Ripley fossils from Coon Creek, Tenn.}

1, 2. Troostella perimpressa Wade, n. gen. and sp., type.(p. 103). 1, Back view; 2, front view. (U. S. Nat. Mus. catalog No. 32830.)

3, 4. Tornatellaea cretacea Wade, n. sp., type (p. 103). 3, Back view; 4, front view. (U. S. Nat. Mus. catalog No. 32831 .)

5, 6. Tornatellaea globulosa Wade, n. sp., type (p. 104). 5, Back view; 6, front view. (U. S. Nat. Mus. catalog No. 32832.)

7, 12. Acteonina parva Wade, n. sp., type (p. 104). 7, Front view; 12, back view. (U. S. Nat. Mus. catalog No. 32833.)

8, 9. Acteonina orientalis Wade, n. sp., type (p. 104). 8, Back view; 9, front view. (U. S.. Nat. Mus. catalog No. 32834.)

10, 11. Ringicula pulchella Shumard (p. 105). 10, Back view; 11, front view. (U. S. Nat. Mus. catalog No. 32835. )

13, 14. Eriptycha? americana Wade, n. sp., type (p. 105). 13, Front view; 14, back view. (U. S. Nat. Mus. catalog No. 32836. )

15-17. Goniocylichna bisculpturata Wade, n. gen. and sp., type (p. 106). 15, Back view; 16, front view; 17, apical view. (U. S.

Nat. Mus. catalog No. 32837.)

18-20. Cylichna recta (Gabb) (p. 106). 18, Back view; 19, front view; 20, apical view. (U. S. Nat. Mus. catalog No. 32838.)

21, 22. Cinulia paraquensis Wade, n. sp., type (p. 105). 21, Front view; 22, back view. (U. S. Nat. Mus. catalog No. 22839.)

23, 24. Conorbis mcnairyensis Wade, type (p. 107). 23, Back view; 24, front view. (U. S. Nat. Mus. catalog No. 32840. )

25, 26. Scaphander rarus Wade, n. sp., type (p. 107). 25, Bark view; 25, front view. (U. S. Nat. Mus. catalog No. 32841.) 


\section{PLATE XXXV}

\section{Ripley Fossils from Coon Creek, Tenn.}

1, 2. Paladmete cancellaria (Conrad) (p. 107). 1, Back view; 2, front view. (U. S. Nat. Mus. catalog No. 32842.$)$

3, 6. Paladmete gardnerae Wade, n. sp., type (p. 108). 3, Back view; 6, front view. (U. S. Nat. Mus. catalog No. 32843.)

4, 5. Cancellaria acula Wade, n. sp., type (p. 108). 4, Back view; 5, front view. (U. S. Nat. Mus. catalog No. 32844.$)$

7, 8. Paladmete densata Wade, n. sp., type (p. 108). 7, Front view; 8, back view. (U. S. Nat. Mus. catalog No. 32845.)

9, 10. Mataxa elegans Wade, type (p. 109). 9, Back view; 10, front view. (U. S. Nat. Mus. catalog No. 32846.)

11, 12. Turris proxima Wade, n. sp., type (p. 110). 11, Front view; 12, back view. (U. S. Nat. Mus. catalog No. 32847.) 

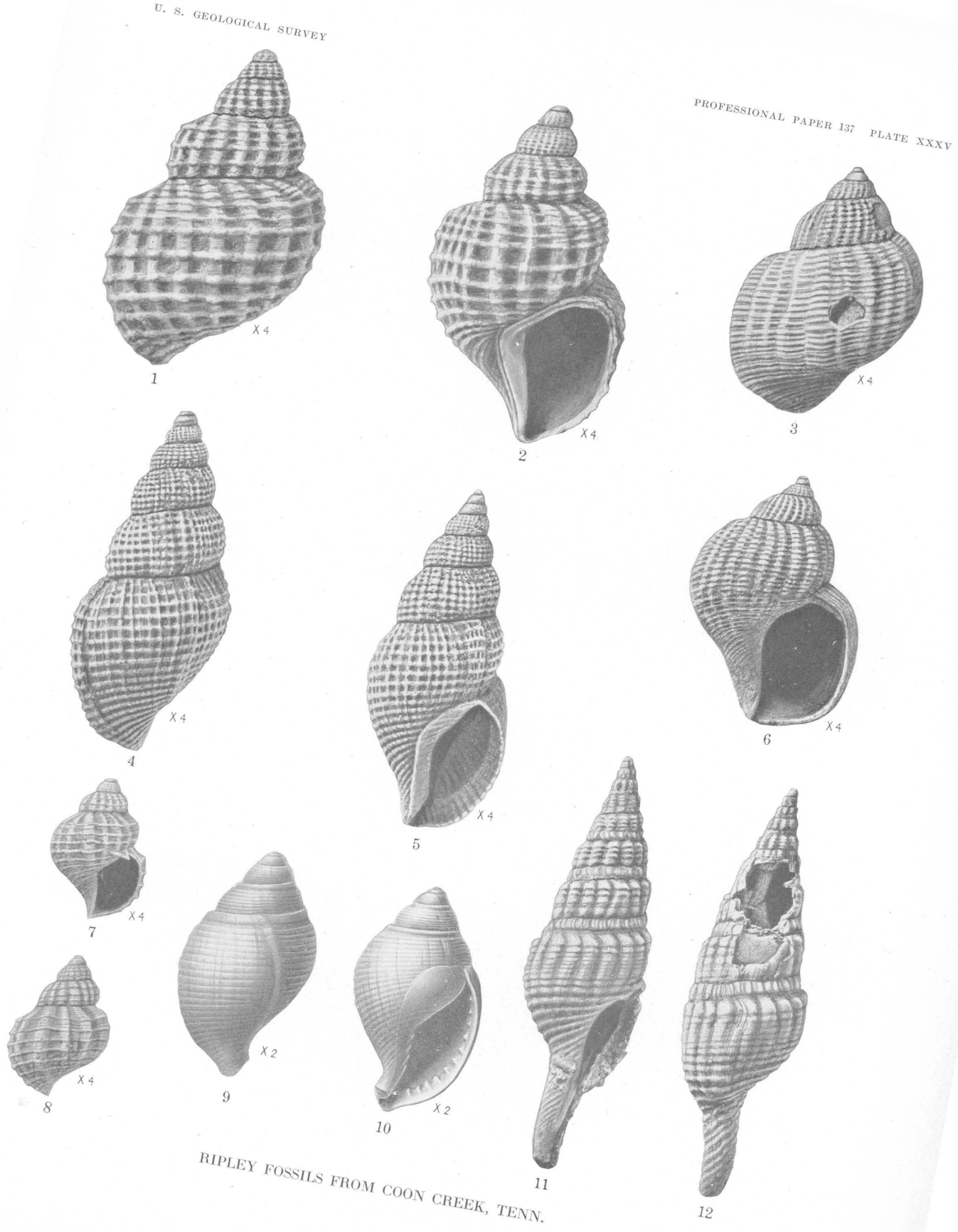
ANES

1049 


\section{PLATE XXXVI}

Ripley Fossils from Coon Creek, Tenn.

1, 2. T'urricula amica (Gardner) (p. 112). 1, Front view; 2, back view. (U. S. Nat. Mus. catalog No. 32848.)

3, 4. Turricula fasciolata Wade, n. sp., type (p. 112). 3, Back view; 4, front view. (U. S. Nat. Mus. catalog No. 32849.)

5, 10. Turris constricta Wade, n. sp., type (p. 110). 5, Back view; 10, front view. (U. S. Nat. Mus. catalog No. 32850. )

6, \%. Turricula iripleyana (Conrad) (p. 111). 6, Front view; 7 , back view. (U. S. Nat. Mus. catalog No. 32851.)

8, 9. Turricula mcnairýensis Wade, n. sp., type (p. 113). 8, Front view; 9, back view. (U. S. Nat. Mus. catalog No. 32852.)

11, 12. Turricula gracilis Wade, n. sp., type (p. 111). 11, Back view; 12, front view. . (U. S. Nat. Mus. catalog No. 32853.$)$

13, 14. T'urricula biacuminata Wade, n. sp., type (p. 112). 13, Back view; 14, front view. (U. S. Nat. Mus. catalog No. 32854.) 


\section{PLATE XXXVII}

\section{Ripley Fossils from Coon Creek, Tenn.}

1, 9. Volutomorpha aspera Dall (p. 113). 1, Back view; 9, front view. (U. S. Nat. Mus. catalog No. 32855.)

2, 3, 5-7. Volutomorpha gigantea Wade, n. sp. (p. 114). 2, 5, Back views; 3, 6, 7, front views. (U. S. Nat. Mus. catalog No. 32856.)

4, 8, 11. Turricula anomalocostata Wade, n. sp. (p. 113). 4, Back view of type; 8, back view of another specimen; 11, front view of type. (U. S. Nat. Mus. catalog No. 32857.)

10. Volutomorpha mutabilis Wade, n. sp. (p. 114), front view. (U. S. Nat. Mus. catalog No. 32858.) 

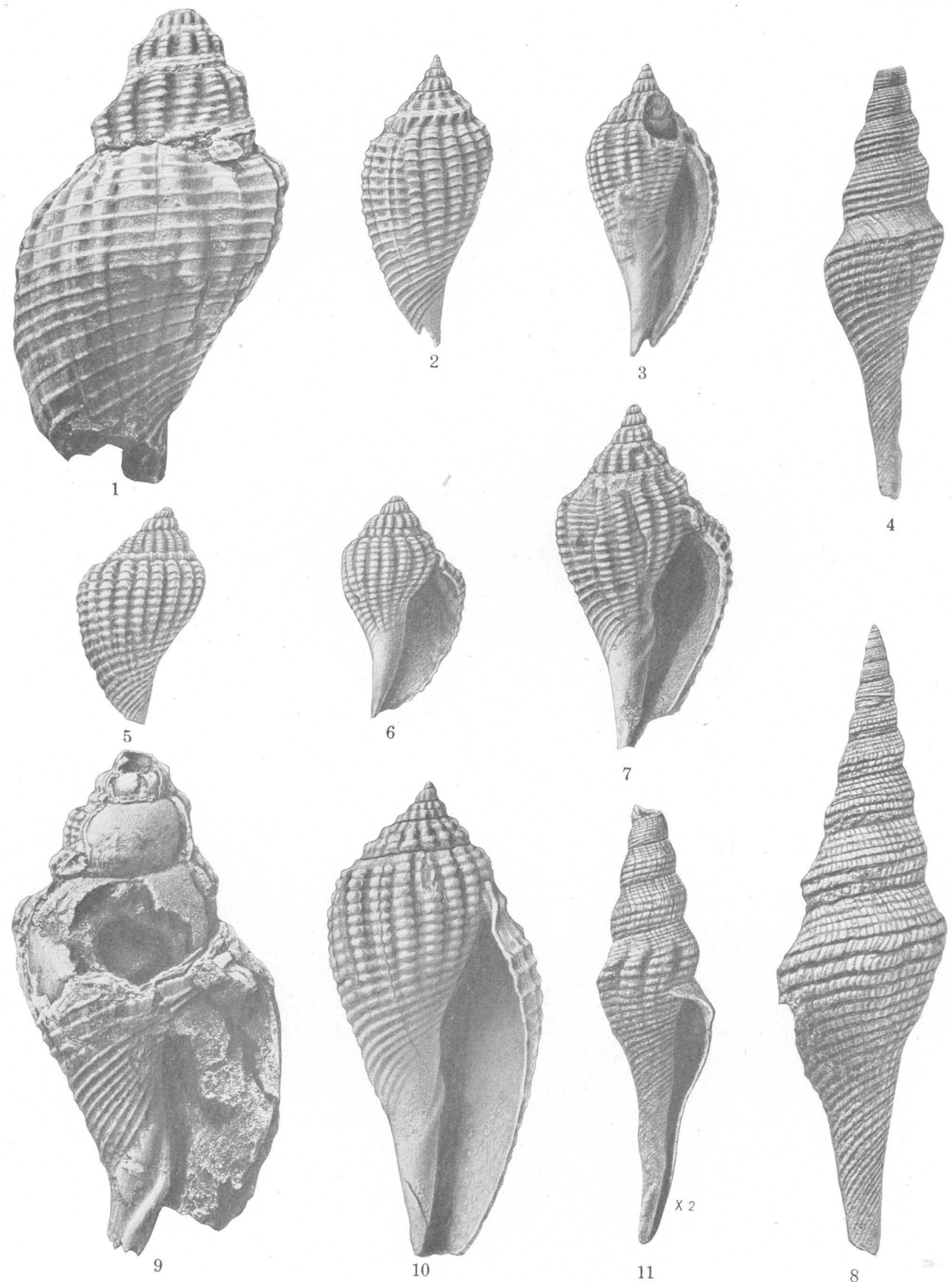

RIPLEY FOSSILS FROM COON CREEK, TENN. 

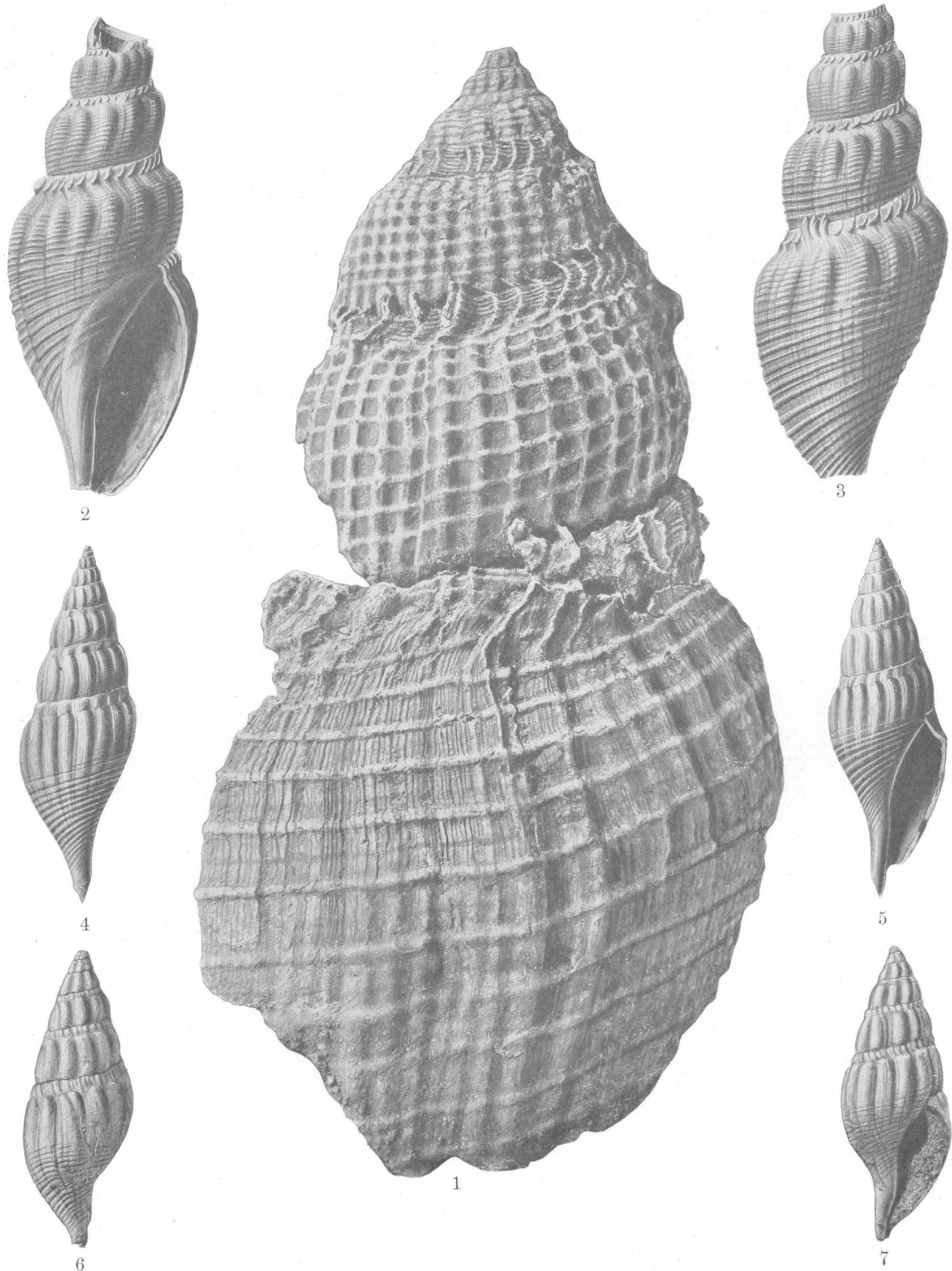

RIPLEY FOSSILS FROM COON CREEK, TENN. 


\section{PLATE XXXVIII}

\section{Rrpley Fossils from Coon Creek, Tenn.}

1. Volutomorpha gigantea Wade, n. sp. (p. 114), back view. (U. S. Nat. Mus. catalog No. 328̃6.)

2, 3. Drilluta major Wade, type (p. 117). 2, Front view; 3, back view. (U. S. Nat. Mus. catalog No. 32859.)

4, 5. Drilluta communis Wade, type. (p. 116), back views. (U. S. Nat. Mus. catalog No. 32860.)

6, 7. Drilluta distans (Conrad) (p. 117). 6, Back view;, , (?). (U. S. Nat. Mus. catalog No. 32861.) 


\section{PLATE XXXIX}

\section{Ripley fossils from Coon Creek, Tenn.}

1, 3. Volutomorpha gigantea Wade; n. sp., type (p. 114). 1, Back view; 3, front view. (U. S. Nat. Mus. catalog No. 32856.) 2, 6. Volutoderma.appressa.Wade, n. sp., type (p. 115). 2, Back view; 6, front view. (U. S. Nat. Mus. catalog No. 32862.) 4. Volutoderma protracta Dall (p. 115), front view of type. (U. S. Nat. Mus. catalog No. 32863.)

5, \%. Drilluta dimurorum Wade, n. sp., type (p. 118). 5, Front view;, , back view. (U. S. Nat. Mus. catalog No. 32864.) 232 

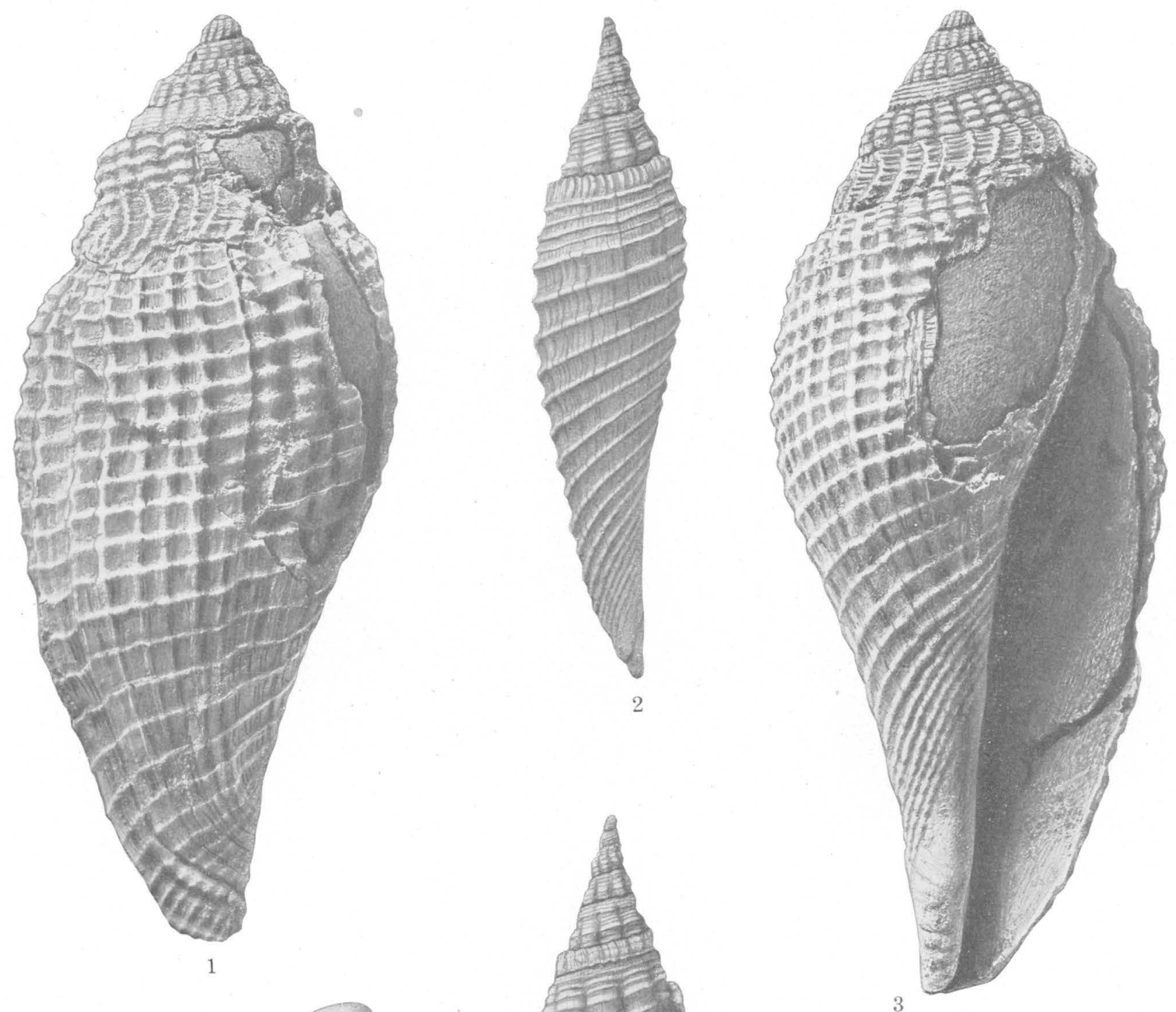

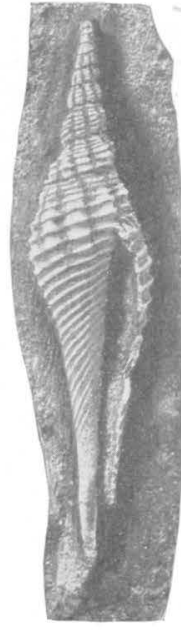

4

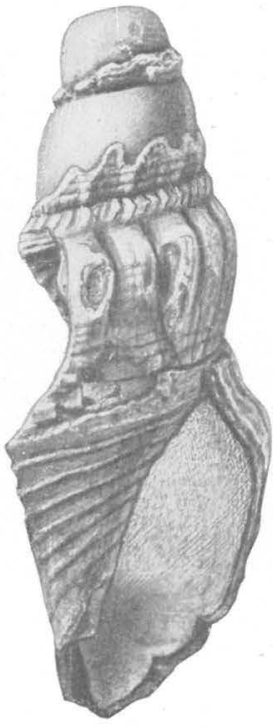

5
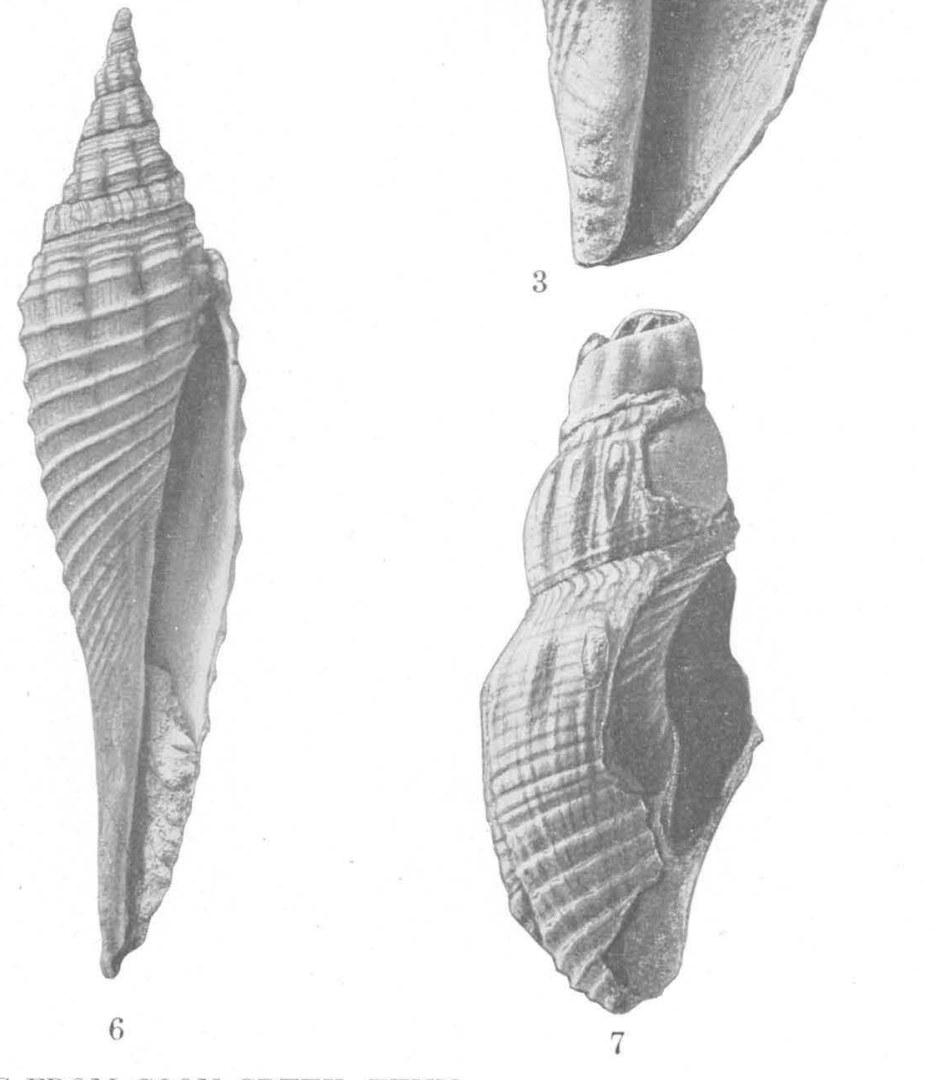

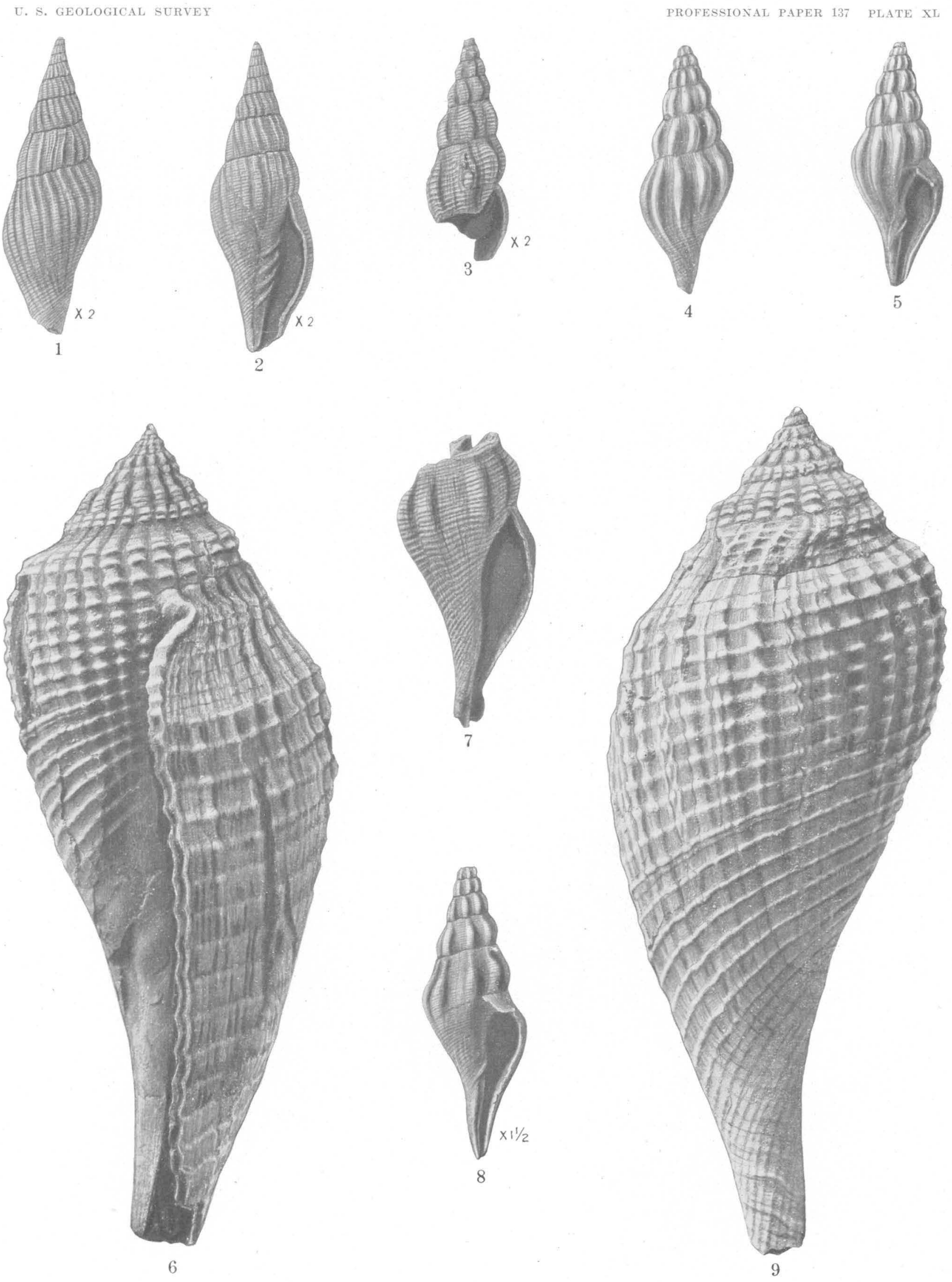

RIPLEY FOSSILS FROM COON CREEK, TENN. 


\section{PLATE XL}

\section{Riplex Fossils from Coon Creek, Tenn.}

1, 2. Fasciolaria? ripleyana Wade, n. sp., type (p. 133). 1, Back view; 2, front view. (U. S. Nat. Mus. catalog No. 32865.)

3, 7. Paleopsephaea pergracilis Wade, n. gen. and sp. (p. 124). 3, Front view of type; 7 , front view of another specimen. (U. S. Nat. Mus. catalog No. 32866.)

4, 5, 8. Paleopsephaea mutabilis Wade, n. gen. and sp. (p. 123). 4, Back view; 5, front view; 8, front view of type. (U. S. Nat. Mus. catalog No. 32867.)

6. Volutomorpha mutabilis Wade, n. sp. (p. 114), front view of type. (U. S. Nat. Mus. catalog No. 32858.) 


\section{PLATE XLI}

\section{Ripley Fossils from Coon Creek, Tejn.}

1, 5. Volutoderma tennesseensis Wade, n. sp., type (p. 115). 1, Back view; 5, front view. (U. S. Nat. Mus. catalog No. 32868 .)

2-4. Liopeplum subjugosum (Gabb). (p. 118). 2, 4, Front views; 3, rear view. (U. S. Nat. Mus. catalog No. 32869.) $\cdot 234$ 


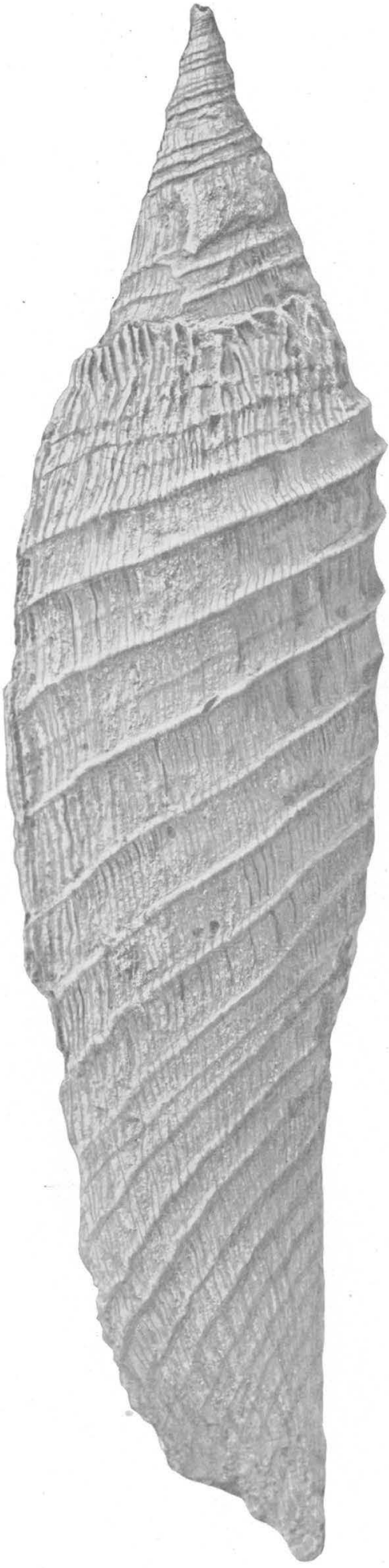

5
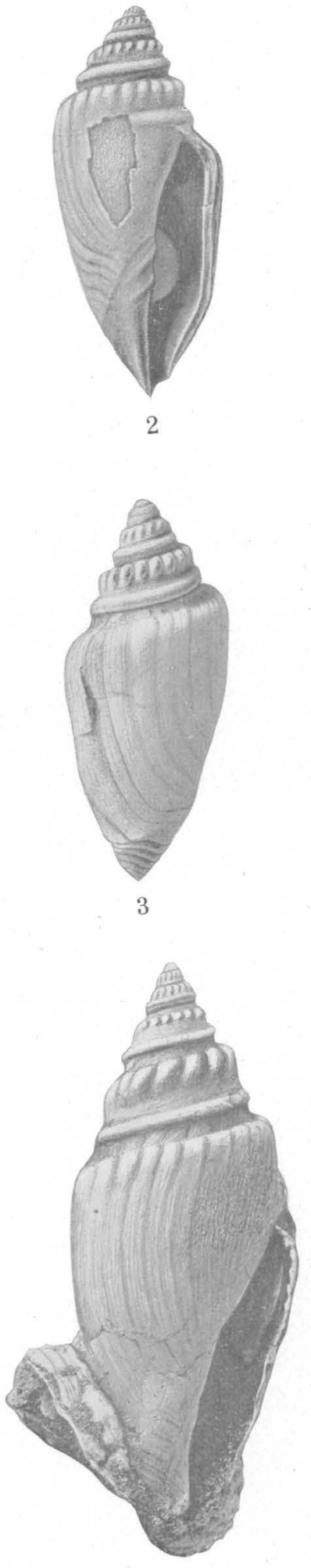

4

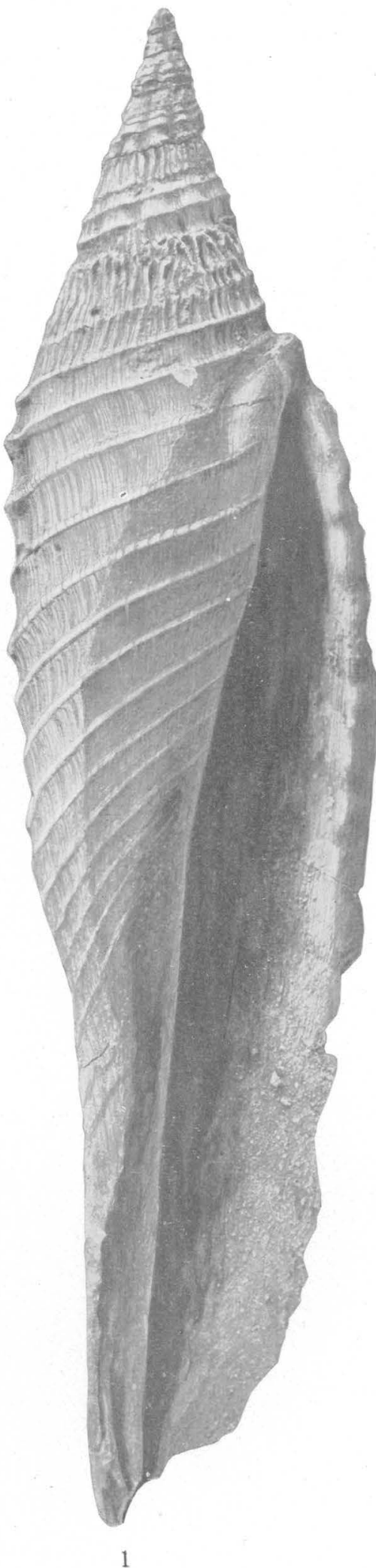

RIPLEY FOSSILS FROM COON CREEK, TENN. 


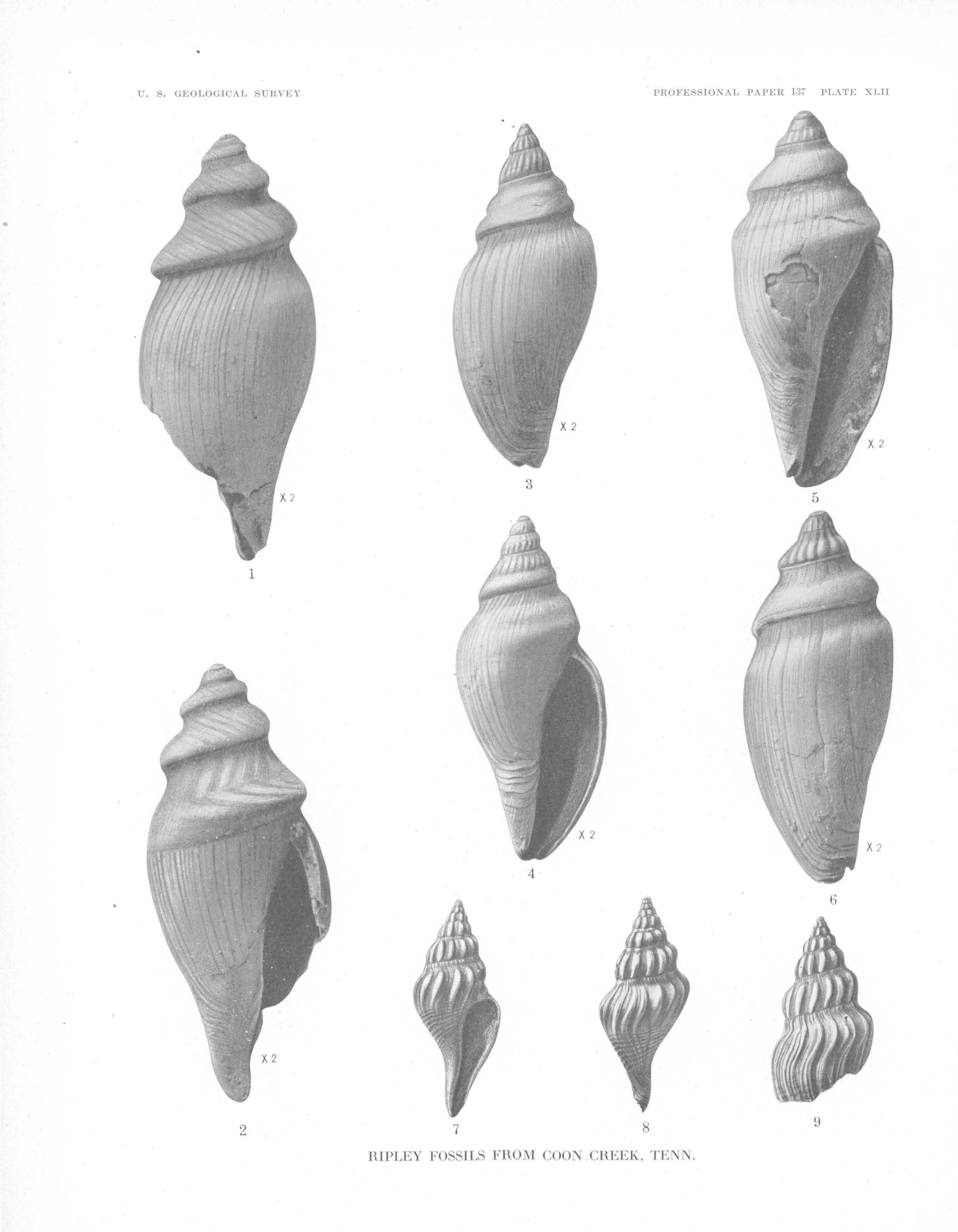




\section{PLATE ${ }^{\circ}$ XLII}

\section{Ripley Fossils from Coon Creek, Tenn.}

1, 2. Liopeplum carinatum Wade, n. sp., type.(p. 119). 1, Back view; 2, front view. (U. S. Nat. Mus. catalog No. 32870. )

3, 4. Liopeplum leiodermum (Conrad) (p. 119). 3, Back view; 4, front view. (U. S.. Nat. Mus. catalog No. 32871.)

5, 6. Liopeplum canalis (Conrad) (p. 119). 5, Front view; 6, back view. (U. S. Nat. Mus. catalog No. 32872.)

7-9. Odontofusus curvicostata Wade, n. sp. (p. 130). 7, Type, front view; 8, type, back view; 9, back view of another specimen. (U. S. Nat. Mus. catalog No. 32873.) 


\section{PLATE XLIII}

\section{Ripley Fossils from Coon Creek, Tenja.}

1, 2. Xancus major Wade, n. sp. (p. 124). 1, Back view; 2, front view. (U. S. Nat. Mus. catalog No. 32874.)

3, 4, 7. Tectaplica simplica Wade (p. 121). 3, Back view; 4, front view; $\boldsymbol{\gamma}$, front view of type. (U. S. Nat. Mus. catalog No: 32875 .)

5, 6. Parvivoluta sp. 5, Back view; 6, front view. (U. S. Nat. Mus. catalog No. 32876.) The description of this form was inadvertently omitted. It is more slender than Parvivoluta concinna, from which it also differs in details of sculpture.

8, 9. Parafusus coloratus Wade (p. 121). 8, Front view; 9, back view of type. (U. S. Nat. Mus. catalog No. 32877.)

10. Parvivoluta"concinna Wade, n. gen. and sp. (p. 122), front view of type. (U. S. Nat. Mus. catalog No. 32878.)

11, 12. Parafusus callilateris Wade, type (p. 120). 11, Back view; 12, front view. (U. S. Nat. Mus. catalog No. 32879.)

13, 14. Fusus? mcnairyensis Wade, n. sp., type (p. 125). 13, Front view; 14, back view. (U. S. Nat. Mus. catalog No. 32880.) 236 

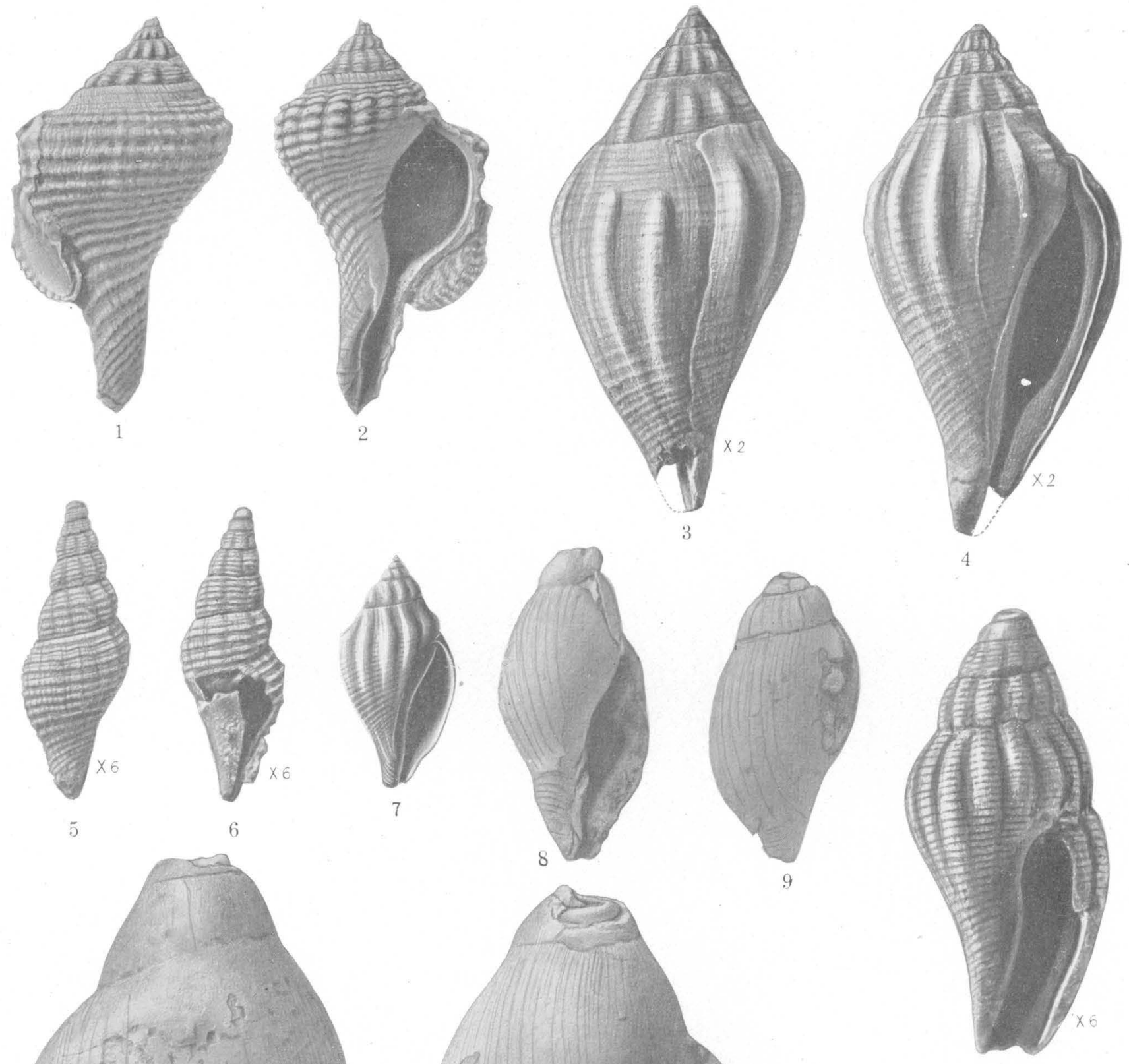

10
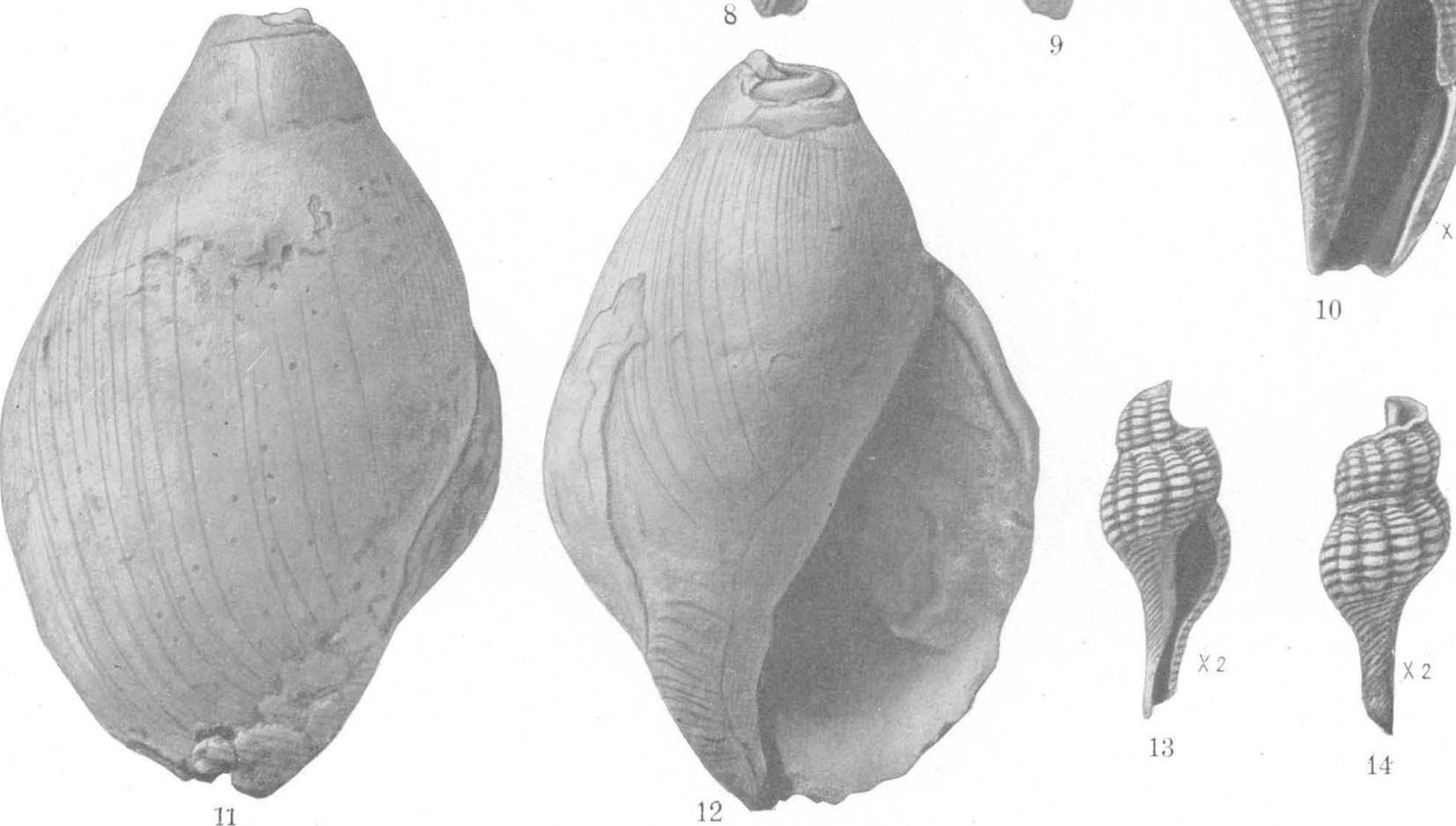

RIPLEY FOSSILS FROM COON CREEK, TENN. 

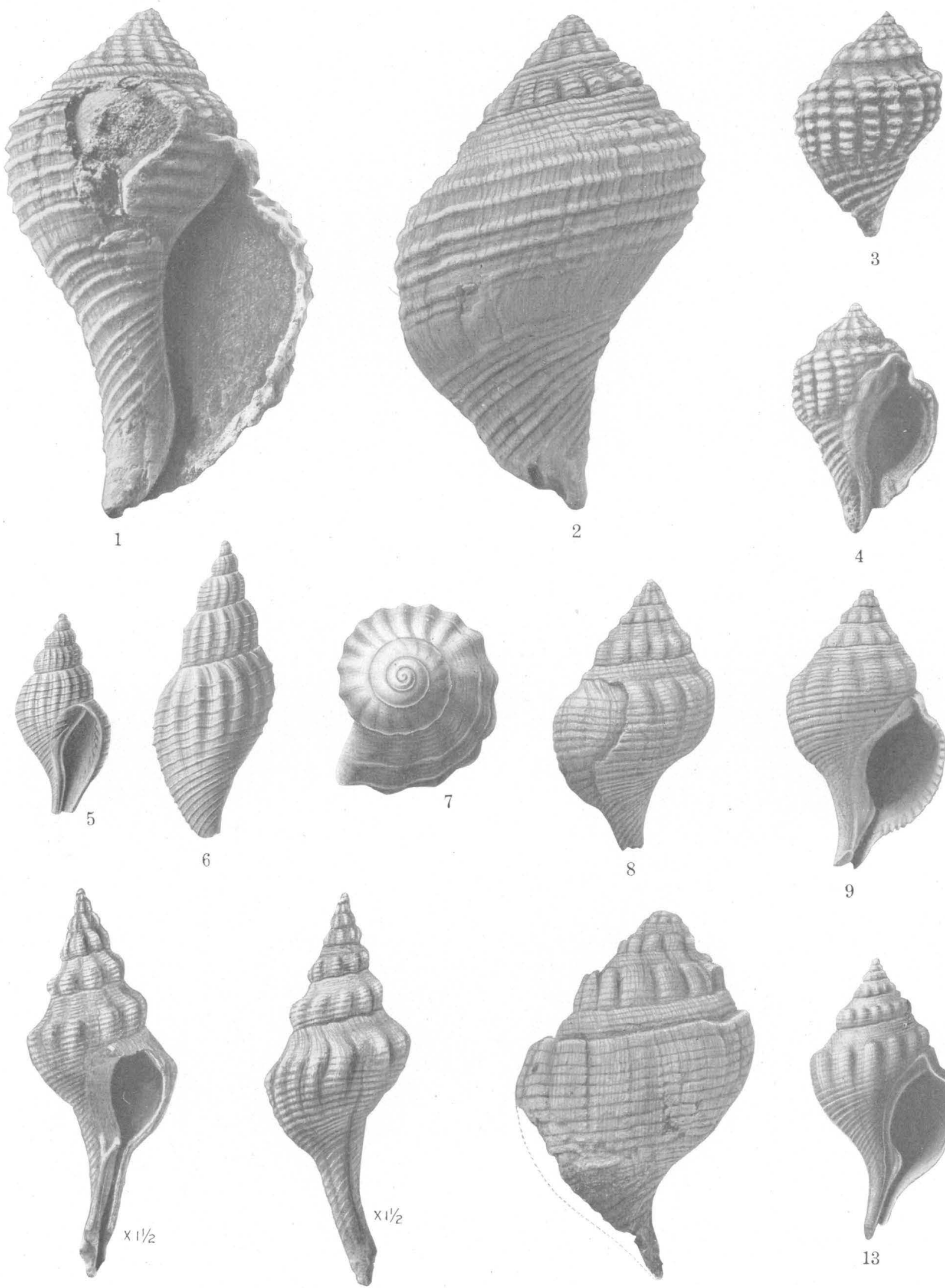

10

11
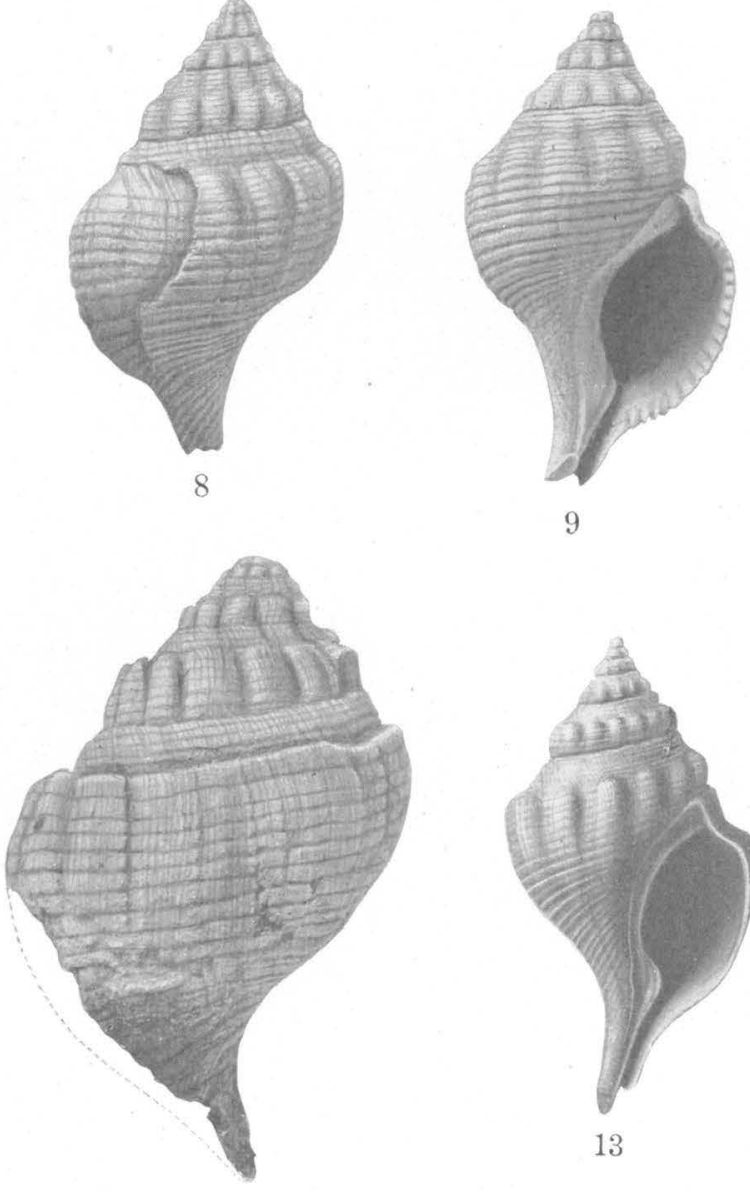

RIPLEY FOSSILS FROM COON CREEK, TENN. 
PLATE XLIV

Rtpley fossils from Coon Creek, Tenn.

1, 2. Xancus major Wade, n. sp., type (p. 124). 1, Front view; 2, rear view. (U. S. Nat. Mus. catalog No. 32874.)

3, 4. Xancus variabilis Wade, n. sp., type (p. 124). 3, Back view; 4, front view. (U. S. Nat. Mus. catalog No. 32881.)

5-7. Anomalofusus substriatus Wade (p. 126). 5, Front view; 6, back view of type; 7 , apical view of type. (U. S. Nat. Mus. catalog No. 32882.)

8, 9, 12, 13. Ornopsis glenni Wade (p. 126). 8, 12, Back views; 9, 13, front views. (U. S. Nat. Mus. catalog No. 32s83.)

10, 11. Ornopsis elevata Wade (p. 127). 10, Front view; 11, back view. (U. S. Nat. Mus. catalog No. 32884.) 


\section{PLATE XLV}

\section{Ripley Fossils from Coon Creek, Tenn.}

1, 2. Ornopsis elevata Wade, type (p. 127). 1, Back view; 2, front view. (U. S. Nat. Mus. catalog No. 32884.)

3, 4. Ornopsis digressa Wade, n. sp., type (p. 127). 3, Front view; 4, back view. (U. S. Nat. Mus. catalog No. 328s5.)

5, 6. Falsifusus mesozoicus Wade, type (p. 128). 5, Front view; 6, back view. (U. S. Nat. Mus. catalog No. 32886.)

7, 8. Stantonella subnodosa Wade, n. gen. and sp., type (p. 128). 7, Back view; 8, front view. (U. S. Nat. Mus. catalog No. 32887.)

9, 10. Piestochilus pergracilis Wade, n. sp., type (p. 131). 9, Back view; 10, front view. (U. S. Nat. Mus. catalog No. 32888.)

11, 12. Falsifusus convexus Wade, n. sp., type (p. 129). 11, Back view; 12, front view. (U. S. Nat. Mus. catalog No. 32889.)

13, 14. Exilia ripleyana Wade, n. sp., type (p. 128). 13, Front view; 14, back view. (U. S. Nat. Mus. catalog No. 32890.)

15, 16. Piestochilus cancellatus Wade, n. sp., type (p. 131). 15, Front view; 16, back view. (U. S. Nat. Mus. catalog No. 32891.) 238 

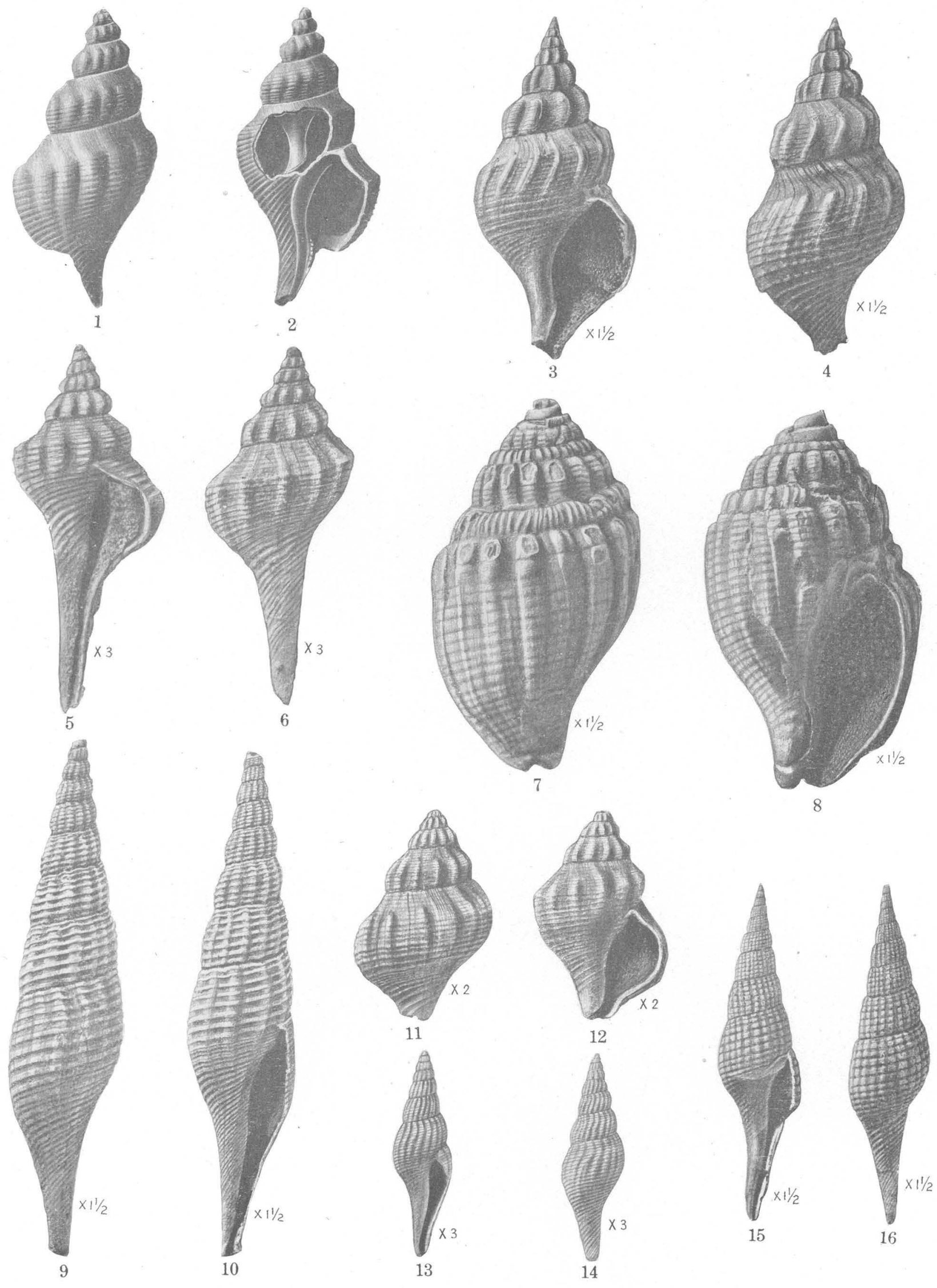

RIPLEY FOSSILS FROM COON CREEK, TENN.

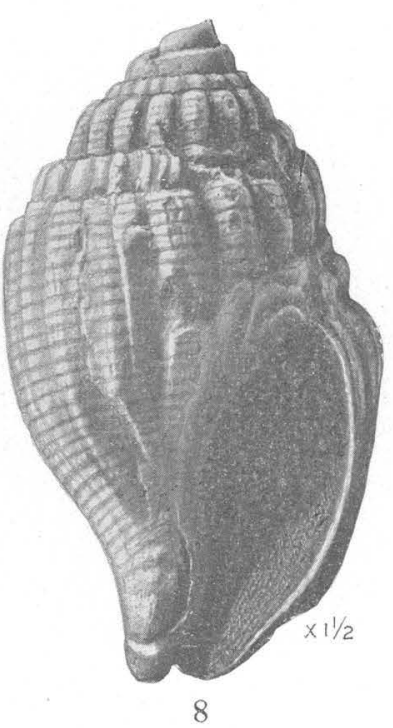



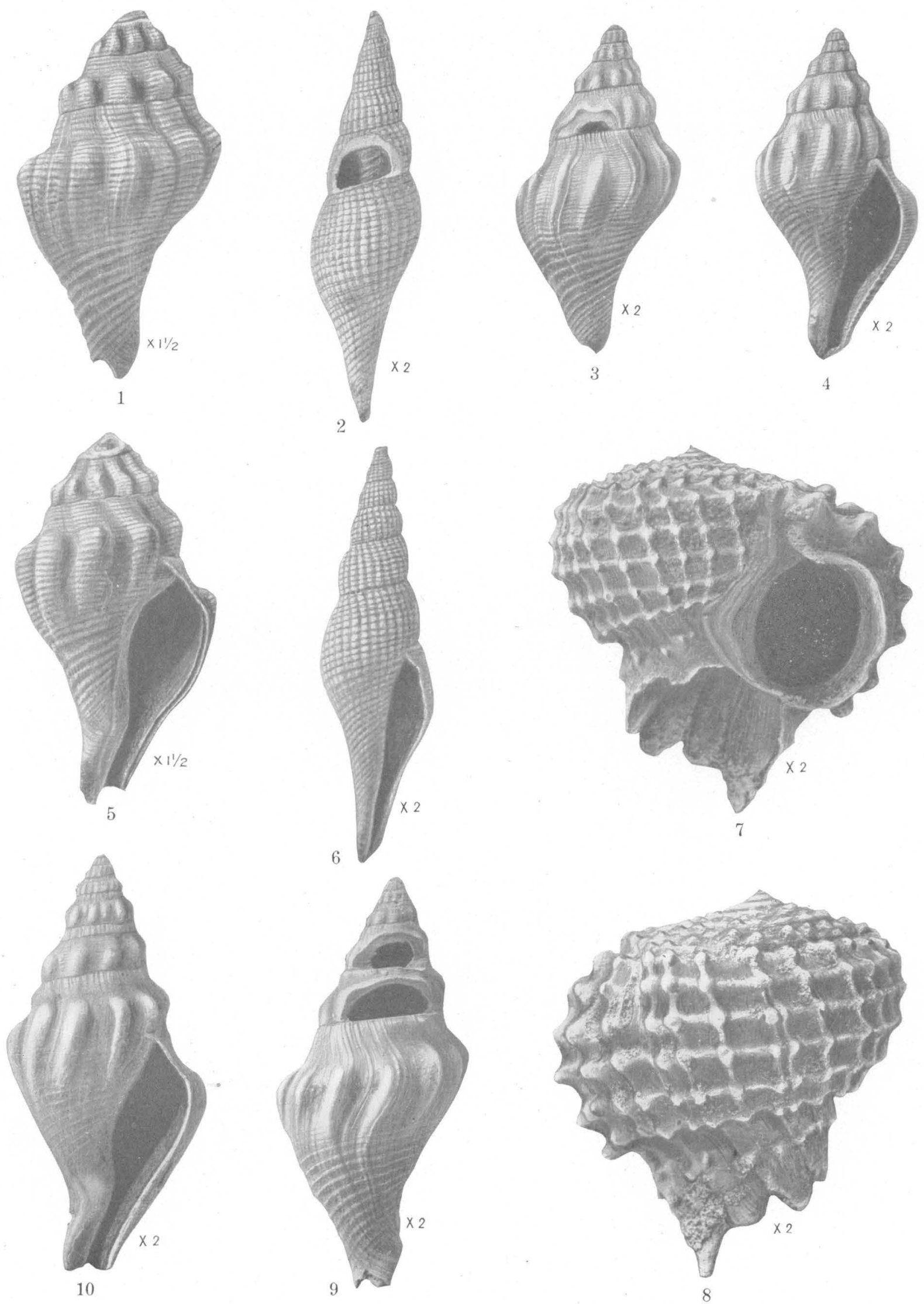

RIPLEY FOSSILS FROM COON CREEK, TENN. 


\section{PLATE XLVI \\ Ripley Fossils from Coon Creek, Tenn.}

1, 5. Woodsella typica Wade, n. gen. and sp., type (p. 130). 1, Back view; 5, front view. (U. S. Nat. Mus. catalog No. 32892.)

2, 6. Mesorhytis obscura Wade; n. sp., type (p. 132). 2, Back view; 6, front view. (U. S. Nat. Mus. catalog No. 32893.)

3, 4. Cryptorhytis nobilis Wade, n. sp., type (p. 131). 3, Back view; 4, front view. (U. S. Nat. Mus. catalog No. 32894 .)

7, 8. Sargana stantoni (Weller) (p. 136). \%, Front view; 8, back view. (U. S. Nat. Mus. catalog No. 32895.)

9, 10. Cryptorhytis torta Wade, n. sp., type (p. 132). 9, Back view; 10, front view: (U. S. Nat. Mus. catalog No. 32\$96.) 


\section{PLATE XLVII \\ Ripley fossils from Coon Creek, Tenn.}

1, 4. Busycon (Protobusycon) cretaceum Wade, type (p. 136). 1, Back view; 4, front view. (U: S. Nat. Mus. catalog No. 32897.)

2, 11. Lirosoma crelacea Wade (p. 139). 2, Front view of type; 11, front view of another specimen. (U. S. Nat. Mus. catalog No. 32898.)

3, 7. Haplovoluta bicarinata Wade, type (p. 138). 3, Back view; 7, front view. (U. S. Nat. Mus. catalog No. 32899.)

5, 6. Boltenella excellens Wade, type (p. 137): 5, Front view; 6, back view. (U. S. Nat. Mus. catalog No. 32900.)

8-10. Pyropsis proxima. Wade, n. sp., type (p. 139). 8, Back view; 9, top view; 10, front view. (U. S. Nat. Mus. catalog No. 32901.) 

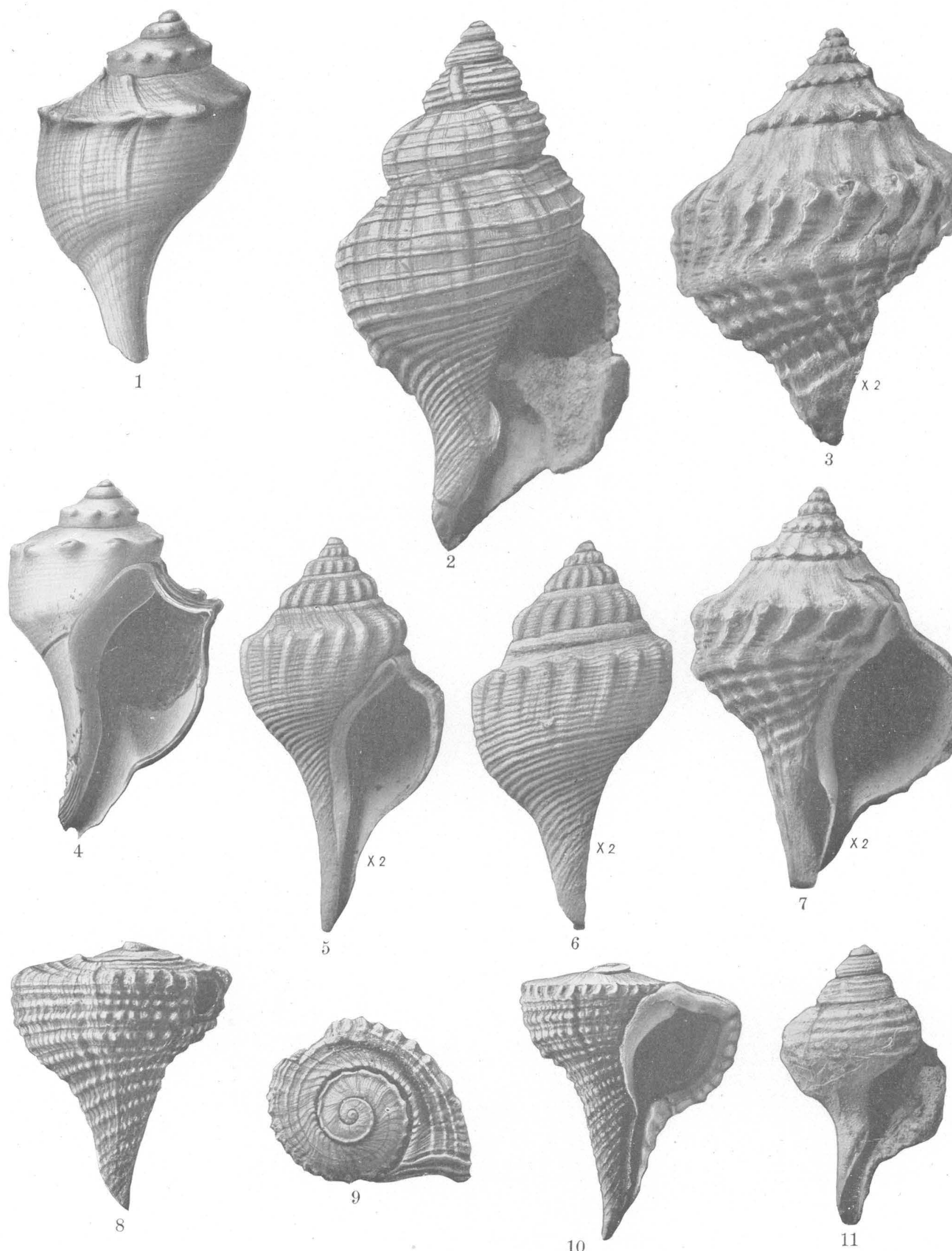

RIPLEY FOSSILS FROM COON CREEK, TENN. 

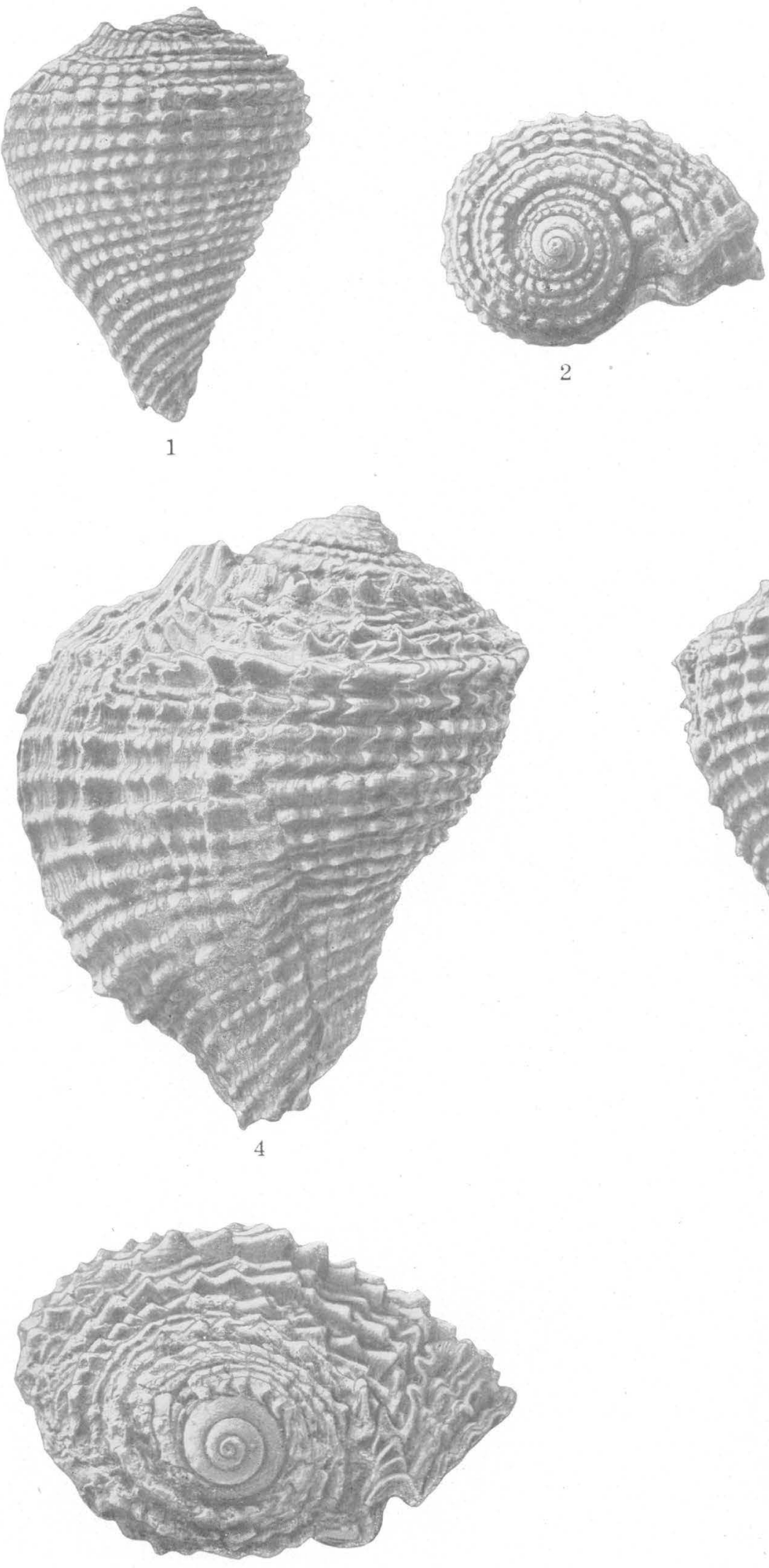

6
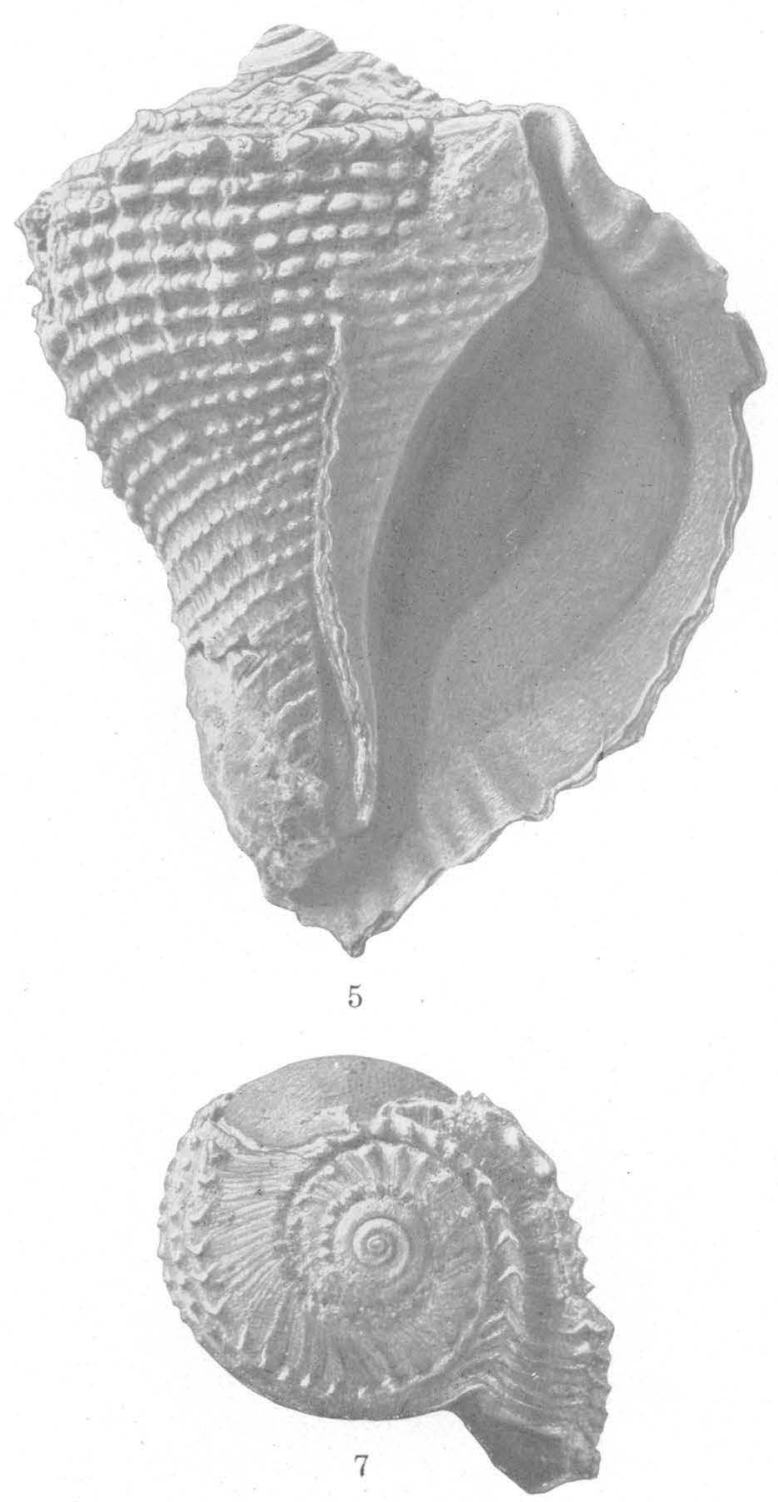

RIPLEY FOSSILS FROM COON CREEK, TENN.

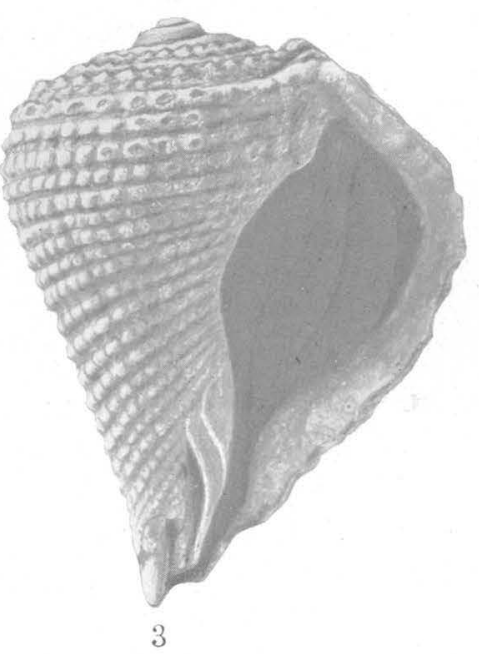




\section{PLATE XLVIII}

\section{Ripley Fossits from Coon Creek, Tenn.}

1-6. Trochifusus perornatus Wade, n. sp. (p. 140). 1-3, Type (1, back view; 2, top view; 3, front view); 4, back view; 5, front view; 6, top view of another specimen. (U. S. Nat. Mus. catalog No. 32902.)

7. Trochifusus spinosus Wade, n. sp. (p. 140), top view of type. (U. S. Nat. Mus. catalog No. 32903.) 


\section{PLA'TE XLIX \\ Ripley Fossils from Coon Creek, Tenn.}

1-3. Trochifusus spinosus Wade, n. sp. (p. 140). 1, Front view of type; 2, back view of type; 3, back view of another specimen. (U. S. Nat. Mus. catalog No. 32903.)

4, 5. Rhombopsis orientalis Wade, n. sp. (p. 142). 4, Front view; 5, back view. (U. S. Nat. Mus. catalog No. 32904.)

6, 9. Perissolax whitfieldi Weller (p. 141). 6, Front view; 9, back view. (U. S. Nat. Mus. catalog No. 32905.)

7, 8. Trochifusus interstriatus Wade, n. sp., type (p. 141): \%, Front, view; 8, back view. (U. S. Nat. Mus. catalog No. 32906.) 242 

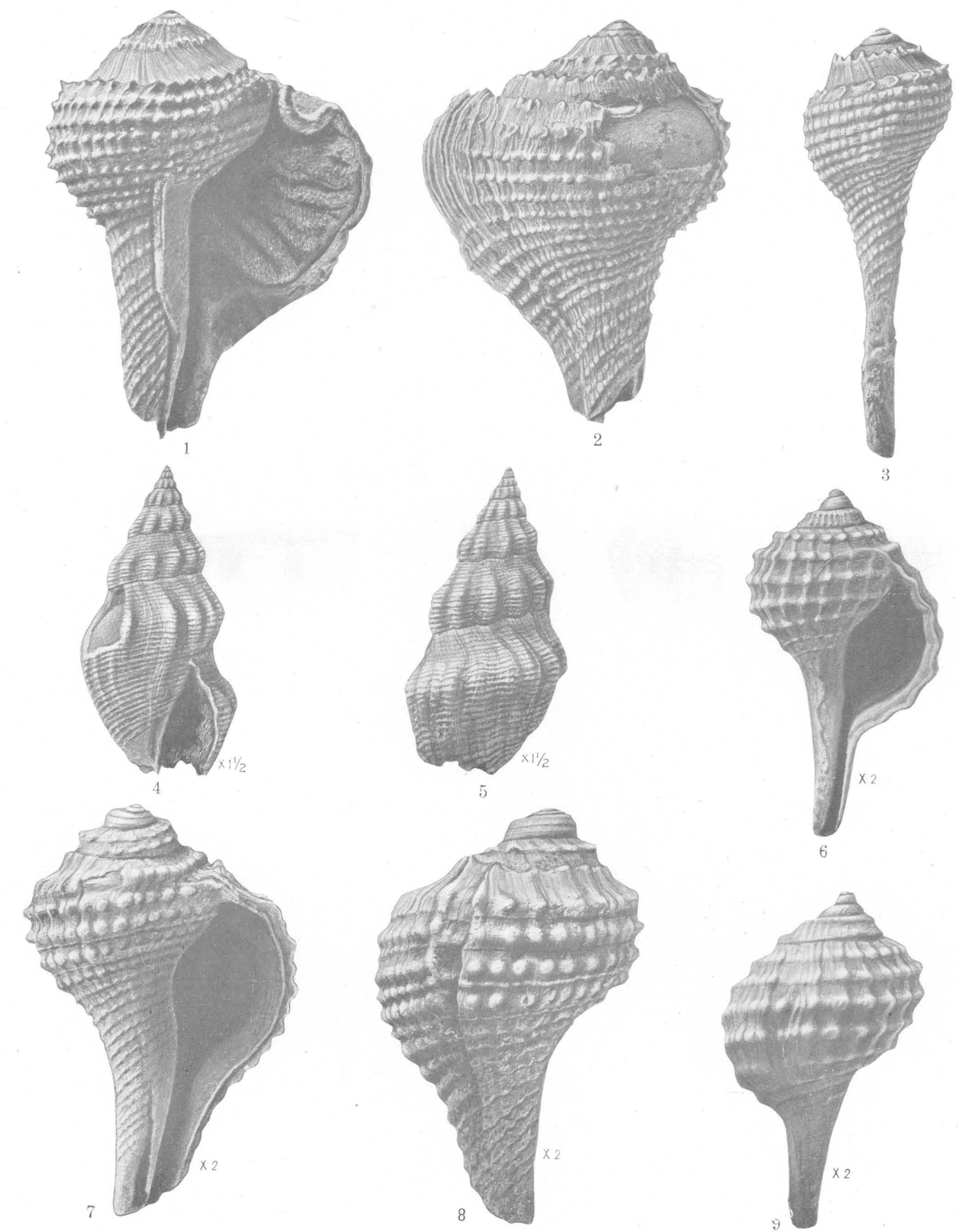

RIPLEY FOSSILS FROM COON CREEK, TENN.

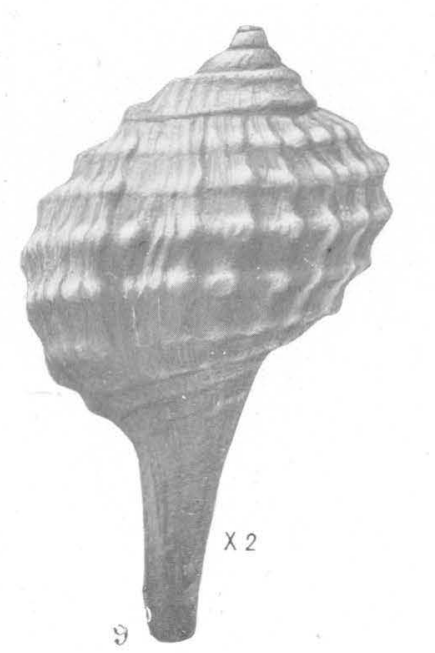


U. S. GEOLOGICAL SURVEY
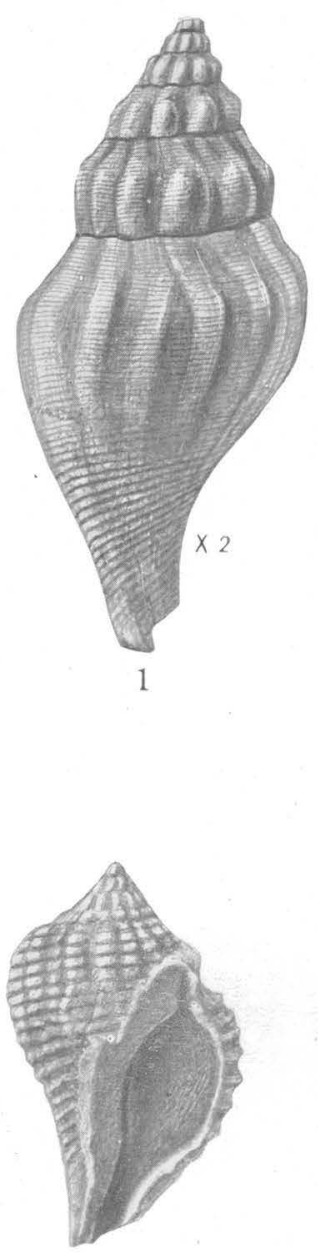

5
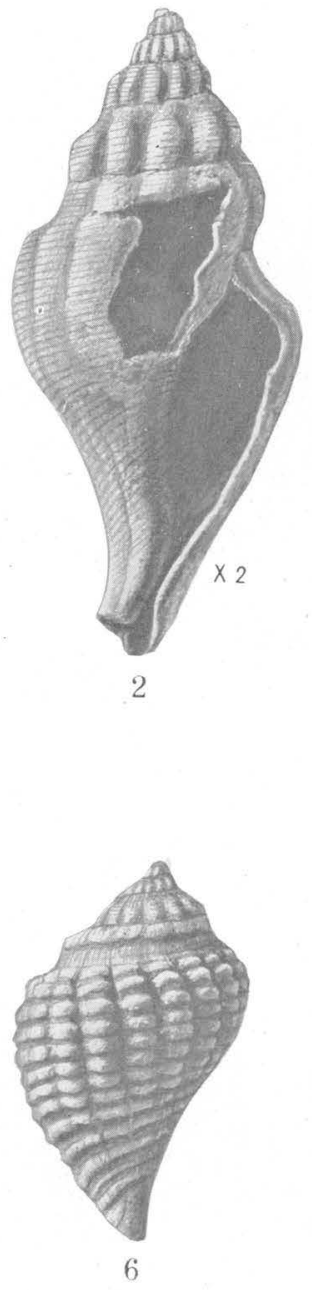
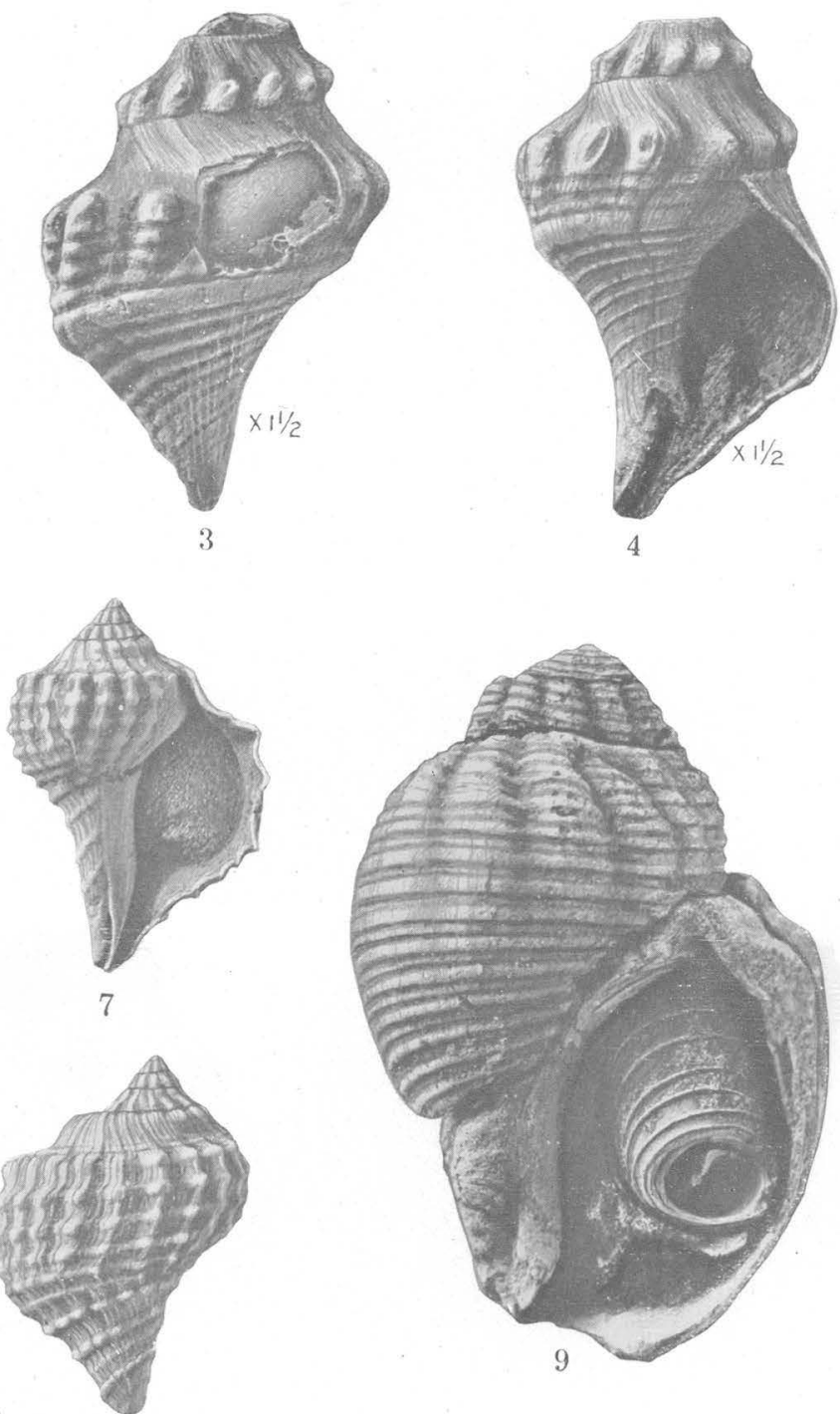

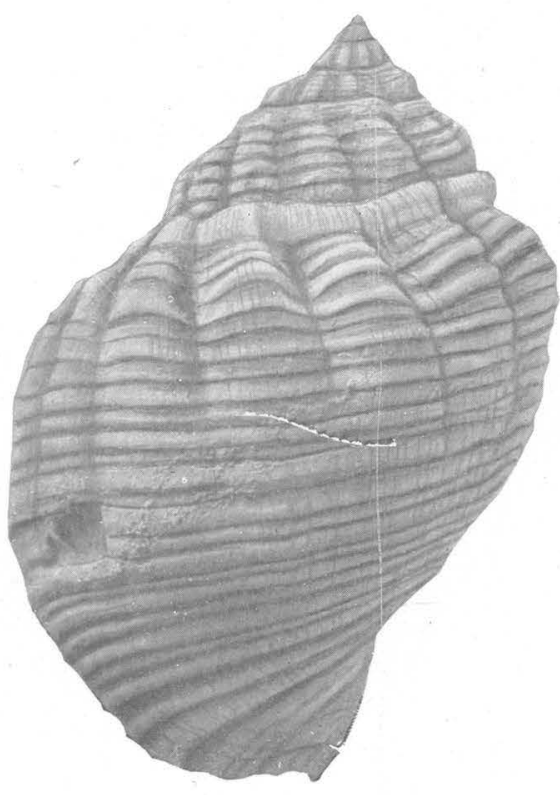

10

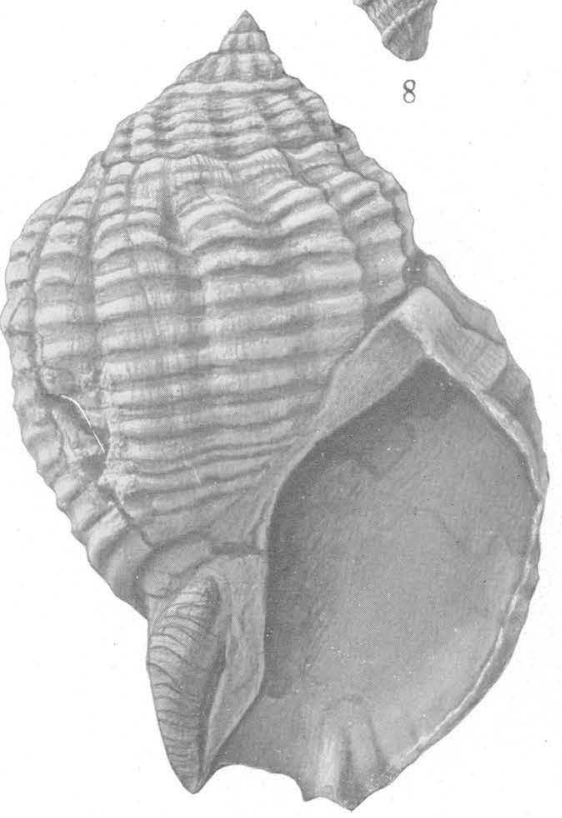

11

PROFESSIONAL PAPER 137 PLATE I

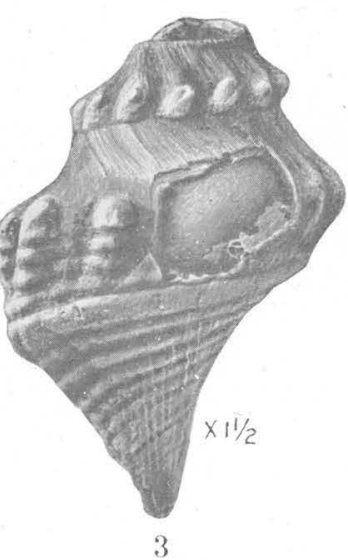




\section{PLATE L}

\section{Ripley fossjis from Coon Creek, Tenn.}

1, 2. Rhombopsis microstriatus Wade, n. sp., type (p. 142). 1, Back view; 2, front view. (U. S. Nat. Mus. catalog No. 32907.)

3, 4. Serrifusus lennesseensis Wade, n. sp., type (p..143). 3, Back view; 4, front view. (U. S. Nat. Mus. catalog No. 32908.)

5, 6. Pyrifusus subdensatus Conrad (p. 143). 5, Front view; 6, back view. (U. S. Nat. Mus. catalog No. 32909.)

7, 8. Pyrifusus subliratus Wade, n. sp., type (p. 143). 7, Front view; 8, back view. (U. S. Nat. Mus. catalog No. 32910.)

9-12. Seminola crassa Wade (p. 145). 9, Front view; 10, back view of type; 11, front view of type; 12, back view of specimen shown in 9. (U. S. Nat. Mus. catalog No. 32911.) 


\section{PLATE LI}

\section{Ripley Fossils from Coon Creek, Tenn.}

1, 2. Seminola solida Wade (p. 145). 1, Back view of type; 2, front view. (U. S. Nat. Mus. catalog No. 32912.)

3, 8. Morea marylandica Gardner (p. 133). 3, Front view; 8, back view. (U. S. Nat. Mus. catalog No. 32913.)

4, 5. Pseudoliva? attenuata Wade, n. sp., type (p. 146). 4, Front view; 5, back view. (U. S. Nat. Mus. catalog No. 32914.)

6, \%. Hydrotribulus nodosus Wade, type (p. 147). 6, Front view; \%, back view. (U. S. Nat. Mus. catalog No. 32915 .)

9, 10. Tritonium univaricosum Wade, n. sp., type (p. 147). 9, Front view; 10, back view. (U. S. Nat. Mus. catalog No. 32916.)

11, 12. Morea cancellaria Conrad (p. 134). 11, Front view; 12, back view. (U. S. Nat. Mus. catalog No. 32917.)

13, 14. Odontobasis australis Wade, n. sp. (p. 146). 13, Front view; 14, back view. (U. S. Nat. Mus. catalog No. 32918.) 

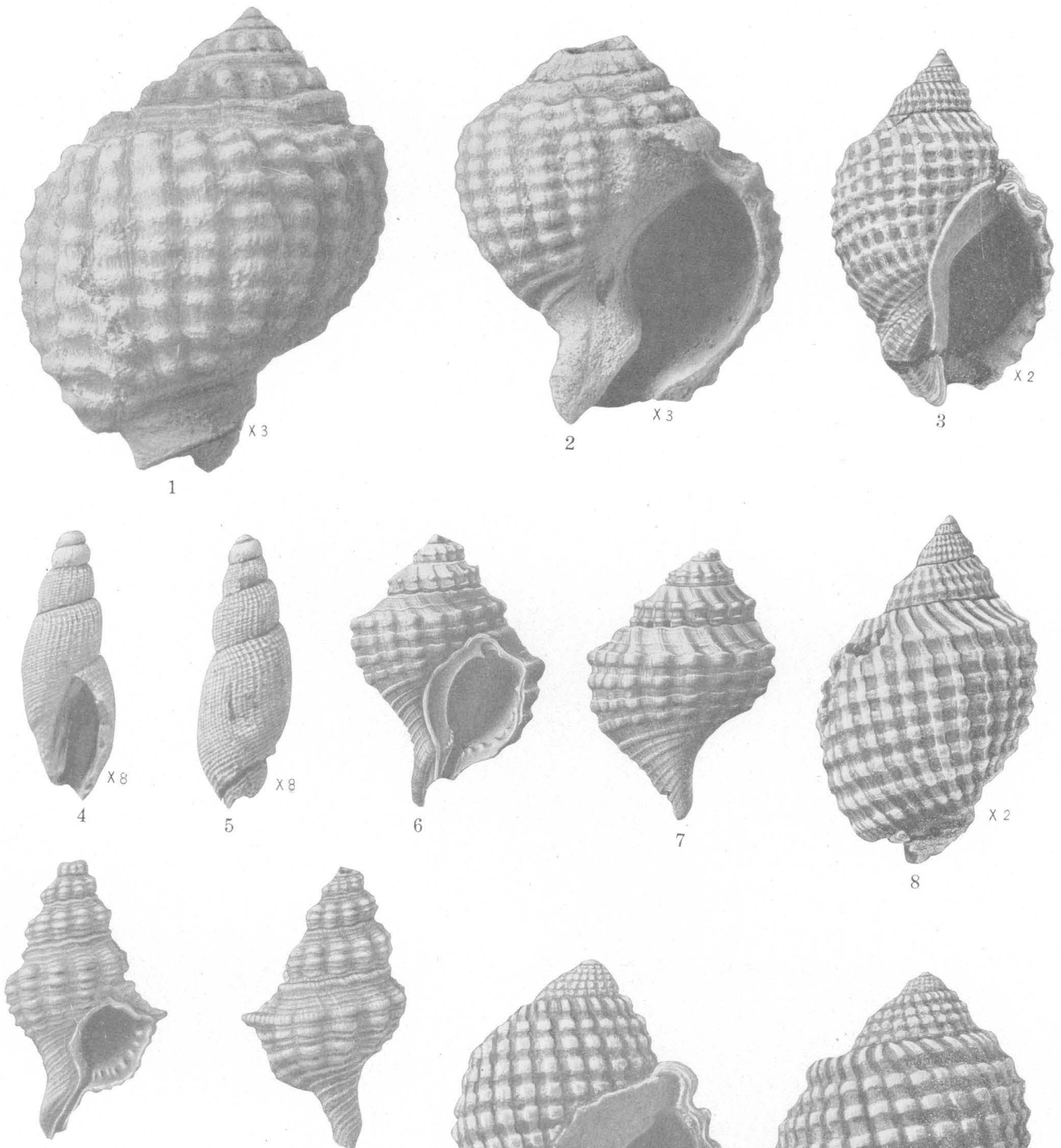

9
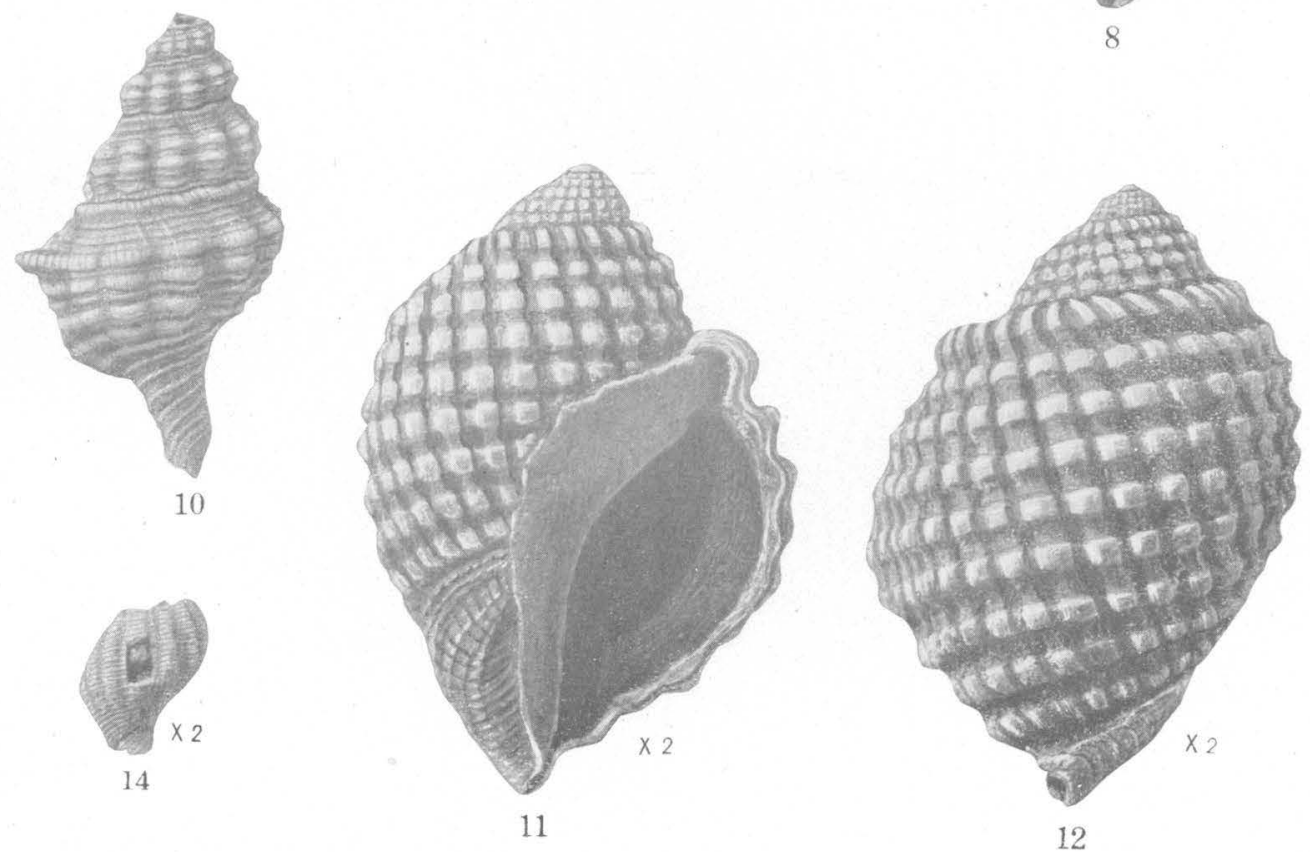

RIPLEY FOSSILS FROM COON CREEK, TENN.
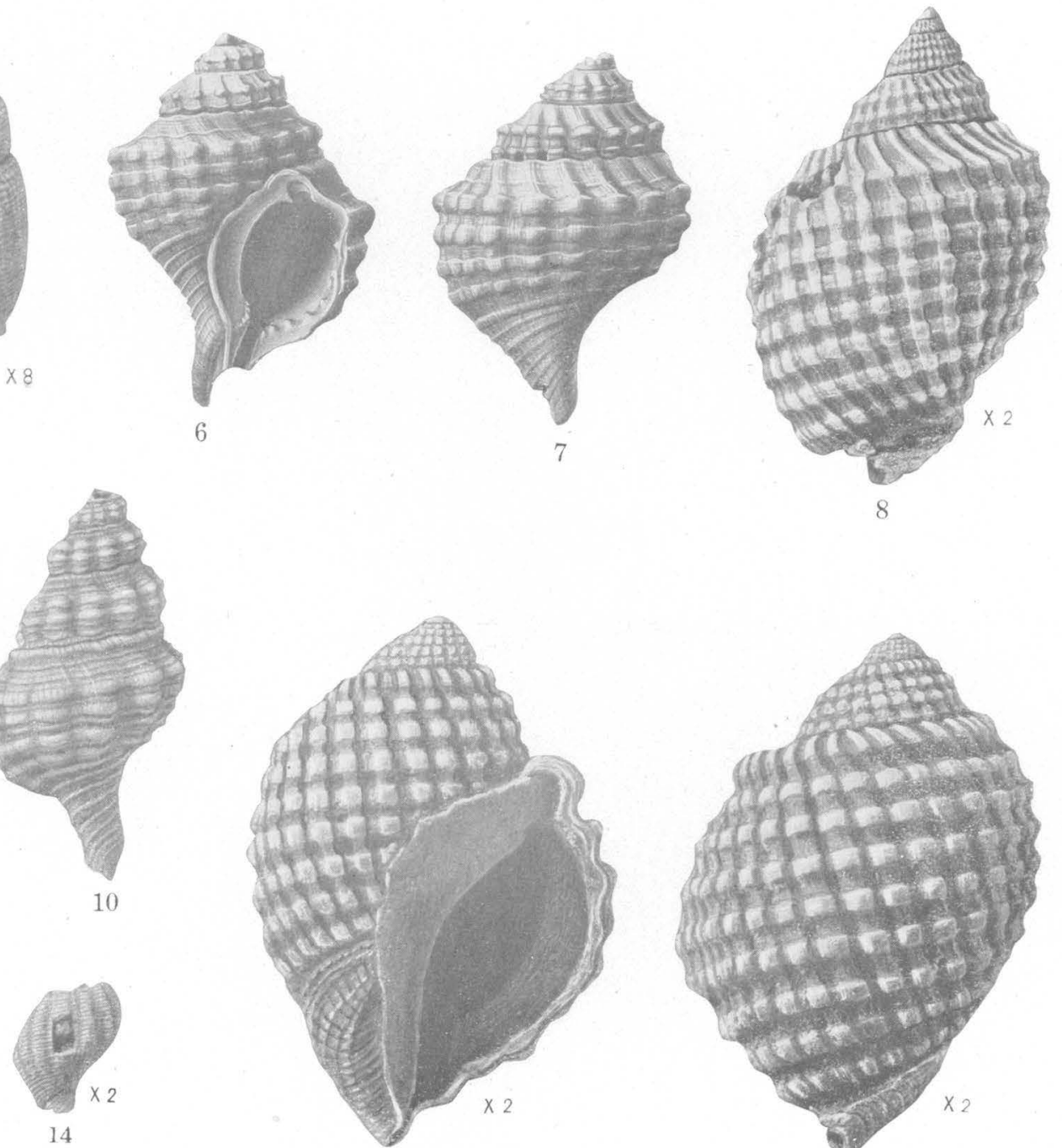

12 

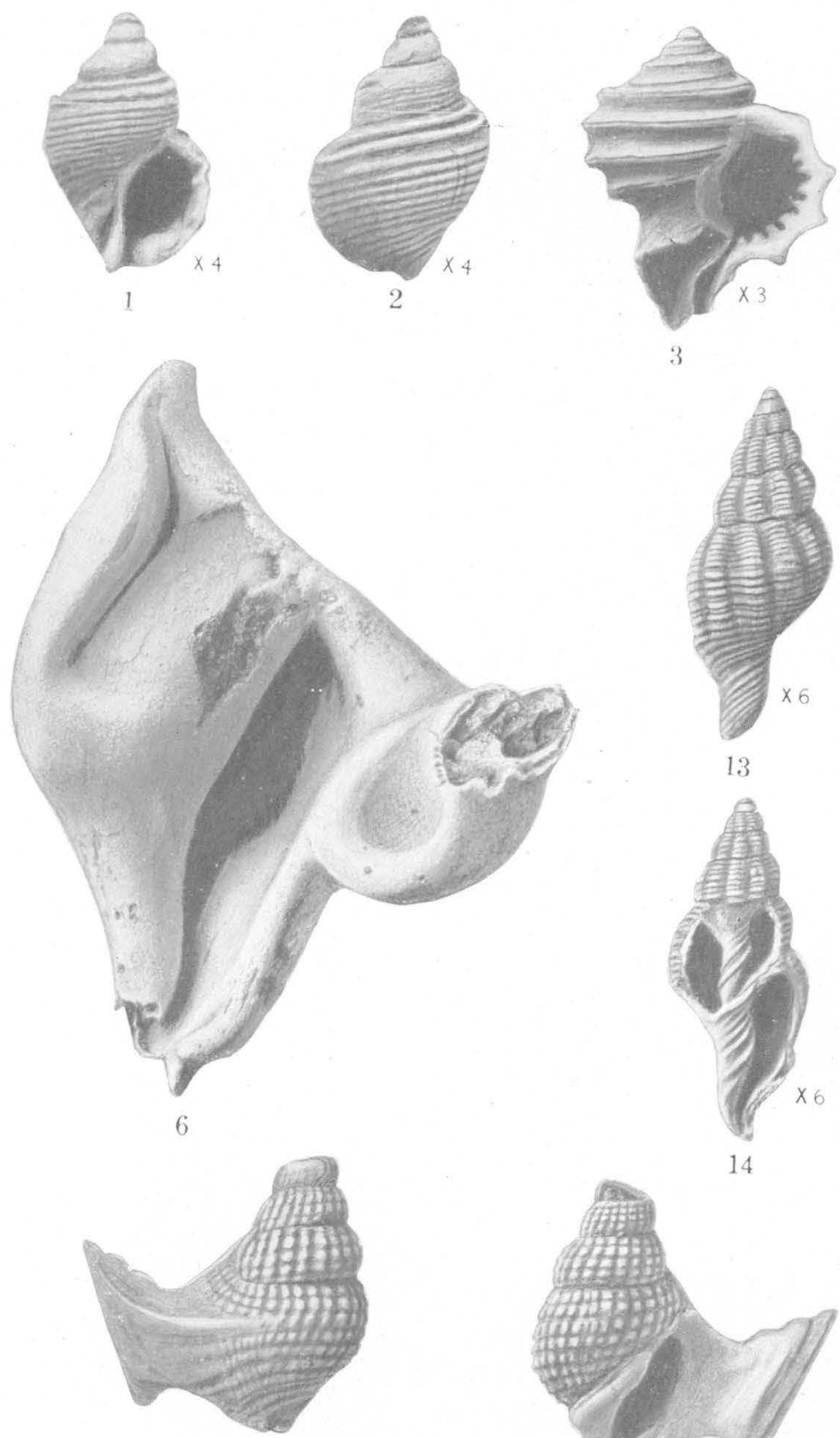

8

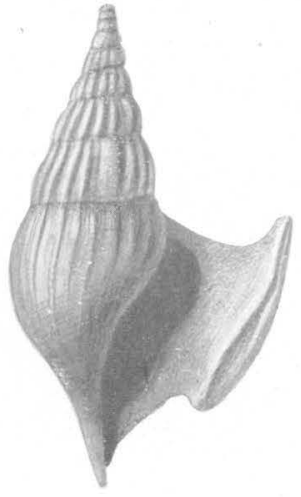

11
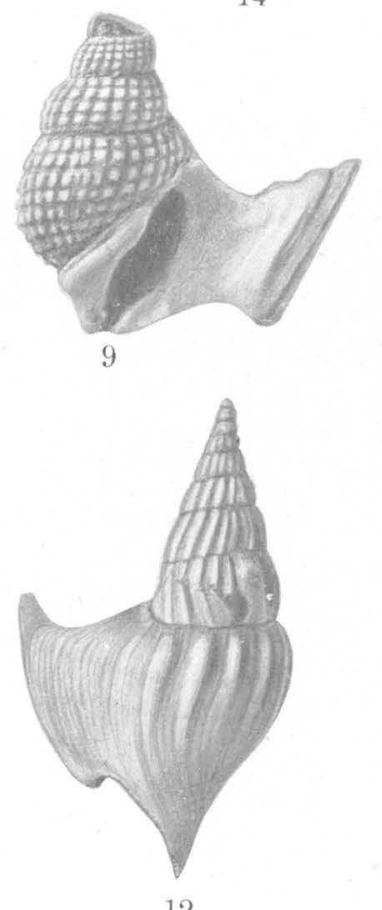

12
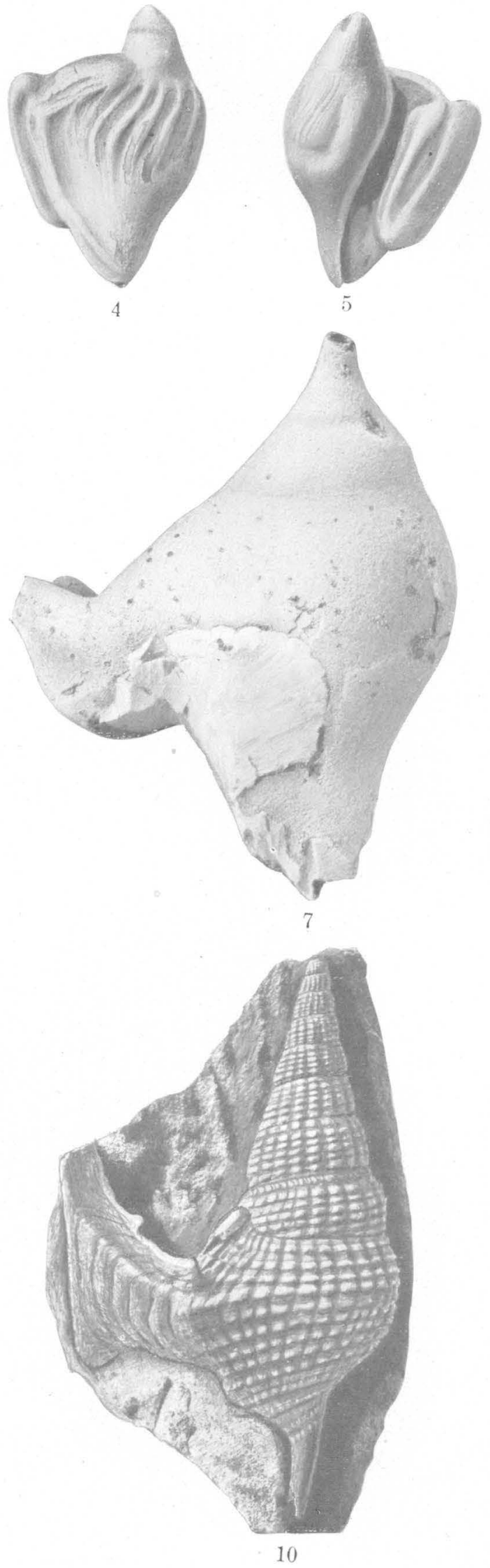

10

RIPLEY FOSSILS FROM COON CREEK, TENN. 


\section{PLATE LII}

\section{Ripley Fossils from Coon Creek, Tenn.}

1, 2. Paramorea lirata Wade, type (p. 134). 1, Front view; 2, back view. (U. S. Nat. Mus. catalog No. 32919.)

3. Ecphora proquadricostata Wade (p. 135), front view of type. (U. S. Nat. Mus. catalog No. 32920.)

4, 5. Pugnellus densatus Conrad (p. 148). 4, Back view; 5, front view. (U. S. Nat. Mus. catalog No. 32921.)

6, 7. Pugnellus abnormalis Wade, n. sp., type (p. 149). 6, Front view; 7 , back view. (U. S. Nat. Mus. catalog No. 32922.)

8, 9. Anchura convexa Wade, n. sp., type (p. 149). 8, Back view; 9, front view. (U. S. Nat. Mus. catalog No. 32923.)

10. Anchura substriata Wade, n. sp. (p. 149), back view of type. (U. S. Nat. Mus. catalog No. 32924.)

11, 12. Anchura lobata Wade, n. sp.; type (p. 150). 11, Front view; 12, back view. (U. S. Nat. Mus. catalog No. 32925.)

13, 14. Odontobasis australis Wade, n. sp., type (p. 146). 13, Back view; 14, front view. (U. S. Nat. Mus. catalog No. 32918.) 


\section{PLATE LIII}

\section{Ripley Fossils from Coon Creek, Tenn.}

1, 2. Anchura? pergracilis Johnson (p. 151). 1, Front view; 2, back view. (U. S. Nat. Mus. catalog No. 32926.)

3, 4. Anchura (Drepanochilus) quadrilirata Wade, n. sp., type (p. 151). 3, Front view; 4, back view. (U. S. Nat. Mus. catalog No. 32927.)

5, 8, 13. Anchura (Drepanochilus) calcaris Wade, n. sp. (p. 152). 5, Front view of type; 8, front view; 13, back view. (U. S. Nat. Mus. catalog No. 32928.)

6, 7. Pterocerella tippana (Conrad) (p. 152). 6, View of broken aperture; 7 , front view of the spire. (U. S. Nat. Mus. catalog No. 32929.)

9, 10. Tuba parabella Wade, n. sp., type (p. 171). 9, Back view; 10, front view. (U. S. Nat. Mus. catalog No. 32930.)

11, 16, 1\%. Mathildia ripleyana Wade, n. sp., type (p. 171). 11, Back view; 16, view of protoconch; 17, front view. (U.S. Nat. Mus. catalog No. 32931.)

12. Cerithium percostatum Wade, n. sp. (p. 153), front view of type. (U. S. Nat. Mus. catalog No. 32932.)

14, 15. Columbellina americana Wade, n. sp., type (p. 153). 14, Front view; 15, back view. (U. S. Nat. Mus. catalog No. 32933.)

18, 19. Promathildia cretacea Wade, n. sp. (p. 171). 18, Front view of the type; 19, front view of another specimen. (U. S. Nat. Mus. catalog No. 32934.) 
U. S. GEOLOGICAL SURVEY
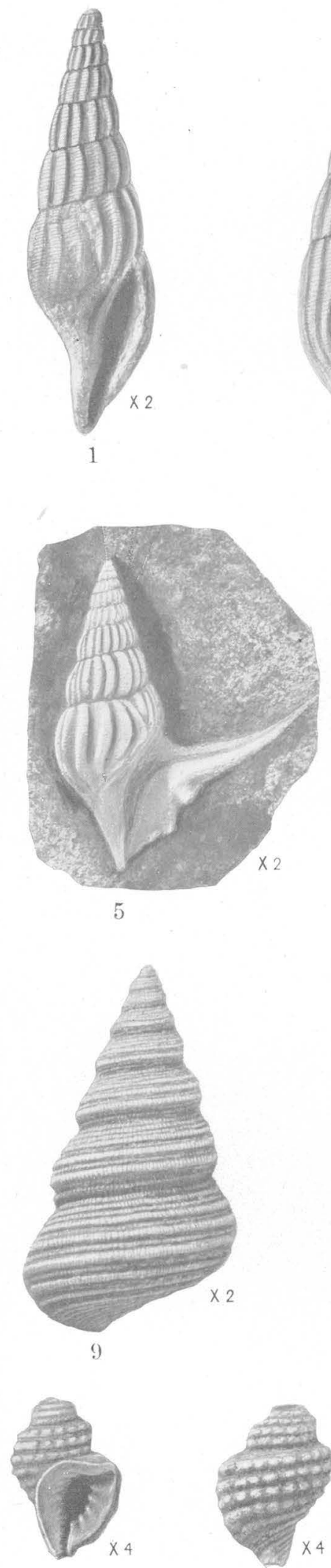

14
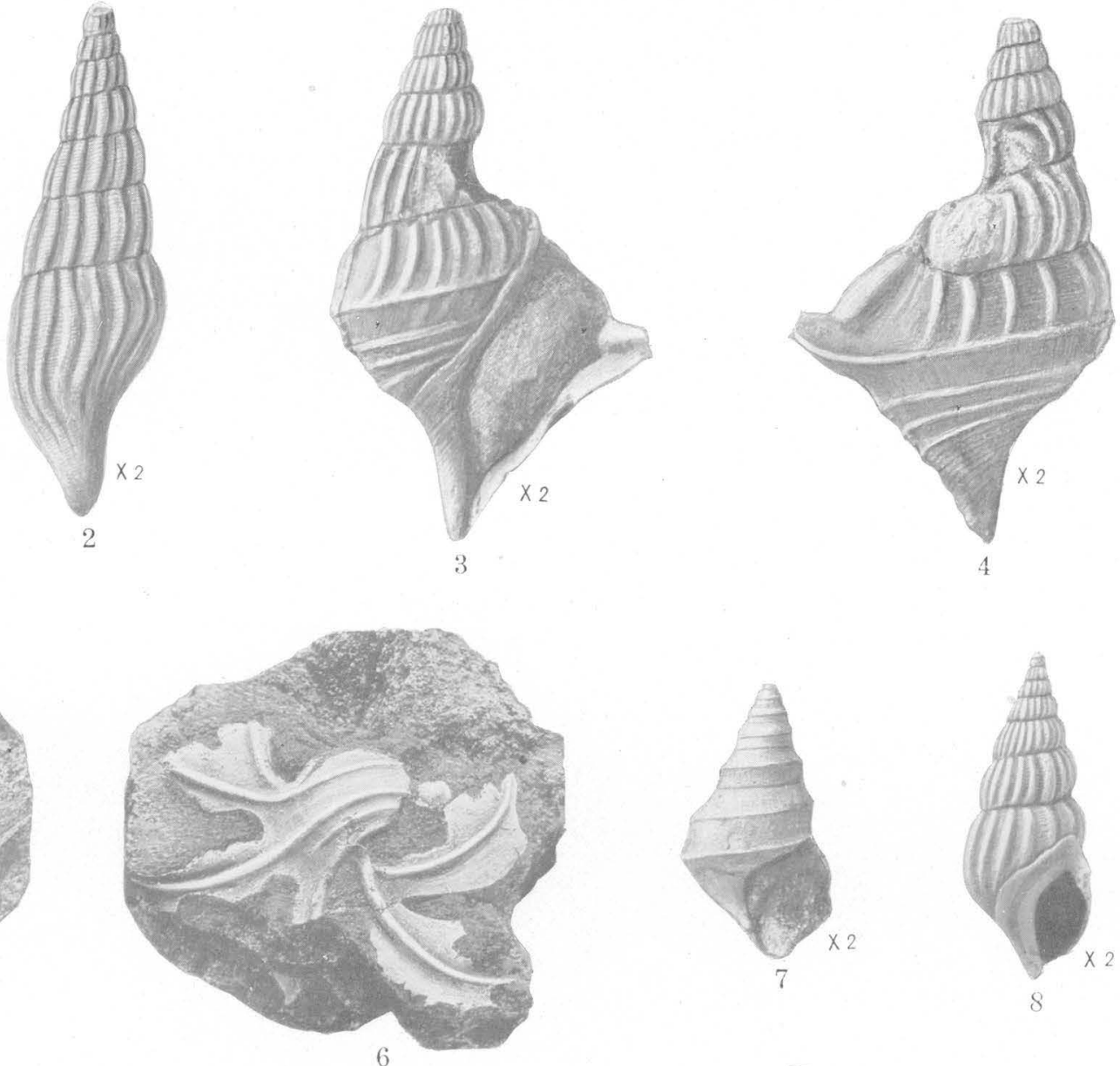

6
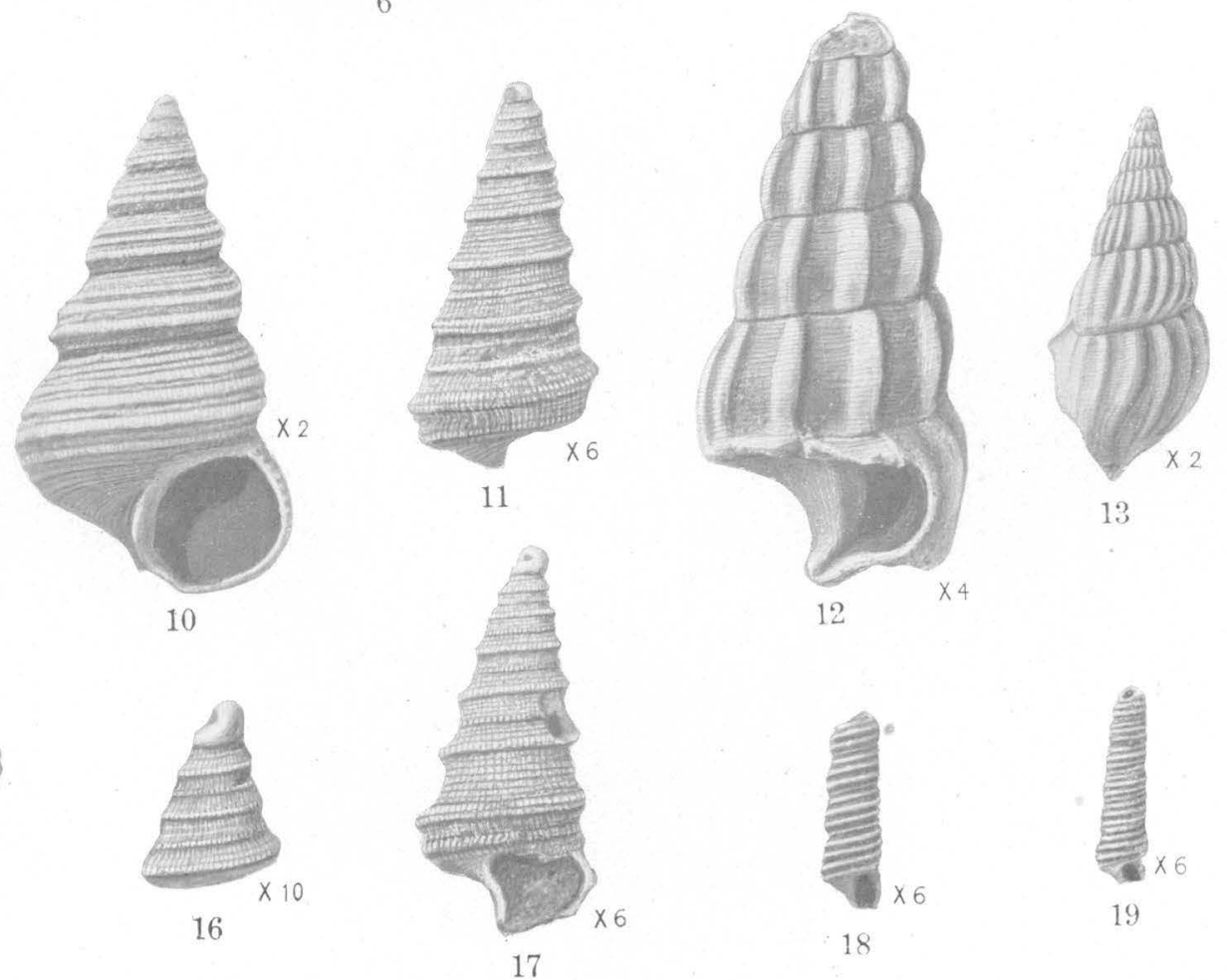

13

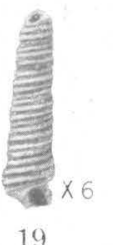

18

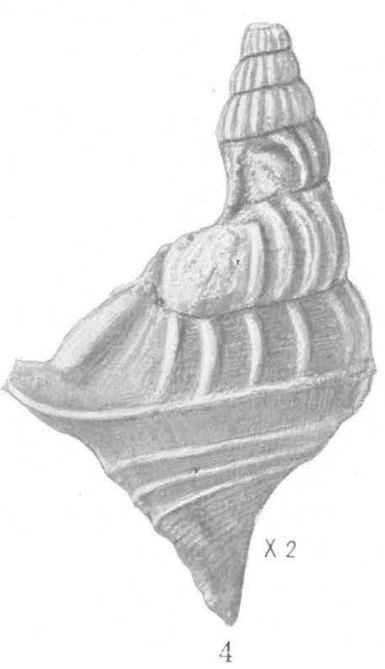



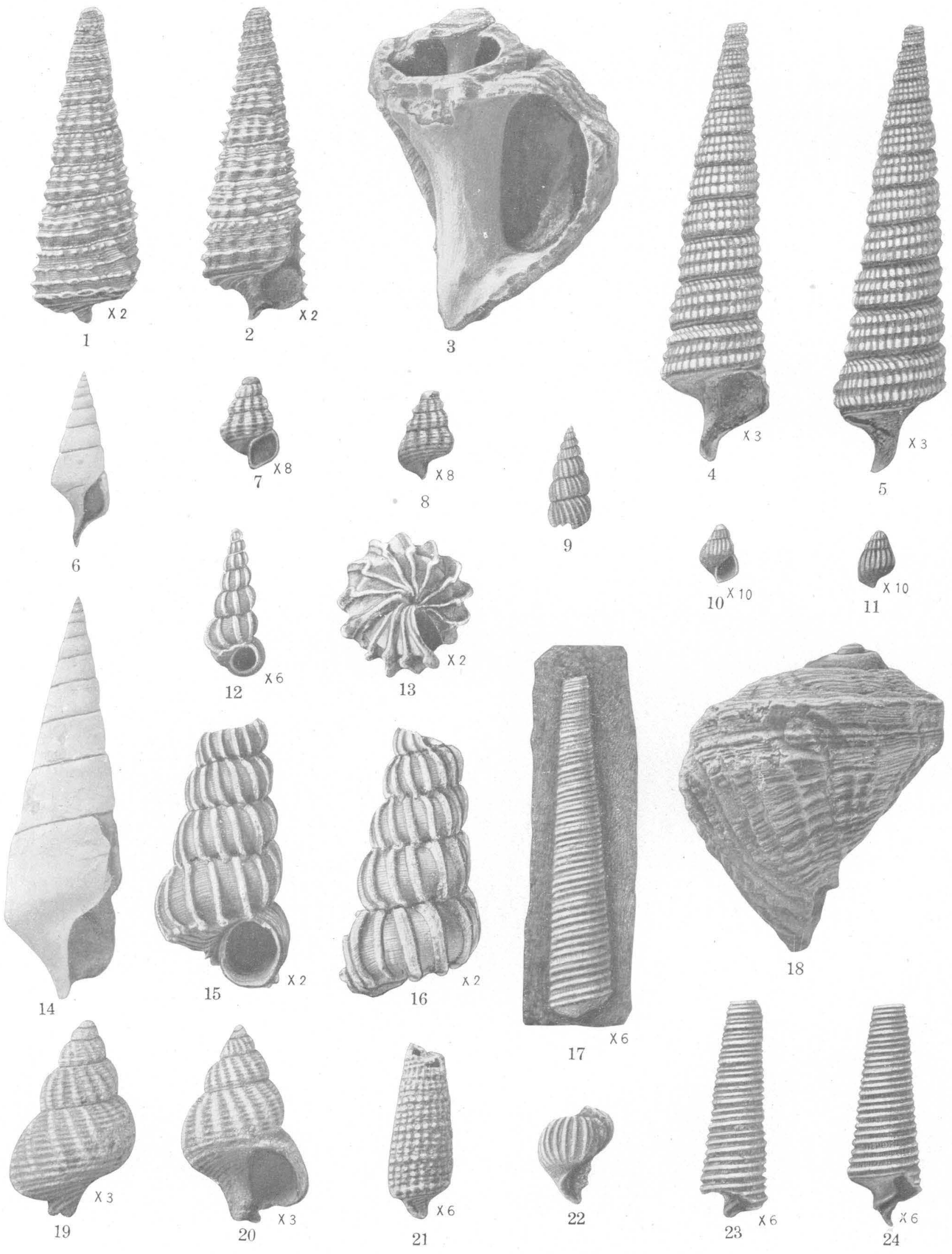

RIPLEY FOSSILS FROM COON CREEK, TENN. 


\section{PLATE LIV \\ Ripley Fossils from Coon Creek, Tenn.}

1, 2. Cerithium weeksi Wade, n. sp., type (p. 154). 1, Back view; 2, front view. (U. S. Nat. Mus. catalog No. 32935.)

3, 18. Trichotropis imperfecta Wade, n. sp., type (p. 157). 3, Front view; 18, back view. (U. S. Nat. Mus. catalog No. 32936.)

4, 5. Cerithium nodoliratum Wade, n. sp., type (p. 155). 4, Front view; 5, back view. (U. S. Nat. Mus. catalog No. 32937.)

6, 14. Nudivagus simplicus Wade (p. 156). 6, Front view of type; 14, front view of another specimen. (U. S. Nat. Mus. catalog No. 32938.)

7, 8. Mesostoma americanum Wade, n. sp., type (p. 155). 7, Front view; 8, back view. (U. S. Nat. Mus. catalog No. 32939.)

9, 22. A cirsa? cerithiformis Meek and Hayden (p. 169). 9, Back view of imperfect specimen; 22, view of another imperfect specimen. (U. S. Nat. Mus. catalog No. 32940.)

10, 11. Mesostoma costatum Wade, n. sp., type (p. 155). 10, Front view; 11, back view. (U. S. Nat. Mus. catalog No. 32941.)

12, 13, 15, 16. Scala sillimani (Morton) (p. 168). 12, 15, Front views; 13, basal view; 16, back view. (U. S. Nat.. Mus. catalog No. 32942.)

17. Cerithiopsis quadrilirala Wade, n. sp. (p. 157), back view of type. .(U. S. Nat. Mus. catalog No. 32943.)

19, 20. Astandes densatus Wade, type (p. 158). 19, Back view; 20, front view. (U. S. Nat. Mus. catalog No. 32944.)

21. Cerithium semirugalum Wade, n. sp. (p. 154), back view of type. (U. S. Nat. Mus. catalog No. 32945.)

23, 24. Cerithiopsis meeki Wade, n. sp. (p. 156). 23, Back view; 24, front view. (U. S. Nat. Mus. catalog No. 32946.) 


\section{PLATE LV}

\section{Ripley Fossils from Coon Creek, Tenn:}

1a, 1b, 2. Melanatria cretacea Wade, n. sp. (p. 158). 1a, Back view of type; 1b, front view of type; 2, back view of another specimen. (U. S. Nat. Mus. catalog No. 32947.)

3. Serpulorbis marylandica Gardner (p. 158), side view. (U. S. Nat. Mus. catalog No. 32948).

4, \%. Serpulorbis tennesseensis Wade, n. sp. (p. 159), side views of the type. (U. S. Nat. Mus. catalog No. 32949.)

5, 8. Laxispira lumbricalis Gabb (p. 159). 5, Apical view; 8, front view. (U. S. Nat. Mus. catalog No. 32950.)

6. Cerithium semirugatum Wade, n. sp. (p. 154), front view of type. (U. S. Nat. Mus. catalog No. 32945.)

9. Hemiacirsa cretacea Wade (p. 170), front view of type. (U. S. Nat. Mus. catalog No. 32951.)

10, 11. Proscala americana Wade, n. sp. (p. 170). 10, Front view of type; 11, back view. (U. S. Nat. Mus. catalog No. 32952.)

12. Acirsa microstriata Wade (p. 168), front view. (U. S. Nat. Mus. catalog No. 32953.)

13. Acirsa corrugata Wade (p. 169), front view of type. (U. S. Nat. Mus. catalog No. 32954.)

14. Cerithium percostatum Wade, n..sp. (p. 153), back view of type. (U. S. Nat. Mus. catalog No. 32932.) 

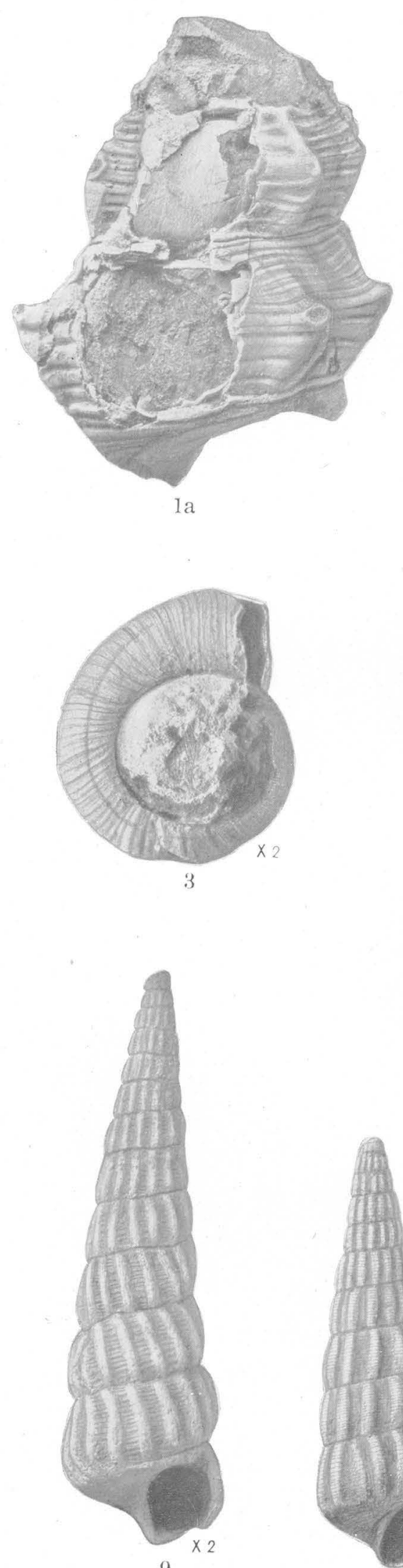

9

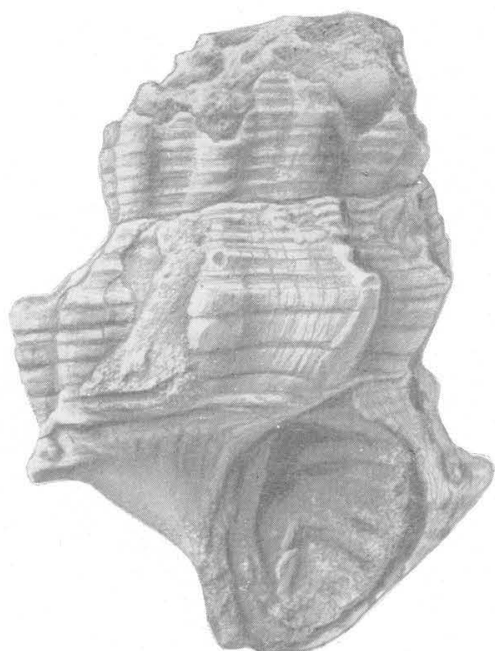

$1 \mathrm{~b}$
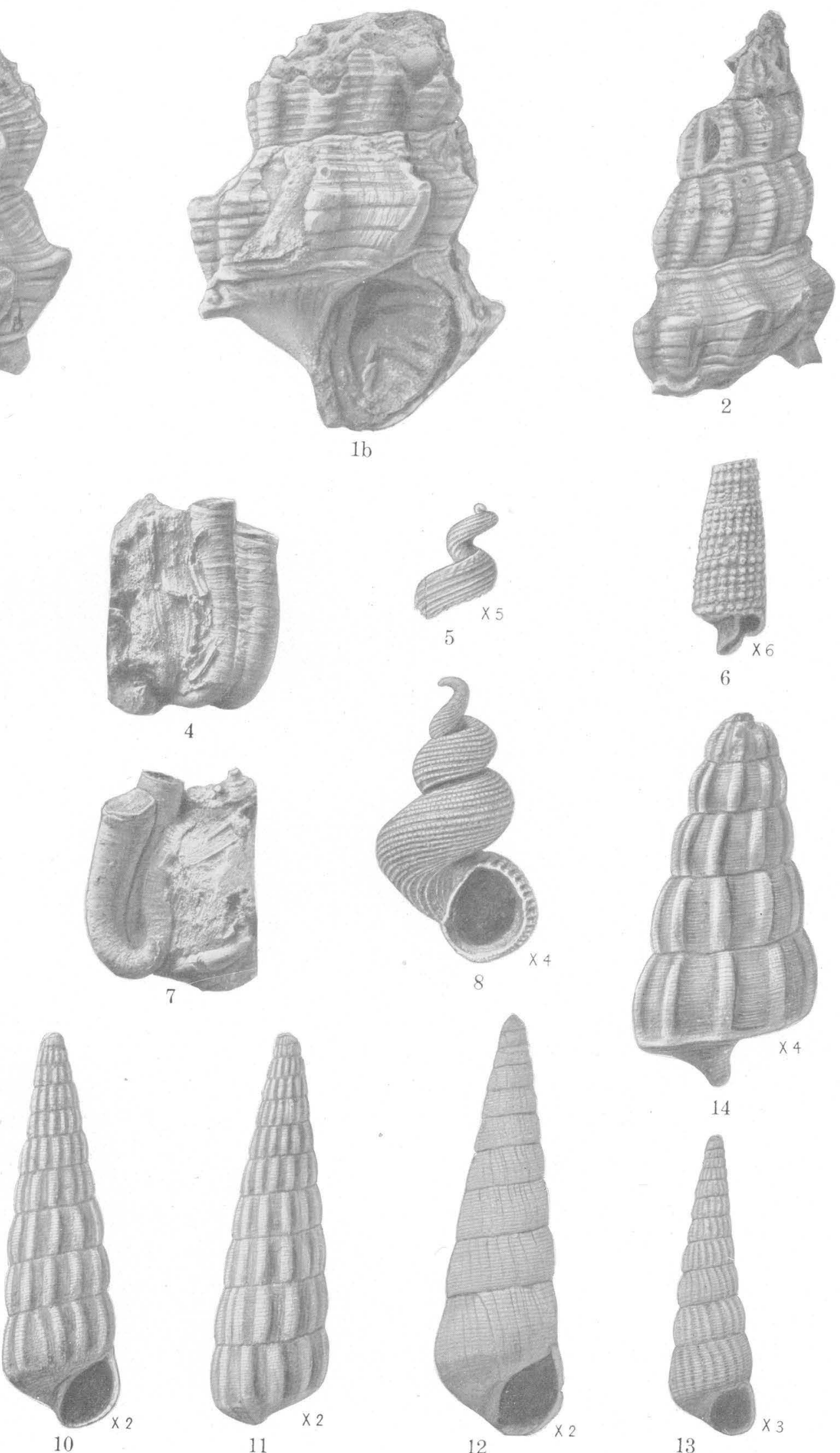

12

RIPLEY FOSSILS FROM COON CREEK, TENN. 
U. S. GEOLOGICAL SURVEY
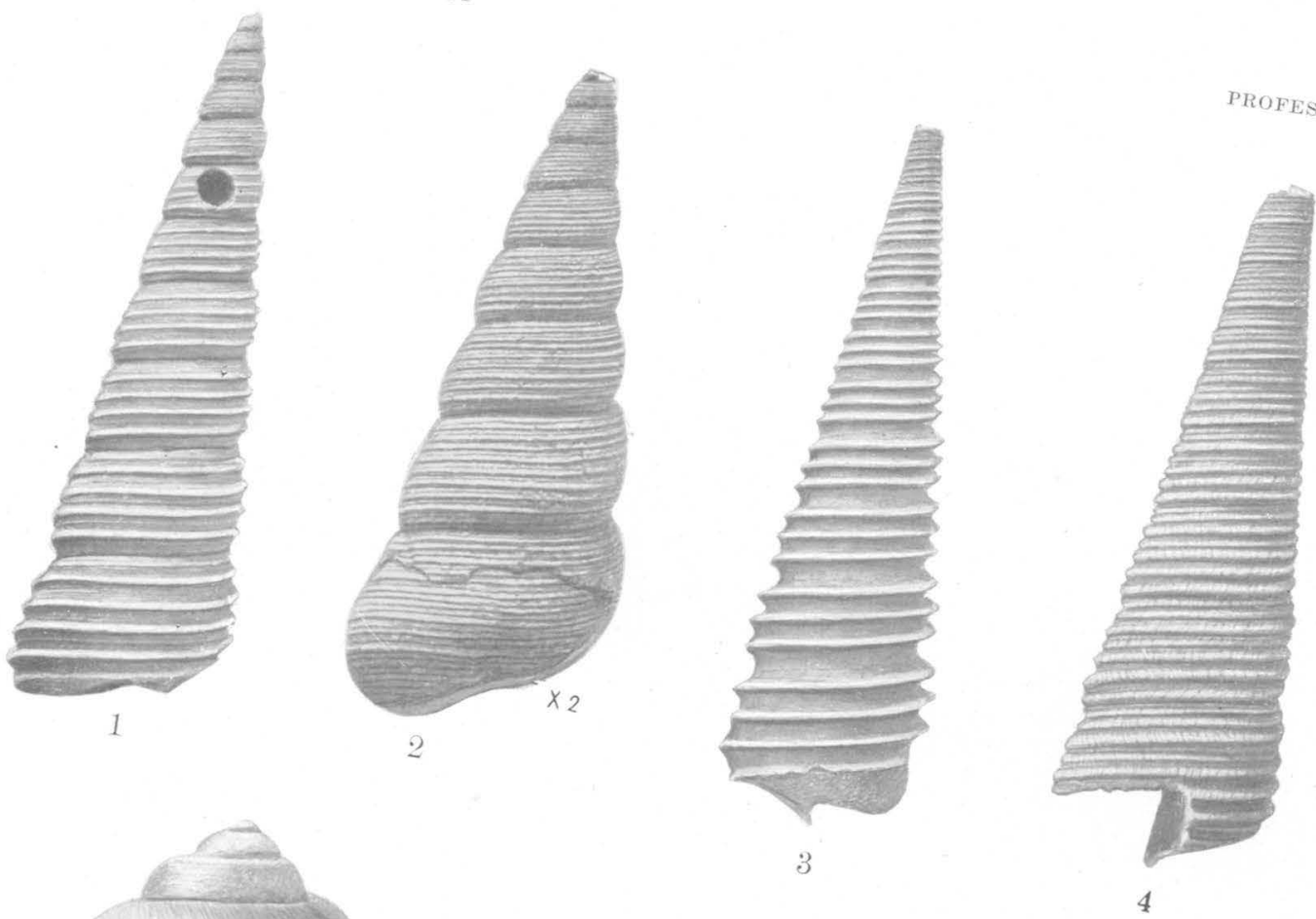

PLATE LVI
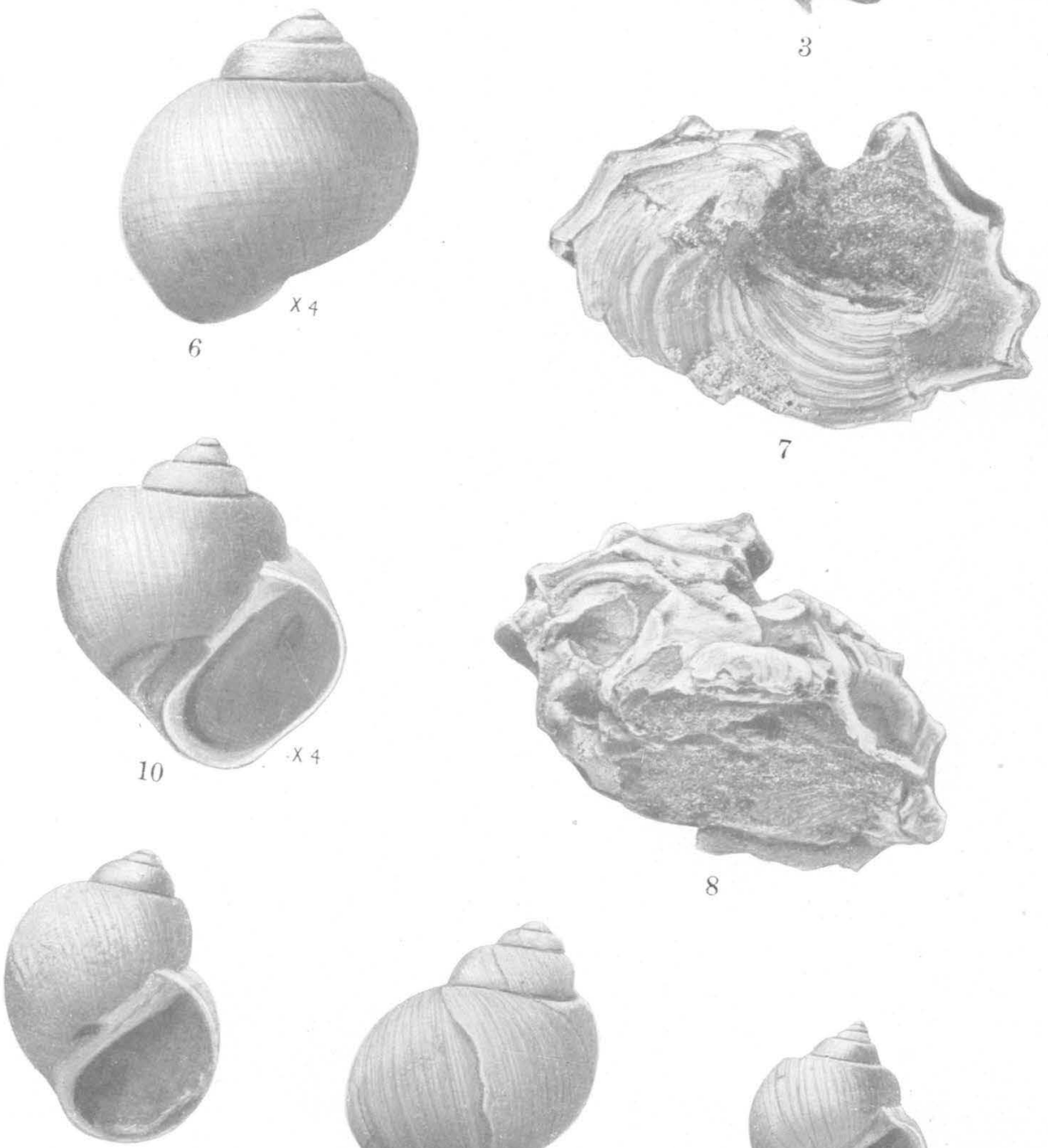

11
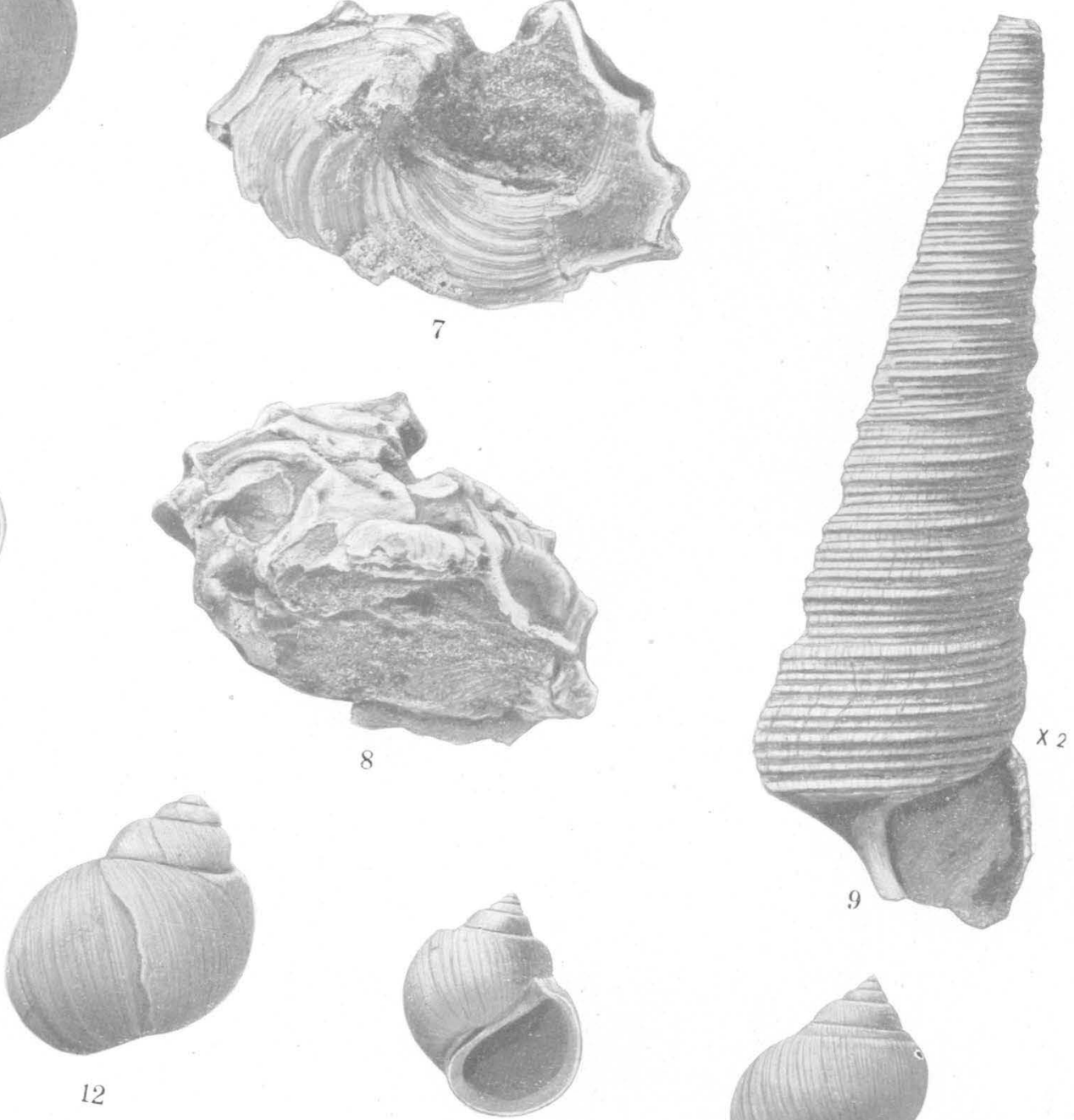

RIPLEY FOSSILS FROM COON 13

CREEK, TENN.

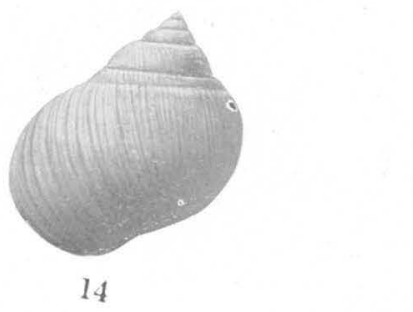




\section{PLATE LVI}

\section{Ripley fossils from Coon Creek, Tenn.}

1. Turrilella vertebroides Morton (p. 161), front view. (U. S. Nat. Mus. catalog No. 32955.)

2. Turritella menairyensis Wade, n. sp. (p. 159), back view of type. (U. S. Nat. Mus. catalog No. 32956.)

3. T'urrilella trilira Conrad (p. 161), back view. (U. S. Nat. Mus. catalog No. 32957.)

4. Turritella encrinoides Morton (p. 160), side view. (U. S. Nat. Mus. catalog No. 32958.)

5. Turritella paravertebroides Gardner? (p. 160), back view. (U. S. Nat. Mus. catalog No. 32959.)

6, 10. Polinices umbilica Wade, n. sp., type (p. 163). 6, Back view; 10, front view. (U. S. Nat. Mus. catalog No. 73071.)

7, 8. Xenophora leprosa (Morton) (p. 162). \%, Basal view; 8, top view of an imperfect specimen. (U. S. Nat. Mus. catalog No. 73072.$)$

9. Turrilella tippana Conrad (p. 162), front view. (U. S. Nat. Mus. catalog No. 73073. )

11, 12. Polinices (Euspira) halli (Gabb) (p. 163). 11, Front view; 12, back view. (U. S. Nat. Mus. catalog No. 73074.)

13, 14. Polinices stephensoni Wade, n. sp., type (p. 163). 13, Front view; 14; back view. (U. S. Nat. Mus. catalog No. 73075.) $106913-26 \dagger-21$ 


\section{PLATE LVII}

\section{Ripley Fossils from Coon Creek, Tenn.}

1-3. Gyrodes crenata Conrad (p. 164). 1, Basal view; 2, front view; 3, top view. (U. S. Nat. Mus. catalog No. 73076.)

4, 7, 11. Gyrodes major Wade, n. sp., type (p.164). 4, Back view; 7 , front view; 11, top view. (U.. S. Nat. Mus. catalog No. 73077.)

5, 8. Amauropsis lirata Wade, n. sp., type (p. 165). '5, Back view; 8, front view.' (U. S. Nat. Mus. catalog No. 73078.)

6, 9. Gyrodes alveata Conrad (p. 164). 6, Front view; 9, rear view. (U. S. Nat. Mus. catalog No. 73079.)

10, 14. Mammilla americana Wade, n. sp., type (p. 165). 10, Top view; 14, back view. (U. S. Nat. Mus. catalog No. 73080.)

12, 13. Ampullina potens Wade, n. sp., type (p. 165). 12, Front view; 13, back view. (U. S. Nat. Mus. catalog No. 73081.$)$ 

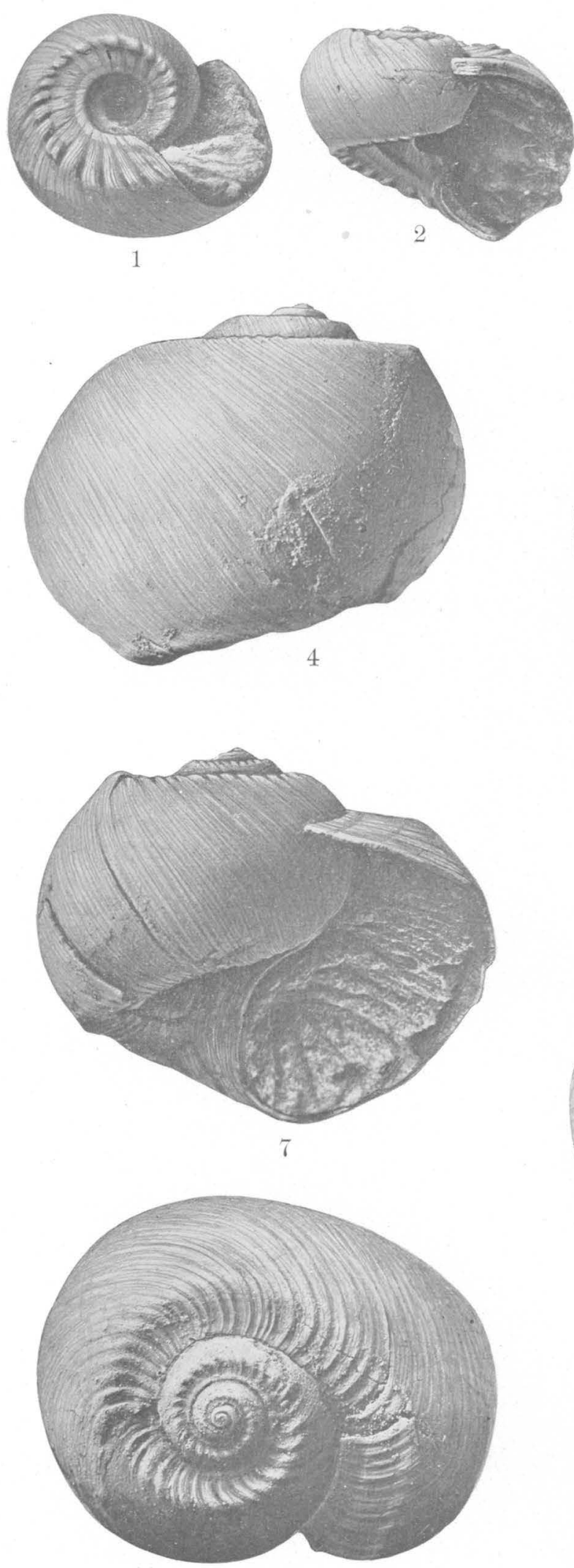

11
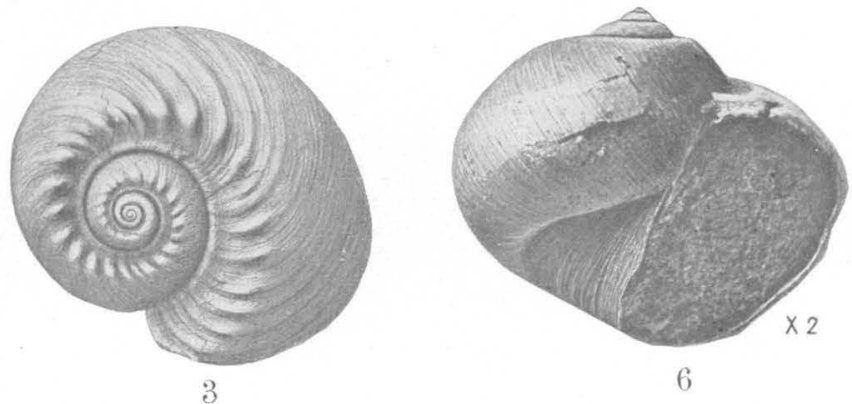

6

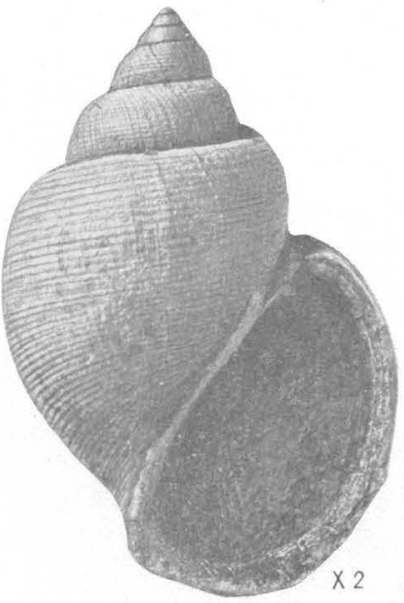

8
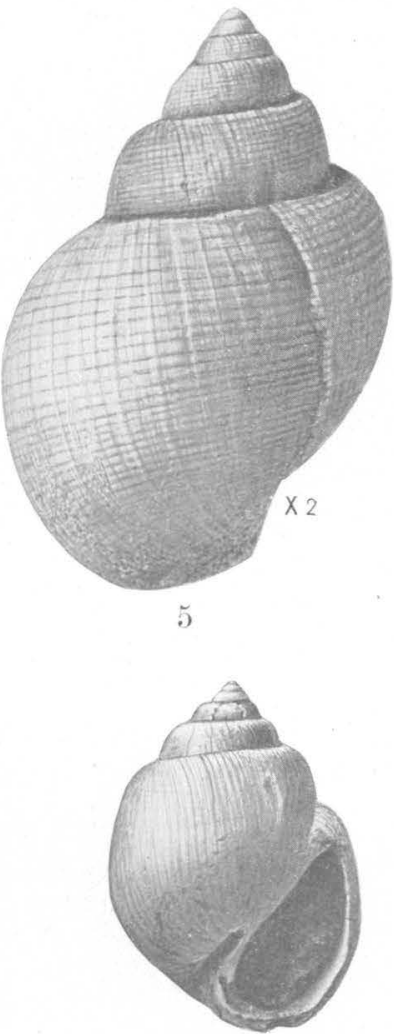

12
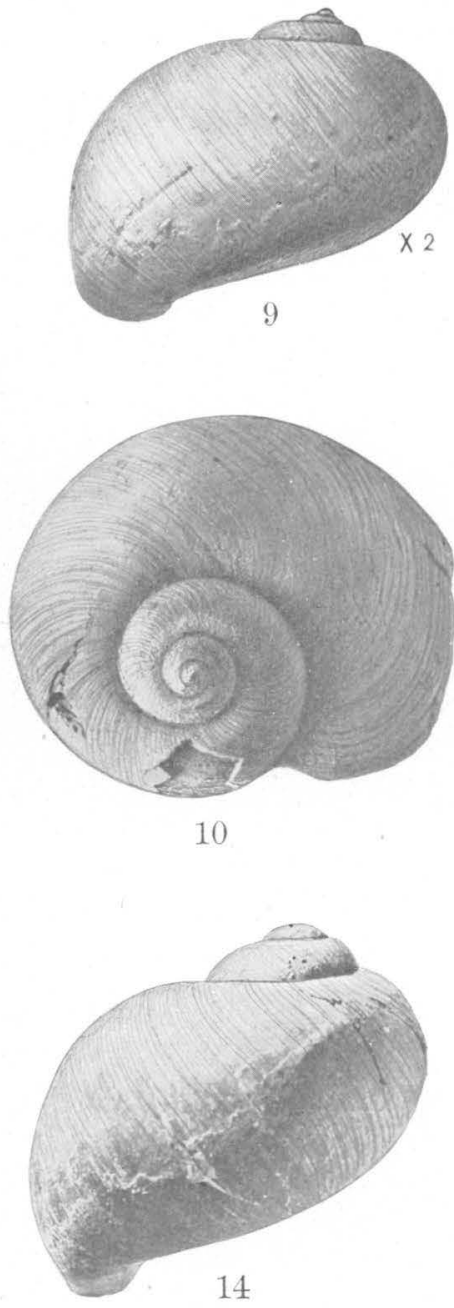

RIPLEY FOSSILS FROM COON CREEK, TENN. 
T. S. GEOLOGICAL SURVEY
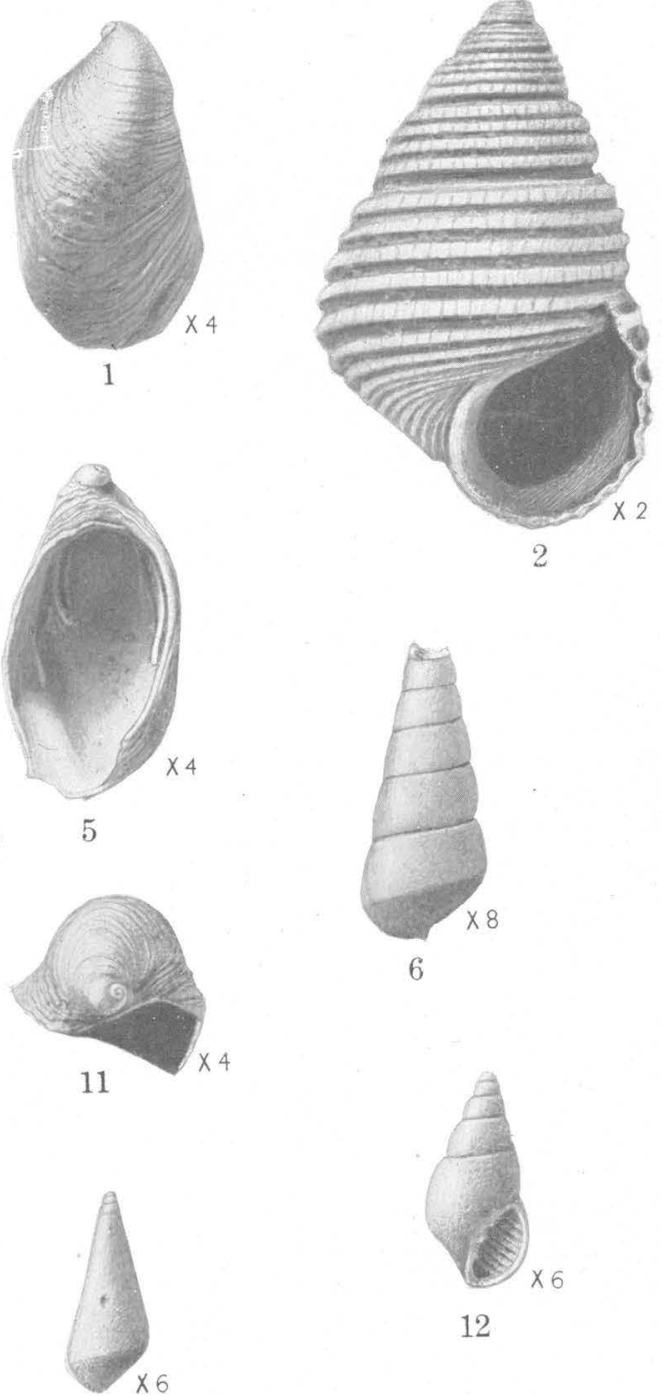

16

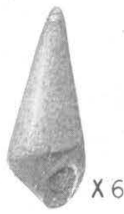

17

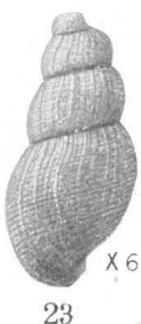

23
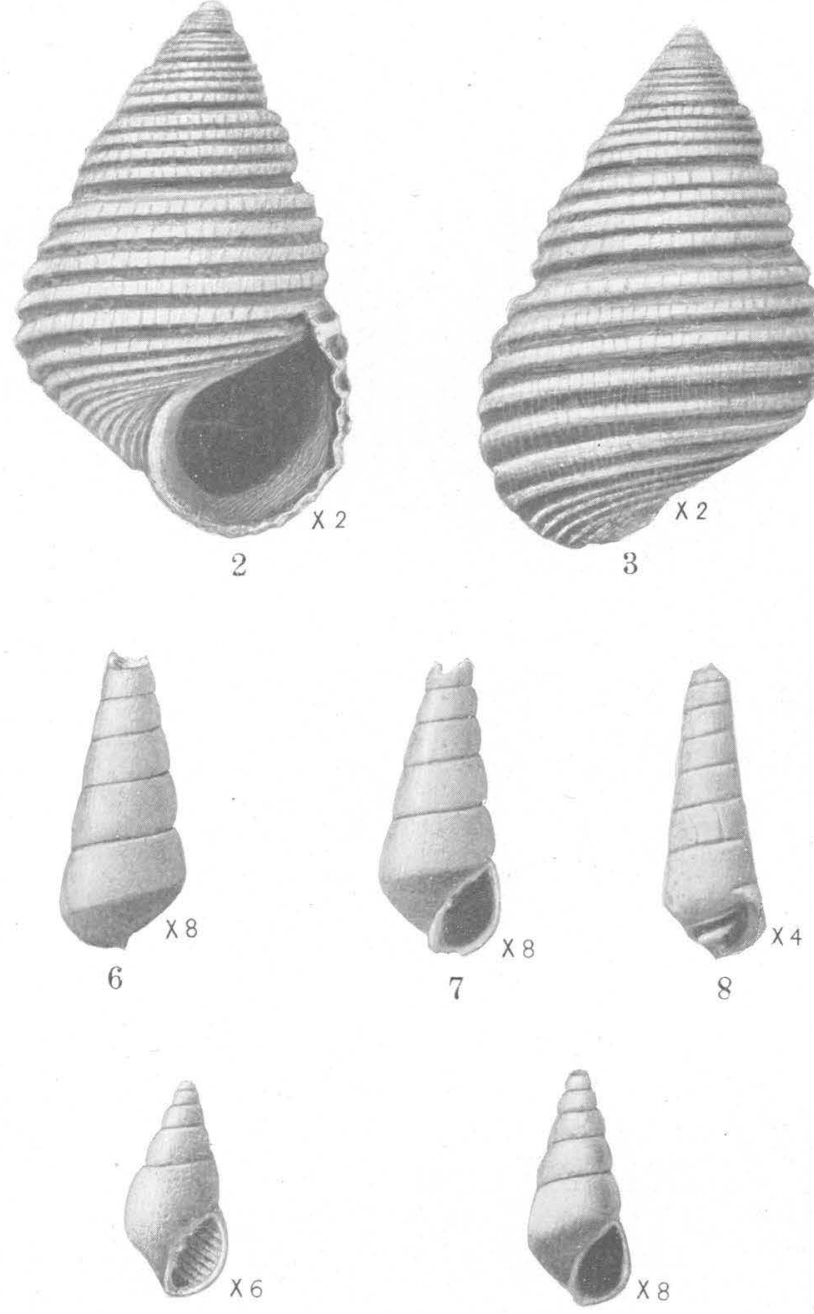

12

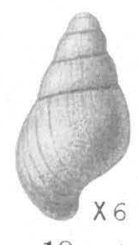

18

13

1920

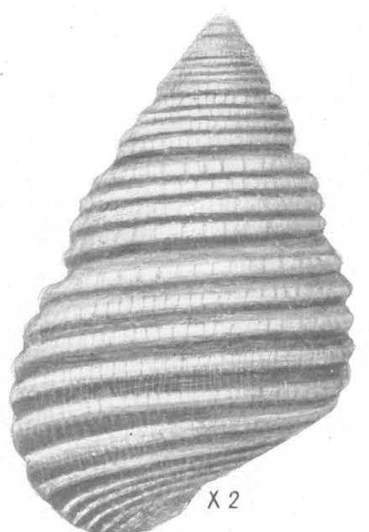

PROFESSIONAL PAPER 137 PLATE LVIII
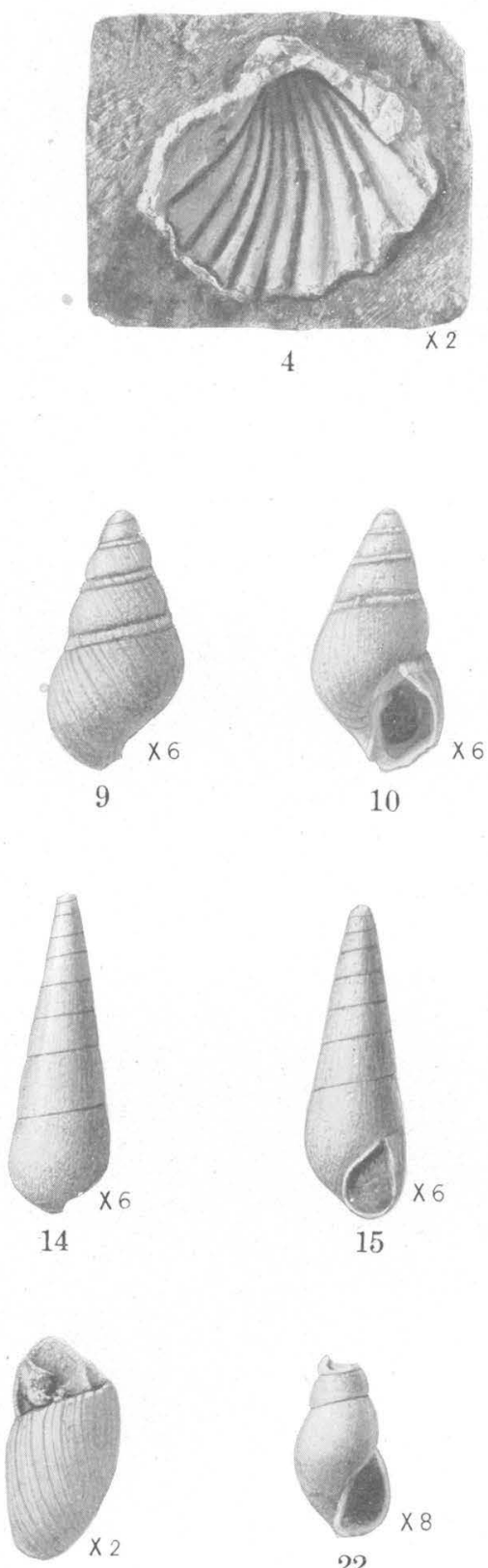

21
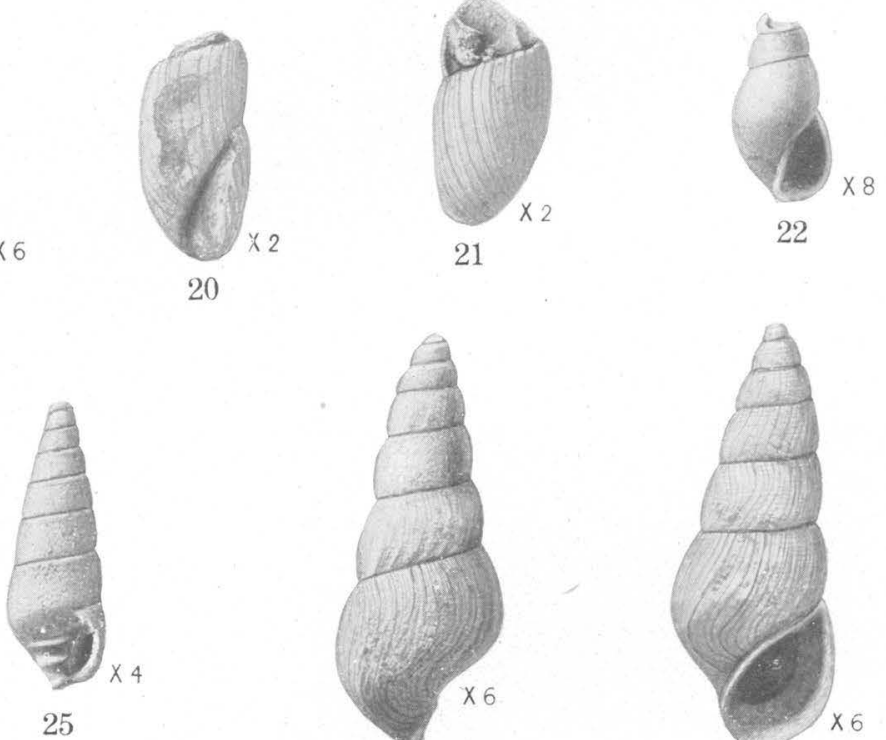

24
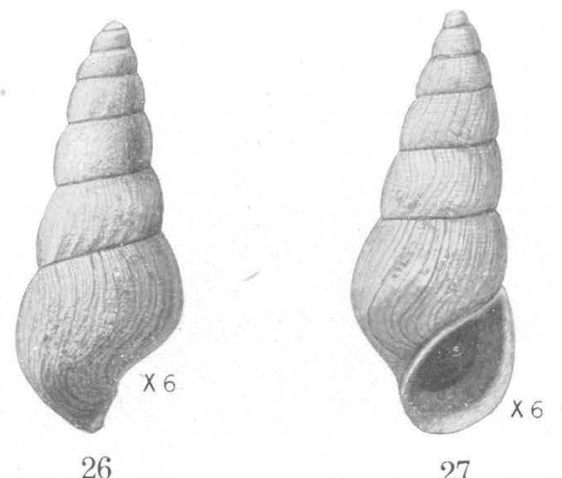

27

RIPLEY FOSSILS FROM COON CREEK, TENN. 


\section{PLATE LVIII}

\section{Ripley Fossils from Coon Creek, Tent.}

1, 5, 11. Thylacus cretaceus Conrad (p.166). 1, Top view; 5, view of aperture; 11, apical view. (U.S. Nat.'Mus. catalog No. 73082.$)$ 2, 3. Littorina berryi Wade, n. sp., type (p. 166). 2, Front view; 3, back view. (U. S. Nat. Mus. catalog No. 73083.)

4. Capulus corrugatus Wade, n. sp. (p. 166), apertural view of type. (U. S. Nat. Mus. catalog No. 73084.)

6, 7. Leiostraca cretacea (Conrad) (p. 17.2). 6, Back view; 7 , front view. (U. S. Nat. Mus. catalog No. 73085.)

8, 25. Creonella triplicala Wade (p. 173). 8, Front view of type; 25, front view of another specimen. (U. S. Nàt. Mus. catalog No. 73086.)

9, 10. Odostomia impressa Wade, n. sp., type (p. 174). 9, Back view; 10, front view. (U. S. Nat. Mus. catalog No. 73087.$)$

12. Creonella secunda Wade, n. sp. (p. 173), front view of type. (U. S. Nat. Mus. catalog No. 73088.)

13. Eulima impressa Wade, n. sp. (p. 174), front view of type. (U. S. Nat. Mus. catalog No. 73089.)

14, 15. Eulima persimplica Wade, n. sp., type (p. 174). 14, Back view; 15, front view. (U. S. Nat. Mus. catalog No. 73090.$)$.

16, 17. Eulima laevigata Wade, n. sp., type (p. 174). 16, Back view; 17, front view. (U. S. Nat. Mus. catalog No. 73091.)

18, 19. Odostomia plicala Wade, n. sp., type (p. 173). 18, Back view; 19, front view. (U. S. Nat. Mus. catalog No. 73092.$)$

20, 21. Eulima clara Wade, n. sp., type (p. 174). 20, Front view; 21, back view. (U. S. Nat. Mus. catalog No. 73093.)

22. Rissoina fragilis Wade, n. sp. (p. 167), front view of type. (U. S. Nat. Mus. catalog No. 73094.)

23, 24. Rissoina subornata Wade, n. sp. (p. 168). 23, Back view; 24, front view. (U. S. Nat. Mus. catalog No. 73095.)

26, 27. Rissoina tennesseensis Wade, n. sp., type (p. 167). 26, Back view; 27, front view. (U. S. Nat. Mus. catalog No. 73096.) 


\section{PLATE LIX}

\section{Ripley Fossils from Coon Creek, Tenn.}

1-4. Pseudomalaxis amplificata Wade, n. sp. (p. 175). 1, Basal view; 2, top view; 3, side view; 4, top view of type. (U. S. Nat. Mus. catalog No. 73097.)

5-8, 12. Pseudomalaxis ripleyana Wade, n. sp. (p. 175). 5, Basal view of type; 6, top view of type; $\boldsymbol{7}$, side view of type; 8, basal view of another specimen; 12, top view. (U. S. Nat. Mus. catalog No. 73098.)

9-11. Hippocampoides serratus Wade, type (p.176). 9, Top view; 10, basal view; 11, side view. (U. S. Nat. Mus. catalog No. 73099.)

13-15. Hippocampoides liratus Wade, n. sp. (p. 176). 13, Top view; 14, bottom view; 15, front view of type. (U. S. Nat. Mus. catalog No. 73100 .

16, 20, 21. Teinostoma prenanum Wade, n. sp., type (p. 178). 16, Top view; 20, front view; 21, basal view. (U. S. Nat. Mus. catalog No. 73101.)

17-19. Schizobasis depressa Wade, type (p.177). 17, Front view;18, basal view; 19, back view. (U. S. Nat. Mus. catalog No. 73102.$)$ 22, 23. Schizobasis immersa Wade, n. sp. (p.177). 22, Front view of type; 23, back view of another specimen. (U. S. Nat. Mus. catalog No. 73103.)

24, 25. Trochus ripleyanus Wade, n. sp., type (p. 178). 24, Back view; 25, front view. (U. S. Nat. Mus. catalog No. 73104. ) 
U. S. GEOLOGICAL SURYEY

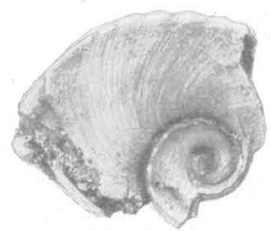

1

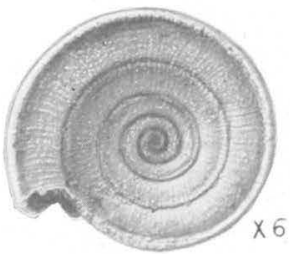

5
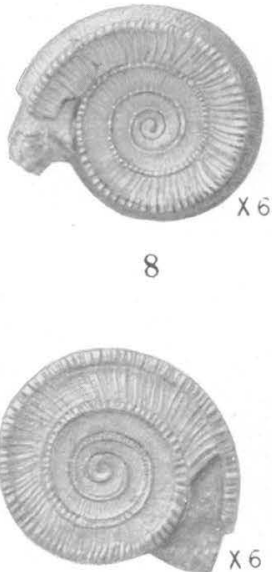

12

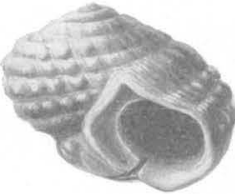

17

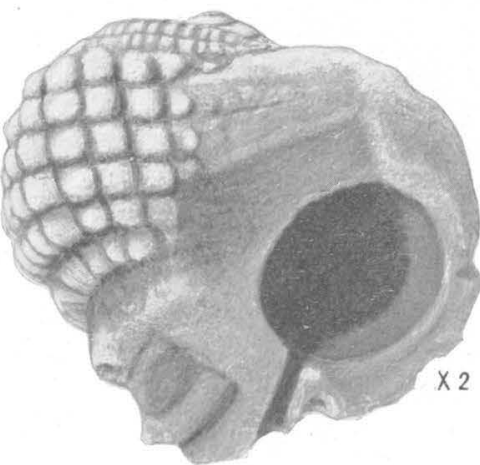

22
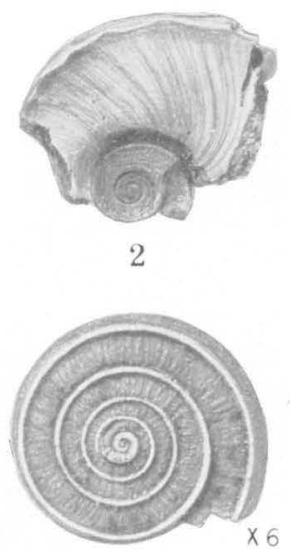

6

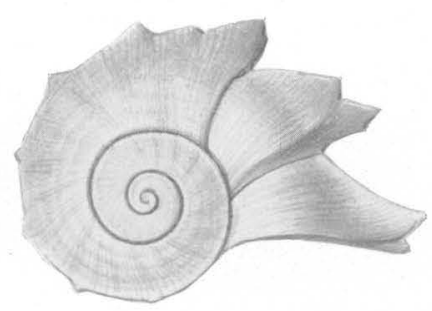

9

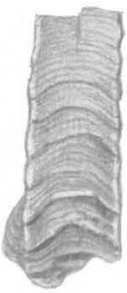

3

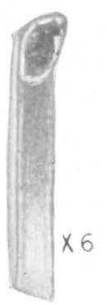

7

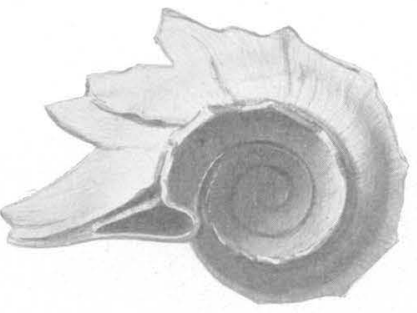

10
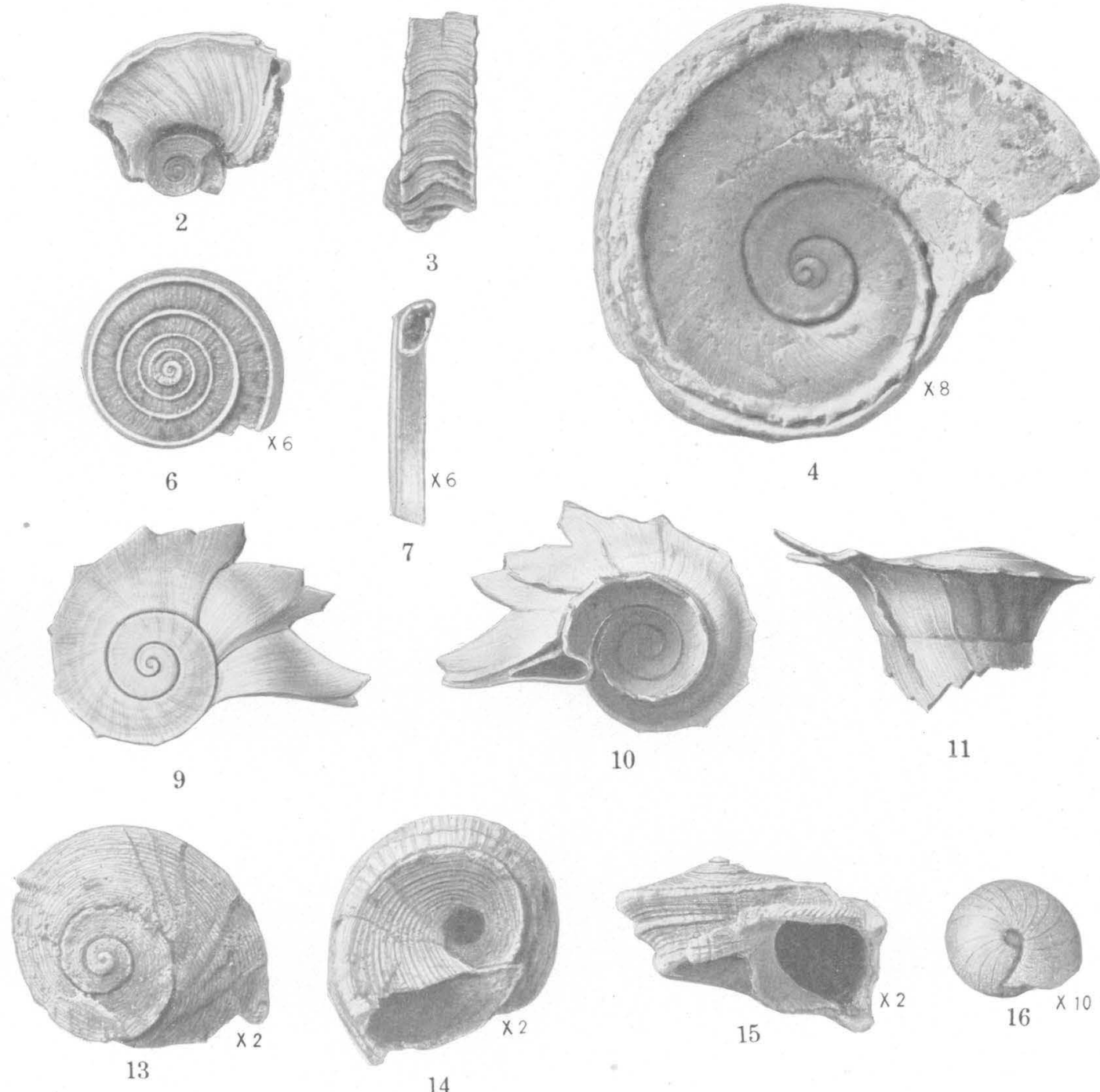

14

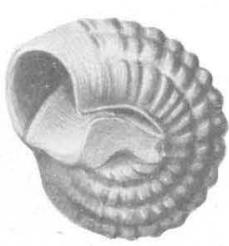

18

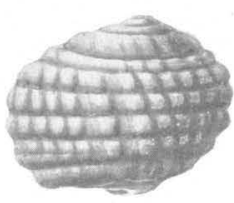

19
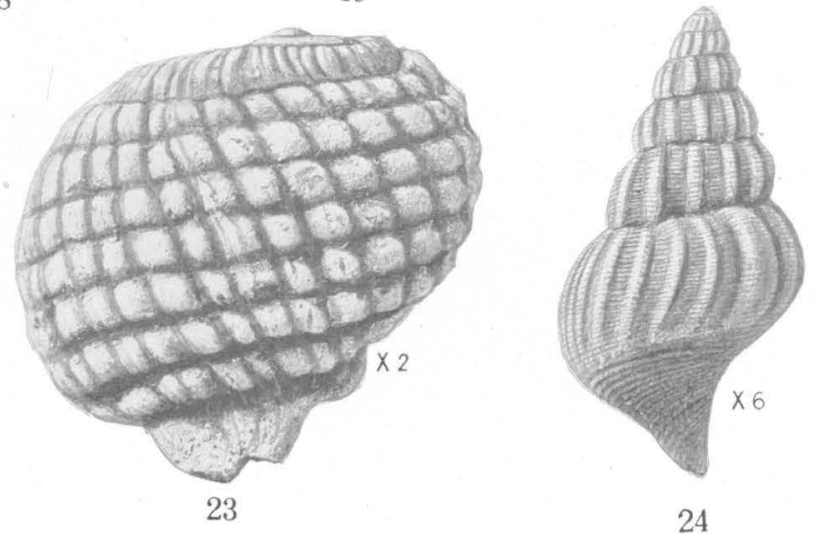

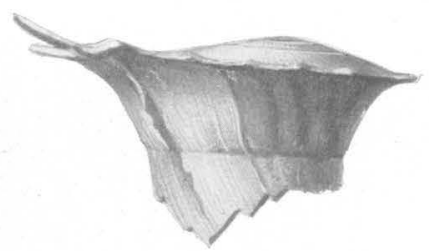

11
24
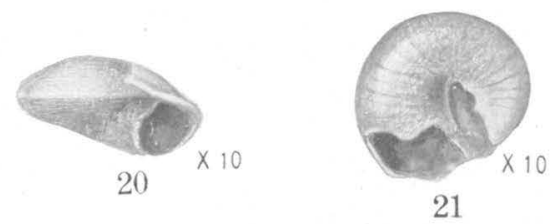

21

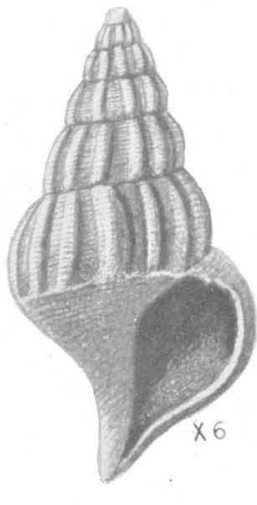

25

RIPLEY FOSSILS FROM COON CREEK, TENN. 
U. S. GEOLOGICAL SURVEY
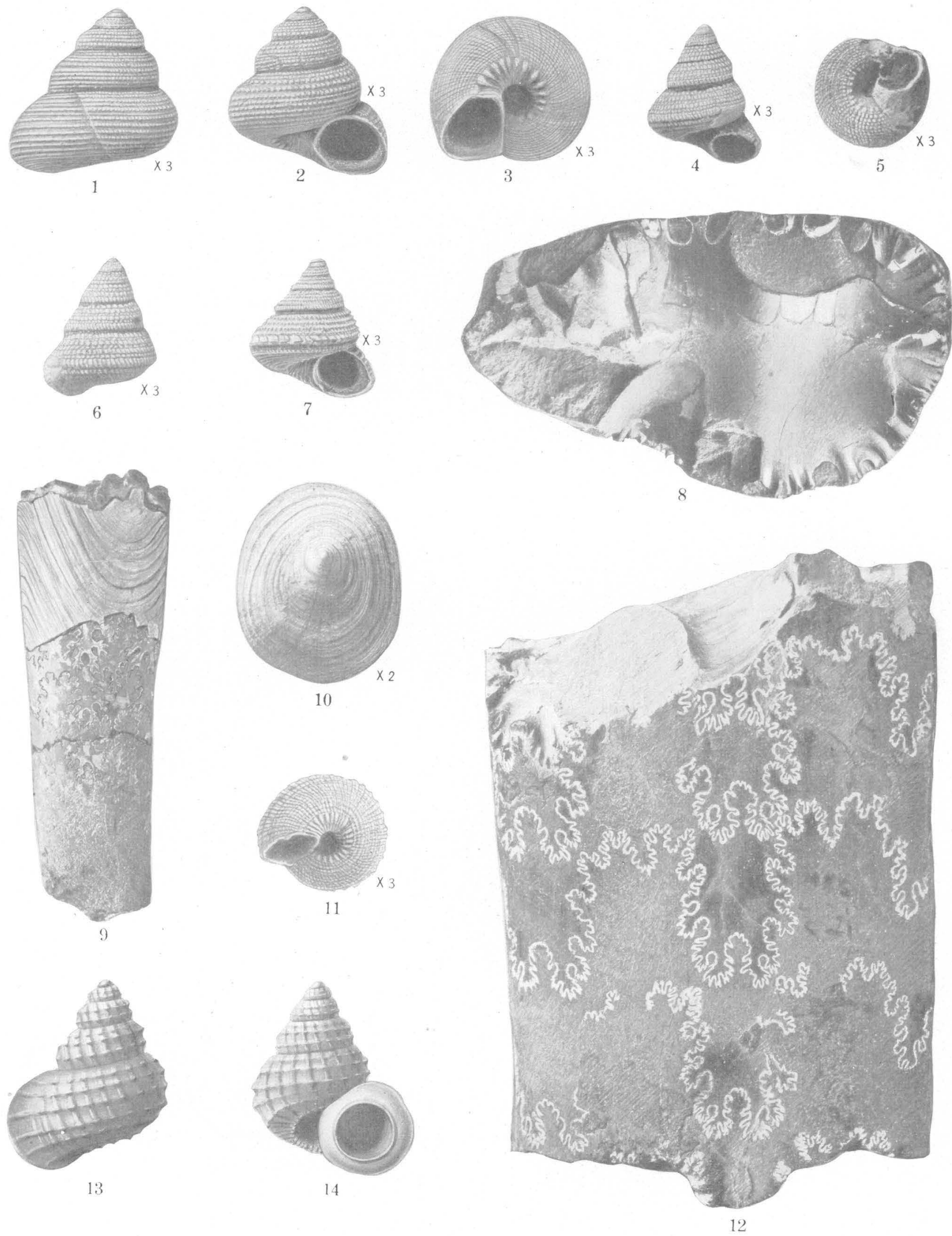

RIPLEY FOSSILS FROM COON CREEK, TENN. 


\section{PLATE LX}

\section{Ripley Fossils from Coon Creekr, Tenn.}

1-3. Calliomphalus americanus Wade, n. sp., type (p. 178). 1, Back view; 2, front view; 3, basal view. . (U. S. Nat. Mus. cata$\log$ No. 73105.)

4-7, 11. Calliomphalus argenteus Wade, n. sp. (p. 179). 4, Front view of type; 5 , basal view of type; 6 , back view of type; $\boldsymbol{7}$, front view of another specimen; 11, basal view. (U. S. Nat. Mus. catalog No. 73106.)

8, 12. Baculites grandis Hall and Meek (p. 182). 8, End view; 12, side view. (U. S. 'Nat. Mus. catalog No. 73107. )

9. Baculites ovatus Say (p. 181), side view. (U. S. Nat. Mus. catalog No. 73108.)

10. Anisomyon wieseri Wade, n. sp. (p. 180), apical view. (U. S. Nat. Mus. catalog No. 73109 .)

13, 14. Eucycloscala luberculata (Wade) (p. 179). 13, Back view; 14, front view. (U. S. Nat. Mus. catalog No. 73110.) 


\section{PLATE LXI}

\section{Ripley Fossils from Coon Creek, Tenn.}

1, 2. Eutrephoceras dekayi (Morton) (p. 180). 1, Side view of an imperfect individual; 2, front view. (U. S. Nat. Mus. catalog No. 73111.)

3-\%. Scaphites reesidei Wade, n. sp. (p. 183). 3, Front view of type; 4, rear view of type; 5, side view of type; $\mathbf{6}$, suture of fourth from last septum of type; $\boldsymbol{\gamma}$, side view of imperfect individual. (U. S. Nat. Mus. catalog No. 73112.)

8-11. Helicoceras navarroense Shumard (p. 184). 8, Bottom view of a fragment of a coil; 9, top view of one and a half coils; 10, top view of a fragment of a coil; 11, a complete suture. (U. S. Nat. Mus. catalog No. 73113.) 


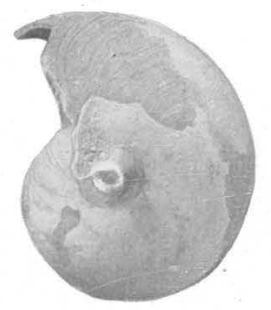

1
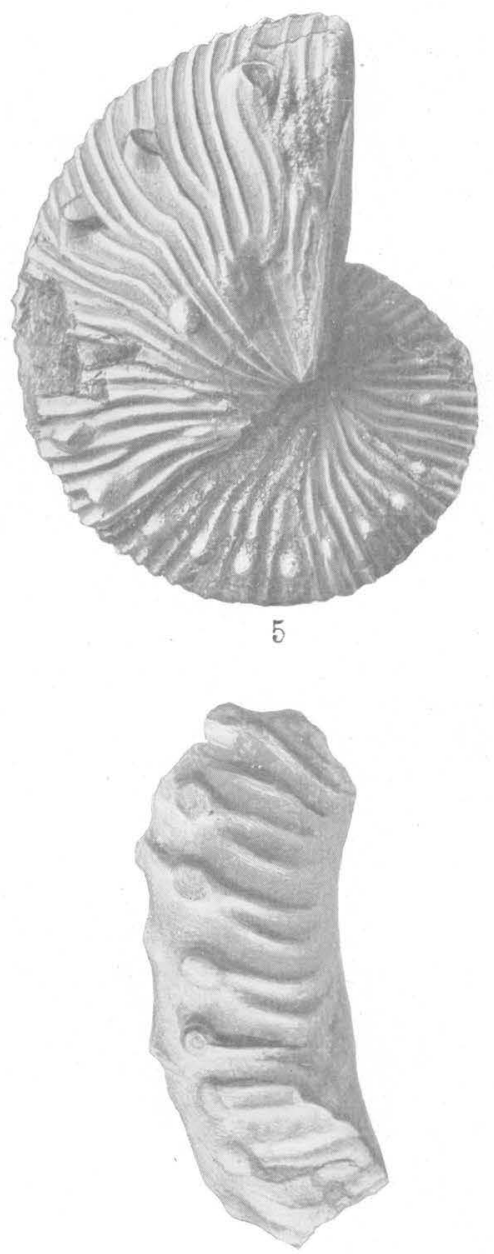

10 है।

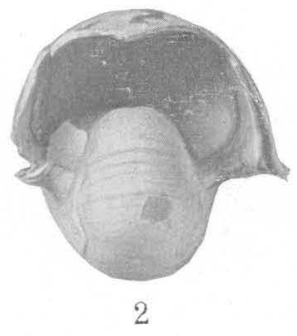

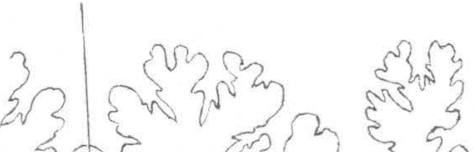
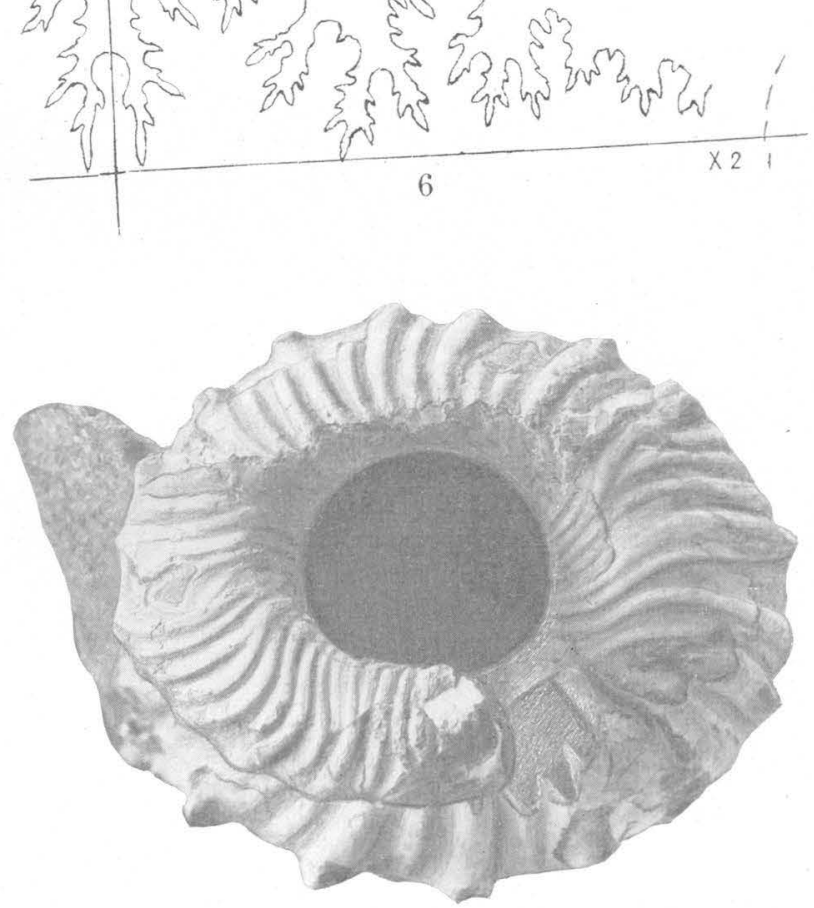

9

1010 ,
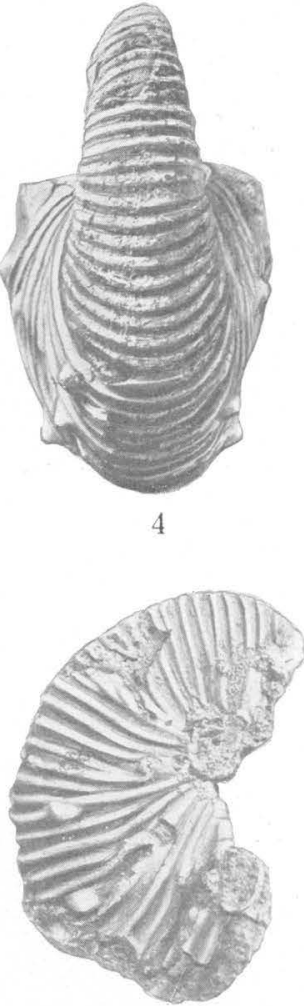

7

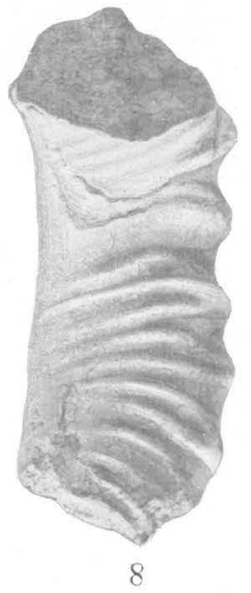
जon

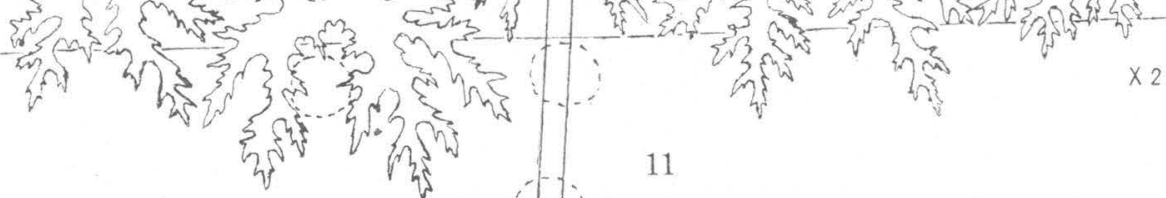

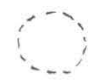

11

RIPLEY FOSSILS FROM COON CREEK, TENN. 

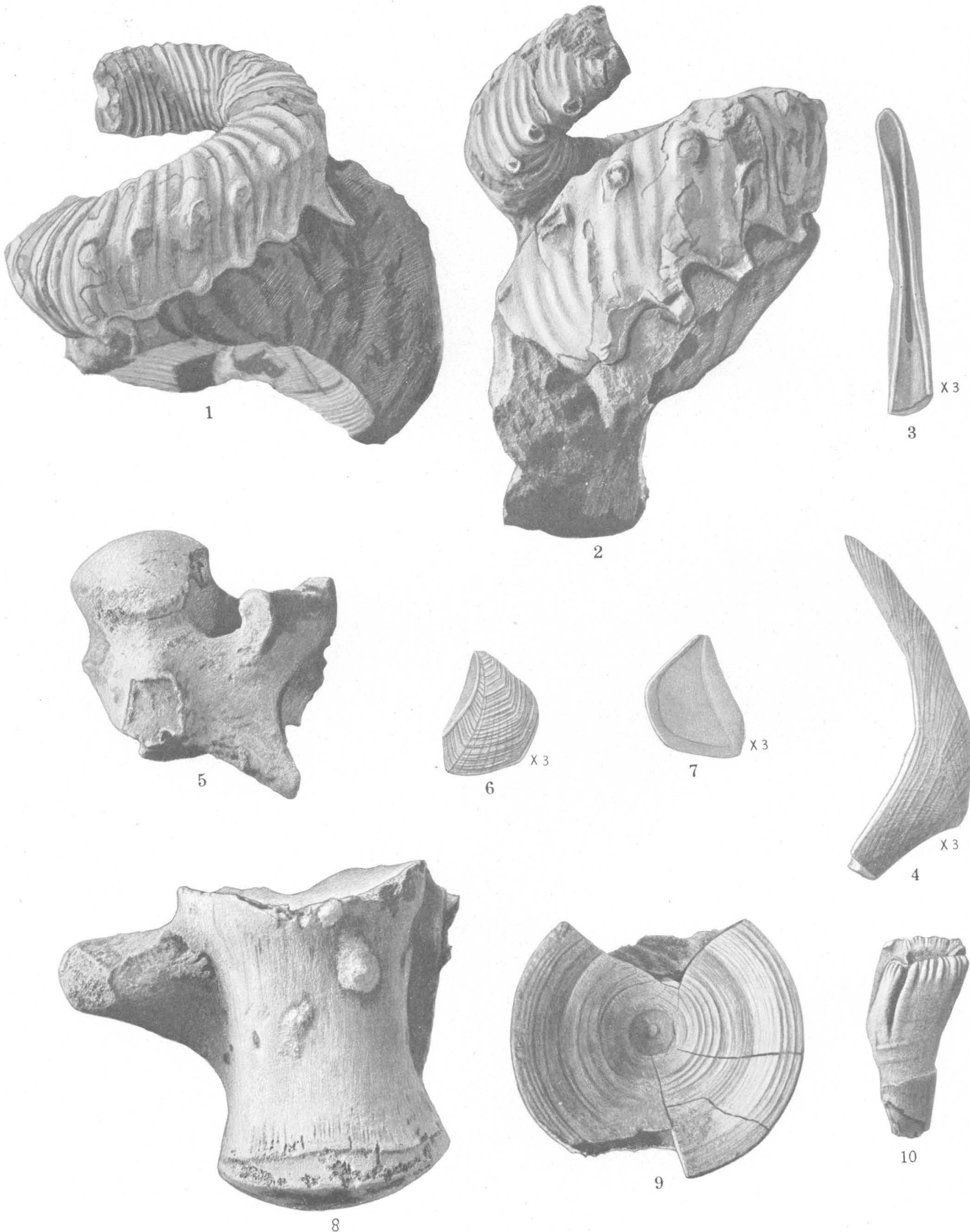

RIPLEY FOSSILS FROM COON CREEK, TENN. 


\section{PLATE LXII}

\section{Ripley Fossils from Coon. Creekr, Tenn.}

1, 2. Helicoceras navarroense Shumard (p. 184), side views. (U. S. Nat. Mus. catalog No. 73113.)

3, 4, 6, 7. Scalpellum sp. (p. 191). 3, 4, Cardinal plate (3, bottom view; 4, side view); 6, 7 , scutal plate (6, exterior view; 7 , interior view). (U. S. Nat. Mus. catalog No. 73114.)

5. Cervical vertebra of a mosasaurian reptile (p. 191). (U. S. Nat. Mus. catalog No. 9607.)

8. Dorsal vertebra of a mosasaurian reptile (p. 191). (U. S. Nat. Mus. catalog No. 9605.)

9. Vertebra of a selachian (Corax sp.) (p. 192). (U. S. Nat. Mus. catalog No. 9608.)

10. Ischyrhiza mira Leidy, side view of tooth, (p. 192). (U. S. Nat. Mus. catalog No. 9611.) 


\section{PLATE LXIII}

\section{Ripley Fossils from Coon Creek, Tenn.}

1-6, 8-11. Peneus wenasogensis Rathbun, n. sp. (p. 185). 1, Telson, paratype $a$, dorsal view; 2, telson, holotype, dorsal view; 3, telson, paratype $c$, ventral view; $\mathbf{4}$, telson, paratype $b$, ventral view; $\mathbf{5}$, same specimen as that shown in $\boldsymbol{2}$, ventral view; 6, same specimen as that shown in $\mathbf{1}$, ventral view; $\mathbf{8}$, same specimen as that shown in $\mathbf{4}$, dorsal view; 9, same specimen as that shown in 3, dorsal view; 10, same specimen as that shown in $\mathbf{1}$ and $\mathbf{6}, \mathbf{0 l e f t}$ profile; 11, same specimen as that shown in $\mathbf{2}$ and $\mathbf{5}$, left profile.

7, 13-15. Eryma flecta Rathbun, n. sp., propodus of left cheliped, holotype (p. 188). \%, Outer view; 13, ventral view; 14, dorsal view; 15, inner view. (U. S. Nat. Mus. catalog No. 73115.)

12, 16. Podocratus canadensis (Whiteaves), carapace (p..185). 12, Right side; 16, dorsal view. (U. S. Nat. Mus. catalog No. 731.16.) 

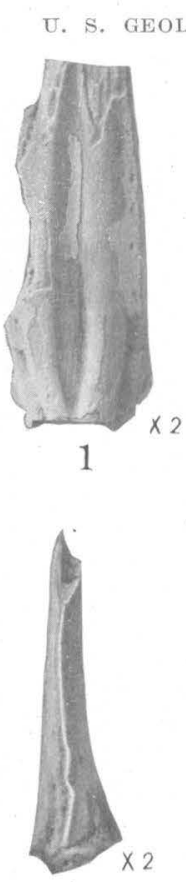

11
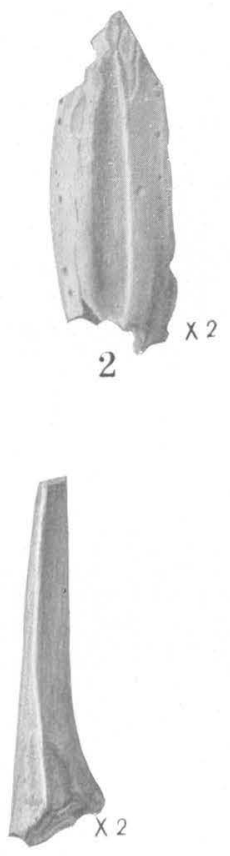

10
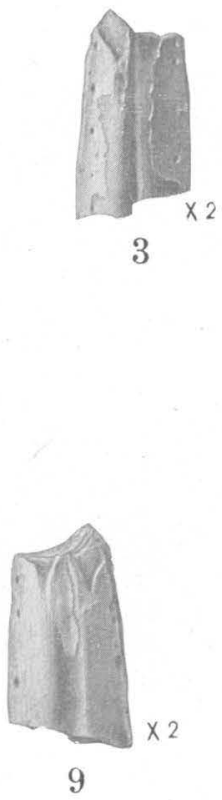

9

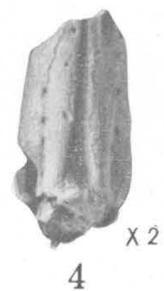

4
PROFESSIONAL PAPER 137
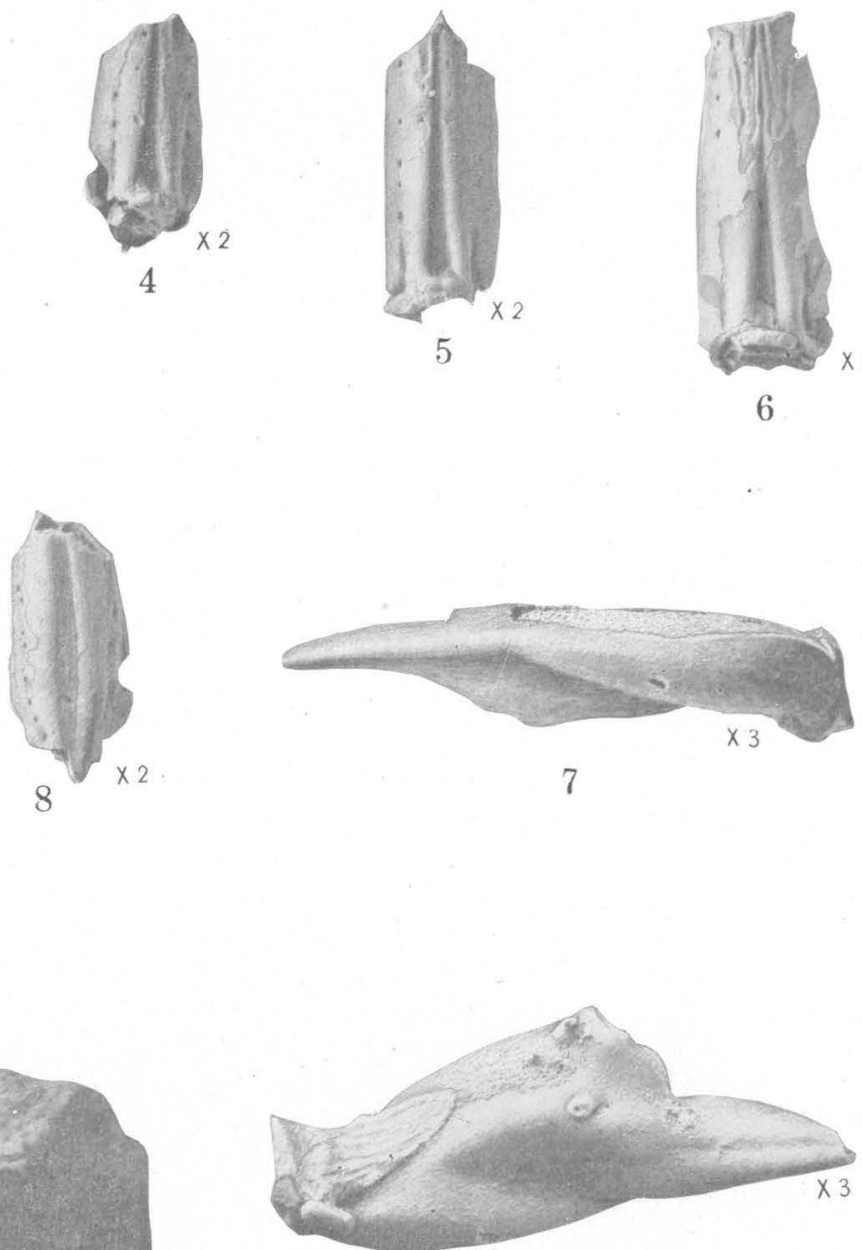

13

12
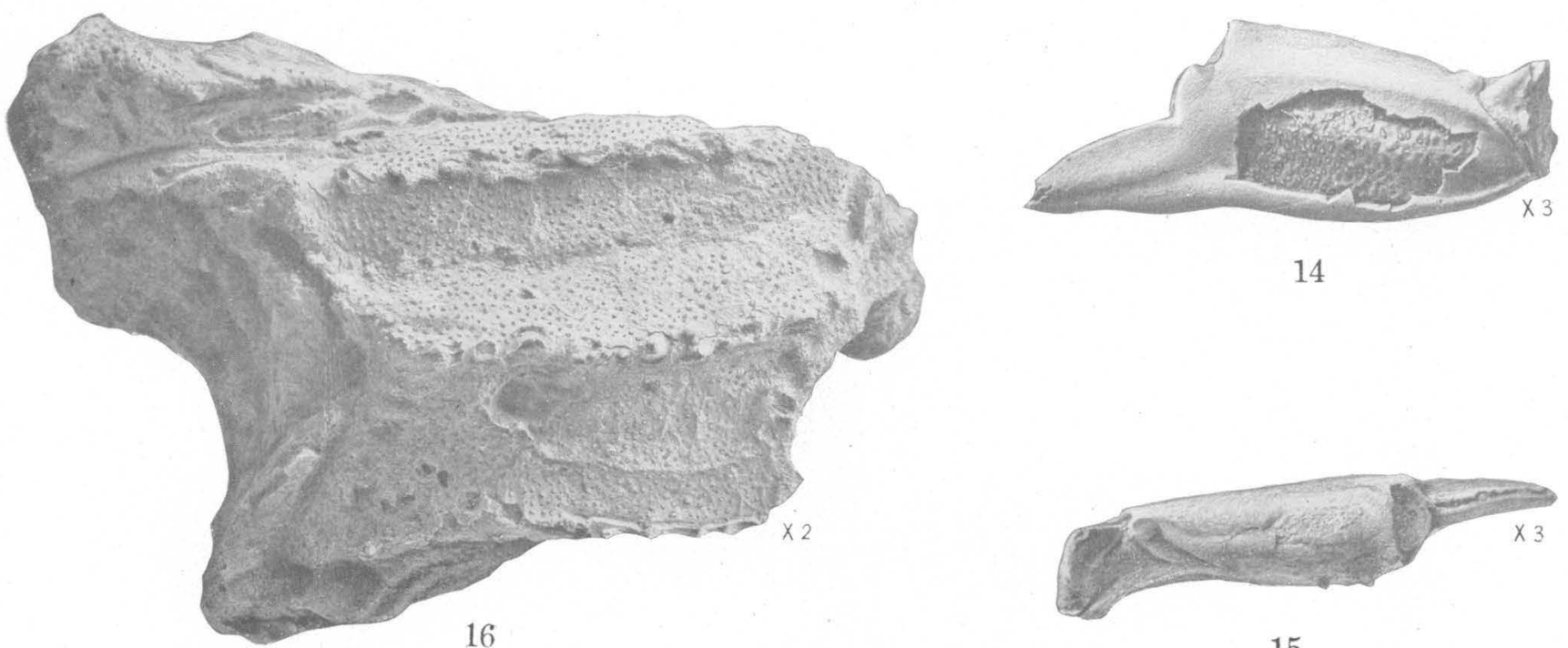

15

RIPLEY FOSSILS FROM COON CREEK, TENN. 
U. S. GEOLOGICAL SURVEY
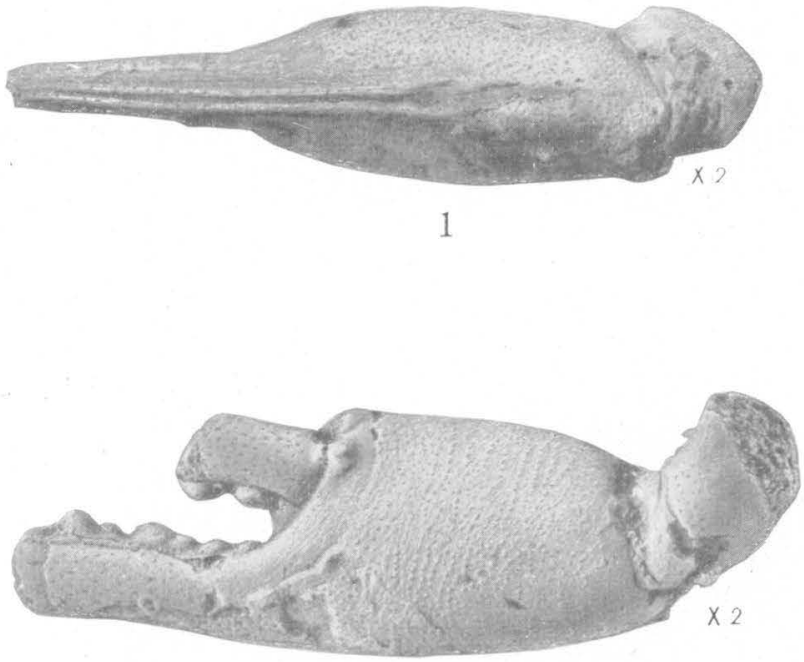

3

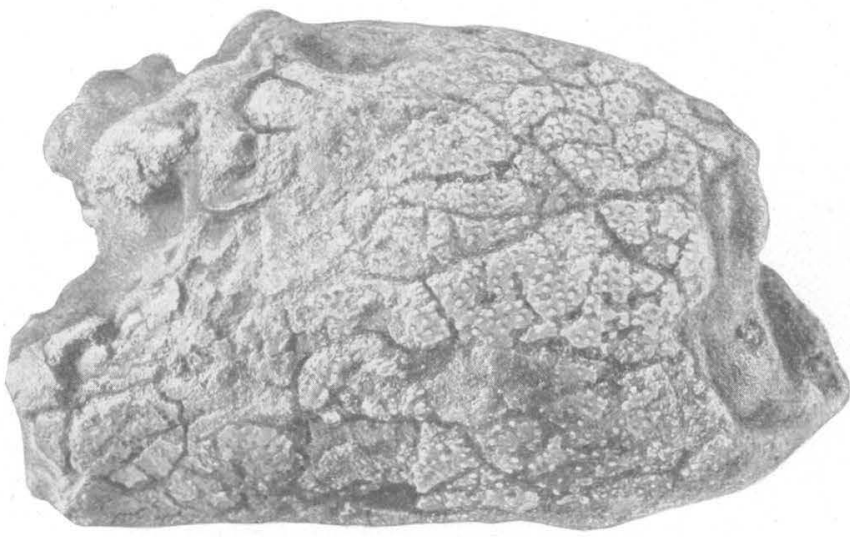

5

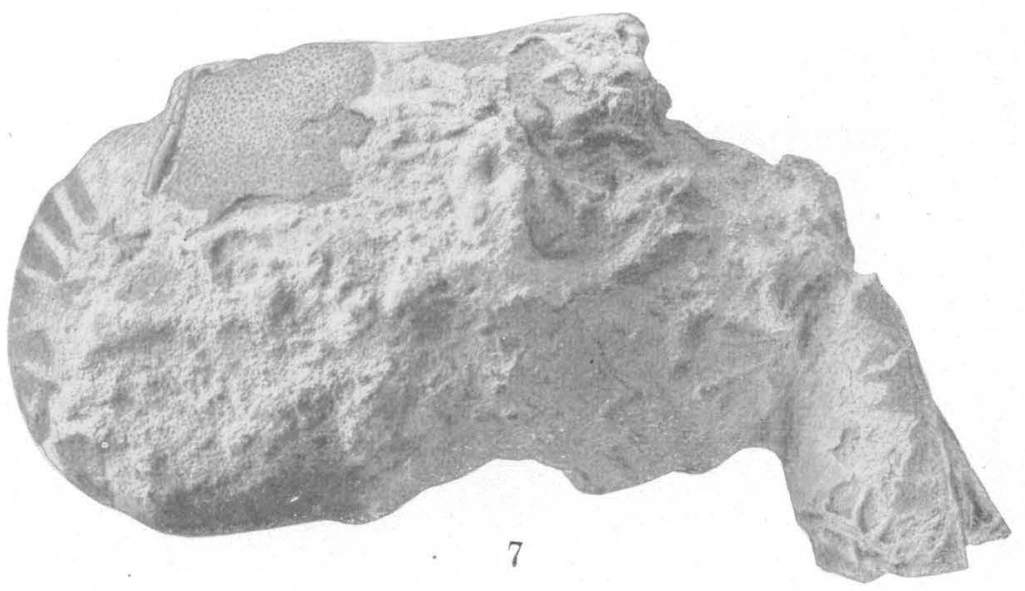

PROFESSIONAL PAPER 137

PLATE LXIV
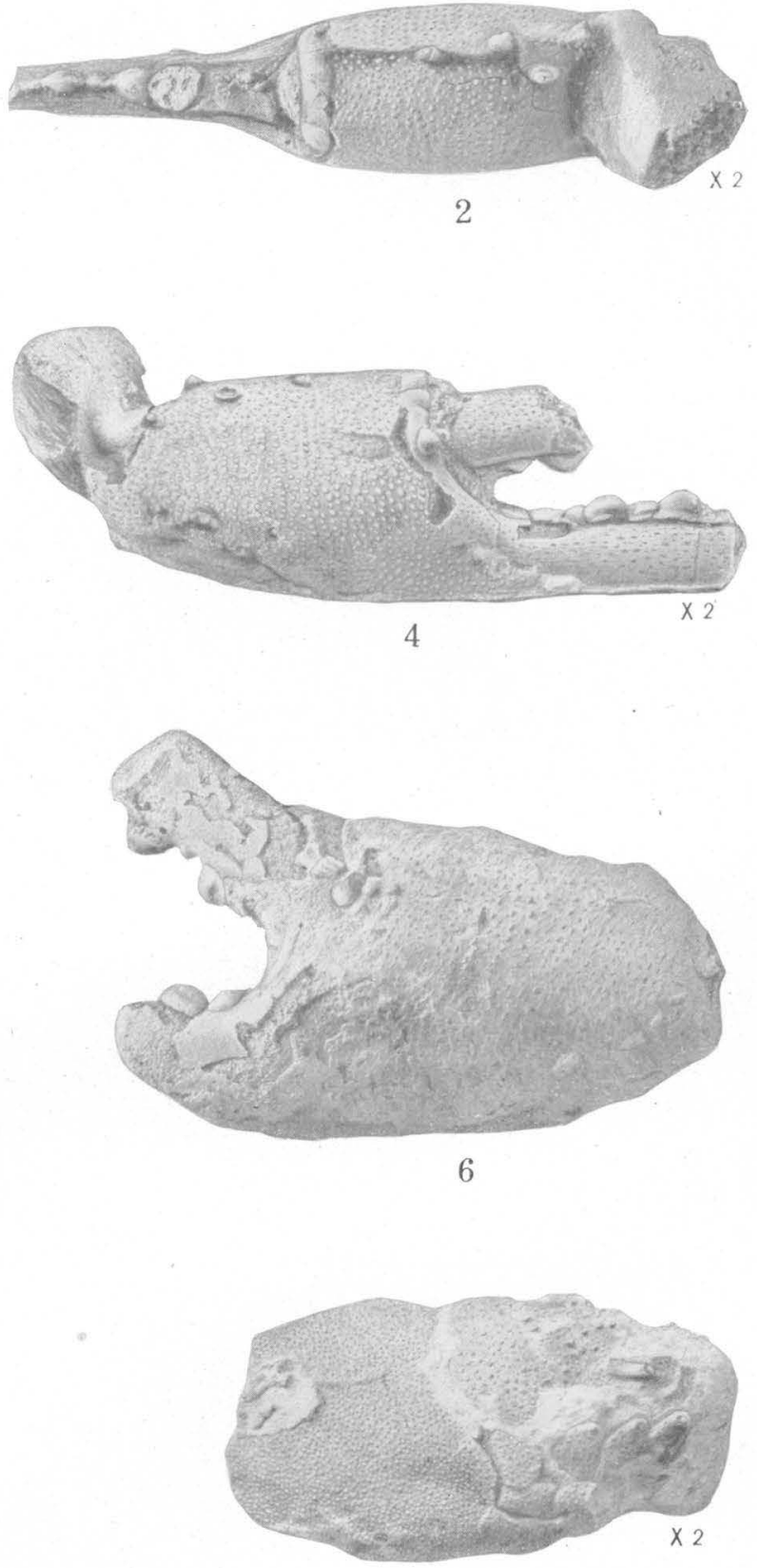

8

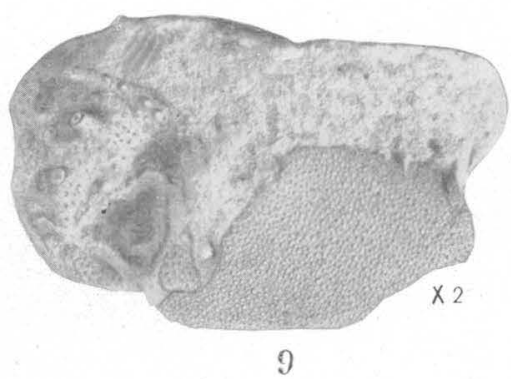

RIPLEY FOSSILS FROM COON CREEK, TENN. 


\section{PLATE LXIV}

\section{Ripley Fossils from Coon Creek, Tenn.}

1-9. Hoploparia tennesseensis Rathbun, n. sp. (p: 186). 1-4, Left chela, holotype (1, outer view; 2, inner view; 3, dorsal view; $\mathbf{4}$, ventral view); $\mathbf{5}$, left chela, paratype $g$, dorsal view; $\mathbf{6}$, left chela, paratype $h$, dorsal view; $\boldsymbol{7}$, right side of animal, paratype $b ; \mathbf{8 , 9}$, carapace, paratype $p$ (8, right side; 9, left side, crushed). (U. S. Nat. Mus. (catalog No. 73117.) 


\section{PLATE LXV \\ Ripley fossils from Coon Creek, Tena.}

1, 3, 6. Hoploparia tennesseensis Rathbun, n. sp. (p. 186). 1, Left chela, paratype $c$, dorsal view; . 3, fingers, paratype $i$, horizontal, view; 6, portion of carapace and abdomen, paratype l, left side: (U. S. Nat. Mus. catalog No. 73117.)

$\mathbf{2 , 4}, \mathbf{5 , ~ 7 , ~ 8 . ~ H o p l o p a r i a ~ m c n a i r y e n s i s ~ R a t h b u n , ~ n . ~ s p . ~ ( p . ~ 1 8 7 ) . ~ 2 , ~ 4 , ~ C a r a p a c e , ~ h o l o t y p e ~ ( 2 , ~ r i g h t ~ s i d e ; ~ 4 , ~ l e f t ~ s i d e ) ; ~ 5 , ~} \boldsymbol{7}, \mathbf{8}$, carapace) paratype (5, right side; $\mathbf{7}$, dorsal view, showing rostrum; 8, left side). (U. S. Nat. Mus. catalog No. 73118.) 

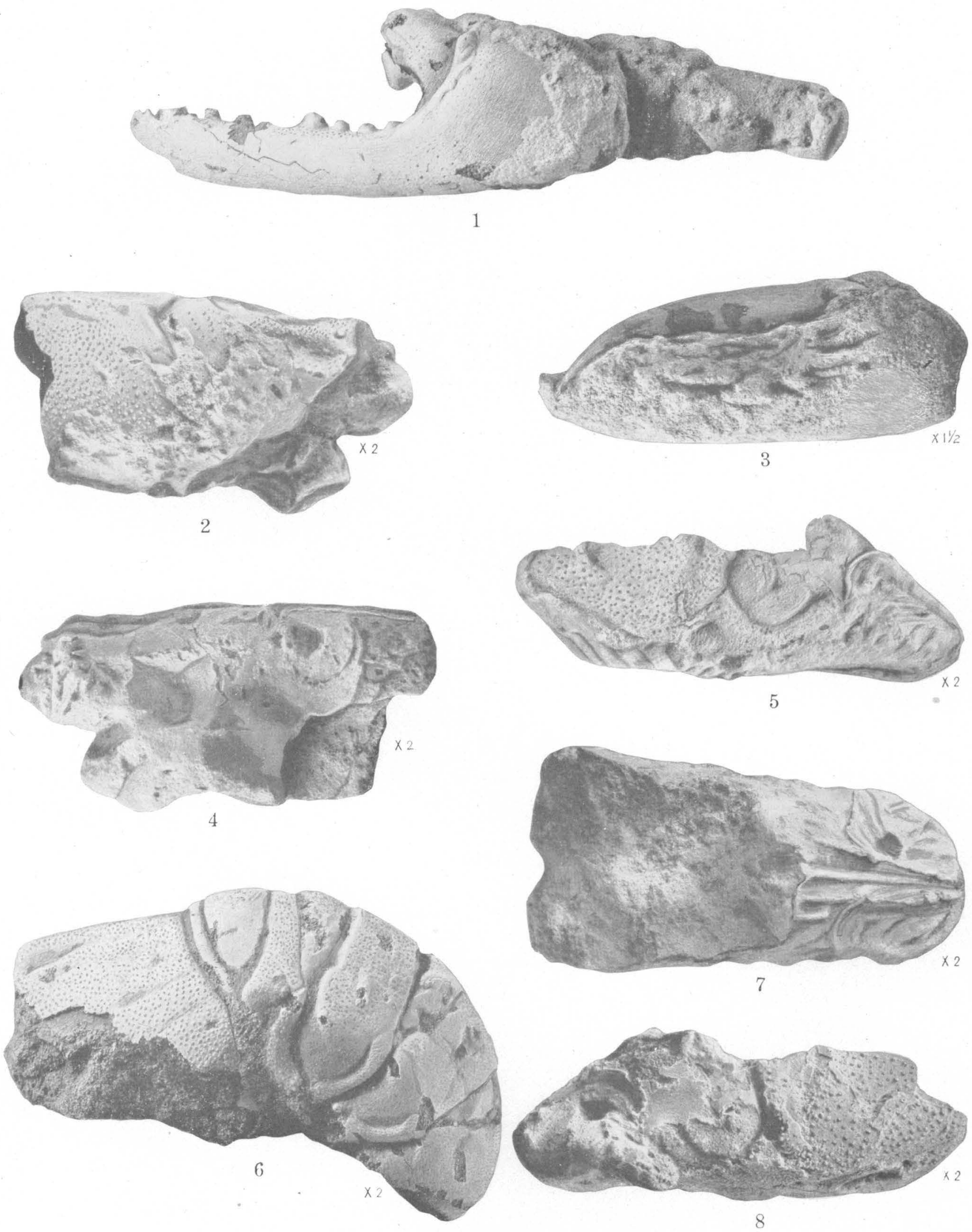

RIPLEY FOSSILS FROM COON CREEK, TENN. 

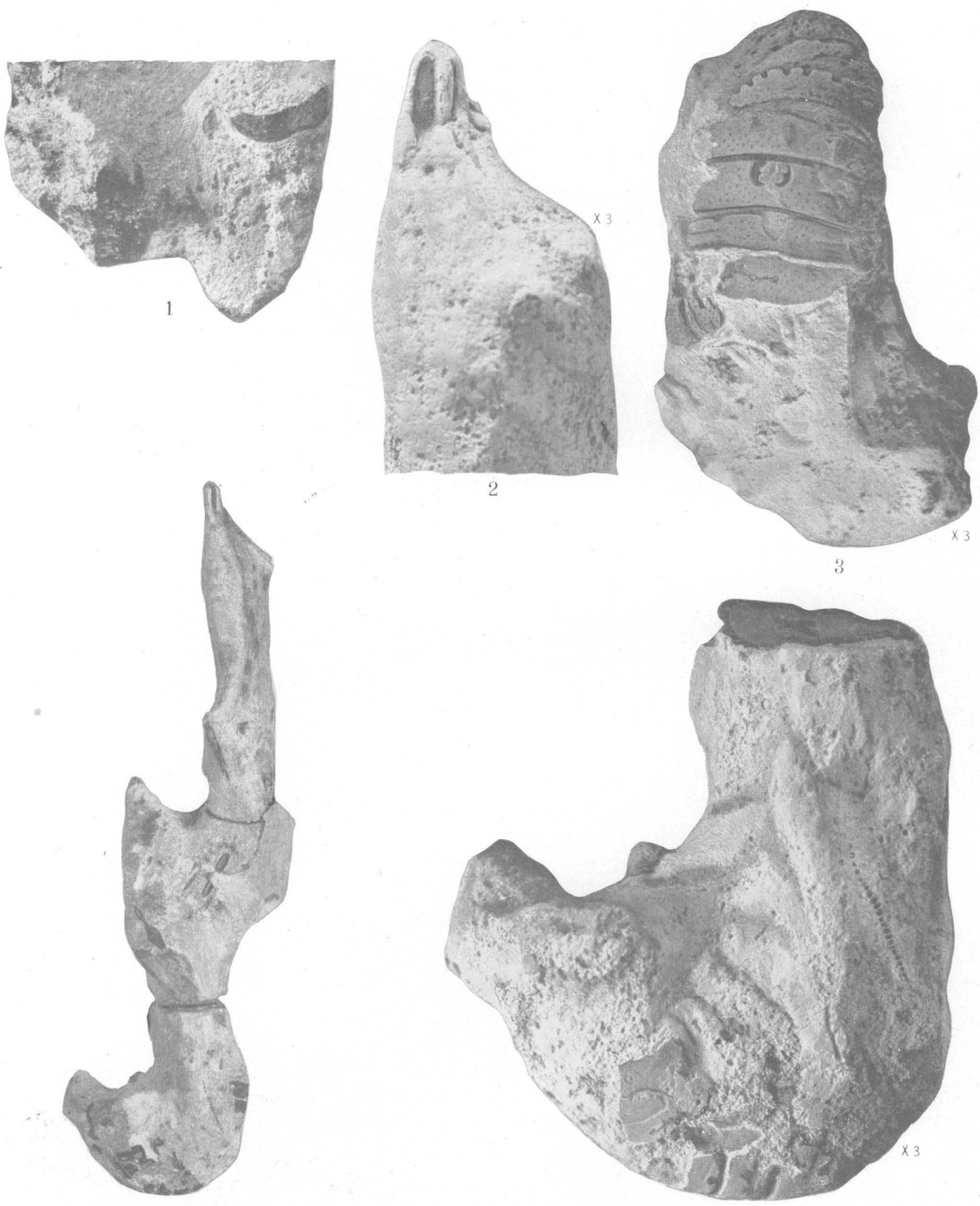

4

5

RIPLEY FOSSILS FROM COON CREEK, TENN. 


\section{PLATE LXVI}

\section{Rtpley fossils from Coon Creek, Tent.}

1-5. Enoploclylia sculpta Rathbun, n. 'sp., holotype (p. 187). 1, Merus of left cheliped (the dark band represents the distal extremity); 2, end of finger, showing grooves and prehensile tubercle; 3, abdomen, dorsal view; 4, whole animal, left profile (the abdomen is curved under, the elongate right pereiopod is extended forward, its left mate is detached and displaced, showing at the side of the thorax); 5 , abdomen, left profile, also fragment of antennal flagellum. (U. S. Nat. Mus. catalog No. 73119.) 


\section{PLATE LXVII}

Ripley fossils from Coon Creek, Tenn.

1, 2, 4-9. Callianassa mortoni Pilsbry (p. 188). 1, 4, 6, Left cheliped (1, upper view; 4, inner view; $;$, outer view); 2, propodus of right chela of female $d$, Vanderbilt University, upper view); $\mathbf{5 ,}, \mathbf{7}, \mathbf{9}$, male specimen showing portions of a pair of chelipeds (5, upper view; $\boldsymbol{7}$, right view; $\mathbf{9}$, left view); $\mathbf{8}$, a second specimen showing portions of a pair of chelipeds. (U. S. Nat. Mus. catalog No. 73120.)

3. Dakoticancer cverana Rathbun (p. 189), male, Vanderbilt University, ventral view, showing sternum and appendages of first segment of abdomen. 

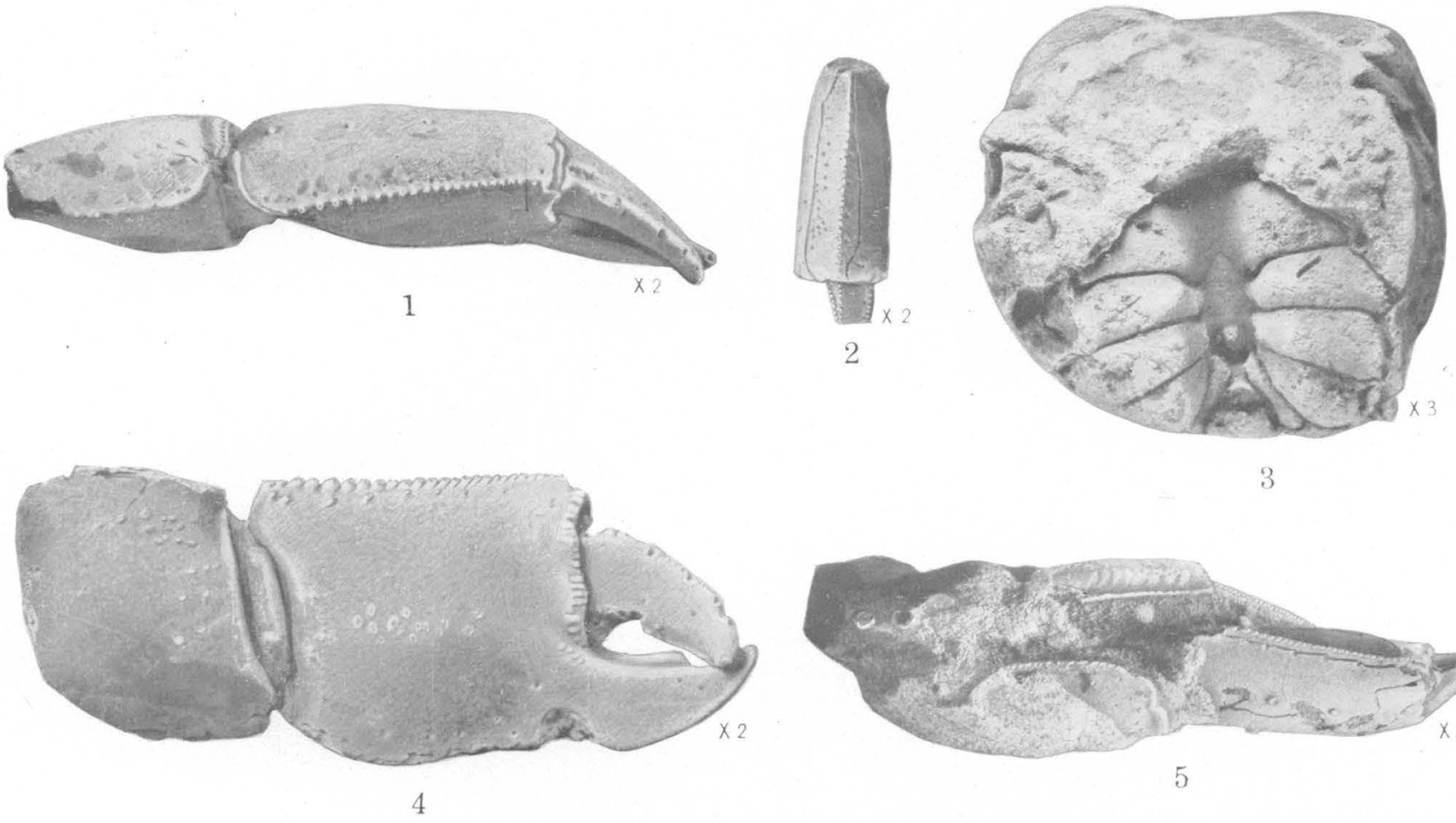

3

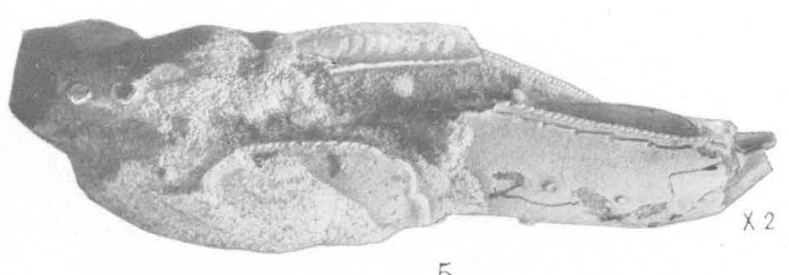

5
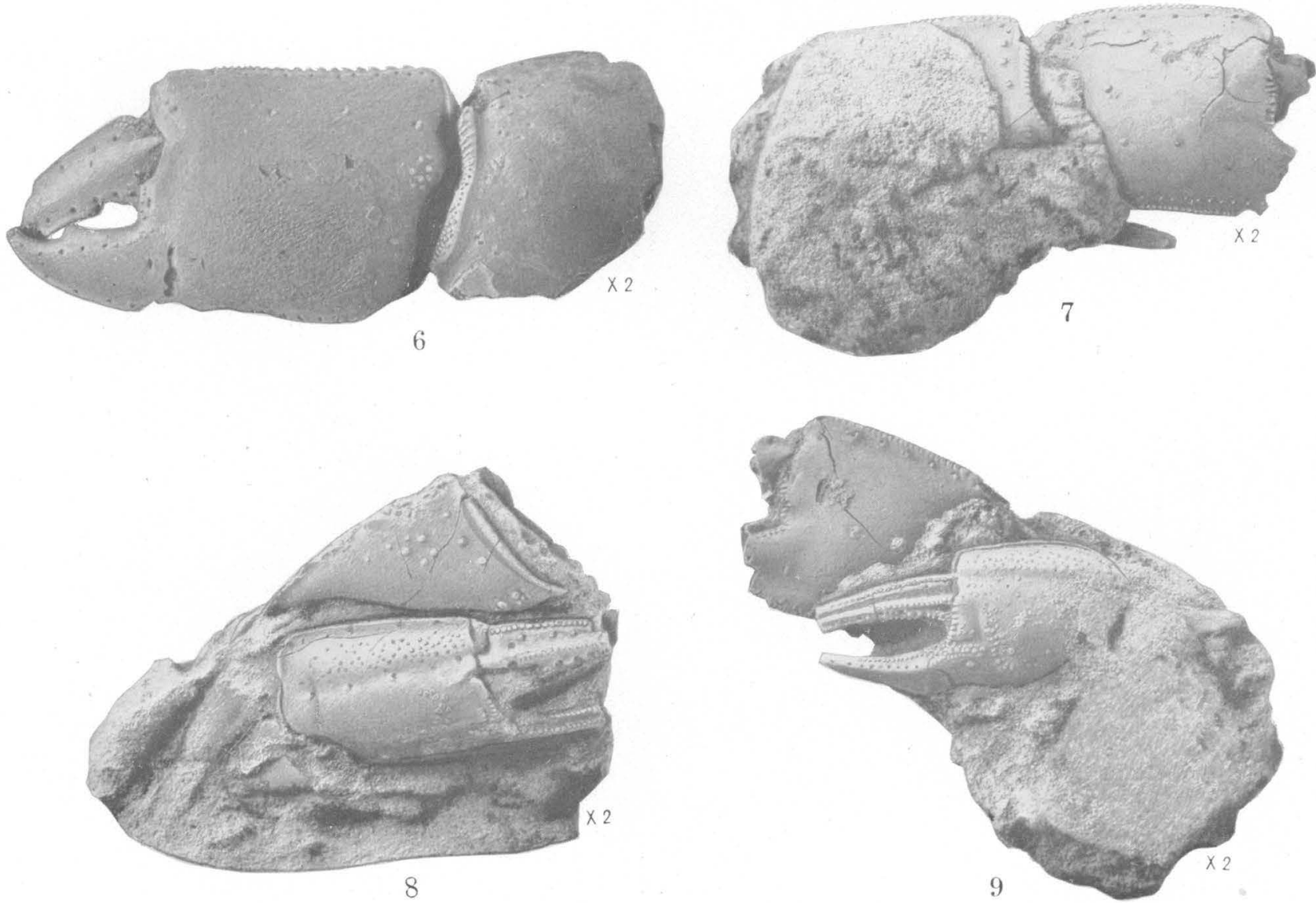

RIPLEY FOSSILS FROM COON CREEK, TENN. 
U. S. GEOLOGICAL SURVEY

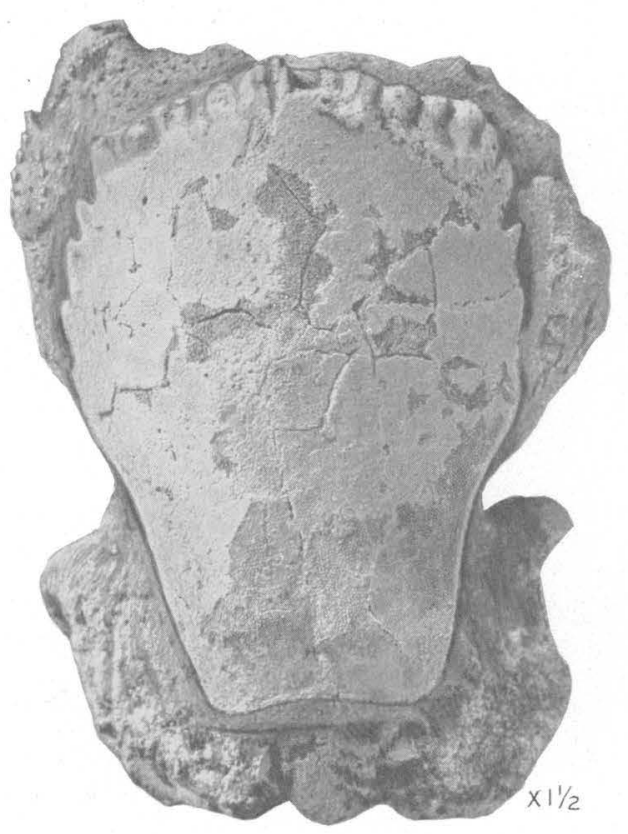

1

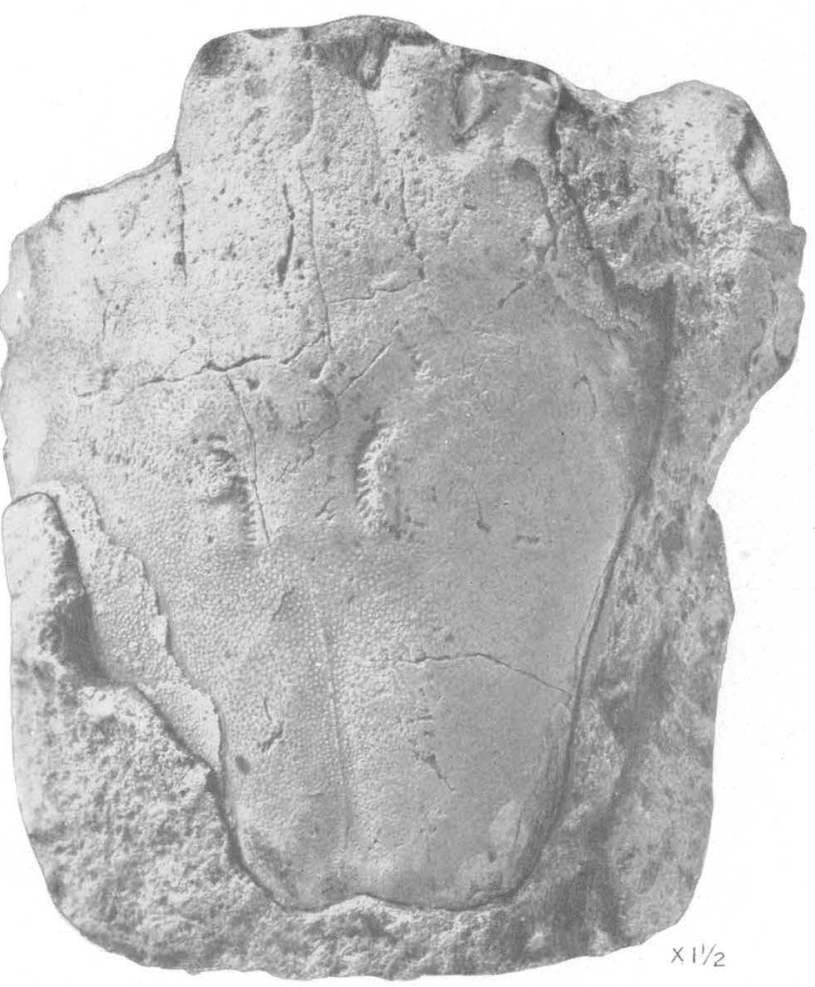

3
PROFESSIONAL PAPER 137 PLATE LXVH
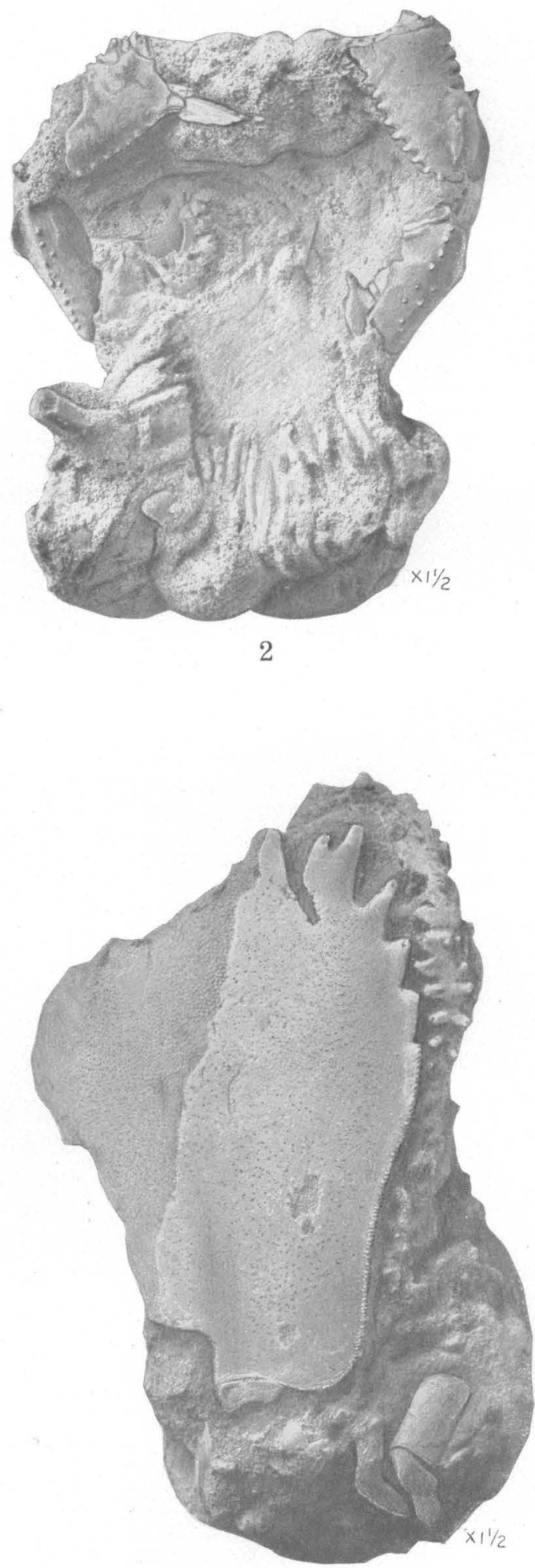

RIPLEY FOSSILS FROM COON CREEK, TENN. 


\section{PLA'TE LXVIII}

\section{Rtpley Fossils from Coon Creen, Tenn.}

1-4. Raninella lestacea Rathbun, n. sp. (p. 190). 1, 2, Holotype (1, dorsal view; 2, ventral view); 3, paratype b, dorsal view; 4, paratype $a$, dorsal view. (U. S. Nat. Mus. catalog No. 73121.) 


\section{PLATE LXIX \\ Ripley. Fossils from Coon Creek, Tenn.}

1-7. Avitelmessus grapsoideus Rathbun (p. 190). 1, Male, Vanderbilt University, showing abdomen and sternum; $2, \mathbf{5}$, male; No. 73122,JU. S. Nat. Mụs., left chela (2, outer face; 5, dorsal view, showing carapace and left cheliped); 3, young male, Vanderbilt University, ventral view, showing right maxilliped; 4, female, Vanderbilt University, ventral view, showing abdomen; 6, male abdomen, detached, Vanderbilt University; 7 , female abdomen, detached, Vanderbilt University. 

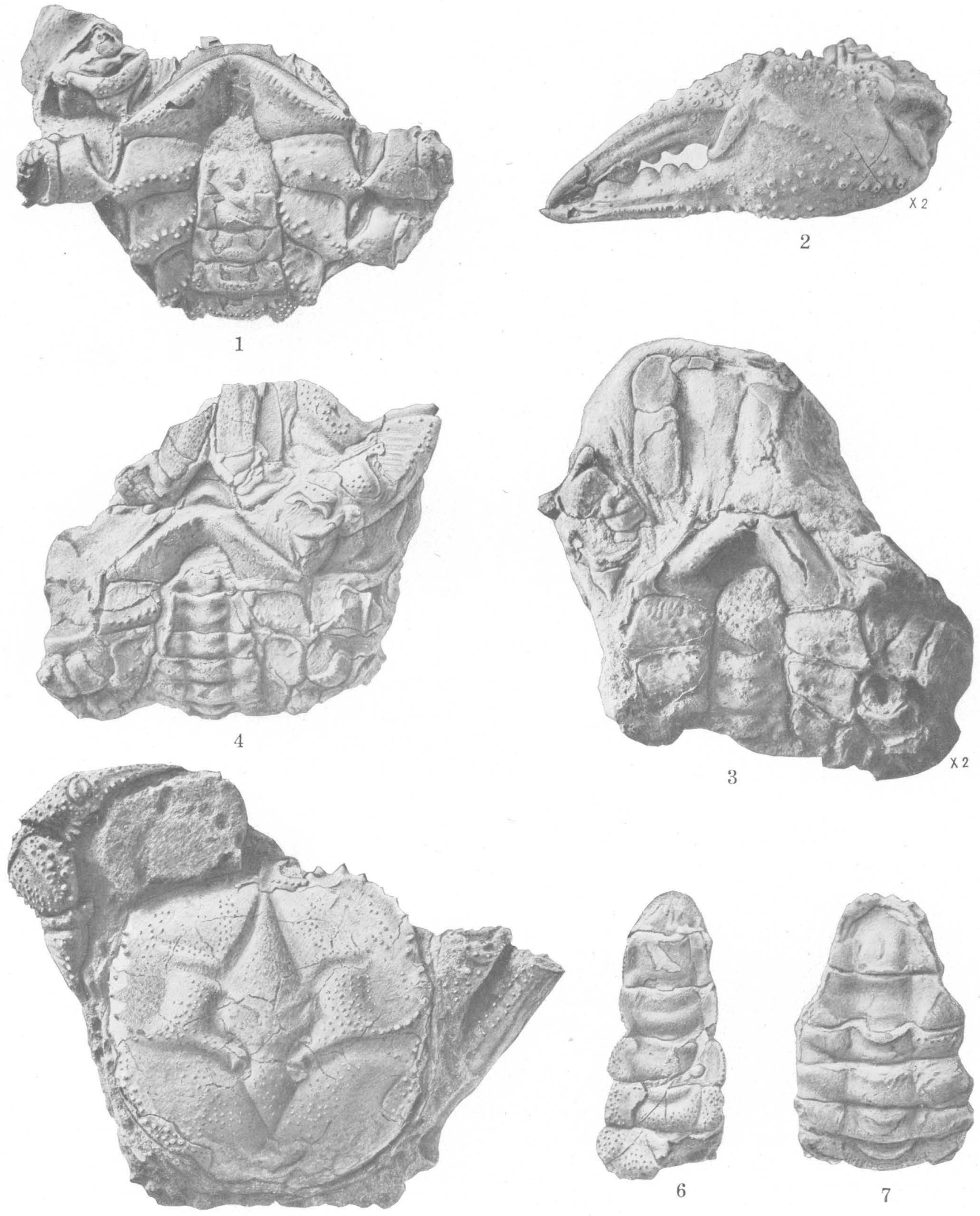

5

RIPLEY FOSSILS FROM COON CREEK, TENN. 

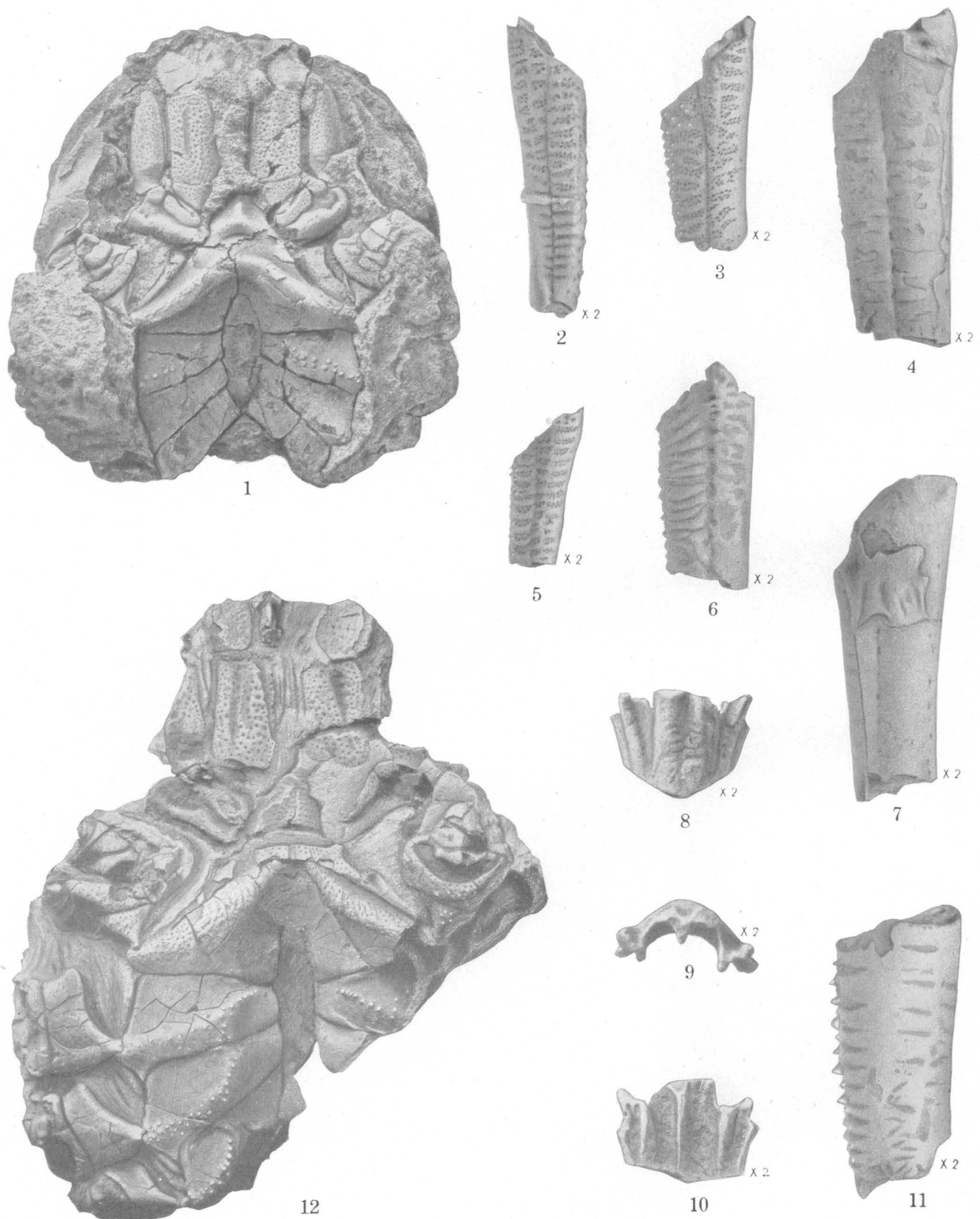

RIPLEY FOSSILS FROM COON CREEK, TENN. 


\section{PLATE LXX}

\section{Ripley Fossils from Coon Creek, Tenr.}

1-1\%. Avitelmessus grapsoideus Rathbun (p. 190). 1, Female, No. 73122, U. S. Nat. Mus., ventral view (without abdomen), showing especially the exognath of the outer maxilliped; $\mathbf{2 , 3 , 4}$, portions of dactyls of ambulatory legs, Vanderbilt University, posterior side; $\mathbf{5}, \mathbf{6}, \boldsymbol{\gamma}$, portions of dactyls of ambulatory legs (5 and $\mathbf{6}$ from. Wade collection, No. 10271, and $\boldsymbol{\gamma}$ from Vanderbilt University), posterior side; 8-10, palate of small specimen, Vanderbilt University (8, dorsal view; 9, anterior view; 10, ventral view, showing palatal ridges); 11, portion of dactyl of ambulatory leg, Vanderbilt University, anterior or concave surface; 12, portion of large male, Vanderbilt University, ventral view, showing maxillipeds and sternum. 


\section{PLATE LXXI}

\section{Ripley fossils from Coon Creek, Tenn.}

1, 2, 5. Tooth of Saurodon sp. (p. 192), side views. (U. S. Nat. Mus. catalog No. 9613.)

3, 4. Otolith (p. 192). 3, Inner surface; 4, outer surface. (U. S. Nat. Mus. catalog No. 9614.)

6, 8. Right coronoid of a mosasaurian reptile (p. 191). 6, inner view; 8, outer view. (U. S. Nat. Mus. catalog No. 9606.)

7. Scale of Enchodus sp. (p. 192). (U. S. Nat. Mus. catalog No. 9609.)

9. 10. Teeth of Enchodus sp. (p. 192). 9, Inner view; 10, outer view. (U. S. Nat. Mus. catalog No. 9612.)

11. Pycnodont tooth of Anomoedus sp. (p. 192). (U. S. Nat. Mus. catalog No. 9610.) 

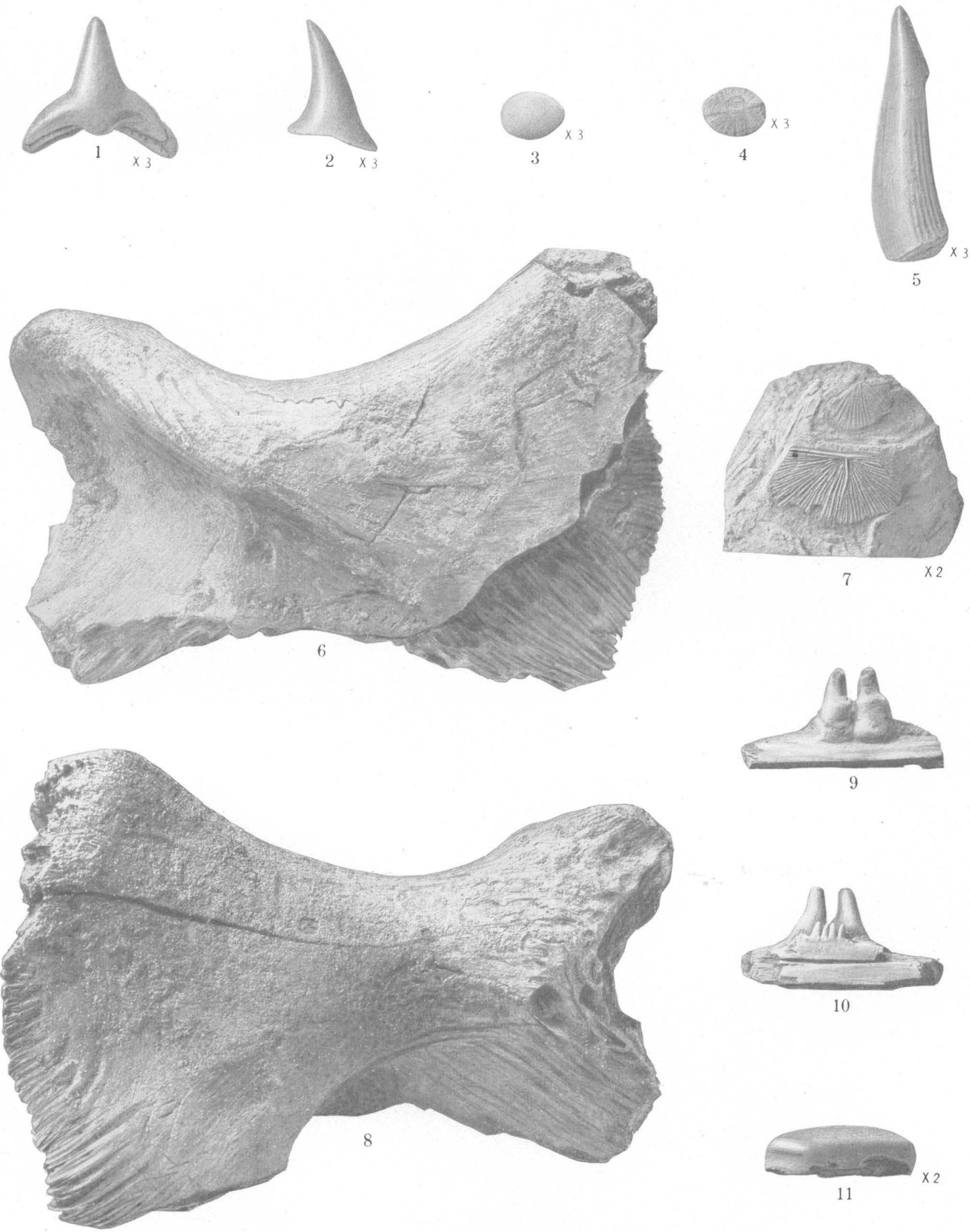

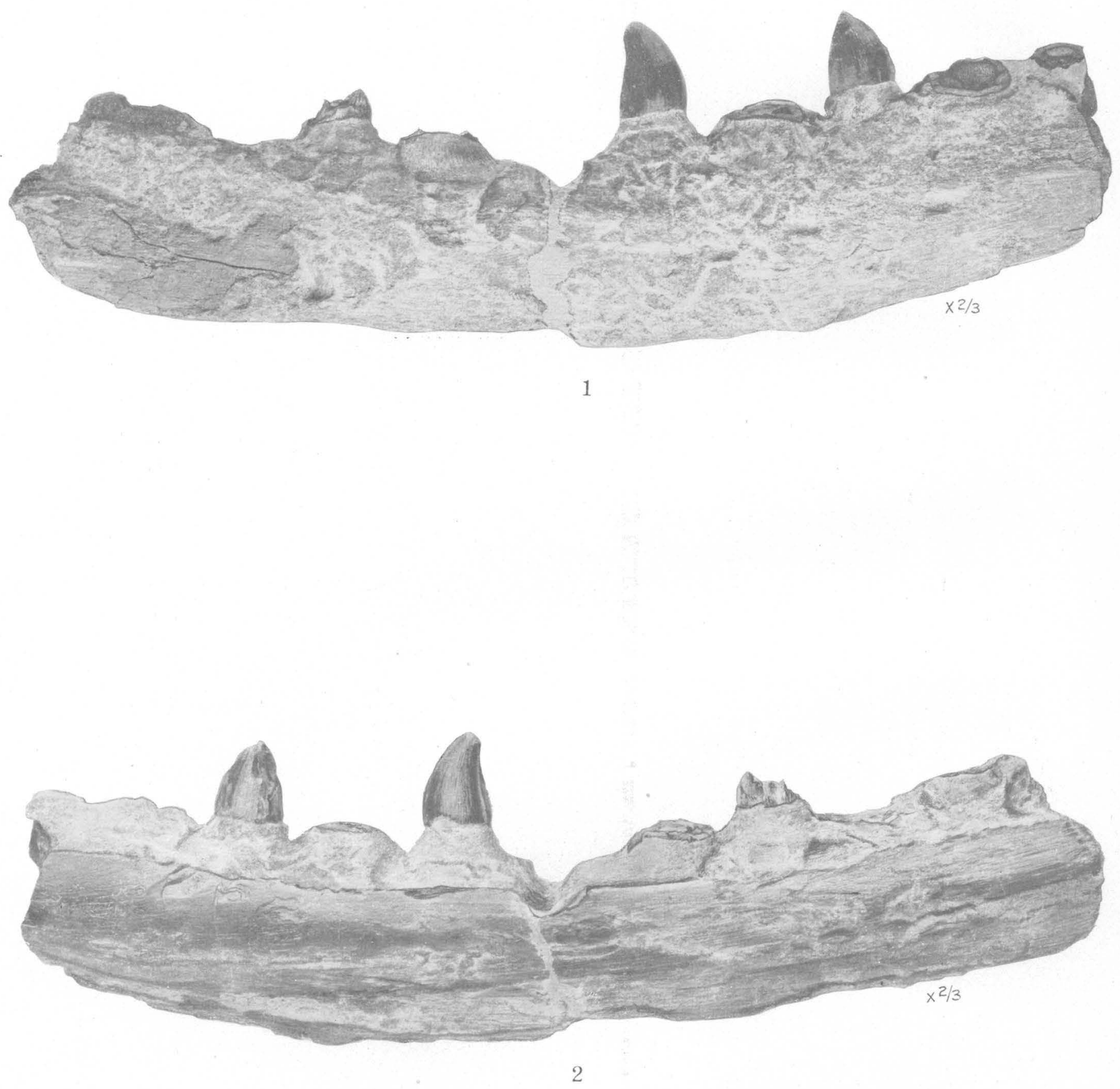

RIPLEY FOSSILS FROM COON CREEK, TENN. 


\section{PLATE LXXII}

Ripley fossils from Coon Creek, Tenn.

1, 2. Right dentary of a mosasaurian reptile, No. 10540, U. S. Nat. Mus., about two-thirds natural size (p. 191). 1, Outer view; 2, inner view.

$106913-26 \dagger-23$ 



\section{INDEX}

Acirsn corrugata Wrde
microstriata Wade cirsa? crit hiformis Meek and Hayden"

Acknow ledgments for aid

Act reonella voluta Zekeli

Acteon conicus Wade, n. sp cretacen Gabb. Wade, n. sp............................ 102, 103, Pl. XXXIII linteus (Conrad) modicellus Conrad mulleri Bosquet substriatus Wade, n. sp...........

Acteonina lineolata Reuss. obesa Stoliczka oriontalis Wade n. sp............. 104, Pl. XXXIV parva Wade n. sp.

105, PI. XXXIV

Actinocamax quadratus Blainville.............. 162

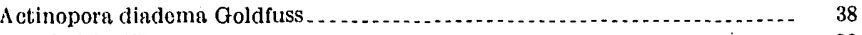
disticha flagenow . . ..................................................... 38 radiobifurcata Canu and Bassler, n. sp ........................ 38, PI. VII robertsoniana Canu

Acnona enfalensis Conrad.

A laria papilionacea Goldfuss. . . . . . tegulata Stoliczka.

Alderina abortiva Canu . .

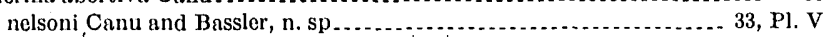
watersiana Canu

A mauropsis cornea Müller

lirata Wade, n. sp.

33
0
165

(165, Pl. LVII paludinaeformis Meck and Hayden......... 165 pannucea Stoliczka............................................... 165

Amber insect, occurrence of.

Ammatophora cretacea Canu and Bassler, $n$. sp $\ldots \ldots \ldots . . . . . .35$, Pl. IV

A mphiblestrum denticulatum Canu and Bassler, n. sp .................... 34, Pl. V

Ampullina bulbiformis (Sowerby) Stoliczka

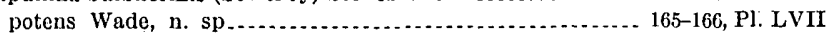

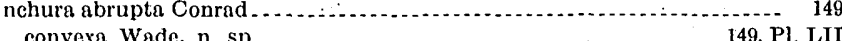

haydeni White

infortunata White

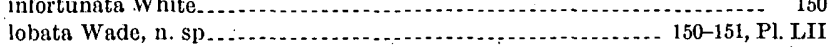

prolabiata White

solitaria Whitfleld

substriata Wade, n. sp

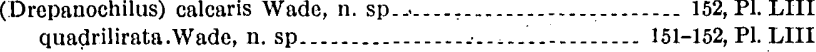

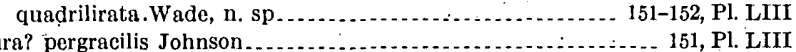
Anchura? pergracilis Johnson $\ldots$

Anisomyon patelliformis Meek and Hayden.............................. 180

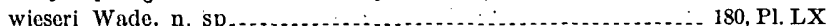
A nomia argentaria Morton................................. 68-69, 70, P1. XXII ephippium.

$68-69,70$, P1. XXII linensis Whiteaves . . ornata Gabb ................... papyracea D'Orbigny

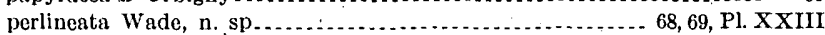

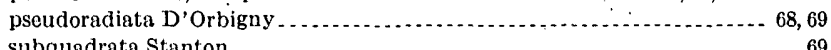
subquadrata Stanton. tellinoides Morton ........................................ nomalofusus Wade
substriatus Wade $\ldots \ldots \ldots \ldots$

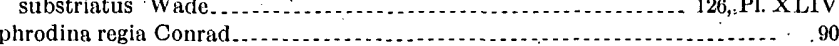

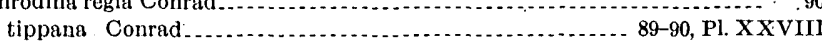

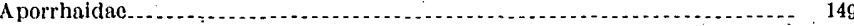

A porrhais castorensis Whitfleld $\ldots$

ruida White securifern Forbes . .

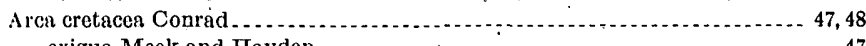
exigua Meek and Hayden . ............................................ 47 menairyensis Wade, n. sp . . . . . . . . . . . . . . . . . . . . . . . . . 46

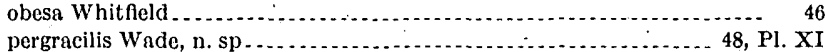
pergracilis Wade, $\mathrm{n} . \mathrm{sp} \ldots \ldots \ldots$
saffordi-Gabb $\ldots \ldots$ securiculata Wade, n. sp........................................... 46
Astandes Wade

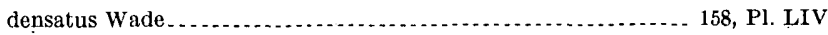

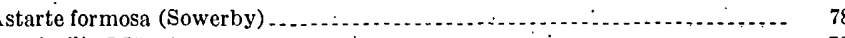
similis Münster

Avitelmessus grapsoideus Rathbun.......... 190-191, Pls. LXIX, LXX

$\vdots \quad B$

Baculites anceps Lamarck.

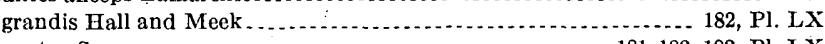
ovatus Say ........................................ 181-182, 182, Pl. LX Barbatia cochlearis Wade, n. sp . . fractura Wade, $n$. sp . . . . . . . . . mackayi Woods

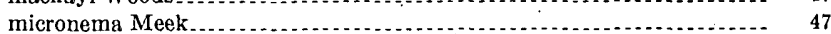
micronema Meek
saffordi (Gabb) $\ldots \ldots \ldots \ldots$ Bassler, R. S., with Canu; Ferdinand, Bryozoa.......................... 32-39

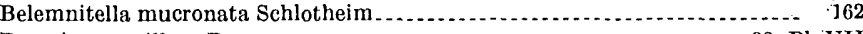

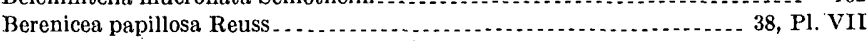

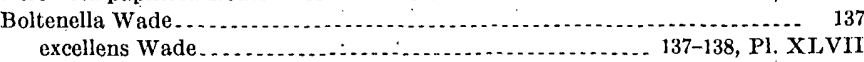
Brachiopoda, representation of, at Coon Creek ........................ 13

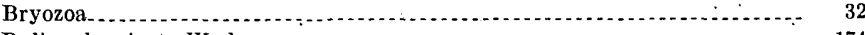

Bulima laevigata Wade

Busycon stellatum Dall . .......... (Protobusycon) cretaceum Wade...... 136-137, Pl. XLVII C

Cadulus obnutus (Conrad)

101, P1. XXXI1I Callianassa mortoni Pilsbry .................................. 188-189, Pl. LXVII Calliomphalus americanus Wade, n. sp........................ 178-179, Pl. LX

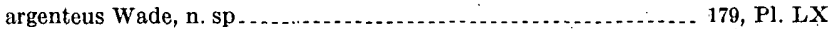

Callopora anatina, Canu and Bassler, $n$, sp..................... 33-34, Pl. IV

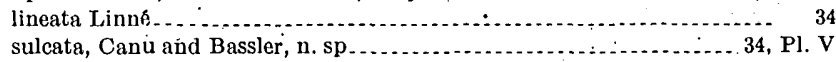

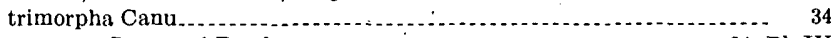
torquata Canu and Bassler, n. sp............................... 34, Pl. IV

Cancellaria acuta Wade, n. sp............................. 108-109, P1. XXXV. cingulata Kaunhowen .............................................. 109

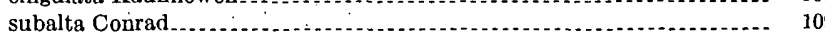

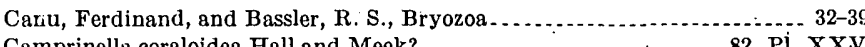

Camprinella coraloidea Hall and Meek?................. 82, PI. XXV

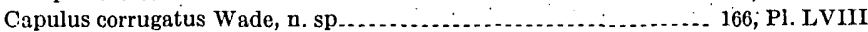

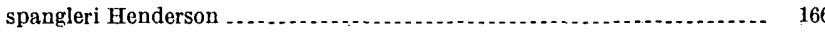

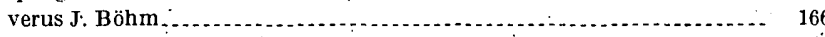

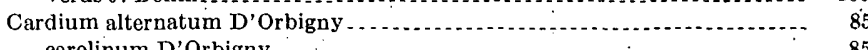
carolinum D'Orbigny . . . . dumosum Conrad ............................... 83-84, 85, 86, Pl, XXV eufalense kümmeli Weller.......... X Xvi moutonianum D'Orbigny . . .

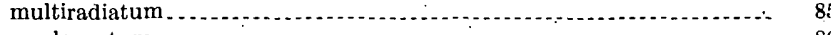
perelongatum . ...................... 86 proboscidium Sowerby . productum Sowerby pustulosum, Münster spillmani.

$86-87$, Pls. XXVI, XXVII tenuistriatum (Whitfeld) . tippana tippana $\ldots \ldots \ldots$
Cellepora velamen Goldfuss $\ldots \ldots \ldots$ (Dermatopora) monilifera Hagenow

Cephalopoda, representation of, at Coon Creek........................ 20

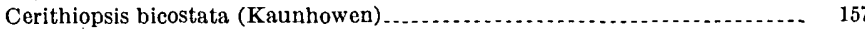
meeki Wade, n. sp............................................ 156-157, PI. LIV moreauensis Meek and Hayden. quadrilirata Wade, $\mathrm{n}$. sp

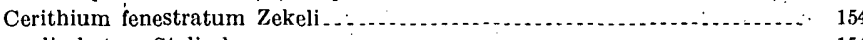

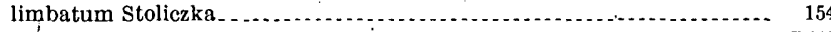
nodoliratum Wade, n. sp ..................................... 154, 155, PIV percostatum Wade, n. sp........ 153-154, Pls. LIII, LV

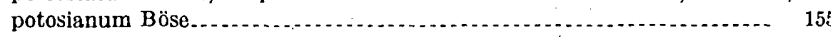

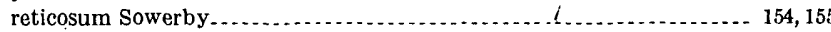
semirugatum Wade, n. sp........................... 154-155, Pls. LIV, IV

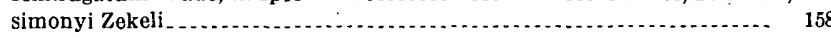
triptychum Kaunhowen . weeksi Wade, n.sp.... LIV (Fibula?) detectum Stoliczka...................................... 136 
Chemnitzia cerithiformis Meek and Hayden interrupta Conrad

Chenopus analogus Deshayes.

Cinulia paraguensis Wade, n. $\mathrm{sp}$ Oligoptycha) concinna Hall and Meek

Clark, W. B., cited

Clavagello armata Morton.

Clementia ovalis (Sowerby)

Coffee sand member, nature and occurrence of . . .

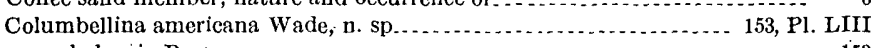
subaloysia Peron .................................................. 153

Conopeum ovatum Canu and Bassler, n. sp......................... 32, Pl. IV

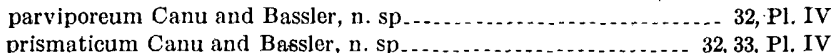

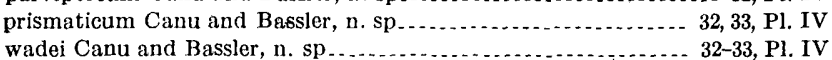

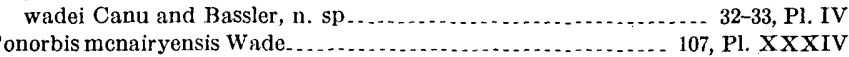
restitutus.

Conrad, T. A., cited........... $10,39,41,51,52,53,62$, $73,75,78,80,82,83,89,92,93,95,98,101,107,111,117,119,143,148,162,164$

Conus dormitor Sowerby

Cook Creek fauna, biologic relations of .

Coon Creek tongue, nature and occurrence of ...................... 7-8, 9-10

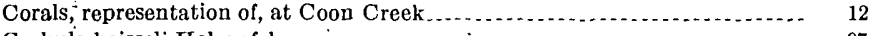

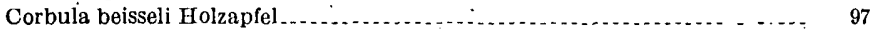

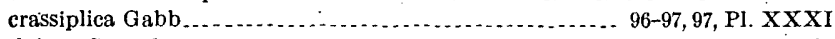
elegans Sowerby $\ldots \ldots \ldots$
monmouthensis Gardner $\ldots \ldots \ldots$

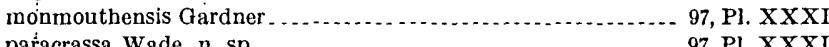
paracrassa Wade, n. sp.........................................

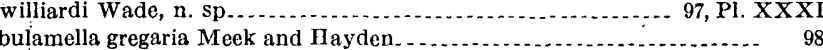

Corbulamella gregaria Meek and Hayden $\ldots \ldots \ldots$
striatula Goldfuss. $\ldots \ldots \ldots \ldots$ striatula Goldfuss.
suffalciata Wade, n. sp............. 98

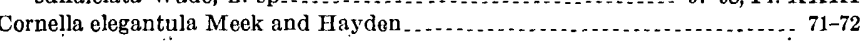

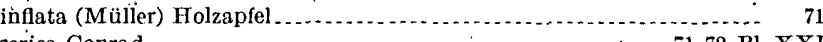
serica Conrad......................................... 71, 72, Pl. XX

Crania gracilis Münster................................................ 39

Crania? americana Wade, n. sp. .................................. 39, Pl. III

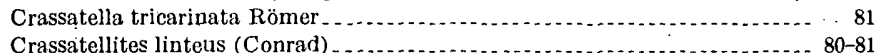

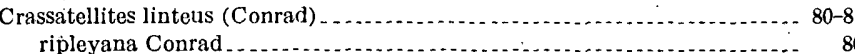

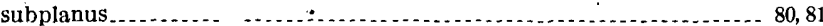

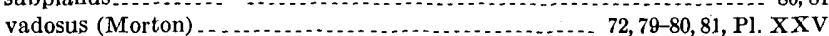

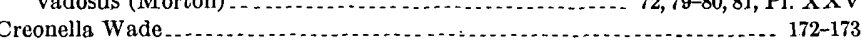
reonella Wade
secunda Wade, $\mathrm{n} . \mathrm{sp} . \ldots \ldots \ldots \ldots$ triplicata Wade. ............................................ 173, Pl. LVII

Cretaceous, Upper, deposits of Tennessee, area of outcrop of Upper, deposits of Tennessee, earlier studies on ..................

Cribrilina crepidula Marsson ....................................... 37

Cryptorhytis flexicostata Meek and Hayden ................................ 132 nobilis Wade, n. sp ............. 131-132, PI. XLVI torta Wade, n. sp ........................................ 132, Pl. XLV

Cucullaea antrosa.

capax Conrad.

glabra Parkinson littlei (Gabb)

muelleri Holzapfel.

shumardi Meek and Hayden

subglabra (D'Orbigny)

vulgaris Morton. (1)

Cylichna griesbachi Etheridge recta (Gabb)

Cylichna? volvaria Meek and Hayden

Cyclina magna Wade, $n$. sp parva Gardner

Cymbophora gracilis (Meek and Hayden)

Cyprimeria alta Conrad major Gardner

(Cyclorisma) faba Sowerby

Cyprina incerta Wade, n. sp.

Cytherea tumida Müller :

n. $\mathrm{sp}$

)....
(n)

D.

D

Dakoticancer overana Rathbun.

Dall, W. H., cited.

Dall, W.

Decapoda.....................

'deformis D'Orbigny...

gracile Meek and Hayden

$\therefore$ inornatum Wade, $\mathrm{n}$ sp

intercalatumi Wade, n. sp.

pauperculum Meek and Hayden....................

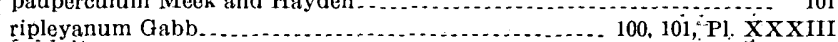

Discohelix leana Gabb.

simplex Holzapfel.

verilli Aldrich.

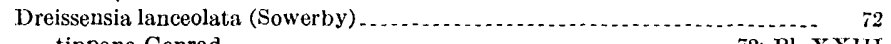
tippana Conrad. ...........................

Drilluta Wade communis Wade.................... 116-117, Pl. XXVIII dimumorum Wade, n. sp................................. 118, Pl. XXXIX

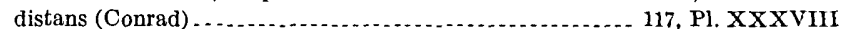
major Wade

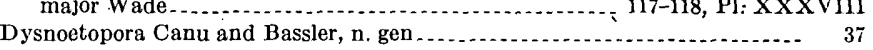
celleporoides Canu and Bassler, n. sp .................. 37-38, Pls. VI, vil E

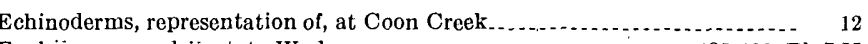

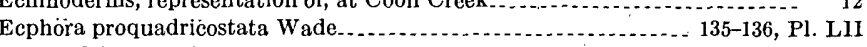

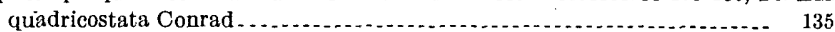

Elliptonodon compressus Emmons ................................... 192

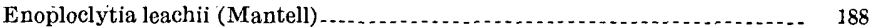
minor Woodward. . . . sculpta Rathbun, n. sp . . . . . .

Entalis gardneri Holzapfel................. 101

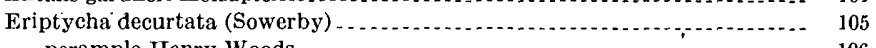
perampla Henry Woods

Eriptycha? americana Wade, n. sp ...... 105, Pl. XXXiv

Eryma flecta Rathbun, n. sp .................................. 188, PI. LXIII

Etea carolinensis Conrad .............. 81-82, PI. XXV

Eucycloscala tuberculata (Wade)

Eulima aquensis Holzapfel. . . . . clara Wade, n. sp . . . . . . . . . . 174-175, Pl. LVIII impressa Wade, n. sp...................................... 174, Pl. LVIII

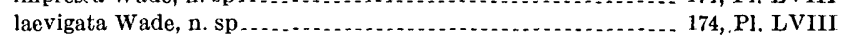
persimplica Wade, n. sp .............. 174, PI. LVIII requieniana D'Orbigny

Euspira spissata Stoliczka ............................................. 163

Eutaw formation, nature and occurrence of . . . .

Eutaw formation, nature and occurrence of
Eutrephoceras dekayi (Morton) $\ldots \ldots \ldots \ldots \ldots$

Exilia cretacea Gardner ripleyana Wade, n. sp

Exogyra cancellata Stephenson ........................ 58, PI. XVI

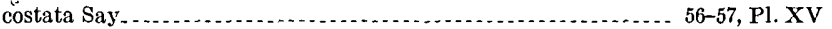
ponderosa Roemer

F

Falsifusus convexus Wade, n. $\mathrm{sp} \ldots$ mesozoicus Wade - 128-129, Pl. XLV Fasciolaria (Piestochilus) culbertsoni Meek and Hayden.................. 131

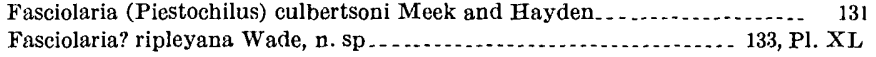
(Mesorhytis) gracilenta Meek....................................... 133

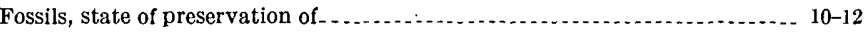

Foveolaria Busk -.................................... 35

Frurionella Canu and Bassler, n. gen........................................... 35 grandipora Canu and Bassler, n. sp......... VI parvipora Canu and Bassler, n. sp......... Fulgur carica (Gmelin) .................................................... 137 Fusus bicinctus Kaunhowen ...................................... 129 binkhorsti Kaunhowen ...................................... 144 koeneni Müller.................................................... 144 (Hemifusus) nereidiformis (Brinkhorst) Kaunhowen

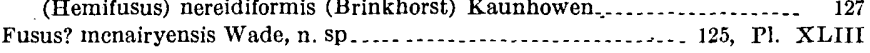
G

Gabb, W. M., cited ...................... 31, 42, 45, 47, 54, 60, 61, 70, 74, 87, 96, 101 Gardner, J. A., cited . .............................................. $39-40$, $40,41,42,43,44,47,53,54,57,59-60,61,62,63,64-65,66,68,70,71,72$, $73,76,77,80,83,87-88,89-90,90,92,93,95,96,97,101,106,107-108$, $112,133,142,158-159,160,161,163$

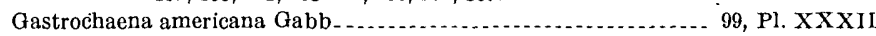
whitfieldi Weller.

Gastropoda, representation of, at Coon Creek $\ldots \ldots$

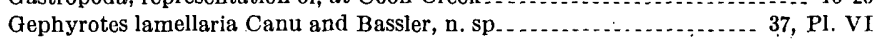

Gervilliopsis ensiformis (Conrad) ................................ 51, PI. XIII

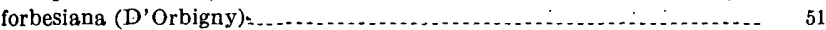
solenoides (Defrance) $\ldots$

Golenoides (Defrance)

Gilmore, C. W., Mosasauridae $2 . .2 \ldots$

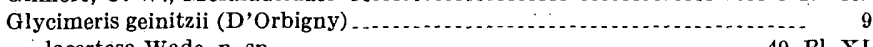
lacertosa Wade, n. sp..................................... 49, Pl. XI

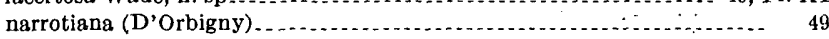
microsulci Wade, n. sp. ......... XI

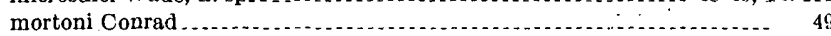
subcrenata Wade, n. sp........ XI subconcentrica (Lamarck) . .......................................... 49

Goniaster mammillata Gabb......................................... 28

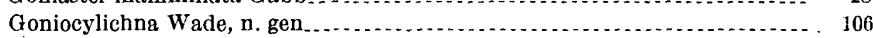
bisculpturata Wade, n. sp................................. 106, Pl. XXIV

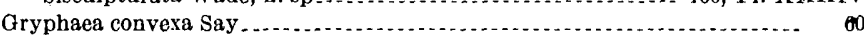
dissimilaris Weller mutabilis Morton,$\ldots \ldots \ldots$ 
Gyrodes alveatn Conrad.

164, Pl. LVII crenata Conrad.

major Wade, n. sp.
pansus Stoliczka.

164, Pl. LVII 164-165, Pl. LVII

H

Habitat of the fauma, character of $20-21$

Hall, James, and Meek, F. B., cited............. 182

Hramulus Morton. angulatus Wade.......... jonahensis (Craigin)

major $\mathrm{Q}_{\mathrm{Bb}} \mathrm{b}$..

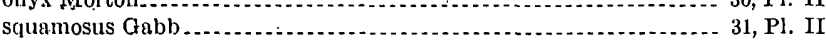

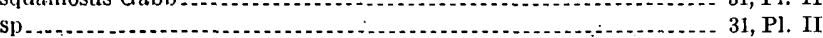

Haplovoluta Wade. bicarinata Wade

Hayden, $\mathrm{E}, \mathrm{V}$, with Meck, $\mathrm{B}, \mathrm{B}$, citod

Holicoceras D'Orbigny ..................................... 184

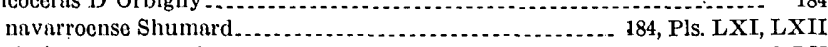
Homincirsa cretacen Wade............................................... 170 perlaqueata (Conrad) Cossmann . ...................................... 170

Heminster comanchei Clark.

dalli.

incrassatus.

lacunosus Slocum . .

parastatus....

stella (MTorton).

ungula (Morton)

wetherbyi

sp.

29

$28, \mathrm{Pl}, \mathrm{I}$

omifusus coronatus (Roemer) Holzapfel

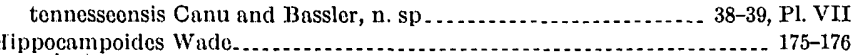

liratus Wade, n. sp ............. 176, PI. LIX

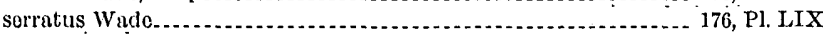

Homalostega biforis Marsson ............. 36 erectu Mirss

exsculpta Marsson.

Toploparia gabbi Pilsbry. tennesseensis Rathbun, n. sp

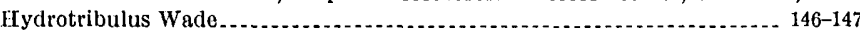
nodosus Wade...................... 147, PI. LI

I

Icanotin pulchra Wade, n. sp................. 91-92, Pl. XXIX

Importance of the Coon Creek fauna.

Inoceramus proximus Tuomey sagensis Owen.

noperna carolinensis Conrad

9-50, Pl. XII

650, Pl. XII

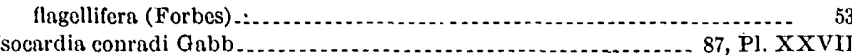
zitteli titolzapfel.

$\mathbf{J}$

Johnson, C. W., cited.

15

L

Laxispira cochleiformis Müller lumbricalis Crabb. pinguis Holzapfel. trochloata Böhm. turritolliformis Vogel

Leda nustralis Wado, n. sp. pinnaformis Gabb. whitfleldi Gardner

Leiosoecia parvicella Gabb and Horn.

Loiostraca cretacea (Conrad)

$172, \mathrm{Pl} . \mathrm{LVIII}$

Leptosolen biplicata Conrad. 94-95, Pl. XXXI conradi Meek.

lima buttoni Woods clypeiformis D'Orbigny decussats Goldfuss.

grenieri Coquand

hoperi Mantill.

obliquistriata Forbes

reticulata Forbes. .

woodsi Wade, n. sp.

159

meoki Wade, n. sp

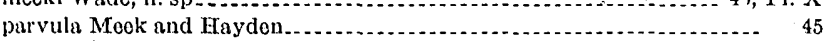

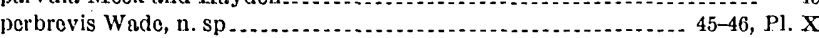

transversa Gabb.
I.inearia concentrica (D'Orbigny). metastriata Conrad ornatissima Weller........................................... 34, PXX

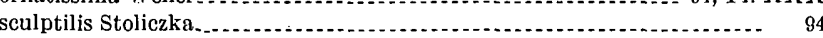

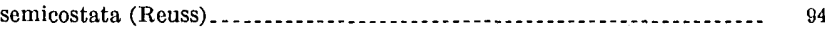
subtenuistriata D'Orbigny

Linearia? formosa Meek and Hayden.

Linuparus atavus Ortmann . . . . .

Linpeplum canalis (Conrad) . . carinatum Wade, n. sp.............. 119, Pl. XLII liodermum (Conrad) . . . . . . . . . . . . . . . . . subjugosum (Gabb) . .

Liopistha aequivalvis (Goldfuss) .

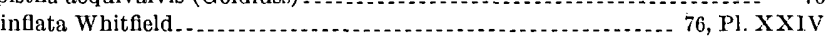
protexta (Conrad) (Papyridea) bella Conrad ........................................ 76

Liothyris carolinensis Conrad................................ \$4, Pl. XXXI

Liotia parva Vogel . . . . . .

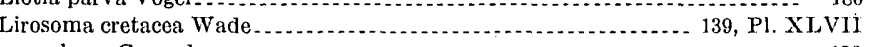

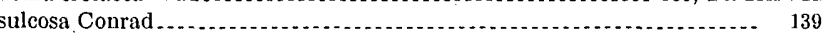

Lithodomus subcylindrica Stoliczka..................... 70

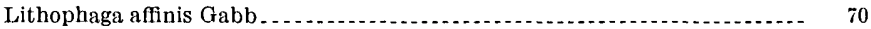
conchafodentis Gardner. . . . . . . . 71, Pl. XXIII ripleyana Gabb........... 70 , Pl. XXII

Littorina acicularis Stoliczka $\ldots \ldots \ldots$ berryi Wade, n. sp.................. 166-167, Pl. LVIII

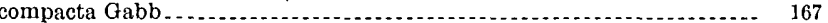

Localities of prolific Cretaceous faunas, list of . . . . .

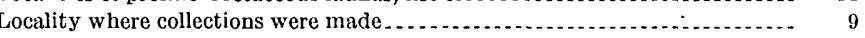

Lucina fallax Forbes. . .

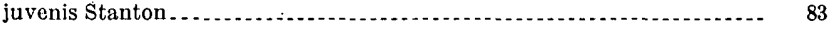
ripleyana Wade, n. sp................................... 82-83, Pl. XXV

McNairy sand member, nature and occurrence of .................... 8-9

Mactra? zulu Etheridge

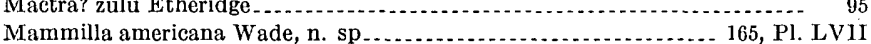
carnatica Stoliczka. .

Martesia constricta (Phillips) . . . .

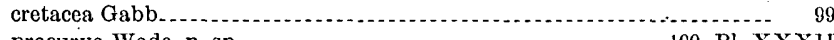
procurva Wade, n. sp.................................. 100, Pl. XXXII truncata Wade, n. sp.................................. 99, Pl. XXXII

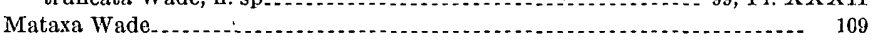

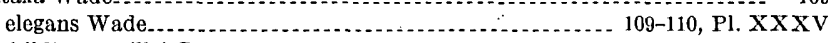

Mathildia douvillei Cossmann......................................... 17 inaequistriata (Meyer) ............................................. 171 regularis (Meyer) ripleyana Wade, $\mathrm{n}, \mathrm{sp}$. Meek, F. B., cited ................... $79,169,180-181,181-182$ and Hayden, F. V., cited...................................... 71-72, 95

Melanatria cretacea Wade, $n$. sp ................................. 158, Pl. LV

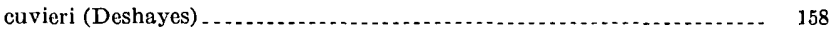
dufresnei (Deshayes) $\ldots \ldots \ldots$

Melo pyriformis Forbes. .

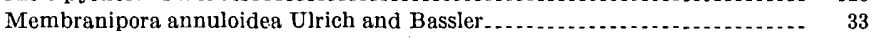
gothea Meunier and Pergens . ............ 34

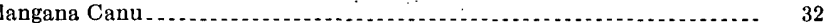

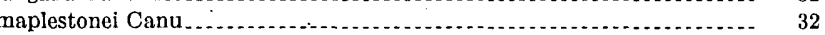
munita Marsson.

Membraniporella abboti Gabb and Horn irregularis Canu and Bassler, n. sp . . . . . . . . . . . . . . . . . . . . . . 36, PI.VI modesta Ulrich..................................................... 36

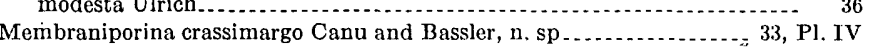

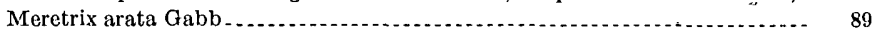

Meretrix cretacea (Conrad) deweyi (Meek and Hayden) $\ldots . . \ldots \ldots \ldots \ldots \ldots$ discoidalis (Stoliczka) . . . eufaulensis (Conrad)

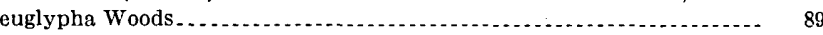

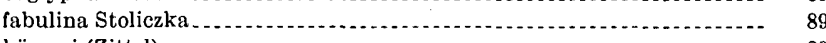

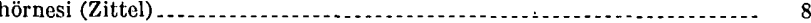

koffraria (Etheridge) $\ldots . . \ldots \ldots \ldots$

Mesorhytis obscura Wade, n. sp...... 132-133, Pl. XLV

Mesostoma americanum Wade, n. sp . costatum Wade, n. sp............. 155, PI. LIV mülleri Holzapfel

striatacostata (Müller) Holzapfel -155

Metopaster parkinsoni Forbes. tennesseensis Wade, n. sp........... I

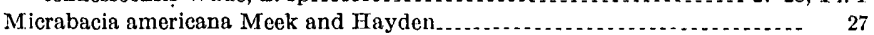
cribraria Stephenson........................................ 27

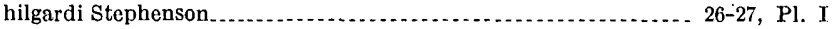

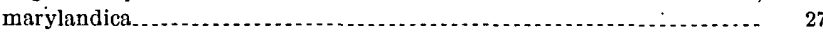
mississippiensis.......................

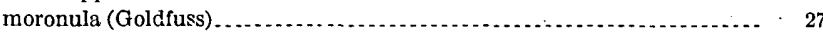
rotatalis $\ldots$ 
Micropora baccata Canu and Bassler, n. sp................... $\quad 36$, Pl. VI convexa Canu ..........

vincentownensis Ulrich and Bassler

Modiola icaunensis (De Loriol) medus (D'Orbigny). perplicata (Etallon) sowerbiana (D'Orbigny)

Morea cancellaria Conrad marylandica Gardner

Morton, S. G., cited

Mosasauridae.

191-192, Pls. LXII, LXXI, LXXII

Sassler, n. sp........................ 35, Pl. IV

\section{$\mathrm{N}$}

Narona eximia Stoliczka 109

Nassa globosa Gabb

144,146

-Natica concinna Hall and Meek

laevis Kaunhowen

obliquata Hall and Meek

Nautilus bouchardianus D'Orbigny

laevigatus D'Orbigny.

orbignyanus Forbes. perlatus. .

spharicus...

Nemodon conradi eufaulensis (Gabb) grandis Wade, n. sp stantoni Gardner.

Nucula amica Gardner

bidorsata Stoliczka

cancellata Meek and Hayden

coloradoensis Stanton

mariae Rathbun

microconcentrica Wade, n. sp

obsoletistriata Meek and Hayden

percrassa Conrad.

slackiana

tamulica Stoliczka

Nudivagus Wade

simplicus Wade.

$134,135, \mathrm{Pl}, \mathrm{L}$

$133, \mathrm{Pl}$. LI

$30,44,53,55,70,73,160$

0

Obeliscus conellus Whitfield

Odontobasis australis Wade, n. sp ventriosa Meek.

Odontofusus curvicostata Wade,

Odostomia impressa, Wade, n. sp.... plicata Wade, n. sp.

trapaquara (Harris)

Omphalia ovata Zekeli ventricosa

Ornopsis Wade. digressa Wade, n. sp. elevata Wade glenni Wade..

ostrea bryani Gabb? crenulimarginata falcata Morton.

menairyensis Wade, n. sp

monmouthensis Weller

penegemmea Wade, $\mathrm{n} . \mathrm{sp}$

plumosa Morton

prudentia White.

tecticosta Gabb.

Owen, D. D., cited

Owl Creek tongue, nature and ocourence of

Paladmete cancellaria (Conrad) densata Wade, n. sp gardnerae Wade, n. sp.

108, Pl. XXXV
$108, \mathrm{Pl}$ XXXV alaeocorystes harveyi Woodward

Paleopsephaea Wade, n. gen... 123 Sp . . ......................... 124, Pl. XL

Panope decisa Conrad..

124, Pl. XL
P1. XXXII clliptica Whitfield. monmouthensis Gardner

Parafusus Wade callilateris Wade coloratus Wade aramorea Wade. lineata...

lirata Wade.
$2-43$, PI. VIII

43; Pl. VIII

$40, \mathrm{Pl}$ VIII

40 III

VIII 40
40

156

72,173 146, Pls. LI, LII 130-131, Pl. XLII 173,174, Pl. LVIII 173-174, Pl. LVIII

I

54

$\begin{array}{ll} & \\ & \end{array}$

Pugn

lippana (Conrad) $\ldots \ldots \ldots$

Conrad...................... 148, Pl. LII

$\begin{array}{ll}\text { uncatus (Forbes) } & 148 \\ \end{array}$

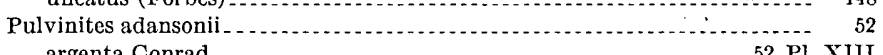

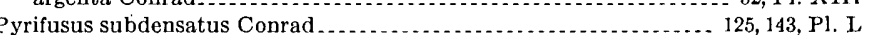

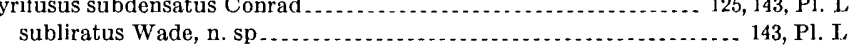

Pyropsis africana Woods $\ldots$ $\begin{array}{ll}\text { hombroniana D'Orbigny } . \ldots \ldots & 140 \\ \text { Octolirata } & \end{array}$

perlata Conrad . . . .

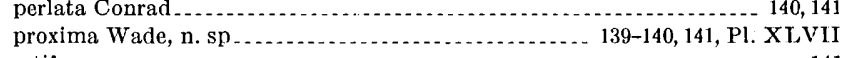
proxima Wade, n. sp

$\mathrm{R}$

Radula denticulicosta Gabb.

Range of the Coon Creek fauna, table showing $2 . \ldots 16$ Raninella testacea Rathbun, n. sp............ 190, Pl. LXVIII Ranularia piraster (Lamarck) $\ldots . . \ldots 139$ Rapa cancellata (Sowerby) Stoliczka . . ............................... 138, 140

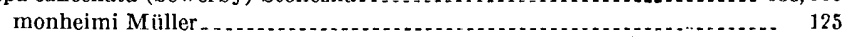


Rathbun, Mary J., Decapoda.

184-191

Rhombopsis Gardner

microstrinitus Wade, n. sp

$142-143, \mathrm{Pl}, \mathrm{I}$

orientalis Wade, n. sp.

subturritus Meek and Flayden

Ringicula pulchella Shumard.

Ripley formation, distribution and subdivisions of

Rissoina acuminata Müller.

alabamonsis Aldrich.

fragilis Wade, n. sp

incorta (Deshayes) D'Orbigny

subornata Wade, n. sp..

tennesseensis Wade, n. sp

Rostellaria lucida Sowerby

noneliana (D'Orbigny)

schlothoimi Roomer.

Rotella crotacea D'Orbigny

\section{.. 142, Pl. XLIX} 105, Pl. XXXIV

(1)

Sagana stantoni (Woller) Scala sillimani (Morton)...

(Opalia) thomasi Crabb.

168

Scalaria denso-striata Kaunhowen.

Sca!pellum conradi Gabb

maximum Sowerby -

quadratum Darwin.

Splata perplana Conrad

Scambula perplaua Conrad......
Scaphander alabamensis Aldrich rarus Wade, n. sp..

167,168

167

167, Pl. J̇VIII

167

, 168

III

151
150

15

178

Scaphites aequalis Sowerby .

binodosus Roemer

compressus Rocmer

constrictus Sowerby

inflatus Roomer.

var. quadrangularis Mcek ............................ 183, 184

n. sp roomeri D'Orbigny $\ldots \ldots \ldots \ldots \ldots \ldots \ldots$
tridens Kner.

Schizobasis wado.

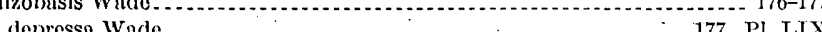

depresșa Wade.....

immersa Wade, n. sp..................................... 177-178, Pl. IAX

Suy, Thomns, cited .................................................. 57, 181

Selmn formation, nature and occurrence of . . . . .

Seminola Wade

crassn Wade

145, PI. L

solidn Wade...

Serpula adnata Wade, n. sp...................... pervermiformis Wade, n. sp................ II septemsulcata Reich and Cotta.......... 30 sexsulcata Munster

vertebralis Sowerby

Serpulorbis marylandica Gardnor- -1

tennesseensis Wade, n. sp.......... 159, P1. IS

Serrifusus dakotensis Meek ........................................... 144

tennesscensis Wade, n. sp................................... 143-144, Pl. I

Shumard, B. F., cited................................................... 184

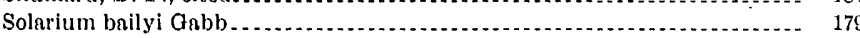

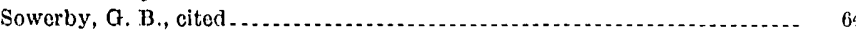

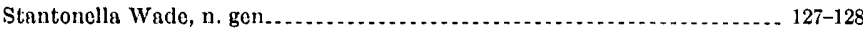

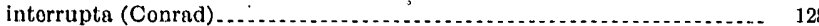

subnodosa Wade, n. sp........................ 128, Pl. XV

Stellaster planensis Geinitr................... 28

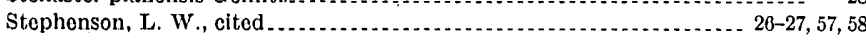

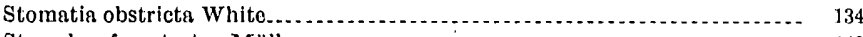

Strombus fenestratus Müller.......................................... 143

Trapes faba (Sowerby)

Tectaplica Wade

121-122, Pl. XLIII

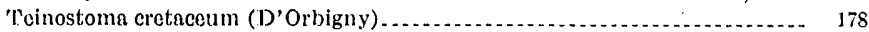

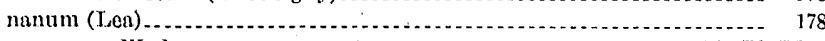

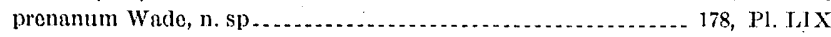

'Tellina multiconcentrien Wade, n. sp.............................. 92, Pl. XXX scitula Meck and Hayden

Tellinimera eborea Conrad . . . . .

Tenea parilis Conrad.

83, Pl. XXVI

Teredo rectus Wade, n. $\mathrm{sp}$.

Thylacus cretacous Conrad

Tombigbee sand member, nature and occurrence of

00, PI. XXXIII

166, PI. LVIII

ornatellaca cretacea Wade, n. sp

$103-104$, Pl. XXXIV globulosa Wade, n. sp.
Tortifusus curvirostra Conrad.

Trichotropis borealis Broderip and Sowerby imperfecta Wade, n. koninckii Müller

Trigonia alaeformis Sowerby

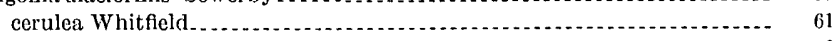

emoryi Conrad

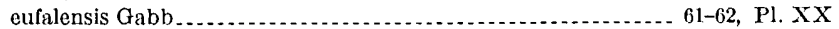

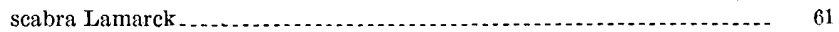

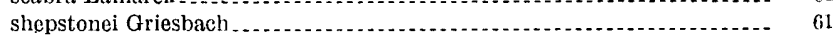
thoracica Morton . . vaalsiensis Böhm.....................................................

Tritonidea granulata

Tritonium gosanicum Zekeli.......................................... 148 loricatum Zekeli univaricosum Wade, n. sp.................. 147-148, Pl. II

Trochacteon semicostatus Whiteaves

Trochifusus interstriatus Wade, n. sp........................ 141, Pl. XLIX

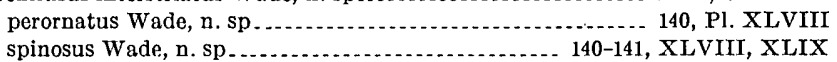

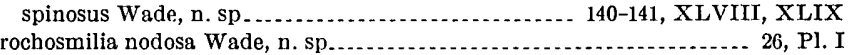

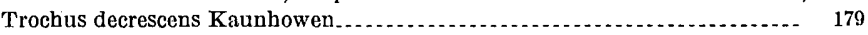
ripleyanus Wade, n. sp . ...

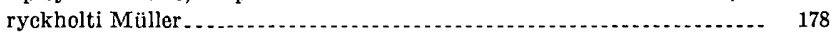

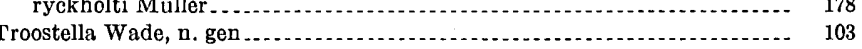
perimpressa Wade, n. sp... Xe Pl. XXIV

Trophon condoni White

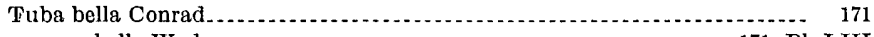
parabella Wade, n. sp.................... 171, Pl. III subcyclostoma (Matheson) Crossmann .............................. 171

Tuomey, Michael, cited.................... 49

$\begin{array}{lll}\text { Turbo boimstorfensis Griepenkerl } \ldots \ldots & 179\end{array}$ $\begin{array}{ll}\text { chihuahuensis Bose } \ldots \ldots & \end{array}$ $\begin{array}{lll}\text { cornutus } & \\ \text { rimosus var. granulata Kaunhowen } \ldots \ldots \ldots \ldots & 177\end{array}$

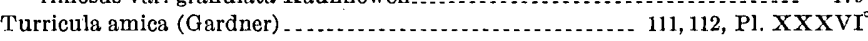
anomalocostata Wade, n. sp............................ 113, Pl. XXXVII

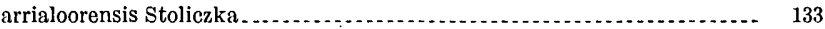
biacuminata Wade, n. sp..... 112, Pl. XXX fasciolata Wade, n. sp .............................. 112, Pl. XXX gracilis Wade, n. sp........................................ XXXV menairyensis Wade, n. sp ................................. 113, Pl, XXXVI minor (Evans and Shumard) ripleyana (Conrad) .................................... 111, Pl. XXXVI

Turris constricta Wade; n. sp............................ 110-111, Pl. XXXVI

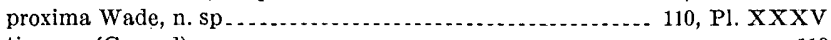
tippana (Conrad)

Turris? kaffrarium (Griesbach)

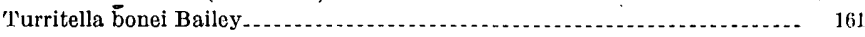

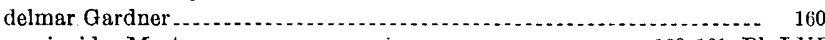
encrinoides Morton ........... 160-161, Pl. LVI mcnairyensis Wade, n. sp.................................. 159-160, Pl. LVI paravertebroides Gardner?.................................. 160, Pl. LVI

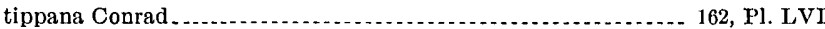

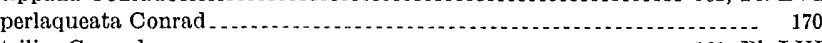
trilira Conrad.......... 161, Pl. LVI vertebroides Morton........... 160, 161, Pl. LVI

Tuscaloosa formation, nature and occurrence of .........................

$$
\mathrm{U}
$$

Unicardium concentricum Wade, n. sp.................. 82, P1. XXV ringmeriense (Mantell) umbonatum Weller

$\mathrm{V}$

Vermes, representation of, at Coon Creek........

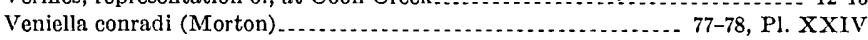
drui (Meunier-Chalmas) . . . . goniophora Meek mortoni Meek and Hayden........................................... 77

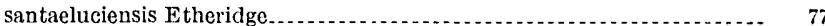

Vetericardia benedeni (Müller) ........................................ 78 crenalirata (Conrad) .............. XXIV gregatia (Meek and Hayden) ......................... 78, 79, Pl. XXV

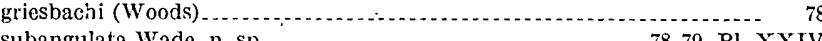

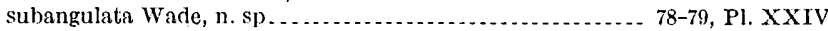

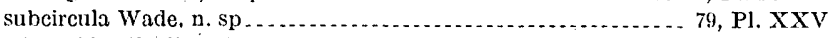
trigonoides (Stoliczka)

oluta florencis Harris . . . . . . . . . .

rigida Bailey .................... 120

Volutilithes nana (Müller) Holzapfel .............................. 123

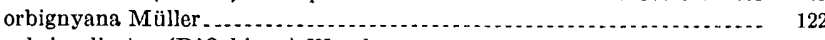

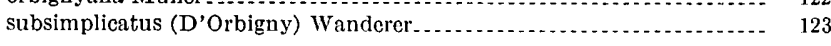


Volutoderma appressa Wade, n. sp.

$115-116, \mathrm{Pl} . \mathrm{XXXIX}$

protracta Dall

(23

tennesseensis Wade, n. sp

texana (Conrad)

$113-114$, PI. XXXVII

XXXII, XXXVII, XXXIX

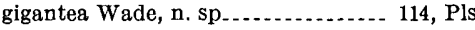

mutabilis Wade, $n$. sp.................

$\begin{array}{ll}\text { retifera Dall } \ldots \ldots \ldots & \end{array}$

W

Weller , Stuart, cited..... $45,49,51-52,54,55,56,61,63,67-68,73,75,81,84,85-86,87,88$ $89,94,99,101,136,141,152-153,159,160,161,162,164$
Whitfield, R. P., cited. .............. 41, 50, $51,65,66,74,76,78,82,84,98,162,168,172$

Woodsella Wade, n, gen ....... 129-130

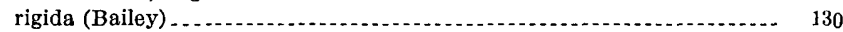

typica Wade, n. sp.............. 130, Pl. XI

Xancus major Wade, n. sp............. variabilis Wade, n. Sp............. 124-125, Pl. XLIV

Xenophora leprosa (Morton) .................................. 162-163, Pl. LVl

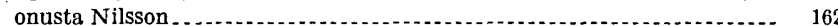

Yoldia longifrons (Conrad) ............................. 41-42, Pl. VIII microdonta Meek.............................................. 42

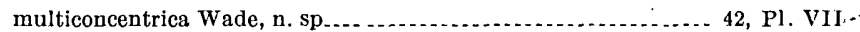

ADDITIONAL COPIES

OF THIS P.UBLICATION MAY BE PROCURED FROM

THE SUPERINTENDENT OF DOCUMENTS

GOVERNMENT PRINTING OFFICE

WASHINGTON, D. C.

$\boldsymbol{A T}$

$\$ 1.00$ PER COPY

$\nabla$ 